\title{
LA CIENCIA ESPAÑOLA
}

\section{Marcelino Menéndez Pelayo}

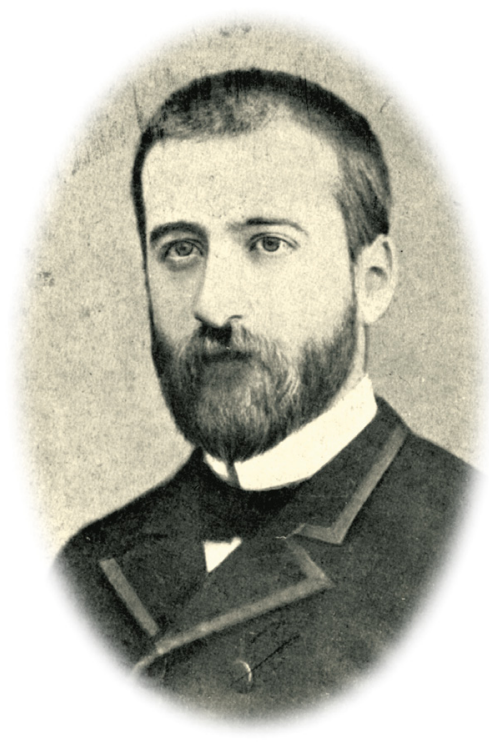

$$
\text { Vol. I }
$$

[Edición en dos volúmenes]

Directores:

Víctor Navarro Brotons, Gerardo Bolado 



\section{LA CIENCIA ESPAÑOLA}





\title{
LA CIENCIA ESPAÑOLA Marcelino Menéndez Pelayo
}

\author{
Volumen I \\ [Edición en dos volúmenes] \\ Directores: \\ Víctor Navarro Brotons, Gerardo Bolado
}

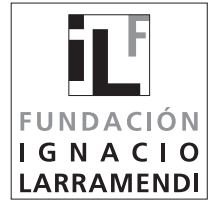

2019

MADRID 
Directores:

Víctor Navarro Brotons, Gerardo Bolado.

Estudios introductorios:

Nicolás Bas, Gerardo Bolado, M. a Dolores Díaz Regadera,

Fernando Hermida de Blas, José Luis Mora García,

Víctor Navarro Brotons, María Cristina Pascerini, Pedro Ribas Ribas.

(C) De los textos introductorios: los autores.

(C) Fundación Ignacio Larramendi

C/ Alenza, 4

28003 Madrid (España)

www.larramendi.es

Índices:

Gerardo Bolado, Víctor Navarro Brotons, María Cristina Pascerini.

Diseño y maquetación: DIGIBÍS

(a cargo de Antonio Otińano Martínez, director de Arte).

DOI de La ciencia española: http://dx.doi.org/10.18558/FIL162

DOI del volumen I de La ciencia española: http://dx.doi.org/10.18558/FIL163

ISBN de la obra completa: 978-84-09-16991-7

ISBN del volumen I: 978-84-09-17169-9

D. L.: M-39024-2019

Imprime:

Reprografía Madrid

C/ Cristóbal Bordiú, 20

28003 Madrid 


\section{ÍNDICE DEL VOLUMEN I}

Prólogo a la nueva edición de La ciencia española, de Marcelino Menéndez Pelayo

Luis Hernando de Larramendi

Prefacio. Una asignatura pendiente:

la bibliografía y las nuevas tecnologías $\mathrm{XV}$

Xavier Agenjo Bullón

\section{ESTUDIOS INTRODUCTORIOS}

La polémica en torno a la cuestión de la ciencia española

en la Espańa contemporánea XXIII

Victor Navarro Brotons

A [casi] ciento cincuenta años de la polémica de la ciencia.

Su noble e involuntario «instigador»: Gumersindo de Azcárate .LVII José Luis Mora García

La polémica de la ciencia en la Espańa de la Restauración (1876-1898). Los racionalistas de la

Revista Contemporánea en la polémica: Manuel de la Revilla LXXVII Fernando Hermida de Blas

La polémica de la ciencia en la Espańa de la Restauración (1876-1898). Los racionalistas de la Revista Contemporánea en la polémica: José del Perojo .LXXXVII M. a Dolores Díaz Regadera y Pedro Ribas Ribas 
La polémica de la ciencia en la España de la

Restauración (1876-1898). Dos tomistas en la polémica:

Aproximación biográfica XCIX

Gerardo Bolado

I. Alejandro Pidal y Mon

XCXI

II. Joaquín Fonseca O. P.

CII

La lucha por el reconocimiento de la cultura hispánica.

Análisis argumentativo de La ciencia española

Gerardo Bolado

La ciencia española en los medios de difusión

cultural de su tiempo

CLIX

Maria Cristina Pascerini

El «Inventario bibliográfico» de La ciencia española desde la perspectiva de la Bibliografía y la Documentación científica CLXXI Nicolás Bas

La ciencia española y el cultivo de las disciplinas

físico-matemáticas en la España moderna. Consideraciones

historiográficas sobre el «Esplendor

y decadencia de la cultura científica española»

CLXXXIII

Victor Navarro Brotons

Historia de las ediciones

CCXXVII

Gerardo Bolado

Nota sobre la presente edición

CCLXXXI

Victor Navarro Brotons, Gerardo Bolado

Selección bibliográfica CCLXXXV

\section{LA CIENCIA ESPAÑOLA}

Advertencia de la segunda edición (1880) ............................................. 3

Advertencia preliminar de la tercera edición (1887) ............................... 5

Carta-prólogo de la primera edición (1876) ............................................ 9 


\section{PRIMERA PARTE}

Al señor Gumersindo Laverde

I. Indicaciones sobre la actividad intelectual de España en los tres últimos siglos [Primera Edición]

II. De re bibliographica [Primera Edición]

III. Mr. Masson redivivo

(Réplica a un escrito de D. Manuel de la Revilla) [Primera Edición] ....73

IV. Monografías expositivo-críticas [Primera Edición]

V. Prosíguese el pensamiento de las cartas anteriores

[Primera Edición]

VI. Mr. Masson redimuerto.

(Segunda contestación a D. Manuel Revilla) [Primera Edición]

Apéndice. Primera parte

1. Fox Morcillo [Tercera Edición]

2. Contestación del Sr. D. Gumersindo Laverde

a la última réplica del Sr. Azcárate [Segunda Edición]

3. Nota final [Segunda Edición]

\section{SEGUNDA PARTE \\ Al señor Alejandro Pidal y Mon}

I. Dos artículos del señor Alejandro Pidal y Mon

sobre las cartas anteriores:

1. Primer artículo [Segunda Edición] ..........................................203

2. Segundo artículo [Segunda Edición] ......................................216

II. In dubiis libertas [Segunda Edición] ...........................................229

III. Respuesta a «La ciencia española bajo la Inquisición», del señor José del Perojo ................................................................251

1. Carta al señor Alejandro Pidal y Mon [Segunda Edición] ........251

2. Carta al señor Alejandro Pidal y Mon (Continuación).

[Segunda Edición] ....................................................................265

3. Carta al señor director de La España. [Segunda Edición] ..........296 
IV. La Antoniana Margarita de Gómez Pereira.

Carta al señor Juan Valera [Segunda Edición]

V. La patria de Ramon Sibiuda (Raimundo Sabunde)

[Segunda Edición] 381

VI. Instaurare omnia in Christo.

Carta al señor Alejandro Pidal y Mon. [Segunda Edición]

Apéndice. Segunda parte

Contestación del señor Alejandro Pidal y Mon

a la carta in dubiis libertas. [Segunda Edición] 


\title{
Prólogo a la nueva edición de La ciencia española, de Marcelino Menéndez Pelayo
}

\author{
Luis Hernando de LaRRAmendi \\ Presidente de la Fundación Ignacio Larramendi
}

C 1 último de los proyectos culturales de mi padre, Ignacio Larramendi como Bibliotecas Virtuales FHL.

En 2000 se publicó un folleto titulado Bibliotecas Virtuales FHL que fue el origen de la primera edición en 2001, ya de forma póstuma, de un librito, al que denominamos «libro blanco», que recogía razonadamente los autores que debían figurar en esa biblioteca virtual, proporcionando para cada uno de ellos un resumen que resaltaba su valor intelectual, su influencia y una pequeña biografía. El «libro blanco» tuvo sucesivas actualizaciones en 2002, 2005 y 2008, hasta que en 2009 sus textos se reutilizaron y rediseńaron para alimentar el sitio web de la Biblioteca Virtual de Polígrafos.

También en su libro Asi se hizo MAPFRE menciona este último proyecto y su origen, Menéndez Pelayo digital, que se publicó ahora hace justamente 20 años, y al que se quiere conmemorar con esta nueva edición de La ciencia española. Dice don Ignacio:

Con una idea similar a la que me impulsó a promover el proyecto «Clásicos Tavera» dentro de la Fundación Histórica Tavera, se comenzó a trabajar en el desarrollo de una colección en CD Rom que reuniera, en soporte informático, las obras completas de una selección de polígrafos europeos e iberoamericanos. Comenzamos a trabajar con Xavier Agenjo, director de la Biblioteca Menéndez Pelayo, con la colaboración de Ignacio Gon- 
zález Casasnovas y del profesor José Andrés Gallego, en la edición de las obras completas de este reconocido polígrafo, que constituye sin duda un proyecto tecnológico, científico y económico, que fue ejecutado por la empresa DIGIBÍS y financiado por la Caja de Ahorros de Cantabria. En estos momentos, ya terminado, ha sido presentado en Santander, Nueva York y México. Constituye un extraordinario avance para la investigación y utilización de las obras de este polígrafo.

En estos momentos estoy promoviendo la continuación del proyecto, con la edición digital de las obras completas de Ramón Llull, Gregorio Mayans, Melchor Gaspar de Jovellanos, Rafael Altamira, Francesc Eiximenic, Arnáu de Vilanova, Jaime Balmes, Eugenio d'Ors, Verdaguer y posiblemente Martín de Riquer y Miguel Batllori, y muchos otros, incluso iberoamericanos, como Andrés Bello y Alfonso Reyes.

Pienso que este tipo de proyectos tendrá una enorme repercusión a lo largo del siglo xxi, y siendo una acción comparable a la que en su día supuso la llamada Escuela de Traductores de Toledo Alfonso X el Sabio, que contribuyó a transferir la cultura helénica en España y Portugal, a través de la cultura árabe. Con Polígrafos se pondrá a disposición de todos los estudiosos del siglo xx el pensamiento de autores de nuestra cultura durante más de cuatro siglos, que se encuentra en obras ya agotadas, difíciles de consultar, y que no es fácil que se reimpriman.

Sobre Menéndez Pelayo digital se publicaron en su día reseñas muy positivas sobre el renacimiento que suponía la edición en formato texto de la obra completa, especialmente las de Gustavo Bueno, en el sitio web Filosofía en español, sobre el proyecto editorial y sobre el propio autor.

En 1999 se puso a la venta Menéndez Pelayo digital, esta vez gracias al empeño de un importante empresario, tradicionalista carlista consecuente, Ignacio Hernando de Larramendi y Montiano. Esta edición digital ofrece la versión electrónica, en formato texto, del contenido íntegro de los 67 volúmenes de la edición nacional, de los 23 volúmenes del epistolario y una bibliografía completada y actualizada respecto a la publicada en 1995 .

Tras su muerte, la Fundación Ignacio Larramendi tomó el acuerdo de proseguir esas iniciativas de mi padre y 20 años después podemos decir que constituyen una realidad incontestable.

La conformación informática de la Biblioteca Virtual de Polígrafos ha corrido a cargo de la empresa DIGIBÍS, tal y como mi padre lo planeó. Su influjo ha sido tal que con el mismo software se han implementado otras cincuenta bibliotecas virtuales en toda España, desde la primera de ellas, que fue la Biblioteca Virtual de Derecho Aragonés en el año 2004, hasta el Archivo y Biblioteca del Ilustre Colegio de Abogados de Madrid en este mismo año 
de 2019 — donde por cierto se puede ver el registro de mi abuelo, el de mi padre y el mío. Mientras tanto, las bibliotecas virtuales que componen la Biblioteca Virtual de Polígrafos han ido aumentando, y justamente coincidiendo con la presentación de esta nueva edición de La ciencia española, de Menéndez Pelayo, se presenta también la Biblioteca Virtual de Novatores.

Durante estos 20 años ha habido hitos verdaderamente importantes que han significado mucho para nosotros por el respaldo tecnológico que han supuesto. Primero, el reconocimiento del Grupo Incubador de Datos Abiertos Vinculados de Bibliotecas, del W3C, y después el de Europeana, la gran biblioteca digital de la Unión Europea. Nuestros proyectos, especialmente el dedicado a la Escuela de Salamanca, han dado lugar a que estableciéramos relaciones con el Max-Planck-Institut für Europäische Rechtsgeschichte, dado que tanto ellos como nosotros nos dedicamos al estudio y la edición digital de las fuentes primarias de los autores que componen la Escuela de Salamanca. En 2018 nuestros expertos han publicado un artículo en la serie Salamanca Working Papers que, con el título «Visibility and Digital Accessibility of the School of Salamanca in a Linked Open-Data Environment», resume y ejemplifica en la Biblioteca Virtual de la Escuela de Salamanca todo el desarrollo teórico y tecnológico de la Biblioteca Virtual de Polígrafos. Por nuestra parte, hemos incorporado a la Biblioteca Virtual de la Escuela de Salamanca todos los registros y enlaces a los textos que el Max Planck Institute está publicando a texto completo sobre una selección de obras. Todo ello da buena muestra del nivel que hemos alcanzado.

Además de las bibliotecas virtuales y de la Biblioteca Virtual de Polígrafos a la que volveré más adelante, hemos publicado nada menos que 152 libros electrónicos dedicados a otros tantos polígrafos y 38 que recogen la obra completa, epistolario y bibliografía de Menéndez Pelayo. Se ha dado sobre todo preeminencia a los autores de nuestras bibliotecas virtuales, los polígrafos, pero también se ha incluido a alguno de los clásicos incontestables del pensamiento hispano. Estos libros electrónicos se pueden descargar en los formatos más usuales en los dispositivos de lectura (PDF, EPUB y MOBI).

No deja de ser curioso, como se puede comprobar en las estadísticas que publicamos trimestralmente, que las obras más descargadas de nuestra biblioteca virtual son las que componen la obras completas de Menéndez Pelayo. También se puede ver, porque proporcionamos de forma transparente nuestras estadísticas de consulta obtenidas a través de Google Analytics, que en 2018 hemos tenido 68.787 usuarios únicos que hicieron 364.410 visitas. En el primer semestre de 2019, las últimas estadísticas disponibles, las cifras son las siguientes: 43.718 usuarios únicos que hicieron 212.220 visitas. 
Mi padre dio mucha importancia a la promoción de Menéndez Pelayo digital. En primer lugar, y como no podía ser menos, se presentó el 20 de octubre de 1999 por un santanderino de pro, Alfonso de la Serna, en la Cátedra Menéndez Pelayo de la Biblioteca de Menéndez Pelayo; presentación que fue seguida de una «tercera» en $A B C$. Sin solución de continuidad, en el mes de noviembre, se presentó también en la Hispanic Society de Nueva York y en la Biblioteca del Museo Nacional de Antropología e Historia de México, donde la presentación corrió a cargo del presidente de la Academia de la Lengua de México, José Luis Martínez (1918-2007). También estuvo presente Miguel León Portilla, que ayudó muchísimo en la revisión y visto bueno de las listas de polígrafos hispanoamericanos que iban barajando mi padre y Xavier Agenjo.

En el marco de la Biblioteca Virtual de Polígrafos se han dedicado sendas bibliotecas virtuales a Menéndez Pelayo y a mi padre y, prácticamente de forma anual, se han ido creando diferentes bibliotecas temáticas, como las dedicadas a la Escuela de Salamanca (2011 y reeditada en 2018), otra dedicada a Francisco Sánchez el Escéptico (2012), la Antigua Escuela de Traductores de Toledo (2013), la Ciencia y la técnica en la empresa americana (2015), los Viajes científicos ilustrados (2017), y esta última dedicada a los novatores (2019). También hemos dedicado una a Cervantes (2016), con motivo de su centenario, y hemos convertido, desde unos discos, los Comentaristas de Aristóteles (2014) y Las retóricas españolas del siglo XVI, así como la mejor colección de textos y estudios de y sobre escritores visigóticos y mozárabes (reunidos en una de nuestras bibliotecas virtuales en 2017), que reeditaba el prólogo de mi madre, Lourdes Martínez Gutiérrez, para el libro La Hispania visigótica y mozárabe: dos épocas en su literatura, que se publicó en 2017.

Mi padre tenía una visión muy positiva de la aportación de España a la historia universal, con todos los defectos que se le pueda achacar, y pensaba que por diferentes razones esa historia se había vendido muy mal. Con ello coincidía con el dictamen de Menéndez Pelayo y, al igual que éste, inició una acción — marcadamente empresarial en su caso- para difundir las ideas de Menéndez Pelayo siguiendo el método utilizado por él. Es decir, acopiar la bibliografía de la ciencia espańola, reunir esa ciencia en un sitio concreto para que los especialistas no cayeran en la tentación de citar de segunda mano y, esto es lo peculiar de la iniciativa de mi padre, digitalizar esas obras para que primero en cederrón, estamos hablando de los primeros ańos 90, y luego en Internet, hacer accesible la aportación hispánica al pensamiento universal. 
Esta idea entroncaba justamente con la serie Clásicos Tavera, una colección de cederrones, de 160 discos y casi 2000 obras digitalizadas, que, a su vez, estaba íntimamente relacionada con las Colecciones MAPFRE 1492. Tanto es así que con motivo del centenario de mi padre en 2021 la Fundación Ignacio Larramendi presentará sendas bibliotecas virtuales dedicadas a esas dos colecciones.

Este planteamiento casaba muy bien con el del director de la Biblioteca Menéndez Pelayo de Santander, Xavier Agenjo Bullón, que desde finales de los años 80 había formado parte de los grupos de trabajo del Instituto Tavera, la Fundación Tavera y, finalmente, la Fundación MAPFRE Tavera, y había iniciado el proyecto de automatización de la Biblioteca Nacional de España, llamado ARIADNA, desde su puesto de director de la Unidad de Coordinación Informática, y el proyecto de digitalización de esa biblioteca desde su puesto de director del departamento de Acceso a la Información y al Documento. Más importante aún, como director de la Biblioteca Menéndez Pelayo formaba parte, junto a una decena de instituciones europeas, del proyecto liderado por la Residencia de Estudiantes del CSIC que, con el nombre de Contemporary Virtual Archives in XML (COVAX), tenía como objetivo la aplicación de los lenguajes de marcado para todo tipo de textos contemporáneos.

El nombramiento de Carmen Caro, que también había formado parte de los patronatos del Instituto Tavera, de la Fundación Tavera y MAPFRE Tavera, como subdirectora general de Coordinación Bibliotecaria, produjo el efecto de extender estas ideas con la creación de los proyectos de digitalización del Ministerio de Cultura, concretados en la Biblioteca Virtual de Prensa Histórica (2004), en la Biblioteca Virtual de Patrimonio Bibliográfico (2004) y, coronándolo todo, Hispana (2006) como agregador nacional de colecciones digitales españolas. De forma muy coherente, la implementación informática recayó en la empresa DIGIBÍS, después de ganar los correspondientes concursos, puesto que era la única empresa - hasta cierto punto sigue siéndolo- que contaba con la tecnología que se requería y que había adquirido en el desarrollo del software y en el tratamiento de textos de Menéndez Pelayo digital.

Cuando empezó el proyecto Europeana, — que dio carta de naturaleza a este conjunto de normas, protocolos y estrategias digitales_ España empezó a jugar un papel preeminente dentro de la estrategia de patrimonio digital europeo, papel que sigue jugando como puede verse en Implementation of Commission. Recommendation on the digitisation and online accessibility of cultural material and digital preservation: Consolidated progress report 2015- 
2017. De hecho, Hispana sigue siendo el primer agregador nacional entre los países que aportan contenidos digitales a Europeana, la biblioteca digital europea. Y entre ellas, la Biblioteca Virtual de Polígrafos de la Fundación Ignacio Larramendi.

Para conocer bien la obra que presentamos no estaría de más recordar que Menéndez Pelayo publicó La ciencia española en 1876, es decir, cumplidos solamente 20 años de su vida. Cuando uno repasa, no ya las polémicas que mantuvo a la izquierda y a la derecha, lo que vale decir con los krausistas y con los neoescolásticos, sino el Inventario bibliográfico de la ciencia españo$l a$, asombra la erudición que llegó a tener a esa edad, a la que muy pocos eruditos llegan al final de una vida entera de esfuerzos. Desde luego esa erudición estaba edificada sobre los cimientos bibliográficos proporcionados por el joven Marcelino, bien para rebatirlos, bien para construir a partir de ellos, pero siempre sin hurtar la vista de todas esas papeletas que el maestro bibliógrafo había allegado a la edad de un aprendiz.

La Fundación Ignacio Larramendi publicó hace 20 años el cederrón Menéndez Pelayo digital, fruto de los esfuerzos de DIGIBÍS y de la Biblioteca de Menéndez Pelayo, con la participación del CSIC y de la Caja de Ahorros de Cantabria mediante un convenio específico. En 1999 los derechos de autor ya habían prescrito y en cualquier caso eran propiedad de la Sociedad Menéndez Pelayo, puesto que pasaron de las manos de la familia Menéndez Pelayo a esta institución, cuyo secretario era el mismo director de la Biblioteca Menéndez Pelayo. En esa época la dirección de la Biblioteca Menéndez Pelayo y la Secretaría de la Sociedad Menéndez Pelayo eran cargos que se reunían en la misma persona, como siempre había ocurrido desde que se constituyeron ambas entidades, aunque ahora no sea así.

Me importa mucho destacar que en 2009 y dentro de la Biblioteca Virtual de Polígrafos se implementó una biblioteca virtual denominada Menéndez Pelayo Digital donde se pueden consultar en forma de corpus toda la obra completa reunida en la denominada Edición Nacional (1940-1959), publicada por el CSIC y editada por el director de la Biblioteca Menéndez Pelayo, Enrique Sánchez Reyes; todo su Epistolario, publicado por la Fundación Universitaria Española (1982-1991), editado por el director de la Biblioteca Menéndez Pelayo, Manuel Revuelta; y la Bibliografía de estudios sobre Menéndez Pelayo, publicada también por la Fundación Universitaria Española (1995) y publicada por Amancio Labandeira (antiguo colaborador de Clásicos Tavera).

Esta nueva edición digital académica de La ciencia española publicada por la Fundación Ignacio Larramendi, al cuidado de los profesores Víctor 
Navarro Brotons y Gerardo Bolado, constituye una revisión crítica sin precedentes donde se acumulan más de 140 años de erudición de buena ley, decantada en las introducciones y las notas que han enriquecido el texto.

No hay un mejor libro que esta "ciencia española» que, como he intentado decir, no solo es el punto de partida de la obra completa de Menéndez Pelayo, sino también el de la Biblioteca Virtual de Polígrafos, e incluso el de muchas de las bibliotecas digitales que, al menos desde el punto de vista de la implementación de la tecnología digital, se han publicado en España.

Este libro, que se publica en dos volúmenes, se suma a los casi 10.000 libros digitales que ha publicado la Fundación Ignacio Larramendi estos años y que son la plasmación de la estrategia de mi padre. Muy difícilmente habríamos escogido un libro que pudiera resumir en tres palabras la visión de Menéndez Pelayo, de Ignacio Larramendi y de la Fundación que lleva su nombre: La ciencia española.

Madrid, 6 de julio de 2019 



\section{Prefacio. Una asignatura pendiente: la bibliografía y las nuevas tecnologías}

Xavier Agenjo Bullón

Director de Proyectos de la Fundación Ignacio Larramendi Director en excedencia de la Biblioteca de Menéndez Pelayo

$\mathrm{E}$ n Menéndez Pelayo siempre son esclarecedoras las muchas páginas de bibliografía que acompañan a sus escritos, pero en esta etapa polémica del «Inventario de la ciencia española» lo es especialmente. Ya en la introducción a «De re bibliographica», recogida en la Antología comentada — publicada en la editorial Estudio de Santander en 2002-, señalé, sin que se me haya hecho mucho caso, que Menéndez Pelayo tuvo la suerte de que el Instituto de Santander contara con un bibliógrafo extraordinario, el asturiano Máximo Fuertes Acevedo, con el que mantuvo toda su vida una relación muy cordial como prueban sus cartas.

Para mí está fuera de duda que Máximo Fuertes Acevedo inició al joven Marcelino en los clásicos de la bibliografía española, especialmente sobre las dos bibliotecas de Nicolás Antonio. Muchas de esas citas bibliográficas que asombraron a sus contemporáneos, sobre todo cuando se trataba de un joven de 20 años, están tomadas de la Bibliotheca Hispana vetus y de la Bibliotheca Hispana nova. Es evidente -insisto, para mí- que Marcelino Menéndez Pelayo salió de las polémicas con bien gracias al apabullante fondo bibliográfico que esgrimía ante sus adversarios, fueran ellos neotomistas o krausistas. De hecho, cuando se publicaron las actas de las IV Jornadas de Hispanismo Filosófico (2000), de las que fui editor junto a Gonzalo Capellán, se hizo con el título Hacia un nuevo inventario de la ciencia española. 
Don Marcelino, basándose en su trabajo de crítica bibliográfica, emprendió un proyecto que en términos biblioteconómicos se denominaría de «acceso al documento», cosa que en el siglo XIX era muy difícil. Ese, y no otro, eran el origen y los propósitos de la biblioteca de Santander, plasmar en una biblioteca concreta todo el aporte bibliográfico que Menéndez Pelayo fue reuniendo todos los días de su vida con una paciencia benedictina.

Es una pena que durante los 18 ańos que han transcurrido desde que tomé la excedencia en el puesto de bibliotecario, como director de la Biblioteca de Menéndez Pelayo, no se haya dado un solo paso para su automatización y mucho menos su digitalización, y eso que su automatización es muy sencilla dado que se trata de un fondo muy delimitado que se puede reconvertir en muy pocas semanas. Aun en el caso de que se hubiera optado por la recatalogación y calculando una carga de trabajo de diez libros al día entre dos personas se obtendrían unos 2.200 libros al año, y dado que en la Biblioteca de Menéndez Pelayo hay 32.000 obras se habría terminado el trabajo en 14 años y medio. Es evidente que se trata de unas ratios de catalogación ridículas, cinco libros al día por persona, y que el $90 \%$ de ellos, si no más, se pueden descargar de diferentes bases de datos, entre ellas del servidor Z39.50 de la Biblioteca Nacional de España, del Catálogo Colectivo de Patrimonio Bibliográfico, del Catálogo Colectivo de la Red de Bibliotecas Universitarias o, incluso, del Catálogo Colectivo de Bibliotecas Públicas.

Ya se hubiera optado por la reconversión o por la recatalogación, o una combinación de ambas, los resultados habrían alimentado un catálogo en línea, un OPAC, lo que habría permitido la consulta de la Biblioteca de Menéndez Pelayo a través de la Web. Es un escándalo que la Biblioteca de Menéndez Pelayo no se pueda consultar desde el exterior. Hay muy pocas bibliotecas en Espańa que no faciliten la consulta de sus catálogos en Internet y ninguna de la importancia de la biblioteca que legó don Marcelino.

Bien se puede comparar con el proceso que se hizo en el marco del proyecto Contemporary Virtual Archives in XML (COVAX, IST-1999-11820 20012002) con el catálogo de La Casona de Tudanca, que se reconvirtió en menos de un mes y se incorporó al Sistema de Lectura Pública de Cantabria (BiblioCan). Habría sido más propio hacer un portal para destacar esta biblioteca, pero, en cualquier caso, hace ya veinte ańos que los usuarios, investigadores o curiosos pueden acceder a ese catálogo reconvertido en BiblioCan donde hay 13.639 registros. Pocos silos de información más dispuestos a su apertura y codificación normalizada que los archivos y, sobre todo, las bibliotecas.

La Biblioteca Menéndez Pelayo de Santander participó en este proyecto europeo justamente con la idea de crear una biblioteca virtual basada en la 
digitalización de sus fondos. El proyecto COVAX, liderado por la Residencia de Estudiantes del CSIC, dio un paso muy importante en la codificación XML de textos literarios europeos. Además de la aportación teórica y práctica de la codificación textual, el proyecto sirvió también para dotar a la Biblioteca de Menéndez Pelayo de una infraestructura tecnológica, haciendo realidad el cableado entre los dos edificios de las bibliotecas santanderinas, la propia Menéndez Pelayo y la Biblioteca Municipal, así como la adquisición de equipos informáticos, imprescindibles para llevar a cabo el proyecto COVAX en Santander, entre los cuales se contaba con ordenadores y, lo que es más importante, con escáneres de última generación. Pero si no había sido posible dar de alta el catálogo, menos se pudo hacer en el proyecto de digitalización de los fondos. A pesar de contar con escáneres apropiados para iniciar la digitalización de la Biblioteca de Menéndez Pelayo, nada se hizo, y lo que es peor, nada se sigue haciendo. Lo único que salió en claro fue un expediente administrativo, desestimado, para el pobre director, o sea yo, por haber buscado fondos europeos para ese proyecto.

Finalmente, lo que iba a llamarse «Proyecto Polígrafos Españoles e Hispanoamericanos» (tal y como se recogía en el tomo LXXV (1999) del Boletín de la Biblioteca de Menéndez Pelayo, en La digitalización de la Biblioteca de Menéndez Pelayo, la fase: Menéndez Pelayo y el Proyecto Polígrafos) se llevó a cabo por otros medios. Ignacio Larramendi vio muy claramente la idea y puso a disposición de ella una formidable actividad, tal y como relaté en Ignacio Hernando de Larramendi, in memoriam en Mecenazgo cultural de Ignacio Hernando de Larramendi y Montiano: crónica y testimonios y, en definitiva, el «Proyecto Polígrafos Españoles e Hispanoamericanos» pasó a ser las Bibliotecas Virtuales FHL, ahora denominadas Biblioteca Virtual de Polígrafos de la Fundación Ignacio Larramendi.

Haciendo de la necesidad virtud la Fundación Ignacio Larramendi y DIGIBÍS (empresa tecnológica de la FIL), dado que no podían contar con los volúmenes de la biblioteca de Santander, empezaron un proyecto nuevo consistente en buscar a través de la web esos libros ya digitalizados por terceras bibliotecas. La localización de las obras digitalizadas se facilitó enormemente cuando, unos años después, Hispana y luego Europeana empezaron a proporcionar los metadatos de las digitalizaciones de bibliotecas de toda Europa a través de complejos procedimientos informáticos, como el servidor SRU de Hispana o la API de Europeana.

Sin embargo, el convenio firmado entre el Consejo Superior de Investigaciones Científicas y la Fundación Hernando Larramendi (hoy Fundación Ignacio Larramendi) sí permitió la digitalización de las Obras completas de 
Menéndez Pelayo de la Edición Nacional, su Epistolario y la Bibliografía, allegada por el profesor Amancio Labandeira -editada al igual que el epistolario por la Fundación Universitaria Española. Hace ahora 20 años se publicó, en las circunstancias que Luis Larramendi describe en el prólogo de esta nueva edición, este conjunto de obras completamente codificadas en HTML en el cederrón Menéndez Pelayo digital, lo que desde luego no era usual entonces, pero tampoco lo es ahora.

Todo esto que se ha ido contando está documentado y publicado en las crónicas del Boletín de la Biblioteca de Menéndez Pelayo, sobre todo en el número del año 2000, donde se recoge la presentación de Menéndez Pelayo digital, el 20 de octubre de 1999, en Santander, en la Cátedra de Menéndez Pelayo; el 9 de noviembre, en Nueva York, en la sede de la Hispanic Society of America; y el 12 del mismo mes, en México, en el Museo Nacional de Antropología. Menos mal que no hubo que hacer nada en Santander, porque si no hoy en día Menéndez Pelayo digital estaría sin publicar. Y a los hechos me remito.

Diez años después, en 2009, Menéndez Pelayo digital se transformó en la Biblioteca Virtual de Menéndez Pelayo -incluida en la Biblioteca Virtual de Polígrafos- al implementarse en el software DIGIBIB, desarrollado por DIGIBÍS para la gestión digital de bibliotecas.

En cualquier caso, no deja de ser una pena que el proyecto, tal y como estaba planeado en su día y tal y como se desarrollaba en ese artículo del Boletín que he mencionado, no se llevara a cabo; habría hecho las cosas muchísimo más fáciles y sobre todo se habría dado todo el valor a esa estrategia de Menéndez Pelayo que consistía en pasar de la bibliografía a los estantes de su biblioteca, y que ahora pasaría, a partir de ahí, a través de las técnicas informáticas, a dar todo el sentido a la idea de aportar, no ya con los textos en la mano, sino con los textos en la red, una historia crítica de la ciencia española.

Es evidente que el siguiente escalón es pasar de HTML a TEI (estándar definido por la Text Encoding Initiative): paulatinamente aumentan en todos los ámbitos proyectos de codificación en TEI incluidos dentro del área de las Humanidades Digitales, entre ellos, el proyecto La Escuela de Salamanca: una colección digital de fuentes y un diccionario de su lenguaje jurídico-politico del Max-Planck-Institut für europäische Rechtsgeschichte. También ahora, cuando se cumplen esos 20 años de la edición de Menéndez Pelayo digital, he participado en un curso de la Universidad Internacional Menéndez Pelayo dedicado a las Humanidades Digitales con el título Humanidades digitales: por qué, cómo y para qué con la comunicación «Archivos y bibliotecas vir- 
tuales españolas: tratamiento textual de recursos bibliográficos» en el que explico los beneficios del etiquetado TEI.

La Fundación Ignacio Larramendi también ha querido trasladar las comunicaciones de las actas de las Jornadas de Hispanismo Filosófico hacia las Humanidades Digitales para, al menos, vincular de forma automática las citas de las ediciones con los textos. A veces, y lo digo con pena, cuando corregía las comunicaciones de esas Actas no dejaba de pensar que estaban escritas como se hubiera hecho en el siglo XIX. Me consta que muchos autores utilizan las ediciones digitales para buscar una cita, pero luego esa cita se refiere a la edición impresa, como si la edición electrónica no existiera o como, si de existir, hubiera nacido por generación espontánea. Esto se comprueba en numerosas ocasiones con el método de Lachmann y su famoso lectio difficilior, es decir, pasando de las musas de la ecdótica al teatro de la redacción se cuelan erratas de las ediciones digitales que son las que han valido para hacer una búsqueda.

Entre los proyectos que está llevando a cabo la Fundación Ignacio Larramendi con el apoyo de DIGIBÍS está la Biblioteca Virtual de Hispanismo Filosófico, donde los registros descriptivos de las comunicaciones estén por lo menos vinculados con las ediciones digitalizadas de los autores tratados en ellas y, con ello, con la Biblioteca Virtual de Polígrafos. La idea es que, si hay un autor mencionado en alguna comunicación, digamos Juan de Mariana, aparecerán estas comunicaciones relacionadas con el registro de autoridad correspondiente a Juan de Mariana, al mismo tiempo que las comunicaciones sobre este autor formarán parte del apartado «Obras sobre este autor» que figura en la ficha de autoridad de Juan de Mariana. Así, el registro de autoridad actúa como un hub de datos de todo tipo, pero especialmente en los enlaces «Obras como autor», «Obras sobre esta persona» $y$ "Obras en las que colabora».

Yo pensaba que esta edición de La ciencia española se iba a adentrar en este terreno de las Humanidades Digitales, al menos en lo que se refiere a las citas bibliográficas. Justamente la última vez que me reuní con los editores de esta nueva edición les hablé del proyecto mencionado sobre $\mathrm{La}$ Escuela de Salamanca e incluso les facilité el borrador del estudio Visibility and Digital Accessibility of the School of Salamanca in a Linked Open-Data Environment que ahora se puede consultar en Salamanca Working Papers Series (ISSN 2509-5080).

No es fácil decir hasta qué punto todo el aporte bibliográfico de $L a$ ciencia española está recogido en la Biblioteca Virtual de Polígrafos de la Fundación Ignacio Larramendi, hay que temerse que falten muchas cosas 
y no ayuda mucho el hecho de que no esté etiquetada la información de lo allegado por Menéndez Pelayo en esta nueva edición, pero no se puede concebir a un bibliógrafo con prisas. Todo ello acrecienta la labor que aquel joven de 20 años fue capaz de desarrollar en muy pocos meses y sin ningún apoyo institucional.

23 de agosto de 2019 


\section{ESTUDIOS INTRODUCTORIOS}





\title{
La polémica en torno a la cuestión de la ciencia espańola en la Espańa contemporánea
}

\author{
Dr. Víctor NaVArRo Brotons \\ Universidad de Valencia
}

$\mathrm{E}$ n 1876, el joven Menéndez Pelayo que contaba 20 años, publicó en la Revista Europea un artículo titulado «Mr. Masson redivivo». El texto no era sino una réplica a un escrito de Manuel de la Revilla en la sección «Revista Crítica» de la Revista Contemporánea. Este autor había apoyado y defendido la idea de que en España había tenido lugar una decadencia científica en los tres últimos siglos XVI, XVII y XVIII. Menéndez Pelayo tituló su respuesta a Revilla «Mr. Masson redivivo» ya que consideró el artículo de Revilla «eco póstumo de aquel Mr. Masson de la Enciclopedia, tan briosamente refutado un siglo ha por Cavanilles, el abate Denina y Forner». ${ }^{1}$ Efectivamente, hacia 1782 un oscuro publicista llamado Masson de Morvilliers había publicado en la Encyclopédie Méthodique un artículo dedicado a España, un auténtico panfleto contra al gobierno español en el que describió a la nación vecina como la más inculta, la más perezosa y la más débil de Europa. ${ }^{2}$ Entre las causas incluyó de forma destacada la gran cantidad de frailes y monjas y

1 Los artículos relacionados con la polémica fueron reeditados en la edición de $\mathrm{La}$ ciencia española en 1953, como parte de la Edición Nacional de las Obras Completas de Menéndez Pelayo, Madrid, CSIC. En nuestra edición, los incluimos como anexos procedentes de esa edición del CSIC. En adelante citaremos de manera abreviada nuestra edición, "MP, $C E$, vol., p.», en la que el artículo de Revilla figura en el vol. II, pp. 809 y ss., y la réplica de Menéndez Pelayo en el vol. I, p. 73.

2 Véase Masson de Morvilliers, «Espagne», en Encyclopédie méthodique. Section «Geographie Moderne», T. I, 1782, Paris, Panckoucke, p. 565. El texto puede verse reproducido 
la Inquisición. Según Masson allí donde este odioso tribunal estaba establecido, restringía la libertad de acción y de pensamiento, sofocaba todas las opiniones grandes y útiles, hacía un pueblo de hipócritas y de esclavos, perjudicaba el progreso de la industria y de las artes y, en consecuencia, destruía la población. «El español -afirmaba Masson- tiene aptitud para las ciencias, tiene muchos libros, y sin embargo es tal vez la nación más ignorante de Europa. ¿Qué cabe esperar de un pueblo que depende de un monje en cuanto a la libertad de leer y pensar?». Y más adelante, planteaba la gran pregunta: "¿qué debemos a España? Y desde hace dos siglos, desde hace cuatro, desde hace diez, ¿qué ha hecho por Europa?». A pesar de todo, al final del artículo Masson señalaba que las cosas estaban cambiando rápidamente: «Un esfuerzo más, concluía Masson y ¡quién sabe entonces hasta dónde puede llegar esta nación soberbia!».

Pero, como es bien sabido, no era la de Masson la única pluma que se refería en esos términos a España. A lo largo del siglo Xvin un buen número de destacados autores tales como Montesquieu, Voltaire, Diderot, el abate Raynal, y otros muchos no se moderaron en sus juicios críticos sobre España, cargando las tintas contra la Inquisición. De hecho, como señala François López, en los primeros ańos del siglo xvin la llamada leyenda negra antihispánica ya estaba plenamente formada. ${ }^{3}$ España se había convertido en el contraste ideal de una Europa que se autodefinía como la civilización del progreso y de la libertad de pensamiento. Esta imagen negativa de la cultura española se difundió incluso por personas muy vinculadas a la Iglesia Católica, particularmente en Italia. En Italia, algunos jesuitas expulsos españoles y particularmente Francisco Lampillas, Juan Francisco Masdeu y Juan Andrés participaron en una polémica con los jesuitas Girolamo Tiraboschi, Saverio Bettinelli y otros autores italianos. Para Tiraboschi y Betinelli los autores españoles, desde la época de Séneca y Marcial, habrían importado a Roma el mal gusto que habría corrompido las letras modernas y en la época moderna Góngora y sus discípulos habrían introducido de nuevo esa misma corrupción en la literatura italiana. Aquí quiero destacar en particular la respuesta de Lampillas en su Saggio storico-apologetico della Letteratura Spagnuola contro le pregiudicate opinioni di alcuni moderni scrittori italiani (1778-1781, 6 vols.).

en Ernesto y Enrique García Camarero, La polémica de la ciencia española, Madrid, Alianza, 1970, pp. 47-53.

3 Una excelente exposición de la suerte de la leyenda negra en el siglo XviII, en F. López, Juan Pablo Forner y la crisis de la conciencia española en el siglo XVIII, Valladolid, Junta de Castilla y León, 1999. Véase también A. Mestre Sanchis, Apología y critica de España en el siglo XVIII, Madrid, Marcial Pons, 2003. 
Lampillas, en la parte dedicada al Renacimiento no sólo se ocupó de la literatura religiosa, poesía o teatro, sino también de un amplio repertorio de las contribuciones españolas a la medicina, náutica, arte militar, filosofía natural y humanismo en sus diferentes corrientes y escuelas, incluidas las relacionadas con la ciencia. Lampillas reconoció que en España no se habían realizado notables progresos en épocas recientes en matemáticas y física, pero rechazó la atribución al clima realizada por sus oponentes así como el concepto de un supuesto «genio nacional» inmutable. Además, Lampillas introdujo una perspectiva histórica y, cabría decir, sociológica. ${ }^{4}$

Pero el primero que reaccionó contra los autores italianos citados, acerca de la acusación a los escritores espańoles de haber llevado el mal gusto a Italia, corrompiendo así la literatura italiana, fue Juan Andrés. Andrés mostró además un especial interés por la historia de las ciencias, redactando varios trabajos sobre las obras de Galileo y sobre dinámica de fluidos. Además, publicó una ambiciosa historia de la cultura escrita («de toda la literatura») en siete volúmenes (1782-1799), que contiene la primera historia general de las ciencias escrita por un autor español. En esta obra Juan Andrés trata de la historia de las matemáticas, mecánica, hidrostática, navegación, acústica, óptica, astronomía, física, química, botánica, historia natural, anatomía y medicina. En cada uno de estos temas, el exjesuita valenciano se preocupó especialmente de incluir las contribuciones de los autores españoles a las distintas ciencias y sus aplicaciones, ponderando su importancia y evitando la mera apología. Desde su exilio italiano, Andrés seguía con interés y optimismo el nuevo impulso que la cultura y las ciencias habían tomado en España:

España, tenaz sostenedora de las sutilezas escolásticas las ha desterrado ya de las escuelas, y se ha aplicado sabiamente a conocimientos útiles. Feijoo, Juan, Ulloa, Ortega y otros físicos, matemáticos y naturalistas; Luzán, Montano y Mayans, ilustradores de la lengua, de la retórica, de la poesía y del teatro; Martí, Flores, Finestres, los dos Mayans, Pérez Bayer, los dos Mohedanos y otros anticuarios y eruditos de todas especies dan una clara prueba del ardor que anima a España en los buenos estudios... 5

4 Sobre la polémica en Italia, véase Miguel Batllori, La cultura hispano-italiana de los jesuitas expulsos, Madrid, Gredos, 1996; y F. Lopez, op.cit., p. 328 y ss. Los textos de Bettinelli, Tiraboschi y Lampillas se publicaron en Roma en 1781. El texto de Lampillas se publicó en Zaragoza en 1782-1784 en traducción castellana de Josefa Amar y Borbón

5 Véase sobre la intervención de Juan Andrés en el debate, las obras citadas de Batllori y François Lopez. La obra de Juan Andrés se titulaba Dell'origine, progressi e stato attuale d'ogni letteratura, 7 vols., Parma, Imp. Real, 1782-1799. Fue reeditada varias veces (12 reediciones completas y 5 incompletas) y traducida al castellano por su hermano Carlos Andrés (10 vols., Madrid, A. Sancha, 1784-1806). La cita procede de la edición castellana, 
Ciertamente, en el siglo XviII, desde la época de los llamados «novatores», es decir, a partir de los últimos años del siglo anterior y todavía en el reinado de Carlos II, se inició en España un notable proceso de renovación científica y filosófica, que hizo posible que en el Siglo de las Luces se difundieran en este país las nuevas corrientes y orientaciones en estas materias: la mecánica newtoniana, la química de Stahl, Boerhaave y Lavoisier, la naciente ciencia de la electricidad, la botánica de Linneo, las diversas corrientes en fisiología y medicina, las nuevas tecnologías, incluida la máquina de vapor, la nueva instrumentación científica, las nuevas organizaciones científicas (sociedades y academias), la introducción de la ciencia en la esfera pública, y otros rasgos de lo que se considera la ciencia-técnica moderna europea, además de la circulación de las nuevas corrientes filosóficas: el mecanicismo, el sensualismo de Locke y Condillac, las corrientes leibnizianas, las corrientes deístas, el hedonismo materialista, etc. ${ }^{6}$

vol. VII, pp. 352-353. Sobre Juan Andrés y la historia de las ciencias, véase V. Navarro Brotons, "Juan Andrés y la historia de las ciencias», en Estudios dedicados a Juan Peset Aleixandre, 3 vols., Valencia, Universidad de Valencia, 1982, vol. II, pp. 81-93; del mismo autor «Science and Enlightenment in Eighteenth-Century Spain: The Contribution of the Jesuits before and after the Expulsion», en J. W. O'Malley et alii, The Jesuits II, Cultures, Sciences and the Arts, 1540-1773, Toronto, University of Toronto Press, 2006, pp. 390-405. Véase también M. A. Puig Samper, «Juan Andrés y la Historia de las Ciencias», en Juan Andrés y la Historia Comparatista, Valencia, Biblioteca Valenciana, 2002, pp. 225-247. El volumen editado por U. Baldini y G. Paolo Brizzi, La presenza in Italia dei jesuiti iberici espulsi. Aspetti religiosi, politici, culturali, CLUEB, 2010, contiene numerosas referencias a los trabajos y actividades de Juan Andrés. La obra de G. E. Mazzeo, The Abate Juan Andrés, Literary Historian of the XVIIIth century, New York, Hispanic Studies, 1965, ofrece una visión de conjunto de la labor del jesuita valenciano que mantiene su interés en diversos aspectos. Un incisivo estudio sobre Dell'origine, se encuentra en M. Garrido Palazón, Historia literaria, enciclopedia y ciencia en el literato jesuita Juan Andrés, Alicante, Instituto de Cultura "Juan-Gil-Albert»-Diputación Provincial de Alicante, 1995.

6 Sobre la actividad científica y filosófica en la Espańa del siglo xvin, la literatura es ya considerable. Véase la síntesis de A. Lafuente y J. L. Peset, «El conocimiento y el dominio de la naturaleza: la ciencia y la técnica», en José María Zamora (dir.), Historia de España (fundada por Menéndez Pidal), XXXI-I, Madrid, Espasa Calpe, 1988, pp. 349-394. También M. Selles, J. L. Peset y A. Lafuente (eds.), Carlos III y la ciencia de la Ilustración, Madrid, Alianza, 1988; los capítulos correspondientes de J. Vernet, Historia de la ciencia española, Madrid, Instituto de España, 1975, y el apartado correspondiente al siglo XVIII de J. M. López Piñero, V. Navarro Brotons, E. Portela Marco, «La actividad científica y tecnológica», en M. Artola (ed.), Enciclopedia de Historia de España, vol. III, Madrid, Alianza Editorial, 1988, pp. 273-327. Sobre la difusión de las ideas científicas y filosóficas hay alguna información de interés en F. Sánchez-Blanco Parody, Europa y el pensamiento español del siglo XVIII, Madrid, Alianza, 1991. Para la física, véase V. Navarro Brotons, «La física en la España del siglo XVIII", en Historia de la física hasta el siglo XIX, Madrid, Real 
Por ello no deja de resultar paradójico, en cierto modo, que en una época de renovación cultural y científico-filosófica surgieran afirmaciones como la de Masson, aunque sin duda Masson no hizo más que hacerse eco de las críticas a Espańa que circulaban en Francia entre los ilustrados, como hemos apuntado. En la Encyclopédie de Diderot y D’Alembert los artículos «España» e «Inquisición» escritos por Jaucourt anticipaban el talante antiespañol de la Historia de las dos Indias del Abate Raynal y contribuyeron al resurgimiento en este siglo de la llamada «leyenda negra» antihispánica. Pero bajo el manto de la crítica a España y de la caricatura que de esta ofrecían autores como Montesquieu, se escondía también la denuncia indirecta al sistema político francés, de modo que Espańa era equivalente a la Persia de Montesquieu. $\mathrm{O}$, como lo expresamos en otro lugar: parte de la explicación del panfleto de Masson residiría en que la historia de la modernidad que los philosophes ilustrados querían describir era una especie de melodrama, con la ciencia y la razón dirigiendo el camino inexorablemente hacia la verdad y la utopía. Como en todo melodrama se requieren héroes y villanos y en esta historia de la modernidad España resultaba ser el quintaesencial antimoderno villano. ${ }^{7}$

Sobre esta así llamada leyenda negra, el historiador Pierre Chaunu decía que era

el reflejo de un reflejo, una imagen doblemente deformada, la imagen exterior de España, tal y como España la ve. La especificidad de la leyenda negra radica no en la supuesta especial intensidad de las críticas, sino que la imagen exterior ha afectado a Espańa más que su imagen exterior ha

Academia de Ciencias, 1983, pp. 317-342; N. Valverde, Actos de Precisión. Instrumentos cientificos, opinión pública y economía moral en la Ilustración española, Madrid, CSIC, 2007; J. Vega, Ciencia, Arte e Ilusión en la España Ilustrada, Madrid, CSIC, 2010. Sobre la botánica y las expediciones, la literatura es muy abundante. Véase, en particular, Francisco Javier Puerto Sarmiento, La Ilusión quebrada. Botánica, Sanidad y politica científica en la España Ilustrada, Madrid, Serbal/CSIC, 1988. La obra clásica de J. Sarraihl, L'Espagne éclairé de la seconde moitié du XVIII siècle, Paris, 1954 (edición española, México, F.C.E., 1957) sigue siendo una buena fuente de información, leído juiciosamente. Dos recientes y excelentes reuniones de trabajos sobre el tema: el vol. IV de la Historia de la ciencia y de la técnica en la Corona de Castilla. Siglo XVIII, dirigido por José Luis Peset, Salamanca, Junta de Castilla y León, 2002; y el vol. II de La ciència en la Història dels Països Catalans. II. Del naixement de la Ciència Moderna a la Illustració, dirigido por Joan Vernet y Ramón Parés, Institut d'Estudis catalans/Universitat de València, 2002.

7 Véase V. Navarro Brotons, W. Eamon, «Spain and the Scientific Revolution: Historiographical Questions and Conjectures», en V. Navarro Brotons y W. Eamon (eds.), Más allá de la leyenda negra. España y la Revolución Cientifica, Valencia, Instituto de Historia de la Ciencia y Documentación López Piñero (Universitat de València-CSIC), 2007, pp. 27-39. 
afectado a cualquier otro país. La leyenda negra es por tanto, por así decirlo, el conjunto de rasgos negativos que la conciencia espańola descubre en la imagen de sí misma. ${ }^{8}$

Esta interpretación de Chaunu nos ayuda a explicar también el desarrollo, intensidad y persistencia desde el siglo XviII de las cuestiones o polémicas sobre la «ciencia española» y las respuestas a las preguntas: ¿Qué se debe a España? ¿Cuál ha sido su contribución al pensamiento y la ciencia europeos?

En la misma línea que Chaunu, François Lopez apuntaba certeramente que toda la Ilustración española fue una gran revisión del legado del pasado y de las tradiciones nacionales. Nunca, añadía, la imagen de España proyectada en los otros países ejerció al recibirse en el país, tanta influencia sobre el pensamiento y el actuar de la élite instruida. Probablemente no hubo en esta época ni una sola gran empresa intelectual que no tuviera por finalidad confesa rehabilitar a la nación denigrada por los extranjeros y abrir los ojos a los propios españoles. ${ }^{9}$

El mismo François Lopez se preguntaba, desde la España defendida de Quevedo (1609), ¿Cuánto tiempo fue necesario para que algunos españoles dejaran de creer con orgullo que su país podía tener razón, solo contra todos los demás? ¿En qué época surge la idea de que España pudo haberse equivocado y que por tanto debía, para corregir el rumbo de su historia, hacer su autocrítica y entrar por nuevos caminos semejantes a los que habían tomado los demás países, ya más prósperos, más poderosos y más ilustrados? La respuesta parece encontrarse precisamente en la época de los novatores y el testimonio más antiguo sobre esa crisis de conciencia sería el del médico Juan de Cabriada en su Carta filosófico-médico-chymica, considerada por López Piñero auténtico manifiesto de la renovación médico-científica: «Que es lastimosa y aún vergonzosa cosa que, como si fuéramos indios, hayamos de ser los últimos en recibir las noticias y luces públicas que ya están esparcidas por Europa». ${ }^{10}$ Otros autores, protagonistas también de la renovación científica, médica y filosófica hicieron afirmaciones parecidas, aunque también reaccionaran contra la vergonzosa reputación que tenía su país entre los extranjeros y reivindicaron las contribuciones realizadas en el mundo hispánico por filósofos, cosmógrafos, médicos, ingenieros, naturalistas y matemáticos, sobre

8 P. Chaunu, «La leyenda negra antihispanique», Revue de Psicologie des Peuples, 19 (1964), pp. 188-233.

9 Véase F. Lopez, op.cit., pp. 332 y passim.

10 Sobre Juan de Cabriada y su Carta, véase J. M. López Piñero, Ciencia y técnica en la sociedad española de los siglos XVI y XVII, Barcelona, Labor, 1979, pp. 347ss.; y, del mismo autor, "Juan de Cabriada y el movimiento «novator» de finales del siglo Xvir. Reconsideración después de 30 años», Asclepio, 45 (1993), pp. 3-53. 
todo en el siglo XVI, pero también en el XVII, a pesar de la indudable decadencia de las actividades médicos-científico-técnicas en este siglo. ${ }^{11}$

Una de las primeras y más célebres apologías de las que se publicaron en la Ilustración en respuesta a las acusaciones derivadas de la leyenda negra, la publicó el monje benedictino Juan Benito Jerónimo Feijoo, gran divulgador de las novedades (con mucha prudencia, por lo demás). Feijoo, en su notable tarea de divulgación, se ocupó de dar cuenta de las «causas del atraso que se padece en España en orden a las ciencias naturales», entre las que mencionaba «el corto alcance de algunos de nuestros profesores», «la preocupación contra toda novedad», el «errado concepto de la inutilidad de las novedades», "las escasas o falsas ideas sobre la filosofía moderna», el «temor del conflicto de lo nuevo con la religión» y finalmente la envidia. Sobre el temor del conflicto con las nuevas corrientes filosóficas y científicas, Feijoo decía que hay que distinguir la teología de la filosofía y recordaba la vigilancia de la Inquisición para evitar que se atravesaran los límites y se introdujeran doctrinas heréticas. Pero insistía en que cerrar la puerta a toda doctrina nueva por temor a la herejía era un remedio muy violento, además de innecesario. Añadía que reprobar la doctrina y lectura de autores como Boyle o Newton permitidos por la Inquisición es acusar de "poca ciencia o de tibio celo» al Santo Tribunal. Pero antes de reconocer los atrasos y proponer sus remedios se había sentido obligado a glosar las «Glorias de España» como respuesta a las acusaciones de los propagandistas de la leyenda negra, aún reconociendo que la «física y las matemáticas son casi extranjeras en España». ${ }^{12}$

11 Véase A. Martínez Vidal y J. Pardo Tomás, «In tenebris adhuc versantes. La respuesta de los novatores españoles a la invectiva de Pierre Régis», Dynamis, 15 (1995), pp. 301-340, sobre la reacción de los médicos renovadores españoles a las afirmaciones de Régis, según las cuales los espańoles, junto con los lusitanos y los moscovitas, permanecían sumergidos en las tinieblas. Los médicos espańoles, para legitimar la nueva ciencia, rechazaron o ignoraron la tradición propia. En cambio, los renovadores en el campo de las disciplinas físico-matemáticas, como los valencianos Corachán o Tosca, se consideraban del algún modo herederos y seguidores de una tradición que les servía para legitimar su propia actividad. Véase sobre estos, V. Navarro Brotons, Tradició i canvi cientific al País Valencià modern (1660-1720): les ciències físico-matemàtiques, València, Eliseu Climent, 1985; y Disciplinas, saberes y prácticas. Filosofia natural, matemáticas y astronomía en la sociedad española de la época moderna, València, Universitat de València, 2014.

12 El artículo sobre las "Causas...» de Feijoo apareció en el tomo II (Madrid, 1745) de sus Cartas eruditas (Carta XVI) y puede verse reproducido en Ernesto y Enrique García Camarero, Op. cit., pp. 25-43. "Glorias de España» apareció en el tomo IV (Madrid, 1730), discursos XIII y XIV, del Theatro critico universal (Madrid, 1730). Véase B. J. Feijoo, Theatro critico universal, 9 vols., Madrid, L. F. Mojador, F. del Hierro, Vda. y Her. 
Tras los novatores y Feijoo, el cirujano y botánico, primer profesor del Jardín Botánico Real de Madrid, José Quer, elaboró una Flora española o Historia de las plantas que se crían en España (1762, 4 vols.), en la que se sintió obligado a rebatir la afirmación de Linneo de que «La flora española ningunas plantas nos ha dado a conocer...». Como respuesta a Linneo, incluyó en su obra un "Discurso analítico sobre los métodos botánicos», en el que presentó una apología de la actividad botánica y médica española y un catálogo biobibliográfico de los autores españoles de historia natural. Linneo rectificó más tarde su juicio y mantuvo relaciones científicas con los naturalistas españoles. ${ }^{13}$

Otros autores, como el médico Andrés Piquer, formado en Valencia en el ambiente de renovación que los novatores habían impulsado y donde disfrutó de la amistad, enseñanzas y consejos de Mayans, amistad que continuó tras su traslado a Madrid, además de ocuparse de cuestiones de historia de la medicina, en varios de sus escritos reivindicó la tradición filosófica y científico-médica nacional: «se puede demostrar con libros Españoles existentes, que muchísimas cosas con que hoy lucen las naciones extranjeras en las Artes y Ciencias, las han podido tomar de nosotros». Y Piquer citaba para mostrarlo las contribuciones de Luis Vives y otros humanistas españoles y médicos como Francisco Valles, Oliva de Sabuco, Luis Mercado y Solano de Luque. ${ }^{14}$

Las bibliotecas de Nicolás Antonio, Biblioteca hispana nova sive hispanorum... (2 vols., 1672) y Biblioteca hispana vetus (1696), reeditadas por la viuda y herederos de Joaquín de Ibarra en 1783-1788, ofrecían un amplísimo repertorio de escritores españoles y de sus obras hasta la época de su autor. De ella se sirvieron todos: Feijoo, Piquer, Quer, Lampillas, Andrés, y los autores de repertorios regionales, como los valencianos José Rodríguez y Vicente Gimeno; y, desde luego, aún se servirán ampliamente de ella, Menéndez Pelayo y los historiadores del siglo xx. Por otra parte, los ilustrados valencianos se cuentan entre los que más destacaron en el ámbito de las aportaciones al conocimiento de los autores españoles relacionados con la medicina, la filosofía natural, las ciencias exactas

F. del Hierro, 1726-1740; y B. J. Feijoo, Cartas eruditas y curiosas, 5 vols., Madrid, Her. de F. del Hierro, 1742-1760.

13 Véase R. Pascual, El Botánico José Quer (1695-1746), primer apologista de la ciencia española, Valencia, Cátedra e Instituto de Historia de la Medicina, 1970, que incluye una reproducción facsímil de los textos citados de Quer.

14 Cit. En A. Sanvisens Marfull, Un médico-filósofo español del siglo XVIII: el doctor Andrés Piquer, Barcelona, 1953, pp. 204-205. Sobre Piquer y sus relaciones con Mayans, véase Gregorio Mayans i Siscar, Epistolario. I. Mayans y los médicos, transcripción, notas y estudio preliminar de V. Peset Llorca, Valencia, Artes Gráficas Soler, 1972. 
y de la naturaleza y sus aplicaciones técnicas, sin duda animados por el notable erudito Gregorio Mayans i Siscar. Mayans, que no se sentía solidario con todas las empresas de la Corona de Castilla (y en particular de La Conquista), no obstante, como señala François Lopez, combatió la leyenda negra a su manera, a saber, editando y dando a conocer los mejores textos de sus compatriotas, trabajando para el restablecimiento de los saberes científicos y la literatura y señalando la que consideraba la más sabia y mejor tradición española. ${ }^{15}$ Además de ocuparse de difundir las obras de los novatores valencianos, como Corachán y Tosca, y de editar y difundir obras de los grandes humanistas, como Luis Vives, del que publicó las obras completas, también elaboró un «Catálogo de los españoles que han escrito de cirugía y anatomía en castellano» y proporcionó información de los autores españoles a sus amigos y corresponsales españoles y extranjeros. Además de Andrés Piquer, otros médicos del entorno de Mayans, como Mariano Seguer y Antonio Capdevila también contribuyeron a las bibliografías de autores médicos, transmitiendo abundante información a destacados autores europeos como Albrecht von Haller. Este utilizó ampliamente la información que le proporcionaron los médicos valencianos en sus famosas Bibliothecae de anatomía, medicina, cirugía y botánica. ${ }^{16}$

Así, en la época en la que se estaba consolidando en varios países europeos el género de las bibliografías, también en España se llevaron a cabo importantes realizaciones en este sentido y en relación con esa revisión del legado del pasado que mencionábamos antes citando a François Lopez. Pero además, como hemos señalado, los eruditos españoles, como Mayáns y su círculo, proporcionaron abundante información a los grandes bibliógrafos europeos acerca de los escritos españoles en las diversas áreas, humanísticas y científicas. ${ }^{17}$ Por otra parte, y paralelamente al desarrollo de las bibliografías, en el siglo xviII y en relación con lo que se ha llamado la toma de conciencia global de la historicidad humana, la narración histórico-científica conoció una gran expansión, bien representada por obras como la Histoire des Mathématiques de J. E. Montucla, La Histoire de l'Astronomie de Bailly (que aplicó el termino de «revolución» a las novedades o al cambio científico y distinguió el orden sistemático del orden cronológico de los saberes científicos), las historias, de la electricidad y de la óptica de Priestley, la historia de la química incluida en la Encyclopédie méthodique (el artículo "Chemie»

15 Véase F. Lopez, Op. cit., pp. 37 y ss.

16 Véase F. Lopez, Ib.; la edición citada de las correspondencia de Mayans; Mestre, Op. cit.; N. Bas Martín, Las bibliografías de la ilustración valenciana, València, Diputació de València, 2002.

17 Véanse las obras citadas en la nota anterior. 
escrito por Furcroy), las historias eruditas de la Universidad de Gotinga y el desarrollo notable de la historiografía médica, que contó con las primeras revistas especializadas de esta materia y con la primera cátedra universitaria. Estas historias eran fiel expresión de las preocupaciones e ideales de la Ilustración y, en general, están realizadas en el marco de la idea de progreso e incluso como el mejor ejemplo de la misma. ${ }^{18}$ La obra de Juan Andrés arriba citada asume y se sitúa dentro de esta corriente de interés del período ilustrado por trazar el desarrollo histórico de los conocimientos científicos. ${ }^{19}$ Andrés pensaba: «no hay monumento más claro de la sublimidad y estoy por decir divinidad del espíritu humano, que el cuadro y la historia de las ciencias naturales» y afirmaba claramente el vector de progreso:

... Se desea ver la continuada derivación y la genealogía, por decirlo así, de los descubrimientos científicos, y conocer los vínculos de mutua dependencia con que están ligados entre sí; se siente complacencia en desenvolver la sucesión de las ideas y, desde las bajas y reducidas de los primeros tiempos venir paso a paso a las grandiosas y sublimes de los filósofos de nuestros días... ${ }^{20}$

Andrés, además, en las Cartas a su hermano Carlos Andrés que éste publicó, dio a conocer el contenido de un buen número de bibliotecas y archivos italianos y de la Viena Imperial. ${ }^{21}$

18 Sobre la historiografía de la Ilustración, la literatura es muy abundante; una buena introducción es G. Gusdorf, Les sciences humaines e la pensée occidental. I. De l'Histoire des sciences a l'histoire de la pensé, Paris, Payot, 1966. Para la química, M. Beretta, "The historiography of Chemistry in the Eighteenth Century: a preliminary survey and bibliography», Ambix, 39, 1992, 1-10. De especial interés para nociones como la de «revolución» en la ciencia es el libro de I. Bernard Cohen, Revolution in science, Cambridge, Mass-London, 1985; para historiadores particulares véase también S. A. Jayawardene, "Biographical notices of historians of science: a checklist», Annals of Science, 36 (1974), 315-394. Sobre la historiografía de la medicina, véase W. Artelt, Einführung in die Medizinhistorik, Stuttgart, 1949 (incluye el trabajo de E. Heischkel, «Die Geschichte der Medizingeschichtschreibung», en pp. 202-237); J. M. López Piñero, «Las etapas iniciales de la historiografía de la ciencia», Arbor, 142, 21-69.

19 En el prefacio al vol. I de Dell'origine (citamos por la edición castellana en 10 vols., Madrid, A. Sancha, 1795-1806) Andrés reconoce que para realizar su obra le han ayudado mucho los precedentes de Montucla, Bailly, Leclerc, Freind, Portal y otros autores y en el vol. II, p. 410, comenta elogiosamente el desarrollo de la historia de las ciencias en Francia.

20 Andrés, Op.cit, vol. VII, pp. I y II.

21 Cartas familiares del abate D. Juan Andres a su hermano D. Carlos Andres: dandole noticia del viage que hizo á varias ciudades de Italia en el año 1785, publicadas por el mismo D. Carlos, Madrid, Sancha, 5 vols., 1786-1793. Véase Bas, Op. cit., especialmente el capítulo: «El abate Juan Andrés y el mundo librario europeo». También P. Garelli, 
Volviendo a Masson de Morvilliers, fue el citado artículo en la Encyclopédie méthodique el que despertó todas las pasiones y reavivó heridas dolorosas, provocando la airada reacción de diversos autores, y no sólo españoles. Los motivos por los que el artículo de Masson tuvo más repercusión que los sarcasmos y burlas tan prodigados por Montesquieu, Voltaire y todo el clan filosófico que se ensañaba con España desde hacía más de medio siglo hay que buscarlos en las expectativas truncadas de esta obra. Su espíritu prometía ser muy distinto a la Enciclopedia de Diderot y D'Alembert; quería interesar a un público muy amplio y conquistar los mercados que se le habían cerrado a su predecesora, debido a su contenido ideológico, sobre todo en Espańa, Portugal y sus posesiones americanas. ${ }^{22}$

La polémica la inició enseguida el abate Antonio Cavanilles. Cavanilles vivía entonces en París y pronto destacaría como botánico y geógrafo. ${ }^{23}$ En 1784 publicó en París su Observations de M. l'abbé Cavanilles sur l'article Espagne de la nouvelle Encyclopédie, obra que fue reseñada en varias revistas francesas, incluido el Journal des Savants. En general la acogida fue favorable o al menos educada. Cavanilles quería demostrar que España había recuperado en parte su pasada grandeza y trató de desmentir las terroríficas fábulas sobre el clero de España y la Inquisición. Para ello recurrió a la ayuda de varios eruditos (como el valenciano Juan Antonio Mayans) y leyó con atención las obras de los jesuitas expulsos. Cavanilles, en su escrito, recorrió diferentes dominios y disciplinas, como la ciencia militar, la marina, las bellas artes, la arquitectura, la literatura, la poesía, las matemáticas, la física o la botánica para mostrar que todas ellas se cultivaban intensamente

«Immagini d'Italia nelle relazioni di viaggio di Juan Andrés», José García de la Huerta, Manuel Lassala», en Baldini y Brizzi, Op. cit., pp. 564-576; G. Sánchez Espinosa, "Juan Andrés: el viaje ilustrado y el género epistolar» en P. Aullón de Haro, J. García Gabaldón y S. Navarro Pastor, Juan Andrés y la teoría comparatista, Valencia, Biblioteca Valenciana, 2002, pp. 279-287.

22 Véase F. López, Op. cit., pp. 340 y ss.

23 Sobre Cavanilles, véase C. Carles, «Cavanilles, Antonio José», en J. M. López Piñero, Th. F. Glick, V. Navarro Brotons y Eugenio Portela Marco (dirs.), Diccionario histórico de la ciencia moderna en España, dirigido por J. M. López Piñero, Barcelona, Península, 1983; y J. M. López Piñero et alii, Antonio José Cavanilles (1745-1804). Segundo centenario de una gran botánico, Valencia, Real Sociedad Económica de Amigos del País, 2004. Esta obra incluye una amplia bibliografía de Cavanilles y de los estudios sobre su vida y obra. Véase también N. Bas Martín, El correo de la Ilustración. Libros y lecturas entre Cavanilles y el librero parisino Fournier (1790-1802), Madrid, Ollero y Ramos, 2014. En esta obra Nicolás Bas indaga en la introducción en España de libros franceses; para ello, describe el entramado comercial y editorial que hizo posible la llegada a España de innumerables libros pese a las prohibiciones que entonces existían poniendo de relieve el papel destacado de Cavanilles en esta empresa. 
y con éxito en España. Además, ofreció un breve recorrido histórico desde la Edad Media hasta el siglo XviII sobre el cultivo de los diferentes saberes y artes en la Península. Reconoció la decadencia general del siglo xvir en todos los órdenes, incluido el económico y el político. «Lo único que nos quedó entonces fue la teología escolástica-dice- con los comentadores de Aristóteles».

En cuanto al clero, el sabio espańol hizo un elogio de su comportamiento, y sobre la Inquisición apenas dijo más que la existencia de este tribunal se justificaría por su función en el respeto de las leyes recibidas en el Estado y en el castigo de los perturbadores de la paz pública.

Otra respuesta a Masson vino de Carlo Denina (1731-1813), profesor italiano exiliado por la audacia de sus ideas sociales en la corte de Federico II de Prusia. En 1786 pronunció en la Academia de Berlín el discurso: «Respuesta a la pregunta: ¿qué se debe a la España?». Denina estaba convencido de que era a Francia a quién había que resistir como modelo cultural. ¿Por qué insistir en atacar a España cuya voluntad de poder ya no hay que temer? Denina trató de mostrar que España había hecho por Francia, desde la época de Carlomagno y de Alcuino, más de lo que Francia había hecho nunca por todas las demás naciones. Para ello, aportó un inventario de las principales contribuciones de España al progreso de las ciencias, las artes y la literatura, desde la Edad Media hasta el siglo Xvi. Al final, Denina se refirió a la decadencia española y dirigió algunas palabras críticas a los españoles, porque con el descubrimiento del Nuevo Mundo y sus casi inagotables recursos, España habría descuidado el comercio con Europa y habría dejado de estar atenta a los progresos del continente; en segundo lugar, España no había encontrado ninguna nación que pudiera servirle de modelo: la antipatía entre franceses y espańoles ha impedido que estos últimos hayan podido sentir la más mínima tentación de imitar los progresos de sus vecinos. Con todo, concluía Denina, la nación española, guiada por reyes nacidos en su seno y por ministros juiciosos, habría comenzado a zanjar definitivamente su crisis. ${ }^{24}$

El discurso de Denina fue traducido al castellano por Juan Pablo Forner, jurista que llegó a ser fiscal del consejo de Castilla. Pero además de traducir el discurso de Denina, Forner compuso una Oración apologética ("por la España y su mérito literario») de la literatura y artes de Espańa para optar al premio

24 Denina, Réponse à la question Que doit-on à l'Espagne?, Berlín, Georges Jacques, 1786. Un amplio extracto del discurso de Denina, en castellano, en Ernesto y Enrique García Camarero, Op.cit., pp. 58-71. Véase F. Lopez, Op.cit., p. 358 y ss., sobre la Respuesta de Denina. 
ofrecido por la Academia de la Lengua, y la presentó en $1786 .{ }^{25}$ La argumentación de Forner se basaba en distinguir entre los conocimientos útiles y prácticos, la verdad y la virtud y lo que él consideraba los sueños hueros de los filósofos, las especulaciones vanas en las que la inteligencia humana gasta sin provecho sus esfuerzos. España no posee inventores de sistemas, dice Forner, y se dedica a cultivar la teología, el derecho, la medicina y la historia. La ciencia debe obedecer a tres fines: el perfeccionamiento del hombre, la satisfacción de sus necesidades y la diversión útil. Para Forner, Luis Vives fue el gigante que restauró los estudios y denunció los errores que desnaturalizaron el saber. Forner justificaba que en España se prohibieran la lectura de determinados libros: «un pequeño número de obras menudas, en cuyas líneas nada se aprende sino lo que no se debe aprender». No obstante y aunque se ha querido ver en la obra de Forner una máquina de guerra contra la filosofía de las Luces, François Lopez ha defendido en un extenso libro que la Oración apologética es una obra característica de la Ilustración. También que el fondo de su alegato debe mucho al Discurso sobre las ciencias y las artes de Rousseau.

La Oración de Forner fue objeto de duras críticas por parte de diversos autores, incluidos destacados periodistas de la época como Luis Cañuelo, alias el Censor. Cañuelo ya había escrito una aguda crítica contra todos los apologistas de España, presentes y futuros. Para Cañuelo,

... aunque en España hubiera muchísimas personas muy sabias y capaces de escribir muy buenas obras, de ilustrar a los demás, de desterrar la ignorancia y el error, de adelantar todas las ciencias y las artes ... ni se atreven a escribir, ni cuando se atreven podrían hacerlo porque el interés particular empeñado en sostener el común error del que saca un gran partido, les obligaría a callar por todos los medios imaginables. ${ }^{26}$

En otros lugares Cañuelo considera como causas directas de la miseria y la ignorancia del pueblo español una «cierta teología» sumada a un "cierta moral» y una «cierta jurisprudencia»..., cosa que Forner negará enérgicamente. ${ }^{27}$ François Lopez insiste en que en todo caso se trata de una confrontación

25 Oración apologética por la España y su mérito literario, para que sirva de exornación al discurso leido por el abate Denina en la Academia de Ciencias de Berlín, respondiendo á la qüestión qué se debe a España?, Madrid, Imprenta Real,1786. La obra de Forner incluía la Reponse de Denina como apéndice. Véase F. López, Op. cit., pp. 363 y ss. y passim.

26 L. Cańuelo, "Discurso CX", El Censor, tomo V, Madrid, 1786, pp. 775-794. Un amplio extracto de este «Discurso» en Enrique y Ernesto García Camarero, Op. cit., pp. 75-83.

27 Cańuelo, «Discurso CXIII», op.cit., tomo VIII, pp. 565-579, Madrid, 1787. Un amplio extracto de este "Discurso" en Enrique y Ernesto García Camarero, Op. cit., 
de puntos de vista entre reformadores e ilustrados sobre el problema político del fin y los medios. A todos los que le atacaron, Forner les respondió básicamente tres cosas: que no ignoraba en modo alguno los abusos que siguen existiendo en el país; que, pese a todo, el deber de un español es defender a su patria cuando es objeto de burlas e insultos sin razón; y, tercero, que es mejor actuar con obras y acciones que extenderse sin fin en amargos y desesperados vituperios. Finalmente, la Revolución Francesa provocó el naufragio de la prensa española y periódicos como El Censor, El Apologista Universal, El Corresponsal del Censor y otros fueron prohibidos por la censura, sin que Forner tuviera algo o seguramente nada que ver con esto.

La crisis de los ideales ilustrados, que se manifestó dramáticamente en los años de la Guerra de la Independencia y el reinado de Fernado VI, hizo de nuevo muy difícil el desarrollo normal de la actividad científica española, aunque no la ahogó totalmente; ello dio de nuevo argumentos a los más pesimistas acerca del papel y posibilidad de la ciencia en la historia espańola. Tras esta profunda crisis del primer tercio del siglo, en la llamada por López Piñero «etapa intermedia» (1834-1868), comenzó una lenta pero progresiva recuperación de la actividad científica española y un interés renovado y creciente por el pasado histórico-científico-técnico español. ${ }^{28}$

Conviene subrayar que, en el siglo xix, la historia de la ciencia o de las ciencias como profesión no existía ni en España, ni en el resto de Europa ni en América. En general, la historia de las distintas ciencias fue realizada, en la mayor parte del siglo, principalmente por científicos. En este sentido, la historia de las disciplinas científicas servía para instituir una tradición científica, colocar los antepasados para dar prestigio al campo y situarse en línea con las ciencias establecidas o para concebirse a sí mismos en la marcha del progreso científico. Hasta finales del siglo xix no comenzó a constituirse la historia de la ciencia como una disciplina autónoma, consciente de la especificidad de sus problemas y métodos. Por otra parte, la información al día de los nuevos hechos y avances científicos pasó a ser el objetivo de la naciente documentación científica, mientras que la procedente del pasado, considerada obsoleta o en desuso y por lo tanto no aprovechable, dejó de interesar, en general, a los científicos, que la arrinconaron en el estrecho reducto de los «antecedentes» o la "génesis» de los conocimientos del pre-

pp. 105-116. Una antología de los artículos de El Censor en E. García Pandabenes (ed.), El Censor (1781-1787), Antología, prólogo de J. F. Montesinos, Barcelona, Labor, 1972.

28 López Piñero lo ha expuesto en diversos trabajos. Véase su «Introducción» en J. M. López Piñero (ed.), La ciencia en la España del siglo XIX, Madrid, Marcial Pons (Revista Ayer, 7), 1992, pp. 19-51. 
sente, que pasaron a convertirse en norma absoluta, y se sirvieron de ella en los términos arriba expresados.

La institucionalización de la historia de la ciencia o las ciencias se inició en algunos países europeos en los años de transición del siglo XIX al XX y se consolidó a lo largo del período de entreguerras, si bien la organización espontánea de los historiadores de la ciencia fue por delante de su integración institucional en el mundo académico oficial. Una excepción la constituye el caso de la medicina, cuyas peculiares condiciones condujeron a que la institucionalización de los estudios históricos sobre la misma fuera más temprana y discurriera por cauces propios.

Pero, hay que añadir que la historia de la ciencia no se desarrolló en el siglo XIX y principios del xx como una disciplina puramente laica, sino que fue uno de los núcleos del debate entre las culturas laicas y las religiosas. Por una parte, los intelectuales laicos trataron de proporcionar a la cultura una legitimidad derivada de las ciencias de la naturaleza: la historia de la ciencia proporcionaría el relato histórico de la lucha de la ciencia por su legitimidad. Por otra parte, los intelectuales católicos trataron de desarrollar una defensa agresiva contra la cultura secular, afirmando que el desarrollo de la ciencia moderna solo podía comprenderse en el contexto de la teología y la filosofía católicas. Finalmente, para obtener autonomía y ganar su propio espacio institucional, la historia de la ciencia tenía que diferenciarse de la filosofía y considerar la ciencia como una actividad puramente tecnológica o experimental. Este fue el camino seguido por los positivistas, que rechazaron la idea del contexto filosófico de los descubrimientos científicos, no sin incurrir en paradojas, contradicciones e insuficiencias, que se deberían resolver asumiendo e integrando otras tradiciones y perspectivas en una concepción más amplia y menos dogmática de la ciencia y su devenir histórico o disimular las tensiones internas que este tipo de discurso histórico implicaba. ${ }^{29}$

Volviendo al caso español, conviene recordar, en primer lugar, el importante esfuerzo bibliográfico de la ya aludida «etapa intermedia» del siglo xix. En segundo lugar, merecen mención algunos trabajos históricos realizados fundamentalmente por cultivadores de diversas áreas científicas. Así, a partir de los años 40 proliferaron bibliografías cerradas de carácter histórico, al igual que ocurría en el resto de países, como continuación de las realizadas en el siglo XviII y que encontraron en el ardor patriótico del Romanticismo un favorable caldo de cultivo. Estos repertorios biobibliográficos, dedica-

29 Véase sobre estos aspectos, G. Motzkin, «The catholic reponse to secularization and the rise of the History of Science as a discipline», Science in Context, 3 (1989), pp. 203-227. 
dos a la medicina, la ciencia y la técnica en la historia de España tendían a la apología en cuanto a su contenido interpretativo y contienen muchos errores y lagunas, pero fueron instrumentos de primera importancia y lo siguen siendo todavía hoy para reconstruir el pasado científico español. ${ }^{30}$

Entre los repertorios mas notables mencionaremos en primer lugar la $\mathrm{His-}$ toria bibliográfica de la medicina española (1842-52), de Antonio Hernández Morejón. Su discípulo y escribiente, Anastasio Chinchilla, dio a luz una Historia general de la medicina española (1841-46) basada en parte en la de Hernández Morejón. ${ }^{31}$ Por su parte, el marino y director de la Academia de la Historia, Martín Fernández Navarrete, le dio una gran importancia a la historia de las ciencias de acuerdo con los ideales ilustrados «como historia de los progresos de la razón y del entendimiento humano» y subrayó el papel destacado del comercio en el desarrollo de las ciencias y las técnicas». Además de varios trabajos de historia de la navegación, elaboró una monumental Biblioteca marítima española, que apareció póstumamente en dos volúmenes (1851). ${ }^{32}$ El catedrático de botánica y, después, a partir de 1868, director del Jardín Botánico de Madrid, Miguel Colmeiro, vio premiada por la Biblioteca Nacional su memoria La Botánica y los botánicos de la peninsula hispano-lusitana (1858). Al mismo concurso presentó Braulio Antón Ramírez su Diccionario de bibliografía agronómica y de toda clase de escritos relacionados con la agricultura (1865). Ya en los años 70, los ingenieros militares Eugenio Maffei y Ramón Rúa publicaron unos extensos Apuntes para una Biblioteca Española de libros ... relativos al conocimiento y explotación de las riquezas minerales y a las ciencias auxiliares (1871-1872) y el brigadier de ingenieros José Almirante fue autor de una extensa Bibliografía militar de España (1876).

En contrate con el relativo optimismo que respiraban estos repertorios y obras de medicina, botánica, agronomía, mineralogía o náutica, otras disciplinas presentaban aparentemente un legado mucho más insatisfactorio. Así lo entendió uno de los científicos españoles más destacados de las décadas centrales del siglo XIx, José de Echegaray, excelente matemático y físico (también literato y dramaturgo mediocre, aunque obtuvo el premio Nobel por su obra literaria)

30 Véase J. M. López Piñero, Ciencia y técnica en la sociedad española de los siglos XVI y XVII, Barcelona, Labor, 1979, pp. 15 y ss.

31 Sobre estos autores, véase F. Bujosa Homar, Filosofía e historiografía médica en España, Madrid, CSIC, 1989.

32 Sobre Fernández de Navarrete como historiador, véase J. L. Peset y A. Lafuente, "Ciencia ilustrada e historia de la ciencia», en S. Garma Pons (ed.), El científico español ante su historia. La ciencia en España entre 1750-1850. I Congreso de la SEHC, Madrid, 1980, pp. 97-127. 
y político liberal. ${ }^{33}$ En1866, con motivo de su ingreso en la real Academia de Ciencias disertó sobre la «Historia de las matemáticas puras en nuestra España». ${ }^{34}$ El discurso presentaba un panorama muy negativo del cultivo de las matemáticas en la España moderna. «La ciencia matemática nada nos debe: no es nuestra; no hay en ella nombre alguno que labios castellanos puedan pronunciar sin esfuerzo». Y añadía que buscando en el famoso repertorio de Nicolas Antonio, la Bibliotheca Hispana Nova (1696), dedicada a los «autores españoles que florecieron desde el año 1500 hasta el 1674» sólo encontró tras muchas hojas de libros teológicos y de místicas disertaciones, «libros de cuentas y geometrías de sastres». Echegaray confesaba francamente que no conocía las causas de por qué en la Espańa invencible y poderosa, "con su unidad política y su unidad religiosa», sólo se conservaron puros la imaginación y el sentimiento, pero no la razón que languideció y decayó. Echegaray concluyó su discurso de forma mas optimista diciendo que «España sabrá ganar el tiempo perdido, conquistando bien pronto honroso puesto entre las naciones de Europa».

El discurso de Echegaray fue contestado pronto por un profesor de matemáticas, Felipe Picatoste, de ideología liberal como Echegaray, con el que colaboraría en el Ministerio de Fomento, del que Echegaray fue titular en los ańos revolucionarios. Picatoste, criticando a Echegaray, lamentaba;

...la desgracia de este país consiste en que sus hijos, lejos de defenderle, le acriminan; lejos de glorificarle, le culpan y ayudan a renegar de un pasado en que hay seguramente mucho bueno, que nos es desconocido, porque no queremos conocerlo. ${ }^{35}$

Picatoste apoyó sus afirmaciones desarrollando un notable trabajo de recopilación de datos reunidos en sus Apuntes para una biblioteca cientifica española del siglo XVI (premiados en 1868, pero publicados en 1891), una obra biobibliográfica de obligada consulta todavía. ${ }^{36}$

33 Véase, sobre Echegaray, J. M. Sánchez Ron (ed.), José Echegaray, Madrid, Fundación Banco Exterior, 1990; del mismo autor, José Echegaray (1832-1916). El hombre polifacético. Técnica, ciencia, política y teatro en España, Madrid, Fundación Juanelo Turriano, 2016.

34 Discurso de Echegaray de ingreso en la Real Academia de Ciencias Exactas, Físicas y Naturales, en Discursos leidos ante la Real Academia de Ciencias Exactas, Físicas y Naturales en la recepción pública del Señor José de Echegaray, Madrid, Imprenta y Librería de don Eusebio Aguado, 1866. Reproducido en Sánchez Ron (ed.), José Echegaray, pp.181-187, y en Enrique y Ernesto García Camarero, Op. cit., pp.161-191.

35 La respuesta de Picatoste a Echegaray se publicó anónimamente en el periódico Las Novedades, del 17 de Marzo de 1866. Un extracto del mismo en Enrique y Ernesto García Camarero, Op. cit., pp. 191-197.

36 F. Picatoste, Apuntes para una biblioteca cientifica española del siglo XVI, Madrid, Tello, 1891. 
En el Sexenio revolucionario se profundizó en el proceso de renovación cultural y científica, se pusieron en marcha una serie de reformas en las instituciones educativas y se impulsó la divulgación de la ciencia. En este sentido Felipe Picatoste se ocupó de la fundación de una red de bibliotecas populares para favorecer la cultura científica desde la jefatura del negociado de Instrucción Pública perteneciente al Ministerio de Fomento, cuyo ministro era José Echegaray, artífice, con Picatoste, del proyecto. ${ }^{37} \mathrm{Y}$ una serie de ingenieros, científicos y periodistas como José Echegaray, Emilio Huelín, Jose Joaquín Landerer y Eusebio Martínez de Velasco comenzaron en esta época un gran esfuerzo divulgador en diversas publicaciones: libros, revistas y prensa diaria. ${ }^{38}$ Esfuerzos y debates que expresaban sin duda una preocupación general por el papel de los conocimientos científico-técnicos en la sociedad española en la época de la expansión del capitalismo.

En esta época aparecieron además una serie de instituciones científicas oficiales y extraoficiales, como el Museo de Ciencias Naturales y la Real Sociedad Española de Historia Natural. Al repertorio de Picatoste y a los anteriormente citados, se sumaron otros de otras materias, y los científicos intensificaron su preocupación por estudiar con rigor el pasado científico español. Creían que el conocimiento del pasado ayudaría a impulsar la actividad científica en un momento de cambios políticos. Todo ello queda muy bien expresado por Laureano Pérez Arcas, catedrático de zoología, en su discurso de ingreso en la Real Academia de Ciencias de Madrid, de 1868, en el que trazó una historia de la zoología española con el fin de ofrecer algunos ejemplos del desarrollo de la zoología en España y de sus cultivadores, para mostrar el error de quienes sostenían «que nuestra raza es poco a propósito para los estudios de las ciencias físicas». Pérez Arcas trató de ser ecuánime entre las posiciones antagónicas acerca del desarrollo de la actividad científica en la historia de España. Además, su discurso representaba muy bien los intereses y preocupaciones de los naturalistas que

37 Véanse los trabajos de L. López Ocón, «Ciencia e historia de la ciencia en el Sexenio democrático: la formación de una tercera vía en la polémica de la ciencia española», Dynamis, 12 (1992), 87-103; y «El fomento de la educación y la ciencia en la sociedad española del Sexenio revolucionario», Boletín de la Institución Libre de Enseñanza, 28 (9) (1992), 127-48, pp.137-40.

38 Véase M. Corell Doménech, Cientificos, vulgarizadores y periodistas: estudio y análisis de la divulgación de la ciencia en La ilustración Española y Americana (1869-1898), tesis doctoral, Universitat de València-Estudi General, 2013; y, de la misma autora, "La botella medio vacía: Emilio Huelín, la vulgarización científica y el debate de la ciencia española en el Sexenio democrático y los primeros años de la Restauración", Asclepio, 65(2), p. 024, (doi: http://dx.doi.org/10.3989/asclepio.2013.24). 
formaron la Sociedad Española de Historia Natural (1871), creada bajo el impulso del propio Pérez Arcas y con el espíritu y voluntad de consenso entre naturalistas de diferentes escuelas y tendencias. Varios miembros de este colectivo de naturalistas continuaron la labor iniciada por Pérez Arcas y Miguel Colmeiro. Particularmente destacada fue la contribución de Jiménez de la Espada, que se dedicó principalmente a los estudios históricos sobre América, con especial atención a la actividad científica que los españoles habían desarrollado en el Nuevo Mundo.

Todo estos esfuerzos, primero de las generaciones de la etapa intermedia $y$, luego, de los que intervinieron activamente en el sexenio revolucionario en diferentes formas, sentaron las bases del desarrollo de la cultura científico-técnica de la Restauración e hicieron posible lo que se ha llamado la Edad de Plata de la Cultura y la Ciencia en España. En el sexenio revolucionario comenzó a configurarse lo que Thomas Glick ha llamado el discurso civil para la ciencia, es decir, la posibilidad de un consenso de manera que las innovaciones científicas y técnicas, y la actividad científico-técnica en general, se desarrollen al margen de los debates políticos e ideológicos. Este discurso civil, sostenido por las "clases medias científicas»: ingenieros, maestros y profesores, clérigos con formación científica, profesionales de la salud, médicos y farmacéuticos, se habría consolidado a partir de 1900, haciendo posible la creación de instituciones como la Asociación Española para el Progreso de las Ciencias, que representaba muy bien ese «discurso civil». ${ }^{39}$ Además, hay que señalar las reformas en la enseñanza y la promoción de la investigación con instituciones como la Junta para la Ampliación de Estudios e Investigaciones Científicas y el Institut d'Estudis Catalans, todo ello ya en el siglo Xx.

Si situamos en este contexto la llamada "polémica de la ciencia española», protagonizada ahora por Menéndez Pelayo, podremos evaluar mejor la naturaleza de su intervención y sus contribuciones para el desarrollo cultural y científico espańol. Quiero decir, si tenemos en cuenta, primero, todos los precedentes históricos de la polémica de Menéndez Pelayo, que he descrito apresuradamente, y su naturaleza de reflejo de un reflejo, como decía Chaunu; en segundo lugar, las reflexiones y aportaciones de diversos eruditos, científicos y técnicos, de orientación ideológica similar o diferente a la de Menéndez Pelayo, al conocimiento de nuestro pasado científico-técnico, muchas de las cuales el santanderino se preocupó por conocer, estudiar

39 Véase, sobre el «discurso civil», T. F. Glick, Einstein y los españoles. Ciencia y sociedad en la España de entreguerras, Madrid, CSIC, 2005. 
y divulgar. Y naturalmente el contexto político-ideológico que contaminó el debate. ${ }^{40}$

La polémica protagonizada por Menéndez Pelayo comenzó precisamente en 1876, el año del comienzo del régimen de la Restauración, consiguiente al fracaso de la I República. La Restauración de la monarquía alfonsina consagró un nuevo pacto político entre las fuerzas oligárquicas del antiguo régimen y la nueva burguesía, ya sin pretensiones revolucionarias. Se publicó un decreto aboliendo la libertad de enseñanza reconocida en la constitución de 1869. Recordemos que en 1867 se había producido la "primera cuestión universitaria» cuando los profesores krausistas Nicolás Salmerón, Julián Sanz del Río, Fernando de Castro y Francisco Giner de los Ríos fueron separados de sus cátedras por la presión de los neocatólicos. Ahora, de nuevo, Salmerón, Giner de los Ríos y Gumersindo de Azcárate, entre otros, fueron separados de sus cátedras, siendo repuestos en $1881 .{ }^{41}$

Debe tenerse muy en cuenta que la polémica de Menéndez Pelayo no la desarrollaron científicos, sino filósofos e historiadores desde posiciones ideológicas enfrentadas y en este contexto de la Restauración. El profesor de filosofía Gumersindo Laverde se puede considerar en cierto modo el verdadero artífice o impulsor de la polémica. Laverde, que ya había polemizado décadas antes sobre la existencia o no de una filosofía española, pretendía replantear sus proyectos de regeneración de la cultura filosófica española, con la creación de cátedras de Historia de la Teología Española, Filosofía,

40 Sobre la «polémica de la ciencia española» protagonizada por Menéndez Pelayo, véase P. Laín Entralgo, España como problema, Madrid, Aguilar, 1992, pp. 14-45; Enrique y Ernesto García Camarero, Op. cit.; A. Nieto Galán, «The images of science in Modern Spain. Rethinking the "polémica»", en K. Gavrolu (ed.), The sciences in the european periphery during the enlightenment, Dordrecht, Kluwer, 1999, pp. 73-94; P. Cerezo Galán, "Ecos de la polémica sobre La ciencia española», en Homenaje a Marcelino Menéndez Pelayo, Madrid, Real Academia de Ciencias Morales y Políticas, 2007, pp. 51-81; R. E. Mandado Rodríguez y G. Bolado Ochoa (eds.), "La ciencia española». Estudios, Santander, Universidad de Cantabria, 2011. Todos los textos de la polémica, tanto los de Menéndez Pelayo como los de Laverde y los autores con los que Menéndez Pelayo polemizó figuran en la edición de La ciencia española de 1953.

41 Véase M. Peset Reig y J. L. Peset Reig, La universidad española (siglos XVIII y XIX). Despotismo ilustrado y revolución liberal, Madrid, Taurus, 1974, y sobre la "cuestión universitaria» (primera y segunda), véase también P. de Azcárate, La cuestión universitaria 1875. Epistolario e indices, Madrid, Tecnos, 1967, y Y. Turin, «Le problème universitaire et la révolution de 1868 en Espagne», Revue d'Historie Moderne et Contemporaine, XVIII (1971), pp. 282-295. Sobre el krausismo, véase la excelente síntesis de E. Díaz, «Panorama del krausismo español", en Fernando de Castro y su legado intelectual, Madrid, Fundación Fernando de Castro, 2001, pp. 33-73. 
Derecho, Medicina, y las diferentes Ciencias Exactas, físicas y naturales, en España, y otras iniciativas para dar a conocer nuestro pasado intelectual y científico. ${ }^{42}$ Ahora, en la nueva coyuntura de la Restauración, quería lanzar un nuevo polemista, defensor de la tradición frente al krausismo y los liberales o frente a los progresistas en general, y encontró la persona ideal en Menéndez Pelayo. Para los progresistas (krausistas y otros), en cambio, la alternativa a la que consideraban estéril tradición era la regeneración científica.

En 1856 el krausista Sanz del Río había cifrado las causas de nuestra decadencia en la ausencia del sentido de la idealidad, la carencia de tradición filosófica y la perpetuación de una tradición religiosa y teológica dogmáticas, que permanecían al margen de la duda y la razón. En esta línea e ideas, el escritor y político Núnez de Arce, en su ingreso en la Academia de la Lengua, pronunció en 1876 un discurso titulado: "Causas de la precipitada decadencia y total ruina de la literatura nacional bajo los últimos reinados de la casa de Austria». Este discurso fue comentado por Gumersindo de Azcárate, ligado al krausismo, en un artículo en la Revista de España en el que afirmaba:

Según que, por ejemplo, el Estado ampare o niegue la libertad de la ciencia, así la energía de un pueblo mostrará más o menos su peculiar genialidad en este orden, y podrá hasta darse el caso de que se ahogue casi por completo su actividad, como ha sucedido en España durante tres siglos. ${ }^{43}$

Otro autor, Manuel de la Revilla, insistió en el tema, añadiendo que la Inquisición fue causa también de la decadencia de las Bellas Artes. Y Salmerón se extendió en sus críticas a la represión religiosa y la intolerancia en el prólogo a la traducción castellana de la Historia de los conflictos entre la religión y la ciencia, de Draper, publicada en 1885 en Madrid.

Los oponentes en esta polémica argumentaban desde concepciones antitéticas de la historia y la tradición. Laverde y Menéndez Pelayo defendían una concepción historicista de la tradición de procedencia romántica, que mitificaba el pasado histórico, a la vez que lo erigía en única fuente de fecundidad histórica. La tradición sería el proceso histórico continuado de los productos esenciales del genio del pueblo, que se manifiesta en las creaciones

42 Véase A. Heredia Soriano, «Laverde y su proyecto de reforma filosófica», El Basilisco, 2a época (Oviedo), 12 (1992), pp. 51-60; y, del mismo autor, "Debate sobre la filosofía española. La polémica de 1857», La Ciudad de Dios, CCXII-2 (1999), pp. 415-439.

43 «Las constituciones irreformables». Artículo $4 .^{\circ}$ de «El selfgovernment y la monarquía doctrinaria", Revista de España, tomo XLIX, n. ${ }^{\circ} 194,28$ de marzo 1876, pp. 145-166, p. 149. 
de sus prototipos religiosos, políticos, morales, científicos, etc... Cada pueblo tendría un destino histórico que dependería de su propia tradición.

Para los herederos del krausismo, la historia es progreso que resulta del libre ejercicio de la razón. La tradición puede ser objeto de un interés erudito. La nación española carecería de tradición filosófica y científica. Era necesaria una regeneración cultural resultante de normalizar nuestra actividad filosófica y científica según los parámetros de la Europa culta.

Para Laverde y Menéndez Pelayo la decadencia sería la consecuencia del menosprecio y olvido de la propia tradición. Ni el catolicismo, ni la Inquisición, que eran para ellos expresión libérrima del genio religioso español, causaron nuestra decadencia científica, que se debió a múltiples factores.

En el escrito preliminar a su Historia de los heterodoxos españoles Menéndez Pelayo manifestaba su creencia en que las claves de la historia de la humanidad eran la Providencia, la revelación de Cristo, y el libre albedrío humano, y de que «El genio español es eminentemente católico, la heterodoxia... ráfaga pasajera». ${ }^{44}$ En esta obra Menéndez Pelayo justificaba la intolerancia del Santo Oficio argumentando que era obra purificadora. La unidad religiosa sólo se podía mantener limpiando a España de conversos, judíos, árabes, protestantes y alumbrados. En todo esto Menéndez Pelayo se manifestaba como un católico en los últimos coletazos del papado de Pio IX, el papa del Sillabus y del Vaticano I. Al propio tiempo creció inmerso en polémicas filosóficas y conflictos políticos. Su mentor, Gumersindo Laverde, quería una filosofía cristiana nacional y no le convencían ni el tomismo ni el krausismo. Su ideal era partir de Luis Vives, mientras que el papa Pio IX había centralizado sus posiciones en torno a la filosofía escolástica de raigambre tomista de manera intransigente.

En cuanto a la Inquisición, Menéndez Pelayo, en sus dos primeras obras, La ciencia española y la Historia de los heterodoxos, trató de refutar que esta institución hubiera sido causa del atraso científico español insistiendo en que en el siglo Xvi no hubo procesos a científicos, salvo a los escrituristas hebraizantes.

En la Historia de los heterodoxos, en particular, Menéndez Pelayo dedicó dos capítulos a la prohibición de libros y a los Índices de libros prohibidos. ${ }^{45}$ En el primero, titulado «Historia externa del Índice expurgatorio» dio noticias

44 Menéndez Pelayo, Historia de los heterodoxos españoles, 3 vols. Madrid, 1880-82. Hemos usado la edición de la Biblioteca de Autores Cristianos, 2 vols., 2006 (I) y 2000 (II) (1 $1^{\text {a }}$ ed., Madrid, 1956).

45 Menéndez Pelayo, Historia de los heterodoxos españoles (1880-82), vol. II de la edición del año 2000, capítulos III y IV, pp. 299-318. 
de la publicación de los Índices y datos bibliográficos. El segundo lo tituló «Índice expurgatorio internamente considerado» y trata del desarrollo de la ciencia española bajo la Inquisición. Incluyó en el término ciencia un amplio repertorio de saberes, desde los estudios bíblicos y religiosos en general hasta las ciencias exactas y naturales. Insistió en que no se acababa de convencer «de que se acuse a la Inquisición de haber puesto trabas al movimiento filosófico y habernos aislado de la cultura europea. Abro los Índices y no encuentro en ellos ningún filósofo de la antigüedad...»; asimismo, se podían leer sin trabas e íntegros a todos los filósofos del renacimiento italiano. Y no dejó de señalar que Giordano Bruno no estaba en los índices (lo que es erróneo, ya que fue incluido en 1632), ni Galileo, ni Descartes ni Leibniz, ni, lo «que es más peregrino, Hobbes o Spinoza». ${ }^{46}$ Por otra parte Menéndez Pelayo, como muestra de la libertad filosófica de que se habría disfrutado en España, mencionó a algunos de los más destacados filósofos españoles, empezando como siempre por Vives y continuando con d'Olesa, Vallés, Gómez Pereira, Fox Morcillo y Benito Perera, a todos los cuales llama "pensadores independientes», frente a las formidables falanges escolásticas.

Y en cuanto a las ciencias exactas, físicas y naturales, aún sería más falsa, en opinión de Menéndez Pelayo, la atribución del poco relieve de su cultivo en España a la Inquisición, porque esta no persiguió a ninguno de sus cultivadores ni prohibió jamás una sola línea de Copérnico, Galileo y Newton. Así, Menéndez Pelayo reconocía que «más pobres fuimos en ciencias exactas y naturales; pero no ciertamente por culpa de la Inquisición, que nunca se metió en ellas». A pesar de lo cual España habría contado con algunos excelentes astrónomos y cosmógrafos que Menéndez Pelayo menciona.

Conviene señalar que esta polémica sobre la ciencia española se desarrolló paralelamente a una polémica más general sobre el Santo Oficio en la que

46 Sobre los autores incluidos o no en el índice y en especial sobre el caso Galileo, véase J. Pardo Tomás, Ciencia y censura. La Inquisición española y los libros científicos en los siglos XVI y XVII, Madrid, CSIC, 1991. Efectivamente, como explica este autor, los Diálogos de Galileo nunca llegaron a incluirse en los índices inquisitoriales españoles, aunque hay documentación precisa acerca de la llegada del decreto romano a territorio hispánico. Pero la Inquisición española no solía sentirse obligada a adoptar todas las medidas censoras tomadas por Roma. Y el decreto que prohibía el Diálogo recogía la prohibición de otras veinticinco obras. El nuncio romano en Espańa, cardenal Monti, remitió el decreto a los obispados para su publicación, sin consultar antes al Consejo de la Inquisición. La Inquisición denunció el hecho ante el rey, poniendo de relieve que la acción del nuncio atentaba contra las prerrogativas del Inquisidor General y por tanto de la propia corona. El conflicto de competencias determinó la no publicación del edicto. Así, la obra de Galileo se vio envuelta en un conflicto que no tenía nada que ver con su contenido, pero que favoreció su difusión en España. 
se debatieron una amplia serie de cuestiones, incluida la relativa al efecto de la represión y la censura en la evolución de la cultura, las ideas y la ciencia. ¿Fue la Inquisición responsable del aislamiento intelectual y político y del atraso económico? La polémica de la ciencia española tuvo una naturaleza más cultural e historiográfica, mientras que la de la Inquisición tuvo un fuerte carácter político y programático. ${ }^{47}$

No voy a entrar aquí en el análisis de la polémica y de todos los argumentos aportados por los contendientes, análisis realizado de manera casi exhaustiva por Gerardo Bolado en este mismo libro. Sólo quiero señalar algunos aspectos relevantes desde la perspectiva de la historia de la ciencia. Uno de los frutos de esta polémica fue el formidable repertorio biobibliográfico que preparó Menéndez Pelayo y, aunque es un trabajo basado en los repertorios que se habían publicado anteriormente, y sin duda se pueden señalar en él muchos errores en los datos y nombres, el esfuerzo de reunión y síntesis fue notable. Con este repertorio Menéndez Pelayo no demostraba la existencia y excelencia de grandes científicos y filósofos comparables a los de los países mas sobresalientes desde comienzos del Renacimiento, y algunas de las grandes cuestiones quedaban sin responder, como la cuestión de la decadencia, de sus causas y de su intensidad. El mensaje era más sencillo para el que lo quisiera entender: mostraba la existencia de un considerable número de cultivadores de las diferentes disciplinas científicas y técnicas, autores de un no menos considerable número de obras que merecían cuanto menos ser leídas, analizadas y contextualizadas con los recursos del análisis histórico. Lo que a su vez indicaba la existencia de una actividad científico-técnica cuyo valor estaba aún por determinar, aun aceptando en determinadas materias la superioridad indiscutible de otros países o autores. Además, y para señalar el camino a seguir a partir del repertorio, Menéndez Pelayo redactó varios estudios monográficos dedicados a médicos y pensadores españoles del siglo XVI. ${ }^{48}$ En cuanto a su monumental Historia de los heterodoxos españoles, como hemos adelantado, Menéndez Pelayo pretendía mostrar con esta obra que la herejía era fundamentalmente ajena al carácter inquebrantablemente católico de la nación española. Sin embargo, el rigor con el que trabajó le condujo a descubrir un número inusitado de herejes y heterodoxos, personas corrientes o personalidades de relieve que habían salpicado la historia hispana, aportando un importante caudal de información cuya consulta todavía sigue siendo útil. Al final, la obra

47 Véase R. López Vela, «Historiografía inquisitorial, catolicismo y España. Análisis de una trayectoria historiográfica», en J. Pérez Villanueva y B. Escandell Bonet (eds.), Historia de la Inquisición, vol. III, Madrid, Biblioteca de Autores Cristianos, 2000, pp. 83-167.

48 El repertorio está en MP, CE, vol. II, pp. 495 y ss., y los estudios monográficos están incluidos en $I b$. Véanse también $I b$. 
desmentía las pretensiones originales de Gumersindo Laverde y Menéndez Pelayo, mostrando hasta qué punto los heterodoxos habían abundado en nuestra historia.

Años después, con el avance en España de la actividad científico-técnica, relacionado con el progreso de la industrialización, los cambios culturales y sociales, y el desarrollo consiguiente del discurso civil, el enfrentamiento ideológico se fue diluyendo. Y es en ese nuevo contexto en el que cabe situar el importante texto de Menéndez Pelayo: «Esplendor y decadencia de la cultura científica española». ${ }^{49}$

En este texto, escrito con gran serenidad y muy alejado del espíritu polémico de su juventud, Menéndez Pelayo planteaba una serie de cuestiones e hipótesis, a modo de precipitado de las preocupaciones y reflexiones a lo largo de los años de los debates y trabajos sobre la «la ciencia española». Como el texto es bien conocido, recordaré la principal hipótesis del texto adelantada por Menéndez Pelayo para explicar la relativa inferioridad de las ciencias exactas y naturales en Espańa:

... en este país de idealistas, de místicos, de caballeros andantes, lo que ha florecido con más pujanza no es la ciencia pura (de las exactas y naturales hablo), sino sus aplicaciones prácticas, y en cierto modo utilitarias. ${ }^{50}$

Menéndez Pelayo no profundizó en las causas de este supuesto excesivo pragmatismo de nuestros científicos, más allá de las alusiones generales a las necesidades de la monarquía, y sus ambiciones imperiales, como el control y dominio de las tierras descubiertas. Ni aceptó los posibles efectos negativos del control y represión por causas ideológicas del pensamiento filosófico y científico por parte de la Inquisición y otras instituciones. E influido por el positivismo de la época practicado por los historiadores de la ciencia que distinguían entre ciencia y filosofía, e ignoraban las estrechas relaciones entre el pensamiento filosófico y el científico en la construcción de la ciencia moderna, consideró el desinterés de nuestros científicos por la especulación teórica como derivado puramente de sus urgencias prácticas. ${ }^{51}$ Pero las cosas

49 Está incluido en el vol. II de La ciencia española. Véase, sobre este ensayo, V. Navarro Brotons, «La obra de Menéndez Pelayo sobre «La ciencia Espańola» en su tiempo y en el nuestro: un ensayo historiográfico», en Mandado Gutiérrez y Bolado Ochoa (eds.), Op. cit, pp. 261-289.

50 «Esplendor y decadencia de la ciencia española», en MP, CE, vol. II, pp. 763 y ss.

51 Algunos autores, como Cerezo, $O p$. cit., han señalado como un defecto la confusión entre ciencia y filosofía en Menéndez Pelayo, lo que sería contradictorio con lo que aquí afirmo. Pero una cuestión es el sentido amplio en el que Menéndez Pelayo emplea la palabra ciencia, en la que incluye, además de las ciencias exactas, físicas y naturales también a la teología, la filosofía, la jurisprudencia, el estudio de las lenguas, 
eran más complicadas: los científicos tenían ambiciones teóricas, atacadas por los filósofos escolásticos y fuertemente condicionadas por su estatus profesional y el control ideológico desde los aparatos del estado.

No obstante, el gran desarrollo de las matemáticas prácticas: la astronomía práctica, la topografía y la agrimensura, la perspectiva, la cartografía, la arquitectura, fortificación, ingeniería y máquinas, el arte de la guerra, la náutica y el diseño de instrumentos que tuvo lugar en el Renacimiento, ha sido considerado por destacados historiadores de la ciencia como un aspecto fundamental del proceso que condujo a la ciencia moderna. Ya Edgard Zilsel, en los años cuarenta del pasado siglo destacó que una serie de artesanos (marineros, constructores de barcos, carpinteros, fundidores, mineros, etc.) liberados de las constricciones de la tradición gremial y estimulados a realizar invenciones por la competencia económica, fueron los auténticos pioneros de la observación empírica, la experimentación y la investigación causal. Aunque les faltaron las herramientas analíticas para sistematizar esos descubrimientos y deducir las leyes de la naturaleza. ${ }^{52}$ Otros autores, como Paolo Rossi, han puesto de relieve la importancia de la nueva valoración de la técnica y el trabajo manual como fuente de conocimiento que tuvo lugar en el Renacimiento y ha destacado a Luis Vives entre los autores que mejor expresaron estas ideas. ${ }^{53} \mathrm{Y}$ recientemente Jim Bennet ha considerado lo que llama «the practical mathematical tradition» como fundamental para la emergencia de la filosofía mecánica o la nueva filosofía natural reformada del siglo XvII. ${ }^{54} \mathrm{El}$ mismo Bennet ha insistido en la necesidad de dirigir nuestra atención a la ciencia como una actividad, como medios de acción y resolución de problemas. Y a integrar el amplio dominio de actividad de las matemáticas prácticas en el relato de la Revolución Científica. Aunque Bennet en sus trabajos sigue ignorando el mundo ibérico, por un prejuicio muy común (sumado a su especial atención al caso inglés): dado que España (y Portugal) participó de manera escasa y marginal en la Revolu-

y lo que llamaríamos ciencias humanas, y otra cosa bien distinta es el estudio propio de las ciencias exactas y de la naturaleza. En esta época y hasta bien entrado el siglo xx los historiadores de la ciencia, que, como hemos dicho, generalmente eran científicos, no atendían a las relaciones entre el pensamiento científico y las ideas filosóficas, metafísicas o teológicas de autores como Copérnico, Kepler, Descartes o Newton, por citar algunos de los autores más destacados y estudiados en el sentido expresado.

52 Véanse los trabajos de Zilsel reunidos en E. Zilsel, Die sozialen Ursprünge der neuzeitlichen Wissenschaft, Ed. por Krohn, W., Frankfurt a. M., Suhrkamp, 1976.

53 P. Rossi, I filosofi e le machine 1400-1700, Milan, Feltrinelli (la primera edición es de 1962; hay una edición en castellano, Barcelona, Labor, 1965).

54 Sobre las obras de Bennet, véase mi trabajo citado en la nota 49 y el capitulo 2 de mi libro Disciplinas, prácticas y saberes, citado en la nota 11 . 
ción Científica del siglo xvII, nada interesante y digno de ser tenido en cuenta debió ocurrir en el período anterior. Y ello a pesar de que historiadores ingleses de la cartografía, la geografía o la náutica, como Charles Cooter, Eva Taylor o David Waters han puesto de relieve hace varias décadas la importancia de las contribuciones ibéricas en estas materias.

Como ya señalé en mi contribución al Congreso sobre «La ciencia espańola», el diagnóstico de Menéndez Pelayo parece ahora más certero de lo que él pensaba, con la importante matización de que el cultivo de las matemáticas prácticas contribuyó de manera más destacada de lo que el sospechaba a la construcción de la ciencia moderna. También acertó al pensar que una orientación exclusivamente utilitaria o empírica, sin ambiciones teóricas, no bastaba para construir la ciencia moderna. Pero no entendió, ni pudo hacerlo en su época, la importancia del contexto filosófico de los descubrimientos científicos.

En este mismo texto que comentamos, «Esplendor y decadencia de la cultura científica española», encontramos otras apreciaciones y consideraciones de Menéndez Pelayo que muestran su capacidad de penetración y su extraordinaria sensibilidad histórica. En primer lugar, su insistencia en la necesidad del estudio de la obras de los autores españoles, antes de llegar a conclusiones definitivas: «ir leyéndolos uno a uno y cotejándolos con sus similares del extranjero en el mismo tiempo». Además, y en todo caso, la ciencia, que es una actividad social, no la hacen sólo las grandes figuras, sino las diferentes colectividades y grupos implicados en las diversas actividades científico-técnicas. Citaré uno de los párrafos más memorables para un historiador de la ciencia de este formidable texto:

La historia de la ciencia es instructiva siempre, no sólo porque presenta en acción el método científico (sobre lo que el gran historiador Alexander Koyré, por cierto, insistía continuamente, destacando que nada podía sustituir a la lectura directa de las fuentes), sino porque de ella se desprende la consoladora enseñanza de que la ciencia es obra humana y colectiva, en que colaboran no solamente los genios, sino los trabajadores humildes; no sólo las naciones opulentas, sino las modestas, oscuras y abatidas. ${ }^{55}$

También apuntaba Menéndez Pelayo que no se debe restar importancia a la labor de difusión de los saberes, esencial asimismo al desarrollo de la actividad científica. Por otra parte, para evaluar los procesos de evolución cultural y científica y el cambio cultural-científico hemos de dar cuenta adecuadamente de los substratos culturales y esclarecer qué fenómenos es-

55 «Esplendor y decadencia de la ciencia espańola». En MP, CE, vol. II, p. 786. 
timularon el cambio y dirigieron su velocidad y dirección. Como lo dice Menéndez Pelayo: hemos de buscar los orígenes de nuestras cosas donde realmente se encuentran, es decir, en las ideas e instituciones de todos los pueblos que han pasado por nuestro suelo.

Recordemos, además, para valorar su obra, que Menéndez Pelayo no era científico ni historiador de la ciencia. Por ello es aún mas admirable el enorme esfuerzo de recopilación que llevó a cabo y, asimismo, el esfuerzo por seguir algunas de las obras mas destacadas de historia de las distintas ciencias que se estaban publicando en Europa desde el siglo XVIII, como las de Bossut y Montucla, de historia de las matemáticas; Leclerc, de historia de la medicina árabe; Sedillot, de historia comparada de las ciencias matemáticas en los griegos y los orientales; Hanckel, de historia de las matemáticas entre los árabes; Libri, de historia de las ciencias matemáticas en Italia, o el Bulletino de bibliografía é di storia delle scienze matematiche de Buoncompagni y otras obras y repertorios bibliográficos de autores europeos.

La polémica de la ciencia española llevada a cabo por Menéndez Pelayo no dio respuestas satisfactorias a los grandes interrogantes planteados acerca de las contribuciones españolas al desarrollo de la ciencia o las ciencias en el panorama universal. Como señala en este mismo libro Gerardo Bolado,

La falta de claridad y de un mínimo acuerdo en la concepción de la filosofía, de las ciencias y de su clasificación, y, sobre todo, lo irreconciliable y discordante de los hechos, las verdades y los valores característicos de los auditorios correspondientes a las distintas posiciones en la polémica, a saber, el racionalismo progresista heredero del krausismo, el historicismo católico, el tradicionalismo tomista y el tomismo íntegro, dejaron de entrada sin una base suficiente de evidencias y valores compartidos a la polémica e hicieron prácticamente inviable su avance dialéctico. ${ }^{56}$

No obstante, Menéndez Pelayo acertó a defender la necesidad de desarrollar los estudios históricos de nuestra filosofía y de nuestras ciencias. También acertó al insistir en que la historia de las ciencias no sólo la escribieron las primeras figuras y los creadores de las grandes teorías, sino también los científicos medianos que hicieron contribuciones o desarrollos parciales, o los científicos prácticos, a saber, los médicos, los ingenieros, los navegantes, los cartógrafos, los arquitectos, los astrónomos prácticos, los topógrafos y agrimensores, los naturalistas, etc., que hicieron descubrimientos fecundos o aportaron hechos y saberes prácticos que prepararon el terreno para esos descubrimientos y para las grandes formulacio-

56 «La lucha por el reconocimiento. Análisis argumentativo de la polémica de la ciencia española», en MP, CE, vol. I, p. CV. 
nes teóricas. Aunque España no aportó en general figuras tan relevantes como Descartes o Newton, en este país surgieron técnicos, filósofos, y cultivadores de las distintas ciencias y sus aplicaciones, que desarrollaron una labor digna de ser estudiada y reconocida. ${ }^{57} \mathrm{El}$ joven polemista católico tenía toda la razón tanto al considerar injusto e inconveniente el descrédito internacional en que se encontraban sumidas la historia filosófica y científica de España, como al promover la lucha por el reconocimiento de nuestra aportación civilizatoria a través de los estudios históricos. No la tenía tanto, y el tiempo se encargó de ponerlo pronto de manifiesto, en su defensa del restablecimiento de nuestra tradición científica y de sus caracteres nacionales.

Con el creciente desarrollo de la actividad científica en España también se mantuvo y aumentó el interés de los científicos por estudiar el pasado científico español y por entender sus peculiaridades. Destacaremos, a fínales del siglo XIX, la obra del químico Ramón de Luanco sobre La alquimia en España, obra basada en el análisis sistemático de textos manuscritos y de fuentes de archivo; las diversas obras de Cesáreo Fernández Duro dedicadas a la historia de la navegación, la geografía y la cartografía; los estudios biográficos y monográficos del químico José Rodríguez Carracido sobre José de Acosta, Juan Escrivá, Barba y los metalurgistas españoles en América; y los del ingeniero Luis de Escosura acerca de Juanelo Turiano y la metalurgia del azogue. En cuanto a la historia institucional, debe destacarse la tarea desarrollada por la Academia de Ciències i Arts de Barcelona, que desarrolló una labor sistemática de recuperación de su historia. En 1895, José Balari-Jovany, uno de sus miembros más ilustres publicó la Historia de la Real Academia de Ciencias y Artes y en el marco de esta academia surgió uno de los primeros intentos de institucionalización de los estudios histórico-científicos. ${ }^{58}$

57 Cuando hablamos de «España» en los siglos XV-XviıI conviene precisar qué entendemos por tal. Una solución habitual es entender por tal el conjunto de reinos de la época que constituyen la actual España, con todas las cautelas que imponen las enormes diferencias administrativa y de otros órdenes. Como señala Maravall, al hablar de la Monarquía hispánica, hay que distinguir tres planos; cada reino peninsular, el conjunto de los reinos de la tradición hispánica y el conglomerado imperial que había venido a constituirse bajo la corona de España. Los tres niveles afectaron a la actividad científicotécnica: el proyecto imperial, la construcción del Estado moderno y la diversidad de los reinos peninsulares, con su propia organización político-social y sus propias tradiciones culturales. Distinciones que Menéndez Pelayo y sus críticos no tenían en cuenta. Menéndez Pelayo, por ejemplo, solía incluir a autores de la tradición portuguesa sin más precisiones. Sobre el asunto de "España», véase J. A. Maravall, Estado moderno y mentalidad social. Siglos XV a XVII, 2 vols., Madrid, Revista de Occidente, 1972.

58 Se trata de una propuesta del académico y farmacéutico Agustín Murúa Valerdi, que había ingresado en la Academia en 1907 con un discurso de historia de la química 
El notable químico Rodríguez Carracido, además de sus estudios históricos, reflexionó sobre las "Condiciones de España para el cultivo de las ciencias» criticando todas las hipótesis deterministas (como el clima, la herencia genética, etc.) y elaboró una teoría de raigambre spenceriana de la evolución social y cultural: la producción científica tendría que ser una fase del desarrollo evolutivo de la sociedad española; se tendría que preparar el medio social, ya que el órgano depende de la función. En todo caso para Rodríguez Carracido nuestro atraso científico no estaría en defecto alguno congénito, sino en las circunstancias accidentales del proceso histórico. ${ }^{59}$

También el histólogo Santiago Ramón y Cajal, uno de los principales protagonistas de la llamada Edad de Plata de la ciencia en España, que llegó a presidir la Junta para Ampliación de Estudios, reflexionó sobre estos temas en su discurso de ingreso a la Real Academia de Ciencias, titulado "Deberes del Estado en relación con la producción científica». Además de exponer los criterios que a su juicio debería regir la política científica, Cajal describió una serie de teorías dedicadas a dar cuenta de «nuestra postración política y social» que consideraba aplicables al terreno de la actividad científica: teorías físicas (térmicas y oligohídricas, es decir, un clima inadecuado par el estudio y la investigación y la escasez de agua que lleva a un bajo nivel de vida y una baja densidad demográfica); teorías político-morales, hipótesis del fanatismo religioso, del orgullo y arrogancia españoles y de la segregación intelectual. Cajal les concedió a todas las teorías alguna influencia, pero las criticó a todas relativizando considerablemente su valor explicativo de las causas de las deficiencias históricas de la actividad científica española en términos comparativos. Sobre la "Hipótesis del fanatismo religioso» Cajal reconoció que la Inquisición «contribuyó bastante a marchitar la flor de nuestra originalidad científica y filosófica». Pero esta hipótesis, para Cajal, era no obstante notoriamente exagerada, como, a su juicio, lo habían probado Laverde, Menéndez Pelayo y otros autores. Para Cajal, además, lo más grave de la teoría religiosa era su tendencia sectaria, ya que «fiados en ella, corremos

orgánica. Véase A. Roca Rosell, «Una perspectiva de la historiografía de la ciencia i de la técnica a Catalunya», en V. Navarro, L. Salavert, Mavi Corell, E. Moreno i V. Rosselló (eds.), Actes II Trobades d'història de la ciencia i de la técnica, Barcelona, SCHCT, 1993, pp. 13-27.

59 La conferencia de Rodríguez Carracido, «Condiciones de España para el cultivo de las ciencias», pronunciada en el Ateneo de Madrid el 6 de abril de 1896, figura incluida en sus Estudios histórico-críticos de la ciencia española, Madrid, Fortanet, 1897 (una segunda edición, aumentada, en 1917). Véase también el texto de la conferencia en Enrique y Ernesto García Camarero, Op. cit., pp. 351-373. 
el riesgo de echarnos definitivamente en el surco, dejando de aplicar al mal los verdaderos remedios». ${ }^{60}$ En cualquier caso, para Cajal «nuestros males no son constitucionales, sino circunstanciales, adventicios».

Durante la primera mitad del siglo xx hasta la guerra civil los estudios históricos sobre la ciencia prosiguieron gracias al esfuerzo personal de una serie de científicos y de algunos historiadores. Agrupando los de varias generaciones, señalaremos que la mayor parte de los estudiosos se concentraron en cinco áreas: matemáticas (Juan Antonio Peñalver, Julio Rey Pastor, José A. Sánchez Pérez, Francisco Vera); cosmografía y náutica (Armando Cotarelo, Salvador García Franco, Julio F. Guillén Tato, José María Millás Vallicrosa); geografía (Ángel de Altolaguirre, Jerónimo Bécker, José María Blázquez, Amando Melón y los Gonzalo de Reparaz) y medicina (Víctor Escribano, Gregorio Marañón, Nicasio Mariscal, Eduardo García del Real, Rodrigo Pertegás). En cambio, contaron con la dedicación de muy escasos autores disciplinas como la química y la farmacia (Rafael Folch Andreu, Rafael Roldán) y la veterinaria (Cesáreo Sanz Egaña), mientras que la ingeniería y, sobre todo, la física sufrieron un auténtico vacío historiográfico.

Con la creación en 1928 de la Academia Internacional de Historia de las Ciencias, presidida por Aldo Mieli, y gracias a la iniciativa de éste de crear, desde 1930, grupos nacionales de apoyo, los historiadores de la ciencia españoles pudieron formar uno de estos grupos. Cabe señalar que la Academia, en 1931, contaba ya con cuatro miembros españoles y un correspondiente: José Ribera, José Augusto Sánchez Pérez, Miguel Asín Palacios y José María Millas Vallicrosa, que era además redactor de Archeion (después, Archives Internationales d'Histoire des Sciences), como miembros y Agustín Barreiro como correspondiente.

En los años de la Segunda República las relaciones entre los historiadores de la ciencia espańoles sufrieron momentos de intensa tensión entre distintas personalidades y grupos, en parte por motivos ideológicos. A pesar de todo se fundó una Asociación Nacional de Historiadores de la Ciencia Espańola, de cortísima vida, cuya única actividad conocida fue la publicación de un volumen titulado Estudios de la ciencia española del siglo XVII, en el que colaboraron diecisiete autores. El libro, que es muy desigual en cuanto a las

60 El texto de Cajal corresponde a su «Discurso" de ingreso en la Real Academia de Ciencias, leído el 5 de diciembre de 1897 y publicado en Madrid, L. Aguado, 1897. Reimpreso en su libro Reglas y consejos sobre investigación biológica (Los tónicos de la voluntad), Madrid, Fortanet, 1899; hubo numerosas ediciones posteriores; la octava, en Madrid, Espasa-Calpe, 1963. Puede verse reproducido en Enrique y Ernesto García Camarero, Op. cit., pp. 373-399. 
aportaciones, algunas de ellas muy notables, recibió elogios pero también duras críticas por el «españolismo a ultranza y la confusión entre la ciencia y la erudición». ${ }^{61}$

Como resumen apresurado cabe decir que durante este período y hasta la Guerra Civil, de desarrollo y débil institucionalización de la historia de la ciencia en España, la historia de la ciencia tuvo una presencia fundamentalmente en publicaciones, aunque no siempre estas respondieron a una seria labor de investigación; asimismo, se realizaron intentos de organización e institucionalización de la disciplina y algunos grupos o personalidades iniciaron contactos con los historiadores de la ciencia europeos y americanos y se vincularon a las corporaciones internacionales; en cuanto a su penetración en los niveles de la docencia universitaria, ésta quedó reducida esencialmente a la farmacia y la medicina.

José María Millas Vallicrosa fue, de todos los autores de este período, el que produjo mayor «impacto» en la naciente comunidad internacional de historiadores de la ciencia por sus contribuciones al conocimiento del cultivo de las ciencias en al-Ándalus y al papel de nuestra Península en la transmisión del saber greco-árabe a la Europa latina.

En 1956 Millás publicó un trabajo titulado «Vindicación de la ciencia española por Menéndez Pelayo». ${ }^{62}$ Entonces, el historiador catalán, que había impulsado una Asociación para la Historia de la Ciencia Espańola (en 1949), se encontraba en plena madurez y disfrutaba ya de un reconocimiento por su obra. Reconocimiento que culminaría con la celebración en Madrid y Barcelona del IX Congreso Internacional de Historia de la Ciencia (1959) y con el nombramiento de Millás como presidente de la Academia Internacional de Historia de las Ciencias, puesto que ocupó entre 1956 y 1959. ${ }^{63}$

Millás, en su «Vindicación», elogió, además de la potencia extraordinaria de erudición y bibliografía de Menéndez Pelayo, su seguridad de intuición y madurez de criterio:

61 Véase Estudios sobre la ciencia española del siglo XVII, Madrid, Asociación Nacional de Historiadores de la Ciencia Española, 1935. El libro se publicó con un prologo de Niceto Alcalá Zamora. Después figuraba una lista de los 21 primeros miembros de la Asociación, comenzando por Agustín J. Barreiro Martínez. Sobre las críticas, véase A. Roca Rosell, «El caso del Congreso Internacional de 1934: «Guerra» entre historiadores de la ciencia», en M. Valera y C. López Fernández (eds.), Actas del V Congreso de la Sociedad Española de Historia de las Ciencias y de las Técnicas, vol. I, Murcia, SEHCT, pp. 1066-1084.

62 En Arbor, 34, n. ${ }^{\circ}$ 127-128 (1956), pp. 410-426.

63 Véase J. Vernet i Ginés, «Josep. M. Millàs Vallicrosa i la seva escola», en Cinquanta anys de ciència i tècnica a Catalunya. Entorn l'activitat cientifica d'E. Terradas (1883-1950) (27 i 28 de setembre del 1984, Barcelona, Institut d'Estudis Catalans, 1987, pp. 193-205. 
Él supo captar los grandes momentos del quehacer científico español: el gran interés de la filosofía y la ciencia - de solera alejandrina, en buena parte- de los árabes y judíos españoles; la labor ingente de traducciones científicas operadas en España, singularmente en Toledo, y su inmediata influencia en Europa; la densidad enorme de nuestro siglo XVI, desde la Teología y Mística, Filosofía y Derecho, hasta la Náutica y Cosmografía orientada hacia el Nuevo Mundo; la continuidad, con ritmo remansado, es cierto, de este quehacer científico a lo largo de los siglos XVII y XVIII con las singulares aportaciones en Botánica y Metalurgia del Nuevo Mundo hasta llegar a la caída vertical, al colapso de fines del siglo xviII y primera mitad del Xix. ${ }^{64}$

También se refería Millás a la tendencia, apuntada por Menéndez Pelayo, de los practicantes españoles de las materias científicas, a «inhibirse de las ciencias puras, abstractas sin aplicación práctica». Pero el erudito santanderino, observaba Millás, supo escapar de los extremismos negativos de autores como Echegaray o de las apologías poco ponderadas como la de Vallín.

Cabe decir que la polémica de la ciencia española, en lo que se refiere a las grandes cuestiones planteadas en ella, como: ¿Por qué en Espańa, donde han nacido escritores y artistas geniales como Cervantes, Velázquez, Lope de Vega, Goya y tantos otros no han surgido científicos como Galileo, Descartes o Newton?, y a sus posibles causas, ha llegado hasta nuestros días y aún se pueden escuchar ecos de la misma. Pero, como muy bien señala Juan Pimentel, esta y otras cuestiones similares planteadas en la polémica son, en general, tan vaporosas como irresolubles, ya que no entran tanto en el reino de los hechos como en el de los relatos. ${ }^{65} \mathrm{~A}$ partir de los años sesenta una nueva generación de historiadores españoles de la medicina y de las ciencias comenzaron a desarrollar un programa de reconstrucción de la actividad científica en la historia de España. Sus protagonistas trataron de superar los planteamientos de la polémica de la ciencia española mediante la investigación rigurosa. Ello produjo una considerable literatura histórico-médica y científica en forma de libros, artículos, comunicaciones y ponencias en congresos, que ha circulado internacionalmente. Pero los prejuicios tienen la piel dura. Recientemente, diversos autores se han sentido (nos hemos sentido) obligados todavía a denunciar o criticar la persistente y casi general ignorancia o escasa consideración por parte de destacados

64 En Arbor, 34, n. ${ }^{\circ}$ 127-128 (1956), pp. 410-426.

65 Véase Juan Pimentel, «Del peso del aire y las disciplinas invisibles. La polémica de la ciencia española como narrativa de una modernidad elusiva», en M. J. Villaverde Rico y F. Castilla Urbano (dirs.), La sombra de la leyenda negra, Madrid, Tecnos, 2016, pp. 425-451. 
historiadores de la ciencia europeos y norteamericanos, autores de obras de referencia en la disciplina, acerca de las contribuciones del mundo ibérico a lo que se llama la Revolución Científica o la construcción de la ciencia moderna ${ }^{66}$ Estas denuncias y críticas han circulado ampliamente y están teniendo una amplia resonancia, gracias a que hoy la historia de la ciencia es una disciplina en expansión en gran parte del mundo, tanto occidental como oriental. En las últimas décadas hemos sido testigos de un notable crecimiento de esta disciplina en términos de los indicadores más obvios: personas (manpower, en inglés), revistas, libros, o instituciones; asimismo, ha tenido lugar una renovación historiográfica tanto en los temas como en los métodos o procedimientos, con una mayor y mejor atención a las dimensiones cultural, social, económica, ideológica y política de la actividad científica y sus resultados. Hay un creciente interés por la historia de la ciencia, no sólo entre los científicos, sino también entre los historiadores del arte, de la literatura, política, economía, así como entre los practicantes de las distintas disciplinas de las humanidades o ciencias sociales. Todo esto esta haciendo posible la labor de nuevas generaciones de historiadores españoles, portugueses, latinoamericanos, estadounidenses y de otros países que están replanteando todas las cuestiones, aportando nuevos hechos e interpretaciones de los mismos, es decir, nuevos relatos, para reconstruir adecuadamente el pasado histórico-científico-técnico y filosófico hispánico (o ibérico), superando aquellos ya viejos enfrentamientos ideológicos y cuestiones mal planteadas. Menéndez Pelayo estaría de acuerdo con estos nuevos desarrollos y se uniría a ellos.

66 Véase Navarro y Eamon, Op. cit. (nota 7). 


\title{
A [casi] siglo y medio de la polémica de la ciencia espańola. Su noble e involuntario «instigador»: Gumersindo de Azcárate
}

\author{
Dr. José Luis Mora García \\ Universidad Autónoma de Madrid
}

$\mathrm{H}$ ace poco más de un siglo se publicaba La leyenda negra, el famoso libro cuyo título ha hecho fortuna (difícil decir si buena o mala) enfatizando la singularidad de España en la historia europea. ${ }^{67}$ Realmente, desde que Francisco de Quevedo pusiera su pluma al servicio de la Espańa necesitada de ser defendida, con dedicatoria a Felipe III, no ha cesado el sentimiento de una España periférica en la construcción del pensamiento moderno y, no solo en el sentido geográfico a medida que la Corte disminuía, sino en el de la construcción de la ciencia y la técnica como base de Europa. Como es bien sabido, esta fue la tesis orteguiana a lo largo de la segunda década del siglo xx, hasta el punto de atreverse a cerrar su famosa conferencia de 1910 en Bilbao con la frase, tan lapidaria como simplista y repetida muchas veces a falta de mejores argumentos: «España el problema, Europa la solución».

A la altura de 1948 María Zambrano, residente entonces en la Isla de Cuba, que alternaba con estancias en Puerto Rico, y a punto de iniciar sus contactos con la ciudad de Roma donde luego viviría por un largo período,

67 La dedicatoria de Julián Juderías al rey Alfonso XIII lleva fecha de 1914, aunque La Ilustración Española y Americana adelantó en 1913 un estudio donde se abordaba «el concepto de España en el extranjero». Posteriormente, cuatro años más tarde salía una edición aumentada: J. Juderías, La leyenda negra, Barcelona, Casa editorial Araluce, 1917. Existe edición reciente (1997 y 2003) de la Junta de Castilla y León. 
retomaba sus reflexiones publicadas en la añorada revista de tiempos de guerra, Hora de España, y en sus conferencias mexicanas, nada más comenzar el exilio, sobre "Pensamiento y poesía en la vida espańola», con un breve artículo publicado en otra revista no menos emblemática: Las Españas, de vida razonablemente larga y cuyos contenidos hubieran debido merecer más atención en los tiempos democráticos. «El problema de la filosofía española» está escrito como respuesta, por más tardía que parezca, al eco duradero de la historia que se escribió por aquellas fechas de 1876, es decir, las de la polémica. Casi tres cuartos de siglo después aún coleaba la duda acerca de la existencia de filosofía en España y nuestra pensadora, tan atenta a lo que significó el «historiador católico», como le recuerda en varios lugares y de manera significada en Delirio y destino, muestra que no le había pasado desapercibida la famosa polémica y que lo allí debatido y sus protagonistas le habían acompañado en su reflexión, si bien ya, a esa altura del siglo xx, el recuerdo pasaba por el tamiz orteguiano. ${ }^{68}$

La ciencia española es una profesión de fe -nos decía la filósofa malagueña-, la más apasionada y ardiente de este hombre de fe que fue don Marcelino. Un acto de fe apasionada, un voto que desearíamos ver cumplido, pero que no podemos aceptar en principio, sino como un voto, justamente, y no como la plena demostración de la tesis que tan obstinadamente defiende. ${ }^{69}$

Valga este testimonio traído aquí para corroborar la sombra prolongada de una polémica que ha superado con mucho los términos de un debate técnico y se ha adentrado en la razón misma de la construcción de Espańa como nación. Quizá la cuestión más de fondo con la tesis orteguiana, que Zambrano hace básicamente suya, tiene que ver con las dos características que se requieren para hablar de filosofía, propiamente hablando, vinculada a un Estado: la continuidad y la vigencia. Si Ortega ya las había puesto en cuestión en su referencia a España, Zambrano, con matices, las aplica para

68 «Menéndez Pelayo, el historiador católico à outrance, enumerador de una especie de libro sagrado, de la ciencia y la filosofía española, como réplica a la acusación lanzada contra España desde los cuatro puntos cardinales del mundo civilizado, de ser país reacio o contrario a las luces del pensamiento, dado solo a la pasión", en M. Zambrano, Delirio y destino, "Nota aclaratoria» de Jesús Moreno Sanz, Madrid, Horas y horas, 2011, p. 78. Según indica Jesús Moreno, el libro debió ser escrito entre 1951 y 1953, es decir, entre tres y cinco años después de escribir el artículo al que nos referimos.

69 M. Zambrano, «El problema de la filosofía espańola», publicado en el número 8 correspondiente al mes de abril de 1948. Recogido en J. Valender y G. Rojo, Las Españas. Historia de una revista del exilio (1946-1963), México, El Colegio de México/Fondo Eulalio Ferrer, 1999, p. 610. 
sostener que, después de leer a Menéndez Pelayo, no podemos pasar de su propuesta como si de una «demostración» se tratara. Era, no olvidemos, el final de la década de los cuarenta, a casi diez ańos de su salida de Espańa, desde una actitud mental escindida entre las razones de la fractura y las bases de la reconstrucción.

Si nos fijamos ahora en la posición de científicos españoles, formados desde los años setenta para acá, provenientes de departamentos anglosajones, que ejercen de historiadores aficionados, se aprecia, en sus intervenciones orales, un cierto tono de «predicadores» de la buena nueva: ¡Por fin, hay ya ciencia en España! ${ }^{10}$ Y que habría sido la generación de la transición la ejecutora de tal «milagro», por más que esta palabra parezca fuera de lugar en este contexto en que hablamos de ciencia. Ortega, también, tras su estancia en Alemania, había certificado la necesidad de construir una nación nueva desde la filosofía y la ciencia, pues estaba convencido de que nos habría faltado lo que «Francia, Inglaterra, Alemania y hasta Italia han tenido siempre: la continuidad cultural. He aquí el factor específico de nuestro problema. Y este defecto no es de hoy, no es de los últimos cincuenta años, sino que nos acompaña desde hace tres siglos». ${ }^{71}$ De nuevo los famosos «tres siglos», estimación que alimentó la polémica de Laverde/Menéndez Pelayo con/contra Gumersindo Azcárate, que se había atrevido a poner ese guarismo en el párrafo que sobresaltó a Laverde hasta escribir al joven Marcelino para que saliera a la palestra. En realidad, si se leen todos los textos de intervenciones públicas del Ortega que acababa de obtener la cátedra en la Universidad Central de Madrid y se abría un hueco en la vida pública española, se comprobará que rezumaban el espíritu nuevo (frente al viejo) que supuestamente habría de superar las posiciones de los contendientes polemistas del comienzo de la Restauración. Pues era la Restauración misma la que deseaba superar, en verdad, la historia completa de España. Espíritu similar ha invadido a intelectuales de la transición democrática.

Con la ventaja que da comprobar cómo discurren las cosas a la altura de la mitad de la segunda década del siglo xxi, hace justamente 140 años,

70 Excluyo aquí a los historiadores de la ciencia provenientes de la escuela de José María López Piñero o a los herederos de la cátedra de historia de la medicina ya estudiados en otro lugar. J. L. Mora García, «Filosofía y ciencia en "Llull. Revista de la Sociedad Española de Historia de las Ciencias y de las Técnicas”» en J. García González (ed.), Fidelidade a Terra. Estudios dedicados ó profesor Xosé Luis Barreiro Barreiro, Santiago de Compostela, Universidade de Santiago de Compostela, 2011, pp. 395-415.

71 Ortega y Gasset, J., «La cuestión moral», en P. Cerezo (ed.), Vieja y Nueva Política y otros escritos programáticos, Madrid, Biblioteca Nueva, 2007, p. 191. Se trata de un artículo publicado en El Imparcial, 1908. En general casi todos los artículos o textos de conferencias de más de una década responden a ecos que nos suenan de los textos provenientes de aquella vieja polémica a la que nos referimos. 
comprobamos que los ecos de la polémica se reavivan como el silbo gomero que contribuye a salvar la profundidad de los valles de una orografía tortuosa, rebotando en las aristas de las montañas. ${ }^{72}$ Cambian las tonalidades según la naturaleza de los minerales o de las modulaciones de la historia; aunque los «avanzados»y «reaccionarios» hoy se llamen de otra manera o hayan desaparecido como tales, mas el fondo de la polémica se resiste a desaparecer del todo. Bastaría un repaso somero a libros, artículos de revistas especializadas o de prensa diaria para comprobar que, en lo concerniente a la construcción del Estado, de la Nación, o de ambos, hay un resurgir del debate en el que hoy «contienden» García de Cortázar o Álvarez Junco o Santos Juliá, por mencionar algunos de los actores principales, acompañados circunstancialmente de otros. ${ }^{73}$ En la entrevista concedida al diario El Pais que llevaba como titular, «Una nación no nace, se hace», realizaba Álvarez Junco la siguiente afirmación que muestra entre líneas que hablamos aún de un debate no cerrado, al tiempo que se posicionaba en el estado actual del debate: «El hecho de que una identidad sea sobre todo cultural, y no natural, no quiere decir que sea un invento arbitrario. En el terreno de las naciones no se puede predicar el todo vale. Construir un proyecto nacional que tenga posibilidades de éxito entre el público requiere, como mínimo, hacerlo sobre rasgos culturales preexistentes y creíbles». ${ }^{74}$ Tomás Pérez Vejo, en un artículo titulado «Un proyecto para España», había ido más lejos al afirmar lo siguiente: «Sin embargo -consecuencia de las dificultades objetivas o de la indigencia nacional de las élites que hicieron la Transición, poco importa-, el régimen político nacido de la Constitución de 1978 abandonó casi por completo cualquier proyecto de construcción nacional e hizo suyo el relato de una nación española a la defensiva, laminada entre proyectos de tipo

72 Prescindo aquí del cruce efectuado entre Laín Entralgo y Calvo Serer en 1949 tras la publicación por parte del primero de España como problema y respondido enseguida por el catedrático de Historia de Filosofía española y Filosofía de la Historia con el libro España sin problema. Más allá de las posiciones de cada uno en aquellos momentos, que luego Laín fue matizando en prólogos y epílogos en sucesivas ediciones, lo interesante fue, por una parte, la utilización de la polémica y el carácter "problemático» de la cultura española para confrontar dos posiciones de la España de posguerra con la ciencia, la religión y la historia como referentes; y, por otra, la apuesta de Laín por favorecer los estudios de historia de la ciencia como forma de superar un problema no insoluble, según su juicio. Cuando José María López Pińero publicó en 1969 La introducción de la ciencia moderna en España (Barcelona, Ariel), se abrió definitivamente una importante línea que ha corregido en buena medida ese desconocimiento de la historia de la ciencia en Espańa de quienes Laín llamaba «avanzados» y «reaccionarios». A ello nos referíamos en la nota 70.

73 J. Álvarez Junco, Dioses útiles, Barcelona, Galaxia Gutenberg, 2016.

74 El Pais, Suplemento Babelia, 16-4-2016, p. 3. 
centrífugo y un horizonte europeo que se ofrecía como solución pero no como proyecto nacional propio. El resultado: un acelerado proceso de desnacionalización de España y de nacionalización de sujetos políticos alternativos». ${ }^{75}$

Por no incidir demasiado en una sobreabundancia de ejemplos que los hay, valga este último como cierre. Se trata de un artículo firmado por José María Ruiz Soroa titulado «España, ¿̇un país chapucero?» que se cierra con el siguiente párrafo:

Quizá convendría volver los ojos a nuestra historia previa al franquismo y comprobar que la autoestima nacional española ha sido siempre bastante baja para nuestras élites culturales y politicas siempre morbosamente acomplejadas ante Europa. Que el escándalo que provocó en ellas la leyenda negra, en un momento, o la Enciclopedia de Masson de Morvilliers en otro, son sintomáticos precisamente de esa inseguridad. ${ }^{76}$

Ruiz Soroa concluye que lo que sucede es tal vez que esas élites carecen de un proyecto político para Espańa.

A cualquier lector atento de los ya centenarios textos de la polémica le resonarán, actualizados, argumentos y estilo. En este estado anímico colectivo no sorprende que las conferencias de científicos metidos a historiadores enfaticen, con buen manejo de la retórica y dotes de persuasión, que habría sido una nueva generación, la de quienes salieron al extranjero -desde los años setenta- la que, ipor fin!, habría consolidado la actividad científica en España. Atrás habrían quedado Unamuno y su casticismo y, por supuesto, todo el siglo xix y la historia entera de España. Si acaso algún héroe: Santiago Ramón y Cajal y luego ya los modernos: Severo Ochoa y los más actuales...

Es indudable el gran progreso de las últimas décadas en el desarrollo científico y técnico en todos los campos (contra los hechos no hay otros argumentos), mas esto no impide que comprobemos una cierta ingenuidad y simplificación cuando de hacer historia se trata y eso tiene que ver con los diagnósticos antes mencionados acerca de cómo ese progreso contribuye al proyecto político de una comunidad nacional en un marco internacional. También se muestra cómo las aportaciones de los historiadores de la ciencia (los auténticos) no se han incorporado suficientemente a los planes de estudio para la consecución de los objetivos que en este punto tiene principalmente el bachillerato. En el caso de la universidad deberíamos hablar de grandes desigualdades en su cultivo: al lado de grupos muy importantes, notables vacíos de lo que dejamos constancia en el trabajo citado en la nota 70 .

75 El Pais, 17-6-2015, p. 12.

76 El Pais, 16-4-2016, p. 12. Las cursivas de ambos textos son mías. 
Con la filosofía, me parece, la situación es más compleja pues no sabemos muy bien qué hacer con ella. Es verdad que se han desarrollado mucho los estudios sobre el exilio en los últimos ańos, tratando de reconstruir los puentes dinamitados - nunca mejor dicho- pero aún andamos en tanteos para saber dónde reubicar a los más importantes de los filósofos exiliados y dónde situar a la propia filosofía en ese mismo proyecto. De eso iba también el contenido de la polémica decimonónica a propósito de la ubicación de la filosofía y de su contribución a la construcción del Estado y la nación. Un fracaso arrastraba al otro. Y ahora mismo una de las dimensiones de la crisis de la filosofía está directamente relacionada con este punto. Lógicamente hay otras dimensiones que deben ser enfocadas desde el análisis de componentes complejos de un mundo globalizado y regido con una orientación tecnocientífica.

En este discurrir de la vieja polémica no ha faltado la publicación de un libro interesante: La sombra de la leyenda negra. ${ }^{77}$ Una de las sensaciones que plantea este libro consiste en mostrar la dificultad de pertenecer a la realidad social y política relatada en los textos de la «leyenda», con lo cual uno se puede sentir víctima que necesita defenderse o, por el contrario, como «élites» estudiosas de esos mismos textos, ser críticos con los mismos al mostrar la falsedad o mitificación de la propia realidad. De la posición que se adopte se derivan consecuencias en cada plano de la escala social, bien sea del conocimiento mismo, bien del ámbito político. $\mathrm{Si}$, por ejemplo, uno se siente víctima, puede sufrir de baja autoestima como miembro de una colectividad incapaz de producir ciencia, filosofía y los más altos saberes o puede, por el contrario, desarrollar un fuerte sentimiento nacionalista, al sentirse agredido por extranjeros. Actitudes ambas muy negativas para asentar la sociabilidad tanto hacia adentro como hacia fuera sobre bases realistas y razonables. Si uno se considera formando parte de la élite y está convencido de que es verdad lo sostenido por esos juicios sobre la insuficiencia de nuestra historia, aunque sea parcialmente, habrá de probar cómo él mismo ha llegado a ser una excepción y desarrollar una campaña de corrección de la ignorancia, la apatía y la intransigencia por medio de la enseńanza, similar a las metas que se fijaron las universidades populares que surgieron a comienzos del siglo xx para formar a la clase obrera.

No es fácil salir de ese círculo, tal como indica Juan Pimentel en el capítulo «Del peso del aire y las disciplinas invisibles. La polémica de la ciencia española como narrativa de una modernidad elusiva». Lo interesante del mismo consiste en mostrar cómo, a pesar de la investigación realizada,

77 M. ${ }^{a}$ J. Villaverde y F. Castilla Urbano, La sombra de la leyenda negra, Madrid, Tecnos, 2016. 
algunos tópicos mantienen su resistencia al cambio, incluso entre las élites. Los 140 años transcurridos desde la famosa polémica y el estado en que se hallan los debates de los que hemos presentado algunas muestras, así lo testifican. Dicho con palabras de Juan Pimentel:

Es decir, aunque en España hubo ciencia, aunque en España hubo Luces, cuestionarlo o proclamar su endeblez ha formado parte de las letanías de esa modernidad elusiva, marginal o insuficiente, como formuló Subirats. Esto obedece a dos hechos muy relacionados. España suele ocupar un lugar también excéntrico en los relatos sobre quiénes y cómo llegaron a ser modernos. Por otro, nos guste o no, somos un país que tiende a desconfiar de su pasado (...) La polémica de la ciencia española, en este sentido, es una cuestión tan vaporosa como irresoluble (...) Esta es, pues, también la historia de cómo los centros lograron serlo, de dónde se ubicó a España en este relato y también de cómo los españoles hemos situado fragmentos de nuestra cultura en lugares excéntricos o marginales de nuestro pasado. ${ }^{78}$

Claro que algo puede ser vaporoso pero no por ello dejar de ser importante; tan solo exige conocer las herramientas con que afrontarlo.

Precisamente, al asunto de fijar las herramientas con que construir un Estado legítimo y autónomo dedicó su tiempo y su saber de jurista, de tan sólida formación histórica como conocedor de las constituciones modernas, durante la primera parte de 1876, Gumersindo de Azcárate (1840-1917), leonés de nacimiento e incorporado al «núcleo krausista madrileńo», tras su paso por la capital asturiana. ${ }^{79}$ Precedió en su viaje a Madrid a personalidades como el propio Francisco Giner y Benito Pérez Galdós que lo harían a comienzos de los sesenta. Con ambos estaría muy relacionado; con el primero, por la coincidencia en la formación jurídica y por ser amigos entrañables de por vida; con el segundo, porque el escritor canario fue director de la Revista de España desde febrero de 1872 a noviembre de 1873 y por el tiempo en que Azcárate publicara en esa revista sus artículos «El selfgovernment y la monarquía doctrinaria» (1876), el cuarto de los cuales daría pie a la polémica de la ciencia, el novelista canario hacía lo propio con su Doña Perfecta. ${ }^{80}$

78 J. Pimentel, «Del peso del aire y las disciplinas invisibles. La polémica de la ciencia española como narrativa de una modernidad elusiva», en Villaverde y Castilla, Op. cit., pp. 425-451, en p. 427.

79 La expresión, al igual que los datos biográficos aquí señalados, están tomados de G. Capellán, Gumersindo de Azcárate. Biografía intelectual, Valladolid, Junta de Castilla y León, 2005, p. 24.

80 Fundada por José Luis Albareda en 1868, - un año antes había fundado El Debate (1867) - la Revista de España tuvo una vida bastante larga, hasta 1895. Ambas de tono 
Aún tendría tiempo de ser su abogado en los problemas que el novelista tuvo con los derechos de propiedad de sus obras. Son detalles que no deben pasar inadvertidos pues nos dan cuenta de las amplias y complejas preocupaciones del momento que luego se verían reducidas intencionadamente por la intervención de Laverde.

Después de realizar estudios de Derecho y de Filosofía y Letras -la filosofía fue su vocación real con la corrección de la formación histórica- y el desempeño de actividades de carácter administrativo, llegó a la cátedra de Legislación Comparada de la Universidad Central en 1873. Tiempos conflictivos tras la marcha de Amadeo de Saboya y la instauración de la República a cuyo frente estuvieron personas de su círculo. Mas pronto todo cambió con estrépito: la disolución de las Cortes a comienzos de 1874 y la imposición del rey Borbón Alfonso XII, a finales de ese año, con el pronunciamiento de Martínez Campos, dio paso a la llamada Restauración. A principios de 1875 algunos de los reconocidos catedráticos, como el propio Gumersindo de Azcárate junto a Francisco Giner y Nicolás Salmerón, estaban camino de sus respectivos lugares de destierro. Con fecha 4 de mayo de 1875 recibía Azcárate el pliego de cargos firmado por el rector Vicente de la Fuente cuyo punto segundo decía textualmente: «Que el catedrático señor Azcárate se alza en abierta rebelión contra la Iglesia Católica y la monarquía» para añadir en el tercero que «El catedrático Gumersindo de Azcárate ratifica más esta rebelión, y desobediencia abierta al Gobierno diciendo que, no pudiendo en conciencia atemperarse a disposiciones cuya legalidad dudosa respecto de unas, es manifiesta respecto de otras y que son incompatibles con la dignidad de la ciencia y con la del Profesorado público, continuará dirigiéndose como hasta aquí, en el desempeño de su ministerio, por los principios que le dicte su conciencia». Ya desde Cáceres y con fecha 12 de mayo envió al rector de la Universidad de Madrid una «Contestación

bastante conservador, mas de orientación británica, una línea muy afín al pensamiento de Gumersindo de Azcárate tanto por sus convicciones ideológicas, sustentadas en sus ideas constitucionalistas, como por su admiración por las «buenas formas» aprendidas en el contacto con la familia Innerarity a la que perteneció su esposa, de corta vida.

No fue casualidad que el propio Laverde se dirigiera a Galdós cuando éste dirigía la Revista de España solicitándole que publicara los once artículos de Donoso Cortés publicados previamente en El Correo Nacional (1838) bajo el título «Filosofía de la Historia. Juan Francisco Vico» así como otros tres titulados "Consideraciones sobre el cristianismo». Galdós habría aceptado la propuesta con la condición de que fuera el propio Laverde quien escribiera una introducción y eso debió frenar el proyecto. Ver: J. L. Mora García, «Galdós, la filosofía y los filósofos», en Y. Arencibia y A. Bahamonde (eds.), Galdós en su tiempo, Cabildo de Gran Canaria, 2006, pp. 71-109. Sobre la postura que adoptó Pérez Galdós ante la "polémica», ver J. L. Mora García, «Un testigo atento de la polémica: el novelista Pérez Galdós», en R. Mandado y G. Bolado (eds.), "La ciencia española». Estudios, Santander, Ediciones de la Universidad de Cantabria, 2011, pp. 55-80. 
al pliego de cargos» muy detallada y pormenorizada exponiendo los fundamentos de Derecho sobre la libertad de cátedra, que concluían con la afirmación tajante y en cursiva: "Niego resueltamente que me haya alzado en abierta rebelión contra la Iglesia católica ni contra la monarquía constitucionalı. ${ }^{81}$ A finales de junio de 1876 estaba proclamada la nueva constitución, asentada la monarquía doctrinaria e implantado de nuevo el catolicismo como religión de Estado, aunque fuera con ligeros matices. Y casi por esas mismas fechas estaba fundada la Institución Libre de Enseńanza y nombrada la primera Junta Directiva en la cual Gumersindo de Azcárate figuraba como uno de sus consiliarios y, tras su nombre, los cargos que había tenido: «Ex Director General de Registros Civil, de la Propiedad y del Notariado; Catedrático que ha sido de la Universidad de Madrid». Quedaba así constituida una institución cuya vida se prolongaría hasta 1936, base de la renovación pedagógica e impulsora de la actividad científica, sobre todo desde los comienzos del siglo xx, nacida de la crisis del liberalismo en los términos que en su día expuso José María Jover:

Que la realidad de la situación histórica en que hubieron de insertarse los acontecimientos de 1873 fuera una cosa - una cosa muy compleja-y otra muy distinta la imagen estereotipada que de aquellos hechos fue instalándose en la conciencia histórica de las generaciones posteriores, constituía una discordancia que no podía dejar de plantear un desafío a la vocación investigadora de cualquier investigador. Ahora bien, cuando hablo de discordancia entre la realidad y el mito no quiero decir que todo en este último fuera una falsedad histórica; una invención de políticos, historiadores y literatos. Lo que ocurrió fue que políticos, literatos e historiadores desconocieron, por lo general, el conjunto de la situación histórica, bien compleja, por cierto y solo recientemente reconstruida por la historiografía, que prestó contexto a la trama eventual de la Primera República; seleccionaron, en función de su propio entorno cultural, ideológico o político, un determinado repertorio de eventos, haciendo recaer sobre ellos una carga valorativa frecuentemente apasionada; acuñaron, en fin, un cliché sometido a variaciones en el transcurso de generaciones sucesivas, pero dotado de una enorme capacidad de difusión y arraigo en razón de su misma simplicidad. ${ }^{82}$

81 Textos recogidos en A. Jiménez Landi, La Institución Libre de Enseñanza y su ambiente, I, Madrid, Ministerio de Educación y Cultura/UCM/UB/UCL, 1996, pp. 499 y 504.

82 J. M. Jover Zamora, Realidad y mito de la Primera República. Del «Gran Miedo» meridional a la utopía de Galdós, Madrid, Austral, 1991, pp. 35-36. Publicado inicialmente con el título La imagen de la Primera República en la España de la Restauración, fue el texto de su ingreso en la real Academia de la Historia (marzo de 1982). Añade, muy significativamente, en esta edición un capítulo largo sobre Manuel de la Revilla: «Manuel de la Revilla, profeta del positivismo político»; además, «La esterilidad del contenido utópico 
Cita un poco larga pero necesaria por ofrecer algunas claves que nos permiten ver las consecuencias que tuvo simplificar la complejidad: fundamentalmente haber perdido una magnífica ocasión para teorizar sobre el Estado desde bases históricas, jurídicas y filosóficas. Según Jover, hubo de ser la literatura tardía de Galdós, ya en el siglo xx, la que tratara de recoger los frutos tardíos del Sexenio. Mas la literatura, importante o hasta imprescindible como forma de conocimiento, tiene sus limitaciones en esta tarea, como el siglo y medio transcurrido desde entonces ha mostrado, según lo expuesto en la primera parte de este estudio. Lo mismo sucede con la educación -la pedagogía y su acción sobre la persona social-, tanto de las élites como de las clases populares, emprendida por la ILE progresivamente, que fue una tarea imprescindible también, pero, igualmente, insuficiente.

Se me escapa la razón por la cual Jover omitió las muchas páginas escritas por Azcárate que iban dirigidas al núcleo mismo de la construcción del Estado y del lugar que la ciencia y la filosofía deben ocupar en esa tarea y que hoy nos resultan claves en este proceso por su contenido, aunque el protagonismo en la polémica lo adquiriera a su pesar. En Azcárate hay una propuesta muy detallada de cómo debe ser el Estado tal como ahora indicaremos.

Por ello, todavía tuvo tiempo para ser elegido y ejercer muy activamente como presidente de la Sección 1a: la de Ciencias Morales y Políticas del Ateneo de Madrid, al tiempo que José Moreno Nieto, exdecano de la Facultad de Derecho de la Universidad Central de Madrid era elegido presidente de la institución (en las elecciones convocadas para el 31 de diciembre de 1875) y sería diputado en las próximas elecciones de enero de $1876 .{ }^{83}$ No solo no era menor esta tarea sino todo lo contrario. En esta sección de Ciencias Morales y Políticas, Gumersindo de Azcárate desarrolló una intensa labor dirigiendo el debate acerca de «si el actual movimiento de las ciencias naturales y filosóficas en sentido positivista constituye un grave peligro para los grandes principios morales, sociales y religiosos en que descansa la civilización». ${ }^{84}$ Si en la Revista de España se había ocupado, como indicábamos,

del 73» es puesta al lado de Menéndez Pelayo: «La cristalización del mito: El veredicto de Menéndez Pelayo» y «Balance de una década de ideocracia».

83 V. Olmos, Ágora de la libertad, I: 1820-1923, Madrid, La Esfera de los Libros, 2015, pp. 271-272. No así Azcárate, que fracasó en el intento de serlo por Léon.

84 G. Azcárate, «El positivismo y la civilización», Revista Contemporánea, IV, 30-61876, p. 230 (pp. 230-250). Es el primero de dos largos artículos sobre esta cuestión. El segundo se publicó el 30-7-1876, pp. 465-489. Con anterioridad ya había publicado el discurso titulado, "El positivismo en el Ateneo de Madrid», como resumen de la discusión 
de señalar las bases teóricas en los planos natural, jurídico y político que deben dar solidez y legitimidad al Estado, dedicó las páginas de la Revista Contemporánea, fundada por José del Perojo el año anterior y convertida en órgano de difusión de las ideas kantianas y de los avances manifestados por las ciencias naturales tras la corrección idealista que la burguesía había introducido a comienzos de la década, a ubicar la ciencia y la filosofía como saberes constitutivos del propio Estado, que ni podía renunciar a la eficacia ni al sentido, pues la vida exige ambos. ${ }^{85}$ Esta idea de la eficacia más el sentido está muy presente en los pensadores y escritores de este grupo.

Quedaba el tercer pivote sobre el que asentar la vida individual tanto como la social desde la tolerancia y la convivencia: la religión. Pues en esta ocupación anduvo durante el mismo año de 1876 Gumersindo de Azcárate. Conocemos todos los detalles de la publicación de la Minuta de un testamento, aparecida en el verano de 1876 (bien llamativa es la coincidencia de fechas de todas las publicaciones que llevamos apuntadas) bajo pseudónimo, gracias a la edición de Elías Díaz. ${ }^{86}$ Era la propuesta de una religión propia del cristianismo liberal, defensora del espíritu evangélico, conciliadora con el liberalismo político y la racionalidad científica.

Cerraba así Gumersindo de Azcárate su diagnóstico sobre la Revolución del 68, la Constitución de 1869 y el sexenio, que habían suscitado tanta esperanza como sensación de fracaso produjo el violento final de la Primera República. Crisis del Estado y de la nación, crisis de la universidad y del saber, crisis del liberalismo como base del estado moderno. Gumersindo hizo una propuesta casi exhaustiva desde los presupuestos del racionalismo jurídico sobre la base de la legislación comparada, desde una posición bastante moderada en la aceptación del positivismo científico y sobre la base de la armonía de la religión con el saber moderno y el respeto a la libertad de conciencia.

Sería imposible realizar aquí un estudio detallado de cada uno de los campos. Solo sus artículos de la Revista de España ocupan más de 200 páginas, obra enjundiosa cuya finalidad queda expresada mejor que en otro

sobre este tema. Revista Contemporánea, III, mayo 1876, pp. 350-367. En total más de setenta páginas de formato folio.

85 Véase D. Núñez, La mentalidad positiva en España, Madrid, Ediciones de la Universidad Autónoma de Madrid, 1987 (primera ed. en Tucar, 1975); A. González de Linares, Obra completa. Edición y estudio preliminar de Carlos Nieto, Santander, Ed. de la Universidad de Cantabria, 2014.

86 G. Azcárate, Minuta de un testamento. Estudio preliminar de Elías Díaz, Madrid, Ed. de Cultura Popular, 1967. En total, unas 180 páginas. 
lugar en el prólogo que puso a la edición en libro de los ocho capítulos que trascriben los artículos publicados un año antes en la Revista bien que ahora con títulos propios: ${ }^{87}$

Haremos notar que nuestro propósito no era otro que procurar poner de manifiesto la incompatibilidad de la Monarquía doctrinaria con el principio del self-goverment, admitido casi sin contradicción en la esfera de la ciencia, reconocido como base esencial de la organización del Estado en los pueblos que a la par son libres y viven en paz, y meta a que se dirigen aquellos otros que todavía no han hallado un equilibrio estable en este siglo de crisis y de revolución. ${ }^{88}$

Azcárate no dejaba de recordar, a continuación, las dificultades que planteaba la "cuestión religiosa, que con razón preocupa hoy a todos los que presencian temerosos y desconfiados las aspiraciones de la teocracia, deseosa de recobrar el poder que seguramente ha perdido para siempre»; ni la «cuestión social, que ciertos partidos y determinadas clases se esfuerzan por confundir e identificar con algunas de sus manifestaciones»; ni, finalmente, «la cuestión jurídica relativa a los derechos de la personalidad, de los cuales unos son a la vez civiles y políticos, como la libertad de prensa y de asociación y reunión, y otros como los de conciencia y de cultos, tan trascendentales que respetarlos es respetar la civilización y desconocerlos es alejarse de ella». En definitiva, lo que trató de fijar Azcárate en estos artículos fueron las bases de un Estado moderno, ni cesarista ni doctrinario sino basado en el autogobierno y la soberanía nacional. Se mostró moderado al afrontar la cuestión de si monarquía o república y no desechó aquella siempre que admitiera los principios antes señalados. Y lo hacía sobre bases tomadas de la filosofía política, jurídica y antropológica con referencias a la historia, pero sin sacralizarla, y al derecho comparado con los países europeos más próximos: Inglaterra, Francia e Italia, principalmente el primero, que le parecía el más sólido y, por tanto, el que mejor garantizaba la paz y el orden. Y esto era lo fundamental.

Mas, como señala Jorge Novella en su bien claro, útil y completo estudio para fijar la cronología y los contenidos de la polémica, «Menéndez Pelayo

87 Fueron publicados en los números 190 (pp. 145-167), 191 (pp. 289-307), 193 (pp. 35-52), 194 (pp. 145-166), 202 (pp. 145-169), 204 (pp. 461-488), 205 (pp. 5-26) у 206 (pp. 145-165). Están disponibles en formato digital en la Biblioteca Nacional de España. En el n. ${ }^{\circ} 208$ se publicó «Influencia del principio democrático sobre el derecho privado», pp. 448-474. Se publicó como libro: El self-goverment y la Monarquía doctrinaria, Madrid, Librería de A. San Martín, 1877. Disponible en formato digital en la Biblioteca Digital de la Universidad de Sevilla.

88 Ibid., p. VI. 
y la polémica de la ciencia española»: «nunca estuvo en su ánimo plantear esta polémica, sus afirmaciones se han descontextualizado y fueron llevadas a un debate de confrontación ideológica, que no tiene nada que ver con él». ${ }^{89}$ Se apoya, aunque con matices, en la opinión sostenida ya por Gonzalo Capellán, quien trató de responder a las preguntas que él mismo se formuló al acercarse a esta cuestión: «ppor qué Azcárate escribe lo que escribe en su texto? ¿por qué ese texto suscita una respuesta tan intensa y agresiva? ¿por qué Azcárate se retira de la polémica tan pronto o la ignora por completo?» ${ }^{90}$

En realidad, Azcárate se limitó a reafirmar, como adelantábamos, sus posiciones liberales desde la experiencia de la política isabelina, las esperanzas puestas en la constitución del 69, la experiencia del fracaso y, podríamos añadir, anticipando la crítica a la Constitución de 1876, que sería aprobada casi al tiempo que finalizaba la publicación de sus artículos. La reedición de estos textos, al año siguiente, adquiría, pues, mucho sentido. ${ }^{91}$ Lo que había era un distanciamiento, cuando no una ruptura, entre liberales de orientación institucionista y los sectores afines al catolicismo, acerca del modelo de Estado y, en vez de dirimirlo abiertamente, se optó por una salida oblicua que mezcló dos o más debates: el del propio Estado con los temas anexos que esto conlleva, el lugar de la filosofía respecto del mismo, la posición que corresponde a la religión y a la iglesia con ecos de viejos y nuevos conflictos entre la propia filosofía racional, incluida la más próxima a las ciencias empíricas, y la teológica. Al fondo estaba aún el Viejo Régimen, las más próximas disposiciones del concilio Vaticano I y las cuestiones relativas a la libertad de conciencia, etc. (Recuérdese que la traducción de Arcimís del libro de Draper Historia de los conflictos entre la religión y la ciencia también es de 1876).

89 J. Novella, «Menéndez Pelayo y la polémica de la ciencia española», en P. Calafate y J. L. Mora (eds.), Filosofía y literatura en la península ibérica. Respuestas a la crisis finisecular, Madrid, Fundación Ignacio Larramendi/Centro de Filosofía de la Universidad de Lisboa/ Asociación de Hispanismo Filosófico, 2012, pp. 107-121.

90 G. Capellán, «Entre «españolismo» y «extranjerismo». El origen de la polémica sobre la ciencia espańola», en G. Capellán de Miguel y X. Agenjo (eds.), Hacia un inventario de la ciencia española, Actas de las IV Jornadas de Hispanismo Filosófico, Santander, Asociación de Hispanismo Filosófico/Sociedad Menéndez Pelayo, 2000, pp. 159-171. Puede verse una versión más completa de su análisis en "Gumersindo de Azcárate», Op. cit, pp. 108-120. Una opinión similar sostiene Pedro Ribas en su artículo «José del Perojo (1950?-1908)», en Mandado y Bolado (eds.), Op. cit., pp. 37-54.

91 Para un estudio del pensamiento político de Azcárate me remito al «Estudio preliminar», en la Minuta de un testamento, realizado por Elías Díaz, ya citado. Y para una actualización del mismo, me remito a los estudios que contiene el vol. I de F. Moreno Luzón y Fernando Martínez (eds.), La Institución Libre de Enseñanza y Francisco Giner de los Ríos: nuevas perspectivas, Madrid, Fundación Francisco Giner de los Ríos/Acción Cultural Española, 2012. 
Así pues, cuando Gumersindo Laverde entresaca esas apenas cuatro líneas de un larguísimo párrafo que llena una página entera del cuarto de los artículos, con muchos matices y donde se compara la evolución de varios países, hizo un flaco favor al fondo del problema -merecedor de otro debate- y prestó poca ayuda al joven Marcelino Menéndez Pelayo, que se vio obligado a utilizar los conocimientos que tenía a mano pertenecientes al campo histórico y filosófico pero no al jurídico. Ampliamos un poco el párrafo citado por Laverde para que se compruebe de qué hablaba Azcárate:

Un pueblo tiene, como solemos decir, una fisonomía, un modo de ser, una constitución interna, que se revela en todo cuanto hace y que informa su vida religiosa, científica, económica, moral, etc., dándole un carácter propio, dentro siempre de las condiciones comunes a toda sociedad humana. Claro es que lejos de ser indiferentes a esta Constitución social las bases de la jurídica, puede esta facilitar o estorbar el libre desarrollo de aquella. Según que, por ejemplo, el Estado ampare o niegue la libertad de la ciencia, asi la energía de un pueblo mostrará más o menos su peculiar genialidad en este orden, y podrá hasta darse el caso de que se ahogue casi por completo su actividad como ha sucedido en España durante tres siglos. Pues aun cuando el derecho dé las condiciones necesarias para el desenvolvimiento de la vida social, ésta se determina por sí y reviste un carácter propio en virtud de una actividad que es independiente de la del Estado. ${ }^{92}$

Azcárate completaba el párrafo con algunas alusiones a lo sucedido en Inglaterra, Alemania y Portugal. Aceptada la falta de matizaciones en su afirmación sobre España, que deberían remitirnos a un estudio, por ejemplo, sobre el papel de la Inquisición y sus planos de intervención, si se lee con detenimiento todo el artículo (y todos los artículos), Azcárate reconoce a la sociedad, por tanto también a la española, un "carácter propio» que le permite sobreponerse incluso al Estado. ${ }^{93}$ Con seguridad, Azcárate reconocía como propios los nombres que Menéndez Pelayo le puso sobre el papel en las contestaciones sucesivas. Mas se trataba de construir un Estado que potenciara ese «carácter propio» en orden a la consecución de los fines para los que el hombre ha sido creado y a los que Azcárate desarrolla en otro lugar.

92 «El selfgovernment y la monarquía doctrinaria», Revista de España, 1876, n. ${ }^{\circ} 194$, p. 149. Por cierto, a diferencia de otros que aparecen firmados en Cáceres en los meses de primavera de 1875, este lo firma en Madrid, febrero, 1876.

93 Además del libro clásico de H. Kamen, La Inquisición española, Barcelona, Crítica, 1988 ( $3^{\text {a }}$ ed.), me parecen muy útiles, para la cuestión aquí planteada, los capítulos 3 y 4 («Procesos de reforma y confesionalización» e "Ilustración e Inquisición») del libro de Martínez Millán, J., La Inquisición española, Madrid, Alianza, 2007. 
Y este fue uno de los puntos que permaneció oscuro durante la polémica, al igual que la atención al concepto defendido por Azcárate sobre el carácter propio de una sociedad, bien problemático por cierto, que remite a las relaciones entre la filosofía y la historia y derivó hacia la teoría del carácter de los pueblos de no feliz recuerdo.

Los contendientes -en este caso los que sustituyeron a Azcárate más el propio Menéndez Pelayo- ofrecieron en la polémica un peso específico a la filosofía y a la historia. Pero cada uno comenzaba la relación con la otra parte, bien apoyándose en la filosofía-los pensadores provenientes del racionalismo-, bien haciéndolo en la historia como el caso de Menéndez Pelayo. Las consecuencias que se derivaban de esta cuestión eran y son, de gran importancia, pero la cuestión de fondo quedó bloqueada o, al menos, oscurecida al ser puesta al servicio de los fines que cada uno perseguía. Fijar con precisión las relaciones de la filosofía con la historia, incluida la suya propia (es decir de la propia historia de la filosofía), sí que hubiera supuesto una aportación de gran valía para la filosofía, para la historia y para la construcción del Estado en España. Al quedar sin resolver entonces (el artículo de Zambrano señalado más arriba es una muestra de esto y hablamos ya de 1948) y que no lo esté suficientemente aún en nuestro tiempo, como apuntábamos al comienzo, a pesar de haberse avanzado, la raíz de la polémica sigue pendiente.

Si en vez de derivar hacia la apologética se hubieran abordado honestamente las cuestiones que los textos de Azcárate presentaban, los resultados, tanto en el plano político como en el epistemológico, y en el que ambos comparten un proceso de reciprocidad, hubieran sido bien positivos. Mas al plantearse en oblicuo, los principales puntos del debate quedaron sin ser incorporados, ni al estado ni a la filosofía española. Fue un debate transcurrido en líneas paralelas en el que quedaron el planteamiento teórico sobre el Estado, de un lado, y la aportación de la tradición histórica española, del otro. Eran valiosos por sí mismos, pero lo determinante era ponerlos en el mismo camino y cruzarlos. Quizá si a Menéndez Pelayo le hubiera llegado la ocasión de polemizar con Azcárate hacia los 90 (cuando madura su Historia de las ideas estéticas), en años próximo a la fecha en que respondió a Benito Pérez Galdós en su discurso de ingreso en la Real Academia de la Lengua (febrero de 1897), con la digestión hecha del «Epílogo» a la Historia de los heterodoxos españoles (1882) los resultados hubieran sido mucho más positivos. ${ }^{94}$

94 Sobre estas cuestiones se ofrecieron importantes aportaciones en el Congreso del Centenario: R. Mandado (ed.), Menéndez Pelayo. Cien años después. Actas del Congreso Internacional, Santander UIMP, 2012. También G. Bolado, Menéndez Pelayo y los historiadores cántabros del pensamiento español, Santander, Ed. Tantín, 2015. Principalmente los cuatro 
Aunque la polémica se extiende hasta la primavera de 1877 con las réplicas de Perojo y del propio Menéndez Pelayo (a la que no faltaron otras réplicas posteriores), Gumersindo de Azcárate escribe en la Revista Europea «Una carta sobre filosofía espańola» como respuesta a la mucho más larga escrita en el número anterior por Gumersindo Laverde, en verdad una arenga con fuerte sentido emocional y gran erudición a su discípulo, el joven Marcelino, a quien agradece su respuesta, sus conocimientos históricos pero, no menos, su valentía. ${ }^{95}$

En ella Azcárate trata de restaurar la memoria de su padre, mencionado por Laverde, desde su condición de hijo y lector de la Exposición histórico-crítica de los sistemas filosóficos modernos y verdaderos principios de ciencia, ${ }^{96}$ al incluirse entre quienes reconocen los méritos de la filosofía española del siglo XVı y señalar, nada más comenzar, lo siguiente:

En una [carta] que le dirigió hace tiempo el Sr. Menéndez Pelayo, y en otra por usted escrita, que acabo de leer en la Revista Europea, sale a plaza mi pobre nombre envuelto en una discusión sobre un tema doblemente importante, porque interesa a la ciencia y a la patria ${ }^{97}$... [Para añadir más adelante] y callé, sobre todo, porque se trataba de las glorias de la patria, y me repugnaba un poco aparecer como disputándolas a esta.

Después vendrían las aclaraciones sobre el significado del libro de su padre con la afirmación que hace suya: «Queremos una filosofía, porque somos hombres; una filosofía para nuestro siglo porque es en el XIX y no en el XVI en el que vivimos; una filosofía apropiada a nuestro país, porque somos espańoles». Y le apostillaba: «Ahí tiene usted, amigo mío, frases y expresiones que parecen escritas por usted o por alguno de sus colaboradores». A continuación venían las

primeros capítulos en los que Bolado aborda la figura de Menéndez Pelayo «en su tiempo y en el nuestro» $\mathrm{y}$ «las verdades de la tradición».

95 La carta de Azcárate figura firmada en Madrid, 30 de octubre de 1876, Revista Europea, n. ${ }^{\circ}$ 141, 5-11-1876, pp. 592-594. La de Laverde en "Prólogo de un libro sobre la filosofía española», 29-10-1876, Revista Europea, n. ${ }^{\circ}$ 140, pp. 553-561. Está firmada en Lugo, septiembre de 1876. Como es bien conocido, estaba ya pensada como Prólogo a la edición de La ciencia española en forma de libro: M. Menéndez Pelayo, La ciencia española (Polémicas, proyectos y bibliografia). Con Prólogo de Gumersindo Laverde Ruiz, 3 tomos, Madrid, Imprenta de A. Pérez Dubrull, 1887. Es la primera edición en tres tomos, al incorporar textos de sucesivos ecos de aquel 1876, ya que las dos primeras lo eran en un solo tomo.

96 Editada en cuatro volúmenes. Madrid, F. Mellado, 1861. Puede consultarse, en el proyecto «Filosofía en español», incluida la referencia de Federico de Castro a la que alude Azcárate en su respuesta a Laverde para desmontar la supuesta falta de patriotismo de los krausistas.

97 Revista Europea, n. ${ }^{\circ}$ 141, p. 592. Las cursivas pertenecen al texto original. 
matizaciones sobre la bien famosa referencia a los tres siglos que había hecho en su texto de la Revista de España, ratificándose en la interrupción "por más de dos siglos,, lo que hace apoyándose también en su padre, el considerado por Laverde «ferviente panegirista» del siglo xv. La discrepancia estaba, pues, en cómo España no habría sabido salir del Antiguo Régimen, según Azcárate, por lo que era, para él, imprescindible la creación de un nuevo estado y una nueva filosofía.

Había sido un debate político y no menos -imposible hacerlo- un debate epistemológico, pero ambos habían quedado pervertidos respecto de su naturaleza intrínseca y de las relaciones entre ambos. Cuando se analizan ahora los textos, se advierte que a esta situación se llegó por los matices, o sea, por el orden en que se ponían los argumentos, que creaban una apariencia de mayor distancia de la realmente existente entre dos modelos conservadores del Estado: uno que pretendía heredar, o mantener, la vieja monarquía mientras el otro apostaba por un Estado liberal parlamentario -república con preferencia a monarquía sin exclusión tajante de esta- de corte británico al que era muy afecto Azcárate. No digo que no hubiera distancia, la había ciertamente, pero es difícil saber hasta dónde Marcelino Menéndez Pelayo la fijaba, en su fuero interno, con(tra) su «instigador» Laverde. Mas esto sería importante para fijar con mayor precisión el modelo político al que optaba y que, con seguridad, estaba próximo a la monarquía doctrinaria que rechazaba Azcárate. Y en esa frontera estarían las posiciones entre tradición: ¿se entendería sin más Viejo Régimen, trono y altar?; y modernidad: ¿`se diría liberalismo, librepensamiento y separación del poder y la iglesia? Es decir, ¿todo se habría concentrado en el lugar político que debía ocupar el credo católico? La historia de la filosofía (de los filósofos) habría sido periférica al problema aunque nos haya sido bien útil a los historiadores posteriores.

Pues esta conclusión no parece muy lejana de lo que sucedió en realidad. Cuando Laverde responde a esta carta de Azcárate: «Contestación del Sr. Gumersindo Laverde a la última réplica del Sr. Azcárate», ${ }^{98}$ no niega la decadencia de los estudios espańoles tras el siglo xvi:

... miradas las cosas en globo, nadie las niega. Fue grande en verdad, en verdad comparada con la altura a que anteriormente habíamos llegado; pero no tan absoluta, general y profunda como V. da a entender y yo mismo, con menos datos que ahora, ha algún tiempo creía. ${ }^{99}$

98 Este es el título con que aparece en la edición de La ciencia española, I, pp. 316-329. En la Revista Europea, 3-12-1876, n. ${ }^{\circ}$ 145, apareció con el título "La ciencia española», pp. 721-723. Firmado en Lugo, 9 de noviembre de 1876, se añade una nota al pie indicando que se publica con retraso "por haberse extraviado".

99 Ib., p. 722. 
Y, en cambio, tiene mucho cuidado en dejar claro, ahora con un tono amable, que las diferencias se centraban solo en el «credo católico», frente a su interlocutor calificado de «libre pensador». Al lado de esta afirmación aparece la referencia a la función de la Inquisición en la que habían situado buena parte de sus argumentos los representantes del racionalismo filosófico. La referencia a si esta filosofía moderna es tan rancia como las antiguas, tal como sostiene Laverde, es digna de consideración pero de tono menor en la polémica.

Se deduce de esta carta, pues, que el debate podía haber discurrido por otros cauces de no haberse concentrado tantas circunstancias en un año que terminó marcando el final del siglo XIX y, seguramente, todo el xx. Lo que realmente sucedió fue que se impuso una monarquía doctrinaria y que los catedráticos expulsados no se integraron hasta 1881 desplazando buena parte del debate filosófico y científico de la universidad a otras instancias, como el Ateneo, a las páginas de los periódicos, las novelas publicadas en folletones, etc. Y estas circunstancias no fueron positivas para la construcción del Estado porque se difería el debate a la periferia de las instituciones centrales como lo debe ser la universidad.

Precisamente hubo de ser el Ateneo donde se debatió sobre el positivismo. Y, como indicábamos anteriormente, Azcárate presidía estos debates sobre cuyos contenidos escribía, al tiempo que lo hacía sobre su modelo político: era preciso hacerlo sobre la "ciencia» y la "patria», por decirlo con sus palabras. Analizar con detalle los largos artículos de la Revista Contemporánea no tiene lugar aquí pues este aspecto desempeñó un discreto papel en la polémica aunque estuviera latente. Me remito al capítulo «Educación, cultura y ciencia» de la monografía de Gonzalo Capellán ya citada para un estudio detallado de la posición de Azcárate en este punto. Valgan como síntesis estos dos párrafos con que cierra su artículo «El positivismo en el Ateneo». El primero respondía a la pregunta, ¿qué significa hoy el positivismo?, formulada a modo de pregunta retórica para poder ofrecer una respuesta concisa:

... representa nuestra época en la historia el punto final de tres edades, cuyos elementos viven y se agitan en el seno de la sociedad moderna, y sobre todos ellos, viene otro nuevo que es la filosofía, a producir manifestaciones importantes y a indicar caminos desconocidos. ${ }^{100}$

El segundo lo hacía a las preguntas, "¿qué elementos sanos encierran las doctrinas positivistas?, ¿qué beneficios pueden producir a la causa de la verdad?». La respuesta dada fue esta:

100 G. Azcárate, «El positivismo...», Op. cit., p. 366. 
Preparar desde luego la conciliación entre la ciencia y la vida, a causa de la insensata separación que de ellas hace. Y, además, no serán perdidos sus adelantos para la ciencia (...) Lo que hace falta es que el positivismo entre por el ancho campo, que tras el fenómeno encuentre la esencia, y que no se oponga a la religión ni a la metafísica, porque la metafísica y la religión representan lo eterno y lo absoluto, que no puede morir ni a manos de las escuelas positivistas ni a manos de ninguna escuela. ${ }^{101}$

Me temo que este lenguaje le resultaba ajeno al joven Marcelino, historiador en ciernes por aquellos años, y cuya orientación se hallaba alejada de estas disquisiciones racionalistas. Menéndez Pelayo fue, desde estos jóvenes años, un historiador documentado, de archivo diríamos hoy, en cuyos datos asentaba la reflexión. Poco dado fue a la especulación racionalista, propia de la escuela krausista. Por aquí el entendimiento con sus interlocutores no era fácil. Sencillamente hablaban lenguajes diferentes.

Una referencia última a la cuestión religiosa que ocupó y polarizó casi todo el debate. Ya hicimos mención a la Minuta de un testamento, el credo que Azcárate contraponía a cualquier tentación de religión de Estado, un asunto que España arrastraba de sus constituciones, excepto la del 69. Su apuesta por el «cristianismo interior» de la vieja estirpe erasmista, con apenas soporte institucional y sin raíces históricas, levantó las sospechas de los historiadores católicos con Laverde y Menéndez Pelayo al frente. Una religión de la conciencia, de la sola conciencia, que favoreciera el librepensamiento, resultó sospechosa. La novela fue el vehículo por el que transcurrió buena parte del debate; un debate que se extiende desde Doña Perfecta (1876) hasta Misericordia (1897), ambas de Pérez Galdós, cuyo recorrido ha merecido muchos estudios. En el ámbito teórico hablamos del cristianismo liberal:

... punto de conjunción en que han venido a encontrarse la filosofía y la religión positiva, el teísmo racionalista y el cristianismo protestante, y que cuenta con numerosos adeptos en Suiza, Francia e Inglaterra, y más aún en los Estados norteamericanos, patria del ilustre Channing y de Parker. ${ }^{102}$

No fue casualidad que coincidieran en la misma revista el artículo de Azcárate que provocó la polémica con la primera entrega de la novela galdosiana. Ahí estaba el nudo de todo el debate: la ubicación del credo católico y de la iglesia en relación con el estado. Y ahí estaban las principales

$101 \mathrm{Ib}$., p. 367. En su artículo «El positivismo y la civilización», también mencionado, desarrolla estas afirmaciones con mayor detalle, pero sus tesis quedan aquí bien reflejadas: aceptación del positivismo metodológico, rechazo del positivismo doctrinal.

102 G. Azcárate, Minuta de un testamento, nota 47, p. 118. 
discrepancias: estado, filosofía, historia y religión eran los ingredientes que desataron una polémica de la que don Gumersindo de Azcárate fue su «instigador» involuntario, como han indicado los estudiosos de la misma y he tratado de resumir aquí.

A casi siglo y medio de aquel cruce de cartas y textos, casi una esgrima intelectual, el fondo del asunto no está plenamente bien cicatrizado, como hemos sugerido ya. A lo largo de este largo tiempo se han sucedido las réplicas, como acontece en los choques tectónicos en los que no quedan bien soldadas las placas, y ha terminado por convertirse en una atmósfera algo vaporosa, como señalaba Pimentel en su capítulo de La sombra de la leyenda negra, pues, efectivamente, todo quedó poco a poco confundido entre otras placas del debate: las que dirimían lo nacional y lo extranjero, si no lo estaban ya en origen. Las circunstancias del siglo xx no ayudaron nada, por no decir que terminaron por arruinar cualquier intento de superación; las desconfianzas hacia lo foráneo de una parte, hacia la propia historia de otra, han dificultado tanto la construcción de la propia nación (me remito a los textos mencionados al comienzo y que son bien recientes) como a la ubicación de la filosofía en esa construcción. No queremos decir con ello que los tiempos sean los mismos. Estamos en el siglo XXI y no en el XIX como recordaban a propósito de su propio tiempo y de los anteriores ellos mismos.

En el campo del conocimiento, la investigación sigue siendo la única herramienta útil, mas es preciso incorporar los resultados de la misma a la enseñanza, sobre todo a la secundaria, cuando, precisamente, se suprime la materia de Historia de la Filosofía. Sin un discurso (relato dicen algunos) suficientemente compartido por los estudiantes de la enseñanza obligatoria no hay posibilidad de construir nación alguna en un marco propio que excluya a los nacionalismos cerrados y a un internacionalismo vacío. Sin coordenadas históricas, sin acontecimientos históricos que surtan de sentido a un presente abierto a la altura de cada tiempo, el ser humano no puede realizar la dimensión social que constituye su misión. Cuando Zambrano hablaba de la necesaria continuidad y vigencia del Estado y de la Filosofía se refería a esto. Por ello recordaba a Menéndez Pelayo y a Pérez Galdós. Esa lección quedó a medias entonces. Mejor la completamos y la aprendemos. 


\section{La polémica de la ciencia en la Espańa de la Restauración (1876-1898). Los racionalistas de la Revista Contemporánea en la polémica: Manuel de la Revilla}

Dr. Fernando Hermida de Blas Universidad Autónoma de Madrid

$\mathrm{M}$ anuel de la Revilla Moreno, crítico, filósofo, poeta y periodista nacido en Madrid el 26 de octubre de 1846, inició sus estudios bajo la orientación de su padre, José de la Revilla Gironza, funcionario de la administración pública y promotor de la introducción en España de la filosofía krausista, quien lo formó en los principios del enciclopedismo francés.

Manuel de la Revilla se dedicó muy tempranamente, desde 1863, al ejercicio del periodismo. Sus primeras colaboraciones fueron en la prensa vinculada al republicanismo federalista y progresista, corriente ideológica a la que se adscribió en un principio. En 1866 obtuvo el grado de Licenciado en Derecho y en 1868 el de Licenciado en Filosofía y Letras, ambos por la Universidad Central.

Tras ocupar varios puestos docentes en el Instituto de Noviciado, en el Colegio Internacional y en la Universidad Central, en 1872 defendió en la Facultad de Filosofía y Letras su tesis doctoral titulada Lo cómico. Su concepto. Su relación con lo bello, lo feo y lo sublime. Sus manifestaciones en la realidad y en el arte. Su efecto en el espiritu del contemplador. Revilla no se aproxima al tema como un historiador de la estética, sino como un filósofo que especula sobre su sentido, sirviéndose de una selección de opiniones relevantes sobre el tema. 
Revilla simultaneó su vida académica con la actividad periodística y la práctica política. Amplió su labor periodística a publicaciones próximas al republicanismo unitario, donde promovió el entendimiento entre los diferentes sectores republicanos y criticó el extremismo revolucionario del liberalismo. El fracaso de sus propuestas le hizo virar hacia el republicanismo reformista, posibilista y conservador, al tiempo que se apartó de la política activa.

En los inicios de su formación, se vinculó a la filosofía idealista, principalmente al krausismo, aunque también hay en su pensamiento una veta netamente hegeliana. Sin embargo, pronto comenzó a abrirse a otras corrientes filosóficas y científicas más modernas, entre ellas las doctrinas naturalistas de Darwin, que defendió desde la tribuna del Ateneo de Madrid, donde ocupó diversos cargos de responsabilidad.

El 2 de diciembre de 1872 Revilla solicitó ser admitido en la oposición a la cátedra de Principios Generales de Literatura y Literatura Española de la Universidad Central, vacante por traslación de Francisco de Paula Canalejas Casas. La oposición se convirtió en un largo proceso de cuatro años del que se le intentó apartar por considerar que sus alegatos a favor del darwinismo eran contrarios a las enseñanzas de la Iglesia católica. Finalmente ganó la cátedra, de la que tomó posesión el 1 de agosto de 1876, si bien su nombramiento no se produjo hasta el 10 de septiembre de 1879 .

Revilla que fue un destacado poeta, recopiló parte de sus composiciones en el libro Dudas y tristezas (1875). El prólogo que Ramón de Campoamor puso a este volumen desató la "polémica del panentheismo", en la que intervinieron los defensores de la escuela krausista, sus detractores y quienes, como Revilla, se mantuvieron en una postura intermedia.

Fueron muchos sus trabajos como crítico en los campos de la literatura, la escena, la filosofía y la ciencia. Cabe destacar su labor en el diario El Globo, a partir de 1875, donde se encargó de las secciones «Revista Teatral» y «Revista Bibliográfica». Su consagración se produjo en la Revista Contemporánea, fundada por José del Perojo en diciembre de 1875, y en la que Revilla fue una de las firmas más destacadas. En concreto se encargó de la sección fija «Revista crítica», en la que desarrolló una crítica literaria más rigurosa y de carácter positivo, en lugar de la tradicional de carácter romántico, inaugurando así un nuevo estilo crítico en el panorama intelectual español. Pero no se limitó a tratar cuestiones meramente literarias, sino que empleó géneros "mestizos» para abordar todo tipo de problemáticas culturales, científicas, ideológicas y sociales; lo cual, unido a que cada uno de sus artículos era prácticamente un mundo propio, dotado de enorme complejidad, y con múltiples lecturas transversales y multidireccionales, 
hace muy difícil sistematizar sus contribuciones periodísticas y ofrecer un análisis cronológico-temático pormenorizado de las mismas.

En los estudios monográficos sobre Revilla se ha sostenido que su pensamiento fue krausista en un primer momento, para evolucionar más tarde, en 1875, hacia el neokantismo por la influencia de José del Perojo. Otros comentaristas ańaden que su planteamiento neokantiano fue un paso intermedio hacia el positivismo que profesó al final de su vida. El propio Revilla afirmó que en un principio militó en el krausismo, pero luego lo abandonó para inscribirse en la corriente positivista. Más recientemente se ha defendido que siempre practicó el eclecticismo: en un primer momento, entre el idealismo krausista y el hegeliano, para, alrededor de 1874, encaminar su filosofía hacia la recuperación del Kant de la Crítica de la razón pura y abrirse a nuevas corrientes como el neokantismo y el positivismo, sin renunciar nunca a ciertos componentes propios del idealismo.

El 30 de mayo de 1876, desde la sección «Revista crítica» de la Revista Contemporánea, Manuel de la Revilla irrumpió sin quererlo en la «tercera polémica de la ciencia espańola», al expresar su apoyo general a la idea de que en España se llevaban viviendo tres siglos de decadencia científica, aunque no literaria. En la época de los Austrias, según él, España habría entrado en una situación de atraso científico, tan acusado respecto al resto de Europa, que casi podría decirse que no colaboró en nada a la historia científica del Continente; pues en ésta no se encuentran grandes científicos españoles y la única escuela filosófica, a la que ha aportado influyentes creadores, ha sido la escolástica. A esta evaluación tan negativa del peso científico de España, añadió asimismo un explosivo análisis de las posibles causas de su decadencia. Nuestra decadencia filosófico-científica habría sido el resultado, a su juicio, de dos causas: ante todo, el despotismo y la intolerancia imperantes cortaron la vida al pensamiento científico, que sólo alienta con la libertad; además, un defecto en el espíritu nacional, el cual sería más fecundo en místicos y sońadores, que en pensadores reflexivos e independientes.

Como se ve, Revilla utilizó por un lado la tesis socio-política e histórica característica de los «modernizadores a toda costa» (la perniciosa influencia de la intolerancia religiosa y el despotismo político, unidos en un poder teocrático, en Espańa, frente a la libertad del pensamiento y la ciencia en Inglaterra, Francia y Alemania) y, por otro, una tesis esencialista y metafísica procedente de la «psicología de los pueblos» (el carácter nacional español adolece de un fallo esencial que dificulta el desarrollo de la racionalidad moderna). En cambio, las letras españolas habrían tenido su época de máximo esplendor en el período álgido de la intolerancia y el despotismo, porque sirvieron 
de válvula de escape a la actividad intelectual: los inquisidores permitieron a la literatura una libertad casi absoluta con el fin de que los intelectuales españoles malgastaran sus energías en entretenimientos inofensivos y nada peligrosos para el despotismo. En definitiva, Revilla manifiestaba así una visión negativa de la literatura española, por razones más ideológicas que literarias, pues lejos de concebirla como un elemento de progreso, dio a entender que fue una auténtica rémora para la modernización de España.

Menéndez Pelayo, desde el campo conservador de los llamados «mestizos», ${ }^{103}$ le contestó el 2 de junio de 1876 en la Revista Europea con el artículo que tituló «Mr. Masson redivivo», alusión evidente a Masson de Morvilliers.

Menéndez Pelayo presentó a Revilla como el nuevo Masson, acusándole de mantener una tesis antipatriótica, atrasada y propia de la "estirpe liberalesca», al mismo tiempo que calificaba a la Revista Contemporánea de antipatriótica y extranjera. Al sostener que la clave de la historia española era la intolerancia religiosa, Revilla habría demostrado su desconocimiento de la filosofía española, verdadera razón por la que negaba su existencia. A juicio de Menéndez Pelayo, que un filósofo no hubiera creado escuela no quería decir que su obra careciera de mérito. De hecho, continuó el polemista santanderino, España habría dado numerosos científicos de segunda fila cuya obra ya contenía, al menos germinalmente, lo que más tarde hicieron grandes científicos europeos, y se extendió en ofrecer una larga lista de nombres de autores españoles que -en su opinión- habrían sido precursores de grandes pensadores y científicos europeos, especialmente durante la época dorada de la cultura española, en el Renacimiento, con la escuela de Luis Vives. Por consiguiente, la relativa pobreza de España en ciencia -que él mismo reconocía- no fue, sin embargo, esterilidad absoluta y, en cualquier caso, aún

103 Simplificando, se los denominaba «mestizos» porque se encontraban próximos ideológicamente a algunos de los planteamientos del integrismo neocatólico, aunque no aceptaban todos y cada uno de ellos y sí, en cambio, admitían ideas pertenecientes a diversas líneas de lo que el pensamiento tradicionalista denominaba "pensamiento moderno» o, de forma aún más genérica, «modernidad». Así se puede entender el caso de Menéndez Pelayo, quien sostiene que los dos elementos genuinos de la nacionalidad espańola, y que la mantienen unida, son el catolicismo y la monarquía: de ahí su defensa de instituciones como la Inquisición o del reinado de un personaje tan negativo para Espańa como fue Fernando VII. Pero, como vamos a ver, por otro lado rechaza que se conviertan en dogmas lo que, para él, son meras opiniones filosóficas de los padres de la Iglesia, oponiéndose así a las doctrinas de los neocatólicos, reivindica el renacimiento español frente al escolasticismo medieval y sostiene la tesis positivista de que en Espańa todo puede explicarse por las condiciones del suelo. Así se da la paradoja de que este defensor del pensamiento espańol «ortodoxo» frente al pensamiento «heterodoxo» al final fue considerado por los integristas un pensador «heterodoxo». 
no había sido estudiada por los historiadores de la ciencia, que eran quienes debian de pronunciarse sobre el alcance y valor reales de la ciencia española en esa época. Menéndez Pelayo terminó diciendo que la intolerancia religiosa y la Inquisición no pudieron ejercer influencia alguna en las ciencias que no rozaban el dogma, y que si hubo intolerancia en España fue sobre todo la de las escuelas y sistemas filosóficos prepotentes y, en especial, la intolerancia de la impiedad que practicaban los liberales, los materialistas y los positivistas. De hecho, afirmó que la libertad y la tolerancia del siglo XIX -que, en su opinión, habían supuesto más bien anarquía y desconcierto- tampoco sirvieron para crear grandes científicos.

Como se aprecia, el trasfondo ideológico de la polémica era más que patente, y fue saliendo cada vez más a la luz, hasta que acabó convirtiéndose en una polémica puramente ideológica en vez de científica, pues tanto la defensa de la ciencia y la civilización modernas como los ataques contra ellas fueron una simple excusa con la que contender con los rivales políticos del campo contrario.

Revilla respondió a Menéndez Pelayo desde la Revista Contemporánea, el 15 de agosto de 1876, con el artículo «La filosofía española». En él, empezó por decir que la furia de su contrincante contra su persona sólo podía explicarse teniendo en cuenta sus opiniones neocatólicas, pues él no había atacado a los católicos, sino únicamente a los que abusaban de la religión y la convertían en instrumento del despotismo al defender instituciones bárbaras como la Inquisición. Estos que utilizaban la religión para otros fines distintos de los que le son propios, eran precisamente los tradicionalistas y neocatólicos. También señaló que la Revista Contemporánea no era antiespañola, ni antipatriótica, pues en ella se publicaban más trabajos de españoles que de extranjeros; sino que contribuía a difundir en España el espíritu científico: algo que era más patriótico que cantar las grandezas pasadas. Además, los verdaderos patriotas debían decirle a la patria verdades provechosas, por amargas que fueran, en lugar de halagar el orgullo nacional ocultándoselas. Por eso se reafirmó en la idea de que habíamos tenido filósofos españoles, pero no una filosofía nacional, una tradición filosófica española. Revilla terminó sentenciando que la historia de la filosofía no era un conjunto de biografías ilustres, sino el desarrollo gradual y sistemático del pensamiento humano, en el que no habrían influido ni los genios si no hubieran sido capaces de darse a conocer e imponer su propio pensamiento: a los escritores no se les tenía que juzgar por el éxito de su obra, pero a las instituciones sociales (como es la filosofía española) sí se las debería de juzgar por ello. A lo que sólo ańadió que no volvería a contestar a su contrincante, sino que daba por zanjada la discusión. 
Menéndez Pelayo volvió a la carga en el artículo «Mr. Masson, redimuerto", aparecido también en la Revista Europea el 24 de septiembre de 1876. En él, acusó una vez más a la Revista Contemporánea de ser anticatólica, antinacional y extranjera, así como de negarse a estudiar la civilización española. Llamó a Revilla "positivista impío» y le achacó sentir odio a su patria por el simple hecho de que aquélla había sido y era católica. Por el contrario, él se declaró católico, como -en su opinión- lo había sido toda la España histórica, y consideró que la verdadera civilización estaba en el catolicismo: un catolicismo que no hacía concesiones a la impiedad ni a la heterodoxia, pero que tampoco convertía en dogmas las opiniones filosóficas de los padres de la Iglesia. Además, Menéndez Pelayo aplaudió a la Inquisición, en cuanto preservadora de la vida nacional y del espíritu genuino del pueblo español. Asimismo, afirmó que era preferible renovar y rejuvenecer lo propio, a copiar y reproducir lo extraño, lo antipático al genio de la raza española y a la índole de la inspiración e historia españolas. Por otro lado, propuso que, antes de afirmar rotundamente que todos los científicos españoles habían sido de segunda fila, habría que estudiarlos e investigarlos para reconstruir la historia de la ciencia en España. Y terminó sosteniendo la idea de que todo en España podía explicarse por las condiciones del suelo y por las leyes históricas del pensamiento nacional; además señaló, como Revilla, que tampoco iba a continuar la discusión.

Paradójicamente, la postura de Menéndez Pelayo disgustó no sólo a los progresistas, sino también a los integristas neocatólicos, quienes no aceptaban su defensa del Renacimiento espańol frente al escolasticismo medieval -al que Menéndez Pelayo no se sentía precisamente vinculado, contra lo que afirma Revilla-, ni tampoco su pretensión de excluir de la categoría de dogma a las opiniones de los padres de la Iglesia. Además, es preciso llamar la atención sobre el hecho de que su apelación a las condiciones del suelo, como uno de los patrones explicativos de la realidad española, suponía adoptar un principio característico del positivismo que él tanto criticaba; en cambio su referencia a las leyes históricas del pensamiento nacional comportaba introducir un supuesto ontológico metafísico. Por fin, también es preciso hacer notar que su llamamiento a reconstruir la historia de la ciencia en España a través de la investigación empírica estaba muy alejado de la postura tradicionalista, y mucho más cercana -aunque le pese- al positivismo.

El motivo de esta aparente paradoja fue la formación de Menéndez Pelayo, en la que concurrieron principalmente dos líneas opuestas de pensamiento: por un lado, la que procedía de la influencia recibida de su familia y su entorno más inmediato, ideológicamente muy conservadores; por otra, la de su 
formación intelectual, que tuvo un fuerte carácter empirista. ${ }^{104}$ Por eso resulta lamentable que quien, como él, habría podido ofrecer opiniones objetivas y de peso acerca de la historia de la filosofía y la historia de la ciencia en España, se sintiera obligado a defender -en aras de su posición ideológicala superioridad sin más de todas las realizaciones culturales españolas sobre las europeas. Mientras que ni los neocatólicos ni los progresistas poseían conocimiento suficiente para pronunciarse con el debido rigor acerca de las cuestiones tratadas e, igualmente, se dejaban arrastrar, a la hora de emitir sus juicios, por las necesidades ideológicas que se habían impuesto, abandonando cualquier criterio objetivo y crítico que hubieran podido manejar: los ultramontanos, porque partían del prejuicio de que el único pensamiento verdadero era la escolástica tomista y de que la única civilización posible era la propiciada por el integrismo neocatólico; los progresistas, porque partían del prejuicio de que en la católica España, al contrario que en la liberal y moderna Europa, no podía haber habido ni filosofía ni ciencia. Y ninguno de los dos estaba dispuesto a permitir que los hechos suministrados por la historia les sacaran de su error, mostrando cómo en España sí se había hecho filosofía y ciencia desde las más variadas corrientes de pensamiento, aunque la hegemonía de la escolástica y la intolerancia hacia otras maneras de entender la cultura hubieran impuesto que el resto de líneas se cultivaran de forma minoritaria, o al menos al margen de la cultura oficial, generando así un atraso de España respecto de la modernidad europea.

La "polémica» no terminó en este punto: desaparecido de escena, por propia voluntad, Revilla, Perojo asumió la tarea de defender a la Revista Contemporánea de las graves acusaciones de que había sido objeto reiteradamente en los textos de Menéndez Pelayo. Por eso escribió en su revista, el 15 de abril de 1877, un artículo titulado «La ciencia espańola bajo la Inquisición», en el que afirmó que la ciencia moderna marcaba el inicio de un nuevo período

104 Es muy probable que en esto se muestre la influencia de la formación que recibió Menéndez Pelayo en la Universidad de Barcelona, pues en ella existía un espíritu de mayor tolerancia y flexibilidad en el estudio de doctrinas filosóficas de diversa índole, si lo comparamos con el mayor dogmatismo o espíritu de confrontación ideológica sin concesiones que se vivió en la Universidad de Madrid. La labor de Francisco Javier Llorens i Barba fue absolutamente trascendental en este sentido de tolerancia hacia el estudio de diversas líneas filosóficas, e incluso hacia la asunción de ideas pertenecientes a varias escuelas, en una suerte de posición ecléctica. Jaume Serra Hunter, discípulo de Llorens, sería el continuador de ese espíritu en la Universidad de Barcelona. Y Marcelino Menéndez Pelayo también fue discípulo de Llorens en Barcelona. Además, en la Universidad de Barcelona predominaba un enfoque historiográfico, vinculado a ese espíritu de apertura y antidogmatismo, del que también participa Menéndez Pelayo. 
histórico, lo mismo que Kant podía ser considerado no sólo el creador de un sistema, sino de una escuela, que a su vez había generado otro período histórico distinto del moderno. Respecto a las ciencias en Espańa, sostuvo que comenzaron en una época remota, pero que fueron los árabes quienes las impulsaron extraordinariamente, para acabar introducidas en la cultura castellana, que las mantuvo a un nivel muy elevado. Sin embargo, las persecuciones inquisitoriales fueron ahogando la iniciativa y la espontaneidad del carácter español: dos condiciones indispensables para el progreso científico. En cuanto a la filosofía, el panorama fue aún más desolador, porque no pudo florecer en un período en el que sufrieron persecución incluso ciencias que requerían una menor libertad o independencia. Al final, el silencio de las tumbas reinó en el movimiento científico y espiritual español. Por eso, afirmó rotundamente que no habíamos tenido en España ninguna filosofía sistemática que hubiera sido conocida en el mundo por el solo adjetivo de «española», ni había existido ningún autor español que hubiera creado escuela, o sea, que hubiera producido una modificación en el modo de ser general del pensamiento: algo que apoyó ofreciendo una larga lista de pensadores influyentes en la vida europea, entre los que no figuraba ningún español. Por último, Perojo señaló que era consciente de haber publicado verdades amargas, pero que los pueblos «viriles» $\mathrm{y}$ "progresivos» querían conocer sus defectos, para corregirlos, y sus desdichas para compensarlas. Por tanto, sus afirmaciones no eran antipatrióticas, sino que tenían el propósito de preparar a su patria a los más altos destinos que le aguardaban, consagrando las fuerzas nacionales a trabajos útiles bajo los auspicios de la libertad, frente a los simples halagos a la vanidad nacional que ofrecían los reaccionarios.

Se trataba de la reiteración de muchas ideas expresadas por Revilla y, nuevamente, del uso de la historia con fines ideológicos: dado que la Espańa de su tiempo era, en buena medida, producto del Antiguo Régimen, partidaria de la tradición ultramontana española y contraria a la modernidad europea, y así había sido durante siglos, Perojo se vió obligado a negar casi por completo la existencia de otra filosofía y otra ciencia en Espańa que no fuera la escolástica. Pero, de hecho, sí existieron otras líneas de pensamiento a lo largo de la historia española, incluso en períodos de dominio escolástico, aunque Perojo no comulgase con ellas. Incluso, habíamos tenido corrientes e individuos que estaban al tanto de la modernidad europea y la seguían, por mucho que él lo niegue, tal vez por desconocimiento.

Pero, ya lo hemos señalado, no se trató tanto de un debate científico en el que se hubiera intentado analizar con rigor la realidad espańola, como de una contienda ideológica en la que a ninguna de las partes pareció importarle 
que se retorciera esa realidad, manteniéndose así los diversos planteamientos políticos enfrentados.

Si se deja al margen todo componente ideológico, es preciso reconocer la presencia en Menéndez Pelayo de un firme interés por reconstruir la historia del pensamiento español a partir de estudios empíricos. Por el contrario, los «modernizadores» negaron sin más ese pensamiento, sin preocuparse de investigar previamente su existencia o inexistencia, pues emplearon un criterio reduccionista, según el cual quedaba excluido del saber filosófico todo aquello que no se ajustara a su propia interpretación particular y dogmática, no de la filosofía europea en general, ni siquiera de la alemana en particular, sino exclusivamente de los sistemas filosóficos alemanes. En este sentido, la actitud de Perojo y Revilla manifiestaba una visión ahistórica, no lo suficientemente alejada de la intransigencia de los integristas neocatólicos que ellos tanto criticaban.

Las formas retóricas de que hizo gala Menéndez Pelayo, en su polémica con Manuel de la Revilla y con José del Perojo, denotan una sorprendente falta de consideración intelectual por su antagonistas, de manera especial por el segundo. Esta circunstancia extraña adquiere algo de luz con la lectura de la correspondencia entre Gumersindo Laverde y Marcelino Menéndez Pelayo. En ella se comprueba que fue Laverde quien le incitó a polemizar cum ira et studio contra los herederos del krausismo y demás «enemigos de la tradición española», ofreciéndole listas de autores españoles que debía citar, instruyéndole en la línea que debía seguir en sus diatribas; y que, en el caso de sus réplicas a Revilla, el polemista santanderino lejos de encontrar el habitual freno de su mentor a su juvenil incontinencia dialéctica, recibió de él con aprobación los conocidos títulos que reforzaron más aún la violencia de sus cartas. Esta dureza dialéctica que parece tener algo de castigo personal, indica que en el trasfondo de la polémica con Revilla latía la oposición a la cátedra de Principios Generales de Literatura y Literatura Española, que se dilató en el tiempo desde 1872 hasta 1876, y en la que se entremezclaron antagonismos ideológicos, controversias intelectuales y enfrentamientos personales, con el telón de fondo de la feroz lucha por el control de las cátedras en un medio académico tan determinante como la Universidad de Madrid. ${ }^{105}$

105 Para conocer el desarrollo de esta oposición y una de las claves fundamentales de la "tercera polémica de la ciencia española», véase Manuel de la Revilla. Obras completas, Ediciones de la Universidad Autónoma de Madrid, 2006, tomo I, pp. 50-58, estudio introductorio, edición y notas de Fernando Hermida, José Luis Mora, Diego Núñez y Pedro Ribas. 
Con el paso del tiempo, Menéndez Pelayo llegó a reconocer lo erróneo de muchas de las opiniones que vertió en su discusión con los neokantianos. ${ }^{106}$ Por otra parte, la segunda y la tercera edición de La ciencia española, que se publicaron bajo la revisión de su autor, fueron eliminando pasajes con referencias hirientes a la persona de Revilla. En la «Advertencia preliminar» de la tercera y definitiva edición, Menéndez Pelayo escribió sobre el gran crítico madrileńo que había fallecido prematuramente en septiembre de 1881, lo siguiente:

Todos mis contradictores han sido amigos míos después de esta controversia, y lo fue muy íntimo, dejándome con su muerte imborrable recuerdo y amarguísimo duelo, aquel gran crítico Manuel de la Revilla, en cuyo generoso espíritu no quedó ni la más ligera sombra de rencor después de nuestro combate literario.

106 Así lo expone en Esplendor y decadencia de la cultura cientifica española, Madrid, La España Moderna, 1894, y en su proemio a A. Fernández Vallín, Cultura cientifica en España en el siglo XVI. Sevilla, Padilla Libros, 1989 (Ed. facsímil). Más explícito se muestra en su poco conocido discurso De los orígenes del criticismo y del escepticismo. $Y$ especialmente de los precursores españoles de Kant, leído el 15 de mayo de 1891 en la Real Academia de Ciencias Morales y Políticas, y publicado ese mismo ańo por Ricardo Fe. En este texto (en Obras completas. Madrid, CSIC, vol. 43, 1948; reproducido y estudiado por Gerardo Bolado en M. Menéndez Pelayo, Antología comentada. Santander, Librería Estudio, Biblioteca Cantabria, vol. 13, 2002), da un giro notable a su interpretación del escepticismo y el criticismo, que ahora contrapone al dogmatismo metafísico, y pasa a considerar más favorablemente corrientes filosóficas como el hegelianismo, el krausismo, el positivismo o el neokantismo, que, a su juicio, constituirían las principales tendencias de la filosofía española en el último cuarto del siglo XIX. Además, presenta a su admirado Juan Luis Vives, a Francisco Sánchez y a Pedro de Valencia como precursores españoles de Kant, y lo hace nada menos que de la mano del neokantiano Friedrich Albert Lange. De hecho, Bolado cree que este pensador alemán es clave en la génesis del discurso. 


\title{
La polémica de la ciencia en la Espańa de la Restauración (1876-1898). Los racionalistas de la Revista Contemporánea en la polémica: José del Perojo
}

\author{
Dra. María Dolores Díaz Regadera \\ y Dr. Pedro Ribas Ribas \\ Universidad Autónoma de Madrid
}

\begin{abstract}
Tosé del Perojo y Figueras (¿1850?-1908) fue una figura clave en la cultura española de la Restauración, lo cual no ha impedido que permaneciera bastante desconocida. La investigación que sobre él realizó María Dolores Díaz Regadera, siguiendo la senda abierta por Diego Núñez, ha contribuido enormemente a mejorar su conocimiento. José Luis Villacañas le ha dedicado asimismo bastante atención en el estudio preliminar de su antología Kant en España. ${ }^{107}$ Perojo, primer traductor al español de la Crítica de la razón pura, de Kant, hubiera sido importante tan sólo por esto; pero su relevante aportación en el contexto del último tercio del siglo xix realza aún más la significación histórica de su figura.

Recordemos que nació en Santiago de Cuba el 19 de enero de 1850. Su padre, Benito del Perojo, era un rico indiano que falleció tempranamente; su madre, Gertrudis Figueras, era natural de la isla. Hizo sus primeros estudios en el Instituto de Enseñanza Media de Santander, provincia de la que procedía su padre. La fortuna heredada de éste, le permitió al joven Perojo estudiar
\end{abstract}

107 José Luis Villacañas Berlanga (ed.), Kant en España. El neokantismo en el siglo XIX. Madrid, Verbum, 2006. 
libremente en distintas universidades. Cursó estudios de Filosofía y Letras en la Universidad Central de Madrid entre el curso 1870 y 1872, pero no llegó a licenciarse. Entre 1872 y 1873, continuó su formación en el Colegio de Francia (París), donde estudió con Paul Janet, Jean Charles Levécque, Hippolite Taine y Claude Bernard. Algunas fuentes indican que continuó sus estudios en Inglaterra; lo cierto es que su formación filosófico-científica recibió un impulso definitivo en la Universidad de Heidelberg, donde estudió con K. Bartsch, Wilhelm Wundt y Kuno Fischer. De hecho, fue en esta Universidad alemana, en el círculo de su admirado maestro, Kuno Fischer, donde tomó contacto con la primera escuela neokantiana, la Escuela de Heidelberg.

En 1875, Perojo publicó el ensayo "Arthur Schopenhauer» en los Philosophische Monatshefte, de Leipzig, que era uno de los órganos neokantianos de expresión. El neokantismo le parecía entonces una vía media para superar la dicotomía entre unos sistemas idealistas, como el krausismo, que eran a su juicio especulación vacía, por carecer del debido fundamento empírico, y el positivismo, que era un conocimiento ciego y sin sentido, por acumular hechos carentes de articulación formal. El neokantismo que él descubrió con fascinación en Heidelberg proponía una vuelta al pensamiento de Kant, entendido en sentido amplio, como una corriente «madre», fuente de distintas doctrinas científicas y filosóficas que eludían la metafísica, sin incurrir en los excesos positivistas. La crítica del conocimiento, en especial del científico, y la sistematización del saber a partir de los conocimientos positivos de las ciencias particulares, constituían a su juicio el objeto más propio de la reflexión filosófica. Perojo creyó que la filosofía neokantiana tendría éxito en la tarea que no llegó a cumplir el krausismo: convertirse en el fundamento intelectual de la modernización de España en los campos científico, económico, social y cultural:

la vinculación de Perojo al ambiente respirado en Heidelberg es tan fuerte, que los ecos de las doctrinas neokantianas seguirán haciéndose perceptibles al final de sus días, siendo constantes a lo largo de su trayectoria intelectual. Las connotaciones modernas de las tendencias neokantianas, que no habían logrado traspasar las barreras de los Pirineos, enseguida cautivan al estudiante español, quien se constituye, sin titubeo alguno y con plena conciencia de ello, en su firme paladín en el combate contra las doctrinas obsoletas y dogmáticas replegadas sobre sí mismas y en vigencia, aún, en la Península Ibérica. ${ }^{108}$

El autor hispanocubano era el primer neokantiano en territorio español. Al volver a España, en 1875, se encontró con un país que había recortado

108 Ma Dolores Díaz Regadera, José del Perojo Figueras (1850-1908). Neokantismo y reformismo. Tesis inédita, leída en la Universidad Autónoma de Madrid, 1995, p. 18. 
drásticamente las libertades conquistadas en la revolución de 1868. De ahí el entusiasmo con que emprendió su aventura intelectual y política, que no era otra sino la de renovar, regenerar, España mediante la incorporación de corrientes nuevas, sobre todo el neokantismo; y, en términos generales, mediante la introducción del sentido crítico, de la libertad de pensar y de la difusión de las corrientes filosóficas y científicas europeas, como apoyo a la crítica y al pensamiento. La aventura intelectual de Perojo fue admirable en su dimensión cultural, pero lo fue más, si cabe, considerando que él apoyó con sus propios recursos económicos empresas culturales como la importante Revista Contemporánea, hasta arruinarse.

Díaz Regadera ha insistido en el paralelismo entre esta revista de Perojo, destinada a difundir en España la filosofía y la ciencia europeas, y el proyecto de Ortega de 1923, la Revista de Occidente. Ciertamente, Ortega encontró el terreno más abonado y no necesitó arruinarse en la aventura, que tuvo, además del apoyo familiar y empresarial, una proyección internacional de cara a Latinoamérica. Diego Núñez había aludido también al papel de Perojo como introductor de la filosofía alemana en Espańa, asignándole «un lugar intermedio entre Sanz del Río y Ortega». ${ }^{109}$ Y Villacañas ha recordado igualmente el paralelismo entre los proyectos de Perojo y de Ortega. ${ }^{110}$

Lo cierto es que la Revista Contemporánea se convirtió en una importante tribuna de corrientes filosóficas y científicas innovadoras, las cuales hicieron germinar un panorama cultural español, muy dominado en los centros educativos por la escolástica oficial y por el krausismo, que había logrado extenderse por la geografía nacional. Y conviene recordar, así mismo, como lo hace Díaz Regadera en su tesis, que Sanz del Río estudió también en la universidad de Heidelberg, desde donde incorporó la filosofía de Krause en Espańa.

Menéndez Pelayo y Perojo compartían el rechazo por la filosofía krausista; la desavenencia entre ambos se hallaba más bien en su valoración de la filosofía moderna, la surgida de la Ilustración y del kantismo. Según Menéndez Pelayo «el olvido y desprecio de nuestra tradición científica se inicia en los últimos años del siglo xvıı, y es debido exclusivamente al enciclopedismo y al espíritu francés, que no podían menos de condenar y tener en poco una cultura católica e indígena». ${ }^{111}$ Esta actitud antiilustrada de Menéndez Pelayo, por ver en la Ilustración una amenaza al catolicismo, es la que enlaza al santanderino con el antiliberalismo que atravesó todo el siglo xIx español, desde los

109 Diego Núñez, La mentalidad positiva en España: desarrollo y crisis. Madrid, Tucar, 1975, p. 42; 2a ed., Madrid, Ediciones de la Universidad Autónoma de Madrid, 1987, p. 28.

110 Véase J. L. Villacañas, Kant en España, Op. cit., p. 106.

111 MP, CE, vol. I, p. 200. 
anticonstitucionalistas (de la Constitución de Cádiz), pasando por Donoso Cortés y el integrismo de los neocatólicos, hasta llegar al nacionalcatolicismo que imperó en la etapa franquista. La tesis de Pedro Laín Entralgo en su libro, La generación del 98, refleja muy bien la continuidad de esa visión antiliberal que en dicha etapa franquista tomó a Menéndez Pelayo como bandera.

El choque de éste con Perojo se produjo, pues, en la contrapuesta valoración de la Ilustración, en su defensa por parte del hispanocubano y su rechazo por parte del santanderino. Naturalmente, una cosa es el pensamiento de Menéndez Pelayo y otra bastante distinta la lectura y utilización de su obra con fines apologéticos. Sin negar que el catolicismo fue un ingrediente esencial de su obra, se puede y debe reconocer que su aportación a la historia y la cultura españolas y europeas fue de una importancia capital, sobre todo en lo que se refiere a propuestas de estudio, a su investigación sobre la literatura española y a su genial Historia de la ideas estéticas en España. En su investigación, especialmente en su período de madurez, Menéndez Pelayo fue capaz de valorar obras, autores y estilos por encima de sus creencias religiosas, como se pone de manifiesto en su positiva estima del idealismo alemán o de autores como Goethe, Heine o Schiller.

En la realización de su proyecto de introducir el neokantismo, Perojo se encontró con que faltaban las bases elementales para que pudiera difundirse y entenderse una filosofía como la de Kant. No era sólo que éste apenas estaba traducido al español, ${ }^{112}$ sino también que resultaba muy difícil en esta lengua la lectura de la obra de filósofos, como Descartes, Leibniz, Espinosa, o de

112 Para las traducciones de Kant al español reproducimos aquí la nota que figura en el último libro de Ribas, Unamuno. El vasco universal, (Madrid, Endymion, 2015), p. 87: Miguel Palacios, «La filosofía de Kant en la Espańa del siglo XIX», en J. Muguerza y R. Rodríguez Aramayo (eds.), Kant después de Kant. En el bicentenario de la "Crítica de la razón práctica». Madrid, Instituto de Filosofía del CSIC/Tecnos, 1989; J. L. Molinuevo, «Breve bibliografía en castellano sobre Kant (1930-1973)», Anales del Seminario de Metafísica, 9, (1974), pp. 203-213; A. López, "Consideraciones históricas del kantismo en España. Primeras manifestaciones», Anuario de Filosofía del Derecho, 3 (1986), pp. 339415; Roberto Albares Albares, «Los primeros momentos de la recepción de Kant en España: Toribio Núñez Sessé (1766-1834)», Actas de las II Jornadas de Hispanismo Filosófico (1995), El Basilisco, n. ${ }^{0}$ 21, 1996, pp. 31-33; Dulce María Granja, Kant en español: elenco bibliográfico. México, Universidad Autónoma Metropolitana/Universidad Nacional Autónoma, 1997; Maximiliano Fartos Martínez, "La recepción de Kant en Espańa», Estudios, LIII (2004), pp. 457-492; Ibón Uribarri Zenekorta: Filosofía, traducción y censura, artículo en Internet, resumen de un proyecto de investigación en la Universidad del País Vasco; J. L. Villacañas Berlanga (ed.), Kant en España: el neokantismo en el siglo XIX. Madrid, Verbum, 2006; Nazzareno Fioraso, De Königsberg a España. La filosofía española del siglo XIX en su relación con el pensamiento kantiano. Valencia, Editorial Cultural y Espiritual Popular, 2012. 
científicos como Darwin, o de defensores del evolucionismo como Spencer. Por eso Perojo fundó, además de la Revista Contemporánea, una editorial que publicara las obras de filósofos modernos. ${ }^{113}$ En esta empresa de difusión del pensamiento moderno, Perojo encontró un gran apoyo en intelectuales catalanes como Pompeyo Gener y Pedro Estasén y Cortada, quienes se habían topado con la oposición del Ateneo de Barcelona, entonces bajo dirección reaccionaria, en su intento de exponer en él sus propuestas culturales y políticas; razón por la cual, estos positivistas y liberales catalanes conectaron muy bien con el hispanocubano que, a su vez, acogió con simpatía su impulso renovador. Perojo vio muy bien, desde el punto de vista político, el paralelismo que existía entre la cicatera actitud del gobierno de España ante la autonomía cubana y la que exhibía ante las demandas catalanas de autonomía; lo cual no significa que Perojo y Estasén coincidieran sin fisura alguna.

Menéndez Pelayo combatió con furor juvenil tanto las propuestas de los krausistas como las de los neokantianos y positivistas. Es curioso que sus andanadas no se dirigieran primero contra Echegaray o Salmerón, sino contra el moderadísimo Gumersindo de Azcárate, por haber afirmado en su artículo, «Las constituciones irreformables», ${ }^{114}$ que la causa de que «durante tres siglos» desapareciese casi por completo la ciencia de nuestro suelo había que buscarla en la falta de libertad. Opinión ésta en la que coincidía con otros krausistas, como Salmerón, quien escribió en su prólogo a la Historia de los conflictos entre la religión y la ciencia, de Draper:

ni en Filosofía, ni en las Ciencias naturales, ni en la Industria, cuyos maravillosos progresos, en oposición al ideal católico y a las imposiciones dogmáticas, caracterizan los tiempos modernos, ha contribuido con obras originales y fecundas nuestro genio nacional por la compresión en que lo ha retenido el absolutismo teocrático. ${ }^{115}$

Por su parte, José Echegaray había dicho en 1866 en su discurso de ingreso en la Real Academia de Ciencias: «la ciencia matemática nada nos

113 La lista de obras publicadas por la editorial Perojo y la editorial Nuevo Mundo se puede encontrar en la mencionada tesis de Díaz Regadera; también en M. ${ }^{a}$ Dolores Díaz Regadera, Fernando Hermida, José Luis Mora, Diego Núńez, Pedro Ribas (eds.), Artículos filosóficos y politicos de José del Perojo (1875-1908). Madrid, Ediciones de la Universidad Autónoma, 2003, pp. 59-62.

114 Revista España, 28-11-1876; incorporado después a su libro El self-government y la monarquia doctrinaria. Madrid, Librería de A. San Martín, 1877.

115 Barcelona. Alta Fulla, 1987, p. XLII. Reedición de Diego Núñez; la edición original de esta traducción española, realizada por Augusto T. Arcimis (no es la primera traducción española), había aparecido en Madrid, Ricardo Fe, en 1885. 
debe: no es nuestra; no hay en ella nombre alguno que labios castellanos puedan pronunciar sin esfuerzo». ${ }^{116}$ Menéndez Pelayo hubiese podido retrotraer incluso hasta el siglo xviII las quejas sobre la falta de cultivo de la ciencia en España, por ejemplo hasta Cañuelo en El Censor. Y suponemos que a él se refiere justamente cuando, polemizando con Azcárate, afirma que el «olvido» de las contribuciones españolas a la ciencia no procede de los tres últimos siglos, XVII, XVIII y XIX, sino de finales del siglo XVIII.

Manuel de la Revilla escribió en la Revista Contemporánea, el 30 de mayo de 1876, que la filosofía española, «en cuya resurrección sueñan hoy eruditos como Laverde o Menéndez Pelayo», era un «mito», ya que "en la historia de la filosofía puede suprimirse sin grave menoscabo el capítulo referente a España». ${ }^{117} \mathrm{Y}$ añadía Revilla en su escrito que la intolerancia religiosa tenía mucho que ver con ello. Menéndez Pelayo respondió que sí existía filosofía española, y lo hizo empleando un tono polémico (empezando por el título de la respuesta, «Mr. Masson redivivo») que más tarde mitigará. El santanderino sostuvo, frente a Revilla, que la obra de Vives y sus seguidores demostraba que había filosofía española fuera de la escolástica; y descalificó al crítico madrileño por considerarle un mero diletante que no había estudiado con detenimiento y rigor la producción bibliográfica española. Pero aceptó de Revilla que «la declinación parcial de la ciencia española en el siglo xvir fuese [a causa de] la intolerancia, pero no la de la Inquisición, tan sólo, sino más bien la de las escuelas y sistemas prepotentes.»

Dejemos aquí la contestación de Revilla al artículo de Menéndez Pelayo, quien replicó en su «Mr. Masson redimuerto», atacando de manera aún más directa al crítico madrileño y a la Revista Contemporánea, insistiendo en que no era «española». Y fijémonos en la irrupción de Perojo en la polémica con el artículo, «La ciencia espańola bajo la Inquisición», que publicó la Revista Contemporánea el 15 de abril de 1877. Perojo replanteó la tesis de Revilla, según la cual «no existe una escuela filosófica que propiamente pueda llamarse española» $y$ «la Inquisición paralizó todo el movimiento científico de nuestro pueblo». ${ }^{118}$ Para mostrar cómo evolucionó la filosofía, expuso el proceso que había realizado desde los griegos hasta el presente. Trazó así un esquema en el que aparecían las grandes figuras, desde jónicos y eleáticos hasta Kant, quien representaba el final de la filosofía dogmática y el comienzo de la filosofía crítica. De ahí que el filósofo de Königsberg no fuera «un simple creador de

116 Ernesto y Enrique García Camarero reproducen este discurso de Echegaray en su recopilación La polémica de la ciencia española. Madrid, Alianza Editorial, 1970. El texto citado corresponde a p. 185.

117 Manuel de la Revilla, «Revista crítica», recogido en La ciencia española, I, p. 86.

118 MP, CE, II, p. 828. 
un sistema, sino el creador de una escuela, de un período histórico». ${ }^{119}$ Lo cual no significaba que todas las direcciones que arrancaron de Kant fueran críticas e ilustradas, como lo mostraban los ejemplos de Schopenhauer o Hartmann. Resulta curiosa, por esto, la admiración que Perojo, neokantiano y, consecuentemente, promotor del progreso científico y de la línea ilustrada del propio Kant, sentía por autores como Schopenhauer, filósofo antiilustrado e irracionalista, por más que éste se situase astutamente bajo el paraguas de aquél. Pero volvamos ahora al recorrido que, según Perojo, había efectuado la evolución de la filosofía y, en concreto, a su desarrollo en suelo español.

El hispanocubano no negaba que hubiera existido en España el cultivo de las ciencias, tanto de la naturaleza, como del espíritu. Al contrario, argumentaba que florecieron hasta la entrada en vigor del Santo Oficio:

Hasta que la Inquisición alcanzó todo su poderío, vemos en España constantemente talentos de primer orden marchando a la cabeza de la civilización, no habiendo ciencia europea en que al lado de los nombres extranjeros más ilustres no se puedan colocar los nuestros, y en los más de los casos con extraordinaria superioridad por nuestra parte. Pero desde el acontecimiento que señalamos, según su poder aumenta, disminuyen nuestros nombres, efecto de la cruda guerra que a su nombre se hacía contra todo lo que era ciencia, investigación, libertad del pensamiento humano. No hay más que recorrer las páginas del sangriento libro del martirologio español para advertir cómo al primer paso de un talento extraordinario, a la primera creación de un espíritu reflexivo, acudía presurosa la Inquisición a extinguir con el fuego de sus hogueras toda su obra, y con los tormentos a descubrir los vestigios que todavía pudieran quedar; ¡cuántos y cuántos hombres ilustres, dignos sucesores de sus antepasados, tuvieron que sucumbir hasta que el Santo Oficio no tuvo que entretenerse en más que con brujas y endemoniados! ${ }^{120}$

Ante la insistencia de Laverde y Menéndez Pelayo en la existencia de escuelas filosóficas españolas, Perojo se reafirmaba en que la ausencia de libertad fue la causa que produjo la paralización de las ciencias y de la filosofía, pues el espíritu sólo puede crear e investigar bajo condiciones de libertad. Dada la falta de ésta, desaparecieron desde la época de Bacon y Descartes hasta Kant, período coincidente con el de la Inquisición.

El autor hispanocubano recordó además que no tenía efectos en la historia de la ciencia y la filosofía desenterrar eminencias desconocidas en el pasado. Con un criterio muy ilustrado, como era de esperar en un neokantiano, Perojo sostuvo que incluso si se descubriera ahora, en un armario antes no explorado, la obra

119 MP, CE, II, p. 833.

120 MP, CE, II, p. 835. 
de un Kant del siglo XvII o de un Newton del siglo xv, este Newton y ese Kant serían un cero en la historia del desarrollo científico y filosófico, ya que, al ser desconocidos, no habrían tenido ningún efecto en tal desarrollo. El berkeleyano esse est percipi sería adecuado para acercarse a lo que dice Perojo, aunque le faltaría la operatividad, el aspecto dinámico, por lo que en realidad sería más conveniente hablar aquí del fieri o del Werden hegeliano en la consideración de la marcha histórica. Quizás por ello encontramos en el artículo de Perojo pasajes como éste:

En la filosofía, además, hay que tener en cuenta que su historia no es meramente real, electiva, y que no se cumple porque a ciegas y a locas se inventen y presenten sistemas y opiniones. La filosofía en su historia es el mismo pensamiento humano que se desenvuelve de un modo lógico y necesario, y no da en su seno cabida al arbitrio ni al capricho. Su única ley es la dialéctica. ${ }^{121}$

La dialéctica a la que se refería Perojo en ese pasaje, no es la de Kant, sino la de Hegel. Pero ¿estamos ante una aplicación del famoso dicho de Hegel «todo lo real es racional y todo lo racional es real»? Teniendo en cuenta la obra entera de Perojo, y la comprensión de la evolución que se extendió en su época, lo más probable es que esa dialéctica no fuera, ni la de las etapas que recorre el espíritu en la fenomenología (de Hegel), ni la de las estadios conforme a los cuales avanza el Weltgeist en la filosofía de la historia (también de Hegel), sino una ley evolutiva que presidiría el desarrollo histórico, mezclando contenidos hegelianos con elementos de la biología evolucionista y de la filosofía de Spencer; cosa nada infrecuente, sino más bien muy común en la Europa del último tercio del siglo XIX.

Perojo extraía así del hipotético descubrimiento de un legajo, en el que hiciera aparición un desconocido sistema genial de filosofía, la conclusión de que entonces tendríamos en el futuro una filosofía renovada gracias al impulso innovador que ese sistema ocasionaría. Es una forma de decir que, salvo la escolástica, no ha habido ninguna escuela filosófica española, y puesto que no la ha habido, de lo que se trata es, de que la haya en el futuro. Pero no sólo eso, no sólo que la haya, sino que esa filosofía española que ha de venir como novedad, sea un impulso en virtud del cual «modificaríamos nuestro pensamiento histórico y le haríamos entrar dentro de las ideas reinantes, lo cual es mucho más de lo que a primera vista parece». ${ }^{122}$

Aquí sale a la luz con claridad la visión según la cual entrar en las ideas reinantes es modificar nuestro pensamiento histórico. Si uno quiere exprimir esta idea puede extraer de ella conclusiones como las siguientes: el pensamiento histórico,

121 MP, CE, II, p. 837.

122 MP, $C E$, II, p. 837. 
el que hemos tenido desde el siglo XvII, nos mantiene fuera de las ideas reinantes en Europa; entrar en ellas supone cambiar de rumbo y este cambio es el que propone Perojo con su programa de modernización. Está claro que Menéndez Pelayo, defensor del catolicismo español como sello de identidad nacional, no está a favor de ese cambio, sino todo lo contrario, a favor de estudiar, conocer y enseñar la tradición española. Cosa muy distinta es que Menéndez Pelayo se resista a dejar entrar, en esa tradición, corrientes de pensamiento que él llama «heterodoxas».

Veamos qué incluía ese programa de modernización que preconizaba Perojo. En el terreno político incluía un liberalismo que integraba muchos puntos de la corriente regeneracionista de finales del siglo xIx y comienzos del xx, pero que sólo era progresista en el terreno de la limpieza y transparencia que él demandaba; lo cual no era poco, pese a no estar exento de elementos racistas. Desde el punto de vista social, estaba por debajo del programa de los krausistas, que era igualmente liberal, pero que buscaba al menos la armonía social y por ello se ocupaba de la moral y de crear instituciones que fomentasen la educación y la legislación del trabajo. Lo más progresista de Perojo se hallaba sin duda en su programa educativo y, como base del mismo, en el cultivo y difusión de la ciencia europea y universal, que intentó promover en la Revista Contemporánea y en sus libros.

Lo fundamental del artículo de Perojo en respuesta a Menéndez Pelayo consistía en negar la existencia de escuelas españolas de pensamiento. Ni siquiera Ramón Llull, que sí tuvo seguidores, fue fundador de una escuela que hubiera supuesto un cambio en el pensamiento. Mucho menos se podría afirmar que fundaron escuela autores, como Huarte, Gómez Pereyra, Francisco Sánchez o Fox Morcillo. $\mathrm{Ni}$ siquiera el más distinguido de todos, Luis Vives, fue fundador de una escuela filosófica. Perojo aprovechó aquí la tesis del integrista Pidal y Mon, para apoyar la suya propia en contra de Laverde y Menéndez Pelayo.

Pidal y Mon que, como Perojo y Revilla, no era un historiador erudito amante de glorias pasadas, vio enseguida los peligros que el vivismo defendido por Menéndez Pelayo comportaba. En este sentido recordó que si hay doctrinas fuera de la verdad única, enseñada por la tradición católica, que son defendidas incluso por Menéndez Pelayo como formando parte de nuestra historia cultural, el riesgo que corría dicha verdad única era evidente:

Si al árbol se le conoce por sus frutos, como dice el Evangelio, ¿qué deberemos pensar de un árbol cuyos frutos son el empirismo baconiano, la duda cartesiana, el psicologismo escocés, el aristotelismo no purificado por los escolásticos, el antiaristotelismo, las ideas innatas y hasta el escepticismo y el sensualismo? ${ }^{123}$

123 A. Pidal y Mon, en MP, CE, I, p. 224. 
Pidal se refería sin duda a lo que el santanderino había escrito en una de sus cartas a Laverde:

¿No son relieves de la mesa de Vives el baconismo, el cartesianismo, y, sobre todo, la escuela escocesa? Y es lo más singular que en el prólogo de que estoy tratando ${ }^{124}$ se encomie altamente el mérito de Bacon (sin duda porque fue inglés y protestante) y se menosprecie el de su maestro, a quien él quedó tan inferior en todos conceptos. ${ }^{125}$

La tendencia de Menéndez Pelayo a ver precursores de la filosofía moderna (de Descartes, de Bacon e incluso de Kant) en autores espańoles del siglo xvı, fue explotada por Pidal y Mon, que comulgaba con el santanderino en otros aspectos fundamentales, para rechazar que tales precedentes fueran una gloria digna de ser rescatada del olvido. Es lo mismo que puso en duda también Perojo, pero por motivos completamente distintos; pues tales precedentes eran para Pidal y Mon una desviación de la única verdad, de la que nunca debía de apartarse la sociedad espańola, mientras que, para Perojo, la insuficiencia de esos autores, mencionados por Laverde y Menéndez Pelayo, residía en que no habían dado lugar a escuelas con influencia y continuidad en el pensamiento.

En el programa de modernización de Perojo tenía un lugar destacado su concepción crítica de la filosofía y la necesaria conexión de ésta con la ciencia. En el artículo que escribió en la Revista Contemporánea en enero de 1876, «Haeckel juzgado por Hartmann», mostraba con claridad las diferentes posiciones de estos dos autores: Haeckel era un naturalista que usaba el método inductivo para llegar a leyes que unificaran los fenómenos observados. Estas leyes eran encuadradas, a su vez, en teorías que explicaban y coordinaban dichas leyes. La unificación de fenómenos gracias a las leyes y teorías tenía siempre carácter provisional, es decir, eran hipótesis que tenían valor mientras no surgieran fenómenos que contradijeran o invalidaran las teorías. Así procedía Haeckel, mientras que Hartmann afirmaba que esa forma de trabajar en la ciencia era incompleta, por no llegar hasta el «principio metafísico» de los fenómenos. De manera siempre respetuosa (y no siempre es respetuoso Perojo con sus interlocutores), objetaba a Hartmann justamente el acudir a tal principio y «caer en las quiméricas construcciones metafísicas que, lejos de favorecer el progreso de las ciencias naturales, impiden y retrasan su definitivo establecimiento». ${ }^{126}$

124 Menéndez Pelayo alude al prólogo de Salmerón para la traducción española de Historia de los conflictos entre la religión y la ciencia, de John William Draper.

125 MP, CE, I, p. 150.

126 Perojo, «Haeckel juzgado por Hartmann», en Artículos filosóficos y politicos de José del Perojo (1875-1908). Madrid, Ediciones de la Universidad Autónoma, 2003, p. 104. 
Basta seguir la comparación que Perojo estableció entre ambos autores para percibir con claridad por quién apostaba. La filosofía de la naturaleza de Hartmann era «ontológica, ha menester un principio oscuro y misterioso que denomina inconsciente», ${ }^{127}$ mientras que Haeckel, sin despreciar la especulación filosófica para relacionar teorías, se limitaba estrictamente a avanzar desde lo particular a lo universal, pero rechazando que las conclusiones tuvieran que derivar de un supuesto principio metafísico. Perojo citaba en este sentido los versos de Goethe:

\section{Je weiter Du wirst anfwaerts aufgehn}

Dein Blick wird immer allgemeiner. ${ }^{128}$

Como hombre educado en el neokantismo, el hispanocubano no entendía la ciencia como amontonamiento de hechos, tal como haría un empirista opuesto a la especulación, sino como explicación de esos hechos gracias a la labor teórica de relacionarlos y comprenderlos desde enfoques progresivamente más universales. Por ello señalaba este método, el de Haeckel, como «el único que podrá seguir el que en lo sucesivo quiera levantarse un poco a la contemplación general de los fenómenos naturales. El paso que Hartmann cree necesario sería fatal para él y para las ciencias naturales». ${ }^{129}$

Perojo no sólo fue admirador de las ciencias naturales, sino que lo era también del sistema universitario alemán. En su artículo "Crónica de la literatura alemana», publicado en la Revista Contemporánea el 20 de febrero de 1876, mostraba su simpatía hacia la forma de enseñanza y de captación de profesorado practicados en Alemania:

Nuestro sistema científico de enseñanza está en un lastimosísimo estado, y los que no lo observan o se contentan con él obran como aquellos que no saben más idioma que el propio, que no saben ninguno, como decía Goethe. Nosotros seguimos aún en las universidades tratando a los alumnos de facultad mayor como a niños de escuela, seguimos preguntándoles la lección, examinándoles a fin de curso y dándoles notas para regocijo de sus padres. Seguimos proveyendo las clases por el pernicioso método de oposiciones, malhadada herencia del escolasticismo y desterrado hoy en toda clase de procedimientos científicos, porque ni prueban ni garantizan

127 Ib., p. 104-105.

128 "Cuanto más arriba te levantes, tanto más general llegará a ser siempre tu vista», $I b$., p. 105.

$129 \mathrm{Ib} ., \mathrm{p} .108$. 
mejor las necesidades de la enseñanza, antes al contrario, ponen en manos de camarillas y compadrazgos lo que sólo al Estado compete. ${ }^{130}$

La enseñanza fue siempre una de las preocupaciones de Perojo. Léanse los artículos que a ella dedica en el periódico Nuevo Mundo, ya en los últimos meses de su existencia, y se verá cuán a fondo conocía el problema, comparándolo con el estado de la enseñanza en Inglaterra, sobre todo, pero también en Francia, Suiza, Alemania, Estados Unidos. Llama la atención el tono regeneracionista de Perojo, que no acudía a los lirismos o declamaciones de otros autores, sino a datos concretos y a propuestas que evitaban ser política de partido, ofreciendo, en cambio, análisis determinados, con indicación de los quehaceres en la formación de niños y en la formación de maestros y, a través de ello, en la formación de una España próspera. Sobre el tema escribió artículos y pronunció conferencias, además de publicar los libros, Ensayos sobre educación (1907) y La educación española (1908). Aunque manifestó animadversión hacia el krausismo, su programa educativo tenía un evidente paralelismo con el de Giner de los Ríos.

Las consideraciones de Perojo sobre Cuba no formaron parte directa de la polémica y por ello no nos detendremos en ellas, pero sí fueron importantes para definir su liberalismo, que en este caso revelaba una concepción elitista, con todos los prejuicios de un blanco europeo racista. Para él, los cubanos blancos eran europeos, los negros eran africanos. Su posición consistió en defender la autonomía en el terreno económico y que Cuba fuera en lo político una provincia más de España. Nunca fue partidario de la revolución independentista y, si nombró alguna vez al héroe de esa revolución, José Martí, fue para hablar negativamente de él. En la polémica que Perojo sostuvo en 1884 con Juan Gualberto Gómez quedó bastante claro su darwinismo social en el sentido racista y elitista en que circuló entre las capas burguesas de Europa y Estados Unidos. Lo que Perojo escribió sobre los negros de Haití, cuya rebelión (la de los esclavos frente a la minoría blanca) dio lugar a la primera república independiente de América Latina, fue de una índole tan ruin, que causa rubor; incluso si se sabe que en Francia, la potencia que dominaba la isla, se oyeron, como se oyeron también en Estados Unidos, las miserables leyendas que cuenta Perojo en artículos como «La raza negra en los pueblos civilizados». ${ }^{131}$ Poco podían esperar los amigos de Martí de un político como Perojo, cuyos méritos no se hallaban ciertamente en tales artículos.

$130 \mathrm{Ib}$., p. 110.

131 Gaceta Universal, 7, 8 y 11 de junio de 1884. Véase el comentario crítico de D. Díaz Regadera en su ya citada tesis, II, pp. 413-419. 


\section{La polémica de la ciencia en la Espańa de la Restauración (1876-1898). Dos tomistas en la polémica: notas biográficas}

Dr. Gerardo Bolado Universidad de Cantabria

I. Alejandro Pidal y Mon (1846-1913) ${ }^{132}$ fue un político e intelectual católico, nacido en Madrid el 26 de agosto de 1846. Era hijo del político y erudito asturiano Pedro José Pidal y Carniado, primer marqués de Pidal, y de Manuela Mon y Menéndez, cuyo hermano Alejandro fue ministro de Hacienda y diplomático. Su educación familiar fue profundamente católica y de compromiso con el orden tradicional. Cursó la enseñanza secundaria en el Instituto de San Isidro de Madrid y se licenció en Derecho en la Universidad Central. En 1868 se unió en matrimonio con Ignacia Bernaldo de Quirós, hija del marqués de Camposagrado, que le dio quince hijos, trece de los cuales llegaron a la edad adulta. Su hermano Luis, jurista de formación, fue el segundo marqués de Pidal, y desarrolló una importante carrera política y académica, paralela a la suya.

La teología y la filosofía de Santo Tomás, en las que tuvo como principal maestro y referente a fray Ceferino González, fueron la base de su ideario tradicionalista y de su práctica política comprometida con la jerarquía católica y la corona. Formó parte del grupo de neocatólicos que puso en marcha el semanario La Cruzada en 1867, en el que publicó con frecuencia artículos sobre el pensamiento del Aquinate. En los escritos de Santo Tomás se encontraban de modo eminencial los principios teóricos, desde los que sistematizar los conocimientos científicos, y los principios prácticos sobre los que edificar

132 Joaquín Fernández, El zar de Asturias: Alejandro Pidal y Mon (1846-1913), Gijón, Ediciones Trea S. L., 1997. 
el orden moral, económico y político católico de las sociedades modernas. La restauración del tomismo era a su juicio la única salida de la profunda crisis cultural a la que habían conducido a la sociedad moderna, el librepensamiento y los movimientos revolucionarios. Un buen exponente del tomismo tradicionalista que representó Alejandro Pidal es su monografía Santo Tomás de Aquino (Madrid: Imprenta de la viuda e hijo de D. E. Aguado, 1875).

En 1872 obtuvo su primera acta de diputado por Villaviciosa (Asturias), dando comienzo así a una larga carrera política dentro del grupo conservador -sólo interrumpida en la legislatura de la primera República. Toda su actividad pública estuvo consagrada a la realización de las directrices de la Iglesia católica dentro del orden político-institucional monárquico. Con este fin fundó en 1874 y dirigió La España Católica, que pasó a llamarse simplemente La España un año después. A lo largo de 1876, Alejandro Pidal sostuvo una dura confrontación con Antonio Cánovas del Castillo por considerar que hacía demasiadas concesiones al liberalismo revolucionario, perdiendo así la ocasión de implementar la restauración efectiva de la monarquía católica. Hasta 1883 se mantuvo en el grupo conservador, pero sin comprometerse con el Estado ni participar activamente en sus instituciones de gobierno.

En marzo de 1877, Alejandro Pidal irrumpió en la polémica de la ciencia española desde el diario que dirigía, La España, con dos artículos titulados "LLa ciencia española” por D. Marcelino Menéndez y Pelayo», I y II. El primero era elogioso y declaraba la victoria del joven polemista católico sobre los racionalistas; el segundo, en cambio, negaba la existencia de una tradición filosófico-científica española, y afirmaba que la filosofía española era la católica por excelencia, el tomismo. La intervención polémica de Pidal se convirtió pronto en colaboración amistosa en La ciencia española (2a edición, 1979), y a él va dedicada la segunda parte de esa obra. De hecho, los hermanos Pidal, Alejandro y Luis, se implicaron decididamente en el cambio de normativa que permitió a Menéndez Pelayo opositar a la cátedra de Amador de los Ríos. Sin embargo, la contradicción manifiesta entre lo defendido por Pidal en los artículos, publicados por La España, dio alas a José del Perojo para intervenir en la polémica, argumentando de nuevo la tesis de Manuel de la Revilla; además, la exhortación pidaliana a que los dominicos intervinieran en la polémica, defendiendo el pabellón tomista, no le pasó desapercibida al padre Joaquín Fonseca, que la reavivó al servicio del integrismo católico en 1882.

En respuesta al cambio de estrategia ante el Estado y sus instituciones de gobierno, pedida por el papa León XIII a los católicos españoles, Alejandro Pidal fundó La Unión Católica a la que dotó de su propio órgano de prensa, el diario La Unión (2 de enero de 1882-8 de octubre de 1887). La prensa integrista atacó 
a la agrupación política católica de Pidal, presidida por el arzobispo-cardenal de Toledo, Juan Ignacio Moreno y Maisanove, dando lugar a la encíclica conciliadora, Cum multa sint (8-12-1882), del nuevo pontífice. Por indicación de éste, La Unión Católica se incorporó en enero de 1884 al Partido Liberal Conservador, y Alejandro Pidal entró a formar parte del gobierno conservador de Cánovas del Castillo, como ministro de Fomento. Menéndez Pelayo que era miembro de $\mathrm{La}$ Unión Católica, obtuvo entonces su Acta de diputado por Palma de Mallorca y colaboró en materias de instrucción pública del Ministerio de Fomento.

Alejandro Pidal desarrolló una influyente actividad política. Fue presidente del Congreso de Diputados en tres ocasiones con gobiernos conservadores: entre marzo de 1891 y diciembre de 1892 , entre mayo de 1896 y julio de 1897 y, finalmente, entre junio de 1899 y abril de 1900. En noviembre de este año fue nombrado embajador ante la Santa Sede, cargo que ejerció hasta enero de 1902, cuando presentó su renuncia, motivada por el proyecto de reforma del Concordato que impulsaba el gobierno progresista de Práxedes Mateo Sagasta. Fue consejero de Estado en el bienio 1906-1908.

Por su actividad política e intelectual a favor del catolicismo, León XIII le otorgó el 8 de mayo de 1891 la Caballero Gran Cruz de la Orden de San Gregorio Magno. Y por su fidelidad a la institución monárquica, fue asimismo nombrado caballero de la Orden del Toisón de Oro.

Alejandro Pidal perteneció a la Real Academia de Jurisprudencia y Legislación de Madrid, de la que fue presidente en el período 1895-1896. Fue miembro, así mismo, de la Real Academia de Ciencias Morales y Políticas, en la que tomó posesión de la medalla n. ${ }^{\circ} 26$, el 3 de abril de 1887, con el discurso titulado De la metafísica contra el naturalismo. Además, fue miembro de la Real Academia Española -a propuesta de Menéndez Pelayo y otros en 1882-, y en la que ingresó el 29 de abril de 1883 con el discurso titulado Elocuencia de la filosofía. En 1906 fue elegido director de la Academia Española, en detrimento de la candidatura de Menéndez Pelayo, lo que desató fuertes críticas en la prensa y motivó la publicación de un manifiesto firmado por un numeroso grupo de intelectuales madrileños de todo signo ideológico. Esta injusta desconsideración distanció de esa Academia a Menéndez Pelayo, que interrumpió entonces sus trabajos de edición del teatro de Lope, y le separó definitivamente de Alejandro Pidal con el que apenas mantenía relaciones entonces.

Alejandro Pidal y Mon fue elegido, así mismo, miembro de la Real Academia de la Historia, pero no llegó a leer su discurso de ingreso, pues falleció en Madrid el 19 de octubre de 1913. Por deseo expreso de la familia, su cadáver fue trasladado al panteón familiar en la cripta de la Colegiata de Covadonga (Asturias), donde recibió sepultura junto a su padre. 
II. Joaquín Fonseca Álvarez (1822-1890). No está escrita la biografía de este teólogo dominico, rector de la Universidad de Santo Tomás de Filipinas, que nació el 10 de noviembre de 1822 en Aramil, parroquia del concejo de Siero (Asturias). Debió de destacar en los primeros estudios, inclinándose en la adolescencia a la carrera eclesiástica. Cuando tenía 18 años ingresó en el convento de Santo Domingo de Guzmán en Ocaña (Toledo), donde hizo el noviciado y profesó el 6 de diciembre de 1841. El joven religioso dominico viajó entonces a Filipinas, para continuar su formación y desarrollar su actividad misionera. Fue adscrito al convento de Santo Domingo de Manila en 1842 y comenzó su formación filosófica y teológica en la Universidad de Santo Tomás de Filipinas. En diciembre de 1844, fue ordenado sacerdote, y tres años más tarde se graduó en Filosofía por la Universidad de Santo Tomás. En esta misma Universidad obtuvo el grado de doctor en Teología el 30 de septiembre de 1853.

Entre 1847 y 1851 enseñó filosofía en la Universidad de Santo Tomás. Posteriormente, desempeño las cátedras de Vísperas y de Prima de Teología. Entre sus estudiantes de filosofía y de teología moral, destacó fray Ceferino González que fue cardenal primado de España y figura clave de la renovación del tomismo en la Península Ibérica. Leyó la lección inaugural del curso universitario 1868-1869 en la Universidad de Santo Tomás, de la que fue poco después vicerrector. En ese período Fonseca revisó y editó los cinco volúmenes de la Historia de los PP. Dominicos en las islas Filipinas... (1871) ${ }^{133}$, obra inédita del rector Fr. Juan Ferrando; además, publicó su diálogo Santo Tomás de Aquino en presencia de San Alberto Magno... (1874). ${ }^{134}$

En 1874 estaba de vuelta en el convento de Santo Domingo, en Ocaña (Toledo), donde fue nombrado regente de estudios y profesor de teología; si bien debió de desempeñar esta función también en el convento de Santo Tomás de Ávila. Fue entonces, cuando Menéndez Pelayo recibió la primera noticia del padre Fonseca a través de una carta, enviada por Gumersindo Laverde desde Valladolid, el 2 de noviembre de 1874, en la cual le sugería ponerse en contacto con algunos filósofos y teólogos tomistas de su red antikrausista:

133 Historia de los PP. Dominicos en las islas Filipinas y en sus misiones del Japón, China, Tung-Kin y Formosa, que comprende los sucesos principales de la historia general de este archipiélago, desde el descubrimiento y conquista de estas islas por las flotas españolas, hasta el año de 1840. Obra original e inédita del M. R. P. Fr. Juan Ferrando, rector y cancelario que fue de la Universidad de Santo Tomás de Manila, y corregida, variada y refundida en su plan, en sus formas y en su estilo por el M. R. P. Fr. Joaquín Fonseca, profesor de Teología y Vicerector de la misma Universidad. Con un apéndice hasta nuestros días. Madrid: Imprenta y Estereotipia de M. Rivadeneyra, 1871. T. I: 264 p.+índice, T. II: 220 p.+índice, T. III: 289 p.+índice, T. IV: 281, 36 p.+índice, T. V: 322 p., XXXVI (Tablas Cronológicas).

134 Manila, Imp. del Colegio de Santo Tomás, 1874. 
El P. Joaquín Fonseca, asturiano, dominico en Ocańa, autor de un Canto épico sobre lo del Callao, de un poema sobre Sto. Tomás de Aquino y Alberto Magno (que forma un tomo) y no sé si de otras obras, es verosímil que sea también traductor. Nada perderá V. con escribirle. Quizá le sea también útil para adquirir noticias de traductores y escritores de Filipinas. El mejor modo de ponerse $\mathrm{V}$. en correspondencia con él será que en mi nombre visite al Ilmo. Sr. Fr. Zeferino González, (Pasión 15), a quién escribo hablándole de V. También, si quiere, puede visitar a Ortí y Lara. ${ }^{135}$

El padre Fonseca intervino en la polémica desatada por la Historia de los conflictos entre la religión y la ciencia (1876), de Juan Guillermo Draper, que estimuló además el concurso de la Academia de Ciencias Morales y Políticas sobre el tema «Demostración de que entre la religión católica y la ciencia no pueden existir conflictos», convocado a expensas del marqués de Guadairo el 13 julio de 1877. Este mismo año hubiera irrumpido en la polémica sobre la ciencia española, respondiendo al escrito «in dubiis libertas» de Menéndez Pelayo, de no habérselo impedido su nombramiento como rector de la Universidad de Santo Tomás en Filipinas, cargo que desempeñó en Manila entre 1878 y 1880. En su «Ofrenda poética al Angélico Doctor Sto. Tomás de Aquino ...» (1880), el rector Fonseca expresó en verso su fe en el triunfo del tomismo y en el vínculo de éste con la labor civilizatoria de España en oriente:

De Alcalá y Salamanca las aulas ya despiertan cantando victorias aspirando las auras de Gloria que Tomás a la Iglesia dará.

De Legazpi la perla preciosa y su ilustre Academia repite ese canto triunfal que transmite armonioso a las brumas del mar. ${ }^{136}$

De vuelta en España, el padre Fonseca intervino en el Triduo dedicado a Santo Tomás de Aquino en marzo de 1881 por los PP. Dominicos del Convento de Corias con motivo del patronato universal de las Escuelas Católicas adjudicado al Angélico Doctor por la Santidad de León XIII. El teólogo dominico le envió a Menéndez Pelayo el impreso del Triduo ${ }^{137}$, cuya «Nota 33» era un ejercicio de exclusivismo

135 EMP, tomo 1 , n. ${ }^{\circ} 140$.

136 «Ofrenda poética al Angélico Doctor Sto. Tomás de Aquino gloriosamente preconizado Maestro Supremo de las Escuelas Católicas por Nuestro Santísimo Padre León XIII en su inmortal encíclica "Aeterni Patris”», Boletín Eclesiástico IV, (12 marzo 1880), pp. 85-86.

137 Oviedo, Imp. Vallina, 1881. 
tomista contra la posición tradicional pelayana. ${ }^{138} \mathrm{El}$ joven polemista no pudo evitar que este tomista íntegro irrumpiera un año más tarde en la polémica de la ciencia espańola, formando parte de la campańa que lanzó la prensa integrista contra los intelectuales mestizos de la Unión Católica. La mencionada «Nota 33» del Triduo fue publicada en agosto de 1882 por El Siglo Futuro, bajo el título "Defensa de la doctrina de Santo Tomás por el R. P. Joaquín Fonseca», y en octubre del mismo ańo por La Ciencia Cristiana, bajo el título «Defensa de la filosofía cristiana». Menéndez Pelayo respondió el 16 de agosto desde La Unión con su escrito "Contestación a un filósofo tomista». El integrista dominico replicó con la serie, «Contestación de un tomista a un filósofo del Renacimiento» que se publicó en diez entregas de El Siglo Futuro entre el 14 y el 23 de septiembre de1882, y en La Ciencia Cristiana entre octubre y diciembre del mismo año.

El padre Fonseca formaba parte del movimiento intelectual que promovió la restauración del tomismo, y en el que destacaba su antiguo alumno y colega en la docencia universitaria, fray Zeferino González. Fonseca sabía que la Aeterni Patris preconizaba una lectura actualizada y contemporánea de la obra de Santo Tomás, y así lo expresó en su lección inaugural del curso 1888-1889 en el Estudio General del convento de Santo Tomás en Ávila: «... procuremos asimismo estudiarla y comprenderla en sus relaciones trascendentales con todas las demás ciencias, las físicas, naturales, ontológicas, experimentales e inductivas... también es necesario estudiar y comprender el contenido profundo de la Summa Theologica en sus relaciones transcendentes con las doctrinas sociales, políticas, filosóficas y artísticas». ${ }^{139}$ Sin embargo, los textos con los que este dominico intervino en la polémica de la ciencia, eran anacrónicos y sectarios, a pesar de su familiaridad con los textos de la Summa theologica, debido, por un lado, a su exclusivismo tomista, y, por otro, tanto a su carencia de sentido y de conocimiento histórico en el campo de la filosofía y de las ciencias, como a su desconocimiento de los desarrollos contemporáneos de la lógica y la metodología científica, de la psicología científica y filosófica, y del pensamiento filosófico-científico.

En los últimos años de su vida residió en el convento de Santo Tomás en Ávila, donde falleció el 18 de enero de 1890 a causa de una pulmonía, cuando contaba con 68 años de edad.

138 Ib., 57-74.

139 José Antonio Varela Silva, «Sobre la formación tomista del cardenal Zeferino González (1831-1894)», Anuario Historia de la Iglesia, 3 (1994) 464. Varela toma la referencia de Álvaro Huerga, "La recepción de la "Aeterni Patris» en Espańa», Scripta theologica, 11:2 (1979), pp. 555-556. 


\section{La lucha por el reconocimiento de la cultura hispánica. Análisis argumentativo de la polémica de la ciencia espańola}

Dr. Gerardo Bolado

Universidad de Cantabria

$\mathrm{L}$ a polémica de la ciencia espańola no fue un debate abstracto de carácter histórico erudito, o académico, ni tuvo por objeto lo que por entonces consideraban «ciencias» los positivistas, sino una polémica antikrausista, por la dirección de la cultura y de la educación, protagonizada por el historicismo católico frente al racionalismo liberal, heredero del krausismo, y en la que terció además el tradicionalismo tomista. Se trató, por tanto, de una manifestación histórica esencial de la dialéctica invertida entre tradición y modernidad que dinamizó la cultura intelectual de la Espańa contemporánea, y que devino especialmente virulenta en la atmósfera positivista y restauradora de los primeros compases del sistema canovista. Aunque no fue tampoco una polémica subjetiva, de autor, en ella comenzó el ascenso meteórico de Marcelino Menéndez Pelayo, autor de una colosal obra histórica, la que más contribuyó a los estudios históricos de nuestra cultura intelectual y literaria en la Restauración.

\section{El contexto histórico de la polémica de la ciencia española}

La regeneración de la tradición nacional que necesitaba la monarquía Alfonsina restaurada, fue precisamente el proceso histórico en el que discurre la polémica de la ciencia española, la cual se desarrolló en distintos contextos argumentativos, relevantes para nuestro análisis, y que no siempre coinciden con los correspondientes a la publicación de las tres ediciones de la obra. 
1. El contexto histórico cultural de Polémicas, indicaciones y proyectos sobre la ciencia española (1876), que resulta de la reacción de los políticos e intelectuales católicos frente a los liberales en los albores de la Restauración, tiene que ver sobre todo con la segunda cuestión universitaria y con el resurgir de las polémicas antikrausistas.

En efecto, el real decreto de 26 febrero de 1975 del ministro de Fomento, marqués de Orovio, impuso a los profesores universitarios la supervisión del libro de texto y del programa de su materia; además, la circular que lo acompañaba, confiaba a los rectores la tarea de velar para que la docencia en sus distritos universitarios respetara tanto el dogma y la moral católica, como la Monarquía constitucional y el orden político vigentes. El resultado de esta medida fue la exclusión de la Universidad de los catedráticos herederos del krausismo que se opusieron en primera instancia a esas restricciones de la libertad de cátedra, y la puesta en marcha de la Institución Libre de Enseñanza.

Entre los catedráticos sancionados se contaban Gumersindo de Azcárate y Nicolás Salmerón, que también había sido apartado de su cátedra en la primera cuestión universitaria de 1867. Las publicaciones de estos herederos del krausismo en el año 1876, que dieron ocasión a la polémica, responden entre otras cosas a su especial compromiso en esos momentos críticos con principios del librepensamiento, como la libertad de cátedra y la incompatibilidad de la investigación científica de la verdad con la falta de libertad política y religiosa, con la Iglesia católica y sus dogmas.

El desencuentro de Menéndez Pelayo con su profesor de Metafísica en la Universidad Central de Madrid, Nicolás Salmerón, propició su encuentro en la Universidad de Valladolid con su paisano, el catedrático de literatura latina de esta Universidad, Gumersindo Laverde. Este tradicionalista, que era uno de los nódulos de la red de polemistas antikrausistas, había reivindicado sin éxito, entre 1856 y 1858, la filosofía española frente a la tendencia extranjerizante de Sanz del Río. Laverde defendía un tradicionalismo filosófico en el que la filosofía era ciencia primera y luz de las restantes ciencias, y aspiraba a la restauración de la tradición filosófica española.

Incapaz de protagonizar el replanteamiento de sus proyectos en aquel momento propicio, Gumersindo Laverde vio en Menéndez Pelayo el instrumento providencial para llevarlos adelante. La intensa correspondencia epistolar, mantenida con el joven licenciado santanderino desde octubre de 1874, fue el medio para transmitirle su programa y convertirle en el precoz polemista de La ciencia española. En el anexo a su carta de 7 abril de 1876, Laverde le propuso responder a Gumersindo de Azcárate y le explicó cómo 
hacerlo, en unas indicaciones que el joven polemista siguió fielmente; además, le trasmitió las posiciones de principio y los tópicos argumentativos, sus hipótesis y muchos de los datos históricos y, desde luego, sus proyectos de recuperación de la funcionalidad socio-histórica de la tradición científica española.

Sin embargo, los tiempos habían cambiado. La alternativa regeneradora de la cultura española frente al Catolicismo y su Teología, ya no era para el racionalismo liberal la incorporación de una filosofía especulativa contemporánea. Los éxitos de las ciencias y el triunfo del positivismo propiciaron la sustitución de la filosofía por la ciencia en el programa progresista de regeneración cultural. La alternativa a la estéril tradición era entonces para los racionalistas la regeneración científica, por lo que la discusión sobre la existencia de la filosofía española dejó su lugar a la polémica de la ciencia española. Por otra parte, el tradicionalismo filosófico de Laverde dejó su lugar al historicismo católico de Menéndez Pelayo que ponía los medios historiográficos al servicio del reconocimiento histórico de la tradición cultural hispánica, y de su restablecimiento.

2. La publicación de La ciencia española. Polémicas, indicaciones y proyectos (1879), se produjo pocos meses después de que el papa León XIII (1878-1903) promulgara su encíclica Aeterni Patris. Sobre la restauración de la filosofía cristiana conforme a la doctrina de Santo Tomás de Aquino (4 de agosto 1879). Aunque los textos incluidos en esa segunda edición corregida y aumentada son anteriores al contexto filosófico católico posterior a esa encíclica, promotora de la restauración del tomismo, lo cierto es que fray Ceferino González y su pupilo Alejandro Pidal y Mon, entre otros, se movían desde el comienzo de la polémica en esa misma dirección restauradora.

En su obra fundamental, Estudios sobre la filosofía de Santo Tomás (Manila, 1864), fray Ceferino González y Díaz Tuñón (1836-1894), además de demostrar un conocimiento de la obra de Santo Tomás, amplio, profundo, y confrontado con la ciencia de su tiempo, se adelantaba a la Aeterni Patris en su concepción del tomismo como philosophia perennis ${ }^{140}$. A comienzos de la década de los setenta pudo transmitir su apuesta decidida por la restauración del tomismo a un grupo de jóvenes que jugarían un papel importante en la misma, si bien con distintas actitudes: Juan Manuel Ortí y Lara, Alejandro Pidal y Mon, Antonio Hernández Fajarnés, Eduardo de Hinojosa, entre otros. La influencia de su figura en el catolicismo español

140 E. Forment, Historia de la filosofía tomista en la España contemporánea, Madrid, Editorial Encuentro, 1998, p. 19. 
no dejó de crecer, desde que fue promovido al cargo de obispo de Córdoba por Pío IX en julio de 1875, hasta que fue nombrado cardenal por León XIII, en noviembre de 1884, y promovido por Alfonso XII a arzobispo de Toledo, patriarca de las Indias y capellán de Su Majestad en marzo de 1885. Muerto en noviembre de 1894, el cardenal Ceferino González es una de las grandes figuras de la renovación del tomismo en la España de la segunda mitad del siglo XIX, así como de la revitalización del estudio de su obra en la Orden de Santo Domingo durante ese período. ${ }^{141}$

Siguiendo la orientación de este gran tomista dominico, Alejandro Pidal y Mon (1846-1913) convirtió la doctrina del Doctor Angélico en la fuente de los principios rectores de su actividad política al servicio de la tradición católica y su Iglesia romana. En su monografía, Santo Tomás de Aquino (1875), escribió que

... todas las grandes cuestiones teológicas, filosóficas, políticas, sociales, económicas, artísticas, de nuestro tiempo están tratadas por Santo Tomás por modo eminente, en cuanto que sentó los principios fundamentales que deben ser la base de las posteriores consecuencias y de las aplicaciones particulares. ${ }^{142}$

En esa misma monografía, expresó su apuesta decidida por «... el advenimiento, de ese día cuya aurora entrevemos próxima, en que la ciencia de Tomás impere en todas las inteligencias... de la cristiandad purificada.» ${ }^{143}$

En marzo de 1877, Pidal y Mon introdujo el punto de vista del tradicionalismo tomista en la polémica de la ciencia espańola, defendiendo que nuestra tradición científica es la escolástica y que Santo Tomás es el príncipe de las Escuelas. De que esta tendencia restauradora estaba vigente y preocupaba en los medios católicos más abiertos, es una prueba el artículo, "La restauración de la escolástica», en el que Pedro Sala y Villaret expone las negativas consecuencias socio-políticas y culturales que se derivarían de la misma. ${ }^{144}$

3. Aunque la tercera edición refundida y aumentada, La ciencia española. (Polémicas, proyectos y bibliografía) (1887-1889), recoge los dos textos pelayanos que completan su polémica con el tradicionalismo tomista, esa

141 Ib. p. 21.

142 A. Pidal y Mon, Santo Tomás de Aquino, Madrid, Viuda e hijos de Aguado, 1875, p. 175.

143 Ib., p. 15-16.

144 P. Sala y Villaret, «La restauración de la escolástica». Revista de España, n. ${ }^{2} 28$, (1877), pp. 459-487. 
publicación pertenece a un momento distinto de la defensa pelayana de la tradición, caracterizado por la aportación del inventario bibliográfico y de los estudios monográfico-reivindicativos. El contexto de esta edición que es el triunfal del prestigioso catedrático y académico, del reconocido autor de la Historia de las ideas estéticas..., del editor de las obras completas de Milá y Fontanals y del mantenedor de los Jocs Florals (1888), etc., no es el contexto polémico del autor del tercer tomo de los Heterodoxos... que respondió al padre Fonseca.

La circunstancia histórica de la polémica con este teólogo dominico fue el ambiente de crispación y enfrentamiento que crearon los carlistas y, en general, los católicos íntegros, a lo largo de 1882, frente a la reciente puesta en marcha de la Unión Católica por parte de Pidal y Mon y su grupo. Con la aprobación de la jerarquía eclesiástica española y del papa León XIII, esa agrupación política aspiraba a aglutinar a todos los católicos, con independencia de sus posicionamientos políticos, en defensa de los intereses de su religión en los distintos ámbitos de la vida pública, en la Monarquía constitucional.

Ese mismo año, la conmemoración del centenario de la muerte de Santa Teresa de Jesús formó parte de la estrategia integrista de sensibilización de la opinión pública católica, no sólo frente al gobierno liberal de Sagasta, sino también contra los católicos mestizos de la Unión Católica que «transigían» con sus políticas. La exaltación integrista de la Santa resaltaba ante la opinión pública católica la pureza de su fe católica romana, profesada de manera íntegra; por lo que no hacía concesiones a los estudios históricos interesados en aspectos intelectuales o estético-literarios de su obra mística. En este contexto tradicionalista, encajó perfectamente la publicación de la extensa «Contestación de un tomista a un filósofo del Renacimiento», del padre Fonseca, que contenía un auténtico vade mecum de la más rancia teología mística tomista.

4. La primera edición de los Ensayos de crítica filosófica (1892), que son histórico-reivindicativos, incluye alusiones polémicas en las que Menéndez Pelayo responde a la desconsiderada crítica de que habían sido objeto su persona y su obra en varios artículos del mallorquín, nacionalizado francés, José Miguel Guardia Bagur (1830-1897). Algunas de las críticas de ese médico librepensador, que sintonizaba con el grupo de la Revista Contemporánea, son expresión de la crisis finisecular del historicismo católico y de la historia erudita, de los que era singular exponente la obra histórica de Menéndez Pelayo, y contra los que reaccionó también Miguel de Unamuno en la serie de cinco ensayos que publicó La España Moderna entre febrero y junio de 1895, y que formaron parte después de En torno al casticismo (1902). 
Menéndez Pelayo era una de las grandes figuras de la cultura en la España finisecular y como tal participó en los fastos del IV Centenario del Descubrimiento de América. Había completado su programa de reivindicación histórica de nuestra tradición de pensamiento con la Historia de los heterodoxos españoles, con la tercera edición de La ciencia española, completada con los Ensayos de crítica filosófica, y con la Historia de las ideas estéticas en España; y, para el citado centenario, preparó por encargo de la RAE su Antología de poetas hispano-americanos (1893-1895), donde mostraba la grandeza que la proyección americana había conferido a nuestra lengua y a nuestras letras. La voz y la pluma del prestigioso catedrático de la Central y académico de la RAE, de la RAH, y de la RACMP, como dejó escrito Rubén Darío, se mantuvieron firmes en su defensa de la grandeza y fecundidad de nuestra Tradición histórica en medio del abatimiento político de España y de la tremenda crisis finisecular que a la postre tendría fatales consecuencias sobre su programa histórico tradicional de restablecimiento de la ciencia española.

\section{Análisis de los auditorios de la polémica}

En este apartado estudiamos los distintos auditorios de la polémica de la ciencia, con el fin de arrojar luz en la cuestión de su viabilidad. En la práctica de nuestro análisis, utilizamos un modelo procedente de Chaim Perelman que distingue los siguientes elementos constituyentes de un auditorio: hechos o creencias que una audiencia tiene sobre el mundo; verdades o conocimientos indiscutibles que son como axiomas o postulados; presunciones o conocimientos discutibles que se basan en argumentación probable; valores o deseos y preferencias de la audiencia; y, en fin, jerarquías o relaciones de primacía y prioridad entre los valores.

1. Auditorio de la primera polémica: historicismo católico versus racionalismo liberal.

La Revista de España, que era una de las revistas intelectuales más reputadas del momento, publicó la serie de artículos de Gumersindo de Azcárate, El Self Government y la Monarquía doctrinaria, el cuarto de los cuales contenía el pretexto que desató la polémica. Sin embargo, los textos de esta primera polémica se publicaron en otras dos revistas rivales que competían por ganar el reducido número de lectores demandantes de cultura filosófico-científica y literaria: la Revista Europea que publicó los textos de Menéndez Pelayo, Azcárate y Laverde; y la Revista Contemporánea que publicó los textos de Revilla, Vidart y José del Perojo. Este hispano-cubano de formación ger- 
mánica acababa de fundar la Revista Contemporánea, después de fracasar en su intento de adquirir la Revista Europea, de los editores Medina y Navarro.

El semanario liberal conservador, Revista Europea, fue una de las revistas de cultura filosófico-científica y literaria que más contribuyó a la renovación filosófica en lengua española durante el último cuarto del siglo xix. Publicó abundantes textos traducidos de importantes figuras del positivismo y del evolucionismo; pero también editó textos de neokantianos como Perojo, de hegelianos como Fabié o Castelar, de krausistas como Sanz del Río, de Canalejas en la polémica antikrausista del panenteísmo, etc. Cuando sacó a la luz los artículos pelayanos de la primera polémica (t. VII y VIII) en 1876, su editor era Eduardo Medina, su redactor jefe Armando Palacio Valdés, $\mathrm{y}$ entre sus lectores, que formaban un auditorio culto y exigente con los argumentos y las prácticas dialécticas, no faltaban los liberales receptivos a las razones de la tradición.

En el período que nos ocupa, 1876-1877, la recién fundada Revista Contemporánea era una publicación periódica de tendencia librepensadora, racionalista y europeísta, que sintonizaba con la Institución Libre de Enseńanza y su concepto de modernización cultural, y combatía decididamente el programa tradicional de Menéndez Pelayo. Su principal redactor, Rafael Montoro, sus colaboradores y lectores compartían las verdades y los hechos de los textos de Revilla que era por entonces una de sus principales firmas.

El auditorio racionalista de herederos del krausismo, que componían los lectores de la Revista Contemporánea y buena parte de la Revista Europea, creía en una serie de hechos inconcusos que les llevaban a descuidar la argumentación histórica, y a descalificar a los defensores de la Inquisición, tachándolos de «neocatólicos» enemigos de la libertad, de la razón y del progreso, y, con ello, de la civilización y de la humanidad. Mencionaré los siguientes:

- No ha existido una tradición filosófico-científica en la España moderna.

—La aportación de la España moderna a la literatura y a las artes ha sido importante.

—La decadencia filosófico-científica en la España moderna es consecuencia de la ausencia de libertad política y religiosa.

—La Inquisición es la causa de la decadencia civilizatoria de la España moderna.

Los valores que inspiraban a estos racionalistas, eran la libertad, la razón y el progreso, y de sus verdades, operativas en la polémica, explicitaré aquí las siguientes: 
— La libertad es condición necesaria del desarrollo de la razón.

—La razón que desarrollan las ciencias y la educación, es condición del progreso.

—La intolerancia católica y sus dogmas son incompatibles con la ciencia y la educación.

—El progreso supone la ruptura con la tradición y la autoridad.

Por el contrario, los tradicionales compartían una serie de hechos que les llevaban a insistir en la argumentación histórica y a considerar enemigos de la patria y del catolicismo, y, con ello, de la civilización y de la humanidad, a los que ignoraban y despreciaban la tradición hispánica. Mencionaré los siguientes «hechos»:

—El genio religioso español es católico, y la Inquisición una expresión suya libérrima.

-Nuestra decadencia civilizatoria se debió a múltiples factores socio-culturales.

-Existió una rica y plural tradición científica en la España moderna.

— La decadencia científica de España se debió a la pérdida de la propia tradición, por la injerencia civilizatoria de la Francia revolucionaria en el siglo XVIII.

Los valores que inspiraban a estos tradicionales eran providencia/libre albedrio, fe/razón, tradición/progreso, y de sus verdades operativas, referiré aquí:

- El catolicismo es la gran fuerza civilizatoria de Occidente.

—La Providencia divina rige los ciclos históricos y el destino de las naciones.

—La tradición preserva el destino histórico de las naciones, manteniendo la continuidad en su progreso histórico a través de la regeneración social y cultural.

—La tradición cumple sus funciones socio-históricas, cuando está viva y se cultiva.

A diferencia de los racionalistas, que creían en el auditorio universal, Menéndez Pelayo era consciente del condicionamiento retórico de los auditorios, y en ningún momento creyó en la posibilidad de convencer al auditorio racionalista de la Revista Contemporánea; ni siquiera moderó sus estrategias ad hominem y ad ridiculum como le sugirió Laverde, a fin de llegar a los lectores liberales de la Revista Europea que no veían con malos ojos la recuperación histórica de lo mejor de nuestra tradición filosófico-científi- 
ca. De hecho, la primera edición de La ciencia española, cuya estructura y estilo lleva la impronta del joven polemista, excluye los textos de Azcárate, Salmerón y Revilla, y se dirige decididamente al abigarrado auditorio católico español de los primeros compases de la Restauración, los últimos del papado de Pio IX.

2. Auditorio de la segunda polémica: tradicionalismo tomista versus historicismo católico; se completa la polémica del historicismo católico con el racionalismo liberal.

Alejandro Pidal y Mon dirigía en 1877 el periódico La España a fin de construir una opinión pública católica, fiel a las directrices de la jerarquía eclesiástica, y al servicio de los intereses de la Iglesia católica en el régimen monárquico restaurado. Se trataba de recomponer la unidad política de los católicos y de convertir al Catolicismo romano, de facto, en la religión del Estado. El director de La España y el entonces obispo de Córdoba, Ceferino González, de quien aquél dependía intelectualmente, representaban un tradicionalismo tomista, organizado y activo en la política liberal conservadora.

Buena parte de los lectores de La España componían un auditorio tradicionalista que creía en el hecho inconcuso de que la escolástica tomista era la auténtica tradición científica española, y de que sólo la restauración del tomismo podría sacarnos de la lamentable decadencia cultural, en especial filosófica, en que el liberalismo y el racionalismo habían sumido a Occidente. Entre las verdades indisputables del tradicionalismo tomista se contaban:

- La fe es la excelencia cognoscitiva superior que ilumina, corrige y completa a la razón.

—La vida histórica y la tradición radican y son inseparables de la revelación cristiana.

- La ciencia por excelencia es la Teología con la que la Philosophia perennis forma una unidad doctrinal.

—El tomismo es la Philosophia perennis.

Pidal y Mon entró en la polémica de la ciencia dirigiendo dos artículos al auditorio católico desde La España. En el primero elogiaba la intervención de Menéndez Pelayo y proclamaba su victoria sobre los racionalistas; pero en el segundo atacaba su concepción historicista de la Tradición filosófico-científica española, frente a la cual reivindicaba su concepción tomista de la misma. Por su parte, el joven polemista defendió frente a Pidal la compatibilidad de su programa tradicional con una bien entendida restauración del tomismo, dirigiéndose al mismo auditorio católico de La España. 
José del Perojo respondió a los dos artículos de Pidal, dirigiéndose al auditorio racionalista desde la Revista Contemporánea en un extenso artículo, en el que defendía la victoria de la posición de Revilla y de su revista en la polémica frente a los defensores de la historia de la filosofía y de la ciencia española. Menéndez Pelayo respondió al artículo de Perojo con tres demoledoras cartas, dirigidas al auditorio católico desde La España, y ya no recibió más réplicas de los racionalistas de la Revista Contemporánea.

En la segunda edición de La ciencia española (1879) que incluye los textos de esta segunda polémica, Menéndez Pelayo se dirige también a un auditorio católico que era aproximadamente el del periódico pidaliano $E l$ Fénix, y se desentiende del auditorio racionalista que le había cancelado su crédito intelectual por «neo». El autor de los Heterodoxos... dedica esta segunda edición a Pidal y Mon, e incluye en ella sus textos, dejando fuera, en cambio, el artículo de Perojo.

3. Auditorio de la tercera edición: tomismo integro versus historicismo católico.

Desde la fundación de la Unión Católica, el 29 de enero de 1881, y hasta más allá de la promulgación de la carta encíclica de León XIII, Cum multa sint... (8 diciembre de 1882), El Siglo Futuro, del carlista Cándido Nocedal, intentó agitar a la opinión pública católica contra esa agrupación política y sus intelectuales más conocidos. No podían permitir estos integristas, enemigos políticos de la Unión Católica, que el autor de La ciencia española, de los Heterodoxos... y del «Brindis del Retiro» se adhiriese a ella sin cuestionar abiertamente la solvencia intelectual de su brillante pluma. La publicación de los ataques de Joaquín Fonseca contra Menéndez Pelayo, y la insistente reclamación de la respuesta de éste, formó parte de esa estrategia de confrontación del diario integrista católico.

Los dos textos con los que Menéndez Pelayo replicó a Fonseca fueron publicados con las justificaciones pertinentes por el diario La Unión, nacido el 2 de enero de 1882 como órgano oficial de la recién constituida Unión Católica. Se le considera continuador de los periódicos pidalianos, orientados a dirigir la opinión pública católica según las directrices de la jerarquía eclesiástica romana.

Pidal y Mon, buena parte de los colaboradores de La Unión, y la mayoría de sus lectores simpatizaban más con el tomismo íntegro de Fonseca que con el historicismo de Menéndez Pelayo.

El tradicionalista Juan Manuel Ortí y Lara que era colaborador de El Siglo Futuro, y director de La Ciencia Cristiana, orientaba esta revista quincenal a preconizar la restauración de la escolástica tomista y a combatir las 
doctrinas filosóficas o científicas rivales, v. g., el krausismo o el darwinismo, incluso las posiciones católicas independientes, como el historicismo de Menéndez Pelayo.

La Ciencia Cristiana se hizo eco de la polémica, omitiendo la última réplica del joven catedrático de la Central, para dar resonancia a los ataques de Fonseca y su defensa de una interpretación integrista de la Aeterni Patris y de una restauración de la doctrina del Doctor Angélico desde la lectura directa de sus textos.

El auditorio integrista y tomista de El Siglo Futuro o de La Ciencia Cristiana que compartía los hechos inconcusos y las verdades del auditorio tomista de La España, a las que me referí anteriormente, consideraba además como un hecho indisputable que la doctrina eminencial del Aquinate se encuentra en sus textos, y que debía de ser restaurada desde una lectura inmediata de los mismos.

Consideraban asimismo un hecho que Santo Tomás disponía de una inteligencia angélica que le dio acceso a los principios verdaderos y permanentes del conocimiento y de la acción humana.

En cambio, la tercera edición de La ciencia española (1887-1889), que vio la luz en un contexto alejado de esta polémica, se dirige con un interés historicista a un auditorio culto, universitario o académico, a fin de inclinarle a desarrollar su programa de reivindicación y restablecimiento de la tradición filosófico-científica y estético-artística española, y de facilitarle esta tarea ofreciéndole las bases bibliográficas y las indicaciones historiográficas de partida. Por eso incluye en ella sus textos de réplica al padre Fonseca, que completaban su defensa de la tradición científica española frente al tradicionalismo tomista, dejando fuera los artículos del dominico; y ańade nuevos textos histórico-reivindicativos y, sobre todo, el «Inventario bibliográfico de la ciencia española».

4. Ni en esta polémica de la ciencia, ni en los sucesivos «tribunales de la historia» que la han juzgado posteriormente, encontramos otra cosa que auditorios concretos y parciales, nunca el auditorio universal. La falta de claridad y de un mínimo acuerdo en la concepción de la filosofía, de las ciencias y de su clasificación, y, sobre todo, lo irreconciliable y discordante de los hechos, las verdades y los valores característicos de los auditorios correspondientes a las distintas posiciones en la polémica, a saber, el racionalismo progresista heredero del krausismo, el historicismo católico, el tradicionalismo tomista y el tomismo íntegro, dejaron de entrada sin una base suficiente de evidencias y valores compartidos a la polémica e hicieron prácticamente inviable su avance dialéctico. 


\section{Posiciones, estrategias argumentativas y tipos característicos de argumentos que intervienen en la polémica de la ciencia española}

En este análisis utilizo el modelo de argumento de Stephen Toulmin y la tipología de argumentos que expongo en "Los esquemas de argumentos y su clasificación, I». ${ }^{145}$ Los argumentos históricos del ejemplo y de la inducción son generalizaciones, es decir, pasos de lo particular a lo universal o de lo menos universal a lo más universal. En el argumento del ejemplo, el dato desde el que se generaliza es la evidencia de un ejemplo paradigmático o modelo; en el argumento de la inducción, el dato es un conjunto de evidencias particulares que fundan la generalización. Por otra parte, los argumentos documentales son las citas de documentos, libros, textos, fragmentos, etc.

\section{Historicismo católico versus racionalismo liberal}

\section{i. Polémicas, Indicaciones y Proyectos sobre la ciencia española (1876).}

En la carta «Indicaciones sobre la actividad intelectual en España en los tres últimos siglos», Menéndez Pelayo se posiciona contra un hecho inconcuso del auditorio racionalista que presentó Azcárate en su El Self Government... como si se tratara de una evidencia ejemplar: el Estado español habría negado la libertad política y religiosa durante los últimos tres siglos, ahogando así casi por completo la energía creadora y la actividad científica de nuestro pueblo. Menéndez Pelayo sostiene, por el contrario, que existió una actividad intelectual considerable en la España moderna que puede ser restablecida mediante el programa editorial e institucional de Laverde, y que debe de serlo, pues de ella depende nuestro futuro científico; además, rechaza que la Inquisición fuera la causa histórica de nuestra decadencia científica. Su argumentación se atiene a las indicaciones de Laverde, por lo que es equilibrada y fáctica. Menéndez Pelayo cuestiona que España experimentara una general decadencia científica entre los siglos XVI y XVIII, repasando las distintas clases de ciencias en ese período, y revisando además el papel de la Inquisición en cada caso. Predomina la argumentación histórica que se compone de argumentos documentales, del ejemplo, de la inducción, de la autoridad positiva y negativa, y se recurre también a la argumentación pragmática. Hay pocos argumen-

145 L. Vega; G. Bolado (eds.), La argumentación en el discurso público. Santander, Parlamento de Cantabria, 2011, pp. 177-215. 
tos ad hominem y separados de la argumentación histórica: «menosprecia lo que desconoce». Incluye una estrategia de reducción al absurdo, basada en contra-ejemplos, en la ignoratio elenchi, etc., y en el argumento negativo del experto para refutar la identificación del Santo Oficio como causa de la decadencia científica.

La carta «Prosíguese el pensamiento de las otras cartas», por su parte, argumenta contra Nicolás Salmerón, que fue un convidado de piedra en la polémica por exponer con especial beligerancia los presupuestos del racionalismo liberal en su prólogo a la versión española de la Historia de los conflictos entre la Religión y la Ciencia, de John G. Draper. Esta carta combina los argumentos ad hominem y ad ridiculum que componen una autocomplaciente estrategia de desautorización del catedrático de Metafísica en materia de historia de la cultura hispánica, junto con una estrategia histórica que incluye argumentos del ejemplo y de la inducción, positivos y negativos del experto, para defender que tuvimos tradición filosófico-científica y que la Inquisición no fue la causa de nuestra decadencia. No faltan las reducciones al absurdo basadas en contra-ejemplos, etc. Defiende la necesidad de restablecer la tradición, aplicando el programa de Laverde, con una estrategia tradicional-funcionalista compuesta de argumentos funcionales, pragmáticos, y de pendiente resbaladiza.

En su reseña del discurso de ingreso de Núnez de Arce en la Real Academia Española, Manuel de la Revilla corregía la posición del nuevo académico, que se remonta al menos hasta Juan Antonio Llorente y, según la cual, la intolerancia católica y su instrumento, la Inquisición, no sólo fueron la causa de la decadencia de nuestra filosofía y nuestras ciencias, sino también de nuestras bellas artes. Así se hacía eco de un hecho inconcuso entre los herederos del krausismo: la Inquisición española, lejos de impedir las letras y las artes, habría favorecido su desarrollo para distraer al pueblo privado de libertad. En este escrito, Revilla ridiculizaba la posición tradicional desde los hechos y las verdades del racionalismo liberal:

...[es] un mito esa decantada filosofía española, con cuya resurrección sueñan hoy eruditos como Laverde Ruiz y Menéndez y Pelayo... si en la historia literaria de Europa suponemos mucho, en la historia científica no somos nada... no es posible dudar de que en tan triste resultado cabe no pequeña parte a nuestra feroz intolerancia religiosa... ${ }^{146}$

Menéndez Pelayo respondió a ese ataque racionalista en su Mr. Masson redivivo, con una argumentación abigarrada y polémica que trenza casi todos

146 «Revista crítica», Revista Contemporánea, 30-05-1876, p. 507. 
sus argumentos históricos con argumentos ad hominem y ad ridiculum de descalificación del adversario. La estrategia histórica incluye argumentos del ejemplo, de la inducción histórica y de la autoridad positiva y negativa. Incluye además contra-argumentos para refutar falacias de la falsa causa, de tránsito, y de ignoratio elenchi, que encuentra en el texto de Revilla. La argumentación se orienta a defender la posición historicista: tuvimos una tradición filosófica y científica digna de estudio y necesaria para afrontar el futuro científico; la Inquisición no fue la causa de nuestra decadencia civilizatoria. Menciono algunos argumentos relevantes:

\section{Argumentación ad hominem:}

—Revilla es Mr. Masson: Desprecia lo que desconoce. Contribuye al descrédito internacional de la nación.

—La Revista Contemporánea es extranjerizante y anti-española.

—Revilla está «abierto a todo viento de doctrina», carece de sentido histórico, y es anticatólico.

Argumentación histórica:

-Del ejemplo histórico.

-El caso Zúniga.

—Las «cartas esféricas» de Alfonso de Santa Cruz y el «nonius» de Pedro Núñez.

- Hay multitud de científicos españoles.

—Vives, Sánchez, son filósofos críticos.

-De inducción histórica.

- La ciencia española despierta el interés de estudiosos de diversas naciones y tendencias.

—Hay escuelas filosóficas españolas relevantes: lulismo, vivismo y suarismo.

De autoridad negativa.

-No hay constancia documental de procesos o persecuciones inquisitoriales contra científicos.

—No hay índices condenatorios de Galileo, Descartes y Newton.

Contra-argumentación:

- Contra la falacia del verdadero tal.

-Formar escuela y tener influencia internacional son criterios externos y dudosos para establecer el valor de una filosofía. 
—La filosofía de Platón es importante por sí misma, no por criterios externos de influencia.

-De reducción al absurdo.

- Si caímos en atraso, hasta entonces estábamos adelantados

- Según ellos la intolerancia religiosa produce efectos contradictorios.

- Contra la ignoratio elenchi.

-No tener grandes científicos no implica carecer de tradición científica.

—La intolerancia religiosa no tenía por qué obstaculizar a las ciencias sin repercusión ideológica, como matemáticas, física, mineralogía, etc.

—La intolerancia no impide ni propicia el surgir del genio científico.

- Contra la falsa causa.

- La intolerancia religiosa no es una causa histórica, sino un arma partidista desgastada.

—La Inquisición no fue la única causa de la decadencia, ni la más decisiva.

- La carga de la prueba.

—Demuestre que la filosofía alemana ha destruido los fundamentos de las creencias.

Revilla replicó en «La Filosofía española. Contestación a un artículo del Sr. Menéndez y Pelayo», donde sostiene que «el Sr. Menéndez no ha dado ninguna razón sólida ni maciza en apoyo de su tesis», y reitera la posición racionalista:

la filosofía española, en el sentido de escuela nacional que haya ejercido verdadera influencia en el pensamiento humano, no existe ni ha existido nunca; como tampoco hemos tenido una historia científica de verdadera importancia. ${ }^{147}$

Su argumentación adquiere tintes polémicos, lo que evidencian, tanto la atención que presta a la estrategia ad hominem de Menéndez Pelayo, como el uso que hace el mismo de este tipo de ataques al adversario. Utiliza especialmente argumentos del verdadero tal y negativo del experto, para sostener

147 «La filosofía española. Contestación a un artículo del Sr. Menéndez y Pelayo», Revista Contemporánea, 15-08-1876, pp. 111-115. 
su afirmación de que España no ha tenido, ni tiene, verdadera historia científica, ni filosófica. Menciono algunos de sus argumentos:

\section{Contra argumentacion:}

\section{-Contra ad hominem.}

- La Revista Contemporánea publica en su mayor parte autores españoles y en español.

- La Revista Contemporánea divulga en España lo mejor que se hace en Europa, como la Revista Europea.

- No ataco a la religión ni al catolicismo, sino a los neos y a los defensores de la intolerancia y el fanatismo religioso.

-Reconocer la verdad histórica no es ser antipatriota.

-Argumentación ad hominem.

- No guarda las formas elementales en una polémica.

-Es un neo, enemigo de la civilización y de la patria, prototipo de una generación aburrida de eruditos.

—La enumeración de estudiosos de la ciencia española es un «desahogo de erudito»

-Argumentos del verdadero tal.

—Los verdaderos católicos no defienden la Inquisición, ni son romanos.

—Las medianías no dan importancia científica o filosófica a un país. En cambio, sí tenemos prosistas, dramaturgos, poetas y místicos de primer orden.

- No existe una creación filosófica española que haya formado una verdadera escuela original, de influencia en el pensamiento europeo, comparable con las producidas en otros países.

- No hay verdadera filosofía en España, no hay escuelas influyentes.

—El misticismo, no es posible identificarlo con la filosofía.

-Argumentos de analogía.

— La historia de las artes es una historia de genios, así debe ser también la historia de la ciencia.

-Como no hay "juanismo», tampoco hay vivismo.

Contra-argumentación histórica:

-Argumentos del ejemplo histórico. 
- Suárez un seguidor de la escolástica, mero expositor secundario de una doctrina extranjera.

—Vives y Fox Morcillo representantes, entre otros muchos, de la antiescolástica renacentista europea.

-Argumentos de inducción histórica.

-Sólo hay dos aportaciones científicas españolas: las cartas esféricas y el nonius.

- Los libros de Historia de la ciencia apenas hablan de autores españoles.

-Argumento ad populum.

—Nadie ha considerado ni a Teresa de Ávila ni a Juan de la Cruz como filósofos místicos.

- Carga de la prueba:

- No ha probado la existencia de creadores españoles fundadores de escuelas filosóficas occidentales.

La respuesta de Menéndez Pelayo a esta réplica de Revilla fue «Mr. Masson redimuerto", donde reitera su posición y con un estilo polémico semejante. Combina la estrategia de desautorización, ad hominem y ad ridiculum, con la argumentación histórica, que incluye argumentos del ejemplo y de inducción histórica, documentales, de analogía y de autoridad positiva y negativa. El progreso de la argumentación histórica es prácticamente inexistente, aunque se infle y enriquezca con algunos datos y ejemplos. Tienen más interés los contra argumentos detectando falacias de tránsito o falacias de autoridad negativa contra la existencia de una historia filosófica y científica española digna de ser historiada. Algunos argumentos nuevos son:

Argumentación ad hominem.

-Antiespañol: sufre cuando encuentra un nombre español en una historia de la ciencia

—Anticatólico: reconoce el mérito de árabes o judíos ibéricos, porque no son católicos.

-Pertenece a una generación de irresponsables charlatanes de ateneo.

Argumentación histórica:

-Argumentos del ejemplo histórico.

- Hay multitud de científicos españoles con contribuciones no despreciables. 
-Argumentos de inducción histórica.

- Hay una actividad científica considerable históricamente.

- Suárez no es discípulo, sino maestro, y maestro que cuenta a centenares los secuaces

—Vives tiene un sistema filosófico y de él parte un movimiento filosófico tan poderoso como el cartesianismo.

Argumentos de autoridad.

— Rousselot, Valera, Canalejas y Martín Mateos han estudiado nuestra filosofía mística.

Argumento de analogía.

- No se distingue entre kantismo y filosofía kantiana, luego tampoco entre misticismo y filosofía mística.

Contra-argumentación

-Refutación ad hominem

- Soy católico romano y partidario de la civilización católica, no neocatólico.

-Es una polémica, digo verdad, no deshonro moralmente y me comporto de manera más moderada que quien me acusa.

-Pertenezco a una generación educada en las bibliotecas con estudios de cal y canto

-Refutación del argumento del verdadero tal.

—Los científicos españoles tuvieron éxito, pero no se cuidaron de la fama.

-Refutación de la falacia de tránsito.

—Los talentos de segundo orden, los expositores, indagadores, etc., son dignos de memoria en la historia de las ciencias, aunque no lo sean en la historia de la estética y las bellas artes

- Juan no es precursor en doctrina, luego no hay comparación con Vives.

En la «Carta prólogo de La ciencia española», Gumersindo Laverde elogia la figura del joven defensor de la tradición española y proclama su victoria en la polémica, a la vez que le recomienda moderar su estrategia de desautorización. En ella encontramos gran parte de los tópicos argumentativos específicos que aparecen en las cartas de Menéndez Pelayo; pero con abun- 
dancia de argumentos funcionales, en los que el joven polemista se prodiga menos y de los que mencionaré los siguientes:

Argumentación funcional:

-Argumento de pendiente resbaladiza, basado en la función de preservar la vida cultural y la integridad de la nación, atribuida a la tradición.

-Argumento funcional, basado en la función de dar continuidad a los cambios en el progreso, que se atribuye a la tradición.

-Argumento funcional, basado en la función regeneradora de la vida científica, que se atribuye a la tradición.

En fin, Las obras de consulta de donde proceden las citas, los ejemplos o las teorías que sustentan la argumentación histórica de Menéndez Pelayo, en esta edición original de la polémica, están recogidas en las cartas «De re bibliográfica», «Monografías expositivo-críticas», «Prosíguese el pensamiento de las cartas anteriores»; también, en su frecuente correspondencia con Laverde. ${ }^{148}$ La idealización de los tópicos de la historiografía europea del período es el sustrato del argumento ad populum contra la tradición hispánica que parece latir bajo la argumentación racionalista.

\section{ii. La ciencia española. Polémicas, indicaciones y proyectos (1879).}

a. En «Una carta sobre la filosofía española», Azcárate entra activamente en polémica con Laverde. Rectifica su afirmación sobre el período de nuestra decadencia científica, que reduce a los siglos XVII y XVIII, pero sigue defendiendo, mediante un argumento de autoridad, la de Montalembert, que la Inquisición fue la causa de nuestra decadencia. Sobre todo, sostiene mediante un argumento por el efecto, "la hemos olvidado y la ignoramos», que nuestra tradición filosófico-científica quedó interrumpida; y que ya no es posible redescubrir y reanudar lo interrumpido, mediante un argumento ad hominem, «pasan... por arranques monomaníacos».

La «Contestación... a la última réplica del Sr. Azcárate», de Laverde, discute que la ciencia española sufriera una decadencia generalizada en los siglos XVII y XVIII, basándose en una argumentación que combina argumentos históricos del ejemplo, v. g., Solano de Luque, Hervás y Panduro, Esteban de Arteaga, etc., con el contra-argumento ad hominem que acusa a Azcárate

148 R. E. Mandado; G. Bolado, La ciencia española. Estudios, Santander, Publican Ediciones/RSMP, 2011, pp. 131-134. 
de dejarse llevar del prejuicio sistemático de libre pensador «que consiste en reputar imposible la vida cientifica donde y cuando quiera que esté vedado el poner en tela de juicio los dogmas religiosos». Reitera contra los argumentos de autoridad que la Inquisición «...no fue la única ni la más eficaz [causa de decadencia], digan lo que quieran Montalembert y otros escritores.»

Entre los apéndices de la segunda edición de La ciencia española, Menéndez Pelayo incluyó el texto de Laverde -no así el de Azcárate-, y su breve Nota final contra el argumento por el efecto de éste que había vuelto a defender el Sr. Vidart en su artículo «La Biblioteca de Autores Españoles y la historia literaria de España»: «sin duda debió interrumpirse el movimiento [científico español] a fines del siglo xvI, porque si así no fuese, ahora no ignoraríamos nuestro pasado científico». Articula para ello una breve argumentación histórica en la que defiende que el movimiento científico español fue interrumpido a finales del siglo XVIII, «debido exclusivamente al enciclopedismo y al espíritu francés», y coincidiendo con los hitos de su desarrollo en España. ${ }^{149}$ Defiende con argumentos del ejemplo que ni a finales del siglo XVII, ni en el XVIII, estaba olvidada nuestra tradición científica. Isaac Cardoso, Caramuel, Nicolás Antonio D. Juan Lucas Cortés, Hugo de Omerique, son sus ejemplos del siglo xvir. Feijoo, Tosca, Mayans, Martín Martínez, Hervás, Piquer, Forner, Lampillas, Andrés, y Cerdá y Rico, son los mencionados del siglo XVIII.

Y aduce las causas que a su juicio explican el olvido de nuestra tradición en el siglo XIX, «las gárrulas declamaciones de los políticos, la extinción de las comunidades religiosas, conservadoras de la tradición; las mal nacidas reformas y planes de estudios, el olvido de la lengua latina, la vandálica destrucción de muchas bibliotecas, la pereza intelectual y falta de seriedad científica que nos corroe, $y$, finalmente, el énfasis germanesco de esos señores que se jactan de ignorar nuestras cosas».

b. El texto más ambicioso de la posición racionalista que construye una argumentación histórica de sus hechos inconcusos, fue «La ciencia española bajo la Inquisición", con el que José del Perojo respondió a la primera intervención de Pidal y Mon en la polémica, aprovechando la cisura abierta por este tomista en la argumentación del historicista católico. Pretendía defender contra Pidal la victoria de Revilla en la polémica, demostrando definitivamente: $1 .^{\circ}$ Que no existe una escuela filosófica que propiamente pueda llamarse española; 2. ${ }^{\circ}$ Que la Inquisición paralizó todo el movimiento científico de nuestro pueblo.

149 MP, CE, I, 200. 
Perojo comienza con una beligerante estrategia de desautorización de Menéndez Pelayo, compuesta de argumentos ad hominem en los que le descalifica por neo y ultramontano, pseudoerudito, persona de escaso mérito, sin ideas ni argumentos, y tergiversador de las tesis de Revilla; y con un argumento ad populum, «todo el mundo comprendió, en vista del artículo del Sr. Revilla y de la réplica del Sr. Menéndez, la justicia con que nuestro compañero procedió».

A continuación defiende la inexistencia de filosofía española moderna con un argumento de la verdadera historia de la filosofía moderna, «en que es imposible introduzcan los que hablan de filosofía española algo que a ésta pertenezca», basado en una interpretación de la misma que la identifica con el proceso de pensamiento que conduce necesariamente de Bacon y Descartes a la filosofía crítica de Kant, concebida a su vez como fuente de la filosofía del siglo xix. Más aún, argumenta la imposibilidad de que exista la filosofía espańola moderna, aunque se diera en el presente el feliz hallazgo de algún sistema filosófico moderno producido con anterioridad en España, mediante una reducción al absurdo basada en un argumento de la verdadera historia de la filosofía que estaría regida por un determinismo teleológico: «La filosofía en su historia es el mismo pensamiento humano que se desenvuelve de un modo lógico y necesario, y no da en su seno cabida al arbitrio ni al capricho. Su única ley es la dialéctica». Los sistemas del pasado descubiertos en el presente, que no formaron parte en su momento de la vida histórica de la filosofía, es como si no hubieran existido. Por lo cual carece de sentido todo intento de búsqueda y reivindicación histórica de nuestro pasado filosófico, pues ningún nuevo descubrimiento podría cambiar lo que fue ni lo que es.

Establecido así que no tuvimos, ni podemos tener hasta el presente, filosofía española moderna, Perojo pasa a revisar «la verdadera importancia y significación que tiene nuestra patria filosofía». A tal fin, empieza estableciendo su propia periodización de la historia de la filosofía en Espańa: 1. ${ }^{\circ}$ Cristianos y paganos. 2. ${ }^{\circ}$ Árabes y hebreos. 3. ${ }^{\circ}$ Escolásticos y neoplatónicos. Por ello, sostiene en primer lugar la imposibilidad de tomar como punto de referencia nuestra filosofía actual, mediante un argumento de la causa histórica, "carecemos por completo de tradición filosófica... pues no hay entre nuestros filósofos proceso alguno del pensamiento y son en su mayor parte comentadores y divulgadores de escuelas...». Y, a continuación, argumenta contra la funcionalidad de la clasificación de Menéndez Pelayo, negándola por arbitraria y confusa: «...sin razón ni criterio mezclan en horrible confusión partidarios de sistemas contrarios y reúnen agrupaciones 
alrededor de un nombre...». Finalmente, defiende con un argumento pragmático que estando así las cosas, «es de todo punto necesario tomar como regla clasificadora el período más importante... los árabes...»

Una vez establecida esa clasificación, Perojo empieza su revisión desde el punto de partida adoptado: el valor de nuestra filosofía árabe y judía. Mediante una inducción histórica, basada en un argumento de autoridad, la de la historiografía alemana (Kayserling, Graetz y Hefferich) del momento, reconoce la importancia de esta filosofía y su influencia en la filosofía europea de la Edad Media y del Renacimiento; pero no se detiene en ella, por no ser objeto de la polémica.

En relación a la categoría de los «escolásticos y neoplatónicos», Perojo defiende, mediante argumentos del ejemplo y de inducción histórica, que «no existe uno creador de una escuela filosófica, es decir, que haya causado una modificación en el modo de ser general del pensamiento». Y justifica su afirmación de que no hay filosofía espańola en el Renacimiento, ni en el Barroco, por el incumplimiento de la obligación pelayana de la carga de la prueba, «...cuando en polémica se sostiene lo que nadie cree, es preciso dar una demostración,...», y Menéndez Pelayo no ha demostrado nada; y en un argumento de analogía, basado en ejemplos históricos, como la filosofía alemana del Renacimiento, que también pasó a un segundo plano, pese a tener tantos autores relevantes como nosotros, y algunos superiores como Eckhart o Jacob Boehme.

Especial atención le merece a Perojo Luis Vives, a quien considera un «filósofo muy notable» y el más importante de nuestros pensadores. Y toma prestada la clasificación del mismo como un neoplatónico crítico con la Escolástica, cuyo legado es el librepensamiento, sin detenerse a justificarla. Sí argumenta en cambio contra la importancia que confieren Laverde y Menéndez Pelayo al humanista valenciano, mediante una estrategia histórica de reducción al absurdo basada en contraejemplos e inducciones históricas. Intenta ridiculizar con argumentos de reducción al absurdo, traídos en ocasiones de la argumentación de Pidal y Mon, la pretensión tradicional de que Vives fuera precursor de Bacon y de Descartes, o de que alcanzara la importancia de Kant. Asimismo discute con una estrategia de reducción al absurdo, tanto la conveniencia, como la necesidad de revitalizarlo: «¿Pues si somos los hijos de ese sistema a qué resucitarlo? ¿No llevamos adelante la obra del gran Maestro? ...».

Perojo argumenta contra la pretensión tradicional de que Vives fuera un filósofo católico del Renacimiento español, con una Reducción al absurdo, basada en contraejemplos históricos, v. g., Vives pertenece al Renacimiento 
francés e inglés, no al español, y Vives es precursor del libre pensamiento y crítico de los precursores de los neos y ultramontanos que lo están reivindicando. Los tradicionales reivindican a quien no les pertenece; un argumento éste que esgrimirá más adelante Guardia Bagur. ${ }^{150}$ En la segunda parte de su artículo, Perojo defiende que la Inquisición es la causa histórica de la parálisis científica y civilizatoria de nuestro pueblo y, así, de su decadencia, mediante una argumentación histórica: «ninguna réplica más elocuente que la historia de las ciencias más importantes en los dos períodos que queremos señalar: antes de la Inquisición y durante la dominación de ésta en España». Mediante argumentos históricos del ejemplo y de inducción, positivo y negativo del experto, intenta demostrar la existencia de una correlación necesaria entre la entrada en vigor y la eficacia de la Inquisición y la decadencia y desaparición de actividad científica en España. ${ }^{151}$

El desarrollo de la argumentación pasa revista histórica de cinco ciencias: la Astronomía, las Matemáticas, la Química, la Física, y la Zoología. Aunque la Astronomía recibe especial atención, y en alguna medida también las matemáticas, el proceder argumentativo es el mismo en todas ellas. Se parte de una inducción histórica, basada en un argumento positivo del experto: que son notas de la exposición de algún manual de historia de la ciencia que no se cita, ensalzando los desarrollos de esas ciencias en Espańa durante el período anterior al establecimiento de la Inquisición. A continuación se hace otra inducción histórica, fundada en argumentos positivos del experto: citas de la exposición de algún tratadista espańol, lamentando la práctica inexistencia de esas ciencias en Espańa durante el período de vigencia de la Inquisición. Finalmente, demuestra la inexistencia de representantes españoles de esas ciencias en el período inquisitorial, mediante un argumento negativo del experto: se presenta una lista de los científicos relevantes para el desarrollo de esas ciencias durante el período moderno, sin especificar la fuente de dicha lista, y se constata la inexistencia de nombres españoles en la misma.

La argumentación histórica de Perojo es ante todo deudora de su concepción racionalista posthegeliana de la historia de la filosofía y de las ciencias, así como de su tendencia librepensadora. Por otra parte, no suelen hacerse explícitas en ella las fuentes de sus ejemplos, ni de sus inducciones históricas. En el caso de la Astronomía, no se especifican las fuentes de sus generali-

150 J. M. Guardia Bagur, "L'histoire de la Philosophie en Espagne». En Revue Philosophique de la France et de l'étranger. París, XXIX, mayo, (1890), pp. 471-490, (488490) ; "La misère philosophique en Espagne». En Revue Philosophique de la France et de l'étranger. París, XXXVI, julio, (1893), pp. 287-293.

151 MP, CE, vol. II, p. 828. 
zaciones, ni de la lista de astrónomos modernos que cierra su argumento negativo del experto; y su fuente para hablar de la astronomía española es el discurso, Breve reseña de la historia y progresos de la Astronomía (1855), de Antonio Aguilar y Vela en la Real Academia de Ciencias. En el caso de las matemáticas, tampoco se especifican las fuentes de sus generalizaciones históricas, ni de su lista de matemáticos modernos; la fuente española es el discurso de ingreso de José de Echegaray en la mencionada Real Academia de Ciencias, que versó sobre la Historia de las matemáticas puras en nuestra España. En referencia a la Química, a la Física y a la Zoología, ni se especifican las fuentes históricas de sus generalizaciones ni de sus argumentos positivo y negativo del experto, ni tampoco las del estado de esas ciencias en la España moderna. La conclusión que se saca del desarrollo de las cinco ciencias revisadas, es siempre la deseada: antes del establecimiento de la Inquisición, nuestros científicos formaban parte de la historia de esa ciencia; una vez que esa institución entró en vigor, dejamos de tener científicos que hicieran historia.

Concluye finalmente Perojo defendiendo la necesidad de reconocer nuestra nulidad civilizatoria moderna, sobre la base de un argumento pragmático, es decir, para "corregir defectos y compensar desdichas»: «... a los halagos de una reacción que en todos los terrenos se está intentando a nuestra vista, contestemos con el enérgico propósito de preparar a la patria más altos destinos, consagrando nuestras fuerzas a útiles trabajos bajo los auspicios de la libertad».

Menéndez Pelayo replicó a «La ciencia española bajo la Inquisición» con tres cartas. La primera comienza con una desautorización de Perojo y su Revista Contemporánea mediante los consabidos argumentos ad hominem, y con una pormenorizada refutación de las descalificaciones lanzadas contra él por el librepensador racionalista. A continuación, rechaza por infundada su pretensión de que Revilla habría dado cumplida respuesta a sus argumentos, y desarrolla dos núcleos argumentativos: el primero contra la concepción poshegeliana de la historia de la filosofía desde la que argumenta Perojo; y el segundo contra el encausamiento de la Inquisición como responsable de la decadencia.

En efecto, trenza una argumentación histórica e historiográfica hecha de reducciones al absurdo mediante contraejemplos, argumentos de inducción y del ejemplo, dilemas, argumentos del verdadero tal y ad hominem, argumentos de analogía y de la causa, con la que defiende su conocimiento de la historia de la filosofía moderna y cuestiona la ficción historiográfica que la reduce a un proceso necesario, regido por el progreso dialéctico, y en el que cada época 
se caracteriza por su problema nuevo y específico; una compleja argumentación que se ordena a defender el lugar de la filosofía española del siglo XVI, en especial la crítica e independiente, como primer momento de la filosofía moderna, relativizando en ésta la centralidad de la filosofía crítica kantiana.

Con un argumento del ejemplo histórico, Menéndez Pelayo discute que «la filosofía moderna, al dar su primer paso, sea dogmática», tesis ésta que considera simplificadora y ahistórica. Sostiene que la filosofía renacentista pertenece al primer momento de la filosofía moderna, y rechaza los esquemas historiográficos poshegelianos que fuerzan la historia de la filosofía. Sirviéndose de tres argumentos de inducción histórica, relativiza el lugar común, asumido por los racionalistas, que establece dos «direcciones principales e indudables del pensamiento moderno, la baconiana y la cartesiana, el empirismo y el psicologismo o idealismo...» que desembocarían en la síntesis kantiana. Según Menéndez Pelayo: 1) «las dos direcciones existen desde que hay filosofía en el mundo...»; 2) «la doctrina de la conciencia o razón universal proclamada por Vives ... está por cima de la una y de la otra, porque dentro de ella caben entrambas...»; 3) "Bacon y Descartes no hicieron más que recoger, cada cual por su parte, mermada y como Dios quiso, la herencia de los filósofos españoles e italianos del siglo XVI.»

Asimismo, con argumentos de referencia documental, de inducción y del ejemplo histórico, defiende «que lo que se llama baconismo es una mera disgregación de la escuela de Vives». Cuestiona la centralidad de la filosofía crítica kantiana con un argumento ad ridiculum y una reducción al absurdo; además, pone en duda con un argumento de referencia documental, y un argumento ad populum que la Crítica de la razón pura sea una superación del escepticismo.

En la segunda parte de la carta, Menéndez Pelayo responde a la argumentación del librepensador racionalista contra la Inquisición española, mediante una estrategia histórica que comienza por denunciar la falta de base documental de sus soflamas antinquisitoriales, continúa definiendo una nueva cronología de la Inquisición en España, y termina por demostrar, mediante argumentos del ejemplo histórico, de la verdadera causa histórica, negativos del experto, y de reducción al absurdo mediante contra ejemplos, que documentalmente no cabe hablar ni de persecución de filósofos y científicos, ni de persecución e inclusión en el índice de libros de ciencia y filosofía; y, como consecuencia, que la identificación de la Inquisición como la causa histórica de nuestra decadencia filosófico-científica y civilizatoria es una afirmación infundada y falsísima. ${ }^{152}$

152 MP, CE, vol. I, p. 260. 
La segunda carta contiene una argumentación histórica -basada en la cronología pelayana de la Inquisición en España y en un argumento de la ley de decadencia- además de argumentos documentales y de inducción, del ejemplo y de la causa histórica, de reducción al absurdo y ad ridiculum, principalmente. Con ellos Menéndez Pelayo discute la correlación entre período de vigencia de la institución inquisitorial y decadencia civilizatoria y científica de España, demostrando por orden cronológico, desde el siglo XIV hasta el siglo XVIII, que cuando la Inquisición estuvo en vigor no decayeron todas nuestras ciencias, artes, etc., y que las verdaderas causas históricas de nuestra decadencia fueron otras. Con argumentos documentales y negativos del experto, rechaza que la Inquisición persiguiera y ajusticiara a astrónomos, matemáticos, físicos, etc., y que tuviera como objetivo perseguir la producción científica: los libros prohibidos fueron «relativamente muy pocos. Llega una época en que los indices expurgatorios no son más que reimpresiones...». Y no faltan los argumentos ad hominem, indicativos de que no argumenta para convencer al auditorio racionalista, sino para satisfacer al auditorio católico de La España: «... Los Perojos, Revillas y compañía, ni hablan nuestra lengua, ni son de nuestra raza».

En efecto, frente a los tres siglos de Inquisición en España, del XVI al XVIII, que consideraban los racionalistas, Menéndez Pelayo establece una nueva cronología que parte del siglo xiv, en que hace su entrada en Cataluña, y alcanza hasta su disolución en España a principios del xIx; si bien considera que dejó de ser operativa en el xviII, de manera especial a partir del reinado de Carlos III. Por otra parte, establece mediante una argumentación histórica la existencia de una ley universal de desarrollo de las ciencias y las artes que rige sus ciclos de crecimiento, esplendor y decadencia de las distintas ciencias y artes: «No hay, no ha habido ni habrá en la tierra pueblo que en una misma época presente en igual grado de desarrollo todas las ramas del árbol de la cultura...». Mediante una estrategia histórica basada en inducción y en ejemplos, sostiene que esa ley histórica se ha dado en las principales naciones de Europa, en EEUU, y en España, durante la época moderna. Además, justifica esa ley de decadencia mediante un argumento de la causa histórica que parece sostenerse últimamente en su visión providencialista de la historia: «...porque es justo designio de Dios que las ciencias peregrinen de unas gentes a otras...». Aquella cronología de la Inquisición y esta ley de decadencia son capitales en su argumentación contra la correlación entre vigencia de la institución inquisitorial y decadencia científica, establecida por Perojo.

Niega que la Inquisición fuese la causa de nuestra decadencia en el siglo XVII, mediante una reducción al absurdo, basada en la ley universal de 
decadencia que prevé en cualquier período histórico ámbitos científicos en plenitud y otros en decadencia: «No es posible que una causa sola haya producido efectos contradictorios». Y explica de manera alternativa la decadencia, sin acudir a la Inquisición, mediante argumentos de la causa histórica, v. g., pérdida de la gloria militar por la defensa de la fe y las malas decisiones políticas, descenso de la población activa, abandono de la agricultura, caída del comercio y de la industria, etc. En relación al siglo XVIII, también mediante argumentación histórica, defiende que la Inquisición, lejos de ser causa, formó parte entonces de la general decadencia de las instituciones religiosas y políticas, y de la alteración de la tradición que sufrió España por el cambio de dinastía. ${ }^{153}$

En su argumentación histórica contra la correlación perojina entre vigencia de la Inquisición y decadencia de la Astronomía, de las Matemáticas, de la Química, de la Física y de la Zoología en la España moderna, juega un papel capital la ley general de decadencia. Además, juega un papel relevante la estrategia táctica de desautorización de Perojo y de sus fuentes históricas, basada en argumentos ad hominem contra su «erudición prestada», o en argumentos ad ridiculum contra las enciclopedias o manuales de que se nutre. En relación a las fuentes de sus resúmenes históricos de las materias o de sus listas de científicos relevantes en las ciencias revisadas, escribe: "...en alguna de esas Polianteas modernas que se llaman enciclopedias y diccionarios, se atarugó bien de vulgaridades y noticias de segunda mano, y las aderezó luego en forma de execrable almodrote...». Otro buen ejemplo de la estrategia pelayana de desautorización de las fuentes de Perojo, es su contundente refutación de la autoridad como bibliógrafo e historiador de José de Echegaray, en su discurso de ingreso en la Real Academia de Ciencias Exactas, Físicas y Naturales, mediante argumentos ad populum y ad ridiculum, de la causa y de reducción al absurdo.

En lo que a la Astronomía se refiere, Menéndez Pelayo intenta reducir al absurdo mediante contraejemplos que los cristianos no aportaron en ese campo otra cosa que su fe cristiana. Sus ejemplos históricos son: la tradición isidoriana; los mozárabes, San Eulogio, Álvaro, Sansón, Gerberto que se educó con «Ato o Athón, obispo de Vich»; «los cristianos no sometidos Elipando y Félix, Heterio y San Beato de Liébana, Claudio de Turín y Prudencio Galindo»; Alpetragio que era un español islamizado.

Argumenta decididamente contra la tesis que encausa a la Inquisición por la decadencia de la astronomía hispánica; pero sin negar que fuera una

153 MP, CE, vol. I, pp. 272-273. 
de las causas históricas que pudieron producirla. Empieza justificándolo con un argumento de la verdadera causa, es decir, la ley universal de decadencia: «A todo gran desarrollo sigue inevitablemente la decadencia... la astronomía... se fue a visitar otros países; y en cambio vinieron a nuestra casa huéspedes nuevos». Insiste en el argumento negativo del experto, «¿Dónde están los procesos de astrónomos?», y una reducción al absurdo basada en un contraejemplo, como el copernicanismo y el caso Zúñiga. ${ }^{154}$ Otra reducción al absurdo utiliza el caso de Italia como contraejemplo: la Inquisición romana actuó contra astrónomos italianos, y, sin embargo, hay nombres italianos en la lista de astrónomos modernos de Perojo. ${ }^{155} \mathrm{Y}$ con un argumento documental insiste contra Perojo en que "no fuimos de los que perseguimos a Galileo, ni sé de dónde ha sacado el Sr. del Perojo tan estupenda noticia».

Mediante ejemplos históricos, argumenta que el copernicanismo no fue perseguido en España: no fue perseguido antes de la condena, y después de ella siguió presente entre nuestros astrónomos y matemáticos. Los siguientes autores forman parte de este argumento histórico: Diego de Zúñiga (15741581), Juan de Herrera (1584), Juan de Zúńiga (1594), inquisidor y reformador de los estudios en Salamanca, Andrés de Céspedes (1606), Suárez Argüello (1608), P. Andrés de León, Francisco García Ventanas (1641), Dr. Lázaro de Flores (1673).

Menéndez Pelayo desactiva el papel argumentativo de la lista perojina de astrónomos modernos, rechazándola como si se tratara de una ignoratio elenchi: «...se reduce a una sarta de nombres de astrónomos, que empieza en Copérnico y acaba en Arago»

En relación a la Biología, mediante ejemplos y basándose en la ley general de decadencia, argumenta una observación de interés para la historia de la ciencia en España. En nuestro gran siglo que fue el XVI, tuvimos primeras figuras en las ciencias constituidas, pero en las ciencias que estaban en ciernes, v. g., Química, Biología, Mineralogía, etc., dispusimos de lo que se podía tener, es decir, observadores diligentes, descubridores de nuevos elementos, especies o minerales, inventores de procedimientos y prácticas, etc. ${ }^{156}$

En la tercera carta, Menéndez Pelayo vuelve a defender la existencia de la tradición filosófica espańola. La primera parte argumenta contra la clasificación perojina de la filosofía espańola, que le parece pobrísima y disparatada, siguiendo una estrategia histórica, compuesta de argumentos de la causa y del ejemplo, de reducciones al absurdo mediante contraejemplos, etc.;

$154 \mathrm{MP}, C E$, vol. I, p. 285.

155 MP, CE, vol. I, p. 286.

156 MP, $C E$, vol. I, p. 295. 
y la combina con una estrategia ad hominem y ad ridiculum que incide en los numerosos errores de nombre y de referencia en que incurre Perojo. En particular, le parece impresentable la clasificación de nuestros filósofos del Renacimiento y del Barroco, en "neoplatónicos y escolásticos», y la refuta con reducciones al absurdo basadas en contraejemplos, v. g., "¿Son escolásticos ni neo-platónicos los "peripatéticos clásicos»? ¿O cree el Sr. Perojo que son una misma gente todos los que en el mundo han invocado el nombre de Aristóteles?», o «Precisamente neo-platónicos decididos no hay más que uno, León Hebreo...», etc.

Menéndez Pelayo rechaza por infundada la afirmación de Perojo según la cual la clasificación pelayana es confusa e inaplicable; y defiende de nuevo su validez mediante una compleja argumentación histórica que combina con argumentos ad hominem y ad ridiculum, y con el rechazo de atribuciones falsas como la de haber afirmado que Huarte, Gómez Pereira, Francisco Sánchez y Fox Morcillo crearon escuela, o que la originalidad de Gómez Pereira está en la proposición del cogito, etc. Y se detiene a demostrar que no había omitido a Ramon Sibiuda, ni a Baltasar Gracián.

Después de defender con una argumentación histórica la existencia del lulismo, Menéndez Pelayo refuta con detenimiento la interpretación perojina de Vives, mediante una estrategia argumentativa compuesta de argumentos históricos, de contraejemplos, y de un demoledor argumento ad hominem que pone en evidencia su procedencia. Muestra, en efecto, que el breve y desafortunado artículo, dedicado al humanista valenciano por el Dictionnaire de sciences philosophiques, es la fuente de su infundada caracterización del mismo. ${ }^{157} \mathrm{E}$ intenta demostrar que Vives fue «a un tiempo peripatético y ramista, escéptico y partidario de las ideas innatas, baconiano y sensualista», mediante argumentos documentales y de testimonio, aportando así una batería de fragmentos, traídos a tal efecto del De tradendis disciplinis, De prima philosophia, De instrumento probabilitatis, De causis corruptarum artium: «Si a cada texto de los que voy a citar quiere que ańada otros ocho o nueve del mismo tenor, no hay inconveniente».

Para responder a la objeción pidaliana que Perojo hace suya, «¿Cómo nacen de Vives cosas tan opuestas y discordantes?», aplica un argumento de analogía con el Kant de la historiografía poshegeliana, no exento de ironía, «Este párrafo [donde Perojo pone a Kant como fuente de toda la filosofía del XIX] viene clavado a mi asunto, con poner Vives donde dice Kant, y hacer luego en los nombres de escuelas las respectivas sustituciones»; y argumentos

157 MP, CE, vol. I, p. 309. 
de la causa, como «...Pero todo se explica refiriéndolo al principio capital del sistema... la conciencia humana en toda su amplitud...»; etc.

El polemista santanderino refuta la afirmación de que Vives era un libre pensador ajeno a la tradición católica inquisitorial con una argumentación histórica que insiste en su condición de católico piadoso y fiel a la disciplina romana: «...Como católico y como español, el hijo de Blanca March es una de las figuras más simpáticas de nuestro gran siglo. ¡Qué extraño que nos refugiemos bajo su bandera!». Y en la misma dirección lanza este argumento ad populum: «No son sus nietos legítimos los impíos de nuestro tiempo, ni nadie ha dicho semejante cosa.»

Un argumento ad ridiculum completa la estrategia ad hominem omnipresente en la argumentación pelayana contra Perojo. Menéndez Pelayo se burla, a la vez que lamenta, la falta de corrección y de pureza de su escritura, lo que le vincula a la estirpe krausista de pésimos escritores y en general a un ambiente extranjerizante que considera letal para la lengua y el pensamiento español.

\section{Tradicionalismo tomista versus historicismo católico:} La ciencia española. Polémicas, indicaciones y proyectos (1879)

La exigencia compartida de mantener la unidad de los católicos, y el reconocimiento mutuo que se profesaban Alejandro Pidal y Menéndez Pelayo, explican la práctica inexistencia de argumentos ad hominem, que dejan su lugar a protestas de amistad y peticiones de complicidad en su confrontación. De hecho el primero de los «Dos artículos ... sobre las cartas anteriores», de Pidal, es un encendido elogio de la figura de Menéndez Pelayo y una defensa de su victoria sobre los racionalistas. Y el propio Pidal dio indicaciones por carta a su oponente sobre cómo debía de componer su «Instaurare omnia in Christo». Sin embargo, una posición de fondo enfrentaba a Pidal con el joven historicista católico: la tradición filosófica espańola seria la escolástica tomista, a cuya restauración debería de adherirse incondicionalmente todo escritor católico. La defensa de esta posición se basa principalmente en tres núcleos argumentativos.

El primer núcleo sostiene que desde el punto de vista del organismo científico no cabe hablar de filosofía española, y desde el punto de vista del proceso no hay una tradición filosófica española, sino más bien filósofos españoles que han producido sistemas filosóficos, es decir, filosofías en España, pero que no representan una tendencia histórica relevante. La primera parte de la afirmación se justifica con un argumento del verdadero tal, basado en 
una concepción teológica de la filosofía como conocimiento de verdades absolutas: "...ni la verdad tiene patria...». ${ }^{158}$ La segunda parte se argumenta mediante una reducción al absurdo: si hubiera una tradición filosófica española, los sistemas de nuestros filósofos tendrían notas características comunes; sin embargo, la única nota existente, que es el Catolicismo, «...es muy vaga y no basta para dar carácter a una filosofía». ${ }^{159}$ La tercera parte se justifica con un argumento del ejemplo histórico: "...el senequismo, el isidorianismo, el averroismo, el maimonismo, y principalmente el lulismo (no admitimos el suarismo como sistema filosófico distinto del tomismo) y el vivismo...».160 La cuarta parte reduce al absurdo la existencia de una filosofía española, basándose en dos contraejemplos: «...ya porque fuese común a los filósofos, como cuando al decir alemana nos referimos al idealismo panteísta...; ya porque fuera única y universalmente reconocida su trascendencia, como cuando decimos francesa nos referimos al cartesianismo...» (Ib.).

El segundo núcleo argumentativo afirma que el tomismo es la filosofía cristiana por excelencia, la auténtica ciencia española, y la única que puede remediar la ruina presente de la filosofía. La primera afirmación se apoya en un argumento del verdadero tal, basado en una concepción teológica de la filosofía: «...el escolasticismo tomista, que es la filosofía cristiana por excelencia, que, completada por la Revelación, forma... la teología escolástica...». ${ }^{161} \mathrm{La}$ segunda afirmación se basa en un argumento del verdadero tal, justificado mediante un argumento de doble jerarquía: «...la teología escolástica, en que tan alto rayaron los colosales ingenios que florecieron en España, cuyas doctrinas y cuyos nombres es necesario recordar para proclamar la existencia de la ciencia española...» (Ib.). La tercera afirmación es un argumento pragmático que llama a restaurar el tomismo a fin de reconstruir la ciencia espańola y superar la presente crisis de la filosofía. (Ib.).

El tercer núcleo argumentativo afirma que la vuelta a la filosofía española debe ser una restauración del tomismo, porque este sistema es la única filosofía espańola que contiene la verdad total y que es filosofía perenne. Argumenta la primera afirmación con una reducción al absurdo basada en contraejemplos, «Entiendo por filosofía española el senequismo, el averroísmo, el maimonismo, el lulismo y el vivismo... la verdad total no se contiene en esos sistemas», ${ }^{162}$ y con un argumento de autoridad, la de Leibniz: «La filosofía escolástica...

$158 \mathrm{MP}, C E$, (vol. I, p. 219).

159 MP, $C E$, (vol. I, p. 220).

$160 \mathrm{MP}, C E$, (vol. I, p. 220).

$161 \mathrm{MP}, C E$, (vol. I, p. 225).

$162 \mathrm{MP}, C E$, (vol. I, p. 221). 
a la que Leibniz llamaba filosofía española... era la verdad toda» (Ib.). Y justifica la segunda con un argumento del verdadero tal, basado también en la autoridad de Leibniz: «Si alguna filosofía merece ... el nombre de perennis philosophia que dijo Leibniz, y el nombre de filosofía española en particular, no es otra que la grande y sublime filosofía escolástica...»(Ib.)

La importancia que confería Menéndez Pelayo a la recuperación de Vives, convierte ésta en un núcleo argumentativo central de esta polémica: «jdeclararse vivista hoy!, ipretender que la filosofía española sea el vivismo! ... Por los clavos de Cristo, que aún hay tomistas en España». ${ }^{163}$ Pidal argumenta contra la conveniencia de volver a Vives, utilizando las afirmaciones sostenidas por Laverde y Menéndez Pelayo sobre el humanista valenciano, como ser «filósofo ecléctico», ser "el más prodigioso de los obreros del Renacimiento»y, sobre todo, un argumento pragmático que lo descalifica por haber sido fuente de errores filosóficos modernos: «... ¿qué deberemos pensar de un árbol cuyos frutos son el empirismo baconiano, la duda cartesiana, el psicologismo escocés, el aristotelismo no purificado por los escolásticos, el anti-aristotelismo, las ideas innatas y hasta el escepticismo y el sensualismo? (I, 224).

No me detendré en dos argumentos históricos, planteados por Pidal, que tendrán desarrollo posterior en la polémica con Fonseca: «el tomismo dio guía y dirección a nuestros místicos», $\mathrm{y}$ «Melchor Cano es tomista, y no recibió influencia de Vives».

Menéndez Pelayo respondió a Pidal en la carta In dubiis libertas. Su tono es conciliador, por lo que intenta justificar, mediante argumentos del motivo, que su escasa atención a la escolástica española en la polémica con los racionalistas se debió a exigencias de la misma, no a menosprecio de nuestra escolástica tomista (I, 229). Sin embargo, su posición historicista chocaba con el primer núcleo argumentativo del tomista: sólo cabe hablar de la filosofía espańola, como de cualquier filosofía o producción científica humana, desde el punto de vista de su proceso histórico, y, desde este punto de vista, hay una tradición filosófica espańola a la que pertenecen sistemas relevantes en la historia de la filosofía occidental. En varios pasajes del texto, Menéndez Pelayo separa el punto de vista absoluto de la teología divina, y el punto de vista histórico de la filosofía y la ciencia humana, y reclama libertad de investigación en este último campo de incertidumbre y duda. Más aún, le advierte a Pidal de que someter la filosofía y las ciencias al punto de vista absoluto de la teología supone dar un paso en la dirección del tradicionalismo, que es «un sistema sensualista y de consecuencias altamente peligrosas y alguna vez censuradas.» (I, 243).

163 MP, CE, (vol. I, p. 224). 
Menéndez Pelayo sostiene la existencia de una tradición filosófica española, basándose en un argumento de la causa que establece una correlación entre identidad étnica y forma de pensamiento, «...es imposible que filósofos de un mismo pueblo y raza no ofrezcan uno y aun muchos puntos de semejanza en el encadenamiento lógico de sus ideas» (I, 232), y en un argumento de inducción histórica, que enumera los rasgos característicos de los filósofos españoles de todos los tiempos: los heterodoxos son «panteístas», y los católicos y castizos son "críticos» $\mathrm{y}$ «armónicos o cuando menos tendentes al sincretismo» (I, 233).

En relación al segundo núcleo argumentativo pidaliano, refuta el argumento del verdadero tal que concluye «el tomismo es la filosofía cristiana por excelencia», deshaciendo el criterio teológico sobre el que se basa, mediante una distinción entre teología cristiana y filosofía aristotélico-tomista: «... una cosa es la filosofía tomista y otra su teología... a esta teología, y formando o no un organismo con ella, pueden aplicarse otras filosofías diversas de la de Aristóteles» (I, 235). El argumento de doble jerarquía que justifica la consideración del tomismo como la auténtica ciencia española, es refutado mediante un argumento histórico: «[a la manifestación filosófica, teológica y artística] las creo iguales, cada cual en su esfera, y pienso que se completan mutuamente.» (I, 234). A este lugar pertenecen también el argumento del ejemplo histórico y el argumento pragmático que aporta para refutar la «feliz idea», de monseñor Ceferino González, de editar una Biblioteca de Teólogos españoles: «... No demos ocasión a que los racionalistas nos digan en son de triunfo que hemos tenido teólogos (lo cual, en boca suya, equivale a sacristanes), y no filósofos.» (I, 245).

Menéndez Pelayo no sólo excusa su escasa atención al tomismo con un argumento pragmático: «A los que me preguntaban por creaciones filosóficas nacionales... no podía responderles con una filosofía extraña de origen, aunque nuestra por derecho de conquista...» (I, 230). Sino que rebate la pretendida preponderancia de la escolástica tomista con un argumento de la causa histórica, en el que la responsabiliza de "la decadencia de la universidad y de la investigación en Espańa» (I, 247).

Por lo que se refiere al tercer núcleo argumentativo, refuta la afirmación según la cual el tomismo es la única filosofía española que contiene la verdad total, mediante una distinción que deshace su confusión con la teología cristiana: ««El tomismo es la verdad toda». En su parte teológica, concedo. En su parte filosófica, nego...» (I, 234). Además, pone de manifiesto que el argumento de autoridad, la de Leibniz, con el que se justifica la identificación de la escolástica tomista con la filosofía perenne, es una falacia: «...Leibniz nunca quiso dar a entender semejante cosa...» (I, 235), 
Menéndez Pelayo creía que Vives personificaba la España científica, pues había sido nuestro filósofo «más originaly de más hondo influjo en el pensamiento europeo» (I, 238). Así que defiende el valor de su filosofía ecléctica y crítica, renacentista, y refuta con una reducción al absurdo, basada en contraejemplos (I, 243), el argumento pidaliano sobre lo dañino de sus frutos, comprometiendo además algo que nunca llegará a cumplir: componer un libro titulado Exposición e historia del vivismo en el que demostrará «cómo el espíritu de la doctrina de Vives informa toda nuestra civilización..., que Vives tiene todas las cualidades buenas del Renacimiento y ninguna de sus exageraciones..., que toda restauración total o parcial de los estudios en España ha sido restauración vivista, y deduciría... la necesidad de volver al espíritu de Vives para salvar la ciencia española del olvido y de la muerte.» (I, 248).

Mencionaré, por último, que Menéndez Pelayo rechaza con argumentos históricos que Melchor Cano fuera tomista "en la forma y en el estilo» de su filosofía; defiende por el contrario que fue "un escritor del Renacimiento» $\mathrm{y}$ «que se aprovechó ampliamente de Vives y los vivistas» (I, 244). Por otra parte, sostiene con argumentos del ejemplo histórico que nuestros místicos fueron la más elevada personificación del platonismo renacentista. (I, 245).

En su «Contestación... a la carta In dubiis libertas», Pidal supone que la causa de la desviación pelayana del tomismo radica en su aprecio del Renacimiento y de las disciplinas humanísticas. Por eso, el primer núcleo argumentativo de su carta es un ataque tradicionalista contra el Renacimiento europeo, al que acusa de ser un movimiento pagano de descristianización, innecesario, inconveniente e inviable, y que dio lugar a la Reforma, basándose en argumentos de inducción histórica, del verdadero tal (I, 408 y ss.), o de la causa, v. g., la inadecuación entre el fondo cristiano y la forma literaria pagana, ad populum, de autoridad, la de Erasmo y el conde Alberto de Carpi, etc. (ib.). Con su ataque al Renacimiento y al Humanismo, Pidal busca la adhesión de Menéndez Pelayo al tomismo, por lo que pone buen cuidado de distinguir entre Erasmo y Vives, entre el Renacimiento español y el italiano o el nórdico, al que acusa de haber desencadenado el proceso que llevó a la Reforma.

El segundo núcleo argumentativo de Pidal es una hiperbólica defensa del siglo XIII y del tomismo. Mediante argumentos de inducción y del ejemplo histórico, v. g., Torquemada, Diego de Deza, Cayetano, Vitoria, etc., sostiene que fue el tomismo el que alimentó la Contrarreforma y salvó a Europa de las consecuencias del Renacimiento; y también salvó a España, donde apenas entró ese movimiento pagano. Y con un argumento de analogía, menosprecia la defensa que los humanistas hicieron del cristianismo romano, exaltando 
el papel del tomismo: «... cuando vino el lobo, tuvo que buscar de prisa su mastín, porque los ladradores gozquecillos no impedían el destrozo de sus ovejas» (I, 417).

Otro núcleo temático lo constituye su réplica a los argumentos pelayanos, procedentes de su admiración por el Renacimiento y el Humanismo, contra la identificación de la filosofía de Santo Tomás con la verdad total. Por inducción histórica sostiene que la obra del Aquinate es la síntesis acabada de las filosofías de Platón y de Aristóteles; y frente al argumento que cuestiona su conocimiento de Aristóteles, basándose en que no leía griego, ni trabajaba con ediciones críticas, replica con un argumento de autoridad, «...escritores muy graves sostienen que Santo Tomás leyó a Aristóteles en griego...» (I, 420), y con un argumento pragmático: «...le fue más útil conocerlo como lo conoció entonces... para bien de la cristiandad y de la filosofía» (ib.). En fin, mediante un argumento de autoridad, la de Erasmo, y un argumento de la causa basado en la adecuación entre forma y contenido, defiende que el lenguaje de Santo Tomás es filosófico, no bárbaro.

Para defender que Melchor Cano fue tomista, no discípulo de Vives, Pidal trenza una compleja réplica basada en su concepción teológica de la filosofía y en su concepción escolástica del método filosófico que menosprecia la función del estilo: Cano pudo tener un estilo distinto, pero mantuvo el método de Santo Tomás «que no es otro que el método escolástico...». Además, aporta un argumento documental para justificar que ambos filósofos dominicos coinciden en «dar la preferencia a Aristóteles con cierta moderación y completándolo con doctrinas platónicas...» (I, 426), replicando así el argumento documental de Menéndez Pelayo sobre el asunto.

Con argumentos del ejemplo histórico, en fin, intenta demostrar que los editores de la Biblia políglota fueron tomistas, o que el tomismo dio dirección y guía a los místicos españoles del Renacimiento.

La réplica de Menéndez Pelayo, Instaurare omnia in Christo, tiene como primer núcleo argumentativo la defensa de su propia concepción del Renacimiento y la refutación de la condena pidaliana de dicho período cultural. El Renacimiento es, a su juicio, la culminación y victoria del clasicismo latino-cristiano en su lucha desde la Edad Media contra la barbarie de los pueblos germánicos. Con argumentos del ejemplo histórico, justifica que la Edad Media significó un avance en la obra que culminó el Renacimiento, del que por lo mismo fue precursor Santo Tomás.

Menéndez Pelayo cuestiona la interpretación pidaliana del Renacimiento a la que califica de tradicionalista, sirviéndose de una estrategia que incluye: un argumento de analogía que compara la posición de Pidal con la del abate 
Gaume; un argumento de clasificación que indica rasgos de esa interpretación; y otro argumento de analogía que compara esa interpretación del Renacimiento con la de los historiadores progresistas que convierten a los jesuitas y a la Inquisición en causa histórica de todos los males de la cultura hispánica. Además, trae un argumento de autoridad, la de una bula de León X contra Lutero, para rechazar la actitud tradicionalista frente a las ciencias, las artes, y, en general, contra el ejercicio de la razón.

Menéndez Pelayo reduce al absurdo con un argumento de la causa que el Renacimiento fuera la causa histórica de la Reforma: «El Renacimiento es cosa demasiado complexa, y la Reforma es una herejía harto sencilla». Asimismo, discute que los humanistas contribuyeran a la Reforma, refutando los dos argumentos documentales del testimonio histórico de Erasmo y de Alberto Carpi, y cuestionando que hubiera humanistas nórdicos, expresión esta que le parece un oxímoron: «Lutero era sencillamente un bárbaro... y su discípulo el dulce Melanchton, en quien bajo la corteza humanística duraba la herrumbre germánica...» (I, 395).

Rechaza con énfasis que el Renacimiento pasara de largo por España, aduciendo dos argumentos: uno pragmático, «sólo probaría, en caso de ser verdad, que habíamos sido más incultos y rudos que los demás meridionales...»; y documental, el otro, «...esta suposición está refutada en todo el curso de este libro y en otros escritos míos...» (I, 396).

En defensa del movimiento humanista, rechaza por ser una falacia de generalización indebida, el argumento que desautoriza por paganos o herejes a los humanistas, basándose en que algunos lo fueron. Para mostrarlo utiliza un argumento de analogía, que los compara con los casos de escolásticos herejes, y un argumento de autoridad: «Ex nobis prodierunt, sed non erant ex nobis,... podemos contestar nosotros, con las palabras de San Juan».

En relación al segundo núcleo temático de Pidal, Menéndez Pelayo defiende su aproximación historicista-católica a la figura y la obra de Santo Tomás. La filosofía del Aquinate es obra humana, y hay que atenerse a su espíritu, no a su letra. Además, como toda obra humana, es controvertida en sus detalles. Así que acepta el tomismo como una de las corrientes tradicionales españolas más relevantes, y según la aproximación de los jesuitas, no de los dominicos. En este punto defiende con un argumento de inducción histórica que «Santo Tomás no puede ser llamado con entera propiedad fundador de un sistema: es un filósofo derivado de Aristóteles y de los Padres». Aduce además un argumento de autoridad, la del papa León XIII: «Por eso la Santidad de León XIII, en su reciente Encíclica, lo que alaba principalmente en Santo Tomás es el haber reunido y congregado los miembros antes dispersos» (I, 397). 
Con una argumentación histórica, vuelve a sostener que Santo Tomás no dominaba el griego, ni la crítica textual. Fue hijo de su tiempo, y las palabras griegas que encontramos en su obra «las toma siempre de las versiones latinas de Aristóteles». Pero encomia el interés del Doctor Angélico por disponer de traducciones latinas fiables, por lo que «debe contársele entre los precursores del Renacimiento, que continuó la tarea de corregir y depurar los textos y las versiones» (I, 397).

Defiende su interpretación abierta del tomismo con un argumento documental, una cita de la Aeterni Patris que repetirá contra Fonseca: «si en los doctores escolásticos se halla algo tratado con demasiada sutileza, o con poca consideración, o algo que no concierte bien con los descubrimientos posteriores, $o$ que de cualquier modo no parezca probable, de ninguna manera debe proponerse como dechado de imitación». Con un argumento de autoridad, la de Josef Jungmann, defiende que la restauración del tomismo va en la dirección de una interpretación renovada y actualizada de la obra de Santo Tomás, no en la de una interpretación integrista de la Summa theologica como la que propugnan los dominicos. E incluye también un argumento pragmático, pues considera que el tomismo íntegro y reductor dejaría impotente a la filosofía cristiana "para resistir la furiosa avenida de las hordas positivistas...». La generalización del tomismo no haría más que debilitar la filosofía cristiana, al privarla «del criticismo de Vives, ni del experimentalismo baconiano (en lo que no tiene de exclusivo), ni de las observaciones psicológicas de la escuela escocesa, ni lo que en la lógica inductiva han adelantado los positivistas, ni de los modernos estudios filológicos que han restaurado del todo la historia de la filosofía griega, ni nada, en suma, de lo que Santo Tomás no alcanzó o no supo». Por eso, la discusión de que la escolástica es deficitaria en métodos inductivos, psicológicos, y filológicos, será central en la discusión con Fonseca.

De nuevo argumenta contra la síntesis que defiende Pidal entre teología cristiana y filosofía aristotélico-tomista, con una reducción al absurdo basada en contraejemplos. Se puede ser tomista en teología, sin aceptar la composición hilemórfica de la materia, o la composición metafísica de esencia y existencia, o la explicación de la percepción y de la intelección mediante especies mentales, etc. Y reitera su distinción entre la verdad perenne de la teología y la filosofía cristiana y la historicidad de la razón humana, con el ejemplo del aristotelismo medieval: «Todo lo que Santo Tomás tiene de teólogo y filósofo cristiano es admirable y vividero: lo que tiene de filósofo peripatético y medioeval puede y debe discutirse, y en algunos casos abandonarse..."

Vuelve a defender que Melchor Cano fue discípulo de Vives y escritor del Renacimiento, con reducciones al absurdo: una basada en rasgos humanistas 
del De locis theologicis, «la crítica de las fuentes de conocimiento, el criticismo aplicado a la teología...», y otra en la ausencia de rasgos escolásticos, «¿Cómo he de tener por escolástico a un hombre que con tanto desdén habla de las cuestiones relativas al principio de individuación, y aun a los universales?» (I, 398). Y reitera con un argumento ad populum que los colaboradores de la Biblia políglota no eran tomistas, como tampoco lo eran a su juicio los místicos espańoles del Renacimiento.

Estas afirmaciones sobre el tomismo fueron tenidas en cuenta por el dominico Joaquín Fonseca, que acudió a la llamada del propio Alejandro Pidal en el comienzo de su escrito de contestación al In dubiis libertas: «...cuando volví a tomar la pluma, no lo hiciese para responder a V., sino para invitar privadamente... a los sabios hijos de Santo Domingo... para que, saliendo a la palestra, contrarrestasen los esfuerzos de V. en contra del renacimiento escolástico en España».

\section{Tomismo integro versus historicismo católico: La ciencia española. (Polémicas, proyectos y bibliografía) (1887-1889)}

En la «Nota 33» del Triduo dedicado a Santo Tomás de Aquino en marzo de $1881 \ldots$. Fonseca ataca la posición de Menéndez Pelayo, tomando como pretexto una afirmación de su discurso de ingreso en la Rel Academia Española, La poesía mistica en España: "toda la filosofía española del siglo XVI, sobre todo la no clásica e independiente, está marcada con el sello del psicologismo». Sus dos textos polémicos, tanto esa «Nota 33», como su Contestación de un tomista a un filósofo del Renacimiento (1882), reaccionan contra el historicismo del joven académico y su distanciamiento de las pretensiones del tomismo íntegro, argumentando que hay una única verdad $y$, por consiguiente, un único teólogo y un único filósofo, Santo Tomás, en cuyas obras se encuentra la verdad toda, cuando menos de manera eminencial; por lo que la necesaria restauración del tomismo en las escuelas debe lograrse desde la letra de sus textos. Su defensa de que la obra del Angélico contiene la verdad toda, le lleva a argumentar que es precursora de la psicología científica y del método introspectivo, de la ciencia experimental y del método inductivo; que dominaba la filología griega y la crítica textual; que la suma tomista es la síntesis filosófica definitiva que esperaban los siglos; que la teología mística tomista fue dirección y guía de nuestra mística en el Siglo de Oro, etc. Los argumentos ad hominem y ad ridiculum se convierten en una estrategia fundamental de Fonseca, y suben de tono hasta los insultos y amenazas inquisitoriales en su Contestación de un filósofo tomista... Asimismo, los ar- 
gumentos teológicos del verdadero tal, de la inducción y del ejemplo histórico, de autoridad y de referencia documental, basados en principios, creencias, tradiciones, etc., no sólo católicas, sino de la corporación dominicana, son capitales en sus principales núcleos argumentativos.

Esa estrategia ad hominem que se ordena a colocar a Menéndez Pelayo en la posición inferior del lego que necesita ser tutorizado, se desarrolla en tres momentos. Ante todo, la descalificación y escarnio del «joven prodigio» al que representa como un literato y humanista superficial que no tiene una lectura meditada de Santo Tomás. En segundo lugar, el aleccionamiento mediante textos del Angélico que probarían las atribuciones que se le hacen, v. g., ser el auténtico precursor de los métodos filosóficos modernos, de la psicología científica moderna, etc. Y, en fin, la tutorización a través de la prescripción de lugares de Santo Tomás que el joven polemista debería leer, para escribir con fundamento sobre el asunto. Sus dos textos polémicos están saturados de argumentos de referencia documental, basados en citas textuales e índices de materias del Aquinate.

Fonseca defiende que Santo Tomás es el único y el más importante de los teólogos y filósofos de la historia, en cuya obra está contenida eminencialmente la verdad toda, mediante una compleja argumentación teológica que se compone de argumentos como los siguientes: falacias de tránsito, «No creemos que exista en el mundo más que una verdadera filosofía, como no hay más que una verdadera teología, unas verdaderas matemáticas» o «La diversidad sólo se halla en el error, y el error está eliminado de la verdadera ciencia...»; de autoridad teológica, la del Pontifice Leon XIII, "[la filosofía de Santo Tomás es] la más sólida solidior, la más segura securior y la más conforme al magisterío de la Iglesia...»; falacia de la causa psico-teológica: "...dada la sublime y poderosa inteligencia de Santo Tomás de Aquino, dadas su intuición casi divina y sus íntimas comunicaciones con el Verbo, poseyó realmente una sabiduría angélica... a la manera que el que conoce y posee los principios eminenciales de una ciencia cualquiera...», etc. Fonseca tiene un concepto teológico de filosofía perenne que la identifica con la filosofía de Santo Tomás.

Su defensa de que la obra de Santo Tomas contiene de modo eminencial la psicología científica y el método introspectivo, las ciencias naturales y el método inductivo, se basa en argumentos de referencia documental que acumulan citas textuales traídas de las obras del Angélico. Un ejemplo de este tipo de argumento documental, que prodiga el tomista íntegro, puede ser la cita de las Cuestiones disputadas (quaest. 10, art. 8), a fin de probar que Santo Tomás estableció el principio cartesiano tres siglos antes que su autor: 
"Oigamos hablar por un momento al Ángel de las Escuelas:

In hoc aliquis percipit se animam habere, et vivere et esse, quod percipit se sentire, et intelligere, et alia hujusmodi vitae opera exercere; unde dicit Philosophus: Sentimus autem quoniam sentimus: intelligimus quoniam sumus (ex eo scilicet quod intelligimus) et ideo pervenit anima ad actualiter percipiendum se esse, per illud quod intelligit et sentit... Es el principio de Descartes formulado en otros términos» (II, 872).

Sus argumentos de referencia documental citan rara vez autores que no sean Santo Tomás o documentos pontificios, como la Aeterni Patris y, cuando lo hacen, suelen ser textos de segunda mano. Por ejemplo, en su argumentación de que los tres métodos filosóficos, el ontológico, el psicológico y el inductivo, están ya eminencialmente en Santo Tomás, y además en su justa aplicación, incluye un argumento de autoridad teológica, la autoridad del Syllabus, para censurar el predominio que concede Luis Vives al método psicológico. La cita del humanista valenciano, aportada por el dominico en su argumentación documental de esa acusación de "psicologismo», está tomada precisamente de la tercera carta de Menéndez Pelayo contra Perojo: «...pasajes de Luis Vives, como el que voy a tomar literalmente de su obra intitulada De Prima Philosophia: Ergo nos quae dicimus esse aut non esse, haec aut illa, talia aut non talia, ex sententia animi nostri censemus, non ex rebus ipsis; illae enim non sunt nobis sui mensura, sed mens nostra. Quocirca censendae sunt nobis res non ipsarum nota, sed nostra aestimatione et judicio... De aquí se va fácilmente al idealismo y aun al racionalismo filosófico que proclama la soberanía de la razón humana...». ${ }^{164}$

En los núcleos argumentativos más comprometidos, el dominico suele añadir a los argumentos de referencia documental la promesa de futuras demostraciones que quedaron incumplidas. Por ejemplo, en su defensa de que Santo Tomás era un consumado helenista, conocedor de los textos originales de Aristóteles y de los autores que estudiaba, añade a un argumento de autoridad, basado en la tradición de la Orden dominica, el compromiso de una futura demostración de tal extremo: "Algún día le he de probar a nuestro joven helenista, ya que tanto se jacta de su griego, que Santo Tomás de Aquino era un profundo helenista, según la tradición constante de la Orden...». Otro de los lugares en que compromete demostraciones futuras, es su contra-argumentación frente a la posición pelayana, «[la filosofía de Santo Tomás es] una congregación de miembros dispersos». ${ }^{165}$

$164 \mathrm{MP}, C E$, vol. II, p. 910.

165 MP, $C E$, vol. II, p. 892. 
Fonseca defiende que la suma de Santo Tomás es la síntesis de aristotelismo y cristianismo esperada por los siglos y la definitiva filosofía cristiana, con el consabido argumento de autoridad, la de la Aeterni Patris, y con el argumento de la causa, basado en lo portentoso y angélico de las facultades del Aquinate: «El mundo esperaba un genio que, utilizando y bautizando en cierto modo la parte sana y aprovechable de la filosofía aristotélica... supiese elevarla al rango de filosofía cristiana..., ese genio portentoso no fue otro que el de Santo Tomás de Aquino» (II, 894).

Otro núcleo argumentativo de los textos de Fonseca se ordena a la defensa de que la teología tomista fue dirección y guía de la mística española del Siglo de Oro, que nada debe en cambio al neoplatonismo. Esta compleja demostración se compone de una argumentación documental, consistente en una exposición textual de la teología mística tomista con proporciones de monografía, de una defensa de su influencia en nuestros místicos y de una refutación de la influencia de la mística neoplatónica en los mismos.

La demostración de la influencia de la mística tomista incluye argumentos: del ejemplo, de Juan Taulero y Enrique Susón, para demostrar la influencia de Santo Tomás en los místicos dominicos; de la causa, basado en que los directores espirituales de Sta. Teresa y de otros místicos fueron dominicos y jesuitas que por fuerza les trasmitieron la teología mística tomista; ad hominem, basado en que Menéndez Pelayo excluye «del catálogo de los místicos puros al venerable Granada», lo que demostraría su aversión invencible al tomismo y su desconocimiento de la mística cristiana; etc. A los que añade el compromiso de aportar en el futuro una demostración definitiva, de carácter histórico, racional y crítico: «...ya le probaré al Sr. Pelayo que los tomistas fueron místicos y maestros consumados en la mística cristiana, cuyos principios eternos e inmutables se encuentran establecidos y planteados en la Suma teológica».

La contra-argumentación ordenada a refutar que la mística neoplatónica influyó en la estética literaria de los místicos españoles, contiene argumentos de reducción al absurdo, basados en citas de autoridad, v. g., la de San Buenaventura, en principios teológicos, como la belleza del Dios cristiano, en la especificidad del objetivo de la mística cristiana, es decir, «...la transformación del alma en Dios por medio de la contemplación unitiva», etc. La demostración incluye además un argumento ad hominem que acusa a Menéndez Pelayo de desconocer la mística cristiana, por afirmar «que nuestros místicos debieron su estética divina al neoplatonismo...»y, de nuevo, un compromiso de aportar una refutación futura: «...yo le he de probar algún día... la imposibilidad de ese monstruoso contubernio entre una ciencia divina, sobrenatural e infusa, y la ciencia pagana de Platón y sus congéneres...» (II, 920). 
El joven académico, que nunca quiso entrar en polémica con el teólogo dominico, no disimuló la irritación y el pathos de la distancia histórica que le merecían sus textos, y repelió de manera contundente su estrategia argumentativa ad hominem. Ante todo, le recuerda que su discurso de ingreso ni tenía por objeto ni mencionaba en ningún caso a Santo Tomás; y le asegura tener una lectura del Aquinate que ciertamente no coincide, ni puede coincidir con la suya, de tomista dominico. Desde luego, le replica que los argumentos de referencia documental, basados en citas aisladas, descontextualizadas y parciales, carecen de valor probativo: «Los textos no son nada cuando se los saca de su lugar y no se los interpreta como Dios y la lógica lo mandan». Además, en su Contestación al R. P. Fonseca, se burla abiertamente del pretendido tutor y de su aleccionamiento por proliferación de citas y de índices temáticos, sirviéndose de un argumento ad ridiculum, en el que pone de manifiesto que los ha tomado de algún Index rerum de los que están provistas las buenas ediciones de las Obras completas de Santo Tomás, como la que él mismo posee. ${ }^{166}$

En sus réplicas, Contestación a un filósofo tomista y Réplica al R. P. Fonseca, trenza la argumentación de un historicista católico que tiene su propia lectura de la Aeterni Patris, y no está dispuesto a hacer concesiones al tradicionalismo ni al tomismo íntegro. Rechaza las visiones ahistóricas y corporativas de la filosofía, de las ciencias, y de su desarrollo histórico, propias del dominico, y defiende la actualidad del Renacimiento español, en el que quiere enraizar nuestra tradición científica: «De ahí que yo, como historiador de la filosofía..., y sin ser precisamente filósofo del Renacimiento... sino filósofo de mi tiempo, que busca en el Renacimiento y algo más allá su genealogía...»

A la argumentación que ya esgrimió en su polémica con Pidal y Mon, frente a la tesis de que las obras de Santo Tomás contienen de modo eminencial la verdad toda, añade aquí una estrategia ad hominem con argumentos como «la gloria de Santo Tomás es gloria de su casa», o «Probablemente, el primer libro de filosofía que cayó en sus manos fue algún compendio tomista. Su educación ha sido y ha debido ser claustral». Y mantiene su posición historicista ante la obra del Aquinate con argumentos de inducción histórica y de autoridad, la de la Aeterni Patris: «La originalidad de Santo Tomás es, ante todo, una originalidad de método, una congregación de miembros dispersos, como dice la Encíclica de León XIII» (II, 461).

Contra la pretensión de que las obras de Santo Tomás contienen de modo eminencial la psicología moderna y su método, Menéndez Pelayo sostiene,

166 MP, $C E$, vol II. p. 477. 
mediante argumentos de inducción y del ejemplo histórico, ad hominem y de reducción al absurdo basada en contra-ejemplos, que antes del Aquinate hubo grandes aportaciones de los filósofos griegos y latinos a la psicología, de las que se aprovechó aquél, y que sus mayores logros en psicología no se encuentran en los lugares seńalados por Fonseca, sino «en mil observaciones agudísimas esparcidas acá y allá en sus tratados, sobre todo en los "de los actos humanos, de las pasiones, los hábitos, virtudes y vicios”" (II, 464); pero que en modo alguno Santo Tomás tematizó su psicología en un tratado específico De anima, ni convirtió el procedimiento introspectivo en el método central del mismo, ni puede considerársele un antecedente directo de Bacon o de la Escuela Escocesa.

Menéndez Pelayo argumenta históricamente, con razón, que las especies inteligibles han desaparecido de la psicología contemporánea, constituyendo las psicologías escolásticas, y no todas, su último reducto. El joven polemista se declara partidario de la teoría hamiltoniana del conocimiento, y hace una breve exposición de la misma que denota un conocimiento profundo, y que constituye una de las piezas más destacables de su Réplica al R. P. Fonseca: «Hay otro sistema muy claro, muy sencillo, que consiste en afirmar el hecho del conocimiento y la distinción del sujeto y el objeto...» (II, 467).

Esta discusión con Fonseca le obligó a concretar la afirmación polémica, incluida en su discurso de ingreso en la RAE, en términos como los siguientes: «...los tratados De anima constituyen una de las secciones más ricas de nuestra literatura filosófica... si además conviene todo el mundo... en que puede sacarse inagotable venero de ciencia psicológica de nuestros libros místicos, bien puedo afirmar yo el carácter predominantemente psicológico de nuestra ciencia del siglo xvı...». También le llevó a precisar el tipo de psicología de la que fueron precursores nuestros filósofos y místicos del Renacimiento, pero no el Aquinate: «La psicología de que yo hablo... existe desde el siglo XvI, con plena y absoluta independencia, como ciencia aparte...» (II, 465).

Menéndez Pelayo defiende, con una argumentación histórica, que la exposición de Santo Tomás sobre el método inductivo es deudora de Aristóteles y que no puede considerarse ni original, ni precedente del método de Bacon. En ella, se sirve de argumentos de inducción histórica, del ejemplo, ad populum, etc.: «He recorrido uno por uno los pasajes que cita el Padre Fonseca, y no he encontrado cosa alguna que no estuviera harto de leer en el Organon y en sus comentadores, ni nada que se pareciera a las reglas del procedimiento de inducción, tal como se encuentran expuestos, v. gr., en el canciller Bacon, y mejor en los libros de Whewell y de Stuart Mill... Esto es lo que cree toda la humanidad sobre la historia del método inductivo». 
Por otra parte, señala las insuficiencias de la argumentación con la que Fonseca pretende demostrar que Santo Tomás fue el único teólogo cristiano que pudo influir en los místicos espańoles del siglo Xvi, o que no fuera deudor de las doctrinas de otros teólogos místicos que le precedieron. Ante todo insiste en que su estrategia documental reducida a la citación de textos del Aquinate y a la exposición de su teología mística no es concluyente al respecto. Con argumentos del ejemplo histórico sostiene tanto la existencia de otros grandes místicos y teólogos cristianos que pudieron influir, v. g., Enrique Susón o San Buenaventura, como la influencia de precedentes de los que el Aquinate es deudor, v. g., San Agustín, el pseudo Areopagita, los dos Victorinos y el mismo Alberto Magno.

Además, Menéndez Pelayo sostiene que los neoplatónicos influyeron en elementos estilísticos, filosóficos o psicológicos de nuestros místicos más doctos, mediante un argumento de referencia documental, «[es] visible para cualquiera que los haya abierto». Sólo una posición tradicionalista inaceptable negaría la historicidad de esos aspectos y reduciría la mística a lo sobrenatural y teológico. Y subraya que una exposición de la teología mística tomista, por sí sola, no excluye esa influencia; se requeriría una argumentación documental que excluyera su existencia, «analizando uno por uno los libros que yo cito", cosa que Fonseca no hace. Y el dominico no ha probado tampoco que "para los neoplatónicos alejandrinos, de quienes es un eco el llamado Areopagita, no era también la mística una sabiduría ocultísima que Dios comunicaba inmediatamente al espíritu humano. Ni Platón, ni Jámblico, ni Porfirio sostenían otra cosa» (II, 487).

Esta discusión sirvió para que el historicista católico precisara su posición en este punto: no pretendía negar la influencia de la teología mística tomista en la mística cristiana, sino poner de relieve la especificidad de los místicos españoles en cuanto «manifestación del pensamiento cristiano en la España del siglo XVI, y mostrar que no puede confundirse con la teología de las escuelas». Y aporta cinco argumentos que lo justifican: del testigo, «así lo declaran a cada paso sus mismos doctores»; de la causa, "la mística experimental... no se aprende en la Summa Theologica ni en ningún otro libro conocidos»; de inducción histórica, "en lo que tiene de doctrinal y didáctico la mística influyen en ella más acentuadamente que Santo Tomás, el Areopagita, San Agustín, San Bernardo, San Buenaventura y Gersón»; del indicio, «no hay cosa más lejana en la forma y estilo escolásticos que la forma y estilo de nuestros libros de devoción»; de la causa, «nadie... deja de respirar la atmósfera de su tiempo. Y los místicos españoles la respiraron ampliamente...» (II, 490). 
Menéndez Pelayo argumenta contra la identificación de Fr. Luis de Granada como místico puro, basándose en un acertado juicio sobre su obra: «...nadie puede negar que es mucho más ascético y moralista que místico». Y, en relación a Santa Teresa de Jesús, precisa que, al hablar de la influencia del platonismo sobre nuestros místicos, se refería exclusivamente a los más cultos, como los agustinos, fray Luis de León o Malón de Chaide, o como el franciscano Fr. Juan de los Ángeles, pero no a «una mujer sin letras, como la admirable reformadora del Carmelo». Incluyo aquí un argumento ad ridiculum que muestra la repulsa que le merece el indocto dogmatismo del tomista dominico: «Baste decir que hasta el Espíritu Santo resulta tomista en la carta del Padre Fonseca, quien nos afirma muy gravemente que Santa Teresa aprendió la doctrina de la Summa, porque el Espíritu Santo se la enseñaba; de donde viene a deducirse implícitamente que el Espíritu Santo no puede enseñar más que lo que hay en Santo Tomás, y que ni siquiera enseña la doctrina mística de otros Santos, v. gr., la de San Buenaventura, sino pura y simplemente la de Santo Tomás, por el modo y forma en que la interpretan algunos reverendos Padres Dominicos, con especies inteligibles y todo» (II, 494).

Menéndez Pelayo no encuentra argumentos creíbles del P. Fonseca, para aceptar su pretensión de que el Aquinate era un consumado helenista que utilizaba ediciones críticas de Aristóteles; y defiende la necesidad de incorporar los procedimientos de la filología crítica contemporánea.

Los textos de Fonseca le llevaron, en su Contestación a un filósofo tomista, a escribir contra la generalización del tomismo que ya una vez acabó con la diversidad de la tradición científica española: «....ahora es cuando comenzamos a entender algo de nuestra ciencia, sobre todo de la no escolástica, que los escolásticos puros procuraron sepultar en el olvido, tratándola con la misma inquina y despego que hoy manifiesta el Padre Fonseca a Vives y a Gómez Pereyra...» (II, 466). Más aún, Menéndez Pelayo condenó una restauración de la escolástica en los cauces del tomismo íntegro con un argumento pragmático: por el devastador efecto que tendría este anacronismo sobre nuestra cultura filosófica y científica.

\section{Ecos de la polémica de la ciencia en la última década del siglo XIX}

Hacía tres años que Menéndez Pelayo había concluido la publicación de la tercera edición de La ciencia española (1887-1889), cuando editó incidentalmente en un volumen, y bajo el inadecuado título de Ensayos de crítica filosófica (1892), tres discursos académicos recientes que tenían por objeto 
temas centrales y predilectos de sus estudios histórico-reivindicativos de nuestra filosofía en el Renacimiento: "Algunas consideraciones sobre Francisco de Vitoria y los orígenes del Derecho de Gentes» (1889), «De las vicisitudes de la filosofía platónica en España» (1889), «De los orígenes del criticismo y del escepticismo y especialmente de los precursores españoles de Kant» (1891). Los discursos recogidos no eran piezas históricas acabadas, sino escorzos tentativos y provisionales en los que el historiador tradicional ponía a prueba conceptos historiográficos que pudieran servir de eje para dinamizar las tendencias fundamentales de la tradición filosófica hispana, como ciclo filosófico, rasgo característico o precursor. Además, estos Ensayos..., publicados con motivo del IV Centenario del Descubrimiento de América, nacieron bajo el signo de la polémica de la ciencia que había sido replanteada un par de años antes desde más allá de los Pirineos, haciéndose presente también en la España de la última década del siglo XIX.

El médico e historiador de la medicina, nacionalizado francés, Miguel Guardia Bagur, retomó la posición del racionalismo liberal en dos libelos contra la filosofía española finisecular que atacaban con injustificable acritud la figura y la obra de Menéndez Pelayo, ambos publicados por la Revue Philosophique de Ribot. En el primero, «L'histoire de la philosophie en Espagne» (XXIX, 1890), negaba la existencia de la «filosofía española» que sólo podía ser defendida por ingenuos como Laverde o Valera, o por neocatólicos y sectarios, enemigos de la libertad y de la razón y, por ende, de Francia y de su cultura, como Alejandro Pidal y Menéndez Pelayo. El artículo extendía los improperios de su persona a piezas esenciales de su proyecto historiográfico, como los Heterodoxos y la Historia de las ideas estéticas..., que descalificaba por ser obras metodológicamente monstruosas, verdadero caos de citas producto de la erudición fácil de un bibliófilo-bibliógrafo, ayuno de pensamiento y de ideas... Engendros merecedores del verso de Horacio a Lucilio: Quum flueret lutulentus, erat quod tollere velles.

En uno de los tres Ensayos de crítica filosófica (1892), el titulado «...de los precursores españoles de Kant», Menéndez Pelayo se defiende con una argumentación ad hominem de lo que considera «injusticias y vituperios» de un escritor «ciertamente docto y digno de mejores empresas», pero que se contradice de continuo, arrastrado por «sus odios y flaquezas de tránsfuga»: aborrece y maldice «hasta el nombre de España», pero solo piensa y escribe sobre temas españoles; es hipercrítico, y sin embargo ningún español ha escrito con tanto entusiasmo como él sobre Gómez Pereyra, Huarte de San Juan y Oliva Sabuco. ${ }^{167}$ En este

167 M. Menéndez Pelayo, Ensayos de crítica filosófica, Madrid, 1892, 132-133 
mismo lugar, trae un argumento de autoridad, la de El porvenir de la ciencia..., de Ernest Renan, contra la tesis librepensadora que identifica la Inquisición y la intolerancia católica como la causa de nuestra decadencia científica.

Guardia Bagur respondió a estas alusiones de Menéndez Pelayo en el artículo «La misère philosophique en Espagne» (XXXVI, 1893) en el cual menosprecia la cultura intelectual de la España finisecular, que considera sumida en la «miseria psicológica y anemia mental», ${ }^{168} \mathrm{e}$ incluye una injusta reseña de los Ensayos... Es cierto que éstos son escorzos parciales e inacabados en los que se ponen a prueba conceptos historiográficos que pudieran servir de eje para dinamizar las tendencias fundamentales de la tradición filosófica hispana, v. g., ciclo filosófico, rasgo característico, o precursor; pero no merecen los improperios que les propina el médico afrancesado: «improvisaciones librescas carentes de madurez», ${ }^{169}$ "mediocridad indigna de Historiadores de la Filosofía», ${ }^{170}$ "tentativa de restaurar el eclecticismo en España, por parte de un hombre sin convicciones», "exponentes de una erudición altiva y de juicios temerarios», etc. Menéndez Pelayo no respondió a ese libelo que adelantaba la posición del grupo más influyente de la generación del 98 literario frente a la Restauración y frente al programa pelayano de restablecimiento de nuestra tradición histórica: «no son serios, no son creíbles».

Además, Guardia Bagur expuso en este escrito dos argumentos dignos de consideración: el primero rechaza abiertamente el historicismo, "la teoría de la sucesión histórica de los sistema es tan insostenible como la teoría positivista de los tres estadios»; ${ }^{171}$ y el segundo, que ya había sido esgrimido por Perojo en relación a Vives, cuestiona la contradicción que entraña considerar propios de la tradición cultural española productos filosóficos de razas y autores perseguidos y proscritos, como árabes, judíos y demás heterodoxos.

Entre las voces críticas que plantearon alternativas al programa histórico-tradicional de Menéndez Pelayo en la España finisecular, destaca la del Miguel de Unamuno de En torno al casticismo (1902). El escritor vasco defiende en esos ensayos su interpretación vitalista e irracionalista de la tradición española que late en la vida presente del pueblo y en su paisaje, frente al tradicionalismo y su historiografía erudita que la sitúan en el pasado y sus documentos. Las referencias históricas y literarias de Unamuno son con frecuencia deudoras y reconocen como su fuente a la obra de Menéndez Pelayo, «uno de los españoles que más y mejor ha penetrado en el espíritu castellano, que más y mejor ha

168 M. Guardia Bagur, «La misère philosophique en Espagne», op. cit., p. 293

169 Ib. p. 289

170 Ib. p. 290

$171 \mathrm{Ib}$. 
llegado a su intra-historia, uno de los pocos que ha sentido el soplo de la vida de nuestros fósiles». ${ }^{172} \mathrm{Y}$ comparte con este "defensor en La ciencia española de la causa del casticismo» que la sustancia de la historia es la tradición. ${ }^{173}$ Sin embargo, hace suyos los hechos inconcusos del racionalismo liberal, y rechaza el historicismo católico pelayano y su programa de reivindicación y restablecimiento de la tradición histórica.

En este logos protreptikós de Unamuno, es capital el argumento de la verdadera tradición, que no es la tradición histórico documental sobre «los que meten bulla en la historia», sino la tradición eterna que es «vida intra-histórica, silenciosa y continua..., no la tradición mentira que se suele ir a buscar al pasado enterrado en libros y papeles y monumentos y piedras...». ${ }^{174}$ Esa vida intrahistórica es el presente vivo y vivido del pueblo y en especial de los jóvenes que son los portadores de la vitalidad popular. Por esto utiliza también el argumento de la verdadera juventud, que es la democrática y cosmopolita que se zambulle en la tradición eterna: «Ojalá una verdadera juventud, animosa y libre... avive con la ducha reconfortante de los jóvenes ideales cosmopolitas el espíritu colectivo intracastizo que duerme esperando un redentor!». ${ }^{175}$

No faltan en el texto de Unamuno las argumentaciones funcionales, como el argumento pragmático: «Los [casticismos] que se buscan en el pasado histórico o a partir de él persisten no más que en el presente también histórico, no son más que instrumentos de empobrecimiento espiritual de un pueblo». ${ }^{176}$ Porque el pasado muerto, interrumpido, ya no puede renacer. Así que aplica también el argumento exhortativo de la lamentación por los defensores de la tradición histórica que practican una historia de anticuario, frente a la cual defiende el lema de la intempestiva nietzscheana, historia para la vida:

Hay un ejército que desdeña la tradición eterna, que descansa en el presente de la humanidad, y se va en busca de lo castizo e histórico de la tradición al pasado de nuestra casta... ¡Lástima de ejército! En él hay quienes buscan y compulsan datos en archivos, recolectando papeles, resucitando cosas muertas en buena hora, haciendo bibliografías y catálogos, y hasta catálogos de catálogos, y describiendo la cubierta y los tipos de un libro, desenterrando incunables y perdiendo un tiempo inmenso con pérdida irreparable. ${ }^{177}$

172 Miguel de Unamuno, Obras completas, vol. VIII, En torno al casticismo, Edición y prólogo Ricardo Senabre, Madrid, Fundación José Antonio de Castro, 2007, p. 100.

173 Ib. p. 68.

174 Ib. p. 80.

175 Ib. p. 199.

176 Ib. p. 198.

177 Ib., p. 84. 
Estos trabajos históricos sólo son fecundos, a juicio de Unamuno, cuando impulsan u orientan la vitalidad presente.

La posición unamuniana frente a la tradición histórica fue la predominante en la generación literaria del 98, y se trasmitió a la generación del 14 que, con Ortega, se asentó en un racionalismo vitalista.

\section{Conclusiones}

Los textos de los librepensadores racionalistas que desencadenaron la polémica de la ciencia, lo hicieron de manera accidental e imprevista por sus autores, pues fueron en realidad expresión incidental de algunos de sus hechos y verdades consagradas. Eran evidencias no necesitadas de demostración, certezas de dominio público, lo que creyeron estar presentando Gumersindo de Azcárate, cuando ejemplificaba con el caso de la España moderna la relación causa efecto entre la ausencia de librepensamiento y la inexistencia de vida filosófico-científica; o Manuel de la Revilla, cuando afirmaba que la filosofía y la ciencia española eran un mito, que España no había aportado nada importante a la filosofía y a la ciencia moderna, debido en gran parte al imperio sistemático de la intolerancia religiosa; o Nicolás Salmerón, cuando encausaba al dogmatismo y a la intolerancia católica, y a la institución que los encarnaba, la Inquisición, como responsable de la nulidad científica de la España moderna.

Las fuentes de los hechos y verdades indubitables de estos librepensadores racionalistas fueron a mi juicio básicamente dos: por un lado, su ideología liberal progresista que les hacía suponer tanto la esterilidad filosófica y científica de la cultura católica de la España del antiguo régimen, y de sus productos, como la necesidad de romper radicalmente con ella y superarla; por otro, su ideologización de los resultados establecidos por la historiografía filosófica y científica europea del período, en especial la alemana y la francesa, en las cuales no se reconocía la existencia de aportaciones importantes de España al desarrollo de la filosofía y de las ciencias en la modernidad, ni muchísimo menos la existencia de una historia española de las mismas digna de ser contada.

La carga de la prueba era sin duda obligación de los tradicionales, que lanzaron la polémica, poniendo en cuestión lo establecido por el pensamiento y la historiografía europea de su tiempo; de ahí que la argumentación tradicional se nutriera de argumentos históricos y de argumentos ad hominem de desautorización de los oponentes por su inepcia histórica. Pero los tradicionales que no compartían los presupuestos historiográficos 
posthegelianos de los racionalistas, ni su concepción de la gran tradición occidental, replantearon el sentido de la polémica y dirigieron la argumentación, no sólo a reivindicar nuestras contribuciones al proceso moderno de la filosofía y de las ciencias, sino también a demostrar la existencia de una tradición filosófica y científica española interrumpida, y la necesidad de hacerla renacer. Los argumentos documentales, del ejemplo y de inducción histórica, positivos y negativos del experto, elaborados desde fuentes históricas nacionales e internacionales, y desde sus propios descubrimientos e hipótesis, constituyeron la base de la argumentación tradicional a favor de la existencia de una tradición filosófica y científica española interrumpida, a su juicio, en el siglo XviII por la injerencia cultural y política francesa; además, a fin de fundamentar la necesidad de restablecerla, introdujeron en ella argumentos funcionales, basados en concepciones románticas, como la herderiana que vinculaba la creatividad de los científicos y filósofos con la tradición y los caracteres nacionales de su pueblo. Por otra parte, los argumentos documentales, del ejemplo y de inducción histórica, y el negativo del experto, compusieron la base argumental de su defensa de que la Inquisición fue una institución castiza con su propia función socio-cultural, la cual, más que causar nuestra decadencia civilizatoria, formó parte de la misma, y, en todo caso, contribuyó a ella como un factor histórico entre otros, y no como el más importante. En fin, la argumentación tradicional se completó con una estrategia ad hominem que descalificaba a los racionalistas por menospreciar la ciencia y la filosofía española que desconocían, al no haberlas estudiado, y por ser extranjerizantes, es decir, por defender y representar el punto de vista y los productos culturales extranjeros, en detrimento de los propios.

El racionalista Manuel Revilla sólo contemplaba la existencia de la gran tradición filosófica y científica occidental, en cuyo proceso moderno no tenían cabida ni nuestros adelantados del Renacimiento, ni los desarrollos erráticos de nuestra escolástica barroca. Con argumentos de la verdadera filosofía o de la verdadera ciencia, de las verdaderas aportaciones filosóficas o de las verdaderas aportaciones científicas, rechazó la relevancia de la argumentación histórica de Menéndez Pelayo, y se mantuvo en sus posiciones: sus documentos, sus generalizaciones, sus ejemplos no probarían nada. No habríamos tenido ningún filósofo moderno que compusiera un sistema propio y creara una escuela de pensamiento occidental, como el empirismo o el racionalismo; tampoco habríamos aportado científicos que desarrollaran teorías científicas modernas, o que contribuyeran de manera considerable a su desarrollo. Además, Revilla descalificó a su oponente tradicional por ser un neo que defendía la Inquisición y el catolicismo romano, y amenazó con 
abandonar la polémica amparándose en sus malas formas. Lo cierto es que, a diferencia de Menéndez Pelayo, cuya actividad intelectual estaba volcada en la recuperación de las fuentes primarias y secundarias de la filosofía y la ciencia española, y en la escritura y reivindicación de su historia, Revilla que desconocía y menospreciaba estos estudios, se vio desbordado por las cuestiones históricas e historiográficas que iba planteando la polémica, y no estaba dispuesto a comprometerse con ellas.

Menéndez Pelayo acertó a defender la necesidad de desarrollar los estudios históricos de nuestra filosofía y de nuestras ciencias, cuestionando los criterios fuertes que presidían los argumentos de la verdadera filosofía o de la verdadera ciencia, de Revilla, y conducían así al menosprecio y al abandono de aquellos. Menéndez Pelayo insistió con razón en que la historia de las ciencias no sólo la escribieron las primeras figuras y los creadores de las grandes teorías, sino también los científicos medianos que hicieron contribuciones o desarrollos parciales, o los científicos prácticos, los médicos, los ingenieros, los navegantes, los astrónomos, los naturalistas, etc., que hicieron descubrimientos fecundos desde el punto de vista teórico. Aunque España no dispuso de Descartes o Newtons, dio filósofos, científicos, técnicos, descubridores, etc., que aportaron contribuciones importantes al desarrollo de la filosofía y de las ciencias occidentales, y que protagonizaron una historia filosófica y científica española digna de ser escrita y conocida. El joven polemista católico tenía toda la razón al considerar injusto e inconveniente el descrédito internacional en que se encontraban sumidas la historia filosófica y científica de España, y al promover la lucha por el reconocimiento de nuestra aportación civilizatoria a través de los estudios históricos. No la tenía tanto, y el tiempo se encargó de ponerlo pronto de manifiesto, en su defensa del restablecimiento de nuestra tradición científica y de sus caracteres nacionales.

José del Perojo intentó demostrar de manera definitiva las tesis de Revilla en la polémica mediante una argumentación histórica concluyente, pero sólo logró poner de manifiesto la insuficiencia de sus fuentes históricas y lo cuestionable que resultaba su concepción especulativa y dogmática del proceso seguido supuestamente por la filosofía y las ciencias en la modernidad. La contra-argumentación de Menéndez Pelayo es concluyente, por un lado, en su demostración de que las fuentes desde las que Perojo nutre sus argumentos del ejemplo o de inducción histórica son dudosas enciclopedias alemanas o francesas, que no cita, o discursos académicos aislados, inaceptables desde un punto de vista crítico, entre otras cosas por no ser completos; $y$, por otro, en su rechazo de la concepción neokantiana de la historia de la filosofía y de 
las ciencias, como un proceso puramente teórico y unitario, determinista y dialéctico, que partiría de la posición dogmática racionalista y tendría en Kant el medio de paso al proceso contemporáneo, por tratarse de una construcción especulativa que contradice los hechos y las fuentes. La contra-argumentación de Menéndez Pelayo puso de manifiesto también que era insostenible, tanto la clasificación de la filosofía española y la interpretación de Vives que defiende Perojo, como su intento de reconstruir la supuesta correlación histórica entre la vigencia de la Inquisición y la decadencia filosófico-científica de España.

Pero la argumentación histórica de Menéndez Pelayo remitía a investigaciones recientes, sobre todo de historiadores nacionales, o a descubrimientos e hipótesis propios, y discutibles, la mayor parte de las cuales no habían alcanzado la difusión y el reconocimiento de la crítica histórica europea del período, en especial de la alemana o la francesa, de los que dependía su general aceptación y en definitiva su fuerza argumentativa, también en Espańa. Razón por la cual, su argumentación histórica no probaba entonces de manera concluyente las tesis tradicionales que defendía, ni siquiera demostraba la importancia de la historia de la filosofía y de las ciencias en la España moderna. No es menos cierto, sin embargo, que Menéndez Pelayo aportaba evidencias suficientes para justificar la necesidad de desarrollar los estudios históricos en esas materias, y de restaurar el reconocimiento de la aportación española a la civilización occidental. Precisamente el desarrollo editorial de La ciencia española, en su tercera edición (1887-1889), no tuvo otro sentido que el de aportar trabajos historiográficos e históricos básicos para el desarrollo de ese programa, entre los que destaca la elaboración del inventario de las fuentes primarias de la historia de los saberes en España, o su estudio de la Antoniana Margarita, de Gómez Pereira.

Ni siquiera Gumersindo Laverde pudo prever que los textos pelayanos a favor de la tradición filosófica y científica española frente a los racionalistas derivarían en una sonada polémica con el tradicionalismo tomista que buscaba restablecer el reinado de la filosofía y de la teología de Santo Tomás en las escuelas, y, por ende, en la filosofía española. Razón por la cual esta derivación de la polémica se desarrolló exclusivamente en el campo de la filosofía y de la mística española.

La ausencia de estrategias ad hominem, incluso la complicidad con que se desarrolló la polémica entre Alejandro Pidal y Menéndez Pelayo, no impidió la dureza dialéctica de la confrontación, debida a la disparidad de posiciones entre el partidario de la restauración del tomismo y el defensor del renacimiento de nuestra tradición científica. La argumentación tradicionalista de Pidal y Mon, que vinculaba la filosofía y la historia a la teología y al dogma, 
a fin de defender que la filosofía de Santo Tomás era la verdadera filosofía, la filosofía perenne, y la auténtica filosofía española que se habría mantenido de manera ininterrumpida, o a favor de la Edad Media y en detrimento del Renacimiento y del Humanismo, no aportó argumentos históricos creíbles, y así lo puso de manifiesto Menéndez Pelayo en sus réplicas. Pero tampoco la argumentación pelayana fue capaz de refutar con evidencias solventes los argumentos de Pidal contra la existencia de una tradición filosófica española, con unos caracteres nacionales, o de otra escuela filosófica española de alcance universal que no fuera el tomismo, considerando al suarismo como un desarrollo particular de aquel. En su argumentación, sin embargo, Menéndez Pelayo acertó a defender una visión más histórica de Santo Tomás como filósofo, y a oponerse a la pretensión hegemónica de la escolástica tomista sobre la tradición filosófica española, pretensión, ésta, a la que llega a denunciar como causa principal de la decadencia de las Universidades y de los centros de investigación y docencia en Espańa.

Lamentable e infundada desde el punto de vista histórico, filosófico y científico, fue a mi juicio la argumentación básicamente tomista-documental que el padre Joaquín Fonseca O. P. desarrolló desde los principios del tomismo íntegro a favor de la entronización del Príncipe de las escuelas y de la ciencia, Tomás de Aquino, y del valor perenne de su doctrina, y en contra de la importancia que concedía Menéndez Pelayo a los pensadores independientes y críticos del Renacimiento espańol, o a la influencia ejercida por la literatura mística neoplatónica sobre nuestros místicos en esa edad dorada de nuestra cultura. La agresividad y el dogmatismo inquisitorial de que hizo gala el dominico Fonseca, con el respaldo general del integrismo y con el corporativo de su Orden, en defensa de la hegemonía del tomismo contra la visión más plural y abierta de la tradición filosófica y científica española, promovida por Menéndez Pelayo, le llevó a éste a escribir unas palabras que me parecen proverbiales, si recordamos el regreso lamentable de ese tomismo a la universidad española medio siglo después de que fueran escritas:

Quizá dé yo excesiva generalidad a las palabras del Padre Fonseca; pero entiendo que en nuestro estado actual de cultura, toda insinuación alevosa del género de las suyas, contra tal o cual estudio real y positivo de los que no están sujetos a sistemas, contribuye a perpetuar el universal atraso y debe condenarse acerbamente, venga de donde venga. ${ }^{178}$

En fin, estas polémicas sobre la ciencia española no llegaron a resolverse en una serie de conclusiones compartidas por las partes confrontadas que

178 MP, $C E$, vol. II, p. 474. 
terminaron más bien por enrocarse en sus respectivas posiciones, después de haber introducido, eso sí, algunas precisiones en sus tesis iniciales. Lo que sí progresó y ganó vida propia, con respecto a las polémicas, fue la obra de Menéndez Pelayo, La ciencia española, que corregida y aumentada en sus tres sucesivas ediciones mejoró e incrementó sus aportaciones bibliográficas e históricas. El tiempo se encargó de decantar las posiciones defendidas en ella a favor del desarrollo de los estudios históricos centrados en el conocimiento de la filosofía y de las ciencias, desarrolladas en la España moderna y contemporánea, así como de la toma de conciencia de la necesidad de conseguir el reconocimiento internacional de sus aportaciones y de su valor. 


\section{La ciencia española en los medios de difusión cultural de su tiempo}

Dra. María Cristina Pascerini

Universidad Autónoma de Madrid

Tas reseñas conocidas de que fueron objeto las sucesivas ediciones de $\mathrm{La}$ cultural, ponen de manifiesto el patrón que presidió la acogida y apreciación de esa obra en su tiempo.

\section{Polémicas, indicaciones y proyectos sobre La ciencia española (1876)}

La primera edición de La ciencia española debió de empezar a circular a principios de noviembre de 1876, según se deduce de la correspondencia entre Marcelino Menéndez Pelayo y José María Pereda. El Epistolario, de finales de noviembre, revela los destinatarios a los que envió ejemplares más personales, como los dirigidos a Carlos Bento, en Lisboa, o a Manuel Milá, en Barcelona, así como las sugerencias de envío que le hizo Gumersindo Laverde a conocidos de especial interés: Ceferino González, Venancio María Fernández de Castro, de Valladolid, Mariano Laita y Moya, de Zaragoza, y Francisco Caminero.

Menéndez Pelayo hizo los encargos de ejemplares al editor Eduardo Medina, que en diciembre le informaba así sobre la distribución de la edición de las Polémicas ${ }^{179}$ : cien ya se le habían enviado, sesenta habían sido repar-

179 Marcelino Menéndez Pelayo, Epistolario, edición al cuidado de Manuel Revuelta Sañudo, Madrid, Fundación Universitaria Española, 1982, vol. 2, carta n. ${ }^{\circ} 116$. En adelante citaremos de manera abreviada por esta edición: "EMP, vol. 2, carta n. ${ }^{\circ} 116$ ". 
tidos entre periódicos y revistas, otros sesenta se habían destinado para los encargos suyos y de Laverde, y treinta habían sido distribuidos a libreros. De los cincuenta restantes, veinticinco se quedaban en la editorial para que la obra no desapareciera del catálogo, y otros veinticinco se los iba a remitir.

A finales del mes de noviembre empezaron a aparecer las reseñas sobre el volumen, que, como vamos a ver, no reflejaban el esfuerzo de difusión realizado por el autor y el editor. Se puede incluso hablar de un impacto limitado de las Polémicas, tanto desde el punto de vista del número, como de la tendencia de las reseńas publicadas.

Un primer grupo de reseñas, que se compone de las de Leopoldo Alas, Clarín, y las de Julián Apraiz, valoró positivamente la labor historiográfica y de rescate de los autores espańoles llevada a cabo por Menéndez Pelayo en las Polémicas, pero criticó sus ataques a la ciencia española contemporánea, al considerar que su desarrollo no es irreconciliable con el estudio de la tradición española. Se trataría, en definitiva, de reseñas en parte críticas con las Polémicas y firmes en frenar su ataque a los planteamientos de sus contemporáneos, pero favorables en cualquier caso a la obra, y que apreciaron su aportación histórica, literaria y bibliográfica.

La primera en aparecer, el 29 de noviembre, en la revista El Solfeo, fue la de su "amigo y condiscípulo», Leopoldo Alas, Clarín, que creía encontrar «algo de excesivo y mucho de injusto al lado de muy legítimas y nobles aspiraciones». ${ }^{180}$ Elogiaba el hecho de que Menéndez Pelayo hubiera vuelto a dar lustre a muchos escritores españoles y hubiera animado al estudio de «la tradición de la ciencia nacional», pero le reprochaba por haberse burlado de las revistas españolas que difundían los conocimientos contemporáneos y los escritos extranjeros. Consideraba un error despreciar «la ciencia patria de hoy» para defender «la ciencia patria de ayer». Sin embargo, y con «los distingos» especificados, terminaba dándole «la más cordial enhorabuena por sus trabajos». ${ }^{181}$

En un artículo sobre los estudios helénicos en Espańa, publicado por la revista del Ateneo de Vitoria en diciembre de 1876, Julián Apraiz elogiaba al joven «de apenas cinco lustros», pero ya «gigante en saber», «que promete ser asombro de propios y extrańos». ${ }^{182}$ Siguiendo los planteamientos de Gumersindo Laverde, Menéndez Pelayo proponía en sus Polémicas dar a conocer a

180 Clarín, «Libros. Polémicas, indicaciones y proyectos sobre la Ciencia española, por D. M. Menéndez y Pelayo", El Solfeo, n. ${ }^{418,} 29$ de noviembre de 1876, p. 2.

181 Ib., p. 2.

182 Julián Apraiz, «Los estudios helénicos en España», El Ateneo. Órgano del Ateneo Cientifico, Literario y Artístico de Vitoria, Tomo V, n.o 2, diciembre de 1876, p. 25. 
través de monografías histórico-críticas «la oscurecida y en gran parte sumida en sinuosos escondrijos, historia intelectual de España, en algunas de sus ramas», y ofrecía «un magnífico programa de la historia de la ciencia española». Con todo, Apraiz consideró una «lástima grande» que el joven polemista, en su identificarse tanto con la ciencia española antigua, se mostrara intolerante con la presente, cuando sus «sabias disertaciones» no dejaban de tener la forma «de las exigencias críticas de nuestro controvertido siglo». ${ }^{183}$

Un segundo grupo de reseñas, ejemplificado por las de José María Pereda, Amós Escalante, Francisco Caminero, o la aparecida anónimamente en $\mathrm{La}$ Civilización, se mostraron completamente conformes con las Polémicas, en las que celebraron incluso su fuerza polémica. Elogiaron su contenido, que mostraba la importancia de las escuelas filosóficas españolas, y apuntaron a ulteriores posibilidades de desarrollo de la materia. En general, vincularon las Polémicas al servicio del catolicismo y de la patria, olvidándose de mencionar su afán historiográfico y su preocupación primera por reconstruir la historia del pensamiento español de la forma más completa posible.

El montañés José María Pereda escribió una halagadora reseña sobre las Polémicas que fue publicada por dos diarios: el 21 de diciembre de 1876 por La Fé, Periódico Monárquico, y el 28 del mismo mes por El Aviso, de Santander. En ella reconoció a Menéndez Pelayo y a Gumersindo Laverde como los defensores de la existencia de la filosofía en Espańa. Menéndez Pelayo, a pesar de su juventud, se movía en la ciencia española "como pez en el agua», y demostraba la existencia de escuelas filosóficas españolas mediante la cita de libros y autores; suyo era el mérito de haber hablado «de la importancia de la ciencia española mucho más que cuanto se ha dicho en lo que va de siglo». ${ }^{184}$ Su mérito consistía sobre todo en haber estudiado y sacado a la luz los antiguos libros de la ciencia espańola, materia que ha demostrado ser «inagotable».

Otro montañés, Amós Escalante, ${ }^{185}$ publicó anónimamente el 15 de diciembre, en La Tertulia, de Santander, una reseña de las Polémicas, libro digno a su juicio de ser «ávidamente buscado y leído por cuantos aman lealmente las glorias del ingenio patrio». ${ }^{186}$ Consideraba que los escritos «de

183 Ib., p. 27.

184 José María de Pereda, "Bibliografía. Polémicas, indicaciones y proyectos sobre la Ciencia española", La Fé, Periódico Monárquico, n. ${ }^{\circ}$ 18, 21 de diciembre de 1876, p. 1.

185 La reseńa de La Tertulia no tiene firma, pero en una carta de 30 de diciembre de 1876 Menéndez Pelayo escribió a Gumersindo Laverde que el autor era Amós Escalante (EMP, vol. 2, carta n. $\left.{ }^{\circ} 129\right)$.

186 «Sección bibliográfica. M. Menéndez y Pelayo, Polémicas, indicaciones y proyectos sobre la ciencia española», La Tertulia. Segunda Época. Ciencias, Literaturas y Artes, n. ${ }^{o}$ 10, 15 de diciembre de 1876, Santander, Imprenta de Solinis y Cimiano, 1876, p. 320. 
crítica, bibliografía e historia religiosa», contenidos en la obra, defendían el valor de la filosofía espańola para que fuera apreciada no solo por sus admiradores, sino también por sus adversarios. Elogiaba en fin al «diestro y animoso polemista», que parecía nacido para dar continuidad a «la tradición gloriosa no solo de nuestros grandes humanistas, sino la de nuestros vigorosos dialécticos y profundos pensadores». ${ }^{187}$

En la revista católica La Civilización, ${ }^{188}$ apareció una reseña anónima de las Polémicas, según la cual el mérito de la obra de Menéndez Pelayo consistía en haber demostrado el valor científico de «la España de nuestros mayores», dando «soberbios varapalos» a sus oponentes, $y$ «acreditando a la vez su amor a la religión, a la patria, a la justicia y a la ciencia». ${ }^{189} \mathrm{El}$ autor puntualizaba que la obra, por su carácter, no podía tener «la unidad deseable», si bien sus trabajos, primorosamente escritos, componían «un conjunto deleitable». Y concluía dando su parabién tanto a la obra como a la patria, la cual estaría próxima a salir de la «decadencia intelectual», en la que la habrían sumido las doctrinas liberales y revolucionarias.

En La Defensa de la Sociedad, de enero de 1877, Francisco Caminero ${ }^{190}$ publicó una elogiosa reseña de las Polémicas, «un libro del portentoso joven D. Marcelino Menéndez y Pelayo», escrito «a vuela pluma» y por efecto de una «indignación santa y patriótica». ${ }^{191}$ El conocido detractor de los krausistas destacaba en su reseña «la abundancia de datos, el brío de la argumentación, la firmeza de carácter y de juicio» de que hacía gala el autor, a la vez que exaltaba el valor patriótico de los artículos que incidían en los «medios de levantar las glorias nacionales en el orden científico y literario», labor ya empezada por Laverde. Caminero concluía definiendo al autor del libro como «una gloria nacional». ${ }^{192}$

La aportación histórica de las Polémicas fue destacada especialmente por el P. Miguel Mir en el primer cuaderno de la revista La Ciencia Cristiana. ${ }^{193} \mathrm{Su}$

187 Ib., p. 320.

188 «Revista de libros españoles. Polémicas, indicaciones y proyectos sobre la ciencia española», La Civilización. Revista Católica, Tomo séptimo, 1876, p. 537.

189 Ib., p. 537.

$190 \mathrm{El}$ artículo está firmado con las iniciales «F. C.». En la carta de 4 de enero de 1877, Laverde escribió a Menéndez Pelayo que el autor era [Francisco] Caminero (EMP, vol. 2, carta n. $\left.{ }^{\circ} 130\right)$.

191 "Polémicas, indicaciones y proyectos sobre la ciencia española», La Defensa de la Sociedad, Tomo décimo, n. ${ }^{\circ}$ 151, 1 de enero de 1877, p. 445

192 Ib., p. 446.

193 Miguel Mir, «Revista de libros. Polémicas, indicaciones y proyectos sobre la ciencia española», La Ciencia Cristiana, Revista Quincenal, primer cuaderno, 1877, pp. 63-68. 
artículo-reseña fue relevante no tanto por los elogios patrióticos a las Polémicas, pues también las reseñas de Clarín y Apraiz o las de Pereda, Escalante y Caminero destacaron la importancia de la obra para el conocimiento de "los antepasados», sino porque acertó a atribuirle el mérito de situar a los autores españoles en la historia del pensamiento. En este sentido, el artículo-reseña del padre Mir fue, a nuestro juicio, el que mejor captó la validez y trascendencia de la rigurosa labor histórica realizada por Menéndez Pelayo en las Polémicas.

El padre Mir destacó desde el comienzo la importancia de la figura de Menéndez Pelayo, al que comparó con importantes estudiosos de los «ingenios españoles», como Nicolás Antonio o Pérez Bayer. El libro, a su juicio, no solo lograba arrojar luz sobre «la extensión, universalidad y eminencia de la sabiduría de nuestros antepasados», sino que mostraba que «es imposible escribir la historia de la civilización europea, sin tener en cuenta sus esfuerzos y adelantamientos intelectuales». ${ }^{194} \mathrm{Un}$ único reproche le hizo y fue que hubiera podido evidenciar más «los altos merecimientos de Balmes», y tributarle «alguna parte de las alabanzas que da al valenciano Luis Vives». ${ }^{195}$ La exhortación final del padre Mir se dirigía a los jóvenes españoles, para que siguieran «el ejemplo de su noble compañero Sr. Menéndez Pelayo», leyendo y estudiando «las obras inmortales de los ilustres españoles, que fueron altísimo honor de su patria y del género humano». ${ }^{196}$

Desde luego, las reseñas más conocidas de la primera edición de La ciencia española, y que más influyeron tanto en el desarrollo posterior de la polémica, como en la segunda edición de la obra, fueron los dos artículos de Alejandro Pidal y Mon publicados, los días 17 y 24 de marzo de 1877, en la Hoja Literaria de La España, el suplemento cultural de los sábados del diario católico $L a$ España. Pues, si el primero de los artículos de Pidal elogiaba hasta la exaltación las cartas de Menéndez Pelayo, al que declaraba vencedor en la polémica con los racionalistas, en el segundo chocaba frontalmente con su programa histórico tradicional de reivindicación y restablecimiento de la tradición filosófica española, frente al que proponía la restauración de la escolástica tomista. El 24 de febrero se había publicado en ese mismo diario el artículo, «Un filósofo español en el siglo XVIII», de F. Gracián, quien en una nota a pie de página se había referido a la obra del «aventajadísimo joven Sr. Menéndez», ${ }^{197}$ citándola con el título aproximado de Indicaciones y polémicas sobre la ciencia española.

194 Ib., p. 64.

195 Ib., p. 66.

$196 I b .$, p. 67.

197 F. Gracián, «Un filósofo español en el siglo xviII. Desengańos filosóficos», Hoja Literaria de La España. Diario Católico, n. ${ }^{\circ} .237$, sábado 24 de febrero de 1877, p. 1. 
Los artículos de Pidal, que fueron incluidos posteriormente en la segunda edición de La Ciencia Española, han sido objeto de un análisis detenido en el apartado anterior de esta introducción. La apuesta de Menéndez Pelayo por la tradición filosófica española, en especial por el vivismo y el pensamiento independiente y crítico del Renacimiento, dio lugar inevitablemente a que la polémica derivara en una confrontación abierta con el tradicionalismo tomista ante un auditorio exclusivamente católico.

De otra naturaleza fue la última reseña conocida de las Polémicas, que apareció en la revista francesa Polybiblion. Revue Bibliographique Universelle en $1877 .{ }^{198}$ Iba firmada con las iniciales de «J. de V.», y era breve y técnica. Describía el contenido de la obra sin emitir juicios, pero dejando claro lo que se podía encontrar en ella: la recopilación de todos los filósofos españoles y la bibliografía relativa al tema; el programa de Menéndez Pelayo para volver a dar fuerza a estos estudios en España; y el plan de trabajo de los heterodoxos. El autor de la reseña no dejó de reproducir la expresión «católico a macha martillo»-que se convertiría en todo un tópico- para indicar la orientación del autor, ni de mencionar la carta-prólogo de Laverde en la que se encontraban resumidas las ideas de Menéndez Pelayo, felicitándole por la obra.

\section{La ciencia española: polémicas, indicaciones y proyectos (1879)}

La segunda edición de La ciencia española empezó a circular a comienzos de 1880. Una revista francesa, la Revue Critique d'Histoire et de Littérature, ${ }^{199}$ fue la primera en anunciar la publicación de la nueva edición de las Polémicas, «considerablemente aumentada». Las reseñas de esta segunda edición, escritas por literatos amigos de Menéndez Pelayo, fueron favorables y más reposadas que las anteriores; y destacaron la importancia de la obra para la cultura española sin la carga nacionalista y religiosa de las reseñas de la primera.

En efecto, esta edición mereció una reseña encomiástica de Emilia Pardo Bazán en el número 5 de la Revista de Galicia. ${ }^{200}$ La escritora gallega

198 «M. Menéndez Pelayo, Polémicas, indicaciones y proyectos sobre la ciencia española», Polybiblion. Revue Bibliographique Universelle. Partie littéraire. Deuxième série. Tome cinquième. XIX de la collection. Première livraison. Janvier. Societè Bibliographique. Paris aux Bureaux du Polybiblion, 1877, pp. 139-140.

199 Revue Critique d'Histoire et de Littérature, n. ${ }^{\circ}$ 3, 19 de enero de 1880, Tome IX, Paris, Ernest Leroux Éditeur, p. 6.

200 La reseña no tiene firma. Pardo Bazán, en la carta de 28 de marzo de 1880 dirigida a Menéndez Pelayo, dejó entender que ella era su autora (EMP, vol. 4, carta n. $\left.{ }^{\circ} 140\right)$. 
consideró que se trataba de una obra «única en su género en España, y por todos conceptos importantísima», ya que hacía renacer «nuestro movimiento intelectual, nuestra actividad literaria, científica y artística». ${ }^{201}$ Bajo la pluma de Menéndez Pelayo recobraban «vida y color figuras borradas ya de nuestra ingrata memoria». ${ }^{202}$ Pardo Bazán, que destacó la «copiosísima e invencible erudición» del joven autor y su "prosa clara y castiza», concluyó afirmando que sus apreciaciones apenas hacían justicia a la obra, e invitando a su lectura.

En mayo de 1880 Francesc d'Assís Masferrer i Arquimbau publicó en La Veu del Montserrat tres artículos sobre esta segunda edición de La ciencia española en forma de cartas dirigidas a su director, Jaume Collell. Se trataba de unas reseńas, de corte catalanista y católico, que exaltaban la figura de Menéndez Pelayo y su formación catalana, a la vez que subrayaban el valor de esta obra para la historia del pensamiento y las letras españolas. En ellas Masferrer expresaba su adhesión plena a las consideraciones de Menéndez Pelayo sobre la oportunidad de promover iniciativas para revitalizar los estudios hispánicos, y sobre la importancia de la figura y la obra de Luis Vives.

En el primero de sus artículos, fechado el 21 de abril en Teruel, Masferrer proclamó su entusiasmo por el joven santanderino, "providencial restaurador de nuestras olvidadas letras», ${ }^{203}$ y recordó que Menéndez Pelayo había sido discípulo de Milá i Fontanals, en los estudios literarios, y, en los filosóficos, de Laverde y de Llorens i Barba que le trasmitieron su vocación de historiador del pensamiento ibérico. Subrayó, además, que el interés del montañés se dirigía sobre todo hacia los filósofos que habían fundado escuela, como Lulio, Vives y Suárez, o que habían llevado los principios de sus doctrinas al extranjero, sin dejar de mencionar el respeto del montañés por Tomás de Aquino y su predilección por Vives.

En el segundo artículo, fechado el 4 de mayo en Teruel, Masferrer recordó la formación de Menéndez Pelayo en la Universidad de Barcelona y su labor de recuperación de la filosofía espańola que, «administrada con el conocimiento y arte que posee el Sr. Menéndez», ${ }^{204}$ habría de convertirse en la mejor medicina contra el positivismo.

201 «Bibliografía. La Ciencia Española (polémicas, indicaciones y proyectos)», Revista de Galicia, ańo I, n. ${ }^{\circ}$, 4 de abril de 1880, p. 43.

202 Ib., p. 43.

203 Francesch Masferrer, "Bibliografía. La ciencia española», La Veu del Montserrat, Any III, n. ${ }^{\circ} 18,1$ de mayo de 1880, p. 151.

204 Francesch Masferrer, "Bibliografía. La ciencia española», La Veu del Montserrat, Any III, n. ${ }^{\circ}$ 20, 15 de mayo de 1880, p. 168. 
La tercera y última de las entregas de Masferrer, fechada el 12 de mayo en Teruel, retomó el programa de Menéndez Pelayo para potenciar los estudios hispánicos, insistiendo en la conveniencia de crear cátedras y doctorados en colaboración con las academias y sociedades «catalanescas»; 205 y aprovechó además para subrayar la importancia de autores como Vives, Lull o Sabunde, y de la escuela filosófica catalana.

En agosto de 1880, Vicente Barrantes publicó en el Diario de Barcelona, bajo el pseudónimo de Publicio, dos artículos que llevaban por título, «La paliza más bien dada. Examen del libro La Ciencia Española, de D. M. Menéndez Pelayo». Barrantes manifestó su plena adhesión a la labor pelayana de revalorización de la cultura española, y denunció el silencio de la prensa en torno a La ciencia española, la cual podría explicar el escaso y parcial número de reseñas que recibió.

En efecto, el primero de los artículos de Barrantes, del 24 de agosto, lamentaba «la conspiración del silencio»" ${ }^{206}$ de que rodean los periódicos y con la que ocultan a ciertos libros, entre los que se contaba La ciencia española. Sostenía Barrantes que esta obra de Menéndez Pelayo estaba siendo silenciada por sus afirmaciones en favor de la religión y la ciencia patria. A pesar de lo cual, la segunda edición de la obra había mantenido las expresiones más polémicas, además de incorporar «los incomparables artículos y cartas» de Alejandro Pidal y las respuestas a los mismos.

En el segundo artículo, de 28 de agosto, Barrantes retomó la tesis de Azcárate sobre la falta de desarrollo científico en España y atacó «la literatura sectaria y antiespañola» que, según él, dominaba en revistas y ateneos, lamentando el desconocimiento de la historia patria. Finalmente, apoyó el «magnífico plan de regeneración de estudios» propuesto por Menéndez Pelayo para que los jóvenes volvieran a «las fuentes purísimas y regeneradoras de la cultura nacional». ${ }^{207}$

Es posible que esta segunda edición de La Ciencia Española diera lugar en 1881 a la edición barcelonesa de una biblioteca económica de libros católicos, que aparecieron en el boletín, de marcado carácter religioso, La Verdadera Ciencia Española, fundado y dirigido por José Palau y Huguet.

205 Francesch Masferrer, «Bibliografía. La ciencia española», La Veu del Montserrat, Any III, n. ${ }^{\circ}$ 22, 29 de mayo de 1880, pp. 186-187.

206 Publicio [pseud. de Vicente Barrantes], «La paliza más bien dada. Examen del libro La ciencia española, de D. M. Menéndez Pelayo», Diario de Barcelona, 24 de agosto de 1880. 207 Publicio [pseud. de Vicente Barrantes], «La paliza más bien dada. Examen del libro La ciencia española, de D. M. Menéndez Pelayo», Diario de Barcelona, 28 de agosto de 1880. 
La noticia de la publicación de La ciencia española llegó más allá de los Pirineos. Prueba de ello fue la breve cita que le dedicó en 1881 la revista alemana Unsere Zeit. Deutsche Revue der Gegenwart, publicada en Leipzig por Rudolf von Gottschall. En el artículo "Literarische Plaudereien aus Madrid», Wilhelm Lauser mencionaba a Menéndez Pelayo, quien pretendía demostrar con esta obra «que los espańoles no han producido para la ciencia tan poco como por regla general se acepta». ${ }^{208}$ Para no hablar de las referencias a la misma que hicieron sus amigos franceses, Morel-Fatio o Auguste Pécoul. ${ }^{209}$

Los ecos de La Ciencia Española llegaron también a la América hispana. A finales de 1882, en Colombia, el Diario de Cundinamarca atacó la obra, apoyando la tesis de que la monarquía cristiana y la Inquisición habían ahogado y alejado la ciencia de España. La defensa de Menéndez Pelayo fue protagonizada en cambio por su amigo, Miguel A. Caro, que a tal efecto publicó dos artículos en el diario El Conservador, de Bogotá.

El primero de los artículos, aparecido el 30 de diciembre de 1882, tenía un fuerte componente religioso y se orientaba sobre todo a la defensa de la Iglesia católica. En él, Caro intentó explicar la presencia de la Inquisición en España como una de las múltiples acciones emprendidas por los Reyes Católicos para lograr la unidad del Estado español, que no habría sido el único Estado europeo en ejercer el control religioso. Recordó que, según el redactor del artículo del Diario de Cundinamarca, la decadencia científica habría empezado en el siglo XVIII, precisamente cuando la Inquisición había perdido ya su vigor, como había puesto de manifiesto Menéndez Pelayo.

En el segundo de los artículos, publicado el 4 de enero de 1883, Caro se encargó de defender La ciencia española y a su autor, subrayando sus méritos científicos. Al escribir este libro, Menéndez Pelayo no sólo habría realizado «una obra patriótica», sino que habría prestado «un gran servicio científico", tanto por las noticias y apreciaciones críticas que aporta, como por los prejuicios que supera-como los concernientes a la Inquisición, que vetaban ocuparse de la historia de España.

La respuesta del Diario de Cundinamarca a los artículos de Caro apareció el sábado 13 de enero de 1883, concerniendo tanto a La ciencia española como a la Inquisición; además formuló un juicio parcial sobre la figura de Menéndez Pelayo. En primer lugar, sostuvo que los libros citados en esa obra eran una

208 Wilhelm Lauser, «Literarische Plaudereien aus Madrid», Unsere Zeit. Deutsche Revue der Gegenwart, Leipzig, F. U. Brodhaus, 1881, p. 11.

209 En la Revue Critique d'Histoire et de Littérature no se ha encontrado la reseña anunciada por Pécoul en la carta a Menéndez Pelayo de 27 de marzo de 1880 (EMP, vol. 4, carta n. $\left.{ }^{\circ} 139\right)$. 
prueba de los conocimientos bibliográficos de Menéndez Pelayo, pero nada más, pues no se especificaban en ella las contribuciones científicas concretas que aportaban. En segundo lugar, se reafirmó en la idea de que los tribunales creados por la Inquisición impidieron el clima requerido para el cultivo de la ciencia. En fin, el Diario aseguraba no tener ninguna animadversión hacia la persona de Menéndez Pelayo, a quien consideraba «un prodigio de estudio, memoria y erudición» que sin duda había escrito mucho, pero estérilmente.

\section{La ciencia española: polémicas, proyectos y bibliografía (1887-1889)}

Antonio Rubió y Lluch, compañero de estudios en Barcelona y amigo íntimo de Menéndez Pelayo, publicó en El Criterio Católico una "Carta al Sr. D. Marcelino Menéndez Pelayo sobre la tercera edición de "La ciencia española”». La primera entrega de la carta, aparecida el 6 de agosto de 1887, subrayaba el cambio de tono retórico experimentado por la obra en sus sucesivas ediciones, hasta llegar a reparar en la tercera los excesos polémicos de juventud, tributando a Manuel de la Revilla «tiernas frases» y «justos elogios». Rubió presentaba en ella con objetividad el contenido del libro, a la vez que reconocía con entusiasmo el acierto de las acciones propuestas por su amigo a fin de poner freno «a la ignorancia que reina en materia de filosofía y de ciencia española»; 210 entre ellas, destacaba especialmente la conveniencia de potenciar las cátedras de literaturas hispánicas y las aportaciones historiográficas de las comunidades religiosas.

La segunda entrega de la carta, fechada en San Boy del Llobregat el 17 de julio de 1887, apareció el 13 de agosto, también en El Criterio Católico. Rubió expresó en ella su nostalgia de los tiempos en que la prensa católica alababa unánimemente a Menéndez Pelayo, y lamentó que «la política de partido» le hubiera convertido en víctima de una conspiración de silencio, no dedicando «ni una modesta gacetilla laudatoria» a quien había levantado «un monumento colosal a la cultura española». ${ }^{211}$

El 15 de septiembre de 1887 terminó de imprimirse el segundo tomo de la tercera edición de La ciencia española; en cambio, el tercero y último de esta edición no acabó de imprimirse hasta el 5 de marzo de 1889, aunque

210 Antonio Rubió y Lluch, «Carta al Sr. D. Marcelino Menéndez Pelayo sobre la tercera edición de «La ciencia espańola»", El Criterio Católico, n. ${ }^{\circ}$ 10, 6 de agosto de 1887, p. 254.

211 Antonio Rubió y Lluch, "Carta al Sr. D. Marcelino Menéndez Pelayo sobre la tercera edición de "La ciencia española". Continuación", El Criterio Católico, n. ${ }^{\circ} 11$, 13 de agosto de 1887 , p. 275. 
apareciera como impreso en 1888. El 16 de marzo de 1889, el diario moderado La Época incluyó al parecer una reseña muy elogiosa de este tercer volumen, en especial del inventario bibliográfico que ponía a disposición de los estudiosos. ${ }^{212}$

En otoño de 1889, la obra de Menéndez Pelayo comenzó a sufrir las críticas de José María Guardia Bagur quien la atacó en varios artículos, verdaderos libelos que publicó la Revue Philosophique, de Théodule Ribot, al otro lado de los Pirineos. En su artículo, «Philosophes espagnols. Gómez Pereira», ${ }^{213}$ el médico mallorquín metido a historiador de la medicina criticó de manera desconsiderada el estudio monográfico sobre Gómez Pereira incluido en La ciencia española, del que por otra parte se había aprovechado ampliamente en su propio trabajo. Pocos meses después, el doctor mallorquín nacionalizado francés se mostró partidario del racionalismo ilustrado de los herederos del krausismo en su artículo, «L'Histoire de la Philosophie en Espagne» (1890), ${ }^{214}$ en el cual volvió a negar la existencia de la filosofía española, al tiempo que descalificaba a sus promotores, con especial acritud en su crítica a Menéndez Pelayo, a quien situó erróneamente en las filas del integrismo junto al tomista tradicionalista Alejandro Pidal. En fin, Guardia Bagur volvió a cargar contra el santanderino en su desafortunado artículo, "La misère philosophique en Espagne» (1893), ${ }^{215}$ esta vez con una injusta reseña de sus Ensayos de crítica filosófica (1892).

En 1893, sin embargo, La ciencia española logró un éxito considerable en el contexto académico español. En su discurso de ingreso en la Real Academia de Ciencias Exactas, Físicas y Naturales, titulado «Cultura científica de España en el siglo XVI», Acisclo Fernández Vallín elogió abiertamente esa obra de Menéndez Pelayo, por quien sentía rendida admiración. El discurso de Vallín, ordenado a poner de manifiesto las contribuciones hispánicas al progreso de las ciencias en ese Siglo de Oro, calificó a La ciencia española de «precioso libro», fuente de «apuntes valiosísimos» para la investigación histórica de los científicos españoles del pasado. ${ }^{216}$

212 Veinticuatro diarios. Madrid, 1830-1890. Colección de índices de publicaciones periódicas. (IV tomos), Madrid, CSIC, Instituto Miguel de Cervantes, 1972, p. 211, 4850. 1889-III-16. No lo hemos encontrado.

213 Revue Philosophique de la France et de l'étranger, París, 1889, tomo 28, p. 273.

214 Revue Philosophique de la France et de l'étranger, París, 1890, tomo 30.

215 Revue Philosophique de la France et de l'étranger, París, 1893, tomo 36.

216 Acisclo Fernández Vallín, "Cultura científica de España en el siglo xvi», Discursos leidos ante la Real Academia de Ciencis Exactas, Físicas y Naturales en la Recepción pública del Excmo. Sr. D. Acisclo Fernández Vallín, Madrid, Est. Tipográfico «Sucesores de Rivadeneyra», 1893, nota de p. 17. 
A medida que avanzaba la década de los noventa, los miembros de la generación literaria del 98 iban marcando su distancia frente a la obra erudita del historiador montañés. Ángel Ganivet lo había hecho en su ensayo, España filosófica contemporánea (1889). Miguel de Unamuno lo hizo en la serie de cinco ensayos que publicó La España Moderna en 1895, recogidos más adelante bajo el título En torno al casticismo. No faltaron, sin embargo, los elogios de la figura y de la obra de Menéndez Pelayo. Antolín López Peláez le dedicó el artículo, «Celebridades católicas» (1896), en el que le considera «uno de los hombres más portentosos que han visto los siglos y recordará siempre con orgullo la historia de la ciencia». ${ }^{217} \mathrm{El}$ artículo mencionaba también $\mathrm{La}$ ciencia española, en la que Menéndez Pelayo planteó «la tesis cuyo desarrollo ha sido la constante y fecunda tarea de su laboriosa vida». ${ }^{218}$

En fin, la reseña del «Homenaje a Menéndez Pelayo en el año vigésimo de su profesorado», publicada por Alfred Morel-Fatio en el Bulletin Hispanique (1899), valoró positivamente La ciencia española como un «útil repertorio al que pueden recurrir quienes no se manejan con facilidad con los instrumentos especiales de la erudición española», ${ }^{219}$ si bien mantuvo algunas reservas sobre la cuestión de la ciencia y filosofía española. En una nota informaba en detalle sobre las tres ediciones de la obra: la primera de 1876, la segunda de 1879 y la tercera de 1887-88.

Los esfuerzos de Menéndez Pelayo por enriquecer desde el punto de vista historiográfico esta tercera edición de La ciencia española no sirvieron para cambiar el patrón general de la acogida de que fueron objeto las dos ediciones anteriores de la obra en los medios de prensa del momento. Entre el silencio de los medios católicos, integristas o más afines a la tesis del tradicionalismo tomista, y la indiferencia de la prensa progresista, volcada en la difusión de la cultura filosófica y científica europea, sólo se abrieron paso un puñado de reseñas y comentarios de críticos amigos del autor o de orientación independiente. Este fue tal vez el destino inexorable de una obra polémica que defendía una tesis minoritaria sobre el pasado filosófico y científico de España, en un país polarizado ideológicamente donde la labor histórica de Menéndez Pelayo no consiguió el reconocimiento que merecía.

217 Antolín López Peláez, «Celebridades católicas. Menéndez Pelayo», El Diario de Galicia: periódico católico e independiente, n. ${ }^{\circ}$ 1659, 30 de octubre de 1896, p. 1.

218 Ib., p. 1.

219 Alfred Morel-Fatio, «Bibliographie. Homenaje a Menéndez Pelayo en el año vigésimo de su profesorado", Bulletin Hispanique, Tome I, n. * 4, Octobre-Décembre, 1899, p. 212. 


\section{El «Inventario bibliográfico» de La ciencia española desde la perspectiva de la Bibliografía y la Documentación científica}

Dr. Nicolás Bas

Universidad de Valencia

$\mathrm{H}$ ablar de la bibliografía española del siglo XIX es referirse indiscutiblemente al santanderino Marcelino Menéndez Pelayo. De hecho, su obra es, en gran medida, bibliográfica. Una pasión, en el amplio sentido de la palabra, que nació en el «bibliógrafo montañés» no por generación espontánea, sino como resultado de un amplio magisterio y de un carácter autodidacta, el de un voraz lector, que hizo de él un modelo de referencia intelectual en Europa y América.

Pero no podemos hablar de Menéndez Pelayo como bibliógrafo, sin acercarnos, aunque sea brevemente, a aquellos episodios que marcaron su formación en esta disciplina y sin los cuales no podemos entender la que es su obra de bibliografía científica incluida en La ciencia española. No sin antes subrayar algunos rasgos que sitúan a Menéndez Pelayo en la estela de los grandes bibliógrafos europeos. Porque al aproximarnos a su dilatada biografía encontramos un detalle que llama poderosamente la atención, la precocidad de su inquietud bibliográfica. Tenía tan solo veinte años cuando redacta su «De re bibliographica», que figura en la epístola a Gumersindo Laverde, en junio de 1876, y que se incluiría en la citada Ciencia española. Algo más mayor era Conrad Gesner, que tenía 29 años cuando publicó su Bibliotheca universalis (1545); el librero Brunet tenía 22 años cuando publicó el suplemento al Dictionnaire bibliographique des livres rares (1790), de 
Duclos et Cailleau; y el célebre bibliógrafo español José Simón Díaz tenía 24 años cuando publicó sus «Documentos referentes a escritores del siglo xviII", en la Revista de Bibliografía Nacional de Madrid. ${ }^{220}$

\section{Fiel heredero de Nicolás Antonio}

Similar precocidad demostró el hispalense Nicolás Antonio, modelo bibliográfico de Menéndez Pelayo, que con veinticinco años aproximadamente ya pensó en «formar un Índice Universal, i Crítico de todos quantos Españoles avian escrito hasta su tiempo desde el imperio de Augusto». ${ }^{221}$ Eran los orígenes de la célebre Bibliotheca Hispana (1672-1696), que se publicaría ya fallecido su autor.

Cuando uno analiza las trayectorias de los dos Bibliógrafos observa los paralelismos existentes entre ambos, que hicieron de sus obras las mejores embajadoras de la cultura española. No en vano, tanto la Bibliotheca Hispana como el «Inventario bibliográfico» de La ciencia española nacieron como respuesta al sentimiento de vacío historiográfico que existía en España en aquellos momentos. Igualmente, ambas obras necesitaron de una enorme labor de documentación y recopilación en archivos y bibliotecas, tanto españolas como europeas. Los dos autores sentían igual desinterés hacia la escolástica, y ambos formaron extraordinarias bibliotecas para su época, si bien la del santanderino tuvo mejor fortuna que la del sevillano. ${ }^{222}$

Es evidente cómo la Bibliografía, entendida en este caso como pasión por los libros, y por ende, por la sistematización del conocimiento, formó parte de la vida de Menéndez Pelayo desde muy tierna edad. Algo que lo situará como un precursor de la Ciencia de la Documentación, de la que forma parte la Bibliografía como disciplina. Y es que la trayectoria del santanderino no puede desvincularse de los orígenes de la Documentación, que inició su andadura a finales del siglo XIX. Más al contrario, sus aportaciones se adelantaron en años a las de los principales fundadores de la materia. Las primeras incursiones al campo de la Documentación fueron ideadas en 1831 por Melvil Dewey, y son más conocidas como la Clasificación Decimal

220 María Vázquez Estévez, Vida y obra del bibliógrafo José Simón Diaz, Madrid, Asociación Española de Bibliografía; Kassel, Edition Reichenberger, 2013, p.104.

221 Gregorio Mayans i Siscar, «Vida de Don Nicolás Antonio», en Nicolás Antonio, Censura de historias fabulosas, Valencia, Antonio Bordazar, 1742, p. II.

222 Luis Arias González; Mercedes del Río Luelmo, Los avatares de la Biblioteca privada de Nicolás Antonio (1687-1690), Studia Historica. Historia Moderna, IX, 1991, pp. 107-115. 
Universal, que no fueron aplicadas hasta 1883 en la Biblioteca de Columbia College. Los padres fundadores de dicha ciencia, los abogados belgas Paul Otlet y Henri La Fontaine, crearon en 1895, en Bruselas, el IIB (Instituto Internacional Bibliográfico) y la OIB (Oficina Internacional de Bibliografía), creando la célebre CDU, Manual de Clasificación vigente en las actuales bibliotecas, que fueron una adaptación de la normas de Dewey a la realidad europea. Todo ello fue el resultado de la I Conferencia Internacional de Bibliografía celebrada en la capital belga el 2 de septiembre de 1895. La idea de los dos abogados, dada la explosión de información que ya entonces existía, era crear un Repertorio Bibliográfico Universal, que se convirtiera en registro y referencia de todos los documentos impresos desde el siglo XV hasta la fecha, organizándolos a partir de la CDU.

Casi veinte años antes de este episodio, que ha pasado a los Anales de la Ciencia de la Documentación, un jovencísimo Menéndez Pelayo intentaba, cuanto menos, adelantarse a Europa. En efecto, bibliográficamente hablando, Menéndez Pelayo se adelantó a los europeos, aunque le faltó el impulso renovador de éstos. Su obra bibliográfica estuvo mediatizada por los clichés que aún pervivían en aquella España de finales del siglo XIX, en la que la modernidad, entendida como contraria a la ortodoxia imperante, se vinculaba a la heterodoxia. Algo que en ningún caso restó mérito a su obra enciclopédica, si bien le impidió una mayor divulgación en Europa. De hecho buscó publicar sus «Herejes», en clara alusión a su Historia de los Heterodoxos, en París, «en alguna de las casas que imprimen libros españoles», sin obtener contestación alguna. Las circunstancias impidieron que su obra fuera finalmente traducida al francés. ${ }^{223}$

\section{De re bibliographica (1876)}

En el año 1876, en la primera edición de La ciencia española, aparece publicado «De re bibliographica». Tras el bibliotecario y el bibliófilo ahora era el bibliógrafo el que entraba en escena. Y lo hacía con apenas veinte ańos y sin apenas soporte bibliográfico adicional, salvo su propia experiencia personal y las escasas bibliografías con las que contaba. La complejidad radicaba en establecer el marco teórico de la Bibliografía que aupaba al rango de ciencia. Tomaba de Brunet el carácter árido de la disciplina, si bien se diferenciaba de éste en que tenía una concepción más genérica del tema en cuestión.

223 Raymond Marcus, «Menéndez Pelayo traducido al francés», Boletín de la Biblioteca de Menéndez Pelayo, XXXIV, 1958, pp. 303-310. 
Todo trabajo parte de una carencia, y en este caso Menéndez Pelayo era consciente del desconocimiento que existía en España de la Bibliografía, y la necesidad de mejorar esa percepción. Un concepto que volverá a repetir un año más tarde, en su Horacio en España (1877), cuando señale que «La bibliografía española adolece aún de notables defectos y presenta no pocos vacíos». ${ }^{224}$ Sus propuestas de fomentar la elaboración de monografías sobre el tema, y la creación de seis cátedras en los doctorandos de las Facultades iban en la dirección de mejorar su consideración pública. Contribuyó al marco teórico de la disciplina, disertando sobre la misma y ofreciéndonos una concepción muy cercana a la actual, es decir, aquella que considera que su finalidad es la elaboración de repertorios o listas de libros (catálogos), que él denomina elementos externos o formales; y la que analiza las variantes, y alteraciones de los libros, más propia de la Bibliografía analítica o crítica. ${ }^{25}$ Y todo ello bajo la batuta del sentido crítico, señala el santanderino, que ha de guiar la actuación de la Bibliografía, de manera que contenga anotaciones, reproducciones de párrafos, y juicios de valor. Seguramente Menéndez Pelayo tuvo en mente cuando redactó estas palabras el Catálogo de Salvá (1872), auténtico modelo de bibliografía crítica, que recoge al pie de la letra los preceptos teóricos del montañés; o la obra de Gallardo (1863), que contiene algo más que un repertorio de portadas de libros y número de hojas, como los datos de autores (biografías) y obras (bibliografías) fundamentales para cualquier disciplina. ${ }^{226}$

Pero Menéndez Pelayo no fue un bibliógrafo al uso, como los de los siglos XVI al XVIII, que se dedicaron a la mera recopilación de títulos, sino que aplicó su capacidad crítica para comentar las obras a las que hacía alusión. ${ }^{227}$ Un elemento diferenciador que marcó un viraje en la forma de elaborar las bibliografías que se hacían hasta entonces en España.

El citado Nicolás Antonio fue con mucho el bibliógrafo más elogiado por Menéndez Pelayo, junto a Bartolomé José Gallardo, cuyos tomos curio-

224 José Ruíz Casanova, «Menéndez Pelayo y la historia de la traducción: un episodio fundacional de la historiografía literaria y el comparatismo españoles», en María José Rodríguez Sánchez de León (Ed.), Menéndez Pelayo y la literatura: estudios y antología, Madrid, Verbum, 2014, p. 117.

225 Fermín de los Reyes Gómez, Manual de Bibliografía, Madrid, Castalia, 2010.

226 Bartolomé José Gallardo, Ensayo de una biblioteca española de libros raros y curiosos, formado con los apuntamientos de Bartolomé José Gallardo, coordinados y aumentados por M. R. Zarco del Valle y J. Sancho Rayón, Madrid, Imprenta y Estereotipia de M. Rivadeneyra, Imprenta y Fundición de Manuel Tello, 1863-1889, T. I, p. VIII.

227 Lia Schwartz, «Menéndez Pelayo, crítico e historiador de los siglos XVI y XVII», en María José Rodríguez Sánchez de León (Ed.), Menéndez Pelayo y la literatura: estudios y antología, op. cit., p. 149. 
sos (1863-1889) se ocuparía de publicar. ${ }^{228}$ Éstos conformaban el grupo de las bibliografías generales. Respecto a las etnográficas, cita el santanderino al maronita Casiri, cuya obra, matiza, necesita una revisión y elaboración de una bibliografía arábigo-española. Tampoco las bibliografías corporativas escapan a los anhelos de Menéndez Pelayo, que apunta a la necesidad de redactar la Bibliografía Universitaria Ibérica. Finalmente, la elaboración de Tipobibliografías sería de enorme utilidad para evitar el centralismo y conocer la diversidad cultural y literaria española. Una reivindicación ésta que señaló posteriormente otro gran bibliógrafo, Simón Díaz, y que ya Menéndez Pelayo puso en evidencia. ${ }^{229}$

Es precisamente a esta sección de bibliografías regionales a las que Menéndez Pelayo dedicó más atención y extensión en su trabajo, no sin antes señalar las deficiencias del mismo. Entre ellas podemos detectar notables omisiones, como la ausencia de las obras de Gregorio Mayans o Sempere y Guarinos, en lo que se refiere a la ciudad de Valencia. ${ }^{230}$ Ciudad ésta, segunda en importancia después de Portugal, que no debería tener una extensión tan escasa en comparación con «Las Asturias», que están en el último lugar del ranking, y a las que dedica casi dos páginas. Además, hay un elemento que distorsiona el discurso de Menéndez Pelayo y es que, dentro de un mismo grupo, por ejemplo en las Bibliotecas por materias, los títulos no siguen un orden cronológico, lo que dificulta mucho seguir la secuencia temática.

Después de hacer un breve esbozo de las divisiones de la Bibliografía, asegura el bibliógrafo que el mayor empeño ha de ir encaminado a la elaboración de bibliografías por materias. Y precisamente a ello dedica una especial atención, haciendo una propuesta de todos aquellos «diccionarios bibliográficos» que quedan por hacer. Ahora bien, el polígrafo olvidaba que aquel designio tenía unas limitaciones, y era que los autores encargados de estas Bibliotecas por materias tenían que tener una doble preparación: la de dominar tanto la técnica bibliográfica, como la de poseer conocimientos sobre la materia tratada. Y puesto que la primera destreza solo la poseían los bibliotecarios, como él, éstos se limitaron a bibliografías generales. ${ }^{231}$ En esta

228 Xavier Agenjo Bullón, «De re Bibliographica», en M. Menéndez Pelayo, Antología comentada. Marcelino Menéndez Pelayo, Santander, Estudio, 2002, p. 46.

229 José Simón Díaz, La Bibliografía: conceptos y aplicaciones, Barcelona, Planeta, 1971 , p. 116.

230 Diversos bibliógrafos han señalado este capítulo como uno de los flancos más vulnerables de toda la producción de Menéndez Pelayo. Véase José Simón Díaz, «Evolución y estado presente de la Bibliografía española», en Primeras Jornadas de Bibliografía, Madrid, Fundación Universitaria Española-Seminario «Menéndez Pelayo», 1977, p. 15.

231 Ib., p. 22. 
misma línea, Menéndez Pelayo abogaba por potenciar el papel de la Biblioteca Nacional y sus concursos y premios anuales de Bibliografía.

Todo ello aparecía nítidamente expresado en este capítulo de La Ciencia española que casi recuerda al De re Diplomatica (1681), de Mabillon, donde se establecieron las bases de la Diplomática y la Paleografía como ciencia.

En la cabeza de Menéndez Pelayo siempre rondó la idea de elaborar una Biblioteca Española a semejanza de la de Nicolás Antonio. Pero sabía que «es una empresa cuanto menos imposible». Para ello se necesitaría la composición de bibliotecas particulares y de monografías especiales. Además, y continuaba, «carecemos de obras de erudición relativas a nuestros teólogos y filósofos»; igualmente «faltan Bibliografías, a lo menos impresas, de matemáticos, físicos y naturalistas»; «tampoco de nuestros humanistas se ha ocupado nadie de formar razonado catálogo». ${ }^{232} \mathrm{La}$ «idea» del polígrafo era magnífica, pero quizás lo que fallaba era el «método». Sus propuestas venían avaladas por una persona que aunaba tres facetas (bibliotecario, bibliófilo, bibliógrafo), pero en España había muy pocos como él para llevar adelante un programa de tales dimensiones. Incluso, a día de hoy, quedan aún por hacer muchos de aquellos «diccionarios bibliográficos» de los que hacía mención. El mérito del santanderino radicó en hacer un estado de la cuestión y, eso sí, en predicar con el ejemplo, lo que le acabaría costando la salud. Era un programa a largo plazo para una persona que se acabó desfondando, creyendo que podía a solas con tamaña empresa, sin valorar los costes personales que ello comportaba.

El escritor francés Morel-Fatio ya señaló cómo la vida de Menéndez Pelayo se limitó «à combattre dans le champ de l'érudition et de la bibliographie». ${ }^{233}$ Una amistad que se inició en París en 1877, un año después de la publicación del «De re Bibliographica», y que se consolidó vía epistolar. Muchas y variadas fueron las reseñas que Morel-Fatio escribió en revistas francesas de renombre para dar a conocer la obra de Menéndez Pelayo entre el público francés, pero en «la retaguardia de la vanguardia» metodológica, el santanderino era un anti-moderno, y eso explica que sus obras, en general, no traspasasen los Pirineos. ${ }^{234}$

232 Ruíz Casanova, Menéndez Pelayo, op. cit., p. 118.

233 Enrique Sánchez Reyes, (prólogo y notas). Epistolario de Morel-Fatio y Menéndez Pelayo, Santander, 1953, p. 12.

234 Carmen García Cela, «Nuestras cosas y los franceses: apuntes sobre la recepción de Marcelino Menéndez Pelayo en Francia», en María José Rodríguez Sánchez de León (Ed.), Menéndez Pelayo y la literatura: estudios y antología, op.cit., 2014, p. 237. 
El mejor complemento al «De re Bibliographica», y como apuntaba el mismo Menéndez Pelayo, sería su carta dedicada a las «Monografías expositivo-críticas», donde de nuevo el santanderino hizo un alarde de sus enormes conocimientos bibliográficos. El título era de por sí bastante alusivo a los objetivos que pretendía, acercarse a los escritores españoles no ya desde la óptica del diccionario o catálogo, sino a través de monografías críticas, extraídas de investigaciones basadas en su correspondencia, documentación de archivo, memorias y demás fuentes de información. Y todo ello desde la percepción de una inferioridad respecto a otros países, que llevaba a la necesidad de potenciar tales estudios. En esta parte, indicaba el polígrafo, "casi todo está por hacer», y entre estas lagunas señala la necesidad de elaborar bibliografías relativas a un solo escritor, caso de Séneca, Averroes, Ramón Llull, Súarez o Cervantes, por citar algunos. ${ }^{235}$ Él, por su parte, intentó predicar una vez más con el ejemplo, con sus trabajos sobre Gómez Pereira, Fox Morcillo y Raimundo Lulio, y con sus proyectos en torno a Luis Vives y Francisco Valles.

Pronto la fama de Menéndez Pelayo llegó a todos los rincones de España y Europa, convirtiéndose en el mentor intelectual de los principales proyectos bibliográficos españoles. Y hasta sus últimos años de vida, Menéndez Pelayo fue el consejero bibliográfico de una importante nómina de intelectuales procedentes de los más diversos rincones del mundo. Entre ellos Roque Chabás, archivero de la catedral de Valencia, que le hizo llegar al santanderino "una bibliografía de impresos en valenciano recogiendo cerca de dos mil obras», realizada por un amigo suyo, para que le diera su parecer ${ }^{236}$. Un médico dentista, José Martínez Sánchez, miembro de varias academias científicas, envió, "al maestro de la Bibliografía, su ídolo», su artículo «Bibliografía dental española», para su supervisión. ${ }^{237}$ Desde Berlín, el historiador del arte, Walter Bombe, le solicitaba referencias bibliográficas para una bibliografía general de Florencia. ${ }^{238}$ También desde Alemania, el insigne bibliógrafo Konrad Haebler, se dirigió al polígrafo español pues «son tantos los adelantos que le deben a Vd. las ciencias bibliográficas en

235 Marcelino Menéndez Pelayo, «Monografías expositivo-críticas», en MP, CE, vol. I, p. 101 (La ciencia española. T. I. Santander: CSIC, 1953. p. 124)

236 EMP (Epistolario Menéndez Pelayo), vol. 18, n. ${ }^{\circ}$ 102. Carta de Roque Chabás a Menéndez Pelayo. Valencia, 10 de marzo de 1905.

237 EMP, vol. 18, n. ${ }^{\circ}$ 171. Carta de José Martínez Sánchez a Menéndez Pelayo. Madrid, 24 de abril de 1905.

238 EMP, vol. 18, n. ${ }^{\circ}$ 518. Carta de Walter Bombe a Menéndez Pelayo, Berlín, 5 de octubre de 1905 . 
España», que solicitaba su ayuda para que España se adhiriera al proyecto de un nuevo repertorio bibliográfico del siglo Xv, para «sobreseer el anticuado de Haim», y del que el alemán era un reconocido especialista. ${ }^{239}$

\section{El «Inventario bibliográfico» de La ciencia española}

En la tercera edición de La ciencia española (1887-1888) Menéndez Pelayo incluyó la que él consideraría su principal aportación: «El inventario bibliográfico de la ciencia española», con el propósito declarado de "dar idea muy somera de los inexplorados tesoros que en ella se encierran». ${ }^{240}$ Con poco más de treinta años, el polígrafo acometía una empresa nunca hasta ahora realizada. Solo él estaba en disposición de encarar un proyecto de tal envergadura, pues conocía al detalle los fondos bibliográficos de las principales bibliotecas españolas y europeas. Se trataba de una bibliografía especializada que comenzaba a tener acólitos en la Europa del siglo XIX, ${ }^{241} \mathrm{y}$ a la que ahora se iba a sumar el espańol. Pero con una salvedad importante, mientras las bibliografías europeas en su mayor parte eran realizadas por profesionales de la materia, no así ocurría con el santanderino, que tenía una formación humanística pero no científica. De ahí que algunos autores hayan señalado las graves limitaciones del inventario en lo relativo a campos como las ciencias exactas y naturales. ${ }^{242}$

Lo que es indudable es que el inventario fue una aportación positiva de primera magnitud. ${ }^{243}$ De partida diremos que la bibliografía científica que aportaba era pionera en su género en Espańa. Hasta ahora, las bibliografías habían sido generales, regionales, especializadas, pero ninguna dedicada a

239 EMP, vol. 18, n.o 925. Carta de Konrad Haebler a Menéndez Pelayo. Dresden, 11 de septiembre de 1906.

240 Él mismo señaló que el mérito de La ciencia española radicaba no tanto en la parte polémica cuanto en «una especie de tabla bibliográfica de nuestros antiguos libros de ciencia. Me ha dado bastante que hacer, y la creo muy incompleta, pero así y todo podrá servir como de vademécum» (MP, CE, vol. II, p. 497).

241 Louise-Noëlle Malclès, «La bibliographie spécialisée au xıxe siècle (à propos d'un ouvrage récent)», Bulletin des Bibliothèques de France, n. ${ }^{\circ}$ 5, 1957 [consulté le 01 avril 2015]. Disponible: http://bbf.enssib.fr/consulter/bbf-1957-05-0389-002

242 Enrique García Camarero, «La regeneración científica en la España del cambio de siglo", Revista de Hispanismo Filosófico, 5, 2000, p. 16.

243 José Luis Abellán, «La regeneración científica como proyecto de modernización», en Ramón E. Mandado Gutiérrez, Gerardo Bolado Ochoa (dirs.), La ciencia española. Estudios, Santander, PUbliCan-Ediciones de la Universidad de Cantabria, 2011, p. 13. 
las disciplinas científicas. Tan solo en Francia y Alemania existían ejemplares similares, si bien no tan ambiciosos.

Lógicamente la obra del santanderino no se puede estudiar de manera aislada, sino en comparación con otras bibliografías que, aunque no de la misma materia, sí que nos pueden ayudar a comprender la metodología que utilizó. Así, Brunet (1810) utilizó el orden alfabético de autor, y el metódico (por materias) para una obra, en tres volúmenes, cuyas descripciones bibliográficas eran muy exhaustivas, incluyendo precios extraídos de las ventas de libros realizadas en diferentes países. En su ordenación metódica, el librero Brunet utilizó la llamada Clasificación de los Libreros de París, que venía utilizándose desde el siglo xviII, y que situaba a la Teología como la más elevada de las disciplinas humanas, seguida de la Jurisprudencia, Ciencias y Artes, Bellas Letras e Historia. Por su parte, Graesse (1859) siguió la ordenación alfabética de autores, con registros bibliográficos muy completos, y precio también de los libros. Y Gallardo (1863), prácticamente, se limitó a copiar los mismos parámetros de sus predecesores, ordenación alfabética de autor y descripción bibliográfica extensa.

En la «Advertencia preliminar» al «Inventario bibliográfico», Menéndez Pelayo señalaba cual iba a ser el método que iba a seguir en su obra. Lo primero que llama la atención, para un bibliógrafo minucioso como él, era la indicación de que sus referencias aparecerían sin datos bibliográficos básicos (lugar de edición, nombre de impresor, tamaño, tomos). Es cierto que los elementos que se pueden incluir en una descripción bibliográfica son múltiples, pero existen algunos (autor, año, título, lugar de edición, extensión, tamaño o formato), que son necesarios en cualquier identificación. ${ }^{244}$ Más chocante resulta ver que sus predecesores sí que habían seguido casi al pie de la letra estos preceptos. No será la única diferencia con éstos. Así, de nuevo, el santanderino marcaba distancias y escogía la ordenación cronológica, muy en la línea nicolasantoniana, para secuenciar sus registros. Ahora bien, y quizás sea el elemento en el que más se diferencia de otros inventarios, dentro de cada ámbito temático, como veremos, los asientos no siguen una ordenación cronológica ni alfabética.

El único elemento en común con sus citados correligionarios es la clasificación temática, es decir, la ordenación por «materias» que era su predilecta, encabezada por la Teología y seguida por la Filosofía, las Ciencias Morales y Políticas, las Ciencias Jurídicas, la Filología y Humanidades, la Estética, la Historia, las Ciencias Matemáticas, las Ciencias Militares, y las Ciencias Físicas.

244 Reyes Gómez, Manual, op. cit., p. 244. 
No sorprende, y algunos así lo han señalado, que la ordenación adoptada por Menéndez Pelayo, tuviera un sentido espiritual al partir de la Teología, seguir por la Filosofía, para llegar a lo más humano, la Biología. ${ }^{245}$

$\mathrm{Y}$ es que la obra respira cierta intencionalidad intelectual que sitúa a la Teología en la cúspide del conocimiento, «dada su importancia jerárquica». Una clasificación similar a la de Brunet, pero con matices. Porque en el «Inventario» del santanderino la sombra de los «heterodoxos» sigue latente. Sólo de esta manera se explican apartados como el de la «teología heredoxa», donde es posible encontrar a destacados erasmistas, como Juan de Valdés, a luteranos, calvinistas, molinosistas (Miguel de Molinos), o al propio Miguel de Servet, que como sabemos pereció víctima de las llamas de la intolerancia religiosa. También encontramos un «misticismo hetedoroxo», donde de nuevo aparece el quietismo de Molinos. Más impresión causa el epígrafe dedicado a «escolásticos degenerados y recalcitrantes de los primeros años del siglo XVI», donde encontramos a destacados erasmistas, algunos de ellos amigos del valenciano Luis Vives, a quien el santanderino veneraba, como Luis Núñez Coronel o el valenciano Juan de Celaya. Algunos de ellos son calificados como «bárbaros», militantes de las «falanges del nominalismo». ${ }^{246}$

Quizás sea esta terminología poco apropiada la que aleja a Menéndez Pelayo de los parámetros bibliográficos europeos. Se percibe cierto maniqueísmo en las expresiones y sus juicios de valor se desvían de la imparcialidad que se requiere para una disciplina tan aséptica como debe ser la Bibliografía. Con sus calificativos estigmatizaba a un grupo de autores que hoy situamos en la avanzadilla de la lógica y de la ciencia de su tiempo. ${ }^{247}$

No en vano, existe en el «Inventario» un desigual tratamiento temático, que demuestra muy a las claras las preferencias intelectuales de Menéndez Pelayo. La Teología, que tiene ramificaciones también en la Filosofía, ocupa casi un 22\% de la obra, seguido de las Ciencias Físicas (20\%) y la Filología y Humanidades (19\%), aunque se trate más bien solo de Filología. Por su parte, las Ciencias Militares, a las que dedica solo tres páginas, aparece como un ámbito temático «raro» que no figura en las bibliografías europeas del momento, y que hubiera sido más aconsejable incluirlo en el apartado de Matemáticas, dada la formación que de ésta y otras disciplinas afines (Geo-

245 Felipe Mateu y Llopis, «La ordenación bibliográfica de La ciencia española», en Archivos, Bibliotecas y Museos, Tomo LXII, núms. 1-2-3, 1956, p. 113.

246 MP, CE, vol. II, p. 541).

247 Vicente Becares Botas, «Escolásticos y humanistas: discursos contrapuestos sobre el Renacimiento español», en IV Reunión Cientifica sobre Humanistas Españoles, septiembre, mayo, 2004, p. 17. 
metría, Fortificaciones) recibían los militares, especialmente los marinos. En este mismo campo añadiríamos la Ciencia de la Guerra, que el polígrafo incluye entre las Ciencias Morales.

Bibliográficamente hablando la obra muestra algunas inconsistencias que en nada desmerecen la obra final, en especial para los medios con los que se contaba en la época. Podemos imaginar las miles de fichas que realizó el polígrafo santanderino, extraídas de su biblioteca personal, donde «se guarda la historia ideológica de España», y me atrevería a decir también científica. ${ }^{248}$ No en vano, entre sus cerca de 50.000 volúmenes se encontraban más de quinientos repertorios bibliográficos de las más variadas especialidades, cuya riqueza tan solo era comparable a los fondos de la Biblioteca Nacional. ${ }^{249}$ De ellos, de su prodigiosa memoria y de los fondos consultados tanto en España como en Europa, salió su «Inventario bibliográfico», que hicieron de él la persona que con más extensión y profundidad trató la producción bibliográfica española. Y es que ante todo, fue un bibliógrafo práctico, que aportó un aparato crítico hasta ahora desconocido. Pasan seguramente de 20.000 las noticias bibliográficas que contienen todas sus obras. ${ }^{250}$

Y entre ellas figura este «Inventario bibliográfico de la ciencia española» que estamos comentando, en el que el término ciencia se entiende en el sentido de disciplina, saber (heredero de la episteme griega), que incluye no sólo lo que retrospectivamente consideraríamos ciencias, como las Matemáticas o la Zoología (las ciencias exactas o naturales), sino también la Filología, el Derecho, la Historia, etc. (lo que llamaríamos humanidades, ciencias humanas o, en alemán Geisteswissenschaften). Si el objeto de la empresa era ya de por sí formidable, más aún era extenderlo a todas las disciplinas «científicas» en ese sentido amplio. Ello comportaba un riesgo, y era el «intrusismo» en diferentes materias, lo que podía causarle el recelo de algunos profesionales del ramo. Técnicamente hablando, Menéndez Pelayo en esta obra intervino más como Bibliógrafo científico que como Documentalista científico. De hecho la Documentación había surgido, a partir de la Bibliografía científica, como respuesta a las necesidades informativas características de la actividad científica contemporánea. ${ }^{251}$ Además, el documentalista debía tener una preparación

248 Manuel Revuelta Sañudo, "La Biblioteca de Menéndez Pelayo», Boletín de la Biblioteca de Menéndez Pelayo, 1979, p. 280.

249 Ib., p. 286.

250 Rufino Blanco y Sánchez, «Menéndez y Pelayo como bibliógrafo y erudito», Revista de Segunda Enseñanza, 1927, p. 106.

251 María-Luz Terrada, La documentación médica como disciplina, Valencia, Centro de Documentación e Informática Biomédica-Universidad de Valencia, 1983, p. 33. 
científica, que no tenía el polígrafo, que sí contaba con una formación más humanística, más propia de los bibliógrafos y bibliotecarios.

Porque hacer una bibliografía tan ambiciosa conllevaba sus riesgos, como seguir una estructura un tanto confusa o dejar vacíos involuntarios. Respecto a la estructura, el criterio de Menéndez Pelayo es un tanto irregular, pues en algunos campos, como "Jurisprudencia», «Filosofía», o «Ciencias Morales y Políticas» se sigue un orden cronológico debidamente indicado, mientras que en otros se prescinde de este mismo orden. Además, vemos que hay algunos campos bastante repetitivos. Así, en la «Teología» se mencionan las escuelas tomistas puras, disidentes y escotistas, que también aparecen en el campo de la "Filosofía», prácticamente con los mismos autores. En otros epígrafes, como el capítulo IX dedicado a las Ciencias Históricas, el panorama que presenta el polígrafo no es ni mucho menos, y lo indica en la «Advertencia preliminar», exhaustivo, pues encontramos notables ausencias. Así, al hablar de la «crítica histórica» faltan nombres tan significativos como los valencianos Cerdá y Rico, o Juan Bautista Muñoz, entre otros. Por otra parte, hay afirmaciones un tanto matizables, como señalar que la Bibliotheca Hispana de Nicolás Antonio tenía el mismo fin que su Censura de historias fabulosas (1742). La primera obra fue el resultado de numerosas pesquisas bibliográficas con un objetivo en clave «nacional», defender y difundir las glorias intelectuales españolas; mientras que la segunda, por su parte, tenía el objetivo contrario, desmontar las tradiciones nacionales de la venida del apóstol Santiago o la tradición de la Virgen del Pilar, entre otras manifestaciones religiosas. Y todo ello, y eso sí, dentro de los principios de la crítica histórica. 


\title{
La ciencia española y el cultivo de las disciplinas físico-matemáticas en la España moderna. Consideraciones historiográficas sobre el «Esplendor y decadencia de la cultura científica española»
}

\author{
Dr.Víctor Navarro Brotons
}

Universidad de Valencia

\section{Introducción}

T no de los principales temas de debate en la llamada «Polémica de la ciencia española» fue la cuestión relativa a la actividad y contribuciones a las matemáticas en la España moderna; debate éste que contribuyó a estimular la producción de una serie de repertorios bibliográficos, el más famoso de los cuales fue el que Menéndez Pelayo incluyó en su libro $\mathrm{La}$ ciencia española que ahora reeditamos. Asimismo, la polémica produjo algunas reflexiones o interpretaciones no carentes de todo interés.

Uno de los escritos derivados de la "polémica» fue el redactado por Menéndez Pelayo con el título «Esplendor y decadencia de la cultura científica espańola» y presentado como comentario crítico al discurso de ingreso de Acisclo Fernández Vallín en la Real Academia de Ciencias: Cultura cientifica en España en el siglo XVI. ${ }^{252}$ En este comentario al trabajo de Vallín,

252 F. Vallín y Bustillo, "Cultura científica en España en el siglo Xvi», en Discursos leidos ante la Real Academia de Ciencias, Exactas, Físicas y Naurales en la recepción pública del Excmo. Sr. D...., Madrid, 1893. Reeditado en Sevilla, Consejería de Cultura/Padilla Libros, 1989. Vallín y Bustillo (1893). Para el texto de Ménéndez Pelayo, publicado en 
Menéndez Pelayo hacía una autocrítica de sus propias obras de juventud y planteaba una serie de importantes cuestiones, a modo de precipitado de las preocupaciones y reflexiones derivadas a lo largo de los años de los debates y trabajos sobre «la ciencia española». Admitía que «la historia de nuestras ciencias exactas y experimentales... tiene mucho de dislocada y fragmentaria»; subrayaba la «falta de continuidad en los esfuerzos... y una especie de falta de memoria nacional», pero, sin dejar de reconocer la «relativa inferioridad» de las disciplinas matemáticas con respecto a otras materias como la historia natural, Menéndez Pelayo observaba que la historia de la ciencia no ha de atender sólo a los grandes resultados y a los grandes descubrimientos. Asimismo, que además de catalogarlos, hay que leer los libros y analizarlos desde una perspectiva comparada. Hay que dar cuenta adecuadamente de los substratos culturales, atendiendo a las huellas de las «ideas e instituciones de todos los pueblos que han pasado por nuestro suelo». Y como explicación general de la inferioridad de las disciplinas matemáticas, aventuraba que, "paradójicamente» «en este país de idealistas, de místicos, caballeros andantes, lo que ha florecido siempre con más pujanza no es la ciencia pura (las exactas y naturales), sino sus aplicaciones prácticas y en cierto modo utilitarias». Así, si por ejemplo la astronomía teórica no hizo más progresos y España dejó definitivamente de ser el centro de ella, la causa principal estaría en que los hombres más dotados para esta materia se dedicaron a la astronomía práctica. Por ello, concluía su discurso diciendo que para la regeneración científica de España había que convencer a los españoles de «la sublime utilidad de la ciencia inútil.»

Menéndez Pelayo no profundizó en las causas del supuestamente excesivo pragmatismo de nuestros científicos, más allá de las alusiones generales a las necesidades de la monarquía y sus ambiciones imperiales, como el control y dominio de las tierras descubiertas. Ni aceptó los posibles efectos negativos del control y represión por causas ideológicas del pensamiento filosófico y científico, por parte de la Inquisición u otras instituciones, como tampoco aportó ninguna reflexión sobre el divorcio entre los filósofos y los matemáticos y sus efectos.

No obstante estas y otras limitaciones que se pueden señalar en el balance, este texto de Menéndez Pelayo planteaba con gran perspicacia una serie de importantes cuestiones y todo un programa de trabajo. Programa de trabajo que sería asumido por las generaciones de la posguerra española a partir

1894 en La España Moderna, año VI, tomo LXII, pp.138-178, he utilizado el incluido en la edición de 1953 de La ciencia española en el vol. II, Apéndice V. 
sobre todo de los años sesenta, cuando López Piñero y sus colaboradores comenzaron a desarrollar el proyecto de una historia social de la ciencia con particular atención al caso espańol. Al propio tiempo, otras personas y/o grupos irían surgiendo en años sucesivos en otros lugares de la geografía espańola. Y más recientemente con la expansión de la disciplina, algunos jóvenes historiadores de otros países, principalmente de Estados Unidos, se han sentido atraídos por el mundo ibérico. No obstante, y como se ha seńalado repetidas veces, y nosotros mismos lo hemos recordado recientemente en nuestra introducción al libro Mas allá de la Leyenda Negra: España y la Revolución Científica, el mundo ibérico sigue estando usualmente ausente o escasamente considerado en los relatos acerca de la Revolución Científica. ${ }^{253}$

\section{La práctica de las matemáticas en la Espańa del Renacimiento}

En este trabajo, con el fin de evaluar las apreciaciones de Menéndez Pelayo sobre la actividad científica en la historia de Espańa, en la época moderna, a la luz de la historiografía de la ciencia de las últimas décadas, me ocuparé en primer lugar de la práctica de las matemáticas en los reinos peninsulares de la monarquía hispánica (más precisamente, de lo que acostumbramos a llamar España) en el siglo xvi. Entiendo el término «matemáticas» tal y como entonces se usaba. En segundo lugar, expondré algunas consideraciones sobre la actividad científico-técnica en el siglo XvII, en el ámbito de las disciplinas matemáticas o físico-matemáticas en términos comparativos con los otros países europeos y el tema de la decadencia espańola. En todo caso, no pretendo llevar a cabo una revisión historiográfica exhaustiva, lo que requeriría muchos más pliegos; tan sólo presentaré algunas notas y consideraciones o reflexiones sobre las cuestiones y temas señalados y algunas indicaciones sobre el estado de la cuestión. Además, situaré el asunto en el contexto más general de la historiografía de la construcción de la ciencia moderna y el mundo ibérico.

En las últimas décadas, el historiador de origen irlandés Jim Bennett, en una serie de trabajos, ha destacado la importancia de lo que él llama «the practical mathematical tradition» para la construcción de la ciencia moderna,

253 V. Navarro Brotons y W. Eamon (eds.), Beyond the Black Legend. Spain and the Scientific Revolution, Valencia, Instituto de Historia de la Ciencia y Documentación «López Piñero", 2007. Véase también el capítulo I del libro: V. Navarro Brotons, Disciplinas, saberes y prácticas. Filosofía natural, matemáticas y astronomia en la sociedad española de la época moderna, Valencia, PUV Universitat de València, 2014. 
especialmente para la emergencia de la filosofía mecánica o la nueva filosofía natural («reformed», dice Bennett), del siglo XVII. ${ }^{254}$

Según Bennet, los historiadores que se han ocupado de la reforma o cambios en la filosofía natural no han sabido apreciar el significado del éxito anterior del programa de matemáticas prácticas, que era a su vez una respuesta a los cambios sociales, políticos y económicos del Renacimiento. En este sentido Jim Bennett ha destacado que la idea de «operative knowledge» de la nueva orientación del conocimiento de la naturaleza a finales del siglo XVII sugiere una relación muy importante con el desarrollo de las matemáticas prácticas. Por ello, Bennet nos invita a que, además de interesarnos por los descubrimientos, ideas, teorías y escuelas de pensamiento, dirijamos nuestra atención a la ciencia como una actividad, como medios de acción y resolución de problemas. Y a integrar el amplio dominio de actividad de las matemáticas prácticas en el relato de la Revolución Científica.

Por matemáticas prácticas entiende Bennett materias como la astronomía práctica, la topografía y agrimensura, la perspectiva, la cartografía, la arquitectura, la fortificación, la ingeniería y máquinas, el arte de la guerra y la náutica. Añade también el diseño de instrumentos, y las proyecciones geométricas y sus usos, como técnicas comunes. Es interesante comparar la lista de Bennett con la que ofrecía Juan de Herrera en el texto que escribió sobre los objetivos de la Academia de Matemáticas de Madrid que le propuso fundar al Rey Felipe II: así, la Academia se dedicaría a formar aritméticos teóricos y prácticos, geómetras, astrónomos, músicos con formación teórica, cosmógrafos, pilotos, arquitectos y fortificadores, ingenieros y maquinistas («entendidos en el arte de los pesos y en todo género de máquinas»), artilleros e instrumentistas, fontaneros y niveladores de aguas, expertos en relojes, expertos en perspectiva y escultores y pintores formados en esta última materia. ${ }^{255}$

Jim Bennett ha insistido especialmente en la necesidad de prestar mayor atención a los instrumentos relacionados con la geometría práctica: esferas, astrolabios, ballestillas o radios astronómicos, cuadrantes, sectores, teodoli-

254 J. A. Bennett, "The mechanics philosophy and the mechanical philosophy», History of Science, 24 (1986), 1-28; Id., "The Challenge of Practical Mathematics», en Stephen Pumfrey, Paolo L. Rossi and Maurice Slawinski (eds.), Science, Culture and Popular Belief in Renaissance Europe, Manchester and New York, Manchester University Press, 1998, pp. 176-191; Id., "Practical Geometry and Operative Knowledge», Configurations, 6 (2) (1998), pp. 195-222.

255 Véase J. de Herrera, Institución de la Academia Real Mathematica, Madrid, 1584, (reeditado en edición facsímil por José Simón Díaz y Luis Cervera Vera, Madrid, Instituto de Estudios Madrileños, 1995). 
tos, etc. Y ha insistido también acerca de la geografía y la cartografía como una parte central del programa matemático, junto con la astronomía y sus aplicaciones. Asimismo, ha indicado que hubo también áreas de intersección entre las matemáticas prácticas y la filosofía natural, y pone como ejemplos la astronomía (y sus implicaciones cosmológicas) y el magnetismo terrestre.

En estos importantes trabajos Bennett no ha prestado, sin embargo, ninguna atención al mundo ibérico, salvo algunas menciones aisladas a autores como Pedro Nunes. ${ }^{256}$ Ello, a mi juicio, por al menos dos razones. La primera por su principal interés por el caso inglés. La segunda, por un prejuicio muy común: dado que España (y Portugal) participó de manera escasa y marginal en la Revolución Científica del siglo XVII, nada interesante y digno de ser tenido en cuenta debió ocurrir en el período anterior. Y ello a pesar de que historiadores ingleses de la cartografía, la geografía o la náutica como Charles Cooter, Eva Taylor o David Waters han puesto de relieve la importancia de las contribuciones ibéricas en estas materias. ${ }^{257}$

Sin embargo, las propuestas historiográficas de autores como Jim Bennett y otros pueden resultar muy adecuadas para el estudio de la cultura matemática, en el sentido expresado anteriormente, en la Espańa del Renacimiento (y en el mundo Ibérico, en general). Especialmente por la importancia que le han dado al conocimiento operativo o práctico y a la estrecha unión entre el conocimiento especulativo o teórico y el manipulativo. También, a la transferencia de prácticas de un domino a otro en la llamada matematización de la naturaleza, un aspecto clave de la Revolución Científica. ${ }^{258}$

256 También se refiere Bennett ocasionalmente a los autores españoles de obras de náutica o arte de navegar, en particular sobre el tema del magnetismo y la declinación magnética. En relación con esto la referencia habitual es la obra de Martín Cortés que fue traducida al inglés y reeditada en Londres seis veces entre 1561 y 1596 . Cortés, como es sabido, en su obra discute la cuestión del magnetismo en relación con la declinación magnética y sugiere una hipótesis explicativa del «nordestear» $\mathrm{y}$ «noruestear» de la aguja, basada en la existencia de un punto de atracción situado «bajo del polo del mundo». Véase M. Cortés, Breve copmpendio de la sphera y de la arte de navegar, con nuevos instrumentos y reglas exemplificado con muy subtiles explicaciones, Sevilla, 1551, (Una edición facsimilar a cargo de Mariano Cuesta Domingo, en Madrid, Editorial Naval, 1990).

257 Véase E. G. R. Taylor, The Haven-Finding Art, London, Hollis and Carter, 1971 ( $3^{\mathrm{a}}$ ed.); C. H. Cooter, A History of Nautical Astronomy, London, Hollis and Carter, 1968; y la monumental obra de D. W. Waters, The Art of Navigation in England in Elizabethian and Early Stuart Times, New Haven, Yale University Press, 1958.

258 Sobre las relaciones entre el conocimiento especulativo y el manipulativo o constructivo, véase recientemente: L. Roberts, S. Schaffer y P. Dear, Inquiry and Invention from the late Renaissance to early industrialization, Amsterdam, Koninklijke Nederlandse Akademie van Wetenschappen, 2007. Y por supuesto los clásicos estudios de Zilsel, 
En 1979 López Piñero publicó una obra de síntesis titulada Ciencia y técnica en la sociedad española de los siglos XVI y XVII. ${ }^{259}$ Combinando diversas técnicas y procedimientos historiográficos: prosopografía, análisis estadístico de las publicaciones, estudio de las instituciones y de las profesiones y ocupaciones científicas, con un estudio interno de las fuentes y una síntesis equilibrada y ponderada de todo lo más relevante escrito sobre el tema; esta obra marcó un punto de inflexión y se convirtió en una obra de referencia indispensable para los estudios históricos de la ciencia en España en la época moderna.

López Piñero se esforzó por evitar la aplicación de categorías y distinciones actuales sobre la ciencia y lo científico, sin rehuir la dimensión retrospectiva de la labor histórica en cuanto diálogo con el pasado. Para ello trató de delimitar diversas áreas de actividad científica, dedicando estudios particulares a cada una de ellas, como las matemáticas, la cosmografía y astrología, el arte de navegar, la geografía, la filosofía natural o la ingeniería, no sin mostrar los solapamientos o intersecciones entre las áreas.

En el libro citado López Piñero realizó un estudio prosopográfico de 572 autores con algún tipo de actividad científica reflejada en publicaciones, manuscritos o aportaciones técnicas. Ofreció una tabla por áreas de dedicación, resultando en matemáticas 67 autores; en cosmografía y astrología, 99;

reunidos en Die sozialen Ursprünge der neuzeitlichen Wissenschaft, editados por Wolfgang Krohn con notas biobliográficas de Jöhr Behrman, Frankfurt am Main, Suhrkamp, 1976 (y en inglés, The social origins of Modern Science, Dordrecht, Kluwer, 2000) sobre el papel de los artesanos «superiores» para la apreciación adecuada de los métodos empíricos, los instrumentos de medida y la cuantificación. Obras, a las que se puede añadir también el clásico libro de P. Rossi sobre la revalorización de las "artes mecánicas», I filosofi e le machine 1400-1700, Milan, Feltrinelli, 1962 (reeditada en 1984 y 2002 y en versión castella, Barcelona, Labor, 1966); y los de Olschki y otros autores de orientación marxista. Para una revisión historiográfica de estos temas y autores vése H. F. Cohen, The Scientific Revolucion. A historiographical Inquiry, Chicago, The University of Chicago Press, 1994; y más recientemente Pamela O. Long, Artisan/Practitioners ad the Rise of the New Sciences, 1400-1600, Corvallis, Oregon State University Press, 2011. Véase, también, de Pamela H. Smith, The Body of the Artisan. Arts and Experience in the Scientific Revolution, Chicago, The University of Chicago Press, 2004. Sobre las matemáticas prácticas en la tradición inglesa, véase también S. Johnston, «Making Mathematical Practice: Gentlemen, Practitioners, and Artisans in Elizabeth England.», Ph. D. Dissertation, Cambridge University, 1994. (https://www.mhs.ox.ac.uk/staff/saj/thesis/). Sobre la importancia de Zilsel ha insistido recientemente A. Sánchez, «La voz de los artesanos en el Renacimiento Científico: cosmógrafos y cartógrafos en el preludio de la nueva filosofía natural», Arbor, CLXXXVI, mayo-junio (2010), pp. 449-460.

259 J. M. López Piñero, Ciencia y técnica en la sociedad española de los siglos XVI y XVII, Barcelona, Labor, 1979. 
en geografía, 66; en arte de navegar, 65; en arquitectura e ingeniería, 25; en arte militar, 26 y en filosofía natural, 66 (tabla 1, en p. CCXIX). También ofreció una tabla de ocupaciones y profesiones (tabla 2, en p. CCXX). El mayor número de éstas, lógicamente, corresponde a los médicos, que suman 188, y a los clérigos, que suman 107; pero tras los médicos y clérigos, el conjunto de ocupaciones más importante están directamente relacionadas con las matemáticas: ingenieros, arquitectos, artilleros, cosmógrafos, marinos, cartógrafos, profesores universitarios, comerciantes; pero además, un número de médicos y clérigos se interesaron por las matemáticas y la astronomía-astrología. Así, si examinamos la tabla de áreas cultivadas por autores con ocupaciones sin relación obligada con la ciencia, como funcionarios, abogados, clérigos o nobles (tabla 3, en p. CCXXI), nos encontramos con que las matemáticas destacan entre las áreas cultivadas.

Posteriormente se han realizado otros estudios prosopográficos relacionados con las matemáticas y sus aplicaciones. Yo llevé a cabo uno de 110 cultivadores de la astronomía en España (1481-1606) y concluí que los tres ámbitos ocupacionales principales de estos autores fueron la medicina $(22,7 \%)$, el académico-universitario $(18,2 \%)$ y todo lo relacionado con las actividades cosmográficas: astronomía náutica, cartografía y geografía, organizadas o dirigidas por la monarquía ${ }^{260}$ (tabla 4, en p. CCXXI). En este trabajo destaqué la práctica ausencia del astrónomo de corte, es decir, de un contexto no académico para la práctica de la astronomía libre de los condicionamientos del curriculum universitario. Asimismo, discutí si hubo o no patronazgo de la ciencia tal y como lo ha descrito Biagioli, y apunté que los cosmógrafos-astrónomos españoles tenían un estatus de funcionarios y no de cortesanos, es decir, pertenecían al ámbito administrativo de la Corte, no al cortesano o simbólico. Más recientemente hemos puesto de relieve en

260 Este estudio prosopográfico lo realicé en colaboracion con Vicente Luis Salavert y Victoria Rosselló. Lo publiqué en el estudio preliminar de V. Navarro Brotons y E. Rodríguez Galdeano, Matemáticas, cosmología y humanismo en la España del siglo XVI. Los "Comentarios al Segundo libro de la Historia Narural de Plinio» de Jerónimo Muñoz, Valencia, Instituto de Estudios Documentales e Históricos sobre la Ciencia, Universitat deValènciaCSIC, 1998, pp. 17-249 [pp.181-189]. Véase también, sobre el cultivo de la astronomía en España en esta época, V. Navarro Brotons, «La actividad astronómica en la Espańa del siglo Xvi: perspectivas historiográficas», Arbor, 142 (558-560) (1992), pp. 185-217; Id. «La astronomía», en J. M. López Piñero (dir.), Historia de la ciencia y de la técnica en la Corona de Castilla, 4 vols., Valladolid, Junta de Castilla y León, vol. 3, 2002, pp. 231-259; Id., "The Cultivation of Astronomy in Spanish Universities in the Latter Half of the 16th Century», en M. Feingold, V. Navarro (eds.), Universities and Science in the Early Modern Period, Dordrecht, Springer, 2006, pp. 83-99. 
algunos casos las tensiones entre las ambiciones de los cosmógrafos (como García de Céspedes) con sus imágenes del conocimiento cosmográfico-astronómico (usando la terminología de Elkana y sus distinción entre cuerpo del conocimiento e imágenes del conocimiento) y los condicionamientos que su estatuto profesional como funcionarios les imponía para realizar sus ambiciones. $^{261}$

Se han realizado otros estudios prosopográficos dedicados a materias o áreas particulares, como la aritmética o la ingeniería-arquitectura. A partir de 47 autores de libros de aritmética (12 de aritmética universitaria y 35 de aritmética práctica) Vicente Salavert, en sus importantes estudios de la aritmética, elaboró la tabla $5^{262}$ (en p. CCXXII). Posteriormente, autores como Javier Docampo han introducido nuevas precisiones sobre los cultivadores de la aritmética. ${ }^{263}$

Por su parte, Nicolás García Tapia, autor de numerosos e importantes trabajos de historia de la técnica en España, hizo una prosopografía de 186 ingenieros que trabajaron en obras civiles en España en el siglo Xvı. García Tapia los clasifica en ingenieros teóricos, el 9,7\%; ingenieros-arquitectos, el 24,7\%; ingenieros prácticos, el 53,8\%, e ingenieros ocasionales o inventores, el 11,08\% (tabla 6, en p. CCXXII). También nos presenta García Tapia la especialidad de los ingenieros (tabla 7, en p. CCXXII), en la que como puede verse la mayoría trabajaron en el ámbito de las practical mathematics en el sentido de Bennett. Y es interesante señalar que el 72,6\% de los ingenieros eran españoles, procediendo el resto de Italia, Países Bajos y Alemania, principalmente. ${ }^{264}$

Continuando con esta descripción estadística de las actividades relacionadas con las matemáticas, nos detendremos brevemente en los libros publicados en España (o por autores españoles). En nuestra Bibliographia

261 V. Navarro Brotons, «Aspects of the History of Cosmography in Spain in the last Decades of the Sixteenth Century (Until 1606)», Archives Internationales d'Histoire des Sciences, 59 (2009), pp. 555-574. Véase también María M. Portuondo, «An Astronomical Observatory for the Escorial of Philipp II: an Exercise in Historical Inference», The Colorado Review of Hispanic Studies, 7 (2009), pp. 101-119.

262 V. L. Salavert Fabiani, "Aritmética y sociedad en la España del siglo xvI», en S. Garma, V. Navarro y D. Flament (eds.), Contra los titanes de la rutina. Encuentro en Madrid de investigadores hispano-franceses sobre la historia y la filosofía de las matemáticas, Madrid, Comunidad de Madrid-CSIC, 1994, pp. 51-69.

263 J. Docampo Rey, La formación matemática del mercader catalán 1380-1521. Análisis de fuentes manuscritas, tesis doctoral, Universidad de Santiago de Compostela, 2004.

264 N. Garcia Tapia, Ingeniería y arquitectura en el Renacimiento español, Valladolid, Universidad de Valladolid, 1990. 
Physico-Mathematica Hispanica (1475-1600) hicimos el inventario de 1085 obras de estas materias y características, siendo las unidades los textos editados y no las primeras ediciones. ${ }^{265}$ Ofrecemos una distribución por décadas y materias, otra por décadas e idiomas y otra por décadas y ciudades (tablas 8, 9 y 10, en pp. CCXXIII, CCXXIV y CCXXV respectivamente). Como puede verse en la tabla 8 , y era de esperar, la filosofía natural concentró el tercio de las impresiones recogidas (32,6\%). Luego destaca la astronomía con una cifra importante (20\%), gracias en gran medida a los lunarios; pero también incluye un número importante de ediciones de la esfera o tratados sobre instrumentos, como el astrolabio, el ecuatorio y los relojes solares; sigue la aritmética (10\%), tanto la académica como la práctica o mercantil, que es la más numerosa (un 73\% de aritméticas prácticas); la náutica y la cosmografía reúnen un 12,4\% y el arte militar y la arquitectura un 5,6\%. A destacar la presencia del castellano y el importante número de obras editadas fuera de Espańa: en París, Venecia, Lyon, Roma, Amberes o Londres. La tabla 9 muestra la importante presencia de las lenguas vernáculas, principalmente el castellano. Si sumamos el catalán, juntos superan al latín. También es interesante observar el apreciable número de ediciones en lenguas no peninsulares. Finalmente, en la tabla 10 se advierte el gran número de ediciones realizadas en talleres no peninsulares. Así, entre las primeras cinco ciudades con mayor número de ediciones tres son extranjeras: París, Venecia y Lyon.

Junto a las obras impresas, hay que tener en cuenta la producción manuscrita, muy difícil de inventariar y cuantificar, pero de enorme importancia. Muchas obras de autores destacados quedaron sin imprimir por diversas razones, desde el secreto impuesto por la monarquía, hasta los problemas económicos de los autores e impresores. Así, autores muy destacados como Alonso de Santa Cruz, Jerónimo Muñoz o Diego Pérez de Mesa dejaron toda o la mayor parte de su obra sin imprimir, lo que no implica que no se difundiera. En las últimas décadas se ha avanzado mucho en el estudio de la producción manuscrita, aunque estamos lejos de tener un inventario aproximado de la misma. Autores como los citados han merecido importantes estudios ya bien conocidos. Entre los trabajos recientes, quiero destacar los estudios de una serie de manuscritos de aritmética que han puesto de relieve

265 V. Navarro Brotons, V. L. Salavert Fabiani, V. Rosselló Botey y V. Darás Román, Bibliographia Physico-Mathematica Hispanica (1475-1900). Vol. I. Libros y folletos, 14751600, Valencia, Instituto de Historia de la Ciencia y Documentación «López Piñero», Universitat de València-CSIC, 1999. 
aspectos muy interesantes sobre el cultivo de esta materia y del álgebra en España en los siglos XV y XVI. ${ }^{266}$

Como hemos apuntado, las exploraciones geográficas llevadas a cabo por los navegantes portugueses y españoles, el control y dominio de las tierras conquistadas, el mantenimiento del imperio y la construcción de los estados plantearon una serie de exigencias técnico-científicas. Se crearon instituciones donde, además de funciones administrativas de todo lo relacionado con las navegaciones, se llevaban a cabo otras tareas como el diseño de instrumentos y mapas, se centralizaba y sistematizaba la información y se impartía instrucción en materias de náutica y cosmografía. Así surgieron la Casa de la Contratación de Sevilla, el Consejo de Indias y sus cargos asociados y la Academia de Matemáticas de Madrid. Como consecuencia aparecieron nuevos grupos de profesionales: cosmógrafos, pilotos y «maestros de hacer cartas», en particular, que se ocuparon de diseñar y poner a prueba los instrumentos, cartografiar mares y tierras, revisar y poner al día las tablas y regimientos, analizar, discutir y poner a prueba los distintos métodos y técnicas de observación, en particular para la determinación de las coordenadas geográficas y la declinación magnética, y elaborar manuales precisos y didácticos para la enseńanza de las nuevas técnicas. Algunos de estos manuales, como los de Pedro Medina y Martín Cortés, tuvieron una gran difusión europea e influyeron enormemente en la expansión de la astronomía náutica y el arte de navegar.

Sobre la actividad y obras de pilotos, cartógrafos y cosmógrafos hay una abundante literatura que se ha enriquecido recientemente con algunas aportaciones como las de Antonio Barrera, Alison Sadman, o María M. Portuondo. ${ }^{267}$

266 Véase la tesis doctoral de J. Docampo Rey, citada anteriormente, y, del mismo autor, «Reading Luca Pacioli's Summa in Catalonia: An early 16th-century Catalan Manuscript on Algebra and Arithmetics», Historia Mathematica, 33 (2006), pp. 43-62; y "Algebraic Diagrams in early Sixteenth-Century Catalan Manuscript and their possible sources», Historia Mathematica, 36 (2009), pp. 113-136. Sobre manuscritos relacionados con el cultivo del álgebra, véase también F. Romero Vallhonesta, "The "Rule of quantity". Spanish Algebra of the 16th century. Possible sources", Actes d'Història de la Ciència i de la Tècnica, Nova època, 4 (2011), pp. 93-116.

267 A. D. Sandman, Cosmographers vs. Pilots: navigation and the State in Early Modern Spain, Ph. D. Dissertation, University of Wisconsin, 2001; A. Barrera, Experiencing Nature: The Spanish American Empire and the Early Scientific Revolution, Austin, University of Texas Press, 2006; M. I. Portuondo, Secret Science. Spanish Cosmography and the New World, Chicago, The University of Chicago Press, 2009 (hay traduccicón castellana: Ciencia secreta: la cosmografía española y el Nuevo Mundo, Madrid, Iberoamericana Vervuert, 2013). Véanse también los trabajos de estos autores incluidos en V. Navarro Brotons y W. Eamon (eds.), Beyond the Black Legend. Spain and the Scientific Revolution. 
Antonio Barrera ha tratado de mostrar la importancia de las actividades españolas en el mundo Atlántico para explicar el surgimiento de las prácticas empíricas en el estudio de la naturaleza en los siglos XVI y XVII. Barrera además ha profundizado particularmente en el impacto del ejemplo español en Inglaterra.

Allison Sadman, continuando los trabajos de Ursula Lamb sobre las disputas legales en la práctica de la navegación, ha estudiado la construcción de la idea de utilidad de la ciencia y el crecimiento del patronzazo estatal de la ciencia. ${ }^{268}$ Un grupo de cosmógrafos españoles de mediados del siglo XVI llamados por Sadman «theory proponents» estaban convencidos del carácter fundamental de los métodos generalizables y aplicables universalmente. Por el contrario, los pilotos, "practice proponents» ponían el énfasis en la prácti$\mathrm{ca}$, la experiencia y el conocimiento detallado de las condiciones locales. La cuestión no se decidió únicamente sobre bases o argumentos técnicos, sino por las implicaciones amplias de tipo político del debate. Según Sadman, este éxito de los «theory proponents» pone de relieve su fundamental impacto: crearon un ámbito institucional para las gentes interesadas en proseguir las ciencias útiles para el Estado.

María M. Portuondo, en su reciente libro Secret Science: Spanish Cosmography and the New World ha tratado de describir y caracterizar las actividades, metodologías y estilos de los cosmógrafos españoles de la segunda mitad del siglo XVI, especialmente los vinculados al Consejo de Indias. Según Portuondo, los trabajos de cosmógrafos como Santa Cruz, López de Velasco o García de Céspedes carecían casi completamente de especulación filosófica. Las exigencias del imperio y las demandas utilitarias asociadas apartaron a los cosmógrafos reales españoles de la filosofía natural especulativa, privilegiando el trabajo que representaba la naturaleza como un inventario del mundo real, visible y tangible. Para Portuondo, la labor de los cosmógrafos españoles tendría que ver con el papel del experimentalismo y las prácticas empíricas refinadas en el socavamiento de los fundamentos epistemológicos de la filosofía aristotélica: la búsqueda de la causalidad. Abundando en estas tesis, Portuondo subraya la indiferencia de los cosmógrafos a las cuestiones «especulativas»: «la misión de los cosmógrafos era describir más que explicar

Habría que añadir asimismo el reciente trabajo de Antonio Sánchez, La espada, la cruz y el Padrón. Soberanía, fe y representación cartográfica en el mundo ibérico bajo la monarquía hispánica, 1503-1598, Madrid, CSIC, 2013.

268 Véanse, además, los trabajos citados de Sandman y los trabajos de Ursula Lamb reunidos en U. Lamb, Cosmographers and Pilots of the Spanish Maritime Empire, London, Variorum, 1995. 
y la filosofía natural aristotélica bastaba para las dos cosas». Y en una nota añade que el desinterés por el pensamiento especulativo no fue raro entre los cultivadores de las matemáticas del siglo xvi, tal y como Jim Bennett habría mostrado. ${ }^{269}$

Por su parte, Bennett, en su esfuerzo por mostrar la importancia de la tradición de las matemáticas prácticas en la construcción de la filosofía mecánica, no sólo ha puesto de relieve la importancia de algunas de sus características más relevantes, tales como su utilidad y aplicabilidad a un amplio dominio de materias, su uso de instrumentos, su recurso a la experiencia y la experimentación (en el sentido de ensayos prácticos) y su carácter progresivo; también ha puesto énfasis, como hemos apuntado anteriormente, en las intersecciones de diferentes aspectos de las matemáticas prácticas con la filosofía natural. Es indudable que los diferentes espacios o ámbitos de cultivo de las disciplinas matemáticas impusieron condiciones en los discursos y prácticas resultantes, pero no impidieron la circulación de gentes, conocimientos y prácticas entre esos espacios. La formación de los cultivadores de las matemáticas fue muy diversa, como también lo fue el papel, estatuto e imágenes del conocimiento de dichos cultivadores. En el caso de la cosmografía, en algunos trabajos recientes me he ocupado de su perfil en el mundo académico así como el de la practicada en el contexto del Consejo de Indias; también he tratado de poner de relieve sus conexiones, semejanzas y diferencias en las últimas décadas del siglo XVI y primeros años del XVII. Resumiré algunos resultados de estos trabajos. ${ }^{270}$

\section{Matemáticas, cosmografía y filosofía natural}

En las últimas décadas del siglo xvi la cosmografía universitaria estuvo dominada por Jerónimo Muñoz y sus discípulos y seguidores. Después de estudiar en Valencia, París, y Lovaina, Muñoz vivió durante algún tiempo en Italia, enseñando hebreo en Ancona y desarrollando alguna labor como geógrafo. A su regreso a España ejerció de profesor de hebreo y matemáticas en Valencia y Salamanca, llegando a adquirir una notable fama como

269 Véase Portuondo, op. cit., p. 304: «Stirking speculative thinking was not uncommon, however, among sixteenth century European mathematical practitioners». No obstante, en su estudio sobre Céspedes ("An Astronomical Observatory...», op. cit.) señala los condicionamientos que pesaron sobre este autor para llevar a cabo trabajos más ambiciosos como el relacionado con el establecimiento de un observatorio astronómico en El Escorial para determinar con precisión las posición de los planetas y estrellas.

270 Véase, en particular, mi trabajo, "Aspects...», op. cit. 
matemático, astrónomo y geógrafo. Directa o indirectamente fue profesor de un buen número de los mejores matemáticos y cosmógrafos del período y sus enseńanzas tuvieron una gran influencia tanto en el mundo universitario como en los cosmógrafos del Consejo de Indias y de la Academia de Matemáticas de Madrid (así como en los de Sevilla). ${ }^{271}$

Muñoz publicó muy pocas obras, pero dejó una importante cantidad de manuscritos relacionados con sus enseñanzas en Valencia y Salamanca. Estos manuscritos contienen textos de geometría, trigonometría, óptica, instrumentos científicos, astronomía, geografía y filosofía natural. En su Introducción a la Astronomía y la Geografía, uno de los textos que escribió en Valencia para sus clases, describe con gran detalle la construcción de globos terráqueos y celestes y dedica mucha atención a las representaciones cartográficas de la superficie terrestre. Para ello describe las proyecciones de Ptolomeo y las usadas por los cartógrafos europeos en su época. Discute la determinación de las coordenadas geográficas. Conservamos de él un magnífico mapa de España y una tabla de latitudes en las que Muñoz fue más preciso que todos sus contemporáneos. También conservamos una descripción de lugares, ciudades, distancias y accidentes geográficos de España y una «Descripción de los límites del Reino de Valencia». Además, el mapa más antiguo del Reino de Valencia, que fue publicado por Abraham Ortelio, se basó en los trabajos de Muñoz.

En suma, Muñoz concentró sus intereses científicos en torno a la cosmografía y las matemáticas prácticas. Pero también se interesó, de manera muy especial, por las cuestiones cosmológicas. Estaba firmemente convencido de la pertinencia de la astronomía para resolver cuestiones de filosofía natural. En sus trabajos sobre la «Nova» de 1572, Muñoz usó argumentos matemáticos, astronómicos y astrológicos para cuestionar los dogmas básicos de la doctrina aristotélica y legitimar sus ideas cosmológicas, mucho más cercanas a la tradición estoica que a la aristotélica. Por ello, es decir, por sus críticas a Aristóteles, fue «rociado de injurias», según él mismo manifestó, por filósofos, teólogos y palaciegos del rey Felipe. Muñoz también insistió en la necesidad de

271 Sobre Muñoz, véase Navarro Brotons y Rodríguez Galdeano, Matemáticas, cosmología y humanismo en la España del siglo XVI..., op.cit.; y los estudios preliminares en J. Muñoz, Introducción al tratado de Astronomía y Geografía. Edición dirigida por V. Navarro Brotons. Traducción del latín de V. Navarro Brotons, A. Pastor y E. Pastor con la colaboración de V. L. Salavert Fabiani. Estudios preliminares de V. Navarro Brotons y V. L. Salavert Fabiani, València, Consell Valencià de Cultura, 2004. Véase también un estudio de conjunto de la obra de Muñoz en V. Navarro Brotons, Jerónimo Muñoz: Matemáticas, Cosmología y Humanismo en la época del Renacimineto, València, Universitat de València PUV, 2019. 
reformar tanto la astronomía como la astrología. Y en geografía y cartografía, Muñoz insistió en la necesidad de revisar todas las tradiciones heredadas, desarrollar nuevas observaciones con nuevos instrumentos y técnicas (fue de los primeros en usar la técnica de triangulación descrita por su maestro Gemma Frisius) y con la mayor precisión posible.

En la época de Muñoz la actividad cosmográfica impulsada y protagonizada por la monarquía se centró en el Consejo de Indias, que llevó a cabo una serie de reformas impulsadas por Juan de Ovando. Un resultado importante fue la creación del puesto de Cosmógrafo-cronista Mayor de Indias, para el que Ovando nombró a López de Velasco, sobre cuyas actividades cosmográficas se han realizado importantes estudios. ${ }^{272}$ Pero mi interés ahora se centra en el desarrollo de la cosmografía a partir de 1580, es decir, del año de la anexión de Portugal, y en las actividades de Juan de Herrera, el arquitecto real y aposentador de palacio.

Herrera fue el principal consejero de Felipe II en cuestiones técnicas y científicas. Como arquitecto, Herrera siguió el modelo de Vitrubio con respecto a la importancia de las matemáticas, la mecánica y las cuestiones tecnológicas. En opinión de Herrera, «la arquitectura... presupone algo de todas las artes y ciencias... particularmente la geometría, la aritmética, la perspectiva, la música, la astrología, la gnomónica y la mecánica». ${ }^{273}$ Además de la arquitectura, Herrera practicó otras disciplinas, incluida la cosmografía

272 Sobre el Consejo de Indias y la actividad de Ovando y López de Velasco, véase E. Schäfer (1935-1947), El Consejo Real y Supremo de las Indias: su historia, organización y labor administrativa hasta la terminación de la Casa de Austria, 2 vols. Sevilla, Escuela de Estudios Hispano-Americanos, $1935-1947$ (reimpr., Madrid, Marcial Pons, 2003); Lamb, op.cit.; D. Goodman, Power and Penury: Government, Technology, and Science in Philip II's Spain, Cambridge, New York, Cambridge University Press, 1998 (versión castellana: Poder y penuria. Gobierno, tecnología y ciencia en la España de Felipe II, Madrid, Alianza, 1990); I. Vicente Maroto y M. Esteban Piñeiro, Aspectos de la ciencia aplicada en la España del Siglo de Oro, Valladolid, Junta de Castilla y León, 1991; R. Álvarez Peláez, La conquista de la naturaleza americana, Madrid, CSIC, 1993; Portuondo, Secret Science..., op. cit.

273 Herrera, op. cit, p. 15. Para los datos biográficos de Herrera véase A. R. de Arcaute, Juan de Herrera, arquitecto de Felipe II, Madrid, Espasa Calpe, 1936; C. WilkinsonZerner, Architect to Philip II of Spain, New Haven, Yale University Press, 1993.

Véase también en J. de Herrera, Discurso del Sr. Juan de Herrera, aposentador mayor de S. M., sobre la Figura cúbica, Re-presentado por Edison Simons y Roberto Godoy, Madrid, Editora Nacional, 1976, una colección de documentos relacionados con Herrera, incluido alguno de sus trabajos como el citado en el título del libro (Discurso sobre la Figura cúbica). También la colección de trabajos dedicados a Herrera en M. A. Aramburu-Zabala y J. Gómez Martínez (coords.), Juan de Herrera y su influencia, Santander, Universidad de Cantabria, 1993. 
y la instrumentación científica. Herrera, que según algunos testimonios ya había diseñado algunos instrumentos, intensificó sus intereses en cosmografía y náutica durante su estancia en Portugal, tras la anexión de este reino a la monarquía hispánica. Los portugueses habían inventado el arte de navegar y algunos de sus matemáticos/cosmógrafos, y en particular Pedro Nunes, habían desarrollado los fundamentos matemáticos del arte y ciencia de navegar más que ningún otro autor. Así, junto a la tradición española, Herrera en Portugal pudo entrar en contacto directamente con las novedades más adelantadas de Europa en el ámbito de la cosmografía y la náutica.

Herrera desarrolló varios proyectos conectados con sus nuevos intereses. Uno de ellos fue la creación de la Academia de Matemáticas en Madrid. ${ }^{274}$ Anteriormente he citado los objetivos de la Academia según Herrera. Para cada materia o actividad Herrera recomendó un grupo relevante de textos, que muestran su gran familiaridad con las disciplinas matemáticas y sus aplicaciones. Además, Herrera recomendó que las clases se enseñaran en castellano. Para facilitar esto, se preparó un amplio plan de traducciones de textos de matemáticas. Pedro Ambrosio de Ondériz, que había estudiado lenguas clásicas, tradujo la Óptica y la Pseudo-Catóptrica, de Euclides, así como los libros XI y XIII de los Elementos; los Esféricos, de Teodosio y Sobre el equilibrio de los planos, de Arquímedes.

Como es bien sabido, Juan Bautista Lavanha, un cosmógrafo portugués, fue nombrado en 1582 "para que se ocupe en nuestra corte y donde se le ordenare en cosas de Cosmografía, Geografía y Topografía, y en leer matemáticas». Al propio tiempo se nombró a Pedro Ambrosio de Ondériz ayudante de Lavanha y se le encargó de la traducción de textos científicos, como ya he seńalado. No tengo tiempo para describir las actividades de esta academia, sobre la que tenemos una información fragmentaria, a pesar de los esfuerzos de algunos estudiosos como Isabel Vicente y Mariano Esteban. ${ }^{275}$ Sólo quiero destacar algunos aspectos relevantes para mis propósitos. En primer lugar, parece indudable que uno de los principales objetivos de la Academia fue la formación de cosmógrafos y pilotos. Pero también tenemos testimonios

274 Véase Vicente Maroto y Esteban Pińeiro, op.cit., sobre la reforma del Consejo de Indias y la fundación de la Academia de Matemáticas. Véase también M. Esteban Piñeiro y M. Jalón, "Juan de Herrera y la Real Academia Matemáticas», en Los instrumentos cientificos del siglo XVI. La corte española y la escuela de Lovaina, Madrid, Fundación Carlos de Amberes, 1998, pp. 55-67. Y, V. Navarro Brotons, «The teaching of the Mathematical Disciplines in Sixteenth-Century Spain, Science and Education (Springer), 15 (2006), 209-233.

275 Véase Vicente Maroto y Esteban Piñeiro, op. cit. 
de que en la Academia se enseñaron, en algunos períodos (al final del siglo, en particular) táctica militar, fortificaciones, artillería y mecánica, todo ello más orientado a la formación de ingenieros y arquitectos. Pero además la Academia ayudó a crear un espacio de sociabilidad y discusión de diversas cuestiones científicas. En otro trabajo me he ocupado de algunos debates entre los académicos, como el relativo al Mechanicorum liber, de Guidobaldo dal Monte, y las proposiciones sobre la balanza. ${ }^{276}$

Uno de los «académicos» que intervino en este debate fue Andrés García de Céspedes, un distinguido cosmógrafo, astrónomo e ingeniero, autor de numerosos trabajos sobre estos temas; dos de ellos fueron publicados: el Libro de instrumentos nuevos de geometría para medir distancias y alturas (1606) y el Regimiento de navegación (1606). ${ }^{277}$

El Libro de instrumentos incluye, además de la descripción y uso de una serie de instrumentos como el cuadrante, la ballestilla y el nivel, un tratado de hidráulica, el más amplio sobre el tema publicado en la España de esta época, según García Tapia. ${ }^{278} \mathrm{El}$ libro también incluye un capítulo sobre balística. García de Céspedes señala que la artillería «se puede llamar máquina de las máquinas» y añade que su escaso progreso se debe a que de ella se han ocupado gentes que no son matemáticos ni filósofos. Para explicar la «potencia» del tiro, según el ángulo del mismo, se basa en el Mechanicorum liber, de Guidobaldo.

El Regimiento de navegación, de Garcia de Céspedes, no era un manual del arte de la navegación para uso de los pilotos, sino más bien un tratado de cosmografía aplicado a la navegación. Además era una auténtica suma y síntesis de los conocimientos y técnicas desarrollados en España y Portugal sobre el arte y ciencia de navegar. La obra constaba de dos partes. La primera era una revisión de todos los regimientos, tablas e instrumentos; la segunda,

276 V. Navarro Brotons, «Mechanics in Spain at the End of the 16th Century and the Madrid Academy of Mathematics», en W. R. Laird and S. Roux (eds.), Mechanics and Natural Philosophy before the Scientific Revolution, Dordrecht, Springer, 2008, pp. 239259 [una versión en castellano de este trabajo con alguna leve modificación en F. Grau, J. M. Maestre y J. Pérez Durá (eds.), Litterae Humaniores. Del Renacimiento a la Ilustración. Homenaje al profesor José María Estelles, València, Universitat de València, 2009, pp. 431455; también en el capítulo VII de mi Disciplinas..., op. cit.].

277 Sobre García de Céspedes, véase Picatoste Rodríguez, F. (1891), Apuntes para una biblioteca cientifica española del siglo XVI, Madrid, 1891, pp. 120-127; Vicente Maroto y Esteban Piñeiro, op. cit. (1998); Navarro Brotons, «La astronomía», op. cit., y "Aspects...», op. cit. Véase también del mismo autor el capítulo VIII de Disciplinas..., op. cit.

278 Véase N. Garcia Tapia, Ingeniería y arquitectura en el Renacimiento español, Valladolid, Universidad de Valladolid. 1990, pp. 158-159. 
una revisión de la construcción de cartas de navegar particulares y del mapa padrón universal de acuerdo con toda la información disponible en la época.

Para revisar el regimiento del Sol y el de la estrella del Norte, García de Céspedes llevó a cabo una serie de observaciones con nuevos instrumentos designados a tal propósito. Quiero indicar que, según mi conocimiento, García de Cépedes, en España, y Thomas Harriot, en Inglaterra, fueron los primero autores de tablas de longitud solar basadas en nuevas observaciones y en el cálculo de la órbita solar (independientemente de Tycho Brahe y orientadas a la astronomía náutica). ${ }^{279}$ García de Céspedes llevó a acabo sus observaciones durante su estancia en Lisboa al servicio del archiduque Alberto, gobernador de Portugal, entre 1583 y 1593. A su regreso a Madrid y entre 1593 y 1596, García de Céspedes le propuso al monarca establecer un observatorio astronómico cuyo principal objetivo sería corregir las tablas astronómicas, tarea que continuó llevando a cabo por su cuenta. ${ }^{280}$

García de Céspedes, como científico cultivador de las matemáticas, tenía ambiciones teóricas que trascendían sus funciones como cosmógrafo del Consejo de Indias, aunque es cierto que en sus obras publicadas encontramos muy escasas referencias a las cuestiones de filosofía natural; más bien hay una defensa de la certeza de las matemáticas frente a la incertidumbre de las especulaciones filosóficas. García de Céspedes estuvo al frente de la Academia de Matemáticas entre 1607 y 1611. En cuestiones astronómicas y cosmológicas tenemos algunos indicios de que sus ideas eran similares a las de Muñoz y sus discípulos, aunque no las expresó públicamente.

El sucesor de Garía de Céspedes al frente de la Academia fue Juan Cedillo Díaz, que ocupó el puesto entre 1611 y 1625, aunque anteriormente ya había ejercido como profesor de la Academia, al menos desde 1597. Cedillo continuó la labor de traducción de textos de matemáticas iniciada

279 Véase V. Navarro Brotons, «Astronomía y cosmografía entre 1561 y 1625 . Aspectos de la actividad de los matemáticos y cosmógrafos españoles y portugueses», Cronos, 3 (2000), pp. 113-144, reproducido en el capitulo VIII de Disciplinas..., op. cit. Y, del mismo autor, "Aspects...", op. cit. Sobre Harriot, véase J. Roche, "Harriot’s "Regiment of the Sun" and its Background in Sixteenth-Century Navigation", The British Journal for the History of Science, 14 (1981), pp- 245-261.

280 Véase en M. F. Navarrete, Disertación sobre la historia de la náutica y de las ciencias matemáticas que han contribuido a sus progresos entre los españoles, Madrid, Viuda de Calero, pp. 215-216 (55), 1846, un resumen del informe de García de Céspedes sobre los instrumentos y objetivos del Observatorio "Dos grandes globos celeste y terrestre de metal dorados...; un gran cuadrante de ocho palmos, y un radio astronómico de diez para averiguar los verdaderos lugares del sol y de la luna... Por este medio se corregirían muchos errores que se notaban en los movimientos celestes...». Véase, sobre el proyecto del Observartorio, también, Portuondo, "An Astronomical...», op. cit. 
por Ondériz. Se conservan manuscritos de sus traducciones del Arte atque ratione navigandi, de Pedro Nunes, de los Elementos de Euclides, de la Nova Scientia, de Tartaglia, de los tres primeros libros del De revolutionibus, de Copérnico, y del Discurso del flusso e reflusso del mare, de Galileo (Cedillo intervino en la traducción, con notas y correcciones). También se conserva entre sus manuscritos, pero no parece obra suya, la traducción del texto de Camillo Gloriosi dedicado a las cometas. Además se conservan observaciones de cometas, suyas y de sus discípulos. En su traducción del texto de Copérnico presentó algunas de sus ideas cosmológicas, no totalmente coincidentes con las de Copérnico y similares a las de Muñoz. Tal es su afirmación de que los planetas de mueven por el aire cósmico como peces en el agua, como Jerónimo Muñoz (su probable profesor de astronomía) había afirmado. Pero Cedillo no publicó sus traducciones. ${ }^{281}$

Diversos condicionantes y el control ideológico pesaron negativamente en el desarrollo del pensamiento libre y creativo indispensable para la actividad científica. Ello promovió el divorcio entre los matemáticos y los filósofos. En otro lugar he indicado como la separación entre la mecánica, practicada por humanistas como Diego Hurtado de Mendoza y matemáticos prácticos como Herrera, García de Céspedes o Cedillo, y la filosofía natural escolástica impidió que la ciencia de las máquinas se vinculara al estudio del movimiento. ${ }^{282}$

En las primeras décadas del siglo XVI, algunos filósofos portugueses y españoles, seguidores de los nominalistas y calculadores de París y Oxford del siglo XIV, que habían estudiado en París, difundieron sus doctrinas en las universidades españolas y desarrollaron el interés por las aplicaciones de las matemáticas a las cuestiones físicas y teológicas. Los llamados «calculatores» ibéricos publicaron en París y en la Península diversos textos de matemáticas siguiendo la tradición bajomedieval.

281 Sobre Cedillo, véase M. I. Vicente Maroto y M. Esteban Piñeiro, op. cit. y M. Esteban Piñeiro y F. Gómez Crespo, «La primera versión castellana de De revolutionibus orbium coelestium: Juan Cedillo Díaz (1620-1625)», Asclepio, 43 (1991), pp. 131-162. Sobre la traducción de Copérnico y las ideas cosmológicas de Cedillo, véase también Navarro Brotons, "La astronomía...", op. cit.; y, del mismo autor, "Astronomy and Cosmology in Spain in the Seventeenth Century: the new practice of Astronomy and the end of the Aristotelian-Scholastic Cosmos», Cronos, 10 (2007), pp. 15-40. Y más recientemente el estudio y edición de Cedillo en Juan Cedillo Díaz: Ydeas astronómicas de la fábrica del mundo y movimiento de los cuerpos celestiales. Traducción del De revolutionibus I-III de Nicolás Copérnico, Miguel Á. Granada y F. Gómez Crespo (eds.), Barcelona, Universitat de Barcelona, 2019.

282 Navarro Brotons, «Mechanics...», op. cit. 
Así, Gaspar Lax publicó varios textos en París y en Zaragoza: entre ellos, Arithmetica speculativa, De proportionibus arithmeticis y Calculationes generales philosophice; Pedro Sánchez Ciruelo publicó la aritmética y la geometría de Bradwardine y un Curso de matemáticas dedicado a la aritmética, geometría, perspectiva y música; también un tratado de aritmética dirigido a estudiantes de filosofía y astronomía; el portugués Álvaro Thomas publicó su importante Liber de triplici motu y Margalho, Silíceo y Pedro de Espinosa publicaron también obras similares.

Los «calculatores» ibéricos también se interesaron por cuestiones de astronomía y cosmografía: Ciruelo, profesor en París y Alcalá, publicó comentarios a la Esfera de Sacrobosco y textos de astrología, y Pedro Margalho, profesor en la Universidad de Salamanca, publicó allí un Physices compendium que incluía un tratado sobre la Esfera basado en Gemino, Arato, Cleómedes y Ptolomeo. Margalho revisó las doctrinas medievales sobre la distribución de las tierras y el agua a la luz de las experiencias de los navegantes. ${ }^{283}$

En la segunda mitad del siglo Xvi el acercamiento nominalista o terminista a la lógica cayó en similar declive al que había sufrido ya en París y en otras universidades europeas. De este modo, temas tratados en los cursos de filosofía natural como la doctrina de la intensio y remissio de las formas, prácticamente desaparecieron de los libros, o se exponían de manera breve y confusa, o eran simplemente rechazados por mezclar las matemáticas con la física, como hizo Francisco Vallés, por ejemplo. Sólo algunos filósofos jesuitas continuaron dedicando alguna atención a estos temas, basándose en particular en Domingo de Soto, en cuyas obras aún se puede encontrar una amplia discusión del tema del movimiento, estudiado tanto desde el punto de vista de las causas como de los efectos.

No obstante, aún no tenemos un estudio amplio y riguroso del estatus epistemológico de las matemáticas y de la existencia o influencia entre los filósofos españoles, sí la hubo de la quaestio certitudine mathematicarum en España en el período que estudiamos. Como ya he recordado, los «calculatores» ibéricos defendieron la relevancia de las matemáticas para la filosofía natural. En esta línea, Pedro Sánchez Ciruelo, en su comentario a los Analíticos posteriores, de Aristóteles (Alcalá, 1529), consideró que en las matemáticas

283 Sobre estos autores, véanse las entradas del Diccionario histórico de la ciencia moderna en España, 2 vols., dirigido por J. M. López Pińero, T. F. Glick, V. Navarro Brotons y E. Portela Marco, Barcelona, Península, 1983. Véase también V. Navarro Brotons, «De la filosofía natural tradicional a la física moderna (siglos XVI-XVII)». En: López Piñero (dir.), Historia de la ciencia y de la técnica en la Corona de Castilla, vol. 3, pp. 383-437. Véase también el capítulo III de Disciplinas..., op. cit., del mismo autor. 
se encontraba el caso más perfecto de demostración aristotélica y, en su comentario a la Esfera de Sacrobosco, situó a las matemáticas por encima de todas las otras ciencias y sólo después de la metafísica. Y entre las disciplinas matemáticas el lugar más elevado correspondería a la astronomía, debido a la dignidad de su objeto. Pero la influencia de los «calculatores» fue disminuyendo progresivamente en Espańa, como hemos señalado. ${ }^{284}$

Algunos filósofos humanistas, tales como Pedro Juan Núñez, uno de los introductores de las orientaciones ramistas en España, afirmaron la importancia de las matemáticas tanto por su valor práctico como porque eran necesarias para entender a Aristóteles, pero no discutieron las cuestiones epistemológicas implicadas. Por otra parte, en los colegios jesuitas la enseñanza de las matemáticas no comenzó hasta el siglo XVII de manera significativa. Este hecho contrasta con la actividad de algunos jesuitas españoles fuera de la Península en la enseñanza de las matemáticas o en el debate sobre la epistemología de las matemáticas (la quaestio certitudine mathematicarum). Recordemos en este sentido a Baltasar Torres, el primer profesor de matemáticas del Colegio Romano; o a Jerónimo Hurtado, que enseñó matemáticas y filosofía en Nápoles; a Benito Perera, profesor de lógica, filosofía, metafísica y teología en el Colegio Romano, bien conocido por su intervención en la quaestio defendiendo que las matemáticas no eran verdaderas ciencias en el sentido aristotélico. ${ }^{285}$

Según lo que hasta ahora sabemos, cabe concluir que el acercamiento que más prevaleció en España en la segunda mitad del siglo Xvi, acercamiento que persisitió de manera bastante general en el siglo XvII entre los profesores de filosofía, era opuesto al uso de las matemáticas en cuestiones de filosofía natural.

Al contrario que los filósofos, Jerónimo Muñoz y sus discípulos, que enseñaron matemáticas en las universidades de Valencia, Salamanca y Alcalá

284 Véanse los capítulos III y IV de Navarro Brotons, Disciplinas..., op. cit.

285 Sobre Baltasar Torres, véase U. Baldini, Legem impone subactis. Studi su Filosofia e Scienza dei gesuiti in Italia, 1540-1632, Roma, Bulzoni, pp. 572 ss, y la bibliografía citada en este trabajo. Sobre Jerónimo Hurtado, véase R. Gatto, «Hyeronimo Hurtado e gli inizi della scuola filosofica del collegio gesuitico napoletano», en Navarro y Eamon (eds.), Beyond of the Black Legend, op. cit., pp. 241-253. Sobre Perera, la literatura es enorme; véase la entrada correspondiente (como Pereira) en el Diccionario histórico de la ciencia moderna en España, vol. I, pp. 153-155, y, recientemente, el trabajo de P. Richard Blum, «Benedictus Pereirus: Renaissance Culture at the Origins of Jesuit Science», Science and Education, 15 (2006), pp. 279-304. Véase también M. Lamanna y M. Forlivesi (eds.), «Benet Perera (Pererius, 1535-1610). A Renaissance Jesuit at the Crossroads of Modernity», Quaestio 14 (2014), Turnhout (Belgium), Brepols. 
(y en Sevilla en una cátedra especial para Pérez de Mesa) defendieron la legitimidad de las matemáticas para tratar cuestiones de filosofía natural, y ello en abierta polémica con los filósofos. Así, en su libro sobre la Nova de 1572, Muńoz se sintió perfectamente autorizado para extraer conclusiones de naturaleza cosmológica (y contrarias a las doctrinas aristotélicas) de sus observaciones y cálculos matemáticos. Por su interpretación de la Nova y sus críticas a Aristóteles, Muñoz fue «rociado de injurias por muchos teólogos, filósofos y palaciegos del rey Felipe», según le escribió el mismo Muñoz a un amigo y colega de Viena. ${ }^{286}$ A pesar de ello, Diego Pérez de Mesa, un discípulo de Muñoz profesor de matemáticas en Alcalá y en Sevilla, defendió ideas similares a las de Muñoz y afirmó que la astronomía es una "ciencia casi mixta con la filosofía y por eso averigua muchas cuestiones hermosísimas de la misma filosofía». Y el sucesor de Muñoz en la cátedra de Salamanca, Antonio Núnez Zamora, en su libro sobre la Nova de 1604 defendió la naturaleza celestial de los cometas y dijo que los filósofos, en particular los seguidores de Aristóteles, habían atacado a los astrónomos por sus puntos de vista cosmológicos. Contra estas críticas, Núñez Zamora afirmó el carácter demostrativo de las disciplinas matemáticas y la certeza con la que las matemáticas establecen sus conclusiones. ${ }^{287}$

Ursula Lamb, destacada historiadora de la cosmografía ibérica, concluyó uno de sus magníficos trabajos diciendo que la España de los Habsburgo desempeñó un papel muy importante en el cambio de la manera en que se construyeron las ciencias de la naturaleza. ${ }^{288}$ Este hecho aún no está suficientemente reconocido por los historiadores de la ciencia extranjeros, como subrayamos el profesor William Eamon y yo en el volumen sobre España y la Revolución Científica, y como hemos visto en el caso de Jim Bennett. No obstante, hemos avanzado mucho en este reconocimiento, a medida que avanzamos también en el conocimiento de nuestro pasado científico,

286 Véase la carta de Muñoz a Reisacher, editada por V. Navarro, en J. Muñoz, Libro del nuevo cometa (Valencia, Pedro de Huete, 1573). Littera ad Bartholomaeum Reisacherum (1574). Summa del prognostico del cometa (Valencia, Juan Navarro, 1578). Introducción, apendices y antologia por V. Navarro. Valencia, Hispaniae Scientia, 1981.

287 Sobre Pérez de Mesa y Núñez Zamora, véase Navarro Brotons, «La astronomía», op. cit.; Id., "Continuity and Change in Cosmological Ideas in Spain Between the Sixteenth Century and Seventeenth Centuries: The Impact of Celestial Novelties», en P. J. Boner (ed.), Change and Continuity in Early Modern Cosmology, Dordrecht, Springer, 2011, pp. 33-50; Id. "Las novedades celestes en España», en M. A. Granada (ed.), Novas y cometas entre 1572 y 1618, Barcelona, Universitat de Barcelona, 2012, pp. 15-43.

288 Véase Lamb, «La nueva ciencia geográfica», Revista de Occidente, 37 (1972), 162 183, reeditado en Lamb, Cosmographers..., op. cit., n. ${ }^{\circ}$ IV. 
con inventarios, biobibliografías, prosopografías y estadísticas y con estudios monográficos desde una perspectiva comparada. Todo ello de acuerdo con el programa de trabajo que ya planteó Menéndez Pelayo, que también reclamaba cátedras de Historia de las Ciencias en las universidades españolas.

La construcción de la ciencia moderna implicó, como es sabido, cambios profundos de varios órdenes: metodológico-instrumentales, teóricos y organizativo-institucionales, todo ello en el contexto de un intenso cambio cultural y de transformaciones profundas de la escena política europea. España (representada por la monarquía española), que llegó a poseer el imperio más grande del mundo, desempeñó un importante papel en este proceso, sobre todo en la etapa renacentista.

\section{Tradición, continuidad y decadencia de la actividad científica}

En el reinado de Felipe II y a partir de la Contrarreforma, el control ideológico y la represión de la libertad de pensamiento comenzó a pesar muy negativamente en el desarrollo de la ciencia y la filosofía. No hace falta recordar la pragmática de Felipe II prohibiendo a los espańoles estudiar o enseñar en el extranjero, que dificultó considerablemente la comunicación con el resto de Europa a los intelectuales españoles. Pero, por otra parte, como ya puso de relieve López Pińero, seguido después por varios autores, y como por nuestra parte hemos tratado de mostrar en este trabajo, también en esa época se dio un impulso notable a determinadas actividades científico-técnicas, en relación con los intereses del estado y la monarquía. Todo ello ha llevado a algunos historiadores a señalar que fue precisamente el carácter excesivamente utilitario y pragmático de la promoción de la actividad científico-técnica, aislada del pensamiento especulativo, y sometido este a un severo control, lo que marcó sus limites y dificultades para desarrollarse creativamente y asimilar las nuevas corrientes de pensamiento en filosofía natural. Según nuestros conocimientos, el primero que propuso la tesis del carácter excesivamente utilitario y pragmático de la promoción de la actividad científica española fue precisamente Menéndez Pelayo, a cuyas afirmaciones en este sentido ya nos hemos referido anteriormente.

En todo caso, los frutos y consecuencias de este considerable desarrollo en las matemáticas prácticas en el ámbito hispánico que hemos descrito sumariamente para la construcción de la ciencia moderna, en particular para la emergencia de la filosofia mecánica o las nuevas corrientes en filosofía natural, no se recogieron en España en la misma medida que en Inglaterra, Holanda, Francia o incluso Italia. En el siglo Xvis, sobre todo en los años centrales de la 
centuria, la actividad científica descrita experimentó una profunda decadencia, paralela a la intensa crisis y decadencia en el ámbito político, económico y social que se experimentó en Espańa, muy especialmente en Castilla, pero también en los otros reinos peninsulares. Los intentos desesperados de los nuevos monarcas y sus ministros para mantener una posición hegemónica en Europa no llevaron sino a nuevos desastres y a profundizar la crisis.

No obstante, conviene recordar, en primer lugar, que la crisis económica, política y social no fue un fenómeno exclusivamente español, aunque España fue sin duda uno de los países donde fue más intensa. Segundo, que la correlación: decadencia político-económico-social y decadencia científico-técnica no es nunca completa. Tercero, que esta decadencia relativa no tiene que confundirse con ausencia de actividad científico-técnica. En su libro Ciencia y técnica..., López Piñero no ofreció una explicación articulada de la decadencia de la actividad científica, paralela a la política, económica y social, aunque a lo largo de su obra presentó o sugirió una constelación de factores: el avance de la Contrarreforma, con la consiguiente hegemonía del escolasticismo contrarreformista y la represión de la actividad científica; el declive económico y la "traición de la burguesía», es decir, el que los estratos medios de las ciudades, que constituían uno de los núcleos básicos de la actividad científica, no se convirtieran en una burguesía propiamente dicha y adoptaran, por el contrario, los valores impuestos por la moral contrarreformista; el retroceso consiguiente de la secularización; la actitud agresiva y excluyente hacia los judíos conversos, entre los que abundaban los médicos y científicos; el cambio regresivo de la mentalidad de los grupos políticos dirigentes y, finalmente, los condicionamientos socioeconómicos, políticos y religiosos. Naturalmente, todos estos factores deben ser cuidadosamente cualificados en cuanto a su verdadero significado, contenido y alcance, y cabe preguntarse también si, aún siendo necesarios son suficientes para ofrecer una explicación convincente. Junto a ellos, habrá que ponderar también las peculiaridades, limitaciones y fragilidad que tuvo, en el siglo xvi la actividad científico-técnica en el ámbito hispánico que compremetió seriamente su continuidad y consolidación.

Menéndez Pelayo, en La ciencia española, reconoció la decadencia científica y filosófica espańola y apunto algunas de sus posibles causas, entre ellas el gran descenso de la población debido a la expulsión de los judíos, la colonización del Nuevo Mundo, las guerras incesantes y la expulsión de los moriscos. Señaló también los errados principios económicos y la impericia de los gobernantes que provocaron la caída del comercio en el Mediterráneo y en relación con América. Además, con la expulsión de los moriscos 
habría quedado atrasada la agricultura, con lo que se llegó a finales del siglo XVII con la población disminuida, sin industria y sin comercio. Total, concluía Menéndez Pelayo «nos habíamos desangrado por la religión, por la cultura, por la patria», de lo que, añade, no debemos arrepentirnos. Junto a estas causas, Menéndez Pelayo introdujo una ley universal de desarrollo de las ciencias y las artes que regiría sus ciclos de crecimiento, esplendor y decadencia: «No hay, no ha habido ni habrá en la tierra pueblo que que en una misma época presente en igual grado de desarrollo todas las ramas del árbol de la cultura...», ley que en última instancia se basaba en una visión providencialista de la historia: "porque es justo designio de Dios que las ciencias peregrinene de unas gentes a otras...». ${ }^{289}$

Sea cual fuere el jucio que nos merezcan hoy las explicaciones sugeridas por Menéndez Pelayo para dar cuenta de la causas de la decadencia, en lo que podemos convenir es en su insistencia en que decadencia, declive, disminuición o como quiera que lo llamemos, y siempre en términos comparativos con otros países o ámbitos culturales, no implica ausencia de actividad científica digna de consideración y no nos ahorra la tarea de investigarla con rigor, como él mismo requería.

\section{Los jesuitas, la actividad científica y novedades}

En el trabajo citado sobre el «Esplendor y decadencia...», al comentar la decadencia o «ruina» de los estudios de las disciplinas físico-matemáticas en la España del siglo XVII, Menéndez Pelayo afirmaba que atribuir esto, «como insinuó Fernández Navarrete y han repertido otros» a los jesuitas sería irse por las ramas y no explicar nada. Y a pesar de que confiesa que fue «gran lástima que el Renacimiento cayese en manos de los jesuitas para degenerar en retórica de colegio" y declara no tener gran entusiasmo por sus métodos de enseńanza, añade que «en honor de los jesuitas debe decirse que hicieron laudables esfuerzos para difundir el gusto de estas enseñanzas (de las mencionadas disciplinas), las cuales no faltaron nunca en el Colegio Imperial».

Efectivamente, y como hemos explicado ampliamente en otros trabajos, los jesuitas desempeñaron en España un papel de primera importancia en el proceso de recepción y asimilación o apropiación de las novedades científicas y ello por varias razones. En primer lugar, porque las únicas instituciones

289 Las ideas de Menéndez Pelayo sobre las características y decadencia (relativa) de la actividad científica en el siglo XVII las expone en diversos capítulos de La ciencia española. Véase el capítulo I, vol. II, pp. 14 y ss. Véase también el trabajo de Gerardo Bolado, «La lucha por el reconocimiento...", en este mismo libro. 
que durante la mayor parte de la centuria mostraron cierta vitalidad en los estudios científicos, sobre todo a través de las cátedras de matemáticas y en el marco de la ideología jesuítica, fueron algunos de los colegios de la Compañía establecidos en España, muy especialmente el Colegio Imperial de Madrid. En segundo lugar, porque la pertenencia a la Sociedad jesuítica les permitió a los profesores, españoles o extranjeros afincados en España, un contacto con los científicos jesuitas europeos y, a través de ellos, con la ciencia europea en general. En tercer lugar, porque el eclecticismo jesuítico resultaba muy adecuado en el ambiente español, reacio y hostil a las novedades, cuando no indiferente. Así, los científicos españoles partidarios de la renovación en estas materias, aun no perteneciendo algunos de ellos a la Sociedad, tomaron a los jesuitas como principal modelo para sus propósitos de introducir en España las nuevas corrientes científicas. ${ }^{290}$

También en Portugal, en el siglo xvII, los jesuitas desempeñaron un destacado papel en el mantenimiento de la actividad científica y en la recepción de las novedades en Portugal, como lo han mostrado con claridad los estudios de Luis Albuquerque, Ugo Baldini, Luis Miguel Carolino, Henrique Leitao y otros autores. ${ }^{291}$ Sin embargo, hay entre los casos de Portugal y España algunas interesantes diferencias en las que convendría profundizar. Y aprovecho

290 Presento aquí un apretado resumen de mis trabajos sobre los jesuitas y la actividad científica, principalmente las disciplinas físico-matemáticas, en la Espańa del siglo xvir. Véase en particular V. Navarro Brotons, «La ciencia en la España del siglo Xvıı: el cultivo de las disciplinas físico-matemáticas», Arbor, 153 (n. ${ }^{\circ}$ 604-605) (1996), 197-252; Id., "Tradition and Scientific Change in Modern Spain: The Role of the Jesuits», en M. Feingold (ed.), Jesuit Science and the Republic of Letters, Cambridge, MA/London, The MIT Press, 2002, pp. 331-389; y los capítulos XIV y XV de V. Navarro Brotons, Disciplinas..., op. cit.

291 Véase L. de Albuquerque, «A “Aula da Esfera” do Colegio de Santo Antão no século xvi», Estudos de Historia, Coimbra, Acta Universitatis Conimbrigensis, 1974, vol. 2, pp. 127-200; U. Baldini, "As assistèncias ibéricas da Companhia de Jesus e a actividade científica nas missóes asiáticas (1578-1640). Alguns aspectos culturales e institucionais», Revista Portuguesa de Filosofia, 54 (1998), pp. 195-245; Id., "L'insegnamento della matematica nel Collegio di S. Antao a Lisbona, 1590-1640», en Nuno da Silva (coord.), A Companhia de Jesus e a Missionação no Oriente: Actas, Lisboa, Brotoeria, Fundação Oriente, 2000, pp. 275-310 (reproducido en U. Baldini, Saggi sulla cultura della Compagnia di Gesì, Padova, CLEUP editrice, 2000, pp. 129-171); Id., "The teaching of Mathematics in the Jesuit colleges of Portugal from 1640 to Pombal», en L. Saraiva y H. Leitao (eds.), The Practice of Mathematics in Portugal, Coimbra, Imprensa da Universidade de Coimbra, 2004, pp. 293-465; L. M. Carolino y H. Leitao, «Natural Philosophy and Mathematics in Portuguese Universities, 1550-1650», en Feingold y Navarro (eds.), Universities and Science in the Early Modern Period, pp. 153-169; L. M. Carolino, Ciência, astrologia e sociedade. A teoria da influência celeste em Portugal (1593-1755), Lisboa, Fundação Calouste Gulbenkian, 2003. Véanse también los trabajos reunidos en el catálogo de la 
para insistir en la importancia de los estudios comparados entre Portugal y España, que sin duda nos ayudarán mucho a comprender nuestro pasado. En primer lugar, la enseñanza de las disciplinas matemáticas, que comenzó en Portugal ya en el siglo XVI, en España no se inició hasta después de 1625 (según lo que sabemos hasta ahora), con la creación de los Reales Estudios del Colegio Imperial de Madrid. Tampoco tenemos una explicación satisfactoria para esto, pero a mi juicio habría que tener en cuenta la competencia de las universidades.

En todo caso, el año 1625 se establecieron los Reales Estudios del Colegio Imperial con diecisiete cátedras (además de las de gramática latina) que incluían dos de matemáticas, una de arte militar, una de historia natural y una de cronología, además de las de lógica, filosofía natural, metafísica, etc. Además de estas cátedras los jesuitas asumieron la cátedra de cosmografía y matemáticas de la llamada Academia de Matemáticas de Madrid y el puesto y tareas del cosmógrafo mayor del Consejo de Indias.

Como en Portugal, en España se recurrió también a matemáticos jesuitas extranjeros. En las primeras décadas de funcionamiento de los Reales Estudios residieron y enseñaron en esta institución el suizo-alemán Juan Bautista Cysat, el belga Jean Charles della Faille, el borgoñón Claude Richard, el polaco Alexius Sylvius Polonus, el escocés Hugo Sempilius, el italiano Francisco Antonio Camassa y dos españoles: el castellano José Martínez y el vasco Francisco Isasi (profesor de Arte Militar). A estos autores habría que añadir a Juan Eusebio Nieremberg, profesor de Historia Natural y Cronología (también llegó a enseñar Sagradas Escrituras y Teología), que también se ocupó de cuestiones de astronomía, cosmología y magnetismo (es el primer autor español que expuso y discutió las teorías de Gilbert en una obra impresa).

Los matemáticos jesuitas del Colegio Imperial publicaron muy pocas obras, pero dejaron un importante volumen de manuscritos de sus clases y de sus trabajos científicos que nos han permitido reconstruir sus enseñanzas y actividades. Entre las obras publicadas figura el tratado De mathematicis disciplinis (Amberes, 1635), del escocés Hugo Sempilius, en el que este autor trataba de ofrecer un panorama general de las distintas disciplinas matemáticas. En esta obra Sempilius discute ampliamente la controvertida cuestión de si las matemáticas son o no verdaderas ciencias en el sentido aristotélico y concluye que los son, pero distintas de las otras ciencias. Esta caracterización y defensa de las matemáticas iba encaminada a apoyar y

exposición (comisario: Henrique Leitão) Sphaera Mundi: A Ciência na Aula da Esfera, Lisboa, Biblioteca Nacional de Portugal, 2008. 
promocionar su enseñanza en España en pie de igualdad con las otras disciplinas y, en general, a llamar la atención de los grupos dirigentes sobre su importancia y utilidad. La obra de Sempilius fue bien conocida por los jesuitas profesores del Colégio de Santo Antáo de Portugal que la usaron para defender el carácter científico de las matemáticas y su utilidad, como lo ha documentado y explicado Bernardo Machado Mota. ${ }^{292}$

En este contexto y bajo estas condiciones, los matemáticos jesuitas del Colegio Imperial se esforzaron por asimilar las novedades en estas disciplinas, como el magnetismo de Gilbert, los descubrimientos astronómicos de Galileo, los trabajos de Scheiner, Galileo y otros autores sobre las manchas solares o los progresos en la óptica y en la mecánica; novedades que incorporaron en sus enseñanzas. Asimismo, asumieron las criticas realizadas por Galileo y otros autores a algunos de los supuestos básicos de la cosmología aristotélica, como las dirigidas contra la incorruptibilidad de los cielos, la doctrina de las esferas celestes, o las ideas sobre la naturaleza de la luna y los planetas. En cuanto al «sistema del mundo», en general se acogían al propuesto por Tycho Brahe y consideraban inadmisible el de Copérnico, de acuerdo con la condena de la Inquisición romana, aunque admisible como hipótesis, en el sentido de supuesto o ficción matemática. O bien no se decidían por ninguno de los dos, afirmando que con los dos se «salvan todos los fenómenos». Esta era la postura del matemático de Amberes Jean Charles della Faille. En uno de los manuscritos conservados de este autor, dedicado a las teorías o modelos de los planetas, Della Faille describe la teoría heliocéntrica y dice que es una «resolución escandalosa para los filósofos que se espantan por poco por su ignorancia de las matemáticas». En las teorías planetarias Della Faille explicaba los distintos modelos heliocéntricos y geocéntricos. ${ }^{293}$

La alusión de Della Faille a los filósofos es expresiva de la manera diferente como los filósofos y los matemáticos afrontaban el impacto de las novedades. Sin que se pueda descalificar en este sentido y globalmente a todos los filósofos, autores de numerosos tratados de lógica, filosofía moral, filosofía natural y metafísica destinados a la enseñanza en las universidades o en las órdenes religiosas, por su ignorancia o rechazo de las nuevas corrientes filosóficas o científicas, el examen de un buen número de estas obras muestra que así fue, salvo algunas pocas excepciones de autores que se mostraron algo

292 Véase B. M. Mota, «O estatuto de matemática em Portugal nos séculos XVI e XVII», tesis doctoral, Universidade de Lisboa, 2008.

293 Véase el manuscrtio de Della Faille, conservado en la Academia de la Historia, Colección Cortes, Ms.9/2751: Tratado de las Theóricas de los Planetas según las dos hipótesis movièndose y estando quieta la Tierra. 
permeables a dichas novedades. ${ }^{294}$ En todo caso, lo que es indiscutible es que las novedades científicas, y en filosofía natural, tanto en lo que se refiere a las teorías y conceptos, como en lo que atañe a las prácticas experimentales, técnicas de observación y uso de instrumentos, fueron introducidas en el contexto de las llamadas matemáticas mixtas convertidas progresivamente en físico-matemáticas. ${ }^{295}$ En este sentido, cobraron una gran importancia los compendios y cursos de matemáticas que se publicaron en la Europa católica, siendo estos compendios uno de los vehículos más adecuados para difundir las novedades físico-matemáticas evitando la confrontación con la filosofía escolástica. Entre estas obras, hay que mencionar la Mathesis biceps vetus et nova del autor madrileño Juan Caramuel y Lobkowitz, publicada en Campania en 1670 en dos gruesos volúmenes en folio, que tuvo una gran difusión en España. En su Mathesis, Caramuel incorporó tanto los resultados de sus estudios sobre las disciplinas matemáticas (con algunas contribuciones originales), como la correspondencia y los debates en los que participó, así como numerosas observaciones astronómicas o experimentos propios o ajenos. ${ }^{296}$ No obstante, el «Curso» de matemáticas (Cursus seu mundus mathematicus) que tuvo mayor difusión e influencia en este país fue el de Claude François Milliet Dechales, publicado en 1674 en tres volúmenes (2a ed., 1690). Calificado por el historiador italiano Antonio Nardi de «galileano eccentrico", este Cursus de Milliet Dechales señala un formidable esfuerzo por integrar en las matemáticas «puras» $\mathrm{y}$ «mixtas» o «físico-matemáticas» los saberes clásicos y las novedades en estas materias. ${ }^{297}$

294 Véase el capítulo XVI de Navarro Brootons, Disciplinas..., op. cit. Y aquí también el estudio comparado entre Portugal y España resulta muy adecuado: de las lecturas de los trabajos de los historiadores portugueses parece deducirse que los filósofos jesuitas en Portugal fueron más permeables y dialogaron más con los matemáticos que los españoles. Véase L. M. Carolino y H. Leitão, "Natural Philosophy and Mathematics in Portuguese Universities, 1550-1650", en Feingold y Navarro (eds.), Universities and Science in the Early Modern Period, pp. 153-169; L. M. Carolino, Ciência, astrologia e sociedade. A teoria da influência celeste em Portugal (1593-1755), Lisboa, Fundação Calouste Gulbenkian, 2003.

295 Véase, sobre esto, P. Dear, Discipline and Experience. The Mathematical way in the Scientific Revolution, Chicago, University of Chicago Press, 1995.

296 Sobre Caramuel, véanse los capítulos XV y XVI de Navarro Brotons, Disciplinas..., op. cit., y la bibliografía citada en estos trabajos.

297 Sobre el Cursus de Milliet Dechales, véase M. Cantor (1880-1908), Vorlesungen über Geschichte der Mathematik, 2a ed., 4 vols., Leipzig, B. G.Teubner, 1880-1908, vol. III, 1901, pp. 3-6 y 15-19; A. Nardi, «Un galileiano eccentrico. Il gesuita François Milliet Dechales tra Galileo e Newton", Archives Internationales d'Histoire des Sciences, 49 (1999), pp. 32-74. Sobre el Cursus y su difusión, asimilación y apropiación en España, véase V. Navarro Brotóns, Tradició i canvi científic al País Valencià modern (1660-1720): Les 
Contemporáneamente a Milliet Dechales, el jesuita valenciano Jose de Zaragoza planeaba la elaboración de un Curso de matemáticas similar al del jesuita francés, que no llegó a concluir aunque publicó varios volúmenes de estas disciplinas, principalmente de aritmética, álgebra, geometría, trigonometría y logaritmos, editadas en Mallorca, Valencia y Madrid, además de un tratado de astronomía y geografía y un libro sobre instrumentos matemáticos que acompańaba una caja de estos instrumentos construidos por Zaragoza y sus colaboradores. Además dejó una serie de manuscritos producto de sus investigaciones o de sus clases. En matemáticas puras, su obra más importante y original es la Geometria magna in minimis, en la que valiéndose del concepto de centro mínimo de un sistema de puntos construyó una teoría isomorfa a la de la estática de un sistema de cuerpos aislados. Con estas técnicas matemáticas Zaragoza pudo demostrar varios teoremas y establecer relaciones matemáticas que serían redescubiertas después por autores como Ceva o Euler. Zaragoza en la década de los años 70 fue el encargado de la enseńanza de las matemáticas en el Colegio Imperial, además de asumir las funciones del cosmógrafo mayor del Consejo de Indias. Es el mejor matemático español del siglo xvir junto con Caramuel y Hugo de Omerique y su influencia fue de la mayor importancia para la renovación científica valenciana y española de las últimas décadas del siglo Xvir. Antes de trasladarse a Madrid, Zaragoza residió en Mallorca, Barcelona y Valencia. En Mallorca entró en relación con Vicente Mut, el mejor astrónomo de la España del siglo xviı, corresponsal de Kircher y Riccioli, siendo uno de los autores más citados por Riccioli en sus obras de astronomía y geografia. En Valencia, Zaragoza residió más de un decenio, enseñando oficialmente teología y dedicándose privadamente a la investigación y la enseńanza de las disciplinas matemáticas. En Madrid, dio un notable impulso a la enseńanza de las disciplinas matemáticas, además de ocuparse de múltiples cuestiones como Cosmógrafo mayor. ${ }^{298}$

ciències Físico-Matemàtiques, Valencia, Tres i Quatre, 1985, pp. 124-135; V. Navarro Brotons, "Descartes y la introducción de la ciencia moderna en España», en La Filosofía de Descartes y la fundación del pensamiento moderno, Salamanca, Sociedad Castellano-Leonesa de Filosofía, 1997, pp. 225-253. V. Navarro Brotons, «El moviment "novator” de les ciències físico-matemàtiques», en J. Vernet, y R. Parés (dirs.), La ciència en la història dels països catalans, vol. 2: Del naixement de la ciència moderna a la Il-lustració, València-Barcelona, Universitat de València-Institut d'Estudis Catalans, 2007, pp. 381-413.

298 Un índice del Curso planeado por Zaragoza se encuentra en la Academia de la Historia, Colección Cortes, 9/2782. Sobre Zaragoza, véase V. Navarro Brotons, «La ciencia en la Espańa del siglo XVII...» (1996), reproducido en el capítulo XIV de Disciplinas..., op. cit.; V. Rosselló Botey, Tradició i canvi científic en l'astronomía espanyola del segle XVII, Valèn- 


\section{La circulación de los conocimientos y prácticas en el ámbito europeo.}

Otro de los temas que apenas puedo esbozar aquí, pero que considero de la mayor importancia, entre otras cosas para acabar de una vez para siempre con las afirmaciones de aislamiento de España en relación a Europa, o al menos relativizarlas y establecerlas en su justa medida, es el de la circulación de los conocimientos. Circulación, difusión, uso o apropiación de obras, objetos o instrumentos relacionados con actividades científico-técnicas por personalidades o practicantes de las disciplinas matemáticas o físico-matemáticas de diversos países, como España, los Países Bajos, Portugal e Italia. Relaciones de amistad, colaboración o de maestro-discípulo entre los practicantes de diversos países. Influencia de cualquier tipo de las obras o contribuciones de los practicantes de uno y otro país, en las dos direcciones. Circulación general del conocimiento a través de libros, objetos o instrumentos, comunicación oral, contacto personal o correspondencia. Habría que ańadir las relaciones de mecenazgo o de cliente-patrón entre los monarcas españoles o nobles/aristócratas y los practicantes de diversos países bajo el dominio español.

Por otra parte, a la hora de discutir el tema de España y la Revolución Científica, conviene delimitar bien qué se entiende por España en estos siglos. Una solución habitual es entender por tal el conjunto de reinos de la época que constituyen la actual España, lo que requiere muchas cautelas. Como señala Maravall, al hablar de la monarquía española hay que distinguir tres planos: cada reino peninsular, el conjunto de los reinos de tradición hispánica y el conglomerado imperial que había venido a constituirse bajo la Corona de España. Los tres niveles afectaron a la actividad científico-técnica: el proyecto imperial, la construcción del estado moderno y la diversidad de los reinos peninsulares, con su propia organización socio-política y sus propias tradiciones culturales.

cia, Universitat de València, 2000; V. Navarro Brotons, E. Recasens Gallart, «El cultiu de les disciplines físico-matemàtiques als anys centrals del segle XvII», en Vernet y Parés (dirs.), La ciencia en la història dels països catalans, 2007, pp. 337-381. E. Recasens Gallart, La Geometría magna in minimis de J. Zaragoza. El centre minim i el Lloc $5^{e}$ d'Appol.loni, tesis de doctorado, Barcelona, 1991; Id., "J. Zaragosa's "Centrum Minimum”, an Early Version of Barycentric Geometry", Archive for History of Exact Sciences, 46 (1994), pp. 285-320. Sobre V. Mut, véase V. Navarro Brotons, Vicenç Mut i Armengol (1614-1687) i l'Astronomia, Palma, Conselleria d'Innovació, Interior i Justícia (Govern de les Illes Balears), 2009: esta obra incluye la edición facsímil y traducción catalana anotada de las obras de astronomía de V. Mut, correspondencia con A. Kircher y estudios preliminares. 
Volviendo al tema de la circulación de conocimientos y relaciones científico-técnicas entre países, en el caso de España las relaciones más intensas fueron entre este país, Portugal, los Países Bajos e Italia, como era de esperar. En este sentido, se puede destacar el importante nivel de cooperación o relaciones, en las últimas décadas del siglo xvi, entre los científicos o practicantes de Espańa y los Países Bajos, sobre todo en el terreno de la botánica y la materia médica y en el de la cosmografía, la cartografía y la náutica. Y ello tuvo lugar en un contexto político e ideológico a priori adverso. Como ejemplos notables cabe señalar la relación que Benito Arias Montano mantuvo con Clusius, Ortelio y Plantin; y, en el caso de la cosmografía y la náutica, la enorme influencia en España del destacado médico y cosmógrafo de Lovaina Gemma Frisius, que contó entre sus discípulos en esta ciudad con los matemáticos españoles Jerónimo Muñoz y Juan de Rojas. También se puede citar la importante difusión en los Países Bajos de las obras españolas de náutica y el patrocinio, por parte de Felipe II, de diversas actividades cartográficas realizadas por practicantes de los Países Bajos, asi como la presencia de la cartografía española en el Theatrum de Ortelio, nombrado "geógrafo real» gracias a Arias Montano. Y no me resisto a citar lo que escribió Arias Montano en el Album amicorum de Ortelio: «Si Montano pudiera hacer por sus amigos todo lo que desea, y servirlos para un propósito preciso, créeme querido Ortelio, nadie estaría más colmado que tú y nadie sería más feliz que Montano». ${ }^{299}$

Como hemos seńalado, para los matemáticos jesuitas, la pertenencia a la orden les facilitó enormemente el contacto y la comunicación con los matemáticos jesuitas de otros países y, a través de ellos, con otros matemáticos europeos. Algunos destacados jesuitas, como Clavius, Kircher o Riccioli, son famosos por la extraordinaria red de corresponsales que establecieron con diferentes propósitos. Clavius, como principal protagonista de la formación de los científicos de la Compañía en las disciplinas matemáticas que divulgaron sus obras casi a escala planetaria. Kircher, entre otros diversos motivos, por su gran plan para reformar el conocimiento geográfico utilizando los datos proporcionados por los jesuitas repartidos por todo el mundo; plan que quedó inacabado pero que Riccioli llevó a cabo, al menos

299 La cita en A. Ortelius, Album amicorum, Cambridge, Prembroke College (editado por J. Puraye, Amsterdam, A. L.van Gendt and Co., 1969). Sobre las relaciones con los Países Bajos, véase J. M. López Piñero y Navarro Brotons, «Las relaciones científicas entre los Países Bajos y España durante el Renacimiento», en Los instrumentos cientificos del siglo XVI. La corte española y la escuela de Lovaina, Madrid, Fundación Carlos de Amberes, 1998, pp. 13-27; y el capítulo XII de Navarro Brotons, Disciplinas..., op. cit. 
en parte, publicando una Geographia reformata. Varios matemáticos españoles, jesuitas o no, mantuvieron correspondencia con estos autores: algunos matemáticos de la Academia de Matemáticas, de Herrera, y profesores de las Universidades de Salamanaca y Alcalá mantuvieron correspondecia con Clavius sobre cuestiones de matemáticas y de la reforma del calendario; Della Faille mantuvo correspondencia con Kircher y con el astrónomo jesuita Niccolò Zucchi; Zaragoza, con Kircher y otros matemáticos jesuitas, como Gottingies, profesor del Colegio Romano. Caramuel mantuvo una intensa correspondencia con Kircher (y otros muchísmos autores, jesuitas o no). Vicente Mut mantuvo correspondencia científica con Kircher y sobre todo con Riccioli, al que le facilitaba regularmente sus observaciones de eclipses y planetas (que Riccioli incorporaba en sus obras) y con el que discutía las técnicas de observación astronómica. ${ }^{300}$

Della Faille fue el principal valedor en Madrid del cosmógrafo, ingeniero y astrónomo belga Michael Floren van Langren, autor del primer mapa publicado de la luna, que aspiraba a resolver el problema de la longitud geográfica, precisamente usando la luna para determinar el tiempo. Además de sus observaciones de la luna, realizó observaciones de eclipses de luna y de sol, del diámetro del sol, de planetas, estrellas y cometas, algunas de ellas en Madrid. Aunque quedaron en su mayoría inéditas, fueron difundidas en las obras de Wendelen (otro destacado astrónomo belga), Caramuel y Riccioli. Van Langren fue nombrado en 1629 cosmógrafo y matemático del rey en Flandes.

La astronomía fue uno de los temas en el que la circulación del conocimiento fue más intensa, formándose importantes redes de relaciones y correspondencia en toda Europa. Autores como Gassendi, Riccioli, Boulliau o Kircher fueron importantes nudos de esas redes de comunicación. Wendeln, Hevelius, Boulliau o Caramuel escribieron numerosas cartas a Gassendi para informarle de sus observaciones y trabajos. Pero seguramente

300 Véanse referencias a esta correspondencia y relaciones en Navarro Brotons Disciplinas..., op. cit. La correspondencia de Clavius en C. Clavius, Corrispondenza di Cristoph Clavius, ed. Ugo Balidini y Pier Daniele Napolitani, 7 tomos en 14 fascículos, Pisa, Quaderni del Dipartimento di Matematica dell'Universitá di Pisa, 1992. Sobre Kircher, entre la abundante bibliografía, véase J. Fletcher, Athanasius Kircher und seine Beziehungen zum gelehrten Europa seine Zeit, Wiesbaden, Harrassowitz, 1988, que incluye una relación de su correspondencia. Véase también P. Findlen (ed.), Athanasius Kircher. The last man who knew everything, New York, Routledge, 2004. Sobre la correspondencia de Della Faille, además de la citada anteriormente, véase U. Baldini, "Una lettera inedite del Torricelli ed altre dei gesuiti R. Prodamelli, J. C. della Faille, A. Tacquet, P. Bourdin e F. M. Grimaldi», Annali dell'Istituto e Museo di Storia della Scuienza di Firenze, 5 (1980), pp. 15-37. 
el autor que acumuló más información sobre astronomía y geografía, gracias sobre todo a la correspondencia, fue Riccioli. Riccioli, además, muestra en su obra un excelente conocimiento de la tradición cosmográfica portuguesa y española del Renacimiento. ${ }^{301}$

\section{La renovación científica y filosófica de finales del siglo XVII y del siglo XVIII}

En las últimas décadas del siglo xvir el proceso de renovación científica y filosófica, correspondiente a la insatisfacción con los saberes tradicionales y sus supuestos, se fue delineando con unos perfiles más claros entre algunos grupos de médicos, cirujanos y matemáticos y se fue constituyendo lo que podríamos llamar un cierto consenso, explícito o no, entre ellos, acerca de la necesidad de establecer un programa de asimilación de las nuevas corrientes filosóficas y científicas. Valencia, Zaragoza, Madrid, Barcelona y algunas otras ciudades españolas fueron escenarios de la actuación de los llamados «novatores» de finales de la centuria y primeros años del siglo Xviır. En Madrid, como nos informa uno de los protagonistas de la renovación en medicina, Diego Mateo Zapata, desde 1687, cuando llegó a la corte, «había en ella las públicas y célebres tertulias que ilustraban y adornaban los hombres de más dignidad, representación y letras que se conocían, como era el excelentísimo marqués de Mondéjar, el señor don Juan Lucas Cortés, del Consejo Real de Castilla, el señor don Nicolás Antonio...; los cuales como de todas las ciencias trataban de la filosofía moderna». ${ }^{302}$ Este mismo año publicó en Madrid el valenciano Juan de Cabriada su Carta filosófica, médico-chymica, considerada por López Piñero auténtico manifiesto de la renovación en el ámbito de la medicina y de los saberes biológicos y químicos

301 Véanse, sobre la correspondencia y relaciones de Della Faille y Caramuel, los capítulos XIV y XV de Disciplinas..., op. cit., y la bibliografía citada en estos capítulos. Sobre Mut, véase también la obra citada en la nota 40, Navarro Brotons, Vicenç Mut i Armengol (1614-1687) i l'Astronomia. Sobre Riccioli; véase tambén M. T. Borgato (ed.), Giambattista Riccioli e il merito scientifico dei gesuiti nell'età barocca, Firenze, Olschki, 2002.

302 Diego Mateo Zapata, "Censura...», p. 18, en Alexandro de Avendaño, Diálogos philosóphicos en defensa del atomismo, Madrid, 1716. Véase J. M. López Piñero, «Los comienzos de la medicina y la ciencia modernas en Espańa en el último tercio del siglo XVII", en Actas del Segundo Congreso Español de Historia de la Medicina, Salamanca, 1965, pp. 271-293; Id., La introducción de la ciencia moderna en España, Barcelona, Ariel, 1969. Sobre Zapata, véase J. Pardo Tomás, El médico en la palestra. Diego Mateo Zapata (1664-1745) y la ciencia moderna en España, Valladolid, Junta de Castilla y León, 2004. 
con ella relacionados. ${ }^{303}$ Cabriada denunciaba en la Carta, con valentía, la situación de atraso científico que vivía el país. Además, proponía, entre otros remedios, la creación de la Academia de Ciencias, análoga a la de París. En Sevilla, el movimiento renovador culminó con la creación, en 1700, de la Regia Sociedad de Medicina y demás Ciencias, primera de las instituciones científicas españolas consagradas al cultivo de los nuevos conocimientos. Entre los socios fundadores figuraban Zapata y Juan de Cabriada. También en Sevilla funcionaba desde 1681 el Colegio de San Telmo, que tuvo una cierta importancia en la renovación de los estudios de náutica. En Zaragoza, el médico italiano Juan Bautista Juanini, afincado en España desde 1667, al entrar al servicio de Juan de Austria, contribuyó decisivamente a la difusión de las ideas modernas entre algunos médicos de esta ciudad.

Uno de los núcleos más activos en relación con la renovación científica española estuvo localizado en Valencia, gracias en gran medida a la actividad desarrollada en esta ciudad por el matemático jesuita José de Zaragozá. El grupo valenciano llevó a cabo su labor principalmente en el marco de tertulias y academias. Una de dichas tertulias, constituida en 1687 como Academia de Matemáticas, tomó como modelo explícitamente las academias y sociedades científicas europeas (las «academias de las naciones» decía uno de sus protagonistas). Los académicos celebraban «congresos» en los que discutían «de casi todo género de ciencias», pero principalmente de las físico-matemáticas.

No obstante, el grupo valenciano también se esforzó por renovar la enseñanza universitaria. Uno de los miembros más destacados del grupo, Juan Bautista Corachán, obtuvo la cátedra de matemáticas en 1696. Corachán elaboró un amplio plan de reforma de la enseñaza en las cátedras de matemáticas y astronomía, en el que insistió en que las materias deberían exponerse «demostradas o probadas con razones naturales y experiencias, con el recurso de instrumentos.»

La labor de los «novatores valencianos» puede considerarse, en cierto modo, continuación de la llevada acabo por autores como José de Zaragoza. De hecho, los novatores estudiaron con mucha atención las obras de los matemáticos jesuitas y pusieron especial cuidado por asumir e integrar las contribuciones de los matemáticos españoles de los siglos XVI y XVII. Pero, además, ampliaron sus intereses a todos los aspectos de las disciplinas

303 Véanse las obras citadas de López Piñero en la nota anterior y J. M. López Piñero, "Juan de Cabriada y el movimiento «novator» de finales del siglo XviI. Reconsideración después de treinta años», Asclepio, 45 (1993), pp. 3-53. 
físico-matemáticas, y mostraron una conciencia mas clara del alcance y significado de la nueva ciencia. ${ }^{304}$

La contribución de los novatores valencianos a la renovación científica española culminó con la publicación de un Compendio mathematico en nueve volúmenes (1707-1715), obra del oratoriano Thomas Vicente Tosca, con la colaboración de sus compañeros de Academia, escrito en castellano e inspirado en obras como la de Caramuel y, sobre todo, en el Cursus de Milliet Dechales. Como el Cursus de Milliet Dechales, Tosca recorre las disciplinas matemáticas «puras» $\mathrm{y}$ »mixtas», y sus aplicaciones a lo largo de veintiocho tratados. En la introducción a la estática, calificada por Tosca como «ciencia Physico-Matemática, que averigua la proporción de los movimientos y el peso de los cuerpos graves», leemos: «En este tratado se echa de ver con gran claridad cuanto necesite la Filosofía Natural de que la ilustre la Matemática con sus luces». Seguidamente, el matemático valenciano expone todo lo relativo al movimiento de los cuerpos graves en caída libre, por planos inclinados, el movimiento de los péndulos, la estática arquimediana y los centros de gravedad. Además, en el tratado de artillería, Tosca expone el tiro de proyectiles de acuerdo con Galileo y Torricelli, apoyándose en la obra del tratadista francés François Blondel L'art de jetter les bombes. El Compendio incluye tratados de hidrostática, hidrotecnia e hidrometría, temas a los que los autores valencianos prestaron gran atención, interesándose de forma especial por la obra de Domenico Guglielmini The aquarum fluentium mensura. También estudia ampliamente la óptica y por supuesto los nuevos instrumentos: el microsopio y el telescopio. El tratado de astronomía, en el que expone ideas atomistas o corpuscularistas inspiradas en Gassendi y Descartes, supera con mucho a todos los textos anteriores editados en Espańa, constituyendo un buen manual del saber astronómico anterior a Newton. El Compendio de Tosca tuvo una gran difusión en todo el ámbito hispánico y también fue estudiado con mucho interés en Portugal.

Junto a la renovación de las disciplinas físico-matemáticas, Tosca abordó también el problema más arduo y complejo de renovar el discurso filosófico

304 Me he ocupado del grupo de novatores valencianos en las disciplinas físico-matemáticas y en la filosofia en varios trabajos: entre otros, en mi tesis de doctorado, Navarro Brotons, La revolución cientifica en España. Tradición y renovación en las ciencias físico-matemáticas, Valencia, tesis doctoral, Universitad de Valencia, 1978; en el libro Tradició $i$ canvi cientific..., op. cit.; en Navarro Brotons, "El moviment "novator" de les ciències físico-matemàtiques», en J. Vernet, y R. Parés (dirs.), La ciència en la història dels països catalans, vol. 2: Del naixement de la ciència moderna a la Il-lustració, València-Barcelona, Universitat de València-Institut d'Estudis Catalans, 2007, pp. 381-413; y en el capítulo XVIII de Disciplinas..., op. cit., en el que se citan bibliografía pertinente y fuentes. 
desde la perspectiva de las nuevas corrientes filosófico-científicas, publicando un Compendium philosophicum en latín. Sin poder detenerme a describir esta obra, indicaré que podemos inscribirla dentro del proceso de renovación progresiva de la enseñanza de la filosofía iniciado en el siglo Xvıı en muchas universidades de Europa bajo la influencia del cartesianismo y de la física prenewtoniana. El Compendium de Tosca, al parecer, también tuvo difusión en Portugal, sobre todo por medio del conde de Ericeira. Los oratorianos de San Felipe Neri trataron de adoptarlo, por sugerencia del conde, como libro de texto en Lisboa.

La labor de los novatores sentó en muchos aspectos las bases del posterior desarrollo científico del siglo XviII, siglo en el que, contrariamente a las afirmación de Anthony Pagden, de que «España nunca experimentó una revolución científica o alguna cosa semejante que se pueda acomodar a una descripción de este tipo», podría decirse que «Espańa experimentó una "revolución científica" o una serie de cambios que pueden plausiblemente acomodarse a su descripción»: la mecánica newtoniana, la química de Stahl, Boerhaave y Lavoisier, la naciente ciencia de la electricidad, la botánica de Linneo, las diversas corrientes en fisiología y medicina, las nuevas tecnologías, incluida la máquina de vapor, la nueva instrumentación científica, las nuevas organizaciones científicas (sociedades y academias), la introducción de la ciencia en la esfera pública, el periodismo científico, y otros rasgos de lo que se considera la ciencia-técnica europea moderna se pueden reconocer en la España del siglo XVIII, además de la circulación de las nuevas corrientes filosóficas: el mecanicismo, el sensualismo de Locke y Condillac, las corrientes leibnizianas, las corrientes deístas, el hedonismo materialista, etc. ${ }^{305}$

Menéndez Pelayo supo reconocer el importante desarrollo científico que tuvo lugar en el siglo XviII en España y en sus escritos abundan referencias a

305 La afirmación de A. Pagden en "The Reception of the "New Philosophy" in Eighteenth-Century Spain», Journal of the Warburg and Courtauld Institutes, 52 (1988), pp. 125-140. Sobre la actividad científica en la España del siglo xvıII, la bibliografía es ya muy abundante y casi inabarcable. Véase la síntesis de A. Lafuente y J. L. Peset, "El conocimiento y el dominio de la naturaleza: la ciencia y la técnica», en José María Zamora (dir.), Historia de España (fundada por Menéndez Pidal), XXXI-1, Madrid, Espasa-Calpe, 1988, pp. 349394; M. Sellés, J. L.Peset y A. Lafuente (eds.), Carlos III y la ciencia de la Ilustración, Madrid, Alianza, 1988. Véanse también las obras más recientes: J. L. Peset Reig (dir.), Historia de la ciencia y de la técnica en la Corona de Castilla. Vol. IV: siglo XVIII, Valladolid, Junta de Castilla y León, 2002; J. Vernet, R. Parés (dirs.), La ciència en la història dels països catalans, vol.2: Del naixement de la ciència moderna a la Il.lustració, València-Barcelona, Universitat de ValènciaInstitut d'Estudis Catalans, 2007. Sobre la diffusion de las ideas científicas y filosóficas, puede consultarse F. Sánchez-Blanco Parody, Europa y el pensamiento español del siglo XVIII, Madrid, Alianza, 1991. 
los más destacados autores españoles de esta época, con la informacón de la que entonces podia disponer. No obstante, no dejó de subrallar el carácter «utilitario de nuestra restaturación científica», ya que esta restauración «no la iniciaron hombres de ciencia pura, sino oficiales de Artilleria y de Marina, médicos y farmacéuticos». Por otra parte, «cuando comenzaba a formarse una generación más propiamente científica, vino la nefanda invasión francesa a ahogarlo todo en germen y a hacernos perder casi todo el terreno que trabajosamente habíamos ido ganando en medio siglo». Sin poder compartir la atribución simplista, y muy condicionada ideológiamente, a la revolución francesa de la nueva crisis que afectó a la actividad científica española en el primer tercio del siglo XIX, no podemos sino reconocer los graves problemas de continuidad y consolidación que han afectado a nuestra historia científica («dislocada y fragmentaria» y «falta de contituidad en los esfuerzos», decía Menéndez Pelayo) para los que aún no tenemos explicaciones totalmente satisfactorias. No obstante, con el progreso de los estudios histórico-científicos descubrimos cada día que hubo más continuidad de la que en principio creíamos o podíamos sospechar.

\section{Tablas}

TABLA 1

Distribución por áreas de las dedicaciones de los cultivadores de la ciencia en España (1481-1600)

\begin{tabular}{lcc}
\hline Áreas científicas & Número de dedicaciones & Porcentajes \\
\hline Matemáticas & 67 & 9,67 \\
Cosmografía y astrología & 99 & 14,29 \\
Filosofía natural & 66 & 9,52 \\
Geografía & 56 & 8,08 \\
Arte de navegar & 65 & 9,38 \\
Beneficio de minerales & 25 & 3,61 \\
Ensayo de metales & 3 & 0,43 \\
Destilación y alquimia & 7 & 1,01 \\
Arquitectura e ingeniería & 25 & 3,61 \\
Arte militar & 26 & 3,75 \\
Historia natural & 44 & 6,35 \\
Medicina & 177 & 25,54 \\
Albeitería & 9 & 1,30 \\
Agricultura & 9 & 1,30 \\
Arte de la caballería & 9 & 1,30 \\
Caza & 6 & 0,87 \\
TotaL & 693 & \\
\hline
\end{tabular}


TABLA 2

Distribución por ocupaciones y profesiones de los cultivadores de la ciencia en España (1481-1600)

\begin{tabular}{lrc}
\hline Ocupaciones y profesiones & Número de biografias & Porcentajes \\
\hline Médicos y cirujanos & 188 & 32,87 \\
Boticarios & 12 & 2,10 \\
Albeitares & 6 & 1,05 \\
Ingenieros & 11 & 1,92 \\
Artilleros e ingenieros militares & 8 & 1,40 \\
Arquitectos y maestros de obras & 9 & 1,57 \\
Cosmógrafos & 21 & 3,67 \\
«Astrólogos» & 3 & 0,52 \\
«Maestros de hacer cartas» & 13 & 2,27 \\
Marinos & 32 & 5,59 \\
Mineros & 16 & 2,80 \\
Ensayadores & 2 & 0,35 \\
«Destiladores» & 1 & 0,17 \\
Orfebres & 1 & 0,17 \\
«Ullerers» & 1 & 0,17 \\
Sastres & 1 & 0,17 \\
Comerciantes & 1 & 0,17 \\
Libreros e impresores & 2 & 0,35 \\
Profesores universitarios de artes & 36 & 6,29 \\
Maestros de estudios de gramática & 3 & 0,52 \\
«Maestros de escribir y contar» & 5 & 0,87 \\
Preceptores privados & 7 & 1,22 \\
Militares & 23 & 4,02 \\
Funcionarios & 7 & 1,22 \\
Abogados & 14 & 2,45 \\
Clérigos seculares & 63 & 11,01 \\
Clérigos regulares & 44 & 7,69 \\
Nobles con título & 10 & 1,75 \\
No consta & 32 & 5,59 \\
Total & & \\
\hline & & \\
& 572 & \\
& &
\end{tabular}


TABLA 3

Áreas cultivadas por españoles con ocupaciones sin relación obligada con la ciencia (1481-1600)

\begin{tabular}{|c|c|c|c|c|c|c|c|}
\hline & $\begin{array}{l}\text { Militares } \\
\text { no técnicos }\end{array}$ & Funcionarios & Abogados & $\begin{array}{l}\text { Clero } \\
\text { secular }\end{array}$ & $\begin{array}{l}\text { Clero } \\
\text { regular }\end{array}$ & $\begin{array}{l}\text { Nobles } \\
\text { con título }\end{array}$ & $\begin{array}{c}\text { Total de } \\
\text { dedicaciones }\end{array}$ \\
\hline Matemáticas & 1 & 1 & 2 & 14 & 6 & 1 & 25 \\
\hline $\begin{array}{c}\text { Cosmografía y } \\
\text { astrología }\end{array}$ & 1 & 2 & 1 & 20 & 12 & 3 & 39 \\
\hline Filosofía natural & - & - & - & 18 & 15 & 1 & 34 \\
\hline Geografía & 4 & 1 & 3 & 5 & 4 & 2 & 19 \\
\hline Arte de navegar & 1 & - & 4 & 1 & 1 & - & 7 \\
\hline $\begin{array}{c}\text { Beneficio de } \\
\text { minerales }\end{array}$ & - & 1 & - & 3 & 2 & 1 & 7 \\
\hline Ensayo de metales & 1 & - & - & - & - & - & 1 \\
\hline $\begin{array}{l}\text { Destilación y } \\
\text { alquimia }\end{array}$ & - & - & - & - & 1 & - & 1 \\
\hline $\begin{array}{c}\text { Arquitectura e } \\
\text { ingeniería }\end{array}$ & 1 & - & - & 4 & 2 & - & 7 \\
\hline Arte militar & 11 & - & 2 & - & - & - & 13 \\
\hline Historia natural & 3 & 1 & 1 & 6 & 3 & 1 & 15 \\
\hline Medicina & - & - & - & 8 & 5 & 1 & 14 \\
\hline Albeitería & - & - & - & 1 & - & - & 1 \\
\hline Agricultura & - & - & 2 & 2 & - & - & 4 \\
\hline Arte de la caballería & 3 & 1 & - & - & - & 1 & 5 \\
\hline Caza & 1 & - & 1 & - & - & 4 & 6 \\
\hline TOTAL & 27 & 7 & 16 & 82 & 51 & 15 & 198 \\
\hline
\end{tabular}

TABLA 4

Distribución por ocupaciones y profesiones de los cultivadores de la astronomía en España (1481-1606)

\begin{tabular}{lcc}
\hline Ocupaciones y profesiones & Número de biografías & Porcentajes \\
\hline Médico & 25 & 22,7 \\
Profesor universitario & 20 & 18,2 \\
Cosmógrafo & 18 & 16,4 \\
Clérigo secular & 9 & 8,2 \\
Clérigo regular & 4 & 3,4 \\
Abogado & 4 & 3,4 \\
Funcionario & 4 & 3,4 \\
Noble & 4 & 3,4 \\
Piloto & 2 & 1,8 \\
Preceptor privado & 2 & 1,8 \\
Maestro de escribir y contar & 1 & 0,9 \\
No consta & 17 & 15,5 \\
TotaL & 110 & \\
\hline
\end{tabular}


TABLA 5

Profesión de los aritméticos españoles (1482-1600)

\begin{tabular}{lcc}
\hline & Ar. Universitaria & Ar. Práctica \\
\hline Maestros (22) & - & 17 \\
Profesores universitarios & 8 & 4 \\
Eclesiásticos & 4 & 4 \\
Nobles & - & 2 \\
Administración monarquía (23) & - & 1 \\
Calígrafos & - & 1 \\
Libreros & - & 1 \\
Desconocida & 3 & 8 \\
TotaL & 15 & 38 \\
\hline
\end{tabular}

TABLA 6

Tipos de ingenieros (España. Siglo XVI) según su formación

\begin{tabular}{lccccc}
\hline & $N^{o}$ totaly $\%$ & $\% E$. & $\% I$. & $\% A$. & $\%$ P.B. \\
\hline Ingenieros teóricos & $18(9,7 \%)$ & $77,8 \%$ & $22,2 \%$ & - & - \\
Ingenieros-arquitectos & $46(24,7 \%)$ & $84,8 \%$ & $10,8 \%$ & - & - \\
Ingenieros prácticos & $100(53,8 \%)$ & $69 \%$ & $15,0 \%$ & $9,0 \%$ & $6,0 \%$ \\
$\begin{array}{l}\text { Ingenieros ocasionales } \\
\quad \text { o inventores }\end{array}$ & $22(11,8 \%)$ & $68,2 \%$ & $22,8 \%$ & $4,5 \%$ & $4,5 \%$ \\
\hline
\end{tabular}

E.: españoles; I.: italianos; A.: alemanes; P.B.: Países Bajos.

TABLA 7

Especialidad de los ingenieros

\begin{tabular}{lrrrrrr}
\hline Especialidad & $N^{\circ}$ total & E. & I. & P.B. & A. & Otros \\
\hline Matemáticas, geometría & 18 & 16 & 1 & 1 & - & - \\
Topografía, nivelación & 21 & 16 & 1 & - & - & - \\
Ingenios y máquinas & 30 & 20 & 3 & 1 & 4 & 1 \\
Relojes y autómatas & 8 & 2 & 3 & 1 & 1 & 1 \\
Náutica & 6 & 5 & - & 1 & - & - \\
Hidráulica & 32 & 28 & 2 & 2 & - & - \\
Construcción y Obras Públicas & 45 & 36 & 7 & - & 1 & 1 \\
Fontanería & 25 & 22 & 1 & - & 1 & - \\
Carpintería & 6 & 1 & 1 & - & 4 & - \\
Arquitectura civil y religiosa & 29 & 27 & 2 & - & - & - \\
Arquitectura y fortificación & 13 & 1 & 12 & - & - & - \\
Artillería y máquinas militares & 7 & 4 & 2 & - & 1 & - \\
\hline
\end{tabular}

E.: españoles; I.: italianos; P.B.: Países Bajos; A.: alemanes. 
TABLA 8

Bibliographia physico-mathematica hispanica (1475-1600).

Distribución por décadas y materias

\begin{tabular}{lrrrrrrrrrrrrrr}
\hline & Antes & 1501 & 1511 & 1521 & 1531 & 1541 & 1551 & 1561 & 1571 & 1581 & 1591 & Sin & \\
Genérico & 1500 & 1510 & 1520 & 1530 & 1540 & 1550 & 1560 & 1570 & 1580 & 1590 & 1600 & año & Total \\
\hline Fil. nat. & 22 & 4 & 22 & 11 & 18 & 32 & 51 & 44 & 49 & 50 & 51 & & 354 \\
Astrono. & 45 & 18 & 26 & 12 & 8 & 22 & 19 & 9 & 22 & 21 & 17 & 218 \\
Aritmét. & 4 & 7 & 17 & 5 & 6 & 16 & 10 & 16 & 9 & 7 & 11 & 108 \\
Náutica & & & & 1 & 2 & 3 & 10 & 12 & 25 & 18 & 9 & 80 \\
Cosmogra. & 3 & & & & 13 & 11 & 15 & 2 & 4 & 5 & 2 & \\
Cómputo & 1 & & 1 & 2 & 1 & 4 & 12 & 8 & 7 & 8 & 2 & \\
Arte mil. & & & & & 2 & & 1 & 3 & & 16 & 21 & 46 \\
Astrolo. & 7 & 7 & 4 & 5 & 3 & 2 & & 1 & 4 & 2 & 9 & 43 \\
Matemát. & 2 & 2 & 2 & 1 & 2 & 1 & 5 & 2 & 2 & 3 & & 22 \\
Magia & 2 & 1 & & 2 & 3 & 4 & 2 & & 1 & 1 & 2 & 1 & 19 \\
Arquitec. & & & & 1 & 2 & 4 & 3 & 2 & 1 & 3 & 2 & & 18 \\
Metafís. & 11 & & 2 & 1 & & & & & & 1 & 3 & & 18 \\
Calendar. & & & 1 & 1 & & 2 & & & 4 & 3 & 4 & & 15 \\
Cosmolo. & & & & 2 & 1 & 7 & 1 & 1 & & 2 & 1 & & 15 \\
Enciclop. & & & & 1 & & 2 & 1 & 7 & 5 & & & & 16 \\
Geomet. & 1 & & 1 & 1 & & 1 & & 1 & 2 & 5 & 1 & & 13 \\
Total & 96 & 39 & 76 & 47 & 60 & 112 & 126 & 111 & 135 & 144 & 138 & 1 & 1.085 \\
\hline
\end{tabular}

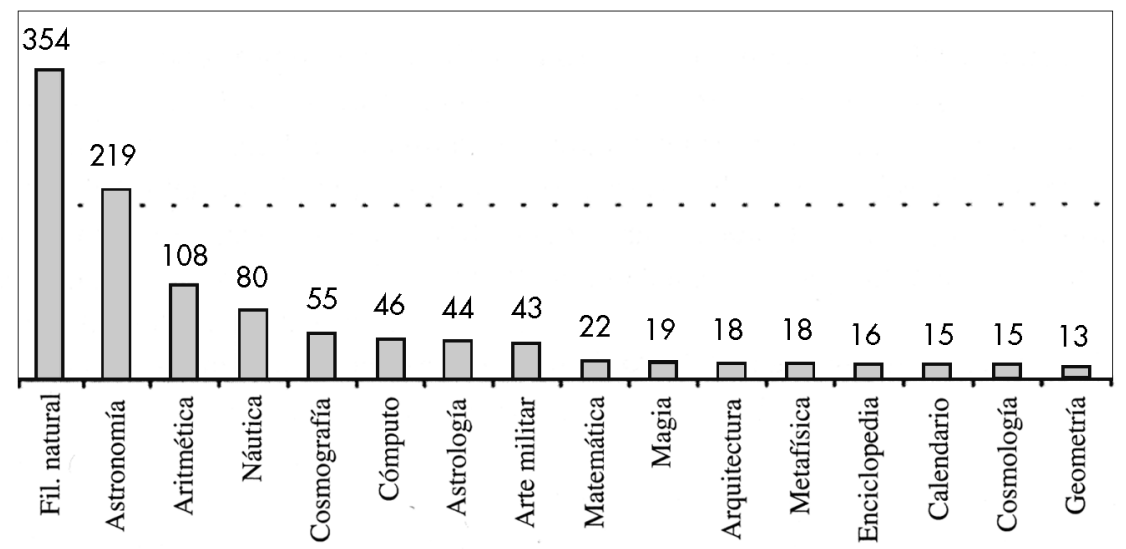


TABLA 9

Bibliographia physico-mathematica hispanica (1475-1600).

Distribución por décadas e idiomas

\begin{tabular}{|c|c|c|c|c|c|c|c|c|c|c|}
\hline Décadas & Lat. & Cast. & Fran. & Ital. & Catal. & Ingl. & Holan. & Alem. & Port. & Total \\
\hline Antes 1500 & 62 & 18 & & 13 & 3 & & & & & 96 \\
\hline $1501-1510$ & 23 & 10 & & 2 & 4 & & & & & 39 \\
\hline $1511-1520$ & 53 & 11 & 1 & 5 & 5 & & & & 1 & 76 \\
\hline $1521-1530$ & 29 & 14 & 3 & & 1 & & & & & 47 \\
\hline $1531-1540$ & 34 & 23 & 2 & & 1 & & & & & 60 \\
\hline $1541-1550$ & 32 & 72 & 2 & 4 & 2 & & & & & 112 \\
\hline $1551-1560$ & 55 & 43 & 14 & 13 & 1 & & & & & 126 \\
\hline $1561-1570$ & 23 & 55 & 16 & 14 & & 1 & & 1 & 1 & 111 \\
\hline $1571-1580$ & 43 & 50 & 26 & 4 & 1 & 10 & 1 & & & 135 \\
\hline $1581-1590$ & 49 & 68 & 13 & 7 & 2 & 3 & 1 & & 1 & 144 \\
\hline $1591-1600$ & 44 & 67 & 7 & 10 & 1 & 3 & 4 & 2 & & 138 \\
\hline $\sin$ año & & 1 & & & & & & & & 1 \\
\hline TOTAL & 447 & 434 & 84 & 72 & 21 & 17 & 6 & 3 & 3 & 1.085 \\
\hline
\end{tabular}

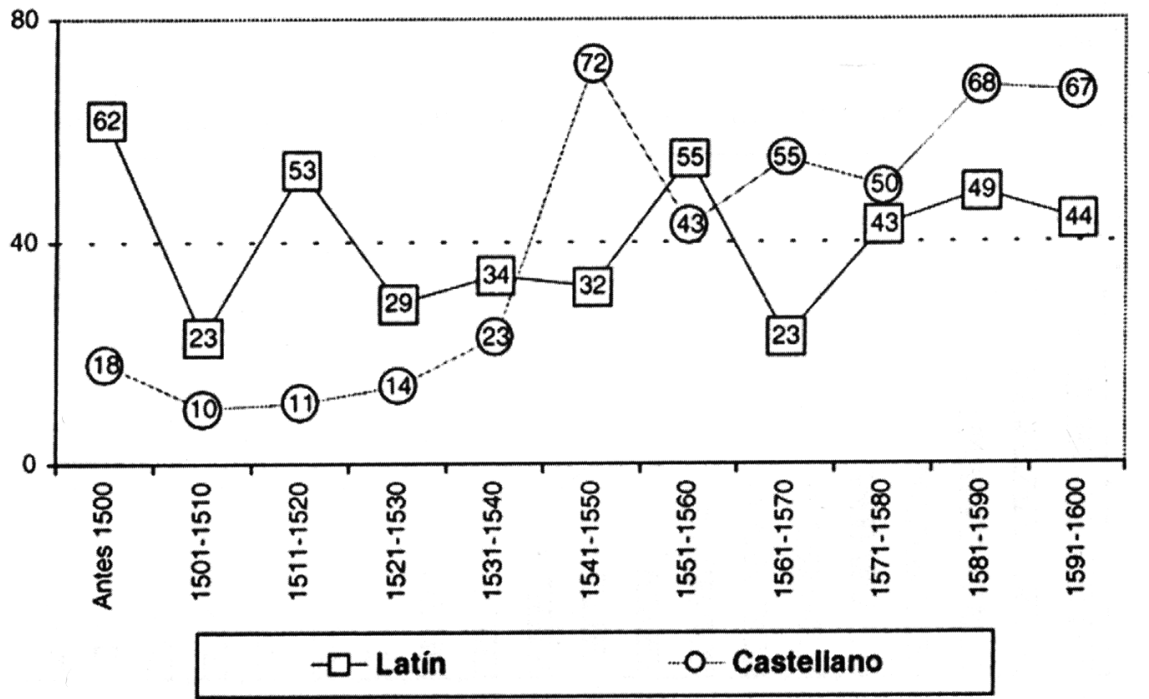




\section{TABLA 10}

Bibliographia physico-mathematica hispanica (1475-1600).

\section{Distribución por décadas y ciudades}

\begin{tabular}{|c|c|c|c|c|c|c|c|c|c|c|c|c|}
\hline Ciudades & $\begin{array}{l}\text { Antes } \\
1500\end{array}$ & $\begin{array}{l}1501 \\
1510\end{array}$ & $\begin{array}{l}1511 \\
1520\end{array}$ & $\begin{array}{l}1521 \\
1530\end{array}$ & $\begin{array}{l}1531 \\
1540\end{array}$ & $\begin{array}{l}1541 \\
1550\end{array}$ & $\begin{array}{l}1551 \\
1560\end{array}$ & $\begin{array}{l}1561 \\
1570\end{array}$ & $\begin{array}{l}1571 \\
1580\end{array}$ & $\begin{array}{l}1581 \\
1590\end{array}$ & $\begin{array}{l}1591 \\
1600\end{array}$ & Total \\
\hline París & 7 & 8 & 16 & 4 & 13 & 9 & 25 & 11 & 19 & 12 & 2 & 126 \\
\hline Salamanca & 10 & 6 & 4 & 1 & 8 & 16 & 15 & 20 & 14 & 10 & 5 & 109 \\
\hline Venecia & 14 & 6 & 7 & 4 & & 8 & 13 & 15 & 8 & 15 & 16 & 106 \\
\hline Sevilla & 1 & 1 & 3 & 4 & 6 & 16 & 7 & 10 & 12 & 18 & 5 & 83 \\
\hline Lyon & 8 & 1 & 9 & 4 & 4 & 3 & 14 & 5 & 9 & 12 & 10 & 79 \\
\hline \multicolumn{13}{|l|}{ Alcalá de } \\
\hline Henares & & & 4 & 11 & 4 & 4 & 5 & 12 & 9 & 8 & 4 & 61 \\
\hline Valencia & 2 & 3 & 5 & & 3 & 4 & 10 & 7 & 7 & 4 & 14 & 59 \\
\hline Zaragoza & 5 & & 5 & 2 & 5 & 11 & 4 & 6 & 4 & 8 & 5 & 55 \\
\hline Barcelona & 9 & 7 & 5 & & 1 & 1 & 1 & 6 & 4 & 2 & 6 & 42 \\
\hline Madrid & & & & & & & & 1 & 9 & 13 & 18 & 41 \\
\hline Roma & 17 & 4 & 9 & 2 & & & & & 2 & 2 & 3 & 39 \\
\hline Amberes & & & 2 & & 1 & 11 & 3 & 4 & 6 & 1 & 6 & 34 \\
\hline Toledo & 1 & 2 & 1 & 2 & 2 & 7 & 6 & 5 & 3 & 1 & 4 & 34 \\
\hline Londres & & & & & & & & 1 & 10 & 3 & 4 & 18 \\
\hline Burgos & 4 & 1 & 2 & 4 & 3 & & 2 & & & & 1 & 17 \\
\hline Colonia & & & & 1 & 2 & 3 & & & 3 & 1 & 7 & 17 \\
\hline Valladolid & & & & & 2 & 7 & 4 & 1 & 1 & 1 & & 16 \\
\hline Bruselas & & & & & & & & & & 8 & 5 & 13 \\
\hline \multicolumn{13}{|l|}{ Medina del } \\
\hline Campo & & & & & & 2 & 5 & 2 & & 1 & 1 & 13 \\
\hline TOTAL & & & & & & & & & & & & \\
\hline CIUDADES & 78 & 39 & 72 & 40 & 58 & 105 & 120 & 106 & 121 & 120 & 116 & 974 \\
\hline
\end{tabular}

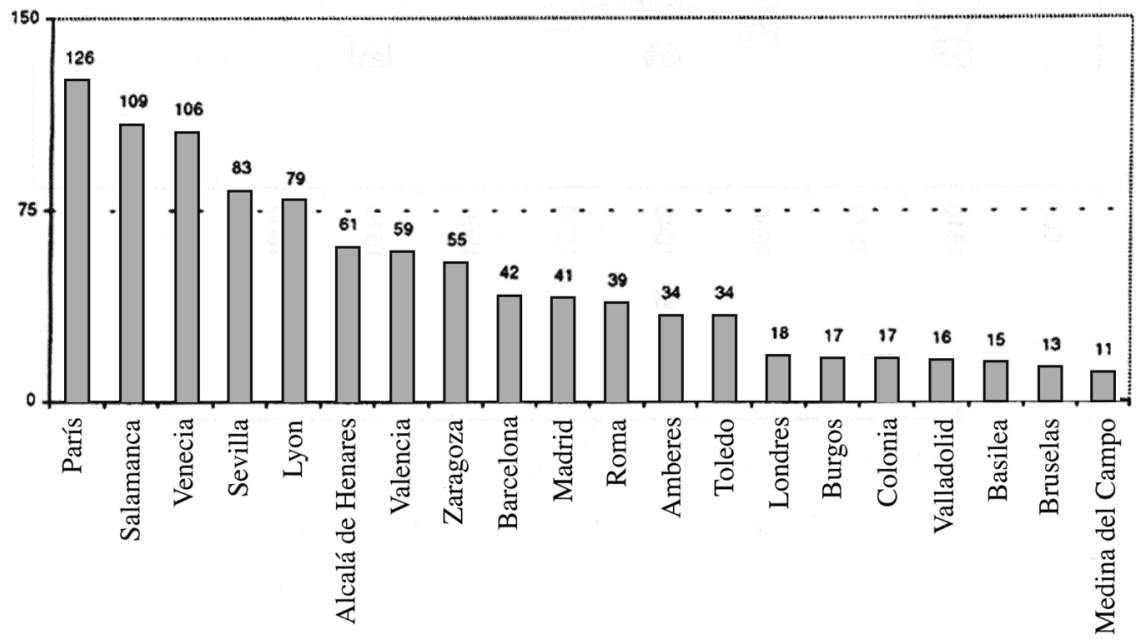





\section{Historia de las ediciones}

Dr. Gerardo Bolado

Universidad de Cantabria

Z $\mathrm{n}$ esta historia exponemos algunos pormenores de los textos que forman - parte de las tres ediciones originales de La ciencia española, sirviéndonos principalmente del epistolario de Menéndez Pelayo. Nos interesan sobre todo los detalles relativos a la autoría y a la fecha de composición de los textos.

\section{Primera edición}

La primera edición de la obra, Polémicas, indicaciones y proyectos sobre la ciencia española, que acabó de imprimirse en los últimos días de octubre de 1876 en la imprenta a cargo de Víctor Saiz, fue publicada por la casa editorial de Eduardo Medina, que era asimismo editora de la Revista Europea. Salió a la luz en un volumen de 292 páginas en octavo, más XXIX de prólogo, y una de erratas. En los primeros días de noviembre, llegó a la opinión pública esta primera edición que contenía el núcleo de la polémica de Menéndez Pelayo con los racionalistas.

Menéndez Pelayo compuso y revisó las pruebas de los escritos reunidos en esa primera edición, que ya habían visto la luz, por separado, en la Revista Europea, publicados entre el 30 de abril y el 29 de octubre de 1876. Las seis epístolas pelayanas incluidas en la primera edición fueron corregidas y enviadas al editor por Gumersindo Laverde, cuya correspondencia con el joven polemista entre el 7 de abril y el 16 de diciembre de 1876, en que ya se derivan correcciones a la segunda edición, nos permite reconstruir la génesis intelectual de la obra, 
así como identificar a sus principales protagonistas. Esta correspondencia pone de manifiesto, además, que los escritos de la polémica representan una ocupación circunstancial, colateral, dentro de la enorme actividad intelectual del joven Menéndez Pelayo, centrada entonces de manera especial en los trabajos bio-bibliográficos de su Biblioteca de traductores españoles, y de su Horacio en España, así como en la preparación bibliográfica y cronológica de dos grandes proyectos: de manera más inmediata de su Historia de los heterodoxos españoles, pero también de su Historia de las ideas estéticas en España.

En el anexo de la carta que envió al joven Menéndez Pelayo el 7 de abril de $1876,{ }^{306}$ Gumersindo Laverde recogía el conocido pasaje del cuarto artículo de «El selfgovernment y la monarquía doctrinaria», ${ }^{307}$ donde Azcárate cita a España como ejemplo de Estado que ahogó casi por completo la actividad científica, por impedir la libertad de pensamiento, y escribía a continuación: «No puede uno leer con calma afirmaciones tan desprovistas de fundamento, que contribuyen a generalizar creencias erróneas respecto a nuestro pasado científico y, por ende, a retraernos de su estudio como de cosa que o poco o casi nada vale...». ${ }^{308}$

Ese anexo invitaba a Menéndez Pelayo a escribir una réplica contra esa tesis de Azcárate, y le aleccionaba con indicaciones sobre el modo de componerla. No era la primera vez que Laverde incitaba a su joven amigo a polemizar con los herederos del krausismo; previamente, le había propuesto entrar en la polémica del panenteísmo, sin conseguir su adhesión. Menéndez Pelayo aceptó, en cambio, con gusto esta invitación a defender nuestra tradición científica cuestionada, ${ }^{309}$ pese a sus temores de no estar a la altura, porque el motivo patriótico y el tema histórico implicados, le atraían de manera irresistible.

El joven polemista envió a su mentor la réplica a Azcárate, la epístola "Indicaciones sobre la actividad intelectual de Espańa en los tres últimos siglos», adjunta a una carta fechada el 16 de abril en la que no se mostraba del todo satisfecho con su escrito: «... es harto ramplón y chapucero, sin gran novedad en noticias ni en ideas». ${ }^{310}$ Por eso autorizaba a Laverde a que lo retocara para su publicación: «En esto como en todo la voluntad de Ud. será norma». ${ }^{311}$ Laverde le respondió dos días después, comunicándole que

306 EMP, vol. 2, n.o 1.

307 Revista de España, tomo XLIX, n. ${ }^{\circ}$ 194, 28 de marzo 1876, pp. 145-166.

$308 E M P$, vol. 2, n. ${ }^{\circ}$ 1, anexo.

$309 E M P$, vol. 2, n. ${ }^{\circ} 3,11-4-1876$.

310 EMP, vol. 2 , n. ${ }^{\circ} 6$.

$311 \mathrm{Ib}$. 
valoraba muy positivamente «su refutación del peregrino aserto de Azcárate», y que procedía a enviársela ese mismo día, «ligeramente retocada», a los editores de la Revista Europea, Medina y Navarro, para su publicación. ${ }^{312}$ Laverde ya sabía que Medina se había quedado con la casa editorial Medina y Navarro, y así se lo había indicado a Menéndez Pelayo, ${ }^{313}$ pero no contaba con que se hubiera convertido en el único editor de aquella revista. El joven polemista, que se alegraba de esa publicación, expresó su deseo de corregir las pruebas. ${ }^{314}$

Menéndez Pelayo vio publicado su «artículo anti-azcaratesco» en la Revista Europea a primeros de mayo, ${ }^{315}$ cuando ya había empezado a elaborar su epístola "De re bibliographica», ${ }^{316}$ en la que ensayaba una caracterización de la labor bibliográfica y un inventario de las fuentes bibliográficas generales de la historiografía de la ciencia en España. Durante todo el mes de mayo trabajó en esta epístola bibliográfica que envió a Laverde el 1 de junio para su revisión y posterior envío a la Revista Europea. ${ }^{317}$ Sin embargo, un acontecimiento intelectual echó nueva leña al fuego de la polémica e interrumpió el trabajo bibliográfico del joven polemista.

El 21 de mayo, Gaspar Núñez de Arce pronunció su discurso de ingreso en la Real Academia Esapañola, "Causas de la precipitada decadencia y total ruina de la literatura nacional bajo los últimos reinados de la Casa de Austria», al que respondió en nombre de la corporación Juan Valera con el discurso, «Del influjo de la Inquisición y del fanatismo religioso en la decadencia de la literatura española». A propósito de aquél discurso, Laverde le había escrito un mes antes a Menéndez Pelayo, que se disponía a leer «algunas atrocidades». ${ }^{318}$

En una carta de 25 de mayo, Menéndez Pelayo le transmitió a Laverde una concisa, pero significativa, valoración de ambos discursos: «El primero parece escrito por el Abate Marchena y es una serie de inocentadas y vulgaridades indignas del talento de su autor; el segundo [de Valera] es cosa bien escrita y bien pensada, aunque harto escéptica y poco resuelta en las conclusiones». ${ }^{319}$ Menéndez Pelayo se congratulaba porque Valera le incluía en su discurso entre los defensores de la ciencia espańola, y adelantaba que esos discursos daban «materia para dos o tres cartas». ${ }^{320}$

312 EMP, vol. 2, n. ${ }^{\circ}$ 7, 18-4-1876.

313 EMP, vol. 2, n. ${ }^{\circ}$ 4: 14-4-1876.

314 EMP, vol. 2, n. ${ }^{\circ}$ 9: 22-4-1876.

315 tomo VII, n. ${ }^{\circ} 114,30$ abril 1876, pp. 330-339.

316 EMP, vol. 2, n. ${ }^{\circ} 14 ; 5-5-1876$.

317 EMP, vol. 2, n. ${ }^{\circ}$ 26: 25-5-1876.

318 EMP, vol. 2, n. ${ }^{\circ}$ 10: 24-4-1876.

319 EMP, vol. 2, n. ${ }^{\circ}$ 26: 25-5-1876.

$320 \mathrm{Ib}$. 
Sin embargo, la Revista Contemporánea publicó el 30 de mayo la «Reseña crítica» sobre el discurso de Núnez de Arce, escrita por Manuel de la Revilla, que atrajo sobre éste la atención del paladín de la ciencia espańola y dejó en un segundo plano su respuesta a Valera. En efecto, en la misma carta de 1 de junio que llevaba adjunta la epístola «De re bibliographica», Menéndez Pelayo le propone a Laverde la conveniencia de publicar antes una respuesta a la tesis formulada por Manuel de la Revilla, a la que se refiere en los siguientes términos: «... en la última Revista Contemporánea [«el bueno de Revilla»] dice que es un mito la filosofía española y unos soñadores los que en ella piensan, citándonos a Ud. y a mí nominatim. También dice que la historia de la filosofía puede escribirse sin hablar de Espańa, y llega a indicar que el Catolicismo ha sido la fuente de todos nuestros males, con otros absurdos y desatinos, todo ello a propósito del discurso de Valera, a quien ferozmente impugna». ${ }^{321} \mathrm{Me}-$ néndez Pelayo debió de componer la réplica contra Revilla en los primeros días de junio, pues confiesa haberla escrito «bajo la impresión del momento». ${ }^{322}$

En su respuesta, fechada el 5 de junio, Laverde le confirmaba que había enviado como segunda carta al editor su epístola "De re bibliographica», corregida ligeramente; además le insistía en la necesidad de refutar el escrito de Revilla, y le alecciona para ello con algunas indicaciones. ${ }^{323}$ Sin embargo, cuando recibió esa carta de Laverde, Menéndez Pelayo había compuesto ya, sin tomar en consideración esas indicaciones, su epístola de refutación a Revilla y se la había enviado a su mentor adjunta a su carta de 9 de junio. Laverde revisó ligeramente el escrito de Menéndez Pelayo, le puso el título de «Mr. Masson redivivo", y se lo envió como epístola tercera al editor Medina. A nuestro joven polemista le gustó el título dado por Laverde a su refutación del escrito de Revilla y tuvo ocasión de revisar las pruebas de ambas epístolas, que la Revista Europea publicó el 16 de julio, «De re bibliográfica», 324 y el 30 del mismo mes, «Mr. Masson redivivo». 225

La idea de reunir las epístolas de la polémica y publicarlas en un libro aparte, que «algo contribuiría a extender la afición a nuestra historia científica», se la propone Menéndez Pelayo a Laverde en una carta fechada el 21 de junio. ${ }^{326} \mathrm{Al}$ parecer Laverde le había hecho ya esta propuesta al editor Eduardo Medina, pero aún no había obtenido respuesta, y así se lo hizo

321 EMP, vol.2, n. ${ }^{\circ} 33,1-6-1876$.

322 EMP, vol.2, n. ${ }^{\circ} 35,9-6-1876$.

323 EMP, vol.2, n. ${ }^{\circ} 34,5-6-1876$.

324 Revista Europea, tomo VIII, n. ${ }^{\circ} 125$, pp. 65-73.

325 Revista Europea, tomo VIII, n. ${ }^{\circ} 127$, pp. 132-140.

326 EMP, vol. 2, n. ${ }^{\circ} 37$. 
saber a su joven amigo. ${ }^{327}$ Eduardo Medina mismo visitó a Menéndez Pelayo en Santander y le confirmó que sus epístolas polémicas se publicarían también reunidas en un volumen aparte con forma de libro; buena nueva que de inmediato le comunicó el joven polemista a su mentor en una carta fechada el 9 de julio: «Medina pasó por aquí y estuvo a verme. Me dijo que se haría tirada aparte de las cartas, según Ud. había indicado». ${ }^{328}$

La cuarta epístola de la polémica, "Monografías expositivo-críticas», que contiene una bibliografía de monografías y avanza un programa para desarrollar este tipo de estudios, se la envió Menéndez Pelayo a Laverde, adjunta a su carta de 11 de julio. ${ }^{329}$ En su respuesta del 20 de julio, ${ }^{330}$ Laverde le confirmó que había recibido esa cuarta epístola que consideraba un «trabajo en extremo erudito y curioso, en el cual solo he tenido que hacer unas cuantas adiciones»; sin embargo, según indica en su carta posterior de 28 de julio, terminó introduciendo «bastantes alteraciones de forma y adiciones de títulos... Algunas de las segundas no he hecho más que indicarlas para que las complete al corregir las pruebas». ${ }^{331}$ Menéndez Pelayo corrigió las pruebas de esta cuarta epístola que vio la luz el 27 de agosto en la Revista Europea, ${ }^{332}$ pero no pudo introducir en ella todas las adiciones de Laverde, ni algunas adiciones suyas posteriores.

Laverde dirigió la atención de Menéndez Pelayo hacia el prólogo que puso Salmerón a la edición española de la Historia de los conflictos entre la religión y la ciencia, de J. W. Draper, a fin de que compusiera una refutación del tenor de la que había escrito contra Revilla. ${ }^{333}$ Pero Menéndez Pelayo, que estaba escribiendo su quinta epístola, «Prosíguese el pensamiento de las cartas anteriores», consideró suficiente incluir de pasada en ésta la refutación de «las necedades de Salmerón», y así se lo hizo saber a Laverde en una carta de 24 de julio, en la que le pidió además que «escribiese una especie de prólogo a mis cartas, en forma epistolar también...». ${ }^{334}$ Menéndez Pelayo empezaba a tener claro entonces qué escritos formarían parte de la primera edición de La ciencia española; y se mantuvo en su concepción a pesar de la insistencia posterior de Laverde, proponiéndole introducir un epílogo de tema estético.

327 EMP, vol.2, n. ${ }^{\circ} 39$, 25-6-1876.

328 EMP, vol.2, n. ${ }^{\circ} 45$.

$329 E M P$, vol. 2, n. ${ }^{\circ} 46$.

330 EMP, vol. 2, n. ${ }^{\circ} 49$.

331 EMP, vol. 2, n. ${ }^{\circ} 51$.

332 Tomo VIII, n. ${ }^{\circ} 131$, pp. 262-272.

333 EMP, vol. 2, n. ${ }^{\circ} 49:$ 20-7-1876.

334 EMP, vol. 2, n. ${ }^{\circ}$ 50: 24-7-1876. 
Adjunta a su carta del 2 de agosto, ${ }^{335}$ Menéndez Pelayo le envió a Laverde la quinta epístola, "Prosíguese el pensamiento de las cartas anteriores», en la que continuaba desarrollando el programa laverdiano de regeneración de la ciencia española y respondía con dureza al prólogo de Nicolás Salmerón. Laverde revisó y valoró también positivamente esta quinta epístola, pero le advirtió repetidamente sobre la inconveniencia del ataque desmedido que encerraba contra quien había sido su profesor de Metafísica en la Universidad Central: «Algunos que en la Coruña leyeron sus epístolas, alababan su erudición; pero añadían: «jesos neos siempre mordaces!» ¿Qué dirán cuando lean la salmerónica?». ${ }^{336}$ Menéndez Pelayo, que en un principio era reticente a rebajar la dureza de su salmeroniana, pues pensaba que «... bien merecido lo tiene D. Nicolás», ${ }^{337}$ terminó por suavizarla ligeramente al corregir las pruebas. La epístola «Prosíguese el pensamiento de las cartas anteriores» fue publicada el 3 de septiembre por la Revista Europea. ${ }^{338}$

La respuesta de Manuel de la Revilla a la epístola «Mr. Masson redivivo» fue publicada el 15 de agosto por la Revista Contemporánea bajo el título «La filosofía española. Contestación a un artículo del Sr. Menéndez y Pelayo». ${ }^{339}$ El joven polemista, que esperaba hacía tiempo esa respuesta, envió a Laverde la epístola de réplica, adjunta a su carta de 22 de agosto. ${ }^{340}$ En su respuesta de 27 de agosto, Laverde le confirmó que había recibido la réplica a Revilla, "que es contundente y a la que pondré por título Mr. Masson redimuerto». ${ }^{341}$ Menéndez Pelayo asumió con gusto ese título y revisó las pruebas de esta sexta epístola que fue publicada por la Revista Europea el 24 de septiembre. ${ }^{342} \mathrm{El}$ quince de octubre Manuel de la Revilla confirmaba y explicaba las razones de su abandono de la polémica en su «Reseña crítica» de la Revista Contemporánea:

Y aquí ponemos fin a la presente revista, en la cual acaso echará de menos el lector la réplica a cierto artículo de un erudito de nuevo cuño, con quien hemos sostenido una polémica que no pensamos continuar, resueltos como estamos a no discutir con los que no saben ventilar con mesura y cortesía las cuestiones científicas, y a no contribuir inocentemente a que, a costa nuestra, se fabriquen reputaciones que distan mucho de ser legítimas. ${ }^{343}$

\footnotetext{
335 EMP, vol. 2, n. ${ }^{\circ} 52$.

$336 E M P$, vol. 2, n. ${ }^{\circ} 57,17-8-1876$.

337 EMP, vol. 2, n. ${ }^{\circ} 55.13-8-1876$.

338 Tomo VIII, n. ${ }^{\circ} 132$, pp. 294-301.

339 Tomo V, vol. 1, n. ${ }^{\circ} 17$, pp. 111-115.

$340 E M P$, vol. 2 , n. ${ }^{\circ} 61$

341 EMP, vol. 2, n. ${ }^{\circ} 62$.

342 Tomo VIII, n. ${ }^{\circ} 135$, pp. 392-403.

343 Tomo V, vol. 1, n. ${ }^{\circ} 21$, p. 114
} 
El joven polemista quiso incluir el texto de Revilla, «La filosofía española...», como apéndice en el volumen de sus Polémicas, y así se lo comunicó a su mentor; ${ }^{344} \sin$ embargo, Eduardo Medina rechazó esta iniciativa por razones editoriales.

Menéndez Pelayo concluyó su primitiva introducción a los Heterodoxos... en la segunda semana de julio, y así se lo hizo saber a Laverde en su carta de 11 de julio: «... llena quince pliegos de mi letra, y en ella va incluido el plan detallado de todos los capítulos...». ${ }^{345}$ En principio, pensó en publicarla por adelantado en alguna revista, y Laverde le propuso hacerlo en la Defensa de la Sociedad, cuyo director y propietario, el Sr. Perier, se la pagaría bien; sin embargo, Menéndez Pelayo prefería una publicación como la Revista Europea que era «de más circulación y leída por tirios y troyanos». ${ }^{346}$

Laverde deseaba por entonces poner a las seis epístolas pelayanas, a modo de epílogo, un ensayo suyo de tema estético, bien su introducción sobre el verso laverdaico, o su espécimen sobre la estética en España, y así se lo comunicó a Menéndez Pelayo; ${ }^{347}$ pero éste le respondió que prefería incluir como epílogo su propia introducción a los Heterodoxos, proponiéndole en cambio escribir una epístola a guisa de prólogo del libro. A Laverde le pareció una «excelente idea» incluir la primitiva introducción a los Heterodoxos... a continuación de las seis cartas polémicas, y aceptó con gusto la tarea de escribir la carta-prólogo. ${ }^{348}$ Pero Laverde no llegó a revisar esa introducción, indicándole en cambio a su joven amigo, con motivo de su viaje a Portugal vía Madrid: «La Introducción a los Heterodoxos debe ir a todo trance en el libro. Puede Ud. llevarla a Madrid y corregir allí las pruebas». ${ }^{349}$ En una carta del 4 de octubre, Menéndez Pelayo le adelantó a su mentor: «He corregido las pruebas de la introducción heterodoxa que da para tres números de la Revista. En la del domingo próximo empezará a publicarse». ${ }^{350}$

La primitiva introducción de los Heterodoxos... fue publicada en efecto por la Revista Europea, bajo el título «Noticia de algunos trabajos relativos a heterodoxos españoles, y plan de una obra crítico-bibliográfica sobre esta materia», en tres entregas dominicales, los días 8 de octubre, 15 de octubre y 22 de octubre. ${ }^{351}$

$344 E M P$, vol. 2, n. ${ }^{\circ}$ 61, 22-8-1876.

345 EMP, vol. 2, n. ${ }^{\circ} 46$.

$346 \mathrm{Ib}$.

347 EMP, vol. 2, n. ${ }^{\circ}$ 51, 28-7-1876.

$348 \mathrm{Ib}$.

349 EMP, vol. 2, n. ${ }^{\circ}$ 66, 4-9-1876.

350 EMP, vol. 2, n. ${ }^{\circ} 87$.

351 Tomo VIII, n. ${ }^{\circ} 137$, pp. 459-476; n. ${ }^{\circ} 138$, pp. 485-491; n. ${ }^{\circ} 139$, pp. 522-529. 
La composición de la carta-prólogo de Polémicas, indicaciones y proyectos... fue un tema recurrente en la correspondencia entre Menéndez Pelayo y Laverde desde que aquél le indicó a éste la conveniencia de que la compusiera, en su carta fechada el 24 de julio, ${ }^{352}$ hasta que llegó la confirmación final de su envío al editor, por parte de Laverde, en la suya de 24 de octubre: «Ayer corregí de priesa las pruebas de la carta-prólogo, y ya va en el correo....». ${ }^{353}$ Esta correspondencia pone de manifiesto que el verdadero autor de la carta-prólogo fue Menéndez Pelayo, ciertamente con las sugerencias, correcciones y añadidos de Laverde, y así lo demostró también Marcial Solana. ${ }^{354}$

Menéndez Pelayo empezó enviando un plan del prólogo a Laverde, quien no fue capaz de desarrollarlo, debido a su enfermedad, y terminó pidiendo a su joven amigo que lo escribiera él mismo. La primera versión de ese prólogo se la envió Menéndez Pelayo a Laverde adjunta a su carta de 30 de agosto, en la que le comentaba: «Medianeja ha salido. Suplícole que en lo posible la refunda y la dé un bańo de su manera y estilo, dejándola como nueva». Más adelante añade en la misma carta una petición que reiterará de continuo en el proceso de revisión del prólogo: «No deje Ud. de poner en el prólogo algún parrafito disculpándome y aun defendiéndome del cargo de dureza, acritud y mordacidad que me hacían esos señores gallegos. Como el ataque es descomedido, también ha de ser fuerte la defensa». 355

Laverde sometió esa primera versión de la carta-prólogo a una detenida corrección conjunta, con su joven amigo, durante todo el mes de septiembre. La exigencia de esta tarea afectó a su salud de tal manera que su esposa, Josefa Gayoso de Laverde, advirtió de ello al joven polemista en una carta de 30 de septiembre: «En fin Ud. obrará como lo crea más conveniente para conseguir lo que a todos nos interesa tanto, su salud». ${ }^{356}$ A comienzos de octubre Menéndez Pelayo se mostraba satisfecho con la última versión de la carta-prólogo, ${ }^{357}$ si bien le volvió a pedir un mayor compromiso con su acritud polémica en las últimas revisiones de pruebas: «Y a propósito del prólogo, quisiera que modificase Ud. un poco aquello de que ni aplaude ni

352 EMP, vol. 2, n.o 50.

353 EMP, vol.2, n. ${ }^{\circ} 95$.

354 Marcial Solana, «Colaboración de Laverde en La ciencia española de Menéndez y Pelayo». Boletín de la Biblioteca Menéndez Pelayo. Número extraordinario en Homenaje a don Miguel Artigas, Santander, Imprenta Librería y Encuadernación Viuda de F. Fons, 1931, pp. 51-98. Editado también como separata, Boletín de la Biblioteca Menéndez Pelayo. Santander, (1932), p. 54.

355 EMP, vol. 2, n. ${ }^{\circ} 63$.

356 EMP, vol. 2, n. 83.

357 EMP, vol. 2, n. ${ }^{\circ} 87:$ 4-10-1876. 
apadrina mis ataques contra Revilla y compañeros, para que no aparezca demasiada discordancia entre nosotros en ese punto». ${ }^{358}$ Laverde se comprometió a ello, ${ }^{359}$ y efectivamente lo hizo. La carta-prólogo fue publicada por la Revista Europea el 29 de octubre bajo el título «Prólogo de un libro sobre la filosofía española», y con la firma de Laverde. ${ }^{360}$

Desde finales de agosto, Menéndez Pelayo estaba dándole vueltas a la cuestión del título más conveniente para el libro que contendría sus seis epístolas polémicas y, tal vez, también la introducción a los Heterodoxos. En carta fechada el 30 de agosto, le pide a Laverde su opinión sobre el asunto del título: «¿Cómo titularemos el libro? Se me ha ocurrido el rótulo siguiente: «Indicaciones y Polémicas / sobre / la Ciencia Espańola. / Cartas de / D. M. M. P. \&. / con otra epístola-prólogo de / D. Gumersindo L. R. \&.». Si nos decidimos a poner la introducción heterodoxa, hay que añadir algo en el título a este propósito». ${ }^{361}$ Todavía tuvo que insistirle en otra carta del 9 de septiembre para que Laverde le diera su opinión: «Cuanto al título de la colección de cartas \&. paréceme que podría ponerse este: Polémicas y Proyectos / sobre / la actividad intelectual de España / en los pasados siglos / por / D. M. M. P. \&.; título que, bien mirado, comprende la introducción heterodoxa, que puede considerarse como otro proyecto. No creo que en la portada [deba] decirse nada de cartas, ni de que va al frente un prólogo mío: eso ya lo verá el lector». ${ }^{362}$ En una carta del 4 de octubre, Menéndez Pelayo le comunica de paso a Laverde el título que ya había decidido para el libro: «Veremos si en todo este mes queda corriente el libro de mis Polémicas, Indicaciones y Proyectos». ${ }^{363}$

Esta primera edición fue publicada finalmente con el título Polémicas, indicaciones y proyectos sobre la ciencia española, y debió de llegar a las manos de los primeros lectores a primeros de noviembre. Menéndez Pelayo le escribió a José María de Pereda desde Lisboa el dos de noviembre, «Ya debe estar corriendo el tomo de mis cartas». ${ }^{364} \mathrm{El}$ índice de la obra se componía de los siguientes elementos:

"Carta a guisa de prólogo», de Gumersindo Laverde.

1. ${ }^{\circ}$ "Indicaciones sobre la actividad intelectual de Espańa en los tres últimos siglos»

358 EMP, vol. 2, n. ${ }^{\circ} 88,7-10-1876$.

359 EMP, vol. 2, n. ${ }^{\circ}$ 91, 13-10-1876.

360 Tomo VIII, n. ${ }^{\circ} 140$, pp. 553-561.

361 EMP, vol. 2, n. ${ }^{\circ} 63$.

362 EMP, vol. 2, n. ${ }^{\circ} 75,15-9-1876$.

363 EMP, vol. 2, n. ${ }^{\circ} 87$.

364 EMP, vol. 2, n. ${ }^{\circ} 98$. 
$2 .{ }^{\circ}$ "De re bibliographica»

3. "Mr. Masson redivivo»

4. "Monografías expositivo-críticas»

$5 .^{\circ}$ "Prosíguese el pensamiento de las cartas anteriores»

$6 .^{\circ}$ «Mr. Masson redimuerto»

7. ${ }^{\circ}$ «Índice resumen de la Historia de los heterodoxos españoles»

8. ${ }^{\circ}$ Adenda a «De re bibliographica», y a «Monografías expositivo-críticas»

La adenda contenía datos bibliográficos que no habían sido incluidos en la corrección de pruebas de las epístolas «De re bibliográphica» y «Monografias expositivo-críticas», y que son añadidos a los capítulos homónimos de la obra, hechos por Menéndez Pelayo al pasar por Madrid: «Yo he repasado también y devuelto, hace días, las de unas páginas de adiciones y erratas que se me ocurrió poner al fin». ${ }^{365}$

El 5 de noviembre la Revista Europea publicó «Una carta sobre la filosofía española», 366 en la que Gumersindo de Azcárate respondía a Laverde, defendiendo que la tradición científica española se interrumpió en el siglo XVII. Laverde le comunicó a Menéndez Pelayo que había compuesto un escrito de réplica de la «benévola epístola» de Azcárate, el cual fue publicado el 3 de diciembre por la Revista Europea: ${ }^{367}$ "Está muy bien la addenda. En otra edición, si se hace, convendrá refundirla en el texto, y poner por apéndice la última carta de Azcárate y mi contestación, aunque esta vale poco. Dígame qué le parece». ${ }^{368}$ En la segunda edición de La ciencia española, efectivamente, Menéndez Pelayo incluyó como anexo esa réplica de Laverde; pero renunció a incluir la carta de Azcárate sobre la filosofía española, por razones que veremos enseguida.

\section{Segunda edición}

La ciencia española. Polémicas, indicaciones y proyectos es una segunda edición corregida y aumentada de la obra. Vio la luz el año 1879 en la «Imprenta Central a cargo de Víctor Saiz», según consta en la primera página. En la cubierta, se lee que fue editada por la Librería de Victoriano Suárez, indicándose en cambio como fecha de publicación, el año 1880. El editor fue Eduardo Medina.

365 EMP, vol. 2, n. ${ }^{\circ}$ 100: 4-11-1876.

366 Tomo VIII, n. ${ }^{\circ} 141$, pp. 592-594.

367 Tomo VIII, n. ${ }^{\circ} 145$, pp. 721-723.

368 EMP, vol. 2, n. ${ }^{\circ} 101,10-11-1876$. 
La correspondencia de Menéndez Pelayo con Laverde pone de manifiesto que esta segunda edición se imprimió entre la tercera semana de mayo $^{369}$ y la última semana de diciembre de $1879,{ }^{370}$ y que en la segunda o tercera semana de enero de 1880 ya estaba encuadernada y en manos de los primeros lectores. ${ }^{371}$ Se publicó en un único volumen de 470 páginas en cuarto, más XXXII de introducción. La obra salió con menos erratas que la primera edición, pero todavía abundantes.

Esta segunda edición lleva un nuevo título sugerido por Laverde en una carta del 29 de diciembre de 1878: «Celebro que estés resuelto a hacer la $2^{\text {a }}$ edición de La ciencia española (este título debe ir en primer lugar, y a continuación, entre paréntesis, Indicaciones, proyectos \&)». ${ }^{372}$ Además, dispone de una nueva estructura que le sugirió reiteradamente el mismo Laverde: ${ }^{373}$ introducción; dos partes, la primera dedicada a Gumersindo Laverde y la segunda, a Alejandro Pidal y Mon; y un apéndice.

La introducción se compone de la breve advertencia que puso Menéndez Pelayo a esta edición y de la carta a guisa de prólogo procedente de la primera edición, que experimentó algún cambio pedido por Laverde: «se escapó un Fernan en lugar de Fermin Caballero. Aunque él no lo merezca, yo suavizaría algunas expresiones fuertes, como impiedad \& que aplicaste a Revilla. Al cabo es hoy tu compańero, y el bien parecer lo pide». ${ }^{374}$

La primera parte contenía las seis epístolas polémicas de la primera edición, numeradas como en ésta, pero corregidas y aumentadas en diversa medida:

I. Indicaciones sobre la actividad intelectual de España en los tres últimos siglos;

II. De re bibliographica;

III. Mr. Masson redivivo;

IV. Monografías expositivo-críticas;

V. Prosíguese el pensamiento de las cartas anteriores;

VI. Mr. Masson redimuerto.

La segunda parte ańadía sin numerar los siguientes escritos, todos ellos nuevos:

369 EMP, vol. 3, n. ${ }^{\circ} 296,14-5-1879$.

370 EMP, vol. 4, n. ${ }^{\circ} 82,22-12-1879$.

371 EMP, vol. 4, n. ${ }^{\circ} 106,28-1-1880$.

372 EMP, vol. 3, n. ${ }^{\circ} 218$.

373 EMP, vol. 2, n.o 190, 23-6-1877; vol. 3, n.o 218.

374 EMP, vol. 3 n. ${ }^{\circ} 218,29-12-1878$. 
— «Dos artículos del señor Alejandro Pidal y Mon sobre las cartas anteriores».

— «In dubiis libertas»

— «La ciencia española bajo la Inquisición, por el señor José del Perojo (I, II y III)»

—La Antoniana Margarita de Gómez Pereira. Carta al señor Juan Valera»

— «La patria de Raimundo Sabunde»

La segunda parte incluía además un «Apéndice» con otros cuatro escritos nuevos:

—Contestación de D. Alejandro Pidal y Mon a la carta in dubiis libertas"

— «Instaurare omnia in Christo. Carta al Sr. D. Alejandro Pidal y Mon»

— «Contestación del Sr. D. Gumersindo Laverde a la última réplica del Sr. de Azcárate»

— «Nota final»

Los escritos nuevos que componen esta obra, tanto los textos nuevos, como las mejoras introducidos en los procedentes de la primera edición, resultaron colateralmente de la intensa actividad bibliográfica y cronológica, centrada en sus dos proyectos centrales de entonces, la Historia de los heterodoxos españoles, y la Historia de las ideas estéticas en España, sobre todo de aquella historia, pues entonces trabajaba en la redacción de su primer volumen y en la cronología del segundo.

Esta segunda edición que parece dirigirse más bien a lectores tradicionales católicos, completa el núcleo de la polémica con los racionalistas, es decir, con Gumersindo de Azcárate, y la amplía al neokantiano José del Perojo; además, contiene la primera parte de la polémica con el tradicionalismo tomista, la que mantiene con Alejandro Pidal y Mon. Por primera vez, incluye textos de carácter histórico-reivindicativo.

a) En efecto, la primera parte de esta segunda edición contiene los seis primeros capítulos de la primera, es decir, todos con la excepción del primitivo índice resumen de los Heterodoxos..., que fue sometido a una considerable revisión, especialmente con motivo de los nuevos hallazgos conseguidos en sus viajes de investigación bibliográfica por las bibliotecas históricas de España, Portugal, Francia, Italia, Bélgica y Holanda en los años 1876 y 1877, y en la que Gumersindo Laverde participó también muy activamente con datos y sugerencias a través de la correspondencia. El 15 de mayo de 1878, cuando tenía ya bastante perfilada la estructura de la segunda edición de la obra, Menéndez Pelayo le explica a Laverde, en los siguientes términos, por qué se proponía excluir el primitivo índice resumen de los Heterodoxos: "Quizá 
Navarro haga pronto la 2a ed. de las Polémicas Con mi réplica amistosa [a Pidal y Mon] se cerrará el tomo, a no ser que convenga meter también la Antoniana, en cuyo caso suprimiré la introducción heterodoxa, porque esta, muy ampliada, forma parte del primer tomo de la Historia. Con eso tendrá más unidad el libro». ${ }^{375}$ Laverde le confirmó enseguida en esa idea: «Desde luego la introducción heterodoxa deberá segregarse de las Polémicas y, en su lugar, ponerse la carta Gómez-pereiresca». ${ }^{376}$

La impresión del primer volumen de los Heterodoxos... y de la segunda edición de La ciencia española corrieron prácticamente paralelas a lo largo de la segunda mitad del año 1879, lo cual puso de manifiesto la inconveniencia de mantener el primitivo plan de los Hetedorodoxos... en esta segunda edición, cuando iba a aparecer el nuevo plan, considerablemente corregido y aumentado, en la primera edición del primer volumen de aquellos.

Los seis capítulos de la primera parte que procedían de la primera edición, fueron sometidos a revisión, es decir, fueron corregidos y aumentados en diversa medida, beneficiándose de los hallazgos bibliográficos cobrados por el joven erudito en las bibliotecas históricas europeas:

i. En la segunda edición, la epístola «Indicaciones sobre la actividad intelectual de España en los tres últimos siglos» experimentó algunas correcciones y considerable aumento, ante todo, a través de la introducción de nuevas citas y, en menor medida, también mediante la inclusión de nuevos datos en el cuerpo de texto que a veces son párrafos con indicaciones bibliográficas y, a veces, sólo nombres.

En efecto, la segunda edición eliminó alguna cita de la primera edición, pero sobre todo introdujo dieciocho nuevas citas de datos bio-bibliográficos, y una cita en la que precisa su juicio sobre la influencia de Gassendi en Tomás Vicente Tosca.

Por otra parte, un ejemplo de párrafo nuevo, que Menéndez Pelayo introdujo en la segunda edición, es el que se encuentra entre el párrafo que comienza «Próximo a Vives...» y el párrafo «De siglo de Oro filosófico...»: "Afirma Foxo que la idea de Platón, la idea sobre las cosas, es la forma aristotélica, cuando se traduce y concreta en las cosas creadas. ¿Quién no ve aquí los elementos de un racionalismo armónico?».377

Un ejemplo de corrección, introducida en la segunda edición, la encontramos en el párrafo que comienza «De siglo de Oro filosófico...» en el que modifica el final:

375 EMP, vol. 3, n. ${ }^{\circ}$ 63, 15-5-1878.

376 EMP, vol. 3, n. ${ }^{\circ}$ 65, 19-5-1878.

377 M. Menéndez Pelayo, La ciencia española. Polémicas, indicaciones y proyectos, Madrid, Lib. Victoriano Suárez, 1879, p. 10. En adelante: MP, CE, 2a ed., p. 10. 


\section{1a Edición}

...el libro admirable de Los nombres de Cristo y el Del amor de Dios de Fonseca.

\section{2a Edición}

...el libro admirable de Los nombres de Cristo y los Diálogos de la conquista del espiritual y secreto reino de Dios de Fr. Juan de los Ángeles.

ii. En la segunda edición, la epístola «De re bibliographica» experimentó algunas correcciones y, sobre todo, considerable aumento a través de la introducción de nuevas citas y de la inclusión de nuevos datos bibliográficos en el cuerpo de texto. La segunda edición introdujo nueve nuevas citas de datos bibliográficos; además, fundió en el cuerpo del texto numerosas entradas bibliográficas procedentes del «Anexo. De re bibliographica» de la primera edición, $\mathrm{y}$ de otras notas posteriores que fue tomando hasta noviembre de 1879 . Me limito a recoger entradas introducidas en la segunda edición, páginas 40-46:

«... Ni los hijos ilustres de Jerez de la Frontera, obra del Sr. Parada». ${ }^{378}$

«Granada.-Bibliografía Granadina hasta fines del siglo xvıII. Ms. de D. Juan F. Riaño, premiado por la Biblioteca Nacional». ${ }^{379}$

«La Biblioteca Nacional premió en uno de sus últimos concursos una colección biográfico-bibliográfica de noticias concernientes a la Historia de Zamora, por D. Cesáreo Fernández Duro». ${ }^{380}$

«León Pinelo. Epitome de la Biblioteca oriental y Occidental, Náutica y Geográfica, Madrid 1629. En un solo tomo, y con adiciones mucho más considerables que el texto por D. Andrés González Barcia, en Madrid, 1737-38, 3 vols.». ${ }^{381}$

"Bibliotheque Americaine de Ternaux Compans.-También son útiles para nuestra bibliografía, la Asiática y la Africana (1841)».382

"Bibliotheca Americana Nova de Rich. Londres, 1846».383

"La Imprenta en America, del mismo. New-York, 1866. Hay una traducción castellana con notables adiciones del Sr. Zarco del Valle». ${ }^{384}$

"Apuntes para un Catálogo de escritores en lenguas indígenas de América, por D. J. García Icazbalceta. Méjico, 1860». ${ }^{385}$

\footnotetext{
378 MP, CE, 2a ed., p. 40.

379 MP, CE, $2^{\text {a }}$ ed., p. 41.

380 MP, CE, 2a ed., p. 42.

381 MP, CE, 2a ed., p. 44-45.

382 MP, CE, 2a ed., p. 45.

$383 \mathrm{Ib}$.

$384 \mathrm{Ib}$.

$385 \mathrm{Ib}$.
} 
"Los idiomas de la América latina, por D. F. Cibdad y Sobrón. Madrid, 1876. Es una especie de catálogo bibliográfico, muestra de otro más extenso que tiene inédito su autor». .386

«Méjico [ampliación]». ${ }^{387}$

"Beristain de Sousa, Biblioteca Hispano-Americana Septentrional o catálogo y noticia de los literatos que educados en la América Septentrional española han dado a luz algún escrito, etc. Méjico, 1816-21. Tres tomos en folio. Obra abundante en noticias, aunque le falta rigor bibliográfico en las descripciones». ${ }^{388}$

«América del Sur [ampliación]».389

«Filipinas.-D. Sebastián Vidal y Soler insertó un Catálogo de libros útiles para la historia y geografía de aquellas islas, al fin de su Memoria sobre los montes de Filipinas. Véase además el Apéndice VI a las Guerras piráticas de Mindanao y Joló, publicadas por el Sr. Barrantes, y algunos artículos del Sr. Pan en la Revista de Filipinas». ${ }^{390}$

iii. La epístola «Mr. Masson redivivo» fue aumentada sólo con una nueva cita de datos bibliográficos en la segunda edición, en la que Menéndez Pelayo introdujo además ligeras correcciones de errores o ajustes en el cuerpo del texto. Elimina por ejemplo la siguiente referencia a Laverde: «Usted, amigo mío, ha de darnos antes de mucho esta obra, digna, sin duda, de su erudición, ingenio y acrisolado juicio»..${ }^{391}$

iv. Las pruebas de la primera edición de la epístola «Monografías expositivo-críticas» no fueron corregidas por Laverde, ni por Menéndez Pelayo. La segunda edición de esa epístola fue sometida a corrección de erratas y de algunos errores y, especialmente, experimentó un considerable aumento por refundición de datos bibliográficos en el cuerpo del texto y por la introducción de nuevas citas.

En la segunda edición, se incluyeron en el cuerpo de texto entradas bibliográficas recogidas en la parte del «Anexo» de la primera edición, dedicado a «Monografías...»; así como otras entradas procedentes de notas posteriores a noviembre de 1876. En esta segunda edición, se introdujeron nueve citas nuevas de datos y dos de precisión de juicio; además, se completaron los

$386 \mathrm{Ib}$.

$387 \mathrm{Ib}$.

$388 \mathrm{I} b$.

$389 \mathrm{Ib}$.

390 MP, CE, $2^{\text {a }}$ ed., p. 46.

391 M. Menéndez Pelayo, Polémicas, indicaciones y proyectos sobre la ciencia española, Madrid, Eduardo de Medina Editor, 1876, p. 77. En adelante: MP, CE, $1^{\text {a }}$ ed., p. 77. 
datos de una cita procedente de la primera edición. Alguna referencia que entra en el cuerpo del texto de la segunda edición de "Monografías...", desaparece en la tercera, v. gr., «Andrés María Santa Cruz, por D. Salvador Bermúdez de Castro en El Iris (1841)». Otra referencia que entra en el cuerpo del texto de la tercera edición, lleva consigo una nueva cita, v. gr., "Michael de Molinos, por C. E. Schaulling (Gotha, 1855). En lengua danesa (1) [la llamada entre paréntesis corresponde a la cita 635 de nuestra edición]».

Algunas citas de la primera edición de «Monografías...» desaparecen en la segunda, v. gr., «(1) En la crónica de los cervantistas, que en Cádiz ve la pública luz, ha insertado el Sr. Mainez algunas muestras de las anotaciones que prepara a los dos elogios de Cervantes». ${ }^{392}$

v. En la segunda edición de la epístola «Prosíguese el pensamiento de las cartas anteriores», Menéndez Pelayo introdujo seis nuevas citas, cuatro de las cuales eran críticas del lenguaje español de Salmerón y los krausistas.

vi. En la segunda edición de la epístola, «Mr. Masson redimuerto», se añaden siete citas nuevas de datos, una cita de precisión de juicio, y otra con una cita latina que antes aparecía en el cuerpo del texto.

b) La Ciencia Española. Polémicas, indicaciones y proyectos incluía además nuevos textos polémicos e histórico-reivindicativos que aumentaron considerablemente su tamaño y llevaron a Eduardo Medina y a Menéndez Pelayo a editarlo en un volumen en cuarto. ${ }^{393}$

Gumersindo de Azcárate había entrado activamente en la polémica con su breve escrito, "Una carta sobre la filosofía española», publicado por la Revista Europea, el 5 de noviembre de 1876, ${ }^{394}$ y a la que replicó Gumersindo Laverde con su breve escrito, «La ciencia espańola», que sacó a la luz asimismo la Revista Europea el 3 de diciembre. ${ }^{395}$ Por lo que este apéndice de la polémica se había quedado fuera de la primera edición de La ciencia española. Laverde le insistió repetidamente a Menéndez Pelayo que debía incluir ambos escritos en la segunda edición de la obra, y así pensó hacerlo también el joven polemista; pero, finalmente, dejó fuera de la misma el texto de Azcárate por la razón que le confiesa a Laverde: «No he reimpreso la carta de Azcárate por no tener su consentimiento, ni ganas de pedírselo». 396

El 17 de marzo de 1877, La España. Diario Católico publicó el primero de los dos artículos de su director, Alejandro Pidal y Mon, titulado «"La

392 MP, $C E, 1^{\text {a }}$ ed., p. 108.

393 EMP, vol. 3, n. ${ }^{\circ} 242,4-2-1879$.

394 Tomo VIII, n. ${ }^{\circ} .141$, pp. 592-594.

395 Tomo VIII, n. ${ }^{\circ} .145$, pp. 721-723.

396 EMP, vol. 4, n. ${ }^{\circ} 106: 28-1-1880$. 
ciencia española” por D. Marcelino Menéndez y Pelayo», en el que elogiaba los escritos polémicos del joven polemista católico y le declaraba vencedor sobre los racionalistas. Al día siguiente Pidal enviaba el artículo a Menéndez Pelayo, con una carta en la que le anunciaba un segundo artículo polémico y, pensando ya en una segunda edición, le advertía de algunas correcciones de errores, sugeridas por monseñor Ceferino González: Suárez no enmendó ligeramente a Vázquez, ni tuvo como discípulo a Toledo. ${ }^{397}$ Menéndez Pelayo y Laverde se congratularon, no sin cierta inquietud, de la elogiosa atención de Pidal que presagiaba la deriva de la polémica hacia el tradicionalismo tomista:

Alejandro Pidal me mandó el artículo de la España acompañado de una cariñosa carta. No me dice aún el motivo de su discordancia de parecer sobre algunos puntos, pero sospecho que serán el tomismo y quizá la filosofía escocesa. Veremos cómo presenta la cuestión. ${ }^{398}$

El segundo de los artículos de Alejandro Pidal, “La ciencia española” por D. Marcelino Menéndez y Pelayo (II)», fue publicado por La España. Diario Católico el 24 de marzo. El joven polemista lo leyó en Italia, tres semanas más tarde, y envió el 16 de abril desde Florencia a Pidal su larga epístola de réplica, «In dubiis libertas», que fue publicada por La España. Diario Católico cinco días más tarde. Cuando estaba componiéndola en Florencia, probablemente el día 16, ${ }^{399}$ recibió una carta de José María de Pereda fechada el 13 de abril, en la que el novelista cántabro escribía lo siguiente:

Dejo para lo último lo más candente, y es, a saber, el artículo bibliográfico de Pidal. Como supongo que has leído sus dos partes, dígote que no pueden darse mejor deseo de ensalzarte, ni contendiente en mejor actitud para meterle el acero hasta la empuñadura. Supongo que con toda la cortesía imaginable, y dentro de las reglas de la más exquisita urbanidad, le habrás emperejilado ya la respuesta. Lego soy en la materia, y admirador del talento de Pidal, pero así y todo, no hay quien me convenza de que no es una inocentada aquel fárrago de reparos. ${ }^{400}$

Menéndez Pelayo pensaba eso mismo de la epístola de Pidal, y así se lo comunicó a Pereda:

En Florencia recibí su muy grata del 17 [se refiere, según creo, a la del trece de abril], y allí mismo escribí la adjunta epístola. Harto breve es, pero

397 EMP, vol. 2, n.o 158, 18-3-1877.

$398 E M P$, vol. 2, n. ${ }^{\circ} 165,1-4-1877$.

399 EMP, vol. 2, n. ${ }^{\circ} 171,25-4-1877$.

400 EMP, vol. 2, n. ${ }^{\circ} 166,13-4-1877$. 
me cogió en mal tiempo, cuando estaba respondiendo a Pidal. Tiene Ud. razón en todo lo que dice. Dígame Ud. qué le parece de mi contestación, la cual, si llegó sana y salva a Madrid, saldrá en uno de los próximos números de la España. No acabo de comprender ese exclusivismo tomista. Creo que el Cristianismo es bastante amplio, para que dentro de él estemos holgadamente todos. ${ }^{401}$

Gumersindo Laverde no se contentó con valorar muy positivamente la réplica de Menéndez Pelayo, sino que le señaló un punto débil de su argumentación, por donde vendría a la postre la contrarréplica de Pidal, a la vez que le indicó cómo proceder en la posterior respuesta:

Me ha entusiasmado la lectura de su carta a A. Pidal. Es admirable. Solo me queda alguna [duda] sobre si será tan cierto, como V. afirma, que el Renacimiento influyó poco o nada en la generación y progresos del protestantismo. Parece que Pidal piensa replicar, y es posible que no se le escape este punto. Veremos entonces como V. se desenvuelve. Por lo demás, se ha colocado $V$. en buen terreno y ha de ser difícil que en él puedan derrotarle. Persista V. en su tono de moderación y de respeto hacia el tomismo. Podría $\mathrm{V}$., si tuviese a la mano las obras de Fr. Zeferino, invocarle en su apoyo... ${ }^{402}$

Las cartas de Alejandro Pidal, que abrían una cisura en la argumentación historicista católica de Menéndez Pelayo, reanimaron la polémica con los racionalistas. El neokantiano José del Perojo volvió a defender la tesis de Manuel de la Revilla en un extenso artículo, «La ciencia española bajo la Inquisición», que publicó el 15 de abril en su periódico, la Revista Contemporánea. ${ }^{403}$ Alejandro Pidal le envió una copia de ese escrito a Menéndez Pelayo, que lo leyó al final de la primera semana de mayo en Venecia. La extensa y contundente réplica que le entretuvo varios días, fueron tres cartas dirigidas a Pidal con el título «La ciencia española bajo la Inquisición, por el Sr. del Perojo», fechadas respectivamente las dos primeras el 6 y el 8 de mayo en Venecia, y la tercera el 9 de mayo en Milán. Pidal y Mon las publicó en La España. Diario Católico, la primera, el 19 de mayo, la segunda, el 26 de mayo, y la tercera, en dos entregas, los días 2 y 9 de junio. Pidal le pidió disculpas por esta publicación en dos entregas de la última epístola.

Sorprende lo extenso y pormenorizado de la réplica que dedica Menéndez Pelayo al escrito de Perojo, que no le merecía aparentemente la más mínima consideración, si hacemos caso de las expresiones íntimas de

401 EMP, vol. 2, n. ${ }^{\circ} 171,25-4-1877$.

402 EMP, vol. 2, n. ${ }^{\circ} 173,3-5-1877$.

403 Tomo VIII, vol. III, n. ${ }^{\circ} 17$, pp. 325-364. 
su correspondencia. En carta a Pereda, califica el «engendro de Perojo» de «tejido de embustes e ignorancias». ${ }^{404}$ A Laverde le escribe sobre el artículo de Perojo que es «tan interminable como sin sustancia», y justifica la dureza de su réplica como sigue: «No sé si habré cargado la mano, pero las blanduras las guardo para los de casa». ${ }^{405}$

Gumersindo Laverde que valoró muy positivamente las tres cartas de Menéndez Pelayo contra Perojo, le advirtió de que concedía demasiado a los racionalistas en lo que se refiere a la supuesta decadencia de las matemáticas, en especial de las aplicadas, en la España del siglo Xvi. En adelante, le insistirá repetidamente en que cuide este argumento al revisar los textos de la polémica:

Con fruición grande leí la segunda perojina, que es contundente. Solo tengo un reparo que ponerle, y es la concesión que $\mathrm{V}$. hace de que la Astronomía y las Matemáticas decayeron en el siglo xvı, siglo de Núñez, Rojas, Chacon, Sta. Cruz, Esquivel, Herrera, Orche y tantos otros matemáticos, que si no fueron descubridores, sabían cuanto entonces se sabía en el resto de Europa. Acaso pudiera admitirse tal decadencia por lo que a Astronomía respecta, si Alfonso el Sabio hubiese florecido, no dos siglos, sino inmediatamente antes». ${ }^{406}$

El 15 de mayo de 1877, la Revista Contemporánea publicó el artículo, «La Biblioteca de Autores Españoles y la historia literaria de España», ${ }^{407}$ del comandante de artillería e historiador de la filosofía española, Luis Vidart y Schuch. Este escrito atrajo enseguida la atención de Menéndez Pelayo que sentía simpatía por ese tradicional en el lado del racionalismo liberal, pero rechazaba su tesis, la misma de Azcárate, según la cual la tradición científica española debió de interrumpirse en el siglo Xvir. Y en este sentido llamó la atención de Laverde en una carta fechada el 30 de mayo:

No sé si habrá visto Vd. en la Revista Contemporánea un artículo de Vidart, que toma cartas en la consabida polémica. Nos trata con gran consideración y miramientos, y dice que Valera está a nuestro lado en este debate. En cuanto a él, viene a darnos la razón, haciendo sólo las salvedades que hizo Azcárate en la carta a Vd. El único argumento que nos opone es facilísimo de destruir. Se refiere a la tradición científica que él supone cortada en el siglo Xvir. Probando que no se cortó hasta el presente, estamos al cabo de la calle. Clama Vidart porque se ańadan a la Biblioteca de Rivadeneyra unos cuantos tomos de filósofos \&. Tiene razón, y ojalá que le hagan caso...

404 EMP, vol. 2, n. ${ }^{\circ} 178,30-5-1877$.

405 EMP, vol. 2, n. ${ }^{\circ} 175,16-5-1877$.

406 EMP, vol. 2, n. ${ }^{\circ} 180$, 3-6-1877.

407 Tomo IX, n. ${ }^{\circ} 1$, pp. 69-89. 
Vd. me dirá cómo se ha de proceder con Vidart, que viene en son de paz y como aliado. Lo mejor será escribir un artículo, agradeciéndole lo que concede, y contestándole en lo que niega. ${ }^{408}$

La pronta respuesta de Laverde, del 3 de junio, que Menéndez Pelayo leyó en París, lleva como de sólito indicaciones de cómo y con qué argumentos responder a Vidart:

Si V. halla justas estas observaciones [poner de relieve que los matemáticos españoles del siglo xvi estaban a la altura de su tiempo], puede darles cabida y desarrollo, al contestar a Vidart. Esta contestación puede V. hacerla en una nueva epístola a Pidal, agradeciéndole lo que concede y corroborándolo y combatiéndole en lo que niega. Para esto, puede V. hacer ver como en la $1 .^{a}$ mitad del siglo 18 continuaron las sectas escolásticas de tomistas, escotistas y suaristas, como se mantuvo el lulismo, como Ferreras, Mayans y otros siguieron en la crítica histórica las huellas de Mondejas, Cortés, \&., como el mismo Mayans, Finestres y otros se enlazan con Salgado, Puga, Ramos del Manzano \&. en punto a Jurisprudencia, como Campomanes ilustró su Educación popular sacando a luz escritos de economistas del siglo XVII, como Tosca, el autor de El Ocaso de las Formas Aristotélicas y otros filósofos, más o menos novadores, procuraban apoyarse en precedentes nacionales, como Forner se mostró vivista citando a la vez con encomio á los grandes escolásticos del siglo XVI, entre ellos a Gabriel Vázquez, a quien pone en las nubes, como las Sociedades médicas de Sevilla y Valencia empezaron ya en el siglo XviI, como el conocimiento y adopción en parte, de la filosofía francesa del siglo XVII, precedió, entre nosotros, al advenimiento de Felipe V (Caramuel, Cardós \&.) y otras muchas buenas cosas que a V. se le ocurrirán en contra de mi buen amigo Vidart. ${ }^{409}$

En junio de 1877, Menéndez Pelayo y Gumersindo Laverde esperaban con impaciencia la prometida réplica de Alejandro Pidal al «In dubiis libertas», para responderla y cerrar con ese escrito la segunda edición de la obra: «Espero la ofrecida contestación de Alejandro, para replicarle a él y a Vidart en una misma carta. Aprovecharé todas las indicaciones de Ud.». ${ }^{410}$ Sin embargo, la respuesta de Pidal no llegó a hacerse pública, y Menéndez Pelayo terminó replicándole más tarde y para la segunda edición, como hizo en el caso de la «Nota final» contra la tesis azcaratesca de Luis Vidart.

El editor Eduardo Medina no compartía por entonces el decidido interés que ya tenían Menéndez Pelayo y, sobre todo, Gumersindo Laverde, en la

408 EMP, vol. 2, n. ${ }^{\circ} 177$.

409 EMP, vol. 2, n. ${ }^{\circ} 180$.

410 EMP, vol. 2, n. ${ }^{\circ} 185,12-6-1877$. 
publicación de la segunda edición de la obra. En una carta fechada el 11 de diciembre de 1876, este editor le había remitido al autor unos números referentes a la distribución de los ejemplares de la primera edición que parecen indicar escasez de ventas:

De la tirada de 300 que se hizo se han remitido a V. á Santander hasta 100, se han enviado unos 60 a periódicos y Revistas, otros 60 repartidos por orden de Ud. y de Laverde, etc.; resultado que solo quedan unos 50 ejemplares, de los cuales remitiré á $\mathrm{V}$. por el correo de mañana 25 , quedándome yo con otros 25 escasos para que el título no desaparezca del catálogo... Además se han repartido 25 o 30 de muestras a libreros, los cuales no han dado resultado, pero si lo hubiesen dado no se les hubiera podido servir. ${ }^{411}$

A finales de Julio de 1877, le escribió Menéndez Pelayo a Laverde: «Hoy remito a P. Santiago el ejemplar de las Polémicas. Todavía me quedan sobre dos docenas, únicas que a mi entender, existen. Sé que Medina ha vendido bien el resto de la edición». ${ }^{412}$

Laverde le insistió a Menéndez Pelayo que urgiera a Medina la puesta en marcha de la segunda edición y, en caso de que su respuesta fuera negativa, que buscase otro editor. Llegó incluso a proponerle que afrontara la edición a sus expensas, convencido de que había demanda suficiente de

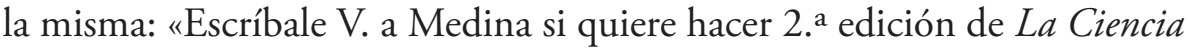
española en la forma que en mis anteriores le indiqué. Si no acepta, será bien buscar otro editor, pues importa mucho la tal edición.... Creo que no se perderá el dinero en una 2. ${ }^{\text {a }}$ edición de La Ciencia española, pues son bastantes todavía las personas que me preguntan por ella». ${ }^{413}$ En noviembre, el propio Menéndez Pelayo se planteó la opción de publicar la edición por su cuenta y riesgo. ${ }^{414}$

Mediado el mes de junio de 1877, Menéndez Pelayo estaba centrado en la redacción del primer volumen de los Heterodoxos...; tenía ya decidido, sin embargo, escribir un artículo sobre la Antoniana Margarita de Gómez Pereira, y así se lo hizo saber a Laverde:

Escribiré el artículo acerca de la Antoniana apenas me desocupe un poco de los heterodoxos de la era hispano-romana... Deseo hacer segunda ed. de La Ciencia Española, y pondré bastantes adiciones al catálogo de mono-

411 EMP, vol. 2, n.o 116, 11-12-1876.

412 EMP, vol. 2, n. ${ }^{\circ} 207,24-7-1877$.

413 EMP, vol. 2, n. ${ }^{\circ} 190,23-6-1877$.

414 EMP, vol. 2, n.o 265, 29-11-1877. 
grafías... Si Pidal no contesta pronto, escribiré una carta sobre los yerros de Vidart y compañía [Zugasti, Concepción Arenal]». ${ }^{415}$

Laverde le recomendó que escribiera también el estudio sobre la $A n$ toniana en forma epistolar, para que toda la obra estuviese homogénea en este punto y dirigida a Pidal. ${ }^{416}$

Menéndez Pelayo que había encontrado significativos materiales sobre la Antoniana Margarita en Lisboa (1876) y en Bruselas (1877), ${ }^{417}$ compuso su extenso artículo que es una monografía expositivo-crítica sobre ella, en las Navidades de 1877. El 25 de diciembre le escribe a Morel Fatio que estaba «ocupado en un estudio sobre la Antoniana Margarita de G. Pereyra, que saldrá probablemente en la Revista de España». ${ }^{418} \mathrm{Y}$ «31 de diciembre de 1877» es la fecha que puso el historiador cántabro al pie de la primera entrega de su artículo en la Revista de España. ${ }^{419}$ A Laverde le escribió el 2 de enero que había concluido su «estudio sobre la Antoniana, que salió largo y tendido. Tiene 24 pliegos. Ayer se lo envié a Valera, certificado». ${ }^{420}$

La Revista de España publicó este extenso artículo de Menéndez Pelayo bajo el título «La Antoniana Margarita de Gómez Pereira. Carta al Sr. D. Juan Valera, de la Academia Española», en cuatro entregas, durante los meses de febrero y marzo de $1878 .{ }^{421}$ Aunque este artículo no responde al género epistolar, lleva el subtítulo de carta, para mantener la unidad de género conferido a los escritos que componen la obra, siguiendo la recomendación de Laverde. La carta está dirigida a Valera porque fue quien hizo la gestión de la que resultó la publicación del artículo en la revista, y a través de quien el historiador santanderino hizo llegar su artículo al editor. El gran escritor y crítico cordobés le confirmó a Menéndez Pelayo en una carta fechada el 12 de enero que el editor de la Revista España había aceptado sus condiciones, advirtiéndole al mismo tiempo de la necesidad de corregir con cuidado las pruebas, para evitar la abundancia de erratas, habitual en los números de esa revista:

Vuelvo a escribir a Ud. hoy para decirle que hablé con D. Fernando León y Castillo, quien conviene en publicar en la Revista de España su estudio de

415 EMP, vol. 2, n. ${ }^{\circ} 194,27-6-1877$.

416 EMP, vol. 2, n. ${ }^{\circ} 197,3-7-1877$.

417 Ver la carta escrita a Laverde el 24 de noviembre 1877 desde Bruselas, vol. 2, n. ${ }^{\circ} 264$.

$418 \mathrm{Ib}$.

419 Tomo LX, febrero, n. ${ }^{\circ} 239$, p. 375.

420 EMP, vol. 3, n. ${ }^{\circ} 5$.

421 Tomo LX, febrero: n. ${ }^{\circ} 239$, pp. 362-375; n. ${ }^{\circ} 240$, pp. 474-489. Tomo LXI, marzo: n. ${ }^{\circ} 241$, pp. 63-80; n. ${ }^{\circ} 242$, pp. 166-192. 
Ud. sobre Gómez Pereira, dando a Ud. en pago 200 ejemplares de dicho estudio, de los que hará tirada aparte. Asimismo ha quedado dicho Don Fernando en hacer que remitan a usted las pruebas, a fin de que no salgan erratas. Para ello debo advertir a Ud. que ha de corregir con sumo cuidado, pues en la tal imprenta son ferozmente chapuceros. ${ }^{422}$

Menéndez Pelayo, Valera y, también, Laverde se congratularon de las excelencias de la monografía pelayana sobre la Antoniana..., lamentando la cantidad de erratas con que aparecieron las entregas de la misma en la Revista de España, de manera especial las dos primeras de febrero.

Gumersindo Laverde le recordaba reiteradamente a Menéndez Pelayo la necesidad de hacer la segunda edición de La ciencia española, cuya composición tenían ambos ya clara; y éste que era receptivo a esa insistencia, también estaba deseando publicar esa segunda edición. Sin embargo, un acontecimiento de la vida del polemista santanderino se interpuso y retrasó casi un año la realización de ese proyecto: la oposición a la cátedra de Historia Crítica de la Literatura Española en la Facultad de Filosofía y Letras de la Universidad Central de Madrid, que había quedado vacante por la defunción de su titular, José Amador de los Ríos, el diecisiete de febrero de 1878 .

Por otra parte, esa oposición a cátedra, que centró la actividad práctica de Menéndez Pelayo hasta 1879, facilitó por varias razones la segunda edición de la obra en la segunda mitad de este año. Mencionaré dos. Ante todo, los hermanos Pidal se implicaron de lleno en la maniobra política que permitió a Menéndez Pelayo presentarse a la oposición, aunque no cumplía en principio el requisito de edad; ${ }^{423}$ esto vino a estrechar los lazos entre el polemista santanderino y Alejandro Pidal, que estaba interesado en formar parte de la segunda edición y que habló también con Eduardo Medina para que la asumiera. Además, el triunfo de Menéndez Pelayo en esa notoria oposición a la cátedra de Amador de los Ríos significó el despegue definitivo de su meteórica carrera académica y literaria: el editor Medina no podía albergar ya ninguna duda sobre el éxito de la edición. Un indicador claro de que esta oposición a cátedra representó un antes y un después en la percepción que tenía del historiador santanderino su entorno intelectual, lo encontramos en el cambio de actitud de José del Perojo ante su paisano: si en el artículo «La ciencia española bajo la Inquisición», le descalificó como a un arribista desconocido y carente de mérito, a finales de agosto de 1878 le proponía

422 EMP, vol. 3, n. ${ }^{\circ} 11$.

423 EMP, vol. 3, n. ${ }^{\circ}$ 50, 8-4-1878. 
dirigir una Biblioteca de Filósofos Españoles para la Revista Contemporánea, más aún, se ofreció a editar su Historia de los heterodoxos. . ${ }^{424}$

Quizá Navarro haga pronto la 2. ${ }^{\mathrm{a}}$ ed. de las Polémicas... [Le escribe Menéndez Pelayo a Laverde], a lo cual le anima Alejandro [Pidal y Mon]. Este tiene escrita y me leyó una larga carta en contestación a la mía. Con mi réplica amistosa se cerrará el tomo, a no ser que convenga meter también la Antoniana, en cuyo caso suprimiré la introducción heterodoxa, porque está muy ampliada, forma parte del primer tomo de la Historia. Con eso tendrá más unidad el libro. ${ }^{425}$

Pues bien, Pidal y Mon había compuesto la esperada réplica «Contestación de D. Alejandro Pidal y Mon a la carta in dubiis libertas", probablemente a finales de 1877, pero no se decidió a publicarla. Menéndez Pelayo que tenía noticia del firme propósito pidaliano de escribirla, ${ }^{426}$ no la conoció hasta mediados de mayo de $1878 ;{ }^{427}$ más adelante la recibió acompañada de una carta o nota a lápiz sin fecha y de unas indicaciones -que se pueden consultar en el anexo- ${ }^{428}$ en las que Pidal le sugería la manera más conveniente de componer la contrarréplica. Esa nota de Alejandro Pidal a Menéndez Pelayo que este debió de recibir antes de enero de 1879, pone de manifiesto que existió mutuo entendimiento y colaboración en los dos últimos escritos polémicos que se intercambiaron:

revolviendo hoy papeles me he encontrado con el mamotreto que escribí tras largos afanes el año pasado para cerrar nuestra polémica y completar el libro de la ciencia espańola. No tengo valor para leerlo, si V. lo tiene léalo V. sin pasión y sin miramientos y teniendo presente las consideraciones apuntadas en las dos cuartillas sueltas, dígame V. francamente su leal parecer sobre el asunto. A mí no me guía, V. lo sabe, más que el deseo de que V. brille como debe y de que Santo Tomas quede como puede, fuera de esto para mí no hay cuestión.

Así pues pongo el asunto en manos de V. y V. después de pensarlo me dirá lo que debemos de hacer para que el libro de la ciencia española tan precioso arsenal para los católicos contra los racionalistas no aparezca con el lunar de ser alguna vez lo contrario. ${ }^{429}$

$424 E M P$, vol. 3 n. ${ }^{\circ} 147,23-8-1878$.

425 EMP, vol. 3, n. ${ }^{\circ}$ 63, 15-5-1878.

426 EMP, vol. 2, n.o 216, 9-8-1877.

427 EMP, vol. 3, n. ${ }^{\circ} 63$.

428 EMP, vol. 3, n. 338.

$429 E M P$, vol. 3, n. 350. 
El segundo momento y culminante de la polémica entre Menéndez Pelayo y Alejandro Pidal no se hizo público hasta que salió a la luz la segunda edición de La ciencia española. De las consideraciones o indicaciones que éste adjuntó a su "Contestación de D. Alejandro Pidal y Mon a la carta in dubiis libertas», a fin de que Menéndez Pelayo las siguiera en su contrarréplica, mencionaré aquí dos: la primera, que procure quedar «bien con los católicos y dejando solo maltrechos a los racionalistas»; y, la segunda, que tenga en cuenta que ha exagerado, «atacando al renacimiento personificándole en el italiano y en los excesos que ha cometido dejándole a V. el campo libre para elogiar el Renacimiento español y Vives», pues los católicos de este siglo «tienden a rehabilitar la Edad Media y a rebajar un tantico el Renacimiento, al revés de los racionalistas que siguen luchando [?] contra la Edad Media». Las recomendaciones de Pidal concluyen insistiendo en la completa inconveniencia de que «se inscriba su nombre de V. entre los adversarios de la escolástica y los enemigos de su renacimiento en España...». ${ }^{430}$

En las vacaciones de Navidad de 1878 Menéndez Pelayo estuvo preparando finalmente la segunda edición de la obra: acabó de decidir los textos que formarían parte de ella, corrigió y aumentó el «De re bibliographica» y el «Monografias histórico-críticas», etc. En una carta fechada el 5 de enero de 1879 , le consultaba a Laverde sobre la conveniencia de introducir en la segunda edición su reseña del libro que el abate Reulet dedicó a Raimundo Sabunde; ${ }^{431}$ a lo que aquel le respondió inmediatamente que le parecía "convenientísimo». ${ }^{432}$ Menéndez Pelayo había empezado la redacción de esa reseña en París en torno al 19 de octubre de 1877 para la Revista de Espa$\tilde{n} a,{ }^{433}$ pero no llegó a terminarla. En algún momento de 1878 concluyó esa defensa del origen español del teólogo y médico, «La patria de Raimundo Sabunde», que quedó entonces sin publicar.

A principios de febrero de 1879, el editor Navarro tenía ya en su poder el índice de la obra y todos los textos que la componían, con excepción del «Instaurare omnia in Christo. Carta al señor Alejandro Pidal y Mon» que no había redactado aún ${ }^{434} y$, probablemente, de la «Nota final». Sin embargo, la edición de la obra que corrió paralela a la impresión del primer volumen de los Heterodoxos..., no se puso en marcha hasta la tercera semana de mayo, ${ }^{435}$

430 EMP, vol. 3, n.o 338, de Pidal a Menéndez Pelayo, sin fecha.

$431 E M P$, vol. 3, n. ${ }^{\circ} 223$.

432 EMP, vol. 3, n. ${ }^{\circ} 230$, 9-1-1879.

$433 E M P$, vol. 2, n. ${ }^{\circ} 246,19-10-1877$.

434 EMP, vol. 3, n. ${ }^{\circ} 242,4-2-1879$.

435 EMP, vol. 3, n. ${ }^{\circ} 296,14-5-1879$. 
y un mes después iba saliendo de manera lenta, pero a gusto de Menéndez Pelayo, que siguió corrigiendo pruebas durante su habitual descanso estival en Santander. ${ }^{436}$ A finales de julio estaban componiendo ya las cartas de Pidal ${ }^{437}$ y a mediados de agosto habían llegado a los apéndices. ${ }^{438}$

La contrarréplica, «Instaurare omnia in Christo. Carta al señor Alejandro Pidal y Mon", Menéndez Pelayo debió de escribirla a finales del verano o en el otońo de 1879, y para la segunda edición de La ciencia española (1880) en la que apareció por primera vez. Pues el Instaurare omnia in Christo... contiene un par de referencias a la Aeterni patris (4-8-1879) de León XIII, que no encontramos en los textos de Pidal.

A comienzos de diciembre de 1879 faltaba muy poco para completar la impresión de la obra, y Menéndez Pelayo tenía la esperanza de poder despacharla a principios del año nuevo. ${ }^{439} \mathrm{La}$ última corrección de pruebas debió de hacerla poco antes de viajar a Santander con motivo de las vacaciones de Navidad, el 22 de diciembre, fecha en la que escribe a Laverde: "Al cabo he corregido las últimas pruebas de la Ciencia Española, que se cierra con tu contestación a Azcárate, y la mía a la última de Pidal, el cual se ha dado por satisfecho con las explicaciones de esta carta, superior en su concepto a todas las restantes». ${ }^{440} \mathrm{La}$ composición de la breve «Nota final», a la que no se refiere en ningún momento, y cuyo concepto tenía ya en mente desde mayo de $1877,{ }^{441}$ debió de redactarla a vuela pluma en el momento en que completaba los apéndices de la obra, a finales del verano o en el otońo de 1879.

El primer ejemplar de La ciencia española. Polémicas, indicaciones y proyectos que llegó a las manos de Menéndez Pelayo, se lo envió a Gumersindo Laverde junto con una carta fechada el 28 enero de 1880, en la que se consolaba del número de erratas pues eran menos que en la primera edición. ${ }^{442}$ Laverde le confirmó la recepción del volumen en una carta del 20 de febrero, en la que se lamenta de la abundancia de erratas y se adhiere por entero a su última réplica a Pidal, ${ }^{443}$ aportándole además otros argumentos contra el tradicionalismo tomista (que se pueden consultar en el anexo). ${ }^{444}$ Laverde

\footnotetext{
436 EMP, vol. 3, n. ${ }^{\circ} 326,23-6-1879$.

437 EMP, vol. 4, n. ${ }^{\circ} 13$.

$438 E M P$, vol. 4, n. ${ }^{\circ} 24$.

$439 E M P$, vol. 4, n. ${ }^{\circ} 72$.

$440 E M P$, vol. 4, n. ${ }^{\circ} 82$.

$441 E M P$, vol. 2, n. ${ }^{\circ} 177$.

442 EMP, vol. 4, n. ${ }^{\circ} 106$.

443 EMP, vol. 4, n. ${ }^{\circ} 122$.

$444 \mathrm{Ib}$.
} 
consideró excelentes todos los escritos que formaban parte de la segunda parte y del apéndice de la obra, ninguno de los cuales pasó por sus manos antes de ser editados.

Los críticos franceses a los que envió esta segunda edición, amigos suyos ambos, tanto el racionalista liberal, Alfred Morel Fatio, como el tradicional Auguste Pécoul, vieron con buenos ojos la obra, en la que sólo encontraron un inconveniente: el escaso rigor y cuidado que Menéndez Pelayo ponía tanto en las citas, como en las referencias bibliográficas de la obra. Así, le escribió Morel Fatio que veía «le morceau de résistance du volume» en su estudio de la Antoniana Margarita: "Quant à la partie bibliographique, il me semble que vous auriez pu être plus méthodique, plus complet et plus précis». ${ }^{445} \mathrm{Y}$ en este sentido le amonestó Pécoul, que hizo una reseña de la obra en la Revue Critique, a fin de que enmendara este defecto en la previsible tercera edición de la obra:

Je regrette que Vous n'ayez pas été plus précis dans vos citations que dans la première édition. Je fais des voeux pour que Vous le soyez davantage dans la troisième. Quel dommage que Vous ne suiviez pas, pour cette précision scientifique, les idées de Morel Fatio! Votre livre serait le manuel indipensable de quinconque s'occupe d'Espagne, dans la Péninsule comme à l'étranger; et que de saines doctrines Vous pourriez répandre par un livre d'érudition écrit avec votre verve habituelle et où l'on trouverait des renseignements exacts! 446

\section{Tercera edición}

La ciencia española. (Polémicas, proyectos y bibliografía) fue una tercera edición refundida y aumentada de la obra y se publicó en la Librería de Victoriano Suárez. La publicación formaba parte de la primera edición de las obras completas de Menéndez Pelayo, dentro de la «Colección de Escritores Castellanos. Críticos» que editaba su propietario, Mariano Catalina Cobo (1842-1913), político conservador, poeta menor y miembro de la Real Academia Espańola, encargado en ésta, por entonces, de la inspección de publicaciones. La impresión del tomo corrió a cargo de la casa de Antonio Pérez Dubrull y se hizo en tres volúmenes en octavo: el primero salió a la luz en 1887, con 333 páginas más LVI, el segundo volumen en 1887, con 387 páginas más LXIX, y el tercero en 1889 con 478 páginas.

445 EMP, vol. 4, n. ${ }^{\circ} 117,15-2-1880$.

446 EMP, vol. 4, n. ${ }^{\circ} 116,14-2-1880$. 
En una carta del dos de agosto de 1888, Menéndez Pelayo le expone, a un Valera quejoso del editor Mariano Catalina, la razón por la cual le mantenía como editor de sus obras completas, y que no era ciertamente económica:

En lo que Vd. me dice de Catalina creo que tiene Vd. razón, a lo menos en parte. Yo me inclino a creer que Catalina no hace gran negocio con sus libros, pero aunque sea pequeño el que haga, siempre será desproporcionado respecto de la ganancia que a nosotros nos concede y que ciertamente es misérrima. Yo, por mi parte, no me atrevo a quejarme, porque chay en España (ni en Francia tampoco) editor capaz de publicar una Historia de la Estética en ocho o diez tomos, dando por ella más de lo que da Catalina? Yo creo firmemente que no, y por eso sigo con él. ${ }^{447}$

Concluida la publicación de los Heterodoxos... (1880-1882), la composición de la Historia de las ideas estéticas... (1883-1891) se había convertido en el eje de la producción intelectual de Menéndez Pelayo, que empezó a preparar la tercera edición de La ciencia española en el verano de $1886^{448}$ al mismo tiempo que acababa de redactar el último volumen dedicado a las ideas estéticas en la España del xvirI. El impulso para afrontar esta tercera edición de la obra, cuando la segunda estaba ya agotada, fue, desde un punto de vista extrínseco, la edición de sus obras completas en la "Colección de Escritores Castellanos. Críticos», y, desde un punto de vista intrínseco, la dinámica de revisión a que su extensa y meticulosa investigación histórica sometía de continuo a los contenidos bibliográficos e históricos de sus obras. Esencial a la dinámica revisionista que dio salida a esta edición, fue la larga y difícil composición del «Inventario bibliográfico de la ciencia española».

En principio, Menéndez Pelayo se proponía imprimir esta tercera edición en dos volúmenes, una vez publicada la historia de la estética española del XVIII y mientras planificaba, y redactaba, la historia de la estética europea y española del xix. Pero a finales de marzo de 1887, cuando estaba acabándose de imprimir el primer volumen, a la vista del tamaño de los textos restantes, decidió publicar la edición en tres volúmenes, y así se lo hizo saber a Valera en una carta del 22 de dicho mes. ${ }^{449}$ El 12 de mayo de ese mismo año terminó de imprimirse el primer volumen, según consta en el colofón del mismo, y en junio estaba ya en manos de los primeros lectores, entre ellos sus amigos Laverde, Valera, Antonio Rubio, Pereda, etc., que le trasmitieron su impresión positiva. El hispanista francés Morel Fatio le

447 EMP, vol. 9, n. ${ }^{\circ} 314$.

448 EMP, vol. 8, n. ${ }^{\circ} 19,21-7-1886$.

$449 E M P$, vol. 8, n. ${ }^{\circ} 342,22-4-1887$. 
escribió: «Con grandísimo placer he recibido la nueva edición de la Ciencia española, siempre más digna de su título y cuyas noticias pienso aprovechar en varias ocasiones». ${ }^{450}$

La aparición del segundo volumen no se demoró mucho, tal vez por la escasa novedad introducida en sus textos que no eran de carácter bibliográfico, sino polémico o histórico-reivindicativo. En efecto, el 15 de septiembre de 1887 terminó su impresión, según consta en el colofón del volumen, y en octubre era de dominio público y lo empezaron a recibir los habituales de su red intelectual que le confirmaron la recepción, trasmitiéndole sus impresiones positivas. Así, Laverde, además de darle indicaciones bibliográficas, le comenta: «Se me olvidaba decirte que recibí el tomo II de la Ciencia Española, gustándome mucho las adicciones que hiciste en las perojinas...». ${ }^{451}$

La publicación del tercer volumen de la edición, en cambio, se demoró año y medio. Menéndez Pelayo fue exponiendo a un Laverde cada vez más impaciente las razones de ese retraso. El 19 de octubre de 1887 le escribía: «El tercer tomo está en la imprenta, pero se retardará un poco, porque antes ha de ir uno de Estética, del cual se han impreso tres o cuatro pliegos...». ${ }^{452}$ El 24 de agosto de 1888 le confiesa abiertamente que no se ha dado prisa en terminar la impresión del tercer volumen: «...por el deseo de ampliar los cuadros sinópticos, que me han dado mucho que hacer, en especial el catálogo de nuestros filólogos, y me han empeñado en prolijas investigaciones sobre las gramáticas de lenguas bárbaras o exóticas de Asia y América». ${ }^{453}$ El volumen acabó de imprimirse el 5 de marzo de 1889, según consta en el colofón del volumen, y a finales de este mes estaba en manos de sus lectores y de los habituales de su red intelectual.

Lo que más apreciaba Menéndez Pelayo de este tercer volumen y, probablemente, de toda la edición, era precisamente el "Inventario...», que consideraba inacabado, como podemos leer en una carta del 11 de enero de 1889 a Alfred Morel-Fatio, en la cual le informaba además de que el esperado tercer volumen se estaba acabando de imprimir: «su principal interés consiste en una especie de tabla bibliográfica de nuestros antiguos libros de ciencia. Me ha dado bastante que hacer, y la creo muy incompleta, pero así y todo podrá servir como de vademecum». ${ }^{454}$

450 EMP, vol. 8, n. ${ }^{\circ} 438$.

451 EMP, vol. 8, n. ${ }^{\circ} 542,15-10-1887$

$452 E M P$, vol. 8, n. ${ }^{\circ} 544$.

453 EMP, vol. 9, n. ${ }^{\circ} 311$.

454 EMP, vol. 9, n. ${ }^{\circ} 461$. 
El «Inventario ...» estaba in fieri, era un proceso para Menéndez Pelayo, quien lo siguió completando después de publicado el tercer volumen. En una carta, fechada el 15 de abril de 1889, le escribe a Laverde: «No dejes de anotar, siempre que se te ocurran, las omisiones que notes en el Inventario Bibliográfico de La Ciencia Española. Tengo que añadir varios teólogos del siglo pasado (especialmente de su primera mitad) que he encontrado en el Nomenclator Litterarius de Hurter, obra que no tenía cuando hice mi catálogo». ${ }^{45}$

Menéndez Pelayo valoraba esta tercera edición de La ciencia española, ante todo, en lo que tiene de "manual bibliográfico», y, en menor medida, por sus escritos polémicos; sin embargo, fue adicionando entre julio de 1886 y octubre de $1887^{456}$ otros escritos polémicos e histórico-reivindicativos que había compuesto por distintos motivos y en diversas circunstancias, entre 1881 y 1886, y a los que me referiré más adelante. Los textos procedentes de la primera y segunda edición fueron sometidos por Menéndez Pelayo a una revisión en la que castigó erratas, corrigió errores, precisó expresiones y juicios, y, sobre todo, aumentó los datos bibliográficos e históricos.

Los criterios a los que se atiene por lo general en esa revisión de los textos procedentes de las ediciones anteriores, se encuentran expuestos con su habitual estilo trasparente en la «Advertencia preliminar» de la tercera edición:

Mi principal tarea ha sido hacerme cargo de los estudios de ciencia española publicados después de las dos primeras ediciones, y de aquellos otros que ya existían entonces, pero que no llegaron sino mucho después a mi noticia. De los primeros hablo en las notas, para no incurrir en contradicción cronológica. La noticia de los segundos he procurado intercalarla en el texto mismo, juntamente con una porción de observaciones y detalles que se me han ido ocurriendo al releer estas cartas en mi biblioteca y con la pluma en la mano.

Si he creído necesario atenuar, modificar o esforzar alguna opinión, lo hago siempre en nota, respetando la integridad de mis ideas primitivas: único procedimiento que tengo por sincero, cuando uno quiere rectificarse a sí mismo y hacer examen de su propio pensamiento. ${ }^{457}$

a) El primer volumen de la tercera edición incluía la primera parte de la obra, a la que añadía una "Advertencia preliminar» nueva y un "Apéndice», compuesto por dos textos procedentes del apéndice de la segunda edición, «Contestación del Sr. D. Gumersindo Laverde a la última réplica del Sr. Azcárate» $\mathrm{y}$ «Nota final»; y por un texto nuevo, la monografía «Fox Morcillo»

$455 E M P$, vol. 9, n. ${ }^{\circ}$ 615. Este Nomenclator llegó a su poder en noviembre de 1888.

456 EMP, vol. 8, n. ${ }^{\circ}$ 544, 19-10-1887.

457 MP, $C E$, vol. I, p. 6. 
que firmaba entonces Gumersindo Laverde, pero que en realidad era obra de Menéndez Pelayo. Así pues, su índice se modificaba ligeramente con respecto a la primera parte de la segunda edición, y quedaba como sigue:

- Advertencia preliminar

- Carta a guisa de prólogo, de Gumersindo Laverde.

1. «Indicaciones sobre la actividad intelectual de España en los tres últimos siglos»

2. "De re bibliographica»

$3 .^{\circ}$ "Mr. Masson redivivo»

4. "Monografías expositivo-críticas»

$5 .^{\circ}$ "Prosíguese el pensamiento de las cartas anteriores»

6. "Mr. Masson redimuerto»

- Apéndice:

I. «Fox Morcillo».

II. «Contestación del Sr. D. Gumersindo Laverde a la última réplica del Sr.Azcárate.

III. Nota final.

Laverde le pidió a Menéndez Pelayo que introdujera algunas correcciones en la carta-prólogo, por ejemplo, «que en vez de filosofía renaciente, pongas filosofía del renacimiento, y atenúes algún tanto la crudeza de la expresión de aquel pasaje donde hablo de reducir a unidad armónica la filosofía española, anteponiendo a esta expresión, la de elementos sanos de, u otra mejor que se te ocurra». ${ }^{458}$ Menéndez Pelayo efectuó esas modificaciones que, a su juicio, en nada modificaban el sentido del escrito. ${ }^{459} \mathrm{Y}$, desde luego, volvió a revisar los seis capítulos de la primera parte que procedían de las ediciones anteriores, precisando algunos datos y juicios sobre autores, y, especialmente, aumentándolos con nuevos datos bibliográficos e históricos.

En la tercera edición, en efecto, la epístola «Indicaciones sobre la actividad intelectual de España en los tres últimos siglos» experimentó algunas correcciones y aumentos a través de la introducción de cinco citas nuevas de datos y novedades, especialmente extensas dos de ellas dedicadas a las matemáticas aplicadas en España.

Un ejemplo de modificación, introducida en la segunda y en la tercera edición, consistente en el añadido y reordenación de nombres de grandes teólogos españoles, dignos de formar parte de una Biblioteca especial de teólogos españoles, es la siguiente:

458 EMP, vol. 8, n. ${ }^{\circ}$ 99, 20[?]-10-1886.

459 EMP, vol. 8, n.o 108, 24-10-1886. 


\section{1. ${ }^{a}$ Edición}

Arias Montano, Maluenda, Maldonado, Mariana, Fr. Luis de León, Fr. Luis de Granada, Francisco de Vitoria, Melchor Cano, Báñez, Soto, Molina, Suárez, Laínez, Salmerón, Lemos, Vázquez, [MP, CE, 1. ${ }^{\mathrm{a}}$ ed. p. 31]

\section{2. ${ }^{a}$ Edición}

Arias Montano, Maluenda, Maldonado, D. Martín Pérez de Ayala, Fr. Luis de León, Fr. Luis de Granada, Francisco de Vitoria, Fr. Luis de Carvajal, Melchor Cano, Báñez, Lemos, Soto, Laínez, Salmerón, Molina, Suárez, Vázquez, Valencia, Sánchez, Álvarez de Paz, Martínez de Ripalda, Tirso González...[MP, CE, 2.a ed. p. 15]

\section{3. ${ }^{\mathrm{a}}$ Edición}

Arias Montano, Cipriano de la Huerga, Maluenda, Maldonado, D. Martín Pérez de Ayala, Fr. Luis de León, Alfonso de Castro, Fr. Luis de Granada, Francisco de Vitoria, Fr. Luis de Carvajal, Melchor Cano, Báñez, Lemos, ambos Sotos, Laínez, Salmerón, Toledo, Prado y Villalpando, Ribera, Luis de Alcázar, Pineda, Fr. Pedro de Herrera, Ramírez de Montoya, Molina, Suárez, Vázquez, Valencia, Sánchez, Álvarez de Paz, Martínez de Ripalda,



La tercera edición de la epístola «De re bibliographica» experimentó aumentos principalmente a través de la introducción de citas. Esa tercera edición añade en efecto veintitrés nuevas citas en las que aporta datos y novedades bibliográficas. Además, completa una cita de la primera edición y cinco citas de la segunda edición, también con datos y novedades bibliográficas. La Edición Nacional se tomó la libertad de incluir dos citas con novedades bibliográficas posteriores.

En la epístola «Mr. Masson redivivo», la tercera edición introdujo dieciocho citas nuevas: dieciséis citas de datos y novedades entre las que destacan ocho de ellas, que son ampliaciones de texto relativas a la historia de las matemáticas aplicadas en la España de los siglos XVI y Xviı, y una referente al Ius gentium hispánico del mismo período; e incluyó también dos citas de precisión o rectificación de juicio, por ejemplo, en relación a Rabelais. Laverde le había sugerido en varias cartas de enero de 1878 que incluyera en esta epístola referencias a otros matemáticos españoles de los siglos XVI y XVII, en especial a Omerique, del que le había hablado el propio Menéndez Pelayo.

La tercera edición de la epístola «Monografías expositivo-críticas» introdujo doce citas nuevas de datos, trece de novedades y una de datos y 
novedades; además, completó con datos y novedades siete citas procedentes de la segunda edición, y una cita procedente de la primera edición y aumentada en la segunda. Por ejemplo, la referencia a la obra del Sr. Fabié sobre Bartolomé de las Casas, que entra en la segunda edición mediante cita y que se completa en la tercera actualizando la cita:

\section{2. ${ }^{a}$ Edición}

El Sr. Fabié prepara una monografía de Fr. Bartolomé de las Casas (1)

(1) Otra acaba de publicar el escritor americano D. Carlos Gutiérrez con el título de Fray Bartolomé de las Casas.-Su tiempo-Su apostolado. Vease además las conaocidas biografías de Quintana y Llorente, esta última en su edición francesa de las obras de Fr. Bartolomé. [MP, $C E$, 2. ${ }^{a}$ ed., p. 102]

\section{3. ${ }^{\text {E Edición }}$}

El Sr. Fabié prepara una monografía de Fr. Bartolomé de las Casas (1)

(1) Otra acaba de publicar el escritor americano D. Carlos Gutiérrez, con el título de Fr. Bartolomé de las Casas, su tiempo, su apostolado. Véanse, además, las conocidas biografías de Quintana y Llorente, esta última en su edición francesa de las obras de Fr. Bartolomé (1822). La obra del Sr. Fabié se publicó en 1879, con el título de Vida y escritos de Fr. Bartolomé de las Casas (dos volúmenes). [MP, CE, 3. ${ }^{\mathrm{a}}$ ed., p. 173]

Alguna referencia que entra en el cuerpo del texto de la segunda edición de «Monografías...», desaparece en la tercera, v. gr., "Andrés María Santa Cruz, por D. Salvador Bermúdez de Castro en El Iris (1841)». Otra referencias que entra en el cuerpo del texto de la tercera edición lleva consigo una nueva cita, v. gr., «Michael de Molinos, por C. E. Schaulling (Gotha, 1855). ${ }^{460}$ También hay citas de la primera y segunda edición que desaparecen en la tercera edición, como la que aporta la siguiente nómina de impugnadores del Enciclopedismo:

(1) Citaré los principales que recuerdo, para facilitar el trabajo a quien emprenda la ilustración de esta interesante materia. El P. Feijoo; el P. D. Antonio Rodríguez (El Philoteo); Valcárcel (Desengaños filosóficos); el P. Ceballos (La falsa filosofia; Juicio final de Voltaire); Forner (Preservativo contra el ateísmo, Discursos filosóficos sobre el hombre); el P. Almeida (Recreaciones filosóficas); el P. Muñoz (Impugnación al Dupuis); Olavide (El Evangelio en triunfo); Peñalosa (La Monarquía); Pereyra (Theodicea); Pérez y López (Principios del orden esencial de la naturaleza); el canónigo Castro (Dios y la Naturaleza); Jovellanos (Tratado teórico-práctico de educación); el

460 En lengua danesa (1). 
P. Vélez (Apología del Altar y del Trono); el P. Alvarado (Cartas del filósofo rancio); el P. Dehajo Solórzano (El hombre en su estado natural); Rentería y Reyes (Filosofía de la religión); Hermosilla (El jacobinismo); el P. Vidal (Origen de los errores revolucionarios); Sánchez y Soto (El filósofo cristiano impugnando al libertino); Cortiñas (Demostración física de la espiritualidad e inmortalidad del alma, El triunfo de la verdad y refutación del materialismo); sin olvidar los escritos de Hervás, Costa y otros jesuitas de los desterrados a Italia. ${ }^{461}$

Asimismo, hay citas que se introducen en la segunda edición y se elaboran con modificaciones y añadidos en la tercera edición, v. gr., la cita 94 de nuestra edición. Hay notas de la segunda edición que desaparecen en la tercera, por ejemplo: «(1) Apunto todas estas que no son verdaderas monografías, sino artículos y discursos, a veces muy breves, para completar en lo posible la enumeración de trabajos útiles para la historia de nuestra filosofía». ${ }^{462}$

La tercera edición de la epístola «Prosíguese el pensamiento de las cartas anteriores", solo añadió dos nuevas citas, una de las cuales es de nuevo un ataque contra el lenguaje castellano de los krausistas; además completó con nuevos datos una cita procedente de la primera edición. En la tercera edición, desaparece una cita que contenía la apreciación siguiente: «(1) Gracias sobre todo al infausto plan de estudios de 1845: remedo torpe de los dictados por el eclecticismo francés». ${ }^{463}$ Encontramos una cita que fue revisada a lo largo de las tres ediciones, y contiene una interesante precisión de juicio:

\section{1a Edición}

(1) ... los compendios de Gil y Zárate, Fernández Espino y algún otro, y la admirable y nunca bastante loada History of Spanish Literature, de Jorge Ticknor. [MP, CE, 1. ${ }^{\mathrm{a}}$ ed. p. 147]

\section{2a Edición}

(1) ...los compendios de Gil y Zárate, Fernández Espino y algún otro, y la admirable y nunca bastante loada History of Spanish Literature, de Jorge Ticknor; el tratado De Hispanorum litteratura, de Martín Panzano (Mantua, 1750), y el Répertoire de l'Histoire et de la Littérature Espagnole et Portugaise, de A. Augusto Liaño (Berlín, 1820). [MP, $C E, 2 .^{\text {a }}$ ed. p. 123]

$461 \mathrm{MP}, C E, 1^{\mathrm{a}}$ ed.

462 MP, CE, 2a ed., p. 91.

463 MP, CE, 2a ed., p. 120. 


\section{3a Edición}

(1) ... los compendios de Gil y Zárate, Fernández Espino y algún otro, y la History of Spanish Literature, de Jorge Ticknor (Primera Edición), tan admirable y digna de toda loa en la parte bibliográfica, como pobre y vulgar en la parte crítica; el tratado De Hispanorum litteratura, de Martín Panzano (Mantua, 1750), y el Répertoire de l'Histoire et de la Littérature Espagnole et Portugaise, de A. Augusto Liaño (Berlín, 1820). [MP, CE, 3. ${ }^{\text {e }}$ d. p. 204]

En la tercera edición de la epístola «Mr. Masson redimuerto» sólo se introduce una cita nueva, que es una precisión de juicio; además, suaviza sus ataques a Manuel de la Revilla, haciendo desaparecer dos citas ofensivas. La primera cita suprimida decía lo siguiente: «(1) Dice el Sr. de la Revilla que no se explica lo que él juzga acritud mía, porque no se acuerda de haberme ofendido nunca. Así es, en efecto, pero yo, que jamás vengaré ofensas propias, gasto poca tolerancia con los desafueros al sentido común y a la patria». ${ }^{464}$ En la segunda cita eliminada se leía lo siguiente: «(1) Así llamaba el Boletín-Revista de la Universidad de Madrid al Sr. Revilla en aquellos venturados tiempos en que era krausista». ${ }^{465}$ Otro comentario ácido que elimina de una cita es el siguiente: «(1) ... Hace poco vimos que a un famoso orador de nuestro parlamento se le iba a hacer doctor por la universidad de Oxford, pero luego se averiguó que no era por las condiciones científicas del susodicho, sino... por haber protegido los intereses de la Alianza Evangélica en España!» ${ }^{466}$

El «Apéndice» de este primer volumen que contenía la primera parte de la obra, la dedicada a Laverde, incluía la "Contestación del Sr. D. Gumersindo Laverde a la última réplica del Sr. Azcárate», y la «Nota final», porque estos escritos eran en realidad el colofón de la primera polémica con los racionalistas, como hemos visto anteriormente. Pero la inclusión en dicho apéndice de la monografía «Fox Morcillo» requiere alguna explicación.

El rector de la Universidad de Santiago de Compostela le encargó de manera ineludible a Gumersindo Laverde el discurso inaugural del curso académico 1884-1885 de aquella Universidad. Postrado por la enfermedad, Laverde urgió reiteradamente a Menéndez Pelayo que le enviara alguna lección de su cátedra: «Cualquiera lección de las que tu explicas en catedra, v. g., la

464 MP, $C E, 1^{\text {a }}$ ed., p. 169; $2^{\text {a }}$ ed., p. 139.

465 MP, $C E, 1^{\text {a }}$ ed., p. 193; $2^{\text {a }}$ ed., p. 159

466 MP, $C E, 2^{\text {a }}$ ed., p. 149 
relativa a la poesía arábigo-española, puede servir para el caso. También seria buen tema y muy oportuno por referirse a un sabio gallego, el de las ideas estéticas del P. Feijoo. En fin, lo que más te plazca». ${ }^{467}$ Menéndez Pelayo le contestó el 21 de mayo de 1884 comprometiéndose a enviarle un embrión de discurso sobre Fox Morcillo del que se ocuparía en julio:

Leo lo que me dices respecto del discurso inaugural de ésa. Como el mes de Junio ha de estar tan ocupado para mí con exámenes, no podré hasta Julio, cuando vuelva a Santander, ocuparme en eso. Desde allí te mandaré un embrión de discurso sobre Foxo Morcillo, con las mismas notas que di a Valera para el suyo de la Academia de Ciencias Morales y Políticas que se quedó en proyecto. Creo que llamará la atención por su novedad. 468

Laverde vio con buenos ojos esta propuesta y así se lo comunicó a Menéndez Pelayo: «Buen tema es Foxo para mi discurso tanto más cuanto que, aunque mezquino, algún precedente tiene en mis antiguas lucubraciones». ${ }^{469}$ Y en esta misma carta incluye el siguiente reconocimiento poético:

Ahí va un epigrama que se me ocurrió uno de estos días.

Recibió de Encarnación

Un rizo, de amor en prenda,

$Y$ dijo con efusión

Enternecido Abelenda:

¡Lo pondré en mi colección! ${ }^{470}$

En agosto de 1884 Menéndez Pelayo envió a Laverde el prometido discurso sobre «Fox Morcillo», a propósito del cual éste le comentó lo siguiente en una carta del 4 de septiembre:

Hace ya días que mandé a Santiago el discurso. Solo cambié algo en el exordio y la peroración, corriendo el riesgo de pegar dos retazos de mal paño a un manto de purpura. Suprimí los textos latinos algo largos por no luchar con el amanuense y también por razón de uniformidad, pues solo venían los correspondientes a una pequeña parte de las citas hechas en el discurso. ${ }^{41}$

467 EMP, vol. 6, n. ${ }^{\circ} 328,19-5-1884$

468 EMP, vol. 6, n. ${ }^{\circ} 330,21-5-1884$.

469 EMP, vol. 6, n. ${ }^{\circ} 396,19-7-1884$.

$470 \mathrm{Ib}$.

471 EMP, vol. 6, n. ${ }^{\circ} 415,4-9-1884$. 
Menéndez Pelayo recibió una copia del discurso y elogió retóricamente por carta esa última mano, dada por Laverde, quien le contestó informándole de algunos pormenores sobre su lectura en el acto académico que hizo en su lugar un compañero de la Universidad de Santiago: «... veo una prueba de tu generosidad en lo que me dices del discurso inaugural. Parece que ha gustado. Dicen todos que Fernández le leyó con alma. Remití ejemplares al padre Ceferino [González], [Alejandro] Pidal, Valera y otros amigos». ${ }^{472}$ El discurso lo publicó la Universidad de Santiago de Compostela en 1885.

A finales de marzo de 1887, cuando se estaba acabando de imprimir el primer volumen y parecía que la edición constaría finalmente de tres, Menéndez Pelayo decidió incluir el discurso sobre "Fox Morcillo», bajo la rúbrica de Laverde, en el apéndice de este primer volumen. Y así se lo comunicó a su amigo y mentor en una carta del 27 de marzo, en la que además le expone la razón por la que lo incluye: «Va adelante la edición de La Ciencia Española, que quizá no quepa en dos tomos. He puesto en uno de los apéndices tu discurso sobre Foxo, para evitar que se pierda, como suele acontecer con los discursos inaugurales». ${ }^{473}$ Laverde, cuya salud se resentía en esa primavera, no le pudo responder hasta mayo: «Has hecho perfectamente en poner entre los apéndices de la Ciencia Española el discurso sobre Fox». ${ }^{474}$

Menéndez Pelayo compuso la "Advertencia preliminar» de la edición el 28 de abril de 1887, según consta al pie de la misma.

b) El segundo volumen no contenía nuevos textos, pero si alguna modificación en la disposición de los textos procedentes de la segunda edición. Los dos artículos de Alejandro Pidal se situaron como prólogo, y el «Instaurare omnia in Christo...» se convirtió en capítulo VII, quedando la "Contestación de D. Alejandro Pidal y Mon a la carta in dubiis libertas» como único texto del «Apéndice» de esta segunda parte:

- «Dos artículos del señor Alejandro Pidal y Mon sobre las cartas anteriores» I. «In dubiis libertas»

II. «La ciencia española bajo la Inquisición, por el señor José del Perojo»,

III. «Carta al Sr. D. Alejandro Pidal y Mon»

IV. «Carta al Sr. Director de La España».

V. «La Antoniana Margarita de Gómez Pereira. Carta al señor Juan Valera». VI. «La patria de Raimundo Sabunde».

472 EMP, vol. 6, n.o 452, 22-10-1884.

473 EMP, vol. 8, n. ${ }^{\circ} 310,27-3-1887$.

474 EMP, vol. 8, n.o 362, 3-5-1887. 
VII. «Instaurare omnia in Christo. Carta al Sr. D. Alejandro Pidal y Mon»; - Apéndice:

«Contestación de D. Alejandro Pidal y Mon a la carta in dubiis libertas».

En la tercera edición, el «In dubiis libertas» no experimentó cambios, y añadió una sóla cita de precisión de juicio. Y lo mismo sucedió con los textos «La patria de Raimundo Sabunde», y el «Instaurare omnia in Christo. Carta al Sr. D. Alejandro Pidal y Mon», en los que no introdujo ninguna cita nueva. Aunque en «La Antoniana Margarita de Gómez Pereira. Carta al señor Juan Valera», amplió dos citas de la edición anterior, ${ }^{475}$ e introdujo ocho citas nuevas, todas de erudición -entre las que destaca una muy extensa, dedicada a la demostración, propia de Pedro Bayle, de que la tesis del «automatismo» procede de Gómez Pereira-, tampoco cabe hablar en relación a ella de cambios significativos.

Donde sí introdujo aumentos considerables, como supo ver enseguida Laverde que los había sugerido, fue en los textos polémicos contra Perojo; para ser más precisos, en el segundo de ellos, pues en el tercero no añadió ninguna cita nueva, y en el primero se limitó a introducir dos nuevas, una en relación al proceso inquisitorial del poeta Esteban Manuel de Villegas. En efecto, en la «Carta al Sr. D. Alejandro Pidal y Mon» amplió una cita de la segunda edición ${ }^{476}$ e introdujo dieciséis citas nuevas, muchas de ellas extensas o muy extensas, con datos relevantes sobre matemáticos, físicos y científicos naturales españoles de los siglos XVI, XVII y XVIII, verdaderamente relevantes en la refutación de la argumentación de José del Perojo. Entre ellas encontramos: referencias históricas novedosas y extraordinariamente significativas, v. g., a Omerique, a Caramuel o a la Academia de Medicina y Física experimental en Sevilla, etc.; citas raras y curiosas, como la de una parte del comentario copernicano de Zúniga al capítulo 9, versículo 6, del Libro de Job, censurado por la Inquisición; o la contundente refutación de la desacertada tesis que en relación a los matemáticos españoles, sostuvo el académico José de Echegaray en su discurso de ingreso en la Real Academia de Ciencias Exactas, Físicas y Naturales.

c) El tercer volumen se componía en su totalidad de textos completamente nuevos, los cuales se integraron en el índice con un orden que no se correspondía con su fecha de composición:

- «Rámon Lull (Raimundo Lulio)»

- «Himno a la Creación», del poeta hispano judío Judah Levi

475 Nuestras citas 739 y 743.

476 Nuestra cita 705. 
- «Contestación a un filósofo tomista»

- «Réplica al Padre Fonseca»

- «Inventario Bibliográfico de la Ciencia Española»

- Apéndice:

«El tradicionalismo en España durante el siglo XviII», por D. Gumersindo Laverde Ruiz.

En la «Contestación de un tomista a un filósofo del Renacimiento» (1882), el entonces regente de Estudios y profesor de Teología en el Convento de los Dominicos en Ocaña, el padre Joaquín Fonseca O. P., confiesa que se habría interpuesto en el camino de Menéndez Pelayo, desde que conoció su polémica con Pidal en La España, de no habérselo impedido entonces su nombramiento como rector de la Universidad de Santo Tomás en Manila, cargo que ejerció entre 1878 y 1880. Sin embargo, el discurso de ingreso del historiador santanderino en la Real Academia Española, La poesía mistica en España (leído el 6-3-1881), le sirvió al dominico para intentarlo mientras intervenía en un Triduo dedicado a Santo Tomás de Aquino en marzo de 1881 por los PP. Dominicos del Convento de Corias con motivo del patronato universal de las Escuelas Católicas adjudicado al Angélico Doctor por la Santidad de León XIII. Con una carta, fechada el 3 de octubre de 1881, ${ }^{477}$ le envió a Menéndez Pelayo el impreso del Triduo..., que incluía una «nota 33», ${ }^{478}$ dirigida contra la posición tradicional pelayana frente a la escolástica tomista.

Debieron de desagradar sobremanera a Menéndez Pelayo, en la mencionada nota, el exclusivismo tomista y el indocto dogmatismo del teólogo dominico que ,tomándole por un neófito, representaba ser su regente de estudios. Y, desde luego, ni tomó en consideración la posibilidad de responderle, extendiendo así su polémica con los partidarios del tomismo íntegro y de su renacimiento en las escuelas, que a su juicio sólo podía servir de argumento a los enemigos del catolicismo. Ya había dejado bien definida su posición ante el tomismo en la polémica con Pidal, de manera terminante en su Instaurare omnia in Christo, siendo bien consciente de que su aceptación era minoritaria en los órganos de opinión católicos. Así que el envío del dominico quedó olvidado entre los papeles del joven académico que no se dignó a contestarle.

Las cosas no quedaron así, sin embargo. La estrategia de confrontación y escándalo frente a la Unión Católica y sus miembros más destacados, seguida de manera creciente por los carlistas a lo largo de 1882, llevó a

477 EMP, vol. 5, n. ${ }^{\circ} 177$.

478 Oviedo: Imp. Vallina, 1881, pp. 57-74. 
estos tradicionalistas íntegros no sólo a publicar en su órgano de opinión, El Siglo Futuro, la citada nota 33 de Fonseca, bajo el título «Defensa de la doctrina de Santo Tomás por el R. P. ...», ${ }^{479}$ sino a exigir repetidamente desde sus páginas la respuesta de Menéndez Pelayo. A esta estrategia de El Siglo Futuro se sumó enseguida otro órgano integrista, La Ciencia Cristiana, dirigido por el tomista íntegro Juan Manuel Ortí y Lara, que lo publicó bajo el ofensivo título "Defensa de la filosofía cristiana». ${ }^{480}$ Obligado de esta manera, el historiador santanderino compuso calamo currente y publicó su "Contestación a un filósofo tomista» en el periódico La Unión (16-8-1882), que era el órgano de opinión de la Unión Católica. El texto fue reproducido también por La Ciencia Cristiana ${ }^{481}$ y por otros diarios de provincias. Varias semanas se demoró la réplica del dominico, "Contestación de un tomista a un filósofo del Renacimiento» que alcanzó dimensiones de libro, se fue publicando por entregas en El Siglo Futuro (14 a 23-9-1882), y fue reproducida también por La Ciencia Cristiana (30 de octubre, 15 y 30 de noviembre, 15 y 31 de diciembre, siempre en 1882). La breve pero contundente respuesta de Menéndez Pelayo que llevaba por título «Réplica al R. P. Fonseca», se publicó en La Unión (2 a 4-10-1882), y ya no fue reproducida por La Ciencia Cristiana. No deja de ser curioso que el historiador santanderino trabajara por entonces principalmente en la composición del tercer tomo de los Heterodoxos...

A finales de 1882, Menéndez Pelayo no asociaba con La ciencia española sus textos polémicos contra el padre Fonseca, y se proponía más bien publicarlos en un folleto aparte. Así lo expresaba en una carta a Laverde del 3 de noviembre de ese año:

Celebro que no te haya parecido del todo mal mi réplica al P. Fonseca. Pienso reimprimir ésta y la anterior en un folleto, corrigiendo las erratas que sacaron en La Unión, pero espero a ver si el susodicho Padre replica algo, o si Ortí y Lara toma la cuestión a su cargo, como parece indicar en La Ciencia Cristiana. Si así fuere, contestaré a Ortí, y añadiré la contestación al folleto. ${ }^{482}$

La polémica con estos tomistas íntegros se cerró con esa «Réplica al R. P. Fonseca» que no fue contestada por ninguno de los dos; pero Menéndez Pelayo no llegó a publicar el mencionado folleto con sus textos polémicos.

479 El Siglo Futuro, 5 y 9-8-1882.

480 La ciencia cristiana, 30-10-1882.

481 Vol. XXIV, n. ${ }^{\circ} 139$, el 30-10-1882)

$482 E M P$, vol. 5, n. ${ }^{\circ} 404$. 
La composición del discurso de ingreso en la Real Academia de la Historia, «La historia considerada como obra artística» (1882), y la preparación de la Historia de las ideas estéticas... le fueron alejando de esa penosa circunstancia.

Menéndez Pelayo debió de tomar la decisión de incluir sus textos polémicos contra el padre Fonseca en la tercera edición de La ciencia española, cuando empezó a prepararla en el verano de 1886.

El «Himno a la Creación», del poeta hispano-judío Jehudah Halevi (1070-1141), fue un descubrimiento que hizo el historiador santanderino mientras preparaba la composición del capítulo tercero de la primera parte de su Historia de las ideas estéticas..., titulado «De las ideas estéticas entre los árabes y judíos espańoles». El entusiasmo de Menéndez Pelayo por esta oda que trasmite a los habituales de su círculo intelectual y se manifiesta en su correspondencia de los años 1883 y 1884, le llevó a publicarla, primero en la Ilustración Española y Americana ${ }^{483}$ y, meses más tarde, en Palma de Mallorca. ${ }^{484} \mathrm{Su}$ interés en difundirla seguía vivo en el verano de 1886, cuando debió de decidir incluirla en la tercera edición de La ciencia española, en la que introdujo además nuevas referencias al autor de El cuzari, procedentes de su Historia de las ideas estéticas..., dentro de los textos «Monografías expositivo-críticas» e «Inventario de la Ciencia Española». El «Himno a la Creación» era a los ojos de nuestro historicista católico un monumento de la ciencia espańola medieval.

En las elecciones de 1884 al Congreso de los Diputados, Menéndez Pelayo se presentó dentro de la lista del Partido Liberal Conservador, de Cánovas, en el distrito electoral de Mallorca. El joven candidato visitó la patria de Ramon Llull, donde tenía bastantes amigos lulianos, con José Ma Quadrado a la cabeza, a instancias del cual preparó entonces su discurso sobre el beato mallorquín. Menéndez Pelayo pronunció el 1 de mayo su discurso «Ramón Lull (Raimundo Lulio)» en el Instituto de la Baleares que lleva su nombre. Con los más de treinta volúmenes de libros raros lulianos, entre ellos las Contemplaciones, el Félix o de las maravillas del orbe, el Ascenso y descenso del entendimiento, los tratados lógicos, los de Medicina, etc., el tomo del Acta sanctorum relativo a Lulio, las Disertaciones históricas..., de Jaime Custurer, etc., que se trajo de su feliz paso por la isla, en la que además vio códices y manuscritos lulianos en bibliotecas públicas y particulares, preparó de vuelta en Madrid, en mayo, la publicación del discurso que envió al editor a primeros de junio.

483 N.o 1, 1884, 8 de enero, páginas 7 y 10.

484 Imprenta de la Biblioteca Popular, MDCCCLXXXIV. 
Menéndez Pelayo fue elegido diputado del Parlamento español el 4 de mayo ${ }^{485}$ y, el 9 de junio, juró y tomo su asiento en el Congreso. En esta legislatura desarrolló alguna actividad política como consejero de Instrucción Pública. El joven diputado corrigió este mes ${ }^{486}$ las pruebas del discurso que debió de salir de la Imprenta de la Biblioteca Popular, en Palma de Mallorca, la tercera o cuarta semana de julio de 1884. Cuando Menéndez Pelayo se puso a preparar la tercera edición de La ciencia española, en el verano de 1886, no dudó en incluir este discurso sobre el gran místico, teólogo y filósofo que, a su juicio, creó una de las tradiciones filosóficas capitales de España, el lulismo; y así lo hizo constar en la «Advertencia preliminar» del 28 de abril de 1877.

El trabajo más largo y costoso de la tercera edición de La ciencia española, que debió de emprender desde el primer momento de su preparación, en julio de 1886, y dar por concluido provisionalmente en enero de 1889, fue la composición del «Inventario bibliográfico de la ciencia española». A finales del verano de 1886, en efecto, Menéndez Pelayo le confirma a Laverde que ha estado muy ocupado preparando la nueva edición de La ciencia española en la que ha incluido

un Inventario Bibliográfico o por mejor decir reseña cronológica del desarrollo de cada uno de los conocimientos humanos en Espańa, reduciéndolo todo al menor espacio posible, para que sea como la quinta esencia de todas nuestras bibliografías con mucho que ellas omiten. Además en el texto de las Cartas he introducido muchas adiciones, corregido bastante el estilo y reforzado los argumentos. Creo, pues, que la tercera edición será un libro casi enteramente nuevo. ${ }^{487}$

Laverde que vio con buenos ojos la inclusión del «Inventario», le sugirió a Menéndez Pelayo en varias cartas numerosas indicaciones bibliográficas que, en su mayor parte, ya había consultado o estaba consultando. A finales de octubre de 1886, Menéndez Pelayo le escribía a Laverde que la nueva edición de La ciencia española empezaría a imprimirse en noviembre, y le exponía las razones por las que el inventario dejaba fuera las obras de los autores contemporáneos y utilizaba una anotación simplificada de las referencias bibliográficas:

En el Inventario Bibliográfico me he concretado a los autores que florecieron hasta fines del siglo XvIII o principios del actual, puesto que la

485 EMP, vol. 6, n.o 319, 4-5-1884.

486 EMP, vol. 6, n. ${ }^{\circ} 372,24-6-1884$.

487 EMP, vol. 8, n. ${ }^{\circ}$ 64, 25-9-1886. 
polémica versó únicamente sobre nuestra ciencia antigua. El incluir a los contemporáneos alargaría desmesuradamente este apéndice, que así y todo no bajará de 200 páginas en letra menuda. He procurado utilizar todos los trabajos bibliográficos de que tengo noticia, presentando el resumen y la quinta esencia de ellos: nombre del autor, títulos de sus principales obras y fecha de la edición. Cuando contienen algún descubrimiento notable, también lo indico en las menos palabras posibles. Los libros de ambos Colmeiros me han servido mucho, el uno para los botánicos y el otro para los economistas. Pero ha habido muchas secciones, en que no he tenido más recurso que mis propios libros y Nicolás Antonio, v. g. los teólogos, escriturarios \&., las cuales, así y todo, creo que resulten muy nutridas, y que ofrecerán bastante originalidad... ${ }^{488}$

La demora de un año y medio sufrida por la publicación de este tercer volumen se debió en gran medida, según expusimos anteriormente, a la larga y difícil composición de este inventario que fue una de sus ocupaciones intelectuales hasta enero de 1889. El 19 de noviembre de 1888, Menéndez Pelayo le explicaba a Laverde la tardanza del tercer volumen como sigue:

Me ha costado un trabajo ímprobo el ordenar tantas papeletas, y así y todo no estoy contento de mi trabajo, ni le considero más que como ensayo o borrador para otra edición. En fin, bueno o malo, le voy a echar a la calle antes de fin de año, e inmediatamente después un tomo de Estética. ${ }^{489}$

Menéndez Pelayo siguió anotando componentes del «Inventario» después de publicada la tercera edición de la obra. Hemos encontrado los tomos de la tercera edición de La ciencia española (Polémicas, proyectos y bibliografía) (1887-1889) que utilizaba el maestro y en los que hizo algunas anotaciones con vistas a la ampliación del «Inventario» en una posterior edición revisada. Tenemos certeza de que las anotaciones son de Menéndez Pelayo, porque así lo atestigua Adolfo Bonilla ${ }^{490}$ en la portada del tomo III de la obra, y por la evidencia misma de la letra, que es de don Marcelino. Estos tomos de la tercera edición pertenecían a la biblioteca particular de Adolfo Bonilla San Martín, que fue el albacea encargado de continuar la edición definitiva de las obras completas de Menéndez Pelayo. Esta biblioteca fue adquirida por Lucio Gil de Fagoaga a la viuda de Adolfo Bonilla, y pasó a constituir el núcleo de

488 EMP, vol. 8, n. ${ }^{\circ} 108,24$ octubre 1886.

489 EMP, vol. 9, n. ${ }^{\circ} 386$.

490 La portada del tomo III de La ciencia española. (Polémicas, proyectos y bibliografía) (1887-1889) que se encuentra en la Biblioteca de la Fundación Fagoaga, lleva la siguiente anotación manuscrita de Bonilla San Martín: "(Con algunas correcciones autógrafas de M. Menéndez y Pelayo)», A. Bonilla. 
su biblioteca, que se conserva dentro de la Fundación Fagoaga en Requena. Por desgracia, no se han encontrado papeles con notas entre las hojas de los tomos, y las anotaciones o marcas escritas en los márgenes de los tomos son escasísimas. En realidad, sólo cuatro de ellas tienen interés desde el punto de vista de la revisión del texto, ${ }^{491}$ pues mencionan piezas del inventario que no fueron incluidas posteriormente ni en la «edición definitiva», ni por la Edición Nacional de la obra. Las cuatro anotaciones relevantes para la edición de la obra son las siguientes: en la página 191, Menéndez Pelayo anota «P. Izquierdo (P. (¿?) all, Pharus scientiarum», ${ }^{492}$ que debía ser introducida entre los lulianos españoles después de la entrada $\mathrm{D}$. Alonso de Cepeda; en el margen de la página 192, al final del apartado «Influencia de la filosofía luliana fuera de España», anotó «Ibo Salzinger»; ${ }^{493}$ entre el margen izquierdo y el inferior de

491 Otras anotaciones parecen marcas de lectura para uso en algún trabajo posterior. Así, en la página 192 marca con una cruz azul de gran tamaño las entradas «Domingo de Soto», «Diego de Astudillo» y "Juan Martínez de Prado»; en la página 398, dentro del apartado «C) Botánica», marca con una línea perpendicular al margen las líneas 11-30; en la página 238, marca en azul el párrafo: «Antonio Gómez: In leges tauri Commentarius (1555)...; en la página 412, «E) Zoología y tratados generales de Historia natural», marca con una línea perpendicular al margen las líneas 22-33; en la página 426, marca con una línea perpendicular al margen las líneas 25-35. Añadiré que en la página 203, línea 5, corrige una errata, «racionalida», añade «ad». Todas estas páginas corresponden al mencionado tomo III de La ciencia española (1887-1889), que se encuentra en la Fundación Fagoaga.

492 En el margen derecho e inferior de la página 191 del tercer tomo de la $3^{a}$ edición de La ciencia española (Polémicas, proyectos y bibliografía) (Madrid, 1887-1889), que se conserva en el Fondo Bonilla San Martín de la biblioteca de la Fundación Fagoaga, en Requena (en adelante citaré este volúmen, CE, 3a ed. [FF], t. III, p. 191), Menéndez Pelayo dejó esa anotación, dispuesta para la posterior ampliación del «Inventario» en una previsible $4^{a}$ edición revisada. Menéndez Pelayo se está refiriendo a la obra «R. P. Sebast. Izqvierdo alcarazensis soc. Iesv, svpremi s. inqvisitionis senatvs censoris et olim complvti ss. theologiae professoris pharvs scientiarvm vbi qvidqvid ad cognitionem hvmanam humanitùs acqusibilem pertinet, vbertim iuxtà atque succincte pertractatur: scientia de scientia ob svmmam universalitatem vtilissima, 1659

493 En CE, $3^{\text {a }}$ ed. [FF], t. III, p. 192, Menéndez Pelayo anota esa referencia a Ivo Salzinger (1669-1728), que fue el editor de la edición maguntina de las obras completas de Ramon Llull en 8 volúmenes, «Moguntiae: ex officina typographica Mayeriana, per Joannem Georgium Häffner, 1721-1742». En el volumen primero incluyó escritos suyos: Testimonia virorum ilustrium...; Perspicilia lulliana philosophica..., que es una defensa de los tratados lulianos de alquimia; y Revelatio secretorum artis, que es una exposición propia del sistema luliano. Salzinger reemprendió este tema en su obra Praecusor introductoriae in Algebram speciosam universalem vel artem magnam universalem sciendi et demonstrandi B. Raymundi Lulli .... Ex officina Typographica Mayeriana: per Joannem Georgium Häffner, 1723». Ver, S. Trias Mercant, Diccionari d'escriptors lul.listes, Palma, Ediciones UIB, Col-lecció Blaquerna 6, 2009, p. 389 y ss. 
la página 206, incluyó la anotación «Democrates alter, sive de justi belli causis apud Indos», que es una nueva obra de Juan Gines de Sepúlveda que Menéndez Pelayo quería introducir entre el Democrates y la Apología del Democrates alter, ${ }^{494}$ en la parte superior de la página 209, escribió «Don José de Olmeda y León, Elementos del Derecho público de la paz y de la guerra, 1771», que es la entrada de esta obra dentro de los tratadistas de política en el siglo XVIII, entre Miguel de la Iglesia Castro y Joaquín Marín y Mendoza. ${ }^{495}$

La inclusión del «Apéndice» del tercer volumen, que contiene «El tradicionalismo en España durante el siglo xvıII», de Gumersindo Laverde, responde a una propuesta que le hizo éste a Menéndez Pelayo en una carta del 24 de septiembre:

Si no pareciese mal, gustaría de ver impreso como apéndice a esta obra, mi artículo sobre El Tradicionalismo en España, porque el libro de mis Ensayos escasea mucho y apenas contiene otro escrito digno de conservarse más que el mencionado. En caso de que te plazca esta idea, harás el favor de suprimir la indicación que hago sobre la identidad del filósofo Pereira y el sordo-mudista del mismo apellido. ${ }^{496}$

A Menéndez Pelayo le pareció muy bien la idea y así se lo hizo saber en su respuesta fechada el 19 de octubre de $1887 .{ }^{497}$ El texto que utilizó Menéndez Pelayo, y sobre el que hizo las correcciones que le pidió Laverde, fue el publicado por García Romero en la Revista España en 1868, ${ }^{498}$ pues ni Laverde, ni él, quisieron desencuadernar los ejemplares contados de los Ensayos... que tenían. 499

\section{Tercera edición, nueva impresión}

Esa tercera edición, La ciencia española. (Polémicas, proyectos y bibliografía), conoció una nueva impresión a cargo de la imprenta Pérez Dubrull (?) en la Tipografía de la Revista de Archivos Museos y Bibliotecas en tres volúmenes en 8. ${ }^{\circ}$ : el primero, impreso en 1915, salió con 412 páginas; el segundo, impreso también en 1915, salió con 486 páginas; y el tercero, impreso en 1918,

494 En $C E, 3^{\text {a }}$ ed. [FF], t. III, p. 206, Menéndez Pelayo introdujo esa referencia al «Democrates alter, sive de justi belli causis apud Indos», de Sepúlveda. Se da el caso de que años después don Marcelino tradujo y preparó una edición castellana de esta obra que publicó en el Boletín de la Real Academia de la Historia, tomo 21 (1892), pp. 257-369.

495 En $C E, 3 .^{\text {a }}$ ed. [FF], t. III, p. 209.

496 EMP, vol. 8, n. ${ }^{\circ} 520$.

497 EMP, vol. 8, n. ${ }^{\circ} 544$.

498 Tomo I, n. ${ }^{\circ} 2,1868$, pp. 219-234)

499 EMP, vol. 9, n. ${ }^{\circ}$ 29, 27-11-1887. 
salió con 506 páginas. En la portada se la presenta como cuarta edición de la obra, dentro de la «Colección de Escritores Castellanos. Críticos», pero en realidad es una reimpresión de la tercera y carece de interés crítico.

\section{Tercera edición, reimpresión}

En 1947, se reimprimió de nuevo esta tercera edición en Buenos Aires. Salió esta edición furtiva en tres volúmenes de los talleres de la Compañía Impresora Argentina, publicada por la editorial Emecé, Editores S. A., dentro de su Biblioteca Emecé, números 74-76: el primer volumen, con 313 páginas, el segundo, con 358 páginas, y el tercero, con 444 páginas. Esta edición carece así mismo de interés crítico.

\section{Cuarta edición: edición definitiva}

En 1911, el editor Victoriano Suárez, propietario de la Librería General Victoriano Suárez, puso en marcha la EDICIÓN DEFINITIVA, revisada por su autor, de las Obras Completas de Menéndez Pelayo, bajo la dirección de éste y con la colaboración de su discípulo Adolfo Bonilla San Martín. El gran editor asturiano publicó ese mismo año un Prospecto de esta edición de las obras completas, que era la segunda, en el que subrayaba su importancia, daba pormenores de la misma y expresaba su firme voluntad de llevarla hasta el final.

La edición era de la máxima importancia, a su juicio, porque se iba a convertir en la edición crítica de las obras de «la gloria más pura y excelsa que registra la Historia de la crítica hispana», ${ }^{500}$ con el texto auténtico establecido de manera definitiva por el propio Menéndez Pelayo, con la colaboración de su discípulo entonces más cercano. ${ }^{501}$

El Prospecto presentaba el título de las XIX series que compondrían esta edición de las obras completas y adelantaba detalles materiales de la misma, como los siguientes: «Los tomos serán de tamaño $4 .^{\circ}$ español, aproximadamente de 500 páginas, e impresos en papel y tipos idénticos a los del presente prospecto. Se publicarán con la posible periodicidad...».502

La prematura e inesperada muerte de Marcelino Menéndez Pelayo el diecinueve de mayo de 1912, lejos de paralizar, estimuló la edición definitiva de

500 «Prospecto», en Adolfo Bonilla San Martín, Bibliografía de D. Marcelino Menéndez y Pelayo, Madrid, Librería General Victoriano Suárez, 1911, pp. 33 ss.

501 El propio Adolfo Bonilla y San Martín fue el autor del «Prospecto».

502 «Prospecto», op. cit., pp. 33 ss. 
sus obras, que siguió desarrollándose bajo la dirección de Adolfo Bonilla San Martín, el discípulo albacea de la documentación dejada por el maestro. El maestro santanderino llegó a ver publicados el primer volumen de la $1 .^{a}$ serie, Historia de los heterodoxos españoles (1911), y el primer volumen de la 5. a serie, Historia de la poesía hispano-americana desde sus orígenes hasta 1892 (1911), y le sorprendió la muerte cuando preparaba el segundo volumen de esta $5 .^{a}$ serie.


(1917, 1918), el segundo volumen de la 5. a serie, Historia de la poesía hispa-


castellana en la Edad Media (1913-1916), el volumen de la 8. a serie, Ensayos de crítica filosófica (1918), y los seis volúmenes de la 19. a serie, Estudios sobre el teatro de Lope de Vega (1919-1927), se publicaron bajo la dirección de Adolfo Bonilla, que murió también prematuramente el 17 de enero de 1926. En octubre de 1923 había fallecido el promotor editorial de la edición, don Victoriano Suárez.

El bibliotecario de carrera e historiador, Miguel Artigas Ferrando, que desde mayo de 1915 se había convertido en el director de la biblioteca histórica legada por Menéndez Pelayo a la ciudad de Santander, asumió la coordinación de la edición definitiva tras la muerte de Bonilla, y como tal preparó la publicación de los cuatro últimos volúmenes de la primera serie, Heterodosos... (19281932), y los dos volúmenes de la novena serie, La ciencia española (1933). La EDICIÓN DEFINITIVA de las obras de Menéndez Pelayo llegó hasta la publicación de esta cuarta edición de La ciencia española, y sufrió la interrupción impuesta por la Guerra Civil; sin embargo, fue retomada de manera consciente por los promotores de la EDICIÓN NACIONAL que la corrigieron y completaron:

Preparándose estaba -escribe Ibánez Martín- la Historia de las Ideas Estéticas y la reimpresión de algunos tomos de la de los Heterodoxos, cuando sobrevino la guerra de liberación gloriosamente vencida por nuestro Caudillo. La guerra, causa de tantas perturbaciones, ha sido el último obstáculo que ha impedido hasta ahora, la publicación de las Obras Completas». ${ }^{503}$

En 1933, en efecto, se publicó la cuarta edición de La ciencia española. (Polémicas, proyectos y bibliografía), como novena serie de la edición definitiva de las obras completas de Menéndez Pelayo, en dos volúmenes en 4. ${ }^{\circ}$ el volumen primero, que era el n. ${ }^{\circ} 20$ de la Edición, salió con 478 páginas; y el volumen segundo que era el n. ${ }^{\circ} 21$ de la Edición, apareció con 479. La edición era en realidad una nueva impresión del texto de la tercera edición y definitiva tras la muerte de su autor, y que corrió a cargo de la casa Antonio Pérez Dubrull para la Librería de Victoriano Suárez.

503 «Prólogo», MP, OC, Madrid, CSIC, 1940, n. ${ }^{\circ} .1$, p. XV. 
Miguel Artigas Ferrando, que se encargó de ordenar y dirigir esta nueva impresión de la obra, mantuvo los mismos textos de la tercera edición y su disposición en la misma, detalló los distintos apartados del «Inventario bibliográfico de la ciencia española» en el índice de la obra, y modificó el «Apéndice» del último volumen de la tercera edición, que pasó a denominarse «Adiciones». En estas «Adiciones», que colocó al final del segundo volumen, mantuvo el texto de Laverde, «El tradicionalismo en Espańa durante el siglo XVIII», y añadió dos textos nuevos de Menéndez Pelayo: «Esplendor y decadencia de la cultura científica española» (1894), y el «Prospecto de la nueva biblioteca de autores españoles» (1905).

«Esplendor y decadencia de la cultura científica espańola» es un texto de Menéndez Pelayo incluido por éste dentro de su «Revista crítica», publicada por La España Moderna en su número de febrero de $1894,{ }^{504}$ en la que reseña el discurso de ingreso de Acisclo Fernández Vallín en la Real Academia de Ciencias Exactas, Físicas y Naturales, del 7 de enero de 1894, que se había publicado previamente en forma de libro: Cultura cientifica en España en el siglo XVI. ${ }^{505}$ Esta reseña del historiador cántabro se reeditó trece años después en Estudios de critica literaria. Cuarta serie, formando parte de la edición de sus Obras Completas en la Colección de Escritores Castellanos, n. ${ }^{\circ} 136 .{ }^{506}$

Menéndez Pelayo escribió este "artículo largo sobre los discursos (muy importantes) de Vallín y D. Miguel Merino en la Academia de Ciencias Exactas...» en los primeros días de febrero de $1894 .{ }^{507}$ Se lo agradecieron por carta, tanto Vallín, ${ }^{508}$ como Merino $^{509}$; y José M. Carracido ${ }^{510}$ le confirmó la buena acogida de que fue objeto por los académicos de la RACEFN:

[Escribe Vallín a Menéndez Pelayo]... hasta hace una hora que el vecino del principal me envió el último número de La España Moderna no tenía noticia ninguna del precioso artículo que ha publicado V. sobre mi discurso de entrada en la Academia de Ciencias.

Acabo de leerle en este momento con satisfacción cumplidísima y por su marcada benevolencia al expresar su juicio acerca de mi trabajo de diez años de constante y fatigosa labor le doy no un millón de gracias sino mil

504 Tomo LXII, año VI, n. ${ }^{\circ}$ 2, pp. 138-178. Las páginas 147-178 contienen la reseña del discurso.

505 Madrid, Ribadeneyra, 1893, 337 páginas.

506 Madrid, Tipografía de la Revista de Archivos, 1907.

507 EMP, vol. 12, n. ${ }^{\circ}$ 542, 6-2-1894).

508 EMP, vol. 12, n. ${ }^{\circ} 548,13-2-1894$.

509 EMP, vol. 12, n. ${ }^{\circ} 555,15-2-1894$.

510 EMP, vol. 12, n.o 551, 14-2-1894. 
millones porque tantas merecen las frases lisonjeras con que me honra, y eso sin contar con que al ocuparse V. con tanta extensión de mi discurso y del muy precioso de Merino, nos da $\mathrm{V}$. una muestra de muy señalada deferencia que no agradeceremos nunca bastante.

En la traducción francesa que se está haciendo en Paris tendré muy presentes las valiosas y eruditísimas observaciones que $\mathrm{V}$. con muy indiscutible autoridad y competencia apunta en su juicio crítico y hasta algunas de ellas pueden servir de nueva confirmación de mis conclusiones del texto... ${ }^{111}$

$\mathrm{El}$ «Prospecto de la nueva biblioteca de autores españoles» es un texto escrito bastantes años después. El veintiuno de marzo de 1903, la Librería editorial de Bailly-Baillière, que fundara el editor madrileño Carlos Bailly-Baillière, confirmó por carta a Menéndez Pelayo que liberado el último obstáculo se ponía en marcha bajo su dirección la Nueva Biblioteca de Escritores Españoles, pidiéndole además el prólogo de su tomo para publicitarla cuanto antes. ${ }^{512}$ Menéndez Pelayo debió de escribir bastante más tarde el «Prospecto editorial» de esa Biblioteca que se publicó por separado en 1905 a fin de publicitarla. ${ }^{513}$

La dirección de la Nueva Biblioteca de Autores Españoles y la composición de Orígenes de la novela, que salió en cuatro volúmenes, los números 1, 7, 14 y 21 de la misma (el n. ${ }^{\circ} 21$, póstumo, ya no contenía materiales del autor), entre 1905 y 1915, se convirtió en una de las ocupaciones centrales de Menéndez Pelayo desde 1903 hasta la fecha de su fallecimiento. En 1943, la Edición Nacional de las obras de Menéndez Pelayo publicó Orígenes de la Novela, en cuatro volúmenes, los números del 13 al 16 de la edición, e incluyó como Apéndice II del volumen cuarto ese «Prospecto de la Nueva Biblioteca de Autores Españoles, publicada bajo la dirección del Excmo. Sr. D. Marcelino Menéndez y Pelayo, de la Real Academia Española, director de la Biblioteca Nacional». ${ }^{514}$

\section{Quinta edición: Edición Nacional}

El ministro de Instrucción Pública del primer gobierno de Franco, Pedro Sainz Rodríguez, asignó, por decreto (del 19 de mayo de 1938), al Instituto de España la tarea de publicar la edición nacional de las Obras Completas de Menéndez Pelayo. Su sucesor en el cargo, una vez acabada la Guerra

$511 E M P$, vol. 12, n. ${ }^{\circ} 548$.

512 EMP, vol. 16, n. ${ }^{\circ}$ 771, 21-3-1903.

513 Enrique Sánchez Reyes, Biografía crítica y documental de Marcelino Menéndez Pelayo, Santander, CSIC, 1974, c. XVIII, p. 310. Ver también, EMP, vol. 17, n. ${ }^{\circ}$ 741, sin fecha.

514 MP, OC, CSIC, 1943 , n. ${ }^{\circ} 16$, pp. 269-280. 
Civil, José Ibáñez Martín, firmó el «Prólogo a la presente edición» que aparecía en el primer volumen de la Historia de las ideas estéticas en España (1940), primera de las series de la Edición Nacional que daba continuidad a la Edición Definitiva. El Consejo Superior de Investigaciones Científicas, recién establecido por ley del 24 de noviembre de 1939, fue finalmente la institución encargada de llevar adelante la tarea, para la cual designó como directores a «Don Miguel Artigas, Director de la Biblioteca Nacional y Don Enrique Sánchez Reyes, Director de la Biblioteca de Menéndez Pelayo, en Santander». ${ }^{515}$ Ibáñez Martín subrayaba con razón el conocimiento y el esmero con el que los editores preparaban los textos de la edición:

La revisión de textos se hace con todo detenimiento, compulsándolos con las obras originales citadas, precisando a veces con más detalles el pasaje y teniendo siempre a la vista los autógrafos del Maestro y las numerosas notas y apostillas que dejó en los márgenes de anteriores ediciones de sus libros. ${ }^{516}$

Aunque los manuscritos de los textos de Menéndez Pelayo que se conservan en su biblioteca histórica, quedaron ordenados siguiendo las series y volúmenes de la Edición Nacional; lo cierto es que esta edición, lejos de recoger las variantes introducidas en las sucesivas ediciones que preparó su autor, y de estas con relación a sus manuscritos conservados -que, v. gr., en el caso de La ciencia española, eran muy pocos y algunos en bastante mal estado-, las ocultó, fijando el texto de la tercera edición que quedó como definitivo tras la defunción de su autor. Lo que ya había hecho Artigas al preparar la cuarta edición.

Esta Edición Nacional se convirtió a la postre en una nueva edición que sacó a la luz las obras completas de Menéndez Pelayo divididas en catorce series y sesenta y cinco volúmenes, entre la publicación de la primera serie, Historia de las ideas estéticas en España (1940), y la publicación de la última, Varia (1956-1959). La Edición Nacional publicó la quinta edición de La ciencia española en tres volúmenes, los números LVIII, LIX y LX de la misma: el volumen I, de 1953, salió con IV+384 páginas; el volumen II, de 1953, contenía 438 páginas; y el volumen III, de 1954, tenía 372 páginas. La Imprenta Aldus de Santander materializó esta quinta edición preparada por Enrique Sánchez Reyes.

En la «Advertencia de esta edición» que firmaron Enrique Sánchez Reyes y Rafael de Balbín Lucas, leemos que se propusieron hacer lo «que pudiéramos llamar quinta edición, grandemente aumentada de La ciencia

515 MP, OC, CSIC, 1940, n. ${ }^{\circ}$ 1, p. XIX.

$516 \mathrm{Ib}$. 
española» que incluyera todos los textos de la polémica, facilitando así su lectura completa. Los editores detallaban así los textos nuevos introducidos y su emplazamiento en la obra:

En el primero de nuestros tres volúmenes aparecen los siguientes escritos no coleccionados en anteriores ediciones: Manuel de la Revilla, Revista critica, artículo al que contestó Menéndez Pelayo con el titulado Mr. Masson Redivivo; otro del mismo Revilla, titulado La filosofía española, que es al que replica D. Marcelino con el llamado Mr. Masson Redimuerto; Gumersindo de Azcárate, Una carta sobre la filosofía española, carta a la que envió respuesta Laverde; José del Perojo, La ciencia española bajo la Inquisición, largo alegato que refuta Menéndez Pelayo nada menos que en tres, tampoco breves, cartas dirigidas a D. Alejandro Pidal.

En el segundo de nuestros volúmenes se insertan como nuevos los dos artículos del P. Joaquín Fonseca, O. P., encabezados con estos titulares: Defensa de la filosofía cristiana y Contestación de un tomista a un filósofo del Renacimiento, trabajos que tuvieron su adecuada réplica en los publicados por Menéndez Pelayo, con los títulos de Contestación a un filósofo tomista y Replica al R. P. Fonseca.

En el tomo tercero de la presente edición faltan, por el contrario, dos artículos que figuraron en ediciones anteriores: El Himno de la Creación para la mañana del Día del Gran Ayuno, poema de Judah Leví, poeta hebraico-hispano del siglo XII, vertido al castellano por Menéndez Pelayo, que tendrá lugar más adecuado en el tomo de Poesias, que aparecerá en la serie siguiente, y el Prospecto de la Nueva Biblioteca de Autores Españoles, ya inserto en nuestra edición de Orígenes de la novela, obra con la que se inauguró aquella famosa y no continuada Biblioteca. ${ }^{517}$

Demasiadas libertades se tomaron los editores de esta quinta edición perdiendo de vista el carácter crecientemente bibliográfico e histórico, no polémico, dado por Menéndez Pelayo a su obra, patente sobre todo en su tercera y definitiva edición. Nos parece por ejemplo inaceptable la exclusión de la oda de Jehudah Haleví que Menéndez Pelayo consideraba un monumento de la ciencia hispano-judía del siglo XII y que, dicho sea de paso, difícilmente pudo haber traducido, aunque dotara a la versión castellana de su indudable primor poético.

Los editores tenían razón, sin embargo, al subrayar que esta publicación facilitó a los lectores el acceso a unos textos polémicos que habían sido publicados en revistas de diversa procedencia entre mayo de 1876 y noviembre de 1882 .

517 MP, OC, CSIC, 1953, n. ${ }^{\circ} .58$, p. II. 
La «Revista crítica», en la que Manuel de la Revilla reseñó el discurso de Núñez de Arce, descalificando la posición tradicional de Menéndez Pelayo y de Laverde, había llegado a la opinión pública en la Revista Contemporánea el treinta de mayo de $1876 ;{ }^{518}$ y el artículo polémico «La filosofía española», del mismo Revilla, fue publicado en esa misma revista el quince de agosto del mismo año. ${ }^{519} \mathrm{El}$ texto de Gumersindo de Azcárate, «Una carta sobre la filosofía española», se hizo de dominio público el cinco de noviembre de 1876 en la Revista Europea; ${ }^{520}$ y el texto más ambicioso de los racionalistas, «La ciencia española bajo la Inquisición», de José del Perojo, vio por primera vez la luz el quince de abril del 1877 en su propia Revista Contemporánea. ${ }^{521}$

La «Nota 33» del Triduo..., escrita contra Menéndez Pelayo por el fraile dominico Joaquín Fonseca, se había publicado por primera vez en 1881, pero llegó realmente a la opinión pública, según vimos, bajo el título de «Defensa de la doctrina de Santo Tomás...», en la revista El Siglo Futuro, por entregas, los días cinco y nueve de agosto de 1882. El mismo artículo se volvió a publicar, bajo el inaceptable título de «Defensa de la filosofía cristiana», como ya indicamos, en la revista La Ciencia Cristiana, por entregas, los días treinta de septiembre y quince de octubre del mismo año. En fin, la "Contestación de un tomista a un filósofo del Renacimiento», del mismo Fonseca, llegó a los lectores, por entregas, en El Siglo Futuro entre los días 14 a 23 de septiembre de 1882; y La Ciencia Cristiana lo puso también a disposición de sus lectores, por entregas, los días 30 de octubre, 15 y 30 de noviembre y 15 y 31 de diciembre del mismo año.

Mención aparte merece la versión en formato electrónico de esta edición nacional de La ciencia española, formando parte del Menéndez Pelayo Digital (1999), que impulsó el entonces director titular de la Biblioteca Menéndez Pelayo, Xavier Agenjo Bullón. Esta versión digital en soporte CD-ROM, editada por DIGIBÍS, contiene los 67 volúmenes de la Edición Nacional de las Obras completas del gran historiador santanderino, los 23 volúmenes de su Epistolario, que habían sido editados por la Fundación Universitaria Española, y una Bibliografía pelayana muy completa. Esta versión incluye además una herramienta de búsqueda que facilita al investigador la localización de materias, autores y textos en las obras completas y en el epistolario de don Marcelino.

518 Tomo III, vol. IV, n. ${ }^{\circ} 12$, pp. 504-511.

519 Tomo V, vol. I, n. ${ }^{\circ} 17$, pp. 111-115.

520 Tomo VIII, n. ${ }^{\circ} 141$, pp. 592-594.

521 Tomo VIII, vol. III, n. ${ }^{\circ} 17$, pp. 325-364. 
En el año 2009, aprovechando las funcionalidades de la aplicación DIGIBIB, desarrollada por la empresa DIGIBÍS, y sus posibilidades en el tratamiento de textos, el Menéndez Pelayo Digital, que ya había sido producido con la tecnología de la empresa mencionada, se convirtió en el núcleo de la Biblioteca Virtual Menéndez Pelayo, dentro de la Biblioteca Virtual de Polígrafos de la Fundación Ignacio Larramendi, editora también del CD-ROM. De esta manera, la Edición Nacional de las Obras completas de Menéndez Pelayo, y dentro de ella, La ciencia española, dispone de una herramienta de búsqueda en línea, y está vinculada con autores y obras que son sus referentes y forman parte de esa biblioteca de polígrafos. La Fundación Ignacio Larramendi ha conferido así, a la Edición Nacional de las Obras completas y, en nuestro caso, en particular, a La ciencia española, las nuevas posibilidades que ofrece para la investigación humanística la digitalización siempre que se trate correctamente y vaya acompañada por metadatos bien ajustados a los estándares internacionales de catalogación.

\section{Los manuscritos}

Los MANUSCRitos de La ciencia española que se conservan en la biblioteca histórica de Menéndez Pelayo, como ya comenté antes, son escasos y están ordenados en correspondencia con los volúmenes y capítulos de la EDICIÓN NACIONAL, tal y como los dejó Enrique Sánchez Reyes. En la «Nota sobre esta edición», indicamos de manera más detallada los manuscritos correspondientes a esta obra que están disponibles en la Biblioteca Museo de Menéndez Pelayo en Santander. 



\title{
Nota sobre la presente edición
}

\author{
Dr. Víctor Navarro Brotons \\ Universidad de Valencia \\ Dr. Gerardo Bolado \\ Universidad de Cantabria
}

C sta publicación de La ciencia española se atiene al índice y los textos de L la tercera edición de la obra (1887-1889), que fue la última compuesta y revisada por su autor, pero incluye como anexos los textos ańadidos a la obra en la Edición Definitiva por Miguel Artigas y, en la Edición Nacional, por Enrique Sánchez Reyes y Rafael Balbín Lucas.

Esta edición está dotada de unos «Estudios introductorios» que sitúan $\mathrm{La}$ ciencia española en su tiempo y en el nuestro, estudiándola desde el punto de vista historiográfico, argumentativo y bibliográfico. Además, el capítulo «Historia de la edición» diferencia y estudia la génesis de las cinco ediciones relevantes de la obra, desde la primera en un volumen, de 1876, hasta la Edición Nacional en tres gruesos volúmenes, de 1953-1954, pasando por la segunda edición en un volumen, de 1880, la tercera edición en tres volúmenes, de 1887-1889, y la cuarta en dos volúmenes, de 1933. Por lo que estos estudios preliminares no sólo aportan al lector un sentido actualizado de la obra, sino que también contribuyen a mostrarla desmitificada en su génesis histórica.

El texto de esta edición de La ciencia española es el mismo de la Edición Nacional que fue establecido con cuidado modélico por los editores a partir del texto de la tercera edición, teniendo en cuenta las dos primeras ediciones y los escasos manuscritos de la obra conservados entre los papeles del maestro. 
Estos manuscritos que se conservan en la Biblioteca Museo de Menéndez Pelayo en Santander, están en la actualidad muy incompletos y ordenados en relación a los tomos de la Edición Nacional de 1953-1954. En nuestra revisión de esos manuscritos, que nos fueron entregados por los encargados de esa biblioteca, Rosa Fernández Lera y Andrés del Rey Sayagués, el 28 de febrero del 2013, encontramos:

1. Un cuadernillo con el título: «V. Contestación al artículo del Sr. Perojo». Ed. Nac. Tomo LVIII (I de «La ciencia esp.») pág. 375.

Contiene: «La ciencia española bajo la Inquisición por el Señor del Perojo, Carta $1^{a} »$. Escrita en Venecia el 6 de mayo de 1877. Va dirigida a Pidal y Mon. Consta de 4 folios grapados y de medio folio que no continúa los anteriores, ni los pone fin. No parece estar completo el texto de la contestación a Perojo. Están trabajados por el editor de la Edición Nacional.

2. Un cuadernillo con el título: "Instaurare omnia in Christo». Ed. Nac. Tomo II de «La ciencia española» pág. 103.

Contiene: El texto completo encuadernado del «Instaurare omnia in Christo", la contestación a Pidal y Mon. Está sin trabajar por el editor de la Edición Nacional.

3. Cuadernillo con el título: «Contestación a un filósofo tomista». Ed. Nac. Tomo II de «La ciencia española» pág. 145.

Contiene: El texto completo de la «Contestación a un filósofo tomista». Está sin trabajar por el editor de la Edición Nacional. Las abundantes correcciones existentes ponen de manifiesto que Menéndez Pelayo reconsideró numerosas formulaciones del texto.

4. Cuadernillo con el título: «Réplica al R. P. Fonseca». Ed. Nac. Tomo LIX (II de «La ciencia esp.») pág. 259.

Contiene: El texto completo de la «Réplica al R. P. Fonseca». Está sin trabajar por el editor de la Edición Nacional. Las abundantes correcciones existentes ponen de manifiesto que Menéndez Pelayo reconsideró numerosas formulaciones del texto.

5. Cuadernillo con el título: «La patria de Raimundo Sabunde». Ed. Nac. Tomo II de «La ciencia española» pág. 357

Contiene: Seis folios, escritos a doble cara, en mal estado, pero legibles. Llega hasta el apartado IV, en el momento en que se empieza a hablar de Sabunde como filósofo.

6. Cuadernillo con el título: «Nota final» de contestación a Vidart.», Ed. Nac. Tomo I de «La ciencia española» pág. 265

Contiene: Tres medios folios, escritos por las dos caras, en buen estado, que contienen el texto completo. 
Menéndez Pelayo realizó por vía de nota buena parte de la revisión y ampliación del texto de La ciencia española durante los procesos de publicación de las tres primeras ediciones: bien eliminando, corrigiendo o ampliando las notas de ediciones anteriores, o bien introduciendo nuevas notas. En esta edición, cada nota o parte de nota lleva indicada la edición en que fue introducida. Utilizamos los números arábigos para indicar las notas del autor. Conservamos las notas introducidas en la Edición Nacional por Sánchez Reyes y Balbín Lucas, pero indicándolas con el signo asterisco «*».

En un ejemplar de la tercera edición, propiedad de Menéndez Pelayo y conservado actualmente en Requena, en la Biblioteca de Lucio Gil de Fagoaga, procedente de la Biblioteca de Adolfo Bonilla San Martín, hemos encontrado algunas anotaciones al margen del propio autor no recogidas en la Edición Nacional, que hemos incorporado indicando mediante una cita su procedencia.

Los directores de esta Edición, Víctor Navarro Brotons y Gerardo Bolado, con la ayuda de María Cristina Pascerini, han preparado el «Índice de nombres», que menciona a los autores según su denominación y grafía corriente en la historiografía actual, manteniendo entre paréntesis el nombre utilizado por Menéndez Pelayo. 



\section{Selección bibliográfica}

\section{a) Manuscritos y ediciones críticas de la obra}

— «VIII.-Marcelino Menéndez Pelayo (M. D.), 1. Manuscritos originales de sus obras (O)». En Manuel Revuelta Sañudo, Rosa F. Lera y Andrés del Rey Sayagués, Catálogo-Inventario de los manuscritos y papeles de la Biblioteca de Menéndez Pelayo (Segunda parte). Santander: Sociedad Menéndez Pelayo, 1994, p. 141.

- (1876). Polémicas, indicaciones y proyectos sobre la ciencia española Madrid: Imprenta a cargo de Víctor Saiz.

- (1880). La ciencia española. Polémicas, indicaciones y proyectos. Madrid: Imprenta Central a cargo de Víctor Saiz.

, (1887, 1889). La ciencia española. (Polémicas, proyectos y bibliografía). Obras completas de Menéndez Pelayo, vols. n. ${ }^{\circ}$ 12, 13 y 15. Madrid: Colección de Escritores Castellanos. Críticos, n. ${ }^{\circ}$ 52, 57 y 64.

, (1933). La ciencia española. Edición definitiva de las Obras completas de Menéndez Pelayo, II vols. n. 20 y 21. Ed. Miguel Artigas. Madrid: Librería General de Victoriano Suárez.

, (1953-1954). La ciencia española. Edición Nacional. CSIC, Enrique Sánchez Reyes. III vols. n. ${ }^{0}$ 58-60. Santander: Imprenta Aldus. Esta edición ha

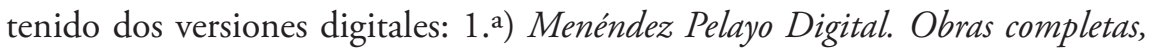
epistolario y bibliografía, 1999 [Recurso electrónico. CD-ROM]. Coordinación general: Tachi Hernando de Larramendi; coordinación científica: Ignacio González Casasnovas, Xavier Agenjo Bullón. Santander: Caja Cantabria, Obra Social y Cultural. 2a) Biblioteca Virtual Menéndez Pelayo. que incluye las Obras completas, epistolario y bibliografía. [http://www.larramendi.es/menendezpelayo/es/ micrositios/inicio.do], Fundación Ignacio Larramendi, 2009. 


\section{b) Estudios sobre La ciencia española}

--Agenjo Bullón, X. (2002). «De re Bibliographica». En M. Menéndez Pelayo. Antología comentada. Marcelino Menéndez Pelayo. Santander: Estudio, pp. 35- 40.

—Becares Botas, V. (2004). «Escolásticos y humanistas: discursos contrapuestos sobre el Renacimiento español». En J. M. Nieto Ibáńez (Coord.), Humanismo y tradición clásica en España y América II (IV Reunión Cientifica sobre Humanistas Españoles), pp. 13-47.

-Bonilla San Martín, A. (1914). Marcelino Menéndez y Pelayo (1856-1912).

Número extraordinario del Boletín de la Real Academia de la Historia. Madrid: Imprenta Fortanet.

-Capellán, G. (2005). Gumersindo de Azcárate. Biografía intelectual. Valladolid: Junta de Castilla y León.

—Cerezo Galán, P. (2007). «Ecos de la polémica sobre La ciencia española», en Homenaje a Marcelino Menéndez Pelayo, Madrid: Real Academia de Ciencias Morales y Políticas, pp. 51-81.

—Cerezo Galán, P. (ed.) (2007). Vieja y Nueva Política y otros escritos programáticos, Madrid: Biblioteca Nueva.

—Cuenca Toribio, J. M. (1965). Menéndez Pelayo y la ciencia española. Madrid: Ediciones Cid.

-Díaz Regadera, M. D. (1995). José del Perojo Figueras (1850-1908). Neokantismo y reformismo. Tesis inédita, leída en la Universidad Autónoma de Madrid.

—Díaz Regadera, M. D.; Hermida, F.; Mora, J. L.; Núñez, D.; Ribas, P. (eds.) (2003). Artículos filosóficos y políticos de José del Perojo (1875-1908). Madrid: Ediciones de la Universidad Autónoma.

-Fernández, J. (1997). El zar de Asturias: Alejandro Pidal y Mon (1846-1913). Gijón: Ediciones Trea S. L.

- García Camarero, Ernesto y Enrique (1970). La polémica de la ciencia española, Madrid: Alianza.

- García Camarero, E. (2000). «La regeneración científica en la España del cambio de siglo", Revista de Hispanismo Filosófico, 5, pp. 17-42.

—González de Amezúa, A. (1927). «Menéndez y Pelayo y la ciencia española». Boletín de la Biblioteca Menéndez Pelayo, IX, pp. 243-274.

- Heredia Soriano, A. (1992). «Laverde y su proyecto de reforma filosófica», El Basilisco, 2a época (Oviedo), 12, pp. 51-60.

. (1999). «Debate sobre la filosofía española. La polémica de 1857», La Ciudad de Dios, CCXII-2, pp. 415-439. 
—Hermida F; Mora J. L.; NúŃEz, D.; Ribas, P. (2006). «Estudio introductorio». En Manuel de la Revilla. Obras completas, Ediciones de la Universidad Autónoma de Madrid, tomo I, págs. 50-58.

—Iriarte, J. (S. J.) (1947). Menéndez Pelayo y la filosofía española. Madrid: Razón y Fe.

-Kamen, H. (1965). La Inquisición española: una revisión histórica. Barcelona: Crítica, 1999.

—Laín Entralgo, P. (1944). Menéndez Pelayo. Historia de sus problemas intelectuales. Madrid: Instituto de Estudios Políticos.

—López Ocón, L. (1992). «Ciencia e historia de la ciencia en el Sexenio democrático: la formación de una tercera vía en la polémica de la ciencia española». Dynamis, 12 (1992), 87-103.

-Mandado, R. E.; Bolado, G. (2011). La ciencia española. Estudios. Santander: Publican Ediciones/RSMP.

-Martínez Millán, J. (2007). La Inquisición española. Madrid: Alianza.

- Mateu y Llopis, F. (1956). «La ordenación bibliográfica de La Ciencia Española». Archivos, Bibliotecas y Museos, Tomo LXII, núms. 1-2-3.

-Menéndez Pelayo, M. (2012). La ciencia española. Edición del Centenario. Santander: Servicio de Publicaciones de la Universidad de Cantabria /RSMP. - (1982-1991). Epistolario. Edición al cuidado de Manuel Revuelta Sañudo. Madrid: Fundación Universitaria Española. 23 vols. . (1955). La Filosofía Española - «Selección e Introducción» de Constantino Lascaris Comneno. Madrid: Rialp.

—Millàs Vallicrosa, J. M. (1956), "Vindicación de la ciencia española por Menéndez y Pelayo", Arbor, XXXIV n. ${ }^{\circ} 127-128$.

—Nieto Galán, A. (1999). "The images of science in Modern Spain. Rethinking the "Polémica"». En K. Gavrolu (ed.), The Sciences in the European Periphery during the Enlightenment. Dordrecht: Kluwer, pp.73-94.

—Novella, J. (2012). «Menéndez Pelayo y la polémica de la ciencia española». En P. Calafate y J. L. Mora (eds.). Filosofía y literatura en la península ibérica. Respuestas a la crisis finisecular. Madrid: Fundación Ignacio Larramendi/Centro de Filosofía de la Universidad de Lisboa/Asociación de Hispanismo Filosófico, pp. 107-121.

—Peña, A. (1986). «La "Völkerpsychologie” y el problema de la ciencia». Boletín de la Biblioteca Menéndez Pelayo, Santander, 1986, LXII, pp. 333-344.

—Pidal y Mon, Alejandro (1875). Santo Tomás de Aquino. Madrid: Viuda e hijos de Aguado.

—Pimentel, J. (2016). «Del peso del aire y las disciplinas invisibles. La polémica de la ciencia española como narrativa de una modernidad elusiva». En Ma. J. Vi- 
llaverde Rico y F. Castilla Urbano (dirs.). La sombra de la leyenda negra. Madrid: Tecnos, pp. 425-451.

—Rey Pastor, J. (1956). «Menéndez Pelayo y la ciencia española». En VV.AA., Homenaje a don Marcelino en el primer centenario de su nacimiento. Madrid. Universidad Central, pp. 83-116.

—Rodríguez Sánchez de León, M. J. (Ed.) (2014). Menéndez Pelayo y la literatura: estudios y antología. Madrid: Verbum.

—Sainz Rodríguez, P. (1919). «La Ciencia Española de Menéndez y Pelayo». En Las polémicas sobre la Cultura Española. Madrid: Imp. Fortanet, pp. 39-42. -SÁnchez Reyes, E. (1974). Biografía crítica y documental de Marcelino Menéndez Pelayo. Ed. Nacional de las Obras Completas de Menéndez Pelayo. Santander: imp. Aldus, 473 páginas.

- Santoveña Setién, A. (1994). Marcelino Menéndez Pelayo. Revisión crítico-bibliográfica de un pensador católico. Santander: Universidad de Cantabria.

—Solana, M. (1931). «Colaboración de Laverde en La Ciencia Española de Menéndez y Pelayo». Boletín de la Biblioteca Menéndez Pelayo. Número Extraordinario en Homenaje a Don Miguel Artigas. Santander: Imprenta Librería y Encuadernación Viuda de F. Fons, pp. 51-98. Editado también como separata, Boletín de la Biblioteca Menéndez Pelayo. Santander (1932) 54.

—Suárez Cortina, M. (Ed.) (2012), Menéndez Pelayo y su tiempo. Santander: UIMP.

-Unamuno, M. DE (1902). En torno al casticismo. En Obras completas, vol. VIII, Edición y prólogo Ricardo Senabre. Madrid: Fundación José Antonio de Castro, 2007.

\section{c) Estudios sobre el contexto de La ciencia española.}

-Abellán, J. L. (1979-1991). Historia crítica del pensamiento español. 8 vols. Barcelona: Círculo de Lectores, 1992, vol. 6, «La crisis contemporánea I. La Restauración canovista», vol. 7 «La crisis contemporánea II. Fin de Siglo. Modernismo. Generación del 98»

—Artelt, W. (1949). Einführung in die Medizinhistorik. Stuttgart: Enke.

-BAtllori, M. (1996). La cultura hispano-italiana de los jesuitas expulsos. Madrid: Gredos.

—Beretta, M. (1992). «The Historiography of Chemistry in the Eighteenth Century: A Preliminary Survey and Bibliography», Ambix, 39, 1-10.

—Bolado, G. (2015). Menéndez Pelayo y los historiadores cántabros del pensamiento español. Santander: Ed. Tantín.

—Bujosa Homar, F. (1989). Filosofia e historiografía médica en España. Madrid: CSIC.

- Campomar Fornieles, M. (1984). La cuestión religiosa en la Restauración. Historia de los heterodoxos españoles. Santander: SMP. 
—Chaunu, P. (1964). «La leyenda negra antihispanique». Revue de Psicologie des Peuples. 19 (1964)188-233.

-Conen, H. F. (1994). The Scientific Revolucion. A Historiographical Inquiry, Chicago, The University of Chicago Press.

—Corell Doménech, M. (2013). «La botella medio vacía: Emilio Huelín, la vulgarización científica y el debate de la ciencia española en el Sexenio democrático y los primeros ańos de la Restauración", Asclepio, 65 (2013), 24 ss.

-Forment, E. (1998). Historia de la filosofía tomista en la España contemporánea. Madrid: Editorial Encuentro.

- Garma Pons, S. (ed.) (1980). El científico español ante su historia. La ciencia en España entre 1750-1850. I Congreso de la SEHC. Madrid, 1980.

—González de Linares, A. (2014). Obra Completa. Edición y estudio preliminar de Carlos Nieto, Santander: Ed. de la Universidad de Cantabria.

—Guardia Bagur, J. M. (1890). «L'histoire de la Philosophie en Espagne». En Revue Philosophique de la France et de l'Étranger. París, (XXIX, mayo). pp. 471-490.

(1893). «La misère philosophique en Espagne». En Revue Philosophique de la France et de l'Etranger. París, (XXXVI, julio). 287-293.

—Gusdorf, G. (1966). Les sciences humaines e la pensé occidental. I. De l'Histoire des sciences a l'histoire de la pensé. Paris: Payot.

-Jayawardene, S. A. (1974). «Biographical Notices of Historians of Science: a Checklist», Annals of Science, 36, 315-394.

-Jiménez Landi, A. (1996). La Institución Libre de Enseñanza y su ambiente, I, Madrid: Ministerio de Educación y Cultura/UCM/UB/UCL.

—Jover Zamora, J. M. (1991). Realidad y mito de la Primera República. Del «Gran Miedo" meridional a la utopía de Galdós. Madrid: Austral.

—Lafuente, A.; Peset, J. L. (1988). «El conocimiento y el dominio de la naturaleza: la ciencia y la técnica». En José María Zamora (dir.). Historia de España (fundada por Menéndez Pidal), XXXI-I, Madrid: Espasa Calpe, pp. 349-394.

-López, F. (1999). Juan Pablo Forner y la crisis de la conciencia española en el siglo XVIII. Valladolid: Junta de Castilla y León.

—López Ocón, L. (1992). «El fomento de la educación y la ciencia en la sociedad española del Sexenio revolucionario", Boletín de la Institución Libre de Enseñanza, 28 (9) (1992), pp. 127-48.

—López Piñero, J. M.; Navarro Brotons, V.; Portela Marco, E. (1988). «La actividad científica y tecnológica». En Artola, M. (ed.). Enciclopedia de Historia de España, vol. III. Madrid: Alianza Editorial, pp. 273-327.

—López Piñero, J. M.; Glick, Th. F.; Navarro Brotons, V.; Portela Marco, E. (dirs.) (1983). Diccionario histórico de la ciencia moderna en España. Barcelona: Península. 
—López Piñero, J. M. (1979). Ciencia y técnica en la sociedad española de los siglos XVI $y$ XVII. Barcelona: Labor.

—López Piñero, J. M. (ed.) (1992). La ciencia en la España del siglo XIX. Madrid: Marcial Pons (Ayer, 7).

-López Piñero, J. M. (dir.) (2002). Historia de la ciencia y de la técnica en la Corona de Castilla, 4 vols., Valladolid: Junta de Castilla y León, vol. 3., 2002, pp. 231-259

—Lyssorgues, J.; Sobejano, G. (1998). Pensamiento y literatura en España en el siglo XIX: Idealismo, positivismo, espiritualismo. Toulouse: Presses Universitaires du Mirail.

- Vicente Maroto, I.; Esteban Piñeiro, M. (1991). Aspectos de la ciencia aplicada en la España del Siglo de Oro. Valladolid: Junta de Castilla y León, 1991

-Mestre Sanchís, A. (2003). Apología y crítica de España en el siglo XVIII. Madrid: Marcial Pons.

-Moreno Luzón F; Martínez, F. (eds.) (2012). La Institución Libre de Enseñanza y Francisco Giner de los Ríos: nuevas perspectivas, Madrid: Fundación Francisco Giner de los Ríos/Acción Cultural española.

-Navarro Brotons, V.; Eamon, W. (eds.) (2007). Más allá de la Leyenda Negra. España y la Revolución Cientifica. Valencia: Instituto de Historia de la Ciencia y Documentación López Piñero (Universitat de València-CSIC).

-Navarro Brotons, V. (2014). Disciplinas, saberes y prácticas. Filosofía natural, matemáticas y astronomía en la sociedad española de la época moderna. València: Universitat de València Servei de Publicacions.

—NúŃEz, D. (1975). La mentalidad positiva en España. Madrid: Ediciones de la Universidad Autónoma de Madrid, 1987.

-Pardo Tomás, J. (1991). Ciencia y censura. La Inquisición española y los libros cientificos en los siglos XVI y XVII. Madrid: CSIC.

-Pérez Villanueva J.; Escandell Bonet, B. (eds.) (2000). Historia de la Inquisición, vol. III, Madrid: Biblioteca de Autores Cristianos.

-Peset, J. L. (Dir.), (2002). Historia de la ciencia y de la técnica en la Corona de Castilla. Siglo XVIII, vol. IV. Salamanca: Junta de Castilla y León.

—Peset Reig, J. L.; Peset Reig, M. (1974). La universidad española (siglos XVIII y XIX). Despotismo ilustrado y revolución liberal. Madrid: Taurus.

-Puerto Sarmiento, F. J. (1988). La ilusión quebrada. Botánica, sanidad y politica científica en la España Ilustrada. Madrid: Serbal/CSIC.

-Rossi, P. (1962), I filosofi e le machine 1400-1700. Milan: Feltrinelli (reeditada en 1984 y 2002, y en versión castellana, Barcelona, Labor, 1966).

- Sala y Villaret, Pedro (1877). «La restauración de la Escolástica». Revista de España, n. ${ }^{\circ} 228,459-487$.

—SÁnchez Ron, J. M. (2016). José Echegaray (1832-1916). El hombre polifacético. Técnica, ciencia, politica y teatro en España. Madrid: Fundación Juanelo Turriano. 
— Sarrainl, J. (1954). L’Espagne éclairé de la seconde moitié du XVIII siècle. Paris: Imprimerie Nationale et Librairie Klincksieck. (Edición española, México, F.C.E., 1957) .

—Selles, M.; Peset, J. L.; Lafuente, A. (eds.) (1988). Carlos III y la ciencia de la Ilustración. Madrid: Alianza.

—SuÁrez Cortina, M. (ed.) (2006). La redención del pueblo. La cultura progresista en la España liberal. Santander: Universidad de Cantabria.

- Valender, J; Rojo, G. (1999). Las Españas. Historia de una revista del exilio (1946-1963). México: El Colegio de México/Fondo Eulalio Ferrer.

- Valverde, N. (2007). Actos de Precisión. Instrumentos cientificos, opinión pública y economía moral en la Ilustración española. Madrid: CSIC.

—VeGA, J. (2010). Ciencia, arte e ilusión en la España ilustrada. Madrid: CSIC.

- Vernet, J. (1975). Historia de la ciencia española. Madrid: Instituto de España.

-Vernet, J.; Parés, R. (dirs.) (2004-2009). La Ciència en la Història dels països catalans, 3 vols., València: Institut d'Estudis catalans/Universitat de València.

-Villacañas Berlanga, J. L. (ed.) (2006). Kant en España. El neokantismo en el siglo XIX. Madrid: Verbum.

—VV. AA. (1972). Veinticuatro diarios. Madrid 1830-1890. Colección de índices de publicaciones periódicas. (IV tomos). Madrid: CSIC, Instituto Miguel de Cervantes.

—ZILSEL, E. (1976). Die sozialen Ursprünge der neuzeitlichen Wissenschaft. Ed. por Krohn, W., Frankfurt a. M.: Suhrkamp. 



\title{
LA CIENCIA ESPAÑOLA
}

\author{
Marcelino Menéndez Pelayo
}





\section{ADVERTENCIA DE LA SEGUNDA EDICIÓN (1880)}

Z 1 inusitado, aunque poco merecido favor con que el público acogió estas Cartas ligerísimas y escritas a vuelapluma, agotando en pocos meses la primera edición, me mueve a hacer esta segunda, del todo refundida y en más del doble aumentada. No sólo he corregido las erratas, inexactitudes, omisiones y faltas de elocución que noté en la primera, sino que he añadido una segunda parte, formada con diferentes escritos acerca de nuestra ciencia por mí publicados en La España Católica y en la Revista de España. En el texto de las cartas ya conocidas he hecho considerables adiciones, sobre todo en la parte bibliográfica. Suprimo, en cambio, la introducción y plan de mi Historia de los herejes españoles, porque esta obra comenzará a publicarse muy luego, y ya no es necesario aquel specimen.

¿Quiera Dios que con tales perfiles y retoques haya quedado este librejo menos indigno de la benevolencia de los doctos! 



\section{ADVERTENCIA PRELIMINAR DE LA TERCERA EDICIÓN (1887)}

E sta nueva edición de La ciencia española difiere considerablemente de las dos primeras en forma y contenido. Lleva muchas correcciones e innumerables adiciones, ya en el texto, ya en las notas, e incluye bastantes escritos no coleccionados hasta ahora, y un extenso trabajo bibliográfico, de todo punto inédito. Lo que fue en la primera edición un solo y pequeño volumen, y en la segunda uno solo también, aunque mucho más abultado, ocupará tres en la presente. Bien puede decirse, sin nota de presunción o atrevimiento, que La ciencia española resulta ahora menos indigna de su ambicioso título y del favor constante que mis lectores la han dispensado. Siempre, no obstante, habrá de resentirse de su carácter de improvisación y del desorden inherente a los libros de polémica y a las colecciones de artículos de revista.

Las seis cartas que constituyen la primera serie, precedidas de otra del Sr. Laverde, que les sirve de prólogo, aparecieron en diversos números de la Revista Europea durante el ańo 1876, y fueron los primeros escritos de alguna importancia por su asunto que di a la estampa. Con estos seis artículos y el primitivo plan de la Historia de los heterodoxos españoles, se formó, al año siguiente, un tomito, que desapareció muy pronto del mercado, sin duda por la novedad del asunto o por el atractivo que la mísera y pecadora condición humana encuentra siempre en todo lo que va mezclado de dimes y diretes personales.

La segunda parte de La ciencia española se compone de nuevas polémicas que sostuve por los años de 1879 en la hoja literaria de La España Católi$c a$, periódico que dirigía mi amigo el elocuente orador parlamentario D. Alejandro Pidal y Mon, con quien también estuve en cariñosa discordancia 
sobre algunos puntos relativos al valor científico que puede concederse a la filosofía escolástica. Las cartas que mediaron entre el Sr. Pidal y yo acerca de esta cuestión, las que escribí en defensa de la filosofía española contra el Sr. Perojo, y, finalmente, un largo estudio sobre la Antoniana Margarita de Gómez Pereira, inserto en la Revista de España, forman todo lo añadido en la segunda edición de La ciencia española (1880), de la cual tampoco se encuentra ya ningún ejemplar en venta.

$\mathrm{Al}$ reproducir en la colección de mis Obras completas ${ }^{522^{*}}$ estos primeros ensayos, algunos de los cuales tienen diez años de antigüedad, fecha bastante larga para trabajos de erudición y de polémica, los he revisado con extremo rigor, pero al mismo tiempo con el natural cariño que siente todo escritor hacia sus primeras y más endebles tentativas. En el estilo, en los juicios, y sobre todo en los datos, se encontrará mucha novedad, y no dudo que el que se tome el trabajo de comparar algunas páginas de esta edición con otras de la de 1880, creerá tener en las manos un libro enteramente nuevo.

Las correcciones no afectan, sin embargo, al espíritu general de la obra, ni siquiera a su forma literaria, a la cual he dejado todo el abandono y soltura que antes tenía, quitando sólo las incorrecciones más notorias, o, a lo menos, las que me han dado en ojos. Mi principal tarea ha sido hacerme cargo de los estudios de ciencia española publicados después de las dos primeras ediciones, y de aquellos otros que ya existían entonces, pero que no llegaron sino mucho después a mi noticia. De los primeros hablo en las notas, para no incurrir en contradicción cronológica. La noticia de los segundos he procurado intercalarla en el texto mismo, juntamente con una porción de observaciones y detalles que se me han ido ocurriendo al releer estas cartas en mi biblioteca y con la pluma en la mano.

Si he creído necesario atenuar, modificar o esforzar alguna opinión, lo hago siempre en nota, respetando la integridad de mis ideas primitivas: único procedimiento que tengo por sincero, cuando uno quiere rectificarse a sí mismo y hacer examen de su propio pensamiento.

He añadido en esta edición todos los artículos que después de 1880 he publicado sobre temas que se relacionan con la historia de nuestra ciencia. Entre ellos figuran mi discurso acerca de Raimundo Lulio y mis polémicas con el dominico P. Fonseca acerca del tomismo. Pero el más positivo aumento consiste en un Inventario bibliográfico de la ciencia española, especie de catálogo abreviado de los autores y libros españoles más dignos de memoria

$522^{*}$ Se refiere a la tercera, que con este título general forma parte de la Colección de Escritores Castellanos. (Edición Nacional). 
en cada ciencia, distribuidos por orden de materias y de siglos, con alguna breve indicación acerca de los servicios y novedades que la ciencia les debe.

Aun siendo tan compendioso y superficial este catálogo, no dejará de ocupar bastantes páginas, y su redacción ha sido para mí larga y difícil, por falta de toda luz y guía en algunos ramos de nuestra cultura, no explorados, ni bien ni mal, hasta el presente, a pesar de su relativa y aun absoluta riqueza. Esta misma penuria de trabajos preliminares me ha hecho perseverar en una faena tan ingrata y deslucida como la de buscar y apuntar nombres y fechas, considerando que alguien podrá sacar utilidad de los materiales que buenamente le ofrezco, agradeciéndomelo acaso más que otras disquisiciones con pretensión de hondas, y perdonándome lo mucho que falta, en gracia de lo que le doy coleccionado en un solo libro. Porque, a mi entender, el único mérito, si alguno tiene, de La ciencia española, no consiste en la parte polémica, condenada a morir en cuanto las circunstancias pasan, sino en lo que tiene de manual bibliográfico, único hasta ahora de su género entre nosotros, por lo cual deben disimularse sus infinitas omisiones, que irán siendo menores en adelante, si no abandona al libro el favor de los aficionados y curiosos.

Y ahora, en descargo de mi conciencia, no de escritor, sino de cristiano y de hombre, debo dar alguna explicación sobre las personalidades, acritudes y virulencias que en estas cartas hay, y que de buen grado habría yo suprimido, si para hacer esto no hubiese sido preciso destruir enteramente el libro y escribir otro nuevo. He vuelto a leer estas cartas diez ańos después de publicadas, con la frialdad de quien lee cosa ajena, y no he encontrado en ellas verdadera injuria personal ni expresión alguna que pueda desdorar el crédito moral de ninguno de mis adversarios.

En esta parte estoy tranquilo, y si ańado que ellos se mostraron en la polémica tan duros y violentos como yo; que por ańadidura escribí estas cartas a los veintiún años, sin conocer del mundo y de los hombres más que lo que dicen los libros, creo que ni aun los más severos han de negarme su indulgencia. Pero es tal mi respeto a la dignidad ajena; me inspira tanta repugnancia todo lo que tiende a zaherir, a mortificar, a atribular una alma humana, hecha a semejanza de Dios y rescatada con el precio inestimable de la sangre de su Hijo, que aun la misma censura literaria, cuando es descocada y brutal, cínica y grosera, me parece un crimen de lesa humanidad, indigno de quien se precie del título de hombre civilizado y del augusto nombre de cristiano. Gracias a Dios, ni aún en mi primera juventud, en la casi infancia en que escribí estas cartas, creo haberme dejado ir a las tropelías y desmanes de la crítica al uso, ni me remuerde la conciencia de haber escrito una sola 
página por animosidad contra nadie. Lo más duro, lo más violento que hay en mis artículos, nace del ardor de mi convicción personal, avivada al choque y contradicción de las ideas opuestas.

Yo peleaba por una idea; jamás he peleado contra una persona ni he ofendido a sabiendas a nadie. Y la mejor y última prueba que puedo alegar de esto, es que todos mis contradictores han sido amigos míos después de esta controversia, y lo fue muy íntimo, dejándome con su muerte imborrable recuerdo y amarguísimo duelo, aquel gran crítico Manuel de la Revilla, en cuyo generoso espíritu no quedó ni la más ligera sombra de rencor después de nuestro combate literario, sino afectos de simpatía, confirmados luego por el lazo estrechísimo con que liga a sus miembros la institución universitaria, haciéndolos, más bien que compañeros, hermanos.

28 de abril de 1887. 


\section{CARTA-PRÓLOGO DE LA PRIMERA EDICIÓN (1876)}

Sr. D. Marcelino Menéndez y Pelayo.

Mi muy querido amigo y paisano: Pasan los años, marchítanse las ilusiones, las esperanzas terrenales se disipan, los desengaños aumentan, desfallecen a una cuerpo y espíritu, el círculo de la existencia se va cerrando, pero el amor al suelo natal permanece vivo en mi corazón: ni el tiempo, ni la ausencia, ni los trabajos y dolores le extinguen; antes bien, crece con ellos de día en día, haciéndose cada vez más íntimo, enérgico y profundo. Paréceme estar oyendo de continuo, tristes y dulces al alma como la memoria de las pasadas alegrías, los ecos vagos y soledosos de las distantes campiñas y de las apacibles tonadas, a cuyo arrullo dormí los sueños primeros, cual si me llamasen a terminar esta vida de tribulaciones allá donde empecé a correrla, feliz y descuidado, entre juegos y risas, caricias y flores. Sumido en amargura y desaliento, sin porvenir ya en el mundo, pocas ideas me apenan tanto como la de exhalar el último suspiro fuera del suelo bendito en que reposan las cenizas de mis abuelos y aun alientan mis padres y hermanos muy amados. ¡Cuán a menudo se me vienen a los labios, con indecible emoción y humedecidos los ojos, aquellos tiernos versos de Lista:

"iDichoso quien nunca ha visto

más río que el de su patria,

y duerme anciano a la sombra

do pequeñuelo jugaba!»

Poseído yo de tales sentimientos, natural es que me complazca en explayar la imaginación por esas tierras cántabro-asturianas, como para consolarme 
de su ausencia, recorriendo en espíritu sus amenísimos valles y enriscadas cumbres, evocando sus antiguas glorias, fantaseando mejoras y progresos y deleitándome con el cuadro halagüeńo de su futura prosperidad y bienandanza. Así, nadie extrañará que experimente indecible gozo al recibir de esas montañas y marinas, señales de cariño, noticias de hechos que enaltezcan a sus hijos, o testimonios de su saber y cultura tan elocuentes como las notabilísimas epístolas literarias que $\mathrm{V}$. ha tenido la bondad de encabezar con mi humilde nombre, honrándole sobre todo encarecimiento, y poniendo el suyo y el de nuestra común patria a grande altura. Nuevo y muy preciado título de gloria será el libro de V. para nuestra literatura regional, hoy en alto grado rica y floreciente; pues, aparte de otros prosistas y poetas estimabilísimos, posee uno de los primeros filósofos contemporáneos en Fr. Zeferino González, en Campoamor uno de los líricos más egregios, un insuperable novelista y pintor de costumbres en Pereda, un tan soberano artífice y maestro de la palabra como Juan García y anticuarios y eruditos tan hábiles, laboriosos y concienzudos como Caveda, Arias de Miranda, Assas y Ríos y Ríos, dignos sucesores de los Campomanes, Sánchez (D. Tomás Antonio), La Serna Santander, Ceán, Floranes, Martínez Marina, La Canal y Pidal de otras épocas. Justo era que de ella saliese la valiente y animada defensa de los merecimientos del espíritu nacional que V. hace en sus Cartas.

Angústiame sólo el motivo que le indujo a escribirlas, que es ciertamente para afligir al más insensible, ver que, en el último tercio del siglo XIx, cuando tanto ha avanzado en todas direcciones el genio de la investigación histórica, aun esté casi enteramente inexplorada la ciencia ibérica de los pasados tiempos, hasta el punto de que escritores nada vulgares por otros estilos, no teman desconceptuarse negándola o menospreciándola con singular uniformidad e insistencia, y haya sido preciso desenterrar la péńola apologética de Matamoros, Lampillas, Forner y Cavanilles, no contra menguados enciclopedistas transpirenaicos, ni frívolos abates italianos de la anterior centuria, sino contra famosos literatos y filósofos espańoles del día presente.

Pero bien mirado todo, no tenemos por qué lamentarnos de su conducta. Oportet haereses esse. Si ellos no hubiesen caído en la mala tentación de remedar las añejas ocurrencias del asendereado colaborador de la Enciclopedia, habríale faltado a V. ocasión de enriquecer la literatura española con sus preciosas Cartas, en que tan brillantes muestras da de estar cortado por el patrón de los Nebrijas, Vives y Brocenses. El caudal de doctrina y de noticias (muchas harto nuevas), la madurez y penetración de juicio, la destreza polémica, el orden amplio y desembarazado y la soltura, originalidad y abundancia de estilo que V. ostenta en ellas, hácenlas dignas de ponerse con los dechados 
del género en nuestra lengua. Maravilloso ciertamente es, en un joven de veinte años, tal conjunto de cualidades, que pocas veces aparecen reunidas. Y el asombro sube de punto al considerar que esas Cartas han sido improvisadas ex abundantia cordis, sin desatender otras tareas literarias, de mucho mayor empeño algunas. Ahí están, para no dejarme por hiperbólico, los Estudios poéticos, donde en breve conocerá el público la maestría envidiable con que V., émulo dichoso de Burgos, Castillo y Ayensa y otros preclaros traductores nuestros, interpreta en verso castellano las inspiraciones de la musa griega, latina, italiana, lemosina, portuguesa, francesa e inglesa; los Estudios clásicos, de que es un fragmento el bello discurso acerca de La novela entre los latinos, por V. leído al recibir la investidura de doctor en filosofía y letras; el Horacio en España, curiosísimo ensayo bibliográfico y crítico sobre los traductores, comentadores e imitadores que entre nosotros ha tenido el gran poeta venusino; el Bosquejo de la historia cientifica y literaria de los jesuitas españoles desterrados a Italia por Carlos III, del cual han salido a luz, valiéndole a $\mathrm{V}$. no pocos plácemes, diversos e interesantes trozos en La España Católica; los Estudios críticos sobre escritores montañeses, inaugurados con el tomo relativo a Trueba y Cosio, modelo de esta clase de monografías, dignamente ensalzado por el sabio Milá y Fontanals en el Polybiblión; la Biblioteca de traductores españoles, vasto tesoro de erudición biográfica y bibliográfica, en su mayor parte, y con infatigable aplicación y diligencia, ya reunida y ordenada; la Historia de la Estética en España, en que, por decirlo así, saca $\mathrm{V}$. de bajo tierra una de las corrientes más fecundas y copiosas de la ciencia patria; y, finalmente, la de los Heterodoxos españoles, cuyo plan, que ahora se publica anticipadamente y a manera de specimen, manifiesta bastante la magnitud e importancia de la empresa, y el talento y saber con que, de fijo, será desempeñada. Opimos frutos prometía para el porvenir la lucidísima carrera universitaria de V., discípulo fiel de la escuela catalana, educado por los Milá, los Rubió y los Llorens, que supieron cultivar y desarrollar sus nativas disposiciones..., la cosecha lleva trazas de exceder a las más galanas esperanzas. Niéguenle su admiración con afectada superioridad la ruin envidia y la vanidosa pedantería; yo no sé reprimirla, ni quiero disimularla; hallo en abandonarme a ella especial fruición, mezclada de noble y legítimo orgullo. ¿Qué mucho, si me cabe parte en la gloria de V. por conterráneo, por amigo y por identificado con sus ideas, sentimientos y aspiraciones?

Pero volvamos a la materia de sus Cartas, de la cual insensiblemente me he venido apartando. Comprendo cuán en lo vivo herirían a V. en su corazón de español y en su alma de erudito los reiterados menosprecios y negaciones de que es objeto nuestra ciencia, y no extraño, por tanto, el tono cáustico 
y desenfadado con que a veces habla de sus, en esta parte, desalumbrados autores. ¿¿Qué buen hijo, y más en el hervor de la juventud, si acaso tiene que vindicar la honra de su madre, pertinaz y sistemáticamente denigrada (no por malicia de la voluntad, sin duda, pero denigrada al cabo), sabe contener su indignación, medir con absoluta serenidad sus expresiones y respetar escrupulosamente al agresor, sobre todo cuando la reputación de éste es lo único que da alguna fuerza y autoridad a sus palabras en la opinión del vulgo circunstante? Paciencia heroica habría menester, y los Job son rarae aves.

Harto más duros e incisivos, y de ordinario sin tantas circunstancias que lo atenuaran, han sido la mayor parte de los polemistas antiguos y modernos. Al cabo V. solamente descarga su vis satírica sobre flaquezas literarias, cuando ellos se entraban por la vida privada de sus contradictores, y hasta de sus defectos físicos hacían chacota, si ya no es que apelasen, para hundirlos, a la difamación y a la calumnia. Recuérdese, si no, cuán feroces y envenenadas solían ser las contiendas literarias del Renacimiento. Dejando aparte a Filelfo, a Poggio, a Lorenzo Valla, a Scalígero, a Scíoppio y a otros, justamente calificados por Nisard de gladiadores de la república de las letras, ¡con qué rudeza atacó Erasmo a sus adversarios en religión y en filología! ¡A qué armas acudió para defenderse! ¡Qué invectivas dispararon contra él Estúniga, Carvajal y Sepúlveda! Y en todo aquel siglo, ¡qué carácter tan personal y virulento no tuvo casi siempre la controversia entre católicos y protestantes, aunque fuesen hombres doctos y pasasen por juiciosos y moderados los sustentadores! El tratarse recíprocamente de locos, asnos, ebrios, licenciosos, ministros de Satanás, demonios, incendiarios y otros excesos, era cosa común y corriente en las disputas que los humanistas trababan, siquier versasen sobre la más insignificante cuestión gramatical o la interpretación de algún pasaje de las clásicos. Una rociada de improperios parecía la salsa de aquellas brutales pelamesas literarias. $\mathrm{Y}$ aun en tiempos de mayor delicadeza social, en el siglo XVII, ¡qué maligno y punzante no aparece Pascal, bien que con formas templadas, en las famosas Provinciales, donde a la par vulnera no pocas veces los fueros de la verdad y de la justicia!

Mas no necesitamos salir de nuestra propia casa. Recorramos la historia de las guerras de pluma en el siglo pasado y encontraremos repetidos ejemplos de intolerancia y descomedimiento increíbles. El P. Feijoo, por lo común tan prudente y circunspecto, mostrase iracundo y altanero en la Ilustración apologética de su Teatro crítico, proporcionada en verdad al modo descortés con que le impugnaran Mañer, Soto Marne y otros escritores de aquella época. Del P. Isla nadie ignora que en toda polémica, aun de las más graves, sazonaba con sangrientos chistes todos los rasgos de su pluma. ¿Y quién ha igualado 
a Forner en el uso de la sátira despiadada contra todo linaje de enemigos? Lean los que a V. le tildan de acre y mordaz sus opúsculos críticos, y entonces sabrán lo que es dureza, furia y personalidades. Ni fue sólo Forner quien se desmandase en este punto: lo mismo hacían sus contrarios; Iriarte, Huerta, Sedano, Sánchez, Vargas Ponce, Ayala, no le iban en zaga por lo tocante a aspereza y destemplanza. $Y$ en este mismo siglo, ¿no hemos presenciado las durísimas fraternas de don Fermín Caballero a Miñano y otros geógrafos del año 29, y más acá, y prescindiendo de lides menos ruidosas, la increíble por lo extremada entre Gallardo, D. Adolfo de Castro y Estébanez Calderón, con motivo de la publicación del Buscapié en 1848? ¿Ha llamado V. caco ni biblio-pirata a ninguno de los herederos de Mr. Masson?

No vengan a decirnos que ésas eran rińas de plazuela entre literatos y bibliófilos, gente levantisca y revoltosa, como que no conocen los mandamientos del Ideal de la humanidad ni saben poner atento oído al Imperativo categórico; ni tampoco nos repitan que muy de otra manera se han en sus controversias los publicistas formales, los científicos y filósofos eximios. Nadie negará que a esta categoría pertenece el sabio escocés Hamilton, el cual, no obstante, empeńado en polémica con el doctor Brown, díjole cosas, por lo menos, tan ásperas como V. a sus adversarios, llegando a afirmar de él que rara vez citaba autores antiguos sin mostrar su absoluta incompetencia en las materias sobre que tan intrépidamente discurría. Esto escribió Hamilton en la sesuda y flemática Revista de Edimburgo, por juzgar comprometida en aquella lucha la causa de la filosofía escocesa. No ha ido V. más lejos, a pesar de su sangre meridional y viveza juvenil, en una contienda en que andaban empeńados juntamente el crédito científico de España y el honor y la vida de la filosofía española.

No dejaré de aconsejarle, sin embargo, que en lo sucesivo, llegado el caso de habérselas de nuevo con los empedernidos sectarios de Mr. Masson, imite en lo que pueda al santo Patriarca idumeo, aunque ellos disten mucho de proponérsele por modelo. Así no les dejará V., para encubrir su derrota, el tradicional recurso de exclamar: «iEsos neos (por lo visto, vuelve a estar de moda la palabrilla, que, para calificar a los admiradores de Vives, no tiene precio) siempre los mismos! ¡Siempre empleando, en lugar de razones, insultos y diatribas! ¿Cómo discutir en serio con tales gentes?» Y privados de esta puerta falsa, ¿por dónde se escaparían?

Porque, a los ojos del buen sentido y de la crítica imparcial, que no se para en la corteza de las cosas, V. ha conseguido sobre ellos señaladísima victoria. Empezaron asentando rotundamente que la vida científica de España estuvo oprimida y paralizada casi por completo durante el período que corre desde los Reyes Católicos hasta la guerra de la Independencia. Sólo 
considerando cuánto suelen ofuscar aun a las más perspicuas inteligencias los prejuicios sistemáticos, acierto a explicarme cómo mi digno amigo y tocayo el Sr. Azcárate pudo aventurar proposición semejante, máxime teniéndola de antemano refutada nada menos que en la Exposición histórico-crítica de los sistemas filosóficos modernos, escrita por el sabio autor de sus días, ferviente panegirista del movimiento intelectual de España en el siglo Xvi. El convencerla de errónea no era por cierto difícil, y V. lo ha hecho cumplidamente, recordando los principales méritos de la filosofía española, enumerando los autores más ilustres que entre nosotros cultivaron las varias ramas del árbol enciclopédico, encomiando cual se merecen sus producciones y enseñanzas y dando alguna idea de los adelantamientos debidos a su meditación y estudio. Su primera carta es un excelente resumen de la inmensa actividad intelectual desplegada por nuestros compatriotas en los tres siglos precedentes, a la vez que una demostración palmaria de la ligereza y falta de verdad con que se pinta al despotismo inquisitorial como la causa única y más eficaz de nuestra decadencia científica y del menor progreso que en algún orden de conocimientos alcanzamos. ¿Qué obstáculos puso el Santo Oficio a Vives para señalar las múltiples fuentes de la corrupción de los estudios, ni al P. Feijoo para fulminar su crítica incansable contra toda casta de errores y preocupaciones? ¿En qué vejó a Vallés, Gómez Pereira, Isaac Cardoso y tantos otros por sus hipótesis y teorías físicas y psicológicas, para aquel tiempo tan osadas? ¿Qué persecuciones descargó sobre nuestros políticos y economistas en castigo de los principios y máximas, con frecuencia asaz radicales, que en sus libros expusieron? Si no impidió el florecimiento de las ciencias médicas, por los mismos adversarios reconocido, ¿con qué justicia puede imputársele nuestra relativa pobreza en las exactas, físicas y naturales?

Desalojados así de sus primeras posiciones, todavía no se dieron por vencidos los massonianos. Reconociendo, aunque a regańadientes, que el espíritu científico no estuvo del todo muerto en nuestros abuelos, han pretendido amenguar su importancia con sostener que aquellos sabios no pasaron de voces aisladas sin enlace ni consecuencia con el proceso de la cultura europea, por donde nada valen en la historia general de las vicisitudes del entendimiento humano. Mas como la negación, sobre todo en absoluto, es siempre arriesgada, tropezaron de nuevo con la formidable oposición de $V$., que en otras dos cartas, amplificando especies ya apuntadas en la primera, puso de resalto a poca costa la inanidad de sus juicios y el ningún fundamento de sus aseveraciones.

No se habrían metido en tan mal paso, si en vez de medir, como sin duda miden, lo pasado por lo presente, parasen mientes en ciertos datos-históricos 
y reflexionaran sobre ellos. Hoy, es verdad, nuestra ciencia halla eco muy débil fuera de los lindes de la Península. ¿Para qué han de venir los extranjeros a buscar pálidas y desfiguradas reproducciones de su saber y enseñanzas? ¿Tenemos en el día pensamiento propio, digno de ser estudiado? Esto hemos adelantado con el insensato empeño de divorciarnos de la tradición nacional y abrirnos a todo viento de doctrina. Excepto un corto número, casi todos producto de neos y oscurantistas como Balmes, Donoso Cortés, Fr Zeferino González, Caminero..., ¿qué libros modernos de ciencia española han salvado los Pirineos? No sucedía así en el siglo XVI, y aun en el decadente XVII. Entonces se traducían y reimprimían y leían con avidez en toda Europa las producciones de Fr. Antonio de Guevara, paisano nuestro muy ilustre; las de Granada, Quevedo, Saavedra Fajardo, Gracián y otros mil, originalmente escritas en castellano, a tal punto, que una bibliografía de sus versiones sería inmensa y para España gloriosísima. Pues si esas obras, no todas de primer orden, obtenían tanta circulación entre los extranjeros, ¿qué no acontecería con las compuestas en latín, cuando éste era el idioma común de los sabios en el orbe cristiano? ¿Dejarían de infiltrarse y germinar en el espíritu de Europa y contribuir a su educación intelectual las doctrinas, las ideas nuevas, los descubrimientos en ellas contenidos? Por otra parte, multitud de sabios españoles desempeñaban a la sazón cátedras en las principales Universidades italianas, francesas y alemanas; hasta en Polonia y Dinamarca tuvimos profesores. ¿Cabe en lo posible que sus lecciones cayesen como semillas muertas sobre los innumerables alumnos que a oírlas acudían? Si tan pobre y estadiza fuese nuestra ciencia, ¿habrían merecido tal aceptación en todas partes los libros y los doctores que la explicaban? ¿No prueba esto que íbamos, no a la cola, sino a la cabeza? ¿Cuándo se ha visto que los pueblos menos cultos manden en tanta abundancia lecturas y maestros a los más adelantados?

Numerosos hechos, cuya certeza e importancia sería monstruosa temeridad poner en duda, vienen en confirmación de estas inducciones tan obvias como legítimas. Juan Luis Vives sembró los gérmenes del baconismo, del psicologismo escocés y aun del cartesianismo, que tuvo también antecedentes más inmediatos en otros filósofos peninsulares; las doctrinas metafísicas y teológicas de Molina, Vázquez y Suárez, que modificaron el tomismo en puntos capitales, dando origen a empeńadas controversias, extendiéronse con la Companía de Jesús hasta los últimos confines del globo; los teólogos españoles fueron los oráculos del Concilio de Trento y de todas las escuelas del continente, adquiriendo superior concepto, aun entre los protestantes; con las obras de los místicos recibidas dondequiera con extraordinario aplauso, nutrieron su espíritu San Francisco de Sales, Bossuet, Fénelon, etcétera, que no les superan ciertamente en profun- 
didad ni en grandeza; en las de nuestros escritores filosófico-jurídicos, Vitoria, Ayala, Suárez, Domingo de Soto, bebieron Grocio y demás organizadores del Derecho natural y de gentes lo más selecto, puro y sólido de sus teorías; las de Huarte, Pujasol, Venegas y Bonet algo representan en el desarrollo histórico de la Frenología y de la Pedagogía, como en el de la Gramática general y de la Filología comparativa las del Brocense, Arias Montano y Hervás y Panduro; ¿qué más?: hasta las de nuestros físicos y naturalistas, en tan baja estima tenidas, aportaron no despreciables aumentos al acervo común de la ciencia europea. De todo esto ha hablado usted acertadamente. Y ante hechos de tal calibre, ¡hay doctores españoles, y de primera nota, que crean posible escribir la historia del saber humano sin contar para nada con España!

No es de admirar, a vista de semejante fenómeno, que los extranjeros miren con poco aprecio la ciencia española y desconozcan sus servicios. Así, no extraño que Rousselot, en su rnonografía de Los místicos españoles, hable de Raimundo Lulio como de un loco verosimil solo en el país de Don Quijote, y llame simples moralistas a todos nuestros pensadores del siglo XvI, citando entre ellos a algunos que, como Sepúlveda, poco de moral escribieron, y hasta regatee su admiración a los sublimes místicos objeto de su libro, con tener por cierto y averiguado que fueron ellos nuestra única filosofía. Menos extraño aún que Emilio Saisset, que a la cualidad de francés une la de no presumir de hispanista, en su obrita de los Precursores de Descartes, ni siquiera miente los nombres de Vives, Juan de Valdés, Fox, Henao, Bernaldo de Quirós, Arriaga, Vallés, doña Oliva Sabuco, Francisco Sánchez, Gómez Pereira, etc., de cuyos libros sacó o pudo sacar el filósofo de la Turena la duda metódica, el entimema famoso, la doctrina del pensamiento y la extensión considerados como constitutivos esenciales respectivamente del espíritu y de la materia, la de las ideas innatas, la teoría de las pasiones, la localización del alma en la glándula pineal, el mecanismo, el automatismo de las bestias, etc. $\mathrm{Ni}$ tampoco me sorprende que otros escritores franceses, que, como, por ejemplo, M. Levèque en la Revue des Deux Mondes, ha ventilado recientemente este último punto - hoy de alguna entidad por lo que se relaciona con la psicología comparativa-, hagan caso omiso de la Antoniana Margarita y de sus impugnadores. ¿Por dónde pretenderíamos que los extraños nos diesen ejemplo de españolismo, cuando no saben (salvo sus intenciones) dárnosle los propios?

Desde el comienzo de la presente contienda vióse asomar, en medio de las varias negaciones, digámoslo así, concéntricas, que la ocasionaron, y cual núcleo de ellas, una negación capital, en cuyo mantenimiento han revelado mayor empeńo los massonianos, así como V., por su parte, lo ha puesto no menor en echarla abajo; la negación de la filosofía española. Arrollados por la 
erudición y la lógica de V., fueron abandonándolas todas sucesivamente; a ésta de que hablo no renunciaron hasta el postrer momento, encastillándose en ella como en su último y más preciado baluarte. Eran harto débiles sus fundamentos para que pudiesen sostenerse mucho tiempo. No sé con qué derecho exigen los adversarios, como condición sine qua non, para que un pueblo pueda blasonar de tener filosofía propia, y con ella opción a figurar honrosamente en los anales de la ciencia, el que ofrezca una serie de filósofos regimentados en forma de escuela, y que el influjo de ésta haya trascendido al resto del mundo. Paréceme que con poseer cierto número de pensadores ilustres que, reflejando la índole del genio nacional, apareciesen unidos por comunes caracteres externos, bastaría. No tuvo más Italia, y de los chinos no sabemos que sus luces hayan llegado mucho más acá de las fronteras del Celeste Imperio. Con todo, a nadie se le ha ocurrido la peregrina idea de calificar de mitos a las filosofías italiana y china, y menos de privarlas de los honores de la historia. Pero no necesitó V. valerse de esta clase de argumentos, supuesto que podía acometer de frente al enemigo, oponiéndole no una, sino tres creaciones filosóficas españolas, tres escuelas originales de influencia en el pensamiento europeo, a saber: el lulismo, el suarismo y el vivismo, aun sin contar el senequismo, el averroísmo y el maymonismo.

La existencia del lulismo y del suarismo por ningún escritor razonable había sido hasta ahora puesta en tela de juicio; la del vivismo era más disputada; yo me atreví a afirmarla años ha; usted la demuestra con pruebas irrefragables, evidenciando al propio tiempo sus extensas y profundas ramificaciones en la variada trama de las modernas teorías filosóficas. ¡Cuán fuera de camino van los que sólo consideran a Vives como censor de la escolástica, cuando su poderosa crítica alcanzó a todos los sistemas entonces conocidos, y de todos formó proceso, y en todos encontró defectos y perfecciones! No sería absurdo un paralelo entre la obra científica de Vives y la de Santo Tomás de Aquino. Si el Ángel de las Escuelas supo encauzar por las vías católicas las torcidas corrientes filosóficas de su siglo, depurando las doctrinas anteriores y organizándolas en una vasta síntesis, el polígrafo valenciano acrisoló la escolástica decadente, combinó con el oro que de ella extrajo lo más acendrado de otros sistemas, abrió nuevo sendero a la especulación, dando importancia al procedimiento inductivo, reformó el método, señaló reglas para evitar los extravíos intelectuales y cristianizó la filosofía del Renacimiento, milagros todos de su espíritu imparcial y comprensivo, que le hizo, no entrever, sino formular con claridad y precisión incomparables cuantos principios habían de disputarse la arena filosófica en aquella edad y en las siguientes; pero sin extremar ninguno ni sacarlo de su lugar propio y valor respectivo. Por tal ra- 
zón, tuvo menos discípulos completos que secuaces exagerados de alguna parte de su doctrina, los cuales, dividiéndose la herencia del maestro, corrieron en diversas y aun opuestas direcciones, porque no abundan las inteligencias tan sintéticas y universales como la de nuestro filósofo, siendo, por el contrario, achaque frecuente, aun en pensadores esclarecidos, el contentarse con un solo principio y deducir de él las últimas consecuencias. Así Bacon, exagerando la experiencia proclamada por Vives, paró en el empirismo y engendró a Locke, como Locke a Condillac, y Condillac a Destutt-Tracy y a Cabanis. Así Reid, huyendo del escepticismo de David Hume, se refugió en aquel juicio naturale instintivo de que habla Vives, y a imitación suya el P. Buffier, y no acertando a salir del sentido común ni a desprenderse de las reminiscencias baconianas, estableció un empirismo psicológico, sabio y fecundo, pero estrecho, que a su vez extremó Hamilton, desterrando de la filosofía toda especulación acerca de lo absoluto e incondicionado, por donde vino a convertirse en fautor del positivismo. Así Descartes, tomando de los vivistas españoles su racionalismo, pero sin atenuación ni límites, dejó al descubierto altas verdades, y, conscia o inconsciamente, abrió la puerta a todos los idealismos posteriores. Y he aquí cómo de Vives procede toda la filosofía moderna anterior a Kant, lo mismo en lo bueno que en lo malo, sin que, esto no obstante, se le puedan achacar las erradas consecuencias que infieles alumnos derivaron de principios suyos mal entendidos o trastocados del único lugar en que tenían solidez y fuerza dentro del conjunto de sus especulaciones. La Europa entera es discípula, aunque ingrata, de Vives, y no sin razón le reputaba Forner por igual a los mayores sabios de todos los siglos. España debe estimarle como la más elevada personificación de su genio científico, y ver en su sistema el molde más a propósito, por lo amplio y conciliador, para reducir a unidad armónica las diferentes teorías de nuestros doctores, y de esta manera dar cuerpo visible, si se me permite la expresión, a la filosofía nacional.

En toda su apología, pero más, si cabe, en esta última parte de ella, hace $V$. ver prácticamente que no son incompatibles la cualidad de crítico profundo y la de consumado bibliófilo, desplegando, al par que un gran conocimiento de los pormenores históricos, recto juicio y perspicacia suma para examinarlos y discernirlos, clasificarlos y componerlos según su respectiva importancia y mutuas conexiones. La notable participación que en el crecimiento y desarrollo de la cultura científica europea, sobre todo de la filosófica, tuvo España, resulta patente y puesta en su debido punto, aunque con la brevedad propia de una polémica. De esta demostración brota otra no menos palmaria, y es que la historia de la ciencia, y especialmente de la filosofía moderna, tal como anda escrita, dejando a nuestra patria 
en casi completo olvido, carece de integridad y de verdad, puesto que no abraza toda la materia que le corresponde abrazar ni refleja con exactitud el enlace real de las causas y de los efectos, y que, por tanto, debe rehacerse radicalmente, dando cabida en ella a la exposición de las ideas de los sabios españoles, y partiendo de Vives, centro de la vida intelectual de Europa en la era del Renacimiento y progenitor de las principales doctrinas que florecieron antes de la kantiana. Abundantes y preciosos materiales para esta obra ha reunido V. en sus Cartas, dirigiendo la atención de los estudiosos hacia puntos poco conocidos, sacando de la oscuridad libros y autores dignos de remembranza y loa, rectificando noticias y juicios equivocados que corrían como indudables, señalando relaciones de que nadie se percataba entre unos y otros pensadores y sistemas y determinando la existencia y entronques de ciertas escuelas hasta ahora confundidas en la masa común e inclasificada de nuestro caudal filosófico. Por ello merece V. bien de la ciencia, ya en cuanto acrecienta desde luego considerablemente sus dominios, ya también en cuanto le abre camino para nuevas y fecundas conquistas.

No es menor el servicio que $V$. presta a la patria volviendo por sus timbres científicos, de cierto más altos y estimables que las conquistas y hazañas sin cuento registradas en nuestros anales. Desmoronóse el poderío fundado en la fuerza militar y en las artes de la política; no perecerán nunca el genio de nuestros sabios ni la levantada inspiración de nuestros poetas. Los segundos son universalmente conocidos y celebrados. Pero de los primeros, ¿quién se acuerda? ¿Quién los lee ni estudia? Tarea en sumo grado loable es la de renovar su memoria y procurar que vuelvan a adquirir popularidad y fama; que al par de los nombres de Fr. Luis de León, Ercilla, Cervantes, Lope, Calderón, Tirso y Quevedo, suenen de nuevo con aplauso, entre propios y extraños como sonaban en mejores tiempos, los de Lulio, Vives, Fox, Vallés, Gómez Pereira, Vázquez, Molina, Suárez, Domingo de Soto, Ángel Manrique, Isaac Cardoso, Caramuel y tantos otros, y que, convirtiendo la vista a sus enseńanzas y tomándolas por base de sus ulteriores disquisiciones, recobre España su prístina personalidad e influencia en el mundo científico.

¡Triste de la nación que deja caer en el olvido las ideas y concepciones de sus mayores! Esclava alternativamente de doctrinas exóticas entre sí opuestas, vagará sin rumbo fijo por los mares del pensamiento, y, como V. con mucho acierto indica, cuando acabe de perder los restos de la ciencia castiza, perderá, a la corta o a la larga, los caracteres distintivos de su lengua, y los de su arte, y los de sus costumbres, y luego... estará amenazada de perder también hasta su integridad territorial y su independencia, que, mejor que con lanzas y cańones, se defienden con la unidad de creencias, sentimientos y gloriosos recuerdos, 
alma y vida de los pueblos. Y ¡cuán cerca de tan desdichada suerte nos hallamos en España! La demolición comenzada en el siglo XVIII, se ha proseguido con ardor creciente en el XIX, amontonando ruinas sin medida ni término. Por el campo de nuestra filosofía han penetrado sucesivamente el cartesianismo, el sensualismo de Locke y Condillac, el materialismo de Cabanis y Destutt-Tracy, el sentimentalismo de Laromiguière, el eclecticismo de Cousin y Jouffroy, el psicologismo de Reid y Dugald-Stewart, el tradicionalismo de Bonald y el P. Ventura de Ráulica, el kantismo, el hegelianismo, el krausismo, y ahora andan en moda el neo-kantismo y el positivismo, estrechamente aliados. La ciencia española ha ido, entre tanto, desapareciendo del comercio intelectual. Precedentes insignes tenían en ella algunas de las referidas escuelas, pero, con una sola excepción, los dedicados a propagarlas aquende el Pirineo, de todo se han cuidado menos de empalmar sus doctrinas con las antiguas, españolizándolas en lo posible, para que así corriesen rodeadas de mayor autoridad y prestigio. Lejos de eso, hasta la forma de exposición ha solido ser anárquica, mestiza, desapacible y de todo punto ajena a la naturaleza del habla castellana.

No ignoro (¿cómo había de ignorarlo?) que la ciencia es una y que la verdad no tiene patria; mas nadie negará tampoco que la verdad y la ciencia adoptan formas y caracteres distintos en cada tiempo y país, según el genio e historia de las razas, a cuyas peculiares condiciones se atenta con la manía de introducir lo extranjero sin asimilarlo a lo propio. Infríngese una ley fundamental de la vida, así espiritual como física, cuando a la asimilación se sustituye la superposición, nunca duradera ni fructuosa. De muy diverso modo proceden los misioneros católicos en las regiones donde reina el paganismo. Van a difundir la verdad, la verdad absoluta, superior a las opiniones y juicios varios de los hombres; no por eso prescinden de las creencias anteriores de las gentes a quienes intentan evangelizar; las examinan a fondo, las cotejan con los dogmas de la Iglesia, y siempre que de éstos no difieren o pueden, mediante plausibles interpretaciones, armonizarse con ellos, las traen y utilizan en su apoyo. ¿Qué hizo San Pablo cuando empezó su discurso en el Areópago diciendo a los atenienses que al entrar en la ciudad había visto la estatua del Dios ignoto, y que cabalmente de ese mismo Dios iba a predicarles?

La tradición es elemento y auxiliar capitalísimo del progreso en todo. La falta de ella, la solución de continuidad entre lo viejo y lo nuevo, explica por qué en la España moderna aparecen y mueren tan pronto los sistemas filosóficos sin llegar jamás a aclimatarse, y la facilidad con que sus adeptos pasan de unos a otros, como si en ninguno encontrasen estabilidad y reposo. ¿A qué debe, en cambio, Alemania el vuelo y preponderancia de sus escuelas sino a haber permanecido fiel en lo que va de siglo al espíritu nativo 
de su ciencia, con tener ésta tantos deslumbramiemtos y trampantojos, corno creación de los que Hamilton llama visionarios filosóficos,

\section{Gens ratione ferox et mentem, pasta chimeris?}

¿A qué debió su prosperidad e importancia la escuela escocesa, sino a su rigurosa consecuencia y disciplina, sólo por el doctor Brown quebrantada, y a su conformidad con el sentido práctico de la gente británica? ¿Por qué ha prevalecido en Francia el moderno eclecticismo, sino por sus conexiones con la doctrina cartesiana, y por invocarla constantemente en favor suyo? ¿Por qué, en fin, rayó a tanta altura la filosofía italiana en los días de Galluppi, Gioberti, Rosmini, Mamiani y Sanseverino, sino por el colorido nacional que éstos le dieron, presentándose como intérpretes y vivificadores de la antigua sabiduría de su patria? ¡Qué diferencia entre el auge y esplendor que entonces tuvo y la pobreza a que ha venido desde que, abandonada aquella senda, la Península transalpina se ha dejado invadir y dominar de las escuelas alemanas y francesas más funestas, favorecidas por el espíritu revolucionario y anticatólico! ¿Qué es al presente ni qué supone Italia en el terreno de la especulación filosófica?

Salta a la vista, pues, que importa en extremo a los pueblos no renegar de su abolengo doctrinal ni limitarse a repetir más o menos servilmente lo que otros pueblos discurren y escriben. Insistere vestigiis, debe ser su divisa; acoger la verdad, sí, venga de donde viniere, pero ingiriéndola en el cuerpo de las que los siglos les legaron, y no aceptándola como prestada siempre que puedan ostentarla como de cosecha propia. Sólo de esta suerte lograrán en la línea científica vida robusta e independiente, consideración y respeto. Impórtale a España muy especialmente seguir esa pauta, ya que, por fortuna, su filosofía de antaño — donde, a lo menos en germen, se contiene casi todo cuanto de razonable y sólido encierran los libros de los modernos pensadores, y aun más que en ellos respecto a no pocas cuestiones - le ofrece, a la vez que seguros métodos, inagotable mina de excelentes materiales para las más variadas, atrevidas y grandiosas construcciones. Restaurarla, ilustrarla, ampliarla, embellecerla, siguiendo los designios de Vives, sea por tanto, de hoy más, su principal empeño, si quiere de influida convertirse en influyente en los futuros desarrollos de la razón humana. A este fin han de contribuir sobremanera las eruditas epístolas de $\mathrm{V}$. y los atinadísimos proyectos que en ellas diseña. Muy conducente sería asimismo, en mi sentir, la composición de una obra metódica, extensa y minuciosa acerca de la Filosofía española comparada con la antigua y la moderna, por el estilo de la relativa a la cristiana, que tan justo renombre ha dado al napolitano Sanseverino. 
Al par que como diligente obrero de la ciencia y como hijo amante de la patria, ha cumplido V. como buen católico, vindicando la verdad histórica en punto al estado intelectual de Espańa en las edades pretéritas, pues con esto pulveriza ipso facto uno de los argumentos que más a su sabor emplean frecuentemente los multicolores devotos del Gran Pan contra la Iglesia de Jesucristo, cual es el suponer efecto de su acción y predominio la que llaman decadencia de las naciones dóciles al magisterio de la cátedra San Pedro. En la guerra que se hace a nuestra antigua cultura científica entran por mucho, entre otras causas, la escasez de conocimientos bibliográficos, la poca afición a leer libros viejos y en latín, la preocupación y el espíritu de secta y de sistema; pero el móvil principal — V. lo ha dicho sin rodeos- es el odio al catolicismo, el insaciable afán de desacreditarle. La adhesión inquebrantable a éste ha sido en todos tiempos una de las notas características del pueblo español; de ella nacieron la mayor parte de las proezas y maravillas obradas por nuestros padres. La heterodoxia intentó en repetidas ocasiones borrarla; siempre en vano. Nunca doctrinas impías ni heréticas echaron raíces en la Península Ibérica; fueron, a lo sumo, accidentes transitorios. V. lo patentiza admirablemente en su Historia de los Heterodoxos españoles. ¿Qué son, en el glorioso y dilatado curso de nuestra civilización, más que aberraciones de un día el gnosticismo de Prisciliano y el adopcionismo de Félix y Elipando? ¿Qué significan los olvidados desvaríos de Hostigesis, Arnaldo de Vilanova. Gonzalo de Cuenca y Pedro de Osma? Ni el protestantismo en el siglo XvI, ni el enciclopedismo a fines del XviII y principios del actual, consiguieron torcer la índole unitaria de nuestra raza. Y en cuanto a los que, fuera de estos grupos, extravagaron de la ortodoxia, sabido es que, no obstante ser a veces hombres de talento privilegiado y mucha doctrina, ni hicieron prosélitos ni dejaron rastros en pos de sí, apareciendo en la historia patria como fugaces meteoros, como fenómenos aislados, sin antecedentes ni consecuencias. Hoy nos embiste el error nuevamente y con formidable aparato, valiéndose de todo linaje de armas, y para abrirse paso con mayor facilidad, pone singular empeño en hacernos ver que todas las dolencias históricas de España provienen de su catolicismo. Una de ellas, acaso la más grave, es, a sus ojos, nuestra pretendida nulidad científica desde el Renacimiento hasta la edad que denominan novísima, y por eso se la atribuye a las trabas e imposiciones dogmáticas, prevalido de la ignorancia que en orden a nuestra pasada actividad intelectual reina generalmente entre doctos e indoctos. Señalado obsequio hace V., pues, a la religión, trabajando por destruir esta ignorancia y dejar, como deja, fuera de duda, que no hubo semejante anulación del pensamiento ibérico, y que, por tanto, carecen de base cuantas deducciones en ella se fundan. 
También la falsa filosofía del siglo último llamó ese argumento en pro de sus dañados propósitos; también hubo entonces quien, a nombre de ella, preguntase enfáticamente: ¿qué se debe a España?; y entonces, como ahora, salieron a la palestra valentísimos defensores de la cultura nacional. Quizá en algún punto anduvieron escasos; quizá en otros comprometieron demasiado su generosa causa. No ha de dudarse, sin embargo, que en la mayor parte de ellos obtuvieron sobre sus adversarios completísimo triunfo. Con todo, aquellas memorables apologías no han impedido a Mr. Masson resucitar en el año de gracia de 1876, ni hecho innecesarios los denodados esfuerzos de V. para repeler sus tenaces acometidas y hundirle de nuevo en el sepulcro; y témome que, semejante a los vampiros, aun vuelva a levantar, cuando menos se piense, la cabeza. Para evitarlo, es indispensable emprender con energía y constancia la ilustración bibliográfica e histórico-crítica del saber de nuestros antepasados en sus diversas ramas, particularmente en la filosófica, llevando a cabo el magnífico programa por V. expuesto, que ha sido siempre el sueño dorado de mi vida. De vano, utópico e irrealizable sé que han de calificarle a boca llena los hombres de voluntad débil y tibio patriotismo; los españoles netos, los verdaderos amantes de las luces, los católicos fervorosos y de elevadas miras, no dejarán de tener fe en su éxito, y con fe contribuir a él, moviendo montañas, si preciso fuere; que la fe a tanto alcanza.

En ningún caso desmayemos: la obra es grande, es santa; requiere el concurso de todas las voluntades no marchitas, de todos los entendimientos no pervertidos por el error, de todos los corazones que no han apostatado de la religión ni de la patria. Con su directa colaboración los doctos, con sus simpatías y aplauso los no letrados, coadyuven todos a esta empresa regeneradora, todavía posible, porque, a dicha, aun alienta el genuino espíritu de Espańa, la cual no está reducida a las dos docenas de doctores más o menos flamantes que se arrogan el derecho de representarla en el estadio de la inteligencia. Pero acudamos pronto; el mal se ha hecho crónico, y cuanto más dilatemos la curación, más difícil será extirparle. A los católicos exhorto muy principalmente. No en los campos de batalla, ni en las de ordinario estériles luchas políticas, sino en el ancho palenque donde V. bizarramente lidia, deben concentrar sus facultades y recursos. No cabe dar más útil aplicación a los talentos y vigilias del apologista ortodoxo; pocas materias, de seguro, la reclaman tanto. Vengan, pues, los sabios todos del orbe cristiano a defender y sacar del olvido la ciencia española. Defendiéndola, defenderán el catolicismo; sacándola del olvido, franquearán un arsenal riquísimo a los paladines de la Iglesia. Multiplíquense los diccionarios bibliográficos, las monografías, las publicaciones de todas especies acerca de nuestro pasado científico; acábese 
de descorrer el velo que lo cubre; no quede en él rincón alguno adonde no lleguen las luces de la erudición y de la recta crítica; désele a conocer, en una palabra, plena, clara y detalladamente, y entonces Mr. Masson, que sólo a favor de la oscuridad revive, habrá muerto para siempre.

Levantada tengo años ha esa bandera, y, ¡loado sea Dios!, no todo ha sido desdén hacia ella. Poco a poco va creciendo el número de los que creen en la ciencia española y desean que su historia se escriba y que su savia torne a vigorizar el espíritu nacional. Usted solo vale por un ejército. Flaco siempre de entendimiento, y ahora, amén de esto, enfermo y dolorido, nada me es dado hacer ya para unir a la predicación el ejemplo: estas líneas, salvo un milagro, pueden considerarse como mi testamento literario. ¿Qué importa? Non omnis moriar. Queda en pie V., joven alentado, corazón sano, cabeza potentísima, para continuar la tradición de mis ideas y proyectos, y si, como ardientemente le pido, el cielo se digna otorgarle vida larga, salud y sosiego, conducirlos todos a felice término y remate. Lo que en mí fue humilde brote, será en $\mathrm{V}$. árbol corpulento y lozano, cargado de sabrosísimo fruto.

¡Cuánto me regocija y consuela, en medio de mis angustias y melancolías, el pensar que es V., como yo, hijo de

«...la gran Montaña en quien guardada

la fe, la sangre y la lealtad estuvo,

que pura y no manchada,

más limpia que su nieve la mantuvo",

y que, tal vez, a esa comarca está reservada la gloria de dar, como dio los primeros, el último y más avanzado paso en el camino de la restauración científico-patriótica que anhelamos! ¡Cuán dulcemente me lisonjea el poder finalizar la presente carta, y con ella mi carrera de escritor, apropiándome esta afectuosa estrofa de la oda de Cadahalso a Meléndez Valdés:

«Y yo, siendo testigo

De tu fortuna, que tendré por mía,

Diré: «Yo fui su amigo,

Y por tal me tenía,

¡Y en dulcísimos versos lo decía!»

Reciba V. el más cordial abrazo de

Gumersindo LaVerde. Lugo, 30 de septiembre de 1876. 


\section{PRIMERA PARTE}

\section{AL SR. D. GUMERSINDO LAVERDE}





\section{INDICACIONES SOBRE LA ACTIVIDAD INTELECTUAL DE ESPAÑA EN LOS TRES ÚLTIMOS SIGLOS}

$\mathrm{M}$ i carísimo amigo y paisano: En una serie de artículos que, con el título de El Self Government y la Monarquía doctrinaria, está publicando en la Revista de España su tocayo de V. D. Gumersindo de Azcárate, escritor docto, y en la escuela krausista sobremanera estimado, he leído con asombro y mal humor (como sin duda le habrá acontecido a V.) el párrafo a continuación transcrito:

«Según que, por ejemplo, el Estado ampare o niegue la libertad de la ciencia, así la energía de un pueblo mostrará más o menos su peculiar genialidad en este orden, y podrá hasta darse el caso de que se ahogue CASI POR COMPLETO su actividad, como ha sucedido en España durante tres siglos.»

Sentencia más infundada ni más en contradicción con la verdad histórica, no se ha escrito en lo que va del presente. Y no es que el ilustrado Sr. Azcárate sea el único sustentador de tan erróneas ideas, antes con dolor hemos de confesar que son hasta vulgares entre no pocos hombres de ciencia de nuestro país, más versados sin duda en libros extraños que en los propios. Achaque es comunísimo en los prohombres del armonismo juzgar que la actividad intelectual fue nula en España hasta que su maestro Sanz del Río importó de Heidelberg la doctrina regeneradora, y aun el mismo pontífice y hierofante de la escuela jactóse de ello en repetidas ocasiones, no yéndole en zaga sus discípulos. ¡Y si fueran ellos solos! Pero es, por desdicha, frecuente en los campeones de las más distintas banderías filosóficas, políticas y literarias, darse la mano en este punto sólo, estimar en poco el rico legado científico de nuestros padres, despreciar libros que jamás leyeron, oír con burlona sonrisa el nombre de Filosofía española, ir a buscar en incompletos tratados extranjeros lo que muy completo tienen en 
casa, y preciarse más de conocer las doctrinas del último tratadista alemán o francés, siquiera sean antiguos desvaríos remozados o trivialidades de todos sabidas, que los principios fecundos y luminosos de Lulio, Vives, Suárez o Fox Morcillo. Y en esto pecan todos en mayor o en menor grado, así el neoescolástico que se inspira en los artículos de La Civiltà y en las obras de Liberatore, de Sanseverino, de Prisco o de Kleutgen, aprendiendo no pocas veces, gracias a ellos, que hubo teología y teólogos espańoles, como el alemanesco doctor que refunde a Hegel, se extasía con Schelling, o martiriza la lengua castellana con traducciones detestables de Kant y de Krause. Cuál se proclama neo-kantista, cuál se acoge al pesimismo de Hartmann; unos se van a la derecha hegeliana, otros se corren a la extrema izquierda y de allí al positivismo; algunos se alistan en las filas del caído eclecticismo francés, disfrazado con el nombre de espiritualismo; no faltan rezagados de la escuela escocesa; cuenta algunos secuaces el tradicionalismo, y una numerosa falange se agrupa en torno de la enseña tomista. Y en esta agitación y arrebatado movimiento filosófico, cuando todos leen y hablan de metafísica y se sumergen en las profundidades ontológicas; cuando en todos los campos hay fuertes y aguerridos luchadores, y todos los sistemas cuentan parciales, y todas las escuelas discípulos, nadie procura enlazar sus doctrinas con las de antiguos pensadores ibéricos, nadie se cuida de investigar si hay elementos aprovechables en el caudal filosófico reunido por tantas generaciones, nadie se proclama luliano, ni levanta bandera vivista, ni se apoya en Suárez, ni los escépticos invocan el nombre de Sánchez, ni los panteístas el de Servet; y la ciencia española se desconoce, se olvidan nuestros libros, se los estima de ninguna importancia, y pocos caen en la tentación de abrir tales volúmenes, que hasta los bibliófilos desprecian en sus publicaciones, teniendo sin duda por más dignos de conservarse el Libro de las aves de caza, el De la Cámara del Príncipe Don Juan, La Lozana Andaluza, o La desordenada codicia de los bienes ajenos, que los tratados De Causis corruptarum artium y De tradendis disciplinis, los De justitia et jure, la Antoniana Margarita, el libro de Gouvea Adversus Petrum Ramum, el de Sánchez Quod nihil scitur, el De morte et immortalitate de Mariana, las obras todas de Fox Morcillo, hoy rarísimas, sin otra multitud de producciones por varios conceptos notables y algunas excelentes. ¿Y qué diremos del olvido en que políticos, economistas y escritores de ciencias sociales suelen tener a sus predecesores? Raros son asimismo los que conocen y estudian a nuestros filólogos y humanistas. De este común descuido nace, cual forzosa consecuencia, el que se sostengan y repitan afirmaciones como la que da ocasión a esta carta. A V., amigo mío, campeón infatigable de la ciencia espańola, conocedor, como pocos, de sus riquezas, toca oponerse con ardor creciente a los descomedidos ataques que contra nuestro pasado 
intelectual cada día y en todas formas y en todos lugares se repiten. Yo, pobre de erudición y débil de entendimiento; yo, que sólo en la modesta condición de rebuscador y bibliógrafo puedo ayudar a la generosa cruzada por V. desde 1855 emprendida, y por pocos, aunque valiosos sustentadores, apoyada, voy a exponer brevísimas consideraciones sobre el párrafo del distinguido filósofo krausista que me ha dado pie para estas mal trabadas reflexiones.

Dice el Sr. Azcárate que se ahogó casi por completo la actividad cientifica de España durante tres siglos, que serán sin duda el XVI, XVII y XVIII. Vamos a verlo. ¿En cuál de las esferas del humano saber tuvo lugar esa opresión y muerte del pensamiento?

¿Fue en la filosofía? Precisamente el siglo xvi puede considerarse como su edad dorada en España. En él continuaron, se rejuvenecieron y tomaron nuevas formas las escuelas todas, ya ibéricas, ya de otros países importadas, que entre nosotros habían dominado durante la Edad Media. El lulismo, la más completa, armónica y pujante de todas ellas, conserva sus cátedras mallorquinas, penetra en Castilla amparado por el Cardenal Jiménez, recibe decidida protección del sombrío déspota Felipe II y cuenta entre sus sectarios nada menos que a nuestro egregio conterráneo el arquitecto Juan de Herrera, y antes y después de él a Alfonso de Proaza, a Nicolao de Pax, a Pedro de Guevara, a Sánchez de Lizarazo, no sin que algunos fervorosos lulianos se arrojen a sospechar que el mismo Fr. Luis de León miraba con buenos ojos la doctrina armónica del solitario del monte Randa. Llega a su apogeo el escolasticismo en sus diversas sectas de tomistas, escotistas, etc.; brota lozana y vigorosa la de los suaristas, y multiplícanse los volúmenes en que semejantes doctrinas se exponen, hasta el punto de que ninguna nación nos excede ni en el número ni en la calidad de tales escritores. De lo primero responda, sin ir más lejos, la Bibliotheca hispana nova de Nicolás Antonio, que sobre la mesa tengo, en cuyos índices, con ser tan incompletos, figuran innumerables filósofos peripatéticos, autores, ya de Cursos de artes, ya de Dialéctica y Súmulas, ya de Física, ya de las materias en las escuelas comprendidas bajo el dictado genérico De Anima, ya, en fin, de Metafísica.

Del mérito e importancia de muchos de estos trabajos dan testimonio los preclaros nombres de Gabriel Báńez, ${ }^{523}$ Domingo Soto, ${ }^{524}$ Téllez, ${ }^{525}$ Váz-

523 Dominico y tomista. De generatione et corruptione. De justitia et jure, etc. Murió en 1604. (Segunda Edición)

524 Tomista. Su obra más celebrada es la De justitia et jure. Merecen leerse además sus comentarios a Aristóteles. Murió en 1560. (Segunda Edición)

525 Baltasar Téllez, Jesuita y suarista. Summa universae philosophiae. Murió en 1675. (Segunda Edición) 
quez, ${ }^{526}$ Rodrigo de Arriaga, ${ }^{527}$ Toledo, ${ }^{528}$ Bernaldo de Quirós, ${ }^{529}$ Pererio, ${ }^{530}$ Molina, ${ }^{531}$ Marsilio Vázquez, ${ }^{532}$ Ángel Manrique, ${ }^{533}$ Juan de Santo Tomás, ${ }^{534}$ y, sobre todo, el de Suárez, de cuyos libros fuera no difícil extraer, abundante y de subidos quilates, aquel oro que Leibnitz reconocía en la escolástica, beneficiada en nuestros días con resultado tan notable. Y no insisto más en este punto, porque harto sé que hoy ningún espíritu serio osa despreciar aquella prodigiosa labor intelectual, de significación tan grande, de tan notable influjo en la historia de la ciencia. Harto se me alcanza asimismo que los parciales de ciertas escuelas idealistas, en una de las cuales milita el distinguido escritor a quien combato, miran, no sólo con respeto, sino con veneración excesiva, envuelta en cierto temor, al renaciente escolasticismo, hoy tan en boga, quizá porque creen descubrir en él su más valiente enemigo, sin que se atrevan tampoco a dirigirle cargos en cuanto a la rudeza y literaria incorrección de las formas, como culpables que son, hasta con creces, del mismo pecado. Justo es, pues, que amigos y enemigos de esa remozada teoría tributen a los nombres y obras de nuestros escolásticos insignes el mismo culto que, no sé si con rendimiento extremado, ofrecen a las doctrinas y libros de ciertos extranjeros contemporáneos.

Y saliendo del campo escolástico, que conozco mal, ${ }^{535} \mathrm{y}$ del que, en ocasiones, instintivamente me aparta algo de aquella santa ira que dominaba a los humanistas del Renacimiento, repulsión en mí más poderosa que la corriente tomista, hoy avasalladora, dirijamos la vista a la falange brillantísima de peripatéticos clásicos, como V. los apellida (denominación feliz por todo extremo), y de aquellos otros pensadores eclécticos e independientes que en su bandera pudieron escribir el lema de ciudadanos libres de la república de las letras. ¡Qué siglo aquel en que Sepúlveda vertía al latín y comentaba con exquisito gusto y clara inteligencia del original La Ética, La Política, los Opús-

526 Jesuita insigne. Murió en 1604. Con las cuestiones metafísicas esparcidas en sus obras se ha formado un tomo. (Segunda Edición)

527 Jesuita de ingenio acre e independiente, que en algunas cosas se aparta de Santo Tomás y de Suárez. Cursus Philosophicus (1632). Fue profesor en Praga. (Segunda Edición) 528 Jesuita y Cardenal. Murió en 1596. Escribió de lógica, de física, De generatione y De anima en cuatro volúmenes. (Segunda Edición)

529 Jesuita. Murió en 1668. Opus Philosophicum (1656). (Segunda Edición)

530 Jesuita. Murió en 1610. De principiis y De anima. (Segunda Edición)

531 Jesuita celebérrimo. Murió en 1600. De justitia et jure. (Segunda Edición)

532 Cisterciense. Murió en 1611. Commentaria in Aristotelis Philosophiam. (Segunda Edición)

533 Cisterciense. Murió en 1649. Comentarios a la Summa. (Segunda Edición)

534 Dominico. Murió en 1644. Ars Logica, Philosophia Naturalis. (Segunda Edición)

535 Después he procurado conocerle algo mejor. (Tercera edición) 
culos psicológicos y otros tratados de Aristóteles; en que D. Diego de Mendoza parafraseaba las obras todas del Estagirita, ${ }^{536}$ y Fonseca trasladaba de nuevo con profundos comentarios la Metafísica, y Pedro Juan Núnez, que desde las filas de Pedro Ramus se había pasado al peripatetismo, explicaba las dificultades de Aristóteles, ponía escolios al Órganon y coleccionaba las memorias históricas de los antiguos peripatéticos, mientras Cardillo de Villalpando y Martínez de Brea dilataban sus explanaciones a los libros todos del discípulo de Platón, defendiendo su doctrina en sabias y elegantes monografías contra los que le acusaban de materialista y reñido con la inmortalidad del alma! ¿Quién podrá enumerar los más importantes siquiera de aquellos trabajos de bibliografía, comentario, crítica y exposición de la doctrina de Aristóteles, bebida en las propias fuentes helénicas? ¿Cómo olvidar, entre otros no menos dignos de estima (cuyos autores no solían escasear, por cierto, las acerbas invectivas contra la barbarie de los escolásticos su ignorancia del griego y su incompleto y torcido conocimiento de Aristóteles), los de Gouvea, ${ }^{537}$ Montes de Oca, ${ }^{538}$ Luis de Lemus, ${ }^{539}$ Pedro Monzó, ${ }^{540}$ Juan Páez de Castro y Simón Abril, ${ }^{541}$ y las traducciones castellanas fidelísimas y completas (en la Biblioteca Nacional se conservan inéditas) que a principios del siglo XVII trabajó el insigne helenista valenciano Vicente Mariner, último de los peripatéticos clásicos, y sucesor no indigno de los Sepúlvedas y de los Núñez? ¡Y en época de tal y tan prodigioso movimiento dicen que estaba dormida la actividad científica de España!

¿Ofreció entonces nación alguna el espectáculo de independencia y agitación filosófica que caracteriza a España en aquella era? Todos los sistemas a la sazón existentes tenían representantes en nuestra tierra, y sobre todos ellos se alzaba el atrevido vuelo de otros espíritus más independientes, osados e inquietos los unos, sosegados y majestuosos los otros, agitadores todos, cada cual a su manera, sembradores de nuevos gérmenes y nuncios de ideas y de teorías que proféticamente compendiaban los varios y revueltos giros del pensamiento moderno. Sólo Italia podía disputarnos el cetro filosófico con su renovado platonismo y con las audaces y más o menos originales doctrinas de sus Pomponazzis, Telesios, Brunos y Campanellas. Si tienen

536 Esta paráfrasis se ha perdido. La cita Paulo Manucio. (Segunda Edición)

537 Adversus Petrum Ramum. (Segunda Edición)

538 De anima y De Physica. (Segunda Edición)

539 De erratis dialecticorum y De interpretatione (1558). (Segunda Edición)

540 Compositio totius artis Dialecticae (Valencia, 1566). (Segunda Edición)

541 Introductiones ad Logicam Aristotelis (1572) y Lógica o Filosofía Racional (1587). (Segunda Edición) 
que envidiarles nada nuestros filósofos, V. lo sabe, amigo mío, que tantas veces se habrá detenido, como yo, en la contemplación y estudio de los tratados admirables de Luis Vives, el más prodigioso de los artífices del Renacimiento, pensador crítico de primera fuerza, como hoy suele decirse, renovador del método antes que Bacon y Descartes, iniciador del psicologismo escocés, conciliador casi siempre, prudente y mesurado aun en la obra de reconstrucción que había emprendido, dechado de claridad, elegancia y rigor lógico, filósofo en quien predominaron siempre el juicio y el sentido práctico, nunca reñidos en él con la alteza del pensamiento, que, para todos accesible, jamás se abate, sin embargo, con aparente y menguada facilidad al vulgar criterio. ¡Qué útil fuera una resurrección de la doctrina vivista en esta época de anarquía filosófica, más enamorada de lo ingenioso que de lo sólido, más que de lo razonado de lo abstruso, siquiera en ello se encuentren únicamente esfuerzos de intelectual gimnasia, útiles tal vez como ejercicio, pero perniciosos si se convierten en hábito y se erigen en sistema!

Próximo a Vives debemos colocar al sevillano Fox Morcillo, que con sin igual fortuna se lanzó, en son de paz, entre platónicos y aristotélicos, intentando resolver en terreno neutral la eterna lucha del discípulo y del maestro, el eterno dualismo del pensamiento humano, que por sí solo explica la historia entera de la filosofía, partida siempre en dos campos, rivales más en apariencia que en realidad, conciliados a veces, nunca del todo, en los sistemas armonistas. Afirma Fox que la idea de Platón, la idea sobre las cosas, es la forma aristotélica, cuando se traduce y concreta en las cosas creadas. ¿Quién no ve aquí los elementos de un racionalismo armónico?

De siglo de oro filosófico habrá de calificar al siglo Xvi quien conozca, siquiera someramente, las obras de los ramistas españoles, muy superiores a su maestro en saber e ingenio, cuales fueron Núnez, en su primera época, el protestante Pedro Núñez Vela, amigo de Pedro Ramus y autor de una Dialéctica, y el Brocense, ingenio agitador por excelencia, que llevó al campo de la lógica aquella su perspicacia y agudeza de entendimiento, aquel horror a la opinión vulgar y a la barbarie de la escuela, que primero había manifestado tan altamente en cuestiones filológicas. $Y$ en punto a novedad y extrañeza de opiniones, pocos libros pueden compararse con el del portugués Sánchez Quod nibil scitur, nacido, más bien de propio impulso que de reminiscencias de Sexto Empírico o del ejemplo de Montaigne. ¿Qué diremos de Gómez Pereira, cartesiano antes que Descartes, así en materias físicas como metafísicas; del divino Vallés, adversario terrible, asimismo, de la cosmología aristotélica, como lo fue después Isaac Cardoso en su egregia Philosophia libera; de Huarte, padre de la frenología y engendrador inconsciente 
de no pocos sistemas materialistas; de doña Oliva, analizadora sutil de las pasiones? ¿Qué de nuestros innumerables moralistas, secuaces de Séneca y estoicos a su manera los unos, apologistas otros de Epicuro, amalgamándolos con frecuencia bajo superiores principios? ${ }^{342}$ ¿Y qué de nuestros místicos, en cuyas obras el entendimiento se abisma y halla luz la fantasía, y alimento el corazón, y regalo el oído, admirando todos de consuno tanta profundidad y tan seguro juicio, tal intuición de los misterios ontológicos y estéticos adonde no llega la reflexión ni el análisis alcanza, tal revelación de maravillas y de grandezas hecha en aquella lengua cuyo secreto se ha perdido, que parece en tales escritores la más grande de las lenguas humanas, y que es, a lo menos, la única entre las modernas que ha logrado expresar algo de la idea suprema, y ha tenido palabras, por grandes y pequeños comprendidas, para penetrar en los arcanos del ser, palabras que en su correr y en su sonar tienen algo de celestial y angélico, como pronunciadas por aquellos que se perdieron en el ancho piélago de la hermosura divina? Imposible es menospreciar el siglo que tales grandezas produjo. Inmortal sería, aunque sólo hubiese dado las Moradas teresianas, la Llama de amor viva y la Subida al Carmelo, el libro admirable de Los Nombres de Cristo y los Diálogos de la conquista del espiritual y secreto reino de Dios de Fray Juan de los Ángeles.

iTan por completo se ahogó nuestra actividad cientifica en aquella época! No acierto a ver esa opresión que pondera el señor Azcárate; por el contrario, me admira a veces la tolerancia y lenidad de los poderes civil y eclesiástico de entonces con ciertas ideas expuestas de buena intención, pero más o menos sospechosas de materialismo o de panteísticas cavilaciones. No encuentro en los Índices Expurgatorios más obras de filósofos ibéricos notables que las de Huarte y dońa Oliva, y éstas sólo para borrar frases muy contadas. Exceptuando al Brocense y Fr. Luis de León, en cuyos inicuos procesos influyeron otras causas, no hallo pensador alguno español perseguido por el Santo Oficio; a nadie castigó aquel Tribunal por haber expuesto doctrinas metafísicas, propias o ajenas, acomodadas o no a las ideas dominantes. En las llamas pereció un crudo panteísta navarro-aragonés; pero fue su suplicio en Ginebra, no en España; ordenólo Juan Calvino, no el Tribunal de la Fe.

542 Por ejemplo, el Brocense, traductor del Manual de Epicteto, verdadero código del Estoicismo, no duda en declarar que «la primera y la mejor de todas las opiniones sobre la vida dichosa fue la de Epicuro, si bien se entiende». El Pinciano decía de Epicuro que «supo este varón más alto de lo que el vulgo piensa, ni sus secuaces». Y en cuanto a Quevedo, sabido es que reunió en un mismo libro El origen y doctrina de los Estoicos y la defensa de Epicuro. (Tercera Edición) 
No me empeñaré en trazar una brillante pintura del siglo XvII, que, notable bajo otros aspectos, fue en lo filosófico degenerada secuela del XVI. Pero V. sabe, amigo mío (y discretamente lo ha dado a entender en uno de sus preciosos Ensayos), que no puede juzgarse muerta la actividad científica de un período que cuenta pensadores como Pedro de Valencia, Pujasol, Isaac Cardoso, Quevedo, Caramuel y Nieremberg, aparte de numerosos escolásticos, discípulos no indignos de los grandes doctores del siglo anterior. Y como la tirantez de la Inquisición en ese tiempo no fue mayor que en la precedente centuria, claro se ve que, no por falta de libertad, sino por causas de otra índole, decayeron tan lastimosamente los estudios. El mal gusto literario, que extendió sus estragos a todas las disciplinas; la universal decadencia de la nación, de múltiples fuentes emanada; la rigidez y tiranía de las escuelas, que se encarnizaban, no en la substancia, sino en los accidentes; las inútiles guerras filosóficas; el despotismo de la ciencia oficial, organizada en poderosas congregaciones, y la natural tendencia de las cosas humanas a descender así que llegan a la cumbre, dieron al traste con buena parte del edificio levantado en el siglo XVI, sin que en tal destrucción ejerciera grande influjo ese poder opresor a quien algunos atribuyen toda la culpa.

El tercero de los siglos ominosos para el Sr. Azcárate es el XviII, época de controversia, de discusión y de análisis, de grandes estudios y de encarnizada lucha; siglo de transición, falto en España de carácter propio, si ya no queremos fijarle en su propia vaguedad e indecisión. ¿Pero cómo ha de estimarse muerta la actividad cientifica de un período en que penetraron sucesivamente en España todas las doctrinas extranjeras, buenas o malas, útiles o dañosas, a la sazón corrientes; en que el gassendismo contó secuaces como el P. Tosca, y el maignanismo fue defendido por el P. Nájera, y la doctrina cartesiana, combinada con reminiscencias de Vives, Gómez Pereira y otros filósofos ibéricos, logró, como más afine de los sistemas peninsulares, el apoyo, siempre condicional, del P. Feijoo, y el más decidido de Hervás y Panduro y Forner, ${ }^{543}$ y el fácil y rastrero sensualismo de Locke y Condillac deslumbró las clarísimas inteligencias de los padres Andrés y Eximeno, no libres en esta parte del tributo que raros pensadores dejan de pagar, más o menos, a las ideas dominantes en su época? Y no se ha de creer por esto que faltaron en el siglo XviII paladines de los antiguos sistemas y acérrimos contradictores, más o menos bien encaminados, de las doctrinas innovadoras. Recuérdese el

543 Este pasaje requiere algún correctivo. Tosca, si bien gassendizó, fue libre, no sistemáticamente. Forner fue vivista decidido, y a la vez admirador de nuestros grandes escolásticos, señaladamente de Vázquez. Feijoo en Física más bien baconizó, pero en todo con libre espíritu. (Segunda edición) 
número prodigioso de libros y folletos que aparecieron con ocasión del Theatro Crítico y de las Cartas del P. Feijoo; recuérdense especialmente las defensas del lulismo hechas por los Padres Fornés, Pascual, Tronchón y Torreblanca; fíjese la consideración en los tratados escolásticos que entonces se dieron a la estampa; estúdiese la porfiada contienda entre revolucionarios y conservadores, primero en el terreno de la Filosofía natural, después en el de la Metafísica y la Moral, y podrá formarse idea del notable movimiento intelectual del siglo qué nos precedió; edad en muchos conceptos gloriosa para Espańa, aunque por nosotros poco estudiada, y aun puesta en menosprecio y olvido. Excelente monografía pudiera escribirse sobre este punto, utilizando las indicaciones esparcidas por $\mathrm{V}$. en diversos artículos, que dan, como diría un krausista, el concepto, plan, método y fuentes de conocimiento para obra semejante. Y en verdad que no sería excusado, antes muy útil y fructuoso, el análisis y juicio de libros tan notables como la Philosophia Sceptica del Dr. Martínez, la Lógica, la Filosofia Moral y los Opúsculos de Piquer; La Falsa Filosofía del P. Ceballos, los Desengaños filosóficos de Valcarcel, El Philoteo del cisterciense D. Antonio Rodríguez, los Discursos filosóficos sobre el hombre de Forner, los Principios esenciales del orden de la Naturaleza de Pérez y López, Dios y la Naturaleza de D. Juan Francisco de Castro, las Investigaciones de Arteaga sobre la belleza, y El Hombre Físico de Hervás, escépticos reformados, o sea, eclécticos los unos, adversarios los otros del enciclopedismo, un tanto sensualista alguno de ellos, y secuaces los demás del espiritualismo cartesiano.

Bastan los nombres de autores y de obras hasta aquí indicados, para demostrar que en dicha época anduvo muy ajena de ser oprimida ni anulada nuestra peculiar genialidad en este orden de conocimientos. Antes bien observamos que las doctrinas más funestas y tumultuosas recibieron en ocasiones decidido apoyo del poder civil, como acaeció con el enciclopedismo francés. En cuanto a la Inquisición, es harto sabido que perdió en aquella era gran parte de su fuerza y prestigio; que desde mediados del siglo estuvo en manos de los jansenistas, convertida a veces en instrumento dócil del regalismo, y que, lejos de perseguir ni coartar en ningún sentido la libertad filosófica, dejó crecer y desarrollarse la mezquina planta del sensualismo, consintió que penetrase en las aulas, y sólo tuvo prohibiciones y anatemas para los libros franceses claramente hostiles a la religión o a las costumbres. Y si molestó a Olavide, a Marchena y a algún otro propagandista o secuaz del enciclopedismo, más digna es de encomio que de censura por haberse opuesto, aunque desgraciadamente sin bastante energía, a la importación de doctrinas pobres, rastreras y monstruosamente impías, hoy, para todo hombre de ciencia, de cualquier campo filosófico, dignas de menosprecio y risa. 
De presumir es que entre las ciencias oprimidas y muertas en los siglos XVI, XVII y XVIII no incluya el Sr, Azcárate la Teología católica, tan cultivada en esas tres centurias como ha podido serlo en cualquier otro momento histórico (hablemos a la manera germanesca...: ¡ como si pudiera haber algún momento que no lo fuese!). Sin más trabajo que el facilísimo de registrar a Nicolás Antonio, ya que por desdicha no existe una Biblioteca especial de teólogos españoles, se encontrarán nombres de escriturarios y expositores, de dogmáticos, controversistas, ascéticos, moralistas, etc., etc., en número verdaderamente prodigioso. ¡Y qué nombres entre ellos! Arias Montano, Cipriano de la Huerga, Maluenda, Maldonado, D. Martín Pérez de Ayala, Fr. Luis de León, Alfonso de Castro, Fr. Luis de Granada, Francisco de Vitoria, Fr. Luis de Carvajal, Melchor Cano, Báñez, Lemos, ambos Sotos, Laínez, Salmerón, Toledo, Prado y Villalpando, Ribera, Luis de Alcázar, Pineda, Fr. Pedro de Herrera, Ramírez de Montoya, Molina, Suárez, Vázquez, Valencia, Sánchez, Álvarez de Paz, Martínez de Ripalda, Tirso González, astros de primera magnitud en el cielo de las letras eclesiásticas. En sus libros se explicó ampliamente nuestra genialidad teológica, que es católica y no heterodoxa, mal que les pesa a algunos. ¡Qué inmensa actividad intetectual no desplegaron estos teólogos en las famosas controversias de auxiliis! ¡De qué sutileza y profundidad de pensamiento no hicieron alarde Molina y Suárez en la concepción y desarrollo del congruismo, sistema teológico admirable, del todo español, que ha llegado a ser la doctrina más corriente en las escuelas católicas! Confesaré de buen grado que la Inquisición se opuso con mano fuerte a la introducción de toda enseñanza herética; en lo cual obró con suma cordura, dada la condición de los tiempos y supuesto el principio fundamental de nuestra civilización, entonces harto amenazado; mas no faltó por eso considerable grey de disidentes que mostraron a su sabor sus propias genialidades, seguros unos del alcance del Santo Oficio, y sujetos otros a sus rigores. Y quien busque teología heterodoxa, acuda a Valdés y a Servet, a Juan Díaz y al Dr. Constantino, a Cipriano de Valera y a Juan Pérez, a Tejeda y a Molinos, y advertirá que, por haber de todo, no faltaron doctores del mal y sembradores de cizańa, aunque por dicha no germinó entonces la mala semilla en nuestro suelo.

Tampoco creo que nuestro articulista incluya en su casi rotunda afirmación el Derecho, así natural como positivo, pues en quien tan dignamente ha ocupado cátedra de esta ciencia, debe suponerse, no vulgar conocimiento, sino meditación y estudio, del tratado De Legibus et Deo legislatore del jesuita Suárez, de los De Justitia et Jure de los dominicos Soto y Bánez y de los jesuitas Molina y Lugo, de los dos De Jure belli debidos a Vitoria y a Baltasar de Ayala, de la Anciclopadia juris de Cristóbal García Yánéez, y de otras producciones del 
mismo género, estimadas y grandemente puestas a contribución por Grocio y demás renombrados maestros extranjeros de Filosofía del Derecho. Y presumo que han de serle asimismo familiares las obras de los grandes jurisconsultos y canonistas Gouvea, émulo de Cujacio; Martín de Azpilcueta, defensor generoso del arzobispo Carranza; Antonio Agustín, de quien hacen derivar los alemanes Schulte y Maassen el período crítico de la historia de la ciencia canónica, por sus diálogos De emendatione Gratiani; D. Diego de Covarrubias, honra al par de la mitra y de la toga; Pedro Ruiz de Moros, admirado en Polonia por sus Decisiones lituánicas; Ramos del Manzano, el más erudito de los jurisconsultos, Fernández de Retes, su discípulo, lumbrera de la Universidad salmantina; Nicolás Antonio, tan docto jurisperito como bibliógrafo consumado; Salgado, Puga, y en tiempos a nosotros más cercanos, Mayáns, Finestres, Castro, y principalmente el insigne conde de Campomanes, por más que su nombre no suene del todo bien, y con harta razón, en muchos oídos.

De legistas a políticos el tránsito es fácil. Conocidos son los tratados De Regno et Regis officio de Sepúlveda, De Regis institutione de Fox Morcillo, De Rege et Regis institutione del Padre Mariana, El Consejo y Consejeros del Principe de Furió Ceriol, El Príncipe Cristiano del P. Rivadeneyra, el libro De República y policía cristiana de Fr. Juan de Santa María, El Gobernador Cristiano del P. Márquez, la Conservación de monarquías de Navarrete, la Política de Dios de Quevedo, las Empresas de Saavedra, y otros libros semejantes, escritos casi todos con gran libertad de ánimo, y llenos algunos de las más audaces doctrinas políticas. Ninguno de ellos (entiéndase bien) fue prohibido por el Santo Oficio, ni recogido por mandamiento real. La Inquisición y el Rey dejaron correr sin estorbo (y perdóneseme lo manoseado de la cita, en gracia de su oportunidad) aquel libro famoso de Mariana, quemado en Francia por mano del verdugo, en cuyos capítulos VI, VII y VIII se investiga si es lícito matar al tirano, si es lícito envenenarle, y si el poder del rey es menor que el de la república, decidiéndose en la primera y tercera de estas cuestiones por la afirmativa, lo cual no deja de ser una prueba de lo oprimida y anulada que estaba la libertad científica, cuando tales genialidades se estampaban como cosa corriente. Esa terrible manía del tiranicidio, nacida de clásicas reminiscencias, y en España poco o nada peligrosa, porque al poder monárquico nadie lo reputaba tiránico, y era harto fuerte y estaba de sobra arraigado en la opinión y en las costumbres para que pudieran conmoverle en lo más mínimo las doctrinas de uno ni de muchos libros, contagió a otros escritores, llegando hasta manifestarse en conclusiones tan audaces como las publicadas en 1634 por el P. Agustín de Castro, de la Compañía de Jesús, donde la consabida pregunta de si es lícito matar al tirano, va acompañada de las siguientes: «¿Es mejor algún gobierno que ninguno? ¿Es 
mejor el gobierno democrático que el monárquico y aristocrático? ¿Es más conveniente la monarquía electiva que la hereditaria? ¿Es lícito excluir a las hembras de la sucesión del trono?»; tesis todas que el buen Padre se proponía sostener en sentido afirmativo; prueba asimismo evidentísima de la formidable opresión y tiranía que pesaba sobre el pensamiento español en materias políticas.

Muy semejante debió de ser la anulación de nuestra genialidad y carácter en las sociales y económicas. De ello dan muestra los tratados de Fr. Bartolomé de las Casas, de Bartolomé Frías de Albornoz, del P. José de Acosta, del P. Antonio de Sandoval, y de tantos otros contra la esclavitud, y los libros de economía social y hacienda pública debidos a las valientes plumas del Dr. Sancho de Moncada, de Francisco Martínez de la Mata, de Fernández de Navarrete, de Álvarez Osorio, de Mariana, de Pedro de Valencia, del contador Luis Valle de la Cerda, de Martín González de Cellorigo, de Damián de Olivares, de Diego Mexía de las Higueras, de Alcázar de Arriaza, de Francisco de Cisneros y Jerónimo de Porras, de Leruela, de Alberto Struzzi, de Dormer y tantos otros economistas, ninguno de los cuales dudó en poner el dedo en la llaga, ora señalando entre las causas de la despoblación de España el excesivo número de regulares y la amortización así civil como eclesiástica, ora combatiendo las absurdas disposiciones gubernativas respecto a la tasa del pan y la alteración de la moneda, ora enunciando principios radicalmente favorables a la libertad de comercio. El número de tales escritores es grande; con ellos pudiera formarse una colección copiosísima; y de sus nombres y obras lógrase sin dificultad larga noticia con sólo recorrer la Educación popular de Campomanes y su Apéndice, la Biblioteca Económico-Política de Sempere, el Sumario de la España Económica de Vadillo, y, sobre todo, la Biblioteca de los economistas españoles y la Historia de la economía politica en España del Sr. Colmeiro. Por lo que al siglo xviII respecta, nadie ignora que se dio a estos estudios especial fomento, y basta recordar, entre los nombres de sus economistas, los del marqués de Santa Cruz de Marcenado, el P. Cabrera, Campillo, Ulloa, Uztáriz, Campomanes y Jove-Llanos, para hacer respetable en lo crematístico la época en que se escribieron La Industria Popular y La Ley Agraria, en que se crearon las Sociedades Económicas, y con tal suerte y tino se comenzaron a explotar los veneros todos de la riqueza pública.

Si con tanta amplitud y libertad discurrieron nuestros ingenios sobre materias filosóficas, políticas y económicas, claro es que no habían de encontrar cerrado el campo de las investigaciones lingüísticas, críticas, históricas y arqueológicas. Que hubo orientalistas, y en especial hebraizantes, dignos de inmortal recuerdo, compréndese con sólo traer a la memoria las dos Políglotas, monumentos de gloria para los que las protegieron y realizaron. 
Que hubieron de tropezar, en España y fuera de ella, con poderosos obstáculos los cultivadores de tales estudios, especialmente en el segundo tercio del siglo XVI, se explica bien por el estado de agitación religiosa de aquella época. Pero si Arias Montano fue envuelto en dilatados procesos, y Fr. Luis de León gimió en las cárceles inquisitoriales, y Pedro de Valencia hubo de luchar con el P. Andrés de León en defensa de la memoria de su maestro, el resultado de estas persecuciones y contiendas fue en definitiva favorable a los agraviados, pues al ilustrador de la Políglota antuerpiense y a su libro los escudó la protección de Felipe II; al místico autor de la Exposición del libro de Job valióle su inocencia y saber contra los encarnizados ataques de León de Castro, y fue absuelto, aunque tarde y con alguna restricción; y el docto filósofo de Zafra sacó a salvo de las detracciones de enconados émulos el nombre y los trabajos del inmortal escriturario de la Peña de Aracena. Mas si en el estudio de la lengua y literatura hebraicas encontraron nuestros filólogos alguna contradicción, no ha de afirmarse otro tanto del de los idiomas clásicos griego y latino, con tanto esmero y gloria cultivados desde fines del siglo Xv, en que a uno y otro seńalaron rumbo y abrieron camino Arias Barbosa y Antonio de Nebrija. De los posteriores progresos responden las numerosas traducciones de ambas lenguas, las gramáticas así griegas como latinas, estas últimas en cantidad prodigiosa, los vocabularios, los comentos e ilustraciones de diversos autores de la antigüedad clásica, los tratados de preceptiva, y crítica en que se exponen y amplían los cánones aristotélicos u horacianos; tareas en alto grado fructuosas, debidas, entre otros mil que al presente omito, a los insignes humanistas Vives, el comendador Hernán Núnez, Sepúlveda, Vergara, la Sigea, Lorenzo Balbo, Encinas, Gelida, A. Agustín, Mendoza, Páez de Castro, Diego Gracián, Pedro Juan Núñez, Oliver, Chacón, Gonzalo Pérez, Alvar Gómez, Matamoros, Pérez de Oliva, Fox Morcillo, Álvarez, el Brocense, Malara, Medina, Girón, Osorio, Calvete, Simón Abril, el Pinciano, Cascales, Bustamante, Barreda, Espinel, Correas, González de Salas, Baltasar de Céspedes, Valencia, Mariner, Tamayo de Vargas, Perpiñá, el P. La Cerda, Martí, don Juan de Iriarte y todos los latinistas y helenistas egregios que después de él florecieron en el siglo XVIII. De otras lenguas, como el árabe, escasearen más los cultivadores, y aun éstos no solían proponerse un objeto literario al aprender tal idioma, relegado casi a los misioneros que habían de usarle en su predicaciones y enseñanzas. ${ }^{544} \mathrm{~A}$ la diligencia y celo de estos piadosos varones debiéronse asimismo

544 Entiéndase esto con relación a los siglos XVI y XVII y primera mitad del XVIII. A fines de éste ya se cultivaban las letras arábigas en España con miras puramente literarias, siendo primicias no despreciables de semejantes estudios entre nosotros los trabajos de 
gramáticas y vocabularios de gran número de lenguas exóticas, catecismos y traducciones de libros sagrados en caldeo, siríaco, etíope, malabar, chino, japonés y sánscrito, en los dialectos americanos y en los de no pocas islas de la Oceanía; riquísima mies lingüística que a fines del siglo Xviı había de cosechar uno de los más esclarecidos hijos del solar español, el jesuita Hervás y Panduro, de cuyo cerebro, como Minerva del de Júpiter, brotó armada y pujante la Filología comparada. ¡Con cuánto gozo vemos a Max Müller en sus inmortales Lectures sobre la Ciencia del Lenguaje, dadas en la Institución Británica en 1861 reconocer y proclamar en alta voz los méritos de Hervás, que conoció y estudió cinco veces más idiomas que Court de Gebelin y los demás lingüistas de entonces, y que, en vez de lanzarse como ellos a sentar teorías precipitadas y absurdas haciendo derivar del hebreo el persa, el armenio y hasta el malayo, huyó cuidadosamente de toda hipótesis que no estuviese fundada en la realidad de los hechos; juntó noticias y ejemplos de más de trescientas lenguas; compuso por sí mismo las gramáticas de más de cuarenta idiomas, y fue el primero (entiéndase bien, el primero, así lo dice Max Müller) en sentar el principio más capital y fecundo de la ciencia filológica; es a saber: que la clasificación de las lenguas no debe fundarse, como hasta entonces empírica y rutinariamente se venía haciendo, en la semejanza de sus vocabularios, sino en el artificio gramatical! A la luz de esta verdadera intuición de genio, probó Hervás y Panduro, mediante un cuadro comparativo de las declinaciones y las conjugaciones en hebreo, caldeo, siríaco, etíope y amharico, que todas estas lenguas eran dialectos de una misma familia, la familia semítica. Hervás enterró para siempre la absurda idea de un hebraísmo primitivo. Hervás notó singulares analogías entre el húngaro, el lapón y el finnés, y estuvo a punto de descubrir la familia uralo-altaica o turania. Hervás probó que el vascuence no era un dialecto céltico, y echó las bases del iberismo de Guillermo Humboldt. Hervás advirtió ya la singular conformidad gramatical que une al sánscrito con el griego, reconociendo la identidad de los verbos auxiliares y de las desinencias de género. Hervás intentó el primero una clasificación de las lenguas americanas, reduciéndolas a once familias, cuatro meridionales y siete septentrionales. Y, finalmente, son palabras de Max Müller, «uno de los más hermosos descubrimientos de la ciencia del lenguaje, el establecimiento de la familia de las lenguas malayas y polinesias, que se extienden por más de doscientos grados de latitud en los mares Oriental y Pacífico, desde la isla de Madagascar, al Este

Casiri, Campomanes, Banqueri, Arteaga, Lozano y Caseda, Conde, Fr. Patricio de la Torre y otros. (Primera Edición) 
de África, hasta la isla de Davis, al Oeste de América, fue hecho por Hervás mucho tiempo antes de ser anunciado al mundo por Guillermo Humboldt».

$\mathrm{Si}$ el Sr. Azcárate sabe todas estas cosas, y yo no puedo creer que las ignore, porque las Lecciones de Max Müller no son un libro oscuro, sino que andan por Europa en manos de todo el que sabe leer, ¿cómo no le ha temblado la mano al escribir que la ciencia española estaba anulada, precisamente en aquel siglo en que salía de las prensas de Madrid, en lengua castellana, el Catálogo de las lenguas?

¿Y qué diremos, amigo mío, de los innumerables cultivadores de las ciencias históricas y arqueológicas, en esas edades que con tanto desdén miran algunos? Materia es ésta ya tratada, y en que no insistiré, por tanto, pues de superfluidad impertinente habría de tacharse el repetir, cual si no fuesen de sobra conocidos, los nombres de Antonio Agustín, padre de la Numismática; de Luis de Lucena, Fernández Franco, Juan de Vilches, Llanzol de Romaní, Ambrosio de Morales, Resende, Rodrigo Caro, Ustarroz, Lastanosa, el deán Martí, Sarmiento, Valdeflores, Finestres, Contador de Argote, Flórez, Pérez Bayer, Floranes, Capmany y tantos otros arqueólogos y diligentísimos investigadores; los de nuestros historiadores generales más o menos eruditos, más o menos críticos, Florián de Ocampo, Morales, Garibay, Zurita, Mariana, Ferreras, Masdéu, etc.; los de aquellos que, como Gonzalo Fernández de Oviedo, el Inca Garci-Lasso, Bernal Díaz del Castillo, Pedro Cieza de León, Antonio de Herrera, etc., etc., dieron a conocer la América y los maravillosos sucesos acrecidos en su descubrimiento y conquista por los espańoles; los de tantos y tantos como ilustraron los anales de ciudades, villas, provincias, monasterios, iglesias, de los cuales formó copiosa bibliografía, que aún puede acrecentarse mucho, el Sr. Muñoz Romero; ${ }^{55}$ los de Sigüenza, Yepes y otros doctísimos cronistas de Órdenes religiosas; los de Pellicer, Salazar de Castro y otros eruditos respetables entre la inmensa balumba de los genealogistas e historiadores de casas nobles, y aun los de los forjadores de falsos cronicones, que demuestran el grande, si bien descaminado, entusiasmo con que se proseguían las indagaciones históricas, entusiasmo que los llevaba a fingir historia donde no la había y a llenar con patrańas los huecos, no sin que, para gloria de la crítica histórica entre nosotros, encontrasen los osados falsarios, cabalmente en el período menos próspero de la cultura espańola, en los últimos reinados de la casa de Austria, la formidable oposición de varones tan preclaros como D. Juan Bautista Pérez, Pedro de Valencia, Fr. Hermenegildo de San Pablo, el marqués de Mondéjar, D. Juan Lucas Cortés y D. Nicolás Antonio.

545 El mismo Muñoz dejó un suplemento a ella. (Tercera Edición) 
Filólogos, humanistas, arqueólogos e historiadores, nos han traído a las fronteras de la República literaria, en la cual no entraré, sin embargo, porque el Sr. Azcárate parece referirse sólo a la actividad científica, y ni él ni nadie ha negado ni niega el prodigioso desarrollo de nuestra genialidad artística, antes bien, suelen afirmar que el poder opresor y tiránico de aquellos tiempos dio libertad y protección a la poesía, a la novela, al teatro y a todos los ramos de las bellas letras, para entretener y aletargar de esta suerte a los espańoles, y hacer que no sintiesen en modo alguna el peso de las cadenas que amarraban la libertad del pensamiento. Esto, expresado en más retumbantes frases y preñados conceptos, se oye cada día en boca de algunos filósofos, y esto quería indicar sin duda Sanz del Río cuando asentaba que, por falta de libertad en el llamado siglo de oro, el ingenio español se desarrolló sólo bajo un parcial aspecto, que, según él piensa, no fue el de la razón ni el del entendimiento; y cierto que sería cosa peregrina un desarrollo intelectual de cualquiera especie sin razón ni entendimiento. Digo, volviendo a mi asunto, que, aunque así hubiese acontecido, siempre tendríamos que agradecer mucho a aquel Estado que en medio de sus iniquidades y tiranías y anulaciones del pensamiento, tanto se desvelaba por que no las sintiésemos, y procuraba divertirnos con poesías, novelas y comedias, discreta y lozanísimamente escritas; secreto administrativo, propio de déspotas, al cual deben nuestras letras muchos días de gloria que jamás les daría un Estado krausista en que fuesen norma de buen estilo y elegante decir la Analítica o el Ideal de la humanidad para la vida. Hablando en serio, creo haber dejado fuera de duda que, excepto en algún caso particular, no hubo anulación de la libertad científica en materias filosóficas, políticas y sociales, las más difíciles de tratar bajo un gobierno de unidad religiosa y monárquica.

Pero se dirá: ¿por qué obtuvieron tan escaso florecimiento las ciencias exactas, físicas y naturales, sino por la rigidez con que el Estado negó siempre la libertad de la ciencia? Entendámonos: en primer lugar, niego el supuesto formulado en términos tan absolutos: verdad es que no apareció en España ningún Galileo, Descartes, Newton, Lagrange, Lavoisier o Linneo; confieso de buen grado nuestra inferioridad en esta parte; no lo da Dios todo a todos; quizá el terreno no estaba tan bien preparado; quizá la genialidad española no tira tanto por ese camino como por otros; quizá la época en que España fue grande y sabia no coincidió con la madurez sino con los primeros ensayos y tentativas del genio analítico y experimental; pero es lo cierto que en esos ominosos siglos debieron las ciencias de la naturaleza considerables adelantos a muchos españoles; acaudaláronse la Zoología y la Botánica con las innumerables noticias sobre la fauna y la flora de los países americanos, esparcidas en los libros de Gonzalo Fernández de Oviedo y otros primitivos 
historiadores de Indias, y luego más científicamente expuestas en los tratados de Nicolás Monardes, Francisco Hernández y José de Acosta; brillaron Quer, Gómez Ortega, Cavanilles y tantos otros sabios ilustradores del reino vegetal, de que en su laureada obra La Botánica y los Botánicos de la Península da cumplida noticia el Sr. D. Miguel Colmeiro; hicieron importantes estudios sobre los metales Álvaro Alonso Barba, Bernal Pérez de Vargas y otros menos conocidos autores; publicáronse notables comentarios y traducciones de Aristóteles y Teofrasto, de Arquímedes y Euclides, de Dioscórides y Plinio; no faltaron matemáticos y físicos tan memorables como Núñez, inventor del nonius; el docto humanista Fernán Pérez de Oliva, que escribió De Magnete y se empeñó en hallar modo de que por la piedra imán se comunicasen dos ausentes ${ }^{546}$ el complutense Vallés, que entre otras novedades, presentó en su Philosophia sacra la doctrina del fuego como unidad dinámica, adoptada e ilustrada posteriormente por el célebre químico Boerhaave; el cosmógrafo Santa Cruz; el ya citado Chacón, que tuvo parte no secundaria en la corrección gregoriana; el arzobispo Siliceo, profundo aritmético; el insigne polígrafo Pedro Ciruelo, cuyo extenso curso de las cuatro artes matemáticas compite con los mejores de su clase dados a la estampa fuera de España en el siglo XVI; el maestro Esquivel, que, por encargo de Felipe II, levantó el mapa geodésico de la Península, ${ }^{547}$ siglos antes que las demás naciones de Europa

546 No incluyo a Blasco de Garay, a quien erradamente se ha supuesto inventor de la aplicación del vapor a la navegación. Véase demostrado lo contrario en la Memoria publicada sobre este asunto por D. J. Rubió y Ors. (Primera edición)

547 De los trabajos geodésicos del maestro Esquivel hay larga y muy interesante noticia en varios contemporáneos suyos, especialmente en las Antigüedades de España de Ambrosio de Morales: «El maestro Esquivel, capellán del Rey nuestro Señor, catedrático de Matemáticas en esta Universidad de Alcalá de Henares, y natural del mismo lugar, de ingenio excelente y singular industria, y doctrina increíble en todo género de Matemáticas, quiso hacer una descripción de España tan entera y tan cumplida, que señalase en ella particularmente todos los lugares, ríos, arroyos y montańas, por pequeños que fuesen, y que tuviesen su situación tan cierta y tan puntual, como tenían por Ptolomeo todas las ciudades, ríos y montańas principales. Para esto fueron menester dos cosas: hallar algún orden y camino, y nueva invención, como el que Ptolomeo había usado para lo que hizo, y hacer después nuevos instrumentos con que él pudiese obrar conforme a lo que había inventado, y pudiese andar por el camino que había descubierto. Este camino él lo halló con su admirable ingenio, llano y muy cierto... Luego tras esto inventó los instrumentos, y fabricólos de madera, y aderezólos muy cumplidamente, y tan grandes hizo los dos más necesarios, que una acémila casi tenía carga entera en ellos... El Rey nuestro Señor D. Felipe II deste nombre, le proveyó de un buen salario, para que anduviese todos estos sus reinos, mirando por vista de ojos todos los lugares, ríos y montańas grandes y chicas, porque pudiese hacer la descripción de España tan cierta y tan cumplida, tan particular y exquisita como Su Majestad la deseaba y el Maestro Esquivel podía hacerla. Dexó la 
se ocuparan en trabajos análogos; el portentoso Caramuel, que, además de sus controversias de Tycho-Brahe, dejó una vasta enciclopedia de todas las matemáticas puras y aplicadas; el gaditano Hugo de Omerique, cuyo tratado de Análisis Geométrica, impreso en 1698 (nótese la fecha), mereció los elogios de Newton; y en tiempos más cercanos, el universal Feijoo, que, no contento con vulgarizar multitud de conocimientos matemáticos y físicos y propagar el experimentalismo, apuntó ideas originales sobre cuestiones geológicas y se adelantó a los extranjeros en la teoría eléctrica de los terremotos; los PP. Tosca y Losada; los sabios marinos Ulloa, Jorge Juan, Císcar y Mendoza; los ingenieros Lanz y Betancurt, inventores de la Cinemática Industrial, sin contar una multitud de tratadistas como los PP. Zaragoza, Cassani, Abad, Alegre y Cerdá, el alférez Fernández Medrano, Bails, etcétera, que, más o menos atinados en la exposición de la doctrina, demuestran que nunca faltaron del todo buenos estudios de ciencias exactas y físicas en nuestro país. ${ }^{548}$ Prueba

mayor parte hecha antes que muriese, como Su Majestad la tiene en su cámara, y dexó comunicada su invención... con D. Diego de Guevara, Gentilhombre de la Cámara de los Príncipes de Bohemia, a quien él había enseñado desde niño las Matemáticas..., y Su Majestad por esto le mandó entregar a él todos los papeles del Maestro después que murió... Y habíaselo comunicado el Maestro, según decía, porque si él muriese, quedase después de sus días quien lo supiese enteramente, y no se perdiese una cosa tan grande y tan provechosa en aquel arte, pues él jamás escribió ni pensaba escrebir nada de lo mucho que sabía... Todo esto hemos dicho para conservar aquí la memoria de una cosa tan señalada como esta ha sido en nuestros tiempos en la perfección de la Geografía, en que un español hizo tan solemne adelantamiento", etc., etc. (Antigüedades de España, ed. de 1792, páginas $11,12,13$ y 14 .)

Estas noticias de Ambrosio de Morales coinciden con las que el mismo D. Felipe de Guevara, discípulo predilecto del maestro Esquivel, nos da en sus Comentarios de la Pintura: «Sin encarecimiento se puede afirmar que después que el mundo es criado, no ha habido Provincia en él descripta con más cuidado, diligencia y verdad, porque todas las demás que hasta ahora por Ptolomeo o por otros están descriptas, es muy cierto ser la mayor parte de ellas por relaciones... Por el contrario, la descripción que V. M. ha mandado hacer, consta cierto no haber palmo de tierra en toda ella que no sea por el autor vista, andada y hollada, asegurándose de la verdad de todo, en quanto los instrumentos matemáticos dan lugar, por sus propias manos y ojos.» (Pág. 220.)

De otros testimonios resulta que el maestro Esquivel se valía para sus triangulaciones del método de Regiomontano, y observando después con el astrolabio la altura de polo de cada lugar, la situaba en su verdadera latitud y longitud. (Vid. Navarrete, Historia de la Naútica, páginas 208 a 214) (Tercera Edición)

548 Entre los matemáticos, cosmógrafos y astrónomos españoles del siglo xvi, además de los ya citados y de los que se citarán en otras cartas, merecen especial recuerdo Abraham Zacuto, autor de las famosas Tablas o Almanaque perpetuo que tradujo al latín Alfonso de Córdoba; los dos hermanos Gaspar y Jerónimo Torrellas, Andrés de Li, Gonzalo de Frías, los cosmógrafos de la casa de contratación de Sevilla, Martín Cortés, que estableció 
son también de ello los numerosos tratados de fortificación, artillería y arte militar en todos los ramos dados a luz en los siglos XVI y XVII por nuestro conterráneo el beneficiado de Laredo D. Bernardino de Escalante, por su homónimo de Mendoza, por Cristóbal de Rojas, Lechuga, Firrufino, D. Diego de Álava, D. Sancho de Londoño, Diego Ufano, Luis Collado, etc., libros que en su mayor parte obtuvieron la honra de ser traducidos a extrañas lenguas. En otra ciencia aplicada, aunque bien diversa de la anterior por su objeto, descollaron notablemente los espańoles. Me refiero a la Medicina, que con orgullo registra en sus fastos los nombres de Laguna, a la vez humanista, orador y poeta; de Villalobos, tan célebre sifiliógrafo como ingenioso y agudo literato, por algunos apellidado el Fracastorio español, del divino Vallés, ya mencionado como filósofo, en unión con Gómez Pereira, Huarte, Cardoso y otros médicos esclarecidos; de Servet, descubridor de la circulación pulmonar, tan famoso por ello como por sus teorías antitrinitarias y su desastrada muerte; de Valverde, Mercado, Gaspar de los Reyes, Lobera de Ávila, etc., y en el siglo pasado los de Solano de Luque, a quien dio universal renombre su doctrina del pulso; de Martín Martínez, el Feijoo de la Medicina, y Piquer, que, continuando como él la gloriosa serie de médicos filósofos, supo a la vez traducir a Hipócrates, analizar las pasiones e investigar doctamente las causas de los errores.

la distinción entre el polo magnético y el polo del mundo, para explicar así la declinación de la aguja, e indicó también el aumento de los intervalos entre los paralelos, abriendo camino a la invención de Alonso de Santa Cruz; el valenciano Jerónimo Muñoz, a quien Tycho-Brahe llama eruditísimo y excelentísimo matemático, inventor de un planisferio paralelogramo; el médico escéptico Francisco Sánchez, que disputó con Cristóbal Clavio sobre algunos teoremas de Euclides, obteniendo la palma, según Brücker; el franciscano Juan Salón, que trabajó mucho para la reforma gregoriana del calendario; Juan Pérez de Moya, Rodrigo Zamorano, traductor de Euclides, y autor de un Regimiento de Navegación, traducido al inglés en 1610 por el famoso Wright; Pedro Sarmiento de Gamboa, en cuyo diario de viaje ese admiran, practicados con feliz éxito, dice Navarrete, métodos que más de dos siglos después se han mirado como el triunfo de la Astronomía Náutica; Andrés García de Céspedes, autor del curiosísimo Libro de instrumentos nuevos de Geometría, muy necesarios para medir distancias y alturas (1606), de una Theórica de los Planetas según la doctrina de Copérnico y de un Libro de mechánicas, donde se pone la razón de todas las máquinas; Diego Ramírez de Arellano, que resolvió difíciles problemas trigonométricos; Antonio de Nájera, secuaz y expositor de Tycho-Brahe; el doctor Lázaro de Flores, que en su Navegación astronómica, teórica y práctica (1673) «se aprovechó de cuanto Copérnico y el mismo Tycho-Brahe habían adelantado sobre el movimiento de las estrellas", autor de un compendio de Trigonometría; D. Antonio de Gaztañeta, que publicó en 1672 su libro Norte de la Navegación hallado por el cuadrante de reducción; D. Sebastián Fernández de Medrano, fundador de una Academia de Matemáticas en Bruselas; los PP. Zaragoza y Kresa, y otros muchos. (Tercera Edición) 
Aparte de todo lo expuesto, conviene observar que, dada la menor relación de las ciencias exactas, físicas y naturales con la religión y la politica, debieron de ser las menos oprimidas y vejadas, si admitimos la teoría de nuestros adversarios. Y es lo cierto que la Inquisición española no opuso trabas a la admisión del sistema copernicano en las aulas salmantinas, ni impidió que Diego de Estúniga le expusiese con toda claridad en su Comentario a Job, libro que mandó expurgar la Congregación de Roma, en cuyos índices figura hasta tiempos muy recientes. Y, hablando en puridad, ¿qué temor podían inspirar a los poderes públicos, así civil como eclesiástico, los grandes descubrimientos astronómicos o físicos? A nadie hubieran dado malos ratos la Inquisición ni el Rey por formular la ley de la atracción, por descubrir el cálculo de las fluxiones, o por entretenerse en profundos estudios de óptica y de mecánica. En una nación en que se permitía defender el tiranicidio, ¿qué obstáculo había de encontrar el que se propusiese hacer nueva clasificación de las plantas, o destruir la antigua nomenclatura alquímica, o revelar la existencia de todos los cuerpos simples hoy conocidos, y de muchos más, si más hubiera? Si como el docto aragonés Gómez Miedes escribió un grueso volumen sobre la sal común, única que él conocía, hubiese tratado de todas las sales hoy descubiertas, ¿hubiérale puesto cortapisas alguien? ¿Se opuso el Estado a que desarrollase ampliamente su estrafalaria genialidad matemática el caballero valenciano Falcó, tan agudo poeta latino como desdichado geómetra, que gastó su tiempo y su dinero en investigar la cuadratura del círculo y se fue al otro mundo pensando haberlo logrado?

Como indicios claros de la situación lamentable a que llegaron entre nosotros las ciencias naturales, suelen citarse esos libros llenos de patrańas y aberraciones que a fines del siglo XvII aparecieron con los títulos de Magia Natural, Oculta Filosofía. El Ente dilucidado y otros ejusdem furfuris. Pero fuera de que en la misma época se escribieron otros tratados con sano juicio y buen seso, y dejando aparte también el que dichas obras fueron vertidas a idiomas extranjeros y acogidas con aplauso, lo cual demuestra que el espíritu de vana credulidad era el mismo en todas partes, es lo cierto que en ningún siglo han faltado autores de obras extravagantes, y aun en este ilustradísimo en que nos tocó nacer, abundan doctrinales de espiritismo y otras ciencias de la misma laya, más estúpidos y menos divertidos que el mismísimo Ente dilucidado, que al cabo todos los curiosos leen con placer y ponen sobre las niñas de sus ojos como tesoro de recreación y mina de pasatiempos.

Estas breves indicaciones, mi Sr. D. Gumersindo, escritas a vuela pluma y casi sin consultar libros, bastan, en mi juicio, para demostrar lo mal fundado e injusto de la opinión del Sr Azcárate respecto a nuestra cultura. 
Y eso que he prescindido de los notables estudios estéticos que desde León Hebreo, Fonseca y Maximiliano Calvi hasta Rebolledo y Nieremberg, desde Barreda y Alonso Sánchez hasta el P. Feijoo y Arteaga, mantuvieron siempre viva entre nosotros la filosofía del arte y de la belleza; y he pasado por alto las sabias especulaciones de Salinas, Montanos, Eximeno y otros sobre la Música; y he hecho caso, omiso de la admirable invención pedagógica del arte de enseñar a los sordo-mudos, imaginada por el benedictino Ponce de León y escrita por el aragonés Juan Pablo Bonet, y nada he dicho, en fin, de otros varios aspectos y merecimientos de la ciencia española, cuya relación me habría llevado más allá de lo que consienten los estrechos límites de una carta. Nunca hubiera tomado la pluma contra escritor tan apreciable, a no estar bien convencido de que refutaba una opinión, no particular suya, sino común y corriente entre muchos preciados de doctos. La ignorancia y el olvido en que estamos de nuestro pasado intelectual; las insensatas declamaciones que se enderezan a apartarnos de su estudio como de cosa baladí y de poco momento; el desacordado empeño de algunos en romper con toda tradición científica, persuadidos de que sólo en su secta y escuela se halla la verdad completa; la facilidad que hoy existe para apropiarnos la erudición forastera, granjeando así la fama de sabios a poca costa, y las dificultades con que tropezamos para conocer, siquiera por encima, la nuestra; el orgullo de la vida (superbia vitae) que caracteriza al siglo actual entre cuantos recuerda la historia, causas son que producen ese menosprecio de todo lo de casa, esas antipatrióticas afirmaciones que afligen y contristan el ánimo. El remedio de tanto mal indicado está por V., amigo mío, en su excelente artículo El plan de estudios y la historia intelectual de España, donde propone el establecimiento de las seis cátedras siguientes para el doctorado de las respectivas facultades:

Historia de la Teología en Espańa.

Historia de la Ciencia jurídica en España.

Historia de la Medicina espańola.

Historia de las Ciencias Exactas, Físicas y Naturales en España.

Historia de la Filosofía española.

Historia de los Estudios filológicos en España.

Cada día van siendo más urgentes las reformas allí pedidas para la enseñanza. ¡Qué vastísimo campo abrirían ante la clara inteligencia de nuestra juventud estudiosa seis profesores, escogidos con acierto, dedicados exclusivamente a exponer de palabra y por escrito el magnífico proceso de la vida científica nacional en todas sus fases y direcciones! ¡Cuánto de honra y provecho no reportarían a España! 
De suma necesidad es también (y esto puede hasta cierto punto estimarse como condición precisa para llevar a cabo el pensamiento de $\mathrm{V}$. en orden a las referidas cátedras) que continúe la publicación, hace años lamentablemente interrumpida, de las obras bibliográficas premiadas por la Biblioteca Nacional, ${ }^{549}$ y que las Reales Academias, principalmente las de la Historia, Ciencias Morales y Políticas, y Ciencias Exactas, Físicas y Naturales, consagren parte de sus certámenes - anunciándolos con más anticipación de la que acostumbran - a promover el estudio de la actividad intelectual de nuestros mayores y de los variados y copiosos frutos que produjo en los diversos ramos del saber humano. ¿Qué serie de temas tan preciosos no ofrecen a la primera de dichas Academias los grandes polígrafos españoles? ¿Qué interesantes monografías no pudiera obtener la segunda si propusiese por asuntos de sus concursos, ya determinados escritores, v. gr., Soto, Molina, Suárez, Fox Morcillo, el P. Ceballos, D. Juan Francisco de Castro; ya ciertos grupos de ellos, como los moralistas, los políticos, los economistas que florecieron bajo la dinastía austríaca? Y la última, ¿cuán curiosos y útiles estudios no lograría premiando Memorias acerca de nuestros físicos, astrónomos, cosmógrafos, metalurgistas y geopónicos, de los españoles que han ilustrado a los naturalistas y matemáticos griegos, de los cultivadores de la Historia de Ultramar y de otros puntos semejantes?

Si el Gobierno y los cuerpos sabios no toman este rumbo, mucho me temo que lleguen a ser, como ya lo están siendo en parte, una verdad tristísima aquellas palabras de nuestro buen amigo, el ilustre literato D. Juan Valera: «Quizá tengamos que esperar a que los alemanes se aficionen a nuestros sabios, corno ya se aficionaron a nuestros poetas, para que nos convenzan de que nuestros sabios no son de despreciar. Quizá tendrá que venir a Espańa algún docto alemán a defender contra los espańoles, que hemos tenido filósofos eminentes.»

Marcelino Menéndez Pelayo

Santander, 14 de abril de 1876.

549 En este punto he perdido toda esperanza. Los futuros bibliógrafos españoles deben proceder como si tales obras no existiesen. (Tercera edición)

* Posteriormente, y gracias principalmente a Menéndez Pelayo, cuando fue Director de la Biblioteca Nacional, se reanudaron estas publicaciones. Ahora son varios los premios anuales para este y otros fines. (Edición Nacional) 


\section{DE RE BIBLIOGRAPHICA}

$\mathrm{M}$ i muy docto amigo y paisano: Días pasados dirigí a V. una breve impugnación de ciertas erradas afirmaciones acerca del pasado intelectual de España, vertidas por el Sr. D. Gumersindo de Azcárate en sus artículos sobre El Self Government y la Monarquía doctrinaria. Dolíame allí del lamentable olvido y abandono en que tenemos las glorias científicas nacionales, en especial las filosóficas, abandono y olvido que, entre otros daños de menor entidad, trae el gravísimo de mantener a nuestra patria falta de todo carácter propio en las modernas evoluciones del espíritu humano, dejándonos a merced de cualquier viento de doctrina que sople de extrañas tierras, y siendo causa eficacísima de la anarquía y desconcierto que hoy nos aqueja y lleva trazas de prolongarse, si Dios no lo remedia. Él solo sabe si es útil o dañoso el sesgo que al presente llevan ciertos estudios en Espańa, y si es el mejor antídoto contra la exageración innovadora la exageración reaccionaria. Lo que si puede afirmarse es que ambos fanatismos se inspiran en libros extranjeros, por más que uno y otro sean de antiguo abolengo en nuestra historia filosófica, y que, tal vez sin darse cuenta de ello, obedecen los secuaces de tan opuestas ideas a las providenciales leyes del pensamiento ibérico, aunque incurriendo en no pocas aberraciones y desvíos respecto de las escuelas peninsulares, por no detenerse a estudiarlas como debieran y a buscar dentro de España el anterior desarrollo de sus respectivos sistemas o los precedentes histéricos que los han motivado. Pero dejando aparte tales consideraciones, vengamos derechamente al objeto de esta epístola y de las que, Dios mediante, han de seguirla, que se enderezarán sólo a desenvolver algunas indicaciones apuntadas en mi anterior, sobre los medios de reparar la ignorancia, hoy generalmente sentida, respecto a nuestra historia cientifica, y aun a una gran parte, no despreciable por cierto, de la literaria. 
Estos medios se reducen a tres:

$1^{\circ}$ Fomentar la composición de monografías bibliográficas.

$2^{\circ}$ Ídem la de monografías expositivo-críticas referentes a cada ramo de la ciencia, o al menos a los que tienen historia importante en Espańa.

$3^{\circ}$ Creación de seis cátedras nuevas en los doctorados de las facultades, con otras instituciones encaminadas al mismo propósito.

Trataré brevemente de cada uno de estos proyectos, dividiendo mi trabajo, a guisa de sermón, en tres puntos:

\section{Estudios bibliográficos}

Acúsase con frecuencia a la Bibliografía, por los extraños a su cultivo, de ciencia árida e indigesta, de fechas y de nombres, superficial y pesada al mismo tiempo, como que sólo fija la atención en los accidentes externos del libro, en la calidad del papel y de los tipos, en el número de las hojas, y limita sus investigaciones a la portada y al colofón, sin cuidarse del interior del volumen, que para ella suele estar tan cerrado como el de los siete sellos. No ha de negarse que hay hartos bibliófilos, si tal nombre merecen, acreedores a esta y aun a otras más acres y no menos fundadas censuras; y en verdad que se duda a veces entre la risa y la indignación al ver a ciertos monopolizadores de libros estimar el mérito de los trabajos del humano ingenio por su mayor o menor escasez en el mercado, despreciando, v. gr., los clásicos griegos y latinos porque se encuentran a todas horas, en cualquier forma y en variedad de ediciones, al paso que dan suma importancia a los tratados de jineta, de esgrima, de cetrería, de tauromaquia, de heráldica o de arte de cocina, por raros y difíciles de encontrar en venta. Y produce ciertamente triste impresión la lectura de muchos catálogos bibliográficos, cuyos autores para nada parecen haber tenido en cuenta el valor intrínseco de los libros, fijándose sólo en insignificantes pormenores, propios más de un librero que de un erudito. Pero no es ése el verdadero procedimiento del bibliógrafo, ni puede llamarse trabajo científico, sino mecánico, el descarnado índice de centenares de volúmenes cuyo registro externo arguye a lo sumo diligencia y buena fortuna, nunca dotes intelectuales ni saber crítico. Y la crítica ha de ser la primera condición del bibliógrafo, no porque deba éste formularla con todo el rigor del juicio estético y de la apreciación histórica diestramente combinados, sino para que sepa indicar de pasada los libros de escaso mérito, entresacando a la par cuanto de útil contengan, y detenerse en las obras maestras, apuntando en discretas frases su utilidad, dando alguna idea de su doctrina, método y estilo, ofreciendo extractos si escasea el libro; repro- 
duciendo íntegros los opúsculos raros y de valor notable, y añadiendo sobre cada una de las obras por él leídas y examinadas, un juicio, no profundo y detenido como el que nace de largo estudio y atenta comparación, sino breve, ligero y sin pretensiones, como trazado al correr de la pluma por un hombre de gusto; juicio espontáneo y fresco, si vale la expresión, como que nace del contacto inspirador de las páginas del libro; impresiones vertidas sobre el papel con candor e ingenuidad erudita. ¡Qué obra más útil, a la par que deliciosa, es un catálogo bibliográfico redactado de esta manera! Así concebida la Bibliografía, es al mismo tiempo el cuerpo, la historia externa del movimiento intelectual, y una preparación excelente e indispensable para el estudio de la historia interna. Los registros de obras hechos sin estas condiciones serán útiles como lo son los catálogos de editores y libreros, pero no serán trabajo de literato, sino de mozo de cordel; no llamemos a sus autores bibliógrafos, sino acarreadores y faquines de la república de las letras. 550

Por dicha, los bibliógrafos españoles, con excepciones raras, han sido fieles al objeto importantísimo que la ciencia por ellos cultivada debe cumplir, y aún algunos pueden presentarse como dechados, si no de todas, de la mayor parte de las cualidades indicadas. No son escasos los frutos de la investigación erudita entre nosotros; pero aún resta no poco que trabajar en este campo. De los Diccionarios y Catálogos hoy existentes, ya impresos, ya manuscritos, puede hacerse la división siguiente:

$1^{\text {a }}$ Bibliotecas generales.

2a Etnográficas.

$3^{\text {a }}$ Corporativas.

4a Regionales.

$5^{\text {a }}$ Por materias.

60 Indices y Catálogos de bibliotecas públicas y particulares.

Tiene nuestra España la gloria de poseer una de las bibliografías generales más extensas y con más diligencia trabajadas, doblemente admirable si consideramos el tiempo en que fue compuesta, en las dos Bibliothecas, Vetus y Nova, de Nicolás Antonio, dadas a la estampa, la segunda en 1672, y póstuma la primera en 1696, gracias a la munificencia del cardenal Aguirre y a los desvelos del deán Martí.

Breves y de escasa importancia eran los ensayos anteriores al colosal trabajo del bibliógrafo sevillano. El comentario elegantísimo De doctis Hispaniae viris, o sea Apología pro adserenda hispanorum eruditione, del docto profesor complutense Alfonso García Matamoros, vertido al castellano en el siglo pasado

550 Expresión del doctor Puigblanch. (Primera Edición) 
por el canónigo Huarte, no es otra cosa que un panegírico de nuestras letras, en que se mencionan muy pocos autores y escasísimos libros, sin indicaciones tipográficas de ninguna especie. La Bibliotheca Hispaniae de Andrés Peregrino, o sea el P. Andrés Scotto, puede aún consultarse con provecho en ciertos lugares, especialmente al tratar de los humanistas, y mereció bien de nuestras letras su extranjero autor, sólo por el intento; pero es de limitada utilidad bibliográfica a pesar de su volumen, pues de los tres de que consta, versa el primero sobre la religión, universidades, bibliotecas, concilios y reyes de España, y en los dos restantes, tras de intercalarse asimismo materias extrañas, se habla más de los autores que de los libros, y, por lo general, sólo de los contemporáneos del jesuita flamenco, que dio a luz su obra en Francfort el año de 1608. Un año antes había salido de las prensas maguntinas un Catalogus clarorum Hispaniae scriptorum a nombre de Andrés Taxandro, índice sucinto y descarnado, que generalmente se atribuye al mismo Scotto. Así en el Catálogo como en la Biblioteca se hace mérito casi únicamente de los escritores que usaron la lengua latina, falta que intentó remediar el toledano D. Tomás Tamayo de Vargas, formando un índice bastante copioso de obras castellanas, con el título no impropio de Junta de libros la mayor que España ha visto en su lengua. Manuscrito permanece en la Biblioteca Nacional este catálogo, hoy de escaso valor como libro de consulta, puesto que le disfrutaron ampliamente Nicolás Antonio y otros bibliógrafos. Con tan escasos auxilios comenzó su tarea, en verdad hercúlea, el autor de la Censura de Historias Fabulosas; prosiguióla con ardor creciente y jamás igualada diligencia, y logró darle cima en lo posible, consagrando a ella el bien aprovechado trabajo de su vida entera. De eterna admiración son dignos sus esfuerzos, pues si reflexionamos las gravísimas dificultades con que se tropieza para formar la bibliografía del ramo menos cultivado del saber humano, el índice de los trabajos relativos a un solo punto de la ciencia, el catálogo de los escritores de una provincia, de un pueblo de limitada importancia, ¡cómo no asombrarnos de esa titánica empresa de dar a conocer en un libro cuanto en Espańa se había escrito desde la era de $\mathrm{Au}$ gusto hasta fines del siglo Xvi, sobre cualquier materia y en cualquiera forma! Y ¿quién ha de parar la vista en los errores, en las omisiones, en las faltas de pormenor inevitables en obra semejante? Aunque mucho más graves fueran, no bastarían a contrapesar las singulares excelencias de erudición y hasta de crítica, sobre todo al tratar de las fuentes históricas, la riqueza incomparable de noticias recogidas en aquellos cuatros volúmenes, que son aún, y serán por mucho tiempo, el monumento más grandioso levantado a la gloria de las ciencias y de las letras espańolas. Conviene consultar la obra de Nicolás Antonio en la reimpresión matritense de 1783 y 1788, en que se agregaron a 
la Bibliotheca Nova las adiciones manuscritas del mismo autor, y se acrecentó la Vetus con las copiosísimas aunque mal digeridas notas del sabio hebraizante y numismático Pérez Bayer.

El segundo ensayo de bibliografía general debiese a D. José Rodríguez de Castro, que con erudición notable, aunque sin método ni crítica, se propuso refundir, acrecentar y continuar las Bibliothecas de Nicolás Antonio en la suya Española, que no pasó del siglo xIv, si bien, con haber quedado tan a los principios, es obra de indispensable consulta en la parte hispano-romana y en la de los tiempos medios, y puede considerarse como el mejor suplemento a la Bibliotheca Vetus.

Al lado de Nicolás Antonio, padre de nuestra bibliografía, debemos colocar el nombre del rey de nuestros modernos eruditos, D. Bartolomé J. Gallardo, en cuyas papeletas, diestramente ordenadas por los Sres. Zarco del Valle y Sancho Rayón, veo casi realizado (un poco más de crítica no sobraría) el ideal de la labor bibliográfica, tal como la concibo y expuse al comienzo de esta epístola. El Ensayo de una biblioteca española de libros raros y curiosos, riquísimo en extractos y noticias, suple gran parte de las omisiones de Nicolás Antonio respecto del siglo XVI, suministra datos y documentos sobre toda ponderación interesantes para la historia de nuestra literatura y en especial de la poesía lírica y de la dramática, y es de utilidad más directa e inmediata que ningún otro libro de bibliografía nacional para todo género de curiosos y de lectores. ¿Por qué desdicha no han visto aún la pública luz los últimos volúmenes de esta obra excelente, suspendida desde 1866 en la letra $F$ ? ¿A qué director de Instrucción Pública estará reservada la gloria de vencer las dificultades que parecen oponerse a la impresión de lo restante?551*

Empresa es harto difícil el formar la bibliografía del siglo en que vivimos, fertil como ninguno en folletos, opúsculos, memorias, periódicos y hojas volantes. Sin embargo, no dejaron de intentarlo, aunque con escasa fortuna, los Sres. D. Dionisio Hidalgo y D. Manuel Ovilo y Otero en sendos Diccionarios de no poco volumen, impreso en cinco tomos el primero, desde 1862 a 1873,552 e inédito en la Biblioteca Nacional el segundo, del cual publicó en París un extracto, con título de Manual, la casa de Rosa y Bouret. Como escritos de bibliografía general pueden considerarse, además de los citados, la Tipografía Española del P. Méndez, adicionada por Hidalgo;

$551^{*}$ La publicación de los tomos tercero y cuarto la dirigió Menéndez Pelayo. Se conserva en su biblioteca de Santander material inédito para un nuevo tomo. (Edición Nacional)

552 Después se han impreso dos tomos más (1879 y 1881) que contienen el índice de autores y el de materias. (Tercera edición) 
los Apuntamientos de nuestro paisano D. Rafael Floranes sobre el mismo asunto, y el specimen de Diosdado Caballero De prima tipographiae hispanae aetate, con otros opúsculos de menor cuantía relativos al primer siglo de nuestra imprenta. ${ }^{53} \mathrm{Y}$ si agregamos la voluminosa Bibliographia critica, no en todo española, del trinitario Fr. Miguel de San José, los trescientos artículos que añadió Floranes a Nicolás Antonio, las adiciones asimismo manuscritas de D. Andrés González de Barcia y el P. Faustino Arévalo que guarda la Biblioteca Nacional, y alguna que otra tentativa semejante, ${ }^{554}$ tendremos casi completo el índice de los estudios generales de bibliografía española realizados hasta el momento en que trazo estas líneas.

Y continuando, amigo mío, en esta reseña de lo hasta hoy trabajado, para indicar después con más holgura lo que aún falta llevar a cabo, mencionaré las dos únicas bibliotecas etnográficas que poseemos, la Arábico-Hispano-Escurialensis de Casiri (1760) y la Rabinico-Española de Rodríguez de Castro (1781), ninguna de las cuales satisface las exigencias de la crítica moderna, por más que la primera fuese, en el tiempo en que salió a luz, una revelación, y hoy mismo parezca de utilidad grandísima, dado caso que no existe obra alguna que pueda con ventaja sustituirla. ${ }^{555}$

Pero, aparte de la falta de método, harto sensible, y de los reparos que la ciencia contemporánea ha puesto a algunas de las traducciones allí incluidas, ha de confesarse que la obra de Casiri, reducida al catálogo de los manuscritos arábigos de una Biblioteca, siquiera sea de las más ricas en este ramo, no puede suplir, sino en parte y muy indirectamente, la falta de una Bibliografía arábigo-española completa, que se va haciendo más necesaria a medida que adelantan los estudios orientales, tan interesantes para la historia de nuestra cultura. A los arabistas españoles toca llenar este vacío, y uno de ellos, el Sr. Fernández y González, está encargado oficialmente de completar

553 Por ejemplo: la Disertación sobre el origen del arte tipográfico en la ciudad de Valencia, de Villarroya, y la de D. Jaime Ripoll sobre la imprenta de Barcelona; las dos Memorias de Antonio Ribeiro dos Sanctos, sobre la imprenta en Portugal hasta fines del siglo XVI (tomo VIII de las Memorias de Literatura Portuguesa, publicadas por la Academia de Ciencias de Lisboa). (Segunda Edición)

554 En alguna parte hemos leído que el Sr. D. Carlos Ramírez de Arellano, residente en Córdoba, tiene hechas adiciones a Nicolás Antonio. (Primera Edición)

555 Ya no es esto verdad, aunque no ha sido un español el que ha rehecho el trabajo de Casiri. La publicación de un nuevo catálogo de los manuscritos árabes del Escorial se debe al profesor de París doctor Hartwig Derembourg, como el catálogo de manuscritos griegos se había debido a otro extranjero, el doctor E. Miller (1848), y la historia de los orígenes de la misma colección, narrada por cierto con exquisito primor y ciencia, a un extranjero también, al malogrado helenista Carlos Graux, de tan buena memoria para quien esto escribe. (Tercera edición) 
y corregir el catálogo de Casiri, lo cual nos da esperanza de ver realizado antes de mucho el común deseo de nuestros eruditos, si, como creemos, el erudito profesor no se limita a esta preliminar tarea, sino que emprende la formación del apetecido índice de autores árabes-españoles, ya conservados en nuestras bibliotecas, ya en las extranjeras. En cuanto a la obra de Rodríguez de Castro, superior en riqueza de noticias a las anteriores de Wolfio y Bartholoccio, táchanla no pocos hebraizantes modernos de superficial y poco exacta, y fuera de desear que, entre la nueva generación masorética, educada por el doctor García Blanco, se hallase algún bibliófilo, docto a la par en la lengua santa y en sus afines y derivadas, que tomase a su cargo las adiciones y enmiendas al trabajo de nuestro bibliotecario.

En la clase de Bibliotecas corporativas pongo en primer término las de comunidades religiosas, limitada alguna de ellas a España, generales las más, y obras por lo común de autores extranjeros.

Por la parte considerable que encierran de nuestra bibliografía, son dignos de especial mención los Anales franciscanos de Wading y su continuador Harold; la Biblioteca de la misma Orden, formada por Fr. Juan de San Antonio; la excelente de Escritores Dominicos, de Quetif y Echard, a la cual precedieron los ensayos de Antonio Senense, Alfonso Fernández y Fr. Ambrosio de Altamira; la Carmelitana de Cosme de Villiers de San Esteban; el Alphabeto Augustiniano de Fr. Tomás de Herrera; los Saecula Augustiniana del P. Lanteri (1858-59); ${ }^{56}$ la Biblioteca Mercedaria de Fr. José Antonio Garí (Barcelona, 1875); las Bibliothecas Cistercienses de Vischio y Muñiz, y otros menos extensos y conocidos catálogos de autores pertenecientes a diversas Órdenes, que no mostraron tanto esmero como las antedichas en la conservación de sus Memorias literarias. ${ }^{557}$

A todo lo cual deben agregarse las numerosas historias de las mismas sociedades monásticas, que, sin ser obras propiamente bibliográficas, contienen, no obstante, un tesoro de noticias acerca de no pocos escritores, siendo notables en tal concepto la Crónica de la Orden de San Benito, de Yepes; la que en muy elegante estilo escribió de los Jerónimos el P. Sigüenza, y otras

556 En la Revista Agustiniana de Valladolid se está imprimiendo un catálogo mucho más copioso de autores de aquella Orden españoles y portugueses. (Tercera Edición)

557 En 1883 se ha publicado en Quito un interesante libro sobre los Varones Ilustres de la Orden Seráfica en el Ecuador, obra de Fr. Francisco María Compte, que en 1885 ha comenzado una reimpresión de su obra con grandes aumentos.

En Brunn (1884) ha impreso el benedictino Dom Francisco Beda Plaine una Series Chronologica Scriptorum O. S. Benedicti Hispanorum qui ab anno 1750 usque ad nostros dies claruerunt, adicionando con ellos la Historia Litteraria Ordinis S. Benedicti, de Ziegelbauer. (Tercera Edición) 
que fuera prolijo y no parece necesario enumerar. Pero ninguna Orden religiosa ha excedido a la Compañía de Jesús en lo esmerado y completo de su extensa y curiosísima bibliografía. Ya en 1608 se publicó en Amberes un catálogo de escritores jesuitas, formado por el ilustre P. Rivadeneyra. Continuáronle Nieremberg, Alegambe y otros egregios varones de la Compañía, así nacionales como extranjeros; y llegados los tiempos de expulsión y extrańamiento, dos jesuitas de la provincia de Aragón, Diosdado Caballero y Onofre Prat de Sabá, formaron en Italia sendos catálogos de los deportados espańoles que tan brillante muestra habían dado de su saber en todas ciencias y disciplinas. A coronar todos estos ensayos, y otros que al presente no recuerdo, vino en 1859 la muy erudita Bibliothèque des ecrivains de la Compagnie de Jésus, publicada en Lieja por los PP. Agustín y Luis Backer, obra que adolece, no obstante, sin duda por la dificultad de la empresa, de omisiones y aun yerros, por lo menos en la parte española, algunos de los cuales se han corregido después en un extenso Apéndice.

No menos poderosos, influyentes, conspicuos y fecundos en ilustres escritores que las Órdenes religiosas, fueron los llamados Colegios Mayores, muertos a mano airada por D. Manuel de Roda en tiempo de Carlos III. De los escritores salidos del seno de tales corporaciones poseemos notable bibliografía, gracias a las vigilias de Rezábal y Ugarte (1805), y encuéntranse además noticias en la Historia del Colegio Viejo de San Bartolomé de Salamanca, que ordenó el marqués de Alventos (1768).

Como incluidos también en la sección bibliográfica de corporaciones, pueden estimarse los catálogos de escritores, alumnos o maestros de nuestras escuelas, que acompañan a las Memorias históricas de la fundación y progresos de la Universidad de Valencia de Orti y Figuerola, a las Memorias Literarias (mejor dicho Universitarias) de Zaragoza de D. Inocencio Camón y Tramullas (1768 y 69), a la Reseña histórica de la Universidad de Salamanca, por los doctores Dávila, Madrazo y Ruiz (1850), a la Memoria histórica de la misma Universidad, por D. Alejandro Vidal y Díaz (1869), y a las historias de las Universidades de Zaragoza, Valencia, Granada y Oviedo, publicadas en estos últimos años por los señores Borao, Velasco y Santos, Montells y Nadal, Canella y Secades, etc., si bien tales apéndices, por su naturaleza, tienen que ser harto breves, y sólo pueden servir de índices o registros para quien emprenda formar la Bibliografía Universitaria Ibérica, no intentada aún por nadie, que yo sepa. ${ }^{558}$

558 Para comprender las vicisitudes del régimen interior de nuestros establecimientos de enseñanza, es obra indispensable la Historia de las Universidades, de que lleva publicados ya dos tomos D. Vicente de la Fuente. (Tercera edición) 
Mucho más rica que la sección anterior es la de Bibliotecas regionales, en la cual comprendo las de reinos, provincias, comarcas y ciudades. A continuación va el índice de las que conozco, muy incompleto sin duda, pero que demuestra el grado de cultivo obtenido en España por esta rama de la erudición bio-bibliológica.

PORTUGAL. Excede en este punto a las demás regiones peninsulares: posee la magna Bibliotheca Lusitana, de Barbosa Machado (1751-1759) (a quien precedieron en su empresa Juan Franco Barreto, Jorge Cardoso y algún otro), ${ }^{559}$ y el admirable Diccionario bibliográfico, de Inocencio da Silva, que aumenta y corrige la obra de su predecesor y la continúa hasta nuestros días (1862-67).

En la Biblioteca Nacional se conserva un manuscrito del señor D. Domingo García Peres, relativo a los ingenios portugueses que han escrito en lengua castellana.

VALENCIA. Sigue inmediatamente a Portugal en materia bibliográfica. Aparte de los ensayos hechos en el siglo XvII por Onofre Esquerdo y D. Diego de Vich, cuenta tres bibliotecas impresas: la del P. Rodríguez, continuada por el P. Saballs (1747); la de Jimeno (1749), y la de su adicionador Pastor Fuster, que la prosiguió hasta 1829. Hanse publicado, además, diversos opúsculos eruditos sobre puntos aislados de la historia literaria de aquel reino, y entre ellos El teatro en Valencia, de D. Luis Lamarca.

ARAGÓN. A ninguna de nuestras bibliotecas regionales cedería la de Latassa (1796-1802), si la falta de método y lo farragoso e indigesto del estilo no oscurecieran las cualidades de erudición y exactitud que en ella resaltan. ${ }^{560}$ Acerca de la Imprenta en Zaragoza, conozco un folleto del Sr. Borao $^{561}(1860)$.

CATALUNA. Aparte de otros catálogos anteriores de menor importancia, posee el Diccionario de escritores catalanes, de Torres Amat (1836), ligero e incompleto, aunque rico en noticias, y el Suplemento al mismo, de Coro-

559 Hay un epítome poco estimable de la obra de Barbosa, formado por Sousa Farinha. (Segunda Edición)

$560 \mathrm{Ha}$ obviado en parte los inconvenientes que resultaban de la mala disposición de los artículos en Latassa el Sr. D. Toribio del Campillo con un Índice alfabético de escritores aragoneses, que facilita mucho toda investigación (1877) (Segunda Edición). Posteriormente (1885-86), D. Miguel Gómez Uriel, oficial del Archivo del Colegio de Abogados de Zaragoza, ha prestado el gran servicio de refundir en forma de diccionario las dos Bibliotecas antigua y nueva de Latassa, adicionadas con muchos artículos. (Añadido Tercera edición)

561 A Latassa precedió en su empresa el cronista Andrés Ustarroz con un Índice de escritores aragoneses. (Primera Edición) 
minas y Aleu (1849), que repara muy pocas de sus omisiones, pero añade escritores más recientes. Aún resta no poco que trabajar en la bibliografía del Principado; pero es de creer que agote la parte de escritos en lengua catalana el docto bibliotecario D. Mariano Aguiló, en su obra premiada, ha no pocos años, por la Biblioteca Nacional, aunque por desdicha no impresa todavía. ${ }^{562^{*}}$ Sobre escritores gerundenses existe una Memoria del Sr. Girbal, y varias monografías del Sr. Grahit y de otros, debidas a la poderosa iniciativa de la Asociación Literaria de Gerona.

ISLAS BALEARES. D. Joaquín M. Bover ha publicado una extensa y erudita Bibliografía balear, de la cual se han hecho dos ediciones, muy aumentada la segunda (1868), que puede considerarse como obra totalmente nueva.

Las regiones del Mediodía, Centro y Norte de la Península han sido en esta parte menos afortunadas que Portugal y la Corona aragonesa. Los estudios bibliográficos, con alguna excepción, han sido más breves en Castilla, y muchos de ellos permanecen inéditos. Tengo noticia de los siguientes: ${ }^{563}$

ANDALUCIA. Sevilla.-Rodrigo Caro (Claros varones en letras, naturales de Sevilla), y sus continuadores D. Diego Ignacio de Góngora y D. Juan Nepomuceno González de León, el analista Ortiz de Zúñiga, Arana de Varflora, o séase el P. Valderrama (Hijos ilustres de Sevilla), Matute y Gaviria, más que todos diligente; muchos contemporáneos nuestros, entre los cuales recordamos a los señores Colom, Álava, Asensio, Gómez Aceves, Bueno, Palomo, Lasso, etc., y la Sociedad de bibliófilos andaluces, ${ }^{564}$ han acopiado innumerables datos para la bibliografía hispalense, siendo de lamentar que no se hallen reunidas en una obra de fácil manejo las noticias hoy dispersas en manuscritos, libros no frecuentes, prólogos y artículos de revistas. La Biblioteca Nacional premió tiempo atrás la Tipografía Sevillana (siglo xv), del Sr. Escudero y Perosso.

Cádiz.- Sólo he visto el Diccionario biográfico de Cambiaso, sobremanera incompleto, y los Hijos ilustres de Jerez de la Frontera, obra del Sr. Parada.

$562^{*}$ Esta Bibliografía, lo mismo que la de García Peres, se han publicado. (Edición Nacional)

563 Hoy es precisa la siguiente adición:

Reino de Murcia.

Estudio sobre la historia de la literatura en Murcia desde Alfonso X a los Reyes Católicos, 1877, por D. Andrés Baquero Almansa.

- Hijos ilustres de Albacete, por el mismo (1884). (Tercera edición)

564 Hoy hay que añadir el Archivo Hispalense, que anuncia la publicación de la obra de Matute Hijos de Sevilla señalados en santidad, letras, armas y dignidad, y además una serie de biografías de hispalenses ilustres omitidos por él. (Tercera edición) 
Córdoba.- Hijos ilustres de esta provincia, manuscrito de don Luis M. Ramírez de las Casas Deza, conservado en la Biblioteca Nacional. Es más biográfico que bibliográfico y crítico, y arguye en su autor más curiosidad que discernimiento.

Granada.-Bibliografía granadina hasta fines del siglo XVIII. Ms. de D. Juan F. Riańo, premiado por la Biblioteca Nacional.

CASTILLA LA NUEVA. Madrid.-El Diccionario de Álvarez Baena (1789-1791) tiene de bibliográfico muy poco, y esto con frecuencia inexacto. Más que a los escritores atiende a los nobles nacidos en Madrid, a quienes, por el solo hecho de serlo, considera ilustres, deteniéndose con fruición a trazar sus genealogías, ya que no a describir sus escudos de armas. ${ }^{565}$

Toledo.-Es muy de sentir que el diligente cronista de la Imperial ciudad, Sr. Gamero, ha poco difunto, no hubiese dedicado una parte de sus aprovechadas tareas a la formación de una Biblioteca toledana. Las únicas noticias que sobre el particular se han recogido hay que buscarlas en su Historia y en las de otros analistas anteriores, que por incidencia traen algo aprovechable para la historia literaria.

Cuenca.-Posee, no un seco catálogo de ediciones, ni un fárrago de apuntes bibliográficos, como otras provincias menos afortunadas, sino una serie de monumentales estudios, que debieran ser luz y espejo de bibliógrafos y eruditos. Cuatro tomos de notable volumen lleva publicados el Excmo. Sr. D. Fermín Caballero, relativos a Hervás y Panduro, Melchor Cano, el Dr. Montalvo y los hermanos Juan y Alfonso de Valdés. En ellos ha dado a conocer, no sólo la importancia científica y literaria de cada uno de sus personajes, sino las ideas y el espíritu de la época en que vivieron y la atmósfera intelectual que respiraron. La tipografía conquense queda asimismo ampliamente ilustrada en el opúsculo La imprenta en Cuenca, del mismo autor. ${ }^{566}$

EXTREMADURA. El Excmo. Sr. D. Vicente Barrantes, infatigable explorador de las glorias de su país natal, es autor de un Catálogo bibliográfico de obras útiles para la historia de Extremadura, premiado por la Biblioteca Nacional, y hoy refundido en el Aparato bibliográfico, del cual han visto la luz pública dos tomos. ${ }^{567}$ En él anuncia el Sr. Barrantes hallarse ocupado

565 El Sr. D. José Escudero de la Peña tenía hechos trabajos sobre la Tipografía Matritense del siglo Xvi. (Segunda Edición)

566 Bien lejano me hallaba yo, al trazar estas líneas, de tener que deplorar al pie la pérdida reciente y dolorosísima de este sabio, pérdida grande para las letras, inmensa para los que fuimos sus amigos. (Primera edición)

567 Ha aparecido en 1879 el tercero y último volumen. (Tercera edición) 
en una bibliografía de extremeños ilustres, que servirá de complemento a sus notables estudios.

CASTILLA LA VIEJA Y REINO DE LEÓN. Doloroso es decirlo, pero necesario. Las provincias castellanas y leonesas han manifestado escasísimo interés en la conservación de sus memorias literarias. Segovia posee el apéndice de escritores que añadió Colmenares a su Historia. ${ }^{568}$ En los anales eclesiásticos y seculares de las demás capitales y poblaciones de importancia se encuentran esparcidas muchas noticias útiles, pero no expuestas con criterio bibliográfico ni en forma erudita. Ni aun ciudades de tan gloriosa historia como Valladolid y Burgos, ${ }^{569}$ ni aun la Atenas española, foco de saber y de cultura, centro además de una escuela literaria en días no muy lejanos, han cuidado de formar los catálogos de sus escritores. Si algo se ha intentado en tal sentido, son tan escasas la extensión e importancia de los ensayos, que sus títulos y los nombres de sus autores se van de la memoria y de la pluma. La Biblioteca Nacional premió en uno de sus últimos concursos una Colección biográfico-bibliográfica de noticias concernientes a la historia de Zamora, por D. Cesáreo Fernández Duro.

LAS ASTURIAS. Asturias de Santillana o Montaña de Santander.Sepárola de Castilla, con la cual no tiene otras relaciones que las puramente administrativas y las comerciales, y la asocio, como más afín, al Principado de Asturias. De extensión territorial harto reducida, pero con historia y costumbres propias, la comarca montañesa, patria nuestra muy amada, recuerda con orgullo no pocos blasones literarios, alcanzados por naturales y oriundos de su suelo. A pesar de haberse contado entre ellos eruditos y bibliógrafos tan eminentes como lo fueron, a fines del siglo pasado, D. Tomás Antonio Sánchez, D. Fernando José de Velasco, Floranes, el P. La Canal y La Serna Santander, ninguno pensó en registrar ordenadamente los trabajos científicos de sus conterráneos. Algo se ha intentado en nuestros días. La Biblioteca Nacional ha premiado en el presente año un Diccionario de obras útiles para la historia de Santander, obra de un extraño a nuestro país, el Sr. D. Enrique de Leguina, a quien debemos agradecimiento por su

568 No en todos los ejemplares, sino únicamente en los que llevan la falsa portada de Madrid, 1640. Añádanse hoy los Apuntes biográficos de escritores segovianos de D. Tomás Baeza (1877). (Tercera edición)

569 Se han publicado unos Apuntes para las biografías de algunos burgaleses célebres por D. Nicolás de Goyri (1878), pero son pobres en la parte bibliográfica (Segunda Edición). Lo mismo puede decirse del libro de D. Policarpo Mingote sobre escritores leoneses. Vid. además Curiosidades bibliográficas de Valladolid, por D. Gumersindo Marsilla (1884). (Añadido de la tercera edición) 
diligencia. ${ }^{570} \mathrm{Y}$ aunque parezca de mal tono literario sacar a plaza el propio nombre, y más cuando éste es de sobra oscuro e insignificante, sabe $\mathrm{V}$., amigo mío, que me he propuesto formar una serie de monografías críticobibliográficas acerca de nuestros escritores, de la cual ha visto la luz pública el primer estudio, dedicado a la apreciación de las producciones del novelista anglo-santanderino D. Telesforo Trueba y Cosío.

Asturias de Oviedo.-A fines del siglo pasado, el docto canónigo de Tarragona, González Posada, acometió la empresa de formar una Biblioteca de escritores asturianos. El primer bosquejo de su trabajo, remitido por él a Campomanes, parece ser el mismo que ha visto la luz pública como anónimo en el tomo I del Ensayo de una biblioteca española formado sobre los apuntamientos de Gallardo. Extendidas con la brevedad que allí aparecen las primeras notas, dio Posada mayor extensión a sus trabajos, y con el título no muy propio de Memorias históricas del Principado, publicó un primer tomo, que abraza sólo la letra $A$ de su Diccionario, no limitado ya a los escritores, sino comprensivo de todos los asturianos ilustres. Perdióse en Tarragona, de la manera que usted sabe, el resto de su obra, harto farragosa y poco crítica, y hasta estos últimos años no se pensó en reparar su falta con una nueva Biblioteca asturiana. La ha formado con diligencia el seńor Fuertes, catedrático de este Instituto, y se guarda el manuscrito en la Biblioteca Nacional..$^{571}$

GALICIA. Existen: un Diccionario de escritores gallegos (lastimosamente interrumpido en su publicación), del Sr. Murguía (1862); un Catálogo de libros útiles para la historia de aquel reino, formado por el bibliotecario de la Universidad de Madrid D. José Villaamil y Castro (1875), y el ensayo (manuscrito en la Biblioteca Nacional) sobre La imprenta y la prensa periodistica en Galicia, del Sr. Soto Freire. ${ }^{572}$

No tengo noticia de más bibliografías peninsulares, ${ }^{573}$ faltando, entre otras (y es falta notable en provincias tan apegadas a sus tradiciones), la

570 Don Eduardo de la Pedraja y Samaniego, poseedor de la más rica colección de libros y papeles relativos a la Montańa, tiene reunidas y ordenadas gran número de papeletas para un Catálogo de autores montañeses. (Tercera edición)

571 Hoy está impreso en su mayor parte con el título de Bosquejo acerca del estado que alcanzó en todas épocas la Literatura en Asturias seguido de una extensa Bibliografía de escritores asturianos, 1885 . (Tercera edición)

572 Véanse además los Códices de las iglesias de Galicia en la Edad Media, por el Sr. Villaamil y Castro (1874). (Segunda Edición)

573 Sobre las Islas Canarias conozco la pequeña biblioteca unida por Viera y Clavijo a sus Noticias de la Historia general de las Islas de Canaria (1778), y las Biografías de Canarios Célebres, por D. Agustín Millares (1878). (Tercera edición) 
vasco-navarra, para la cual sólo se halla noticias sueltas esparcidas en muy desemejantes libros y folletos. ${ }^{574}$

Existen además las siguientes Bibliotecas americanas, sin otras que de seguro no habrán llegado a mi noticia. ${ }^{575}$

GENERALES-León Pinelo, Epitome de la Biblioteca Oriental y Occidental, Náutica y Geográfica Madrid, 1629, en un solo tomo; reimpresa con adiciones mucho más considerables que el texto, por D. Andrés González Barcia, en Madrid, 1737-38; tres volúmenes.

Bibliothèque Americaine de Ternaux Compans.—También son útiles para nuestra bibliografía, la Asiática y la Africana (1841).

Bibliotheca Americana Nova de Rich. Londres, 1846.

Harrise (Enrique), Bibliotheca Americana Vetustissima. A description of woks relating to America, published betwen the years 1492 and 1551, NewYork, 1846.—Additions, París y Leipzig, 1872.

La Imprenta en América, del mismo. New-York, 1866. Hay una traducción castellana con notables adiciones del Sr. Zarco del Valle.

Apuntes para un Catálogo de escritores en lenguas indígenas de América, por D. J. García Icazbalceta. Méjico, $1860 .{ }^{576}$

Los idiomas de la América latina, por D. F. Cibdad y Sobrón. Madrid, 1876. Es una especie de Catálogo bibliográfico, muestra de otro más extenso que tiene inédito su autor.

México.-Eguiara y Eguren. Bibliotheca Mexicana, sive eruditorum historia virorum qui in America Boreali nati vel alibi geniti, in ipsam domicilio

574 No hacen excepción los Varones ilustres alaveses, de Landazuri (blanco de las iras de nuestro Floranes), el folleto de D. N. Soraluce Más biografías y catálogo de varias obras vasconavarras, el Diccionario biográfico de encartados de D. Martín de los Heros (Ms.), ni los estudios sueltos de varios bibliófilos bilbaínos. También hay noticias útiles en Los Vascongados del Sr. R. Ferrer (Primera Edición). Después de escrito lo que precede, supe que la Biblioteca Nacional había premiado una Bibliografía del vascófilo, original de mi malogrado amigo y condiscípulo D. Ángel Allende Salazar. (Añadido de la Segunda edición)

575 Véanse citadas algunas que no he visto, en el prólogo de la Bibliotheca Vetustissima de Harrise. (Segunda Edición)

576 A este infatigable erudito se debe, entre otros excelentes trabajos, una Colección de documentos para la historia de México, y ediciones de la Historia eclesiástica indiana de Fr. Jerónimo de Mendieta, de tres diálogos latinos de F. Cervantes de Salazar (México en 1554) y de los Coloquios de F. González de Eslava, con copiosas ilustraciones. (Segunda Edición)

En el momento en que corregimos estas pruebas llegan a Madrid los primeros ejemplares de la monumental Bibliografía Mexicana del siglo XVI, del Sr. Icazbalceta. (Añadido de la tercera edición) 
aut studiis asciti, quavis lingua scripto aliquid tradiderunt. Méjico, 1755. Un tomo que comprende hasta la letra $C$. Los borradores del autor alcanzaban hasta la $J$.

Beristain de Sousa, Biblioteca Hispano-Americana Septentrional o Catálogo y noticia de los literatos que educados en la América Septentrional española han dado a luz algún escrito, etc. Méjico, 1816-21. Tres tomos en folio. Obra abundante en noticias, aunque le falta rigor bibliográfico en las descripciones. ${ }^{577}$

Isla de Cuba.-Apuntes sobre las letras y la instrucción pública en Cuba, por D. Antonio Bachiller y Morales.

En la Biblioteca Nacional se conserva un manuscrito moderno, más biográfico que bibliográfico, acerca de los ingenios nacidos en esta colonia. No recuerdo el nombre de su autor.

América del Sur.-Biblioteca de escritores venezolanos contemporáneos, por D. José María Rojas. París, 1875.

Ensayo sobre la historia de la literatura Ecuatoriana. por Pablo Herrera. Quito, 1860.

Estadistica Bibliográfica de la literatura chilena, por D. Ramón Briseño (1862). Dos tomos folio.

Gutiérrez (J. M.). Apuntes biográficos de escritores, oradores, etc., de la República Argentina. Buenos Aires, 1860.

Ídem. Bibliografía de la primera imprenta de Buenos Aires, con noticias sobre los orígenes del arte de imprimir en América. Buenos Aires, 1866.

Ídem. Estudios biográficos... sobre algunos poetas sud-americanos anteriores al siglo XIX. Buenos Aires. 1865.

Torres Caicedo. Ensayos biográficos sobre los principales publicistas, oradores, historiadores, poetas y literatos de la América latina. ${ }^{578}$

Filipinas.-D. Sebastián Vidal y Soler insertó un Catálogo de libros útiles para la historia y geografía de aquellas islas, al fin de su Memoria sobre los montes de Filipinas. Véase además el Apéndice VI a las Guerras piráticas de Mindanao y Joló, publicadas por el Sr. Barrantes, y algunos artículos del Sr. Pan en la Revista de Filipinas.

Con intento más científico que el de las bibliotecas regionales, se han formado en España algunas por orden de materias. Su número es por desgracia

577 Es de aplaudir la diligencia del bachiller Fortino Hipólito Vera, que ha hecho accesible esta obra, ya rara y costosísima, reimprimiéndola en Amecameca, el año pasado de 1883, si bien con pobres tipos y papel y escasa corrección tipográfica. (Tercera edición)

578 Ahora hay que añadir Apuntes sobre bibliografía colombiana, por Isidoro Laverde Amaya (1882); Anuario Bibliográfico de la República Argentina. (Se han publicado siete tomos, el último en 1886), por Alberto Navarro Viola. (Tercera edición) 
harto breve. Entre ellas merecen especial recuerdo la Historia bibliográfica de la medicina española de Hernández Morejón, y la que con el título de Anales publicó don Anastasio Chinchilla, la Bibliografía médica-portuguesa de Fonseca Benavides, La Botánica y los Botánicos de la Península hispano-lusitana, obra del Sr. Colmeiro (D. Miguel); la Biblioteca mineralógica de los Sres. Maffei y Rúa Figueroa, el Diccionario de bibliografía agronómica de D. Braulio Antón Ramírez, los Apuntes bibliográfico-forestales de D. José Jordana y Morera (Madrid, 1875), la Biblioteca Maritima de Navarrete, la Bibliografía Militar del Sr. Almirante, ${ }^{579}$ la de los Economistas españoles del Sr. Colmeiro (D. Manuel), la Económico-Política de Sempere y Guarinos, la de Historiadores de reinos, ciudades, villas, iglesias y santuarios de D. Tomás Muñoz Romero; el admirable Catálogo del teatro antiguo español del malogrado y eruditísimo La Barrera, libro que en saber y diligencia deja muy atrás los ensayos antecedentes. ${ }^{580} \mathrm{Si}$ a estas obras, nacidas en buena parte de los concursos de la Biblioteca Nacional. agregamos la Hispania Orientalis de Paulo Colomesio, publicada y adicionada por Wolfio en 1730; el Commentarius de praecipuis Rhetoribus Hispanis de Cerdá (publicado con su edición de la Retórica de Vossio en 1781); la comenzada Biblioteca de traductores de Pellicer (1778); el Specimen del P. Pou sobre la misma materia; los Apuntes del Sr. Apráiz para una historia de los estudios helénicos en España; el Catálogo de piezas dramáticas anteriores a Lope de Vega que acompaña a los Orígenes del Teatro Español, bellísimo estudio de Moratín; el Índice del Teatro del siglo XVIII que puso el mismo egregio dramaturgo al frente de sus Comedias; los muy copiosos y esmerados Catálogos de pliegos sueltos y libros que contienen romances, unidos por el sabio Durán a la última edición de sus Romanceros; los de Poemas heroicos, misticos, históricos, burlescos, etc., publicados por los Sres. D. Cayetano Rosell y D. Leopoldo A. de Cueto ${ }^{581}$ en los tomos XXIX y LXVII de la Biblioteca de Autores Españoles; los Índices cronológicos de dramáticos del siglo XVII, incluidos en la misma colección por el Sr. Mesonero Romanos; el de Libros de caballerías españoles y portugueses del Sr. Gayangos; la Biblioteca Genealógico-Heráldica de Franckenau (1724);

579 Hay otros libros concernientes a la Bibliografía de la ciencia de la guerra y a la de militares escritores; v. gr.: Capitanes ilustres y Revista de libros militares, por D. M. J. Diana (1851); Letras y Armas, por D. Luis Vidart (1871); La Pluma y la Espada, por D. Manuel Seco y Shelly (1877) (Segunda Edición) y sobre todo el Memorial Histórico del arma de artillería, por el General D. R. de Salas. (Añadido de la tercera edición)

580 Barrera dejó un suplemento a su propia obra. (Tercera Edición)

581 Formada tiene este eminente literato una Reseña bibliográfica de los poetas del siglo XVIII, que sería de desear viese la pública luz. (Primera Edición) 
el Ensayo Bibliográfico sobre los principales poetas portugueses de Costa e Silva (Lisboa, 1855); los Apuntes Bibliográfico-jurídicos de D. Fernando de León y Olarrieta (1871); y descendiendo a trabajos de menor extensión o importancia, la Biblioteca militar española de García de la Huerta (1760), la Biblioteca histórica portuguesa de Figanière, el ensayo de una Biblioteca antirrabinica de Ribeiro dos Sanctos (tomo VII de las Memorias de la Academia de Ciencias de Lisboa), el Catálogo de escritores de veterinaria del Sr. Llorente y Lázaro, la Bibliografía venatoria de Gutiérrez de la Vega y la de libros de jineta de Balenchana, la Bibliographie Parémiologique de Duplessis, la Sacra Themidis Hispanae Arcana de Franckenau, que puede considerarse como el ensayo de una Biblioteca jurídica (1703), tendremos casi completa la lista de las monografías bibliográficas, por orden de materias, dadas hasta hoy a la estampa. ${ }^{52}$ Pero inéditas se conservan algunas más, premiadas o adquiridas casi todas por la Biblioteca Nacional, cuales son: el Catálogo de escritores de Bellas Artes en España del Sr. Zarco del Valle; el de Relaciones y Fiestas de don Genaro Alenda, inteligentísimo ordenador de la sala de Varios de dicho establecimiento; la Monografía acerca de las colecciones de refranes, obra del Sr. Sbarbi, que se dispone a publicarla, a par de la rica y curiosa colección que con el título de Refranero da a la estampa, llevando ya impresos cinco volúmenes; ${ }^{583}$ el Catálogo de periódicos del Sr. Hartzenbusch (D. Eugenio); el de Escritores de matemáticas en el siglo XVI, formado por el Sr. Picatoste; el del Moderno teatro español de D. Manuel Ovilo y Otero; la Biblioteca jurídica de Fernández Llamazares, y la de Poetas líricos antiguos y modernos, citada sin indicación de su autor en la Memoria de la Biblioteca Nacional correspondiente a 1872.

En punto a índices y catálogos de Bibliotecas públicas y particulares, con mencionar, aparte de los registros e inventarios de diversas colecciones formados en los siglos XV, XVI y XVII sin rigor bibliográfico suficiente, ${ }^{584}$

582 Pueden añadirse hoy Datos bibliográficos sobre la Sociedad Económica Matritense, por D. Juan Catalina García (1877), la Bibliografía de la Tauromaquia de D. L. Carmena (1883) y varios trabajos de D. Manuel Torres Campos sobre la bibliografía del Derecho, especialmente moderna. (Tercera edición)

583 Luego han llegado a diez. (Tercera edición)

584 Véanse, entre otros, los de las librerías de la Reina Doña María (mujer de Alfonso V de Aragón), del príncipe de Diana, la Reina Católica, el duque de Calabria, Zurita, Antonio Agustín, Páez de Castro, etc. Entre todos descuellan el Registrum de D. Fernando Colon, trabajo ya verdaderamente de bibliófilo (Primera Edición), y la importantísima Bibliotheca Manuscriptorum de Antonio Agustín (Tarragona, 1587). Del siglo XvII existen catálogos impresos rarísimos de las librerías del conde-duque de Olivares, del inquisidor D. Diego de Arce y Reinoso, de la condesa de Villaumbrosa (Vid. Mayáns en la Vida de 
el Casiri ya citado; la Bibliotheca Graeca Matritensis de Iriarte (D. Juan), trabajo el más esmerado que ha salido de manos de nuestros helenistas; el Specimen bibliothecae hispano-majansianae; el ligerísimo Catálogo de Mss. del Escorial del Sr. Llacayo; la memoria de Valentinelli, Delle biblioteche della Spagna (1860); el Índice de los manuscritos españoles conservados en las Bibliotecas de Roma de Hervás y Panduro, el Catalogue of the Spanish Mss. in the British Museum del Sr. Gayangos; el de Manuscritos españoles de las Bibliotecas de París, dado a la estampa años ha por D. Eugenio de Ochoa; el que tiene dispuesto para la prensa mi docto amigo Morel-Fatio, ${ }^{585}$ corrigiendo los infinitos yerros de su predecesor; ${ }^{586}$ los diversos Índices ${ }^{587}$ de la Universidad de Salamanca; la Memoria descriptiva de los códices notables conservados en los Archivos eclesiásticos de España del Sr. Eguren, y los tres ricos y extensos Catálogos de nuestro La Serna Santander (Bruselas, 1803; 5 volúmenes), del marqués de Morante y de Salvá; el comentario latino de Fr. Fortunato de San Buenaventura sobre los códices de la Biblioteca de Alcobaza (1827); el Relatorio acerca de la Biblioteca Nacional de Lisboa, por José Feliciano de Castilho; el Catálogo de los Mss. de la Biblioteca de Évora, formado por Joaquín Heliodoro da Cunha Rivara, y el de Mss. portugueses del Museo Británico, tendremos expuesto lo más notable que sobre el particular recuerdo. ${ }^{588}$

A estas seis especies de bibliotecas pudieran añadirse otras dos, la de épocas y la de sectas religiosas. Pero no habiendo de la primera clase más ejemplos

Ramos del Manzano), y del Dr. Gabriel Sora, obispo de Albarracín (1610) (Añadido de la tercera edición).

585 Son de indispensable consulta para el bibliógrafo español, como para todo investigador de cosas históricas, la España Sagrada, el Viaje Literario del P. Villanueva, las Cartas del P. Andrés sobre las Bibliotecas de Italia (1791 a 1793), las dos misiones literarias de Morel-Fatio a Mallorca (1882) y a Valencia (1885), el viaje literario de Ewald a España en 1878 y 79 para estudiar los códices tocantes a la historia de la Edad Media (Hannover, 1881), los dos Anuarios del Cuerpo facultativo de archiveros, bibliotecarios y anticuarios (1882 y 1883), la colección de la Revista de Archivos, Bibliotecas y Museos en sus varias épocas y formas, las Memorias anuales de la Biblioteca Nacional (en la de 1865 está incluido el inventario de los libros de D. Agustín Durán), etc., etc. (Tercera edición)

$586 \mathrm{El}$ interesante catálogo del Sr. Morel-Fatio ha aparecido en 1881, pero falta todavía el segundo cuaderno, que contendrá la Introducción, el Suplemento y las Tablas. (Tercera edición)

587 El de Mss. se publicó en 1855. (Segunda Edición)

588 Deben añadirse hoy el Catálogo de los códices existentes en la Biblioteca de la Universidad Central, por D. José Villaamil y Castro (1876), el Catálogo de manuscritos del Instituto de Jove-Llanos en Gijón, por D. Julio Somoza (1883), y sobre todo el precioso Catalogue of the Ticknor Collection, 1879, que, unido al Salvá, puede suplir la falta de un Brunet español. (Tercera edición) 
que el Ensayo de una biblioteca de los mejores escritores españoles del reinado de Carlos III de Sempere y Guarinos, y estando limitada por hoy la segunda a la Biblioteca Wiffeniana del erudito profesor de Strasburgo, doctor Boehmer, relativa a los protestantes españoles del siglo XVI, no he juzgado necesario hacer clase aparte de tales libros. Por razón Análoga omito las bibliografías especiales de cada autor, de su escuela, discípulos, imitadores, etc.; pues, fuera de la Biblioteca Luliana de Roselló, inédita todavía, no conozco ninguna que forme libro aparte, dado que suelen acompañar como apéndices a las monografías crítico-bibliográficas de cada autor, que citaré en sazón más oportuna. ${ }^{589}$

A todo este arsenal erudito han de añadirse las bibliografías generales de Brunet, Graesse, La Serna Santander, Hain, Fabricio (especialmente la De la media e infima latinidad), y aun los anticuados libros de Vogt, Pope-Blount, Morhof, Peignot, De Bure, y tantos otros que fuera prolijo citar aquí, libros de indispensable consulta, debidos en su mayor número a autores extranjeros. ${ }^{590}$ En la que parece más inútil se tropieza a veces con algo nuevo e inesperado.

Tal es, salvas inevitables omisiones, el caudal bibliográfico hoy existente. ${ }^{591}$ ¿Cuál de los métodos hasta ahora adoptados para la composición de este linaje de obras es más cientifico, más útil y satisface mayor necesidad en España?

589 Trabajos bibliográficos sueltos de notable curiosidad dieron a la estampa, entre otros que en sazón oportuna recordaremos, los señores D. Benito Maestre y D. Luis Usoz y Río, sin rival el segundo en el conocimiento de las obras de nuestros heterodoxos del siglo Xvi. (Primera Edición)

590 No son obras de bibliografía, pero tratan incidentalmente de algunos escritores, las Noticias de los arquitectos de Llaguno, el Diccionario de profesores de Bellas Artes de Ceán Bermúdez, y algunas obras de Stirling, así como la Historia de la Música de Soriano Fuertes, etc. (Segunda Edición)

591 Hay una muestra de Bibliografía autobiográfica, si vale la frase, en la que D. José Pellicer de Ossau y Tovar formó de sus libros y obras publicadas.

El periodismo bibliográfico fue representado entre nosotros por el infatigable D. Dionisio Hidalgo en las tres series de su Boletín. El mismo da cuenta de otras publicaciones anteriores con el mismo objeto. Hoy no tenemos otra que el Boletín de la Librería que da a luz el inteligente librero Sr. Murillo. Hace dos o tres años aparecieron algunos cuadernos de una Revista Bibliográfica Católica (Segunda Edición).Y mucho antes habían existido La Censura (1844 a 53) y la Bibliografía Católica Española, que duró muy poco (1862). Hasta los catálogos de libreros y los de ventas públicas son a veces de utilidad inapreciable. ¿Dónde encontraremos, por ejemplo, tantos artículos preciosos de nuestra literatura rabínica y de los trabajos a ella referentes, como en el Catalog von Hebraischen und Indischen Büchern Handschriften, etc., procedentes de las bibliotecas de Almanzi, Jacob Embden y M. J. Lewenstein, vendidos en pública subasta por el librero de Amsterdam Federico Muller en 1868? (Añadido de la tercera edición)* 
No dudo responder que el de materias. La Bibliografía general es, hoy por hoy, imposible en España, como en todas partes. Debe ser el desideratum de la erudición y de la crítica, pero no conviene empeñarnos en tentativas directas, y sin duda infructuosas, para conseguirlo. Deben fomentarse los trabajos eruditos acerca del movimiento intelectual en cada una de las regiones de nuestra Península, para que por tal camino se conserve la autonomía científica y literaria de que algunas ciudades, como Barcelona y Sevilla, disfrutan; adquieran otras la independencia, carácter y vida propia de que hoy, a pesar del número y calidad de sus ingenios, carecen; crezca en nosotros el amor a las glorias de nuestra provincia, de nuestro pueblo y hasta de nuestro barrio, único medio de hacer fecundo y provechoso el amor a las glorias comunes de la patria, y sea posible contrarrestar esa funesta centralización a la francesa que pretende localizar en Madrid cuanto de vida literaria existe en todos los ámbitos del suelo español, borrando por ende toda diferencia y todo sello local, para obtener en cambio una ciencia y un arte, reflejos pálidos de la ciencia y del arte extranjeros, no pocas veces antipáticos y repulsivos a nuestro carácter. Aparte de esta capital consideración, los catálogos de escritores provinciales conducirán en un término no lejano a la formación de la bibliografía general; los estudios sobre la imprenta en cada una de nuestras ciudades formarán unidos la Tipógrafa Española, y los índices de libros útiles para la historia particular son materiales para el Aparato bibliográfico a la historia de España, obra que falta aún, como asimismo faltan el Arqueológico y el Diplomático, trabajos preparatorios indispensables, sin los cuales, y numerosas colecciones de documentos a más de las existentes, y mejor ordenadas que éstas, nunca lograremos poseer una Historia formal, erudita y digna de su nombre.

Pero aún más necesarias que las Bibliotecas regionales, de las cuales existe al cabo gran número, son las compuestas por materias, muy escasas todavía en España; libros que satisfacen de lleno las condiciones que la historia literaria tiene derecho a exigir de la bibliografía, pues su unidad interna no está limitada por las condiciones de tiempo y espacio, sino por la naturaleza de cada rama del saber, apareciendo los escritores en ellos incluidos como eslabones de la misma cadena. De este género de bibliografías, formadas con los requisitos que señalé al principio de la presente carta, es muy fácil el tránsito a las monografías histórico-críticas.

[*]Parece ocioso advertir al lector que desde 1887, fecha de la tercera edición de La ciencia española, el caudal de la Bibliografía española ha crecido considerablemente, y que las adiciones llenarían tal número de páginas que podrían formar gruesos volúmenes. Foulché-Delbosc y Barrou-Dihigo han publicado dos tomos del Manuel de L'Hispanisant (1920-1925), que en cierto modo son el desarrollo de esta carta. (Edición Nacional) 
Por desgracia, consideraciones materiales de poco elevada índole limitan en España, del modo que V. sabe, la producción de libros eruditos. No hay público para esta clase de trabajos, y su impresión, con frecuencia harto costosa, suele no ser accesible a las fuerzas de un particular, que teme empeñar sus recursos en un libro de difícil o imposible venta. Por tal razón, hallo digna de toda alabanza la institución de premios anuales para este objeto en la Biblioteca Nacional, institución provechosísima, de que nuestras letras son deudoras al insigne erudito D. Aureliano Fernández-Guerra y Orbe. En el escaso tiempo transcurrido desde el primer concurso hasta hoy, ha dado por naturales frutos un número de obras bibliográficas superiores en extensión y en importancia a cuanto se había trabajado en Espańa en el medio siglo antecedente. Algo se ha detenido este movimiento desde el ańo 67, por una causa verdaderamente lamentable, que dará ocasión a la muerte de toda actividad bibliográfica, si pronto no se acude al remedio. Desde aquella fecha no se ha impreso una letra de ninguna de las obras premiadas, y, lo que es aún más de sentir, ha quedado incompleto el importantísimo Ensayo de Gallardo, Zarco del Valle y Sancho Rayón. ¿Cuál es la causa de semejante atraso? La ignoro: tal vez los malos tiempos que hemos corrido; tal vez la indiferencia con que en Espańa se miran estas cosas. ${ }^{592}$ Pero sí afirmo que de no remediarlo presto quien puede y debe, daráse ocasión a que el público no tenga medio fácil de apreciar el acierto del Jurado en sus calificaciones; se confiscará en provecho de los pocos literatos que en Madrid residen y pueden a toda hora concurrir a la Biblioteca Nacional lo que debiera ser patrimonio común de la erudición española; se hará cada día más difícil el conocimiento de nuestras riquezas literarias, y a la postre faltarán aspirantes a los premios, pues no es grande estímulo la mezquina recompensa pecuniaria a ellos aneja, ni aun la entrada en el Cuerpo de Bibliotecarios, para que consienta nadie en enterrar en la sala de manuscritos una obra, fruto tal vez de largos afanes y vigilias.

Es, pues, urgentísima la publicación de los trabajos hasta hoy premiados, y si arredrare a la Superioridad el escasísimo coste de tal empresa (pues aquí para todo lo útil se tropieza con dificultades increíbles, al paso que nadie para mientes en los gastos que ocasionan tantas y tantas cosas superfluas), creo que fuera preferible suspender por algunos ańos los concursos y publicar en tanto las obras existentes, a dejar de cumplir lo que se anunció en las condiciones de los concursos como parte (y la más esencial) del premio.

592 A estas horas parece que tal estado de cosas ha cesado, puesto que se imprimen ya las obras premiadas anualmente. Así se ha hecho con la Bibliografía Numismática del Sr. Rada y Delgado y se hará con La Imprenta en Toledo, del Sr. Pastor. Confiamos que esta buena fortuna alcanzará también a las obras antiguas. (Tercera edición) 
Pero tal vez se me dirá: ¿A qué tanta protección a esos estudios? ¿A qué fomentar la composición de obras bibliográficas, cuando existen tantas como ya dejo citadas, aparte de las muchas que habré omitido? ¿No se ha trabajado bastante en ese campo? ¿Quedan aún puntos sin explorar? ¿No sabemos bastante de nuestros escritores? La respuesta es muy sencilla: a continuación va el índice de algunos de los Diccionarios bibliográficos que nos faltan todavía. Elijo sólo aquellas materias de mayor y más reconocido interés, prescindiendo de otras muchas que solicitan de un modo menos imperioso la curiosidad erudita:

I.-Biblioteca de Teólogos.

Escriturarios.

Escolásticos.

Dogmáticos.

Moralistas.

2.-De Místicos y Ascéticos.

3.-Filósofos.

4.- Moralistas no teológicos.

5.- -Jurisperitos.

Civilistas.

Canonistas.

6.- Políticos y tratadistas de Derecho público.

7.-Escritores de Alquimia, Química y Física. (Pudieran dar materia a dos Bibliotecas, cuya fonación incumbe de derecho a mi sabio amigo y maestro en materia bibliográfica, D. José R. de Luanco, autor de la excelente monografía acerca de Raimundo Lulio considerado como alquimista, y al Sr. Rico y Sinobas, ilustrador de las obras científicas del Rey Sabio.)

8.-Zoólogos.

9.-Geógrafos y Cronologistas.

10.-Arqueólogos.

11.- Historiadores generales y de sucesos particulares.

12.- - Historiadores de Órdenes religiosas y monasterios, Genealogistas, etc. (Sobre el segundo de estos grupos existe la Bibliotheca Genealógico-Heráldica, de Franckenau, o sea D. Juan Lucas Cortés; pero es incompleta)..${ }^{593}$

593 Cítase otra de Salazar y Castro, que no hemos visto. (Primera Edición) 
13.-Estéticos, preceptistas, críticos e historiadores de la literatura.

14.- Orientalistas.

15.-Humanistas.

16.-Autores que han escrito de o en lenguas exóticas.

17.- Poetas españoles que han escrito en griego, en latín o en alguna de las lenguas vulgares no habladas en la Península Ibérica.

18.-Líricos castellanos, galaico-portugueses y catalanes.

19.- Poetas épicos.

20.--Novelistas.

21.-Biógrafos y Bibliógrafos.

22.--Anónimos, pseudónimos, plagiarios, curiosidades literarias. (Obra análoga al Diccionario de supercherías bibliográficas de Quérard, y al de los Anónimos de Barbier.)

23.- - Heterodoxos españoles. (Completar a Boehmer con la noticia de todos los que en Iberia extravagaron de la fe católica antes y después de la Reforma protestante del siglo xvi). ${ }^{594}$

24.-Biblioteca de Traductores de lenguas clásicas y de Poetas modernos. (Llevo muy adelantada esta Biblioteca.)

25.- - Traductores de idiomas vulgares.

26.-Escritores oriundos de España, aunque hayan nacido y escrito en país y lengua extranjeros. Escritores extranjeros que han usado cualquiera de las lenguas peninsulares en todos o en alguno de sus escritos.

27.--Autores extranjeros que han escrito de cosas de España.

28.-Matemáticos ibéricos anteriores y posteriores al siglo XVI.

29.-Escritoras españolas.

30.-Obras prohibidas. Pudiera hacerse un trabajo curiosísimo cotejando los diversos índices expurgatorios de la Inquisición. ${ }^{595}$

Cuando esté realizado todo o la mayor parte de este programa, podrá decirse con fundamento que la bibliografía española queda ampliamente ilustrada. Hasta tanto, y mientras sigamos ignorando la mitad de nuestro

594 Véase mi Historia de los Heterodoxos. (Tercera edición)

595 Trata de realizarlo el norteamericano William Knapp en el Thesaurus Bibliographical of prohibited literature que prepara. Como muestra, ha publicado una lista de Official editions and reprints of the "Index» (1880). La Bibliografia de los libros condenados al fuego, de Peignot (1806), contiene muy pocos artículos españoles. (Tercera edición) 
pasado intelectual, no me cansaré de solicitar protección y apoyo para este linaje de estudios, de suyo áridos e ingratos, que reportan fatigas considerables, aunque no honra ni provecho.

En mi próxima epístola trataré del segundo medio de promover el estudio de nuestra historia científica, o sea de las monografías expositivo-criticas.

Marcelino Ménendez Pelayo

Santander, junio de 1876 


\section{MR. MASSON REDIVIVO \\ (Réplica a un escrito de D. Manuel de la Revilla)}

$\mathrm{M}$

i muy querido amigo y paisano: Parece que algún revoltoso duende anda empeñado en hacerme prolongar esta correspondencia. He aquí que cuando pensaba continuar hablando con todo reposo acerca de los medios de facilitar a la generación actual el conocimiento de nuestra ciencia antigua, se me atraviesa el ingenioso y agudo crítico D. Manuel de la Revilla, que en el último número de la Revista Contemporánea nos lanza tremenda filípica, llamando mito a la filosofía española, y soñadores a los que en ella nos ocupamos, citándonos a V. y a mí (aunque indigno) nominatim, y honrándonos con un calificativo que por mi parte no acepto, aunque se lo agradezca de veras. Justo parece que, a modo de paréntesis, nos hagamos cargo de las afirmaciones de este caballero, eco póstumo de aquel Mr. Masson de la Enciclopedia, tan briosamente refutado un siglo ha por Cavanilles, el abate Denina y Forner, ya que no duda en lanzarlas al mundo, suscritas con su nombre y apellido. Y comenzaré por advertir que ninguna extrañeza me ha causado el verlas en letras de molde en la Revista citada, pues parece que esa publicación profesa odio mortal a todo lo que tenga sabor de españolismo, y yo, por mi parte, juro que desde que apareció por estas playas, ando buscando en ella a moco de candil algún artículo, párrafo o línea castellanos por el pensamiento o por la frase, y muy pocas veces he logrado la dicha de encontrarlos. Como no sé el alemán, ni he estudiado en Heidelberg, ni oído a Kuno Fischer, no me explico la razón de que en una revista escrita, al parecer, en castellano y para españoles, sea extranjero todo: los artículos, los doctrinales, las novelas, las poesías y hasta los anuncios de la cubierta. Dios nos tenga de su mano. Si esto sigue así algunos años, ¿qué será de los desdichados que jamás entramos en el Sancta Sanctorum del Deutsche, y 
que en vez de leer a Hartmann y a Schopenhauer y a otros pensadores y filósofos eximios (ahora los hay ya no sólo germánicos, sino eslavos, cuyos nombres acaban en of y en graf, como los de los héroes de El Gran Cerco de Viena), gastamos el tiempo y la paciencia en los ańejos y trasnochados libros de esos pobres españoles de las tres centurias antecedentes, que se llamaban del modo más prosaico: Soto, Vázquez, Suárez..., y que vivieron bajo el triple yugo de todos los despotismos, de todas las intolerancias, de todas las supersticiones? Afortunadamente, los redactores de la Revista Contemporánea no paran mientes en esa grey servil, aherrojada por el despotismo y la Inquisición, y siguen impertérritos su camino. Con ellos me entierren, que son inteligencias abiertas a todo viento de doctrina y libres de preocupaciones históricas. ¿Qué extraño que menosprecien la filosofía española?

Cosas más raras estamos viendo cada día. Parecía que ya era tiempo de que callase esa literatura progresista de perversa ralea, cuyas inocentadas han sido la delicia de tres generaciones. Pues he aquí que el eminente lírico Núnez de Arce, nombre caro a nuestras musas, al tomar asiento en la Academia Española, se acuerda de haber sido periodista y diputado constituyente y gobernador de Barcelona después del movimiento septembrino, y con mengua de su buen juicio y talento poderoso, jdebilidades humanas!, nos regala un trocito de poesía doceañista, capaz de hacer llorar a las piedras. El Sr. Núñez de Arce es de los que para todo encuentran una explicación: la intolerancia. ¡Felices ellos, que así poseen la clave de nuestra historia!

El vulgo de los mortales nos devanamos el seso para comprender cómo esa intolerancia puede producir efectos contradictorios. Unos dicen que las letras españolas florecieron gracias a la intolerancia, pero que ésta mató toda actividad científica; otros afirman que la susodicha intolerancia echó a perder ciencia y arte y costumbres, todo en una pieza. De éstos es el señor Núñez de Arce. Al leer su discurso, me parecía tener a la vista el estudio crítico que antepuso el abate Marchena a sus Lecciones de Filosofía Moral y Elocuencia, o algún otro de los alegatos que por el tiempo de éste aparecieron en defensa de la imbecilidad y estupidez de nuestra raza. El nuevo académico está, por lo visto, en tales cuestiones a la altura de los críticos del año de gracia 1820 . No le envidio la triste gloria de sustentar causa tan antipatriótica y atrasada. El Sr. Núnez de Arce, que como poeta tiene no pocas semejanzas con el gran Quintana, se le parece mucho más en ideas religiosas y políticas uno y otro se hacen insoportables cuando se acuerdan de haber pertenecido a la 
incorregible y reacia estirpe liberalesca de comienzos del siglo presente, que se empeñó en sobrevivirse a sí misma hasta días muy cercanos. ${ }^{596}$

Pero dejemos el discurso del nuevo académico, ya que con tanta brillantez le trituró su compañero el Sr. Valera (pocas veces se pudo decir con igual exactitud que ahora: Paz a los muertos), y hablemos algo del artículo del Sr. de la Revilla, al cual dio principal asunto la solemnidad literaria en que fue leído aquel sangriento ataque a nuestra cultura. El crítico ex-krausista se entusiasma con él y bate palmas de gozo al hallarse con una nueva catilinaria contra la Inquisición y la gente de sotana. A otro le causaría empalago tan enfadosa repetición de lugares comunes; al Sr. de la Revilla, no; en este punto es insaciable: trivialidades, contradicciones, absurdos, todo sirve para su propósito. Examinemos punto por punto los párrafos que dedica a esta materia, y no espere V., amigo mío, descubrir una idea, ni una noticia nueva; es la peroración eterna, con algunas variantes, no siempre atinadas.

Ante todo, ha de advertirse que el Sr. de la Revilla no conviene en absoluto con las ideas del autor de los Gritos del Combate, y hace algunas salvedades respecto a la literatura, aunque ninguna en punto a la ciencia. Vea V. cómo se explica en cuanto al segundo de estos dos ramos de la cultura patria: «A despecho de los que se obstinan en descubrir en aquella época un supuesto florecimiento de la ciencia espańola, es lo cierto que en este punto caímos bien pronto en lamentable atraso». Contradicción lastimosa en el pensamiento y en la frase. Si caímos en atraso, sería porque hasta entonces estábamos adelantados; sería porque antes había florecido la ciencia en nuestro suelo, pues mal se puede decir que decae lo que primero no ha existido; no se queda atrasado el que no se pone en camino. Ahora quisiera yo que el Sr. de la Revilla fijase las épocas de florecimiento y de decadencia en nuestra actividad científica, no con vagas afirmaciones de es cierto y es indudable, sino con ejemplos al canto, como discuten los míseros mortales que no han penetrado los arcanos de las novísimas filosofías. Yo le aseguro que el determinar estos límites es más difícil de lo que parece. En general, el siglo XVII puede estimarse como de atraso científico respecto al XVI; pero, aun en este punto, cabe establecer sus excepciones: la crítica histórica, por ejemplo, rayó mucho más alto en el reinado de Carlos II que en el de Carlos

596 Después he rectificado bastante mi juicio sobre Núñez de Arce, aunque no en el punto particular de que aquí se trata. Véanse mis Estudios de Crítica Literaria, donde expreso toda mi admiración por el poeta y hago los oportunos deslindes y reservas acerca de su doctrina, mucho menos racionalista y liberal de lo que él mismo se figura. Es de presumir que también el Sr. Núñez de Arce habrá modificado después de diez años sus opiniones sobre la cultura española. (Tercera edición) 
I el Emperador; Hugo de Omerique era un matemático mucho más original y profundo que Pedro Ciruelo. ¿¿Sabe el Sr. de la Revilla que en materias de erudición conviene proceder con tiento? El ingenio y la agudeza y el desembarazo sirven de mucho; pero en cuestiones de hecho, los hechos deciden.

$\mathrm{Y}$ añade nuestro crítico: «Regístrense los nombres de todos los físicos, matemáticos y naturalistas que entonces produjimos, y ninguno se hallará que compita con los de Copérnico y Galileo, Newton y Kepler, Pascal y Descartes.»

Al Sr. de la Revilla se debe el asombroso descubrimiento de que todo geómetra, físico y astrónomo que no llegue a la altura de los citados, es un pigmeo indigno de memoria. ¿Ignora el arrojado crítico que esos genios poderosos aparecen muy de tarde en tarde, para cumplir una Providencial misión en la vida de las ciencias? ¿Ignora que no hay intolerancia que logre cortar su vuelo, ni libertad que baste a producirlos? Y si no, ¿¿dónde están los grandes astrónomos, físicos, matemáticos y naturalistas que ha dado España en este siglo, no ya de libertad y tolerancia, sino de anarquía y desconcierto? Y ¿qué es aquí la intolerancia más que una palabra vana, una verdadera garrulería, arma de partido, buena para los tiempos en que se quemaban conventos y se degollaba a los frailes, pero hoy desgastada y sin uso? ¿Qué influencia buena ni mala había de ejercer la intolerancia religiosa en ciencias que no se rozaban, o se rozaban poquísimo, con el dogma? No nació en España Copérnico, porque no quiso Dios concedernos la gloria de que aquí naciese; pero nació Diego de Stúñiga, que abrazó inmediatamente su sistema y le expuso con toda claridad, sin que nadie le pusiese trabas. ¿Quiere decirme el Sr. de la Revilla en qué indice expurgatorio del siglo XVII, en cuál de esos libros de proscripción del entendimiento humano, como dijo el Sr. Núñez de Arce, ha visto prohibidas las obras de Galileo, de Descartes y de Newton? Pues si a nadie se prohibía su lectura, ¿con qué derecho se afirma hoy que el Santo Oficio coartó la libertad científica? Luego si no tuvimos Galileos, Kepleros ni Newtones, por otra razón sería, y no por los rigores inquisitoriales.

En mi primera carta, que sin duda no leyó el Sr. de la Revilla, porque tan insignificante escrito no merecía solicitar su atención, apunté algo sobre el particular, y a lo dicho entonces me remito. ${ }^{597}$

597 Ahora sólo añadiré que, a mis ojos, la causa principal es la que ya apuntó D. Martín Fernández de Navarrete en su Disertación sobre la historia de la Náutica; es, a saber: que en el siglo Xvi, las Matemáticas puras se miraban como un estudio abstracto, de pocas o muy remotas aplicaciones. Y que en este punto la opinión no ha variado mucho, nos lo prueba el hecho tristísimo de estar desiertas nuestras Facultades de Ciencias, donde bien o mal se profesa la ciencia por la ciencia misma, sin consideración a ningún fin ulterior, al paso 
que rebosan de alumnos las escuelas especiales civiles y militares. Algo parecido, salvo la diferencia de los tiempos, pasaba en el siglo xvi, y por eso tuvimos tantos y tan excelentes autores e inventores de fortificación, de artillería, de arte de navegar, de cosmografía y de arquitectura naval, y relativamente tan pocos geómetras y astrónomos; tantos y tan gloriosos médicos, y relativamente tan pocos cultivadores de la Física experimental y de la Química. Hay aquí un misterio de raza, que conviene dilucidar apartándose de las vulgaridades admitidas, por lo mismo que lleva consigo cierto germen de imperfección que importa combatir y desarraigar. La gente española propende a la acción, y se distingue por el sentido práctico y por la tendencia a las artes de la vida. Hablo de la España verdadera e histórica, no de la fantástica y caballeresca que tienen metida en los cascos los extranjeros, y de la cual ya es imposible desengańarlos. Pero quien con imparcialidad examine nuestra ciencia y nuestro arte, no dejará de reconocer, en la abundancia de moralistas y de jurisconsultos, de políticos y de publicistas, en las digresiones éticas a que los mismos metafísicos propenden, en el gran número y excelencia de los geopónicos y economistas, en la observación desnuda y franca de la vida que caracteriza a nuestros grandes novelistas, en el naturalismo de los pintores (hablo del naturalismo de Velázquez), y en otras mil formas y manifestaciones del genio nacional, un estrecho parentesco y un signo de raza. Claro es que esta tendencia que, a falta de otro mejor nombre, llamaremos positiva, jamás ha sido única ni nos ha llevado nunca al desprecio de la especulación, porque ha tenido que combinarse con otros impulsos, v. gr., el Cristianismo, que por sí solo había bastado ya para despertar la vitalidad metafísica en el ánimo de nuestros padres los latinos, tan semejantes a nosotros en todo. Añádase a esto el cruzamiento con otras razas, especialmente con la judía, dotada de tan excepcionales condiciones para la especulación de lo absoluto y de lo eterno; añádase el largo y duro aprendizaje de la Filosofía escolástica, de la cual participamos, como toda Europa, y, finalmente, el influjo del Renacimiento, y se comprenderá como España pudo ser y fue de hecho, a pesar de su genialidad positivista, país de grandes y sutiles metafísicos. Pero no había la misma razón para que lo fuese de grandes matemáticos. La Metafísica estaba enlazada estrechamente con los estudios teológicos, principal nervio de nuestra cultura de entonces; en parte les servía de base, y en parte se apoyaba en ellos. Era natural que floreciese mucho y que participase de las grandezas de la batalla en que nuestro genio teológico andaba empeńado. Y obsérvese que con toda intención he escrito batalla, para mostrar el carácter activo, crítico, polémico, práctico, en fin, que aun en sus mayores audacias ostenta nuestra ciencia. Pero otros estudios, en los cuales no se daba este interés de actualidad, tenían que languidecer, no por la persecución, sino, al revés, porque nadie se cuidaba de ellos, ni siquiera para perseguirlos; porque no tenían relación alguna con lo que entonces se debatía y acaloraba los ánimos; porque eran verdades abstractas, cuya aplicación todavía no se vislumbraba, al paso que se veía clara la aplicación de las verdades filosóficas. Y en Espańa, ni entonces ni ahora ( $y$ ahora menos que entonces, porque los vicios del carácter nacional han ido creciendo, y han venido muy a menos sus virtudes), ha tenido ni tiene la ciencia desinteresada, la ciencia cuyo mayor título de nobleza está en no servir para nada (según la opinión del vulgo), muchos aficionados que persigan sus exquisitos y rarísimos deleites. Esta es la verdadera causa del fenómeno, sobre el cual tanto se desbarra, echando la culpa a antiguas instituciones, en vez de echársela a nuestros defectos, como si las instituciones no hubiesen desaparecido y los defectos no siguieran cada vez más subidos de punto. Y si a alguno de los que lean estas líneas se le ocurre preguntar cómo pecando 
Y sigue hablando el Sr. de la Revilla:

«Por doloroso que sea confesarlo, si en la historia literaria de Europa suponemos mucho, en la historia científica no somos nada, y esa historia puede escribirse cumplidamente sin que en ella suenen otros nombres españoles que los de los heroicos marinos que descubrieron las Américas y dieron por vez primera la vuelta al mundo. No tenernos un solo matemático, físico ni naturalista que merezca colocarse al lado de las grandes figuras de la ciencia».

Punto y aparte. Cargad aquí la consideración, como decía aquel predicador portugués. El Sr. de la Revilla cree, por lo visto, que la historia de la ciencia se reduce a las biografías de seis, siete u ocho hombres prodigiosos; ellos dieron la luz; en los intermedios, completa oscuridad. Pero a cualquiera se le alcanza, sin ser filósofo ni crítico de la Revista Contemporánea, que una historia de la ciencia escrita de esa manera, ni sería historia, ni sería ciencia, sino un libro muy ameno y entretenido, à l'usage des demoiselles, como las Vidas de los sabios que publican Luis Figuier y otros franceses. Una historia formal no puede escribirse de este modo: ¿qué unidad ha de tener obra semejante?, ¿`cómo ha de componerse una historia de la astronomía saltando de Copérnico a Galileo, y de Galileo a Kepler y Newton, y de Newton a Laplace? Concibo que pueda escribirse una historia de la literatura dejando aparte las obras de los autores medianos, no obstante la importancia grandísima que suelen tener bajo el aspecto histórico, y a pesar de las grandes bellezas que con frecuencia se hallan en los libros de escritores de segundo orden, merecedores de estudio y de aplauso, aunque no se llamen Homero, Dante, Shakespeare, Cervantes, Calderón o Goethe; comprendo, repito, que se escriba tal historia, aun a riesgo casi seguro de dejar sin explicación infinitos fenómenos literarios y sociales producidos en el mundo por poetas y prosistas oscuros, y hasta malos; pero en la historia de la ciencia, ¿cómo olvidar la infatigable labor de esos modestos cultivadores que han abierto y allanado el camino a los genios y que, si no han sido grandes hombres, han sido por lo menos hombres eminentes y útiles para los progresos del entendimiento humano, lo cual vale en ocasiones tanto o más que lo primero? En ciencias de observación y experimento como las naturales, o de cálculo como las exactas, ¿̨no significan tanto como los descubridores de

los españoles de abuso y exceso de espíritu positivo, hemos dado en nuestra historia y damos cada día tantos pasos en falso, contestaré que uno de los modos más inciertos de acertar en la práctica es volver las espaldas a la teoría. Nadie negará que sea cosa muy práctica el arte de la navegación, y, sin embargo, infaliblemente se pierde el que no lleva puestos los ojos en las estrellas. (Tercera edición) 
leyes y los forjadores de hipótesis, esas generaciones de observadores, analizadores y calculistas, que día tras día, en incesante lucha y noble cumplimiento de la ley del trabajo, han ido adquiriendo nuevos hechos y demostraciones no sospechadas? Las tareas de esos hombres, ¿no merecen un recuerdo en la historia de sus respectivas ciencias? ¿A qué recompensa pueden aspirar en el mundo, si no se les otorga ésta?

El Sr. de la Revilla debe de pensar que los grandes hombres aparecen aislados en el mundo, y que nada les precede ni les sigue nada. Puede afirmarse, por el contrario, y muchas veces se ha demostrado, que cuanto ellos supieron, pensaron, fantasearon y dijeron, estaba en germen en los trabajos de modestos sabios antecedentes, aunque no expuesto en fórmulas claras, ni sistemáticamente enlazado, ni reducido a unidad científica. Siendo esto tan evidente, que por sabido debiera callarse, yo le aseguro al Sr. de la Revilla que gran trabajo había de costarle escribir la historia de ninguna ciencia sin tropezar una y muchas veces con los espańoles, a pesar de la mala voluntad que muestra y el desprecio con que mira a cuanto haya salido de manos de sus compatricios. ¿Qué historia de la botánica sería la que para nada mencionase a Diego Álvarez Chanca, el primer hombre del mundo que dio cuenta de algunos vegetales de América (1494); a Tomé Pérez, que, poniendo en aventura su vida, llegó hasta la China en demanda de nuevas drogas y plantas medicinales; a Andrés Laguna, que apuntó ideas tan notables sobre la fecundación de las plantas fanerógamas, y estableció en Aranjuez (1555) un jardín botánico más antiguo que los de Montpellier y París; a Nicolás Monardes, Francisco Hernández, García de Orta, Juan Fragoso, Cristóbal y José de Acosta, a quienes debió Europa el conocimiento de la Flora de entrambas Indias; al sevillano Simón Tovar y al valenciano Juan Plaza, tan elogiados por Clusio como descubridores de plantas rarísimas; a Lorenzo Pérez, el émulo de Maranta, según frase de Sprengel en su Historia rei herbariae; a Bernardo Cienfuegos, que en pleno siglo XVII escribió una vastísima Historia general de las plantas, que ocupa siete tomos en folio muy voluminosos; a los jesuitas Pedro Chirino y Francisco Ignacio Alsina, que estudiaron la Flora del archipiélago filipino; al boticario catalán Jaime Salvador, apellidado por Tournefort, a quien tanto ayudó en sus exploraciones, el Fénix de España, tronco de una familia de naturalistas que se ha prolongado casi hasta nuestros días; a Juan Minuart, honrado por el aprecio de Linneo, y, finalmente, a toda la brillante legión de botánicos de fines del siglo pasado y principios de éste: a Quer, fundador del Jardín Botánico de Madrid y autor de la primera Flora Española; a Barnades, autor del primer curso de Botánica en nuestro idioma y colector de un famoso herbario; a Serra, explorador de la Flora Balear; al infatigable Gómez Ortega; a Mutis, 
director de la gloriosa expedición científica enviada en 1783 por nuestro Gobierno a explorar el territorio americano; a Molina, Ruiz y Pavón, tan beneméritos de la Flora Chilena y Peruana; a Palau, gran propagandista entre nosotros del sistema de Linneo; a Cavanilles, que modificó el mismo sistema, reduciendo las veinticuatro clases a quince, e hizo singulares observaciones de organografía y fisiología vegetal; a Martí, que con sus Experimentos y observaciones sobre los sexos y fecundación de las plantas, publicados en 1791, destruyó los argumentos de Spallanzani en pro de la fecundación artificial; a Vicente Cervantes, a Mociño y a Sessé, colectores de aquella insigne Flora Mexicana, de cuyos manuscritos con tanto dolor hubo de desprenderse Decandolle; y, últimamente, por no hacer interminable esta enumeración, a Lagasca y a Rojas Clemente, a Zea y a Caldas, para juntar en un mismo elogio nombres españoles, portugueses y americanos? Recorra nuestro crítico el Prodromus florae hispanicae del alemán Wilkomms, y el Genus Plantarum de Endlicher, alemán también, y verá continuos elogios y citas de nuestros autores. Aún en las antiguas bibliotecas botánicas de Linneo, Haller, Seguier, Miltitz y Krüger figuran bastantes nombres españoles. Desengáńese el Sr. de la Revilla: no hay medio humano de omitir a los españoles en esa obra. ¿Tanto exceden los botánicos extranjeros del siglo Xvi a los españoles? Aunque esa historia se escribiese con la deliberada intención de oscurecer nuestros méritos, muchos o pocos, ¿podría el narrador, siquier lo fuese el Sr. de la Revilla, dejar de decir, al llegar a esa época: «Diversos españoles dedicados a estos estudios dieron a conocer infinitas especies de plantas ignoradas en el antiguo mundo»? Y ¿no basta esto para que se recuerde con respeto a nuestros fitógrafos? ¿Cree el Sr. de la Revilla que sólo marinos y aventureros pasaron el nuevo continente, y que sólo les debe agradecimiento la humanidad por la exploración material del territorio?

Fuerte cosa es que los españoles seamos tan despreciadores de lo propio. Los autores de la Biblioteca mineralógica, recientemente dada a la estampa, dicen en su prólogo que tiempos atrás se les acercó un extranjero pidiéndoles noticias sobre el particular, y manifestándoles su extrańeza de que no se hubiese escrito tal obra. Si este extranjero, en vez de dirigirse a aquellos dos ingenieros de minas, doctos y bien intencionados, que se creyeron en la obligación de apurar el asunto, hubiese tropezado con el Sr. de la Revilla, éste no habría dudado en decirle las siguientes o parecidas palabras: «No hay noticia de que esta tierra, atrasada e ignorante, haya producido ningún Haüy, Werner ni Beudant; he oído hablar de ciertos rancios librotes que tratan de metales, de minas y de otras cosas semejantes; pero todo ello es despreciable: aquí no se ha hecho nada digno de memoria en esas materias; la Inquisición 
y el despotismo nos han impedido estudiar las piedras y los metales, porque, ya ve $V$., tales estudios ponían muy en peligro la inviolabilidad de esa creencia inflexible, divorciada de toda dirección cientifica, que nos ha mantenido apartados de todo comercio intelectual, y ha sido causa de todas las plagas de España». Y el extranjero se iría tan persuadido de que los españoles habíamos sido unos salvajes, gracias a la Inquisición, y no dejaría de decirlo en letras de molde apenas llegase a su país. Porque ese terrorífico nombre de Inquisición, coco de niños y espantajo de bobos, es para muchos la solución de todos los problemas, el Deus ex machina que viene como llovido en situaciones apuradas. ¿Por qué no había industria en España? Por la Inquisición. ¿Por qué había malas costumbres, como en todos tiempos y países, excepto en la bienaventurada Arcadia de los bucólicos? Por la Inquisición. ¿Por qué somos holgazanes los españoles? Por la Inquisición. ¿Por qué hay toros en España? Por la Inquisición. ¿Por qué duermen los españoles la siesta? Por la Inquisición. ¿Por qué había malas posadas y malos caminos y malas comidas en España en tiempo de Mad. D’Aulnoy? Por la Inquisición, por el fanatismo, por la teocracia. Involuntariamente recuerda uno cierta sátira latina del siglo XVII. Adán y Eva pecaron aconsejados por los jesuitas. Caín mató a Abel porque Caín y Abel se confesaban con aquellos Padres.

Volviendo a nuestro asunto, yo diría al Sr. de la Revilla si, a su juicio, debe mencionarse en una historia de la ciencia la invención de las cartas esféricas o reducidas y la del nonius. Pues a dos españoles fueron debidas: la primera a Alfonso de Santa Cruz, ${ }^{598}$

598 En su Disertación sobre la historia de la Náutica y de las ciencias matemáticas que han contribuido a su progreso entre los españoles (obra póstuma, Madrid, 1846), nos da D. Martín Fernández de Navarrete larga razón de los inventos de Santa Cruz, y noticia y extracto de sus obras inéditas (páginas 176 a 198). De ellas resulta que Santa Cruz «hizo un instrumento semejante a una aguja azimutal, con el cual, hallando la línea meridiana por dos alturas de sol, conocía la variación de la brújula; presentó al Emperador una carta marina de variaciones magnéticas..., tentativa hecha siglo y medio después por el Dr. Halley, que pasa por el primero que, a costa de muchos y grandes trabajos, publicó en 1700 una carta para representar la variación de la aguja..., examinó las opiniones de Plinio y otros antiguos sobre las propiedades, origen, nombres y clases del imán..., y, no satisfecho de su tentativa de conocer la longitud por las variaciones magnéticas, ni por los demás procedimientos hasta entonces ideados, ni por un círculo graduado que él inventó, conoció la imperfección de las cartas planas y la necesidad de trazar las esféricas, y así llegó a hacerlas, con muchos años de antelación a Eduardo Wright o a Gerardo Mercator, a quienes generalmente se atribuye esta invención». El Maestro Alejo de Venegas, en su Diferencia de libros (1539), nos refiere que Santa Cruz «había hecho cartas de marear por alturas y por derrotas, y varios planisferios en secciones del globo, ya por la equinoccial, ya por los meridianos, y otras para conocer la proporción que tiene lo redondo a lo plano». Y en otra parte declara aún más expresamente que "Alonso de Santa Cruz ha hecho una carta abierta por los meridianos desde la equinoccial a los polos, en la cual, sacando por el 
la segunda a Pedro Núñez. ${ }^{599}$ Preguntaríale asimismo si no son dignos de recuerdo en una historia de las matemáticas (o de la matemática, como dicen los krausistas con insufrible pedantería), aparte del Rey Sabio y de los que le ayudaron en sus grandiosas tareas científicas, aparte de Raimundo Lulio y no pocos de sus discípulos, ${ }^{600}$ aquellos insignes españoles que en el siglo Xvı enseñaron con

compás la distancia de los blancos que hay de meridiano a meridiano, queda la distancia verdadera de cada grado, reduciendo la distancia que queda, a leguas de línea mayor». Claro es que Santa Cruz no llegó a determinar la proporción en que debían aumentarse los grados de latitud en la carta, según que sean mayores las alturas y menor la extensión de los paralelos: proporción que es la del radio al coseno de la latitud, según después se ha fijado; pero no puede negarse, como dice Navarrete, que «él sentó el principio y los elementos de la teórica para la construcción de las cartas esféricas». (Tercera edición)

599 «Las observaciones astronómicas adquirieron, en general, un nuevo grado de exactitud, en tiempo de Copérnico, por el método que Núnez propuso para multiplicar las divisiones de los instrumentos destinados a medir los ángulos. Antes se contentaban los matemáticos con dividir la circunferencia, o más bien, el cuarto de circunferencia, en tantas partes iguales como podían permitirlo la naturaleza y las dimensiones del instrumento; pero esto no era suficiente cuando se trataba de medir ángulos muy pequeńos o fracciones de ángulos.» (Bossut, Histoire Générale des Mathématiques, 1810, pág. 354 del tomo I.)

El instrumento de Núñez fue perfeccionado en 1631 por Vernier, y hoy se designa indistintamente con su nombre o con el del primitivo inventor (Nonius).

Núñez fue, además, el primero que estudió las propiedades de la curva loxodrómica: resolvió dos siglos antes que Bernouilli el problema de la menor duración del crepúsculo, que por sí solo, dice Montucla, bastaría para honrar a un matemático..., se ocupó, además, en la resolución de otros varios problemas útiles y curiosos, v. gr., el de determinar la latitud mediante dos alturas de sol y el azimut intermedio, y el de la retrogradación de la sombra en un cuadrante solar. (Vid. Navarrete, en la disertación ya citada, páginas 170 a 175.)

Pedro Núñez nació en Portugal; pero su famoso Libro de Álgebra en Arithmética y Geometría (1567), que pasa por la más importante de sus obras, está escrito en lengua castellana. Por lo cual ha podido decir con patriótico orgullo su docto biógrafo portugués Antonio Ribeiro dos Sanctos que «Pedro Núñez es el matemático de más nombre que tuvo Portugal y toda España en el siglo XvI». Vid. Memorias de litteratura Portugueza, publicadas pela Academia Realdas Sciencias de Lisboa. Tomo VII (página 250). Sería prolijo copiar los elogios que hacen de él Montucla, Bailly y otros historiadores de las Matemáticas y de la Astronomía. (Tercera edición)

600 «Raimundo Lulio trazó un astrolabio utilísimo para que los navegantes conociesen por él las horas de la noche, e inventó una figura constituida de ángulos rectos, obtusos y agudos, en la que, conociendo el rumbo que sigue una nave y su andar, según el viento que sopla, deduce, por una operación práctica y sencilla, el punto de llegada o el lugar en que se halla en medio de los mares en un momento o tiempo determinado; invento admirable que acaso fue el origen del quartier de reduction, perfeccionado y tratado científicamente por Blondel St.-Aubin y D. Antonio Gastañeta, y todavía de uso continuo en la práctica del pilotaje... Su sistema sobre las mareas es también muy singular e ingenioso puesto que atribuye la causa del flujo y reflujo del Océano a que, siendo la 
general aplauso las ciencias de la cantidad y de la extensión en aulas españolas y extranjeras, como fueron, entre otros que al presente omito, el cardenal Silíceo y su discípulo el doctísimo Hernán Pérez de Oliva, el aragonés Pedro Ciruelo, Álvaro Tomás, Pedro Juan Monzó, Núñez, ${ }^{601}$ los numerosos autores de tratados de la esfera, ${ }^{602}$ los no escasos comentadores de Euclides y Tolomeo, los que, como nuestro paisano Juan de Herrera, fundador de una academia de matemáticas protegida por el sombrío déspota Felipe II, ${ }^{603}$ hicieron estudios

tierra esférica, se forma en aquel mar un dilatado arco de agua que, estribando por una parte en las costas occidentales de Europa y África, y por otra en un continente que él suponia haber en las regiones opuestas de Occidente, y gravitando las aguas sobre la tierra, expuestas alternativamente al calor del sol; a quien atribuye el flujo, y a la humedad de la luna, a quien aplica el reflujo; debía producir en tan vasta superficie estas alteraciones, que apenas se perciben en el Mediterráneo, porque siendo muy corta la extensión de su arco, no tenía toda la esfericidad o curvatura necesaria para sentir o percibir el influjo de aquellos astros. Trató también de los vientos y sus calidades, dividiendo los cuatro principales en otros cuatro, y subdividiéndolos en ocho más, en los cuales completaba los dieciséis que formaban su rosa náutica... Los maravillosos fenómenos del magnetismo llamaron mucho su atención, aunque no sea cierto, como pretendieron el P. Pascual y otros, que él fuese el inventor de la brújula, conocida entre nosotros muchísimo antes.» (Vide Navarrete, en la disertación ya citada, páginas 48, 49 y 69.)

Lulio habla siempre de la aguja náutica como de cosa sabida y corriente, y saca símiles y comparaciones de ella (Sicut acus per naturam vertitur ad septentrionem dum sit tacta a magnete... Sicut acus nautica dirigit marinarios in sua navigatione, etc.).

Entre los lulianos cultivadores de las Matemáticas hay que citar a Juan Llobet, que escribió un libro de Astronomía. Y de Mallorca procedía también aquel Maestre Jácome, hombre muy docto en el arte de navegar, que hacía cartas e instrumentos, a quien el infante de Portugal Don Enrique llevó a enseñar su ciencia a la Academia de Sagres hacia 1415. (Tercera edición)

601 Entre otros muchos nombres, puede y debe añadirse el de Antonio de Nebrija, que fue el primero que hizo observaciones y experiencias para medir la extensión de un grado terrestre, hallando que tenía 62 y media milla, o sea 62,500 pasos geométricos. Para fijar esta medida con mayor exactitud, había trabajado antes en fijar el tamaño o valor del pie español, midiendo el circo y la naumaquia de Mérida... Compuso e imprimió una tabla muy curiosa de la diversidad de los días, y las horas y minutos que tenían de aumento y disminución en varios pueblos de España y de Europa, sus paralelos y latitudes respectivas. (Navarrete, página 106.) (Tercera edición)

602 Entre ellos figuran, además de Martín Cortés, que es sin duda, el más importante y original de todos, Pedro de Espinosa, Andrés García de Céspedes, Fr. Domingo Alegre, Fr. Luis de Miranda, Jerónimo de Chaves, Rodrigo de Santayana, D. Ginés de Rocamora, el Brocense, etc. (Tercera edición)

603 Ceán Bermúdez, en sus adiciones a las Noticias de los Arquitectos, de Llaguno (tomo II, páginas 358 y siguientes), inserta algunos curiosos documentos relativos a esta Academia. Figuran entre ellos tres cédulas reales nombrando a Juan Bautista Labańa y a Pedro Ambrosio de Ondériz "para leer en nuestra corte las Matemáticas», con sueldo de dos cientos escudos, que montan setenta y cinco mil maravedís en un año, el segundo, 
acerca de la figura cúbica y otras materias semejantes, adquiriendo fama de aventajados geómetras, los tratadistas de arte militar que lograron renombre europeo y fueron traducidos a diversas lenguas, ${ }^{604} \mathrm{y}$ los celebrados matemáticos que en el siglo XviII atajaron la decadencia de estos estudios, cuales fueron,

y de cuatrocientos ducados, o ciento cincuenta mil maravedís anuales, el primero. Viene después una carta de Juan de Herrera a Cristóbal de Salazar, secretario de la embajada de Espańa en Venecia, pidiéndole libros para la Academia (10 de enero de 1584). Pide, entre otros, un ejemplar de Copérnico. En otra carta al secretario Antonio de Eraso (7 de septiembre de 1584), indica Herrera que "para que se vayan prosiguiendo las liciones que se han empezado en esta Academia de Matemática, que tanto provecho comienza a hacer, es necesario, porque las liciones son en romance, traducir los libros de esta profesión en nuestro vulgar castellano». De otros documentos consta que el local de la Academia estaba «a la puerta de Balnadú, en la calle del Tesoro, junto a palacio».

Los estatutos de esta Academia no han llegado a nosotros, pero sí los nombres y trabajos de muchos profesores. Entre ellos figuran (además de Labaña, que comenzó a leer en la Academia de Madrid su tratado del Arte de Navegar en 1588, y de Ondériz, que en 1584 había publicado traducidas la Perspectiva y Especularia de Euclides, y en 1592 leía su tratado original del uso de los globos), el doctor Julián Firrufino, que expuso la Geometría de Euclides y el tratado de la Esfera; el capitán Cristóbal de Rojas, célebre por su Teórica y Práctica de Fortificación; el licenciado Juan de Cedillo, que explicó la materia de Senos, y luego el tratado de la carta de marear, geométricamente demostrada; Juan Ángel, comentador de Arquímedes; el alférez Pedro Rodríguez Muñiz; D. Ginés de Rocamora, y otros varios. Concurrían a esta Academia muchos soldados virtuosos, según la peregrina expresión del ingeniero Rojas. La mayor parte de los libros de Matemáticas puras y aplicadas que entre nosotros se imprimieron a fines del siglo Xvi y principios del siguiente, parecen haber salido de esta Academia, la cual prolongó su existencia, con varias alternativas, hasta el reinado de Felipe IV.

En cuanto a Herrera, además de su Discurso de la figura cúbica, que más pertenece a la metafísica luliana que a las matemáticas, acreditan su pericia en éstas los nuevos instrumentos que inventó para la navegación, y en especial el de las longitudes. (Tercera edición)

604 Baste citar a D. Diego de Álava y Viamont, verdadero creador de la Nueva Ciencia de Artillería, en que no tuvo más predecesor que Nicolás Tartaglia, reduciendo, como él dice, a demostración matemática el uso de la artillería; a Luis Collado, autor puramente práctico, pero que «descubriendo y enmendando (son palabras de D. Vicente de los Ríos) las suposiciones, errores o descuidos de los célebres teóricos Tartaglia, Busceli y Cataneo..., por la fuerza de sus observaciones conoció que los alcances sobre el semirecto eran menores que los equidistantes baxo de él, acercándose así, aunque de un modo empírico, al descubrimiento de las verdaderas leyes del movimiento de proyección, más que el mismo Galileo y Torricelli»; a Cristóbal Lechuga, autor de una importante reforma en el calibre de las piezas; a Diego Ufano, Julio César Firrufino y otros varios, de quienes da un extenso juicio D. Vicente de los Ríos en su Discurso sobre los ilustres autores e inventores de Artillería (Memorias de la Academia de la Historia, tomo IV) (Tercera edición) 
aparte de otros menos conocidos, los PP. Tosca, Cerdá, Andrés y Eximeno, y el ilustre autor del Examen Marítimo. ${ }^{605}$

Yo soy enteramente extraño a tales disciplinas, y aunque conozco de visu los libros de muchos españoles cultivadores de las ciencias exactas, nunca he caído en la tentación de leerlos (otro tanto digo de los extranjeros, y juzgo que lo propio le habrá sucedido al Sr. de la Revilla); pero sí puedo afirmar que las obras de los autores citados y de otros que fuera prolijo referir, lograron en su tiempo aceptación grande, y son alentadas con aprecio por críticos e historiadores, si no como prodigios científicos precisamente, como obras apreciables, doctas y juiciosas, no inferiores al estado de los conocimientos en su época, y que tales cuales son bastan para demostrar que nuestra relativa pobreza en este punto no llega a esterilidad absoluta. Por lo demás, a algún docto matemático incumbe la resolución de este punto, no al señor de la Revilla ni a mí, meros profanos que hablamos al aire en tales materias, gracias a la manía que hoy reina de generalizar las cuestiones y de confundirlo todo. Tractent fabrilia fabri.

Pero antes de dejar este asunto y entrar en materias que nos tocan más de cerca, permítame el Sr. de la Revilla aconsejarle que, si desea saber lo

605 Pueden añadirse otros muchos, v. gr.: D. Pedro Manuel Cedillo, autor de una Trigonometría aplicada a la navegación (1718).

Del nombre de Jorge Juan es inseparable el de D. Antonio Ulloa, que estuvo asociado con él en la expedición científica para determinar la verdadera figura de la tierra. A uno y otro corresponde la gloria de haber propagado en Espańa los principios de Newton, al mismo tiempo que Voltaire los difundía en Francia. Pero la obra que ha inmortalizado el nombre de Jorge Juan es su tratado de mecánica aplicada a la construcción naval, obra clásica en su género y respetada como tal en toda Europa. Aunque es libro de Matemáticas aplicadas, ofrece también mucho interés para las Matemáticas puras.

Del Cuerpo de Marina salieron casi todos los matemáticos españoles del siglo XviII, como lo prueban los nombres de Mendoza Ríos, autor de un Tratado de navegación (1787), y de unas Tablas todavía más famosas (1800), inventor de nuevos métodos para calcular la longitud por las distancias lunares, y para hallar la latitud por medio de dos alturas de sol, del intervalo del tiempo pasado entre las dos observaciones y de la latitud estimada, y autor también de elegantes soluciones de los principales problemas de astronomía náutica; Alcalá Galiano (D. Dionisio), célebre, no sólo por su muerte gloriosa, sino por el profundo saber de que dió pruebas en su Memoria sobre las observaciones de latitud y longitud en el mar (1796); Ciscar (D. Gabriel), que, además de su conocidísimo Curso de estudios elementales de Marina, y de la parte que tomó en la creación del sistema métrico, inventó varios métodos gráficos para corregir las distancias lunares con la aproximación necesaria para determinar las longitudes en la mar (1803); D. José Luyando, autor de unas Tablas lineales para resolver los problemas del pilotaje astronómico, y Tofiño, Mazarredo y otros y otros, que eran la más bella corona científica de España en los años próximos al heroico desastre de Trafalgar. (Tercera edición) 
mucho que la Medicina debió en todos tiempos a los españoles, hojee las obras conocidísimas de los señores Morejón y Chinchilla, en las cuales, aparte de mucho fárrago, hallará noticias copiosas que de plano le convenzan de que es imposible escribir la historia de dicha ciencia sin hacer mérito, no de uno, sino de muchos nombres españoles. Tengo, no obstante, por cierto, dada su erudición, que sabe todas estas cosas, y sin duda por eso no incluye a nuestros médicos nominatim en el general anatema que contra la ciencia española fulmina.

Y aún nos falta la cola por desollar, y la cola es lo siguiente: «Sutilícese el ingenio para descubrir portentos y maravillas en las ignoradas obras de nuestros filósofos; búsquense en ellos precursores de Bacon y Descartes, encómiense los merecimientos de Vives y Suárez, Pereira y Morcillo, Huarte y Oliva Sabuco, y, por más que se haga, forzoso será reconocer que, salvo los que siguieron las corrientes escolásticas, ninguno logró fundar escuela ni alcanzar legítima influencia, siendo por tanto un mito esa decantada filosofía española, con cuya resurrección sueñan hoy eruditos como Laverde Ruiz y Menéndez y Pelayo». Gracias por la lisonja, y vamos al grano. Cualquiera, al leer el párrafo transcrito y fijarse en lo magistral y decisivo de sus afirmaciones, diría que el señor de la Revilla se había pasado la vida estudiando nuestra filosofía y desempolvando los libros de nuestros filósofos, convertido en hurón literario, dividiendo sus horas entre los estantes de las bibliotecas públicas, los de las particulares y las madrigueras de los libreros, para sacar por fruto de todas sus investigaciones, lecturas y molestias, el convencimiento tristísimo de que la decantada filosofía española era cosa absolutamente despreciable, como engendrada, ya se ve, en país de Inquisición y fanatismo.

Yo también juzgué piadosamente que el Sr. de la Revilla había hecho esta preliminar e indispensable indagación, aunque algo me daba que sospechar lo rotundo y destemplado de sus negaciones, siendo propio de los que han mascado un poco el saludable polvo de los antiguos volúmenes, no decidir de ligero y en redondo las cuestiones, hacer en todas no pocas salvedades, desconfiar mucho del propio juicio, y no aventurar palabras, todo lo cual se deja, no para críticos como el Sr. de la Revilla, sino para esos filósofos que discuten en el Ateneo y sentencian en las Revistas sobre todo lo discutible y sentenciable. Pero volviendo a leer con alguna detención las precipitadas líneas, convencíme de que el Sr. de la Revilla no debe de haber penetrado mucho en el estudio de nuestros filósofos, puesto que dice que sus obras son ignoradas, y que la filosofía española es un mito, palabra que no se aplica a lo que es malo, sino a lo que no existe, a lo que es fábula y mentira, si no miente la etimología griega, o no he perdido yo los papeles desde que 
regresé a la Montaña. Y ahora ayúdeme V. a discurrir, amigo mío: el Sr. de la Revilla dice que la filosofía española es un mito y que está ignorada; ergo el Sr. de la Revilla es los que la ignoran y dudan de su existencia. De lo que está ignorado y se tiene por mito no hay derecho a afirmar que sea bueno o malo, que valga o que no valga la cuestión es de existencia o no existencia. Sed sic est que existe la filosofía española, como está superabundantemente demostrado; ergo póngase a estudiarla el Sr. de la Revilla, y cuéntenos después sus impresiones. Tome el Sr. de la Revilla las obras de Lulio, Vives, Fox (a quien llama Morcillo a secas, semejante a aquel buen hombre que llamaba a Cervantes D. Miguel de Saavedra), Servet. Suárez, Soto, Gómez Pereira y tutti quanti, léalos con la misma atención y amore con que leería a Darwin o a Hæckel, y entonces podrá decirnos con algún fundamento si tales escritores son despreciables o dignos de veneración y loa. Entretanto, ni el Sr. de la Revilla, a pesar de su agudeza de ingenio y poca aprensión, ni en el sabio más eminente de los nacidos, aunque se llame Platón, o Aristóteles, o Leibnitz, reconozco ni reconoceré nunca el derecho de sentenciar sobre doctrinas que no conoce y sobre libros que no ha leído. ¿No se reiría de mí el Sr. de la Revilla, si magistralmente comenzase yo a hablar del darwinismo, del positivismo y de otras doctrinas, hoy a la moda, que poco más que de nombre y por referencias conozco? Pues en el mismo caso se encuentra él con respecto a las obras y sistemas filosóficos peninsulares. El talento más claro no libra a nadie de dar traspiés en lo que ignora. Por eso, sin duda, ha tropezado tantas veces el Sr. de la Revilla en las breves líneas que copié antes.

Sólo a quien desconozca por entero la filosofía española se le puede ocurrir el citar entre nuestros grandes pensadores a Huarte y a Dońa Oliva Sabuco de Nantes, colocándolos en la misma línea que a Luis Vives, Suárez y Fox Morcillo. Con ser el Examen de ingenios y la Nueva Filosofía de la naturaleza del hombre, dos libros discretos, amenos y originalísimos, por ningún concepto pertenecen a la alta filosofía, ni pueden, en manera alguna, ser puestos al mismo nivel que los tres De prima philosophia de Vives y el De Platonis et Aristotelis consensione de Fox Morcillo, la Metafisica y el tratado De Ánima de Suárez, ni aún el Quod nibil scitur de Francisco Sánchez, el Christianismi restitutio de Servet, o la Antoniana Margarita de Gómez Pereira (no le llame Pereira a secas el Sr. de la Revilla, porque corre riesgo de confundirle con otro filósofo portugués del siglo pasado, autor de una Theodicea escrita en castellano). Apreciables los libros de Huarte y Doña Oliva como manifestaciones del empirismo sensualista en nuestra historia filosófica, curioso el primero por sus vislumbres de frenología, y el segundo 
por su delicado análisis de las pasiones, son, a pesar de todo, de más interés en la relación fisiológica que en la psicológica, según entiendo.

El Sr. de la Revilla se engańa de todo punto si imagina que somos V. y yo los únicos defensores de la filosofía ibérica. Esta, por el contrario, cuenta, así en la Península como en el extranjero, numerosos aficionados. Sonlo en España el Sr. Valera, a pesar de ciertas proposiciones dubitativas que alguna vez aventura, pues le debemos, aparte de otros artículos, un notable estudio, inserto en La América, acerca de Quevedo considerado principalmente como filósofo; el Sr. Campoamor, que en su discurso de entrada en la Academia Española llamó a Gómez Pereira el fundador del psicologismo moderno, y al canciller Bacon, el más prosaico de los discípulos de Vives; el Sr. Canalejas, autor de una extensa Memoria sobre Las doctrinas del iluminado Dr. Raimundo Lulio, de las cuales casi se declara partidario, manifestando deseos de su restauración, y llegando a afirmar que el solitario del monte Randa fue más sintético que Santo Tomás; D. Adolfo de Castro, que ha llegado a formar un tomo de filósofos, moralistas los más, para la Biblioteca de Rivadeneyra; D. Luis Vidart, autor de un tomo de Indicaciones bibliográficas sobre nuestros filósofos; los dos krausistas D. Facundo de los Ríos Portilla y D. Federico de Castro, expositor el primero de las doctrinas vivistas, biógrafo el segundo de Pérez y López; el hegeliano de la extrema izquierda Sr. Pi y Margall, que en su discurso preliminar a las obras del P. Mariana encomia altamente el valor filosófico del libro De morte et immortalitate; el escolástico Fray Zeferino González, cuya Philosophia Elementaria, aparte de numerosas citas, incluye en la parte histórica noticias de varios filósofos peninsulares; ${ }^{606}$ el Sr. Azcárate (D. Patricio), que muy atinadamente declara nuestro, en el concepto filosófico, el siglo XVI, al analizar los tratados panteístas de Servet en la Exposición de los principales sistemas filosóficos modernos; el neo-cartesiano Sr. Martin Mateos, que en 1857 apoyaba en la Revista de Instrucción pública los proyectos de V., amigo mío, y posteriormente ha dado a la estampa estudios acerca de nuestros místicos; el empírico Sr. Weyler y Lavińa, expositor y crítico de las doctrinas de Raimundo Lulio; el portugués López Praza, historiador de la filosofía de su país; el Dr. Guardia, que, aunque español de nacimiento, ha escrito en lengua francesa un notable libro sobre Huarte, y el erudito mallorquín Roselló, bibliógrafo infatigable del lulismo, sin otros que al presente no recuerdo.

606 Mucho más extensas y copiosas las ha dado después en las dos ediciones de su Historia de la Filosofía, escrita en castellano. Durante los diez años corridos desde la primera publicación de esta carta, han fallecido el Sr. Azcárate (D. Patricio), el médico Weyler, el Sr. Canalejas y otros a quienes en el texto se da como vivos. (Tercera edición) 
Fuéronlo entre los muertos el Dr. D. Ildefonso Martínez, editor e ilustrador de Huarte y Doña Oliva; el Sr. Sánchez Ruano, panegirista de la segunda; el suarista P. Cuevas, digno de muy honroso recuerdo por haber trazado ya en 1854 un compendio de nuestra historia filosófica, destinada a la enseñanza de los Seminarios; el bibliotecario ovetense Suárez Bárcena, erudito biógrafo de los Abarbaneles, Sabunde y Servet; el Sr. González Múzquiz, vindicador de Vives en 1839; el ilustre Martí de Eixalá, importador de la filosofía escocesa a Cataluña, ${ }^{607}$ y su sabio y nunca bastante llorado discípulo del Dr. Llorens, eminente profesor de Metafísica en la Universidad barcelonesa, de quien todos los que alguna vez tuvieron la dicha de oírle, recordarán el respeto con que citaba siempre a Vives, el largo estudio que de sus obras había hecho, dejando traducida e ilustrada la De anima et vita, y las relaciones que hallaba entre las doctrinas del insigne pensador valenciano y la del sense common de Guillermo Hamilton, por él con tanta gloria defendida. Y no es cosa de ayer la creencia de una tradición científica en España, pues quien haya leído las notas sabias y asaz olvidadas de los Discursos filosóficos de Forner, una de las inteligencias más claras y poderosas que en el siglo XviII produjo España, y la Oración apologética, el Preservativo contra el Ateísmo y otras obras del mismo, no podrá menos de contarle con igual o mayor razón que a V. y a mí en el número de los soñadores. En igual categoría deberá poner a Cerdá y Rico, editor de diversas obras de nuestros filósofos, y que por desdicha no llegó a reimprimir, como deseaba, las de Fox Morcillo; a los Padres Andrés y Lampillas, y al infatigable y eruditísimo Mayáns, a quien tanto deben estos y otros estudios de parecida índole. Y, en general, puede afirmarse que hasta fines del siglo pasado, nadie dudó de que España hubiese tenido en todas épocas filosofía y filósofos eminentes.

Pues si al extranjero pasamos, no quiero suponer que el señor de la Revilla desconozca los libros y artículos de Adolfo Franck, Munk, Ernesto Renan, Rousselot, Saisset, relativos a Maimónides, Avicebron, Averroes, los místicos, Miguel Servet y otros filósofos peninsulares, hebreos, árabes o cristianos, ni pienso que ignore la existencia de una Historia alemana de la Psicología en España, y no dudo que habrá leído en la antigua Revista de Edimburgo un estudio de James Mackintosh, a propósito de ciertos ensayos de historia de la filosofía publicados por Dugald-Stewart, y en él encarecidos

607 Martí de Eixalá escribió en 1842 (doce años antes que el P. Cuevas, como se ve) una reseńa breve, pero muy substanciosa, De la Filosofía en España, para que sirviera de apéndice a un Manual de Historia de la Filosofía, que tradujo del francés. Son notables sus consideraciones sobre Luis Vives, en quien encuentra singulares coincidencias con los principios de la escuela escocesa. (Tercera edición) 
elogios de Suárez, Domingo de Soto, Francisco de Vitoria y otros españoles cuyos nombres no le sonaban, por lo visto, al crítico escocés tan mal como al Sr. de la Revilla. ${ }^{608}$ ¿Qué más? Hasta soñaron con la filosofía española

608 En su primer artículo sobre la Introducción de Dugald-Stewart a la Encyclopedia Británica (septiembre de 1816, volumen XXVII de la Revista de Edimburgo), dice Mackintosh que los orígenes del derecho natural, del derecho público y del derecho internacional deben buscarse en la filosofía escolástica, $y$, sobre todo, en los españoles del siglo $X V I$, que estaban animados de un espíritu más independiente que los antiguos escolásticos, como lo prueba el libro De Justitia et Jure de Domingo de Soto, donde pueden notarse los progresos que el Renacimiento había traído a las escuelas españolas. Añade Mackintosh que Domingo de Soto fue el primer escritor que condenó la trata de negros, honrando así desde su cuna a la nueva ciencia del derecho público, cuyos principios le sirvieron para reprobar aquella abominación. Y continúa diciendo el célebre publicista que España, por haber sido en el siglo xvi la primera potencia militar y política de Europa, sosteniendo grandes ejércitos y guerras continuas, sintió también, antes que otro país alguno, la necesidad de sentar sobre bases sólidas el derecho de la guerra, como es de ver en el libro de Baltasar de Ayala.

En su famosa historia de la Ética (Progress of ethical philosophy), insiste Mackintosh en las mismas proposiciones, llamando a la España del siglo XVI «la más poderosa y magnífica de las naciones europeas», y añadiendo que nuestros teólogos cultivaron la ciencia con una penetración no menos grande que la de los doctores de la Edad Media, pero añadiéndola una claridad y una elegancia desconocidas antes del Renacimiento». Menciona los tratados de Vitoria, de Juan López, de Francisco Arias de Sepúlveda, etc., sobre cuestiones de derecho internacional. Elogia mucho a Francisco de Vitoria, «el primero que expuso las doctrinas de la escuela en la lengua del siglo de León X», y a él y a Soto y a Fr. Bartolomé de las Casas los declara dignos de memoria eterna, por haber condenado la esclavitud de los indígenas de América y África; a Soto, en especial, por haber sentado el gran principio de que «el derecho de gentes es el mismo para todos los humanos, sin distinción de cristianos e infieles» (Neque discrepantia, ut reor, est inter christianos et infideles, quoniam jus gentium cunctis gentibus aequale est). "Apenas acierta un hombre de nuestros tiempos, ańade Mackintosh, a tributar todos los elogios que ellos merecen a esos excelentes religiosos, que defendieron los derechos de hombres que jamás habían visto, contra las preocupaciones de su orden, el supuesto interés de la Religión, la ambición de su Gobierno, la avaricia y el orgullo de sus compatriotas y las opiniones dominantes en su tiempo». A las obras de Suárez las califica de "exposición la más accesible y más clara de la filosofía teológica bajo su última forma...». "Grocio, que aun siendo, como era, el más justo y cándido de los hombres, no hubiera alabado a un jesuita español más de lo que merecía, llamó a Suárez el más penetrante de los filósofos y teólogos. Suárez comprendió el primero que el derecho internacional no se compone únicamente de principios abstractos de justicia aplicables a las relaciones entre los Estados, sino también de costumbres y prácticas, largo tiempo observadas en sus relaciones con la raza europea. En este punto sus opiniones son mucho más claras que las de su contemporáneo Alberico Gentili, y hay que confesar que el mismo Grocio, posterior a él, da una idea menos clara de la misma doctrina.»

Como si todo esto no bastara, Mackintosh, en una nota (marcada con la letra $L$ ), después de recordar otros timbres de la ciencia espańola, verbigracia, la Minerva de Francisco 
Montaigne, traductor y apologista de Raimundo Sabunde; Lessing, que vertió al alemán la obra de Huarte; Hamilton, que llama a Vives filósofo tan profundo como olvidado, y cita y aplaude doctrinas suyas sobre la Lógica; Leibnitz, en cuya opinión los libros de nuestros escolásticos contenían mucho oro, ${ }^{609}$ y los doctores de la Universidad de Jena que, según cuenta Puffendorf, no obstante ser luteranos, tenían a Suárez, Molina, Vázquez, Valencia y Sánchez por escritores dignisimos de eterno renombre (con perdón sea dicho del Sr. de la Revilla y de los que como él piensan y juzgan). ${ }^{610}$

Sánchez, padre de la Gramática filosófica, exclama con acento de íntima convicción: «iVéase con qué ardor cultivaba Espańa la filosofía en el siglo de Cervantes!»

Siguiendo, en parte, las huellas de Mackintosh, Wheaton, en su Historia de los progresos del derecho de Gentes en Europa y en América (1846), extracta con mucho cuidado las Relectiones quinta y sexta de Vitoria, y el De Jure Belli de Baltasar de Ayala, no sin advertir que «las Universidades españolas produjeron en el siglo Xvi una multitud de escritores notables, que cultivaron aquella parte de la ciencia de la moral que enseña las reglas de la justicia.»

Hallam, todavía más explícito en su Introduction to the Literature of Europe, defiende a Baltasar de Ayala de los reparos de Grocio: «Grocio se engaña cuando dice que Ayala no ha tratado de las causas de la justicia o de la injusticia de la guerra. Su segundo capítulo trata de este asunto en treinta y cuatro páginas, y aunque no haya profundizado enteramente la materia ni restringido tanto como Grocio los derechos de la guerra, merece, no obstante, elogio por haber sentado los principios generales, sin sutilezas ni subterfugios.» (Tercera edición)

609 El pasaje de Leibnitz sobre la escolástica, tantas veces citado, y pocas con exactitud, es el siguiente:

«Hay que hacer esta justicia a los escolásticos más profundos, como Suárez: hay que confesar que se encuentran en ellos discusiones muy importantes sobre lo continuo, sobre lo infinito, sobre la contingencia, la realidad de las abstracciones, el principio de individuación, el origen y la privación de las formas, el concurso de Dios con las criaturas, y aun en Moral sobre la naturaleza de la voluntad y los principios de la justicia: en suma, hay que confesar que se encuentra oro entre estas escorias; pero sólo las personas ilustradas pueden extraerle. Y cargar a la juventud con un fárrago de cosas inútiles sólo porque se encuentra algo bueno de trecho en trecho, es malbaratar la más estimable de todas las cosas, quiero decir, el tiempo.» (Nuevos ensayos sobre el entendimiento humano, lib. IV, capítulo VII.)

Ya ven los escolásticos que Leibnitz no los admiraba tanto como ellos se figuran y propalan. (Tercera edición)

610 En Italia están tenidos hoy mismo en altísimo aprecio nuestros pensadores del siglo XVI, sobre todo los escolásticos. Así lo manifiestan recientes ediciones de tratados de Suárez, de Molina y de Toledo, hechas en Nápoles, Roma y Bolonia, y así tuve el gusto de ó́rlo de labios de los bibliotecarios de la Vaticana, de la Laurenciana y de la Ambrosiana, que sólo elogios tenían para la ciencia española del buen tiempo y hasta para la del siglo pasado. Por decoro nacional no quise decirles que había españoles que menospreciaban todo esto... No lo hubieran creído. En París ha habido editor con alientos bastantes para reimprimir en 28 gruesos volúmenes las obras de Suárez. Casi al mismo tiempo, y como 
¿Cómo olvidar tampoco que el semi-positivista Lange, en su reciente y docta Historia del Materialismo, tributa magníficos elogios a Luis Vives por su tratado De anima et vita, llamándole el mayor reformador de la filosofía de su época, el precursor de Bacon y Descartes, una de las inteligencias más luminosas del siglo XvI, autor de un tratado de las pasiones, riquísimo en observaciones delicadas y en rasgos ingeniosos; hombre, en suma, que tuvo la intuición de los verdaderos principios del estudio de la naturaleza, cuando escribía: «Los verdaderos discípulos de Aristóteles deben dejar sus libros a un lado y estudiar la naturaleza en sí misma, como hacían los antiguos; para conocer la naturaleza, no se debe seguir una tradición ciega, ni fiarse de hipótesis sutiles, sino estudiarla directamente por vía de experimentación.»

Todos estos autores y algunos más, célebres u oscuros, españoles y extranjeros, buenos, medianos y malos, representantes de todas las tendencias filosóficas o simples eruditos, antiguos y modernos, vivos y muertos, han soñado o sueñan, y continuarán soñando los que aún viven, con la filosofía y con los filósofos españoles. ${ }^{611}$

Hormiguean las contradicciones y los errores en el párrafo del Sr. de la Revilla. Ante todo, conviene advertir que, a pesar de ser la filosofía española un mito, nos concede la existencia de grandes escolásticos y de místicos incomparables, esto es, las dos terceras partes, y me quedo corto, de nuestra filosofía.

Excluye a los primeros en términos expresos, «salvo los que siguieron las corrientes escolásticas», aunque ésta sola concesión bastaría para invalidar su doctrina. Pero fuera de cerrar los ojos a la luz, no veo otro medio de negar el mérito y la influencia de Suárez y del suarismo, ni la importancia grande de muchos tomistas y escotistas espańoles.

Concede, pues, el Sr. de la Revilla que tuvo un gran florecimiento la ciencia escolástica en España. Y como el escolasticismo abraza sin duda algunos de los sistemas más completos, luminosos y prepotentes que han ejercitado al entendimiento humano (aunque no el sistema primero ni único de la filosofía cristiana, digan lo que quieran los neo-tomistas), síguese, por lógica consecuencia, que España, madre de los más ilustres escolásticos después de Santo Tomás, ha tenido una grey de verdaderos y profundos filósofos dentro

en competencia, aunque con mucho mayor esmero, comenzó a publicarse otra edición en Bruselas, y el obispo de Brujas, Mons. Malou, dio a luz un tomo en folio de obras inéditas del insigne teólogo granadino. Quid tibi videtur? (Segunda edición)

611 Otros muchísimos nombres pueden citarse, especialmente extranjeros; pero los omito, porque de casi todos se dará razón al tratar de las Monografías críticas acerca de nuestra ciencia. (Tercera edición) 
de las vías católicas, y que aunque esto sólo hubiese producido, siempre sería ligereza indisculpable, por no darle otro nombre, llamar mito a la filosofía española, y que así como fuera absurdo suprimir el escolasticismo en la historia de la filosofía, absurdo sería, y mayor, omitir en el capítulo a tal materia dedicado los nombres y obras de los doctores escolásticos peninsulares, por más que el Sr. de la Revilla afirme, con inquebrantable patriotismo, que en la historia de la filosofia puede suprimirse sin gran menoscabo la parte relativa a España.

Pero aun es más peregrino lo que dice de los místicos. Para el Sr. de la Revilla, el misticismo no es filosofía, puesto que pone en parangón y contraste la riqueza del uno con la pobreza de la otra entre nosotros. Y, sin embargo, todos los católicos y muchos racionalistas están de acuerdo en considerar el misticismo, no sólo como filosofía, sino como la más alta y sublime de las filosofías existentes. Si el Sr. de la Revilla me dice que el misticismo es más que filosofía, que el misticismo empieza donde la filosofía concluye, y que sólo él resuelve hasta cierto punto las perpetuas dudas de la primera, porque la intuición del alma iluminada y abrasada por el amor divino es siempre más poderosa que el mezquino análisis psicológico y las eternas logomaquias de los sofistas, estaré de acuerdo con él; pero entonces la cuestión será de palabras, y a mí me será lícito decir: «España, además de sus escolásticos y de sus pensadores independientes, precursores de Bacon y Descartes, tuvo una casta de hombres, hoy perdida, que no fueron filósofos, sino mucho más que filósofos, pues por intuición soberana y nunca igualada supieron y entendieron lo que nunca han sabido ni entendido los filósofos; dijeron clara y hermosamente lo que los filósofos han envuelto en laberínticos juegos de palabras, y vieron a toda luz lo que los filósofos nunca han visto sino a medias y envuelto en mil nebulosidades.»

Tenemos, pues, que el Sr de la Revilla admite la existencia y el mérito de nuestros místicos y escolásticos. Del resto de nuestros filósofos dice que son un mito, porque, según él piensa, no formaron escuela ni ejercieron legitima influencia. ¡Peregrina regla para juzgar el mérito de los filósofos! Figúrese el Sr. de la Revilla que hasta ahora hubiesen estado inéditas y desconocidas o no estudiadas por nadie, aunque impresas, las obras de Platón, y que hoy las publicase o reimprimiese, ilustrase y comentase algún erudito, apreciándolas en su altísimo valor. Si el Sr. de la Revilla es consecuente con su doctrina, tendría que decir Platón es un mito; no ha formado escuela ni ejercido influencia en el mundo. O bien: Imagine el Sr. de la Revilla que él mismo da mañana a la estampa un libro portentoso de alta filosofía, que, por uno de aquellos azares bibliográficos tan comunes, habent sua fata libelli, nadie 
compra, ni lee, ni estudia, hasta que al cabo de los años mil sale un doctor alemán proclamando su excelencia: ¿Querrá que, aplicándole entonces sus principios, diga alguno: No leáis el libro del Sr. de la Revilla; Revilla es un mito, no ha formado escuela ni ejercido influencia en el mundo? Es método muy aventurado a errores estimar el mérito de los libros por el ruido que han hecho o por el número de los secuaces de las doctrinas de sus autores. No se ha dicho en el mundo absurdo ni desatino que no haya tenido secuaces; ahí está, sin ir más lejos, el mormonismo, para comprobarlo. Para el Sr. de la Revilla, la religión de los mormones será un sistema prodigioso, porque a la voz de Smith se congregó muy pronto numeroso enjambre de aventureros y de ilusos. No hay idea que no tenga partidarios, en religión, en filosofía, en sociología, como hoy se dice bárbaramente; y cuanto más grosera sea la doctrina, más elementos de anarquía envuelva y más halague los apetitos humanos, tanto más seguro será su efecto.

Niego, además, que los españoles que filosofaron fuera del escolasticismo y de la mística no formasen escuela ni ejerciesen influencia. Luis Vives es el patriarca de una serie de pensadores críticos: sus discípulos se llaman Dolese, Gélida, Melchor Cano, Fox Morcillo, Gómez Pereira (con ciertas vislumbres de empirismo en ocasiones), Isaac Cardoso, Pedro de Valencia y Caramuel, y en el siglo XviII el deán Martí, Tosca, Feijoo, Mayáns, Viegas, Piquer y su ilustre sobrino Forner, que hace profesión de vivismo clara y descubiertamente en repetidos lugares de sus obras impresas y manuscritas. Esta doctrina crítica, cuya restauración no sería un sueño ni mucho menos, constituye, con el lulismo y el suarismo, la gran triada de los sistemas peninsulares ortodoxos. En cuanto a los peripatéticos clásicos, los ramistas, los partidarios del empirismo sensualista y los moralistas, ya estoicos, ya epicúreos, nadie negará que constituyen grupos perfectamente definidos, si bien casi todos ellos pueden considerarse como derivaciones más o menos próximas de la corriente vivista. En cuanto a si ejercieron o no influencia en el mundo, baste repetir lo que hasta ahora no se ha convencido de falsedad, que Vives y el vivismo son los precedentes históricos de Bacon y el baconismo y de Descartes y el cartesianismo; que el libro De augmentis scientiarum del famoso canciller inglés en nada supera, si es que iguala, a los De disciplinis; que Fox Morcillo intentó, al decir del sabio francés Boivin, la más docta conciliación entre Platón y Aristóteles, y que desde su época hasta la nuestra se viene trabajando en el mismo sentido, sin haber mejorado gran cosa lo que él dejó escrito.

A algunos ha de extrañar la tenacidad sin ejemplo con que los sectarios de ciertas escuelas niegan el mérito de nuestros filósofos, sin haberlos leído ni querer leerlos. Muy sencilla me parece la explicación de esta terquedad 
y de esta ignorancia (llamemos las cosas por su nombre) en que voluntariamente se mantienen. Si llegasen a confesar que España había dado grandes filósofos en esa época de Inquisición y fanatismo, ¿qué peso tendrían sus declamaciones contra la intolerancia? De suerte que, por mantener una vulgaridad y un absurdo, tolerables sólo en gacetillas de periódico, consienten en cerrar los ojos, tapiar los oídos y mantenerse apartados de toda investigación erudita. El Sr. de la Revilla desprecia la erudición, sea en hora buena; dice que expone a grandes extravíos; a mayores expone la falta de ella. Yo estoy firmemente persuadido de que la erudición conduce siempre a algún resultado provechoso; el charlatanismo y las discusiones de omni re scibili, a ninguno. De sofistas y oradores de Ateneo estamos hartos en España. La generación presente se formó en los cafés, en los clubs y en las cátedras de los krausistas; la generación siguiente, si algo ha de valer, debe formarse en las bibliotecas: faltan estudios sólidos y macizos.

Nuestros flamantes filósofos desprecian a los antiguos sabios españoles, porque fueron católicos y escribieron bajo un régimen de unidad religiosa y monárquica. Muchas veces me he sentido tentado a tomar alguna de sus obras, traducirla en la jerga bárbara de la Analítica y ofrecérsela a esos señores, gente poco escrupulosa en materias bibliográficas, como traducción de un libro alemán desconocido. De seguro que les hacía buen efecto y que la ponían en los cuernos de la luna.

La prueba de que sólo por ser católica desprecian nuestra ciencia, nos la da el Sr. de la Revilla cuando, al refutar a su modo al Sr. Valera, dice pocas líneas más adelante: «En esa Inglaterra... nacieron las más avanzadas sectas del protestantismo y propagaron Bacon, Hobbes y Locke los más radicales principios de la filosofía; en esa Francia... minó Ramus los fundamentos de la escolástica, ${ }^{612}$ abrió Gassendi el camino al materialismo, zahirió Rabelais los más altos ideales, proclamaron escépticas doctrinas Montaigne y Charron y fundó Descartes el racionalismo moderno; y esa Alemania... fue la cuna de la filosofía novísima que ha conmovido los cimientos de toda creencia». Bien por el Sr. de la Revilla. ¿Conque para él significan más en la historia de la filosofía el pedante Ramus, cuyas innovaciones fueron cínicamente de palabras, y el bufonesco Rabelais, que ni fue filósofo ni hizo cosa de provecho jamás, y el sensualista Locke, y Hobbes apologista de la fuerza bruta y de toda tiranía; conque estos escritores, digo, representan más que Lulio, Fox, Vives, Suárez y toda nuestra filosofía junta? ¿Con que hasta el Pantagruel, ${ }^{613}$

612 Después que Luis Vives, y mucho peor que él. (Tercera edición)

613 Claro es que hoy pienso de una manera algo distinta acerca del valor literario de Rabelais, el cual, vencida la primera dificultad de leerle, y pasando por alto (no es poco 
libro estrafalario si los hay, excede a todas las concepciones de nuestros filósofos? ¡Imposible parece que la pasión ciegue tanto a hombres de claro entendimiento! Si Montaigne y Charron fueron escépticos, escéptico fue Francisco Sánchez, y más radical que ninguno de ellos. Si Francia engendró el materialismo, guárdese esa triste gloria, que aquí no la necesitamos. Si el Sr. de la Revilla juzga que la filosofía alemana ha conmovido los fundamentos de las creencias, yo creo y creeré siempre que éstas permanecen firmes y enteras; y después de todo, España dio a Miguel Servet, que ni en audacia ni en talento cede a ninguno de los pretensos demoledores de allende el Rhin.

Del resto de la lucubración del Sr. de la Revilla nada diré, porque se alarga ya en demasía esta carta, y los restantes párrafos de su artículo no nos interesan de un modo directo. Con decir que constituyen una sinfonía patriótica sobre motivos inquisitoriales, quedarán calificados como merecen. No falta ninguna de las campanudas expresiones de rúbrica, «intolerancia sistemáticamente organizada», «bárbara fiereza», "crueldad fría y sistemática», "muerte del pensamiento», "poder teocrático implacable y tenaz», «uniformidad de la muerte», «calma de las tumbas», «sangría lenta, jamás interrumpida», "opresión constante», «siglo de hierro», "tiranías de todo género" y otras ejusdem furfuris, dignas de La Inquisición sin máscara del recalcitrante novicio cartujo Dr. Puigblanch, o de la Histoire Critique del canónigo volteriano Llorente, escritor venal y corrompido, cuya buena fe y exactitud niego, aunque no dispute su erudición.

Respecto a la literatura, juzga el Sr. de la Revilla, discorde en esto del Sr. Núnez de Arce, que no fue oprimida por el Santo Oficio, lo cual, dice, da singular prueba del talento y habilidad de los Inquisidores, porque la actividad intelectual del hombre necesita desahogo, y toda máquina que la comprima ha de tener válvulas para darla salida. ¡Benditos Inquisidores aquellos que abrian semejantes válvulas!

Dos palabras, para acabar. Yo no niego que una de las mil causas ocasionales de la declinación parcial de la ciencia espańola en el siglo xvir fuese la intolerancia; pero no la de la Inquisición tan sólo, sino más bien la de las escuelas y sistemas prepotentes, harto más dañosa, como V. apuntó ya en

pasar) todas sus extravagancias, groserías, barroquismos de dicción y de pensamiento, todos sus pecados contra el aticismo, la urbanidad y el buen gusto, resulta una personalidad literaria original y curiosa. Pero nunca me avendré a que se le cuente en serio entre los pensadores, por más que siendo como era hombre erudito y humanista, participase del general ambiente de reforma que en el siglo Xvi se respiraba, y coincidiese en algo, v. gr., en sus teorías pedagógicas, con el sentir y con las aspiraciones de los verdaderos filósofos de entonces. (Tercera edición) 
uno de sus Ensayos críticos. Y esto ha sucedido y sucederá en todos tiempos: las sectas filosóficas dominantes, lo propio que los partidos políticos, tienden a la intolerancia y al exclusivismo, cohibiendo de mil maneras la iniciativa individual. Sin ir más lejos, ahí están los krausistas, de cuya tolerancia pueden decir muy buenas cosas los que alguna vez han asistido a sus aulas.

El Sr. de la Revilla no es ya krausista, no es siquiera hegeliano, por más que tal se le creyera en algún tiempo, ha renegado de esas sectas por reaccionarias y atrasadas; hoy no gusta de espiritualismos e idealismos, según nos informa en el mismo artículo a que contesto; hoy tiende con toda claridad al materialismo positivista en crudo, y rompe lanzas en pro de la teoría darwiniana. Pero en medio de todas estas transformaciones ha conservado el Sr. de la Revilla la intolerancia de la impiedad, como otros la de la creencia; habla siempre con desdén del catolicismo y de los católicos y afecta mirarnos con cierta compasión, cual si se tratase de razas o castas inferiores. Yo, por mi parte, ni acepto la compasión ni tolero el desprecio. El verdaderamente digno de lástima es quien camina a ciegas, sin fe, sin amor ni esperanza en las cosas de este mundo ni en las del otro.

Antes de terminar, diré a V. que me parece muy dudosa la propiedad de expresión con que el Sr. de la Revilla incluye a Pericles entre los déspotas protectores de las letras. El llamar déspota a un hombre que gobernó bien y legalmente en una república pasaría por grave lapsus, aun en sujeto de menos campanillas que el crítico de la Revista Contemporánea.

Marcelino Menéndez Pelayo Santander, 2 de junio de 1876. 



\section{MONOGRAFÍAS EXPOSITIVO-CRÍTICAS}

$\mathrm{M}$ i carísimo amigo y paisano: Una vez terminado el incidente que vino a torcer el hilo de nuestra correspondencia literaria, hora es de continuar las indicaciones de re bibliographica, extendiéndolas hoy a las monografías expositivo-criticas, segundo medio de fomentar el cultivo de la ciencia española y medio aun más útil y seguro que el de los diccionarios bio-bibliográficos. Pero ante todo debo reparar tres omisiones que noté en mi segunda carta al releerla.

Pasé en silencio los elogios en verso de escritores españoles, no muy recomendables en clase de poesía, ni propiamente trabajos eruditos, pero de utilidad suma, dado el gran número de ingenios que sin estas letanías hubieran quedado en olvido. Nombrando sólo las que conozco, recordaré algunas octavas de la bella imitación que hizo Boscán del Templo de amor del Bembo, sin las cuales no tendríamos hoy noticia del poeta barcelonés Gualbes y del andaluz Haro; el canto $38^{\circ}$ del Carlo famoso, de Luis Zapata; la Casa de la memoria, de Vicente Espinel; el Viaje de Samnio, de Juan de la Cueva; el Canto del Turia, de Gil Polo; el de Caliope y el Viaje del Parnaso, de Cervantes; el Laurel de Apolo, el Jardín y algunos trozos de la Jerusalem, de Lope de Vega; la epístola de cierta señora peruana a Diego Mejía, acerca de los poetas de aquellas regiones; la Aganipe de los cisnes aragoneses celebrados en el clarín de la Fama, peregrino poema del cronista Andrés de Ustarroz; la Elegía in priscos et celebres Valentini Regni poetas, del docto helenista Vicente Mariner; el Enthusiasmus Poeticus, del P. Antonio dos Reís, en alabanza de los poetas portugueses; los Epigramas latinos del P. Tomás Serrano en loor de españoles ilustres; el romance endecasílabo de González Posada, en alabanza de diversos poetas asturianos; otro de don J. Julián de Castro, famélico coplero del siglo pasado, en que se refieren los nombres de gran número de dramáticos 
españoles, buenos y malos, y otros y otros que en este instante no recuerdo. No ha de dudarse que estos catálogos son utilísimos, puesto que sólo en el Laurel de Apolo se mencionan más de 300 poetas, lo cual no es un grano de anís para el investigador curioso. Y sube de punto el interés de semejante mina bibliográfica si agregamos los comentarios que algunos de estos registros poéticos han merecido, especialmente las extensas y eruditísimas notas de Cerdá y Rico al Canto del Turia, y las más breves, pero no menos ricas en noticias, de La Barrera al Canto de Caliope y al Viaje del Parnaso, y de Rossell al laurel de Apolo. Aun en el siglo xv encontraríamos algún ensayo, si bien harto breve, de este género de coronas poéticas, a cuyo lado deben ponerse ciertos escritos en prosa, muy semejantes en la índole, cuyo primer modelo fue la carta o prohemio famosísimo del Marqués de Santillana.

Entre las bibliografías que faltan y conviene que se formen, apenas hice mérito de las relativas a un solo escritor, cuando por el gran número de ediciones, comentarios, críticas y escritos relativos a su persona, o por haber fundado escuela y tenido numerosos secuaces, merece estudio y libro aparte. En este caso se hallan, por lo que a nosotros toca, Séneca, Averroes, Raimundo Lulio, Suárez, Cervantes y alguno más. La Biblioteca cervántica, ya preparada por gran número de trabajos parciales, saldrá poco menos que perfecta de manos del infatigable, erudito y entusiasta cervantista barcelonés D. Leopoldo Ríus, que ha dado en la Crónica de Cádiz una exposición del plan que se propone seguir en sus tareas. No ha podido caer en mejores manos la empresa: el amor del Sr. Ríus a su asunto y la riqueza asombrosa de ediciones de Cervantes que ha logrado reunir en su biblioteca, sin rival en Europa, nos aseguran un pronto y feliz desempeño. ${ }^{614}$

¡Ojalá pudiéramos abrigar igual esperanza respecto a las bibliotecas senequista, averroísta y suarista! ¿Para qué eruditos estará guardado el dar feliz remate a tan gloriosas aventuras? Desdichadamente hoy nos gusta más discutir sobre el positivismo que revolver libros viejos.

614 El Sr. D. José María Asensio de Toledo ha publicado, entre otros curiosos opúsculos cervantescos, un Catálogo de algunos libros, folletos y artículos sueltos referentes a la vida y obras de Cervantes, 1872.- (Segunda edición)

Más adelante ha dado a luz el Catálogo de su Biblioteca Cervantina (1883), y una Nota de algunos libros, artículos y folletos sobre la vida y las obras de Cervantes (1885). Edmundo Dorer, en un interesante opúsculo Cervantes und seine Werke (Leipzig, 1881), ha reunido la literatura o bibliografía alemana acerca de Cervantes. Del mismo autor hay un trabajo análogo sobre Calderón (Die Calderons Literatur in Deutschland) (1881). Teófilo Braga es autor de una esmeradísima Bibliographia Camoniana (1880). Sobre el mismo asunto hay peregrinas noticias en el Anuario de la Sociedad Camoniana de 1881. (Añadido de la Tercera Edición) 
Suplidas ya del modo posible las omisiones que cometí, y que de fijo no serán las únicas, en la referida carta, paso a tratar en ésta del segundo punto de nuestro sermón, o sea de las

\section{Monografías expositivo-críticas}

Reunidos, clasificados en alguna manera, y aun juzgados brevemente los materiales por el bibliógrafo, se ofrece una nueva y más importante tarea: el estudio detenido y formal de cada una de las secciones y de cada uno de los escritores, y de su espíritu, doctrinas y significación histórica; obra propia del crítico, destinada por su índole a ser más leída y ejercer mayor influencia en el común de las gentes, y aun entre los sabios no bibliófilos, que los catálogos y diccionarios de que hasta ahora he venido hablando. En esta parte podemos decir con dolor que casi todo está por hacer en España, mucho más si tenemos en cuenta el gran número de tales obras, tan útiles como agradables, que poseen las principales literaturas extranjeras. No hay escritor inglés del cual no se hayan publicado sus memorias, su correspondencia y luego innumerables estudios, unos simplemente biográficos, otros críticos, no sólo de todas, sino de parte de sus producciones; no hay autor francés, por mediano e insignificante que a los extraños parezca, que no haya dado ocasión a prolijas investigaciones y minuciosos análisis, que a veces rayan en lo ridículo. ¿Quién será capaz de enumerar los estudios sobre Lafontaine, Corneille, Racine, Molière, Pascal, Voltaire, Rousseau, que cada día y en todas formas aparecen? ¿Quién contará los trabajos a que ha dado motivo el bueno de Rabelais, ídolo del Sr. de la Revilla? Hasta Beaumarchais, autor de dos sainetes interminables, en que es más lo impertinente y chocarrero que lo chistoso, da asunto a un muy curioso y bien escrito libro de L. de Lomènie. Seńálanse algunas de estas obras por la erudición, otras por la crítica, y muchas por la amenidad y ligereza del estilo, que en ocasiones les quita algo de su valor científico.

Pero en Espańa, ni las monografías ligeras ni las pesadas abundan, y por demás está decir que las pocas existentes se refieren a cosas nacionales, pues nadie tiene vagar para ocuparse en erudiciones extrańas, y los mismos filósofos y literatos germanescos y afrancesados harto hacen con seguir, según su expresión, el movimiento de la ciencia, pendientes siempre del último libro y de la última doctrina que asome por Ultra-Puertos. Y en cuanto a lenguas y literaturas clásicas, vale más no meneallo, porque esto daría ocasión a largas lamentaciones que no vienen al propósito de esta carta. Nuestros sabios de Ateneo han olvidado el latín y el griego, si algo aprendieron, y en cambio se han dado al alemán con todas las potencias de su alma: los 
Don Hermógenes de nuestros días hilan más delgado que el de la Comedia Nueva; en zend y en sánscrito suelen ser eminentes, si hemos de atenernos a su honrada palabra; no citan en griego la Poética de Aristóteles, pero recitan slokas del Ramayana; no hablan de la prótasis y de la epitasis, sino del nirvana y mazdeísmo; saben al dedillo las leyes de Manú y los preceptos de Zoroastro, y de los concilios budistas entienden más que del Concilio de Trento. No es maravilla, pues, que anden tan de capa caída ciertos estudios en la patria de Vives y Sepúlveda, de Núñez y del Brocense; nada tiene de extrańo el que, para vergüenza nuestra, apenas contemos en el período contemporáneo tres o cuatro opúsculos relativos a asuntos de literatura griega y romana, cuando en otros países se suceden sin interrupción las publicaciones.

En modo alguno censuraría esta indiferencia, y diérala hasta cierto punto por bien empleada, si en cambio se dirigiera nuestra actividad científica a exponer y quilatar los tesoros allegados por las generaciones literarias que nos precedieron en el suelo ibérico. Antes de estudiar lo de fuera, conviene conocer lo de casa; una vez despertada la afición a esta clase de trabajos y de lecturas, lo demás vendría natural y fácilmente.

A pesar de no ser grande el número de las actuales monografías expositivo-críticas, haylas excelentes entre ellas, así absoluta como relativamente consideradas. No pocas han salido de plumas extranjeras, lo cual, si nos mueve a agradecimiento, contrístanos más y más por el abandono sin ejemplo que en nosotros revela. Voy a formar breve catálogo de las que conozco, aunque con seguridad de dejar olvidada alguna, quizá de superior importancia, que, o no ha llegado a mi noticia, o no ocurre a mi memoria en este momento.

Por su carácter general menciono en primer término (y no me pesa) la excelente monografía del P. Tailhan sobre las bibliotecas espańolas en el primer período de la Edad Media. ${ }^{615}$

Con el título de La Filosofía española; indicaciones bibliográficas, publicó D. Luis Vidart en 1866 una colección de apuntamientos acerca de nuestros filósofos, apreciable como ensayo, no bibliográfico, según impropiamente se intitula, sino expositivo, y más aún que expositivo, crítico. Casi igualan al libro del Sr. Vidart en extensión, y en riqueza de noticias le superan, los excelentes artículos que V., amigo mío, escribió sobre él en La Abeja Montañesa, periódico santanderino de grato recuerdo, y recogió posteriormente en sus Ensayos críticos. Son también dignos de leerse los amplios capítulos que, al fin de sus respectivos cursos latinos de filosofía, han dedicado a reseñar

615 Appendice sur les Bibliothèques Espagnoles du Haut Moyen Age par Jules Tailhan (en las Nouveaux Mélanges d'Archéologie del P. Cahier.-París, Didot, 1877, páginas 217 a 346). (Segunda edición) 
la historia de la española los ilustres filósofos asturianos el P. Cuevas y Fr. Zeferino González. Por su extensión merece aún más que estos trabajos el nombre de monografía, aunque tampoco se haya impreso aparte, el Discurso preliminar de D. Adolfo de Castro a su colección de filósofos españoles (tomo LXV de la Biblioteca de Autores Españoles de Rivadeneyra).

Ullesperger. Historia de la Psicología y de la Psiquiátrica (curación de las enfermedades mentales) en España, Würzbug, 1871 (en alemán).

Fuera de estas tentativas generales, y dejados en silencio, por ser más conocidos y en gran número, los libros y memorias que acerca de Séneca y otros escritores hispano-romanos vienen publicándose desde el siglo XVII, ${ }^{616}$ hay relativas a filósofos peninsulares las monografías siguientes:

616 Dictamen de la Academia Nacional Greco-Latina acerca de la obra "De re rustica", de L. Junio Moderato Columela. Madrid, 1840. Aunque ligero, merece recuerdo, por ser el único trabajo español (suelto) sobre Columela, de que haya noticia.

G. Lindner. (De M. Porcio Latrone Commentatio, Breslau, 1855). De Junio Gallione (1868).

B. Schmidt. (De L. Junio Gallione rhetore, Marburgo, 1866).

J. Körber. Sobre Séneca el Retórico y la Retórica Romana de su tiempo (en alemán). (Marburgo, 1864).

O. Gruppe. Quaestiones Anneanae (Stettin, 1873).

Acerca de Marcial, Lucano y Séneca el Trágico, hay numerosos estudios antiguos y modernos. Véanse, entre otros, el Syntagma tragoediae latinae del P. Martin del Río (París, 1619), y tres de los Estudios de Nisard sobre poetas latinos de la decadencia (tercera edición, París, 1867). Cada uno de ellos puede estimarse como una monografía ingeniosa, aguda y discreta, aunque de sobra apasionada (Segunda edición), y llena de alusiones contemporáneas que van contra Víctor Hugo y los poetas románticos, más que contra Lucano.

Sobre las tragedias que andan a nombre de Séneca, han escrito muchos alemanes sosteniendo las opiniones más diversas; v. gr.: H. G. Pilgramm (De vitiis Tragoediarum quae Senecae tribuuntur, 1765); F. G. C. Klotsch (Prolusio de Annaeo Seneca uno tragoediarum quae supersunt omnium auctore, Wittenberg, 1802); G. Richter (De Seneca tragoediarum auctore, Naumburg, 1862); R. Peiper (Praefationis in Sen. Tragoedias nuper editas supplementum, Breslau, 1870); C. E. Sandström (De Senecae tragoediis, Upsala, 1872); B. Schmidt (De emendandarum Sen. tragoediarum rationibus prosodicis et metricis, Berlín, 1868); M. Hoche (De los metros de las Tragedias de Séneca, Halle de Sajonia, 1862). Añádanse interesantes artículos de Federico Jacobs, de J. G. Welcker, de L. Müller, y ediciones críticas, entre las cuales brillan la de Peiper y la de Richter. De este último hay también un estudio sobre la composición de los cantos del coro en las tragedias de Séneca. En Francia sólo puede mencionarse la disertación de Gastón Boissier sobre este problema: «¿Las tragedias de Séneca han sido representadas?»

Sobre Lucano deben consultarse, además: Lucani sita per annos digesta, de C. F. Weber (en tres partes, 1857-58). - De Livio Lucani in carmine de bello civili auctore, por G. Baier (Schweidnitz, 1874).-_Meusel y Bürger, De Lucano (Halle, 1767)._-Leloup, De poesi epica et Pharsalia Lucani (1827).- A. Preime, De Lucani Pharsalia (Marburgo, 1859).Hermann Genthe, De Lucani vita et scriptis (Berlín 1859).-A. Schaubach, Sobre el valor 
histórico de la Farsalia (en alemán, Meiningen, 1869).-CCreizenach, La Eneida y la Farsalia en la Edad Media (en alemán, 1864, Francfort), y otras muchas monografías alemanas, entre las cuales hasta hay una de Körber sobre la sintaxis de Lucano. En castellano no he visto otra cosa que la tesis doctoral de D. Emilio Castelar: Lucano, su vida, su genio, su poema (1857).

Sobre Marcial han escrito, entre otros muchos, A. Brandt, De Martialis poetae vita (Berlín, 1853); L. Friedlander, De temporibus librorum Martialis Domitiano imperante editorum (Königsberg, 1862), y con su habitual profundidad Lessing (Martial als Mensch und Dichter).

Acerca de Quintiliano pueden consultarse H. Babucke, De Q. doctrina et studiis capita duo (Königsberg, 1866); E. Bonnell, De Grammatica Quintiliani; R . Törnebladh, De Elocutione Quint. (Upsala, 1858); De usu particularum apud Quintilianum (Holm, 1861).

Otras varias pueden verse citadas en la excelente Historia de la Literatura Romana de Teuffel, de la cual tomamos las indicaciones anteriores.

No quise hacer mérito de los trabajos que tienen por asunto a Séneca el Filósofo, por ser tantos que, aun limitándonos a los espańoles, tenemos una verdadera literatura senequista, como dirían los alemanes. Basten para muestra la Vida de Séneca, por Mártir Rizo (Madrid, 1625); Séneca y Nerón, por D. Fernando Álvaro Diez de Aux (Madrid, 1641); Séneca impugnado de Séneca en cuestiones políticas y morales, por D. Alonso Núñez de Castro (1651); L. Anneo Séneca ilustrado... y su impugnador impugnado de sí mismo, por D. Juan Baños de Velasco (Madrid, 1670); Comentarios estoicos a Séneca, del mismo (1671); Por Séneca sin contradecirse; Séneca juez de su causa, y muchos más. (Añadido de la Tercer Edición).

Útil fuera un estudio comparativo de todos estos libros y de los extranjeros inspirados por Séneca o compuestos en ilustración y defensa de su doctrina, v. gr., la Manuductio in philosophiam stoicam de Justo Lipsio; el Ensayo de Diderot (fanático admirador del filósofo de Córdoba) sobre la vida de Séneca el Filósofo, sus escritos, y los reinados de Claudio y de Nerón; el Estudio sobre las supuestas relaciones entre Séneca y San Pablo, de Aubertin (1857); Séneca y San Pablo, de Fleury (1853); La Moral estoica en las cartas de Séneca, de Martha (1865); L. Annei Senecae disciplinae moralis cum Antoniana contentio et comparatio, de Doergens (1857); De Senecae philosophiae dissertatio, de Ernesto J. Mauricio Werner (Vratislaviae, 1825) (Segunda edición); De L. Annaei Senecae vita et moribus, de E. F. Gelphe (Berna, 1848); De Senecae vita et de tempore quo scripta ejus philosophica... composita sint, de A. Martens (Altona 1871); De ordine librorum Senecae Philosophi, de Fr. Jonas (Berlín, 1870); De Senecae philosophia, de Herzog (Bernburg, 1828); De Seneca ejusque in philosophiam meritis, de B . ten Brink (Gante, 1827); Seneca und sein Wert auch für unsere Zeit, de P. Böhm (Berlín, 1856); el estudio sobre Séneca y San Pablo, del famoso exegeta de Tubinga F. Ch. Baur (1858); el de Gastón Boissier sobre el cristianismo y la moral de Séneca (1871, en la Revue des Deux Mondes); las disertaciones de Baarts y de Fichert sobre las opiniones teológicas de Séneca (Seneca de Deo, Marienwerder, 1848; Séneca de Natura Deorum, Breslau, 1857). Sobre el mismo asunto han escrito en alemán Siedler (1863) y R. Burgmann (Seneca's Theologie... Berlín, 1872), así como W. Bernhardt sobre la concepción cosmológica de Séneca (Wittenberg, 1861). Acerca de la latinidad de Séneca hay varias monografías, v. gr., la de E. Opitz (Naumburg, 1871), la de A. Hoppe (Lauban, 1873). Luego entran los comentarios, las ediciones críticas de cada tratado y los prolegómenos a ellas, en todo lo cual han sido fecundísimos los alemanes, distinguiéndose de una manera muy especial Fickert, Haasse y M. Haupt. No sólo han sido objeto de la crítica filológica los tratados de Séneca que hoy existen, sino también los que se han perdido. Véase, por ejemplo, F. Osann, De Senecae scriptis quibusdam deperditis (Giessen, 1846-48), M. Cl. 
L'Ecole de Séville sous la monarchie des Visigoths, par l'Abbé Bourett (París, 1855). Averroes et l'Averroisme, de Ernesto Renan (París, 1852, 2a edición, 1861); libro erudito compuesto con singular talento literario, y quizá el único digno de leerse sobre la materia, pero no exento de errores teológicos e inspirado con frecuencia por un criterio escéptico y vacilante. De desear sería que algún arabista católico y filósofo emprendiese la tarea de completarle, refutando, al propio tiempo, sus aventuradas aserciones. ${ }^{617}$

Estudios orientales, de Adolfo Franck (París, 1861). Dos de ellos versan sobre Avicebrón y Maymónides. El mismo autor francés publicó un libro titulado La Kábala (París, 1843), muy superior a la Kaballa denudata del barón Knor de Rosenroth, contemporáneo de Leibnitz, y cuya materia es en gran parte judaico-española. Sostienen opiniones muy diversas de las de Franck, y hoy más autorizadas que las suyas, Luzzato, S., en sus Diálogos (hebreos) sobre la Kabala y el Zohar (1852), y Jellinek en su Beiträge zur Geschichte der Kabbala (Berlín, 1852).

Del mismo Franck hay otro estudio acerca de Maymónides (El racionalismo religioso en el siglo XII) en su libro Philosophie et religion. Escribióse, lo mismo que el de Saisset, con ocasión del libro de Munk (Le Guide des égarés).

Extractos de LA Fuente de LA VIDa de Salomón ben Gebirol (Avicebrón).Misceláneas de filosofía arábiga y judaica, de Munk (París, 1859). Al mismo se debe una excelente versión francesa, con eruditas ilustraciones, de El guía de los extraviados o Director de los que dudan, obra capital de Maymónides (París, 1856-61-66, 3 vols.).

Vida y escritos de Rabi Moisés ben Maimon (Maymónides), por Peter Beer (en alemán), Praga, 1854. Sobre este libro publicó un artículo notable Derembourg en el Anuario Teológico de Geiger (Francfort, 1851).

Gertz, Studia critica in Sen. dialogos, 1874. ¿Qué más? Hasta sobre el uso de las partículas concesivas e interrogativas en Séneca hay una disertación de G. Nägler (1873, Halle).

Esta división atomística del trabajo tiene sus inconvenientes. Gracias a ella poseen los alemanes una Biblioteca entera de tesis y monografías sobre Séneca; pero el libro de conjunto ni ellos le han escrito, ni los franceses tampoco. ¿Será temeridad esperar que algún día se escriba en la patria de Séneca? ¡Qué riqueza de materiales ya labrados con piadoso celo por manos extrańas encontraría el que sintiese la ambición de levantar ese monumento! (Añadido de la Tercera edición)

617 Anterior a los libros de Munk y de Renan, y, por consiguiente, algo anticuado ya, es el de Schmoelders, Essai sur les écoles philosophiques chez les Arabes (París, 1842), que para la filosofía de los árabes españoles sirve poco. En cambio, puede leerse con fruto la Histoire des Philosophes et des Theologiens Musulmans de G. Dugat (París, 1878), aunque el autor demuestra tener más de arabista que de filósofo, y su crítica parece harto superficial. Por otra parte, nada dice de las cosas de España, refiriéndose sólo a las de Oriente. (Tercera Edición) 
Moisés ben Sem Tob de León (compilador de la Kábala), por Jellinek (Leipzig, 1851). El mismo Jellinek ha antepuesto un notable estudio crítico bibliográfico a su edición del Libro de los deberes de los corazones, del moralista Bachia ben Joseph (1846, Leipzig).

De la filosofía religiosa de R. Abraham ben David ha-Levi (Augsburgo, 1850), por Gugenheimer.

Maymonides y Spinosa. Estudio de Emilio Saisset, en la Revista de Ambos Mundos de 15 de enero de $1862 .{ }^{618}$

Los cantos del gran poeta toledano Jehudá Leví, que fue a la par profundo filósofo, cuyo libro de El Kuzari puso en castellano Jacob de Avendaña, han sido traducidos al alemán por Geiger, rabino de Breslau (1851).

La Ética de Maymónides, por Rosen (1876).

Eisler. Conferencias sobre los filósofos judíos de la Edad Media, anteriores a Maymónides.

Existen otros estudios alemanes sobre filósofos judíos españoles; pero ni sus títulos ni los nombres de sus autores han llegado a mis oídos. ${ }^{619}$

Las doctrinas del doctor iluminado Raimundo Lulio, por don Francisco de P. Canalejas (Madrid, 1872). A este opúsculo hay que agregar varios artículos concernientes a Lulio dados a luz por el Sr. Canalejas en la Revista de España y en otras publicaciones. ${ }^{620}$

Raimundo Lulio juzgado por símismo, obra erudita, aunque sobrado empirica, o más bien positivista, de D. F. Weyler y Laviña (Palma de Mallorca, 1867).

618 De artículos de revistas citaré únicamente los que por su extensión o interés puedan figurar entre las monografías. (Primera Edición)

619 Citaré algunos otros estudios sobre sabios judíos, no filósofos. Moisés ben Ezra, de Granada, por Dukes (Altona, 1839).

Noticia sobre Aben Schaprut Hasdai, médico del siglo X, por Filoxeno Luzzato (París, 1852). (Segunda edición)

Noticia sobre el célebre gramático Abulgualid Meruan aben Djanach, y sobre otros gramáticos hebreo-hispanos de los siglos x y XI, por Munk (en el Journal Asiatique de 1850).

Para formar cabal idea del movimiento científico y literario de los judíos, hay que leer la brillante Geschichte der Juden de H. Graetz. (Leipzig, 1856 a 1868). Un extracto que comprende la parte espańola desde 945 a 1205 ha sido publicado en francés por Jorge Stenne (1872), con el título de Les Juifs d'Espagne. Es el mejor libro de vulgarización sobre el asunto.

Finalmente, para no hacer interminable a poca costa esta reseńa, baste citar con el grande aprecio que merecen la extensa introducción y el comentario de David Cassel a su versión alemana del Kuzari de Judá Leví (Das Buch Kusari des Jehuda ha-Levi nach dem hebraischen Texte des Jehuda Ibn Tibbon herausgegeben... Leipzig, 1853), y la de Salomone de Benedettis a su traducción italiana del Diván de Judá Leví. (Il Canzionere Sacro di Giuda Levita. Pisa, 1871.) (Añadido de la Tercera Edición)

620 Por ejemplo, el titulado R. Lulio y Don Juan Manuel. (Segunda edición) 
Biografía de R Lulio, por D. Jerónimo Roselló. Precede a las Obras Rimadas de Lull (Palma, 1864).

De vita R. Lulli specimen, auctore Loew (Halle, 1830).

Biografía de Raimundo Lulio, por Delécluze, en la Revista de Ambos Mundos de 15 de noviembre de 1840.

Raymond Lull und die Anfänge der Catalanischen Literatur, por Helfferich (Berlín, 1858).

Ramón Lull (Raymundo Lulio) considerado como alquimista (Barcelona, 1870). Excelente trabajo de mi sabio amigo D. José Ramón Luanco, catedrático de química en la Universidad barcinonense. ${ }^{621}$

621 Por no tener el carácter de monografías expositivo-críticas (género que puede calificarse de moderno), omito una multitud de libros que versan sobre Lulio y su doctrina (Primera Edición), v. gr., Doct. Petri Bennazar Breve ac compendiosum rescriptum, nativitatem, vitam... R. Lulli complectens (Mallorca, 1868).- Disertaciones históricas del beato Raymundo Lullio, por el Padre Custurer, 1700.- Vindiciae Lullianae... auctore D. Antonio Raymundo Pasqual (Aviñón, 1778, cuatro volúmenes).- Vida y hechos del admirable doctor y mártir R. Lull, por el Dr. Juan Seguí (Palma, 1606).-Vida admirable del inclito mártir de Cristo B. Raimundo..., por Fr. Damián Cornejo (Madrid, 1686).Acta B. R. Lulli, por Juan B. Soler (1708) (Añadido de la Segunda Edición)._-Adversarias críticas y apologéticas sobre R. Lulio, por Fr. Manuel do Cenáculo y Villasboas, obispo de Beja (1752).

Desde la fecha de la segunda edición de nuestro libro se ha enriquecido la bibliografía luliana, no sólo con nuevas ediciones de varios tratados y con las primicias de una edición completa que va saliendo a luz en Palma de Mallorca bajo la dirección del Sr. Roselló, sino con la aparición verdaderamente inesperada de un grueso volumen de 400 páginas en $4^{\circ}$, obra póstuma del eruditísimo Littré (más digno de buena memoria como erudito y filólogo que como pensador y jefe de escuela). Littré no pudo terminar este trabajo; lo que faltaba lo ha añadido Barthélemy Hauréau, el historiador de la Escolástica, y en esta forma se ha publicado su estudio, que ocupa la mayor parte del volumen $29^{\circ}$ de la Histoire Litteraire de la France, en la cual sus autores se han creído obligados a incluir a todos los personajes extranjeros que por uno u otro concepto han ejercido influencia en la cultura francesa, como la ejerció Raimundo Lulio por medio de su enseńanza directa y de sus numerosos discípulos. El trabajo de Littré y de Hauréau se resiste no poco a las habituales preocupaciones de uno y otro contra la metafísica, contra el misticismo y contra el realismo escolástico; pero así y todo, no hay mejor libro sobre la materia, y sería ingratitud en los espańoles no reconocerlo. El punto de vista en que Littré y Hauréau se colocan respecto de la filosofía de Raimundo Lulio, no es el nuestro; pero hay que confesar que ellos han sido los primeros en analizar uno por uno hasta trescientos trece tratados del filósofo mallorquín, y exponer su contenido; servicio inapreciable y que hace olvidar cualquier frase irreverente.

Acerca de Raimundo Lulio ha escrito también su paisano el doctor Guardia en la Revue de l'Instruction Publique y en la Revue Germanique (1862), y quizá en otras partes.

El Museo Balear ha dado alguna muestra de los notables estudios que tiene emprendidos acerca de la filosofía luliana el actual obispo de Orihuela, Dr. D. Juan Maura. Otro 
Le Roman de Blaquerna, por A. Morel-Fatio (Romania, tomo VI).

De Theologia naturali Raimundi Sabunde, por Holberg, impreso en Halle de Sajonia.

Ídem por Kleiber (Berlín, 1856). De Raymundi S. vita et scriptis.

Une inconnu célèbre, recherches historiques et critiques sur Raymond de Sebonde, par l'Abbé D. Reulet (París, 1875).

Raymundo Sabunde, por D. Aquilino Suárez Bárcena, en el tomo de la Revista de Instrucción Pública correspondiente a 1857. Por ser meramente biográfico-bibliográficos, aunque muy curiosos, omitiré los estudios sobre León Hebreo y Miguel Servet, publicados por el mismo escritor en la citada revista, años de 1856 y 57.

Vita Joannis Ludovici Vivis ... a Gregorio Majansio, generoso valentino, conscripta. Precede a la magnífica edición valenciana de las obras de Vives (1782), pero por su extensión y mérito debe, como otras producciones análogas de Mayáns, colocarse en el catálogo de las monografías. ${ }^{62}$

Vindicación de Juan Luis Vives, por D. Ricardo González Múzquiz (Valladolid, 1839).

Luis Vives en sus tres libros De prima philosophia combina las doctrinas de Platón y Aristóteles con las de los Padres de la Iglesia. Tesis doctoral de D. Facundo de los Ríos Portilla (1864).

J. Luis Vives considerado como teólogo. Monografía holandesa de W. Francken (Rotterdam, 1853).

mallorquín egregio, D. José María Quadrado, prepara hace años un extenso trabajo biográfico, del cual ha adelantado algunas muestras en la misma revista. (Añadido de la Tercera Edición)

622 Las monografías sobre nuestros filósofos del siglo xvi se han acrecentado notablemente en estos últimos años. Es digna de especial elogio la del profesor D. Joaquín María de los Reyes García acerca de El Doctor Eximio (Francisco Suárez) considerado como flósofo, teólogo y jurisconsulto, premiada en un certamen literario de Granada en 1879, e impresa en La Ciencia Cristiana al ańo siguiente (números 81, 82, 83, 88, 89 y 90). Merecía una impresión aparte.

Todavía es de superior importancia, y a mi entender puede considerarse como el fruto mejor y más maduro que hasta ahora ha dado el renacimiento de la tradición espańola, el libro intitulado Fr. Luis de León y la Filosofía Española del siglo XVI, por Fr. Marcelino Gutiérrez, de la Orden de San Agustín (Madrid, 1885). El autor, aunque escolástico, se muestra libre y exento de casi todas las preocupaciones que suelen dominar a los escolásticos espańoles. El vigoroso y reposado entendimiento del P. Gutiérrez brilla, no sólo en esta obra, sino en la que luego ha publicado bajo el título de El misticismo ortodoxo en sus relaciones con la Filosofía (Valladolid, 1886). Para mayor encarecimiento del mérito de este libro, diremos que ha merecido la honra de ser impugnado por $L a$ Ciencia Cristiana, revista que dirige el Sr. Ortí Lara. (Tercera edición) 
J. Luis Vives como filántropo cristiano (Amsterdam, 1851). Opúsculo escrito también en holandés, por Bosch Kemper.

Mémoire sur la vie et les écrits de Jean Louis Vives, por A. J. Namèche (profesor en la Universidad católica de Lovaina), 1840-41. Se publicó en las Mémoires couronnées de l'Académie Royale des Sciences et Belles Lettres de Bruxelles (tomo XV).

Jean Louis Vives. Eclaircissements et rectifications biographiques, par Emile Van den Busch (Brujas, 1871).

Dissertatio theologica exhibens Jo. Ludovici Vivis Theologiam Christianam (tesis doctoral de Enrique Gerardo Braam), Groninga, 1853.

Discurso preliminar a las Obras del P. Juan de Mariana, tomo XXX de la Biblioteca de Rivadeneyra, por D. F. P. M. (Francisco Pi Margall). Cítole en este lugar, por referirse principalmente a la filosofía del P. Mariana, que expone y juzga con elocuencia, pero torcidamente.

Juan Huarte.—Diego Alvarez, autor de una impugnación inédita de la obra de Huarte. Estudios de D. Ildefonso Martínez insertos en el Círculo cientifico y literario (Madrid, 1854).

Ensayo sobre la obra de Huarte, por J. M. Guardia (París, 1855). ${ }^{623}$

Doña Oliva Sabuco de Nantes; su vida, sus obras, su valor filosófico, su mérito literario. Tesis doctoral de D. Julián Sánchez Ruano (Salamanca, 1867).

De vita et scriptis Joannis Genesii Sepulvedae commentarius. Precede a la edición de las obras de Sepúlveda hecha por la Academia de la Historia, y lo escribió Cerdá y Rico (Madrid, 1780).

Francisci Sanctii Brocensis vita, scriptore Gregorio Majansio. Al frente de las obras del Brocense, en la edición hecha por los hermanos Tournes (Ginebra, 1766).

Biografía del maestro Francisco Sánchez de las Brozas.. Dala a luz el marqués de Morante (Madrid, 1859), en el tomo V del Catalogus librorum. Hay ejemplares sueltos. Compúsola el distinguido humanista D. Raimundo de Miguel, aunque no lleva su nombre.

El estoicismo en España, artículo de D. Fernando Belmonte en la Revista de España.

El tradicionalismo en España durante el siglo XVIII, artículo de D. Gumersindo Laverde Ruiz en la Revista de España y en los Ensayos críticos. (Lugo, 1867). Casi todo el contenido de este libro tiene interés para la historia de la ciencia española.

623 El Dr. Guardia acaba de publicar dos notables artículos sobre Doña Oliva, en la Revue Philosophique de Ribot (julio y septiembre de 1886). (Tercera edición) 
Francisco Suárez, monografía alemana de Werner.

Francis Suárez, por el P. Coleridge, en The Month de Londres (1865).

Études sur le P. Suárez por el P. Ramière, en la Revue du monde catholique (1861 y 62).

Elogio de Suárez, discurso inaugural de D. Francisco J. Simonet, en la Universidad de Granada (1876).

Vida religiosa de Suárez, por el P. Guéau de Reverséaux (Bruselas, 1875).

Vida de Suárez, por el P. Antonio Descamps (Perpiñán, 1671 y 72).— Ídem por el P. José Massei (Roma. 1687, en italiano, traducida al latín por el P. Benito Rogazzi, 1694, en Tyrnau).-Ídem por el P. Benito Sartolo (Salamanca, 1693). ${ }^{624}$

Memorie della vita di Giovanni Caramuel, por Tadisi (Venecia, 1760).

Vida del P. M. Feijoo, atribuída a Campomanes y puesta al frente de la edición de 1774 de las obras del sabio benedictino. Hay otra extensa, escrita, según creo, por Roca y Cornet en la Biografía eclesiástica completa (Barcelona, 1847). El P. Feijoo, su vida y escritos, oración inaugural de la Universidad de Oviedo en 1852, por D. José María Anchóriz. Estudio acerca de Feijoo, por doña Concepción Arenal, en la Revista de España (1876). Otro por doña Emilia Pardo Bazán, premiado en un certamen de Orense (1877).

D. Antonio Xavier Pérez y López, estudio del Sr. D. Federico de Castro en la Revista de la Universidad de Madrid (1873).

Los libros y Memorias de Blanche Raffin, Roca y Cornet, García de los Santos, etc., sobre Balmes, y la biografía de Donoso Cortés, puesta al principio de las Obras de éste por D. Gabino Tejado, cierran la lista de los escritos de algún interés que recuerdo relativos a nuestros filósofos, en cuya categoría deben contarse también Piquer, Forner y algún otro, de quien haré mérito más adelante por distintos conceptos. ${ }^{625}$

Historia da Philosophia em Portugal, por López Praza. No he visto más que el primer tomo.

Acerca de los teólogos ortodoxos españoles, incluso escriturarios y místicos, son poquísimos los estudios que existen, cuya escasez contrasta notablemente con la inmensa riqueza del asunto. En cambio, reúnen mérito nada común casi todos. ${ }^{626}$

624 Otras menos importantes o inéditas se hallarán enumeradas por el Sr. Simonet. (Vid. la Ciencia Cristiana, núm. 49) (Segunda Edición)

625 Vid., además, El Filósofo rancio_L La Unidad Simbólica, de Álvarez Guerra, artículos del Sr. Caminero en la Revista de España. (Segunda Edición)

626 Incluyo en esta sección a nuestros poetas latino-eclesiásticos de los primeros siglos y algún historiador (Segunda Edición) en quien predomina el carácter religioso (Añadido 
De C. Vettii Aq. Iuvenci vita et scriptis, por A. R. Gebser (Jena, 1827). O. Korn ha trabajado mucho sobre los Mss. de la Historia Evangélica de Juvenco.

Prudentiana, de D. Faustino Arévalo. Es un doctísimo y extenso comentario sobre la vida y escritos de Prudencio, que antecede a la edición de este poeta hecha en Roma, 1788. Impreso aparte podría formar una voluminosa monografía. ${ }^{627}$

Deben leerse también las ilustraciones de Arévalo a su edición de Juvenco y a la Himnodia Hispánica. Son excelentes trabajos. También merecen recuerdo los prolegómenos del P. Merenda a su edición de San Dámaso (1754), y los de Noguera y Ramón a la suya de San Paciano (1780).

Damasus et Laurentius hispanis asserti et vindicati. Disertación de Pérez Bayer (Roma, 1756).

Hosius vere Hosius (vindicación de la santidad de Osio), por el P. Maceda (Bolonia, 1790).

Disertación sobre la verdadera patria de Paulo Orosio, que fue Tarragona, en Cataluña, y no Braga, en Portugal, por D. Pablo Ignacio de Dalmases y Ros (Barcelona, 1702). Esta disertación es erudita, pero no prueba nada de lo que pretende.

De Orossi vita ejusque hist. Iibris VII adversus Paganos, monografía de Teodoro Mörner (Berlín, 1844). ${ }^{628}$

Isidoriana, de Arévalo. Comentario dilatadísimo y muy rico en noticias que antecede a la edición de San Isidoro, hecha en Roma, 1802, y ocupa por sí solo dos volúmenes. ${ }^{629}$

de la Tercer Edición).

627 De Prudentio et Theologia Prudentiana, por H. Middeldorp (Berlín, 1823 y 27).De Lyrica apud Prudentium poesi (Tolosa, 1848), por F. Delavigne.- De vita et scriptis Prudentii, por J. B. Brys (Löwen, 1855). Prudentiana de C. G. Schmidt (1866)._-Aurelio Prudencio Clemente y la Iglesia de su tiempo, por Cl. Brockhaus (1872). Léase, además, el excelente capítulo que Ebert dedica a Prudencio en su Historia de la literatura de la Edad Media, obra magistral y digna de toda recomendación bajo el aspecto crítico. (Tercera edición)

628 Hay además acerca de este padre de la filosofía de la historia los siguientes trabajos:

G. F. H. Beck. De Orosii historiae fontibus et auctoribus, Marburgo, 1832.

E. J. Mejean. Paul Orose et son apologétique contre les paiens, Strasburgo, 1862.

Sauvage (De Orosio, tesis de doctorado, 1874).

Sobre Idacio véase la edición y monografía del P. D. M. Garzón, S. J. (Idatii Chronicon illustratum a J. M. Garzón, edidit F. X. de Ram. 1845, Bruselas). (Tercera edición)

629 Vid. además H. Hertzberg (Sobre las historias y las Crónicas de San Isidoro de Sevilla. Gottinga, 1874).-Dressel, De Isidori Originum fontibus (en la Rivista di Filologia de Turín, tomo III, 1874). (Tercera edición) 
Vida de San Beato de Liébana, escrita en latín por el P. Flórez, al frente de su comentario al Apocalipsis, dado a luz por vez primera en $1770 .{ }^{630}$

Elogio de D. Alonso Tostado, Obispo de Ávila, por D. José Viera Clavijo, en las Memorias y Premios de la Academia Española.

Elogio de Benito Arias Montano, monografía rica en noticias y bellamente escrita por González Carvajal, traductor ilustre de los Libros poéticos de la Biblia. Está inserta en el tomo VII de las Memorias de la Academia de la Historia. ${ }^{631}$

Vida de Melchor Cano, obra eruditísima de D. Fermín Caballero (Madrid, 1871). Ocupa el segundo tomo de la serie de Conquenses ilustres.

Vida de Fr. Luis de León, por D. José González de Tejada (Madrid, 1863).

Fr. Luis de León. Ensayo histórico, por el licenciado don A. Arango y Escandón. México, 1866. Excelente libro, el mejor que tenemos sobre Fr. Luis.

Fr. Luis de León y la Inquisición, estudio alemán del doctor Reusche, publicado en el presente año de 1876. Considera especialmente a Fr. Luis como escriturario. El autor es católico-viejo, de la secta de Döllinger.

Biografía del Maestro León de Castro, por D. Vicente de la Fuente, en el Catalogus librorum del marqués de Morante (tomo VII, 1860). Tiráronse ejemplares aparte.

Vida del Ven. Fr. Luis de Granada, por el licenciado Luis Muñoz (primera edición 1639).

San Juan de la Cruz, por el difunto lectoral de Jaén D. Manuel Muñoz Garnica (Jaén, 1875).

Histoire du Père Rivadeneyra, por el P. Prat, S. J. (1862).

Maldonat et l'Université de Paris dans le XVI siècle, por el mismo Padre (París, 1856).

Vida del P. Vieyra, por el P. Prat.

630 Acerca del español Teodulfo, obispo de Orleáns, el mayor de los poetas de la época carlovingia, deben leerse: un estudio de Barthélemy Hauréau en sus Singularités historiques et litteraires (París, 1861), una tesis doctoral de Baunard (Theodulphe, évêque d'Orleans, 1860), dos disertaciones alemanas (Theodulf, Bischof von Orleans, de Rzehulka, Breslau, 1875. Die Gedichte Theodulfs... Halle, 1880). Pero nadie le ha estudiado con tanto amor como Ebert, al cual, y a Hauréau, debemos el haber puesto en claro y fuera de discusión la patria de este fecundo y olvidado ingenio.

Al grupo de los sabios españoles que brillaron en las Galias durante la dominación carlovingia, pertenece asimismo Claudio de Turín (del cual han escrito el danés Rudelbach, Claudii Taurinensis Episcopi ineditorum operum specimina: praemissa de ejus doctrina scriptisque dissertatione, Copenhague, 1824, y C. Schmidt), y Prudencio Galindo, obispo de Troyes, que ha sido estudiado en calidad de historiador por Girgensohn en su opúsculo Prudencio y los Anales Bertinianos, Riga, 1875. (Tercera edición)

631 Homenaje a la memoria de Arias Montano (Frexenal, 1881). Contiene, entre otros trabajos, una bibliografía de Arias Montano, formada por el Sr. Barrantes. (Tercera edición) 
Vida del Venerable Juan de Palafox, por Dinouart (Colonia, 1767). En lengua francesa.

Les Mystiques espagnols, por Rousselot (París, 1867). Sobre el mismo asunto ha publicado una serie de artículos en la Revista de la Universidad de Madrid el docto filósofo D. Nicomedes Martín Mateos.

Historia de la vida de D. Félix Amat, arzobispo de Palmira, por su sobrino

D. Félix Torres Amat (con un extenso Apéndice) (1835 y 1838).

Vida de Fr. Diego de Cádiz, por el capuchino Fr. Luis Antonio de Sevilla (Málaga, 1806).

Añádanse las varias Vidas de Santa Teresa de Jesús, en especial la compuesta por el obispo de Tarazona, Fr. Diego de Yepes, y la publicada modernamente en Bélgica por los jesuitas continuadores de las Acta Sanctorum de los Bolandos, que llena un tomo en folio, riquísimo en erudición y crítica, ${ }^{632}$ y tendremos registrado casi todo lo digno de memoria que hay escrito relativamente a nuestros teólogos católicos. ${ }^{633}$

Mayor ilustración han recibido, aunque no de plumas españolas por lo común, los heterodoxos, con ser infinitamente menos numerosos e importantes.

De secta Priscillianistarum dissertatio, por el P. Girves (Roma, 1753).

Estudios históricos sobre el Priscilianismo, por D. Antonio López Ferreiro (Santiago, 1878).

Historia adoptianorum, por Walch (se refiere a Félix y Elipando) (Gottinga, 1755).

632 Acta Sanctorum Octobris... illustrata à Josefino Vandermoere et Josepho Vanheeke S. J. ... (tomus septimus, octobris). Bruxellis, typis Alph. Greusse, 1845). Otras muchas obras relativas a la Santa pueden verse citadas por el Sr. La Fuente en los preliminares de su excelente edición de Santa Teresa. (Biblioteca de Autores Españoles) (Segunda Edición)

633 En estos últimos años la cosecha se ha acrecentado mucho. Baste citar las siguientes obras, todas dignas de estimación por varios conceptos, aunque no todas inspiradas por el mismo criterio:

Vida y escritos del Beato Alonso de Orozco, por Fr. Tomás Cámara, de la Orden de San Agustín (actual obispo de Salamanca), Valladolid, 1882.

Santa Teresa de Jesús y el P. Bánez, por el Rdo. P. Fr. Paulino Álvarez, de la Orden de predicadores Madrid, 1882.

Controversiarum de Divinae Gratiae Liberique Arbitrii Concordia, initia et progressus enarravit Gerardus Schneemann, S . J. (Friburgo, 1881.)

Bañes et Molina. Histoire, Doctrines, Critique Metaphysique, par le P. Th. de Regnon, de la Compagnie de Jésus, París, 1883.

Santa Teresa de Jesús y la crítica racionalista, obra premiada en un certamen de Salamanca en 15 de octubre de 1882, por el Dr. D. Juan Maura, lectoral de Mallorca (actualmente obispo de Orihuela). Palma, 1883.

Vida del P. Pedro de Calatayud por el P. Cecilio Gómez Rodeles, S. J., 1882. (Tercera edición). 
Histoire van Michael Servetus (Rotterdam, 1729). Traducción holandesa del libro latino de Allwoerden y Mosheim, Historia Michaelis Serveti (Helmstadt, 1727).

Michel Servet, estudio de Emilio Saisset en la Revista de Ambos Mundos (1848).

Michael Servet und seine Vorgaenger. Erstes Buch: Die Protestantischen Antitrinitarien von Faustus Socin, por Trechsel (Heidelberg, 1839).

Das Lehrsystem Michael Servets... von Tollin (Gütersloh, 1876). Del mismo autor hay las siguientes memorias: Lutero y Servet, Melachton y Servet, Infancia y juventud de Servet, Servet y la Biblia, Servet y la Dieta de Ausburgo, Servet y Bucero, Miguel Servet como geógrafo, Miguel Servet como médico, Panteísmo de Servet, Servet descubridor de la circulación de la sangre, etc., etc., unas sueltas, y otras en revistas alemanas. ${ }^{634}$

Servetus and Calvin... by R. Willis (London, 1877).

Servet ocupa también un lugar señalado entre los filósofos.

History of the progress and supression of the reformation in Spain (Londres, 1829). Obra de M'Crie, muy incompleta.

Historia de los protestantes españoles, por D. Adolfo de Castro (Cádiz, 1852).

Cenni biografici sui fratelli Giovanni è Alfonso di Valdesso. Opúsculo del Dr. Boehmer, que acompaña a su edición italiana de las Consideraciones divinas de Juan de Valdés.

Life and writings of Juan de Valdes otherwise Valdesso, Spanish reformer in the sixteenth century. By Benjamin Barron Wiffen (Londres, 1865). Va seguida de la traducción inglesa de las CX Consideraciones divinas.

Alfonso y Juan de Valdés, por D. Fermín Caballero. Tomo IV de la preciosa galería de Conquenses ilustres (Madrid, 1875).

Alfonso y Juan de Valdés, tesis sostenida por Eugenio Stern ante la Facultad de Teología Protestante de Strasburgo en 21 de noviembre de 1868.

Damián de Goes y la Inquisición de Portugal, por Lopes de Mendoça. En los Annaes das Sciencias e Lettras de Lisboa (1858). Damián de Goes fue erasmista y algo más. Su proceso se conserva en la Torre do Tombo.

No incluyo los Spanish Reformers. Bibliotheca Wiffeniana del Dr. Boehmer, por ser obra más propiamente bibliográfica que expositivo-crítica. Por igual razón omito los prólogos e ilustraciones de Usoz y Río a su colección de Reformistas españoles.

634 Posteriormente (1883) ha dado a luz dos nuevos opúsculos contestando al francés Chéréau, que en vano ha intentado despojar a Servet del lauro de descubridor de la circulación pulmonar, atribuyéndoselo al italiano Realdo Colombo. (Tercera edición) 
Life of Reverend Joseph Blanco-White, written by himself with portions of his correspondence. By John Hamilton Thom (1845, tres volúmenes).

El Abate Marchena, por D. G. Bono Serrano en su Miscelánea religiosa, politica y literaria, y por M. Latour en el último volumen de sus Estudios sobre España (1867).

La España Protestante, artículos del Sr. Guardia en la Revista Germánica, en la Nacional y en la de Ambos Mundos.

Michael de Molinos, por C. E. Schaulling (Gotha, 1855). En lengua danesa. ${ }^{635}$

Pasando ahora a la clase de humanistas, citaré, además de las de Vives, Sepúlveda, el Brocense y algún otro mentados ya, las monografías siguientes:

Aloysia Sigea et Nicolas Chorier, por Mr. Paul Allut (Lyon, 1862). Tirada de 112 ejemplares.

Elogio de Antonio de Lebrija, por D. Juan B. Muñoz, en el tomo III de las Memorias de la Academia de la Historia (1799). ${ }^{636}$

De vita et scriptis Alphonsi Garsic Matamori Commentarius, por Cerda y Rico, al frente de las obras de Matamoros (Madrid, 1769).

Vida del P. Perpiná, escrita en muy elegante latín por el P. Lazzeri, para acompañar a las obras de aquel famoso orador académico, en la edición romana de 1749 .

635 Para ampliar estas indicaciones véase nuestra Historia de los Heterodoxos españoles, en cuyas notas hemos procurado dar razón de todos los libros, folletos y artículos enlazados con nuestro asunto. Posteriormente a la publicación de nuestra obra, han aparecido, entre otras, las monografías siguientes, de que nos haremos cargo en la segunda edición:

Priscillian, ein neuaufgefundener lat. Schriftsteller des 4 Iabrhunderts... Von Dr. Georg. Schepss (Würzburg, 1886).

- Arnaldo de Vilanova (Monografía de Barthélemy Hauréau, inserta en el tomo XXVIII de la Histoire Littéraire de la France, 1881). Hauréau reconoce la patria española de Arnaldo, como antes había reconocido y puesto en claro la de Teodulfo.

- Alfonso et Juan de Valdés, leur vie et leurs écrits religieux. Étude historique, por Manuel Carrasco (1880).

—Casiodoro de Reina. Estudio biográfico de Tollin en el Bulletin Historique et Littéraire que publica la Sociedad Histórica del Protestantismo Francés (1882 y 1883).

—Golden Thoughts from the «Spiritual Guide» of Miguel Molinos (Glasgow, 1883). Con un prefacio histórico de J. Henry Shorthouse, autor de la famosa novela John Inglesant, saturada de molinosismo. Sobre el mismo asunto hay una monografía de Bigelow (Molinos the quietist).

-Blanco White por Gladstone (1879). Este estudio se publicó por primera vez en la Quarterly Review (1845). (Tercera edición)

636 Hoy hay que añadir el estudio crítico biográfico, muy apreciable, que sobre Nebrija ha publicado el Dr. D. Emeterio Suaña, catedrático de latín en el Instituto del Noviciado (1879). (Tercera edición) 
Juliana Morell, por D. Joaquín Roca y Cornet, en el tomo II de Memorias de la Academia de Buenas Letras de Barcelona (1868).

Emmanuelis Martini Ecclesiae Alonensis Decani vita... à Gregorio Majansio conscripta. Impresa con las Epistolas latinas y otros opúsculos del deán Martí, por Pedro Wiseling (Amsterdam, 1738).

Biografía de Nicolás Antonio, por Mayáns, en la Censura de Historias fabulosas (1742).

Memorias para la vida de Luzán, por su hijo D. Juan Antonio (1789).

Elogio de Pérez Bayer, por Fuster (incorporado en su Biblioteca Valenciana). Ídem, por D. Gaspar Bono Serrano en su Miscelánea (1870).

Elogio del P. Manuel Aponte, por el cardenal Mezzofanti (único escrito impreso de aquel polígloto estupendo). ${ }^{637}$

Biografía de Eximeno, por el Sr. Barbieri, en la edición del D. Lazarillo Vizcardi que publico la Sociedad de Bibliófilos Españoles (1872).

Memoria sobre la vida y escritos de Capmany, por D. Guillermo Forteza. Premiada por la Academia de Buenas Letras de Barcelona en 1868.

Elogio histórico de D. Agustín Montiano, por D. Cándido María Trigueros. En el II tomo de Memorias de la Academia Sevillana de Buenas Letras (1843).

Completa la serie de trabajos, harto escasos, por desgracia, acerca de nuestros filólogos, la monografía de Hervás y Panduro, que forma el tomo I de Conquenses ilustres, por D. F. Caballero (1866).

Antes de entrar en el campo de la historia y de las bellas letras, mencionaré de pasada el Examen histórico critico de los trabajos concernientes a la Flora hispano-lusitana, de D. Miguel Colmeiro; las Memorias sobre Valles, Piquer y otros insignes médicos, premiadas por la Academia de Medicina de Madrid e insertas en El Siglo Médico; el Discurso sobre los autores de artillería de D. Vicente de los Ríos; las monografías de D. Eduardo de Mariátegui sobre Escribá, Cristóbal de Rojas y otros ingenieros militares del siglo xvi; y los no mucho más numerosos estudios que tenemos referentes a jurisconsultos, políticos y economistas, y son:

Vidas de los jurisconsultos. Ordenólas nuestro eruditísimo Floranes, y existen algunas en la Academia de la Historia y otras en poder del Sr. Gayangos.

Noticias del Dr. Alonso Diaz de Montalvo. Tercer tomo de Conquenses ilustres, por D. Fermín Caballero (1873).

Vida de Antonio Agustín, arzobispo de Tarragona, publicada en castellano por Mayáns al frente de los Diálogos de armas y linajes, y en latín precedien-

637 Su título es: Discorso in lode del P. Emmanuele... Aponte dall' Abate Giuseppe Mezzofanti... (Bologna, 1820) (Segunda Edición). 
do a la edición completa de las obras de aquel memorable jurisconsulto y anticuario, hecha en Luca en 1766.

El mismo Mayáns escribió para el Tesoro de Meerman las biografías de Ramos del Manzano y Retes, y separadamente la de Puga y otros intérpretes del Derecho Romano. ${ }^{638}$

De las doctrinas politicas de los españoles en la época austriaca. Estudio del Sr. Cánovas del Castillo en la Revista de España (1869).

De vita et scriptis Josephi Finestres. Elegante biografía latina, escrita por el jesuita catalán D. Luciano Gallisá (Cervera, 1802). ${ }^{639}$

De los políticos y arbitristas españoles, discurso del Sr. Colmeiro (1857).

Elogio de Campomanes, por D. Vicente González Arnao (1803). Reimpresa en las Memorias de la Academia de la Historia.

Memorias para la vida de Jove-Llanos y noticias analiticas de sus obras, por D. Juan A. Ceán Bermúdez (Madrid, 1814).

Vida de Jove-Llanos. Precede a las Obras del esclarecido polígrafo asturiano, coleccionadas por el Sr. Nocedal para la Biblioteca de Rivadeneyra. Se ha impreso también aparte, en unión con el Discurso preliminar al tomo II de la propia colección. ${ }^{640}$

Llegamos, por fin, al terreno propiamente literario, que ha sido el mejor cultivado. A continuación va el índice de los estudios de esta especie que ofrecen más carácter monográfico:

Introducción de Damas Hinard al Poema del Cid (París, 1858).

Du Poème du Cid et de ses analogies avec la Chanson de Rolland, por Baret (1863).

638 Vid. los tomos V y VI del Thesaurus juris civilis et canonici. (Tercera Edición)

639 Véase, además, el discurso de Dou: In funere D. Josephi de Finestres en sus Gratulationes Oratoriae (Barcelona, 1826).

En la apertura del curso académico de 1877 en la Universidad de Oviedo disertó sobre la historia de la enseñanza del Derecho civil en España el Dr. D. Fermín Canella y Secades, que prepara un trabajo bibliográfico sobre el mismo asunto.

En la Revista de Legislación y Jurisprudencia (1864) publicó D. Pedro Gómez de la Serna un estudio sobre el progreso de los estudios juridicos en España durante el reinado de Isabel II.

En la misma Revista se hallarán varias biografías de antiguos jurisconsultos, especialmente la de Palacios-Rubios, por D. Vicente de la Fuente, y la de Ramos del Manzano, por el Sr. Cantero. (Tercera edición)

640 Noticia de casi todos los escritos acerca de este autor se hallará, en el volumen publicado por D. Julio Somoza en 1885, con el título de Jove-Llanos: nuevos datos para su biografía. Entre ellos merecen especial recuerdo un estudio de D. Antonio Alcalá Galiano, inserto en la antigua Revista de Madrid; otro de D. José Amador de los Ríos en La América, y el de D. Fortunato de Selgas sobre Jove-Llanos, considerado como crítico de artes. (1883, en la Revista de España). (Tercera Edición) 
Estudios sobre los judios de España, por D. José Amador de los Ríos (Madrid, 1848). Su mayor parte es de crítica literaria, a diferencia de la Historia social, política y religiosa de los judios de España y Portugal, que el mismo renombrado escritor ha dado recientemente a la estampa.

Poesía y Arte de los Árabes en España y Sicilia, del barón Adolfo Federico de Schack, admirablemente traducida por el Sr. D. Juan Valera (Madrid, 1867 a 72$).{ }^{641}$

De la poesía religiosa de los judios en España, por el Dr. Miguel Sachs (Berlín, 1845). Obra excelente, que merecía una traducción castellana.

De la Poesía Sinagogal entre los judíos españoles de la Edad Media, por Zunz (Berlín, 1855-1865).

Poesias Hebreas de la escuela italiana y española, por Abraham Geiger (en alemán) (Leipzig, 1856).

Salomo Gabirol, und seine Dichtungen. Estudio de Abraham Geiger (Leipzig, 1867).

De la poesía romance de los judios en España, por Kayserling (Leipzig, 1859).

Les vieux auteurs castillans (París, 1861). - La cour littéraire du Roi D. Jean II (Ibid., 1874). Obras eruditas, discretas y amenísimas del conde de Puymaigre.

Ricerche intorno al libro de Sindibad, por Comparetti (Milán, 1869). Hay una traducción inglesa con grandes aumentos (Londres, 1882).

Los Trovadores en España (Barcelona, 1861).- Observaciones sobre la poesía popular (1853).- - Ressenya dels antichs poetes catalans (1865). - De la poesía heroico-popular castellana.-Poetes catalans. Les Noves Rimades. - La Codolada (Montpellier, 1876)._- Trabajos del eminente escritor catalán D. Manuel Milá y Fontanals, que ni en madurez de juicio, ni en copia de datos, ni en delicadeza de análisis, ni en sobriedad y concisión, tienen superiores en nuestra literatura.

Essai sur la littérature catalane, por F. R. Cambouliou (1857). Hay una edición posterior muy aumentada.

De primitiva cantilenarum epicarum, vulgo romances apud Hispanos forma. Tesis de Huber (Berlín, 1844).

641 Sobre la poesía de los árabes andaluces versa una tesis doctoral de D. Leopoldo Eguílaz. También trataron de asuntos de literatura arábigo-hispana D. José Moreno Nieto en su discurso de entrada en la Academia de la Historia (sobre los historiadores árabes españoles, con una bibliografía de ellos, 1864); D. Francisco X. Simonet en muchos artículos y opúsculos; D. Francisco Codera, en una oración inaugural de la Universidad de Zaragoza, De literatura aljamiada, el Sr. D. Eduardo Saavedra, en su discurso de recepción en la Academia Española. (Segunda Edición) 
Darstellung der Spanischen Literatur in Mittelalter de Luis Clarus (1846). Clarus es pseudónimo de W. Volk.

Studien der Spanischen und Portuguesischen National Literatur, de Fernando José Wolf (Berlín, 1859). Este sabio hispanista publicó además diversos estudios sueltos muy notables. ${ }^{642}$

Recherches sur le texte et les sources du libro de Alexandre, por A. MorelFatio (París, 1875). ${ }^{643}$

Ilustraciones al Conde Lucanor, de D. Juan Manuel, traducido al francés (París, 1854), por M. Puibusque, autor también de la Historia comparada de las literaturas francesa y española (1843).

Sobre las versiones españolas de la Crónica Troyana. ${ }^{644}$ Memoria de Mussafia (Viena, 1871).

642 Los compendios en su obra principal versan, entre otras materias, sobre Juan de la Enzina, la Celestina, los Romances, el drama espańol y la literatura portuguesa. (Segunda Edición)

Entre los estudios sueltos de Wolf, merecen especial mención los siguientes:

-Ein Spanischen Frohnleichnamsspiel vom Todtentanz... (Esta Danza de la Muerte es la de Juan de Pedraza) (1852).

-Ein Beitrag zur Bibliographie der Cancioneros und zur Geschichte der Spanischen Kunstlyrik am Hofe Kaiser Karl's V (1853). (Estudia principalmente el Cancionero de Zaragoza, de 1554, que luego ha sido reimpreso en su integridad con eruditas ilustraciones por Alfredo Morel-Fatio en su interesante libro, L'Espagne au XVI et au XVII siècle, 1878.)

- Ueber den Hofnarren Kaiser Carl's V, genannt el Conde Don Francés de Zúñiga, und seine Chronik (1850).

- Antonio José da Silva (1860).

- Ueber Lope de Vega's Comedia Famosa de la Reina Doña María (1855).

-Ueber eine Sammlung Spanischer Romanzen in fliegenden Blättern auf der UniversitatsBibliothek zu Prag. (1849).

-Zur Bibliographie der Romanceros, etc., etc. (Añadido de la tercera edición)

643 Morel-Fatio ha publicado después, además de otros opúsculos, todos útiles:

—El Mágico Prodigioso, de Calderón (edición crítica con extensas ilustraciones) (1877).

—La "Comedia» Espagnole du XVII siècle (1885).

-Notice sur trois manuscrits de la Bibliothèque de Osuna (1885), (Importante para la historia del humanismo español).

—El Libro de Exemplos, de Clemente Sánchez de Vercial (1878).

- El Lazarillo de Tormes. (prefacio a una nueva traducción francesa, 1886).

—Estudio sobre las obras del Maestre D. Juan Fernández de Heredia, al frente de su Crónica de Morea, impresa por la Société de l'Orient Latín (1885). Sobre el mismo personaje hay una monografía alemana de Carlos Herquet (1878). (Tercera edición)

644 En diversas revistas alemanas hay muchos e interesantes trabajos de Mussafia, Knust, etc., que no cito por su corta extensión, aunque el mérito sea grande (Segunda Edición). De Mussafia deben mencionarse, no obstante, los dos opúsculos, cuyos títulos van a continuación: 
Traductores o imitadores españoles de Dante, erudito artículo de D. Cayetano Vidal y Valenciano en la Revista de España (1869). El autor prepara un trabajo mucho más extenso sobre la materia.

Discurso preliminar y observaciones que anteceden al Romancero general, coleccionado por el sabio D. Agustín Durán (Madrid, 1859). Reunidos pueden formar una excelente monografía.

De la poesía popular gallega, por D. M. Milá (en la Romanía, tomo VI).

De la poesía castellana en los siglos XIV y XV. Estudio de D. Pedro José Pidal, que sirve de introducción al Cancionero de Baena (Madrid, 1851). Estudio (en francés) sobre el Cancionero de Baena, por D. Leopoldo A. de Cueto en la Revue des Deux Mondes (1857).

Crónica del Cid.-Poema y Romancero del Cid. Estudios de D. Pedro José Pidal en la Revista de Madrid.

Sobre la legitimidad del Centón Epistolario, artículos del mismo. ${ }^{645}$

De la poesía mistica española, Malón de Chaide. Artículos del mismo en la Revista de Madrid. De estos y los demás estudios literarios, históricos y jurídicos de Pidal tendremos muy pronto colección esmerada y completa.

Elogio del Arzobispo D. Rodrigo Jiménez de Rada, por D. Vicente de la Fuente.

Vida literaria del Canciller Pero López de Ayala, por D. Rafael Floranes, en los tomos XIX y XX de Documentos inéditos para la Historia de España.

Vida del Marqués de Santillana, antepuesta por D. José Amador de los Ríos a su excelente edición de las Obras de aquel ilustre prócer (Madrid, 1852).

Ensayo histórico-crítico sobre los poetas valencianos de los siglos XIII, XIV y $X V$, por D. Rafael Ferrer y Bigné.

Estudio histórico crítico de los poetas valencianos de los siglos XVI, XVII y XVIII, por D. J. M. Puig Torralva y don F. Martí Grajales.

Ein Beitrag zur Bibliographie der Cancioneros aus der Marcus-Bibliothek in Venedig (1866). (Estudia principalmente el Cancionero de Stúniga)

-Über eine spanische Handschrift der Wiener Hofbibliothek. (El manuscrito es una colección de opúsculos jocosos de D. Diego de Mendoza y otros).

Ha publicado además una versión catalana del Libro de los Siete Sabios, con ilustraciones.

De Knust hay muy interesantes trabajos en el tomo CXLI de la Biblioteca publicada por el Círculo Literario de Stuttgart, que contiene Mitteilungen aus dem Eskurial (1879), y en el que ha impreso la Sociedad de Bibliófilos Españoles con el título de Dos obras didácticas $y$ dos leyendas (1878).

Baist ha ilustrado mucho la biografía de D. Juan Manuel al publicar su Libro de la Caza (Halle, 1880). (Añadido de la tercera edición)

645 Se publicaron en la Revista Española de Ambos Mundos. Sobre el mismo asunto hay un opúsculo de D. Adolfo de Castro, dos veces impreso (Cádiz, 1857.—Sevilla, 1875) (Segunda Edición). 
Ausias March, por D. José María Quadrado (en la Revista de Madrid, 1841). ${ }^{646}$

Vida de Alonso de Palencia. Discurso de entrada del Sr. Fabié en la Academia de la Historia.

Vida de Gonzalo Fernández de Oviedo, con que encabezó el Sr. Amador de los Ríos la Historia general y natural de las Indias, publicada por la Academia de la Historia de 1851 a 1855.

D. Fernando Colón, historiador de su padre, por el autor de la Biblioteca americana vetustíssima (Harrise). Monografía impresa por la Sociedad de Bibliófilos andaluces. (Sevilla. 1871)

Vida y obras del Dr. Lorenzo Galindez de Carvajal, por don Rafael Floranes. (Tomo XX de Documentos inéditos para la Historia de España).

Vida de Ambrosio de Morales, por el P. Flórez, en su edición del Viaje Santo (1765).

Progresos de la Historia de Aragón y elogios de sus cronistas, obra comenzada por Andrés de Ustarroz. El tomo I, concerniente a Zurita, fue publicado por el arcediano Dormer en 1680. El segundo permanece manuscrito.

Biografía del P. Juan de Mariana. Atribúyese a D. Vicente Noguera, ilustrador de la edición de la Historia general de España hecha en Valencia por Benito Monfort a fines del siglo pasado (1783 a 1790).

Biografía de D. Diego de Mendoza, atribuida a Mayáns. En la edición de la Guerra de Granada, hecha en Valencia, 1776, por Monfort.

Teniendo en cuenta su brevedad, no apunto las de Moncada y Calvete de Estrella, por Cerdá y Rico; la de Melo, por Capmany; la de Solís, por Mayáns, y otros historiadores de menor cuantía.

El Sr. Fabié prepara una monografía de Fr. Bartolomé de las Casas. ${ }^{647}$

646 Referentes a asuntos de literatura catalana se han publicado después de la fecha de esta carta las siguientes monografías, aparte de otras que no recuerdo:

—Dell' Antica Litteratura Catalana, Studii di Enrico Cardona (Nápoles, 1878). Trabajo ligerísimo de principiante mal informado.

- Ausias March y su época, por D. Joaquín Rubió y Ors (1882).

-Dr. Vicente García (Rector de Vallfogona). Su biografía y juicio de sus obras por el mismo Rubió. (Tortosa, 1879).

—Frá Anselm Turmeda, por D. Estanislao Aguiló (Palma, 1885).

- Biografía de D. Buenaventura Carlos Aribau, por D. Joaquín Riera y Bertrán (1883).

- Piferrer, por J. Sardá (1884).

—Ensayo histórico-critico sobre el teatro catalán, por D. José Ixart (1879).

- Historia del Renacimiento literario contemporáneo en Cataluña, Baleares y Valencia, por D. F. M. Tubino (1880). (Tercera edición)

647 Otra acaba de publicar el escritor americano D. Carlos Gutiérrez, con el título de Fr. Bartolomé de las Casas, su tiempo, su apostolado. Véanse, además, las conocidas 
Biografía de D. Carlos Coloma. Discurso de recepción de don Alejandro Llorente en la Academia de la Historia (1874).

Vida de Garcilaso de la Vega, por D. Eustaquio Fernández de Navarrete (Madrid, 1850).

Vida del Br. Francisco de la Torre. Discurso de recepción en la Academia Española, por D. Aureliano Fernández-Guerra, y contestación del Marqués de Molins.

Historia y juicio crítico de la escuela poética sevillana de los siglos XVI y XVI, por D. Ángel Laso de la Vega y Argüelles (Madrid, 1870).

Pablo de Céspedes. Memoria del Sr. D. Francisco María Tubino, premiada por la Academia de San Fernando (1868).

Francisco Pacheco, sus obras artísticas y literarias, en especial su libro de Descripción de verdaderos retratos, etc., por D. José María Asensio de Toledo (Sevilla, 1867). ${ }^{648}$

Góngora. An historical and critical Essay by Edward Churton (Londres, 1862). Dos volúmenes.

Biografía de Francisco de Rioja, trabajo eruditísimo de don Cayetano Alberto de la Barrera, preliminar a las Poesías de Rioja, edición de los Bibliófilos españoles (1867). Pueden servirle de complemento:

La canción a las ruinas de Itálica, ya original, ya refundida, no es de Francisco de Rioja. Informe leído a la Academia Española por D. Aureliano Fernández-Guerra, e inserto en el tomo I de las Memorias de aquel cuerpo literario (1870). Demuestra que el verdadero autor de dicha composición fue Rodrigo Caro.

La Epistola moral a Fabio no es de Rioja. Descubrimiento de su autor verdadero por D. Adolfo de Castro (Cádiz, 1875). Evidencia que la escribió el capitán Hernández de Andrada.

Biografía de los dos Argensolas, por Pellicer, en su Ensayo de una Biblioteca de traductores españoles (Madrid, 1878). ${ }^{649}$

Vida de D. Esteban Manuel de Villegas, por D. Vicente de los Ríos, a la cabeza de las Obras de aquel ingenio, edición de 1774.650

biografías de Quintana y Llorente, esta última en su edición francesa de las obras de Fr. Bartolomé (1822). (Segunda Edición)

La obra del Sr. Fabié se publicó en 1879, en el título de Vida y escritos de Fr. Bartolomé de las Casas (dos volúmenes). (Añadido de la Tercera Edición)

648 De este trabajo hay nueva edición, muy ampliada por su autor, en 1868, para acompañar a la reproducción foto-tipográfica del Libro de Retratos. (Tercera edición)

649 Sobre el mismo asunto versa el discurso de entrada del duque de Villahermosa en la Academia Española (1884) (Tercera edición).

650 El Sr. Cánovas del Castillo ha dado a conocer nuevos y peregrinos datos acerca de Villegas. Véase la carta que va al fin del tomo III de nuestros Heterodoxos, 1881(Tercera edición). 
De la poesía lírica castellana anterior al siglo XVIII. Discurso preliminar de Quintana a los tres primeros tomos de su Colección de poesías selectas castellanas.

De la poesía épica castellana. Introducción de Quintana a su Musa épica.

Vida de Ercilla, por D. José de Vargas Ponce. Quedó inédita e incompleta. Ha aprovechado parte de sus noticias el Sr. Ferrer del Río para el prólogo de la edición de La Araucana, hecha por la Academia Española en 1867. Sobre el mismo poema hay un buen estudio de Andrés Bello.

Estudio sobre Balbuena, por Lista. En la Revista de Sevilla, tomo III.

Vida de Quevedo, por D. Pablo A. de Tarsia (la primera edición es de 1663).

Vida de D. Francisco de Quevedo y Villegas. - Discursos preliminares a las Obras del célebre polígrafo en los tomos XXIII y XLVIII de la Biblioteca de Rivadeneyra. En ellos luce su autor, el Sr. D. Aureliano Fernández-Guerra, exquisita erudición, método excelente y gallardísimo estilo.

Sobre las obras sueltas de Lope de Vega. Artículo de Southey en la Quarterly Review de 1818, número 35.

Origenes del teatro español, obra póstuma de D. Leandro Fernández de Moratín, dada a luz en 1830 por la Academia de la Historia.

Discursos sobre la tragedia española, por D Agustín Montiano y Luyando (Madrid, 1750 y 53).

Lecciones de Literatura dramática, por D Alberto Lista (Madrid, 1836).

Sobre la tragedia española. - Sobre la comedia. - Sobre la poesía didáctica.Sobre el poema épico.-Apéndices del Sr. Martínez de la Rosa a su Poética.

Discurso sobre el influjo de la critica moderna en la decadencia del Teatro español (Madrid, 1828). - Estudios sobre Lope de Vega (en la Revista de Madrid), por D. Agustín Durán, a quien se deben asimismo excelentes análisis de algunas comedias de Tirso.

De poeseos dramatica genere hispanico, praesertim de Petro Calderone de la Barca (Hafniæ, 1817, 12º). Por Heiberg, poeta danés.

Ensayo histórico-filosófico sobre el Teatro español, diez artículos de D. Fermín Gonzalo Morón (en la Revista de España, de Indias y del extranjero, tomo VII).

Historia de la Literatura y del Arte dramático en España obra preciosa, escrita en alemán por el barón Adolfo Federico de Schack (Berlin, 1845), de la cual empezó a publicarse en 1862, no pasando del primer tomo, una buena traducción española hecha por el Sr. D. Eduardo de Mier. ${ }^{651}$

651 Al cabo de veinticuatro años, el Sr. Mier ha conseguido ver impresos los dos primeros volúmenes de su traducción del Schack, y no es de recelar que se queden inéditos los restantes, puesto que están en prensa cuando escribimos estas líneas. Entre los trabajos alemanes útiles para la historia del teatro español, debemos recordar el de H. Ulrici (Ueber 
Del drama religioso antes y después de Lope de Vega. - Prólogos a las Farsas de Lucas Fernández y a la Josephina de Micael de Carvajal. Opúsculos del Sr. Cañete, que hacen desear su prometida Historia del Teatro Español antes de Lope de Vega.

Discurso preliminar al tomo de Autos Sacramentales de la Biblioteca de Rivadeneyra. Notable trozo de crítica, debido a la pluma del malogrado escritor D. Eduardo González Pedroso (1865).

De las antiguas colecciones dramáticas españolas. Monografía alemana del barón Federico Halm de Münch-Bellinghausen (Viena, 1852).

Carácter dramático de Don Juan Ruiz de Alarcón. - Discurso de entrada del Sr. Hartzenbusch en la Academia Española. El mismo ilustre literato ha coleccionado e ilustrado para la Biblioteca de Rivadeneyra las obras dramáticas de Lope, Calderón, Alarcón y Tirso.

Don Juan Ruiz de Alarcón y Mendoza, peregrino libro compuesto por el Sr. D. Luis Fernández-Guerra y premiado por la Academia Española (1871). Al propio literato somos deudores de la muy estimable biografía de Moreto que encabeza las Obras de este preclaro dramaturgo en la tantas veces citada Biblioteca de Rivadeneyra.

Life of Lope de Vega... By lord Holland (1806).-Y acompañada de otra biografía de Guillén de Castro (Londres, 1817).

Lope de Vega, por Fauriel (Revue des deux mondes, 1839).

Étude sur la vie et les ouvres de Lope de Vega, par Ernest Lafond (París, 1857).

Crónica biográfica y bibliográfica de Lope de Vega, manuscrito de La Barrera, premiado por la Biblioteca Nacional, donde se conserva. ${ }^{652^{*}}$

Vida de Tirso de Molina. Manuscrito que perdió, según él refiere, D. Bartolomé José Gallardo en el famoso día de San Antonio de 1823.

Estudios acerca de Calderón, por el Sr. D. Patricio de la Escosura en la Biblioteca escogida de Autores españoles de la Academia Española, y en la Revista de España.

Sobre la tragedia de Calderón «El Mágico prodigioso». Disertación de Carlos Rosenkranz (Halle y Leipzig, 1829).

Shakespeare's dramatische Kunst, sein Verhältniss zu Calderon und Goethe (Halle, 1839); la Historia del Drama de Eichendorf (Leipzig, 1854); la más reciente y extensa de J. L. Klein (1874-75); el tratado de Leopoldo Schmidt Ueber die vier bedeutendsten Dramatiker der Spanier (Bonn, 1858); el estudio de Wolfg. Menzel sobre el influjo de Calderón y del teatro de las naciones latinas en Alemania (Stuttgart, 1859) (Tercera edición).

$652^{*}$ Publicado como vol. Io de la edición académica de las Obras de Lope de Vega, por D. Marcelino (Edición Nacional). 
Sobre «El Principe constante», disertación de Schulze (Weimar, 1812).

Die Schauspiele Calderon's dargestellt und erläutert, von Fried. Wilh. Val. Schmidt (Elberfield, 1857). ${ }^{653}$

Acerca de Calderón pueden verse, entre otros trabajos breves, el discurso de entrada del Sr. D. Adelardo L. de Ayala en la Academia Española, y el discurso sobre los Autos Sacramentales, leído en la misma corporación por D. F. de Paula Canalejas. ${ }^{654}$

Discurso sobre la primitiva novela española, por D. Buenaventura Carlos Aribau, en el torno III de la Biblioteca de Rivadeneyra.

Discurso sobre la novela española, por D. Eustaquio Fernández de Navarrete, en el tomo XXXIII de la misma publicación.

Discurso preliminar de D. Pascual de Gayangos al tomo de Libros de Caballerías de la propia Biblioteca (1857).

De l'Amadis de Gaule, son influence sur les maurs et la littérature au XVI et au XVII siècle (París, 1873), por Baret.

Kritischer Versuch über den Roman Amadis von Gallien, del Dr. Braunfels (Leipzig, 1876).

Jerónimo de Urrea y su libro inédito D. Clarisel de las Flores, por D. Jerónimo Borao (Zaragoza, 1867).

Los estudios relativos a Cervantes son innumerables, aunque muchos de ellos sobran. Por evitar prolijidad, sólo mencionaré los siguientes, dejando

653 El mismo Schmidt había publicado mucho antes una disertación sobre La Cisma de Inglaterra (Berlín, 1819), y su hijo Leopoldo otra sobre los dramas mitológicos de Calderón, en el tomo X del Neues Rheinisches Museum. Sobre La Cisma hay otra disertación de H. Vebrich (1863), autor también de un libro de Quaestiones Calderonianae (Bonn, 1865). Tampoco debe olvidarse la disertación de W. Beyschlag De Cypriano Mago et Martyre, Calderonianae tragadia persona primaria (Halle, 1866); la del celebrado estético Moritz Carriere sobre el Mágico y el Fausto (1876), y la de Guillermo Meyer sobre La Sibila de Oriente (1879). También La vida es sueño ha sido objeto de varios trabajos especiales, que pueden verse catalogados por Dorer. (Tercera edición).

654 Nuestro pomposo centenario de Calderón (1881) resultó harto estéril para el progreso de la crítica calderoniana. De la pobreza de sus resultados puede juzgarse leyendo la interesante revista crítica que Morel-Fatio publicó aquel mismo año, y amplió después en otros artículos. Limitándonos a los trabajos que contienen algo nuevo, citaremos:

-Biografía de Calderón, por D. Felipe Picatoste (en un libro titulado Homenaje a Calderón, 1881).

- Memoria acerca de "El Mágico Prodigioso" de Calderón, y en especial sobre las relaciones de este drama con el "Fausto» de Goethe, por D. A. Sánchez Moguel (Madrid, 1881).

-Discurso acerca de las costumbres de los españoles en el siglo XVII, fundado en el estudio de las comedias de Calderón, por D. Adolfo de Castro, 1881.

- El sentimiento del honor en el teatro de Calderón, por D. A. Rubió y Lluch, 1882. (Tercera edición). 
a cargo del Sr. Ríus la tarea de formar un catálogo completo de esta rama de la bibliografía cervántica.

Vida de Cervantes, por Mayáns. (En la edición de Londres de 1738).

Análisis del Quijote, por D. Vicente de los Ríos. (En la edición académica de 1780.)

Vida de Cervantes, por D Juan Antonio Pellicer (1797).

Vida, etc., por D. Martín Fernández de Navarrete (Madrid, 1819).

Notas a la vida de Cervantes, de Navarrete (en la Revista de Sevilla, tomo III), por D. Cayetano Alberto de la Barrera.

Vida de Cervantes, por Quintana (1797).

Cervantes vindicado en ciento quince pasajes del Ingenioso Hidalgo que no han entendido o han entendido mal sus comentadores, por D. Juan Calderón (Madrid, 1854).

Elogio de Cervantes, por D. José Mor de Fuentes (1835).

Vida de Cervantes, por D. Buenaventura Carlos Aribau (1847).

Cervantes, sa vie, son temps, ses auvres, por Emilio Chasles (París, 1867).

Vida de Cervantes, por D. Jerónimo Morán, en la lujosa edición del Quijote hecha por Dorregaray (1863).

Comentarios filosóficos al Quijote (en La América). - La estafeta de Urganda.-El Correo de Alquife. - Segundo aviso de Merlin.-La verdad sobre el Quijote.- Monografías sobre el sentido esotérico del Quijote, por D. Nicolás Díaz de Benjumea.

El Quijote y la estafeta de Urganda (1862)._- Cervantes y el Quijote (1872). Estudios críticos del Sr. Tubino.

Sobre el carácter del Quijote, discurso académico del Sr. Valera (1864). Apología de Cervantes por Eximeno (Madrid, 1806).

Pericia geográfica de Cervantes, por D. Fermín Caballero.- Bellezas de Medicina práctica descubiertas en el Ingenioso Hidalgo, por Hernández Morejón.- Jurisprudencia de Cervantes, por don Antonio Martín Gamero.- Cervantes teólogo e Intraducibilidad del Quijote, por D. José María Sbarbi.-Cervantes y la filosofía española, por D. Federico de Castro.-Ideas económicas del Quijote, por D. Luis Piernas y Hurtado. ${ }^{655}$

La sepultura de Cervantes, por el marqués de Molins (1870). ${ }^{656}$

655 Confieso que muchos de los estudios sobre Cervantes, en especial los que quieren demostrar la aptitud del gran novelador para tal o cual arte o ciencia, más bien pertenecen a una biblioteca lúdicra que a una seria, pero nunca es malo conocer los descarríos de la crítica, siquiera para apartarse de ellos. (Segunda edición).

656 Pudieran ańadirse muchos más; pero nos limitaremos a los siguientes, que por un concepto o por otro nos parecen curiosos. Van por orden alfabético: 
Lecciones sobre la literatura española, francesa, italiana e inglesa del siglo XVIII, dadas en el Ateneo por D. Antonio Alcalá Galiano. La parte española es harto escasa. El mismo escritor publicó en El Laberinto notables estudios críticos acerca de Meléndez, Cienfuegos, Moratín, Arriaza y otros poetas del siglo pasado, y en la Crónica de ambos mundos otro sobre la Escuela sevillana de la misma época; asunto tratado también por Lista en la Revista de Madrid (primera época). ${ }^{657}$

Acosta y Lozano (D. Zacarías)._- Demostraciones críticas contra el texto de la edición de Argamasilla. En el tomo IX de El Museo Universal.

Asensio (D. José María). - Nuevos documentos para ilustrar la vida de Cervantes (1864).—Dos cartas literarias de Asensio y D. Aureliano Fernández-Guerra (1867 y 1870).- Cervantes y sus obras: Cartas críticas (1870). - Los continuadores del Ingenioso Hidalgo, en la Revista de España (1873)._- Cervantes inventor (1874)._- El Conde de Lemos, protector de Cervantes (1880). Son muchos más, aunque generalmente de poco volumen, los trabajos de este infatigable cervantista.

Armas y Cárdenas._- El Quijote de Avellaneda y sus críticos. La Habana, 1884. El autor ha publicado después otro folleto sobre la Dorotea de Lope.

Biedermann.- Don Quichotte et la tâche de ses traducteurs (1837).

Duffield (A. I.). Don Quixote, his critics and commentators (Londres, 1881).

Fernández-Guerra (D. Aureliano). —Noticia de un precioso códice de la Biblioteca Colombina, etc. (1864).

Mainez (D. R.).—Vida de Cervantes (Cádiz, 1877).

Mérimée (Próspero).-_Prólogo al Quixote en la traducción francesa de Luciano Biart.

Montégut (Em.)._- El Quixote, artículo incluido en su libro Types littéraires et fantaisies esthétiques (1882).

Pi y Molist (D. Emilio).- Primores del Quixote en la relación médico-psicológica (Barcelona, 1886).

Revilla.-La interpretación simbólica del Quixote.—La verdad sobre el Quixote, etc., etc. Estudios incluidos en la colección de sus Obras (1883).

Saint-Víctor (Paul).—Don Quixote. Artículo inserto en su libro Hommes et Dieux (1867).

Sainte-Beuve.-Estudio sobre Cervantes en el tomo VIII de los Nouveaux Lundis.

Salvá (D. Vicente)._ ¿Ha sido juzgado el Quixote como esta obra merece? (En El Liceo Valenciano, 1838.)

Edmundo Dorer ha coleccionado una interesante antología de los principales juicios acerca del Quixote formulados por escritores alemanes, entre los cuales figuran nombres tan ilustres como los de Herder, Goethe, Schelling, Hegel, Schopenhauer, Humboldt, Tieck, ambos Schlegel, Juan Pablo Richter, Rosenkranz, Enrique Heine, Uhland, etc., etc. Aparte de estas apreciaciones luminosas, pero generales, no hay en alemán monografía sobre Cervantes, a no ser la de R. Baumstark (Cervantes. Ein Spanisches Lebensbild, Friburgo, 1875). El autor ha publicado otra análoga sobre Quevedo (Don Francisco de Quevedo. Ein Spanisches Lebensbild... 1871). Esta obra ha sido totalmente oscurecida por la que sobre el mismo asunto acaba de publicar Ernesto Mérimée. (Tercera edición)

657 Prestaría un buen servicio a las letras quien imprimiese coleccionados los escritos literarios sueltos de estos críticos y de otros contemporáneos, como Gallego, Pidal, Estébanez Calderón, Burgos, Durán, Ochoa, Hartzenbusch, Cañete, etc., etc. (Primera Edición) 
De la poesía castellana del siglo XVIII. Discurso de Quintana, puesto al principio del tomo IV de su colección de Poesías selectas, en la segunda edición (1830).

Juicio crítico (sic) de los principales poetas españoles de la última era. Obra póstuma de D. José Gómez Hermosilla (París, 1845). Vale poquísimo. Refutóla Gallego en la parte relativa a Meléndez. También lo hizo Andrés Bello, como puede verse en la Biblioteca Venezolana de Rojas.

Bosquejo histórico-crítico de la poesía castellana en el siglo XvIII, antepuesto por el Sr. D. Leopoldo Augusto de Cueto a la muy copiosa colección de Líricos de dicho período en la Biblioteca de Rivadeneyra. El título de este precioso trabajo peca de modesto en demasía y no da bastante idea de su mérito e importancia: no debiera llamarse Bosquejo, sino Historia crítica. ¡Pluguiera a Dios que abundasen en España producciones semejantes a ésta en riqueza de datos, severidad de juicio y amenidad y corrección de estilo! De este Bosquejo se ha hecho en París una edición fraudulenta en dos tomos con destino a América. De esperar es que el Sr. Cueto lo reimprima por separado, agregándole la Reseña bibliográfica de poetas del siglo XVIII, que tiene inédita, y puede considerarse como su complemento.

Historia de la crítica literaria desde Luzán hasta nuestros días. Memoria del Sr. D. Francisco Fernández y González, premiada por la Academia Española en 1870. Suplemento indispensable a esta obra son los artículos que sobre ella publicó usted en La Enseñanza y reprodujo en sus Ensayos criticos (Lugo, 1868).

Noticias para la vida del P. Flórez, recogidas por el P. Méndez (1780).

Elogio de D. Juan Pablo Forner, leído por D. Joaquín Sotelo en la Academia de Jurisprudencia en 23 de mayo de 1797. Reimprimióle el Sr. Cueto al frente de las Poesías de Forner en el tomo LXII de la Biblioteca de Rivadeneyra.

Vida de D. Juan Meléndez Valdés, por Quintana (1820).

Historia y juicio crítico (sic) de la escuela poética sevillana en los siglos XVIII y XIX. Madrid, 1876, por D. Ángel Lasso de la Vega.

Breve reseña del actual Renacimiento de la Lengua y Literatura Catalanas, por D. Joaquín Rubió y Ors (1877).

Datos y apuntes para la historia de la moderna literatura catalana, por D. J. Leopoldo Feu. En el tomo II de Memorias de la Academia de Barcelona. Vida de Don Nicolás Fernández de Moratín, por su hijo don Leandro (1821). Vida de Don Leandro F. de Moratín, por Aribau. Impresa con la anterior en el tomo II de la Biblioteca de Rivadeneyra.

Vida de Don Leandro Fernández de Moratín, por D. Manuel Silvela (1845 y 1867). 
Quintana considerado como poeta lírico. Discurso leído por el Sr. Cueto al tomar asiento en la Academia Espańola.

Conforme nos vamos acercando a la edad presente, disminuyen más y más las monografías. Así que, relativas a contemporáneos, sólo recuerdo (limitándome a las de alguna extensión, y que forman libro aparte) la $\mathrm{Me}$ moria sobre la vida política y literaria de Martínez de la Rosa, por Rebello da Silva (1863); la auto-biografía de D. Joaquín Lorenzo Villanueva (Londres, 1825); la Biografía del Conde de Toreno, y el extenso discurso necrológico del Duque de Rivas, trabajos ambos del Sr. Cueto; la vida de don Próspero Bofarull, escrita por el Sr. Milá y Fontanals (1860), y algunos discursos académicos que por sus dimensiones e importancia merecen contarse entre las monografías, cual es, por ejemplo, el del Sr. Escosura sobre Espronceda, Vega y Pardo, leído en la Academia Española en 1870.

No ha sido mucho más beneficiada mediante monografías la literatura lusitana. Las principales son las siguientes:

Ensayo sobre el origen y progreso de las matemáticas en Portugal, por Garção Stockler.

Memoria sobre la literatura sagrada de los judios portugueses hasta fines del siglo XV.-Biografías de los matemáticos Pedro Núnez y Francisco de Melo.Sobre algunas traducciones biblicas en lengua portuguesa.-De los orígenes $y$ progresos de la poesía en Portugal, etc. Memorias de Antonio Ribeiro dos Sanctos en las de la Academia Real das Sciencias de Lisboa. Manuscritas dejó, entre otros muchos importantísimos trabajos, este docto bibliotecario unas Memorias para la Historia de la poesía en Portugal, con noticias de los antiguos cancioneros.-Memoria sobre las controversias de Jerónimo de Santa Fe con los judios. - Memoria acerca de los libros raros de las bibliotecas de Portugal. Están entre los manuscritos del mismo Ribeiro dos Sanctos, conservados en gran parte en la Biblioteca Nacional de Lisboa.

Sobre los antiguos Cancioneros Portugueses, estudio de Bellermann (Berlín, 1840).

Über die erste portuguesische Kunst und Hofpoesie, von Friederich Díez.

Discurso sobre el Palmerin de Inglaterra y su verdadero autor, por D. N. D. de Benjumea (Lisboa, 1875). ${ }^{658}$

Antonio Ferreira, por Julio de Castilho.

Los estudios de Teófilo Braga sobre literatura portuguesa llegan a 15 volúmenes, constituyendo generalmente cada cual monografía separada. Y son:

658 Sobre el mismo asunto hay un folleto de Manuel Odorico Mendes (1860). (Segunda Edición) 
Epopeyas de la raza mozárabe.

Trovadores gallego-portugueses.

La poesía palaciega en el siglo XV.

El Amadis de Gaula.

Los Qinhentistas (escritores del siglo xvi): Sá de Miranda y su escuela.

Bernaldim Ribeiro, y los bucólicos.

Historia del teatro portugués. Cuatro tomos:

$1^{\circ}$ Gil Vicente y su escuela.

$2^{\circ}$ La tragedia clásica y las tragi-comedias (teatro del siglo XVII).

$3^{\circ}$ La Baja Comedia y la Opera (siglo XviII).

40 Almeida-Garret y los dramas románticos.

Historia de Camoens. Forma dos tomos, uno de ellos dividido en dos volúmenes.

Además de este extenso y luminoso estudio sobre Camoens, hay otro biográfico-bibliográfico del vizconde de Juromenha, que sirve de tomo primero en su edición de las obras del gran poeta lusitano (1860), y en inglés uno de Adamson (Memoirs of life and writings of Camoens, 1820).

La Introducción de Braga a su Historia forma un volumen. Ha publicado, además, una Historia de la poesía popular portuguesa (introducción a su Romancero) y una colección de Estudios da Edade Media. Entre las demás monografías portuguesas mencionaré:

Ensayo sobre la vida y escritos de Gil Vicente, antepuesto por Monteiro a las obras del Plauto lusitano en la reimpresión de Hamburgo (1835).

Biografía de F. Luis de Sousa, por D. Francisco Alejandro Lobo, obispo de Viseo.

Memoria biographica e litteraria, acerca de M. M. Barbosa de Bocage, por Luis Augusto Rebello da Silva (Lisboa, 1854). Sobre el mismo poeta hay un extenso trabajo de José Feliciano de Castilho (París, 1867, dos volúmenes de la Livraria classica), y otro posterior de Teófilo Braga.

Rebello da Silva publicó estudios sobre otros ingenios de la Arcadia, como Domingo dos Reis Quita, Garçao y Antonio Diniz.

Le Brésil Littéraire, por Fernando Wolf (Berlín, 1863).

Los estudios sueltos de Revistas, Memorias de Academias, etcétera, así en Portugal como en Castilla y Cataluña, son numerosos e importantes; pero ni he pensado nunca en apurar la materia, ni es posible citar todos los que recuerdo sin alargar demasiado este apéndice. Con pequeño trabajo podrá acrecentar cualquier lector curioso este catálogo.

En punto a trabajos de escritores castellanos sobre la literatura portuguesa, conocemos sólo uno relativo a Camoens, escrito por el Sr. Canalejas 
en la Revista Ibérica; la biografía de Antonio Feliciano del Castilho, impresa en Cádiz, 1837, con las iniciales T. G.; y el erudito libro del Sr. Romero Ortiz, titulado Literatura portuguesa del siglo XIX. ${ }^{659}$

Considerable parecerá, a primera vista, este catálogo, sin duda incompleto, y tendrán de fijo por infundadas nuestras quejas quienes ignoren que pocos, muy pocos, de los estudios referidos, tienen el verdadero carácter expositivo crítico, que muchos son puramente biográficos, que otros pecan de brevedad excesiva, y que, por consecuencia de todo esto, conviene rehacerlos casi todos bajo un plan más amplio y completo. Nótese, además, que la mayor parte de ellos conciernen a la literatura y no a las ciencias ni a la filosofía, y que muchos de los mejores son parto de plumas extranjeras y aún no han sido castellanizados, habiendo numerosas materias enteramente intactas, no obstante ser de igual o superior interés que las hasta hoy dilucidadas. El publicar estudios sueltos sobre determinados escritores, cuando éstos no son muy conspicuos e importantes, no me parece método tan acertado como el de considerarlos agrupados, historiando el género que cultivaron, la escuela a que pertenecieron, etc. Por eso convendría que se publicasen libros semejantes a Los Misticos españoles, de Rousselot; Los trovadores en España y La poesía heroico-popular, de Milá; La corte literaria de D. Juan II, de Puymaigre; la Historia de los falsos cronicones, de Godoy Alcántara; el Bosquejo de la poesía castellana en el siglo XVIII, de Cueto, y algún otro de la misma índole.

A. tres puntos principales debe, en mi concepto, dirigirse la actividad erudita, por lo que a monografías respecta, a saber:

I. Exposiciones histórico-críticas de la vida y doctrinas de los grandes pensadores ibéricos y de las escuelas de que respectivamente fueron cabeza, v. gr.:

Séneca y el Senequismo. Damos este nombre a la doctrina moral estoica tal como la modificó y formuló Séneca, doctrina que en toda la Edad Media y en los siglos XVı y XVII ejerce muy señalada influencia en España y fuera de ella.

San Isidoro y la tradición Isidoriana.

Averroes y el Averroismo.

659 A la lista de los trabajos sobre Camoens, deben añadirse:

-Oliveira Martins. Os Lusiadas, ensaio sobre Camoes e a sua obra em relaçao à sociedade portugueza e ao movimiento da Renascença. Porto, 1872.

—Latino Coelho. Luis de Camoes, 1880. (Es el primer volumen de su Galería de varones ilustres de Portugal).

-Magnin (Carlos). Biografía de Camoens en su libro Causeries et Méditations, 1843.

De otros muchos da razón la Bibliographia Camoniana, de Th. Braga. (Tercera edición) 
Maymónides y el Maymonismo. En este libro deben estudiarse los progresos del panteísmo hispano-judaico, hasta Espinosa, y sus relaciones con la moderna filosofía germánica.

Lulio y el Lulismo.

Vives y el Vivismo.

Suárez y el Suarismo.

En la misma línea pueden entrar otros preclaros sabios españoles que, si no dieron origen a escuelas o sectas filosóficas propiamente dichas, personifican grandes fases de la vida intelectual de la Península, aparecen como iniciadores de trascendentales movimientos en la esfera de las ideas o descuellan por la originalidad y universalidad de su doctrina, de tal suerte, que para darlos a conocer debidamente es preciso trazar en torno suyo el cuadro de la época en que florecieron, con sus antecedentes y consiguientes. A esta clase corresponden:

El arzobispo D. Rodrigo Jiménez de Rada.

Alfonso el Sabio.

Antonio de Nebrija.

Antonio Agustín.

Arias Montano.

Caramuel.

Feijoo.

Campomanes.

Jove-Llanos.

Hervás y Panduro.

Más o menos próximos por su significación histórica a los que acabo de mencionar, figuran en los anales de la ciencia espańola otros muchos egregios varones, dignos asimismo de que sus hechos y escritos sean expuestos críticamente, bajo la forma monográfica, en sendos volúmenes. Sólo citaré, por no ser prolijo, los nombres de Quintiliano, Thofail, Jehudah Leví, Avicebrón, Pedro Hispano, San Raimundo de Peñafort, el infante D. Juan Manuel, Arnaldo de Vilanova, el Tostado, los Abarbaneles, Fray Antonio de Guevara, Sepúlveda, Gouvea, Gómez Pereyra, Fox Morcillo, Miguel Servet, Vallés, Mariana, Fr. Luis de Granada, Domingo de Soto, Vitoria, Molina, Vázquez, Fr. Luis de León. Azpilcueta, el Brocense, Martín del Río, Quevedo, Gracián, Nieremberg, Isaac Cardoso, el P. Tosca, Martín Martínez, Piquer, Luzán, Mayáns, Pérez Bayer, Andrés, Eximeno, el P. Ceballos, los autores de La España Sagrada, Forner, Martínez Marina, Lista, etc., etc.

II. Estudios biográfico-críticos extensos, por el estilo del Don Juan Ruiz de Alarcón, del Sr. Fernández-Guerra (D. Luis), acerca de los principales in- 
genios peninsulares, no juzgados todavía con el detenimiento y profundidad necesarios, ni menos relativamente a su tiempo y a la influencia que tuvieron en las vicisitudes de la bella literatura. Hállanse en este caso (y únicamente recuerdo los de primera marca) Lucano, Prudencio, Ausias March, Juan de Mena, Torres Naharro, Garcilaso, Ercilla, Balbuena, Góngora, los Argensolas, Lope de Vega, Tirso de Molina, Moreto, Rojas, Calderón, los Iriartes, D. Ramón de la Cruz, los Moratines, Meléndez, Arriaza, Quintana, etc., etc., ninguno de los cuales tiene en nuestra lengua libro aparte de crítica (que yo sepa), cuando en Francia y otras naciones no hay poeta mediano que no esté juzgado y aquilatado en todos sus aspectos y relaciones.

III. Historia de los principales períodos, ramas y corrientes de nuestra cultura, de determinados grupos de escritores, y de las opiniones profesadas por los españoles en orden a ciertos puntos de la ciencia. Por ejemplo:

Los Padres toledanos.

Sabios españoles que brillaron en las Galias bajo la dominación Carlovingia. Los Kabalistas españoles.

Impugnadores del judaísmo y del mahometismo.

El escolasticismo tomista en España.

Anti-aristotélicosespañoles.

La antropología filosófica en España. Estudios fisionómicos y frenológicos.

Doctrinas de los filósofos espańoles sobre la naturaleza y origen de las ideas.

Ídem sobre los primeros principios de los cuerpos.

Ídem sobre el alma de los brutos. ${ }^{660}$

Filosofía del derecho en España.

El derecho romano en España.

Políticos españoles.

Moralistas.

Místicos.

Casuistas.

660 Quien historie este punto y el anterior deberá examinar, entre otras obras, la $D e$ opere sex dierum, de Suárez; los Cursos filosóficos de Bernaldo de Quirós, Henao y Arriaga; la Philosophia sacra, de Vallés; la Antoniana Margarita, de Gómez Pereyra; las Objectiones, de Miguel de Palacios; el Endecálogo contra la Antoniana Margarita; la Philosophia libera, de Isaac Cardoso; el Diamantino escudo atomístico, de Guzmán; los tratados de los PP. Tosca y Nájera; El ocaso de las formas aristotélicas, de Zapata; la Philosophia sceptica, de Martín Martínez; el Theatro critico y las Cartas eruditas, del P. Feijoo; la Física moderna y el Discurso sobre el mecanismo, de Piquer; las Institutiones philosophicae et mathematicae, de Eximeno, y la Filosofía fundamental, de Balmes, que ofrecen toda variedad de opiniones, algunas harto originales y atrevidas. (Primera Edición) 


\section{Canonistas.}

Escriturarios rabínicos.

Ídem católicos.

La oratoria sagrada.

Heterodoxos españoles.

Impugnadores del enciclopedismo.

Las controversias de auxiliis.

Hebraizantes españoles.

Arabistas.

Helenistas.

Latinistas.

Cultivadores de lenguas exóticas.

Arqueólogos.

Geógrafos.

Historiadores de Indias.

Geopónicos.

La estética en España.

Las doctrinas sobre la Historia. ${ }^{661}$

Poetas hispano-latinos modernos.

El culteranismo en España.

La poesía lírico-dramática.

La tragedia clásica.

Escuela poética salmantina.

Los jesuitas españoles en Italia a fines del siglo XVIII, y otros mil temas semejantes a éstos, que sin orden he ido apuntando a medida que acudían a la memoria y a la pluma.

El promover la composición y publicación de tales Memorias toca a las cinco Academias, según su especialidad respectiva, pero más particularmente a la de la Historia, que tiene por instituto cultivar, no sólo la política, civil y religiosa, sino también la intelectual de la Península. Y para que esos trabajos se hiciesen con el debido esmero, convendría que dichas corporaciones señalaran para los certámenes plazos más largos que los de costumbre, teniendo en cuenta las dificultades inherentes a la busca de datos, ordenación del plan y redacción correcta y elegante. Bien puede asegurarse que cuantos autores han sido laureados por nuestras Academias y en méritos de obras eruditas de cierto bulto, las tenían ya compuestas, o cuando menos, habían acopiado

661 Sobre esta materia disertó el Sr. Godoy Alcántara en su discurso de entrada en la Academia de la Historia, pero con la brevedad que convenía a su intento. (Segunda Edición) 
para ellas gran cantidad de materiales al anunciarse los concursos, siendo, por tanto, una casualidad el que éstos no resultasen estériles.

También seria medio muy conducente para obtener buenas monografías del género indicado, el exigir que las tesis doctorales, en vez de reducirse, cual vemos comúnmente, a breves disertaciones, sean escritos de mayor extensión, verdaderos libros, como en otras naciones acontece, y que éstos versen precisamente sobre puntos de la historia científica o literaria de nuestra patria. Lo que hoy se pide, para el caso, a los graduandos es tan poco y de tan poco momento y utilidad, que bien podría suprimirse sin inconveniente alguno, más aún que por las exiguas dimensiones de los discursos, por la facilidad de hallar en libros modernos y sin la menor fatiga las especies necesarias para componerlos. ¿№ es un dolor el ver cuál nuestros aspirantes a doctores hacen alarde de una erudición postiza ante el claustro de la Universidad Central, disertando ostentosamente sobre el Budismo, y Sócrates, y el Petrarca, y Descartes, y Kant, y el Darwinismo, y otras materias tan poco trilladas como éstas, mientras dejan en despreciativo olvido las obras y las doctrinas de nuestros antepasados, sobre las cuales tanto bueno y verdaderamente nuevo pudieran decirnos?

En la próxima carta seguiré conversando con usted, mi señor D. Gumersindo, sobre los medios de fomentar el estudio de nuestra pasada cultura, y lograr, en un plazo más o menos breve, historias de las diversas ciencias en España. ${ }^{662}$

Soy de V. siempre devoto amigo y servidor.

\section{Marcelino Menéndez Pelayo Santander, 10 julio $1876 .{ }^{663}$}

662 No terminaré esta carta sin hacer mérito de dos notabilísimas monografías, que sólo en parte dicen relación a nuestra literatura: los Apuntes para la historia de la sátira en la antigüedad y en la Edad Media, de don Joaquín Rubió y Ors (Barcelona, 1868), y La Sátira Provenzal, de don José Coll y Vehí (1861). (Primera Edición)

Entre las bibliografías he omitido la Disquisitio de quibusdam libris hispanis rarioribus, de D. Ignacio de Asso (1794), y su Bibliotheca Arabico-Aragonensis (1782 y 83). (Añadido de la Segunda Edición)

663 Después de la segunda edición de esta carta han aparecido algunos importantes trabajos de Literatura Espańola que sería injusto omitir. Prescindiremos de los que van citados en notas anteriores.

Poema del Cid. Tal es el título de un libro póstumo de Andrés Bello, publicado en Santiago de Chile en 1881, como segundo tomo de las Obras de aquel insigne filólogo. El trabajo de Bello, admirable dada su fecha (anterior a 1862), y tenido en cuenta el aislamiento en que el autor vivía, anuncia ya algunos de los resultados más importantes obtenidos después por la erudición moderna. Otro tanto debe decirse de algunos de sus Opúsculos literarios y críticos, que ocupan tres volúmenes de la edición chilena (1883- 
85), mereciendo especial recomendación los titulados Origen de la epopeya romancesca.Uso antiguo de la rima asonante en la poesía latina de la Edad Media y en la francesa.Observaciones sobre la "Historia de la literatura española» de Ticknor.-Del Ritmo y de la Rima, etc.

Para esta edición ha escrito una extensa biografía de Bello, uno de sus más aventajados discípulos, D. Miguel Luis Amunátegui.

- Essai Sur la vie et les auvres de D. Francisco de Quevedo por E. Mérimée, profesor de la Facultad de Letras de Tolosa de Francia, 1886. Es una de las mejores y más sólidas monografías que en lengua alguna se hayan compuesto acerca de un escritor español.

- Saavedra Fajardo. Sus pensamientos, sus poesias, sus opúsculos..., por el conde de Roche y D. José Pío Tejera. Murcia, 1884.

- El conde de Villamediana, estudio biográfico-crítico, por D. Emilio Cotarelo, 1886.

-Don Diego Hurtado de Mendoza, estudio biográfico-crítico, por don Eloy Señán y Alonso (1886, Jerez de la Frontera).

-Vida y escritos de Francisco López de Villalobos, por D. Antonio María Fabié, 1886. (Precede a las obras de Villalobos, publicadas por la Sociedad de Bibliófilos Españoles).

-Essai sur le Théâtre Espagnol, por Luis de Viel-Castel. París, 1882. Dos volúmenes. Este libro, escrito hace más de cincuenta años, ha sido publicado por su autor sin tener en cuenta para nada los numerosos trabajos críticos impresos en este medio siglo. A pesar de todo, la obra de Viel-Castel tiene cierto valor literario, y puede decirse que él y Viguier iniciaron en Francia el estudio de nuestro teatro. A Viguier se deben los mejores estudios sobre las fuentes espańolas de Corneille. Vid. su libro Fragments et Correspondance, 1875

Entre las más recientes monografías consagradas a asuntos de literatura contemporánea, es imposible omitir la de Bretón de los Herreros, por el marqués de Molins (1883), la de El Solitario (D. Serafín Estébanez Calderón), por Cánovas del Castillo; los tres volúmenes de Gomes de Amorim acerca de Almeida-Garret (1881-1884), la Historia do romantismo de Teófilo Braga (1880), y el libro de Antonio de Serpa sobre Alejandro Herculano (1881).

Citaremos, por último, tres libros de asunto hispano-americano: la Historia de la literatura en Nueva Granada, por José María Vergara (Bogotá, 1867); la Historia de la literatura colonial de Chile, por D. José Toribio Medina (tres volúmenes, 1878), y la Historia de la literatura y de las ciencias en México, por D. Francisco Pimentel (1885). En el Repertorio colombiano ha publicado D. Miguel Antonio Caro excelentes estudios sobre Juan de Castellanos, Olmedo, etc. (Tercera edición) 


\section{PROSÍGUESE EL PENSAMIENTO DE LAS CARTAS ANTERIORES}

M i docto y entrañable amigo: Apuntados quedan en anteriores epístolas los dos medios primeros e indispensables para facilitar el conocimiento de la antigua ciencia española y poner término (si posible fuere) a las eternas e insensatas declamaciones contra ella, inspiradas por la ignorancia y el fanático espíritu de secta a nuestros rimbombantes sabios, y dócilmente repetidas por la juventud dorada, que los venera como oráculos. Hoy me toca dar fin a esta materia, indicando otros recursos para atajar el mal que lamentamos, recursos tan importantes o más que los diccionarios bibliográficos y los estudios expositivo-críticos, y de cierto más generales y más en grande concebidos, pero que no exigen explicación tan larga y menuda y pueden sin dificultad agruparse. Y como está de Dios que estas cartas han de tener siempre algo de polémica, y que yo, con ser de natural tan inofensivo como V. sabe, he de reñir forzosamente con los filósofos a cada triquitraque, me haré cargo, después, de las rotundas aseveraciones de otro Mr. Masson, y de primera magnitud, que ya tenemos en campaña. Dios los cria y ellos se juntan.

Entrando en el primero de los puntos que hoy me propongo exponer, diré dos palabras de la creación de nuevas cátedras en los doctorados de las facultades, proyecto ya indicado en mi primera epístola, germen de todas las restantes.

Ya ha reunido la bibliografía los materiales; ya han sido aquilatados en las monografías expositivo-criticas; tenemos ya elementos para la historia de la ciencia española en sus diversas ramas. ¿Qué falta, pues? Dos cosas aún: primera, enseñar esa historia; segunda, escribirla. Ahora bien: entrambas cosas pueden realizarse a la par, y conviene que así se realicen. ¿Cómo? Creando 
esas seis cátedras, dotándolas dignamente e imponiendo a sus profesores la obligación de componer con extensión y profundidad la historia de las respectivas disciplinas en España.

La enseñanza en España apenas tiene de española en el día más que el nombre; está casi del todo desligada de nuestra tradición científica, y los esfuerzos de algunos sabios profesores no bastan para infundirle el carácter nacional de que mucho ha la despojaron las torpezas oficiales. Las obras de texto que corren en buena parte de nuestras aulas son extranjeras, extranjeros los autores que en ellas se citan, extranjeras las doctrinas en ellas enseñadas (y malas, que es lo peor, pues al cabo la verdad no tiene patria, aunque aparece con muy diversas fortunas, que importa respetar, según las condiciones del suelo, el carácter y la historia de las razas); todo extranjero. Ha reinado aquí una insensata manía de remedar fuera de propósito todo lo que en ultrapuertos estaba en boga; y sin pararnos en barras, importamos (siempre tarde, mal y a medias) teorías, libros, planes de enseñanza, programas, todo a medio mascar y sin cuidarnos de si encerraban o no elementos discordantes. Así, nuestro actual sistema de estudios es un mosaico, en que hay de todo y para todos los gustos, menos para el gusto español puro y castizo. En nuestras cátedras se puede aprender la historia de la filosofía india o china, pero no la de la filosofía española: de la escuela Vedanta y de la Mimansa saldrán muy enterados los discípulos, que tal vez no hayan oído en su vida mentar el suarismo; de Gotama y de Patandjalí sabrán divinidades, pero ni una palabra de Luis Vives o de Fox Morcillo. Tal vez asistirán a cátedras de literatura latina en que no oigan hablar de Séneca, ni de Marcial, ni de Lucano. ¡Y gracias si vergonzantemente, y como de limosna, tenemos un poco de literatura española agregado a la literatura general en un solo curso, y una cátedra, una sola, a ella exclusivamente dedicada en el doctorado de la Facultad de Letras, cátedra que (para ignominia nuestra) estuvo suprimida durante algunos ańos! Y si esto se hace tratándose del arte literario ibérico, por todos estimado como uno de los más ricos, originales y poderosos que ha producido la fantasía de ningún pueblo, ¿no sobra motivo para afirmar que si tal estado de cosas continúa, ha de llegar día en que reneguemos hasta de nuestra lengua y de nuestra raza, y acabemos de convertirnos en un pueblo de babilónicos pedantes, sin vigor ni aliento para ninguna empresa generosa, maldiciendo siempre de nuestros padres, y sin hacer nada de provecho jamás? Sólo un antídoto puede oponerse a tanto daño: el cultivo oficial de la ciencia española, el establecimiento de esas seis cátedras, cuyos títulos repetiré, aunque peque de prolijo. 
Historia de la teología española.

Historia de la ciencia del Derecho en España.

Historia de la Medicina espańola.

Historia de las Ciencias Exactas, Físicas y Naturales en Espańa.

Historia de la Filosofía española.

Historia de los estudios filológicos en nuestro suelo.

Y como la historia de la literatura espańola es de suyo tan extensa y raya en imposibilidad absoluta el exponerla en un solo curso, además de la cátedra general, hoy dignamente desempeñada por un profesor sapientísimo, ${ }^{664}$ conviene establecer las cuatro siguientes:

Historia de la literatura hispano-latina.

Historia de las literaturas hispano-semíticas.

Historia de la literatura catalana.

Historia de la literatura galaico-portuguesa.

La primera debiera establecerse en la Universidad de Salamanca, emporio un día de los estudios clásicos; la segunda en la de Sevilla o Granada; la tercera en la de Barcelona, y en la de Santiago la cuarta, pues no parece justo que Madrid disfrute de todo género de ventajas y preeminencias, antes conviene vigorizar el espíritu provincial en dondequiera. En cuanto a las seis cátedras primeramente indicadas, convendría asimismo distribuirlas entre nuestras provincias universitarias, para evitar su centralización en la corte; pero atendiendo a la mayor comodidad de profesores y discípulos, a la abundancia mayor de libros y medios de investigación, y a otras consideraciones hoy ineludibles, fuerza será agregarlas a la Universidad llamada (con irritante distinción) Central y aguardar el día en que puedan extenderse tales estudios a los otros nueve centros de enseñanza superior que en Espańa poseemos. No existiendo hoy facultad de Teología en las Universidades, y no enseñándose (por desdicha grande) los elementos de la ciencia de Dios y de sus atributos en la Facultad de Filosofía, a la cual debieran servir de corona, la historia de la Teología entre nosotros habrá de guardarse para el gran Seminario central, cuya necesidad, cada día más urgente para la Iglesia y para la nación, ha sido encarecida por V. en diversas ocasiones.

Los catedráticos de estas nuevas asignaturas, retribuidos con menos mezquindad de la que aquí se acostumbra, habrían de unir a las tareas de la enseñanza la composición de libros, en que largamente diesen a conocer el desarrollo de cada una de las ciencias en España, a la manera que el

664 Éralo el Sr. Amador de los Ríos (q. d. D. g.) cuando se escribió esta carta. Hoy le he sucedido yo, el más oscuro de sus discípulos. (Segunda Edición) 
ilustrísimo Sr. D. José Amador de los Ríos ha escrito con diligencia suma y erudición pasmosa la Historia crítica de la literatura española, lastimosamente interrumpida en su publicación ha no pocos ańos. ${ }^{665}$

No faltará quien censure, y con apariencia de fundamento, la protección oficial concedida a la ciencia española. Para no incurrir en graves errores, conviene distinguir cuidadosamente los términos de la cuestión. La protección oficial no debe condenarse en absoluto. ¡Ojalá pudiéramos prescindir de ella!; pero no estamos ahora en ese caso, ni veo gran peligro para la dignidad e independencia del científico, como dicen los krausistas, en que sea subvencionado y protegido en sus estudios e investigaciones por el Estado. Hay obras que en ninguna manera deben implorar ni recibir auxilios ni subvenciones: su único juez natural es el público. Tal acontece con las de ingenio. La teoría que sostiene Alfieri en su hermoso tratado de El principe y las Letras es (aparte de sus exageraciones) exactísima: el favor oficial, venga de donde viniere, sirve sólo para menoscabar la alteza del ingenio, rebajar y empequeñecer sus creaciones, y si alguna vez han sido grandes las de las letras protegidas (en general más elegantes y correctas que enérgicas y sublimes), hanlo sido a pesar de la protección, no en virtud de ella. En los tiempos que corren es, además de inútil y hasta ridículo, en alto grado anacrónico todo lo que huela a patrocinio y amparo dado por príncipes o gobiernos a las bellas letras. Éstas pueden vivir por sí y no mendigar socorros de nadie: pasó el tiempo de los Mecenas y de los Augustos. Si la obra favorecida es mala, el público se reirá de ella, aunque la escuden regios patronos; si es buena, tiene ilustración sobrada para leerla o asistir a su representación, sin que de arriba le avisen que aplauda.

Pero hay otros modestos ciudadanos de la república de las letras que ni pueden aspirar a triunfos ruidosos, ni obtener siquiera para sus libros un

665 Para completar en lo posible la noticia de las obras históricas relativas a nuestra cultura, aparte de las memorias expositivo-criticas y las bibliografias, mencionaré, como trabajos de bastante generalidad, los Orígenes de la poesía castellana de Velázquez, las Memorias para la historia de la poesía y poetas españoles, del P. Sarmiento; la Historia de la literatura española, de los PP. Mohedanos; el Ensayo histórico apologético de Lampillas; las obras de Bouterweck y Sismondi (conocidísimas entrambas, y traducidas, aunque sólo en parte la primera, al castellano); la Historia comparada de las literaturas española y francesa, de Puibusque; los compendios de Gil y Zárate, Fernández Espino y algún otro, y la History of Spanish Literature, de Jorge Ticknor (Primera Edición), tan admirable y digna de toda loa en la parte bibliográfica, como pobre y vulgar en la parte crítica; el tratado De Hispanorum litteratura, de Martín Panzano (Mantua, 1750), y el Répertoire de l'Histoire et de la Littérature Espagnole et Portugaise, de A. Augusto Liaño (Berlín, 1820) (Añadido de la Tercera Edición). 
despacho que les indemnice de los gastos de impresión, ya que no de las incalculables fatigas y dispendios que ocasionan las investigaciones previas, tal vez por largos ańos y con generoso aliento proseguidas. El que en Espańa emprendiese hoy por su cuenta y riesgo la publicación de ciertas obras, a no ser un potentado o un capitalista, se arruinaría en la empresa, y ni aun tendría el consuelo de terminarla. ¿Quién ha de atreverse a lanzar al mundo una Historia de la filosofía española o una Biblioteca de filósofos, cuando la eterna e implacable posteridad de Mr. Masson clamorea sin cesar en libros, revistas y discursos, por boca de sus más espectables individuos, que la historia de la ciencia puede escribirse sin que en ella se mencione una sola vez a España? ¿Qué más? En España no se pueden publicar libros de literatura española. Dígalo la excelente obra del señor Amador de los Ríos, cortada en el tomo VII; dígalo la Historia del Teatro, compuesta por Schack y traducida por Mier, que no pasó del primero. Apareció, habrá dos años, un admirable trabajo, dechado de sagacidad y erudición, acerca De la poesía heroico-popular castellana, obra de un eminente profesor catalán, a quien no supera ninguno de nuestros críticos contemporáneos. En otro país, la Prensa se hubiera deshecho en elogios y agotado la edición en pocos días. Aquí sucedió todo lo contrario: los sabios de Madrid no lo leyeron, o si lo leyeron, no lo entendieron; las revistas callaron o sólo dijeron boberías. Doblemos la hoja, pues, y convenzámonos de la verdad tristísima que apunté más arriba, a saber, que si el Estado no protege los estudios de erudición, ;pobres estudios de erudición y pobre Estado! Como forzosa consecuencia del abandono de aquéllos, irá borrándose todo sello nacional en el arte, en la ciencia y en las costumbres, España acabará de perder sus históricos caracteres, y después... vendrá lo que Dios quisiese, porque nada es imposible en un pueblo que olvida y menosprecia las glorias de sus mayores.

Y ahora, espiritus fuertes, libres de imposiciones dogmáticas y esclavos del primer charlatán que os embauque, tétricos y cejijuntos krausistas, incansables discutidores de Ateneo, traductores aljamiados, sapientísimos autores de introducciones, planes y programas, alegres gacetilleros, generación novísima de dramaturgos y novelistas fisiológicos, reíos de mí a carcajada tendida, porque voy a proponer como medio indirecto, aunque poderoso, de adelanto para la historia de la ciencia espańola, el restablecimiento de ciertas comunidades religiosas, de frailes, si lo queréis más claro, ya que para vosotros lo mismo son monjes que frailes y frailes que freiles, y no satisfechos con trastrocar el color de los hábitos, soléis confundir la corona con el cerquillo. No frailes, sino monjes, serán los míos, y de la familia de Montfaucon, de Mabillon y de Calmet, hermanos de aquellos que hicieron el Arte de comprobar fe- 
chas, la Gallia Christiana, la Antigüedad explicada y la Historia literaria de Francia; benedictinos, en fin, como lo fueron Yepes, cronista y paleógrafo insigne; Feijoo, el hombre a quien más debió la cultura española en el siglo XVIII; Sarmiento, de erudición universal y portentosa, y tantos otros que hicieron algo más que artículos de revista y disertaciones sobre el concepto, plan, método y fuentes de enseñanza de la ciencia, tareas favoritas de nuestros doctores iluminados, que, después de recoger con tal objeto todas sus fuerzas, comienzan invariablemente con parrafadas de este jaez: «Para saber qué cosa sea la Metafísica, es preciso que la Metafísica venga a mi o que yo vaya a la Metafísica». Y cierto que debe de sudarse el quilo para descubrir verdad tan recóndita, semejante a aquella filosófica distinción del P. Fernández en su Crotalogía: "Las castañuelas pueden tocarse bien y pueden tocarse mal», a la cual sólo falta un meditemos por contera, dicho con ademán grave y reposado, para ser acabadísimo modelo de oratoria krausista.

\section{Oh curas hominum! Oh quantum est in rebus inane!}

Pero volvamos a nuestros monjes, y dispense V. esta digresión ligerísima. Si en España hubiera de hecho libertad para las sociedades monásticas, como la hay para todo género de asociaciones; ${ }^{666}$ si fuera menos brutal la intolerancia de los que se dicen sabios, y filósofos, y políticos, sería utilísimo el establecimiento de dos o tres comunidades de benedictinos, que, como la antigua de los Maurinos y la moderna de Solesmes, en Francia, tuviese por instituto el cultivo de la ciencia patria y el de los estudios de erudición en general. Recuerdo a este propósito, amigo mío, que cuando tiempo atrás hablamos de este asunto, me decía $V$. en una de sus preciosas cartas familiares: «Podría fundarse (un monasterio de San Benito) en Covadonga, en vez del cabildo colegial que ahora existe, compuesto de gente allegadiza y que, en su mayor parte, desea y merece mejores colocaciones y mira aquello como un punto de paso; estaría más en relación con el carácter venerando de aquel santuario; haría que éste prosperase más, como más identificado con su porvenir, y ofrecería, por ende, mayores estímulos a la piedad y al patriotismo para contribuir con donativos a la erección de un templo digno de lugar tan glorioso y memorable. El presupuesto de la actual colegiata bastaría para su sostenimiento. Enviando comisionados idóneos a los archivos y bibliotecas de dentro y fuera de España para sacar copias o extractos de libros y docu-

666 No se ha de olvidar la fecha (ya algo remota) en que se escribieron estos párrafos, que, por muchas razones, no me ha perecido conveniente mortificar ahora. (Tercera edición) 
mentos, iría reuniendo allí los elementos todos conducentes a los fines de su instituto. Tampoco sería difícil montar al lado del monasterio una fábrica de papel y una imprenta para las publicaciones de la comunidad». Y ańadía V. y repito yo, aun a riesgo de que en altas regiones (si allá llegan estas líneas) se nos tache de visionarios: "Ahora que se piensa en pactar un nuevo Concordato con la Santa Sede, sería la mejor ocasión para realizar este pensamiento, tanto más, cuanto que, siendo los benedictinos una Orden cuyos individuos han permanecido de todo punto ajenos a nuestras discordias políticas, no hay, o no debe haber al menos, prevención alguna contra ellos... Sólo una comunidad semejante responderá dignamente a la majestad incomparable de aquel sitio, que tan hermosamente describe Ambrosio de Morales».

Referíase V. en esto al Viaje Santo del docto cronista cordobés, que en el título (o capítulo) vigésimotercio de su curioso libro, pinta, en efecto, con lindeza de frases por extremo notable, el santo lugar cuya extrañeza no se puede dar a entender bien del todo con palabras. Supongo que todos mis lectores, exceptuando los sabios que no leen libros, y menos libros viejos, y construyen por sí propios la ciencia en cuya unidad comulgan, tendrán en sus estantes el referido Viaje o alguna vez le habrán registrado, y por eso no transcribo las palabras de Morales.

Idea es también de V., y no sé si ya en alguna parte manifestada, el establecimiento de otra comunidad benedictina en el Sacro Monte de Granada, comunidad que especialmente se dedicase a la ilustración de la historia árabe española. Y dando igualmente a los Benitos de Montserrat el encargo y los medios de explorar las antigüedades catalanas y aragonesas, no hay duda que veríamos surgir de tales congregaciones trabajos inmensos, hoy inaccesibles a las fuerzas aisladas de eruditos que viven en el siglo, rodeados y distraídos dey en (juntemos preposiciones, al modo de Sanz del Río) mil ocupaciones y cuidados. Pero hoy por hoy, y sin pecar de pesimista, reputo muy difícil el que algo de esto llegue a efectuarse, pues en pleno (y ya decadente) siglo XIX hay que luchar aún con inverosímiles preocupaciones contra el monacato, hijas de la falsa y mezquina filosofía francesa de la pasada centuria. Y ahora recuerdo que el ilustre literato D. Juan Valera, a quien nadie tachará de místico ni mojigato, conviene en substancia con nosotros, pues en su discreto análisis del Ensayo de Donoso Cortés, no teme decir: «Quisiera yo que se volviesen a poblar algunos monasterios, y principalmente los que por ser grandes monumentos de nuestras glorias nacionales deben conservarse siempre». Esto escribía el Sr. Valera en 1856, y no dudo que lo mismo diría hoy, si preciso fuese. Pero repito que estos buenos propósitos no llevan camino de ponerse en práctica, quizá porque en España estemos condenados 
a no tener Órdenes religiosas y a seguir enviándoselas a la volteriana Francia, a la protestante Inglaterra y a la racionalista Alemania, hasta que sintamos imperiosamente su falta, y acabe de cumplirse la tremenda expiación que sobre nosotros pesa por aquel espantoso pecado de sangre (así le llama el protestante Usoz) cometido en 1834, y que (son palabras del mismo erudito cuákero) pesa mucho sin duda en la balanza de la Divina justicia.

Aun puede hacerse mucho en otro sentido en pro de la ciencia patria, dando a conocer las obras, ya completas, ya escogidas, de los pensadores ibéricos en elegantes e ilustradas ediciones por el estilo de las que publican las cinco o seis sociedades de bibliófilos hoy establecidas en España. Algo de esto pudieran hacer las Academias, en especial la de Ciencias Morales y Políticas, ya que no existe, cual debiera, una especial de Filosofía Española.

Tampoco ha de desconfiarse en absoluto de la iniciativa y de los esfuerzos particulares, pues si es cierto que hoy no soplan vientos muy favorables a nuestras ideas, y son muchos los bien hallados con su ignorancia, no faltan eruditos curiosos y entusiastas por la ciencia de nuestros padres, y quizá lo que hoy parece difícil no lo sea mañana. Abrigo la esperanza de que no ha de que darse en proyecto aquel generosísimo de la Biblioteca de Filósofos ibéricos, por V. iniciado en Oviedo de 1859. Convendría formar con tal objeto una nueva sociedad de bibliófilos, dado que de las actuales poco o nada podemos prometernos; de unas, por su índole local (andaluces, catalanes, valencianos, etc.), y de otras por su afición decidida a Celestinas, libros de caza, relaciones históricas y otros escritos semejantes, curiosos sin duda, pero de escaso valor científico. Nuestra Sociedad debería ir publicando ediciones (en latín y castellano) de Lulio, Fox, Vives, Suárez, Sánchez, Servet, Gouvea, Gómez Pereira y sus impugnadores, Vallés, Domingo de Soto, Arriaga e Isaac Cardoso, etc., y de muchos opúsculos de Cardillo de Villalpando, Sepúlveda, el Padre Juan de Mariana, Pedro de Valencia y tantos otros, así como de los más notables tratados filosóficos escritos en lengua castellana, tanto por místicos y moralistas de los siglos XVI y XVII, como por muchos pensadores del pasado.

A las obras de cada autor habría de preceder una introducción en que, aparte de las noticias bio-bibliográficas, se hiciese la exposición y juicio de sus doctrinas, apreciándose a la par sus precedentes históricos y su influencia en los sistemas posteriores.

Urge asimismo, y pudiera realizarse por la Sociedad proyectada, la fundación de una Revista, que exclusivamente tuviese por objeto la propaganda en favor del estudio de la Filosofía Española, ya que existen revistas dedicadas en todo a la ciencia alemana. 
Ofrecería, sin embargo, no pocas dificultades la constitución de tal Sociedad, ora por la indiferencia con que muchos tenidos por sabios miran nuestra cultura, ora por la resistencia y los obstáculos que opone siempre a toda empresa común el especialismo, verdadera plaga erudita. Son muy pocos los que saben desprenderse de sus gustos, aficiones y terquedades en pro del interés general.

Por tales razones, es indispensable la iniciativa oficial, cuando menos para abrir la marcha y hacer que tome cuerpo y cobre fuerzas el movimiento a favor de dichos estudios. Fuera de que pueden coexistir sin inconveniente, antes bien, con notable ventaja, la acción oficial y la particular en sus respectivas formas y con sus peculiares procedimientos.

Y ahora que he desarrollado, aunque brevemente, nuestros planes, paso a hacerme cargo, por lo mucho que con ellos se rozan, de las magistrales decisiones del nuevo Mr. Masson, a quien aludí antes. El cual no es ningún doctrino, sino un hierofante, un pontifice máximo, un patriarca del krausismo, jefe reconocido, por lo menos, de una fracción o cofradía, personaje influyente y conspicuo en épocas no lejanas, varón integérrimo y severísimo, especie de Catón revolucionario, grande enemigo de la efusión de sangre, y mucho más de la lengua castellana. Todos le conocemos, y yo dejaré de nombrarle, porque al cabo me acuerdo de haber sido discípulo suyo, y le debo, entre otros inestimables beneficios, el de afirmarme cada día más en las sanas creencias y en la resolución de hablar claro y a la buena de Dios el castellano... per contrapositionem a las enseñanzas y estilo del referido maestro.

Este, pues, eximio metafísico ha puesto un largo, grave, majestuoso, sibilino y un tanto soporífero prólogo a cierto libro crudamente impío de cierto positivista yankee, traducido directamente del inglés por cierto caballero particular, astrónomo excelente. según nos informa el prologuista, y persona muy honorable (¡manes de Cervantes, sed sordos!); al cual caballero debe de parecerle portentosa hazańa traducir del inglés un libro, supuesto que añade muy orondo directamente, como si se tratase del persa, del chino o de otra lengua apartada de la común noticia, siendo así que hay en España ciudades, como esta en que nací y escribo, donde son raros los hombres y aun mujeres de alguna educación que más o menos no conozcan el inglés y no sean capaces de hacer lo que el señor traductor ha hecho. Pero no voy a hablar del traductor, ni siquiera del libro que en son de máquina de guerra anticatólica se nos entra por las puertas, libro digno del barón de Holbach o de Dupuis, escrito con la mayor destemplanza y preocupación, y lleno de errores de hecho garrafales, como los de afirmar que la ciencia nació en 
Alejandría y que los Santos Padres fueron hombres ignorantísimos, sin instrucción ni criterio.

Tampoco hablaré detenidamente del prólogo, escrito en la forma campanuda y enfática que caracteriza todas las producciones y todos los discursos de su autor. Léale V., amigo mío, y allí verá maravillas. Allí se habla de las pretensiones de imperio temporal en la Iglesia; allí se dice que los católicos estamos sumidos en abyección moraly en fanatismo, que la religión y la ciencia son incompatibles (como si no hubiera más ciencia que la que los impíos cultivan y preconizan, y como si ellos mismos hubiesen logrado nunca ponerse de acuerdo en los principios); allí de la antropolatría del Pontifice (sexquipedalia verba); allí de la mística, sublime cópula verificada en Alejandría entre el Oriente y la Grecia; allí de la solidaria continuidad y dependencia de unas determinaciones individuales con otras que permite inducir la existencia de un Todo y medio natural que constituye interiores particulares centros, donde la actividad se concreta con limite peculiar cuantitativo y sustantiva cualidad en intima contraposición de esencia factible o realidad formable y poder activo formador $^{667}$ (esto será castellano de Morería, o latín de los Estados Unidos. ¡Vaya unos rodeos para ir a parar en la rancia doctrina del alma del mundo, que puede exponerse clara y hermosamente en dos palabras!); y allí, en fin, con tolerancia digna de Atila, de Gengis-Kan o de Timurbeck, se presenta en perspectiva a los católicos la justicia de la espada, y se aplauden las persecuciones y atropellos cometidos por el tolerantísimo, ilustrado y filosófico Gobierno de Prusia. ¿¿ónde nos esconderemos de esa espada con que se nos amenaza? Aunque tengo para mí que la espada de este caballero krausista ha de parecerse algo a la de Bernardo (no el de Roncesvalles, sino el compañero de Ambrosio), o a aquella hoja toledana del fabulista, la cual fue asador en sus primeros años. Pero yo voy a hacer caso omiso de todo lo anterior y del modo cómo aprecia el prologuista lo que él llama religiones positivas, como si pudiera haber alguna religión negativa o como si la negación constituyese dogma. No diré tampoco una palabra del logos platónico y del verbo cristiano, a cuya cuestión no sé cómo vuelve nuestro sabio después de la brillante fraterna que en otra ocasión le enderezó Fr. Zeferino González.

Lo que sí nos importa son los yerros y falsedades históricas que, hablando de España, entreteje en su relato: lo de afirmar, por ejemplo, que se debió al Rey Sabio la traslación de las academias hebreas a Toledo, cosa que hasta entonces el fanatismo de la clerecía no había consentido, siendo así que dichas academias estaban en Castilla desde el tiempo de Alfonso

667 A esto creo que lo llaman ahora monismo. (Segunda Edición) 
VII, expulsadas de Andalucía por el fanatismo musulmán. ${ }^{668}$ Pero aun esto es leve pecado, y tampoco he de hacer grande hincapié en que llame con desdén a España la patria de los dominicos y de los jesuitas, porque hay cosas que sólo desprestigian al que las dice, no a aquellos a quienes se dirige la ofensa. Gloria y muy grande es para España el que de ella saliese el fundador de aquella Orden cuyo hábito vistieron Alberto Magno, Santo Tomás de Aquino, Savonarola, Fr. Bartolomé de las Casas, Melchor Cano, Domingo de Soto, Fr. Luis de Granada y tantos otros varones eminentes hasta nuestros contemporáneos Lacordaire y Fr. Zeferino González, lumbreras de la ciencia cristiana. Y no lo es menos el que fuese compatricio nuestro el capitán de aquella Compañía en que militaron San Francisco de Borja, San Francisco Javier, Simón Rodríguez, Laínez, Alonso Salmerón, Rivadeneira, Molina, Gabriel Vázquez, Suárez, Mariana, La Puente, Martín del Río, Nieremberg, Cordoníu, Andrés, Eximeno, Hervás, etc., etc., y en que aún militan hombres como los Padres Secchi, Félix, Kleutgen, Liberatore; la cual con sus misioneros evangelizó (y civilizó por ende) gran parte del mundo, y con sus maestros, insignes humanistas y poetas, adoctrinó a la juventud desde las cátedras, inicióla en el conocimiento de la antigüedad clásica, y encarriló las tendencias paganas del Renacimiento, impidiéndolas llegar a la exageración que alguna vez habían mostrado en Italia, y de que hoy los pios secuaces del abate Gaume se escandalizan.

Unas veinte líneas dedica mi anónimo maestro a hablar de la Filosofía española, repitiendo con escasas variantes las absolutas de los señores Azcárate y de la Revilla, y añadiendo de su cosecha nuevos dislates, que me limitaré a registrar con leve comentario, porque hay cosas que a sí propias se alaban y no es menester alaballas.

$1^{\circ}$ «Mientras los demás pueblos europeos convertían, mediante el Renacimiento clásico-naturalista y la Reforma, a propia libre reflexión su espíritu,

668 ¿Para quién habrán escrito sus libros de magistral erudición Jourdain, Hauréau, Luciano Leclerc, Graetz y tantos otros? ¿No habrá entre los krausistas quien haya oído mencionar siquiera el colegio de traductores que fundó en Toledo el Arzobispo D. Raimundo, Canciller de Alfonso VII? ¿No han leído siquiera el Averroes de Renán? ¿No tienen noticia alguna de los trabajos de Domingo Gundisalvo, de Juan Hispalense; ni de los viajes científicos de Gerardo de Cremona, de Herman el alemán y de Miguel Escoto a las escuelas de Toledo? ¿No saben que, según Renán, la introducción de los textos orientales en las aulas cristianas (debida en su mayor parte a la iniciativa del Arzobispo D. Raimundo) divide en dos períodos absolutamente distintos la historia científica de la Edad Media? Pues si de nada de esto se han enterado todavía, ¿con qué derecho se abreven a formular juicios sobre la cultura de un pueblo que les es más desconocido que el pueblo chino, o que las hordas tártaras? (Tercera edición) 
y se despertaban a la observación diligente y profunda, nosotros quedábamos adheridos y como petrificados en las viejas imposiciones dogmáticas». ${ }^{669}$

Error histórico imperdonable, aunque se explica bien en un sabio que no lee libros viejos y construye su propia ciencia, bajo la superior unidad en que comulga con todos los seres racionales finitos. En España influyó el Renacimiento tanto como en Italia y algo más que en los países protestantes. Traiga a la memoria nuestro prologuista el número prodigioso de humanistas que en el siglo XVI y aun en el XVII florecieron, y se convencerá del culto tributado a la antigüedad en nuestro suelo. Españoles fueron, entre otros mil, Nebrija, Arias Barbosa, Vives, Núneez, Sepúlveda, Oliver, Encinas, Gélida, el Comendador Griego, Antonio Agustín, Páez de Castro, Verzosa, Matamoros, los Vergaras, Luis de la Cadena, Aquiles Stazo, el Brocense, Álvar Gómez de Castro, Calvete de Estrella, Pedro Chacón, Fernán Ruiz de Villegas, el Padre La Cerda, Vicente Mariner, González de Salas, Baltasar de Céspedes, Pedro de Valencia, etc., sin contar no pocas damas que entendían de letras griegas y latinas más que todos los krausistas juntos. ${ }^{670}$

De muchos de los citados humanistas ya he hecho mérito anteriormente, debiendo añadir ahora que entre ellos los hubo, y en número no escaso, que ni en erudición ni en sagacidad ceden a los Erasmos, Scalígeros, Lipsios, Casaubones y Sciopios, por más que la fama no se haya mostrado con los nuestros bastante equitativa. Precisamente el escritor que más fielmente compendia y personifica las ideas todas y el saber acaudalado por el Renacimiento, es un español, Vives. El padre de la Gramática general es otro español, Sánchez de las Brozas. Pocos hombres influyeron tan activamente en los trabajos filológicos del siglo Xvi como los españoles Antonio Agustín y D. Diego Hurtado de Mendoza, ya en calidad de obreros, ya en la de Mecenas. El mejor comentario de Virgilio se debió al jesuita P. La Cerda; la mejor ilustración de Petronio, a D. Jusepe G. de Salas. Y ciego se necesita ser para no advertir en la poesía lírica, en la historia y en los tratados didácticos del siglo XvI, la influencia del Renacimiento clásico-naturalista, como nuestro sabio le apellida. Cabalmente el primero de los líricos de esa era, el que cristianizó la musa pagana, trabajando con manos católicas el mármol de la antigüedad, el que verificó la fusión del genio clásico y de la poesía nueva, fue un fraile español, teólogo

669 ¿Qué será petrificarse en una imposición?¡Qué monstruosa amalgama de lo concreto y de lo abstracto! ¡Y todavía se tienen por exageradas nuestras censuras contra la hórrida barbarie del estilo krausista! (Segunda Edición)

670 Si en lo del Renacimiento clásico-naturalista quiere aludir nuestro sabio a aquellos renacientes fanáticos que paganizaron en religión, contestarele que, a Dios gracias, de estos locos de atar estuvimos libres en España. (Primera Edición) 
de la Universidad salmantina. Y en cuanto a la Reforma, si no arraigó aquí, a Dios gracias, menos por los rigores de la Inquisición (que no hubieran bastado) que por rechazarla el espíritu nacional, también tuvo secuaces en España, y algunos de no poco entendimiento y ciencia, como saben muy bien los bibliófilos, o séase librovejeros: los que, al parecer, lo ignoran son los filósofos de campanillas que hablan de lo que no entienden.

Después de lo transcrito viene un párrafo muy turbio en que se habla de la falta de intimidad religiosa que degradó la conciencia de nuestro pueblo. Como no sé qué es esto de intimidad religiosa, paso a coger el lapsus.

$2^{\circ}$ "Voces aisladas a lo sumo, sin enlace ni consecuencia directa con el proceso de la Edad Moderna, son las que ofrece Espańa, y aun éstas con el sentido y el carácter peculiar a los siglos medios: ${ }^{61}$ Vives, Fox Morcillo y Gómez Pereira se distinguen sobre todos». ${ }^{672}$

Lejos de ofrecer Vives, Fox Morcillo y Gómez Pereira el espíritu y el carácter de los tiempos medios, son en grado sumo innovadores y revolucionarios, enemigos de la Edad Media y del escolasticismo, hombres, en cuerpo y alma, del Renacimiento. ¿No levantó Vives contra las viejas enseñanzas la formidable máquina de sus siete libros De causis corruptarum artium? ¿No maldijo de Averroes e invectivó In pseudo-aristotelicos? ¿Es de la Edad Media el espíritu platónico-conciliador del sevillano Fox? ¿No fue Gómez Pereira cabeza de motin contra la dominación de Aristóteles?

$3^{\circ}$ «Vives (a quien concede nuestro antiguo profesor saber inmenso, sin duda porque, como añade, se educó en medio de Europa) no lleva su sentido (palabra mal usada y sobre toda ponderación impropia) más allá de un concierto, que ni siquiera sincretismo, entre las doctrinas de Platón y Aristóteles y las de los Santos Padres.»

Aquí hay cosas estupendas. Yo entendí siempre que los sistemas armónicos significaban en la historia de la filosofía más que los sincréticos, puesto que los primeros entrañan verdadera composición, y los segundos sólo yuxtaposición de elementos. Creía también hasta ahora que la palabra concierto era en castellano sinónima de armonía (dícelo Capmany, que sabía lo que se pescaba en tales materias); pero ahora me enseńa el maestro que un concierto es menos que un sincretismo, y que, por lo tanto, el racionalismo armónico de Krause es una filfa de ningún valor respecto al sincretismo, que cualquiera puede formar metiendo juntas en el cesto las doctrinas de Pedro, Juan y Diego, aunque se den de calabazadas. Pero no es esto lo más grave. El hierofante de quien vengo hablando no

671 ¡España ofrece voces! Plaudite cives! ¡Pobre lengua! (Segunda Edición)

672 ¿Quiénes son todos: las voces o los siglos?¡Vaya una concordancia vizcaína! (Segunda Edición) 
hace en su juicio de Vives más que repetir adpedem littere un tema del antiguo cuestionario de la Universidad de Madrid para ejercicios del doctorado, tema que desgraciadamente estaba equivocado en los términos, por donde puso en grave aprieto a nuestro paisano el Sr. de los Ríos y Portilla cuando le cupo en suerte el explanarle, aunque era el tema, según parece, parto del cacumen de Sanz del Río. Luis Vives no intentó semejante conciliación entre las doctrinas de Platón y Aristóteles y las de los Padres de la Iglesia, ni esto encierra sentido alguno, pues los Padres de la Iglesia, colectivamente considerados, no tienen sistema metafísico propio, sino el de Platón unos y el de Aristóteles otros (como todo el mundo sabe), modificados naturalmente con arreglo al dogma cristiano. Mal pueden conciliarse dos cosas cuando una de ellas no existe. El decir las doctrinas de Platón y de Aristóteles, como si fueran exactamente lo mismo, y contraponerles las de los Padres de la Iglesia, es una de las ocurrencias más peregrinas que pueden imaginarse. La verdad es, y nuestro sabio lo sabría si hubiese leído a Vives, que dotado éste de alto sentido ecléctico, procede en sus libros De prima philosophia con gran libertad de espíritu, acostándose, ya a las doctrinas de Platón, ya a las de Aristóteles, sin soñar en sincretismos, ni conciertos, ni Padres de la Iglesia, de los cuales no recuerdo que cite más que a San Agustín, al hablar del tiempo. Unas veces se acerca al peripatetismo clásico, y otras al platonismo mitigado que más tarde profesó Fox Morcillo.

¿Y bastan las frases arriba transcritas para calificar a Vives, a aquel que, según una expresión tan ingeniosa como profunda y exacta del Sr. Campoamor, sembró no las ideas, sino los sistemas a granel? ¿Quién negará su importancia como metodólogo? ¿Quién los altos servicios que a la ciencia psicológica prestó con el tratado De anima et vita? ¿No son relieves de la mesa de Vives el baconismo, el cartesianismo, y, sobre todo, la escuela escocesa? Y es lo más singular que en el prólogo de que estoy tratando se encomie altamente el mérito de Bacon (sin duda porque fue inglés y protestante) y se menosprecie el de su maestro, a quien él quedó tan inferior en todos conceptos. ${ }^{673}$

$4^{0}$ «Gómez Pereira... no pasa de enunciar en forma silogística un razonamiento análogo al que constituye el principio del método cartesiano, pero sin el carácter de criterio de indagación, ni la intención sistemática que determina su valor científico». ${ }^{674}$

673 Barthélemy Saint-Hilaire llama a Bacon presuntuoso y soberbio, y a Luis Vives adversario serio de Aristóteles, encomiando la mesura y el juicio del segundo en contraste con la petulancia del primero, de quien dice que nunca comprendió la doctrina que atacaba, y que destruyó la verdadera filosofía. (Primera Edición)

674 mática-tífico... ¡Qué sonsonete tan agradable hacen estos esdrújulos! La prosodia anda tan lucida como la sintaxis con las lucubraciones krausistas. (Segunda Edición) 
Es casi seguro que el maestro no sabe de la Antoniana Margarita otra cosa que lo que leyó en el discurso de entrada del señor Campoamor en la Academia Española. Las citas de segunda mano se conocen en seguida. Gómez Pereira atacó en todas sus partes la psicología aristotélica, con ocasión del automatismo de las bestias; identificó el hecho del conocimiento con la facultad de conocer, y ésta con la substancia del alma; afirmó que las cualidades sensibles no son accidentes entitativos de los cuerpos; refutó la antigua teoría de las especies inteligibles, defendiendo la del conocimiento directo; echó por tierras las formas substanciales, propugnando el atomismo, como lo hicieron también Vallés e Isaac Cardoso, y asentó otros principios fundamentales de filosofías posteriores, de todo lo cual pudiera nuestro sabio estar al tanto, aun sin registrar la Antoniana Margarita (libro rarísimo), con sólo haber leído las notas a los Discursos Filosóficos de Forner, la Apología del P. Castro por la Teología Escolástica, los Anales de la Medicina Española de Chinchilla, y los Ensayos Criticos de usted, obras todas corrientes y comunes.

Pero ahora reparo que estoy perdiendo la pólvora en salvas, pues no era de esperar que mi maestro hiciese justicia a Vives y Gómez Pereira, cuando en otro párrafo de su lucubración nos enseña que la Crítica de la razón pura de Kant, redujo a un mero interés histórico toda la filosofía precedente. Así quedamos todos iguales. Platón, Aristóteles, San Anselmo, Santo Tomás de Aquino, San Buenaventura, Bacon, Descartes, Leibnitz, eran tan mentecatos como Raimundo Lulio, Vives, Suárez, Fox Morcillo y Gómez Pereira. Hasta que el filósofo de Koenigsberg lanzó al mundo su Crítica famosa, nadie había pensado ni discurrido en el mundo.

«iCierto que se ven impresas

Cosas que no están escritas!»

Resumen: Yo comprendía que se construyese ciencia (krausista) sin libros ni otras zarandajas, porque para decir perogrulladas no es menester gran erudición; mas ya veo con asombro que para juzgar las doctrinas de un autor, tampoco es necesario leerle ni hojearle siquiera, y basta con cuatro especies cazadas al vuelo en alguna tesis doctoral o en tal cual discurso académico. Con esto y el tono de oráculo y la severidad estoica y algo de aquella fama que autoriza a un hombre para echarse a dormir, basta y sobra para decidir ex cathedra de cuanto Dios crió y mirar con desdén a los pobres mortales que no han llegado a semejante pináculo de sabiduría y buena andanza. Pero tanto, tanto..., en verdad, que no lo consienten mis tragaderas. ¿Qué menos puede exigirse de un filósofo, si no español, nacido en España, que el que conozca, siquiera por el forro, la Filosofía española? Veremos si después 
de su proyectada conversión al positivismo, de la cual ya por estas tierras corren rumores, muda de estilo y tono este mi antiguo e inolvidable maestro.

Y con esto se despide de V. hasta la primera, su apasionado amigo, admirador y paisano.

\section{Marcelino Menéndez Pelayo}

Santander, 25 de julio de 1876.

P. D. En el último número de la Revista Contemporánea vuelve a las andadas el Sr. de la Revilla. De lo que dice daré larga cuenta y razón a V. y al público en mi próxima epístola.

20 de agosto de 1876. 


\section{MR. MASSON REDIMUERTO \\ (Segunda contestación a D. Manuel de la Revilla)}

$\mathrm{M}$ i distinguido paisano y amigo: Picó Mr. Masson en el cebo; ya le tenemos en campańa. Si yo no conociera un poquito, aunque de oídas, el carácter de mi adversario, extrañaría una contestación tan descomedida, contradictoria y poco meditada, en asunto que requiere moderación y estudio.

Empieza por decir el Sr. de la Revilla, en el último número de la Revista Contemporánea, que mi carta rotulada $M r$. Masson redivivo está escrita con ira, furia y no sé qué más cosas, y que tiene un carácter personalísimo. No sé qué ultrajes, furias o personalidades ha visto allí el Sr. de la Revilla. Le he llamado crítico ingenioso y agudo, he hablado de su claro entendimiento, y me parece que todo esto (dicho con la mayor sinceridad del mundo) ha de sonar a elogio. ¿Qué más quiere el Sr. de la Revilla? ¿Que le llamemos más filósofo que Descartes, más poeta que Byron, mejor crítico que Villemain o Sainte-Beuve? ¿Que tengamos por obras inmortales, asombro de los nacidos, las Dudas y tristezas, el Curso de literatura o las revistas críticas que en diversos periódicos ha dado a la estampa? ¿Que reconozcamos su competencia hasta en cuestiones que no ha saludado, como la de la Filosofía espańola? ¿Qué es, pues, lo que quiere el Sr. de la Revilla? ¿Han de ser los artículos polémicos un continuo sahumerio para el autor refutado? ¡Cuánto, según esto, deberán de escandalizarle las contiendas literarias de los humanistas del Renacimiento, que se decían en seco los más atroces improperios! Convengo en que la cultura moderna exige más cortesía y miramientos; pero ¿̇he faltado a ellos por ventura? ¿He proferido alguna expresión que desdore su crédito moral? Si lo que digo de los oradores de Ateneo y de las discusiones de omni re scibili es aplicable en algún modo al Sr. de la Revilla, el público 
y la propia conciencia han de decírselo. Si dicen que sí, y él se enoja, ¿qué culpa tengo yo, ni por qué he de ser víctima de sus arrebatos y furores?

Lo que hay en mi pobre artículo son verdades como el puño, que mi contrincante ha tomado por donde queman, hasta el punto de salir desaforado y lanza en ristre contra un oscuro bibliófilo, procedente de una ciudad de provincia y poco o nada conocido en la república de las letras, sobre todo en el barrio que han tomado por asalto el Sr. de la Revilla y sus amigos. Y para confundir y aniquilar a semejante pigmeo, ignoto estudiantillo y principiante, emplea todo un artículo, titulado con mucho énfasis La Filosofía española, y en él se defiende y defiende a su amada Revista (solidaria sin duda de sus ideas y opiniones, por lo cual hice bien en atacarla), y hasta la redacción de ésta encaja una nota al pie de ciertos cuadros de la enseñanza que se da en la Universidades alemanas (muy substanciosos sin duda para quien asista a esos cursos, pero inútiles o poco menos para los españoles, quienes adelantan harto poco con saber que el profesor Nablowsky explica este verano la teoría del sentimiento en la Universidad de Czernowich), quejándose de la recelosa y estrecha suspicacia que se abstiene de estudiar la civilización de otros pueblos, cuando precisamente la que no se estudia poco ni mucho es la española.

Pero como ni los exabruptos del Sr. de la Revilla, ni las notas de la Revista Contemporánea me hacen perder la tranquilidad ni el aplomo, voy a contestar al nuevo Mr. Masson, cuyo artículo (adviértase esto), infinitamente más destemplado y furibundo que el mío, está escrito además en un tono autoritario y dictatorial verdaderamente delicioso. Yo no tengo el mal gusto de enfadarme como el Sr. de la Revilla, ni me reputo agraviado por estas cosas, pues bien sé que flechas de pluma no hieren cuando se tiran a bulto y desatentadamente. Tengo por honra grandísima el que el Sr. de la Revilla me llame neo-católico, inquisitorial, defensor de instituciones bárbaras, y otras lindezas. Soy católico, no nuevo ni viejo, sino católico a machamartillo, como mis padres y abuelos, y como toda la España histórica, fértil en santos, héroes y sabios bastante más que la moderna. Soy católico apostólico romano sin mutilaciones ni subterfugios, sin hacer concesión alguna a la impiedad ni a la heterodoxia, en cualquiera forma que se presenten, ni rehuir ninguna de las lógicas consecuencias de la fe que profeso, pero muy ajeno, a la vez, de pretender convertir en dogmas las opiniones filosóficas de este o el otro doctor particular, por respetable que sea en la Iglesia. Estimo cual blasón honrosísimo para nuestra patria el que no arraigase en ella la herejía durante el siglo XVI, y comprendo, y aplaudo, y hasta bendigo la Inquisición como fórmula del pensamiento de unidad que rige y gobierna la vida nacional a través de los siglos, como hija del espíritu genuino del pueblo español, y no 
opresora de él sino en contados individuos y en ocasiones rarísimas. Niego esas supuestas persecuciones de la ciencia, esa anulación de la actividad intelectual, y todas esas atrocidades que rutinariamente y sin fundamento se repiten, y tengo por de mal gusto y atrasadas de moda, lucubraciones como la del Sr. de la Revilla. No necesitábamos, en verdad, ir a Alemania, ni calentarnos mucho los cascos para aprender todo eso. Ya lo sabían los bienaventurados liberales del año 20 .

Por lo demás, no me quitan el sueño los calificativos de enemigo implacable de la civilización y de la patria que me prodiga el Sr. de la Revilla. Creo que la verdadera civilización está dentro del catolicismo, y que no es enemigo de la patria el que sale mejor o peor a su defensa.

El Sr. de la Revilla dice que nunca ha pertenecido a la escuela hegeliana. En hora buena: me interesan poco sus transformaciones filosóficas. Hoy pasa por neo-kantiano, pero no niega sus tendencias al positivismo. Lo averiguado y cierto es que siempre ha militado en las filas de la impiedad, con una u otra bandera. No sé de qué católicos ha hablado con respeto el Sr. de la Revilla; sería sin duda de los llamados católicos viejos, que tienen tanto de católicos como yo de turco, siendo en realidad unos protestantes nuevos. Y también es peregrina ocurrencia la del Sr. de la Revilla al asegurar que no hace caso de ciertos ataques, y no necesita de ciertas defensas, y empeñarse en ellas con tanto calor dos líneas antes.

Dice que, al censurar de extranjerada a su Revista, no he pensado lo que digo, y debí leer los índices para convencerme de que eran más los escritos de autores españoles que los de extranjeros. Sin hacer grande esfuerzo de pensamiento, leí a su tiempo dichos índices, y aun examiné la colección entera, y por eso dije lo que vio el Sr. de la Revilla. Muy pocas veces (éstas fueron mis palabras) he tenido la dicha de encontrar algún artículo, párrafo o linea, castellanos por el pensamiento o por la frase. Claro es que al decir pocas veces, exceptuaba un artículo del Sr. Valera, otros dos del Sr. Escosura, poesías varias del Sr. Campoamor, etc., etc.; pero del resto digo que no es español ni en el pensamiento ni en la forma, por más que sean españoles (sin duda por equivocación) sus autores, pues nadie me hará creer que sean castellanas las ideas ni el estilo de los Sres. Montoro, del Perojo y tantos otros bien conocidos del Sr. de la Revilla. Y considero semejante Revista como empresa anti-católica, anti-nacional y anti-literaria, pues lo que hoy importa no es propagar en malas traducciones arreglos y extractos la ciencia extranjera, que ésa por todos lados entra y es de fácil adquisición, sino trabajar algo por redimir del olvido la española, cuya existencia es muy cómodo negar cuando no se la estudia ni se la conoce. En cuanto a los chistes de mal gusto que el 
Sr. de la Revilla me reprende, ya sabía yo que no hay más chistes cultos ni delicados que los de la Puerta del Sol o los del Casino. ¿Qué chistes, sino frailunos y de sacristía, ha de decir un neo-católico de provincias, falto de esa chispa cortesana que tanto enaltece al Sr. de la Revilla?

Tras estos preliminares, el Sr. de la Revilla entra en materia, dando una en el clavo y ciento en la herradura, aunque a él, ofuscado por la pasión y el orgullo, se le antoja lo contrario. Dice que yo no niego por completo su aserto respecto a la inferioridad de los españoles en las ciencias exactas, físicas y naturales. Esto, que para el Sr. de la Revilla es curioso, maldita la curiosidad que tiene, pues ni implica contradicción, ni favorece a mi adversario en nada. Desde mi primera carta vengo diciendo que hay relativa inferioridad en este punto, mas no absoluta pobreza, y el Sr. de la Revilla, en vez de admirarse de ello, hubiera hecho bien en contestar a las proposiciones siguientes, que en diversas partes he sostenido y razonado:

$1^{\text {a }} \mathrm{La}$ intolerancia religiosa no influyó poco ni mucho en las ciencias que no se rozaban con el dogma. No hubo prohibiciones de libros útiles, ni persecuciones de sabios (sino en casos raros, y eso por otras causas), ni nada, en fin, que impidiese nuestro progreso en dichos ramos del saber. El Sr. de la Revilla no se ha acordado de destruir ni aun de mentar mi argumentación en este punto. Él sabrá la razón..., y yo también la sé.

$2^{\text {a }}$ Los talentos de segundo orden en las ciencias, los expositores, indagadores, etc., son dignos de muy honrosa memoria en la historia de las mismas, y nunca será completa la que no abrace sus tareas y descubrimientos. Sostuve esta verdad en la carta a que el Sr. de la Revilla contesta, haciéndose cargo de la fuerza del argumento, pero procurando eludirle con un sofisma de tránsito, que no deslumbraría a un mal principiante de lógica. Dice que en la historia literaria suponen poco los autores de segundo orden, y deduce que lo mismo acontecerá en la científica. Pues cabalmente sucede todo lo contrario, porque en las obras de índole estética no se toleran medianías, según aquello de Horacio:

\section{Mediocribus esse poetis}

Non $D i$, non homines, non concessere columnae,

que saben hasta los chicos de la escuela; al paso que en las destinadas a un fin útil, cuales son las científicas, caben los esfuerzos de todo hombre investigador y laborioso, lo cual advirtió también el Venusino en el muy sabido pasaje cuyo final he recordado. El Sr. de la Revilla insiste en creer que los sabios nacen y viven como los hongos, y para él nada son ni significan los modestos cientificos (hágote sustantivo por la gracia de Dios: ¡resabios krausistas!) que 
les allanan el camino, ni los que siguen sus huellas y explican, explanan o completan su doctrina. Sería ciertamente lucida la historia de la ciencia que escribiese el Sr. de la Revilla. Él no sabe ver más que cosas grandes y como el puño; lo demás son puerilidades y miserias. El desdén soberano con que trata de cuantos en España han cultivado la ciencia, teniéndolos por dignos de todo olvido y menosprecio porque no le parecen genios, me recuerda el caso de aquel jándalo fachendoso que tiraba con desgaire el pańuelo de seda al entrar en su pueblo, añadiendo: «Camarada, no le levante, que diez llevo perdidos desde Reinosa». Al Sr. de la Revilla debe de importarle muy poco perder los pañuelos, o séase la ciencia española, porque, en su entender, todo lo que no sea Galileos, Kepleros y Newtones es cosa de ninguna monta. A bien que ahora vamos a tener cosecha de ellos, gracias a la Revista Contemporánea.

El que las historias de la ciencia no hablen, o hablen poco, de los españoles, nada tiene de extrańo. Son, en su mayor parte, obra de autores extranjeros que no conocen el desarrollo de nuestra actividad intelectual, muy difícil de estudiar hoy, por la rareza de los libros que produjo, y hasta por la falta de Diccionarios bibliográficos que indiquen sus títulos y paradero. Siempre fuimos pródigos en hazañas y cortos en escribirlas, y no es maravilla que los de fuera desdeñen lo que con soberbia ignorancia niegan los de casa. Pero aun en esas historias escritas con falta de noticias en esta parte, hallamos celebrados a algunos españoles. En casi todos los anales de la botánica se habla con elogio de Acosta, Hernández, ${ }^{675}$ Laguna, García de Orta, Monardes y los demás que he recordado en otras cartas. Apenas hay historia de la astronomía y de las matemáticas en que no suenen las Tablas Alfonsinas y otros monumentos del saber de nuestros antepasados de diversos siglos. La historia de la Medicina (y esto no lo niega el Sr. de la Revilla) está llena de nombres españoles, y sin gran esfuerzo pudieran citarse aquí como famosos y consignados en libros corrientes los de muchos matemáticos, químicos, metalurgistas y geopónicos. Debe de pasar un mal rato el Sr. de la Revilla cada vez que ve mentado a un espańol en libros de ciencia: a tal punto le arrastra el odio ciego que las cosas de su patria le inspiran, sólo porque esta patria es y ha sido católica. Valor se necesita para olvidar la escuela náutica y matemática de Sagres, fundada por un portugués y dirigida por un mallorquín; las cartas hidrográficas planas de los catalanes, el famoso Atlas de la Biblioteca de París, y la carta de Juan de la Cosa, la primera que se hizo

675 El cual escribió por mandato de Felipe II, gran protector de estas investigaciones, su asombrosa Rerum Medicarum Novae Hispaniae Thesaurus, seu Plantarum, seu Animalium, seu Mineralium, Mexicanorum Historia. (Segunda Edición) 
de los mares americanos; y no he querido omitirla, puesto que es de un paisano mío.

Con habilidad (llamémosla así) impropia de polémicas serias, dice el Sr. de la Revilla que, por confesión mía, únicamente dos descubrimientos (fuera de los marítimos) se deben a los españoles: las cartas esféricas y el nonius. En ninguna parte he dicho semejante cosa: cité esos dos, exempli gratia, como hubiera podido citar otros veinte, v. gr.: el de la circulación de la sangre, debido a Miguel Servet; el del suco nérveo, hecho por doña Oliva Sabuco de Nantes; el de que los colores no residen en los objetos, sino que son la misma lux refracta, reflexa ac disposita, consignado por Isaac Cardoso con estas mismas palabras en su Philosophia libera, donde también se apartó de la escolástica respecto a otros puntos físicos y psicológicos; el del platino, dado a conocer por Ulloa en 1748; el del tungsteno, debido a Elhuyar; el de infinitos ejemplares de los reinos vegetal y animal; el de algunos medicamentos, como el palo santo o guayaco, la raíz de China y la corteza de la quina, y si a libros extranjeros hubiéramos de creer, el del ácido nítrico y el de la destilación alcohólica, atribuidos hasta ahora a Raimundo Lulio. Pero como la ciencia española no necesita engalanarse con ajenas plumas, a un español, grande amigo nuestro y gran bibliófilo, se ha debido la demostración de lo contrario, como a otro sabio español, gloria de la moderna literatura catalana, se debe la más completa aclaración respecto al verdadero invento de Blasco de Garay. Así procede la erudición, no negando ni condenando en redondo, como la ciencia de los contemporáneos, sino distinguiendo y apurando cada cosa.

Los nombres mismos de muchas especies de plantas pregonan la gloria de los botánicos espańoles: Queria, Minuartia, Meletia, Monarda, Ovieda, Ortegia, Salvadora, Barnadegia, Mutisia..., ¿eran calmucos o daneses los naturalistas en cuyo honor se titularon así estas especies? Y si hasta en los nombres está consignada su memoria, ¿cómo ha de faltar en los libros de historia de la ciencia? ¿Y por ventura son para relegados al olvido los descubrimientos médicos de Luis Mercado en lo relativo a las intermitentes (en cuyo estudio se adelantó a Morton y a Torti), y las observaciones de Solano de Luque sobre el pulso?

No amontonaré nombres propios, puesto que no agrada esto al Sr. de la Revilla, sin duda porque es más cómodo para él no citarse más que a sí propio y a sus amigos. Pero sí le diré que hipótesis muy célebres (por más que él lo niegue); v. gr.: la del fuego como unidad dinámica, claramente presentada por Vallés en su Philosophia sacra, y la del P. Feijoo sobre los terremotos considerándolos como fenómenos eléctricos, son de origen es- 
pañol; que Arias Montano explicó ya por la presión atmosférica el ascenso del agua en las bombas; que Valverde figura al lado de Vesalio entre los primeros anatómicos; que hasta fines del siglo pasado fue de autoridad suma en punto a metalurgia el libro de Alonso Barba, a quien no se desdeñaron de traducir ingleses, alemanes y franceses; que los astrónomos españoles del siglo Xvi, entre ellos Alfonso de Córdova y Juan de Rojas ${ }^{676}$ (de quienes no puede decirse que están ignorados, puesto que los cita Montucla en su conocidísima Historia de las Matemáticas), eran estimados por de los más eminentes de Europa, y venían los extraños a recibir sus enseñanzas; que Núñez puede estimarse, al igual de Viète, padre del álgebra, y que no está tan averiguado, como el seńor de la Revilla supone con ligereza imperdonable, que sean de segundo orden todos los cientificos españoles, por la sencilla razón de que ni el Sr. de la Revilla ni nadie, que sepamos, se ha tomado la molestia de probarlo. Trabajen y averigüen estas cosas los doctos en las ciencias positivas (sin duda en oposición a la negativa, muy común en estos tiempos); pesen y quilaten ellos los méritos respectivos de nuestros sabios y de los extranjeros, y cuando estos doctos matemáticos, físicos, químicos y naturalistas (bibliófilos además, circunstancia precisa para estar en autos) hayan sentenciado en pro o en contra, yo acataré su decisión, porque, si soy implacable con la universalidad superficial y el saber aparente, nadie me gana en respeto al especialismo profundo y tolerante y al saber sólido y verdadero. Pero lo que desde luego puede afirmarse, mediante el sentido común y la ligera noticia que de tales cosas puede tener un profano, es que la ciencia alcanzó un desarrollo muy notable en España, produciendo infinidad de libros más o menos útiles (sobre lo cual no ha de decidir el Sr. de la Revilla sin examinarlos antes uno a uno, si tiene competencia para ello) y multitud de descubrimientos y observaciones parciales consignables, y consignados ya algunos, en cualquiera historia formal, todo lo cual es título de gloria bastante para que se hable de Ciencia española, no pomposa, sino justamente, y en el tono de piedad filial con que debemos hablar todos de nuestra patria, sin atribuirle ajenas glorias, pero procurando investigar y poner en su punto las verdaderas; sin adularla, pero guardándonos de dirigirle a tontas y a locas

676 Autor del Commentarium in Astrolabium, quod "Planisferium» vocant (1551). Alfonso de Córdova publicó las Tablas Astronómicas en 1517, y Juan de Aguilera sus Canones Astrolabii Universales en 1527. Entre los matemáticos españoles del gran siglo merece recuerdo muy honroso Pedro Juan Monzó por su elegante tratado De locis apud Aristotelem mathematicis (Valencia, 1550). Consideraba, al modo de los antiguos, el estudio de la Aritmética y el de la Geometría como preliminares al de la Lógica. (Vid. sus Elem. Arithm. Valen., 1559) (Segunda Edición) 
infundadas injurias. Y convénzase el Sr. de la Revilla de que no hay historia de la ciencia sin España, porque la ciencia no se compone sólo de dos teorías, y de tres o cuatro hipótesis, y de uno o dos principios fundamentales, sino de una larga serie de cabos sueltos, que suponen el trabajo y el esfuerzo de pueblos y generaciones enteras, esfuerzos que deben quedar registrados en la historia, si ésta ha de ser completa, enlazada, útil y fructuosa. Y repito que es excusada y sofística la comparación con el arte literario, porque si en éste montan poco cien poemas malos o medianos, puesto que ningún fruto directo saca la humanidad de las tareas poéticas realizadas con escaso numen, de trabajos científicos de segundo orden saca la humanidad incalculables ventajas. Poco aprovecharemos a nadie el Sr. de la Revilla ni yo con lanzar sendos tomitos de poesías líricas al mundo; maldito si la posteridad ha de descalabrarse investigando nuestras vidas y milagros, ni nos ha de levantar estatuas y monumentos; al olvido iremos, como tantos otros dignos de mejor suerte; pero ¿cómo ha de olvidarse nunca al que descubre un cuerpo simple, o un fenómeno fisiológico, o estudia por primera vez un mineral o una planta, o demuestra algún ignorado teorema?

Y diré, para terminar esta materia, que más honra a un país, y más actividad científica demuestra en él, la circunstancia de que haya producido doscientos sabios modestos y útiles, que un solo genio, porque el genio le da Dios (así lo creemos los neos y oscurantistas), al paso que el trabajo y la constancia y el estudio, previas ciertas condiciones, dependen en gran parte de la voluntad humana. Olvidábaseme advertir que no está aplicado con bastante propiedad el nombre de descubrimientos al de las cartas esféricas y al del nonius, que deben calificarse de invenciones, lo mismo que la del telégrafo eléctrico, vislumbrado por Fernán Pérez de Oliva, y llevado en parte a ejecución por el físico catalán Salvá en los primeros años de este siglo; el arte de enseñar a los sordo-mudos, debido al benedictino Fr. Pedro Ponce y al aragonés Juan Pablo Bonet; el de enseñar a los ciegos, expuesto por el maestro Alejo de Venegas en su Tratado de ortografía, impreso en 1531, y tantas otras que fuera prolijo enumerar. ${ }^{677}$

677 Otra de las pruebas más señaladas de la gran difusión e influencia de la cultura espańola, y de lo enlazada que estaba con el movimiento general de Europa, es el gran número de profesores de todas materias y enseñanzas que tuvimos en aulas extranjeras. En París leyeron filosofía, teología y matemáticas Álvaro Tomás, Gaspar Lax, los hermanos Coronel, Pedro de Lerma, Juan de Celaya, Juan Dolz de Castellar, Jerónimo Pardo, Pedro Ciruelo, Juan Martínez Siliceo, Mariana, Juan Maldonado y otros innumerables. En Burdeos fue rector Juan Gélida. En Tolosa enseñó leyes Antonio Gouvea, y medicina Luis de Lucena y el escéptico Francisco Sánchez. En Dilingen e Ingolstat, Pedro de Soto, Martín de Olave, Alfonso de Pisa, Gregorio de Valencia. En Polonia, Pedro Ruiz 
Dice el Sr. de la Revilla que en la defensa de la filosofía española no ando muy afortunado, y que le doy lecciones pueriles, como la de advertirle que Fox Morcillo y Gómez Pereira se llamaban así, y no Morcillo y Pereira, según él los nombra. En primer lugar, lo de los nombres es en mi artículo un paréntesis, que no influye poco ni mucho en la argumentación. En segundo, esta cuestión de nombres no es tan impertinente como al Sr. de la Revilla le parece. Hay en nombres y apellidos formas consagradas por el uso, y que no conviene alterar para no exponer al lector a confusiones. Al decir Cervantes y Calderón, todos entendemos que se trata del autor de El Ingenioso Hidalgo y del de La vida es sueño; pero nadie nos entenderá si al primero le llamamos Saavedra o al segundo D. Pedro de la Barca, o Henao, o Riaño, por más que llevase todos estos apellidos. Y es tal la tiranía de la costumbre (fundada siempre en algo) respecto a este particular, que nos causaría suma extrañeza oír llamar Vega a secas a Lope, o Mendoza, al Marqués de Santillana, mucho más cuando la nueva forma, tras de inusitada, induce a errores, como en el caso de Gómez Pereira. E hice esta observación (disculpable en un pobre bibliófilo que no está a la altura de la ciencia moderna), porque he notado que hasta en la manera de citar los títulos de los libros y los nombres de los autores se conoce el grado de familiaridad que con ellos tiene el seńor crítico.

También le parece excusado al Sr. de la Revilla el que yo insistiese en la distancia que separa a Huarte y a Dońa Oliva, de Vives, Suárez y Fox y dice (con evasiva sofística, aunque inocente) que los colocó en la misma línea de imprenta, no de categorías. Pues qué, ¿en el mero hecho de citar a estos cinco filósofos en los términos en que lo hizo, no dio a entender bastantemente que los tenía a todos por de primer orden y los estimaba como la flor y nata de esa decantada filosofía española? ¿Por qué citó a Huarte y a Doña Oliva, y a otros? ¿Por qué se dejó en el tintero a Alfonso de Córdova, Rodrigo de Arriaga, Gabriel Vázquez, Domingo de Soto, Báñez, Fr. Juan de Santo Tomás, Ángel Manrique, Marsilio Vázquez, Pererio, Molina, Miguel de Palacios, Francisco de Vitoria, Fonseca, Toledo, los dos Sánchez, Servet, Gouvea, Valdés, Sepúlveda, Pedro Juan Núñez, Montes de Oca, Luis de Lemus, Cardillo

de Moros y Alfonso Salmerón. En Lituania, Manuel de Vega. En Bohemia, Rodrigo de Arriaga. En Oxford, Vives y Pedro de Soto. En Cambridge, Francisco de Encinas. En Lovaina, Vives, el jurisconsulto Antonio Pérez y muchos jesuitas. En Padua, Juan Montes de Oca. En Roma, Francisco de Toledo, Mariana, Benito Pererio, y otros innumerables. Basta decir que hasta el siglo pasado el catedrático de filosofía en el Colegio Romano fue siempre un espańol. Todo esto prueba lo atrasada que estaba entonces nuestra ciencia, y lo adelantada que está ahora, en que nadie se acuerda de nosotros, ni para un remedio. (Segunda Edición) 
de Villalpando, Pedro de Valencia, Mariana, Vallés, Caramuel, Nieremberg, Martínez, Piquer, Ceballos, Pérez y López y tantos otros? ¿Por qué calló el gran nombre de Raimundo Lulio? Sin pecar de malicioso, puede afirmarse que el Sr. de la Revilla se acordó de Huarte y Doña Oliva, porque escribieron en romance y son de los filósofos peninsulares más conocidos, habiendo de sus obras ediciones modernas muy comunes. El Sr. de la Revilla manifiesta grandes simpatías hacia Huarte, y yo le felicito por ello. Bueno es que se vaya aficionando a lecturas españolas, aunque no escoja, para principiar, a un filósofo de los de primera marca. ¿Ve el Sr. de la Revilla cuán notable es el libro de Huarte, con no contarle entre los mejores los aficionados a estas cosas? Pues juzgue lo que serán los filósofos que no conoce: ex ungue leonem. Tenga calma el Sr. de la Revilla y lea mucho de pensadores españoles, que su clarísimo entendimiento ha de llevarle a reconocer la verdad, o, por lo menos, a respetarla, ya que le falte valor para confesar su antiguo yerro. $\mathrm{Y}$ si le interesan los discípulos de Huarte, no deje de leer la Filosofía sagaz y Anatomía de ingenios, escrita en el siglo Xvir por el catalán Esteban Pujasol, y el Discernimiento de ingenios, que en el XviII publicó el P. Ignacio Rodríguez, el primero de cuyos libros contiene ideas tan nuevas, atrevidas y peregrinas corno el celebrado Examen del médico de San Juan de Pie de Puerto.

Mas, a pesar de sus aficiones huartistas, obstínase por ahora el Sr. de la Revilla en el quod dixi, dixi, y truena contra mí, sin duda porque dudé de su infalibilidad crítica; pecado imperdonable para los amantes de la tolerancia y de la libertad del pensamiento. Pero como yo tengo la mala costumbre de decir las cosas muy claras, aun a sabios como el Sr. de la Revilla,

"Y así a lo blanco siempre llamé blanco, y a Mañer le llamé siempre alimaña»,

según cantó allá Jorge Pitillas, repito ahora lo que a su tiempo dije y explané largamente, y lo que el Sr. de la Revilla ha tenido buen cuidado de no mentar en su contestación, sin duda por miedo de quemarse; es, a saber: que niego y continuaré negando su competencia en esta cuestión, mientras no dé pruebas de conocer algo más que de oídas la filosofía española. E insisto en este punto, porque no veo en el Sr. de la Revilla trazas de enmienda, puesto que su llamada contestación a mi artículo deja las cosas tan mal como se estaban, y a él le coloca en situación más falsa y peligrosa que antes, haciendo patentes la ligereza con que habló primero y la terquedad insigne con que ahora se aferra a lo dicho, sin reparar en la calidad de las armas que emplea para sostener una malísima causa. Y si al Sr. de la Revilla le parece todo esto personalidades, tenga en cuenta que aquí son indispensables y precisas, 
y que en nada hieren su buena fama, a no ser que pretenda ser omniscio o tener ciencia infusa, lo cual no sospecho de su perspicaz discernimiento.

Dice el Sr. de la Revilla que para probar la existencia de la filosofía española cito a todos los que se han ocupado de ella, lo cual califica de desahogo de bibliófilo. Perdone el Sr. de la Revilla: no los cité para eso, sino para demostrar que no somos $V$. y yo solos los creyentes en la existencia de la filosofía ibérica. Ahí está mi carta, que no me dejará mentir. Entre eso y lo que el Sr. de la Revilla dice hay bastante diferencia. Aquí vendría bien la usada cortesía de que el señor de la Revilla no me había entendido; pero como yo me pago poco de fórmulas y sé que el Sr. de la Revilla me entiende perfectamente, coma yo a él, diré sin rebozo (y si es personalidad, no le ofenda) que no quiso entenderme, porque así le convenía.

Y sepa el Sr. de la Revilla, aunque nada quiere saber de boca mía, que, aun empleado como argumento de autoridad, ese catálogo sería de gran fuerza:

$1^{\circ}$ Por contener nombres ilustres y de primera importancia científica y bibliográfica;

20 Por haber entre ellos sectarios de todas las escuelas filosóficas, desde las más radicales hasta las más ortodoxas, lo cual excluye hasta la sospecha de ser el nombre de filosofía española bandera de secta o de partido;

$3^{\circ}$ Por haber florecido los autores allí citados en muy diversos tiempos y naciones, lo cual excluye asimismo toda idea de confabulación y acuerdo.

Por eso, y porque no soy tan inmodesto que prescinda de la autoridad de los que me han precedido, me permití aquel desahogo que tan mal ha sentado al Sr. de la Revilla, y tan triste idea le ha hecho formar de la generación educada en las bibliotecas con estudios de cal y canto. Quizá esa generación, que aún está por ver, no competirá

«En sal, en garabato, en aire y chiste»

con la dorada juventud que hoy puebla los Ateneos y habla con sublime aplomo de transformar el Cristianismo, como si se tratase de remendar unos calzones viejos; pero de seguro tendrá la buena condición de no tratar cuestiones que no entienda, ni entretenerse en denigrar y escarnecer por sistema cuanto hicieron y pensaron nuestros abuelos. El Sr. de la Revilla, que me tiene a mí (aunque indigno) por de esa generación, dice que será divertida, a juzgar por la muestra. Es posible que yo no divierta al Sr. de la Revilla; en cambio, él me divierte mucho, muchísimo, y sentiría verme privado de sus donosas y eruditísimas lucubraciones acerca de la Filosofía española.

En todos estos preliminares, que en rigor pudieran calificarse de pólvora en salvas, gasta el Sr. de la Revilla muy cumplidas las tres primeras páginas 
de su artículo. Y cuando podíamos creer que iba a entrar en materia y a decirnos grandes cosas, y después de anunciarnos que va a hablar por partes y a tratar la única cuestión seria que apunté en mi artículo, sale con lo siguiente: Cuando hemos dicho que la filosofía española es un mito, no hemos querido decir que no haya filósofos españoles, sino que no existe una creación filosófica española que haya formado una verdadera escuela original, de influencia en el pensamiento europeo, comparable con las producidas en otros paises. Y a renglón seguido, y como si no lo hubiera dicho bastante claro, torna a remachar lo que él llama argumento, y es sólo una escapatoria por los cerros de Úbeda, diciendo que para que haya filosofía nacional es preciso que constituya escuela $y$ tradición en un pais; y no contento con esto, dice más abajo que ha de llevar su influencia más allá de los límites estrechos de la patria; cuyas condiciones, puramente externas y accidentales y que no afectan al mérito de las doctrinas, son, en concepto del Sr. de la Revilla, indispensables para que se pueda hablar de Filosofía española. Pues ahora voy a dar gusto al señor de la Revilla, mostrándole, no una, sino varias creaciones filosóficas que forman tradición y escuela e influyen en España y fuera de ella. Y se habría ahorrado el Sr. de la Revilla mucho mal camino y muchos tropiezos si hubiese comenzado por aquí, en vez de adoptar el tono de un artículo de La Iberia y llamarme neo y retrógrado sin venir a cuento.

Para que el Sr. de la Revilla vea que no abuso de las ventajas que con su ceguedad notoria se empeña en proporcionarme, prescindiré del senequismo, por ser doctrina más bien moral que metafísica, y porque tal vez pertenezca nuestro crítico al número de los que se niegan a reconocer la influencia del genio nacional en las obras de los hispano-romanos. Pero lo que no negará es la grandísima importancia histórica de esa transformación del estoicismo, que en la Edad Media influye sobremanera, llegando a bautizar con el nombre del filósofo cordobés no pocos libros ajenos y de origen cristiano, como el De quatuor virtutibus de San Martín Bracarense; que en el siglo $\mathrm{xV}$ domina sin rival en las inteligencias de nuestros primeros moralistas del Renacimiento (D. Alonso de Cartagena, Pedro Díaz de Toledo, el marqués de Santillana, Juan de Lucena, Fernán Pérez de Guzmán, el rey de Aragón Alfonso $\mathrm{V}$, etc.); que en el Xvi y en el xvir llega a su apogeo dentro y fuera de España con Justo Lipsio, Montaigne, Quevedo, Saavedra Fajardo, Gracián, Núñez de Castro, Baños de Velasco, Fernández de Heredia, Ruiz Montiano, Fernández Navarrete, el portugués Antonio López de Vega, y otros ciento, expositores unos, comentadores y defensores otros y moralistas los más, a la manera del filósofo de Córdoba; que en el siglo xvIII inspira buena parte de sus paradojas y atrevidos pensamientos a Rousseau y provoca en Francia 
de parte de Diderot y de Lagrange defensas tan extremadas como las que por entonces hacían en Italia los jesuítas españoles Serrano y Lampillas.

Hago caso omiso de esta doctrina, que siempre ha tenido secuaces de bulto en España y en otros países. Dejo también el averroísmo, o teoría del intelecto uno, porque de seguro me negará el Sr. de la Revilla que sea escuela filosófica española, aunque Averroes fuera tan cordobés como Séneca; pero de seguro, también, me confesará el predominio incontestable de esta filosofía arábigo-hispana en las escuelas de Occidente desde el siglo XII; predominio que (entre paréntesis) de nadie recibió más duros golpes que del mallorquín Raimundo Lulio, viniendo a sucumbir casi bajo los recios anatemas del valenciano Luis Vives en los días del Renacimiento. Tampoco significará nada para el Sr. de la Revilla, como parte de nuestra historia filosófica, ese panteísmo judaico-hispano, personificado en Avicebrón (Ben Gabirol) mejor que en Moisés ben Maymon (Maymónides), aunque malamente apellidado maimonismo, sistema tan real y poderoso que, no sólo inspira en el siglo Xvi a Miguel Servet y a Giordano Bruno (confundiéndose en ellos con reminiscencias neoplatónicas) y se amalgama en el XVII con el cartesianismo y el método geométrico en los libros de Benito Espinosa, e influye en otro panteísta, también de origen hebraico portugués, aunque menos conocido, David Nieto ben Pinhas, sino que en el presente vive y palpita, más o menos modificado, en el fondo de muchos sistemas idealistas alemanes.

De estas tres creaciones del pensamiento ibérico admitirá el Sr. de la Revilla el mérito y la importancia, y dirá que formaron tradición y escuela en la Península y fuera de ella, porque, como no fueron católicos sus autores, sino paganos, musulmanes o judíos, no hay riesgo en alabarlos; pero tendrá buen cuidado de advertir que Séneca, Avicebrón, Averroes y Maimónides fueron españoles, sólo por el hecho de haber nacido en España, sin considerar que grande debió de ser el elemento español en Séneca, cuando a éste siguieron e imitaron con preferencia nuestros moralistas de todos tiempos, y cuando aún hoy es en España su nombre el más popular de los nombres de filósofos y una especie de sinónimo de la sabiduría, lo cual indica que sus doctrinas y hasta su estilo tienen alguna esencial y oculta conformidad con el sentido práctico de nuestra raza y con la tendencia aforística y sentenciosa de nuestra lengua, manifiesta en sus proverbios y morales advertencias, de expresión concisa y recogida como los apotegmas de Séneca, que pugnan con el genio de la lengua latina y la cortan seca y abruptamente; y sin reparar, en cuanto a Averroes y Maimónides, que al primero refluye todo el genio filosófico de los árabes españoles, como al segundo toda la labor intelectual de los hebreos peninsulares, razas ambas sumamente modificadas por las 
condiciones de nuestro suelo y clima, y partícipes de las condiciones y leyes históricas del pensamiento nacional; leyes y condiciones por las cuales puede explicarse hasta cierto punto la inclinación al panteísmo, manifiesta lo mismo en los filósofos hispano-árabes y judíos que en todos los herejes españoles antitrinitarios, hayan sido o no filósofos, como Prisciliano, Gundisalvo, Miguel Servet, Alfonso Lincurio, Marchena y Martínez Pascual, porque el pensamiento español es lógico hasta en sus aberraciones.

Pero no cante victoria el Sr. de la Revilla, que aún hay, a falta de una, otras tres creaciones filosóficas españolas, con influencia en el mundo, con escuela y tradición dentro y fuera de casa, con todos los caracteres, en fin, que su merced exige (sin necesidad algunos) para que haya filosofía que en rigor pueda llamarse nacional. Y estas escuelas son el lulismo, el vivismo y el suarismo, de los cuales voy a decir cuatro palabras, suficientes para mostrar el encadenamiento de su tradición científica, remitiendo a quien desee más noticias a los libros (muy pocos por desgracia) que tratan algo de esto, y, mejor aún, a las obras de los mismos filósofos, que ahí están muriéndose de risa en los estantes de las bibliotecas, y que cualquiera puede leer, si sabe latín y tiene curiosidad de aprender lo que en su alta sabiduría desdeñan los señores del Ateneo y de la Revista Contemporánea.

Y comenzando por el buen Ramón Lull, a quien el pueblo católico venera en los altares como mártir de la fe, y a quien, cual a heroico obrero de la ciencia, debieran venerar los sabios incrédulos o creyentes, y como gloria inmortal del nombre patrio, los españoles todos; nadie, sin presunción y ligereza notorias, osará llamar estimable ingenio de segundo orden al gran filósofo del siglo XIII, inteligencia de las más colosales, profundas y sintéticas de todos tiempos, padre y constructor de un sistema armónico tan sencillo como ingenioso, que no me detendré a exponer aquí, porque ya lo ha hecho brillantemente el Sr. Canalejas; sistema que, a la manera del de Hegel, engarza con hilo realista el mundo de la Metafísica y el de la Lógica, los principios del ser y del conocer, tendiendo a reducir las discordancias y resolver las antinomias, para que, reducida a unidad la muchedumbre de las diferencias (como dijo el más elegante de los lulianos), venza y triunfe y ponga su silla en todo, no como unidad panteística, sino como última razón de cuanto existe, aquella generación infinita, aquella Expiración cumplida, en quien la esencia y la existencia se compenetran, fuente de luz y foco de sabiduría y de grandeza. ¿No llena todas las condiciones de unidad científica la concepción luliana, desde el árbol elemental hasta el divino, mediante el cual se halla luego la solución del árbol de las cuestiones? ¿Qué hay más ingenioso que el artificio de la lógica luliana y el juego de los universales y de 
los predicados? Después del Órganon aristotélico no se había excogitado cosa semejante. El gran pensamiento de la unidad de la ciencia rige y gobierna todos los trabajos de Raimundo Lulio. Él aplicó su método a la ética, a la cosmogonía, a la teodicea, consideréndolas a todas como ramas del mismo tronco. No fue expositor de ninguna filosofía extraña, sino fundador de una escuela, de existencia reconocida en todos los países de Europa, que en Mallorca tuvo hasta nuestro siglo cátedras oficiales, y que cuenta entre sus sectarios españoles a Raimundo Sabunde, ${ }^{678}$ Fray Anselmo de Turmeda, Pedro Dagui, Juan Llobet, Nicolás de Pax, Lavinheta, Alonso de Proaza; Arias Montano, ${ }^{679}$ Juan de Herrera, Fr. Luis de León, Pedro de Guevara, Suárez de Figueroa, D. Alonso de Zepeda, Sánchez de Lizarazu; escuela que revive en el siglo pasado, no sin gloria, representándola en polémica con el P. Feijoo, los PP. Fornés, Pascual, Tronchón y Torreblanca, y que aún vive en el presente, coronando la serie de ilustres lulianos el Sr. Canalejas, si hemos de atenernos a estas palabras; que conviene mediten el Sr. de la Revilla y sus compañeros de la Revista Contemporánea, porque nada tiene de neo ni de inquisitorial el escritor que las dice: «Si para la educación filosófica de nuestro pueblo es o no camino más llano y fácil el de exponer a Lulio interpretándole latísimamente en el sentido moderno, que el importar enseñanzas extranjeras muy propias de sajones o germanos, pero antipáticas al genio de nuestra raza y a la indole de nuestra inspiración y de nuestra historia, es tesis que hoy no resuelvo, pero que confieso me solicita con energía... En lo político, como en lo científico, las nacionalidades constituyen un organismo necesario para que la verdad se produzca en el transcurso de una edad, bajo todas sus fases y en todas sus maneras. ¿No se atenta a esta ley histórica cediendo al deseo de copiar y reproducir lo extraño sin consultar lo propio? ¿No es preferible renovar y rejuvenecer que comentar, cuando el fin se alcanza mejor de aquella manera?». Y si el Sr. de la Revilla juzga condición indispensable para la existencia de la escuela el que lleve su influencia más allá de los límites de la patria, en este caso se halla el lulismo, doctrina bien conocida en el mundo científico, como lo demuestran los nombres del abad Tritemio, Cornelio Agrippa, Valerio de

678 Luliano acérrimo (aunque lo niegue su moderno biógrafo el abate Reulet); como que, a la manera del solitario mallorquín, se propone demostrar por razones naturales los dogmas de la fe. Sobre su patria española véase una nota en el tomo siguiente. (Segunda Edición)

679 En su Historia generis humani sigue a Lulio en lo de explicar racionalmente el proceso de las personas de la Santísima Trinidad. Por cierto que este racionalismo pugna con otras frases de sabor crudamente tradicionalista que hay en el mismo tratado, y que colocan a nuestro grande escriturario entre los predecesores de Bonald. (Segunda Edición) 
Valeriis, el P. Kircher, Giordano Bruno (que llamaba a Lulio hombre divino), Alstedio, Ibo Zalzinger, y otros lulianos extranjeros, grandes admiradores del Ars Magna y del Arbor scientiae, y secuaces en todo o en parte de las doctrinas del filósofo de Mallorca. Ya tenemos una creación filosófica nacional que llena las condiciones requeridas por el Sr. de la Revilla. La grande edición de las obras de Lulio se hizo, no en Palma, sino en Maguncia, por diligencia de Zalzinger, y es seguro que Italia y Alemania han dado al lulismo tantos y $\tan$ fogosos secuaces como España. ${ }^{600}$

El segundo sistema peninsular influyente, conspicuo y famoso en el mundo, es el suarismo, respecto al cual anda muy fuera de tino el Sr. de la Revilla cuando dice que Suárez fue un aventajado discípulo del escolasticismo, como si dijéramos un buen chico, un joven aplicado y estudioso, dando a entender con ese tono despreciativo, en él familiar, que nada aportó a la ciencia; que no tuvo originalidad alguna, ni fundó escuela, ni ejerció influencia, y que fue, en suma, un buen expositor de una filosofía extraña. ¡Parece imposible que tales cosas se digan en serio y por gentes que presumen de autoridad crítica! Suárez no es discípulo, sino maestro, y maestro que cuenta a centenares los secuaces. En sus múltiples obras desarrolla un sistema completo que abraza la Ontología, la Cosmología, la Psicología, la Teodicea, la Ética y la Filosofía del Derecho; sistema que se aleja bastante del tomismo, y está con él en la misma relación que las escuelas alemanas modernas con el kantismo, padre de todas ellas. Hasta en la Teodicea se aparta notablemente del tomismo rígido. Sus doctrinas de la ciencia media y el congruismo, en que mitigó las atrevidas pero peligrosas opiniones de Molina y Lessio, son esfuerzos sublimes para conciliar en lo posible a los ojos de la razón humana la predestinación, la gracia y el libre albedrío. La misma originalidad de pensamiento muestra en el análisis de la idea del ente, en la no distinción entre la esencia y la existencia ${ }^{681}$, en el conocimiento intelectual de los singulares, y en cuestiones de menor importancia; y bien puede afirmarse que Suárez cifra y compendia la filosofía jesuítica, viva y poderosa hoy todavía, y tan suarista como en el siglo XVI. Un mero expositor de filosofías extrañas no funda escuela, ni tiene discípulos, ni ejerce influencia más allá de su patria, como lo hizo Suárez, seguido de cerca por los Conimbricenses, Pererio, Henao, Oviedo, Téllez, Bernaldo de Quirós, Rodrigo de Arriaga, Peinado, Losada, Pons y otros mil jesuitas españoles y extranjeros, hasta llegar a los contemporáneos Perrone, Cuevas, Tongiorgi, Curci, ${ }^{682}$

680 No es esto decir que sea pequeño entre nosotros el número de escritores lulianos. De 65 mallorquines da noticia Bover en su curiosa Biblioteca. (Segunda Edición)

681 Defendida antes por Gabriel Vázquez. (Segunda Edición)

682 En su primera época, se entiende. (Tercera edición) 
Taparelli, Kleutgen, Jungmann, Mendive, por no citar más, que mantienen hoy el suarismo no menos fuerte y lozano que en sus mejores días. Tampoco sé a punto fijo con qué razón llama el Sr. de la Revilla extranjera a la filosofía escolástica (aun la tomista y escotista); pues, aparte de la tradición isidoriana, de la levadura averroísta y de las Súmulas de Pedro Hispano, puede decirse que esa filosofía es nuestra por derecho de conquista, vistos el número y la importancia de los escolásticos peninsulares, y por eso Leibnitz, que entendía de crítica filosófica más que el Sr. de la Revilla y que todos nosotros, llamó filosofía irlandesa y española al escolasticismo. ${ }^{683}$

La tercera creación filosófica española es el vivismo, o sea la filosofía crítica, escuela menos conocida que las anteriores, porque tuvo la desgracia de fraccionarse (como que no era gloria especial de una provincia ni de una orden religiosa) y no recibir el nombre de su fundador, sino los de discípulos suyos, más o menos fieles. El Sr. de la Revilla dice que esta escuela es un mito, y voy a demostrarle lo contrario. Imagina nuestro articulista que Vives, Fox Morcillo, etc., no son más que colaboradores del movimiento antiescolástico representado en el Renacimiento por otros muchos filósofos italianos y franceses, en lo cual yerra de todo punto, pues entre el que edifica y el que destruye hay siempre diferencia grande. De los filósofos a que alude el Sr. de la Revilla, unos, como Pedro Ramus, se limitaron a afirmar ex cathedra que cuanto Aristóteles había enseñado era error y mentira, y sustituyeron palabras a palabras, sin utilidad alguna para la ciencia; otros renovaron el platonismo, o más bien la filosofía alejandrina; algunos, como Pomponazzi y Vanini, resucitaron los errores materialistas de ciertas escuelas paganas; otros cayeron en los sueños teosóficos y cabalísticos, entonces de moda, y pararon en el panteísmo; ninguno fundó escuela, ni trajo doctrinas nuevas al campo del saber, ni aun llegó a constituir sistema; todos trabajaron en la demolición del edificio escolástico, pero sin levantar nada propio ni duradero. ¡Cuán diversa fue la obra de Vives! No atacó éste el aristotelismo por sistema; no se

683 Claro que las diferencias entre dos sistemas católicos y escolásticos, como el de Santo Tomás y el de Suárez, nunca pueden ser tan radicales como las que median entre una escuela católica y otra racionalista. Por eso los modernos racionalistas, que no paran mientes en esas importantísimas cuestiones de la esencia y la existencia, de la ciencia media, de la predeterminación física, etc., confunden a todos los filósofos cristianos en la misma reprobación y anatema, y no ven que ellos mismos dan un nombre distinto a cada una de las variedades del panteísmo alemán, y que distinguen el pesimismo de Hartmann del de Schopenhauer, y el materialismo del positivismo, y éste del monismo, y no confunden en modo alguno la escuela positivista francesa con la inglesa, etc., siendo así que muchas de estas enseñanzas y tendencias difieren entre el sí no más que por levísimos accidentes, a veces más de exposición que de fondo. Cur tam varie? (Segunda Edición) 
adhirió sistemáticamente a Platón; juzgó el mayor daño para los progresos de la ciencia auctoritate sola acquiescere et fide semper aliena accipere omnia; enfrente del principio de autoridad colocó el de razón: Tantum mihi habeatur fidei, quantum ratio mea vicerit... Patet omnibus veritas, nondum est occupata; asentó la necesidad de reforma y de progreso en la ciencia, porque nulla ars simul est et inventa et absoluta, y con este criterio examinó las causas de la corrupción de todas las disciplinas, buscándolas, ante todo, en los vicios propios del entendimiento humano (idola tribus de su discípulo Bacon), en la oscuridad voluntaria, en el espíritu de sistema, en la adhesión a la palabra del maestro, en la veneración supersticiosa a la antigüedad, en el abuso de la disputa; censuró con juicio tan elevado y sólido los extravíos del Renacimiento como las sofisterías de la escolástica, los primeros en el libro De corrupta grammatica, las segundas en el De corrupta dialectica; dijo antes, y lo mismo que Bacon, que la filosofía natural sólo podía adelantar experimentis et usu rerum; señaló reglas para corregir el engaño de los sentidos; tronó contra el afán de generalizar sin que precedieran experimenta et observationes variarum rerum in natura, exclamando con profunda verdad: Ignorant quae jacent ante pedes, scrutantur quae nusquam sunt; y después de haber visto y considerado con erudición y sagacidad maravillosas cada parte del saber tal como entonces se cultivaba, procedió a trazar un método de renovación de las ciencias, harto más completo, juicioso, armónico y ordenado que el de Verulamio, reputando proprium tanti instrumenti opus intueri omnia, colligere, componere inter se, et universam hanc naturam quasi possessionem suam peragrare.

Para enderezar a tan alto fin el entendimiento, comenzó por definir la inducción y la experiencia y señalar sus fueros, no extremándolos como el canciller inglés, pero dándola reglas con igual o mayor acierto: «Ex singularibus aliquot experimentis colligit mens universalitatem quae compluribus deinceps experimentis adjuta et confirmata, pro certa explorataque habetur.. Ceterum experientiae temerariae sunt ac incertae, nisi a ratione regantur, quae adhibenda est illis tanquam clavus aut gubernator in navi: alioqui ferentur temere, et fortuita erit ars omnis, non certa... Quod est in iis cernere, qui solis experimentis ducuntur de quorum ingenio judicium non censet, rem, locum, tempus et reliquias circumstantias inter se conferens, fieri enim convenit ut experientia artem pariat, ars experientiam regat», ${ }^{684}$ consideraciones que explana después y en varios lugares largamente. La importancia de Vives como metodólogo no ha de ocultársele a nadie que haya leído los libros De tradendis disciplinis. Mas no se limitó a esto

684 Tomo las citas de Vives de la edición príncipe de Basilea, 1555, apud Episcopum. (Primera Edición) 
la actividad científica del sabio valenciano. En los libros De prima philosophia desarrolló con sentido ecléctico su sistema metafísico, inclinándose alguna vez a Platón, y con más frecuencia a Aristóteles; en los De anima et vita dio maravillosos ejemplos de análisis psicológico; en los tratados lógicos simplificó considerablemente e intentó reducir a la pureza del Organon la dialéctica; en los libros De veritate fidei christianae aplicó a la teología su sistema filosófico con lucidez de entendimiento y delicadeza de análisis asombrosas; sentó los fundamentos de la filosofía de la legislación con el nombre de ars justitiae; en el discurso In pseudo-dialecticos clamó como ninguno contra la barbarie de la escuela, y, por último, convirtió sus principios a la crítica filosófica en la censura de las obras de Aristóteles, en el librito De initiis, sectis et laudibus philosophiae y en otros opúsculos, por los cuales le da Brucker la primacía entre los restauradores de la historia de la filosofía al modo de los antiguos.

Tenemos, pues, un sistema completo sustituido al antiguo, con su Metafísica, Lógica, Psicología y Teodicea, en parte muy fundamental, nuevas, clara y metódicamente enlazadas. Voy a mostrar ahora el desarrollo de la doctrina vivista en el siglo XVI y siguientes, para que el Sr. de la Revilla se convenza de su importancia histórica y acabe de entender que de Vives parte un movimiento tan poderoso como el que arranca de Descartes.

Ante todo, conviene advertir que la mayor parte de los filósofos italianos y franceses a que el Sr. de la Revilla se refiere, son posteriores a Vives, cuyas enseñanzas recibieron, aunque sin aprovecharlas bastante, porque les faltaba el juicio, cualidad capital del pensador valentino, y la tendencia conciliadora y amplio espíritu que asimismo le distinguen.

Telesio es el que más se acerca a Vives en estas condiciones; pero no acertó a desarrollar sino bajo un parcial aspecto (naturalista o experimental) el criticismo vivista. Mucho más adelantaron en el proceso de esta fecunda doctrina los filósofos españoles, aunque no se haya mostrado justa con ellos la fama. Dejando aparte a los que, como Gélida, Vergara, etc., en nada substancial alteraron la doctrina del amigo o del maestro, vemos surgir de la filosofía critica cuatro direcciones principales:

$1^{a}$ El peripatetismo clásico, muy conforme con la tendencia de Vives, que admiraba y seguía en mucha parte a Aristóteles puro y sin mezcla averroísta ni escolástica. Representan esta dirección, a más de otros no tan notables, Sepúlveda, Gouvea, Cardillo de Villalpando, Martínez de Brea y Pedro Juan Núnez (caudillo de la que pudiéramos llamar escuela valenciana), ${ }^{685}$ después de su conversión del ramismo.

685 A esta escuela pertenecen Monzó, Monllor, Serverá, etc. (Primera Edición) 
2a El ramismo español, tendencia de oposición dura y sistemática a Aristóteles, mitigada por un elemento vivista sobremanera poderoso. Son corifeos de esta secta el salmantino Herrera, el valenciano Núñez en sus primeras obras, otro Núñez (Pedro... Vela), protestante abulense, que publicó en Ginebra una Dialéctica, y fue grande amigo de Pedro Ramus, y con más tenacidad que ninguno el Brocense, cuya filiación vivista puede apreciarse en aquellas palabras del prólogo de su Minerva: «Multa veteres philosophos latuerunt quae Plato eruit in lucem; multa post eum invenit Aristoteles, multa ignoravit ille quae nunc sunt passim obvia; latet enim veritas, sed nibil pretiosius veritate, etc., etc.»; ${ }^{686}$ que es en substancia el principio capital del racionalismo progresivo de Vives, expuesto en el prefacio De causis corruptarum artium.

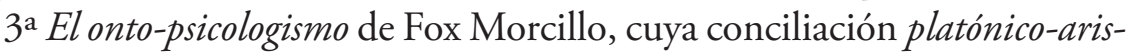
totélica no es más que un desarrollo admirable de la metafísica vivista, si bien inclinándose más a la doctrina del gran discípulo de Sócrates, señaladamente en la cuestión de las ideas innatas, que entiende a la manera de San Agustín. Por su libro De studii philosophici ratione, modificación de la metodología de Vives, se da la mano Fox con el grupo siguiente.

$4^{\mathrm{a}}$ El cartesianismo ante-cartesiano, sostenido en filosofía natural por Dolese, G. Pereira, F. Vallés, Torrejón y Barreda, y en psicología por Vallés y Pereira, aunque discordes en muchas cuestiones. Si Descartes dice en el Discurso del método: "Le premier precepte est de ne recevoir jamais aucune chose pour vraie que je ne la connusse évidemment être telle», ya el divino Vallés había dicho en el capítulo 640 de la Philosophia sacra: "Necesse est ut in rationum investigatione... etiam de his quae sibi videntur probabilissima, nisi se ipsos velint (homines) fallere, dubident».

Como exageración de la tendencia racionalista del vivismo y fenómeno aislado, aparece el libro del portugués Sánchez De multum nobili, prima et universali scientia, quod nibil scitur. También pudiera sostenerse que el empirismo sensualista de Huarte y Doña Oliva tiene ciertas relaciones con la filosofía en cuestión, como dependiente que es de Gómez Pereira y de la Antoniana Margarita. Pero júzguese de esto lo que se quiera, que al cabo no es de esencia, siempre podrá afirmarse que los pensadores independientes (en el buen sentido de la palabra), los ciudadanos libres de la república de las letras, que en España florecen durante el siglo xvi, proceden, en su inmensa mayoría, del vivismo.

Llevó esta escuela su influencia más allá de los límites estrechos de la patria, y de ella nacieron:

686 Edición lugdunense de 1789, apud Pestre et Delamolière. (Primera Edición) 
1. ${ }^{\circ}$ La filosofía de Bacon, que, tomando por punto de partida los libros De disciplinis, proclamó las excelencias del método experimental (como ya lo había hecho Vallés en las Controversiae medicae et philosophicae), desarrolló la teoría de la inducción, sabida de Aristóteles y no ignorada, ni mucho menos, de Vives y sus discípulos; analizó, de igual manera que el valenciano, las causas de los errores, e insistiendo en un punto menos atendido, aunque no olvidado por Vives, trajo la magna instauratio a las ciencias naturales.

2..$^{\circ}$ El cartesianismo, desarrollo parcial y exclusivo, lo mismo que el anterior, de otra fase de la doctrina de Vives y sus discípulos. Dice Julio Simón que el principio de la filosofía para Descartes fue la duda: éste fue todo su método; el porvenir de la filosofía estaba en este principio. Ahora bien: esa famosa duda había sido proclamada como principio de método por Vives, Fox Morcillo, Sánchez el escéptico, Gómez Pereira, Vallés y otros infinitos. En cuanto al famoso entimema, está en San Agustín, en Ochino, en Gómez Pereira y en cien partes más. El resto de sus principios, propiamente filosóficos, apenas encierra novedad, como es sabido. Leibnitz lo demostró, y yo no necesito repetirlo. Lo que en su física y en su psicología tomó de Gómez Pereira y de Vallés, nadie lo ignora. Ya su contemporáneo el célebre Daniel Huet, obispo de Avranches, lo puso de manifiesto en su Censura de la filosofía cartesiana.

3. ${ }^{\circ}$ La filosofía del P. Buffier y la modesta, prudente y sabia, aunque incompleta, escuela escocesa, que en punto al análisis psicológico tiene sus precedentes en el tratado De anima et vita, ${ }^{687} \mathrm{y}$ en cuanto al criterio de verdad, al common sense, en este pasaje del libro I De prima philosophia, y en otros que pudieran citarse y a los cuales corresponde bien la tendencia general de las obras filosóficas de Vives: "Quod naturale est, non potest esse ex falso (llama naturale al testimonio de conciencia)... nec potest certius esse veri argumentum, quam omnes naturaliter sic sentire... Nam si magni alicujus et sapientissimi viri auctoritas jure habet momenti plurimum, quanto habebit majus auctoritas generis humani?». Que es, en substancia, lo que dice Reid: "El asentimiento en virtud del cual todos los hombres se afirman a si mismos proposiciones verdaderas y universales, es un juicio natural (expresión idéntica a la de Vives, que le distingue del juicio artificial o segundo), instintivo, que debe afirmarse, pero que no se razona». ¿Y me preguntará ahora el Sr. de la Revilla si el nombre de Vives debe colocarse al lado de los de Descartes,

687 En él recomienda la observación interna con preferencia al razonamiento y a la disputa: "Pro meditatione atque exercitamento est tacita cognitio... qua altius in rei notitiam penetramus, quam disputationibus vel altercationibus...", "Consideratio... mentem quasi in se ipsam reflectit ut recognoscat quid contineat, quale, quantumque sit». (Segunda Edición) 
Kant y Hegel? Sí, por cierto; y si no suena tan alto como debiera, es por una grande injusticia histórica, incomprensible para el Sr. de la Revilla y otros fanáticos adoradores del éxito. Así como el hemisferio de Colón lleva aún hoy el nombre de Américo Vespucio, así se han bautizado con los pomposos nombres de baconismo, cartesianismo y escuela escocesa diversos jirones del manto de Vives, para quien espero que llegue pronto el día de la solemne reparación, hoy retardada sólo por el clamoreo de los sofistas.

Esperanza tengo de que retoñe esa escuela, nunca enteramente muerta en España, escuela de Melchor Cano, de Pedro de Valencia, de Isaac Cardoso, de Caramuel, de Feijoo, de Piquer; escuela cuya restauración dos veces se ha intentado en el siglo XVIII y en el presente, frustrándose por hado enemigo entrambas tentativas, la del animoso Forner, portento de doctrina, y la del sabio matemático Llorens, secuaz de la escuela escocesa, la cual procuró enlazar con la tradición de Vives, en cuya empresa le sorprendió la muerte.

Ya está servido el Sr. de la Revilla a medida de su deseo; ahí tiene, aunque sólo rápidamente bosquejadas, las escuelas y las influencias que tanto deseaba conocer. Aunque de las seis me rechace tres, tiene que reconocer la existencia y nacionalidad de las restantes. Ya ha visto que hay lulistas, suaristas y vivistas dentro y fuera de Espańa: pereiristas, no, pues Gómez Pereira no fue caudillo de secta, porque no tenía condiciones para tanto, a pesar de su claro entendimiento, perspicuidad y audacia.

¿Y qué diré del resto del artículo del Sr. de la Revilla, en el cual no hay una idea de provecho ni una noticia erudita, mostrándose el autor cada vez más desalumbrado y fuera de tino, como quien anda por sendas que no conoce, y a cada paso tropieza? ¿No es ridículo comparar la obra científica de Vives, Gómez Pereira y demás filósofos peninsulares, con la misión de San Juan Bautista, que no predicaba una doctrina, precursora ni madre de otra doctrina, sino que anunciaba la venida del Salvador, diciendo: Haced penitencia, porque se acerca el reino de los cielos, y bautizaba en el agua para la penitencia, esperando que viniese el que habia de bautizar en el Espiritu Santo y en el fuego? ¿Y me pregunta el Sr. de la Revilla qué me parecería del que intentase propagar y defender el juanismo? ¿Pues qué había de parecerme tal empresa? Un desatino, y más desatinado me parece el símil y más traído por los cabellos el argumento (!) del Sr. de la Revilla, que sin duda cuenta mucho con la tolerancia de su público especial, cuando tales cosas escribe como si fuesen razones sólidas y macizas (estas palabras mías se le han indigestado, y no es extraño).

En cuanto a los místicos, el Sr. de la Revilla se vale de otra evasiva sofística, distinguiendo entre lo que él llama misticismo y la filosofía mistica, que es lo 
mismo que si distinguiésemos entre el kantismo y la filosofía kantiana. El Sr. de la Revilla es muy dueño de hacer los distingos que guste y de interpretar las palabras como le plazca; pero el misticismo o la filosofía mistica es indudable que ha florecido en España como en ningún otro país del mundo, y todo el que no sea positivista y haya leído Las Moradas, Los Nombres de Cristo y la Subida al Carmelo, reconocerá que no hay filosofía más alta y sublime que aquélla, y tendrá a Santa Teresa por filósofa tan grande y mayor que Hipatía (de quien, después de todo, sólo ha quedado la fama), y a Fr. Luis de León y a San Juan de la Cruz por filósofos profundos y excelentísimos, tanto, por lo menos, como Schelling, Hegel y sus satélites, con cuyos nombres, sin cesar repetidos, quieren aturdirnos los críticos germanescos. Ya supongo la idea que tendrá el Sr. de la Revilla de la filosofía y mal puede admitir en ella el misticismo, la filosofía divina, siendo secuaz de Comte y de Littré. Mas en cuanto a suponer que nadie considera como filósofos a los místicos citados, perdóneme que dude de su honrada palabra. Sin recurrir a neos y oscurantistas, ahí están Rousselot en su libro de Les Mystiques Espagnols, el Sr. Valera en cien artículos y discursos, el Sr. Canalejas en su juicio del libro francés antes citado, el Sr. Martín Mateos en una serie de artículos publicados en la Revista de la Universidad de Madrid, y el malogrado estético Núñez Arenas en un discurso inaugural de la propia escuela, todos los cuales convienen en estimar como filosofía el misticismo y como filósofos a los místicos españoles.

El Sr. de la Revilla insiste en juzgar por el éxito las doctrinas filosóficas, y dice que, si Platón no hubiese fundado escuela, sería un gran filósofo; pero no un objeto importante en la historia de la filosofía. Pues si la historia de la filosofía no habla de los grandes filósofos y de sus doctrinas, ¿¿de qué ha de hablar? ¿Esperará a que venga el servum pecus para decidir del mérito de los sistemas? Pero, bien mirado todo, no es el éxito, sino la fama del éxito, lo que no lograron los filósofos españoles. Más se han olvidado sus nombres que sus doctrinas. Lo dicho de Vives en particular, puede aplicarse a todos ellos considerados colectivamente. Las limitadas noticias que tenemos de su influencia en el movimiento intelectual de la Edad Moderna nos bastan para creer fundadamente que aquélla fue poderosa y fecunda. La Ontología, la Teodicea, la Cosmología, la Antropología, la Ética, el Derecho natural, la Estética, todas las esferas de la filosofía les deben copiosas luces; sólo falta que reconozcan la deuda, mucho mayor, sin duda, de lo que por los datos hasta ahora conocidos aparece. Tulit alter honores...

Aquí tiene V., amigo D. Gumersindo, la contestación del señor de la Revilla, contestada, sin añadir, ni quitar, ni desfigurar ninguno de sus argu- 
mentos, al revés de lo que él ha hecho con los míos. Escrita su réplica en momentos todavía de irritación y cólera, es, bajo todos aspectos, indigna de su reputación y notorio talento; nada prueba, nada resuelve; puede pasar únicamente como evasiva. Un solo argumento fastidiosamente desleído; algunas declamaciones de $c l u b$ patriótico; mucho contar al público lo que yo digo, suprimiendo (cosa es clara) las amenidades contra su persona y con ellas otras cosas que no son para el ingenioso crítico amenidades, sino espinas; un rebajar poniendo por bajo, cuando lo raro y peregrino sería rebajar poniendo por cima; no poco de aquellas sabidas frases: baste con lo dicho... mucho pudiéramos decir... pero ya dijimos... pero no lo diremos... porque el señor Menéndez es neo: he aquí el artículo del Sr. de la Revilla.

Al final anuncia que no discutirá conmigo mientras no vea que empleo más comedidas formas. En cambio, yo que de formas me cuido poco, que no soy catedrático de Literatura como el Sr. de la Revilla, y que no tengo reputación literaria buena ni mala que aventurar en este lance, discutiré con él en cualquiera forma, aunque use él la peor de todas, la progresista, aunque toque el himno de Riego, y me llame neo y troglodita... y cuanto se le antoje, que por eso no he de ofenderme; pero a condición de que dé muestras de haber estudiado la materia y conocer de la filosofía española algo más que vagas generalidades.

De V. apasionado amigo y paisano.

Marcelino Menéndez Pelayo Santander, 22 de septiembre de 1876. 


\section{APÉNDICE. PRIMERA PARTE}

\section{Fox Morcillo}

Discurso inaugural del curso Académico de 1884 a 1885 en la Universidad de Santiago, por el Dr. D. Gumersindo Laverde y Ruiz ${ }^{688^{*}}$

EXCMO. SR.:

Aquejado por graves padecimientos que postran el cuerpo y abaten el vigor del espíritu, robándole la tranquilidad tan necesaria para los trabajos intelectuales, sólo en cumplimiento de un precepto reglamentario puedo presentarme ante vosotros en esta ocasión, a la par solemne y dolorosa para mí, que, más que un discurso, vengo a leeros una especie de testamento literario. Los desalińados apuntes con que he de ocupar vuestra benévola atención y poner a prueba vuestra sabia indulgencia, no son más que un laborioso esfuerzo para llenar este deber hasta donde es asequible a un entendimiento flaco y sin bríos, y a una imaginación desprovista de fuego y de colores.

Nunca tiene la memoria de los alegres días de la juventud tanto hechizo y halago como cuando, cano ya el cabello, las sombras del dolor anublan el alma. No extrańéis, pues, que, al tratar de elegir tema para la presente oración, haya vuelto los ojos hacia el campo en que primero ejercité la tosca pluma, hacia el vasto campo de la filosofía española.

688* La colaboración, casi redacción íntegra de este artículo, puede atribuirse a Menéndez Pelayo, aunque está firmado por D. Gumersindo Laverde. Véase el trabajo publicado por Marcial Solana en Menéndez-Pelayismo n. ${ }^{\circ}$ I, pág 225: Un nuevo opúsculo de Menéndez Pelayo. Menéndez Pelayo, autor del discurso académico sobre Fox Morcillo... (Edición Nacional) 
¡La filosofía española! Ella fue, casi desde la adolescencia, el asunto preferente de mis humildes lucubraciones, a pesar del profundo descrédito en que, por entonces, había caído, o, mejor dicho, a causa de ese mismo descrédito. Tal y tan grande era éste, que para nada la tenían en cuenta los tratadistas e historiadores de la filosofía, a la sazón en boga, no ya solamente los desafectos a la tradición nacional, pero aun aquellos en quienes, como en el esclarecido Balmes, más viva y acendrada ardía la llama del españolismo. Impulsado por cierto instinto patriótico, que se rebelaba en mi interior contra semejante menosprecio, dime a vindicarla, encareciendo sus excelencias y aun fantaseando, para mayor realce de su fecundidad y riqueza, escuelas, ciclos y contentes doctrinales, más o menos conformes con la verdad de las cosas.

De poca o ninguna consecuencia habrían sido aquellas endebles, aunque bien intencionadas, tentativas apologéticas, si otros escritores, entre ellos algunos de alto renombre, obedeciendo a los estímulos del patriotismo y del amor a la ciencia, no vinieran luego a laborear más profundamente el terreno que yo apenas había desflorado. Excuso deciros el gozo que experimenté al ver cómo prosperaba el grano de mostaza. Llegó, empero, mi júbilo a su colmo cuando, obligado ya a desistir de toda suerte de empresas literarias, tuve, como en compensación, la dicha de conocer al portentoso joven, entonces oscuro, hoy célebre y celebrado en ambos mundos, propugnador acérrimo de La Ciencia española y caudalosísimo historiador de los Heterodoxos españoles y de las Ideas estéticas en España, a cuya voz, como al conjuro de un mago, surgen continuamente de las ruinas de lo pasado tantos y tan preciosos monumentos, hasta aquí inéditos u olvidados, de nuestra antigua sabiduría. ¡Cuán largo camino ha recorrido, desde mis débiles y premiosos ensayos hasta sus admirables obras, donde se muestra ya victoriosa e incontrastable la reacción en favor de la filosofía y de los filósofos peninsulares, antes en tan baja estima tenidos!

De uno de estos filósofos voy a daros idea, aunque somera y breve. No dudo que su nombre sonará extraño en muchos oídos. Sebastián Fox Morcillo (que así se llama el varón insigne a quien aludo) ha sido poco afortunado en punto a lograr biógrafos y comentadores, ${ }^{689}$ sin embargo de merecerlo tanto o más que otro cualquiera de los maestros del pensamiento ibérico (exceptuados los Dii Majores, Séneca, Averroes y Maimónides, Lulio, Vives y Suárez). La mayor parte de los sucesos de su vida permanecen envueltos

689 El artículo sobre Fox Morcillo incluido en mis Ensayos críticos es tan ligero, que no invalida la exactitud de este aserto.-El tomo II de la Historia de las Ideas estéticas en España, donde el Sr. Menéndez y Pelayo le dedica un bello estudio, no era aún del dominio público al escribirse el presente discurso. (Tercera Edición) 
en nieblas; todo lo que de él nos dicen nuestros bibliógrafos y críticos, cabe en muy pocas líneas. Sus libros son tan extraordinariamente raros, que quizá no hay biblioteca en Europa que los posea todos, y, por supuesto, nadie se ha cuidado de reimprimirlos en colección ordenada y correcta, que a tanto alcanza nuestra proverbial incuria. ¿Qué más? El sapientísimo filósofo que ocupa la Sagrada Cátedra de San Isidoro ofreció, no ha mucho, un premio para el autor de la Memoria en que mejor se expusieran las doctrinas de Fox Morcillo. ¿Creeréis que allí, en la culta Sevilla, en la cuna misma de este clarísimo ingenio, nadie ha respondido al llamamiento del ínclito Prelado?

Asombro causa, en verdad, tan adversa fortuna, cuando reparamos que Fox Morcillo, ni en su tiempo ni en la edad siguiente, fue un escritor oscuro, sino antes bien muy conocido y encomiado, como lo demuestran las triples y cuádruples ediciones que de algunos de sus libros se hicieron y los honoríficos y singulares epítetos de filósofo prestantísimo, elegantísimo, doctísimo, sólido, fundado, etc., con que, a porfía, le honraron, en años bastante posteriores a su muerte, críticos de tanto peso como Auberto Mireo, Gabriel Naudé, Gerardo Juan Vosio y Mr. Boivin, para quien su obra de la concordia platónico-aristotélica era la mejor y más sabia que sobre el asunto se había escrito desde el Renacimiento hasta el siglo xviII. Y crece y sube de punto la extrañeza al considerar que los libros del humanista y filósofo sevillano, aunque bastante numerosos, son, por lo común, de poca extensión y de muy amena lectura, mostrándose el autor, no sólo pensador profundo, sino también elegante literato, y, como ahora dicen, estilista consumado, enriquecido con los tesoros de la elocuencia griega y latina, que él amorosamente estudiara en los Diálogos de Platón y Marco Tulio, a cuya imagen y semejanza compuso los suyos. A casi todos ellos puede aplicarse lo que del De Historiae institutione dijo el erudito y malogrado investigador Sr. Godoy y Alcántara, autor de la inapreciable Historia de los Falsos Cronicones; es a saber: que el estilo y los procedimientos del escritor sevillano estaban, con el arte de los antiguos, en la misma relación que, con la escultura ateniense, las obras de Benvenuto o de Juan de Bolonia. Y realmente, al leer los diálogos foxianos, parece como que se respira la misma atmósfera de serenidad y buen gusto que en los de Cicerón o en las Institutiones de Quintiliano. ¿Cómo explicarnos, pues, el olvido en que vinieron a caer escritor de tal nombradía y libros de tanto precio? ¿Diremos que la negra suerte que persiguió al filósofo platónico, haciéndole naufragar cuando, no cumplidos aún seis lustros, venía a España para ser maestro de un príncipe, se ensañó también con su memoria, a lo menos aquí donde más viva y enérgica debiera subsistir, para gloria y enseńanza de sus compatriotas? 
Si la diligencia del famoso arqueólogo y poeta Rodrigo Caro, en su obra, todavía manuscrita, de los Claros varones en letras de la ciudad de Sevilla, no hubiese salvado de total olvido algunos pormenores de la vida de Fox Morcillo, consignados luego, aunque no textual ni íntegramente, por Nicolás Antonio en la Bibliotheca nova, nada sabríamos del año de su nacimiento, que fue el de 1528, ni del lugar, que fue la calle de las Palmas de Sevilla. En cuanto a su linaje, el mismo Fox Morcillo nos advierte, en su diálogo De informandi styli ratione, que derivaba de la nobilísima alcurnia provenzal de los condes de Foix, a la cual pertenecía, bien que algo remotamente, uno de los caballeros franceses que asistieron a la conquista de Sevilla con San Fernando. Esta noticia, confirmada por Rodrigo Caro, deshace todas las dudas acerca del verdadero apellido de nuestro filósofo, que es, sin duda, Fox (corruptela de Foix), aunque tampoco deban rechazarse las variantes latinizadas Foxo y Foxio, que tienen en su abono la autoridad de antiguos y graves escritores.

La familia sevillana de Fox Morcillo debía de ser tan opulenta como noble, pues dio a su generoso vástago la educación más completa en las artes liberales, primero en su ciudad natal, cuyo florecimiento literario y artístico superaba entonces al de casi todas las otras ciudades españolas, excepto Valencia y Salamanca; y luego en los Países Bajos, en la célebre Universidad de Lovaina, en cuyos libros de matrículas ${ }^{690}$ aparecen inscritos su nombre y el de un hermano suyo durante dos cursos sucesivos. El mismo Fox Morcillo, en las dedicatorias y en el contexto de algunos de sus diálogos, habla con extraordinario cariño y noble entusiasmo de sus maestros los filósofos Pedro Nannio y Cornelio Valerio y el matemático Jerónimo Frivio.

Desde este punto, toda fuente de información biográfica nos falta: la vida de Fox Morcillo se reduce a sus libros y a la eficacia de sus doctrinas. Sólo sabemos que la reputación por él adquirida fue tal, que movió el ánimo del prudentísimo Felipe II a elegirle por maestro de su hijo el príncipe D. Carlos, prefiriéndole a tantos y tantos otros ilustres varones como en aquella dichosa edad honraban las letras españolas. Pero las olas del mar del Norte, sepultando en su seno la nave que le conducía a la Península, frustraron las esperanzas del Rey y del filósofo cuando éste no había traspuesto aun los linderos de la juventud.

Trece son las obras, escritas todas en latín, que vinculan a la posteridad el nombre del filósofo sevillano; y para ocuparnos, aunque brevemente, en

690 Los ha examinado mi íntimo amigo el Sr. Menéndez y Pelayo, a quien debo éste y demás datos nuevos del presente discurso. (Tercera Edición) 
su estudio, convendrá dividirlas en dos secciones. A la primera pertenecen las literarias; a la segunda, las filosóficas. En el grupo literario incluimos la titulada In Topica Ciceronis paraphrasis et scholia, primer ensayo de Fox Morcillo, compuesto a los veintidós ańos de edad, dedicado al prócer sevillano D. Perafán de Ribera, e impreso en Amberes en 1550; los dos bellísimos diálogos retóricos De imitatione, sive de informandi styli ratione (Amberes, 1554) y De Historiae institutione (París, 1557). Las diez obras restantes, ya originales, ya comentarios de las de Platón, abarcan, casi íntegro, aunque en una forma libre, el sistema de las ciencias filosóficas, y pudieran graduarse y eslabonarse del modo siguiente. El libro De studii philosophici ratione (Amberes, 1621), dedicado por el autor a su hermano Francisco, sirve de introducción general y como de propedéutica a la doctrina de Fox Morcillo. Su parte lógica se contiene en los De demonstratione, ejusque necessitate ac vi y De usu et exercitatione dialecticae (Basilea, 1556), su Física y su Metafísica, en el De naturae philosophia, seu de Platonis et Aristotelis consensione, en el In Platonis Timaeum, seu de Universo commentarius (Basilea, 1554), y en el In Phoedonem Platonis, seu de animarum immortalitate (Basilea, 1556); su Moral y su Política en el Compendium Ethices (Basilea, 1554), en el comentario a la República, que anda impreso con el Fedón, en el tratado De Regno et Regis institutione (Paris, 1557), y en los breves diálogos De Juventute y De Honore, dados a luz con el libro De Demonstratione, y el segundo de ellos traducido al francés por Francisco Barraud (París, 1759).

No cabe en los reducidos límites de esta disertación académica un estudio detenido y minucioso sobre tantos y tan variados libros. Pasaremos, pues, rápidamente por los que no son de índole filosófica pura; y aun en los de filosofía atenderemos sólo al principio capital que los enlaza y que constituye la mayor gloria y originalidad de Fox Morcillo.

No se propuso nuestro sabio ilustrar todas las partes de la Retórica siguiendo servilmente las huellas de los antiguos, sino tratar solamente de la imitación y del modo de formar el estilo, para lo cual imaginó un coloquio socrático entre su hermano y un condiscípulo suyo, español también, a quienes presenta paseando y conversando por los alrededores de Lovaina.

Admite Fox Morcillo el principio de imitación; pero ¡de qué manera tan amplia y libre la entiende, a pesar de las preocupaciones clásicas de su tiempo! No la hace consistir, ciertamente, en apropiarse ajenos períodos y sentencias, formando un centón y cayendo en el plagio, sino que busca su raíz y fundamento en una oculta semejanza psicológica, en una simpatía de naturaleza entre el imitador y el modelo (in naturae similitudine). Toda cosa se hace a semejanza de otra, y Dios mismo creó el mundo conforme 
a su Idea ejemplar. El que por naturaleza es seco, de pocas y mal trabadas razones, ¿cómo ha de pretender imitar la pompa, el número y la verbosidad de Cicerón? Al contrario, el que propende a la afluencia y gala del estilo, ¿podrá ceñirse a la brevedad de Salustio o al austero y nervioso laconismo de Tácito? Además, el estilo debe acomodarse a las cosas de que se trata, sometiendo la forma a la materia y no la materia a la forma. Para Fox Morcillo, por consiguiente, tiene la teoría del estilo una parte subjetiva y otra objetiva, cumpliéndose en éste, como en los demás puntos de su enseñanza, el principio de conciliación armónica, a que rinde constante culto. La belleza de la forma literaria nace de la conjunción perfecta entre el objeto del discurso y la índole del escritor. La sentencia de Buffon: el estilo es el hombre, a la cual corresponde esta otra de Fox Morcillo: es más fácil conocer el interior de un hombre por su estilo, que por su rostro ni por su trato, sólo expresa el elemento subjetivo; no nos da más que la mitad del concepto del estilo. Nuestro humanista le completa y redondea con este otro aforismo: naturam subjectae rei observare. Sólo así logrará unidad la composición, a semejanza de la Idea, que liga todas sus partes en el entendimiento.

Es de notar asimismo en este diálogo la libertad de espíritu con que Fox Morcillo, sin embargo de ser ciceroniano fervoroso, no recomienda exclusivamente la imitación de Marco Tulio, sino que pone por ejemplares dignos de estudio a todos los autores latinos que florecieron desde el Príncipe de la elocuencia hasta Quintiliano, y a todos los griegos desde Platón hasta Plutarco.

Completa las especulaciones literarias de Fox Morcillo su bello tratado De Historiae institutione, en que expuso una verdadera teoría del arte histórica, más cabal y filosófica que las que en Italia habían ensayado Pontano, Patricio y Robortello. Definió la historia: «Narración culta, elegante y verdadera de algún suceso, para que su conocimiento se imprima hondamente en el ánimo de los hombres, perpetuándose, consignadas en los monumentos históricos, las cosas, de suyo frágiles y perecederas». Se aparta toto coelo de la opinión de los que sienten que el argumento de la historia ha de ser agradable al lector; y él, por su parte, enseña que todo debe contarse, aunque parezca áspero, duro e inameno, puesto que al historiador no le es lícito elegir entre los hechos, ni omitir nada digno de saberse, por más que favorezca a la parte contraria y sea, para nosotros, molesto y peligroso.

Si Bacon llamo a la Geografía y la Cronología ojos de la historia, Fox Morcillo, aun concediéndoles importancia suma, exige, con espíritu filosófico, algo más que la distinción de los lugares y tiempos, la investigación de las causas de los hechos y de los pensamientos humanos. No circunscribe la historia a la estéril y desabrida tarea de contar genealogías de príncipes y 
sangrientas batallas; quiere que su mayor interés se cifre en dar a conocer las vicisitudes de las leyes, los conflictos y sediciones populares, la fundación de colonias, las navegaciones y los descubrimientos; en una palabra, todos los elementos y aspectos de la civilización. Semejantes ideas, tan comúnmente recibidas hoy, aunque todavía haya no pocos historiadores que están lejos de practicarlas, eran rarísimas en tiempo de Fox Morcillo. De mí sé decir que no conozco escritor alguno que antes de él las proclamase, fuera del incomparable Juan Luis Vives.

No es menos digno de alabanza en este peregrino tratado el singular amor que Fox Morcillo profesa a la verdad histórica, inculcando en cada página la máxima, tan moral como luminosa, de que la historia no ha de escribirse para lisonjear el orgullo de una nación o de un partido, ni para vanagloria del autor, ni por ejercicio académico de estilo, sino en obsequio a la verdad y a la justicia. No oculta al historiador los peligros que ha de acarrearle esta austera consagración al culto de la verdad, y no sólo reclama de él profundos conocimientos en las divinas y humanas letras, y especialmente en las ciencias jurídicas, sino además largos viajes y haber practicado las costumbres de muchos pueblos e intervenido en negocios de paz y de guerra, viéndolo todo con sus ojos y palpándolo con sus manos. Y lleva tan allá su concepción absoluta de las perfecciones del historiador, que desearía colocarle, si posible fuera, en tal altura, que no llegasen a él los embates de la realidad, sin ser ciudadano de ninguna república, ni súbdito de ningún monarca, ni pariente o amigo de nadie; exento, en suma, de todo vínculo y de toda pasión o afecto, semejante a un dios helénico que desde la cima del Olimpo contemplase las cosas humanas, sin tomar parte en ellas, con perfecta serenidad y alto sosiego. Nadie ha ensalzado con tal elocuentes frases como Fox Morcillo el poder y la eficacia social de la historia, que él considera como una pintura o espejo de la vida humana, como una escuela continuamente abierta a la meditación de los hombres y de las repúblicas.

Pero si tan dignos de remembranza y loa son los escritos literarios de Fox Morcillo, todavía raya más alto la estimación que nos inspira cuando recorremos la riquísima serie de sus obras filosóficas, en las cuales vive para nosotros y difunde inmortal aroma la flor del platonismo del siglo xvi, que es tan espańol como italiano, aunque se le llame por excelencia florentino, no más que por haberse establecido a orillas del Arno sus primeras academias y por haber brillado allí su primer intérprete Marsilio Ficino.

Nunca se presentó tan ardiente y viva la pugna que, más o menos declarada, ha existido siempre entre los secuaces de Platón y los de Aristóteles, como en los siglos XV y XVI, o sea en la época llamada del Renacimiento. 
La autoridad de Aristóteles era casi absoluta durante la Edad Media, en que, por un lado los árabes, sobre todo los averroístas, y por otro los escolásticos, si bien modificando su doctrina y haciéndola pasar por el tamiz del Catolicismo, corno es de ver en la maravillosa construcción del Ángel de las Escuelas, habían contribuido a acrecentar su prestigio y afirmar su universal imperio. Pero las relaciones cada día más estrechas entre Italia y Grecia desde las Cruzadas, la reunión transitoria de una parte de la Iglesia Griega con la Latina en el Concilio de Florencia, y la toma de Constantinopla por los turcos, que arrojó a las playas italianas las reliquias del antiguo saber bizantino, produjeron en el Occidente un poderoso movimiento de variedad e independencia filosófica que vino a socavar la antes indisputada supremacía de Aristóteles. Platón fue el lema que en su bandera escribieron los adversarios del Estagirita. Dos períodos principales pueden señalarse en esta memorable lucha, que constituye uno de los episodios más interesantes de la historia del pensamiento humano. El primero, de oposición declarada y fanática al nombre y a la autoridad de Aristóteles, aparece personificado en el filósofo griego Jorge Gemisto Plethón, que comenzó a enseñar en Florencia el ańo 1438, siendo acerbamente combatido por otros griegos adictos al Peripato, tales como Jorge de Trebisonda y Teodoro de Gaza. Mas no tarda en iniciarse, cobrando fuerzas paulatinamente, por el cansancio de unos y otros contendientes y por la mejor comprensión de los términos del problema metafísico, la tendencia conciliadora, aunque predominantemente platónica, que apunta en el cardenal Bessarión y llega a su apogeo en nuestros eximios filósofos León Hebreo y Fox Morcillo.

El antagonismo entre el fundador de la Academia y el del Liceo, aunque se extiende a todas las esferas de la filosofía, concéntrase principalmente en la doctrina de las ideas y la doctrina de las formas. En la Edad Media el problema se formulaba de otro modo: llamábase disputa de los universales, y se ventilaba en el terreno dialéctico. En los tiempos modernos, esta cuestión, que constantemente renace y que no acabará mientras duren las actuales condiciones del espíritu humano, porque en ella sola se resume, hasta cierto punto, toda la filosofía, llamase cuestión onto-psicológica, y los sistemas que aspiran a resolverla distínguense con el calificativo de armónicos. Pero de cualquier modo que se plantee, ora en el campo metafísico, ora en el cosmológico, ora en el antropológico, la cuestión, en el fondo, será siempre la misma, es decir, la oposición entre lo absoluto y lo relativo, entre lo universal y lo particular, entre lo incondicionado y lo condicionado, entre el mundo de las ideas y el mundo de los fenómenos, entre lo permanente y lo transitorio, entre lo inmutable y lo fugitivo. 
En el siglo Xvi se preguntaba: ¿Existe en las cosas algo distinto de las cosas mismas? ¿Tienen éstas valor por sí propias, o le reciben del principio que las informa? ¿Está la realidad en el fenómeno, o depende de la idea? La idea misma, ¿es algo real y separado, o algo real que radica en la mente humana, o pura abstracción y concepto de la mente? ¿El mundo se explica por las ideas, o por las formas? ¿Cómo podrán estas formas o estas ideas reducirse a unidad?

Tales preguntas constituyen la llamada cuestión de Principiis rerum naturalium. Los aristotélicos, así escolásticos como clásicos o helenistas, entre los cuales descuella por su profundidad y elegancia el jesuita valenciano Pererio, resolvíanla con su doctrina de la composición de los cuerpos de materia y forma recíprocamente distintas, siendo la primera como el principio femenino y subordinado, y como el principio masculino, activo y vivificador, la segunda. Los platónicos, por el contrario, encerrados en la altísima región de las ideas puras y abstractas de toda materia, para explicar el tránsito de este mundo ideal al mundo físico, acudían al sobrenatural auxilio de un demiurgo, o bien declaraban fantástico, engañoso y aparente el mundo de los fenómenos, sosteniendo que sólo tiene valor por las ideas, de las cuales es borrosa impresión o pálido reflejo, y que el conocimiento de éstas constituye la única ciencia, la ciencia del ser, la ciencia de lo real, que ellos, tomando la palabra en una acepción enteramente distinta de la de los aristotélicos, denominaban Dialéctica.

Tal era la posición de los dos opuestos campos, del empirismo y del idealismo, cuando Fox Morcillo, pertrechado de inmenso saber, bebido en las mismas fuentes de la filosofía griega, y animado por el generoso ardor de su lozana edad, se lanzó a la arena, en son de paz, con su libro inmortal De naturae philosophia, seu de Platonis et Aristotelis consensione, el cual produjo tan honda impresión entre los doctos, que en breve tiempo alcanzó repetidas ediciones. (Lovaina, 1554; París, 1560; Wittenberg, 1594...)

El autor empieza su libro con una declaración de independencia filosófica análoga a la de Descartes: «El método que siempre me propuse en mis estudios filosóficos fue no seguir por sistema a ningún maestro, sino abrazar y defender lo que me parecía más probable, ya viniese de Platón, ya de Aristóteles, ya de cualquier otro. No dudo que esta manera de filosofar desagradara a hombres divididos en varias sectas y pertinacísimos en defenderlas; pero juzgo que el amor de la verdad debe anteponerse a toda autoridad humana. Mi fe la reservo para los testimonios divinos y para los de la Iglesia católica, únicos que acato y defiendo en todo, como infalibles y eternos oráculos.» 
Fue nuestro Fox Morcillo uno de los primeros en aplicar a la filosofía el método geométrico que, partiendo de algunos axiomas, definiciones e hipótesis va sacando de ellos todo lo restante del discurso. Tal es el orden que siguió en el tratado De naturae philosophia. Expongamos en pocas palabras su sistema.

Forma el objeto de la filosofía todo aquello que puede caer bajo el conocimiento humano, ora esté separado de los cuerpos y sólo sea perceptible por la inteligencia, ora esté adherido a la naturaleza corpórea. El objeto particular de la Física o Filosofía de la Naturaleza no es ni puede ser el ente movible, como algunos peripatéticos afirman: los entes movibles y transitorios no pueden ser materia de ningún conocimiento propiamente científico, porque la ciencia debe elevarse a los principios, a las últimas razones de la composición de todos los cuerpos. Dos procedimientos distintos se han seguido para investigar estas supremas razones. Aristóteles comienza por las cosas sensibles (in sensum cadentibus); Platón por las nociones ideales. Pero lo mismo Platón que Aristóteles convienen en suponer un primer principio incorpóreo y eterno, llámese primera naturaleza o motor primero. Convienen asimismo en admitir un segundo principio, que Aristóteles apellida naturaleza segunda y Platón alma del mundo. Y convienen, finalmente, entre sí y difieren de la doctrina católica, en enseñar la eternidad del mundo y la incorruptibilidad de la materia, que consideran como una capacidad incorpórea, susceptible de recibir innumerables formas y sujeto de mutaciones infinitas.

¿En qué consiste, pues, la contradicción entre el discípulo y el maestro? Consiste, sobre todo, en la doctrina de las ideas profesada por Platón, y en la doctrina de las formas, que Aristóteles propugna. ¿Y cómo resuelve Fox Morcillo esta antinomia? Ampliando el concepto de la forma hasta confundirle con el de la idea, y concretando la idea hasta adherirla a los cuerpos para que los informe. Sus palabras son terminantes y muy dignas de ponerse aquí, vertidas a nuestra lengua, porque encierran todo el pensamiento de su tratado.

«La forma, o, lo que es igual, la idea, sepárala Platón de las cosas corpóreas y concretas y la coloca en la mente de Dios, como ejemplar y dechado de la creación. Aristóteles la une y liga a los cuerpos, como si fuera una parte de su substancia. Al concepto divino le llama Platón causa ejemplar de todas las cosas. Y esta idea, que reside en la mente divina, difiere del pensamiento humano en ser eterna, estar dotada de virtud productiva y carecer de toda mancha y contagio corpóreo; mientras que en nosotros la idea es corpórea, quiero decir, ligada al cuerpo, y nada puede producir por sí. Platón enseña en el Parménides que esa Idea es una, infinita y eterna, abrazando en su unidad las ideas de todas las cosas singulares. Lo mismo nos declara Plotino en el 
libro De las ideas y de la multitud. Esta idea va imprimiendo su sello en las formas de las cosas singulares. Aristóteles, por el contrario, no considera la idea sino bajo el aspecto de forma unida a los cuerpos, y ésta quiere que sea el principio de su constitución. Pero así y todo, en el segundo libro de la Física confiesa la existencia de una forma digna, de la cual todas las demás formas proceden, porque ella sola las comprende todas. En lo cual me parece que viene a decir lo mismo que Platón, o que se resbala hacia el dictamen de su maestro sin sentirlo. Porque si hay una forma primera y divina, a la cual, como a su fin, se refieran todas las demás, tiene que ser un algo universal, separado de la cosa misma.»

«Si sólo tuviésemos que tratar de los principios anejos a las cosas naturales, bastaría con la materia y la forma de los aristotélicos para explicar la composición de los cuerpos. Pero como, por confesión del mismo Aristóteles, el físico debe remontarse a los principios universales, hemos de buscar algo anterior y superior a la materia y la forma, algo que no pertenezca al género de las cosas compuestas, sino que preceda a toda composición y exista por sí mismo simplicísimamente.»

Tales son las Ideas que Fox Morcillo, interpretando el pensamiento de Platón en el sentido de San Agustín y de los teólogos, supone colocadas en el entendimiento digno; aunque sobre este punto haya grandes oscuridades y contradicciones en los diálogos del discípulo de Sócrates.

No seguiremos a Fox Morcillo en todos los ingeniosos pormenores de esta concordia. Sería menester para ello trasladar íntegro su libro, en el cual unas veces rectifica y explana a Aristóteles por medio de Platón, y otras a Platón por medio de Aristóteles, separándose de ambos siempre que los encuentra en oposición con el dogma, v. gr., en cuanto a la eternidad del mundo, a la personalidad de Dios, a la transmigración de las almas y a la reminiscencia. De esta suerte cumple en todas sus partes el programa de libertad cristiana que formuló al principio, y que es, en substancia, el de toda la ciencia española del siglo Xvi, tan bien avenida con Dios y con su Iglesia, como rebelde a cualquier otro yugo de autoridad filosófica y humana.

Las teorías ideológicas de Fox Morcillo se deducen principalmente de sus dos libros De demonstratione, ejusque necessitate ac vi y De usu et exercitatione Dialecticae, que se imprimieron juntos en Basilea el año 1556. Como ferviente platónico que es, admite las ideas innatas, que llama naturales nociones del alma; pero aun en este punto lleva su afán de armonizarlo todo hasta querer incluir debajo de esa doctrina el aforismo peripatético, atribuido a Estratón de Lampsaco, que exageró las consecuencias sensualistas de algunas ideas de Aristóteles, su maestro: Nibil est in intellectu quod prius 
non fuerit in sensu. «Esto se ha de entender (dice el sutilísimo Fox Morcillo, anticipándose mucho a Leibnitz) en cuanto que nuestra noción innata se ejercita sobre las cosas percibidas por los sentidos. Nada hay, pues, en el entendimiento que antes no haya estado en los sentidos, excepto las nociones naturales del mismo entendimiento.»

«Si no tuviésemos—añade—conocimiento más firme y seguro que el que procede de los sentidos, no podríamos formar juicio alguno, porque los sentidos perciben sólo las formas de las cosas, no las disciernen. Necesariamente ha de haber en nuestro entendimiento ciertas ideas o nociones de las cosas, impresas por la misma naturaleza, porque si el alma no usara de tal instrumento para la intelección, la mente percibiría y comprendería, no ya las formas de las cosas, sino las cosas mismas, y observamos que sucede todo lo contrario.»

Vemos, pues, que Fox Morcillo debe ser contado entre los adversarios del conocimiento directo, defendido con tanta habilidad en su mismo tiempo por Gómez Pereira y en días posteriores por los filósofos escoceses; pero tampoco admite las especies inteligibles de los escolásticos, sino que, procediendo de dentro afuera, en vez de proceder de fuera adentro, como ellos, las sustituye con las ideas innatas, por cuyo medio la mente purifica y hace incorpóreas las imágenes que de los cuerpos le transmiten los sentidos.

De este modo se atenúa, ya que no se resuelva por completo la contradicción entre Platón y Aristóteles, aun en la cuestión sobre los medios de conocer, en que parece más radical y profunda. "Ni los sentidos sin las nociones, ni las nociones sin los sentidos (repite Fox Morcillo): Nec sensus sine iisdem notionibus satis ad scientiam pariendam sunt, nec sine sensibus ipsae notiones». Así se explica también la contradicción que algunos han querido ver en nuestro insigne Vives, cuando enseńa, por una parte, que «el alma posee las semillas de todas las artes y ciencias, las cuales son como unas anticipaciones y advertencias grabadas en ella por la naturaleza", y, por otra, afirma que «entramos al conocimiento de las cosas por las puertas de los sentidos, y que no tenemos otras mientras estamos encerrados en este cuerpo.»

Sólo la ciencia de los primeros principios es para Fox Morcillo cierta e inmutable, porque, conocidos los principios, se conoce en cierta manera todo lo que en ellos, como en germen, se contiene. La ciencia que Fox Morcillo imagina no es cualquiera clase de conocimiento, sino la que es y no puede ser de otro modo, la que se funda en la objetividad y realidad mismas, la que tiene por campo y jurisdicción las cosas fijas y verdaderamente existentes, no las movedizas y pasajeras; la que arranca de los principia per se nota; en una palabra: la ciencia de los universales, no la de los singulares; la ciencia que, 
derramada en nuestra mente como fecunda semilla por la próvida naturaleza, nos obliga a decir que tres y dos son cinco, aunque no hayamos visto antes ni dos ni tres; la que nos hace buscar el bien y huir del mal, por una aptitud irresistible del alma (ut mens... quasi apta et proclivis per se sit); la que, al reconocer la verdad, parece que no verifica sino un acto de memoria. ¡Tan misteriosa conformidad tiene lo verdadero con esas ideas o nociones que dormitan en el fondo del alma y que despiertan alborozadas a su presencia!

De estas ideas innatas, la primera y más general es la idea del ser, que, aplicada a las percepciones de los sentidos, nos da ya un conocimiento confuso de las cosas, en el cual no cabe error alguno, porque todo lo que se percibe es. A esta noción se van añadiendo otras, v. gr., la de esencia y accidente, que tampoco es falible ni está sujeta a rectificación. Entonces comienza a verse distintamente lo que antes se percibía tan sólo bajo una razón confusa y universalísima. El entendimiento ve ya concreta y distinta la cosa percibida, y le agrega las notas de ser ésta o la otra esencia, de serlo de este modo o del otro, de ser simple o compuesta. Ser, esencia, accidente, cualidad, modalidad...: tales son los grados del conocimiento en el sistema de Fox Morcillo; tal la cadena de ideas innatas, por las cuales, según él, forzosamente va pasando y modificándose la percepción de lo sensible. En la aplicación de las últimas categorías caben muchos errores, ya por adición, ya por sustracción indebidas; pero siempre el alma parte del concepto más universal e indeterminado, que es el del ser, al paso que los sentidos sólo aprehenden lo singular, que por su multiplicidad misma viene a producir un conocimiento confuso, aunque en razón inversa al conocimiento intelectual, cuya confusión y vaguedad proceden de su misma unidad, cifrada en la noción del ser (aliquid esse). A estos dos modos del conocimiento, que van, el uno de lo singular a lo universal, el otro de lo universal a lo singular, corresponden dos procedimientos: la sintesis, que compone varias cosas entre sí, unificándolas, y el análisis, que descompone un todo en sus partes, diversificándolas. La sintesis es más útil para constituir las ciencias, el análisis para transmitirlas y enseñarlas.

Bastan estas someras indicaciones para comprender toda la trascendencia del sistema de Fox Morcillo, que implica una verdadera revolución en la dialéctica tradicional y el regreso a la dialéctica platónica, pero ensanchada en términos de caber dentro de ella hasta la inducción de Vives y de Bacon, a la cual nuestro filósofo sevillano confía la tarea de demostrar a posteriori las mismas verdades per se notas.

Como Fox Morcillo creía que la ciencia filosófica no debe encerrarse en la pura especulación, sino proponerse fines prácticos, compuso, además de su Comentario a la República de Platón, un tratado de Ética y otro de 
Política. En todos estos libros explana su idea armónica, pero dando muy señalada preferencia a Platón, cuyas opiniones adopta al tratar del sumo bien y al declarar innatos y no adquiridos los afectos humanos. En la República platónica no le parece mal el despotismo del Estado, pero sí la comunidad de mujeres y la participación de éstas en los negocios públicos. A Aristóteles le acusa de subordinarlo todo a un principio utilitario de interés y conveniencia pública. La conciliación de Platón y Aristóteles, depurados en el crisol del espiritualismo cristiano, era para Fox Morcillo el ideal de la ciencia política como de toda ciencia.

Si una concepción trascendental de la naturaleza y del espíritu humano, si una idea luminosísima, perseguida con infatigable ardor y enorme caudal de erudición y doctrina, bastan para hacer que la figura de un pensador resalte con individualidad poderosa en los anales de la ciencia, Fox Morcillo, no hay que dudarlo, ha merecido esta gloria. Sea cualquiera la opinión que se adopte sobre el origen de las ideas, ora se parta del mundo interior, ora del mundo exterior, siempre habrá que reconocer extraordinario vigor de pensamiento en el filósofo que intentó componer en una teoría sintética estos dos elementos. Sea cualquiera la solución que se dé al temeroso problema de la composición de los cuerpos, siempre habrá que descubrirse con respeto ante el joven filósofo que, ligando el mundo ideal con el real, excogitó la sencilla y sublime teoría de la idea sobre las cosas y de la idea en las cosas (la forma). Pueden discutirse, y de fijo se discutirán hasta la consumación de los siglos, estas soluciones; pero tales como son, y aunque no nos den, ni mucho menos, la verdad entera (negada quizá para siempre a las fuerzas naturales de nuestro entendimiento), nos inspiran sed inextinguible de alcanzarla, nos hacen vislumbrar la correspondencia armónica que, en maravilloso triángulo, media entre las cosas creadas y las ideas o razones eternas, y entre unas y otras y la mente humana, y nos infunden un cierto modo de pensar generoso y alto, que desdeña los valles y ama las cumbres. El hecho mismo de haber planteado con tanta precisión y claridad las dos cuestiones capitales de la filosofía, en un tiempo en que la erudición, desbordándose, anegaba lo esencial bajo la balumba de los pormenores, es ya indicio seguro de un soberano talento filosófico. ¡Desdicha grande fue que la muerte, impidiéndole llegar a perfecta madurez, privase a España de los frutos de su fecundo magisterio y de la gloria de poder inscribir su nombre al lado de los más insignes que en la historia del espíritu humano resplandecen!

Quien algo entienda de estas materias y no cierre los ojos a la luz, no podrá menos de reconocer la regularidad con que, a través de los siglos, se reproducen entre los filósofos españoles unas mismas tendencias, dando 
color al pensamiento nacional y unidad a su historia. El espíritu critico y el espiritu armónico se disputan desde remota fecha el predominio en nuestra filosofía, tendiéndose a veces amorosamente la mano. Fox Morcillo, aunque educado cuando estaba en todo su auge el impulso crítico del Renacimiento, cuya más alta expresión es Vives, obedece de lleno a la corriente armónica, adelantándose al gran Leibnitz en más de un siglo. ¡Y cuán antiguos y autorizados precedentes no tenía en España!

Séneca abre la serie de los filósofos ibéricos, y Séneca afirma ya, en su Epístola 58, la identidad de la idea y de la forma, diciendo: Eidos in opere est: Idea extra opus, nec tantum extra opus est, sed ante opus. El eidos, la forma aristotélica, es la idea en las cosas, la manifestación concreta del ejemplar eterno.

¿Y cuál otro es el sentido de la doctrina de nuestro célebre poeta y filósofo judío del siglo xI, Salomón Ben-Gebirol, llamado por los cristianos Avicebrón, cuando en su libro de la Fuente de la vida nos enseña que «las formas sensibles son al alma lo que el libro escrito es al lector, porque cuando la vista percibe los caracteres y los signos, el alma recuerda el verdadero sentido que bajo ellos se oculta»? Sólo que Ben-Gebirol, como panteísta, aunque inconsecuente, supone que la forma universal es la impresión del Uno Verdadero, y que ella constituye la esencia de la generalidad de las especies, es decir, de la especie general, en cuya idea están contenidas todas las especies particulares. La cual en otra parte formuló en términos todavía más claros, diciendo que la forma es la unidad que abraza todas las cosas y en todas las cosas reside. Las formas corpóreas son para él imágenes de las formas psíquicas, vistas en sueños, y éstas lo son de las formas inteligibles.

Cuando el Racionalismo, que se decoraba con el apellido de armónico y que, sin duda, por lo que de armónico tenía o aparentaba tener, sedujo y fascinó a muchas, y, algunas, muy nobles inteligencias: cuando esa panteística filosofía, en mal hora venida de allende el Rin, quiso, para obtener mejor acogida en nuestro suelo, ostentar antiguo abolengo español, no hizo bien en invocar el nombre de Raimundo Lulio; debió remontarse más allá y no detenerse hasta la Fuente de la Vida, con cuyas doctrinas presentan las suyas no pocos puntos de parentesco. El realismo de Lulio es cosa muy distinta; es el realismo platónico con las diferencias que forzosamente habían de mediar entre la filosofía antigua y la filosofía escolástica. Su gigantesca idea de una ciencia general, aplicable a todas las ciencias particulares, con principios generalísimos en los cuales estén implícitos y contenidos los principios de cada una de ellas, como está contenido lo particular en lo universal, nos ofrece la expresión más completa y original del armonismo español. Concepciones 
sintéticas muy semejantes vemos aparecer, más o menos desarrolladas, en los Diálogos de Amor de León Hebreo y en Los Nombres de Cristo de Fray Luis de León.

¿Será posible negar, en vista de tales datos, que el armonismo tiene oculta y extraordinaria eficacia para cautivar a entendimientos españoles; que las tentativas de Fox Morcillo, encaminadas a formularle, no constituyen un fenómeno aislado en el proceso histórico de nuestra filosofía?

Legítima, por lo mismo que natural, como aspiración implícita del alma a un mundo mejor, donde todas las antinomias temporales se resuelven en perdurables armonías; legítima es, sin duda, esta tendencia a conciliar las antitéticas doctrinas del idealismo y del empirismo, reduciendo a unidad la muchedumbre de sus diferencias, bien como el Hacedor Supremo concertó en el hombre por alta manera los opuestos polos de la Creación, el espíritu y la materia. ¡Quiera Dios, empero, que nunca degenere de armonista en violentamente unitaria, ni vaya, por ende, a precipitarse en el tenebroso caos del panteísmo, término fatal de los grandes extravíos de la especulación filosófica! ¡Quiera Dios que los futuros pensadores españoles, conteniendo el anhelo de unidad dentro de justos límites, sepan, como Fox Morcillo, conservar clara, precisa, incólume la distinción entre el sujeto y el objeto, entre lo finito y el infinito, la personalidad divina, la libertad humana, principios vitales de toda filosofía que no quiera demostrar prácticamente con sus mismas aberraciones que entre la razón humana y el absurdo hay una afinidad secreta, un amor invencible! Lograránlo, de fijo, si, a ejemplo de nuestro memorable hispalense, acatando rendidamente como infalibles y eternos oráculos los testimonios divinos y los de la Iglesia católica, los llevan siempre por norte al internarse en el inmenso piélago de las disquisiciones metafísicas. No los pierdan nunca de vista, y bien podrán, como el poeta, desplegar las velas del pensamiento

«... en golfo tan remoto

Que no descubran sino mar y cielo".

¡Que a vosotros también, dorada juventud compostelana; que a vosotros también os guíen constantemente en el curso de los estudios aquellas luces sublimes, a fin de que, prosiguiéndolos con seguro rumbo, lleguéis a coronar un día las halagüeńas esperanzas que, a una con los que os dieron el ser, fundan en vuestro talento y aplicación la Universidad y la Patria! Llamados estáis a ser en lo venidero maestros de la verdad, sacerdotes de la justicia, promovedores del bien, intérpretes de la belleza, cabezas y rectores de la sociedad, combatiendo en primera línea al error y al mal en las diversas esferas de la ciencia y de la vida. Para haceros dignos de tan elevados mis- 
terios, entregaos de lleno al cultivo de vuestra noble vocación, procurando que en vosotros crezcan de continuo el amor y el entusiasmo por las santas obras del espíritu, de tal modo que ni el placer os enerve, ni la voz de sirena del mundo os atraiga, ni las contrariedades os desalienten, ni los triunfos y alabanzas os engrían y desvanezcan. No olvidéis jamás que, como el sol en las aguas limpias y serenas, la luz del saber únicamente reverbera con claridad perfecta en las almas puras y reposadas, donde no hierven pasiones bajas, sórdidas ni tumultuosas. ¡Cuán elocuentes pruebas de esta verdad nos dejaron nuestros antiguos sabios en los peregrinos monumentos de su ciencia gigantesca, tanto más asombrosa cuanto a mayor distancia de tiempo la contemplamos! Seguid la senda por donde ellos ascendieron a la cumbre de la inmortalidad; seguidla sin titubear, rechazando, como ellos, con viril denuedo todo embate de forasteras y anticristianas enseñanzas, no menos contrarias al orden natural que al sobrenatural, por más que de naturalismo blasonen. Seguid particularmente las huellas del preclaro escritor, objeto de este breve discurso, aprendiendo de él, sobre todo, a armonizar en vuestra conciencia los documentos de la fe y los dictámenes de la razón, a unir en fecundo consorcio la erudición sagrada y la profana y a exornar la excelsa majestad de la filosofía con las flores inmarcesibles del arte. De esta suerte alcanzaréis la dicha incomparable de contribuir eficazmente a renovar, engrandecido y perfeccionado con los adelantamientos positivos de la Edad Moderna, el siglo de oro de la ciencia patria, el gran siglo de los Vives y Suárez, de los Sotos y los Arias Montanos, de los Agustines y los Gouveas, de los Mercados y los Valverdes. ¡Ojalá que esa era gloriosa, que mi patriotismo presiente y se complace en vaticinaros, pueda transmitir a la posteridad, acrecentando los timbres de esta ilustre Escuela, algunos de vuestros nombres, rodeados de aureola tan brillante como la que mereció para el suyo el prestantísimo filósofo español Sebastián Fox Morcillo!

He dicho.

\section{Contestación del Sr. D. Gumersindo Laverde a la última réplica del Sr. Azcárate}

\section{Sr. D. Gumersindo de Azcárate.}

Mi distinguido amigo: Quebrantando, aunque levemente, mi propósito, involuntario por desgracia, de no volver a tomar la pluma para otra cosa que la correspondencia privada, voy a hacerme cargo, con la mayor 
concisión que me sea posible, de la carta benévola y discreta, como suya, que V. ha tenido la bondad de dedicarme en el último número de la Revista Europea. Muévenme a ello la cortesía y buena correspondencia que V. tanto se merece, juntamente con el deseo de poner en su verdadero punto algunas especies, no el intento, que sería ya inoportuno, de renovar una discusión para la que me faltan fuerzas.

Cordialmente felicito a V. y me felicito a mí mismo-que, a fuer de amigo suyo y justo apreciador de sus relevantes dotes personales, sentía en el alma verle capitaneando a los detractores de nuestras glorias científicas-por los términos en que rectifica la inteligencia, sobrado literal según veo, que, tanto el señor Menéndez y Pelayo como yo, dimos al párrafo de su artículo de la Revista de España, de donde tomó pie aquel amigo para escribir la serie de eruditísimas epístolas insertas en la Europa. No iba tan allá su intención como sus palabras. Con su muy respetable padre, reconoce y proclama V. los merecimientos de la ciencia española del siglo xvi. Con nuestro común amigo el doctor D. Federico de Castro, ama la antigua filosofía nacional y desea que, saliendo del olvido en que la tenemos, sirva de base y punto de partida a las futuras especulaciones de los pensadores españoles.

Verdad es que, a pesar de tan satisfactorias explicaciones, todavía subsisten entre V., por una parte, y el Sr. Menéndez y Pelayo y yo, por la otra, diferencias de no escaso bulto; pues si convenimos en la estimación del siglo XVI, no así en la de los dos siguientes, durante los cuales ve V. casi por completo - y nosotros mucho menos-paralizada la actividad intelectual de la Península. Como el prejuicio sistemático de que en mi Carta-prólogo a las del Sr. Menéndez le suponía a V. imbuido, no precisamente por su cualidad de krausista, sino por otra más genérica, la de libre pensador; prejuicio que consiste en reputar imposible la vida cientifica donde y cuando quiera que esté vedado el poner en tela de juicio los dogmas religiosos; como este prejuicio, digo, de ser cierto, lo mismo y aún más implicaría la negación de la cultura patria de la primera que de las demás centurias referidas, no puedo ya atribuir a él la pobrísima idea que de éstas tiene $\mathrm{V}$. formada, y debo considerarla hija de otras, aparentemente al menos, más positivas razones. ¿Cuáles? Una sola apunta V. (aparte la cita del absurdo paréntesis de tres siglos de Donoso, fácil y victoriosamente refutado tiempo ha por el Sr. Valera); la de que «si el movimiento intelectual del siglo Xvi no se hubiese interrumpido, no le ignoraríamos». ¿Era preciso para esto que semejante interrupción durase dos siglos, ni mucho menos? Cabalmente en España abundan, de un modo lamentable por cierto, los ejemplos de obras científicas del todo o casi del todo olvidadas por nuestras compatriotas a poco de haber salido 
a luz. Recordaré algunos por vía de muestra. Necesario fue que un médico residente en París participase al P. Feijoo, que de los escritores allí en boga, era uno por aquel tiempo «el nunca bastantemente ponderado Solano de Luque» para que el erudito polígrafo benedictino supiese que había existido pocos años antes y ejercido su profesión en Antequera el célebre autor del Lapis Lydius Apolonis. Con no ser muy posterior al marqués de Santa Cruz de Marcenado, el general Álvarez de Sotomayor, enviado a Berlín por el Gobierno español para estudiar la táctica prusiana, lo que hace presumir que no sería sujeto indocto, hubo de confesar, sin embargo, a Federico el Grande que sólo de oídas conocía las Reflexiones militares de mi ilustre paisano, de las cuales aquel monarca sacara el procedimiento bélico a que debió tantas victorias. De Hervás y Panduro y de su Catálogo de las lenguas, ¿quién se acordaba en nuestro suelo, mientras no comenzaron a divulgar su nombre los Discursos del cardenal Wiseman sobre las relaciones entre las Ciencias y la Religión revelada? ¿Quién recordaba tampoco al sabio anatomista Martín Martínez, médico de Felipe V, y al profundo matemático Tomás Vicente Tosca, lumbreras de la ciencia de su época, hasta que la Academia Española los incluyó en su precioso Catálogo de Autoridades? ¿Quién hacía caso de las Investigaciones filosóficas sobre la belleza ideal, de Arteaga, impresas, como la obra de Hervás, a fines del siglo último, hasta que el Sr. Fernández y González las encomió en su Historia de la crítica literaria en España desde Luzán, premiada por la Academia Española? A vista de estos y otros muchos casos que pudiera aducir, ¿cabe dar valor alguno al argumento u observación que V. propone en apoyo de su dictamen sobre la casi completa nulidad científica de nuestra nación en los siglos XVII y XviII?

No pretendo con estas reflexiones negar la decadencia de nuestros estudios después del siglo xvi; miradas las cosas en globo, nadie la niega. Fue grande, en verdad, comparada con la altura a que anteriormente habíamos llegado; pero no tan absoluta, general y profunda como V. da a entender y yo mismo, con menos datos que ahora, ha algún tiempo creía. La falta de una bibliografía que continuase hasta el reinado de Carlos III la de D. Nicolás Antonio, ha influido no poco en que erróneamente nos figuremos como de tinieblas palpables todo ese período. Por de pronto, en ciertos ramos del saber humano hubo, bajo los últimos reinados de la dinastía austríaca, manifiesto progreso, según ha puesto fuera de duda el Sr. Cánovas, contestando en la Academia Española al discurso de recepción del Sr. Silvela. Aunque es largo el pasaje del Sr. Cánovas, lo inserto a continuación, en interés de la causa que defiendo, ya que las Memorias de la Academia Española, de donde le tomo, no son tan conocidas como merecen. 
"Grave error sería deducir de los falsos principios y extraños ejemplos citados hoy por el Sr. Silvela, que fuera el décimooctavo siglo, no ya a los fines o a la mitad, sino ni aun al comienzo, período de general decadencia de la cultura patria. Es ésta de aquellas cosas que se dicen más que se piensan, pasando tal vez de boca en boca por pereza de analizarlas. Porque la poesía lírica había ya caído del todo hacia la segunda mitad del siglo XviI, sin que el brillo de ésta ni el de la dramática pudiera renovarse en los dos primeros tercios del siguiente, se suele condenar de plano una época, por otros conceptos digna de honrada memoria en nuestros anales literarios. Sabido es por demás que el cultivo de las ciencias entonces conocidas, de la erudición, de las lenguas, fue no menos asiduo que el de las bellas letras en los reinados de Carlos V y Felipe II; debiéndose, a no dudar, el maravilloso vuelo que tomaron aquí a un tiempo todos los ramos de cultura, al frecuentísimo trato que tenían a la sazón nuestros compatriotas con los pueblos más civilizados del mundo. Vióse a los españoles, durante el siglo XVI, aprender y enseñar en las sabias Universidades de Francia o Flandes; rimar y construir estrofas en la ribera de Nápoles o las orillas del Po, al tiempo mismo que el Ariosto y el Tasso, estudiando a la par con ellos al Petrarca y al Boccaccio; predicar en Inglaterra la verdad católica a los mal convertidos súbditos de la reina María; disputar doctamente en Alemania, secundando con sus silogismos los golpes de la temida espada de Carlos V; plantear, profundizar, ilustrar en Trento las más complicadas cuestiones teológicas; contribuir más que nadie a extender el imperio de la filosofía escolástica, produciendo, con arreglo a su método y principios, abundantes y preciados libros, no ya sólo de teología, sino de derecho natural y público, de jurisprudencia canónica y civil. Ni los estudios lingüísticos, ni los escriturarios, ni las matemáticas, ni la astronomía, ni la topografía, ni la geografía, ni la numismática, ni la historia en general, materias tan descuidadas más tarde, dejaron de florecer tampoco durante el período referido, con ser aquel mismo el que vio nacer, por causa de la oculta y amenazadora invasión del protestantismo, los mayores rigores de la censura real y eclesiástica en España. Pero desde los días de Felipe III hasta ya bien entrados los de Carlos II, la decadencia en todo género de estudios graves, eruditos y profundos fue luego rápida, palpable, total, precisamente a la hora misma que con rayos más altos resplandecía en nuestras letras la inspiración dramática. Plena prueba es de este aserto una consulta, que poseo inédita, acerca de las personas que deberían acompañar a Inglaterra a la infanta María, presunta mujer del príncipe de Gales, y en la cual el Consejo de Estado recomendó muy particularmente a Felipe IV, que comenzaba a reinar entonces, cierto jesuita escocés, «porque tenía (dice textualmente el documento citado) todos 
los estudios que allá estiman y acá no se usan, como son lenguas, controversias y matemáticas». Hablando en secreto al Rey sobre asuntos de público interés, y siendo los que tal hablaban sabios ministros, no hay más remedio que prestar fe a esta mala noticia literaria. En el postrer reinado de la dinastía austríaca, los primeros diez y seis años del cual iluminó Calderón, como espléndida luz de ocaso, notóse otra vez cierto calor en los buenos estudios, comenzando por los históricos, cuyas excelencias ya había celebrado, mejor que nadie, Fr. Jerónimo de San Josef en su conocida obra intitulada El genio de la historia, y continuando por los de lenguas y controversias, erudición y crítica, derecho civil y canónico, cual se echa de ver en las obras insignes de D. Nicolás Antonio, Ramos del Manzano, D. Juan Lucas Cortés, el Arcediano Dormer y el Marqués de Mondéjar, predecesores o maestros de Macanaz, Ferreras, Berganza, Burriel, Flórez, Mayáns, Velázquez y Pérez Bayer, útiles faros aun de la literatura nacional. El Santo Oficio, siempre inflexible con los judaizantes y moriscos, ni vigilaba, ni asustaba mucho realmente a las personas de calidad y fama en los días de Carlos II, porque el poder real, de donde tomaba fuerza, andaba tiempo hacía en manos flacas; y en el entretanto, el espíritu de examen, dejando en paz por de pronto las cosas divinas, ocultándose bajo el manto de las ciencias positivas, se abría fácil paso por todas partes, llegando a penetrar inadvertido hasta en la misma España. A tales causas se debió, en mi concepto, aquel inesperado renacimiento literario. Mas, sea cualquiera el origen del fenómeno, su realidad no puede negarse; y no será culpa mía, sino de la verdad estricta, que falte en esta ocasión también aquella rigurosa unidad o simetría, tan pretendida por algunos teóricos, y que tanto suele escasear en la sucesión verdadera de los hechos humanos.»

Tampoco hallo que en estudios económico-políticos retrogradásemos ni tuviésemos nada que envidiar a las naciones entonces más adelantadas: tal impresión, al menos, deja en mi ánimo la lectura de la Biblioteca de los economistas españoles del Sr. Colmeiro. En jurisprudencia sospecho que no eran unos pigmeos, v. gr., Salgado, Ramos del Manzano y Fernández de Retes, cuyos libros alcanzaban crédito allende los Pirineos, y eran reimpresos en Holanda por Meerman. Y para no amontonar citas, ¿̨cuántos sabios ha producido la España contemporánea, con todas sus luces y libertades, dignos de ponerse al lado de Pedro de Valencia, Isaac Cardoso, Caramuel y Nieremberg, o siquiera de Quevedo y Saavedra? Pues ¿qué diremos del siglo XVIII? Sírvase V. citarme, si desea que asienta a su opinión, una serie de escritores de época posterior que en calidad y número compitan con Tosca, Feijoo, Campomanes, Piquer, Pérez Bayer, el P. Ceballos, los autores de La España Sagrada, Ulloa, D. Jorge Juan, D. Juan Bautista Muñoz, Cavanilles, 
Jove-Llanos, Andrés, Serrano, Eximeno, Hervás y Panduro, los canónigos Castro y Martínez Marina, Capmany, etc., etc. ¿Puede reputarse aletargada la actividad científica en un siglo que tan esclarecidos varones produjo? Que fuese inferior a la del XvI, concedido; pero ¿negarla casi en absoluto?...

Aquello «del ingenioso procedimiento de añadir a ciertos nombres la terminación ismo y de las listas de escritores, no muchos para dos siglos, y eso que no se olvida ninguno", téngalo por una broma hiperbólica de V., nacida acaso de su continuo trato con los filósofos andaluces, pues no puedo suponerle lector tan ligero de las cartas del Sr. Menéndez y Pelayo y de la mía, que no haya advertido que en ellas sólo suena un ismo de nuestra invención, el vivismo, sobradamente justificado, y amén de esto, no correspondiente a los siglos XVII y XVIII, ni figurármele tan ayuno de noticias bibliográficas, que desconozca que dicho amigo y yo, lejos de apurar la materia, hemos omitido centenares de autores, entre ellos algunos que, si hoy vivieran, tal vez pasasen por de primer orden.

Cuanto a las causas de la decadencia en cuestión, V. sigue considerando como la principal, si no única, la tiranía del Santo Oficio; yo, a mi vez, persisto en creer que no fue la única ni la más eficaz, digan lo que quieran Montalembert y otros escritores. Los argumentos expuestos en pro de esta opinión no han sido invalidados, ni se ha intentado siquiera contestarlos, y paréceme innecesario repetirlos.

Sobre mi modo de pensar en orden a la filosofía moderna, o a la que tal se denomina, aunque en el fondo sea tan ańeja como las que pasan por rancias, diré a $\mathrm{V}$. que únicamente la rechazo en lo que tiene de incompatible con el Credo católico. Fuera de esto, entiendo que podrán extraerse de ella, como en otros tiempos se extrajeron de la ateniense y de la alejandrina, materiales para ampliar y perfeccionar el edificio de la española. No me permiten más laxitud respecto al particular mis convicciones religiosas.

Por lo tocante a «la absolución que otorgo a ciertas formas de discusión», séame lícito observar que en el caso de que se trata no hubo ni aun asomo de ofensa verdadera, sino vivezas y frases irónicas, que podrán menoscabar un tanto, cuando más, el crédito científico o literario, nunca declarado inviolable, pero de ningún modo el honor y reputación moral del adversario, que es lo único que constituiría pecado grave. ¿No están haciendo continuamente lo mismo, sin que nadie se escandalice, no ya los críticos de gacetilla, sino los más encopetados de las revistas contemporáneas? Y si al propio tiempo, como la equidad exige, tenemos en cuenta la holgura y franqueza propias del género epistolar, el calor de la improvisación y de la controversia, la índole de las negaciones contrarias, y más aún la pertinacia en sostenerlas sin oponer pruebas a pruebas, que todo esto contribuye a encender el ánimo y a 
desatar la pluma sin que lo advierta el que la maneja, ¿a qué queda reducida la culpa por cuya absolución V. amigablemente me censura?

Deseándole prosperidades, es de V. siempre apasionado amigo,

Gumersindo LaVerde

\section{Nota Final}

Esta carta de mi amigo Laverde puede servir de cumplida respuesta, no sólo a la del Sr. Azcárate (que tuvo buen cuidado de no mentarme en la suya, él sabrá por qué: sin duda por desprecio de sectario), sino a lo que apunta D. Luis Vidart en unos artículos sobre la Historia literaria de España, insertos en la Revista Contemporánea. El Sr. Vidart, que ha escrito un libro sobre la filosofía española, no incurre ni podía incurrir en tan enormes yerros como otros racionalistas, llamando, v. gr., como el Sr. Azcárate, siglo de absoluta nulidad científica al siglo en que un español, jesuita por añadidura, creó la Filología comparada. Tales cosas se quedan para los krausistas, y el Sr. Vidart a estas fechas ya no lo es. Pero, con todo eso, tiene por irrefutable el argumento del Sr. Azcárate de «que sin duda debió interrumpirse el movimiento a fines del siglo XVI, porque si así no fuese, ahora no ignoraríamos nuestro pasado científico». A lo cual responderé con dos o tres proposiciones, para no repetir cosas ya dichas:

$1{ }^{\circ}$ Que a fines del siglo XvII no estaba ignorado el movimiento, puesto que nuestros escolásticos no se cansaban de leer y citar a los escolásticos del siglo XVI, y otro tanto hacían los filósofos independientes, como el judaizante Isaac Cardoso, que tenía una erudición estupenda en materia de filosofía espańola, no habiendo pensador nuestro cuyas obras no hubiese leído y no aprovechara en su Philosophia Libera, impresa en 1673. Y no digamos nada de Caramuel, de Aguirre y de otros filósofos de entonces; sin que la intolerancia religiosa perdiera el tiempo en ahogar el recuerdo de nuestra pasada gloria científica. Lo que digo de los filósofos y teólogos es aplicable a los economistas y políticos, a los humanistas, a los eruditos como Nicolás Antonio y D. Juan Lucas Cortés, y hasta a los matemáticos como Hugo de Omerique.

$2^{\circ}$ Que tampoco se cortó la tradición en el siglo XviII, y nos lo prueban, entre otros ejemplos, Feijoo, aprovechando doctrinas de Vives sobre la Reforma de los Estudios; el P. Tosca, continuando la serie de nuestros atomistas; Martín Martínez, reimprimiendo la Nueva Filosofía de Doña Oliva; Mayáns, sacando a luz innumerables obras de sabios españoles, principalmente todas las de Vives; un editor de Madrid reimprimiendo la Antoniana Margarita, 
y otro de Granada el Examen de ingenios; Hervás, utilizando los trabajos lingüísticos de nuestros misioneros, y Piquer, Forner, Lampillas, Andrés y Cerdá y Rico, con sus citas, apologías y reimpresiones de todas clases.

$3^{\circ}$ Que el olvido y desprecio de nuestra tradición científica se inicia en los últimos años del siglo XVIII, y es debido exclusivamente al enciclopedismo y al espíritu francés, que no podían menos de condenar y tener en poco una cultura católica e indígena.

$4^{\circ}$ Que a extender este desprecio y esta ignorancia han contribuido, en lo que va de siglo, las gárrulas declamaciones de los políticos, la extinción de las comunidades religiosas, conservadoras de la tradición; las mal nacidas reformas y planes de estudios, el olvido de la lengua latina, la vandálica destrucción de muchas bibliotecas, la pereza intelectual y falta de seriedad científica que nos corroe, y, finalmente, el énfasis germanesco de esos señores que se jactan de ignorar nuestras cosas (como si ninguna clase de ignorancia fuera mérito), y traen su propia insipiencia por prueba de su dicho, como si las cuestiones históricas se resolviesen con un trabalengua o un sofisma.

Tenía, pues, razón el Sr. Azcárate en afirmar que la vida intelectual en España debió interrumpirse durante largo tiempo; sólo que este largo tiempo comienza por los ańos de 1790 (plus minusve) y continúa en el presente, sin que se vean trazas de remedio; puesto que la decadencia intelectual de España, lejos de coincidir exactamente, como el Sr. Vidart dice, con la unidad católica fundada y sostenida por el Tribunal de la Fe (¡es decir, con el tiempo de los Reyes Católicos!), coincide, con exactitud matemática, con la corte volteriana de Carlos IV, con las Constituyentes de Cádiz, con los acordes del himno de Riego, con la desamortización de Mendizábal, con la quema de los conventos y las palizas a los clérigos, con la fundación del Ateneo de Madrid y con el viaje de Sanz del Río a Alemania.

Y bueno será advertir, a propósito de nuestra decantada intolerancia, que, habiendo dominado los españoles por cerca de tres siglos en Italia, hizo la suerte que del espańolísimo reino de Nápoles saliesen, bajo nuestra dominación, los más audaces pensadores de la península itálica: Giordano Bruno (a quien quemó la Inquisición de Roma, pero no la nuestra), Telesio, Campanella, Vanini (ajusticiado en Francia), y, finalmente, Juan B. Vico. ¡Qué maña nos dábamos los españoles para matar la luz de la ciencia!

Marcelino Menéndez Pelayo. 
SEGUNDA PARTE

AL SR. ALEJANDRO PIDAL Y MON 



\section{DOS ARTÍCULOS DE DON ALEJANDRO PIDAL Y MON SOBRE LAS CARTAS ANTERIORES}

\section{Primer artículo}

T o hace muchos años que los eruditos y laboriosos investigadores de 1 los tesoros literarios que encierran nuestras bibliotecas, paraban su atención, solicitada por tan extraño espectáculo, en un joven, casi un nińo, que con un infolio en pergamino o con algún empolvado manuscrito delante, tomaba de cuando en cuando apuntes en unas cuartillas de papel, con aquella naturalidad y desembarazo que acusan largos hábitos y gran familiaridad en el trato y manejo de tan venerandas antigüedades.

La asiduidad con que concurría a su puesto, el carácter de letra de los manuscritos que estudiaba, el idioma en que estaban escritos los libros que pedía, unido con su tierna edad e infantil aspecto, despertaban de tal modo la curiosidad de los observadores, que en breve se esparció el rumor de que un nuevo erudito, ratón de biblioteca y tragador de polvo y de polilla, iba a salir a luz en la patria de los Gallardos, Calderones, Gayangos y Duranes.

Justificaba tal apreciación el relato de varias anécdotas que corrían entre los aficionados. Contábase el caso acaecido a uno de nuestros literatos más ilustres, encargado de comentar los poetas españoles del siglo décimoctavo, y que en sus laboriosísimas investigaciones no había podido dar con el códice manuscrito de cierto fraile poeta, viéndose obligado a consignarlo así en la obra e inclinándose al parecer de que tales versos no existían; cuando días después recibió una carta, suscrita por desconocido nombre, en la que se le indicaba la biblioteca, la sala, el armario, el estante y el legajo en que los tales desconocidos versos dormían el sueño del olvido. Maravillóse, al parecer, 
nuestro literato, corrió al sitio que se le indicaba, con gran desconfianza y temor de ser juguete de una broma, y halló en el mismo punto señalado las obras del poeta, inquirió diligente las señas de la casa del Colón de aquellas desconocidas rimas, y fuéle a visitar agradecido. No le halló en ella, y decidió esperarle. Introdujéronle en una reducida habitación colmada de papeles y libros, y cuál no sería su asombro cuando, pensando hallarse con un hombre provecto cuyas canas justificasen su sabiduría bibliográfica, se encontró cuando, de vuelta ya nuestro erudito, penetró por fin en su habitación, con un joven imberbe, vestido con una chaquetilla, y con más trazas del jugador de marro o de las cuatro esquinas, que de rebuscador de archivos y desenterrador de códices apolillados. Entablaron conversación animada sobre puntos oscuros de nuestra literatura, y horas después, según es fama, salía el insigne literato haciéndose cruces de ver compendiada tanta erudición en tan cortos aunque tan bien aprovechados ańos.

Estos relatos y otros, como la noticia de que en un solemne certamen abierto por una rica casa editorial, y del que fueron jueces nuestras notabilidades literarias más ilustres, sólo se habían considerado dignas de premio dos obras, y abiertos los pliegos en que venía el respectivo nombre de su autor, se encontraron los jueces con que ambos trabajos llevaban el mismo nombre, que no era otro que el de nuestro joven, vinieron a aumentar nuestros ya vivos deseos de conocerle, deseos mezclados con el temor de que fuese el tal joven uno de esos prodigios de memoria en quienes la casi total ausencia de entendimiento abona la teoría de que una facultad se desarrolla siempre a expensas de las otras, y justifica el dicho vulgar de que la memoria es el talento de los tontos.

Conocímosle, por fin, una noche en unas modestas veladas literarias, en que, no para hacer aparatosos alardes de postizos conocimientos, sino para estudiar y dilucidar detenidamente las cuestiones más importantes que nos ofrece la historia científica y política de nuestra patria, nos reuníamos algunos jóvenes deseosos de aprender, y algunos ancianos de nombre ilustre en la república de las letras. Tratábase aquella noche de la decadencia de España en el reinado del último representante de la Casa de Austria, y de su renacimiento en el del primer representante de la Casa de Borbón; y habiendo hecho uso de la palabra personas ilustradísimas, que habían estudiado de propósito el tema, y algún sabio encanecido en el estudio de la historia patria, parecía ya agotado el asunto, cuando el que esto escribe rogó al joven recién presentado, que hasta entonces había permanecido silencioso, que dijese algo de su cosecha sobre el particular, aunque ya nada nuevo pudiese, al parecer, decirnos. 
Excusóse con natural modestia al principio; pero, vista nuestra insistencia, usó de la palabra incontinenti, y sin afectación ni pretensiones, y en un estilo claro y llano, y con un lenguaje castizo, desarrolló con tal novedad, profundidad y extensión el tema, demostrando tal copia de erudición, tan serena crítica y tanto ingenio, que desde entonces quedó para nosotros inconcuso, no sólo que el joven en cuestión, además de una erudición vastísima, hija de largos y concienzudos estudios, poseía profundos conocimientos científicos, puesto todo al servicio de un entendimiento sólido y elevado, sino que la tan decantada decadencia literaria de Espańa en el reinado de Carlos II, y su tan ponderado renacimiento en el de Felipe V, era uno de tantos lugares comunes sin fundamento, inventados por la pasión y propalados por la ignorancia, como corren de boca en boca por los labios de los eruditos a la violeta del presente siglo.

Pocos días después, en el despacho del director de La España Católica, escuchábamos atentos unos cuantos aficionados a la literatura unas magníficas composiciones poéticas, debidas al mismo joven. Eran unas versiones escrupulosamente hechas de los clásicos griegos y latinos, y de los más afamados poetas italianos, ingleses, franceses, portugueses y lemosines, y aquel mismo día, y en la misma España Católica, veía la luz el primer artículo de aquella larga serie de estudios acerca de los jesuitas españoles en Italia, que tanto llamaron la atención de los críticos, y en los que tan soberanamente se demostraba lo atroz del desafuero cometido contra el saber, no menos que contra la justicia, la virtud y la religión, por aquel acto que ha calificado la historia con el nombre de bárbaro por boca de los mismos corifeos de la impiedad, que acaso por eso no vacilan en repetirlo.

Por aquellos días también adquirimos completas noticias de casi todos sus trabajos, publicados ya unos, inéditos otros, y algunos por acabar todavía, y cuya sola enumeración asusta, pues fuera bastante cualquiera de ellos a ocupar la vida de un hombre, si habían de ser desempeñados con la conciencia que su asunto requería y con la que evidentemente los había él desempeñado todos. Tales eran los Estudios poéticos a que antes nos hemos referido; los Estudios clásicos, de que forma parte La novela entre los latinos, precioso opúsculo que deja agotada la materia, y que presentó el autor como tesis doctoral al recibir este grado en la Facultad de Letras; el Ensayo bibliográfico y crítico sobre los traductores españoles de Horacio; el Bosquejo de la historia cientifica y literaria de los Jesuitas españoles desterrados a Italia por Carlos III, de que ya hemos hecho mención; los Estudios criticos sobre escritores montañeses, inaugurados con el tomo referente a Trueba y Cosío; la Biblioteca de traductores españoles, que ha merecido el nombre de «tesoro 
de erudición biográfica y bibliográfica»; la Historia de la estética en España; y, finalmente, la Historia de los heterodoxos españoles desde Prisciliano hasta nuestros días, digno pendant de la Historia de los herejes italianos, que con gloria suya y de la Iglesia ha dado a luz el inmortal César Cantú.

Tales y tantas obras, fundamentales las más de ellas, nos llenaron de admiración ante el mero desarrollo de sus planes. Planes asombrosos por la vastedad de su extensión, por el número y novedad de sus datos, por la naturaleza y copia de sus fuentes, por lo ordenado de su método y por la unidad de su pensamiento.

Y, sin embargo, debemos decirlo, y lo diremos: nada de todo esto nos sorprendió tanto como la absoluta imposibilidad en que nos vimos de darle alguna noticia nueva, algún dato desconocido, alguna fuente ignorada, algún argumento o consideración importante, olvidado en el desarrollo de sus temas. Siempre que le apuntábamos el nombre de algún autor, el título de algún libro, las aseveraciones de algún crítico, la fuente de algún estudio, siempre nos confundía, saliéndonos al paso, atajándonos en nuestra indicación y completando todo aquello que le decíamos con nuevos hechos y razones, que nos probaban que, no sólo conocía aquel escritor o aquella obra, sino que los conocía a fondo y sabía distinguir, tanto en materia de erudición como de doctrina, lo bueno de lo malo que en ellos se hallaba.

Y lo más notable de este saber y de esta erudición era que como se echaba de ver en seguida, no habían sido adquiridos por segunda mano y en libros de referencia, sino en sus propias fuentes, bien fuesen éstas españolas o extranjeras, manuscritas o impresas, raras o comunes, antiguas o modernas; fuentes cuyo detenido análisis, así como el de sus comentaristas, traductores y plagiarios, nos hacía bajo el punto de vista filosófico de su doctrina, histórico de sus hechos, literario de su estilo, bibliográfico de su edición y hasta bibliománico de sus ejemplares, si éstos eran raros.

Así, sin exageración ninguna de nuestra parte, conocimos nosotros hace tres años al joven D. Marcelino Menéndez y Pelayo, natural de la provincia de Santander y de edad ¡de diecisiete años!

Y, dicho esto, vamos, con el respeto que nos merece y con la desconfianza de nuestras propias fuerzas que el caso nos impone, a juzgar su última producción, verdadera improvisación literaria, con algunas de cuyas aseveraciones nos atrevemos a no estar completamente conformes.

Titúlase esta producción Polémicas, indicaciones y proyectos sobre la ciencia española, y dala comienzo un prólogo tan bien escrito como bien pensado del Sr. D. Gumersindo Laverde Ruiz, bien conocido en la república de las 
letras, paisano del autor, y cuya delicada salud le obliga a calificar esta última producción de su bien tajada pluma, de su «testamento literario».

Es el Sr. Laverde y Ruiz el porta-estandarte, por decirlo así, de los concienzudos entusiastas de la ciencia española, e, indignado ante el voluntario olvido en que la profunda ignorancia de los modernos sabios deja sumidos los tesoros de la sabiduría patria, para correr a rendir humilde tributo de admiración y de homenaje ante las más triviales y chabacanas producciones de la ciencia extranjera, ha dedicado su vida a la investigación y recuento de nuestros sabios teólogos, filósofos, eruditos y naturalistas, y de sus más notables producciones y descubrimientos más importantes, dándonos, como resultado de sus trabajos, la evidencia de nuestra superioridad científica, y como causa de nuestra actual decadencia, el desconocimiento de nuestros grandes hombres y de los monumentos que produjeron, señalando al mismo tiempo el modo de remediarla por medio de estudios críticos y de catálogos bibliográficos, y, sobre todo, por la resurrección de nuestras antiguas Universidades y la creación de cátedras para los diversos ramos de la ciencia española.

Gastó en esta noble cruzada sus juveniles fuerzas el Sr. Laverde, produciendo curiosísimos y eruditísimos trabajos; pero al cabo, «pasáronse los años», "marchitáronsele las ilusiones», "disipáronse sus esperanzas terrenales», "aumentaron sus desengaños», "desfallecieron a una su cuerpo y su espíritu», hasta el punto de retirarse "a exhalar su último suspiro en el suelo bendito en que reposan las cenizas de sus abuelos»; pero sin arriar por eso su bandera, antes bien, manteniéndola enhiesta y tremolándola sobre los jóvenes adictos de la ciencia española.

Cuando he aquí que la Providencia le envía, cuando ya, «enfermo y dolorido, nada le es dado hacer para unir la predicación al ejemplo», al joven Menéndez y Pelayo, que, como dice Laverde, «él solo vale por un ejército», y ante refuerzo tan inesperado, se le ensancha el pecho, se le enardece el corazón, y como si ya no le aterrara la muerte, que pálida y callada se le aproxima, arroja el espańol ¿qué importa?, exclamando: Non omnis moriar. Si yo me voy, «queda en pie V., joven alentado, corazón sano, cabeza potentísima, para continuar la tradición de mis ideas y proyectos, y conducirlos todos a feliz término y remate».

Y en verdad que el resto de la obra que estamos examinando justifica plenamente sus esperanzas y consuelo.

Constituye su núcleo, como se echa de ver por el título, algunas polémicas sobre la existencia de la ciencia espańola, varias indicaciones sobre los medios de generalizar su conocimiento y el proyecto de una obra fundamental 
acerca de los heresiarcas españoles, que no es otro que la introducción y el índice de dicha obra, compuesta por el autor, que en breve verá la luz, según tenemos entendido.

Con decir que el libro que vamos examinando es, a pesar de haber sido escrito al correr de la pluma, para las columnas de un periódico, y sin más plan que las exigencias de la polémica, un manantial inagotable de erudición española, un tratado crítico de nuestra cultura intelectual y un libro amenísimo escrito en lenguaje castizo y lleno de sal ática ad usum de los Don Hermógenes del krausismo, tenemos dicho todo cuanto de él se puede decir en conjunto, concluyendo por añadir que todo escritor español, más aún, católico, no puede prescindir de tenerlo sobre su bufete, si ha de contestar fácil y victoriosamente a los enemigos de nuestra fe, que niegan sistemáticamente la cultura intelectual de España, como prueba evidentísima de las tinieblas en que se sumen las naciones, donde sin rival impera seńora y reina absoluta de los corazones y de los entendimientos la Fe católica revelada por Dios y por su Santa Iglesia.

Motivó las cartas que forman este libro una de tantas proposiciones como la soberbia pedantería racionalista, que desprecia a bulto y montón los tesoros de la Edad Cristiana, para prosternarse extática ante la última exhumación de alguna necedad, fiambre ya de muchos siglos, arroja desde lo alto de las cátedra que ha tomado por asalto, merced, antes que a nada, al abandono de la juventud católica, más gustosa, por regla general, y hasta ahora, de encerrarse en el cómodo pero estéril círculo de las declamaciones, exageraciones y pesimismos políticos, que de trepar por la áspera pero gloriosa cumbre del estudio y de la meditación, por donde tan airosamente asciende nuestro Menéndez y Pelayo, y proposiciones que arrojan también desde las columnas de las revistas que forman ya, comparadas con los periódicos, los estudios serios de estas generaciones tan raquíticas de espíritu como de cuerpo, para quienes sería empresa inverosímil atreverse con uno de esos libros con que se desayunaban nuestros mayores.

La tal proposición era más grave por ser hija de uno de los pocos escritores concienzudos que cuenta la secta, laborioso y de talento nada común; el Sr. Azcárate. Pero ¿qué pueden ver los ojos del entendimiento, por poderosos que de suyo sean, cuando los ciega la tupida venda que la pasión amarró sobre ellos?

Así fue que el Sr. Azcárate afirmó que por falta de libertad en la ciencia, España había perdido por completo su actividad científica durante tres siglos.

Pocos más a propósito para destrozar esta afirmación que Menéndez y Pelayo. Para el que niegue el movimiento, no hay mejor razón que moverse. 
Menéndez y Pelayo no se movió; pero a un solo signo de su pluma brotaron por encanto, como evocadas del fondo de sus olvidados sepulcros, legiones de sabios de todas clases que florecieron en España durante esos tres siglos, y cuyos nombres la fama, pasando callada sobre las cunas de sus ingratos hijos, repite todavía por los lejanos países que conservan, como cicatrices honrosas, los recuerdos de nuestra potente gloria.

Pero Menéndez y Pelayo no se contentó con hacer desfilar esta procesión interminable por ante los ojos del escritor krausista; hizo más: hizo que cada uno de ellos le fuese enseñando, por decirlo así, su hoja de servicios, sus méritos, para él totalmente desconocidos. ¡Qué asombro! Se nos concedían algunos teólogos; pero se creía que teólogos era cosa así como sacristanes, no hombres que pasaron su vida pensando en Dios y avalorando sus infinitas perfecciones: se nos otorgaban algunos misticos, como quien dice, algunos beatos, ponderando todo lo más su lenguaje; pero sin reconocer su intuición poderosa, a la luz de la cual descubrieron los arcanos de la eternidad en medio de las efusiones del amor divino: se confesaban nuestros poetas, novelistas $y$ dramaturgos; pero como válvula que la conspiración tenebrosa contra nuestra libertad dejó abierta a las expansiones inevitables de la inteligencia, no como fruto natural y lozano del árbol frondoso de nuestro ingenio, que engalanó con sus flores la imagen de la verdad que en nuestros altares se veneraba. ¡Pero filósofos!, ¡pero naturalistas!, ¿por dónde?

Vedlos ahí; ahora pasan, con su genio profundo y filosófico verdaderamente español, con su erudición, con sus verdades. ¿¿No os asombráis, racionalistas? Lo comprendo; pero prosternaos ahora y adorad, porque pasan también con sus errores.

Con sus errores, sí; con esos errores que el buen sentido nacional dejó morir sobre el para ellos estéril suelo de la patria y que vosotros adoráis, hoy que os los presentan con papel dorado y con etiqueta francesa y alemana, como las novísimas revelaciones de lo absoluto.

Ahí los tenéis: la duda de Cartesio, el escepticismo de Hume, el sensualismo de Locke, el empirismo de Bacon, el panteísmo de Espinosa. Ahí los tenéis: adoradlos. Vives, Gómez Pereira, Sánchez, Huarte, Servet, os los presentan; inscribid sus nombres en las lápidas del templo que el día que se realice el ideal de la humanidad en el archipiélago de la Oceanía, elevaréis a la lenteja.

¿No podéis? Lo comprendo; sus errores no eran errores trascendentales. Todos eran errores sometidos a la fe. La Iglesia no los perseguía; no podéis, por lo tanto, glorificarlos; sólo hay aquí una víctima de la intolerancia, Servet; pero no lo ha quemado la Inquisición; le achicharró el libre examen. ¡Qué desgracia! 
Y después de los filósofos como Báñez, Soto, Téllez, Vázquez, Rodrigo de Arriaga, Henao, Toledo, Bernaldo de Quirós, Pererio, Molina, Suárez, Sepúlveda, Fonseca, Pedro Juan Núñez, Cardillo de Villalpando, Martínez de Brea, Gouvea, Montes de Oca, Luis de Lemus, Pedro Monzó, Simón Abril, Vicente Mariner, Luis Vives, Fox Morcillo, Núńez, Herrera, el Brocense, Sánchez, Gómez Pereira, Vallés, Isaac Cardoso, Huarte, Doña Oliva Sabuco de Nantes, Pedro de Valencia, Quevedo, Caramuel, Nieremberg, Tosca, Nájera, Feijoo, Hervás y Panduro, Forner, Viegas, Andrés, Eximeno, Martínez, Piquer, Ceballos, Valcárcel, Rodríguez, Pérez y López, Castro y Arteaga, vendrán los políticos, como Fox Morcillo, Mariana, Furio Ceriol, Rivadeneyra, Santa María, Márquez, Navarrete, Quevedo y Saavedra, que escribieron con más libertad bajo reyes como Felipe II e inquisidores como Torquemada, que pueda hoy escribir periodista alguno de oposición en materias de gobierno, y cuyos libros, como dice Menéndez y Pelayo, escritos casi todos con gran libertad de ánimo, y llenos algunos de las más audaces doctrinas políticas, no fueron (ni uno solo, entiéndase bien) prohibido por el Santo Oficio, ni recogido por mandamiento real, a pesar de que en ellos o en los trabajos que de ellos derivaban se sostuviera públicamente, no ya que fuera lícito matar al tirano, sino que el gobierno democrático era mejor que el monárquico y aristocrático, como se propuso defender en sus conclusiones, publicadas en 1634, el P. Agustín de Castro, de la Compañía de Jesús.

¡Hasta tal punto estaba sofocada por la tiranía del Estado, como afirma el Sr. Azcárate y su escuela, la actividad o libertad científica en España durante estos tres siglos!

Hacemos gracia a nuestros lectores de la interminable tarea de escritores de ciencias sociales y económicas que la implacable erudición del Sr. Menéndez y Pelayo obliga a desfilar ante los ojos del escritor krausista, así como la de los orientalistas, hebraizantes, humanistas, griegos y latinos, arqueólogos, historiadores y naturalistas, si bien su corazón hubo de ablandarse cuando le llegó el turno a la consabida válvula, o sea a los grandes astros de nuestra literatura, contentándose sólo al fin con cerrar esta gloriosa columna con algunos sabios originales, como el benedictino Ponce de León, que imaginó el arte de enseñar a hablar a los sordo-mudos, y con poner término a su carta con una instancia a los gobiernos y academias para que fomenten los estudios patrios, si no quieren ver realizada la tremenda profecía de Valera con que acaba, y dice así: "Quizá tengamos que esperar a que los alemanes se aficionen a nuestros sabios, como ya se aficionaron a nuestros poetas, para que nos convenzan de que nuestros sabios no son de despreciar. Quizá 
tendrá que venir a España algún docto alemán para defender contra los españoles que hemos tenido filósofos eminentes.»

Esta última parte de la profecía del Sr. Valera ha salido fallida: el alemán no hace falta.

Y no por falta de españoles (si es que basta para serlo haber nacido en España) que niegan la existencia de nuestros filósofos, pues apenas vio la luz pública la carta del Sr. Menéndez y Pelayo, cuando, como si se sintiera herido en las entretelas de su corazón, enristró la pluma el Sr. Revilla, joven de claro y agudo ingenio, de gran facundia y no vulgares conocimientos, aunque afeado todo por un sabor volteriano que ofende y por las tenebrosas enseñanzas de sus sibilíticos maestros. El Sr. Revilla ha sido primero krausista; después conoció lo vacuo de esos idealismos panteístas, y fue positivista. «Hoy, como dice el Sr. Menéndez y Pelayo, pasa por neo-kantiano; pero lo cierto es que siempre ha militado en las filas de la impiedad, con una u otra bandera.»

Sea de esto lo que fuere, el Sr. Revilla escribió un artículo en la Revista Contemporánea, con motivo de la entrada en la Academia del Sr. Núñez de Arce, refutando al Sr. Valera, y censurando a los Sres. Laverde y Menéndez y Pelayo por sus afirmaciones sobre la ciencia española; artículo que viene a ser una paráfrasis de la proposición del Sr. Azcárate, sazonada con todos aquellos naturales ornatos de la escuela, o sean las consabidas declaraciones sobre el despotismo, la superstición, la intolerancia, y, finalmente, la INQUISICIÓN, "coco de niños y espantajo de bobos», como la llama Menéndez y Pelayo; socorrido "Deus ex machina, que les viene como llovido en las situaciones apuradas», para resolver los más intrincados problemas de nuestra historia, ornatos que califica con extremada agudeza el Sr. Menéndez de «Sinfonía patriótica sobre motivos inquisitoriales.»

En este artículo asevera el Sr. de la Revilla que «en la historia científica de Europa no somos nada (los espańoles»); que la tan «decantada filosofía es un mito», y que "en la historia de la filosofía puede suprimirse sin gran menoscabo la parte relativa a España.»

Oportet haereses esse, dijo San Pablo, y repite oportunamente con este motivo el Sr. Laverde en su prólogo-carta al Sr. Menéndez. Si el Sr. de la Revilla no hubiese escrito las anteriores frases, no hubiera escrito tampoco Menéndez y Pelayo su incomparable refutación en la carta que lleva por título Mr. Masson Redivivo, y en la que, comparando al Sr. de la Revilla con el escritor enciclopedista que tan injustamente trató a España en aquel monumento de la ignorancia del siglo XVIII, cierra con su «eco póstumo», y le prueba por activa y por pasiva, con hechos y razones, que somos mucho en 
la historia científica de Europa; que no son un mito los filósofos españoles, y que no puede suprimirse, sin gran menoscabo de la historia de la filosofía, la parte relativa a Espańa; y no es lo peor que le pruebe esto, sino el modo y manera con que se lo prueba, poniendo tan de relieve las contradicciones y las inconsciencias de los modernos sabios, que el lector no sabe qué admirar más, si la erudición que atesora o si la gracia y el chiste con que la presenta en confirmación evidente de lo hueco y vacío de las declamaciones de los sabios que construyen su propia ciencia, como inteligencias que son abiertas a todo viento de doctrina.

Pero como si los Sres. Azcárate y Revilla no se bastaran por sí solos para despojar a España de sus más esclarecidas glorias, testimonio vivo de la benéfica influencia de su religión, acudió a la palestra, bien que indirectamente, no ya un discípulo aventajado de la secta, como los dos citados, "sino un hierofante, un Pontifice máximo, un Patriarca del krausismo, jefe reconocido de cofradía, personaje conspicuo, varón integérrimo y severísimo, especie de Catón revolucionario, grande enemigo de la efusión de sangre, y mucho más de la lengua castellana». «Todos le conocemos», añade el Sr. Menéndez Palayo. ¿Y quién no le conocerá ante semejante retrato, trazado de mano maestra, por más que el Sr. Menéndez no quiere nombrarle, "porque al cabo ha sido discípulo suyo, y le debe, entre otros inestimables bienes, el de afirmarse más y más cada día en las sanas creencias y en la resolución de hablar claro... per contrapositionem a las enseñanzas y estilo del referido maestro»?

Este, pues, «eximio metafísico», ha puesto un prólogo «largo, grave, majestuoso, sibilino, y un tanto soporífero", al libro de cierto positivista yankee, traducido nada menos que directamente del jinglés! por una "persona muy honorable» (¡manes de Cervantes, sed sordos!), en el cual prólogo, después de aplaudir un libro que dice que "la ciencia nació en Alejandria» y que «los Santos Padres fueron hombres ignorantísimos, sin instrucción ni criterio», llama a la mistica, sublime cópula entre el Oriente y la Grecia, y nos habla en un idioma que, como dice Menéndez y Pelayo, debe de ser «castellano de Morería o latín de los Estados Unidos», de la "solidaria continuidad y dependencia de unas determinaciones individuales con otras que permiten inducir la existencia de un todo y medio natural que constituye interiores y particulares centros, donde la actividad se concreta con limite peculiar cuantitativo y substantiva cualidad en intima composición de esencia factible o realidad formable y poder activo formador». Este escrito, que presenta a los católicos en perspectiva la justicia de la espada, y que aplaude las persecuciones religiosas de Alemania, después de hablar con evidente ignorancia de nuestra historia, del fanatismo de la clerecía en España, a la que llama con desdén Patria de los Dominicos y de 
los Jesuitas, asegura que «mientras los demás pueblos europeos convertían, mediante el Renacimiento y la Reforma, a propia libre reflexión su espíritu y se despertaban a la observación diligente y profunda, nosotros quedábamos adheridos y como "petrificados en las viejas imposiciones dogmáticas»; "error histórico imperdonable, aunque, como dice Menéndez y Pelayo, se explica bien en un sabio que no lee libros viejos y construye su propia ciencia."

Pero a bien que, si el maestro no sabe, aquí está el discípulo que le enseńe, si no con el merecido acompańamiento de palmeta, con cada cogida capaz de poner espanto en el más imperturbable constructor de ciencias, mediante la propia libre reflexión de su espiritu abierto a todo viento de doctrina y libre de todo yugo o imposición dogmática; y es lo cierto que, si él no aprende, los demás aprendemos que los oráculos del krausismo en España son una casta de impíos, con cuya impiedad sólo compite su ignorancia, siendo ambas sólo superadas por el inaguantable barbarismo de su lenguaje.

Dejemos, pues, a un lado al maestro, y volvamos a su antiguo discípulo el Sr. de la Revilla, que con más ingenio y más literatura (a causa sin duda de lo poco que pernoctó en la escuela), volvió a la carga en otro artículo, en el que, ampliando sus aseveraciones anteriores, y confirmándolas de nuevo, se desata en toda clase de invectivas contra la "generación educada en las bibliotecas con estudios de cal y canto», contra los neo-católicos, inquisitoriales, defensores de instituciones bárbaras; que tales son, a los ojos de los defensores del moderno germanismo, los paladines sostenedores del buen nombre y de las glorias tradicionales de nuestra patria.

Y comprendemos perfectamente la ira del Sr. de la Revilla, no contra la generación (¿đónde está, por desgracia?), sino contra los individuos educados en las Bibliotecas con estudios de cal y canto. Al Sr. de la Revilla le gustan más, y tiene razón, las generaciones de católicos educadas en la redacción de algún periódico, donde sólo aprenden a declamar contra el liberalismo y la civilización moderna, sin pararse a investigar las razones y causas, y alcance y sentido de su justa condenación, y donde sólo aprenden a lanzar excomuniones a troche y moche sobre todo el que se permite no seguir las exageraciones de su carácter o de su mal humor; generaciones que cuando llega el caso y ven alzarse enfrente de sí enemigos serios de la religión y de la patria, se encuentran desprovistas de armas científicas y doctrinales con que combatirlos, y tienen que limitarse a huecas declamaciones de un vago sentimentalismo o reducirse a un silencio vergonzoso.

Contra esta generación no le va del todo mal a la generación que, como dice el Sr. Menéndez y Pelayo, "disputa en el Ateneo de omni re scibili, y se propone transformar el Cristianismo, ni más ni menos que si se tratase 
de remendar unos calzones viejos»; contra la que siguiera las huellas del Sr. Menéndez, ya sería otra cosa. Ésta no declamaría lugares comunes; razonaría con arreglo a la lógica; no negaría los hechos que ignorase; aduciría los pertinentes evidenciándolos y explicándolos; no se encerraría en vanas excomuniones, y demostraría con documentos lo fuera de las vías de la razón y de la verdad que iban los enemigos de la religión y de España.

Lean nuestros lectores la segunda carta que el Sr. Menéndez y Pelayo dedica, no ya a Mr. Masson Redivivo, sino a Mr. Masson Redimuerto, y encontrarán de sobra justificado su título con las inestimables páginas que emplea en probar que la intolerancia religiosa no influyó en poco ni en mucho en las ciencias que no se rozaban con el dogma; que los expositores e investigadores que florecieron en nuestra patria son dignos de honrosa memoria; que el que en las historias de la ciencia se hable poco de los españoles, no reconoce otra causa que el ser sus autores extranjeros, y el que siempre fueron los españoles pródigos en hazañas y cortos en escribirlas; que a españoles se deben las invenciones del nonius, de las caras esféricas, de la circulación de la sangre, del suco nérveo, de que los colores son la lux refracta, reflexa ac disposita, del platino, de los rudimentos del telégrafo eléctrico, de infinidad de plantas y minerales; así como de hipótesis geológicas, de descubrimientos médicos, del arte de enseñar a los mudos y del de enseñar a los ciegos; y, en cuanto a la filosofía, que no sólo hubo filósofos eminentes, sino que éstos constituyeron escuelas a las que se afiliaron nombres ilustres de otros países, y que no fue el éxito, sino la fama del éxito, lo que les faltó a estos filósofos, de los cuales se puede decir que «más se olvidaron sus nombres que sus doctrinas.»

Pero ¿qué digo? Lean nuestros lectores esta carta, lean todo el libro; que en él encontraran, además de estas cartas, tres capítulos De re bibliographi$c a$, en que propone medios para reparar la ignorancia hoy generalmente sentida respecto a nuestra historia científica. Fomentar la composición de monografías bibliográficas y de monografías expositivo-críticas, y crear seis cátedras nuevas en los doctorados de las facultades, con otras instituciones encaminadas al mismo propósito. ¿Sabéis cuáles son estas instituciones? Escuchadlo, espiritus fuertes, libres de imposiciones dogmáticas y esclavos del primer charlatán que os embauque, tétricos y cejijuntos krausistas, discutidores de ateneo, traductores aljamiados, alegres gacetilleros, generación novísima de dramaturgos y novelistas fisiológicos; escuchadlo: son los frailes.

En él encontrarán además abundante copia de noticias y datos bibliográficos, curiosas observaciones histórico-críticas, párrafos tan elocuentísimos y tan magistralmente escritos como el relativo a los místicos españoles, juicios 
filosóficos tan notables como el del vivismo, y profesiones de fe católicas y españolas tan magníficas como la siguiente, que, como modelo en el género, trasladamos, para contento de los verdaderos sabios y asombro y risa de los que se lo llamen sin serlo:

«Soy católico (dice con acento firme y sereno el Sr. Menéndez y Pelayo, contestando a las imputaciones del Sr. de la Revilla), no nuevo ni viejo, sino católico a machamartillo, como mis padres y abuelos, y como toda la España histórica, fértil en santos, héroes y sabios, bastante más que la moderna. Soy católico apostólico romano, sin mutilaciones ni subterfugios, sin hacer concesión alguna a la impiedad ni a la heterodoxia, en cualquiera forma que se presenten, ni rehuir ninguna de las lógicas consecuencias de la fe que profeso; pero muy ajeno, a la vez, de pretender convertir en dogmas las opiniones filosóficas de éste o el otro doctor particular, por respetable que sea en la Iglesia.

«Estimo, cual blasón honrosísimo para nuestra patria, el que no arraigase en ella la herejía durante el siglo XVI, y comprendo, y aplaudo, y hasta bendigo la Inquisición como fórmula del pensamiento de unidad que rige y gobierna la vida nacional a través de los siglos, como hija del espíritu genuino del pueblo español, y no opresora de él, sino en contados individuos y en ocasiones rarísimas. Niego esas supuestas persecuciones a la ciencia, esa anulación de la actividad intelectual y todas esas atrocidades que rutinariamente y sin fundamento se repiten, y tengo por de mal gusto y atrasadas de moda lucubraciones como la del Sr. de la Revilla. No necesitábamos, en verdad, ir a Alemania ni calentarnos mucho los cascos para aprender todo eso. Ya lo sabían los bienaventurados liberales del año 20.»

Y en él encontrarán, por fin, un capítulo VII, relativo a los heterodoxos espańoles, del que no se puede decir una palabra, pues es necesario leerlo para formar cabal juicio de su mérito extraordinario, tanto por los conocimientos que revela, como por la fe ilustrada y el patriotismo sensato que respira.

Todo esto, y mucho más que omitimos, encontrarán nuestros lectores en este epistolario, en que, dirigiéndose a su paisano y amigo el Sr. Laverde, ha triturado tan por completo a los señores Azcárate, Salmerón y Revilla, eminencias de la ciencia racionalista en España, reduciéndolos de tal modo al silencio, que el primero se ha visto precisado a decir que en los tres siglos de falta de actividad científica a que se refería, no incluía al siglo xvi, sino al XIX; y al último, a pesar de su indisputable talento y de sus grandes medios, sólo se le ha ocurrido abandonar el campo con una salida tan impertinente como desventurada, diciendo que no quería continuar la polémica, para evitar que a su costa se fabricasen reputaciones ilegitimas, añadiendo en otro lugar 
que el Sr. Menéndez y Pelayo es un neo indigesto y atrabiliario, notable sólo por su apego a las más rancias preocupaciones y su odio a toda idea de libertad $y$ de progreso.

Palabras que, aparte aquello de reputaciones ilegitimas, que no tiene precio, se parecen bastante a las que el pavo de la fábula arrojaba al cuervo, viéndose en la imposibilidad de seguir su vuelo.

$\mathrm{Y}$ examinado ya, aunque muy superficialmente, el trabajo del Sr. Menéndez y Pelayo, otro día, y en otro artículo, expondremos nuestro diferente modo de pensar en algunos de los interesantísimos puntos que en él trata con tan indisputable superioridad este nuevo atleta de la Religión católica y de la ciencia patria, de quien se puede decir que si sigue estudiando con la misma aplicación y provecho, y Dios le concede larga vida, será con el tiempo la personificación majestuosa de la ciencia española, que se levanta en el último tercio del siglo XIX para derramar sobre los hijos espurios de la patria que corren tras los fuegos fatuos de la impiedad extranjera, los raudales de luz que el sol de la verdad católica arrojó en tiempos más felices sobre el glorioso suelo español.

Alejandro Pidal y Mon

\section{Segundo artículo de don Alejandro Pidal sobre las cartas anteriores}

D ocos son los días que, por una u otra razón, no recordemos una chistiempo en un periódico ilustrado del extranjero. Representaba esta caricatura tres cucañas de esas que, con un premio en lo alto, levantan en forma de un palo, untado de sebo, en las plazas de nuestros lugares en los días de fiesta y de regocijo. Por la primera trepaba un robusto mozo en presencia de un numeroso público, que le animaba con sus voces y ademanes, para que llegase a desatar el premio, y un rótulo decía debajo, en caracteres rojos: Cucaña francesa. Por la segunda ascendía otro individuo, y la gente le veía subir silenciosamente, aunque atenta, y otro rótulo de letras blancas decía al lado: Cucaña inglesa. Por la última se esforzaba en subir un tercero, y la gente que por allí había, en vez de ayudarle en su ascensión o de verle subir tranquilamente, procuraba desanimarle con gritos y silbidos, y hasta había algunos que se colgaban de sus pies para echarle abajo. Esta tercera y última cucaña ostentaba en caracteres negros este lema: Cucaña española. 
Y así es, en efecto. Apenas despunta en nuestra patria una notabilidad en cualquier arte o ciencia, y se apresta a trepar con brío por las ásperas cumbres de la gloria, cuando le sale al encuentro la ruin envidia que, como herencia, nos legaron, con su sangre, los moros, para hacer estériles sus esfuerzos, introduciendo en su ánimo el desaliento y la confusión.

Y luego, los mismos que esto hacen se quejan de nuestra falta de sabios y de artistas.

Estos mismos días vimos en un periódico de esta corte amargas quejas y lamentos porque los estudios históricos no florecían en España, y en el mismo periódico y por aquellos mismos días se censuraba agriamente el que la Academia de la Historia, respondiendo a los fines de su instituto, hubiera elegido para académico a uno de nuestros más ilustres epigrafistas, infinitamente más conocido en el extranjero que en España, al sabio hijo de San Ignacio, el P. Fidel Fita.

No; no nos faltan, ciertamente, sabios; lo que falta en España, por desgracia, es público que los estudie y gobiernos que los protejan.

¿No tenemos bien a la vista numerosos ejemplos de hombres doctísimos, cuyas obras, que corren impresas por el extranjero, apenas son conocidas en España?

Citemos, entre mil que pudiéramos, tres ejemplos:

Don Aureliano Fernández-Guerra, verdadera gloria nacional, sabio historiador e ilustradísimo literato, cuyos trabajos encomian los sabios alemanes con admiración y con respeto, tiene, entre sus colosales trabajos históricos, propios de un benedictino, escrita una obra histórico-geográfica referente a épocas y lugares importantísimos de España. Fragmentos de esta obra han visto ya la luz en Alemania. En España no se ha podido publicar, porque el Sr. Fernández-Guerra, modesto empleado que fue en la Dirección de Instrucción pública, no podía costear la edición de una obra que, de seguro, en España no se habría vendido.

Don Pascual Gayangos, cuyo nombre es familiar a todo literato en Inglaterra y Francia, recorre hoy los archivos de España, es verdad, pensionado... ¿por el Gobierno español o por encargo de alguna rica casa editorial? No; por encargo del Gobierno inglés, que, más atento que los nuestros a sus grandes intereses intelectuales, tan íntimamente relacionados con los morales y materiales, desea conocer los documentos referentes a su historia que encierran los archivos espańoles.

El difunto marqués de Pidal, de cuyas condiciones personales no hemos de decir una sola palabra, pero cuyo nombre, conocido de antiguo en la república de las letras, y la circunstancia de haber encontrado en los 
archivos de la Inquisición documentos inéditos importantísimos, parece que debía despertar la curiosidad sobre una obra histórica relativa al punto más importante de nuestra historia, tuvo que regalar la edición que hizo de Las alteraciones de Aragón durante el reinado de Felipe II, mientras M. Magnabal, que la tradujo al francés, vendió en el extranjero con profusión la misma obra.

Estas reflexiones, que casi sin querer se nos vienen a los puntos de la pluma, atraídas por sucesos recientes, tienen aquí un lugar oportuno, tratándose del joven español D. Marcelino Menéndez y Pelayo.

Apenas vio la luz pública nuestro artículo referente a este ilustradísimo joven, en La España del sábado último, cuando algunas personas se apresuraron a tacharlo de hiperbólico, fundadas en que, si no hubiese exageración en lo que decíamos, el señor Menéndez y Pelayo sería mucho más conocido; error manifiesto e imperdonable en personas que conocen nuestro modo de ser.

Hubiera nacido en Francia o en Alemania el Sr. Menéndez y tendría fuerza el argumento; hubiera él sentado plaza en las filas del armonismo, del neo-kantismo, o del positivismo; escribiera en tono dogmático y sibilino párrafos en jerga de la moderna germanía, o frecuentase el Ateneo, el Casino de la prensa o el salón de Conferencias del Congreso, y ya sería otra cosa. La Correspondencia nos tendría al pormenor hasta de sus más íntimos detalles; pero tratándose de un individuo de la generación que se educa con estudio de cal y canto; tratándose de un ultramontano, que es ultramontano porque sabe, y que no vocifera en los clubs, ni excomulga desde los periódicos, ¿quién se ha de acordar de él, como no sean los que, aunque de lejos, siguen el movimiento del verdadero progreso intelectual de nuestra patria? Y los que esto hacen, se encuentran con que, lejos de ponderar con exceso los merecimientos de Menéndez y Pelayo, los hemos expuesto con moderación manifiesta, por temor a la inverosimilitud que de su cotejo con la edad de su poseedor resulta.

Pero más audaces (sin duda por la autoridad que les asiste), pregonáronlos filósofos ilustres, como Fr. Zeferino González y Caminero; literatos y críticos, como Laverde y Ruiz, y Milá y Fontanals; y escritores como el P. Mir, el cual asegura «que contrasta a maravilla el verdor de sus años con la grandeza del ingenio, la madurez del juicio y su erudición inmensa y bien aprovechada», "que sus obras honrarían a cualquier autor cuya cabeza hubiera encanecido en el estudio, y cuya pluma se hubiese ejercitado largos años en escribir sobre las cuestiones más arduas y difíciles», asegurando Laverde que «ha dado muestras de estar cortado por el patrón de los Nebrijas, Vives y Brocenses» y que «el caudal de doctrina y de noticias (muchas harto nuevas), 
la madurez y penetración de juicio, la destreza polémica, el orden amplio y desembarazado, y la soltura, originalidad y abundancia de estilo que ostenta en sus Cartas, hácenlas dignas de ponerse con los dechados del género en nuestra lengua», considerando «maravilloso en un joven de veinte años tal conjunto de cualidades, que pocas veces aparecen reunidas», y llamándole «émulo de Burgos» por sus Estudios poéticos; todo lo cual autorizó a Caminero para considerarle ya como «una gloria nacional», y para que el P. Zeferino, en cartas que tenemos a la vista, declare que, «atendidos su extraordinaria erudición, su criterio recto y bastante seguro, podrá ser con el tiempo una gloria del Catolicismo y de España, y una espada temible a los adversarios de la patria y de la Iglesia.»

¿Qué tiene, pues, de extraño que nosotros, que después de todo no hemos hecho más que relatar sucesos y mencionar hechos incontrovertibles, rindamos tributo a tales merecimientos, haciendo, por fin, nuestras estas palabras de Laverde, relativas a Menéndez y Pelayo: «Niéguenle su admiración con afectada superioridad la ruin envidia y la vanidosa pedantería; yo no sé reprimirla ni quiero disimularla; hallo en abandonarme a ella especial fruición, mezclada de noble y legítimo orgullo»?

Y dicho esto, fácilmente se comprenderá la natural repugnancia y embarazo con que entramos en la segunda parte de nuestro estudio, descartada ya la primera, que consistía en dar a conocer a nuestros lectores a Menéndez y Pelayo, y la victoria que sobre los ejércitos racionalistas había obtenido.

Pero si el nombre y las condiciones de Menéndez y Pelayo nos imponen cierto justo temor al oponer a algunas de sus afirmaciones doctrinales otras nuestras, aliéntanos en tan difícil empresa la firme y arraigada convicción que abrigamos de la bondad y la justicia de la causa que defendemos.

¿Hay filosofía española? ¿Fue ésta la mayor manifestación de nuestro genio? En la ruina de toda verdadera filosofía a que asistimos, ¿debemos volver los ojos, para reparar tanto daño, a la filosofía española?

He aquí, con la mayor claridad que es dado a nuestra pluma, planteados los tres problemas más fundamentales relativos a la existencia, importancia y valía de la ciencia española en su parte filosófica o especulativa.

Procedamos con método, y procuremos fijar bien los términos de cada cuestión. ¿Hay filosofía española? Si por filosofía entendemos aquel conocimiento de verdades relativas a Dios, al mundo y al hombre, que con determinadas limitaciones nos da la ciencia filosófica, claro está que no puede haber filosofía española, ni alemana, ni francesa, porque ni la verdad tiene patria, ni los conceptos de Dios, del hombre y del mundo se pueden encerrar en los estrechos límites de una nacionalidad cualquiera. 
Si en vez de considerar la filosofía bajo el punto de vista de su organismo científico, la consideramos bajo el punto de vista de su desarrollo histórico, claro es que allí donde haya habido filósofos habrá habido filosofía, y en este punto el Sr. Menéndez y Pelayo ha puesto la ceniza en la frente a los Sres. Azcárate, Sanz del Río, Salmerón y Revilla, como dijimos ya en otra parte.

Pero la existencia de filósofos en un país, ¿̨autoriza para bautizar con su nombre a un organismo científico, cuando no se considera el aspecto histórico de la ciencia? Más claro: ¿se puede decir, en lenguaje técnico, filosofía alemana y filosofía española? Distingo: si los caracteres generales o dominantes de todos los filósofos de aquel país coinciden en una nota característica, sí; si no, no. El término filosofía alemana, en rigor, es malo (siempre bajo el punto de vista filosófico, no histórico), porque comprende bajo una común denominación filosofías tan distintas y aun opuestas como las de Leibnitz y Hegel; y sólo se admite en cuanto bajo este nombre comprendemos el conjunto de los sistemas que, a partir de Kant y hasta Krause, vienen más o menos informados por la nota común y característica del idealismo panteísta.

En este sentido, propiamente hablando, no se puede decir que hay filosofía española; pues la única nota característica de gran importancia que une a casi todos nuestros filósofos y sistemas, es la del Catolicismo; pero esta nota, considerada sólo, por decirlo así, negativamente, es muy vaga, y no basta para dar carácter a una filosofía. Para que el Catolicismo imprima este carácter, no basta que en ella se salve el Catolicismo quoad substantiam; «es necesario, como dice elocuentemente el sabio filósofo español Fr. Zeferino González, que el principio católico se revele y palpite en el fondo de la solución, no sólo de todos los grandes, sino hasta de los secundarios problemas filosóficos; es necesario que el principio católico informe y vivifique el organismo filosófico hasta en sus derivaciones más remotas y en sus miembros todos, a la manera que el alma informa y vivifica y extiende su acción basta las extremidades y partes menos principales del cuerpo».

Así, pues, podremos decir, contra lo que creen los racionalistas, que en España hubo filósofos ilustres y originales, fundadores de sistemas tan célebres como el senequismo, el isidorianismo, el averroismo, el maimonismo, y principalmente el lulismo (no admitimos el suarismo como sistema filosófico distinto del tomismo) y el vivismo; podremos decir que estos últimos sistemas representan las tendencias del genio nacional en dos momentos distintos de su historia; podremos decir que sería incompletísima toda historia de la filosofía que no tuviese en cuenta estos y los anteriores sistemas que florecieron en España; pero no podemos decir que con nombrar la filosofía española hemos indicado una tendencia importante, ya porque fuese común 
a los filósofos, como cuando al decir alemana nos referimos al idealismo panteísta, que en su momento más importante domina; ya porque fuera única y universalmente reconocida su trascendencia, como cuando decimos francesa nos referimos al cartesianismo, única y trascendental, aunque con bien infausta trascendencia, filosofía original y propia que poseen los franceses.

¿Fue la filosofía la mayor manifestación de nuestro genio?

Entendiendo por filosofía los sistemas puramente filosóficos a que hemos aludido, no; pues por eminentísimos que fueran, que lo fueron mucho, nuestros filósofos, y por variados y completos que fueran sus sistemas, más brillaron todavía nuestros teólogos y nuestros literatos, sin que por eso pretendamos nosotros disminuir en lo más mínimo el mérito que en ellos, con mayor fundamento que nosotros, reconoce el Sr. Menéndez y Pelayo.

En la ruina de toda verdadera filosofía a que asistimos, ¿debemos volver los ojos a la filosofía española?

Entendiendo por filosofía española el senequismo, el averroismo, el maimonismo, el lulismo y el vivismo, claro es que no; y la razón es obvia: el error total sólo con la verdad total se destruye, y para nosotros la verdad total no se contiene en esos sistemas, incompletos unos, erróneos otros, y otros, a nuestro humilde parecer, un tanto kabalísticos o un tanto eclécticos.

No faltará seguramente alguno que, al leer nuestras respuestas, no acierte a comprender cómo salen de nuestra pluma semejantes afirmaciones, ni pueda concordarlas con todo lo que anteriormente llevamos dicho; pero su asombro cesará fácilmente cuando le hayamos manifestado el resto de nuestra opinión sobre el asunto, con lo que se da fácil solución a todas estas dudas.

Si alguna filosofía merece el nombre de filosofía en absoluto, el nombre de perennis philosophia que dijo Leibnitz, y el nombre de filosofía española en particular, no es otra que la grande y sublime filosofía escolástica, tal como la fijó la diestra inmortal del Doctor Angélico Santo Tomás de Aquino.

España, fiel a la tradición de las escuelas cristianas de Sevilla y de las mozárabes de Córdoba, vio con pena arribar a sus costas al averroismo, el gran corruptor de la filosofía de las escuelas, y vio, a ruegos de uno de sus mayores santos, venir escrita especialmente para ella misma la Suma contra gentiles de Santo Tomás de Aquino. Los hijos de Santo Domingo de Guzmán, maestros en esta filosofía, esparcieron su conocimiento en Espańa, cuna de su Orden, y cuando la cristiandad llamó a concilio a sus sabios, España asombró a la cristiandad, convocada en Trento, con el número y calidad de sus filósofos y teólogos.

La filosofía escolástica, esta filosofía a la que Leibnitz llamaba filosofía española, no tenía nombre particular, porque no era una idea ni sistema 
parcial, una invención particular; era la verdad toda, y completada por la teología, que explicaba a su vez, formaba un todo vivo y compacto, un verdadero organismo científico, al que venía estrecho el nombre de filosofía, $y$ al que hubiera sido menoscabar bautizarle con un nombre particular que no fuera el de filosofía del Ángel de las Escuelas.

$\mathrm{Y}$ no porque no tuviera nombre indígena, como el vivismo o el lulismo, ni pudiera llamarse a secas filosofía, dado que estaba completada con la teología, formando completo y acabado organismo, hemos de negarle el carácter de filosofía española, dado que la profesaron nuestros mayores sabios, se enseñó en nuestras más célebres Universidades y se informó con ella nuestra literatura, nuestro derecho y hasta nuestras artes.

Considerada así la cuestión, tenemos ya respuestas que dar a las anteriores preguntas, muy diferentes de las que dimos antes.

¿Hubo filosofía española? Sí, la hubo, mayor que en alguna otra parte, salvo Italia, patria de Santo Tomás. ¿Fue ésta la mayor manifestación de nuestro genio? Sí; que nunca alcanzó España gloria más grande que la que le dieron sus teólogos escolásticos en el siglo Xvi. En la ruina de toda verdadera filosofía a que asistimos, ¿̇debemos volver los ojos a la filosofía española? Sí; porque esta filosofía es la perennis philosophia de que nos hablaba Leibnitz, la única verdadera, la única completa, la única católica, entendiendo por católica, no la que salva el catolicismo quoad substantiam, en cuanto no se opone a él, sino la que informa el Catolicismo, como informa el alma intelectual al cuerpo humano hasta en sus más apartados e imperceptibles átomos.

Pero ya estamos oyendo decir a algún admirador del señor Menéndez y Pelayo, que nosotros pecamos exagerando lo mismo que el Sr. Menéndez y Pelayo confiesa; pues, tanto enfrente del Sr. Azcárate como del Sr. de la Revilla, ha proclamado como filosofía española, al par de las otras, la filosofía escolástica, y que los nombres con que les abrumó pertenecen la mayor parte de ellos a adeptos de esa filosofía.

Así es, en efecto; pero si bien es cierto que el Sr. Menéndez y Pelayo encarece enfrente de los racionalistas a la escolástica, considerándola como la tercera parte de la filosofía española, asegurando que es nuestra por derecho de conquista, y llamándola «uno de los sistemas más completos, luminosos y prepotentes que han ejercitado el entendimiento humano", también lo es (aparte otros pecadillos sobre que volveremos luego) que para el señor Menéndez y Pelayo el escolasticismo «no es el sistema primero ni único de la filosofía cristiana», sino "un campo del que en ocasiones le aparta algo de aquella santa ira que dominaba a los humanistas del Renacimiento», para volver los ojos a «la falange brillantísima de peripatéticos clásicos y de esos otros 
pensadores eclécticos e independientes que pudieron escribir en su bandera el lema de ciudadanos libres en la república de las letras», y para entusiasmarse con el «siglo aquel» en que, entre otras muchas cosas, no "solían escasear las acerbas invectivas contra la barbarie de la escolástica», y que "ofrecía el espectáculo de independencia y agitación filosófica que caracteriza a España en aquella era en que todos los sistemas a la sazón existentes tenían representantes en nuestra tierra, y sobre todos ellos se alzaba el atrevido vuelo de esos espíritus, osados e inquietos los unos, sosegados y majestuosos los otros, agitadores todos, cada cual a su manera, sembradores de nuevos gérmenes y nuncios de ideas y teorías que proféticamente compendiaban los varios y revueltos giros del pensamiento moderno».

Y como si esto no bastase, no es menos cierto que, lo mismo el Sr. Menéndez y Pelayo que su paisano y amigo el Sr. Laverde, se entusiasman con Vives, que es para el Sr. Laverde un segundo Santo Tomás de Aquino, y con la resurrección de cuya doctrina sueñan, exclamando el Sr. Menéndez y Pelayo: «iQué útil fuera una resurrección de la doctrina vivista en esta época de anarquía filosófica!»

Para rebatir estos asertos, usaremos de nuestra razón y nuestro criterio; pero seguros de no hallarlos mejores en otra parte, nos atendremos a los mismos datos que los Sres. Laverde y Menéndez y Pelayo nos proporcionan.

Luis Vives es, a los ojos de Laverde, un filósofo ecléctico que «combinó el oro que extrajo de la escolástica decadente con lo más acendrado de otros sistemas»; que "cristianizó la filosofía renaciente»; del que "procede toda la filosofía moderna anterior a Kant, lo mismo en lo bueno que en lo malo»; de quien «la Europa entera es discípula ingrata», y al que «España debe estimar como la más elevada personificación de su genio científico», y ver en su sistema «el molde más a propósito, por lo conciliador y comprensivo, para reducir a unidad armónica las diferentes teorías de nuestros doctores, y de esta manera dar cuerpo visible a la filosofía nacional».

Y para Menéndez y Pelayo, Vives es «el más prodigioso de los obreros del Renacimiento", "renovador del Método antes que Bacon y Descartes, iniciador del psicologismo escocés, conciliador y prudente aun en la obra de demolición que habia emprendido», que "tronó contra las sofisterías de la escolásticas», y "clamó como ninguno contra la barbarie de la escuela», y que «sustituyó con un sistema completo el antiguo», siendo punto de partida «de un movimiento tan poderoso como el que arranca de Descartes", puesto que nacieron del vivismo, el peripatetismo clásico, o aristotelismo puro, sin mezcla de averroismo ni escolasticismo; "el ramismo español, tendencia de oposición dura y sistemática a Aristóteles»; «el onto-psicologismo de Fox Morcillo», «defensor de las ideas 
innatas»; "el cartesianismo ante-cartesiano», "el escepticismo de Sánchez», "el empirismo sensualista de Huarte y Doña Oliva», "y pensadores independientes y ciudadanos libres de la república de las letras», cuya influencia traspasó los límites de la patria, y de la cual "nacieron la filosofía de Bacon», "el cartesianismo» y "la filosofía escocesa», debiendo, por lo tanto, colocarse su nombre "tan alto como los de Descartes, Kant y Hegel, porque se han bautizado con los pomposos nombres de baconismo, cartesianismo y escuela escocesa diversos jirones del manto de Vives.»

De propósito hemos subrayado muchas palabras de las que anteceden, para que, fijándose en ellas, pueda conocer cualquiera, por medianamente versado que se halle en ciencias filosóficas, el carácter y significación de Luis Vives; y cuenta que nada hemos dicho de nuestra cosecha; nos hemos limitado a entresacar algo de lo mucho y bueno que de él dicen sus entusiastas admiradores los Sres. Laverde y Menéndez y Pelayo.

Nosotros (juzgando sólo por los datos de estos señores) le admiramos también como un sabio, muy superior a Bacon y a Descartes, sembrador, no ya de ideas, sino de sistemas a granel, como le llama Campoamor; pero, por lo mismo, nos limitamos a admirarle y no queremos resucitar su sistema.

Si al árbol se le conoce por sus frutos, corno dice el Evangelio, ¿qué deberemos pensar de un árbol cuyos frutos son el empirismo baconiano, la duda cartesiana, el psicologismo escocés, el aristotelismo no purificado por los escolásticos, el anti-aristotelismo, las ideas innatas y hasta el escepticismo y el sensualismo?

Sin duda que su nombre será de gran peso para probar al Sr. Azcárate y al Sr. Revilla que hubo filósofos españoles muy ilustres, muy originales, muy fecundos; que los filósofos extranjeros más célebres no hicieron más que plagiarlos, echando a perder sus invenciones; es más: que, dado el tiempo en que florecieron, hicieron mucho bien, ya conteniendo y encauzando las asoladoras corrientes que devastaban los campos de la ciencia, ya fustigando inveterados abusos; pero... ¡resucitar su doctrina!, ¡declararse vivista hoy!, ¡pretender que la filosofía española sea el vivismo! ... Por los clavos de Cristo, que aún hay tomistas en España.

No; ni el lulismo, por más respeto que nos merezca; ni el suarismo, que como sistema filosófico no puede distinguirse fundamentalmente del tomismo; ni el vivismo, por importancia que le concedamos, pueden, ni aspirar al título de filosofía española por excelencia, ni a resucitar como remedio definitivo y como arma irresistible contra las modernas filosofías que algunos de ellos engendraron.

En vano pretenderá el Sr. Menéndez engalanarlos con ajenas galas, presentando como discípulo de Vives a Melchor Cano, que es tomista de pura 
raza, ni elevar a las nubes el congruismo, sistema teológico acerca de la gracia incapaz de competir con el que sobre la misma cuestión ofrece el tomismo.

En vano censura a los neo-escolásticos que prefieren Liberatore o Sanseverino a Sánchez o a Huarte. No es posible que lo desconozca. La religión única informó la única filosofía, y resultó el escolasticismo tomista, que es la filosofía cristiana por excelencia, que, completada por la Revelación, forma, como hemos dicho, un organismo vasto, profundo y elevado, que se llama la teología escolástica, en que tan alto rayaron los colosales ingenios que florecieron en España, cuyas doctrinas y cuyos nombres es necesario recordar para proclamar la existencia de la ciencia española; para demostrar que esta ciencia fue la más alta manifestación de nuestro genio, y para asegurar que en la ruina de toda verdadera filosofía a que asistimos debemos volver los ojos a esta ciencia como remedio a tanto daño.

No somos solos, por fortuna, los que así pensamos; el P. Zeferino, en sus Apuntamientos sobre una Biblioteca de teólogos españoles, regocijándose ante la idea de que se iba a formar una sociedad literaria con objeto de publicar una Biblioteca de filósofos españoles, objeto a sus ojos "patriótico, digno y elevado», por «no ser él de los que miran con injustificado desdén la filosofía española», ni de los que «afirman que no merece figurar al lado de la de las otras naciones», ni «asentir al dictaminen de los que parecen estar persuadidos de que la filosofía española carece de todo mérito y originalidad», se pregunta, sin embargo, "si no sería más conveniente, más útil y hasta más patriótico publicar una Biblioteca de teólogos españoles», y se decide por la afirmativa, porque "cualquiera que sea la opinión que se adopte sobre la importancia absoluta o relativa de la filosofía española, es innegable que el movimiento filosófico realizado en la Península Ibérica no puede ponerse en parangón con el movimiento teológico que comunica especial brillo a la historia eclesiástica de España, y siempre será preciso reconocer que la importancia de la filosofía en España es muy inferior a la de la teología española, la cual se puede decir, con razón, que ocupa un lugar, no sólo preferente y distinguido, sino acaso el primero en la historia de las ciencias teológicas»; "porque la verdad es, añade el sabio dominico, que si España puede presentar algunos filósofos más o menos recomendables y distinguidos, no puede presentar escritores que rayen tan alto en filosofía como rayaron en teología Torquemada, los dos Sotos, Cano, Carranza, Molina, Suárez, Vázquez, Alfonso de Castro, Pérez de Ayala, Báñez, Lemos, Valencia, con tantos otros que dieron gloria inmortal a nuestra patria».

«Sin duda alguna, continúa el obispo de Córdoba, que una Biblioteca de teólogos españoles que, arrancando de San Isidoro y Tajón y pasando por 
Juan de Torquemada, con otros teólogos de los siglos xIV y Xv, y después por los grandes teólogos del siglo XVI, para terminarse en el siglo XVII, ya que no se quiera continuar hasta el Xviı con el oratoriano Calatayud, sería un monumento literario digno de la gran nación que en siglos anteriores figuró al frente de las demás.»

Así, pues, no vacilaremos en repetirlo, aunque sea enfrente de adversarios tan temibles por lo eruditos como los Sres. Laverde y Menéndez. Proclamen en buen hora la superioridad científica de España sobre las demás naciones; afirmen una y otra vez que la intolerancia religiosa y la Inquisición favorecieron, en vez de coartar, el libérrimo vuelo de la ciencia; aseveren que el genio español es de suyo filosófico y profundo, sin estar tocado de la ligereza francesa, de la nebulosidad alemana, ni de la lentitud inglesa; exhiban como nacionales glorias, en testimonio de esta verdad, los nombres ilustres de Séneca, de Lulio, de Vives, y hasta los de Averroes y Maimónides; vindiquen el nombre de Vives del olvido que sobre él pretenden esparcir los discípulos de Sanz del Río; celebren su genio poderoso, su maravilloso saber, su buen juicio, sus sanos propósitos; recuerden, para justificarle, la decadencia a que por entonces habían llegado algunas ramas desgajadas del tronco vigoroso de la escolástica; pero no traten, por Dios, de sincretizar en un eclecticismo vivista todas las escuelas españolas, reivindicando como glorias de España el empirismo de Bacon, la duda de Descartes, el psicologismo escocés, ni los demás errores o verdades incompletas que sucedieron al abandono de la escolástica, y, sobre todo, no traten de hacer olvidar, presentando a Vives como superior a Soto, a Suárez o a Melchor Cano, y al vivismo como superior al tomismo, que la doctrina de Santo Tomás, único organismo completamente científico y católico, fue, si no por casualidad de su nacimiento, por derecho de conquista, la filosofía española, como la llamó Leibnitz; la que hizo brillar a Juan de Torquemada en Basilea; la que predicó Vicente de Ferrer en toda Europa; la que fomentó Cisneros y restauró Francisco de Vitoria, el Sócrates de la teología española; la que inspiró a Diego de Deza, el protector de Cristóbal Colón; la que inmortalizó a Carranza, el gran campeón del Concilio de Trento; a Domingo Soto, el encargado por los Padres del mismo Concilio de redactar sus decisiones y decretos; a Pedro Soto, el restaurador de las Universidades de Dilingen y Oxford, el primer teólogo de Pío IV en el Concilio Tridentino, que le calificó de "príncipe de los teólogos», y que pareció, según dice Palavicini, que quedaba sumido en la oscuridad con la muerte de una de sus mayores lumbreras; la que profesó Melchor Cano, que, pensando como Santo Tomás, escribía como Cicerón; la que formó a Báñez y a Lemos, a Salmerón y a Laínez, a Pérez Ayala y a Juan de Santo 
Tomás y al gran Suárez, que, lejos de proponerse separarse de Santo Tomás, le siguió en su filosofía y pretendió no apartarse de él en sus innovaciones teológicas; la que se enseñó en nuestras Universidades de Salamanca y Alcalá; la que dio dirección y guía a nuestros místicos como Santa Teresa y Fr. Luis de Granada, y la que inspiró a nuestros artistas, dándonos, entre otras obras maestras, el gran lienzo de Zurbarán, en el que el Emperador de las Españas y el clero secular y regular español y la nobleza de Castilla asisten de hinojos al Triunfo de Santo Tomás de Aquino.

¡Que no procuren hacerlo olvidar, por Dios; antes bien, dediquen su maravilloso saber y su incontestable talento a recordarlo; que sólo así podrá renacer en España el estudio de la teología filosófica, de la filosofía escolástica, y, con ella, nuestra grandeza intelectual, moral y política; sólo así volverá a florecer, como floreció en otros tiempos, la ciencia española!

Alejandro Pidal y Mon 



\section{IN DUBIIS LIBERTAS}

Florencia, 13 de abril de 1877.

Sr. D. Alejandro Pidal y Mon.

Mi bueno y docto amigo: En Roma tuve ocasión de leer los dos brillantes artículos que V. ha dedicado a mi pobre librejo acerca de La Ciencia Española. De inmodesto pecara yo si no dijese que me parecieron en alto grado hiperbólicos los elogios que V., a manos llenas, ha derramado sobre aquel pobre trabajo, que si alguna consideración merece, ha de alcanzarla tan sólo por el fin a que se encamina y como anuncio de ulteriores tareas, que, de ciertos no le superarán en mucho. Pero de ingrato se me tacharía, con razón, si no diese a V. alguna muestra de mi agradecimiento por la lluvia de flores con que ha tenido a bien regalarme. Por eso escribo estas líneas, y añado a ellas, a modo de postdata, algunas observaciones sobre el segundo artículo, en que V., a vuelta de mil encomios, manifiesta aguda y sabiamente su discordancia de parecer en alguno de los puntos que directa o incidentalmente he tocado en mi libro.

Superfluo me parece advertir que en esta polémica no me mueve otro interés que el de la ciencia española, por cuya mayor difusión y esclarecimiento trabajo. Afortunadamente para mí, los puntos en que disentimos no son capitales. En lo substancial estamos conformes y no juzgo imposible que en lo demás lleguemos a entendernos. Harto conocía yo al tiempo en que escribí aquellas cartas el vigor y pujanza actual del tomismo entre nosotros. Entonces como ahora, confesaba y confieso que esa restaurada escuela es en España el más firme valladar contra las invasiones del racionalismo. Pero como a éste se le puede combatir de muchos modos, y no era lo más oportuno en aquella discusión, puramente histórica, afectar exclusivismos de 
escuela, no quise hacer hincapié en el tomismo, ni empeñarme de propósito en demostrar a los adversarios que España había dado grandes expositores de la doctrina del egregio Aquinate; cosa generalmente sabida y que ellos no negaban, por lo cual hubiera tenido escasa fuerza el argumento. A los que me preguntaban por creaciones filosóficas nacionales, por escuelas y sistemas peninsulares, claro es que no podía responderles con una filosofía extraña de origen, aunque nuestra por derecho de conquista, como ya tuve cuidado de advertir. Bajo el aspecto histórico nacional, único que yo entonces consideraba, pesa y significa más Averroes que los expositores de Santo Tomás.

Aquí tiene V. explicada una de las causas de lo que en mí pudo parecer ligereza o desdén respecto al tomismo. Yo hablaba entonces como bibliógrafo español: nada más. Los tomistas no me servían para el caso; era necesario presentar filósofos de grande originalidad de pensamiento, bien o mal encaminada, que de esto hablaremos luego. Por eso acudí a Séneca, a Averroes, a Maimónides, a Lulio, a Vives, a Fox, a Suárez y a algunos más, sin desdeñar, no obstante, la escolástica, a la cual varios de ellos pertenecieron, y de la cual dije que era, no una, sino dos terceras partes de nuestra filosofía. Pero de estas dos partes hice gracia a los contrarios, e insistí en la tercera, en la más curiosa y menos estudiada hasta ahora, en la de los pensadores independientes.

Y precisamente por lo menos estudiada me fijé en ella. Yo veía que el neo-tomismo cobraba de día en día mayores fuerzas, y que sus sectarios, tan respetables por el número como por el saber, eran muy capaces de ilustrar, docta y concienzudamente, los anales de su escuela. Justo era, pues, dejarles el campo libre y no meter la hoz en mies ajena. Pero advertía en ellos, al mismo tiempo, cierto espíritu, sobrado exclusivo, que los llevaba a seguir y ensalzar tan sólo las obras y doctrinas del Ángel de las Escuelas, con veneración laudable, sí, pero, según mi pobre entender, dañosa por lo extremada. Proyectábase una edición de las obras de Santo Tomas, tantas veces reproducidas por la estampa, tan conocidas, que se encuentran en todas las bibliotecas, en todas las manos. Y esto, cuando en Italia, patria del Santo, y en Francia, y en Alemania, y en todo el orbe cristiano, se trabaja sin cesar sobre sus admirables escritos, y en cien formas se los expone y reproduce. $Y$ mientras se pensaba en esta empresa magna, a nadie se le ocurría, sino a mi docto y entrańable amigo Laverde, no ya publicar una biblioteca de filósofos ibéricos, sino reimprimir el más insignificante opúsculo de cualquiera de nuestros pensadores. Tenemos una reimpresión completa, aunque no muy esmerada, de las obras de Suárez; pero no se ha hecho en España, sino en París. Tenemos una buena traducción del Guía de los extraviados o Director de los que dudan, de Maimónides; pero no la ha hecho ningún español, 
sino el francés Munk. Al mismo y a otros compatriotas suyos debemos el conocimiento de la Fuente de la vida, de Avicebrón. El Filósofo autodidacto o Régimen del solitario, de Aben Thofail, está traducido al latín, al inglés y al alemán; pero no al castellano. El Cuzary, de nuestro gran pensador y poeta Jehuda-Ha-Levi, hemos de buscarle en la vieja y rara versión de Jacob de Avendaña. En todos los países civilizados se han hecho ediciones completas de Séneca, menos en Espańa. De San Isidoro no han reproducido las prensas españolas, en lo que va de siglo, un solo tratado. A Raimundo Lulio hay que estudiarle en la vetusta edición maguntina, que, tras de incompleta, es rara y de difícil manejo, y tampoco contiene los textos primitivos, ni los da en su lengua original. Pues no digamos nada de los filósofos posteriores al Renacimiento...

No piense V. por esto que yo juzgase inútil (blasfemia científica sería) una reimpresión de Santo Tomás hecha en España. Pero, hoy por hoy, importa más a nuestro crédito científico popularizar nuestros sabios que los extranjeros, aunque, como el Ángel de las Escuelas, sean de los que tienen por patria el mundo y la humanidad por discípula.

Todo esto pensaba yo, y encontrando demasiado tirante el arco por una parte, probé a doblarle por la otra, quizá con exceso. Exceso, digo, no respecto al mérito de nuestros filósofos, que cada día reconozco mayor que cuanto yo acierto a encarecer, sino exceso respecto a la alteza del tomismo, que tal vez ofendí (si ofensa cabe) con palabras ligeras o indiscretas.

En ello influyeron además otras causas que tampoco quiero ocultar. No soy tomista a la hora presente: quizá lo seré mañana. Lo cual no quiere decir que yo tenga pretensiones filosóficas, que en un pobre bibliófilo fueran absurdas. Pero sé que cada hombre está obligado a tener más o menos su filosofía, no sólo práctica, sino especulativa. Ahora bien: esa filosofía, por lo que a mí toca, no es otra que el criticismo vivista. Pero como éste no es adverso al tomismo, ni mucho menos, aunque sí distinto, de aquí que venere, respete y acate yo la doctrina tomista como puede hacerlo el más fervoroso de sus adeptos. Es más: sospecho que el no haber llegado yo a ella depende más de mi debilidad de entendimiento que de otra razón alguna. También pueden influir en ello ciertas preocupaciones literarias o humanisticas de que no es preciso tratar ahora, y a las cuales quise aludir con lo de la santa ira. Ocasión tendré de volver a este punto.

Si V. ha seguido con paciencia todo el relato anterior, habrá comprendido las causas de mi posición (si tal puede llamarse) respecto al tomismo. Ahora entraré a examinar parte por parte las discretas y amistosas reflexiones que vienen apuntadas en su artículo. 
Fijándose en un punto claro y luminoso, pregunta V.: «¿Hay filosofía española?», y, distinguiendo, contesta: "Bajo el punto de vista de su organismo cientifico, no hay filosofía española, ni alemana, ni de ningún otro pais: la verdad no tiene patria». Hasta aquí vamos conformes. "Bajo el punto de vista de su desarrollo histórico, donde haya filósofos habrá filosofía». Tampoco en esto cabe duda, aunque siempre es necesario que entre estos filósofos medie algún lazo más o menos íntimo. Yo creo que le hay siempre entre los pensadores de un mismo pueblo, y, en tal concepto, ninguno carece de filosofía nacional, más o menos influyente y desarrollada. Y si nunca oímos hablar de filosofía rusa ni de filosofía escandinava, será, o porque estos y otros países no han tenido pensadores de primero ni segundo orden, o porque nadie se ha cuidado de investigar sus relaciones y analogías, o porque estas investigaciones no han entrado todavía en el general comercio científico. De otra suerte, es imposible que filósofos de un mismo pueblo y raza no ofrezcan uno y aun muchos puntos de semejanza en el encadenamiento lógico de sus ideas.

Y sigue V. preguntando: «¿Se puede decir en lenguaje técnico filosofía alemana, filosofía española?». Y la contestación es: «Si los filósofos coinciden en una nota característica, si; si no, no». Por eso, en concepto de V., y en el mío también, es exacto el nombre de filosofía alemana aplicado a los sistemas germánicos que han aparecido desde Kant hasta nuestros días, y no a la doctrina de Leibnitz, ni a la de Wolfio, ni a ninguna otra anterior. Tiene V. asimismo por exacto el término de filosofía francesa aplicado al cartesianismo exclusivamente, y yo añado que en este sentido es también legítimo el nombre de filosofía escocesa, con que se designa el psicologismo de Reid, Dugald-Stewart y Hamilton, y nunca el escepticismo de Hume, aunque éste naciera en Escocia. Pero en cuanto a España, no descubre V. más nota característica que una a sus filósofos que el Catolicismo, nota de suyo harto vaga y no suficiente para justificar el nombre de filosofía española.

En rigor, la cuestión de los nombres importa poco; pues, una vez admitida la existencia y confesado el mérito de nuestros filósofos, de alguna manera hemos de designar el conjunto de sus especulaciones, puesto que no aparecen aisladas ni independientes unas de otras. Mas, por lo que importe, conviene aclararla. Y se aclara con dos preguntas sencillísimas: ¿Existe la filosofía griega? ¿Es exacto este nombre? A lo que yo entiendo, no hay medio humano de reducir a esa violenta unidad aquella variedad y riqueza de sistemas. ¿Cuál toma V. por tipo del genio filosófico de la Grecia? Y aun limitándose a los dos principales, ¿llamará V. filosofía griega a la platónica, y negará este nombre a la aristotélica, o viceversa? $\mathrm{O}$, más bien: ¿̨reconocerá $\mathrm{V}$. 
que el ingenio filosófico de los helenos no ha de buscarse en una ni en otra de sus escuelas, sino en el conjunto de todas y en su desarrollo histórico?

Sin duda que en esto último; y por eso es legítimo el término de filosofía griega, y no menos legítimo, aunque no tan usado, el de filosofía española. Inexactos fueran uno y otro si indicasen series de fenómenos aislados, sin más enlace que el de lugar y el de tiempo.

Mas no sucede así en estos dos casos. Nadie lo duda en cuanto a Grecia; y por lo que toca a Espańa, vese claro el organismo de su historia científica, a poco que en ella se penetre. En Séneca están apuntados ya los principales caracteres del genio filosófico nacional. Dos de ellos, el espiritu crítico y el sentido práctico, llaman desde luego la atención del lector más distraído.

Séneca es uno de los tres grandes maestros de la raza ibérica: todos nuestros moralistas descienden de él en línea recta. Séneca, gentil en verdad, pero a quien San Jerónimo llama noster, y pone en el catálogo de viris illustribus al lado de los primeros cristianos, preludia nuestra filosofía ortodoxa. La heterodoxa (tomado de vocablo en su más lato sentido) presenta siempre un carácter distintivo: el panteísmo.

Porque hay una filosofía panteísta española, resuelta y clara, que se anuncia por primera vez en Prisciliano; asombra al mundo en Averroes y en Maimónides, con todas las escuelas árabes y judías que preceden y siguen al uno y al otro; pasa a Francia con el español Mauricio; se vislumbra en Fernando de Córdoba, que en pleno siglo xv formula el principio ontológico de $l o$ uno, en que se resuelven el ser y la nada; inspira en el siglo XvI al audaz y originalísimo Miguel Servet, y alcanza su última expresión en el xvII, bajo la pluma de Benito Espinosa, cuya filiación hebraico-española es indudable.

Si el panteísmo está en el fondo de toda la filosofía española no católica e informa lo mismo el averroísmo y el avicebronismo que el misticismo quietista de Molinos, y persigue como un fantasma a todo español que se aparta de la verdadera luz, en cambio la filosofía española ortodoxa y castiza de todos los tiempos conviene en ser crítica y armónica, y cuando no llega a la armonía, tiende al sincretismo. Obsérvelo V. en todos nuestros pensadores de las grandes épocas. San Isidoro condensa y sincretiza la ciencia antigua. Raimundo Lulio forma un sistema admirablemente armónico y levanta el espíritu crítico contra la enseńanza averroísta. Luis Vives es la crítica del Renacimiento personificada. Fox Morcillo, en su tentativa de conciliación platónico-aristotélica, formula el desideratum del armonismo. Todas las escuelas nacidas al calor de la doctrina de Vives son críticas por excelencia; sobre todo, la valenciana. De todo lo cual deduzco que al principio, ya formulado por varios escritores, «la filosofía española es esencialmente dogmática y creyente», principio que usted juzga 
demasiado elástico, debe añadirse este otro: «la filosofía española ortodoxa es crítica y armónica; la filosofía española heterodoxa es panteísta, y, como tal, cerrada y exclusiva». Tales son, salvo error, las notas características de la filosofía ibérica. Harto más difícil de señalar y más controvertibles son las de la italiana, y nadie duda de su existencia, por lo menos desde que Mamiani publicó su libro del Rinnovamento.

No hemos de reñir por averiguar si la manifestación filosófica es la más brillante de nuestro genio, y si es igual o superior a la teológica y a la artística. Yo las creo iguales, cada cual en su esfera, y pienso que se completan mutuamente. Y pienso más: que hasta hoy no se ha entendido bien la historia de nuestra literatura, por no haberse estudiado a nuestros teólogos y filósofos.

«En la ruina de toda verdadera filosofía a que asistimos, debemos volver los ojos a la filosofía española?» «No», contesta usted, «si por filosofía española entendemos esos sistemas, incompletos unos, erróneos otros, porque el error total sólo con la verdad total se destruye». Y aquí siento disentir de $\mathrm{V}$., y precisamente por las mismas razones en que V. se funda. La verdad total no la ha alcanzado el tomismo ni ninguna filosofía, como tal filosofía, pero debemos aspirar a ella. ¿Y dónde encontrar mejor dirección que en el armonismo de la filosofía española, sobre todo en Fox Morcillo? Él no hizo más que indicar la concordia; pero tuvo en cuenta los dos términos del problema. El aristotelismo, aunque sea el aristotelismo tomista, no nos da más que uno. ¿Por qué hemos de pararnos en el tomismo? ¿Cree V. que si Santo Tomás hubiera conocido a Platón y a Aristóteles en sus fuentes, como los conocieron los sabios del Renacimiento, se hubiera detenido donde se detuvo? En suma: «El tomismo es la verdad toda». En su parte teológica, concedo. En su parte filosófica, nego. Es una gran parte de la verdad, pero no toda. La verdad total está en la deseada armonía de Platón y Aristóteles, polos eternos del pensamiento científico. ¿Por ventura se agotó en Santo Tomás el entendimiento humano?

Dice V. que la perennis philosophia de Leibnitz es la escolástica. Yo creo que Leibnitz nunca quiso dar a entender semejante cosa. Para él, esa filosofía perenne era tan sólo el conjunto de aquellos principios fundamentales e inmutables, leyes comunes a toda inteligencia, y que, más o menos, yacen en el fondo de todo sistema no panteísta. Dudo mucho que Leibnitz, que llamaba bárbaro estiércol a la escolástica, aunque en ella encontrase oro, viera allí otra cosa que materiales aprovechables para nuevas construcciones. Equivocábase en lo primero, como todos los de su siglo; pero, en rigor, ¿qué es la escolástica? ¿Dónde principia y dónde acaba? ¿Es escolástica la ciencia compilatoria de Casiodoro y de Boecio, la de San Isidoro, la de Beda o la 
de Alcuino? Pues más vale conocer la antigüedad en sus fuentes que en alterados extractos. ¿Es escolástico el panteísmo de Scoto Erígena? ¿Lo es el antitrinitarismo de Roscelín, o el racionalismo de Abelardo, o alguna otra de las infinitas herejías que brotaron en las escuelas de la Edad Media? ¿Son escolásticos los místicos educados con el libro falsamente atribuido a Dionisio Areopagita? ¿Sonlo los averroístas, con su panteística teoría del entendimiento uno? ¿Dónde está la verdadera escolástica? En el tomismo, dice V. Pero entonces se enojarían los escotistas y los ockamistas, si alguno queda, y se enojarían también los suaristas, a no ser por el fervor architomista que en estos últimos años ha entrado a los en otro tiempo disidentes Jesuitas.

«España vio con pena arribar a sus costas al averroísmo, al gran corruptor de la filosofía de las escuelas». A pesar de esto, no deja Averroes de ser una gloria muy española. Y lo cierto es que la escuela, sin Averroes y antes de Averroes, estaba harto corrompida, y había sido un semillero de herejes: testigos Scoto Erígena, Berengario, Roscelín, Abelardo y muchos más. El averroísmo, con traer un nuevo elemento de impiedad, fue útil por la reacción poderosa que provocó, y de la cual nacieron el tomismo y el lulismo.

Subraya V. algunas frases mías relativas a la escolástica. Dije que «no era el sistema primero ni único de la filosofía cristiana». Y, en efecto, no es el único ni el primero, so pena de excluir de la filosofía cristiana a todos los padres de la Iglesia griega ${ }^{691}$ que fueron más o menos platónicos, y a San Agustín, que sin serlo tan resueltamente, tomó más de Platón que de Aristóteles. Repito que una cosa es la filosofía tomista y otra su teología. Sólo ésta puede llamarse el sistema primero y único, por no ser otra cosa que la teología cristiana metódicamente expuesta y defendida. Pero al servicio de esta teología, y formando o no un organismo con ella, pueden aplicarse otras filosofías diversas de la de Aristóteles.

Que yo aplaudo las invectivas del Renacimiento contra la barbarie de la escuela. ¿Y por qué no? La barbarie literaria es censurable dondequiera, lo mismo en los escolásticos antiguos que en los krausistas modernos. No participo de la preocupación, en otro tiempo general, contra el lenguaje y estilo de los escolásticos. Sé que se encontraron con una lengua como el latín, decadente por una parte, y por otra de malas condiciones para la filosofía, sobre todo por su carencia de artículos. Sé que crearon una lengua y un estilo especiales, de perversas condiciones estéticas, pero analíticos y precisos. Sé que algunos escribieron, si no con elegancia y agrado, con vigor y fuerza. Pero en

691 Exceptúo, por supuesto, a San Juan Damasceno, que pertenece a una época muy posterior. (Segunda Edición) 
muchos maestros y en el servum pecus de los discípulos, ¿quién negará que hubo barbarie, y barbarie espantosa? Yo los disculpo; pero no los aplaudo. ¿Quién dudará que es mejor escribir como Platón que como Alejandro de Hales o como Escoto? Y a pesar de las muchas defensas que de él he visto, todavía no he logrado persuadirme que el estilo de Santo Tomás sea un gran modelo. El Santo (y dispénseme V. este atrevimiento) tenía más de pensador que de artista. En la prosa didáctica muestra Santo Tomás grandes cualidades, reflejo de su grande alma; pero no igualdad, ni corrección, ni gusto. Quizá no eran posibles en su tiempo. Mas no he de ser yo quien haga observaciones literarias, tratándose de un Santo Tomás de Aquino.

Censura V. más adelante varias frases de Laverde y mías relativas a Luis Vives. Pero yo no veo en ninguna de esas frases motivo de escándalo, y procuraré demostrarlo, aunque brevemente, examinándolas una por una.

Luis Vives es un filósofo ecléctico. Sí, por cierto, como lo es todo filósofo digno de tal nombre, máxime cuando nace en épocas de transición, en épocas críticas. Ecléctico en cuanto admite la verdad, venga de donde viniere; ecléctico en cuanto no sobrepone a la propia razón y al propio criterio la razón de los maestros y el criterio de una escuela determinada; ecléctico en cuanto no acata la autoridad sino en las cosas que son de fe; ecléctico en cuanto profesa el gran principio In necesariis unitas, in dubiis libertas; ecléctico porque no desdeña ninguno de los elementos y tendencias del pensamiento humano, sino que los comprende y armoniza todos, como están comprendidos y armonizados en la conciencia; ecléctico en cuanto no declara guerra a Platón en nombre de Aristóteles, como los escolásticos, ni a Aristóteles en nombre de Platón, como la escuela de Florencia. Pero no ecléctico a la manera de los franceses, pretendiendo conciliar la verdad y el error en una síntesis; que esto sólo fuera lo peligroso y censurable.

Combinó el oro que extrajo de la escolástica decadente con lo más ACENDRADO DE OTROS SISTEMAS. Esta bella frase encierra otra verdad innegable. ¿Quién puede olvidar que la escolástica estaba decadente, pero muy decadente, en los días de Vives y en los próximamente anteriores? Ya no producía Tomases ni Escotos. Estaba representada por aquellos doctores que disputaban sobre la diferencia de estas dos frases: Vidi Papam y Papam vidi; por los averroístas de Padua, impíos brutales y negadores de la inmortalidad del alma; por aquellos catedráticos de prima de teología que razonaban de esta suerte: «Nuestra fe está fundada en Santo Tomás, y Santo Tomás en Aristóteles; luego decir mal de Aristóteles es ir contra nuestra santa fe». ${ }^{692}$

692 Proceso del Brocense. (Segunda Edición) 
Las tan renombradas Universidades yacían en general y manifiesta decadencia. La de Salamanca apenas dio más señal de vida, en el último tercio del siglo xv, que la herejía del escolástico Pedro de Osma. La de París, si hemos de juzgar por lo que cuenta Vives, que estudió en ella, era un foco de ignorancia y de barbarie. Y aun algo más tarde decía graciosamente $\mathrm{D}$. Diego de Mendoza: «No sé por qué Aristóteles, en sus libros De animalibus, dijo que no había asnos en Francia, cuando vemos tantos bachilleres como se hacen en París cada año». Tal era, sin excepción (puesto que nada montan algunas individualidades, como el cardenal Cayetano), el estado de la enseñanza escolástica cuando escribió Vives. Y, sin embargo, Vives tuvo el buen juicio de no confundir el escolasticismo en una general censura, de guardar sus mayores anatemas para los averroístas, de atacar, no a los aristotélicos de veras sino a los pseudo-aristotélicos.

Tomó de otros sistemas distintos del tomismo, sistemas que Santo Tomás no pudo poner a contribución porque en su siglo no se conocían, a lo menos directa e íntegramente. Utilizó Vives doctrinas platónicas; utilizó todo el saber de Aristóteles, que no se conoció íntegro y puro hasta los días del Renacimiento; aprovechóse de toda aquella ciencia antigua, cuya noticia sólo había llegado a Santo Tomás, de segunda mano, en incorrectas traducciones, cuando no en resúmenes y extractos. La ciencia de la Edad Media es muy respetable, pero su erudición valía poquísimo.

Cristianizó la filosofía renaciente. En lo de cristianizar no veo mal alguno, y el término filosofía renaciente no quiere decir otra cosa que filosofía del Renacimiento. Esta filosofía era de origen griego, como toda filosofía moderna, y Luis Vives la cristianizó, de la misma manera que Santo Tomás había cristianizado el pseudo-peripatetismo que corría en su tiempo. Así como el Angélico Doctor apartó las espinas del averroísmo, el gran filósofo de Valencia salvó su sistema de otros nuevos escollos, huyendo cuidadosamente del neoplatonismo teosófico de Marsilio Ficino, que era por entonces el mayor peligro, y de las extravagancias gentílicas de aquellos gramáticos que se habían dado a resucitar en crudo la doctrina del alma del mundo, la unidad eleática o el atomismo de Leucipo.

De Vives procede la filosofía moderna, asi en lo bueno como en lo malo; pero lo malo procede ocasionalmente, como proceden del dogma las herejías. Si no hubiera un dogma de la Trinidad, no habría herejes anti-trinitarios. Si no hubiera un misticismo puro y sano, no habría místicos heréticos, como los quietistas y otros. De la misma manera (si licet parvis componere magna), si Vives no hubiese formulado las leyes del procedimiento experimental, recomendando su uso en los casos en que debe aplicarse, no hubiera venido 
Bacon proclamando corno único, o poco menos, este procedimiento, extendiéndole a todo, anulando la ciencia pura, y encerrándose en el empirismo; ni hubiera venido, como legítima consecuencia, el brutal materialismo del siglo pasado, ni el positivismo que ahora nos aqueja. Esto es evidente. Pero como el procedimiento experimental no deja de ser legítimo aunque de él se abuse, maldita la responsabilidad que le corresponde a Vives por los yerros de sus discípulos.

Que Vives es la más elevada personificación de la España cientifica, me parece indudable. Si ese calificativo está reservado para el filósofo más originaly de más hondo influjo en el pensamiento europeo, ¿quién podrá disputárselo al polígrafo de Valencia? No en modo alguno los tomistas; no Suárez, a pesar de su maravillosa Metafísica, de la cual dijo Vico que encerraba cuanto hay que saber en materia de filosofía; no el mismo Ramón Lull, entendimiento sintético de primer orden, pero no iluminado por aquella ciencia antigua que dio alas a Vives; no Moisés ben Maymon; no Avicebrón, padre de todo el panteísmo moderno; no León Hebreo, de quien desciende toda la estética platónica del siglo Xvi; no Séneca, el gran moralista, ni otra ninguna de las grandes figuras de nuestra historia científica. La filosofía española, dogmática y creyente al par que crítica y armónica, sólo alcanza su cabal desarrollo en Vives y Fox Morcillo. Pero Vives, por la universalidad de la doctrina, ha eclipsado el nombre de su discípulo.

Vives fue el más prodigioso de los artífices del Renacimiento, y como la obra del Renacimiento era grande y necesaria y santa, y no debe confundirse con las excentricidades de Pomponio Leto o de cualquier otro pedante, cábele gloria, no pequeña, por ello. Artífices del Renacimiento, y no tomistas, habían sido los que trabajaron en la Políglota Complutense. Mientras dos judíos conversos, tres humanistas y un griego fugitivo de Constantinopla levantaban aquel monumento, los escolásticos disputaban sobre suposiciones y restricciones. Artífices del Renacimiento fueron los que cuidaron de las primeras ediciones de los Santos Padres, y nadie trabajó en esto tanto como Erasmo. Cuando el semi-escolástico Pomponazzi, que en pleno Renacimiento ignoraba el griego y escribía perversamente el latín, dudó de la inmortalidad del alma, no se levantó para responderle ningún tomista (que yo sepa), sino un artifice del Renacimiento, un humanista, un peripatético clásico, muy de segundo orden, Agustín Nipho. Cuando arreciaba la gran tormenta de la Reforma, nacida en los claustros nominalistas de Alemania, no en las escuelas de Letras humanas de Italia, encontró, cual valladar firmísimo, los libros De veritate fidei christianae, de Vives, y los De libero arbitrio, de Sepúlveda, hombres uno y otro del Renacimiento. Al cabo, y como reacción contra el 
protestantismo, despertó con nueva pujanza la escolástica, pero despertó influida, muy influida, por el Renacimiento. ¿Se concibe antes del siglo XvI un libro como el de Melchor Cano? ¿Se parecen Vitoria ni Soto a los escolásticos del siglo XIV ni a los del XIIr? ¡Oh! ¡Qué gran bien hizo el Renacimiento desterrando la barbarie de la escuela; los nuevos escolásticos no fueron ya bárbaros, por lo menos con aquella barbarie pertinaz y repugnante de los anteriores; no se entretuvieron en sofisterías, a lo menos deliberadamente y con insistencia; fueron grandes filósofos, grandes teólogos, dignos discípulos de Santo Tomás. Y todo gracias a los artífices del Renacimiento. Hora es de hacerles justicia, ya que por medio siglo ha sido moda repetir contra ellos las declamaciones de aquel fanático, elocuente y desdichado demagogo tomista, Fr. Jerónimo Savonarola. De todos esos humanistas, muy pocos, y ninguno de primera talla, si se exceptúa a Melanchton, cayeron en el protestantismo, al paso que éste alistó falanges enteras entre la gente universitaria, que los otros llamaban bárbara. No fueron tomistas, por lo general, aunque alguno hubo, y de primera nota. Todo su saber teológico no salvó a Carranza de luteranizar, aunque de buena fe, en la cuestión de la fe y las obras.

Vives renovó el método antes que Bacon y Descartes. Pero como la reforma del método era necesaria, aplausos y no censura merece nuestro autor. Dice V., amigo mío, que si el árbol se conoce por los frutos, ¿qué hemos de pensar de un árbol cuya fruta son el aristotelismo no purificado por los escolásticos, el anti-aristotelismo, las ideas innatas, el empirismo baconiano, el cartesianismo, el psicologismo escocés, y hasta el sensualismo y el escepticismo?

Vayamos por partes. El aristotelismo clásico. ¿Valía más leer a Aristóteles en aquellas depravadas traducciones latinas que corrían en la Edad Media, que estudiarle en su original griego? ¿Cómo habían de purificar los escolásticos a Aristóteles, si no le conocían más que a medias? ¿Qué hubiera dicho el Estagirita de sus comentadores, que solían trabajar sobre un ilegible texto latino, vertido de otro árabe, que tampoco era traducción directa? El Aristóteles escolástico, purificado o sin purificación, recuerda aquello de

«Criada de las criadas

De las criadas de Aurora...»

Los peripatéticos clásicos buscaron el agua en su fuente e hicieron muy bien. Merced a ellos murió el averroismo, que sólo vivía por la ignorancia filológica (digámoslo así) de los escolásticos. El tomismo era impotente para acabar con aquella plaga de panteístas y naturalistas que se escudaban con el nombre de Aristóteles, porque ni los tomistas de aquel tiempo solían saber griego, ni tomaban parte en el movimiento literario de entonces. Pero así 
que apareció el genuino Aristóteles, Averroes quedó confinado a la escuela de Padua, donde arrastró lánguida vida algún tiempo más; pero sin influjo en el pensamiento europeo.

El peripatetismo clásico, que hizo tan gran bien, no cayó, por otra parte, en ninguno de los pecados reales y positivos de Aristóteles. Ni afirmó la eternidad del mundo, ni manifestó dudas sobre la inmortalidad del alma. ${ }^{693}$ Al contrario: se esforzó en defender a su maestro, mostrando que no se encontraban en él tales errores. Para evitarlos, tampoco necesitaron recurrir al "Aristóteles purificado» de la ciencia escolástica, a la cual se mostraron indiferentes, cuando no hostiles. Bastábales ser católicos para no ser panteístas ni materialistas.

El anti-aristolelismo o ramismo español es otra tendencia del todo inocente. No se encaminó más que a la lógica y a la física y casi siempre con acierto. Hicieron varias innovaciones dialécticas, atacaron la autenticidad de algunas partes del Organon, y clamaron mucho y bien en pro de la legítima libertad filosófica.

El onto-psicologismo de Fox Morcillo, defensor de las ideas innatas, también es fruta sana, porque las ideas innatas las entiende Fox a la manera de San Agustín, autoridad tan respetable como la del mismo Santo Tomás. La doctrina de las ideas innatas en el terreno filosófico es discutible; pero tal como la sostiene Fox, no es ninguna herejía. Ni puede decirse que sea fruta de árbol de Vives, pues éste no enseñó el innatismo, doctrina que Fox añadió con otras al caudal recibido de su maestro. En éste predominó la tendencia psicológica; en Fox la platónica y ontológica, que es lo que da originalidad y carácter propio a sus especulaciones.

En cuanto al empirismo baconiano, ya he indicado cómo y por qué nace del vivismo. El procedimiento de inducción y el experimentalismo fueron conocidos y practicados por los griegos, sobre todo por Aristóteles, a quien malamente se ha acusado de ignorarlos. Los escolásticos los olvidaron un poquito, sin que pueda hacerse otra excepción que la de Rogerio Bacon, y quizá la de Alberto el Magno. Vives los resucitó, señaló sus límites, dictó sus leyes, y, merced a ello, adelantaron prodigiosamente en los tres últimos siglos las ciencias naturales, las históricas y todas las de aplicación, que, digámoslo en puridad, no andaban muy medradas con el escolasticismo.

El sensualismo en ninguna manera es doctrina de Vives, ni puede lógicamente deducirse de sus principios. Tampoco la he dado yo por tal,

693 Todo esto es rigurosa verdad, tratándose de España. No lo es tanto si extendemos la observación a Italia, donde cayeron en graves errores algunos de los partidarios del Comento de Alejandro de Afrodisia. (Tercera edición) 
limitándome a decir que Huarte y Doña Oliva, campeones de ese sistema entre nosotros, tienen alguna relación con Vives. Mas no la tienen como sensualistas, sino como filósofos independientes, y como sutiles y delicados observadores psicológicos. El análisis de las pasiones, hecho por Doña Oliva, se parece mucho a ciertos capítulos del tratado De anima et vita, y buena parte de las sagaces y agudas observaciones de Huarte sobre la variedad de los ingenios y de los estudios que convienen a cada uno, están fundadas en conceptos de la obra De disciplinis. Lo cual no es decir que Huarte carezca de originalidad; antes la tiene grandísima, al exponer a su modo el recíproco influjo de lo moral y de lo físico, la doctrina de los temperamentos, la de los climas, y los principios y bases de la frenología y de la craneoscopia. En algunas de estas enseñanzas tiende al materialismo, por lo cual la Inquisición mandó borrar en su libro algunas frases, además de aquel singular capítulo en que cometió la inocentada de describir el temperamento de Jesucristo. Pero de nada de esto es responsable Vives, en cuyas obras no hay una sola frase que pueda torcerse en sentido materialista. Cúlpese sólo al ingenio raro y paradójico, aunque agudo y encumbrado, de aquel docto médico aragonés.

Del cartesianismo ante ni post cartesiano no debe responder Vives, sino hasta cierto punto. Real y verdaderamente él no parte de la duda metódica, aunque aconseja muchas veces suspender el juicio. Quien la pone por base es el escéptico Francisco Sánchez, y antes de él Fox Morcillo en su tratado De demonstratione, ejusque necessitate ac vi. Empieza por prescindir de todos los conocimientos adquiridos, a excepción del concepto generalísimo del ser, principio ontológico, no puramente psicológico como el entimema de Descartes, que no pasa de ser un principio subjetivo, una mera afirmación de conciencia. Pero el de Fox es objetivo, lo cual salva, a mi modo de ver, la dificultad, y no encierra la ciencia en un estéril y peligroso yoísmo. No está el mal del cartesianismo en la $d u d a$, estado ficticio y transitorio, que equivale en estos filósofos a la usada declaración de "prescindiremos de toda autoridad no fundada en razón, en aquellas materias que Dios entregó a las disputas de los hombres»; declaración que con unas u otras palabras se lee al frente de casi todos nuestros libros de filosofía, inclusos los de algunos escolásticos, como Rodrigo de Arriaga. Aunque la duda sea metódica, como lo es en Fox y en Descartes, no veo gran mal en ello. El quid del cartesianismo está más adelante, en el entimema.

Hay un singular hereje español que proclamó la duda, aun tratándose de las verdades reveladas. Mas para salir de tal estado, no recurrió al cogito, ni al principio del ser, ni al de la existencia, sino a una luz interior y sobrenatural que Dios comunica a sus elegidos. Puesto ya en tal camino, negó 
todo valor a la ciencia humana y se encerró en un misticismo antitrinitario y ontologista. Mas ¿qué tienen que hacer las ideas y especulaciones de Juan de Valdés con las de Vives, espíritu práctico por excelencia? Sólo por un lazo tenuísimo pueden unirse.

En cuanto a la construcción ontológica de Fox, que procede, en el libro suyo que he citado, por método geométrico, nada veo que merezca censura, nada que pueda tacharse de inductivo al espinosismo. Los demás que llamo cartesianos antes de Descartes, sonlo, no en la base de su sistema, sino en doctrinas particulares, especialmente físicas y psicológicas. No eran, en verdad, dogmas las opiniones de los escolásticos antiguos sobre estos puntos, y la prueba es que no las siguen todos los escolásticos modernos.

De Vives procede la filosofía escocesa. Sí, por cierto, y en todas sus partes; mas ¡cuándo ni por qué razón ha sido peligrosa la escuela escocesa? Tímida e incompleta, tal vez pueda llamársela; pero ¿¿dañosa? ¿Es censurable, por ventura, la observación psicológica? ¿Hemos de rechazar, como criterio, el común sentido, la conciencia en toda su amplitud, que decía el introductor en Cataluña de esta escuela? ¿Qué mayor barrera puede oponerse a los extravíos y exageraciones idealistas, al predominio de una sola facultad o tendencia? ¿No es una gloria para Vives haber distinguido con lucidez suma los dos momentos del juicio, señalando el carácter necesario, infalible y universal de aquel primer juicio, que él llama naturale, y que los escoceses apellidan espotáneo? El mal de la doctrina escocesa está en ser puramente psicológica y lógica; en carecer de metafísica. Por horror a los sistemas germánicos de $l o$ absoluto, negó Hamilton la filosofía de lo incondicionado, sin sospechar que tal negación había de ser arma terrible, a la vuelta de pocos años, en manos de los positivistas, que, por boca de Stuart Mill, le han acusado de contradicción flagrante. Pero ni de esta contradicción ni de aquellas negaciones tiene que responder Vives, porque no se detuvo en el psicologismo, sino que coronó el edificio de su sistema con una metafísica, con una prima philosophia.

También tiene V. por fruta dañada los pensadores independientes y ciudadanos libres de la República de las Letras. Pero usted sabe muy bien que estos audaces ingenios eran al mismo tiempo católicos fervorosos, y empezaban y acababan sus libros con protestas, absolutas y sin restricciones, de sumisión a la Iglesia católica, y limitaban siempre sus audacias a materias controvertibles. Así entendido, el título de ciudadano libre de la República de las Letras, es el más hermoso y apetecible que puede darse, y yo, por mí, no le trocaría por ningún otro, ni siquiera por el de tomista, que al cabo indica adhesión a una escuela determinada. Los principios y tendencias del vivismo dan, según yo entiendo, ese libérrimo derecho de ciudadanía. 
Poco diré del escepticismo de Sánchez. A decir verdad, sólo procede de Vives por la tendencia crítica, aunque exagerada y fuera de quicio. Pero no hemos de engañarnos sobre el carácter de este escepticismo. Sánchez es buen católico: de tejas arriba no duda de nada. Su escepticismo es de tejas abajo. En ocasiones parece un devaneo literario, por la forma ligera y un poco francesa en que vienen envueltos sus anatemas contra toda ciencia, y hasta contra la posibilidad de saber nada. Montaigne se contentaba con dormir en la almohada de la duda; pero Sánchez es violento y agresivo; lo resuelve todo, o, más bien, no resuelve nada, con su eterno Quid?, y se burla de la necedad humana, asomada constantemente al pozo de Demócrito. No niega, sin embargo como Hume, el principio de causalidad, ni rechaza, como los pirrónicos, el testimonio de la experiencia. Realmente era observador sagaz, y en sus comentarios, o más bien refutaciones semi-burlescas de algunos tratados psicológicos de Aristóteles, notó y corrigió con buen juicio errores graves de la ciencia antigua. Si en esto y en algunas observaciones sobre la incertidumbre de las ciencias parece discípulo de Vives, en lo demás es un insurrecto.

Resulta de toda esta disquisición, en verdad harto prolija, que fueron sanos en el árbol todos los frutos vivistas, aunque llevados algunos a tierra extraña, se pudrieron o se malearon, cosa naturalísima. Y que el vivismo no es responsable en modo alguno de ciertas consecuencias, harto lo prueba la misma enumeración que de sus frutos venimos haciendo; pues ¡cómo un mismo sistema había de pecar a la vez de "aristotélico y de anti-aristotélico, de baconista y de cartesiano, de partidario de las ideas innatas y de sensualista»? ¿No fuera esto absurdo? La verdad es que no peca por ninguno de estos capítulos, sino que encierra en una vasta síntesis lo mejor y más sólido de todos, sin las exageraciones ni el exclusivismo de ninguno. Por eso, y porque no contiene ningún error grave, que sepamos, y porque es creación del todo española, queremos resucitarle y nos decimos vivistas. Y como este sistema salva el catolicismo quoad substantiam, y no tiene la pretensión de ser la «filosofía católica», sino la "filosofía española», pide y alcanzará de seguro el derecho de vivir, crecer y multiplicarse al lado de su hermano mayor el tomismo y a la sombra de la Iglesia, por lo menos con la misma razón que el tradicionalismo, por ejemplo, sistema sensualista y de consecuencias altamente peligrosas y alguna vez censuradas. Por cierto que de ningún vivista, a pesar de ser tan dañosos los frutos del árbol, se podrá citar una proposición tan mal sonante como aquélla: «La razón y el absurdo se aman con amor invencible.»

Harto he molestado a V., amigo mío, y a los lectores con estas prolijas y acaso inoportunas observaciones. Hora es de terminar. Mas no he de hacerlo 
sin advertir que Melchor Cano tiene bien poco de tomista, a no ser que por tomista se entienda vestir el hábito de Santo Domingo, y seguir la doctrina de Santo Tomás en lo teológico; doctrina oficial, digámoslo así, en la Orden a que pertenecía Melchor Cano. Pero en lo demás, el autor de la obra De locis theologicis pertenece a la pléyade de escritores del Renacimiento. No es tomista en la forma ni en el estilo, porque Santo Tomás escribió como se escribía en su tiempo, y Melchor Cano escribe maravillosamente. No es tomista en filosofía, porque entre Platón y Aristóteles no se atreve a decidir, y escribe: Divo Augustino summus est Plato, Divo Thomae Aristoteles... Mihi quidem nec Augustini nec Thomae videtur contemnenda sententia. Lo cual equivale a decir que en filosofía no desprecia la autoridad de Santo Tomás, pero tampoco la sigue, ni más ni menos que hacían los vivistas. Y no vale decir que Melchor Cano fue poco afecto a Vives, y afirmar de él que «señaló con acierto las causas de la corrupción de las ciencias, pero que no anduvo tan atinado en proponer los remedios», puesto que en realidad él se aprovechó ampliamente de Vives y de muchos vivistas, como Juan de Vergara, cuyo libro de las Cuestiones del Templo trasladó en cuerpo y alma, al tratar de la historia humana. Y nada mejor podía hacer, puesto que Vergara es el padre de la crítica histórica entre nosotros.

En resumen: todo lo que en el libro De locis no es teología pura, procede de fuentes distintas del tomismo. Por eso he llamado y sigo llamando vivista a Melchor Cano. Su gloria está en haber puesto al servicio de la teología la ciencia profana y el criticismo de Vives.

Nada diré del congruismo, cuestión para debatida entre los Dominicos y los Jesuitas. Yo he ensalzado el congruismo, por ser creación cientifica española. El sistema tomista sobre la gracia no lo es, y por eso no hice particular mención de él.

No censuro a los escolásticos que prefieren Sanseverino o Liberatore a Sánchez o a Huarte. Puede perdonárseles el que desconozcan a estos escritores, pero en ningún modo el que dejen de estudiar a Suárez o a Domingo de Soto, con preferencia a los renovadores italianos y franceses del escolasticismo. Sobre esto versaba únicamente mi censura, que, por otra parte, no se dirige a los doctísimos filósofos que hoy son en España cabeza del movimiento neo-tomista. Harto sé que éstos conocen de perlas el desarrollo anterior de sus doctrinas en nuestra Península. Pruébamelo el curso de Philosophia Elementaria de Fr. Zeferino González, y el áureo artículo de V. sobre mis desdichadas Cartas.

Y a propósito del ilustre obispo de Córdoba (cuyas bondades para conmigo de nuevo y públicamente, y con toda la efusión de mi alma agradezco), uno mis votos a los suyos respecto a la Biblioteca de teólogos españoles, sin 
que para encarecer su importancia sea preciso rebajar en un ápice el mérito de nuestros filósofos. Nequid nimis, amigo mío. Muchos de los autores que Fray Zeferino cita, tienen tanta o mayor importancia como filósofos que como teólogos. Testigo Suárez, ninguna de cuyas obras teológicas llega en mérito a su Metafísica. No demos ocasión a que los racionalistas nos digan en son de triunfo que hemos tenido teólogos (lo cual, en boca suya, equivale a sacristanes), y no filósofos.

Suscribo, con todo el entusiasmo de que soy capaz, a los elogios que V. hace de los tomistas españoles. Llenan, en efecto, una de las páginas más brillantes de nuestra historia científica. Pero tampoco hemos de exagerar las cosas. Cisneros fomentó muy poco el tomismo; lo que más poderosamente alentó fueron los estudios orientales y escriturarios. $Y$ como era muy buen español, favoreció asimismo la escuela luliana, manifestando su deseo de que «se enseñase en todas las escuelas», como es de ver en la carta que dirigió a los mallorquines. En cuanto a los estudios del Renacimiento, que habían de obtener su más cabal expresión en Vives, sabida es la benéfica influencia de Fr. Francisco Ximénez comparable, en algún modo, a la de Lorenzo el Magnífico o a la de León X.

Nada diré de Carranza, tan respetable por su saber como por su desdicha. Pero es lo cierto que sus méritos científicos se reducen para nosotros al opúsculo De la residencia de los Obispos, a la Summa Conciliorum, que es una compilación, y a los Comentarios al Cathecismo christiano, en que hay frases de sabor protestante, como lo demostró ampliamente Melchor Cano, y vino a confirmarlo la sentencia de Gregorio XIII, seguida de la abjuración por el mismo Arzobispo, de diversas proposiciones.

No creo que el «tomismo diese dirección y guía a nuestros místicos». A lo sumo, puede decirse esto de Fr. Luis de Granada y algún otro ascético de los que impropiamente se llaman misticos. Los misticos puros no son tomistas. Es seguro que Santa Teresa había leído muy pocos tratados escolásticos. En cuanto a los demás, aunque sea cierto que conocían bien la Summa, como todo el mundo entonces, eslo también que seguían con preferencia a Hugo de San Víctor, a Gerson, a San Buenaventura, y aun a Suso y a Tauler, sin olvidar la fuente común de todos, que era el libro De divinis nominibus, atribuido al Areopagita. Fuera de esto, tenían muy bien leído a Platón, y aun a los neo-platónicos de Alejandría, y a los de la escuela toscana del Renacimiento. Cuando Malón de Chaide, en La Conversión de la Magdalena, quiere tratar de la "hermosura y del amor», no pide enseñanzas a Santo Tomás, sino que acude al Convite de Platón, y le glosa y comenta. El que haya leído a León Hebreo sabrá de dónde bebió Cristóbal de Fonseca gran parte 
de sus especulaciones sobre el amor divino. Tan verdad es esto, que en el trabajo que preparo sobre la Historia de la Estética en España, no he podido menos de considerar a nuestros místicos como la más brillante personificación del platonismo del Renacimiento, ensalzándolos, no con los tomistas, sino con los poetas eróticos de entonces. Y no cede esto en desdoro, sino en gloria suya; porque la doctrina estética contenida en los diálogos del hijo de Aristón es tan alta y subviene, que, aun en nuestros días, el escolástico Padre Jungmann ha escrito un tratado «de la belleza y de las bellas artes, según los principios de la filosofía socrática y de la cristiana», considerándolas para el caso poco menos que como idénticas.

Ni tampoco creo que contará V. entre los tomistas al incomparable Fr. Luis de León, aunque pongamos en cuarentena aquel poco verosímil dicho, que le atribuye el Dr. Suárez de Figueroa, es a saber: que «tres sabios había tenido el mundo»: el primero Adán; el segundo, Salomón, y el tercero..., no Santo Tomás de Aquino, sino Raimundo Lulio. Bien clara está la tendencia al armonismo luliano en muchos pasajes de aquellos platónicos diálogos sobre los Nombres de Cristo. Como poeta, se inspira en todo, hasta en la "teoría de los números pitagóricos», pero pocas veces en el tomismo. Que Suárez, y antes de él otros Jesuitas, y después todos hasta el siglo pasado, son disidentes y constituyen una disgregación del tomismo, harto lo han repetido y ponderado en todas épocas los tomistas puros, especialmente los Dominicos. Hasta qué punto llega esta disidencia, y si basta a constituir escuela aparte, es lo difícil de determinar con precisión. En la parte teológica no cabe duda, y V. lo confiesa, puesto que opone el congruismo al sistema tomista sobre la gracia. En la filosófica no es menos honda la división. Ni puede decirse que Suárez sea en ella expositor de Santo Tomás, pues lo que expone directamente es la Metafísica de Aristóteles, separándose en muchas cuestiones de Santo Tomás, planteando otras que a éste no le pasaron por las mientes, y mostrándose tan original en desarrollos y conclusiones, que su Ontología es uno de los más preciosos monumentos de la ciencia ibérica. «Pretendió no separarse de Santo Tomás», porque todos los escolásticos hacían otro tanto; pero Santo Tomás, como Aristóteles, como Averroes y otros grandes nombres, ha sido un pabellón que ha cubierto todo género de mercancías.

Aparte esto, ¿no pasan por sistemas distintos del tomismo, el escotismo, el okamismo y otros? ¿Pues por qué no ha de serlo el suarismo, que es tanto o más independiente que ellos? Cada una de las infinitas divisiones y subdivisiones de la filosofía griega tiene un nombre especial, y a buen seguro que muchas de ellas no difieren tanto entre sí como la doctrina del Doctor Angélico y la del eximio jesuita de Granada. 
«El tomismo es filosofía española, porque fue enseñado en nuestras Universidades». Pero no fue la única filosofía enseñada en ellas, puesto que el lulismo tuvo cátedras aparte, y las tuvieron los demás sistemas escolásticos, y, lo que es más, las tuvo «en todo el siglo XVI» el peripatetismo clásico, lo cual, para gloria de nuestra nación, dejaron registrados las extranjeros. Según ellos, en las aulas españolas se enseñaba a Aristóteles íntegro y en griego. Y sin que ellos lo dijeran, sabémoslo por los escritos de Pedro Juan Núńez, fundador de la gloriosa escuela valenciana, en la cual fue tradicional el culto de la sabiduría antigua ex ipsis primis fontibus. A. Núñez sucedieron en la misma enseñanza Monzó, Monllor y Serverá. En Barcelona propagó su método el mismo Núñez; en Zaragoza, Simón Abril; en Alcalá, Cardillo de Villalpando, a quien muchos, malamente, juzgan tomista; en Coimbra, Pedro de Fonseca, lazo de unión entre los peripatéticos clásicos y los suaristas. A la sombra de este peripatetismo ilustrado, tolerante y de acendradas fortunas literarias, se desarrolló nuestra libertad filosófica. Merced a él levantaron la cabeza los ramistas, especialmente en Salamanca; proclamó Dolese el atomismo en Valencia; siguiéronle Vallés en Alcalá y Gómez Pereira en Medina del Campo; examinó Pedro de Valencia con segura crítica todas las opiniones de los antiguos sobre el criterio de la verdad, e hizo Quevedo la apología de Epicuro al mismo tiempo que Gassendi.

El escolasticismo no contrarió sistemáticamente este movimiento, antes bien recibió su influencia. Siglo y medio dura esta época, la más gloriosa, en todos conceptos, para España. De los peripatéticos clásicos salió Gouveia, el vencedor de Pedro Ramus; salió Sepúlveda, el adversario terrible de Erasmo y de Lutero. De las demás disgregaciones del vivismo salieron los fundadores de todos los sistemas modernos.

Usted recordará lo que sucedió al pararse este movimiento. Llegó un día, allá a mediados del siglo XvII, en que el escolasticismo se presentó intolerante, y aspiró a dominar solo en las aulas. Y entonces, como por encanto, huyó de nuestras Universidades aquella grandeza, no se estudió la filosofía en sus fuentes, olvidóse la crítica de Vives, faltó independencia y serenidad en el juicio, dióse de mano a las ciencias auxiliares, y, ¡cosa rara!, el escolasticismo, alcanzado el absoluto imperio a que aspiraba, empezó a decaer rápidamente, se durmió sobre sus laureles, y no produjo ya Sotos, ni Molinas, ni Vázquez, ni Suárez, sino sumulistas y compendiadores de compendios y disputadores en el vacío. ¡Y cuándo se durmieron! Precisamente cuando se levantaba el cartesianismo y venían en pos de él Malebranche y Espinosa. La ciencia escolástica, que en el siglo XVI y en la primera mitad del XviI estaba al nivel de la ciencia independiente, empezó a quedarse atrasada. En la España de 
Carlos II quedaba todavía mucho arte y mucha ciencia, aunque uno y otra decadentes, pero no estaban en las Universidades. Había que buscarlos en aquel grupo de críticos históricos que se reunían en la celda de Fr. Hermenegildo de San Pablo; grupo formado por Nicolás Antonio, D. Juan Lucas Cortés, el marqués de Mondéjar y otros; o en las producciones de algún erudito que conservaba la tradición antigua, más o menos alterada, o en las de los últimos místicos, o en el teatro, o en algunos médicos y matemáticos aislados. El escolasticismo de las aulas sólo despierta con algún brío cuando asoma en nuestro horizonte científico la estrella vivista del P. Feijoo.

¡Tan necesaria es una prudente libertad en las indagaciones del espíritu!

Y ahora, si no temiera prolongar esta carta, mostraría cómo el espíritu de la doctrina de Vives informa toda nuestra civilización. Mostraría que a él debemos lo poco o mucho que hemos trabajado en ciencias naturales; que de él arranca una reforma en la enseñanza de la teología y del derecho; que nuestra crítica histórica, desde Juan de Vergara hasta el presente, es una aplicación del vivismo; que él dio luz y guía a los estudios de erudición y humanidades, y que sin él, acaso nuestra literatura clásica del gran siglo no hubiera tomado el sesgo que llevó y que la condujo a la gloria. Haría ver que Vives tiene todas las cualidades buenas del Renacimiento y ninguna de sus exageraciones; que no es un fanático enemigo de la Edad Media; que no condena en poco ni en mucho la civilización cristiana, y que él fue el primero en señalar las bellezas literarias de autores entonces tenidas por bárbaros. Pondría en claro que toda restauración total o parcial de los estudios en España ha sido restauración vivista, y deduciría de todos estos hechos, y de otros que puedo alegar y alegaré en su día, la necesidad de volver al espíritu de Vives para salvar la ciencia española del olvido y de la muerte. Pero todo esto, Dios mediante, hallará oportuno lugar en un libro que con el título de Exposición e historia del vivismo pienso escribir. Libro será malo y rudo como de tosca pluma y pobre entendimiento, pero útil si llama la atención de los doctos hacia nuestra prístina y olvidada ciencia.

Siento, amigo mío, tentaciones de romper esta carta. Ha salido larga, machacona y llena de repeticiones. Parece un quodlibeto escolástico de los malos tiempos. No he escrito nada peor, con haber escrito cosas tan malas. ¡Y pensar que la he escrito en Florencia, en la moderna Atenas, donde parece que aun vagan las sombras de Lorenzo el Magnífico y de Ángelo Poliziano, uno de mis amores literarios más íntimos y verdaderos! ¡También es fatal coincidencia!

Mas no es lo peor el estilo, ni el haber escrito esta carta a pedazos y sin ver un libro. Es el temor que me aqueja de haber hablado con irreverencia 
del tomismo, sistema tan luminoso, tan sublime, tan fecundo. Es, de otra parte, el recelo de haberme mostrado ingrato con V., que es todo bondad para conmigo, y que ha honrado mis borrones de estudiante con elogios correspondientes sólo a un trabajo maduro y sazonado, pero elogios que no olvidaré nunca, porque sé que nacen de una alma nobilísima.

Decididamente rompo la carta... Pero no, porque anda mezclado el buen nombre de Vives en el asunto. Lo mejor es remitírsela a V. para que, una vez leída, haga de ella lo que le plazca. Publíquela V., si quiere; rásguela o quémela si no, que nada se perderá en ello. Pero en ningún caso la considere V. como réplica a su artículo ni como escrito anti-tomista, sino como observaciones y notas que tienden a explicar, más que a defender, mi opinión en ciertos puntos. 



\section{RESPUESTA A «LA CIENCIA ESPAÑOLA BAJO LA INQUISICIÓN» DEL SEÑOR JOSÉ DEL PEROJO}

\section{Carta al señor don Alejandro Pidal y Mon [Segunda edición]}

Venecia, 6 de mayo de 1877.

Sr. D. Alejandro Pidal y Mon.

Mi querido amigo: A tiempo llega el récipe de la Revista Contemporánea. Ya comenzaba a impacientarme el largo silencio de esos señores sabios. ¡Loado sea Dios, que al fin han resollado, y de veras! Ya no es el caballero de la Revilla quien entra en liza, sino su amigo y conmilitón el caballero del Perojo, como si dijéramos, el de la ardiente espada o el de la triste figura. Tristísima la van haciendo ellos en este lance. Pero loado sea Dios una y mil veces, pues tengo otra vez enfrente a los perpetuos enemigos de la Religión y de la patria, y con ellos he de cruzar las armas,

"Aquí do la lanza cruel nunca yerra»,

y no con V., mi buen amigo, de quien sólo me separan diferencias relativamente mínimas y casi imperceptibles. A mí, corno en ocasión semejante decía Caminero, me consuela y me anima la polémica con los impíos, al paso que me contrista y desalienta la discordia con mis hermanos. Demos, pues, de mano por un instante a nuestras rencillas domésticas, y acudamos a los bárbaros, ya que los bárbaros llaman a las puertas. Comencemos, pues, y que Dios nos ayude, pues sin Él no hay principio ni obra buena. 
Si no mienten mis cálculos, el artículo del Sr. Del Perojo tuvo (como ahora dicen) la génesis siguiente:

Allá, por agosto del año pasado, escribí, para refutar ciertas afirmaciones del Sr. De la Revilla, un articulejo que al Sr. De la Revilla le amoscó grandemente, y dio ocasión a aquel su célebre exabrupto, rotulado por mal nombre La Filosofía española.

En el mismo número de la Revista Contemporánea en que salió aquel portento, vino cierta notita al pie de unos cuadros de enseñanza alemana, en la cual nota (que sonaba como de redacción) hacíase causa común, o poco menos, con el Sr. De la Revilla. Desde aquel momento (y aunque me hubiesen faltado otros datos) no podía yo menos de considerar a la Contemporánea como publicación anti-española y órgano oficial de los negadores de nuestra ciencia. Y como la Contemporánea viene a ser el corazón y los ojos del caballero contrincante, que, después de todo, se gasta en ella honradamente su dinero, como otros en coleccionar cajas de fósforos, hubo de enojarse grandemente el Sr. Del Perojo por lo que yo decía de aquella hija de sus entrañas, merced a la cual, y como per saltum, ha llegado él a jefe de cofradía y aun de escuela.

En la misma carta a que aludo (y perdone V. la necesidad, ahora inevitable, de citarme a mí propio) tuve la desdichada ocurrencia de decir no sé qué respecto al elegante estilo y castiza frase de los contemporáneos, citando entre ellos a los Sres. Montoro y del Perojo, si la memoria no me es infiel. Con cuya inocente observación literaria bastó para que el segundo de estos caballeros, herido en lo que más le dolía, sin duda porque apunté bien, perdiese los estribos y comenzase a jurar y perjurar que haría y que acontecería, y que yo se las había de pagar todas juntas. Mas como por reparos de estilo no está bien romper la cabeza a nadie, y como, por otra parte, hubiera sido soberanamente ridícula de parte suya una apología de sus méritos filológicos y literarios, húbose de contentar por entonces con el deseo de armarla, aleccionado, sin duda, por aquel rasgo sublime con que cortó la pelea el Sr. De la Revilla. Pero otra le quedaba en el cuerpo al director de la Contemporánea, y tengo para mí que sólo le detenía el temor de dar con su réplica demasiada importancia a tan menguado antagonista.

A pesar de lo cual, afanoso, y día tras día, iba cogiendo de aquí y de allí noticias, hechos y apreciaciones útiles para la grande empresa que meditaba, sin que dejase al propio tiempo de construir tal cual silogismo en bárbara, y vociferar, triviis et angiportis, en loor del triunfante y esplendente Sr. De la Revilla.

En esto aparecieron los dos excelentes artículos de V. sobre mi libro, y a tal aparición, el Sr. Del Perojo vio el cielo abierto, comprendió que podía 
jugar por tabla, y sacó del horno la torta que por tanto tiempo había estado calentando.

Resumen: $1^{\circ}$ El Sr. Perojo escribe contra mí por un pique literario; es, a saber, porque dije mal de su estilo.

$2^{\circ}$ El Sr. Del Perojo ha limado y lamido su nuevo parto durante cinco o seis meses por lo menos.

$3^{\circ}$ El Sr. Del Perojo no quiere escribir directamente contra mí, por no darme importancia, y prefiere hacerlo contra V., con la precaución (jsi será listo el mozo!) de elogiar a V. mucho (no tanto como V. se merece), y ponernos a Laverde y a mí a los pies de los caballos: exagerando además las diferencias que a unos de otros nos separan, con la sanísima intención de ponernos en contradicción y en discordia. ¡Como si no tuviéramos bien entendida la treta, que, por lo demás, revela escasísimo ingenio!

Tras estos preliminares, útiles para fijar la situación del señor Perojo en este lance, entremos a considerar punto por punto su lucubración, que tiene la friolera de 40 páginas en $4^{\circ}$. Necio sería yo si emplease otras tantas para refutarle. En su parto sietemesino, el Sr. Del Perojo ha echado el resto; ha dicho cuanto sabía y mucho más. Allí hay de todo,

«Botánica, blasón, cosmografía, sacra, profana, universal historia»;

allí exposiciones de sistemas filosóficos, altas y encumbradas disquisiciones históricas, peregrinos apuntes bibliográficos, catálogos de todos los sabios del globo terráqueo, arranques oratorios dignos de Fr. Gerundio de Campazas. Para que sea un cumplido tratado de todas las cosas y otras muchas más, sólo falta un poco de espiritismo y otro poco de arte de cocina.

El título es ya resonante y terrorífico: La ciencia española bajo la Inquisición. Si a esto se añadiese una portada a seis tintas y algún grabado que representase un quemadero, el alegato sería mucho más convincente.

Prescindiré casi del todo de las lindezas que de mí se dicen en el artículo. El enfadarse por tales cosas sería una inocentada propia del Sr. De la Revilla. Para mí no hay música más agradable que las insolencias racionalistas. Harta fuera mi desgracia si me aplaudiese el Sr. Perojo. Sería prueba indudable de que yo andaba dando por las paredes.

Pase, pues, lo de la sociedad de socorros mutuos, como si los krausistas por un lado, y los contemporáneos de otro, no diesen los mejores modelos de tales sociedades. Entre los católicos puede haber exceso de benevolencia mutua; pero no abundan rasgos parecidos al siguiente: Anunció cierto día la Revista de Westminster, allá en la nonagésima plana, cerca de los anuncios, 
que había recibido un librito español intitulado Ensayos sobre el movimiento intelectual de Alemania, del cual se deducía que el autor era un joven muy guapo y muy aprovechado, y muy al tanto del movimiento germánico, añadiendo que le daba gracias por su regalo. Todo esto dicho en cuatro líneas, a modo de suelto de La Correspondencia. Pues he aquí que cierta Revista, de la cual era director y propietario el autor del libro, reproduce a los pocos días, muy satisfecha y muy oronda, el encomio antedicho, precedido de un comentario suscrito por cierto amigo íntimo del autor, empeñado en hacernos creer que aquella fórmula de cortesía era una glorificación y una apoteosis, sin duda porque estaba en lengua anglosajona. Si el Sr. Perojo sabe estas y otras cosas, ¿por qué habla de sociedades de socorros mutuos?

Que yo he buscado deliberadamente ocasión de camorras, tampoco es exacto. Yo no me acordaba del Sr. Azcárate, hasta que el Sr. Azcárate dijo que la intolerancia habia anulado por tres siglos toda actividad intelectual en España; ni pensaba en el Sr. Revilla, hasta que el Sr. Revilla afirmó que la ciencia española era un mito; ni en el Sr. Salmerón, hasta que escribió todas aquellas barrabasadas en el prólogo del Draper. Estos señores fueron los que buscaron camorra al sentido común y a todo sentimiento patriótico, con sus destempladas negaciones. Yo no hice más que lo que debe hacer todo buen hijo cuando se ataca a su madre. En lo demás, soy enemigo de dimes y diretes, porque sé el tiempo precioso que se pierde en ellos. No he lidiado ni lidio más que por el honor literario de la patria.

Al Sr. Giner no le he atacado nunca, y de los Sres. Montoro y Perojo he escrito una sola frase, que no llevaba sabor polémico, pero que al segundo se le ha atravesado en las entrańas. Y ciertamente que, si era injusta, no valía la pena de tomarla por lo serio, viniendo de tan oscuro escritorzuelo como yo.

Dice el Sr. Perojo que yo buscaba ser sacado a pila por cualquiera de los ingenios a quienes atacaba. ¡Buenos padrinos me hubiera echado! ¿Y qué es eso de sacar a pila? ¿Será a fuerza de pila, como si dijéramos a fuerza de palanca? En tierra castellana se dice y ha dicho siempre sacar de pila, o tener en la pila.

Niego que el Sr. Revilla dejase en el artículo de marras resuelta la cuestión de la filosofía española en modo alguno, y remítome sobre este punto a la contestación que entonces le di, y que el Sr. Perojo no se ha tomado la molestia de leer, como mostraré luego. Niego asimismo haber tergiversado los puntos que tocó el Sr. Revilla. Ésta es una de tantas afirmaciones sin pruebas como llenan el artículo del Sr. Perojo, que es largo, pero de poquísima substancia.

Que yo llevé inocentemente al Sr. Revilla a la polémica. El inocente será él, que se dejó llevar. Años tiene y experiencia para que no le engañe un 
estudiantuelo inocente como yo. Y si inocencia fue el contestar primero, inocencia mayor fue callarse después. Pero todas estas inocencias tienen una explicación muy fácil, que el Sr. Perojo, con su natural travesura, no dejará de vislumbrar.

Entramos ya en la miga del artículo, y es forzoso proceder con más seriedad..., digo, con la que consiente el argumento. A la manera de aquel abogado de los Litigantes de Racine, que comienza su arenga desde la creación del mundo, y va discurriendo por los babilonios, los persas y los medos, sin llegar nunca al asunto en litigio, el Sr. Perojo toma también las cosas $a b$ ovo, y con toda la seriedad de un doctor alemán cuando prorrumpe en una perogrullada, nos enseña primeramente que la filosofía tiene siempre en su historia problemas que presenta al espiritu humano.

Enunciado este descubrimiento, nos habla de los jonios, de los pitagóricos, de los eléatas, de Heráclito y su proceso (que será, sin duda, alguna causa criminal que le formaron los Efesios, pues el vocablo proceso, así a secas, no tiene otra significación en castellano), de los eleáticos y su explicación (no dice de qué), de los sofistas con su imposibilidad de conocimiento y su demostración (como si imposibilidad de conocimiento y demostración cupiesen en el mismo saco). Dice también (¡recóndita noticia!) que en la antigüedad encontramos a Sócrates, Platón, Aristóteles, tras de lo cual pone dos et caetera, y termina con gran satisfacción: Toda época filosófica tiene, pues, su problema.

Está bien, dice, al llegar aquí, el lector; pero de todo eso se deduce que la antigüedad tuvo, no uno, sino muchos problemas filosóficos, y los tuvo de todas castas, unos cosmológicos, otros teológicos, otros morales, otros lógicos, pues nadie dirá que sean uno mismo el problema de la fuerza y de la materia, y el problema de las ideas; el problema del conocimiento y el de la voluntad, etc. Yo sé bien, o por lo menos adivino, lo que el Sr. Del Perojo ha querido decir. En la historia de la filosofía griega se distinguen generalmente, y con bastante, aunque no con entera exactitud, tres períodos: el cosmológico, en que mecánicos y dinámicos, quieren explicar a su modo la constitución del universo; el dialéctico o lógico, en que imperan los eleáticos y sofistas; el metafísico, que empieza con las escuelas socráticas, aunque Sócrates, por lo que de su doctrina alcanzamos, fue, más que todo, moralista.

Repito que esta división es muy imperfecta; pero apoyado en ella el Sr. Perojo, ha querido decir que en cada época de la filosofía helénica predomina una tendencia sobre las restantes, lo cual, dicho así, es una verdad como un templo. Pero ha de advertirse que muchas de esas direcciones coexistieron, y que muchos de esos filósofos tendieron a resolver diferentes problemas y aplicaron su actividad a varias ramas de la ciencia. $Y$ advierto esto, porque las 
ideas del Sr. Perojo, aunque confusamente expresadas, me parecen nacidas de un criterio pobre y estrecho, que se empeña en encerrar la historia de la filosofía en un molde inflexible y reducirla a una especie de mecanismo, mediante el cual, en una época determinada, ha de plantearse tal problema y resolverse tal cuestión, sin que pueda plantearse otra ni resolverse de distinto modo, cuando precisamente la historia demuestra que en todas las épocas se plantean todos los problemas y se resuelven bien o mal todas las cuestiones, y que nada hay nuevo debajo del sol, y que en el terreno filosófico no pueden presentarse ni resolverse más cuestiones que las presentadas y resueltas por la filosofía griega, a no ser que añadamos una nueva facultad al entendimiento humano o alteremos esencialmente sus condiciones. En filosofía no se concibe el progreso de la manera que nuestros adversarios le entienden. Puede formularse en distintos términos el problema, puede trabajarse sobre los datos del conocimiento, dando más importancia a unos que a otros, perfeccionando los métodos, haciendo aplicaciones, etc., pero de ahí no se pasa.

Formular un problema realmente nuevo es tan imposible como crear un sexto sentido. Lo que hacen los problemas es tomar forma nueva en cada época; pero una de dos: o están bien puestos, y entonces son idénticos a los antiguos, o están mal puestos, y son abortos de una mente enferma, nacidos de torcimientos y mutilaciones de la conciencia. La conciencia humana, una y entera, no formula más cuestiones que las que ha formulado siempre. Todas las ideas filosóficas (ha dicho un contemporáneo ilustre) pueden escribirse en una cuartilla de papel. Esa conciencia universal, verdadera piedra de toque para toda creación filosófica, es la que Vives proclamó en toda su amplitud, como iremos viendo.

De lo expuesto se deducirá que yo no creo, como el Sr. Perojo, que la filosofia moderna tiene un problema propio y peculiar, sino que digo y sostengo que tiene los mismos problemas que la filosofía de todos tiempos. Y si no los tiene, no debe llamarse filosofía, sino aberración del entendimiento humano. ¿No tiene cada facultad humana su objeto propio? ¿Han variado estos objetos desde Platón y Aristóteles hasta nosotros? Pues si son los mismos, aun suponiendo que se hayan perfeccionado las facultades cognoscitivas, éstas habrán llegado a ver con más claridad y precisión sus respectivos fines; pero no a crear otros nuevos.

Y no variando la facultad ni su objeto, el problema sigue planteado de la misma manera que para los griegos, y así estará hasta el fin del mundo, si Dios no nos infunde sobrenaturalmente nuevos medios de conocer, o algo por el estilo.

Y, en efecto, el problema que el Sr. Perojo supone propio y exclusivo de la filosofía moderna, a saber: el conocimiento de las cosas mediante nues- 
tras solas facultades, lejos de ser nuevo, es el más viejo de la tierra, es el que debió proponerse el primer hombre que filosofó..., ¿qué digo?, nuestro padre Adán cuando abrió los ojos en el Paraíso: es la definición y la esencia misma de la filosofía. Mediante nuestras solas facultades: ¿qué quiere decir esto? ¿Rechazando el yugo de la autoridad? ¿Pues no lo hicieron todos los pensadores griegos que fueron cabezas de sectas? ¿No lo hicieron asimismo muchos escolásticos? ¿Qué filósofo, que lo haya sido de veras, ha reconocido en el campo puramente filosófico otro medio de conocer que las facultades humanas? La proposición del Sr. Perojo es, o una perogrullada, o un error muy común en los filósofos de su temple. Es un error, si el desprecio a la autoridad y el examen individual se entienden en el sentido absurdo de que cada cual, por su cuenta y riesgo, como si nadie hubiera pensado ni discurrido antes, construya, como dicen los krausistas, su propia ciencia, cual si hubiese una ciencia al gusto de cada consumidor. No; la conciencia individual, que es siempre imperfecta y está siempre oscurecida por el predominio de una facultad sobre las restantes (de lo cual nace la diferencia personal), debe acrisolarse y purificarse en la conciencia universal, en la conciencia histórica, que pocas veces yerra ni sufre mutilaciones. De ahí la justa importancia de las grandes doctrinas y de los grandes nombres en la indagación filosófica.

Por lo demás, repito que, antes del advenimiento de la filosofía moderna, estaba reconocida universalmente la necesidad del racionalismo en metafísica. Nadie la había afirmado con más brío que San Anselmo. ${ }^{694}$ Y algunos escolásticos habían pasado más allá del justo límite, extendiendo la razón adonde no puede llegar. Tal fue el pecado de Abelardo.

Cita el Sr. Perojo unas palabras que atribuye a Vives y que le parecen encerrar esa proclamación del libre examen: «Nada rebaja más el espiritu humano que la costumbre de pensar por otro, y de conceder a la autoridad lo que sólo a la razón corresponde». Realmente Vives condena en un pasaje que yo mismo cité en otra ocasión, el auctoritate sola acquiescere, et fide semper aliena accipere omnia; pero no basta copiar estas palabras, sino parar mientes al sentido en que Vives, fervoroso católico, las toma. Más adelante volveré sobre esto.

No es exacto que la filosofía moderna, al dar su primer paso, sea dogmática. Al contrario: presenta un carácter crítico, y muchas veces escéptico. Pero

694 Fides quaerens intellectum... Fide stabilitus, in rationis ejus indagine se voluerit exercere... Veritatis ratio tam ampla, tamque profunda est, ut a mortalibus nequeat exhauriri... Sacra pagina nos ad investigandam rationem invitat... Mens rationalis quanto studiosius ad se discendum intendit, tanto efficacius ad Dei cognitionem adscendit..., y otros muchos textos del Monologium y del Proslogium. (Tercera Edición) 
todas estas son generalidades que pierden mucho de su fuerza, puestas en cotejo con la realidad de los hechos. Entre los filósofos del Renacimiento los hay críticos, como Vives; dogmáticos, como los peripatéticos clásicos y los mismos neo-platónicos de Florencia; escépticos, como Sánchez, Montaigne, Charrón y alguno más; en una palabra: los hay de todas castas y condiciones. Es absurdo el empeño de ponerlos a todos en fila, como reclutas, y hacerlos dogmáticos a la fuerza, sólo porque así nos viene bien para la clasificación, y porque así se retrasa el criticismo hasta la época de Kant.

Establece el Sr. Del Perojo las dos direcciones principales e indudables del pensamiento moderno, la baconiana y la cartesiana, el empirismo y el psicologismo o idealismo que él dice.

Pero no han de olvidarse varias cosas: primero, que las dos direcciones existen desde que hay filosofía en el mundo; segundo, que la doctrina de la conciencia o razón universal proclamada por Vives (como el mismo Sr. Perojo reconoce) está por cima de la una y de la otra, porque dentro de ella caben entrambas; tercero, que Bacon y Descartes no hicieron más que recoger, cada cual por su parte, mermada y como Dios quiso, la herencia de los filósofos españoles e italianos del siglo Xvi.

El Sr. Del Perojo nos hace un cargo tan injusto como gratuito, suponiéndonos ignorantes de lo que él llama proceso histórico de la filosofía moderna. Imagina, además, que la historia de la filosofía española, tal como nosotros la concebimos, contradice a ese proceso. Para contestar a estas afirmaciones, no necesito más que remitirle a la brillante carta con que mi buen amigo Laverde encabezó mis Polémicas. Allí verá de qué manera entroncamos nosotros con Vives el movimiento filosófico moderno. Allí verá que «Bacon, exagerando la inducción proclamada por Vives, paró en el empirismo, y engendró a Locke, como Locke a Condillac, y Condillac a Destutt Tracy y a Cabanis». Allí leerá asimismo que «Descartes, tomando de los vivistas españoles (no precisamente de Vives) su racionalismo, pero sin atenuación ni límites, y dejando al descubierto altas verdades, abrió conscia o inconscientemente la puerta a todos los idealismos posteriores». Y allí, finalmente, escribió mi docto amigo que «Reid, huyendo del escepticismo sensualista de David Hume y no acertando a salir del sentido común ni a desprenderse de las reminiscencias baconianas, creó un empirismo psicológico, sabio y fecundo, pero estrecho, que a su vez extremó Hamilton desterrando de la filosofía toda especulación acerca de lo absoluto e incondicionado.»

Todo esto, y algo más, dijo Laverde; y si el Sr. Del Perojo hubiera leído aquella carta, se hubiera ahorrado el trabajo, bien inútil, de escribir algunas páginas y repetirnos cosas que sabe cualquier alumno de segunda enseñanza. De Hobbes ni de Berkeley no habló entonces mi amigo, porque no venía a 
cuento. Ni tampoco es muy oportuno en el artículo del Sr. Perojo aquello de "¿Quién será tan insensato que pretenda introducir en la evolución de la escuela de Bacon un nuevo aspecto, una nueva forma?». Nadie pretende semejante cosa: lo que decimos y afirmamos es que la historia de esa escuela no empieza donde debe empezar; pues, prescindiendo de sus antecedentes en la antigüedad y en los tiempos medios, no cabe desconocer que lo que se llama baconismo es una mera disgregación de la escuela de Vives, como probé en la carta contra Revilla y repetiré luego, y es indudable asimismo que con Telesio y Galileo, y antes y después de ellos, tiene el empirismo un verdadero proceso (como diría Perojo) en Italia. No decimos, por tanto, que la historia de la filosofía baconista no tenga pies, sino que le falta cabeza.

Sigue el Sr. Del Perojo exponiendo a sus anchas los sistemas cartesianos y desarrollando todo lo que aprendió en Heidelberg de la historia de la filosofía.

Pero como la historia de la filosofía no salva a nadie de cometer solecismos, el Sr. Del Perojo da un batacazo tremendo en aquello de la causa efficientis, que (según el latín que yo aprendí en la Montaña) debe ser causa efficiens. Y, ciertamente que para hacer una concordancia vizcaína, poniendo en genitivo lo que ha de ser nominativo, no era preciso gastar tanta prosa, ni hablar con solemnidad tan enfática.

En la página siguiente, el Sr. Perojo comete la debilidad de llamar filósofos a Voltaire, La Mettrie, Holbach y otros pobrecillos del siglo pasado, que fueron cabalmente la caricatura más perfecta de la filosofía. Verdad es que también el Sr. De la Revilla llamó filósofo a Rabelais. ¿Y por qué no al Aretino, y al autor de La lozana andaluza, y a Beroaldo de Verville, o quienquiera que sea el autor de Le Moyen de Parvenir? Allá se van todos en punto a filosofía y no sé por qué ha de ser preferido el alegre cura de Meudon.

Luego nos anuncia el Sr. Perojo la aparición de Kant en estos retumbantes términos: "Kant fue la involución de la evolución de la filosofía». No diría otro tanto Feliciano de Silva, y tengo para mí que este rasgo había de dejar patitieso al doctor Miguel de Silveira, pues en todo su Macabeo no hay mayor embrollo. Verdad es que el Sr. Del Perojo habla aquí en términos hegelianos. ¡Bendito sea el lujo y quien lo trujo!; es decir: ¡quien nos trajo esta sal a Castilla! ¿Ha terminado el Sr. Perojo sus preliminares? No, que ahora habla de Kant, y dice que fundió las dos direcciones en que venía dividido el pensamiento bumano, como si a nadie se le hubiera ocurrido fundirlas antes, y truena luego contra los que confunden el criticismo con el escepticismo, error en que no sé quién habrá podido incurrir. Lo que dicen muchos, y pienso que con razón, es que el criticismo kantiano (que es cosa muy distinta de la critica, la cual es en el mundo harto más antigua que Kant), si no es el escepticismo puro, es el 
camino más derecho para llegar a él, a poca lógica que pongamos en la mollera del raciocinante. Kant salvó, como pudo, las consecuencias de la Crítica de la razón pura en la Crítica de la razón práctica; pero los remedios de ésta han parecido generalmente pańos mojados, cuando no contradicciones palmarias.

Pero todo esto, dirá V., viene tanto al asunto, como las coplas de Calaínos, o la glosa de la mal maridada. Y yo le confesaré que tiene razón; pero la culpa es del Sr. Perojo, que se ha empeńado en demostrarnos que posee toda la dosis de filosofía necesaria para aspirar al grado de bachiller en artes. Ahora que estamos plenamente convencidos de ello, a pesar de aquel lapsus de latinidad notado más arriba, veamos si entra en harina. Y van ya nueve páginas de las cuarenta.

Pues tampoco en la décima encontramos nada de provecho, sino la afirmación, muy verdadera, de que las ciencias florecieron extraordinariamente durante la antigüedad y en los tiempos medios en nuestro suelo, y la afirmación falsísima, y destituida de pruebas, sin duda por economía, de que la Inquisición paralizó este movimiento, ensañándose con toda clase de hechos (¿qué será esto de ensañarse con un hecho?) que en algo manifestaran actividad e independencia. Y no deja de añadir que el Santo Oficio encontraba en cada pensador u hombre cientifico un hereje contaminado con los sacrilegios que por el mundo se estaban propagando.

El Sr. Del Perojo, que tanto aparato científico ha desplegado hasta aquí, se pone ahora sencillamente al nivel de cualquier orador progresista. A todas esas afirmaciones absolutas sin pruebas, que vienen después de medio siglo de trabajos históricos que demuestran lo contrario, se contesta en dos palabras por el método de Scalígero en su controversia con Cardano, poniendo si donde dice no, y no donde dice si. De todas esas declamaciones inquisitoriales me he hecho cargo repetidas veces, refutando a los Sres. Azcárate, Salmerón y Revilla: al analizar mis cartas ha hecho V. de nuevo la debida justicia de ellas; y, no obstante, como si nada hubiera pasado ni nada se hubiera dicho, el Sr. Del Perojo, sin invalidar uno solo de nuestros datos, una sola de nuestras afirmaciones, vuelve, tan fresco, a despotricar como sus aláteres. Esto será procedimiento neokantiano, pero no racional ni lógico. Ciertamente que si algo hubiera capaz de desalentar a quien sólo trabaja por la verdad y la justicia, y espera y confía que la justicia y la verdad triunfen siempre, sería esa terquedad sin ejemplo con que, a pruebas y hechos cien veces alegados, se responde, por todo argumento: no, porque no.

¿Es esto la ciencia moderna? ¿Se concibe que en 1877 se haya escrito, para afrenta de la cultura española, un párrafo del tenor siguiente?:

"No hay más que recorrer las páginas del sangriento libro del martirologio español, para advertir cómo al primer paso de un talento extraordinario, a la 
primera creación de un espiritu reflexivo, acudia presurosa la Inquisición a extinguir con el fuego de la hogueras toda su obra... ;Cuántos hombres ilustres tuvieron que sucumbir!... ;Larga sería la lista de cientificos que perecieron en las hogueras de la Inquisición!»

Y yo ahora, con la conciencia tranquila, seguro de la verdad y de la razón que sustento, pido al Sr. Perojo las pruebas de todo eso; le pido, es más, le ruego que me nombre un sabio, un solo sabio español que pereciera en las hogueras inquisitoriales. ¿Dónde están? Yo no los veo. Las víctimas de la Inquisición pueden distribuirse del modo siguiente:

Judaizantes: Todos gente oscura: ni un solo nombre ilustre entre ellos. Algunos dicen que Menaseh ben Israel fue atormentado; pero es falso. El atormentado fue su padre, mercader de Lisboa y hombre sin letras. El único judaizante literato que, según mis noticias, padeció tormento, fue David Abenatar Melo, mediano traductor de los Salmos. Pero nadie le persiguió por poeta, sino por judaizante. La Inquisición de Portugal quemó a principios de este siglo (cuando en el resto de la Península apenas se quemaba a nadie) a otro judío dramaturgo, Antonio José da Silva. Cientificos, cero. Entre los conversos y los judaizantes hubo hombres de gran valía; pero nadie los persiguió mientras fueron cristianos, a lo menos en apariencia. Isaac Cardoso, Isaac Orobio de Castro y otros muchos, después apóstatas, habían alcanzado en España honores y reputación, desempeñando cátedras en nuestras Universidades, sin que fuera obstáculo la mancha de su origen. Es más: en España imprimieron libros filosóficamente muy atrevidos, y nadie les fue a la mano, ni los quemó, ni los puso en el indice.

Moriscos: Gente indocta todos. Los que algo sabían, como Miguel de Luna y Alonso del Castillo, vivieron en paz con los cristianos, y lograron hacer su agosto. Quemados, cero. Atormentados, idem.

Protestantes: Ni uno solo de los que algo valieron fue chamuscado por la Inquisición. Juan de Valdés murió tranquilo y respetado en Nápoles. A Servet le tostó Calvino. El doctor Constantino Ponce de la Fuente murió en las cárceles, y lo que quemaron fue su estatua. Juan Pérez, Casiodoro de Reina, Cipriano de Valera, etc., anduvieron casi toda su vida por el extranjero. Ninguno de ellos era un sabio del otro jueves. Total de sabios protestantes quemados, cero.

Nigromantes y brujas: No creo que los sabios abundasen en el aquelarre de Zugarramurdi. De nigromantes doctos sólo se procesó (que yo recuerde) al Dr. Torralba, que era un loco de atar. Así lo entendió la Inquisición, y por eso no perdió el tiempo en atormentarle ni en quemarle. 
Alumbrados, confesores solicitantes y otros excesos: Tampoco en esta sección parece ningún sabio. Dios nos tenga de su mano.

Procesos politicos de Aragón: Ídem. Íd.

Resumen de todo: La Inquisición de Portugal quemó a un judío, que hacía sainetes, no por hacer sainetes, sino por haber judaizado.

La Inquisición de Valladolid dio garrote a un predicador de fama, llamado el Dr. Cazalla, por haber esparcido el luteranismo en aquella ciudad.

La Inquisición de Sevilla quemó los huesos de otro predicador famoso, por igual causa.

Tenemos, pues, que el sangriento martirologio de más de cinco siglos, desde fines del XIII, en que entró la Inquisición en Cataluña, hasta principios del $\mathrm{XIX}$, se reduce a tres, por mejor decir, a dos hombres, un poeta dramático y un predicador, entrambos medianos, y sin los cuales se pasaría muy bien nuestra historia literaria. De Cazalla ni aun sabemos que imprimiera nada, por lo cual nadie le nombra, sino los que escribimos de herejías. A Antonio José le ha dado alguna fama su trágico fin; pero sin la circunstancia de haber trabajado para un teatro tan pobre como el de Portugal, maldito si representaría nada en la historia de las letras.

Que entre las gentes castigadas en diversos conceptos por la Inquisición podía haber muchos sabios inéditos, como el poeta $\mathrm{D}$. Pánfilo, ni lo niego ni lo afirmo. Pero esto de los ingenios ahogados en flor, y a quienes la suerte no concedió manifestarse, es bueno para dicho en la elegía de Gray sobre el cementerio de una aldea, no para aducirlo en una discusión científica. $\mathrm{Ni}$ es cierto que la Inquisición anduviese a caza de sabios para tostarlos. La Inquisición, como todo tribunal, se componía de hombres, y, según las ocasiones, procedió más o menos rectamente, pero nunca con esa intención deliberada y sistemática de matar el pensamiento, a no ser que por pensamiento se entienda únicamente el pensamiento heterodoxo.

Pues ¿qué diremos de esos famosos procesos con que siempre se da en cara a los defensores de la Inquisición? La Inquisición procesó a Carranza, porque Carranza había enseñado proposiciones de sabor luterano. La Inquisición procesó a Damián de Goes, porque Damián de Goes era protestante, o poco menos. Pero no procesó al primero por teólogo, ni al segundo por humanista; como en el siglo pasado no procesó a Anastasio da Cunha por matemático, sino por volteriano. Pero ¿̨a qué prolongar esta reseña? De otros procesos he hablado más de una vez, y no quiero repetirme. El del Brocense fue una cuestión de escuela: era ramista y se conjuraron contra él los aristotélicos salmantinos. La Inquisición, para hacerlos callar, le llamó a su tribunal tres veces; pero no le impuso castigo alguno personal ni aflictivo. Lo de Fr. Luis de León fue 
cuestión más honda; sus acusadores no eran gente vulgar, y por eso duró tanto la causa; pero ni Bartolomé de Medina ni León de Castro pudieron impedir que se hiciese la luz y se reconociese la inocencia del procesado. Hay otros procesos, que son (como diría el Sr. De la Revilla) verdaderos mitos; en esta categoría coloco los que se suponen fulminados contra Fr. Luis de Granada, Pablo de Céspedes, Arias Montano, el P. Sigüenza, y no sé cuántos más; procesos que nadie ha visto y que, según toda probabilidad, no han existido nunca sino en la imaginación de Llorente, que convertía en procesos la más insignificante referencia, el más leve registro que encontraba en los libros de la Suprema. Esos que él llama procesos fueron acusaciones frustradas, que ni la Inquisición ni tribunal alguno del mundo puede impedir.

Si la Inquisición no extinguió el pensamiento con hogueras ni con potros, ¿de qué otra suerte ejerció su maléfica influencia? Con la prohibición y expurgo de libros, se dirá, aunque no lo dice el Sr. Del Perojo. Otra preocupación infundada. Los libros que la Inquisición podía condenar, se reducen a las clases siguientes:

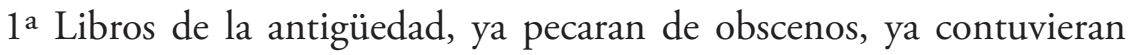
errores anticristianos. La Inquisición los permitió todos "propter elegantiam sermonis». Prohibió únicamente que se enseñasen en las aulas los poetas demasiado eróticos, y vedó asimismo una o dos traducciones en lengua vulgar.

$2^{\text {a }}$ Libros licenciosos modernos, especialmente italianos y españoles. Prohibió algunos, pero sin proceder con excesivo rigor en este punto. En los que eran modelos de lengua y de estilo, como la Celestina, mandó borrar sólo breves pasajes. Por lo demás, en todo lo que toca a amena literatura, pecó más bien de laxa que de rígida, como todo el mundo confiesa.

$3^{\text {a }}$ Libros protestantes. Prohibió todos los que llegaron a su noticia, e hizo perfectamente.

$4^{\mathrm{a}}$ Libros de filosofía y ciencias escritos por españoles. No prohibió ninguno, a no ser una de las tres versiones de los Diálogos de León Hebreo, quizá por contener rasgos cabalísticos que, no obstante, se dejaron correr en el texto latino e italiano. Quitó en el libro de Huarte un capítulo sobre el temperamento de Jesucristo, y con él algunas frases de sabor excesivamente materialista. Las expurgaciones en el libro de Doña Oliva fueron de poca monta. Fue expurgado asimismo un discurso de Ambrosio de Morales, en que el cronista pretendía demostrar que las estrellas tienen poderio sobre todo el hombre. ¡Ésta es toda la persecución contra nuestra filosofía!

695 La Violeta del alma, prohibida en los índices, no tiene que ver con el compendio de la Teología Natural de Sabunde, que lleva el mismo título. (Tercera Edición) 
5a Libros de filosofía, escritos por extranjeros. No prohibió casi ninguno, ni siquiera la Ética de Espinosa.

Y no se diga que las doctrinas de Bacon, Descartes, Gassendi, etc., eran desconocidas en España, pues afortunadamente quedan los libros de Isaac Cardoso, Caramuel y otros, en que están expuestas, y aun comentadas y defendidas. Esto por lo que hace al siglo XVII. En el XVIII, muy a principios, el P. Tosca enseñó, sin que nadie le pusiera trabas, el gassendismo, y hasta tuvo muchos discípulos. Por el mismo tiempo, el P. Feijoo y otros ensalzaban sin reparo a Bacon.

A la entrada del cartesianismo no se opuso la Inquisición en manera alguna. Prohibió todos los libros materialistas e impíos del siglo pasado, e hizo muy bien, y merece alabanzas por ello. Ése era su oficio.

6a Libros de mística. Recogió o mandó expurgar los que encerraban doctrinas de alumbrados y quietistas, o los que, mal interpretados por el vulgo ignorante, podían conducir a tales errores. Por eso se prohibieron temporalmente algunos de Fr. Luis de Granada y otros varones piadosísimos y hasta santos. Pero pasado el peligro, o hechas las oportunas correcciones por los autores, volvieron a circular sin trabas, coincidiendo esto con el mayor desarrollo y esplendor de nuestra mística.

$7^{\text {a }}$ Libros de nigromancia, hechicería, etc. Obró cuerdamente en vedar tales simplezas.

Ésta es, reducida a breves términos, la historia de las persecuciones y prohibiciones inquisitoriales. Con esto sólo, queda reducida a humo toda la argumentación del Sr. Del Perojo. Y cuenta que para hacerlo, no he tenido que acudir a datos recónditos, sino repetir noticias que sabe todo bibliófilo, algunas de las cuales fueron ya presentadas con análogo intento por mi erudito amigo D. Adolfo de Castro en una ocasión semejante.

Si después de estas demostraciones de hecho, y de las que añadiré cuando sea necesario, continúa el Sr. Del Perojo hablando de los sabios quemados y de otras vulgaridades por el estilo, tolerables sólo en una gacetilla, yo tendré el derecho de encogerme de hombros y dejarle por incurable. A lo más, aplicaré el procedimiento de Scalígero, que, para ahuyentar a todo género de tábanos literarios, es probado.

No me tache el Sr. Del Perojo de duro ni de incisivo. Vim vi repellere licet. Lo cual, en castellano, quiere decir que donde las toman, las dan. Su artículo, por el bulto, ya que no por la substancia, merece que le dediquemos una segunda carta. En ella llegaremos a la cuestión capital, a la filosofía española. Harto persuadido estoy de que nada de cuanto yo diga ha de hacer mella en la dura cerviz de esos señores; pero puede convencer a otros que piensan y raciocinan, aunque no son neo-kantianos. 
Quedamos, pues, en la sección tercera del artículo perojino. La síntesis de lo que llevamos recorrido es ésta: "Larga sería la lista de los hombres de mérito cientifico que perecieron en las hogueras de la Inquisición."

La síntesis de lo que yo he contestado es esta otra: «Ningún hombre de mérito cientifico fue quemado por la Inquisición.»

Yo he demostrado la mía. La del Sr. Del Perojo está sin pruebas. Búsquelas, y se lo agradeceré en el alma.

Quedo borrajeando la segunda carta.

Marcelino Menéndez Pelayo

\section{Carta al señor don Alejandro Pidal y Mon (continuación) [Segunda edición]}

Venecia, 8 de mayo de 1877.

Sr. D. Alejandro Pidal y Mon.

Charissime: Tras breve descanso, vuelvo a la comenzada y enojosa tarea; es decir, a la disección anatómica del engendro perojino. Estábamos en la sección tercera, folio 336, en que el discípulo de Kuno Fischer, pregunta: ¿Es sostenible que hayamos tenido filosofía española? Desde luego puede V. imaginarse cómo resolverá la cuestión; pero siendo infinitos los modos de errar y de hacer las cosas mal, el Sr. Del Perojo yerra de distinto modo y por diverso camino que el Sr. De la Revilla y los demás. Elige posición opuesta y trae al combate nuevas armas, que él cree de finísimo y bien templado acero toledano, pero que son realmente de mala y quebradiza hoja de lata.

Empieza por decir que el desarrollo de la filosofía moderna, desde Bacon y Descartes hasta Kant, es próximamente el tiempo mismo del dominio de la Inquisición; por lo cual, en su concepto, no pudieron filosofar los españoles. Ahora echemos cuentas: la Inquisición nace en el siglo XIII como protesta e instrumento contra la herejía albigense; sigue dominando en Cataluña durante los siglos XIV y XV, y a fines de éste se establece en Castilla, donde dura tres siglos justos. Total de dominio de la Inquisición en una u otra forma, con tribunales más o menos regulares, pero siempre activos e independientes de la jurisdicción episcopal: cinco siglos. No se pierda de vista el dato, porque es importante. Ni se diga que en las dos primeras centurias la Inquisición estuvo reducida a una parte sola del territorio, pues cabal- 
mente era entonces Cataluña lo mejor y más ilustrado de España y lo que más participaba del general movimiento europeo. Ni se alegue tampoco que esta Inquisición fue benigna y tolerante, pues vemos a aquellos buenos Dominicos, entre los cuales se distinguió Eymerich, perseguir y condenar implacablemente todo vestigio de heterodoxia. Así fueron sucesivamente castigados con penas espirituales y temporales los herejes siguientes, y alguno más que ahora omito: Durán de Baldach y varios albigenses; Pedro Oler, cabeza de los Begardos; Arnaldo de Vilanova, Jacobo Juste y sus discípulos, también Begardos; Berenguer de Montfalcó, Raimundo de Tárrega, Nicolás de Calabria y Gonzalo de Cuenca, Bartolomé Janoesio, Fr. Arnaldo de Montaner. Todos estos procesos son de corifeos de herejías. Quizá no tuvo que instruir tantos la Inquisición castellana en todo el tiempo de su influencia.

El modo de proceder de esta Inquisición está expuesto en el famoso Directorium de Eymerich. Tampoco se puede decir que faltasen tizonazos. Pedro Oler y Fr. Bonanato fueron quemados en Barcelona; Durán de Baldach, lo fue en Gerona; los cadáveres de Guillermo Gelabert, Bartolomé Fuster y otros herejes, fueron entregados a las llamas en Valencia. Nicolás de Calabria, fanático rabioso, pasó al brazo secular en Barcelona, y no hay que preguntar cuál fue su suerte. Esos dos siglos de Inquisición dura y constante debían, a ser verdad la teoría de nuestros adversarios, haber extinguido toda actividad; pero como la historia se empeña en ser ultramontana, nos dice (¡qué lástima!) que durante esos doscientos años fueron los catalanes el pueblo más rico, ilustrado y feliz de la tierra. Disfrutaban de libertad política; tenían una industria para aquellos tiempos muy respetable; el comercio de Barcelona competía con el de las más florecientes ciudades italianas; sus armas triunfaban en todas partes; el terror de su nombre penetraba hasta el remoto Oriente; los peces no se atrevían a moverse sin llevar las barras en sus escamas, y, en fin, aquel pueblo gigante engendraba al mismo tiempo reyes del temple de Pedro III, de Pedro IV y de Alfonso V; filósofos como Raimundo Lulio; médicos de la casta de Arnaldo de Vilanova; alquimistas al modo de Raimundo de Tárrega; historiadores como Desclot y Muntaner; poetas como Mosén Jordi y Ausias March; novelistas como Juan de Martorell, y juristas y teólogos, y cuanto puede engendrar una potente raza en todo el vigor de la juventud y de la vida. Doscientos ańos de Inquisición deben de bastar para matarlo todo, y, sin embargo, a medida que el tiempo pasa, el movimiento crece, y Cataluña cierra ese período abriéndose en cuerpo y alma al Renacimiento, que entra en el arte con el petrarquismo de Ausias March y con las imitaciones ovidianas de Mosén Ruiz de Corella, y entra en la ciencia filológica con los humanistas de la corte de Alfonso V. Cuando 
Cataluña se une a la España Central, no trae un solo síntoma de decadencia, a pesar de las dos centurias inquisitoriales.

Establécese la Inquisición en Castilla (y no mucho después en Portugal), y comienza la segunda y más famosa época, el tercer siglo de Inquisición, el xvi. En él no hubo opresión alguna para la ciencia; lo he mostrado en la carta anterior; hubo sí mucha persecución de judaizantes, menor de moriscos, alguna de protestantes, casi nada de brujas, y mucha de malos clérigos, en lo cual la Inquisición se mostró severísima y cooperó a la gran reforma iniciada a fines del siglo xv por la Reina Católica y por Cisneros. En este período, que abraza todo el siglo xvı, fue políticamente España la primera potencia de Europa. Si descendió de este rango, no fue por la Inquisición, sino a consecuencia de la lucha generosa y desesperada que, en cumplimiento de un deber sagrado como católicos y como españoles, sostuvimos contra el torcido espíritu de la época y contra media Europa coligada en defensa de la Reforma. Fuimos, a la postre, vencidos en la liza, porque estábamos solos; pero hicimos bien, y esto basta: que las grandes empresas históricas no se juzgan por el éxito. España, en ese siglo, fue el brazo de guerra del Catolicismo en todos los campos de batalla de Europa. En la política interior cometimos desaciertos o aciertos, de que en manera alguna es responsable el Santo Oficio, a quien sólo a última hora empleó como instrumento Felipe II, cuando las alteraciones de Aragón.

Pues en lo relativo al desarrollo intelectual de esa era, ¿quiere el Sr. Perojo que (para no repetir lo que tengo dicho noventa veces) condense en dos docenas de nombres, de todos sabidos, nuestras grandezas científicas? Pues elijo los siguientes:

Teólogos. Fr. Luis de Carvajal, que renovó del todo el método y la fortuna en su libro De restituta Theologia, uno de los más bellos que produjo el Renacimiento.-Francisco de Vitoria, el Sócrates de la escuela de Salamanca.-Alfonso de Castro, cuyos libros De haeresibus han sido por más de dos siglos la única autoridad en la materia, y hoy mismo son de provecho grandísimo para teólogos y no teólogos por lo rico y portentoso de la doctrina y lo maduro y reposado del juicio.-Diego Laínez, primera gloria de la Compañía de Jesús, después del fundador.-Salmerón, oráculo de Trento y expositor de la Escritura, puesto hoy mismo en las nubes por todos los que entienden de esto.-Maldonado, restaurador de la enseñanza teológica en París, uno de los más grandes teólogos que han existido, encomiado a porfía por católicos y protestantes.-Domingo de Soto, cuyos libros De natura et gratia constituyen el ataque más terrible que el luteranismo padeció en toda aquella centuria.-Melchor Cano, de quien basta el nombre.-Molina, padre 
del congruismo. - Domingo Báñez, tan digno de ser su émulo.-Suárez, Valencia, Vázquez...

Pero no quiero seguir, porque para el Sr. Del Perojo todo esto será paja. Sus grandes teólogos serán el zapatero Jacobo Boehme y aquel Schleiermacher, que decía (sin que le llevasen a un manicomio, porque en Alemania se oyen cosas muy raras): "Ofrezcamos un rizo de nuestros cabellos a los manes del Santo Espinosa" (o Spinoza, como diría el Sr. Perojo). A la profundidad y elocuencia de ese rasgo, nunca llegó ciertamente la teología de Domingo de Soto ni la de Melchor Cano.

Escriturarios. El nombre solo de Arias Montano basta para llenar un siglo, y es por sí tan grande como el de cualquiera de esos luminares de las ciencias de la materia, que para el Sr. Del Perojo parecen ser las únicas en el mundo. Pero España posee, además, una larga serie de cultivadores ilustres de las ciencias bíblicas, serie que empieza con los colaboradores de la Políglota Complutense, y con aquel Diego López de Estúniga que tan malos días y tan malas noches hizo pasar a Erasmo, y termina, bien entrado el siglo XVII, con Pedro de Valencia y Fr. Andrés de León. No hay libro de la Escritura sobre el cual no poseamos algún comentario de un español, célebre en las escuelas católicas. ¿Cuándo se olvidará en ellas el de Prado y Villalpando sobre Ezequiel, el de Pineda sobre Job, el de Rivera sobre los Profetas Menores, el de Héctor Pinto sobre Isaías, el de Benito Pererio sobre Daniel, el de Maldonado sobre los Evangelios, el de Salmerón sobre las Epístolas de San Pablo, los de Hortolá y Fr. Luis de León sobre el Cántico de los cánticos? Todos estos hombres, así como Mariana y Manuel Sa, y Celada y Luis de Tena y Maluenda, y otros que la memoria no puede abarcar, no eran meros teólogos escolásticos, sino verdaderos filólogos, helenistas, hebraizantes y arqueólogos, que habían estudiado la Biblia en sus fuentes, y que para interpretarla acudían a todos los recursos que podían suministrarles las ciencias exegéticas en su tiempo. Pero en vano es esperar justicia ni misericordia para ellos de gente que, en esta materia, no ha pasado más allá de Renán y de Alberto Réville, o de algún artículo popular de la Revista de Ambos Mundos.

Místicos. ¿Quién no conoce a San Juan de la Cruz, a Santa Teresa, a Fr. Juan de los Ángeles, a Malón de Chaide?... El señor Perojo es muy dueño de preferir a los místicos alemanes, que probablemente no habrá leído. ${ }^{696}$ Nosotros nos quedamos con los nuestros, y creo que ganamos en el cambio. Así como así, en la redacción de la Contemporánea está el Sr. Revilla, a cuyo

696 Como que hace vivir al maestro Eckart cerca de siglo y medio después de su muerte. (Segunda Edición) 
juicio nuestros místicos son quizá los primeros del mundo. Allá ajusten el Sr. Del Perojo y el Sr. Revilla estas cuentas. Yo borro el quizá, a pesar del respeto que tengo a San Buenaventura, y sigo adelante.

Juristas. A los dos grandes luminares de la jurisprudencia extranjera en la época del Renacimiento, que son Alciato y Cujacio, opone la España inquisitorial del siglo XvI, sin desventaja alguna, otros dos: Gouvea y Antonio Agustín. Los de segundo orden no tienen cuenta. En otro género de disquisiciones, Vitoria, Soto, Molina, Suárez y Baltasar de Ayala fundan (puede decirse) el derecho de gentes. No lo digo yo: lo indicó ya Brucker, respecto a Francisco de Vitoria. Lo han afirmado de los restantes: Mackintosh, en la Revista de Edimburgo; Weathon, en la Historia del derecho natural. ${ }^{697}$ Creo, no obstante, que exageraron un poco. Algunos de esos autores son tomistas, y en Santo Tomás bebieron los fundamentos de la doctrina que maravillosamente desarrollaron. Pero es indudable que en la constitución de ese derecho, como ciencia separada, precedieron a Grocio, Puffendorff, etc., los españoles.

Médicos. El Sr. Revilla dijo ya que la nulidad de la ciencia española no se entendía de este ramo del saber. El Sr. Del Perojo tampoco ha insistido en semejante punto, y ha hecho bien. Bastarían Laguna y Vallés, Mercado y Valverde para poner muy alta la ciencia médica española de los tiempos inquisitoriales.

Humanistas. No se interrumpe la serie en todo el siglo xvI. Si el Sr. Del Perojo quiere saber algunos nombres, vaya a mis Cartas polémicas. Entretanto, le citaré sólo a Antonio de Nebrija, Juan de Vergara, Fernán-Núñez Pinciano, Lorenzo Balbo, Arias Barbosa, Andrés Resende, Pero Juan Núñez, Antonio Agustín, Alvar Gómez de Castro, Juan de Verzosa, Antonio Lull, Alfonso García Matamoros, Aquiles Estaço, Francisco Sánchez de las Brozas, Juan Luis de la Cerda, Vicente Mariner... y mil más, cuantos quiera, que no me duelen prendas en el asunto y estoy dispuesto a darle un compendio de la vida y milagros de cada uno.

Crítica histórica. Sienta las bases Juan de Vergara. Continúan su obra Fox Morcillo, el aragonés Costa, Ambrosio de Morales, Luis Cabrera, Fr. Jerónimo de San José. Esta ciencia sólo llega a cumplida sazón a fines del siglo XVII, como a su tiempo veremos. En cuanto a lo que hoy llaman filosofía de la historia, uno de cuyos fundadores, juntamente con San Agustín,

697 Y más recientemente, A. de Giorgi, profesor de la Universidad de Parma, en su libro Della vita e delle opere di Alberico Gentili (1876), dice de Francisco de Vitoria que "se le debe saludar como verdadero padre de la ciencia del Derecho Internacional». (Tercera edición) 
fue nuestro Orosio, algo y aun mucho puede aprenderse en el admirable prólogo de Fr. José de Sigüenza a su Vida de San Jerónimo.

Nada digo de otras ciencias como la Estética, cuya Historia en España trazaré en su día con la mayor copia de datos que me sea posible, no siendo pocos los que ya tengo recogidos.

Literatura. Es excusado hablar de ella, porque nadie niega su prodigioso desarrollo a pesar de la Inquisición; antes bien, el Sr. Revilla la considera como válvula abierta a las expansiones del genio nacional. Sólo diré que en ese siglo nace y se acrisola la prosa didáctica, se perfecciona la histórica, llega la poesía lírica a su mayor auge con Fr. Luis de León y Herrera, obtiene inusitado cultivo en variadas formas la novela, y crece y se agiganta por días el teatro, a pesar de las trabas que alguna vez le opuso la Inquisición, prohibiendo tal cual obra demasiado liviana. Los nombres de este período no hay para qué recordarlos. Debe saberlos todo el que ha mamado leche castellana.

De las ciencias exactas y naturales hablaré después.

Si a todo esto se agrega el progreso de las artes plásticas y de la música, así en la práctica como en la teoría; item más, dos o tres invenciones, de distintos géneros, tan benéficas como ingeniosas, tendremos casi completa la herencia intelectual del siglo de oro, herencia bastante para que la contemplemos y traigamos a la memoria con legítimo orgullo, en contraposición a la miseria y bajeza de los tiempos presentes.

Todo esto produjo España bajo el dominio de la Inquisición en el tercer siglo de su existencia. Todo esto, y además capitanes de la talla de D. Hernando Dávalos, Antonio de Leiva y el duque de Alba; marinos como D. Alvaro de Bazán; embajadores al estilo de Vargas y de D. Diego de Mendoza, y navegantes y conquistadores de regiones incógnitas, a quienes los griegos hubieran puesto en el número de sus semidioses.

Ésta fue España desde el 1500 al 1599. ¿Qué importa que en ocasiones decayese una rama de la actividad, cuando al propio tiempo surgía otra lozanísima y pujante? Todo no se da en un día, ni maduran todos los frutos al mismo tiempo.

En el último tercio, y sólo en el último tercio de este siglo, tercero ya de dominio inquisitorial, es cuando aparece en Inglaterra la filosofía de Bacon, que ni era gran novedad ni tuvo mucho séquito por entonces. ¿Qué digo en el último tercio de aquel siglo? Sólo a principios del XvII, en 1605. La primera edición del tratado De dignitate et augmentis scientiarum fue en inglés, como es sabido, y apenas la leyó nadie fuera de Inglaterra. A los diez y ocho años apareció una traducción latina, obra de varias manos, corregido por Bacon, que refundió y aumentó considerablemente su trabajo, dividiéndole 
en nueve libros, cuando antes tenía dos tan sólo. El Novum Organum no se imprimió hasta el año 1620.

Con esto empezó a ser conocido en Europa el nombre de Bacon, y no fueron los espańoles los últimos en tener noticia de sus obras. La Inquisición no las prohibió nunca. Conste, de todas suertes, que, lejos de haber sido contemporáneos el predominio de la Inquisición y el de la filosofía baconiana, fue anterior la primera en tres siglos a Bacon, en tres siglos y medio a Hobbes y a Locke, en cuatro siglos y medio a Berkeley y a Hume. La época baconiana por excelencia fue el siglo XviII, en que el poder de la Inquisición estaba completamente anulado.

La filosofía de Descartes vino cerca de medio siglo después de la de Bacon. Su desarrollo llena la segunda mitad del siglo xvir. Malebranche, Espinosa, Leibnitz, son todos de este tiempo.

Volvamos ahora la hoja, y veamos lo que entretanto sucedía en España.

Muchos consideran el siglo XVII como ominoso y de fatal recordación. A decir verdad, es decadente respecto del anterior; pero no en todo ni por las causas que generalmente se señalan. Investigar el modo y ocasión de esta decadencia, no es muy fácil. Los críticos de la Revista Contemporánea lo resuelven a las mil maravillas con el Deus ex machina consabido; pero está probado hasta la saciedad:

$1^{\circ}$. Que en los tres siglos anteriores, la Inquisición no había estorbado el progreso de los estudios, aunque harto tiempo tuvo a su disposición para hacerlo.

$2^{\circ}$. Que en este siglo la intolerancia fue menor, mucho menor que en los anteriores.

Y la cosa es clara: en el siglo Xvi encontramos algún proceso de gente docta, aunque generalmente con resultado favorable a los procesados; el único escritor del siglo XVII ${ }^{698}$ encausado por la Inquisición (que yo recuerde) fue el P. Froilán Díaz autor de un Curso filosófico que corrió con algún aplauso. Pero el motivo de la causa (que por cierto pertenece ya al siglo XviII) no fue su filosofía, que es harto mediana, sino una intriga política de funesta recordación. En el siglo XVI se quemaba a los protestantes; en el siglo XVII, en los tiempos de Carlos II, a Jaime Salgado, fraile apóstata, que en Inglaterra había abjurado públicamente el Catolicismo, se le mandó por toda penitencia a reclusión en un convento de su Orden. No fue mucho mayor la pena que se impuso al famoso jesuita Juan Bautista Poza, aunque (si hemos de creer a su acusador, Juan del Espino) estaba convicto de herejías enormes. Las listas de los autos de fe en esta época no contie-

698 Ahora hay que añadir al poeta D. Esteban Manuel de Villegas, sobre cuyo proceso ha dado tan curiosas noticias el Sr. Cánovas en la carta que va al final de mis Heterodoxos. (Tercera edición) 
nen más que nombres oscuros de judaizantes, apóstatas o sacrílegos, de sacerdotes concubinarios, de bígamos, etc.; ni uno solo de pensadores, ni de filósofos, ni de copleros, ni de autores de artes de cocina. Nada, absolutamente nada. ¿Era porque no había hombres de ciencia a quienes quemar? Eso lo veremos luego. En el siglo XVI se prohibieron muchos libros; en el XVII, relativamente muy pocos. Llega una época en que los indices expurgatorios no son más que reimpresiones. Ergo, las causas de la decadencia hay que buscarlas por otro camino.

No es posible que una causa sola haya producido efectos contradictorios. $Y$ contradicción perpetua e inexplicable debe de ser la historia española del siglo XVII para quien con ese criterio parcial y errado la examine. En esa centuria descendió España del apogeo de su gloria militar y política, por la causa que señalé a su tiempo, y además por los sucesivos desaciertos de gobernantes y consejeros, de todo lo cual la misma culpa cabe a la Inquisición que al moro Muza. La Inquisición no era Lerma, ni Uceda, ni Olivares, ni el hijo de la Calderona. A fines del siglo XvıI podía notarse un espantoso descenso de población respecto al tiempo de los Reyes Católicos, descenso producido, no por una causa, sino por muchas, casi todas inevitables: primera, la expulsión de los judíos, medida política que vino a salvar a aquella desdichada raza del continuo y feroz amago de los tumultos populares, que era imposible contener, como lo demostraban recientes casos en la mayor parte de las ciudades de España; segunda, la colonización del Nuevo Mundo, en el cual sembramos a manos llenas religión, ciencia y sangre, para recoger más tarde larga cosecha de ingratitudes y deslealtades; tercera, las guerras incesantes de dos siglos, y en veinte partes a la vez; cuarta, la expulsión de los moriscos, providencia necesaria para salvar de peligros muy ciertos y muy graves la unidad y la integridad nacionales; quinta, el excesivo número de religiosos de ambos sexos. Contra este exceso, nacido de intenciones muy piadosas y muy respetables, clamaron repetidamente nuestros economistas y clamó el Consejo de Castilla en su célebre Consulta; pero no fue posible atajarle, porque el espíritu de la época iba decididamente por ahí. A, consecuencia de la expulsión de los judíos había bajado considerablemente la balanza del comercio en nuestras ciudades marítimas; el comercio de Levante, que ya no tenía la importancia que en la Edad Media, lo monopolizaron los venecianos; el de América que podía ser fuente inagotable de riqueza, lo monopolizamos nosotros; pero lo hicimos pésimamente, gracias a los errados principios económicos y a la impericia de nuestros gobernantes. Caído el comercio, cayó la industria, ni había brazos para ella, porque lo esencial entonces (lo digo de todas veras) no era, tejer lienzo, sino matar herejes. ${ }^{69}$

699 Tómese esto por expresión desenfadada y extremosa. Más cristiano es trabajar y no matar a nadie. Lo cual no es condenar la licitud de las guerras por causa de religión, ni dejar de comprender su razón histórica. (Tercera edición) 
Por todas las causas hasta aquí indicadas, y además por la expulsión de los moriscos, grandes cultivadores del suelo, quedó atrasada la agricultura. Y llegamos a fines del siglo XVII con la población disminuida, sin agricultura, sin industria y sin comercio. Pero, en cambio, habíamos sido el único pueblo de Europa que mantuvo intacta su conciencia religiosa y su conciencia histórica en la época de la pseudo-Reforma; habíamos permanecido fieles al espíritu de nuestra civilización en todo y por todo; éramos tan cristianos y tan españoles en 1699 como en 1492; habíamos regalado a la civilización un mundo. Total nos habíamos desangrado por la religión, por la cultura, por la patria. No debíamos ni debemos arrepentirnos de lo hecho. Por eso, ni V. ni yo renegamos de nuestros abuelos, sino que los admiramos en sus grandezas y los compadecemos en sus desdichas. Pero hay que tener sangre española en las venas para sentir y entender esto. Los Perojos, Revillas y compañía, ni hablan nuestra lengua, ni son de nuestra raza.

¿Fue en lo científico y artístico siglo de decadencia el xvir? En unas cosas sí, en otras no. Por lo que hace al arte, no, en el primer período; sí, en el segundo. Las maravillas de nuestras escuelas pictóricas pertenecen casi todas a ese siglo. Por lo que hace a la literatura, si, en cuanto a la prosa y a la poesía lírica; no, en cuanto al teatro, cuya época de oro es el siglo XVII. Por lo que hace a la ciencia, si, en cuanto a la teología, que se sostiene con honra sin embargo; no, en cuanto al derecho, que produce aún los Ramos del Manzano y los Fernández de Retes. Sí, en cuanto a la mistica, cuya decadencia es manifiesta, aunque gloriosa, como que la cierran Sor María de Agreda y el P. Nieremberg. No, en cuanto a la crítica histórica, que cabalmente toca a su apogeo en los tiempos de Carlos II, fenómeno que sin duda sorprenderá al Sr. Del Perojo, pero que a mí no me sorprende, porque es ley de la humanidad que cuando unos estudios suban, otros bajen. La crítica histórica en España había nacido muy a principios del siglo xvi con Vergara, que trituró y desmenuzó con segura mano las ficciones de Anio Viterbiense. A Vergara siguió considerable grey de escritores que se afanaron en trazar, cada cual a su manera, los principios del arte histórico. Zurita los llevó a la práctica con tal éxito, que aún hoy asombra. Vino en seguida Ambrosio de Morales para constituir un verdadero aparato científico a la Historia de España, aplicando la numismática, la epigrafía, la diplomática, cuantas ciencias auxiliares halló a mano. Al lado de esta corriente crítica había existido, durante todo el siglo XVI, otra manera infantil y candorosa de escribir la historia, representada por cronistas generales, como Ocampo, y más aún por los crédulos biógrafos, historiadores de ciudades, etc. De ambas partes la elaboración era inmensa. Llega el siglo xvII, y se inaugura con una serie 
estupenda de falsificaciones, que a muchos escandalizan y asustan. Esos falsos cronicones son, como si dijéramos, los estudios prehistóricos de aquel tiempo, una tentativa para poner historia donde no la hay. Mas precisamente de esa tentativa escandalosa nace una reacción, que ha de levantar nuestra crítica histórica al más alto punto. Los primeros intérpretes de ese movimiento son Pedro de Valencia en su fulminante informe sobre el pergamino de la Alcazaba, y el insigne obispo de Segorbe, D. Juan Bautista Pérez. Crece la ola de las falsificaciones, y cuando parece haberlo inundado todo, surgen de un golpe, y se reúnen por instinto común, allá en los calamitosos tiempos de Carlos II, que muchos recuerdan con rubor, cinco o seis eruditos de tal calidad, que, para encontrarlos iguales, no mayores, hay que venir hasta el P. Flórez. Fueron (conviene no olvidarlo) Fr. Hermenegildo de San Pablo, D. Gaspar Ibáñez de Segovia, marqués de Mondéjar, D. Juan Lucas Cortés, D. Nicolás Antonio, el cardenal Sáenz de Aguirre y el futuro deán de Alicante Manuel Martí. Y no fueron ellos solos; pero en estos seis nombres, a los cuales puede agregarse el de Pellicer, después de su conversión, se cifran y compendian las grandezas críticas de este período. Lo que esos hombres hicieron no hay necesidad de recordarlo; que no habrá erudito (si es español) que lo ignore. Sus obras se llaman la Collectio Maxima Conciliorum Hispaniae, la Bibliotheca Hispana, la Censura de Historias Fabulosas, la Bibliotheca Genealógico-Heráldica, la Themis Hispana, las Disertaciones Eclesiásticas, la Era Española, las Memorias de Alfonso VIII y de Alfonso el Sabio, la Disertación sobre el teatro de Sagunto... ; en una palabra, el desbrozamiento de toda maleza, la luz llevada a todos los senos de nuestra historia política y eclesiástica, de nuestra cronología, de nuestra arqueología, de nuestra bibliografía, de nuestra jurisprudencia. ¿Va comprendiendo el Sr. Perojo que no andaban en cuatro pies los hombres del tiempo de Carlos II? ¿Se convence de que no éramos una nación de frailes, de beatas y de mendigos? ¿O es que no hay más estudios útiles que la astronomía y las matemáticas? Pero hay más, y es preciso decirlo. La raza de los humanistas no se había extinguido. La prosa y versos latinos del deán Martí son un portento de pureza y de elegancia. Otro tanto acontece con los de su amigo Fr. Juan Interián de Ayala. Uno y otro hacían, además, con primor, versos griegos. Hoy nos extasiamos con las dos odas anacreónticas que forjó Leopardi; pero ciertamente que no superan, ni poética ni filológicamente, a una tentativa exactamente igual hecha por el P. Ayala. El deán Martí tradujo en dísticos griegos gran número de epigramas de Marcial; y, a lo que yo alcanzo, estas versiones, por lo poéticas y por lo concisas, son de gran precio. Otro famoso humanista, amigo de los anteriores, fue el trinitario Fr. Manuel Miñana, elegantísimo historiador en 
prosa latina. Estos tres escritores alcanzaron al siglo XVIII, pero se educaron y formaron y escribieron sus principales obras en los últimos años del xviI, es decir, en el ominoso período de marras.

Niegue el Sr. Perojo todos estos hechos, si le place. Niegue que en 1698 teníamos un matemático como Hugo de Omerique, a quien no se desdeñó de estudiar y de elogiar Newton. ${ }^{700}$ Niegue que por entonces se

700 Del libro de Omerique (de quien dice el Sr. Perojo que la Inquisición no le pudo alcanzar, ignoramos por qué causa, puesto que bien a su alcance le tuvo en Sanlúcar de Barrameda, donde vivía, y en Cádiz, donde imprimió su Analysis, bajo la protección de los Padres de la Companía de Jesús, que le ponen en las nubes en una serie de cartas que anteceden al libro) juzga así persona tan competente en ciencias matemáticas como el Sr. D. Lucio del Valle, cuyo nombre no se olvidará fácilmente en nuestra famosa Escuela de Caminos:

«España (dice Montucla) ha tenido hacia fines del siglo XvII un analista geómetra que mereció consideración y alabanzas de Newton, a saber: Hugo de Omerique. Su objeto era, en la obra que a este fin publicó, unir el análisis algebraico moderno con el de los antiguos, y de este modo deduce, en efecto, soluciones elegantes y sencillas para gran número de problemas... La obra a que Montucla se refiere, tiene este título: Analysis Geometrica, sive nova et vera methodus resolvendi tam problemata geometrica quam arithmeticas quaestiones. Pars I. de Planis. Gadibus typis Christophori de Requena, 1698.

„El método empleado por Omerique es el analítico, aplicado ya por los griegos y los árabes: suponer el problema resuelto, establecer relaciones entre los datos y las incógnitas, y deducir de dichas relaciones el valor de las cantidades o magnitudes desconocidas, es la verdadera esencia de dicho método; pero hay dos circunstancias que dan valor a la obra del geómetra sanlucarense.

"Es la primera la unidad, la completa y admirable unidad que a toda ella preside: no es una serie de problemas geométricos resueltos por artificios más o menos ingeniosos; es un método general, cuya potencia, por decirlo así, se pone a prueba por una serie de ejemplos o casos particulares.

"A más de esta primera circunstancia, hay otra digna de tenerse en cuenta, al apreciar la importancia científica de este notable libro. El método empleado por Omerique es una combinación del análisis algebraico y geométrico, lo cual constituye algo grandemente parecido a lo que en la ciencia moderna se llama aplicación del Álgebra a la Geometría. ¿Quién sabe si en otro siglo y con otros estímulos hubiera sido Omerique el Descartes de nuestra Espańa?

„Las relaciones algebraicas que emplea, son casi siempre proporciones que compone y transforma con gran sagacidad e ingenio, hasta llegar a una en que no entra más que un término desconocido.

Quizá hoy parezcan sobradamente sencillos los problemas que Omerique resuelve; pero téngase presente el estado de la ciencia en aquel siglo, los adelantos que de entonces acá ha hecho el álgebra, la potencia de los nuevos métodos, y se comprenderá el mérito de la idea que el geómetra español desarrolla.

»Nótese, además, que el libro de Omerique es la primera parte de una obra cuya continuación, según el autor, hubiera comprendido cuestiones de un orden más elevado, y que aun en las publicadas se nota una gran facultad de abstracción y generalización, una 
establecía en Sevilla una Academia de Medicina y Física experimental. ${ }^{701}$ Diga que fue broza todo lo que he citado, que dispuesto estoy a probarle que no ha hecho más ni quizá tanto la España del siglo xIx con todas sus iluminaciones y grandezas. Otros estudios decayeron, pero no hasta el punto de desaparecer en un día. El último fulgor de los estudios orientales fue la brillante controversia de Pedro de Valencia y del Padre Andrés de León. El último hebraizante ilustre es Trilles, que no encuentra sucesor digno hasta mediados del siglo xviıI, en Pérez Bayer.

A muchos les extrañará el oír que todavía se cultivaba la estética en los últimos ańos de la fatal centuria. Y, sin embargo, entonces vieron la luz dos tratados de no poco precio, el Discurso de la hermosura y del amor, del conde de Rebolledo, y el libro De la hermosura de Dios, del P. Nieremberg, fieles entrambos a la gran tradición platónica de los León Hebreo, los Cristóbal de

gran tendencia a enlazar la aritmética, el álgebra y la geometría, ya sirviéndose del análisis para resolver cuestiones geométricas, ya dando a problemas aritméticos representación gráfica, propia y adecuada casi siempre.»

(Discurso de contestación al de D. José Echegaray en la Real Academia de Ciencias Exactas, Físicas y Naturales, 1866.)

El mismo Sr. Echegaray, que tan pobre idea tiene de nuestros antiguos matemáticos, hace una excepción en favor del verdadero y profundo talento de Hugo de Omerique, que mereció, igloria envidiable!, las alabanzas del gran Newton. (Pág. 21 de su discurso.)

El libro de Omerique, no obstante su fecha relativamente moderna, es de singular rareza. Poseo un ejemplar en mi colección de libros de Ciencia Española.

Lo mismo el autor que sus aprobantes los PP. Kresa, Cañas y Powell se muestran muy enterados de los trabajos de Viète, Descartes y Schooten. Dice, por ejemplo, el P. Cańas, profesor de Matemáticas en el colegio de Cádiz. Geometricam Analysim hucusque in cassum plurimis e nobilissimis hujus aetatis ingeniis tentavere, in quibus palmam sibi praeripere autsi sunt Viète, Descartes, Schooten symbolis quibusdam adjuti latentis quantitatis et obvolutae speciem et imaginem subobscure repraesentantibus... Nunquam tamen Geometrica demonstratione (licet de iis concinnandis eruditum ediderit tractatam Schooten) viam quam monstrarunt utcumque sternere potuere. Inerat ea vis Euclidianis elementis, abdita tamen et incomperta, ut in magnete verticitas, quam non casu aliquo, uti de magnete perhibetur, sed acri et pene divino ingenio, nec minus indefesso studio primitus detectam novo isto conatu a lucidissimo et eximio viro D. Antonio Hugone de Omerique.

Ninguno de los que han hablado de Omerique cita otro libro suyo que la Analysis Geometrica. Pero yo tengo además unas Tablas Artificiales o séanse Tablas de Logaritmos, con aplicación al Comercio de las Barras de Plata, que publicó en 1691 (Cádiz, Imp. del Colegio de la Compañía de Jesús).

Lo que no he podido adquirir es ninguna noticia biográfica de este ilustre matemático, a quien no alcanza la Biblioteca de Nicolás Antonio. Sirvan estos apuntes para despertar el celo y la curiosidad de los eruditos de Cádiz y de Sanlúcar. (Tercera edición)

701 Esta sociedad se estableció en 1697, y Carlos II la aprobó por Real cédula de 25 de mayo de 1700. Sus trabajos, completamente experimentales, llenan doce tomos, publicados en distintos tiempos. (Tercera edición) 
Fonseca, los Malón de Chaide y los Calvi. Luego, tampoco se interrumpió la historia de la ciencia en este punto.

¿Y no tuvo filósofos y pensadores el siglo xvir? Sí que los tuvo, y muy notables. Tuvo al sapientísimo Pedro de Valencia, que, en su áureo libro De judicio erga verum, mostró decidida tendencia al escepticismo de Sexto Empírico. Tuvo al infatigable peripatético Vicente Mariner, que dotó a la lengua castellana de una traducción completa, fiel y esmeradísima de Aristóteles. Tuvo a Isaac Cardoso, propugnador eximio del atomismo gassendista, que enlazó con precedentes peninsulares. Tuvo al obispo Caramuel, uno de esos portentos de sabiduría y de fecundidad que abruman y confunden el pobre entendimiento humano. Este hombre extraordinario proclamaba y seguía el libre examen filosófico, y estaba muy al tanto de todas las doctrinas cartesianas, gassendistas, etc., de entonces, doctrinas que discute, sin adoptarlas a tontas y a locas, como hacemos hoy con cualquier sistema extranjero $^{702}$. Tuvo a Uriel de Acosta, fogoso materialista, y a David Nieto, panteísta decidido en el tratado De la naturaleza naturante, y a Molinos, partidario de la aniquilación y del nirwana. ¿Ha leído el Sr. Del Perojo la Guia Espiritual? Pues léala, y verá que aquel hereje no era ningún sacristán de monjas, y que su doctrina tiene más intríngulis de lo que parece, como que ahora mismo renace en Inglaterra, y tiene muchas analogías con el pesimismo moderno ${ }^{703}$. Tuvo además el siglo XvII moralistas como Quevedo y Gracián, políticos como Saavedra, Hernández Navarrete y bastantes más, porque, como arreciaban los males de la monarquía, pululaban los arbitrios y los remedios, sin que faltasen economistas como Struzzi y Dormer que solicitasen la libertad de comercio. ${ }^{704}$

702 Son dignos de leerse los párrafos que dedica a Caramuel Brucker en su Historia Critica Philosophiae (Leipzig, 1743, tomo IV, parte 1a, páginas 132 a 135). Le llama hombre de singular ingenio, le atribuye peregrinos estudios en las lenguas orientales, incluso el chino, y le considera como un innovador enciclopédico, autor de una nueva escolástica. En su Mathesis Audax se propuso resolver por método geométrico todas las controversias lógicas, físicas y matemáticas. Proclamó audazmente la libertad filosófica: Tandem iterum excussimus servile jugum, et veritatem unam potius hodie quam totum Peripatum curavimus. Respecto de Descartes, vaticinó que, «quitadas o alteradas muy pocas opiniones suyas, las demás triunfarían y llegarían a ser comunes». (Pauculis opinionibus decircinatis aut sublatis, ceteras irrepere et fore aliquando communes). Brucker transcribe la extraña clasificación que Caramuel hizo de las ciencias filosóficas. (Tercera edición)

703 Véanse los libros de J. Henry Shorthouse, especialmente su novela John Inglesant, y sus Golden Thoughts from the spiritual Guide of Miguel Molinos (Glasgow, 1883). (Tercera edición)

704 Dice el Dr. D. Diego Josef Dormer en los Discursos histórico-políticos que en 1684 dirigió a las Cortes de Aragón, congregadas por Carlos II: 
Todo esto, más la pintura, la crítica histórica y el teatro, nos dejó en herencia el cuarto y más calamitoso de los siglos inquisitoriales.

«Estando prohibidas las mercaderías extranjeras, se quita necesariamente la ocasión y el medio para el despacho de los frutos y cosas propias, pues el que trae lo uno, lleva lo otro, consistiendo en esto el arte del mercader. Y últimamente se ha de reparar que la prohibición no sirve, como se tiene experiencia, sino para que se vendan más caras las mercaderías y de menos provecho, porque la misma dificultad de ellas hace que no haya elección y que se deseen y soliciten más, y a su interés se añade el de los mercaderes y de los que los cubren, que todo lo reclama el mercader; y la generalidad no saca fruto alguno, sino muchísimo daño, por cargar en otras cosas lo que se excusan en esto por ocasión de haberlo prohibido.»

Alberto Struzzi, en su Diálogo sobre el Comercio de estos reinos de Castilla (1624), sostiene que por ley natural el comercio es libre; que siendo las tierras de diversas disposiciones, es necesaria la permuta de las cosas; que la libertad del tráfico procura la abundancia y baratura de los frutos y artefactos; que la prohibición de las mercaderías necesarias es perjudicial; que la naturaleza del comercio lleva consigo la compensación de las mercaderías que salen del reino; que empeñarse en matar el contrabando es querer poner puertas al campo; que el oro y la plata de España no deben quedar en ella, porque si no, dejaría de haber comercio y alcabalas para S. M.; que no entrando las mejores obras del extranjero, los naturales no podrán imitarlas; que no bastando nuestras fábricas a surtir los mercados de Indias, excluir las mercaderías extranjeras sería privarnos de la mitad del oro y la plata que viene de aquellas partes, o dar lugar a que los extranjeros las llevasen directamente. «El decir prohíbanse las mercaderías, es cosa fácil, mas la ejecución es muy dificultosa.»

(Colmeiro.- Biblioteca de economistas españoles, en el tomo I de las Memorias de la Academia de Ciencias Morales y Políticas, pág. 195.)

Véase cómo hasta los libre-cambistas pueden encontrar precedentes en nuestra ciencia tradicional, aunque el Sr. Orti y Lara, que es casi tan forastero en ella como los krausistas, pretendió probar un día que la doctrina económica del libre-cambio era novedad pésima de estos tiempos y contraria al espíritu del catolicismo. No pensaban así los inquisidores del siglo XVII, que dejaron correr con aprobación de estos y otros libros nada proteccionistas.

Otro arbitrista del mismo tiempo, autor de una obra manuscrita intitulada Arcanos de la dominación, que ha desenterrado el Sr. Cánovas, establece claramente el principio o ley de población, que ha dado tanta celebridad a Malthus: «No puede la tierra suplir a la propagación humana, que continuamente se va multiplicando. Conque, siendo de naturaleza contraria estas dos producciones, no obstante que dependen la una de la otra, es constante que ésta y aquélla buscan en vano su remedio, quedando sujetas a los siniestros accidentes que cada día se encuentran. Y para dar más luz a esta verdad, conviene saber cuánta es la superficie de la tierra, supuesto que siempre el número de los vivientes excede a su capacidad y a la cantidad de alimentos que puede producir, sin duda ninguna será violenta la curación de su mal, no pudiendo repararse sino por medio de la hambre, de la peste o de la guerra.»

Prosigue diciendo el autor anónimo, que «la tierra, en menos de cuatro siglos, estará mucho más poblada de lo que puede sustentar», y recomienda, entre otros remedios, más o menos humanos, el celibato eclesiástico y aun el mero celibato, la limitación de los matrimonios, la exclusión de los casados de los destinos públicos, etc., etc.

Como se ve, el sistema de Malthus está completo en el anónimo, sin que falte siquiera el principio de la coacción moral.

(Vid. Cánovas, Problemas Contemporáneos, tomo I, páginas 329 a 360). (Tercera edición) 
El quinto, o sea, el XVIII, nada tiene de inquisitorial, y, por lo tanto, es excusado hablar de él. Religiosa y políticamente, la dinastía francesa nos trajo grandísimas calamidades: el jansenismo y el enciclopedismo; la centralización y el cesarismo administrativo, manifestados con hechos brutales, e inconcebibles casi, como la expulsión de los Jesuitas; la ruina completa de nuestras libertades provinciales que, a lo menos en la forma, habían respetado mucho más los reyes austríacos. Torcióse completamente el espíritu de la civilización española, torcimiento que dura aún por desgracia; no se combatió ya por el Catolicismo, sino por el pacto de familia; mudó de carácter la literatura; alteróse radicalmente la lengua. El Santo Oficio, una de nuestras más españolas y castizas instituciones, siguió la universal decadencia.

Su último acto de energía fue el proceso de Macanaz. Después, regalistas y jansenistas le oprimen, le anulan y le convierten en instrumento. De otra suerte, ‘se conciben siquiera los infinitos atropellos contra la Iglesia cometidos por los Consejeros de Carlos III? Cuando hombres como Aranda y Roda podían con un decreto deportar Órdenes religiosas, llamar a juicio Obispos, anular fundaciones pías, ¿qué podía ser la Inquisición sino un nombre y una sombra? ¿Qué podía ser allá a los fines del siglo, cuando eran inquisidores Arce, Llorente y Villanueva? No se hable, pues, de la Inquisición del siglo XVIII, porque se reirán hasta las piedras.

Por fortuna, como la nación no estaba reducida a sus ministros, continuó su desarrollo literario y científico, que fue notable, aunque no tan español ni tan influyente como el de tiempos anteriores. Pero en muchas ciencias hubo evidente progreso, y otras renacieron, sin contar una, y es la filología, en que nos pusimos a la cabeza del mundo con Hervás y Panduro. ¡Lástima que la Espańa del siglo XIX no haya recogido la tradición gloriosa de aquel jesuita, y que alemanes y rusos sean los que hayan venido a continuarla! Y eso que no ha habido Inquisición en más de cincuenta años. Pero la había cuando se imprimió el Catálogo de las lenguas. ¿Si tendremos que convenir en que la Inquisición era un gran medio para purificar la atmósfera y avivar los ingenios?

Ya lo ve V.; con el simple objeto de poner en claro la cronología inquisitorial, embrollada de propósito por los adversarios he tenido que tocar un poco de todo, lo cual no me pesa, porque así quedan sentadas las bases históricas que nos han de servir para resolver la cuestión magna. Ésta es la de la filosofía; pero como esta carta se va prolongando con exceso, y no es cosa, de atropellar en cuatro líneas punto de tanta entidad, prefiero guardarle íntegro para una tercera epístola. Así como así, el engendro del Sr. Perojo es tan clavadito y tan mono, que lo mismo da cogerle por los pies que por 
el cogote. Salto, pues, provisionalmente, a la página 348, y sección cuarta, en que nuestro sabio comienza a hablar de las ciencias exactas y naturales.

Acostumbraban los malos predicadores de la época gerundiana, cuando les faltaba verdadero asunto o no sabían desarrollarle, acudir a ciertos registros o almacenes llamados Polianteas y Teatros de la vida humana. En tales fuentes hacían acopio de una erudición indigesta, que propinaban luego, pegara bien o no, a sus cristianos oyentes. Por lo visto, el Sr. Perojo topó en Heidelberg con algún discípulo de estos predicadores, que le enseñó a las mil maravillas el susodicho método. Para escribir su kilométrico artículo, sepultase en alguna de esas Polianteas modernas que se llaman enciclopedias y diccionarios, se atarugó bien de vulgaridades y noticias de segunda mano, y las aderezó luego en forma de execrable almodrote. Con lo cual pensó haber puesto una pica en Flandes, y es seguro que dijo para sí: «QQué fácilmente se hace uno erudito en este siglo de las luces!». Ahora bien, todo ese castillo de naipes se viene a tierra con una observación sencillísima. No hay, no ha habido ni habrá en la tierra pueblo que en una misma época presente en igual grado de desarrollo todas las ramas del árbol de la cultura. Ni los griegos mismos, privilegiados dentro de la humanidad, consiguieron eso. ¿Cuándo florecen las ciencias naturales en Grecia? En tiempo de Aristóteles y de Teofrastro, es decir, en tiempos de decadencia literaria, cuando a los oradores empezaban a sustituir los retóricos semejantes a Demetrio Falereo, cuando la tragedia agonizaba, cuando a la vigorosa comedia antigua había sustituido la prosaica y burguesa (como ahora dicen) comedia nueva. ¿Cuándo florecen las matemáticas? En tiempo de Arquímedes y de Euclides, es decir, en tiempo de una decadencia todavía más general y señalada desde la época alejandrina hasta la romana inclusive. Pues vamos a las naciones modernas.

La literatura alemana de los siglos XVI y XVII, ${ }^{705}$ por lo que de ella alcanzamos con hastío y con asco los meridionales, o no existe, o es barbarie pura o pedantería insufrible. El Sr. Perojo habrá aprendido en Heidelberg a

705 No hablo de la de la Edad Media, que tiene altísimo mérito, bastante más que la de la época de la Reforma (Segunda Edición), de la cual puede decirse que empezó por matar la literatura alemana, que no renace hasta fines del siglo XVIII. ¿Qué cosa hay en la poesía alemana de los siglos XVI y XVII, que de cerca ni de lejos emule a la gigantesca creación épica de los Niebelungen, o a las obras de Wolfram de Eschenbach, de Gotfrido de Strasburgo, de Gualtero de la Vogelweide? Este mérito negativo de la Reforma es uno de los que suelen dejar en la sombra sus panegiristas. ¡Valiente movimiento de civilización el que acelera la ruina de la arquitectura, rebaja la escultura y la pintura del noble oficio de expresar el ideal religioso, al trivial y mezquino de expresar sin poesía y sin ideal la vida doméstica, y condena a doscientos ańos de esterilidad literaria a una de las razas de Europa más activas, poéticas e inteligentes! (Añadido de la tercera edición) 
entusiasmarse con esos poetas tudescos; pero a los que en esos dos siglos produjimos Ariostos y Tassos, Cervantes y Calderones, Shakespeares y Míltones, Corneilles y Racines, nos crispa los nervios toda esa literatura hiperbórea. Total, que para llegar los alemanes al punto a que han llegado en este siglo, con dirección buena o mala, que esto no es del caso, han tenido que pasar por doscientos años de ignominia literaria, en que italianos, españoles, franceses e ingleses podíamos llamarles a boca llena (y se lo llamábamos) bárbaros. ¿Carecía entretanto Alemania de todo género de cultura? Nada de eso: presenta grandes nombres en ciencias naturales, en ciencias exactas, en erudición histórica, en humanidades; posee además algunos místicos...; pero en cuanto a gusto, Dios le dé. La barbarie se mascaba. Pues veamos otro punto: ¿Dónde nació Copérnico? En Polonia. ¿Qué más dio Polonia en el siglo xvı? Nada, que sepamos. ¿Cuándo florecen Galileo y Torricelli en Italia? A principios del siglo XVII, cuando decaía a todo andar el gusto literario en la península transalpina. ¿Cuándo nacen en Francia los Laplace, los Monge, los Lavoisier? En el siglo XviII, época de espantoso descenso filosófico, teológico, moral y literario. ¿¿Dónde nació Franklin? En la América inglesa. ¿Qué literatura, qué filosofía, qué crítica histórica poseían entonces aquellas colonias? Ninguna.

Y siempre lo mismo, porque es justo designio de Dios que las ciencias peregrinen de unas gentes a otras. A veces sucede que tres o cuatro o cinco de ellas se encuentran en el viaje; pero todas jamás coinciden. Y esto ha sucedido en España.

En los tiempos medios florecen aquí la astronomía y las matemáticas, que recibimos de los árabes, y que de nosotros recibió toda Europa, después que las hicimos hablar en lengua castellana. En cambio, nuestra literatura de esos tiempos es ruda e incompleta aún; nuestra teología no llega, ni por asomo, a la que tuvimos en el siglo xvi. Humanidades no podía haberlas, los estudios históricos estaban asimismo en la infancia. Por el contrario, en el siglo Xvi florecen la teología, la filosofía, la jurisprudencia, las humanidades, la medicina, la poesía lírica, la prosa, y si no decaen (porque esto no está probado), a lo menos quedan relegados a segundo término los estudios matemáticos y astronómicos. En el XVII imperan el teatro y la crítica histórica y decaen la teología y otras ciencias, decaen la poesía lírica y la prosa. En el XVIII desaparece, o poco menos, el teatro; renacen la lírica y la prosa, falta casi del todo la teología, cultívanse con empeño las ciencias naturales, prosigue su camino la crítica histórica, y nace con Hervás la filología comparada, y con Andrés la historia literaria. Y éste es el giro constante y perenne que han llevado las ciencias en nuestro suelo. Hasta podemos decir que somos 
afortunados entre todos los pueblos de la tierra; pues, más o menos, y en una época o en otra, lo hemos tenido todo. Con lo cual quedan, ipso facto, invalidadas todas las deducciones que el Sr. Del Perojo saca malamente del menor adelanto de algunas ciencias en diversas épocas, atraso reconocido por mí una porción de veces. Ahora voy a hacer algunas observaciones de pormenor sobre el fárrago perojino.

Astronomía. En ésta se detiene con particular predilección, haciendo grandes y justos encomios de la ciencia árabe y hebrea, en todo lo cual estamos conformes. ${ }^{706}$ También lo estoy en cuanto a las Tablas Alfonsinas, y

706 Pero aun en esto mismo aparece muy mal enterado, o, por mejor decir, muy atrasado de noticias. ¿Qué nos dice, por ejemplo, del madrileño Abul Cassem Moslema, escritor del siglo x, a quien llama el Dr. Leclerc, en su reciente y eruditísima Historia de la Medicina Árabe, el primer gran nombre de la España sabia», célebre, no sólo por sus comentarios sobre el Almagesto de Tolomeo y las tablas de Albategni, y por su libro del Astrolabio, sino por haber fundado en Córdoba una escuela, que tuvo numerosos y muy ilustres discípulos? Moslema era, no solamente matemático y astrónomo, sino alquimista, zoólogo, mineralogista, y, en suma, un hombre enciclopédico, que influyó portentosamente en el desarrollo científico de aquella edad remota. Nada nos dice tampoco de las tablas de Aben Essamej (que enseñó y murió en Granada); ni de su Introducción a las Matemáticas, ni de su tratado de la construcción y uso del astrolabio, materias en que se ejercitó también su contemporáneo Aben Essoffar, discípulo, como él, de Moslema.

Al ilustre astrónomo sevillano Alpetragio (Abu-Isaac-al-Bitrogi) le llama, no sé por qué, Alpetrarga, y omite su principal mérito, que es haberse opuesto al sistema del mundo de Tolomeo, no sólo en puntos particulares, como ya lo habían hecho el cordobés Azarquel, en cuanto al movimiento de la esfera de las estrellas fijas, y Jaber ben Afla de Sevilla, en cuanto al orden de las esferas del sol, de Venus y de Mercurio, sino atacando el fondo mismo del sistema, en sus hipótesis más esenciales, como la de los epiciclos, la de las excéntricas y la de los dos movimientos opuestos de las esferas. En esto Alpetragio era un eco de las ideas cosmológicas de nuestros filósofos Avempace, Thofail y Averroes, que siempre advirtieron gran discordancia entre las hipótesis de Tolomeo y las teorías de Aristóteles acerca del movimiento. Alpetragio, pues, trató de poner de acuerdo la astronomía con la física, excogitando un nuevo sistema del mundo, según el cual, todas las esferas siguen el movimiento e impulso de la esfera superior y vacía que está sobre la de las estrellas fijas. Todas las esferas se mueven de Oriente a Occidente; pero conforme están más lejanas de la esfera, su movimiento es menos rápido, porque reciben con menos intensidad el impulso de la esfera motriz. Esto basta para explicar su recessus aparente, sin que sea preciso atribuirles un movimiento retrógrado de Occidente a Oriente. Las diferentes esferas tienen sus polos particulares, con desviación respecto de los polos de la esfera superior: cada una de ellas, siguiendo el movimiento diurno de la esfera superior, realiza otro alrededor de su propio eje. De estos dos movimientos resulta un movimiento espiral, que produce la desviación de los astros hacia el Norte o el Mediodía. Así se explican las desigualdades que se advierten en el movimiento de los astros, sin que sea necesario recurrir a las hipótesis de las excéntricas y de los epiciclos. La obra de Alpetragio tuvo mucho crédito en la Edad Media, y fue traducida al latín en 1217 por Miguel Scoto. 
todo lo demás que luego dice. ${ }^{707}$ Hay, sin embargo, en este párrafo dos lapsus de cuantía: primero, suponer que nuestros padres, antes de la infiltración del saber semítico, no tenían otra cosa recomendable que su fe cristiana. Este es un despropósito que no merece respuesta. ${ }^{708}$ Los cristianos conservaban en cuanto a ciencia, nada menos que la tradición isidoriana y ni un momento se interrumpió durante la Edad Media el estudio de las Etimologías. En los tiempos más calamitosos, en el siglo viII y en el Ix, vive, y no sin gloria, la ciencia española. Los mozárabes cordobeses, San Eulogio, Álvaro, Sansón, Spera in Deo, conservan por su parte el tesoro de las antiguas enseñanzas. Que entre los cristianos no sometidos duraban de igual modo las ciencias teológico-filosóficas, nos lo demuestran Elipando y Félix, Heterio y San Beato de Liébana, Claudio de Turín y Prudencio Galindo. Repito que hay en el mundo algo más que astronomía. Prescindamos, por otra parte, de la

(Vide Munk, Mélanges de philosophie arabe et juive, págs 518 a 522, y Leclerc, Histoire de la médicine arabe: París, 1876.)

Nótese, y esto es importante, que Alpetragio, el astrónomo más original de todo el arabismo, era cristiano español renegado, según Casiri y Leclerc, que cita, en apoyo de esta opinión, pasajes de sus propias obras (Tercera edición)

707 Sin que esto sea menoscabar en un ápice el mérito de las empresas científicas de Alfonso el Sabio, hay que recordar siempre que en ellas había sido precedido, desde los tiempos del Emperador Alfonso VII, por la escuela de traductores de Toledo, que fundó y protegió el Arzobispo D. Raimundo. A ella pertenecía el converso del judaísmo Juan de Sevilla o Juan de Luna, que hizo conocer en Europa los Elementos de Astronomía de Alfergán (Liber de scientia astrorum et radicibus motuum coelestium), el Quadripartito y el Centiloquio de Tolomeo, la Isagoge, o Introducción de Albumazar a la Astrología, la de Alchabitio, y muchas obras del astrónomo judío Macha Allah. Con estos trabajos se enlazan los de varios extranjeros, que vinieron a España anhelosos de conocer en sus fuentes la ciencia arábigo-judaica. De ellos parece haber sido el más antiguo el llamado Plato Tiburtinus (Platón de Tívoli), traductor del Compendio de Astronomía de Albategni (De numeris stellarum et locis motuum earum), del Tetrabiblón de Tolomeo, de la Astrología de Alkassem, del libro de Aben Essoffar sobre el astrolabio, etc. Y el más célebre de todos, por lo fecundo e infatigable, fue Gerardo de Cremona, el hombre de la Edad Media que puso en circulación mayor copia de materiales científicos. Gerardo de Cremona casi pertenece a Espańa, puesto que pasó en Toledo la mayor parte de su vida, en Toledo llevó a cabo sus innumerables traducciones, que se extienden a todos los ramos de la ciencia, y forman juntas una especie de enciclopedia. Entre ellas figuran, traducidas siempre de fuente arábiga, las Esféricas de Teodosio y de Menelao, el libro de Alkindi De Adspectibus, los Rudimentos de Astronomía de Alfergán, con el título De aggregationibus stellarum; el Almagesto de Tolomeo (la más importante y la más conocida de estas versiones), el Comentario del astrónomo español Geber a dicho Almagesto, las Tablas de Azarquel, y otros muchos libros astronómicos. Entre los que siguieron sus huellas es célebre Miguel Scoto, gran privado del emperador Federico II. (Tercera edición)

708 Y si alguien lo duda, lea el extenso y magistral estudio del P. Tailhan contra Dozy, sobre las Bibliotecas Españolas del primer periodo de la Edad Media. (Tercera edición) 
opinión eruditamente sostenida por nuestro Simonet y otros orientalistas, según los cuales, mucha de la que pasa por ciencia árabe es ciencia mozárabe y de cristianos renegados, de suerte que, en vez de infiltrarse el saber árabe (que al tiempo de la conquista no era gran cosa) en el pueblo vencido, se infiltró en el pueblo vencedor la poderosa ciencia hispano-romana de la era visigótica. Alguna exageración habrá en esto, pero hay hechos que hablan muy alto. Alpetragio, por ejemplo, el más original de los astrónomos árabes, era un renegado español. Y, por otra parte, sábese muy bien hoy que Gerberto (después Silvestre II) no se educó con los árabes, como parece indicar el Sr. Perojo, sino bajo el magisterio de Ato o Athón, obispo de Vich, en Cataluña, es decir, en la parte de España que menos tiempo estuvo sometida y menos participó de la influencia sarracena, y lo que Athón le enseñó, no pudo ser otra cosa que la ciencia isidoriana, mejorada y ampliada.

El segundo lapsus es la inocente repetición de aquel cuento de viejas con que historiadores sin crítica pretendieron oscurecer el nombre de Alfonso el Sabio, cuento que han repetido otros en son de elogio. ¿Qué cronista contemporáneo del Sabio Rey asevera semejante patraña? ¿Cómo había de decir Alfonso la blasfemia que se le atribuye (es decir, que si él hubiera asistido a la creación del Mundo, éste hubiera salido mejor ordenado), él, que, lejos de ser despreocupado, o séase impío, cantaba con la devoción más pura y candorosa los loores de Nuestra Señora; él, que, como legislador, tan altos puso los derechos de la Iglesia? ¡Ah! No busquen los contemporáneos antecesores tan ilustres como Alfonso el Sabio. ${ }^{709}$

Resumen de lo que el Sr. Perojo dice en esta sección: «En astronomía fuimos los maestros de Europa». Y luego añade: «Decaímos en el siglo XVI». Y pregunta ¿por qué?, sin reparar que él ha respondido pocas líneas antes con decir: «Es difícil mantener ab aeterno esta posición, porque las ciencias no se casan con ningún pueblo, y no siempre habiamos de guiar al mundo». Pues ¿qué es esto sino lo que decimos nosotros? A todo gran desarrollo sigue inevitablemente la decadencia; y cuanto mayor es el primero, más terrible es la segunda. Todo lo cual equivale a decir que la astronomía, que había estado algunos siglos entre nosotros, se fue a visitar otros países; $y$ en cambio vinieron a nuestra casa huéspedes nuevos. Ni más ni menos.

Lo de la Inquisición (repítolo por centésima vez) es falso. La Inquisición española no persiguió a ningún astrónomo. Cíteme uno el Sr. Perojo, y le daré las gracias. Lo demás es andarse por las ramas. Nosotros no fuimos los

709 El marqués de Mondéjar, en sus Memorias Históricas de Alfonso el Sabio (página 637 y siguientes), prueba eruditamente que el inventor de esta calumnia fue el rey de Aragón, Don Pedro IV el Ceremonioso, como ya había indicado Zurita. (Tercera edición) 
que condenaron el sistema de Copérnico, hasta que vino de Roma el decreto de la Congregación Apostólica que prohibía enseñarle como tesis. Entonces hicimos lo que todo el pueblo católico: someternos. Hasta entonces la Inquisición no había tomado cartas en el asunto, y más de un español había enseñado y defendido el sistema famoso. Ahí está Diego de Estúniga en su Comentario a Job, que no me dejará mentir. ${ }^{710}$ Cuando Roma condenó el trozo de este libro que se refiere al sistema del mundo, la Inquisición (que hasta entonces le había dejado correr sin reparo) le puso en sus Índices con la frase donec corrigatur, pero advirtiendo que no era prohibición suya, sino de la Santa Sede, con lo cual ni prejuzgaba la cuestión ni hacía otra cosa que cumplir una orden superior.

No fuimos de los que perseguimos a Galileo, ni sé de dónde ha sacado el Sr. Del Perojo tan estupenda noticia. A Galileo le procesó la Inquisición romana, y si en el tribunal había algún español, no por eso diremos que a Galileo le procesó España, porque ni uno, ni dos, ni veinte españoles, y más estando fuera de su tierra, son España.

Lo que pasaba entre los españoles, de España, se lo voy a contar ahora al Sr. Perojo:

En 1574 publicaba por primera vez, y en 1581 reimprimía, Fr. Diego de Zúñiga, sus Commentaria in librum Job, donde francamente profesa la doctrina copernicana, como la más científica y la más acomodada a la letra de la Sagrada Escritura.

En 1584, el arquitecto Juan de Herrera, fundador de una Academia de Matemáticas protegida por Felipe II, hace a Cristóbal de Salazar, secretario de la embajada de Venecia, entre otros encargos de libros, el siguiente: «Si el Copérnico se hubiere traducido en vulgar, se me envie uno». La petición de

710 Diego de Zúñiga (fraile Agustino, por cierto) defiende de esta manera su tesis de que «el movimiento de la tierra no es contra la Escritura»:

"Nec dubium est quin longe melius et certius planetarum loca ex Copernici doctrina quam ex Ptolomaei magna compositione et aliorum placitis reperiantur. Certum est enim Ptolomaeum non potuisse neque aequinoctiorum motum explicare, neque ostendere certum et stabile anni principium... idque inveniendum reliquit in posterum ab astrologis iis, qui observationes maiore quam ipse intervallo distantes possent comparare. Et quamquam Alphonsini et Thebit Ben Core explicare tentarunt, nibil tamen profecisse constat; nam Alphonsinorum positiones inter se pugnant, ut probat Riccius: Thebit autem ratio, licet acutior sit, et ex ea stabile tradat anni principium, id quod Ptolomaeus desiderabat; tandem iam apparet aequinoctia longius progressa fuisse quam ipse opinabatur progredi posse. Tum sol multo propinquior esse nobis cognoscitur quam erat olim, plus quadraginta millia studiorum. Cuius motus rationem neque Ptolomaeus neque alii astrologi cognoverunt... Denique, nullus dabitur Scripturae Sanctae locus qui tam aperte dicat terram non moveri quam hic (v. 6, cap. IX, Job: "Qui commovet terram de loco suo...») moveri dicit». (Tercera edición) 
que el libro fuese en vulgar, se explica, porque era estatuto de aquella Academia el que las lecciones no fuesen en lengua latina, como destinadas que estaban principalmente para soldados y gente que no había roto bayetas en los bancos de las Universidades. Como muchos de ellos habían andado por Italia, una traducción en vulgar italiano les era tan inteligible como en lengua propia y por eso Herrera pregunta si existe.

En 1594 D. Juan de Zúńiga, del Consejo Real de la Inquisición y posteriormente Inquisidor General y Obispo de Cartagena (¡un Herodes!), al reformar, como visitador, por comisión de Felipe II, los estudios de la Universidad de Salamanca, plantea en ella una verdadera facultad de Ciencias, mandando enseñar el Arte Militar, la Náutica, la Astronomía Moderna, la Geografía, la Gnomónica, señalando, como texto para la parte astronómica, a Nicolás Copérnico, Purbach, Clavio y Regio-Montano. No se negará que este inquisidor era persona bastante ilustrada y tratable, para haber vivido en tiempos tan tenebrosos.

En 1606, Andrés de Céspedes tenía ya compuestas unas Teóricas que contienen tres partes: en la primera, las Teóricas según la doctrina de Copérnico; en la segunda se declara, según nuestras observaciones, la causa porque van errados los movimientos del sol y luna, asi en Copérnico como en el rey D. Alonso; en la tercera se dice de las estaciones de los Planetas, con un tratado de Paralaxis.

Antes de 1608, fecha en que el astrónomo castellano Suárez Argüello imprimió sus Efemérides arregladas al meridiano de Madrid, el P. Andrés de León, de los Clérigos menores, tenía corregidas las Tablas Alfonsinas, procurando ajustarlas con las observaciones de Copérnico y Tycho-Brahe, según dice el mismo Argüello.

En 1641, el matemático Francisco García Ventanas, natural de Ciudad Rodrigo, en el prólogo de sus Tabulae Alphonsinae perpetuae motuum coelestium denuo restitutae et illustratae, cita con elogio los nombres de Copérnico, Tycho-Brahe y Keplero, que «con las observaciones perficionaron el arte».

En 1673 (nótese la fecha), el Dr. Lázaro de Flores publica su tratado de Navegación astronómica, teórica y práctica, basado en las teorías de Copérnico y Tycho-Brahe.

¿A qué amontonar más testimonios?

Y a propósito de Galileo, no sé cómo el Sr. Del Perojo concebirá el desarrollo de las ciencias astronómicas en Italia, donde se procesó a copernicanos y se quemó a Giordano Bruno, que también lo era. Aquí tendría alguna probabilidad su teoría; pero los hechos la contrarrestan, porque los hechos son ultramontanos, y nos dicen a voz en cuello que Italia, perseguidora de astrónomos y matemáticos, es la patria de Maurólico, de Comandino, de 
Benedetti, de Tartaglia, de Cardano, de Cavalieri, de Galileo, de Cassini, de Mascheroni, de Lagrange y de tantos otros que apenas puede retener la memoria. ¡Y, sin embargo, se persiguió a Galileo, el más grande de todos ellos! Luego no está en la persecución la clave del misterio.

Lo demás que el Sr. Del Perojo dice de la astronomía, se reduce a una sarta de nombres de astrónomos, que empieza en Copérnico y acaba en Arago, a una declamación ridícula contra la mil veces maldita Inquisición (que sin duda le habrá dado muchos disgustos), y a algunos insultos contra Laverde y contra mí, de los cuales hago caso omiso.

Matemáticas. Otra disertación sobre la ciencia árabe, tan pedantesca e impertinente como la anterior. Mucha cita del Al-gebr wél mukabala de Alkhowarezmi, advirtiendo en una nota que almukaba significa oposición. ¿Sabe árabe el Sr. Del Perojo? Pues si no lo sabe, escriba esos títulos en cristiano, como hacemos los demás, y no se empeñe en echarnos humo a los ojos, convertido en nuevo D. Hermógenes. Y, a propósito, tampoco estaría de más (y este es aviso para él y para otros) que en la transcripción de los nombres arábigos siguiese la costumbre y la práctica de nuestros orientalistas, y no se empeñase en ponerlos a la tudesca, porque siendo ellos de suyo enrevesados y confusos, transcritos de esa manera cruda y bárbara, llegan a ser ininteligibles, a más de no haber oreja castellana que los resista. Cómo se traducen al castellano los nombres morunos, ya lo enseñó Fr. Pedro de Alcalá, y recientemente lo ha explanado mi buen amigo Eguílaz, que sabe lo que se pesca en tales cosas. ${ }^{711}$ Pero precisamente los que menos árabe saben son los que más empeño tienen en dar formas exóticas y desusadas a las palabras de aquella lengua introducidas en el habla común, para dejar a los profanos extáticos ante tal erudición aljamiada.

En cuanto a las persecuciones de cientificos y pensadores, lo de siempre: cíteme uno solo, y veremos.

Usted comprenderá bien cuán desvariada es la manera de discurrir de estos señores. La Inquisición no impidió que brotase en nuestras escuelas el congruismo, sistema teológico referente a un punto delicadísimo, el de la gracia, y esto con los protestantes a la puerta. La Inquisición no impidió que se enunciasen libremente atrevidas ideas filosóficas. La Inquisición permitió en política defender el gobierno democrático, la soberanía popular y el tiranicidio. La Inquisición permitió discutir la autoridad de la Vulgata. La Inquisición no impidió a nuestros críticos relegar al país de las quimeras multitud de

711 Vide: Estudio sobre el valor de las letras arábigas en el alfabeto castellano, y reglas de lectura... Madrid, 1874. (Tercera edición) 
Santos y de mártires, con cuyas reliquias se envanecían muchas ciudades. La Inquisición permitió atacar el mal gobierno y los errores administrativos. La Inquisición consintió todo género de licencias al teatro, a la novela y a la sátira. ¡Y habla de meterse la Inquisición con los pobrecillos matemáticos, que son la gente más inofensiva de la república de las letras! ¿Qué importa que algún fraile ignorante confundiese a los matemáticos con los astrólogos judiciarios? La Inquisición sabía distinguirlos.

Sigue otra sarta de matemáticos de las siete partidas del mundo, y como entre ellos ha tenido buen cuidado de no incluir a ningún español, el Sr. del Perojo triunfa y se recrea en su obra, y clama contra la Inquisición, que quemó a tanta buena gente, toda, ¡ya se ve!, de genio colosal. ${ }^{712}$ Y luego nos cita como autoridad excepcional en materia de bibliografía matemática al señor Echegaray. ¡Por los clavos de Cristo! ¿Cómo ni por dónde ha adquirido el Sr. Echegaray autoridad entre los bibliógrafos españoles? Podrá el Sr. Echegaray hacer llorar a diputados progresistas con el descubrimiento de la trenza incombustible, o sustituir el Catecismo del P. Astete con las nebulosas, o crispar los nervios del auditorio en dramas a lo Bouchardy, tejidos de horrores morales, apagaduras de luz, engendramientos por sorpresa, y puñalada final a modo de sangría de barbero $;^{713}$ pero, ¿cuándo se ha visto citado su

712 Y ¡asómbrese el lector!, pone a Hugo de Omerique, contemporáneo del Rey Hechizado, entre los matemáticos anteriores al establecimiento de la Inquisición, puesto que dice que ésta no le alcanzó. (Segunda edición)

713 Hoy me parece este párrafo de notoria injusticia en lo que toca a la persona del Sr. Echegaray, cuya reputación de físico y matemático es bien sentada e indiscutible, no menos que la que tiene y debe tener de entendimiento grande y robusto, nacido para las ciencias del cálculo y de la abstracción. Así lo proclaman su Introducción a la Geometría superior, sus Disertaciones Matemáticas y sus Teorias modernas de la Física. Si en mal hora, descaminado por fáciles aplausos, se apartó un tanto de estos senderos que con tanta gloria recorría, privando a la vez a la ciencia española de uno de los cultivadores que más la honraban, disculpa de sobra tiene en nuestro mísero estado intelectual, donde el trabajo científico es el secreto de poquísimos iniciados, y no obtiene siquiera la limosna del respeto y del agradecimiento de parte del mismo vulgo que sanciona y alienta las mayores iniquidades literarias. Pero aun empeñado en dar tormento a su vocación, el Sr. Echegaray ha pecado como gran pecador, y nunca sus aberraciones se han confundido con las aberraciones de los necios.

Previa esta salvedad, que debo a mi conciencia y a la justa estimación en que tengo al Sr. Echegaray, debo insistir en que su discurso sobre las matemáticas en España (escrito, por lo demás, con brillantez y fuego) nada prueba ni resuelve, y a veces nos suministra armas contra la propia tesis de su autor. Ańadiré un ejemplo.

Dice el Sr. Echegaray en la página 10 de su Discurso:

«España fue entonces (en la primera Edad Media) el centro del saber en Europa: en las célebres escuelas de Córdoba, de Sevilla, de Murcia y de Toledo se enseñaba toda la ciencia 
testimonio en asuntos de bibliografía ibérica? ¿Y qué nos dice el Sr. Echegaray en el párrafo de su discurso que copia el Sr. Perojo? Pues nada en substancia: que fue a buscar matemáticos al índice de Nicolás Antonio, y que encontró libros de cuentas y geometría de sastres. Yo me contentaré con observar:

$1^{\circ}$. Que el Sr. Echegaray no encontró nada, porque si no vio más que los títulos de los libros, mal pudo saber (ni por adivinación) su mérito o demérito.

$2^{\circ}$. Que en ninguna rama de bibliografía española podemos atenernos únicamente a la autoridad de Nicolás Antonio, porque Nicolás Antonio era un hombre solo, y su trabajo, aunque titánico e incomparable, adolece de inevitables errores y omisiones. ¡Enterado saldría de la historia del teatro español el que fuese a buscarla a Nicolás Antonio! También es una y menguada la página del teatro en el índice de nuestro insigne bibliógrafo,

acumulada durante tantos y tantos siglos en Oriente. De todas partes, de Inglaterra, de Francia, de Italia, de Alemania, acudían extranjeros ganosos de saber, buscando entre los árabes españoles los ricos tesoros de la codiciada ciencia. Alberto el Grande, Gerberto, Pedro el Venerable, Platón de Tívoli y Gerardo de Cremona vinieron a esta nuestra tierra a aprender lo que más tarde en las suyas enseñaron. Entonces tuvimos en ciencias matemáticas sabios ilustres: el obispo Aitón, Josef, el renombrado Juan de Sevilla y otros varios... Pero cuenta que aquellas nuestras glorias son glorias de los árabes españoles», etc.

Sobre este párrafo no se me ocurren más que las siguientes observaciones:

1. ${ }^{\text {a }}$ Que Alberto el Magno jamás estuvo en España, que sepamos

2. ${ }^{\text {a }}$ Que Gerberto (luego Silvestre II) sí estuvo, pero no en la España árabe, sino en la llamada Marca Hispánica, o sea en el Condado de Barcelona, una de las comarcas en que la dominación árabe pudo echar menos raíces, por haber sido de las primeras que se reconquistaron. Véase cualquier biografía documentada de Gerberto, v. gr. la incluida en el tomo VI de la Histoire Littéraire de la France, y allí se leerá, que el abad de Aurillac, Gerardo, envió a Gerberto, recomendado al conde Borrell II de Barcelona, que le puso a estudiar las matemáticas con Ato o Aitón, obispo de Vich. El año 968 Aitón y Borrell hicieron un viaje a Roma, llevando en su compañía a Gerberto, que no volvió a España.

3. a Que se compadece mal lo de que todas nuestras glorias científicas de la Edad Media son glorias de los árabes españoles, con lo de citar a renglón seguido, por única prueba de tal dicho, tres nombres de matemáticos espańoles, de los cuales cabalmente ninguno es árabe de raza ni de religión: el obispo Aitón, que rigió gloriosamente la diócesis de Vich desde 957 a 971, época en que las ciencias exactas estaban todavía en la infancia entre los árabes de Espańa; Josef el español, de quien nada sabemos sino que escribió un tratado de la multiplicación y división de los números (que es posible que sea alguno de los atribuidos a Gerberto), pero que de seguro no era musulmán, puesto que se llamaba Josef, y no Jusuf; y el converso Juan de Sevilla o de Luna, que era de origen judío, y no musulmán, y que trabajó protegido por el arzobispo de Toledo D. Raimundo y ayudado por el arcediano de Segovia Domingo Gundisalvo.

Esta es una prueba, entre tantas, de la ligereza con que el Sr. Echegaray redactó aquel discurso suyo. Y esto mismo doy a entender en el texto, aunque de una manera harto descomedida y virulenta. (Tercera edición) 
y precisamente el teatro español es el más fecundo y copioso de la tierra. La misma pobreza se nota en la sección de novelistas, y en la de traductores, y en la de humanistas, y en la de escritoras, y en la de filósofos, y en la de botánicos, y en la de historiadores, y en todas aquellas, finalmente, que han sido exploradas hasta ahora, o en las que yo he explorado personalmente. Y puede afirmarse que en las secciones donde está más completo, Nicolás Antonio presenta tan sólo la mitad de la riqueza positiva, y en el mayor número de secciones, una tercera parte escasa. Los dos voluminosos tomos impresos del Ensayo de Gallardo constan en su mayor parte de títulos omitidos por Nicolás Antonio. Y así de los demás.

$3^{\circ}$. Que tampoco debió contentarse con ver el indice, sino acudir a los artículos mismos, donde se da mayor noticia de cada libro.

$4^{\circ}$. Que tampoco es exacto que todos los títulos allí registrados sean de libros de cuentas ni de geometrías de sastres. No son geometrías de sastres las obras de Pedro Núñez, a quien el mismo Sr. Echegaray llama eminente geómetra, y del cual dice que "escribió una excelente obra de Álgebra» (en castellano, por cierto); que resolvió el para aquella edad dificilísimo problema del menor crepúsculo, problema que aun al genio poderoso de Bernouilli se resistió por algún tiempo; que inició la teoría de las loxodromas, y que se elevó como astrónomo a grande altura. $\mathrm{Ni}$ es libro de cuentas vulgares el Tratado sutilíssimo de Arithmética de aquel dominico Fr. Juan de Ortega, a quien por méritos de ella cita el mismo Sr. Echegaray nada menos que al lado de Leonardo de Vinci y de Regiomontano. La Arithmetica Speculativa duodecim libris demonstrata de Gaspar Lax, bien indica con su solo título que no iba destinada a los sastres precisamente, como tampoco su tratado de Proportiones (1515). Jerónimo Muñoz tampoco debía de ser ningún geómetra de sastrería, puesto que Tycho-Brahe, de quien hemos de suponer que algo entendería del caso, le llamó excelentísimo y prestantísimo matemático. De Pedro Juan Monzó, que tan altas ideas tenía sobre la conexión entre las disciplinas matemáticas y la filosofía, también hemos de suponer que dilató su especulación más allá de la esfera de las cuentas domésticas, y que no se quedó encerrado en ellas Juan Martínez Silíceo, puesto que, a pesar de nuestra bien probada barbarie, no se desdeñó la Universidad de París de tenerle por catedrático de Matemáticas. Manuel Bocarro Francés y Rosales no hubo de ser personaje tan despreciable, cuando el mismo Galileo se convirtió en editor suyo. El título del libro de Alonso de Molina Cano, Descubrimientos geométricos (1596), tampoco induce a tenerle por un mero calculista práctico; ni lo era ciertamente el P. José de Zaragoza, que en los últimos años del siglo XviI publicaba Arithmética Universal y Álgebra vulgary 
especiosa, Geometría Especulativa y Práctica de planos y sólidos, Trigonometría, con la resolución de los triángulos planos y esféricos, y el uso de los logaritmos, Fábrica y uso de instrumentos mathemáticos, Trigonometría aplicada a la esfera celeste, Trigonometría aplicada a la esfera terráquea, Comentario al libro de las secciones cónicas de Apolonio de Pérgamo, Tratado de la Elipse y del Círculo, etc., dejando además inédito un Curso Matemático en seis tomos en folio, tamańo poco a propósito para andar rodando por las mesillas de los oficiales de sastrería. Ni debemos creer tampoco que tenía puestos los ojos no más que en el jabón de los alfayates de su tiempo el obispo Caramuel, cuando escribía aquellos formidables volúmenes de su Mathesis Vetus novis operationum compendiis et demostrationibus dilucidata, de su Mathesis Nova, veterum inventis confirmata, de su Mathesis Astronomica, y de su Mathesis Audax, curiosa y extrañísima aplicación del cálculo matemático a la Lógica, a la Física y a la Teología. Todos estos autores y libros constan en aquella menguada página de Nicolás Antonio, que por lo visto leyó muy de prisa el Sr. Echegaray, puesto que tampoco alcanzó a ver en ella los nombres de Álvaro Tomás, de Juan de Segura, de Marco Aurelio Alemán, autor de un tratado De Arithmética Algébrica, impreso (nótese la fecha) en 1552: de Andrés García de Céspedes, inventor de nuevos instrumentos de Geometría. Finalmente, los trabajos de Rodrigo Zamorano, de Luis Carduchi, del Padre Kresa sobre el texto de Euclides, valdrán más o menos, pero es indudable que pertenecen a la ciencia pura, y no a sus mecánicas e ínfimas aplicaciones. Y cuenta que por dar gusto en todo al Sr. Echegaray, me he limitado a las páginas de Nicolás Antonio que él cita, sin meterme por ahora en más averiguaciones, y he llevado mi longanimidad hasta el punto de prescindir, como quiere el mismo señor, de todas las aplicaciones de las Matemáticas (Astronomía, Gnomónica, Cosmografía, Náutica, Geodesia, Ciencia Militar, teoría de la Arquitectura, Mecánica, etc.), por más que todos los historiadores de la ciencia, desde Montucla, Bossut y Libri, hasta los más recientes, se crean obligados a dedicar largos capítulos a todas estas especialidades, cuyo cultivo es de todo punto imposible sin el conocimiento profundo de las Matemáticas. Lo que hay es que en esta parte el Sr. Echegaray hubiera tenido que recoger velas, y hacer muchas excepciones, semejantes a las que, tratando del siglo XVIII, hace en favor de D. Jorge Juan.

Yo no entiendo de matemáticas (porque el entender de todo se queda para la escuela del Sr. Perojo), y no le podré decir con seguridad si alguno de los nombrados y de los que omito trajo algún progreso a la ciencia o la dejó como estaba, porque para esto sería preciso conocer la ciencia, y yo no la conozco. Sin duda por tal razón me suenan poco en el oído los nombres 
de esos Pretorius, Stifel, Reise, Van Colen y Van Roomen, que él cita como grandes matemáticos extranjeros del siglo Xvi. Allá en su tierra serán muy conocidos esos caballeros pero lo que yo puedo decir es que Núńez, Pedro Ciruelo, Rojas, Jerónimo Muñoz y algún otro tuvieron en su tiempo tanta notoriedad como cualquiera de ellos, y que sus libros se imprimían y traducían, y corrían grandemente en tierras extrañas, lo cual, siendo geometría de sastres, no tiene explicación plausible.

Y a propósito de los matemáticos españoles modernos, no sé de dónde haya sacado el Sr. Perojo que son la mejor antítesis de los del siglo Xvi. Lo que los profanos vemos en España son hombres doctos y serios, que parecen estar al corriente del estado de la ciencia en otras partes pero de ninguno sabemos que haya dado su nombre a teorema alguno, ni asombrado al mundo con ninguna demostración inaudita. Fuera de Rey Heredia, que (al decir de los que entienden estas cosas) mostró verdadera originalidad de pensamiento en la Teoría trascendental de las cantidades imaginarias, no sé que ninguno haya excogitado cosa nueva digna de particular memoria. Más bien podía decirse esto a principios de nuestro siglo, cuando Lanz y Betancourt crearon la Cinemática; cuando Chaix y Rodríguez unían sus nombres a los de Biot y Arago en las operaciones hechas para la prolongación del meridiano de Francia hasta las Islas Baleares; cuando Mendoza Ríos inventaba nuevos métodos para calcular la longitud por las distancias lunares; cuando Sánchez Cerquero daba a conocer nuevas fórmulas para calcular la aberración de los planetas en longitud y latitud, y fórmulas también nuevas para el cálculo de la aberración de los cometas. Pero de entonces acá (con la excepción antedicha), no sé que hayamos tenido más que buenos calculistas y buenos expositores.

Química. Nueva disertación sobre la ciencia árabe, y luego una serie de errores de grueso calibre respecto de los alquimistas españoles. Todo el mundo sabe, o debe saber, que la Clavis Sapientiae, atribuida al Rey Sabio, es apócrifa; que es apócrifo el descubrimiento del ácido nítrico por Ramón Lull; que son apócrifos todos los libros de alquimia publicados a nombre del gran pensador mallorquín, y que está en el aire la autenticidad de la mayor parte de los atribuidos a Arnaldo de Vilanova, a quien llama Villanueva el Sr. Del Perojo. Mi doctísimo amigo don José R. de Luanco demostró irrefragablemente, ante la Academia de Ciencias Naturales de Barcelona: $1^{\circ}$, que Raimundo Lulio jamás creyó en los trampantojos de la Crisopeya, ni siquiera en la posibilidad teórica de la transmutación; $2^{\circ}$, que sus obras auténticas están llenas de invectivas contra los alquimistas; $3^{\circ}$, que los tratados susodichos son un laberinto de anacronismos y contradicciones y están 
llenos de fechas y alusiones a cosas posteriores a la muerte de Raimundo Lulio; $4^{\circ}$, que las operaciones químicas atribuidas a éste no están apoyadas por ninguna autoridad sólida; $5^{\circ}$, que el ácido nítrico y la destilación alcohólica se conocían mucho antes de R. Lulio.

Y yo añadiré que los tratados alquímicos de A. de Vilanova (que real y verdaderamente fue alquimista) son, en gran parte, y con uno o con diversos títulos, los mismos atribuidos a Ramon, y les cogen muchas veces las mismas razones de ilegitimidad, aunque no a todos. Luanco sospecha asimismo que el Ramon alquimista fue real y verdaderamente Ramon de Tárrega; pero, ¡ya se ve!, los libros alemanes del Sr. Perojo dicen otra cosa, y no es vergüenza desconocer los trabajos de la erudición espańola y seguir llamando alquimista a Raimundo Lulio. Los libros transmutatorios atribuidos a éste, así como a Alberto el Magno y a Santo Tomás, son tan auténticos como el Testamento de Hermes Trismegisto. Fueron falsificaciones de alquimistas proletarios que quisieron escudarse con aquellos grandes nombres, y por eso un mismo tratado anda a nombre de varios autores.

De los metalurgistas dice el Sr. Del Perojo que acabaron con Bernal Pérez de Vargas, olvidando varias cosas:

$1{ }^{\circ}$ Que la obra De re metallica pertenece a la segunda mitad del siglo Xvi; como que está dedicada al príncipe D. Carlos, hijo de Felipe II, y no se imprimió hasta 1569.

$2^{\circ}$ Que Bernal Pérez de Vargas no es el último, sino el primero y más antiguo de los que en castellano imprimieron libro que trate de propósito acerca de los metales.

$3^{\circ}$ Que su obra tiene originalidad escasa, y está tomada en substancia de Jorge Agrícola, aunque el autor hizo experimentos propios sobre el antimonio, el arsénico, la aplicación de la manganesa al blanqueo del vidrio, etc., etc. En cambio, no dice una palabra del laboreo de las minas de América, ni da muestras de conocer la amalgamación y el beneficio por azogue, que ya se usaba, no sólo en las minas del Nuevo Mundo, sino en las nuestras de Guadalcanal, desde 1562. Todo lo cual indica que Bernal Pérez de Vargas estaba atrasado respecto de la ciencia española de su tiempo, si bien no fue obstáculo esto para que en Francia se le tradujese en 1742.

$4^{\circ}$ Que hay otros metalurgistas españoles, posteriores a Pérez de Vargas, y de mayor originalidad que él, especialmente Álvaro Alonso Barba, el primero que escribió sobre la amalgamación en su célebre Arte de los metales, en que se enseña el verdadero beneficio de los de oro y plata por azogue, el modo de fundirlos todos, y como se han de refinar y apartar unos de otros (1640), obra verdaderamente clásica en su línea, basada en experiencia propia, y llena 
de procedimientos nuevos: obra de la cual ciertamente no puede decirse tampoco que haya tenido mala fortuna en Europa, puesto que en 1674 se tradujo al inglés, en 1676 al alemán, reimprimiéndose en esta lengua en 1726,1739 y 1749 . Hay, además, una traducción italiana incompleta, y dos francesas completísimas, una de 1733 y otra de 1751, que se reimprimió al año siguiente, todo lo cual prueba que el libro no estaba anticuado, ni mucho menos, en el siglo XVIII. ¿Es posible que de nada de esto se haya enterado el Sr. Perojo, y que crea firmemente que la Metalurgia española acabó con Bernal Pérez de Vargas? El Quilatador de Juan de Arphe (1572), que pasa por el más antiguo y uno de los más excelentes libros de joyería y aleaciones; los trabajos propiamente metalúrgicos del doctor Berrío de Montalvo, de Mosén Antonio Boteller, de Bartolomé de Medina, de Pedro García de Tapia, de Pedro de Mendoza Meléndez, de D. Juan del Corro Segarra, del Dr. Juan de Cárdenas, de Lope de Saavedra, de D. Pedro de Contreras, Alonso Pérez y Rodrigo de Torres Navarra, inventores o perfeccionadores todos de nuevos procedimientos de explotación, como también lo fueron el bachiller Garci-Sánchez, D. Carlos Corzo y Lleca, D. Lope de Saavedra, D. Juan Alonso Bustamante, y otros innumerables, de quienes se da razón en la copiosa Bibliografía Mineralógica de los Sres. Maffei y Rua Figueroa, bastan ellos solos para probar que la Metalurgia práctica fue extraordinariamente cultivada en España y sus colonias durante el siglo xvi, y que debió a los españoles muy positivos adelantamientos.

La Inquisición no acabó con la química, por la sencilla razón de que no había verdadera química entonces, ni en España ni fuera de ella. Cuando la verdadera química apareció, a mediados o a fines del siglo xviII, la Inquisición estaba dando las boqueadas.

Sigue la lista consabida, en la cual no sé por qué faltan don Antonio de Ulloa, los dos hermanos Elhuyar, y D. Andrés del Río, que dieron a conocer tres nuevos metales: el platino, el tungsteno o wolfram y el vanadio.

Física. No hay más que una lista de nombres, a la cual se puede contestar: Quedamos enterados. Y no sé por qué falta en ella Salvá, a quien se debe algo más que atisbos de una invención de primer orden, como recientemente ha demostrado la Academia de Ciencias de Barcelona. ${ }^{714}$

714 Vide: Memorias de la Real Academia de Ciencias Naturales y Artes de Barcelona (Barcelona, 1876), cuadernos primero y segundo, donde se insertan las tres Memorias de Salvá sobre la electricidad aplicada a la telegrafía, sobre el galvanismo, y sobre el galvanismo aplicado a la telegrafía, compuestas respectivamente en 1795, 1800 y 1804 . Ya en 1790 había construido Salvá un telégrafo eléctrico, del cual se habló en los periódicos de entonces. El lauro de esta prodigiosa invención debe compartirle con el ilustre ingeniero 
Zoología. Bajo este título habla también el Sr. Perojo de los botánicos, como si las plantas fuesen animales. En lo demás tenemos la canción acostumbrada: grandes ponderaciones del estado de la ciencia en la Edad Media; grandes lamentaciones de la tiranía inquisitorial que la ahogó. Y yo digo que el verdadero desarrollo de la zoología y de la botánica españolas no se verifica sino en el siglo xvi, con los Oviedos, los Acostas, los García de Orta, los Monardes, los Hernández, que se suceden durante todo aquel siglo. Si el movimiento cesa o se va disminuyendo y no se continúa hasta el siglo pasado con los Ortegas, los Mutis, los Quer, los Cavanilles y los Lagascas, la culpa no es de la Inquisición, que no persiguió a ningún naturalista. No se hable de ciencia zoológica en la Edad Media. Aunque a los tres autores citados por el Sr. Perojo añadamos otros, y especialmente Fernando de Córdoba, que aventuró una clasificación ictiológica; aunque busquemos los autores de libros de caza, y todas las fuentes directas e indirectas que pueden hallarse, todo ello es nada respecto de lo que se hizo en el siglo xvi. Tenemos, pues, que la zoología y la botánica se desarrollan en el siglo inquisitorial por excelencia, como se desarrolla la metalurgia y un poco también la mineralogía, de todo lo cual la Edad Media estaba en ayunas. Total: que las ciencias decadentes, caso que lo estuviesen, son la astronomía y las matemáticas, pues la física no existía como ciencia empírica y aparte. En cuanto a la química, ya he dicho que es fábula la mayor parte de lo que se cuenta de nuestros alquimistas, y que no hubo ciencia seria y formal de los metales hasta el siglo XVI, con Jorge Agrícola, cuyos principios adoptaron en seguida los nuestros. Conque la decadencia se reduce a astronomía y matemáticas, es decir, a dos ciencias que se reducen a una sola. Pero en este tiempo hubo filosofía, hubo teologia, y jurisprudencia, y medicina, y otras cien cosas más. Y a propósito de la medicina: ¿cómo se concibe su desarrollo sin el de las ciencias naturales?

Observe V. una cosa. En todas las ciencias que en el siglo xvi estaban adultas y formadas, tuvimos hombres de primer orden, porque nadie negará que lo fueron Luis Vives, Melchor Cano, Domingo de Soto, Arias Montano, Suárez, Nebrija, el Brocense, Vallés, Laguna, Antonio Agustín, Fr. Luis de León, etc. En las que estaban en la cuna, como la zoología y la botánica, tuvimos lo que podíamos tener: observadores diligentes y concienzudos, comparables a cualquier extranjero de su siglo. Por eso en la lista de zoólogos y de botánicos que da el Sr. Perojo, noto la omisión de siete

canario D. Agustín de Betancourt y Molina (el colaborador de Lanz), que ya en 1787 había ensayado la aplicación de la electricidad a la obtención de señales desde Madrid a Aranjuez. Pero Salvá trabajó sin tener noticia de las experiencias de Betancourt, acercándose mucho más a lo que luego fue el telégrafo eléctrico. (Tercera edición) 
u ocho españoles a quienes la ciencia debe mucho. ¿Qué nos faltó, pues, y esto nunca del todo? Astrónomos y matemáticos; es decir, lo que habíamos tenido en la Edad Media.

Nada diré de aquella barrabasada del Sr. Echegaray sobre los libros misticos y los casos de conciencia. ¡Desdichado el que no concibe en el mundo más que ecuaciones y cotangentes! El alma humana tiene abismos más insondables que todos los abismos de la materia, y con frecuencia solían poner el dedo en la llaga esos místicos y casuistas.

En la carta siguiente hablaré de la filosofía española.

Marcelino Menéndez Pelayo

\section{Carta al señor director de La España [Segunda edición]}

Milán, 9 de mayo de 1877.

Sr. Director de La España.

Mi buen amigo: Hora es de terminar con la famosa perojada. Comprendo que he incurrido plenamente en la necedad de contestarla largo y tendido; pero ya no tiene remedio, y lo que conviene es acabar pronto.

En la tercera sección de su artículo habla el Sr. Del Perojo de la filosofía española, y decide ex cathedra que no tuvimos tradición, y que no hay enlace entre los filósofos. Sobre esto me remito a lo que dije en la carta a V. escrita hace veinte días, y publicada en La España. A continuación llama «erróneas, sin razón ni criterio", a las clasificaciones de filósofos que hacemos Laverde y yo, y propone por su parte otra, con gran satisfacción. Divide, pues, la historia de la filosofía española en tres períodos:

$1{ }^{\circ}$ ¡Grupo en que comprendemos (dice) cristianos y paganos: San Isidoro, Séneca y Columela! (!!!)

20 Árabes y hebreos.

$3^{\circ}$ Escolásticos y neo-platónicos.

El desatino del primer miembro de la división salta a la vista. ¿Cómo es posible identificar a cristianos y paganos, cuando está por medio nada menos que el cristianismo? Pero lo más original es poner a San Isidoro antes de Séneca, y comprender entre los filósofos a Columela, que escribió únicamente de agricultura. Esto de meter el libro De re rustica entre los de filosofía, me recuerda el caso de aquel bibliógrafo que puso entre los libros 
de matemáticas un tratado de cálculos... de la vejiga, o el de Auberto Mireo, que incluyó entre las obras que tratan de los deberes del cura párroco, el Pastor Fido de Guarini. Al menos, éstos tuvieron alguna disculpa por el sonsonete de los títulos. ¡Si tendrá bien leído a Columela el Sr. Del Perojo! Y en cambio omite a los verdaderos filósofos de este período, cuales fueron (prescindiendo de Séneca y San Isidoro) el gnóstico Prisciliano, que hizo un sincretismo de todas las herejías anteriores, como observa San León el Magno en la epístola donde largamente expone los errores de aquel heresiarca. Prudencio, autor del bello poema filosófico de la Psicomaquia y del de la Hamartigenia; Liciniano, cuya carta sobre el alma puede considerarse como el germen de la psicología escolástica; Prudencio Galindo, digno de honrosísima memoria por su libro De la predestinación contra Escoto Erígena. Estos y otros varios que pueden citarse son verdaderos pensadores, no Columela, escritor elegantísimo de las cosas del campo.

Luego habla de los árabes y de los hebreos, y elogia justamente sus méritos, aunque cometiendo el error imperdonable de afirmar que, mediante ellos, resucitó en Europa el pensamiento filosófico. Pues qué, ¿̇no habían tenido pensamiento filosófico, en bien y en mal, Escoto Erígena y Prudencio, Berengario y Lanfranco, San Anselmo de Cantorbery y Roscellino, Guillermo de Champeaux y Pedro Abelardo, Gilberto de la Porrée y Hugo de San Víctor? ¿Debieron algo a la ciencia árabe? ¡Cuándo nos veremos libres de esa manía de judíos y de moros!

Entre los nombres de filósofos que el Sr. Del Perojo cita (casi todos mal, según su sistema), los hay que no fueron españoles, como Avicena, que fue persa, y Al-Gozel, que será Algazel, el cual real y verdaderamente nació en el Khorasán. En cambio, se le quedó en el tintero nada menos que Avempace. $\mathrm{Ni}$ tampoco hace distinción alguna entre árabes y judíos, siendo así que los segundos rayaron mucho más alto que los primeros, como lo pueden demostrar, a falta de otros nombres, Avicebrón, Judá Leví y Maimónides. De los dos primeros hace también caso omiso. Al terminar este párrafo hay otro descubrimiento estupendo: el referir a los árabes y hebreos «el origen de nuestra mística». ¡Por amor de Dios!, ¿cuándo de las tinieblas ha salido la luz? La mística española, ¿es, por ventura, cosa distinta de la mística cristiana? ¿No son bien sabidos sus orígenes? ¿No tuvo la Iglesia una serie de místicos desde los primeros tiempos? ¿No hay misticismo en San Agustín? ¿No fueron místicos Hugo de San Víctor, Gerson, San Buenaventura? ¿No se amamantaron en las obras atribuidas por error al Areopagita? Nuestra mística sólo difiere de la de la Edad Media en la perfección artística y en un poco de platonismo que entró durante el Renacimiento. ¿Cómo, de sistemas 
francamente panteístas, cual los de Avicebrón y Maimónides, había de salir una escuela mística ortodoxa? Es seguro que nuestros místicos no supieron el nombre de Rabi Moseh sino por las referencias de León Hebreo. Fr. Luis de León, el único de ellos que conocía a los rabinos, no presenta vestigio de más influencia semítica que la de la Escritura. Y lo mismo los restantes. En cuanto a los alumbrados y quietistas, es decir, a los místicos heterodoxos, ninguno de ellos sabía árabe ni hebreo, y aunque coinciden en ciertas doctrinas, es coincidencia casual y derivada de leyes generales del pensamiento humano, y de leyes particulares del pensamiento ibérico. Juan de Valdés es mistico también, y místico heterodoxo; pero forma campo aparte. Desciende, por línea recta, de los místicos alemanes, aparte de su originalidad, que es grandísima.

El tercer grupo, el de escolásticos y neo-platónicos, está horrorosamente formulado, aunque él nos acusa de "confusión horrible» en las clasificaciones que hacemos. ¿Quién le ha dicho al Sr. Del Perojo que son escolásticos y platónicos todos los filósofos españoles del siglo Xvi? ¿Son escolásticos ni neo-platónicos los "peripatéticos clásicos»? ¿ $\mathrm{O}$ cree el Sr. Perojo que son una misma gente todos los que en el mundo han invocado el nombre de Aristóteles? Pues medrado está, de veras. Por esta regla, Alejandro de Afrodisia y Averroes, Avempace y Santo Tomás, Pomponazzi y Suárez, Escoto y Núñez, pertenecen a la misma escuela y caben en el mismo saco. Y, en efecto, todos son peripatéticos. Pero apurado se ha de ver el Sr. Perojo para conciliar a los que afirman la eternidad del mundo y a los que la niegan a los que dudan de la inmortalidad del alma y a los que la afirman; a los que defienden el intelecto único y a los que le suponen múltiple, et sic de caeteris. Hubiera ido el Sr. Del Perojo a uno de aquellos cultos ingenios del Renacimiento, que se llamaban «Peripatéticos helenistas», a Melanchton, por ejemplo, o a Gouvea, o a Juan Ginés de Sepúlveda, o a Gaspar Cardillo, a decirles que eran escolásticos, y buena cara le hubieran puesto. ¿ No se le ocurrió siquiera decir, en vez de escolásticos, peripatéticos, y salvaba, en apariencia, la dificultad, aunque juntando siempre cosas irreductibles?

Y continúo diciendo: ¿Es escolástico ni neoplatónico Gómez Pereira? ¿Lo es Francisco Vallés en su segunda época, es decir, en la Philosophia Sacra? ¿Lo era el Brocense, que llegó hasta a aborrecer el nombre de Aristóteles, sin ser platónico a pesar de eso? ¿Lo son Huarte ni Doña Oliva? ¿Lo es Sánchez el Lusitano? ¿Lo son Pedro de Valencia e Isaac Cardoso, etc., etc.? Porque de esta manera iríamos sacando gente que está fuera de la clasificación del Sr. Del Perojo. Precisamente neo-platónicos decididos no hay más que uno, León Hebreo. Fox Morcillo es en muchas cosas aristotélico, y lo mismo Fernando 
de Córdoba, que le precedió en medio siglo. Los que más participan del platonismo, en cierto sentido, son los místicos.

Vamos a ver por qué son erradas nuestras clasificaciones. Niego, desde luego, que en ellas estén confundidos horriblemente partidarios de sistemas distintos. Los dos o tres errores de pormenor que hay, no los sabe «ni los puede saber» el Sr. Del Perojo, pero yo los mostraré luego.

Todo el mundo ha venido considerando, por espacio de tres siglos, al lulismo como sistema aparte. Ni los lulianos han entrado en otras sectas, ni otras sectas han recibido a los lulianos. El Sr. Del Perojo habla de Lulio sin conocimiento alguno, y creyendo que su sistema se reduce a una combinación de nombres. Si el tiempo que ha gastado en leer librotes alemanes lo hubiera empleado mejor, sabría a qué atenerse en este punto. Si hay en la Edad Media una creación original, completa y coherente en todas sus partes, es la de nuestro mallorquín, hombre de "genio verdaderamente divino", como le llamó Giordano Bruno. El arte cabalística es lo menos de su filosofía, y solo a ojos llenos de telarańas puede aparecerles otra cosa. Eso que el Sr. Del Perojo llama "combinación de nombres», es un ingenioso y, en gran parte, nuevo sistema de lógica. ¿Y qué es la lógica sino el método y la forma, es decir, más de media filosofía? Y una escuela que emplea procedimientos lógicos, distintos de los comunes, ¿no está por este solo hecho bastante separada de las demás? Pues ¿en qué se diferencian peripatéticos y baconianos sino en la lógica? ¿Cree, además, el Sr. Del Perojo que sólo de lógica discurrió y escribió Raimundo Lulio? Pues se equivoca grandemente. ¿Qué es lo más alto de la filosofía? La Teodicea, sin duda alguna. Ahora bien, Lulio tiene una Teodicea con ideas atrevidas (a veces demasiado atrevidas) y originalísimas. ¿Quiere saber el Sr. Del Perojo cómo expone el filósofo mallorquín la doctrina de las relaciones entre la fe y la ciencia, punto capital, si hay alguno en filosofía? Pues sin más trabajo que ir al capítulo LXIII del Ars Magna, verá que, según el pensador del monte Randa, "la fe está sobre el entendimiento, como el aceite sobre el agua. El hombre que no es filósofo cree que Dios es; el filósofo entiende que Dios es. Con esto el entendimiento sube con la intelección a aquel grado en que estaba por la creencia. No por esto se destruye la fe, sino que sube un grado más; como si ańadiésemos agua en el vaso, subiría sobre ella el aceite. El entendimiento alcanza naturalmente muchas cosas. Dios le ayuda con la fe y entiende mucho más. La fe dispone y es preparación para el entendimiento, como la caridad dispone a la voluntad para amar el primer objeto. La fe hace subir el entendimiento a la inteligencia del ser primero. Cuando el entendimiento está en un grado, la fe le dispone para otro, y así de grado en grado hasta 
llegar a la inteligencia del primer objeto, y reposar en él, identificándose la fe y el entendimiento»... «El entendimiento (dice en otra parte) es semejante a un hombre que sube con dos pies por una escalera. En el primer escalón pone el pie de la fe, y luego el del entendimiento, cuando el pie de la fe está en el segundo; y así va ascendiendo gradualmente. El fin del entendimiento no es creer, sino entender; pero se sirve de la fe como instrumento. La fe es el medio entre el entendimiento y Dios. Cuanto mayor sea la fe, más crecerá el entendimiento. No son contrarios entendimiento y fe, como al andar no es contrario un pie al otro.»

Esta doctrina peligrosa, por no decir «heterodoxa», pero profesada de buena fe por un mártir y bienaventurado; esta doctrina alta, profunda, ingeniosa, pero en la cual se confunden dos órdenes de verdades que están perfectamente distinguidos en la doctrina tomista; esta doctrina de la $f e$ propedéutica, ni era la adoptada en el siglo XIII, ni puede negarse que es trascendentalísima, y separa a Raimundo Lulio de todas las corrientes escolásticas de su tiempo. Y cuenta que no es un pasaje aislado, sino uno de los puntos cardinales de su doctrina, punto que él desarrolla dondequiera con particular fruición, y que es su gran de argumento contra los averroístas que distinguían la verdad teológica de la filosófica, aseverando que una cosa podía ser verdadera según la fe, y falsa según la razón. A este error monstruoso e impío contesta Lulio con la soberana concepción que hemos visto, cayendo, es verdad, en el error opuesto, por no advertir que la identificación de fe y ciencia, en los términos en que él la establece, equivale a la destrucción de la primera. Pero ¿¿de cuántas escuelas alemanas modernas, de carácter teosófico, no puede descubrirse la filiación en esa doctrina?

Y doctrina es que informa toda la filosofía de Raimundo Lulio, desde la metafísica hasta la moral, y hasta los últimos ramos del Arbor scientiae. De ahí su unidad, que responde a la «unidad de la ciencia», tal como la concebía Lulio, con dos medios de conocer, que se reducen a uno solo. Esa teoría es el centro adonde convergen todos los radios de la doctrina luliana. «Dios no es parte, es todo», dijo Lulio en París; y estas palabras, bien entendidas, dan la clave de su sistema, fundado sobre «la verdad única», de la cual a veces está a pique de pasar a «la única substancia».

Por lo demás, los pasajes que se refieren a la doctrina antedicha abundan tanto en sus obras que, abriendo a la ventura el grueso volumen luliano que llevo en la maleta, ${ }^{715}$ he tropezado con el texto que traduje, y sé bien

715 Es la edición de Strasburgo, 1599, con los comentarios de Cornelio Agrippa y Giordano Bruno. (Segunda edición) 
que por cualquier tratado que hubiera abierto el libro, me hubiera acontecido otro tanto. Tiene, además, Raimundo Lulio notabilísimas doctrinas "psicológicas, morales y políticas», enlazadas todas con su metafísica y con su lógica. Si todo esto, y el haber tenido la ciencia luliana cátedras aparte y haber sido considerada como escuela y sistema por hombres como Cisneros, Juan de Herrera, Cornelio Agrippa, Giordano Bruno e Ibo Salzinger, no basta para que la demos ese nombre, allá se las haya el Sr. Perojo. Será en todo caso una disputa de nombres ociosa y ridícula. Es doctrina, y doctrina importante y en partes nueva, la de Lulio; ha tenido hasta el siglo pasado «representación visible y oficial» (digámoslo así) en Mallorca; ha promovido acres polémicas y contado gran número de secuaces, todos los cuales se han honrado con el título de lulianos, y esto en toda Europa..., y, sin embargo, no es escuela. Venga Dios y véalo.

¿Y dónde está la «horrible confusión» en los que señalamos como discípulos de Lulio? Invalídeme el Sr. Perojo un solo nombre, y veremos. Hay uno, sin embargo, que está fuera de su lugar, aunque él ni lo ha notado ni podido notarlo. Es Fernando de Córdoba. La notabilísima obra de este filósofo, intitulada De artificio omnis scibilis, que se conserva manuscrita en las bibliotecas del Vaticano y de San Marcos de Venecia, y de la cual poseo copia cotejada con los dos y sacada por estos pulgares, no pertenece a la escuela luliana, antes comienza con una invectiva contra Lulio. Pero cuando hice aquella clasificación, no había examinado yo el manuscrito de Fernando de Córdoba, y para suponerle luliano me dejé llevar, no del título de la obra, sino de los respetables testimonios de Zetzner, Ibo Salzinger y los Padres Tronchón y Torreblanca. Ahora que he visto que se equivocaban, soy el primero en corregir el yerro.

Y luego dice el Sr. Perojo: «Señalan como fundadores de sistemas los Sres. Laverde y Menéndez a Huarte, Suárez, Gómez Pereira, Francisco Sánchez y Fox Morcillo.»

¿Dónde ha visto el Sr. Perojo semejante cosa? Exceptuando a Suárez, de los demás, ¿quién ha dicho que sean «fundadores de sistemas»? ¿Cómo se llama en castellano esta manera de discutir, diciendo exactamente lo contrario de la verdad? Ni Laverde en sus Ensayos críticos y en la carta que precede a mis Polémicas, ni yo en éstas, hemos dicho semejante cosa. Laverde, en los primeros ańos de su generosa cruzada en pro de nuestra ciencia, cuando no tenía aún los datos que tuvo después, publicó en una Revista un artículo en que interinamente y no como sistemas, sino como direcciones (lo cual no es inexacto), habló de huartismo y de pereirismo. Pero cuando reprodujo aquel artículo en sus Ensayos, 
impresos el año 67, suprimió ese párrafo, y ni él ha vuelto a decir nada que se parezca, ni yo lo he dicho en todo el curso de esta polémica. El primer artículo de Laverde es poco conocido, y a buen seguro que el Sr. Perojo no sabía lo que acabo de contarle, cuando creó aquellos fantasmas para tener el gusto de combatirlos..., digo, de declarar que insistía en que no son sistemas. ¡Vaya un descubrimiento! ¡Combatir ahora una idea emitida en el ańo 59 y retirada por su autor antes de que pudiese combatirla nadie!

Por lo que a mí hace, torno a decir que he hablado del armonismo de Fox Morcillo y no de su escuela, porque no tuvo discípulos; del escepticismo de Sánchez y no de su escuela, por idéntico motivo; del sensualismo de Huarte, y no del huartismo; del cartesianismo antecartesiano de Gómez Pereira, y no del pereirismo. ¿Hablar del racionalismo del Sr. Perojo, es decir que el Sr. Perojo sea fundador del racionalismo?

Jamás hemos creido nueva la cuestión platónico-aristotélica, como supone el Sr del Perojo, con la buena fe que acostumbra. Es la cuestión más vieja de la tierra; es, digámoslo así, la expresión más clara del dualismo en el pensamiento humano. Históricamente se ha presentado más de una vez, y seguirá presentándose hasta el fin del mundo: como que su resolución es el desideratum de la filosofía. Bessarion no es superior, sino inferior, harto inferior a Fox Morcillo; Bessarion no trató de conciliar a Platón y Aristóteles; lo que hizo fue defender a Platón de los ataques que en nombre de Aristóteles le dirigía Jorge Trapezuntio. Bessarion es platónico puro, y nada tiene que ver con Fox. Si el Sr. Del Perojo insiste en esta cuestión, yo, que (aunque «erudito de lomos de libros») he leído, gracias a Dios, de capo a fondo, como dicen los italianos, las obras de Bessarion y las de Fox, le presentaré un paralelo entre ambas, y celebraré que le haga provecho, y le enseńe a andarse con un poco de tiento en juicios y decisiones.

Otro tanto digo de Gómez Pereira. Estamos hartos de saber que el cogito cartesiano es muy antiguo, como que es pura afirmación de conciencia; y no está ciertamente en el cogito la originalidad de Gómez Pereira, ni nadie podrá sostenerlo, so pena de confesar que no ha leído la Antoniana Margarita. No por el Sr. Del Perojo, que es incurable, sino por lo que pueda conducir al mayor conocimiento de un libro de que tanto se ha hablado en todos tiempos y que tan pocos han llegado a ver, ofrezco a usted un artículo sobre él, y antes de mucho.

Que el cogito es el modo de salir de la duda cartesiana, y, por tanto, la base del cartesianismo y la causa principal de sus errores, no lo duda nadie que tenga ojos en la cara, ni lo dudó el obispo Huet, que sabía algo más 
que los redactores de la Contemporánea, aunque no había sido discípulo de Kuno Fischer.

Después nos da el Sr. De Perojo una muestra de su erudición peregrina, diciendo que hemos omitido, entre los nombres de nuestros filósofos, dos «que están por cima de todos», a saber: «Raimundo Sabunde»y «Baltasar Gracián». ¡Pobre Sr. Perojo! Empiezo por advertir que R. Sabunde está citado en su lugar correspondiente, es decir, entre los lulianos, a quienes no sigue en el método, pero sí en el empeño de explicar racionalmente las verdades de la fe, de tal modo, que la Teología Natural puede considerarse como una ampliación del Llibre dels articles de la Fe. A Baltasar Gracián no le he citado, ni debido citarle, porque no es escritor de filosofía. Es un literato agudo y singularísimo; un moralista delicado e ingenioso; pero no escribió de filosofía. El Sr. Del Perojo le cita, sin duda, porque le tradujo al alemán Schopenhauer; pero esto es oír campanas, y no saber dónde. Los que hemos leído a Gracián en castellano podemos afirmar que de sus obras se saca bastante filosofía, aunque más práctica que teórica; pero también se saca de los poetas, y de los novelistas, y de otras cien castas de escritores que no son filósofos. El Criticón es una novela alegórica, filosófica en su base, y en algunos incidentes muy ingeniosa, pero no es un tratado de metafísica. Lo que predomina allí es la observación de costumbres y la crítica contemporánea. El Héroe y El Discreto son libros de moral; pero no de moral especulativa. El Político es un panegírico de Fernando el Católico. Y El Oráculo Manual, que es el traducido por Schopenhauer, sin duda porque es muy oscuro y enmarañado, es sencillamente el que menos vale de todos los escritos de Gracián. Se reduce a una serie de máximas, algunas ingeniosas, otras notables sólo por lo enredado de la expresión. ¡Es curioso que estos señores alemanes, tan doctos y tan graves, vengan siempre a traducir y copiar lo peor o menos bueno que dimos en nuestros siglos de oro! De citar a Gracián (y ahora que me acuerdo, creo que lo cité), ¡cuántos moralistas nuestros habría que enumerar!

Después dice que los filósofos alemanes del siglo XvI, especialmente Eckart ${ }^{716}$ y el zapatero Boehme, valen más que los nuestros. Él sabrá por qué. Y luego dice otro tanto de los italianos, porque ¡ya se ve!, los espańoles hemos de ser siempre lo peor de la tierra. Con la particularidad de que cita malamente casi todos los nombres italianos, sin duda porque los aprendió en algún diccionario alemán, que, tratándose de cosas de Italia, es para un

716 ¡El Maestro Eckart, que floreció en el siglo xIv, puesto entre los filósofos del siglo xvi! (Segunda edición) 
español la fuente inmediata y el camino más derecho. Así es que nos habla de un Ficinius, que será Marsilio Ficino, y de un Gemistus y un Pleto, que serán probablemente una sola persona, es a saber: Gemisto Plethon, el cual, entre paréntesis, no fue italiano, sino griego, y tampoco descubrió, que sepamos, la piedra filosofal. También mienta a un Patritius, que será, si no me equivoco Patrizzi (Francisco). Y hasta al pobre Giordano Bruno, él, o el cajista, le llaman Breno, como si se tratase del jefe de los galos que asaltaron el Capitolio. Y también asegura que toda esta gente existe en Italia, cuando yo a ninguno de ellos he podido echar la vista encima. Será que existieron...

Todo aquello de los nombres a derecha e izquierda, es faramalla y afirmación sin pruebas. Demuestre el Sr. Del Perojo que no son escolásticos, peripatéticos clásicos, etc., los que yo doy por tales, y habrá hecho una cosa útil. Al Sr. Revilla no le presenté nombres, sino agrupaciones, ninguna de las cuales ha destruido el Sr. Perojo, en medio de tanta prosa. Ni puse los nombres en el orden que el Sr. Perojo los pone. Ni ha notado el señor Perojo los verdaderos defectos de la clasificación. No ha advertido que Toledo no debía ir después de Suárez, porque escribió y murió antes; ni al salmantino Herrera se le puede llamar discípulo de Pedro Ramus, porque fue anterior en algunos años; ni Juan Montes de Oca está con propiedad entre los aristotélicos puros, sino entre los averroistas mitigados.

Éstos, que son verdaderos lapsus notados por mí o por muy doctos amigos míos, tengo aquí especial gusto en corregirlos, como corregiría ciento que notase, porque trovando e riprovando es como se hace la historia de la ciencia. Con la particularidad de que casi siempre estas rectificaciones son a mayor honra y gloria de nuestra filosofía. ¿No es un gozo descubrir que Fernando de Córdoba no fue un simple discípulo de Lulio, sino que excogitó una nueva doctrina lógica y ontológica, y esto en el siglo xv? ¿No he debido experimentar íntima satisfacción al ver en tres rancios y enredados manuscritos pruebas irrefragables de que Montes de Oca fue un pensador original e ingeniosísimo, contradictor en parte, y en parte secuaz de su comprofesor Pomponazzi, y al ver asimismo que aquel olvidado profesor nuestro planteó en 1523, a su modo, pero clarísimamente, el famoso problema del conocimiento con que nos vienen rompiendo la cabeza los admiradores de Kant? ¿No es gloria que la rebelión anti-aristotélica entre nosotros, el ataque en toda regla a las formas substanciales, iniciado con las ocho levadas de Herrera, preceda a la tentativa de Pedro Ramus?

De los yerros antes notados pudo haber sacado el Sr. Del Perojo algún provecho; pero lejos de parar mientes en ellos, fue a estrellarse contra la barrera dando nada menos que en Vives. ¡Y cómo! Clama contra Forner y 
contra nosotros porque aplaudimos «todas las obras de Vives, sin reparar que las hay con dos tendencias opuestísimas». ¿Y cómo lo prueba? De ningún modo. Esa es una afirmación al aire un distingo de los que se suelen hacer cuando hay empeńo en darse tono y fingirse competentes en una materia dada; un medio como otro cualquiera de cazar moscas y de sorprender a los incautos.

El Sr. Del Perojo nos dice con una frescura que verdaderamente asombra y que no sé admirar bastante: El pensamiento de Vives tuvo dos periodos, el primero escolástico entusiasta, el segundo anti-escolástico y neo-platónico.

No V., mi buen amigo, sino los que no están al tanto de los procedimientos polémicos de cierta escuela, se quedarán asombrados cuando yo diga que «no hay tales dos momentos», y que «el pensamiento de Vives tuvo siempre las mismas tendencias». Y las fechas van a cantar muy claro. La cronología de los tratados filosóficos de Vives es la siguiente:

1518. El opúsculo De initiis, sectis et laudibus philosophiae, en que hay elogios de Aristóteles y censuras para sus intérpretes latinos. Cosa breve y de poca monta.

1519. In pseudo-dialecticos liber. Ataque virulento y terrible contra la escolástica.

Desde 1520 a 1531 estuvo trabajando Vives en las obras siguientes, todas las cuales dedicó en el año 31 al rey de Portugal:

De causis corruptarum artium. Libro lleno de ataques a la escolástica y a toda la filosofía antigua.

De tradendis disciplinis. Exposición de sus métodos, que nada tienen de escolásticos y están sazonados con nuevas invectivas.

De prima philosophia. Tratado de metafísica, nada escolástico.

De explanatione cujusque essentiae.-De censura veri.—De instrumento probabilitatis.-De disputatione. El último lleva la fecha de 1531, lo cual indica que fue el postrero que escribió Vives para cerrar esta enciclopedia. Unidos los cuatro, forman un curso de lógica, aristotélica en gran parte, pero no escolástica, y ajustada al plan que el autor había trazado en la obra De tradendis disciplinis.

1538. De anima et vita. Tratado de psicología. En el prefacio promete la obra siguiente, que vino a completar la serie de sus trabajos filosóficos, y ocupó los últimos años de su vida:

De veritate fidei christianae. Tiene alguna semejanza con la Summa contra gentiles de Santo Tomás, en la materia, no en la forma.

Ahora sería bien que el Sr. Perojo nos dijese cuáles fueron los libros en que Vives se mostró escolástico fanático. Entre los que andan impresos (y no 
se sabe que quede ninguno inédito), no he encontrado cosa alguna que justifique semejantes afirmaciones. Por tanto, Forner, Laverde y yo, «con pleno conocimiento de causa", hicimos bien en elogiar todas las obras filosóficas de Vives, porque todas forman un organismo coherente.

Tampoco es exacto que Vives, «en su segunda época», sea neo-platónico. Vives, en su única época, escribió algunas frases de "pronunciado sabor platónico", que citaré luego, pero no neo-platónico, que es cosa muy diversa. $\mathrm{Ni}$ constituye tampoco el platonismo la base de su sistema, pues al lado de esas frases, en el mismo tratado, encontramos otras de sabor absolutamente diverso.

El Sr. Perojo no se ha tomado la molestia de leer mi segunda carta contra Revilla, y para juzgar lo que digo de Vives, se limita a transcribir un párrafo en que V. resumió, con la brevedad que a su intento convenía, mis conclusiones. Y luego hace mil apóstrofes y mil aspavientos, porque llamamos al neo-platónico Vives, "predecesor de Bacon», y dice que «nos ha cogido en una contradicción grande», y nos invita a que «sin subterfugios de ningún género» (no califico esta frase, porque basta copiarla: ¿cuándo hemos empleado subterfugios?) le probemos, texto a mano (será en mano), con citas de Vives, «que fue a un tiempo peripatético y ramista, escéptico y partidario de las ideas innatas, baconiano y sensualista», etc.

¡Pues la cosa tiene dificultad! Aunque estoy en viaje, y tengo a mano pocos libros, no tan pocos que falte en mi maleta algo de Vives, con lo cual hay sobrado para dar gusto al Sr. Perojo.

Si a cada texto de los que voy a citar quiere que ańada otros ocho o nueve del mismo tenor, no hay inconveniente.

Sensualismo. Ingredimur ad cognitionem rerum januis sensuum, nec alias habemus clausi hoc corpore; ut qui in cubiculotantum habent speculare unum qua lux admittitur, et qua foras prospiciunt nihil cernunt nisi quantum especulare illud sinit. Lo cual, en castellano, quiere decir: «Entramos al conocimiento de las cosas por las puertas de los sentidos, y no tenemos otras, mientras estamos encerrados en este cuerpo, a la manera que los que están en una habitación donde sólo entra la luz por una vidriera, no ven más que lo que aquella vidriera les consiente ver». Este pasaje es del tratado De prima philosophia, perteneciente al año 1531, en que (según las cuentas del Sr. Perojo) Vives debía de ser neo-platónico ¡Buen platonismo está el de ese trozo! ¿Se quiere otro más claro aún, y que no deje lugar a dudas? Pues en el tratado De anima et vita se lee esta proposición: Prima ergo cognitio est illa sensuum simplicissima, hinc reliquae nascuntur omnes; lo cual quiere decir en nuestra lengua: «El primer conocimiento y el más sencillo es el de los sentidos: de 
aquí nacen todos los demás». Y el libro de donde está tomado es de los últimos que compuso Vives.

Baconismo. Dados estos precedentes, ya no se escandalizará el Sr. Del Perojo porque supongamos al neo-platónico $\left({ }_{j}\right)$ Vives predecesor del empírico o experimentalista Bacon. Y así es la verdad. Vives, en el libro I De prima philosophia, declara natural e infalible el testimonio de los sentidos y de la experiencia: Naturaliter dicuntur judicari quae ab omnibus eodem modo et semper, ut quae usurpantur a sensibus. Quod naturaliter est, non potest esse ex falso; que, traducido, es: «Llamamos natural al juicio que es siempre y para todos el mismo, como es el que versa sobre las cosas que conocemos por los sentidos. Lo que es natural no puede ser falso». ¿Cómo se constituye para Vives la ciencia experimental? Del mismo modo que para Bacon. Allá va una muestra, tomada del mismo tratado: Ex singulis enim aut quae viderunt oculi vel audierunt aures et alii sensus in sua quisque functione cognoverunt, mens nostra praecepta efficit universalia, postquam illa inter se contulisset nec quidquam simile observaret in contrarium. Que en romance es como si dijéramos: «De todas y cada una de las cosas observadas por los sentidos, deduce el entendimiento los universales, después de comparar los datos unos con otros y ver que nada hay en contrario». Es decir: observación, cotejo, inducción. Total: empirismo puro. Así se forman los universales. ¿Confunde Vives la observación con la experimentación? De ningún modo. A la primera la llama observatio et usus rerum; a la segunda, experimentatio. ¿Cómo adelantan las ciencias naturales? Empleando los dos procedimientos. ¿Cómo se comprueban los universales así obtenidos? Sujetándolos a nueva experimentación. Ex particularibus aliquot experimentis colligit mens universalitatem, quae compluribus deinceps experimentis adjuta et confirmata, pro certa explorataque habetur. Digámoslo en lengua vulgar: «De algunos experimentos particulares deduce el entendimiento el principio general; y comprobándole luego con muchos experimentos, podemos asegurarnos de su certeza». Este pasaje es del primer libro De tradendis disciplinis. Si ahora quiere el Sr. Del Perojo enterarse de las demás condiciones que Vives señala a la experiencia, siempre en sentido baconiano, vaya a mi carta segunda contra Revilla, que allí transcribo un pasaje relativo a esto. Y allí está copiado a continuación otro, que es la condenación anticipada de los extravíos experimentalistas, porque nuestro filósofo atendía a todo.

Ahora vamos a ver una cosa del todo distinta.

Ideas innatas, Et quemadmodum vis quaedam indita est terrae ad producendas herbas omnis generis, ita animae nostrae... artium omnium ac 
disciplinarum sunt indita semina. Sunt anticipationes et monitiones a natura impressae et infixae. Ea est causa cur puer evidentissime veritati statim consentit, nunquam ante visae. Esto es: "A la manera que la tierra posee una virtud natural para producir todo género de hierbas, así nuestra alma posee las semillas de todas las artes y ciencias. Son como unas anticipaciones y advertencias impresas y grabadas en nuestra alma por la naturaleza. Esta es la razón de que el niño consienta con plena evidencia a la verdad, sin haberla visto antes». ¿De quién es este pasaje? Del mismo filósofo que los anteriores. ¿Está tomado de alguna obra compuesta en distinto período que las demás? No: se lee en la De tradendis disciplinis, donde está la proclamación del experimentalismo antes transcrita. ¿Y en qué parte del libro? Inmediatamente después del pasaje empírico que copiamos antes. ¡Buenos andan los dos períodos de la vida filosófica del ilustre valenciano que señalaba el Sr. Del Perojo! ¿Se quieren otros pasajes del mismo sabor? Allá van dos: Mens humana, quae est facultas veri cognoscendi, naturalem quamdam habet cognitionem atque amicitiam cum veris illis primis et tanquam seminibus, unde reliqua vera nascuntur. Esto es: «El entendimiento humano, que es facultad de conocer lo verdadero, tiene estrecho parentesco y amistad con aquellas verdades o semillas primeras, de donde nacen todas las demás verdades». Y prosigue diciendo: «De aquí nació la opinión platónica, según la cual recordamos y no aprendemos, porque las almas de los hombres han tenido el conocimiento de muchas y grandes cosas antes de ser sumergidas en los cuerpos. Pero realmente no tienen más noticia que la que los ojos pueden tener de los colores, antes de verlos; es decir, potencia, no acto. De estas primeras verdades va deduciendo la inteligencia otras, como de las semillas crecen las plantas.» Este pasaje, cuyo texto no copio, porque no es necesario y quiero abreviar, está en el libro De instrumento probabilitatis.

Ramismo. Vives no es discípulo, sino maestro de Pedro Ramus, y esto debe constar ante todo. Por lo demás, abundan las pruebas. ¿Qué atacó Pedro Ramus? La dialéctica de Aristóteles. Pues Vives nos dice en el libro III De causis corruptarum artium, que de las partes del Organon las Categorias son embrolladas, confusas e incompletas; que el libro de la Hermeneia pertenece a la gramática y no a la lógica; que los Analíticos primeros son útiles, agudos y doctos, pero están llenos de cuestiones superfluas; que los Analíticos posteriores no pertenecen a la dialéctica, porque tratan de la demostración, y ésta no la alcanza la lógica, y que los Tópicos son un índice de botica, aunque tienen buenas cosas. Tras de esta disección, que es larguísima, por lo cual no la reproduzco, cierra contra Porfirio y los averroístas. Y ha de observarse que 
casi todos los argumentos de Vives contra el Estagirita fueron reproducidos exactamente por Ramus, aunque con menos tino. ${ }^{717}$

Ahora volvamos la hoja.

Aristotelismo. En el tratado De disciplinis, que es exactamente una continuación del anterior, en la cual el filósofo se propone edificar un método de enseñanza sobre las ruinas amontonadas en los siete libros precedentes, ¿qué lógica recomienda? La de Aristóteles, escardándola de todo lo superfluo. ¿Qué es Aristóteles para Vives, desde el primero hasta el último de sus tratados? «El más docto y perspicuo de los filósofos gentiles». ¿¿Qué libro de Metafísica recomienda al que siga su método? El de Aristóteles. ¿Quién, entre los infieles, se elevó más en la consideración del fin del hombre? Aristóteles, según el autor de los libros De veritate fidei christianae. Y si quisiera transcribir ditirambos en loor de Aristóteles, hay en Vives dos o tres a pedir de boca.

No era difícil prolongar este análisis. ¿Quiere ver el Sr. Del Perojo a Vives, afirmando la subjetividad de las sensaciones, a la manera cartesiana... digo mal, la subjetividad de todo conocimiento, y pasar más adelante, y declarar con Protágoras que el hombre es la medida de todas las cosas? Pues en el De prima philosophia leemos: "Ergo nos quae dicimus esse aut non esse, haec aut illa, talia aut non talia, ex sententia animi nostri censemus, non ex rebus ipsis: illae enim non sunt nobis sui mensura, sed mens nostra. Quocirca censendae sunt nobis res non in ipsorum nota, sed nostra aestimatione et judicio». Lo cual reza así en el habla materna: "Cuando decimos que una cosa es o no es, o que es de este modo o del otro, juzgamos por el parecer de nuestro ánimo, no por las cosas en sí. La medida de las cosas para nosotros es nuestro entendimiento, no las cosas mismas». ¿Quiere verle escéptico o poco menos? Pues repare el trozo en que parece dudar hasta de la posibilidad de la demostración. ${ }^{718}$ Y así podríamos continuar usque ad infinitum, que textos hay para todo.

¡Éstas son las grandes contradicciones en que nos ha cogido el Sr. Del Perojo, y que le han dado pie para llamarnos admiradores fósiles, y calificar de entusiasmo a priori el nuestro, y decir que somos poco serios, y despreciar nuestros datos, cómo si él los diera buenos ni malos! ${ }^{119}$ Contradicciones que pueden apoyarse en textos expresos y que no admiten interpretación ni doble sentido. ¿Y no tenemos derecho para seguir afirmando que no han leído a Vives los que nos piden en son de mofa cosas que con tan poco

717 Y reproducidos también por el insigne filósofo escocés William Hamilton, en su ensayo contra la Lógica del Dr. Watheley. (Segunda edición)

718 Lib. III, De causis corruptarum artium. (Segunda edición)

719 Bueno será advertir que toda su erudición sobre este punto está tomada de un detestable artículo del Dictionnaire de sciences philosophiques. (Segunda edición) 
trabajo podemos presentar? ¡Estos son los errores estupendos y los engendros sobrenaturales!

Y si ahora me objeta el Sr. Del Perojo: « Cómo nacen de Vives cosas tan opuestas y discordantes?, no tengo más que remitirle a la página 333 de su aborto, en que dice ni más ni menos lo siguiente: «Kant no es un simple creador de un sistema, sino el creador de una escuela, de un período histórico. En él se funden las dos direcciones en que venía dividida la filosofía. De Kant... arrancan multitud de direcciones: la idealista de Fichte, Hegel y Schelling; la pesimista, la realista, la experimental y todas las que hoy llamamos neo-kantianas, positivistas, naturalistas, etc. Sólo los que inician un período pueden producir creaciones tan aparentemente opuestas, pero que se explican y resuelven con facilidad, retrocediendo a la fuente madre de sus diferentes cursos». Este párrafo viene clavado a mi asunto, con poner Vives donde dice Kant, y hacer luego en los nombres de escuelas las respectivas sustituciones.

Ahora retrocedamos a la fuente madre para ver cómo en Vives se explican y resuelven las que parecen contradicciones. Advierto que algunas lo son o me lo parecen realmente, aunque me las explico, habida consideración al tiempo crítico en que escribía Vives, como me explico las inconsecuencias de la Razón práctica respecto de la Razón pura. Esto, aparte de las debilidades, flaquezas y vacilaciones inseparables del entendimiento humano, aun en gigantes como Platón y Aristóteles. Por eso no extraño que de vez en cuando asomen la cabeza en Vives ciertas ideas que no apruebo, y que, por otra parte, riñen con el resto del sistema. La fecundidad portentosa de aquel sembrador de sistemas las engendra: su juicio reposado y certero, como pocos en el mundo, las mata en seguida. Tiene la doctrina de Vives, como yo la entiendo, la ventaja grande, y por muy pocos alcanzada, de abrazar con lucidez igual todos o casi todos los términos de la indagación filosófica. De aquí resulta que en ocasiones parece que da predominio a un elemento, y en ocasiones a otro, lo cual es fuente de contradicción para quien esté acostumbrado a ver un solo aspecto de las cosas, y ése mal. Pero todo se explica refiriéndolo al principio capital del sistema. Éste no es otro que la conciencia humana en toda su amplitud, lo mismo que en la moderna escuela escocesa; pero más amplia y libérrimamente entendido. ¿Cómo caben dentro de este sistema las semillas innatas? Vives nos ha dado la respuesta: en potencia, no en acto, es decir, no como ideas, sino como disposición para formarlas, como actividad del alma anterior a las sensaciones. ¿Por dónde comienza históricamente el conocimiento? ¿Nacen de los sentidos las demás ideas? No, sino de la actividad del alma que trabaja sobre el dato de la experiencia. Pero 
histórica y ocasionalmente puede decirse que nacen de los sentidos, y por eso Vives unas veces les atribuye un origen, otras otro, y por eso unas veces parece partidario de las ideas innatas, otras sensualista. ¿No hay más ideas que las que directa o indirectamente se fundan sobre el dato sensible? En modo alguno. Hay en el hombre otra facultad superior y capaz de las ideas puras, capaz de la divinidad, es decir, de llegar a ella. ¿Qué facultades tiene, pues, el hombre, prescindiendo de la primitiva actividad del alma? Seis, en concepto de Vives; a saber: los sentidos, que perciben los objetos sensibles particulares; la fantasía, que percibe las cualidades sensibles generales; el juicio, facultad de comparación, y la razón, facultad de las ideas puras. La conciencia humana, pues, está completa.

¿Por qué ensalza Vives la experiencia, sin que por eso debamos calificarle de empírico? Porque la experiencia es el instrumento propio de las ciencias naturales. Él lo dice expresamente. Pero la experiencia, a juicio de Vives, ha de ser guiada por la razón, que es como el piloto en la nave. De otra suerte, la experiencia será fortuita y el arte incierto. ¿Quién puede decidir si las condiciones de lugar, tiempo, etc., en la experiencia, han sido cumplidas, y si la experiencia es válida? La razón, que está sobre la experiencia. Pero la experiencia cabe perfectamente en el sistema de Vives, aunque no es única, como en el de Bacon, sino que está en su propio lugar y con su valor legítimo.

La contradicción aristotélico-ramista es fácil de explicar. Vives no ataca a todo Aristóteles; se fija principalmente en la Dialéctica, y no quiere destruirla, sino depurarla de lo que él juzga inútil. Por eso es ramista (antes de Ramus), porque censura algunas partes del Organon; y es peripatético porque acepta otras, y en la esencia lo acepta todo, con un poco más de procedimiento inductivo y un poco menos de deductivo. Respecto de la Física, juzga que no se ha de tener a Aristóteles por el límite de la inteligencia humana, y que el gran maestro es la naturaleza observada y experimentada.

Los vislumbres escépticos no son más que excesos de criticismo o ráfagas pasajeras. Por lo demás, no solo de los sistemas citados, sino de algunos otros, se pueden encontrar formulados duramente los principios en sus obras. Hasta tiene más de un pasaje tradicionalista, en que parece rebajar las facultades humanas y fundar toda enseńanza en la palabra, al paso que en otros anatematiza como en profecía el escepticismo místico de los Pascal, los Huet y los Donoso Cortés, afirmando con maravillosas palabras, como él sabe encontrarlas siempre, el poder e independencia de la razón en las cosas que son de su esfera.

Cómo entendía Vives esta independencia, qué límites la puso y en qué sentido es partidario del libre examen, sábelo quien haya tomado alguna vez 
sus libros en la mano. Vives no exagera nada ni incurre en herejías. Era católico piadosísimo, y consideraba como juegos pueriles (pueriles lusus) todas las ciencias que directa o indirectamente no sirviesen para el gran fin. Aunque contemporáneo y amigo de algunos de los corifeos de la Reforma, jamás se rindió a sus halagos ni empañó en un ápice la pureza de su fe católica y española. La intolerancia que él combatió no es la de la Iglesia, sino la de las escuelas. Una de las razones que más excitan sus iras contra Aristóteles y Averroes, es la impiedad de las consecuencias que algunos sacaban de estos autores. La tercera parte de sus obras son tratados ascéticos a cual más ortodoxos. Acaudilló el Renacimiento sin contagiarse con ninguna de sus exageraciones. Como católico y como español, el hijo de Blanca March es una de las figuras más simpáticas de nuestro gran siglo. ¡Qué extraño que nos refugiemos bajo su bandera!

No son sus nietos legítimos los impíos de nuestro tiempo, ni nadie ha dicho semejante cosa. Son, a lo más, descendientes de una rama ilegítima, que en cada individuo ha ido bastardeándose más y más y mezclándose con peor sangre. Pero esto reza con los impíos de veras, no con los de la Contemporánea, que son gente inofensiva y de pocas agallas.

No he leído en los días de la vida rasgo más chistoso que aquel apóstrofe del Sr. Perojo: «iOh, Vives, ilustre pensador!...». Me trae a la memoria aquel de Diderot que tanto hizo reír a Voltaire: « $\mathrm{Oh}$, Rousseau, mi bueno y respetable amigo!». Veo que ciertas lindezas retóricas aún deben de estar en auge allá por Heidelberg.

Y luego cita en vano, como si dijéramos en falso, al pobre Gassendi, en el prólogo de su obra, sin decir cuál, siendo así que escribió siete tomos en folio. Pero yo lo diré por él. El pasaje en que Gassendi habla de Vives está en el proemio de las Exercitationes Paradoxicae adversus Aristotelicos. ¿Y sabe V. cuál es el temor de que dice Gassendi que le libró la lectura de Vives y de Charron? El temor a los peripatéticos, y a lo arraigado de tal escuela. No se nos venga, pues, con temores, que los hay de muchas clases en el mundo, y no ha sido el de la Inquisición el más fuerte.

Tan enterado está de las cosas de Charron, que le llama amigo de Vives, cuando ni siquiera fueron contemporáneos, y el libro De la sagesse se imprimió en 1601, cuando ya Vives pudría en el sepulcro desde 1546. Pero de éstas hay tantas, que ya es pesadez señalarlas. Hora es de cerrar esta carta. Las tres páginas en que habla de V., a V. le tocan, y V. sabrá dar cuenta de ellas.

Una observación final sobre el proceso de Servet. El catolicismo puede ser intolerante, porque es infalible y proclama esta infalibilidad; el protestantismo, es decir, el libre examen, no tiene el derecho de serlo nunca, so pena de faltar 
a su esencia misma. Y bueno es saber que el primer proceso de Servet, el de Viena del Delfinado, se formó por intrigas y manejos de Calvino, manejos odiosos y viles, si los hubo nunca. El tribunal que allí le procesó no era la Inquisición, sino un tribunal eclesiástico ordinario, que, entre paréntesis, sólo fulminó la sentencia cuando ya el pájaro había escapado de la jaula, y, según toda probabilidad, haciéndole puente de plata sus carceleros, y hasta el Obispo, que le estimaba mucho como médico. El suplicio de Servet (ya lo dijo Voltaire) es mil veces más censurable que todas las hogueras de la Inquisición española, porque éstas no abrasaron a un solo sabio.

Y basta ya de perojismo. Por todo lo que el director de la Contemporánea dice de mí, no he de quejarme. Motivos tiene por aquella endiablada frase para estar de mal humor conmigo. Yo no le cité ni censuré como filósofo, ni había para qué, sino como a uno de los infinitos que exornan y atavían con peregrinas galas nuestra pobre lengua. Lo que procedía después de esto era enmendarse, y el Sr. Del Perojo se enmienda escribiendo un artículo donde, entre otras gallardías de estilo, se halla un a fuer de ser pesados, capaz de conmover en sus cimientos a la Academia de la calle de Valverde.

Sé, por experiencia propia, cuán fácilmente se deslizan en artículos de revistas y periódicos incorrecciones graves, como aquel rebajar por bajo y aquel ocuparse de, que nos espetó en la de marras el Sr. De la Revilla, con ser catedrático de literatura, y escritor que, cuando quiere, habla bien el castellano. Pero no comprendo que se deslicen, ni aun en conversación familiar, vocablos y frases con sentido absolutamente diverso del que tienen en la lengua. A fuer de podrá significar en el castellano de Heidelberg a riesgo de, pero, lo que es en nuestra tierra, significa una cosa distinta, y conforme en todo con el origen del modismo. Éstas que parecen puerilidades, son cosas serias. La perversión de la lengua indica siempre perversión y trastorno en las ideas. Por eso, apenas se puede hoy coger un libro español, sin que se revuelvan los hipocondrios. De esto a la lengua franca de los piratas argelinos no hay más que un paso. Cuando un pueblo llega a no entenderse, y cada individuo se forja una lengua aparte, a ese pueblo se le llevan infaliblemente, y a todo andar, los demonios.

Suplico, finalmente, al Sr. Perojo que en las invectivas que dirija contra mí no incluya al Sr. Laverde, de cuyos zapatos no merezco yo desatar la correa, ni lo merecen el Sr. Perojo ni el Sr. Revilla, ni otro alguno de esa schiera infinita d'immortali. El Sr. Laverde, que, como hombre, es un ángel, sin más defecto que la tolerancia excesiva, es, como literato y erudito, una de las glorias más puras y acrisoladas de la España de nuestros días. Nadie le excede en amor a la ciencia y en inteligente laboriosidad (harto mal recom- 
pensada por desdicha), y poquísimos se le acercan en la erudición, que es inmensa, en el gusto finísimo y delicado, en el juicio alto, firme y maduro. Sus ideas, sus proyectos todos, llevan un sello de grandeza que asombra. Oprimido por dolores tenaces y heroicamente sobrellevados, que ya en vida le dan la corona del martirio, no vive ni respira sino para la ciencia patria. Hablista castizo, poeta genial y de una pureza exquisita, prosista limpio y acendrado, su nombre y sus escritos están demasiado altos para que puedan alcanzarlos los mal certeros tiros de la insolencia racionalista. Ahora que me separan muchas leguas de mi buen amigo, y él no puede borrar este párrafo, repito, con toda la efusión de mi alma, que soy indigno de figurar a su lado, ni aun en los artículos del Sr. Perojo, como no sea en concepto de aprendiz y discípulo oscuro.

Adiós, por ahora, amigo mío. Continúe el Sr. Del Perojo sus doctas lucubraciones; forme un martirologio de científicos quemados por la Inquisición, ya que (según él) es larga la lista; repase un poco en el Arte de Nebrija la declinación de efficiens, efficientis, que va por prudens, prudentis, y en el Diccionario de la Academia la definición del modismo a fuer; descubra esas obras inéditas en que Vives fue escolástico entusiasta, y escriba luego contra mí más pliegos que legajos tiene el Archivo de Simancas, si es que los suscritores de la Contemporánea son de tan buena pasta que quieren, no ya leer (que fuera mucho pedir), sino contemplar, artículos tan exorbitantes e inverosímiles como el de La ciencia española bajo la Inquisición.

Y V., amigo mío, que estará ya cansado del fárrago presente, en que casi he excedido, a fuer de molesto, al Sr. Perojo, no le deje de la mano, sino cumpla y ejecute en él la justicia, como de V. se espera.

Marcelino Menéndez Pelayo 


\section{LA ANTONIANA MARGARITA DE GÓMEZ PEREIRA}

\section{Carta al Sr. D. Juan Valera, de la Academia Española}

$\mathrm{M}$ i docto amigo: A V., que es de los pocos y escogidos defensores del pensamiento nacional y castizo, enderezo esta carta, con el declarado propósito de arrimarla a buena sombra, y cubrir mis audacias (ya que pasa por atrevimiento nefando toda palabra de paz y de justicia hacia la antigua Espańa) con el nombre y la amistad del escritor que hoy simboliza entre nosotros la alianza de la pureza clásica y de la gracia española. Mi voz tendría poca o ningua autoridad para que se leyeran y tomasen en alguna consideración mis escritos. Y casi estoy tentado a no firmarlos, Usted sabe cómo he sido recibido en esta república de las letras, de ordinario tan quieta y pacífica. Apenas dije algo en pro de la ciencia española, que me parecía y sigue pareciéndome la cosa más clara y evidente de la tierra, no hubo piedra ni palo que no se levantase contra mí. Unos me dijeron soñador; otros, neo; los de más allá, erudito indigesto, falto de criterio y de ciencia; no faltó quien supusiese caritativamente, que de los libros sólo conocía yo los tejuelos, $e$ cosi via discorrendo. Todo esto y mucho más debía de merecer yo por mis pecados; pero como quiera que semejantes calificativos no daban luz grande, que digamos, sobre la cuestión debatida, claro está que no me convencieron ni por asomos. Contesté; replicaron; torné a contestar; respondieron, tomándose un año de tiempo para la respuesta; volví a la carga con un fárrago escrito de prisa en una posada veneciana, y hasta la fecha han callado, quién dice que por desprecio, quién que por esperar otro año... o dos, porque esos señores gustan sólo de escritos lamidos y limados.

Con tales y tan perversos antecedentes, necesario era que para asomar de nuevo la cabeza a ese escenario, donde basta ser español y cristiano 
viejo para ser recibido con silbidos y alharacas, buscase yo el amparo y patrocinio de un Mecenas como V., respetado y bien quisto de todas las banderías, y simpático en grado particular a mí y a todos los amantes de la cultura indígena. Por que $\mathrm{V}$. ha dicho que la historia de la filosofía española debe escribirse; que en la filosofía del Renacimiento, España disputa a Italia la primacía, y casi la vence con Vives, Soto, Suárez, Gómez Pereira, Fox Morcillo, Servet, Sánchez, y tantos otros, sin olvidar a nuestros prodigiosos e inspirados misticos. ${ }^{720}$ Usted ha tenido valor para decir esto y otras cosas más, sin temor de desprestigiarse ni perder su envidiable fama, a la faz del Ateneo y demás centros de ciencia movediza y extranjerizada. A V. tampoco le han de tener por sospechoso de ultramontanismo los nuevos apóstoles. Usted será, pues, mi padrino en esta demanda.

De tiempo atrás es convicción mía que el principal obstáculo para que la idea de la filosofía española cunda y se propague (aparte de las preocupaciones anti-nacionales y antirreligiosas), es la rareza de nuestros libros, la lengua en que por lo general están escritos, y la pereza y falta de resolución que a mucha gente aparta de leerlos. Usted lo dijo con su habitual gracia ante la Academia Española. ${ }^{721}$ A unos les falta la paciencia del bibliófilo, y no leen los libros porque no los encuentran a mano, o por que no quieren buscarlos ni gastarse en ellos buena cantidad de dineros. A otros, por carestía de latinidad, les estorba lo negro. Los bibliófilos, que tanto podían ayudarnos, hacen coro con los enemigos de nuestra cultura, y cuando de reimprimir rarezas se trata, no salen de Celestinas y libros de jineta. Temiendo estoy que el mejor día nos obsequien con el Libro de guisados de Ruperto de Nola, obra de grande trascendencia; como que se refiere al llamado arte útil; que es, a no dudarlo, el mismo que los krausistas (séales la tierra ligera) mandaban estudiar en los Institutos, en el célebre plan de estudios de 3 de junio de 1873.

Por todas estas causas y otras que fuera prolijo exponer, son contados los que tornan en la mano un libro español de filosofía, aunque por otra parte no haya gran mérito ni dificultad en tomarle. Algunos salen del paso con decir que la filosofía española es un mito, disimulando (como decía Moratín de los despreciadores del teatro castellano) con un desatino su ignorancia. ${ }^{722}$ Otros (y de éstos soy, aunque indigno) procuran haber a las manos esos libracos y estudiarlos. Desde que supe (gracias a mi incomparable amigo Laverde, a quien corresponde la primera honra y prez en este campo) que

720 Prólogo a los Estudios de Laverde. (Segunda edición)

721 Véase la contestación al discurso del Sr. Núñez de Arce. (Segunda edición)

722 Prólogo a los Orígenes del teatro. (Segunda edición) 
había filósofos españoles y quiénes eran, tuve empeño en conocerlos un poco de cerca, y con tal mira he ido y voy reuniendo una coleccioncita de libros filosóficos espańoles, donde no faltan algunas rarezas, y extractando, y copiando casi, en las bibliotecas públicas los que ni poseo ni tengo apenas esperanza de poseer nunca. Uno de estos es, por mi desdicha, la Antoniana Margarita, de la cual pudiera decir, parodiando a otro propósito unas palabras de Escalígero, que en más estimaría poseer un ejemplar que ser rey de Celtiberia. ${ }^{723}$

Pero aunque no la tengo (iquiera Dios que algún día se me muestre de buen talante el numen que preside a las empresas bibliománicas!), la he leído entera dos veces, muy despacio, y con la pluma en la mano, y tengo de ella extractos bastante copiosos, en los cuales irá fundado este análisis, que no será (Dios mediante) el último que yo haga de libros de filósofos españoles. Discurramos, pues, familiarmente y sin aparato científico acerca de Gómez Pereira, y reciba V. este trabajo como leve muestra de mi gratitud y amistad, ya que (como decía Catulo):

\section{Tu solebas}

meas esse aliquid putare nugas.

Del autor se sabe poco; casi nada. Los dos diligentes historiadores de nuestra Medicina no han añadido cosa alguna a lo que de su libro resulta. Su nombre y su patria andan en controversia. Llámanle casi todos los que de él escriben Antonio; algunos extranjeros mal informados y de poca autoridad, y a su frente el abate Ladvocat, compendiador de Moreri, le apellidan Jorge. ${ }^{724} \mathrm{La}$ verdad es que su nombre no fue Antonio ni Jorge, sino Gómez, y su apellido Pereira; de la misma manera que se llamó Gómez Arias aquel mal caballero cuyas fechorías pusieron en las tablas Luis Vélez de Guevara y Calderón, y de la misma suerte que conocemos por Gómez Manrique al autor del Regimiento de Príncipes: no siendo en ninguno de estos casos patronímico el Gómez, como no lo es en el caso de Pereira. Así lo indica la misma forma de latinización de su nombre: Gometius Pereira. Nicolás Antonio debió de pensar como yo en esta parte, y por eso colocó a nuestro filósofo en la letra $\mathrm{G}$ de su Diccionario, y no en la lista de los autores nominis ignoti.

723 Afortunadamente para mí, ya no puedo decir esto. Hoy tengo en mi biblioteca, gracias al librero Quaritch de Londres, el más bello ejemplar que puede verse de la primera edición de la Antoniana Margarita, de las Objectiones de Miguel Palacios, con la réplica de Gómez Pereira, y del tratado de éste intitulado Nova Veraque Medicina. (Tercera edición)

724 El Jorge debe proceder de que algún extranjero vio escrito G. Pereira, y leyó Georgius en vez de Gometius. (Segunda edición) 
Lo que se ignora de todo punto es su patria. El apellido Pereira ha inducido a muchos a suponerle, sin otra razón alguna, gallego o portugués; el jesuita Ulloa, en un pasaje que citaré adelante, le llamó resueltamente, y en latín bastante macarrónico, gallegus; pero la verdad es que en sus libros, ni a Galicia ni a Portugal alude una sola vez, que yo sepa. ${ }^{725}$ Lo que de él consta, es que vivió y escribió en Medina del Campo, donde verosímilmente habría nacido, aunque sus padres o abuelos procediesen de otra región de España. Si es verdad, como ha dicho Florentino, ${ }^{726}$ en su biografía de Pomponazzi, que un filósofo es ciudadano del pueblo donde piensa y escribe, como un guerrero toma nombre y patria de la bandera bajo la cual combate, la gloria de Gómez Pereira pertenece sin duda a Medina, que por tal hijo será famosa e insigne entre las villas castellanas, más que por los recuerdos de su antigua prosperidad y de sus riquísimas ferias.

El padre de Gómez se llamó Antonio; su madre, Margarita: nombres que él mismo dejó registrados con piedad filial en el título de su obra maestra, y aun interrumpe en una ocasión el hilo de sus razonamientos para rogar cristianamente a sus lectores que encomienden a Dios el alma de sus padres.

La Providencia, que destinaba a Gómez Pereira al alto empleo de reformador científico del siglo Xvi, le hizo nacer casi al mismo tiempo que dicho siglo: en 1500. En 1554, cuando publicó su obra, estaba próximo a cumplir los cincuenta y cuatro de su edad, como él mismo escribe en la dedicatoria Me in quinquagesimum quartum agentem annum.

Estudió en Salamanca filosofía y medicina, inclinándose de preferencia, según discurro, al sistema de los nominalistas, que él transformó en sensualismo a la moderna. Los Nominales habían penetrado a fines del siglo xv, no sin oposición, en Salamanca, donde fue su primer corifeo Alfonso de Córdoba. Sus discípulos llegaron a tener igual número de cátedras que los reales o realistas. ${ }^{727}$ Allí se explicaron las doctrinas de Gregorio de Rímini,

725 Pereiras había establecidos, desde el siglo xv, en Toro y Zamora, ciudades no lejanas de Medina. Procedían sin duda de aquellos Pereiras portugueses que tomaron partido por D. Juan I de Castilla, y combatieron a su lado en la batalla de Aljubarrota. De esta familia descendieron el protestante Juan de Ulloa Pereyra, penado en el Auto de Valladolid de 1559, y el poeta D. Luis de Ulloa Pereyra, autor de la Raquel, y grande amigo del conde-duque de Olivares. (Tercera edición)

726 Pietro Pomponazzi. Studi Storici. Firenze, 1868. (Segunda edición)

727 «Extendióse por todas partes la fama de los filósofos y teólogos nominales que en la Universidad de París florecían, y porque al estudio de Salamanca no le faltase nada de lo que en otros había, enviaron ciertos hombres doctos a París para que con grandes salarios trajesen los más principales y famosos hombres que de los nominales hallasen, y así trajeron personas de mucho nombre para leer Teología nominal, de que entonces se 
las de Durando, y quizá las de Occam, aunque por traer este nombre cierto sabor de heterodoxia no sonó tanto como los otros dos. Gómez Pereira los cita a todos, y es visible la influencia que en su ánimo y enseńanzas ejercieron, a pesar de la independencia de su carácter y de su marcada tendencia a la paradoja. Además de los autores nominalistas, estudió a Santo Tomás y a sus principales expositores; leyó todas las paráfrasis y comentarios averroístas, entonces tan en boga en la escuela de Padua; y aun penetró en la filosofía de los Padres de la Iglesia latina, haciendo mucho caudal de las doctrinas de San Agustín. Su libro muestra erudición copiosa, aunque no rara en los filósofos de aquel siglo. Su ciencia médica rayaba muy alto, según parece por el libro De las fiebres; y a esta ciencia reunía larga práctica, como lo manifiestan las copiosas observaciones que en su libro trae, hechas, no sólo en Medina, sino también en Burgos, Segovia, Ávila y otros pueblos de Castilla adonde se le llamó en consulta. El mismo Felipe II le hizo ir a la corte para asistir al príncipe D. Carlos.

Gómez Pereira, sin ser en su latín rudo ni bárbaro, tampoco puede ser calificado de humanista. No había hecho con preferencia una educación literaria como Vives, Sepúlveda, Gouvea, Cardillo, Fox, Núñez y tantos otros pensadores sexcentistas. Habíase educado entre los gritos de la escuela; allí aguzó con la disputa su ingenio sutilísimo, y de allí tomó el arté de separar, distinguir y subdividir hasta lo infinito, robando a la escolástica sus propias armas para combatirla con ellas, y enriqueciendo a la nueva filosofía con los despojos de Egipto. Luce, sin embargo, cualidades de escritor en la $A n-$ toniana, a despecho de la prolijidad y falta de proporciones artísticas de tal libro, cortado a la continua por interminables digresiones y controversias, que apartan de la vista y de la memoria del leyente el principal asunto. Pero Gómez Pereira no se pierde nunca; cuando más distraído parecía, vuelve a tomar el hilo, y prosigue eslabonando consideraciones, a veces por largo rodeo, siempre con verdadero artificio lógico. ¡Lástima que estas cualidades externas de la obra hagan un tanto fatigosa su lectura! El latín no es mejor ni peor que el de los buenos escolásticos de entonces, Domingo de Soto, verbigracia. Pero el autor no se dirigía a los humanistas, sino a los médicos, filósofos y teólogos; así lo anuncia desde la portada.

A falta de otras noticias acerca del carácter e ingenio de Gómez Pereira, de sus libros se deduce que era buen cristiano y buen hijo; pero en lo demás,

hizo una cátedra, en que se leía a Gregorio de Arimino y ahora a Durando, y para cuatro cursos de Lógica y Filosofía, dos por la orden de los nominales y dos de los reales por el modo y forma que en la Universidad de París se leían.» (Pedro Chacón, Historia de la Universidad de Salamanca). (Segunda edición) 
hombre arrojado, impaciente de todo yugo, rebelde a toda autoridad no fundada en razón; amigo de ir contra la corriente, y de sacar a luz paradojas extrańas que asombraran a los nacidos; y al mismo tiempo observador sagaz, dialéctico agudísimo, hombre, en suma, de poderosas y no mal dirigidas facultades intelectuales.

Médico se titulaba de Medina del Campo, cuando en 1554 y 58 divulgó en aquella villa los dos volúmenes, hoy rarísimos, a que debe toda su fama. Titúlase el primero, cuyo rótulo copiaré exactamente para satisfacción de los bibliófilos:

"Antoniana Margarita, opus nempe Physicis, Medicis et Theologis non minus utile quam necessarium. Per Gometium Pereiram, medicum Metimnae Duelli, quae Hispanorum lingua Medina del Campo appellatur, nunc primum in lucem editum. Anno MDLIV, decima quarta die Mensis Augusti». ${ }^{728}$

Tiene 6 hojas no foliadas de preliminares, 832 columnas y 10 hojas más sin foliar, con las erratas e índices.

Al fin dice:

"Metymnae Campi excussum est hoc opus ex officina Chalcographica Guilielmi de Millis 1554.»

Esta primera edición es el colmo de la rareza. He tenido a la vista dos ejemplares de ella, perteneciente el uno a la Biblioteca de la Academia de Ciencias de Lisboa, y el otro a la Nacional de Bruselas, que lo adquirió con los demás libros del bibliófilo gantés Van Hulthem, amigo y discípulo de mi paisano La Serna Santander. ${ }^{729}$

La segunda edición de la Antoniana se hizo en Francfort (si hemos de creer a N. Antonio), medio siglo después que la primera, en 1610. Pero yo jamás la he visto, ni encuentro otra noticia de ella.

728 Ostenta esta portada en la parte superior las armas del cardenal Silíceo, con el lema Eximunt tangentia ignem. (Segunda edición)

729 Otro ejemplar poseyó D. Anastasio Chinchilla, autor de los Anales históricos de la Medicina Española: hoy está, según creo, en la Biblioteca de San Carlos. Otro se conserva en la Universidad de Oviedo, según me informa el bibliotecario de aquella escuela. En tiempos antiguos, las dos obras de Gómez Pereira alcanzaban un valor exorbitante en el mercado: hay noticia de ejemplares enajenados en ventas públicas por 800, 1.000, 2.280 y 3.360 reales.

Este último precio es el del catálogo de Gaignat. Hoy las obras de Gómez Pereira han sufrido la suerte común de todos los libros científicos en lengua latina. El gusto de los aficionados ha tomado otros rumbos más floridos, y los libros del género de la Antoniana, aunque cada vez más estimados por razón de su contenido han dejado de ser objeto de vana curiosidad, de especulación o de lujo. (Tercera edición) 
La tercera es de Madrid, 1749, por Antonio Marín. La portada es idéntica a la de la edición antigua, excepto en el final.

"Ex integro correcta in hac secunda editione. Tomus Primus. Cum licentia. Matriti. Ex Typographia Antonii Marin, anno MDCCXLIX.» Tiene 355 páginas, y se titula tomo primero, porque hace de segundo el otro tratado de Gómez Pereira, impreso por primera vez en 1558, y encabezado así:

"Novae Veraeque Medicinae experimentis et evidentibus rationibus comprobatae per Gometium Pereiram Medicum», etc. (lo demás igual que en el frontis de la Antoniana, excepto el nombre del impresor, que aquí es Francisco del Canto).

De este libro no sé que haya otra reimpresión que la de Marín, que hace juego con la Antoniana.

"Nunc secundum in lucem edita: quae in hoc volumine tractantur elenchus versae paginae docebit. Tomus Secundus. Cum licentia. Matriti. Ex Typographia Antonii Marin, anno MDCCXLIX». 452 páginas. Con aprobaciones que para esta reimpresión dieron los PP. Aravaca y Gallo.

Este segundo libro tiene mucho interés médico, pero poco o ninguno filosófico. Su objeto es combatir la doctrina de Galeno acerca de las fiebres, porque, a juicio de Pereira (hombre en todo de singulares opiniones y nullius addictus jurare in verba magistri), el médico de Pérgamo ignoró las causas, esencia y especies de la fiebre, y con su ignorancia causó irremediables daños a las sucesivas generaciones, que le tuvieron por luz y espejo de la Medicina.

Gómez Pereira era enemigo nato del principio de autoridad en todas las esferas de la ciencia. Para él, en las cosas físicas no hay más autoridad que el experimento. Morejón le considera como el patriarca de los anti-galenistas. Nuestros médicos helenistas del siglo xvi habían enterrado la medicina de los árabes bajo el peso de sus dicterios. Gómez Pereira llega mucho más allá: no era él hombre que trocase una servidumbre por otra. Aplica a Galeno la misma medida que aplicaban Laguna o Vallés a Avenzoar, a Rasis, a Avicena y a Averroes. Sostiene contra los aristotélicos que el calor febril no se diferencia del natural por la especie, sino por el grado de intensidad; y rechazando la doctrina de la putrefacción de los humores, se adelanta cien años a Sydenham en echar a volar la hipótesis de que la fiebre es un esfuerzo de la naturaleza para restablecer el equilibro de la salud. ${ }^{730}$

730 Véanse las palabras textuales de Gómez Pereira, ya recordadas oportunamente por entrambos historiadores de nuestra Medicina: Febrem non in alium usum natura gignit, quam ut per eius vim superflua quae corpus humanum male afficiunt, diffluantur, aut concoquantur et concocta per sensibiles corporis meatus patentissimos redditos per febriles calorem excernantur et alia naturae humanae incommoda resarciantur. 
Los inteligentes conceden gran valor histórico a las observaciones clínicas de Gómez Pereira sobre la lepra y la elefantiasis, sobre las lesiones locales, sobre las fiebres intermitentes o, como entonces se decía, interpoladas, sobre la calentura lenta hética, sobre el tifus y las viruelas. Aun a los profanos no deja de sorprenderles agradablemente la sencillez de sus planes terapéuticos, viva antítesis del bárbaro y pedantesco tratamiento aconsejado por los doctores Sangredos de entonces. Otra de sus ideas más arrojadas y originales consiste en negar la transmisión del contagio por medio del aire.

Morejón, arrebatado por el furor apologético, quiere encontrar en Gómez Pereira hasta los fundamentos del vitalismo de Stalh. Yo no he tenido tanta suerte, y a la verdad hubiera sido extrañísimo caso encontrar vitalismo de ninguna clase en un hombre que suponía a los brutos meros autómatas, que atribuía todas sus operaciones a fuerzas mecánicas, y que, por lo tocante al hombre, establecía una separación todavía más profunda que Descartes entre las operaciones de la materia y las del espíritu. Bástale a Gómez Pereira, para su gloria como médico, haber roto el primero las cadenas del galenismo, y haber leído, o deletreado a lo menos pero directamente y por sí mismo, algunas páginas en el gran libro de la naturaleza.

Pero dejando este punto para que los inteligentes le discutan y sentencien si en los descubrimientos del terapéutico de Medina, y en los de Doña Oliva Sabuco de Nantes, que levantó asimismo bandera contra Galeno, hay (como parece) ideas, al par que atrevidas y originales, útiles y basadas en larga experiencia, cerremos nosotros esta parte bibliográfica, haciendo constar la inusitada escasez de la última edición de la Antoniana y de la Vera Medicina. Dada su fecha, relativamente moderna, debía de abundar, $y$, sin embargo, es casi tan peregrina como las dos anteriores. He visto un ejemplar de ella en la Biblioteca de la referida Academia de Ciencias, y sé que existen dos en la del Colegio de San Carlos de Madrid, y otros en las Universidades de Oviedo y Salamanca. ${ }^{731}$

A la vuelta de la primera hoja de la Antoniana hay un Elenchus o resumen de las materias de la obra, especie de hilo de Ariadna, muy útil para no perderse en aquel laberinto de cuestiones incidentales. La dedicatoria es a Nuestro Señor Jesucristo, y ni aun así pudo contener el autor su índole satírica y des-

No faltan en la Nueva y verdadera Medicina algunas ideas de carácter filosófico omitidas en la Antoniana. Entre ellas cuento una extraña teoría sobre la animación del feto. Según nuestro autor, primero se imprime el alma vegetativa, luego la sensitiva, y finalmente la racional. (Col. 864 de la primera edición). (Tercera edición)

731 También la Biblioteca Nacional de París posee las dos ediciones de la Antoniana, según me avisa Morel-Fatio. (Segunda edición) 
enfadada. Una de las razones que aduce para dar tan santa nuncupación a su libro, es la siguiente: «Muchas veces tropiezo con libros de antiguos escritores, conservados y tenidos en no poca estima, aunque su utilidad sea ninguna y su lección nada tenga de deleitosa. Lo cual atribuyo a la piedad de sus autores, por cuyos méritos concedióles Dios que sus obras durasen largas edades, al paso que se perdieron las de otros autores mucho más doctos pero impíos.»

En pos de esta dedicatoria viene una carta al cardenal arzobispo de Toledo D. Juan Martínez Guijarro, alias Siliceo, a quien se muestra muy agradecido, no sin indicarle que fue su intención primera ofrecerle la obra, pero que luego lo pensó mejor y la enderezó al Rey de los reyes y Señor de los señores.

Una breve advertencia informa a los lectores de la razón del título de la obra, que no se llama Paradojas, para que el rótulo no parezca, soberbio; y otro prólogo, algo más extenso, muestra el fin y propósito del autor en la composición del tratado. Su profesión de fe filosófica no puede ser más explícita: «Sabed (dice) que sólo el celo de la verdad me mueve a divulgar esta obra y muchas otras que irán saliendo (si Dios quiere), unas especulativas, otras de medicina práctica, tan útiles como nuevas y singulares. Porque yo comencé a dudar de muchas opiniones que médicos y filósofos tenían por indubitables y seguras; probélas en la piedra de toque de la experiencia, y resultaron falsas; al paso que mis doctrinas, confirmadas primero por la razón y luego por el éxito, más y más se arraigaron en mi ánimo. ${ }^{732}$

Entonces deliberé dar a la estampa estas primicias de mi labor, para que, difundidas por toda Europa (si no me engaña el amor propio), sean como nuncios de la verdad que sustento». "Hablaré de cosas que nadie ha dicho ni escrito antes que yo. En no tratándose de cosas de religión, no me rendiré al parecer y sentencia de ningún filósofo, si no está fundado en razón. En lo que atañe a la especulación y no a la fe, debemos despreciar toda autoridad. La razón sola es la que puede inclinar el entendimiento a una parte o a otra». ${ }^{733}$

Como ve V., Gómez Pereira es racionalista en el buen sentido de la palabra, y no tomada in malam partem, según ahora hacemos: es pensador

732 «Quam in re medica exequens adeo prospere et ad votum quae ratus fueram contingebant, ut dein plus eventibus nostra opinio roboraretur quam prioribus rationibus esset fulta. Quo firmior in decretis propriis effectus», etc., etc. (Segunda edición)

733 "Audebo in his disserere quae nullus ante nos nec scriptis nec verbis protulit... Prius vos moneo me nullius quantumvis gravis authoris sententiam recepturum, dum de religione non agitur, sed tantum rationibus innixurum... In rebus quae speculationi et non fidei attinent, authoritatem quamlibet contemnendam... Rationes enim sunt quibus intellectus potius in unam quam in aliam partem labitur duciturque.» (Segunda edición) 
independiente y ciudadano libre de la república de las letras, al modo de muchos otros filósofos nuestros. Dice, como Vives, de quien en línea recta desciende: «Tanta fe se me conceda, cuanto mi razón persuada. Tomaré mis argumentos de la naturaleza, no de los sagrados libros, porque no es lícito el tránsito de la Filosofía a la Teología». ${ }^{734}$

También Vives juzgaba cosa mala y dañosa auctoritate sola acquiescere et fide semper aliena accipere omnia, y repetía con Séneca: Patet omnibus veritas, nondum est occupata. Multum ex illa etiam futuris relictum est. "No quiero (dice en otra parte) que se me compare con los antiguos, sino que se pesen sus razones y las mías..., ni deseo ser autor o fautor de ninguna secta; ni quiero que nadie jure en mis palabras o sistemáticamente me siga. Si encontráis algo de verdad en mis escritos, seguidlo y defendedlo, no por ser mío, sino por ser verdadero. No rompáis lanzas en mi defensa...; sed discípulos y secuaces de la verdad dondequiera que la encontréis». ${ }^{735}$ ¡Cómo había de sospechar Vives que precisamente por su independencia y manifiesto propósito de filosofar con libertad, habían de negarle algunos hasta la cualidad de filósofo, fundados en que no formó escuela! Efugio pobre y miserable a todas luces. Pues qué, ¿̇no fundó la mejor y más amplia escuela, la del pensamiento libre? ¿Qué otra cosa es lo que yo he llamado y sigo llamando vivismo? Como Vives y Gómez Pereira pensaba el Brocense cuando pronunció aquellas memorables palabras registradas en su proceso: "que en cuanto a las cosas que son artículo de fe, él siempre tenía captivado el entendimiento a la obediencia de la fe, pero que en las otras cosas que no lo eran, no quería captivar su entendimiento, sino interpretar conforme a lo que ha estudiado, y que lo mismo hacía con los autores antiguos, porque a Platón y a Aristóteles, si no es que le convenciesen con razón, no quería creerlos, y así tenía escrito contra ellos; y que cuando comenzó a estudiar Súmulas, a las tres o cuatro lecciones dijo: juro a Dios y a esta cruz, de no

734 «Tantum mihi habeatur fidei quantum ratio mea evicerit... Ideoque rationes attuli petitas ex natura, non e divinis oraculis, ne ex Philosophia in Theologiam transirem». Praefatio a los libros De disciplinis. Poseo cuatro ediciones: la de Lyon, 1551; la de Basilea, 1555; la de Leyden, 1636, y la de Nápoles, 1764; prueba evidente de lo conocida y estimada que fue siempre y en todas partes la doctrina del filósofo valenciano. (Segunda Edición)

735 «Neque vero ipse me aequari antiquis illis postulo, sed rationes eorum comparari cum meis... Nolim quemquam se mihi addicere, nec auctor nunquam sectae nec suasor ero, etiam si in mea verba jurandum sit. Si quid vobis, o amici, recte videbor admonere, tuemini illud quia verum, non quia meum. Nam pro me digladiari nec proderit mihi et oberit vobis... veritatis sectatores, ubicumque eam esse putabitis... (Prefacio citado). (Segunda edición) 
creeros palabra que me digáis... y que así tenía por malo creer a los maestros, porque para que uno sepa, es necesario no creerles, sino ver lo que dicen, como Euclides y otros maestros de matemáticas, que no piden que los crean, sino que con la razón y estridencia entiendan lo que dicen». ${ }^{736}$

En lo cual, si bien se mira, no hacía Francisco Sánchez más que glosar lo que había dicho en el tratado De los errores de Porfirio ${ }^{737}$ al combatir la máxima: Oportet addiscentem credere: "Mihi certe divinus arbitror contigisse, ut per totum triennium quo Philosophicis studiis impenditur opera, magistris meis nunquam aliquid assentirem». («Fue, sin duda, providencia divina, que en los tres años que estudié Filosofía, nunca pudiera yo estar conforme con nada de lo que me enseñaron mis maestros»). Y en la obra admirable donde formuló por primera vez, con aplicación a la lengua latina, las leyes de la filosofía del lenguaje, no se hartó de encarecer el daño que resultaba de no investigar las causas y las razones, y contentarse con ver por ajenos ojos y oír por ajenos oídos. ${ }^{738}$ "Muchas cosas se ocultaron a Platón, que luego descubrió Aristóteles; muchas ignoró éste, que fueron después sabidas, porque la verdad está oculta, pero nada hay más precioso que la verdad».

No de otra manera pensaba Sebastián Fox Morcillo cuando, al frente de su áureo libro De naturae philosophia seu de Platonis et Aristotelis consensione, escribía: «El método que siempre me propuse en mis estudios y escritos filosóficos fue no seguir por sistema a ningún maestro, sino abrazar y defender lo que me parecía más probable, ya viniese de Platón, ya de Aristóteles, ya de cualquier otro. No dudo que esta manera de filosofar desagradará a hombres divididos en varias sectas y pertinacísimos en defenderlas; pero juzgo que el amor de la verdad debe anteponerse a toda autoridad y respeto humanos. Yo sólo doy fe a los testimonios divinos, y a los de la Iglesia católica, y los acato y defiendo en todo como infalibles y eternos oráculos». ${ }^{739}$ "Eam enim semper rationem inire in studiis meis vel scriptis decrevi, ut nullius in verba auctoris jurare velim, sed quae mihi magis probabilia videantur, ea maxime complectar, sive ab Aristotele, sive a Platone, sive a quovis alio dicatur; quae vero minus probabilia, rejiciam. Hoc sane philosophandi genus, quamvis multis

736 Colección de documentos inéditos, tomo II, Proceso del Brocense. (Segunda edición)

737 Tomo I de sus obras, edición de Ginebra, pág. 453. (Segunda edición)

738 «Itaque nisi te totum inquisitioni tradideris, nisi artis tuae quam tractas, causas rationesque probe fueris perscrutatus, crede te alienis oculis videre, alienisque auribus audire.» (Minerva, pág. 2; edición de Ginebra, 1789). (Segunda edición)

739 Sebast. Foxii Morzilli, Hispalensis, De naturae philosophia. He cotejado dos ediciones de este libro: la una de Lovaina, 1554; la otra de París, 1560. (Segunda edición)

Después he adquirido la de Wittenberg, 1593, que no encuentro citada por los bibliógrafos. (Añadido de la Tercera edición) 
qui ut varias sectas adamarunt, ita pugnacissime tuentur, displicere, adeoque in varias reprehensiones incurrere me posse non dubito, tamen... anteponendum est studium veritatis opionioni de alterius auctoritate temere sumptae. Nos tantum divinis et Ecclesiae catholicae testimoniis fidem adhibemus, eaque tanquam certa et stabilia oracula amplectimur et tuemun.

En el tratado de Studii philosophici ratione ${ }^{740}$ señala Fox, como una de las principales fuentes de error, el jurare in verba magistri, y adherirse a un sistema. Y tan allá lleva el filósofo hispalense este principio, a pesar de sus tendencias platónico-aristotélicas, que en el tratado De demonstratione ejusque necessitate ac $v i^{741}$, quizá el más original de todos los suyos, anuncia que prescindirá de todo lo que halló escrito, guiándose sólo por sus propias observaciones, basadas muchas de ellas en el estudio de las matemáticas.

Esta tendencia crítica se extrema en manos del Hipócrates complutense, Francisco Vallés, que juzgó necesario, para no caer en error, «dudar de todo, hasta de lo más probable». ${ }^{72}$ "Necesse est ut in rationum investigatione... etiam de his quae sibi videntur probabilissima, nisi se ipsos velint fallere (homines) dubitent»; a pesar de lo cual, Vallés dista mucho de ser escéptico, dado que admite las verdades per se notas, con todas sus consecuencias, siempre que tengan aquella evidencia matemática que el Brocense pedía. En cuanto al conocimiento de las cosas sensibles, no pasa de opinión más o menos probable, y ni hay ni puede haber verdadera ciencia física. ${ }^{743}$

De tales doctrinas al escepticismo puro y neto no había mucho camino, y de cierto le anduvo el médico portugués Francisco Sánchez, cuyo agudo e ingenioso libro De multum nobili, prima et universali scientia quod nibil scitur, ${ }^{744}$ conoce V. sobradamente. Pero justo será advertir que la ciencia que Sánchez principalmente ataca es la de su tiempo, no la ciencia en general, sobre cuyo método ofrece escribir un tratado: "Interim nos ad res examinandas accingentes, an aliquid scitur et quomodo, libello alio praeponemus, quo

740 Ed. de Leyden, 1621. (Segunda edición)

741 Ed. de Basilea, por Juan Oporino, 1556. (Segunda edición)

742 Philosophia Sacra: de iis quae scripta sunt physice in libris sacris, cap. LXIV. (Ed. de Turín, 1587). (Segunda edición)

743 «Materialium vero notitia cum pertineat ad sensum, non potest ultra opinionem procedere». (Pág. 478 de la Sacra Philosophia). (Segunda edición)

Por eso ha dicho con razón Fr. Zeferino González que Vallés admite la tesis dogmática, pero con restricciones y reservas escépticas. (Añadido de la tercera edición)

744 Este libro se imprimió por vez primera en 1577. La edición que yo tengo es de Francfort, 1618, sumptibus Joannis Berneri Bibliopolae. Está además incluido en la colección completa de las obras de Sánchez. Francisci Sanchez Opera Medica. His juncti sunt tractatus quidam Philosophiae. Tolosae Tectosagum, 1636, 4º. (Segunda edición) 
methodum sciendi, quantum fragilitas humana patietur, exponemus». Pero como este libro falta, y sólo queda el de las dudas y objeciones, de aquí que el nombre de Sánchez aparezca en primera línea entre los escépticos. Acaso acertaría más el que le considerase como precursor del criticismo kantiano.

Con audacia no menor, aunque con tendencias empíricas en vez de escépticas, mostraron igual desprecio de la tradición Doña Oliva Sabuco de Nantes en su Nueva filosofía de la naturaleza del hombre, y Juan Huarte de San Juan en su conocido Examen de ingenios. A juicio de la doctora de Alcaraz, los antiguos se habían dejado intacta la filosofía que ella daba a luz, «con ser la verdadera, mejor y de más fruto para el hombre. Y el que no la entendiere ni comprendiere (dice en otra parte) déjela para los otros y para los venideros, o crea a la experiencia y no a ella». ${ }^{745} \mathrm{La}$ experiencia es para Huarte, lo mismo que para Dońa Oliva, la piedra de toque de todo conocimiento.

Estas citas, a las cuales fácilmente pudieran añadirse muchas, así de aristotélicos clásicos como de ramistas, escépticos, etc., bastan, según entiendo, para establecer cierta manera de conformidad en cuanto a independencia filosófica entre nuestros pensadores no escolásticos del siglo Xvi. El influjo de Vives es, en mi juicio, la causa inmediata de esta dirección. Por lo demás, cada autor, según las particulares aficiones de su espíritu, escogió diverso criterio de verdad, inclinándose unos a la experiencia, otros a la razón como facultad de las ideas puras, algunos al sentido común, y otros a la evidencia matemática. Pero todos convinieron en ser ciudadanos libres de la república de las letras.

Así se mostró en los fines de aquel siglo y principios del siguiente, Pedro de Valencia, al exponer y analizar con vislumbres escépticas las doctrinas de los antiguos sobre el juicio de la verdad (de judicio erga verum), en el precioso opúsculo que intituló Academica. ${ }^{746}$ Así, en tiempo de Felipe IV, el P. Poza, en su lección de placitis philosophorum. Así el jesuita logronés Rodrigo de Arriaga, que con ser escolástico, no dudó en contradecir a Santo Tomás y a Suárez, «teniendo ante los ojos la sola y desnuda verdad, despojándose de todo afecto de escuela, y considerando que el ingenio humano no quedó agotado en Platón ni en Aristóteles». Así, en 1673, Isaac Cardoso, que en su egregia Philosophia Libera se propuso no dar nunca a meras opiniones el

745 Prólogo al lector. Carta dedicatoria a Felipe II, en la Nueva Filosofía, ediciones del Dr. Martín Martínez y de D. Ildefonso Martínez. (Segunda edición)

746 Academica. Antuerpiae, ex officina Plantiniana, apud viduam et Joannem Moretum, 1596. (Hay dos reimpresiones la de Cerdá en sus Clarorum Hispanorum Opuscula, y la incluída en el tomo XII de las obras de Cicerón, impresas en Madrid, 1797). (Segunda edición) 
valor de demostraciones o dogmas. "Ita mentem disponemus ut neque alicui sectue addicti aut sapientiae primoribus alligati, illius tantummodo placita, aliis despectis, amplectamur, nec opiniones tanquam fides aut demonstrationes recipiendae» ${ }^{747}$. Así el obispo Caramuel, que en su Metalogica, exclama: «No soy enemigo de los peripatéticos, aunque tampoco sea ni quiera ser llamado peripatético; busco la verdad sola; sólo la verdad amo». ${ }^{748}$

Lo mismo Caramuel que Cardoso, pertenecen a los últimos años del siglo XVII; a dos pasos de ellos están los PP. Tosca y Feijoo. ¿Dudará alguno de la persistencia del espíritu vivista en nuestra cultura? Si mayor prueba se necesitara, bastaría recorrer las inestimables páginas de la Philosophia Libera, donde hormiguean las citas de nuestros pensadores, desde Vives en adelante.

Harto me he detenido en esta digresión, encaminada a probar que la tendencia crítica de Gómez Pereira es sólo una fase del espíritu general de nuestra ciencia libre en los dos siglos XVI y XVII, aunque menoscabada en el segundo. Ahora conviene entrar en el examinen de la Antoniana, que, por no ser un tratado metódico de psicología, de física ni de metafísica, sino un libro de controversia, una serie de paradojas, presenta las cuestiones en orden poco riguroso y sistemático. Como la exposición que voy a hacer es puramente analítica, no hay inconveniente en tratarlas por el orden en que él las trae. Lo que me propongo no es reconstruir el sistema, sino dar a conocer la obra.

I. Automatismo de las bestias. - Acepto esta expresión como admitida por el uso, aunque no es del todo exacta ni corresponde a la verdadera tesis de Gómez Pereira. Por lo demás, si hace algunos años podía juzgarse vano ejercicio escolástico y pura sofistería la cuestión del alma de los brutos, a nadie ha de parecerle tal, hoy que anda en boga esa nueva ciencia apellidada con escasa propiedad psicología comparativa. Cuestión de psicología comparativa o comparada es la que discute el médico castellano, y justo será oír los fundamentos de su primera paradoja la cual está formulada en estos términos: Bruta sensu carere (los brutos carecen de la facultad de sentir).

Nada más opuesto a la psicología peripatética, la cual, concediendo al bruto alma sensitiva, sólo le negaba la racional. Y no faltaban filósofos y aun teólogos que admitiesen en los brutos cierta manera de raciocinio, negándoles sólo el conocimiento de lo universal. ${ }^{749}$ En cuanto al valor de la

747 Proemio de la Philosophia libera. Ya volveré a hablar de este libro. (Segunda edición)

748 «Non ago peripateticorum hostem, tametsi nec esse neu dici velim peripateticus, unicam veritatem quaero: veracitatem amo». (Cita ya aducida por nuestro amigo Laverde. Es del lib. IV, disp. VIII de la Metalogica). (Segunda edición)

749 «Verum cum sciam non defuisse ex Theologorum numero aliquos asseverantes etiam ratiocinari aliqua bruta, indeque inferant non ex hoc solum homines a brutis 
palabra ratio, casi todos decían con Pereira que es vis animi distinguendi ac connectandi (la facultad de distinción y relación).

La doctrina del alma de los brutos pasaba por axioma tan cierto como éste: el todo es mayor que una de sus partes. Algunos suponían del todo idénticos los juicios del bruto y los del hombre, afirmando que si hablara el primero, llamaría, como nosotros, album al color blanco, y quadratum a la figura cuadrada.

El primero y más fuerte de los argumentos de Gómez Pereira es éste:

«Si el animal siente, tiene forzosamente que juzgar; si juzga, raciocina; si raciocina, forma proposiciones universales: luego no habrá distinción especial entre él y el hombre; consecuencia inadmisible y absurda». Esta conclusión, a primera vista tan precipitada, se funda en las premisas siguientes:

«Si los brutos ejerciesen los actos de los sentidos exteriores como el hombre, al ver un perro o un caballo a su dueño, concebiría lo mismo que concibe un hombre cuando ve a su señor, y afirmaría mentalmente que aquél era su dueño... Y si no queréis confesar esto, ni conceder tanto a los brutos, no negaréis, a lo menos, que el bruto forma proposiciones mentales, lo cual no puede hacerse sin alguna facultad interior estimativa o cogitativa. El bruto distingue al amigo del enemigo; luego hay que concederle la distinción, que es la más importante entre las operaciones racionales.»

«Pensarán algunos destruir esta razón, diciendo que no todos los que conocen afirman la existencia de un objeto, puesto que en el conocimiento de simple aprehensión no se afirma ni se niega nada. Por simple aprehensión pueden conocer los brutos las cosas sensibles, sin afirmar que sean o no tales cuales son.»

La cuestión toma aquí nuevo giro, y Gómez Pereira impugna de esta manera el primer modo de conocimiento imaginado por los peripatéticos:

«Si la sensación y el conocimiento de la cosa que se desea antecede forzosamente al movimiento prosecutivo hacia la cosa misma, necesario es que la noción de la cosa apetecida sea una noción distinta, con afirmación de lo que es y dónde está (quod est aut ubi est). Fuera absurdo imaginar que el bruto se mueve hacia un fin, ignorando cuál es y dónde se halla. No niego que se dé algún conocimiento sin afirmación de existencia como el de la quimera; pero tengo por imposible huir de una cosa cuando se ignora hasta su existencia. ${ }^{750} \mathrm{El}$ que afirma que los brutos conocen a sus amigos

distingui, sed alio quodam proprio modo, pura cognitione universalis» (Ant. Marg.). Cito siempre por la primera edición. (Segunda edición)

750 «Si sensus et cognitio rei quae diligitur et quam consequi cupimus, antecedit motum prosequutivum, necessario non tantum sensus simpliciter aprehendens antecedere debet 
o enemigos, ha de confesar que forman juicios o proposiciones mentales. Si el cordero conoce al lobo presente, será porque forma esta proposición mental: el que está presente es el lobo. Afirmación particular, que sólo puede fundarse en el conocimiento universal del lobo y todo lobo, como dirían los modernos sofistas. El cordero, por tanto, deduce la conclusión de las premisas.»

«En nada favorece a los adversarios la distinción de los dos modos de conocimiento excogitada por Aristóteles. No basta la simple aprehensión sin juicio para buscar la cosa apetecida, o huir de ella. También hemos de conceder a las bestias la segunda operación del entendimiento, la facultad de componer y dividir, porque nadie puede afirmar: esto debo hacer, sin haber aseverado antes: esto es lo que es, estableciendo una relación entre dos juicios.»

Y a los que recurren al instinto, les responde: "O el instinto es una facultad y propiedad natural, o es algo diverso. Si lo primero, ¿para qué introducir una facultad distinta de la razón? Si lo segundo, será bien que los adversarios expliquen lo que es el instinto, porque yo no veo medio entre la propiedad que nos mueve hacia una cosa o nos aparta de ella, y la facultad de sentir y juzgar, que busca lo útil y huye de lo dañoso». ${ }^{751}$ El instinto era (como las especies inteligibles, la materia prima, etc.) uno de los fantasmas de la filosofía escolástica que daban más pesadilla a Gómez Pereira.

De las obras admirables de los animales, de sus costumbres, referidas por Aristóteles y Plinio, saca el autor de la Margarita la consecuencia de que son máquinas prodigiosamente organizadas, so pena de concederles las mismas facultades que al hombre, si no mayores.

Y razonando siempre por reducción al absurdo, afirma que pensarán en la inmortalidad del alma y temerán los castigos de la otra vida,${ }^{752}$ puesto que hacen todo lo posible por conservar ésta, defendiéndose de la inclemencia de las estaciones y de todo linaje de peligros. Argumento éste de bien poca fuerza, porque basta el amor a la conservación natural para explicar tales actos.

hunc motum, sed cognitio distincta rei prosequendae cum assertione quod est aut ubi est: aliter enim capere intellectus non potest brutum sic aliquid cognoscere, ut nesciat an sit vel non sit, neque ubi sit. Quippe non negamus aliquid cognosci posse absque assertione... ut de chimaera... sed imposibile reputamus fugi quod esse ignoramus». (Segunda edición)

751 «Si quid aliud, cum instinctum naturalem dicunt, intelligunt, id explicent, nam medium nullum inter proprietatem qua trahitur aut fugatur quidpiam, et vim sentiendi et existimandi qua prosequitur utile et fugatur inutile, percipi potest».(Segunda edición)

752 «S concedatur quod periti atque indocti philosophorum opinati sunt, convenire in sentiendo homines ac brutos, ipsa etiam de sede animorum suorum post obitum curam habitura». (Segunda edición) 
Tendrán asimismo los brutos el don de pronosticar los fenómenos naturales, como lo advertimos en los alciones cuando se acerca la tormenta, según aquello de nuestro poeta:

$\mathrm{Ni}$ baten las alas ya los alciones,

$\mathrm{Ni}$ tentan jugando de se rociar.

Los cuales amansan la furia del mar

Con sus cantares y lánguidos sones.

¿No indica maravilloso discurso, apenas por el hombre igualado, la industria de las abejas y el buen orden y regimiento de su república?, et sic de caeteris, porque Gómez Pereira prosigue acumulando ejemplos.

«Si los brutos sienten como nosotros y juzgan, componen y distinguen, sacarán de las premisas la conclusión, y conocerán, por tanto, los universales. Si huyen del fuego, es porque conocen la proposición universal: Omnis ignis est calidus, ${ }^{753}$ la cual han inducido de muchas proposiciones singulares. ¿Dónde queda la diferencia específica del hombre? ¿Por qué le llamamos animal racional?"

«Síguese otro inconveniente mayor: las almas de los brutos tendrán que ser indivisibles como el alma humana, porque una substancia divisible no puede engendrar el pensamiento. Lo que conociese la parte anterior, no sería percibido por la posterior, y viceversa. La distinción fuera imposible. Mas, por experiencia, se ve claro que el bruto distingue y conoce la cantidad». ${ }^{754}$

«Concedida la sensibilidad, hay que conceder a los brutos la conciencia. Conocerán que ven, conocerán que oyen; podrán juzgar de sus propios actos y distinguir los accidentes de la súbstancia.»

Dejemos a un lado otros argumentos de menor fuerza, y vamos a la extraña solución que Gómez Pereira da al problema.

«Los brutos (según él) se determinan a obrar y a moverse mediante ciertas cualidades transmitidas por los objetos extrínsecos a los órganos de los sentidos, o por los accidentes que producen en la economía animal los fantasmas encerrados en el órgano de la memoria (in loco memorativo).»

Gómez Pereira cree en las cualidades ocultas, y por ellas explica el movimiento de los graves, la reflexión de la luz, etc. («Est enim talis naturae ordo

753 «Eliciunt enim ex omnibus singularibus universalem propositionem». (Segunda edición)

754 «Illius cognitionis dimidia pars certae parti cognitivae inhereret, et altera dimidia alteri... Ea pars facultatis cognitricis bruti quae afficitur sensatione anterioris partis non poterit cognoscere posteriorem, neque quae cognoscit posteriorem valebit percipere anteriorem. Ergo nulla pars bruti poterit distinguere inter utraque». (Segunda edición) 
quod quanto a magis elato loco grave descendit, ac cum majore impetu cadit, tanto in altiorem partem resilit.")

De aquí procede también, y no de la sensación, el movimiento de los brutos. Conviene saber que los brutos se mueven:

$1^{\circ}$ Por las cosas presentes que mandan su imagen o algo equivalente a los órganos que impropiamente decimos sentidos. De aquí que huya el animal cuando alguno le amenaza, y se arroje sobre el alimento cuando le ve cerca.

$2^{\circ}$ Por los fantasmas de las mismas cosas que, presentes, fueron causa de movimiento en otra ocasión. Así buscan los perros a su dueño ausente, etc.

$3^{\circ}$ Por hábito y enseñanza.

$4^{\circ}$ Por causas ocultas, que es lo que llaman instinto natural. Sólo así pueden explicarse ciertas operaciones de las hormigas y de las abejas.

No valía la pena de haber destruido con hábil dialéctica el sistema antiguo, para levantar después tan frágil edificio. Estas soluciones son una pura contradicción; admite el instinto o algo parecido a él, después de haberle negado; supone al bruto capaz de enseñanza, cuando antes ni aun le concedía sensibilidad, y vuelve a los fantasmas y a las cualidades ocultas de la escuela, faltándole poco para decir que el fuego quema porque tiene virtud ustiva.

En la explanación del sistema hay cosas muy peregrinas y de sabor crudamente materialista.

La primera especie de movimiento puede ser de tres clases: natural (el de los graves), voluntario (el del hombre), orgánico o vital (el de los brutos). La especie o imagen del objeto, recibida en algún órgano, se trasmite a aquella parte del cerebro de donde arrancan los nervios motores. La cual parte produce una reacción que contrae o dilata los miembros del animal, forzándole a moverse. Este movimiento es doble: de simpatía o de antipatía. ${ }^{755}$

Al dar esta explicación fisiológica, ¿̨no pensó Gómez Pereira, no vieron los calificadores del Santo Oficio, que con un poco de lógica era fácil aplicarla a los actos humanos? A uno y a otros su firme creencia en la espiritualidad del alma y en la libertad humana debió de ocultarles las consecuencias de aquella atrevida paradoja, sostenida con una cadena de sofismas.

Segunda especie de movimiento. Los fantasmas son para Gómez Pereira unos corpúsculos sutilísimos (spirituosa) transmitidos de oculto modo por los objetos exteriores. En ausencia de los objetos mismos, se conservan en el triclinio de la parte posterior de la cabeza, asiento de la memoria, y obrando

755 «Species rei inductae per nonnullum organum usque ad eam partem cerebri quae origo nervorum est, quae necessario sic statim contrahit et distendit diversas partes animalis ut eas decet ad motum exequendum». (Segunda edición) 
a veces sobre la parte anterior, determinan un movimiento análogo al que produjo la primera vista del objeto. ${ }^{756}$

Lo peor es que Gómez Pereira aplica proporcionalmente esta misma explicación de la memoria y de la abstracción al hombre. «Habéis de saber que tienen los brutos en la parte occipital una celdilla, donde se conservan al vivo las imágenes de los objetos. En esto somos muy parecidos a las bestias. Pero además de esta potencia conservadora de los fantasmas que decimos memoria, tenemos en el synciput otra facultad para conocer los objetos de quienes los fantasmas proceden, por vista y consideración del fantasma mismo que ante la parte anterior de la cabeza se presenta: y este conocimiento es el que llamamos abstractivo. En el bruto hay algo semejante, situado también en la parte syncipital. Cuando esta facultad entra en ejercicio, los miembros del animal se mueven». ${ }^{757}$

Tercera especie de movimiento. Para explicar la educación de los animales, cosa apenas compatible con su sistema, supone que la onda sonora hace mover las cosas que toca y hiere. El sonido de la voz humana se transmite, hiere los nervios; llega la impresión al cerebro, éste reacciona y produce el movimiento: «quemlibet aerem motum sic conari movere quascumque res ab eodem contactas, prout ipse moveturn.

De la cuarta y última razón de las operaciones del bruto dice poco o nada. Dase por satisfecho con atribuirlas a una causa exterior y oculta, llámese occulta vis, causa prima, alma del mundo, etc.

Tal es, sucintamente, pero con fidelidad expuesto, el famoso automatismo de Gómez Pereira, acerca del cual corren muchas ideas incompletas y equivocadas entre los que sólo de oídas conocen su libro. Dicen que negó el alma a las bestias; pero la verdad es que les concede un alma divisible y perecedera, que se engendra por partes, como el alma de la planta («quae ab ortu usque ad interitum deperdatur et gignatur per partes, ut anima plantae»). Unas veces la identifica con el aliento vital, otras con el organismo. Tiene cuantidad y está sujeta a la muerte ("quanta et interitui obnoxia»).

756 «Phantasmata esse quaedam corpuscula spirituosa, occulto quodam modo afecta $a b$ extrinsecis objectis afficiendo partem cerebro anteriorem... Bruta moventur phantasmatibus illarum rerum mutis in partem anteriorem cerebri proportionalem nostrae cognoscenti abstractive, indeque ipsa bruta compulsa versus rem qua indigent ferri». (Segunda edición)

757 «Scire decet in occipiti brutorum esse quoddam scrinium seu cellam quamdam in qua imagines eorum... ad vivum... asservantur... qua in re brutis simillimi sumus. Sed in nobis ultra potentiam hanc servatricem phantasmatum, quae memoria appellatur, est in syncipite facultas alia qua cognoscimus res illas a quibus phantasmata genita fuere», etc., etc. (Segunda edición) 
Cuando hacemos pedazos a un gusano, queda en cada trozo un alma que le hace moverse, vivir y propagarse, y en cada una de las partes divididas se conservan los fantasmas.

Pedro Bayle demostró prolijamente (y no hay para qué rehacer su trabajo) que esta opinión del automatismo (llamémosle así para excusar rodeos) fue parto del ingenio de Gómez Pereira, sin que se encuentren rastros de ella en toda la antigüedad griega y latina. ${ }^{758}$ Algunos la han atribuido a los

758 Es cierto que en tiempo de San Agustín, como parece por su libro De quantitate animae, capítulo XXX, se disputaba sobre el alma de las bestias, y no faltaba quien la negase. (Quod autem tibi visum est non esse animam in corpore viventis animantis, quamquam videatur absurdum, non tamen doctissimi homines quibus id placuit defuerunt, neque nunc arbitror deesse). Es cierto también que los estoicos, en particular Séneca, no reconocían en los brutos pasiones ni afectos, semejantes a las pasiones y afectos humanos: Irasci magis sciunt quam ignoscere, et quantumvis rationi inimica sit ira, nusquam tamen nascitur, nisi ubi rationi locus est. Tota ferarum, ut extra, ita intra, forma humana, dissimilis est, leemos en el libro De Ira, cap. III. Por último, Diógenes el Cínico (si hemos de atenernos a la autoridad del pseudo Plutarco) enseñaba que las bestias, por exceso de humedad y densidad de temperamento, no eran susceptibles de conocer ni de sentir.

Estas razones fueron alegadas por un tal M. de Rondel, en carta a Bayle, extractada por éste en las Nouvelles de la Republique des Lettres de octubre de 1684, y en una Memoria que luego le remitió en marzo de 1696, y que está copiada en parte en las notas al artículo Pereira del celebérrimo Dictionnaire Historique et Critique.

Pero nada de esto tiene que ver con el automatismo de Gómez Pereira. La originalidad de éste consiste, no en haber negado el alma de las bestias (hemos visto más arriba que la admite en cierto sentido materialista), sino en la cadena de razonamientos que le condujeron hasta suponer insensibles a los brutos, y en el sistema completamente original que inventó para explicar sus operaciones, y que, en substancia, es el mismo de Descartes.

Bayle demuestra, en una larguísima nota del Diccionario (pág. 2.230, ed. de Rotterdam, 1720), que ni los cínicos ni los estoicos tenían verdadera conciencia de la distinción entre el alma humana y la materia. En cuanto a Séneca, el pasaje del libro De Ira no puede pasar más que por una hipérbole oratoria, puesto que está contradicho formalmente por otro lugar más explícito de la Epístola 124, en que se afirma con toda claridad que los brutos sienten las cosas presentes y se acuerdan de las pasadas (Mutum animal sensu comprehendit praesentia; praeteritorum reminiscitur); y hasta les concede Séneca cierta manera de bien, de virtud y de perfección. Plutarco escribió un tratado entero para probar que los brutos gozan de razón; pero no indica que a nadie se le hubiese ocurrido negarles potencia sensitiva. El tratado De placitis philosophorum, en que se refiere la extraña opinión de Diógenes, es contado hoy entre los escritos apócrifos de Plutarco.

El obispo Huet, empeñado en encontrar por todas partes gérmenes de la doctrina cartesiana, para demostrar que nada tiene de original, quiere hacer partidarios del automatismo a Cicerón (en el lib. IV de las Tusculanas), y a Platón y a Proclo (Vide: Censura Philosophiae Cartesianae, cap. VIII.). Pero Cicerón no hace más que exponer la distinción estoica entre los afectos del hombre y los del bruto. Proclo, siguiendo la doctrina corriente entre los platónicos, se limita a decir que las demás almas, comparadas con el alma racional, apenas merecen el nombre de simulacros. (Vide sobre este punto la 
estoicos; pero hubieran salido de su error con sólo leer en el libro I de las disertaciones de Arriano sobre Epitecto el capítulo VI, donde se niega que los brutos tengan razón, pero no se pone en tela de juicio el que sientan.

De los nuestros llevó la misma opinión Juan Luis Vives, en el libro II de su bello tratado De anima et vita, ${ }^{759}$ donde leemos: «Brutum sequitur id quod vel sensu est simpliciter cognitum, vel a phantasia copulatum compactumque, vel ab extimatrice stimulatum, tanquam tacito calcari naturae; homo autem componit ac dividit, et ab aliis ad alia transit, conferens ea inter se, ex quibus aliquid pariat atque eliciat». Admite Vives en los brutos sensación, fantasía y estimativa, pero de ningún modo razón, ni menos inmortalidad ("irrationabiles esse et mortalibus animis praeditas»).

Ésta era la doctrina corriente entre escolásticos y no escolásticos, con muy leves diferencias. Esta misma se formuló repetidas veces en lengua castellana. Por ejemplo, Francisco Cervantes de Salazar, en la continuación del Diálogo de la dignidad del hombre, enseña que éste «es igual con las plantas en el crecer, lo cual en ellas se llama ánima vegetativa; igual con los animales en el sentir, lo cual en ellos se dice ánima sensitiva; pero tiene

25 Disertación de Máximo de Tiro, cuya doctrina es idéntica a la de Arriano, y prueba la armonía de estoicos y académicos en este dogma).

Bayle, que tenía especial cariño a esta cuestión, como a todas las extravagantes y desusadas, que ofrecían vasto campo a su espíritu curioso y errabundo, vuelve a tratarla con grandes desarrollos en el artículo sobre Jerónimo Rorario, autor de un tratado en defensa de la racionalidad de las bestias. Mucho antes la había defendido con genialidad humorística el singular poeto mallorquín de principios del siglo xv, Fr, Anselmo de Turmeda, en la extrańa alegoría satírica que compuso en Túnez (1417) con el título de Disputa del Ase contra frare Enselme Turmeda sobre la natura é noblea dels animals, obra de la cual no se conoce hasta hoy el texto catalán, aunque consta que se imprimió en Barcelona en 1509, ni la traducción castellana que al parecer existió, según se infiere de los antiguos Índices Expurgatorios, pero sí una versión francesa, que se imprimió en Lyon, 1548, y en París, 1554. El libro es una especie de novela, que luego imitó Maquiavelo en los Capitoli de su Asino d'Oro, obra que algunos, guiados por el sonsonete del título, creen mera imitación de Apuleyo, siendo así que tiene mucho más de Fr. Anselmo. En la novela de éste, el autor, perdido en un espeso bosque, halla congregados a los animales, y se ve precisado a disputar con un asno, que le prueba las excelencias de los animales sobre el hombre. En Maquiavelo, es un puerco quien sostiene el peso de la disputa. Contra el libro de Turmeda se escribió en francés otro, que no hemos visto: La Revanche et contredispute de frère Anselme Turmeda contre les bêtes, por Mathurin Maurice, 1554.

Sobre Turmeda, véase el interesante opúsculo biográfico recientemente publicado en Mallorca por D. Estanislao Aguiló. (Tercera Edición)

759 Joannis Ludovici Vives Valentini, De anima et vita libri tres. Opus insigne, nunc primum in lucem editum. Basileae, 1538. Ej. de mi Biblioteca. Es la ed. príncipe. Pág. 69. (Segunda edición) 
razón, de la cual las plantas y bestias carecen». Y el sentir, en opinión del humanista toledano, "es de dos maneras, interior y exteriormente, porque el hombre (lo que no hace el animal) siente dentro el mal y el bien», es decir, tiene conciencia. ${ }^{760}$

Los tomistas glosaron en diversos sentidos estas palabras de la Summa contra gentes (libro III): "Actus creaturarum irrationalium prout ad speciem pertinent, diriguntur a Deo quodam naturali inclinatione (el instinto) quae naturam speciei consequitur. Ergo supra hoc dandum est aliquid hominibus, quo in suis personalibus actibus dirigantun». Algunos escolásticos, entre ellos nuestro insigne Francisco de Toledo, juzgaron que en ciertas especies de animales, notables por la sabiduría y prudencia de sus operaciones, había una fantasía o imaginación (que de ambos modos la llamaron); pero no disciplinable ni capaz de enseñanza: «Bene concluditur habere illa animalia (formicae et apes) phantasiam, sed non disciplinabilem». ${ }^{761}$

Júzguese qué escándalo produciría en las aulas la resbaladiza paradoja de Gómez Pereira. El primero que salió a impugnarla fue el granadino Miguel de Palacios, teólogo y filósofo peripatético de los más notables, autor de un comentario al tratado De anima, y profesor muchos años en Salamanca. El opúsculo que escribió contra algunas paradojas de la Antoniana se imprimió en 1555 en Medina del Campo, y es muy raro. He visto un ejemplar, encuadernado con la obra de Gómez Pereira, en la Academia de Ciencias de Lisboa, y su descripción bibliográfica es ésta:

Objectiones Licentiati Michaelis a Palacios, Catedratici Sacrae Theologiae in Salmantina Universitate, adversus nonnulla ex multiplicibus Paradoxis Antonianae Margaritae, et Apologia eorumdem.

Al fin: Excussum est Methymnae Campi in officina chalcographica Guillelmi de Millis vigesima die Martii, Anni 1555.

El argumento principal, el Aquiles, como dicen, de Gómez Pereira, está contestado en los términos siguientes: «Dices que si los brutos están dotados de sensibilidad, también lo estarán de razón. ¿Pero no ves que la fuerza sensitiva interior en los brutos es sólo aprensiva y no discursiva o judicativa? ¿No basta la aprehensión interior para excitar el apetito, y éste el movimiento exterior? Nosotros mismos experimentamos esto en los movimientos repentinos, huyendo a la sola aprehensión de un mal terrible que de pronto se nos ofrece. El que nunca oyó el estruendo de las bombardas, ni sabe qué cosa

760 Obras de Francisco Cervantes de Salazar, páginas 156 y 157 (ed. de Cerdá y Rico. Madrid, 1772). La primera es de Alcalá, por Juan de Brocar, 1546. (Segunda edición)

761 D. Francisci Toleti... Commentaria una cum quaestionibus in tres libros Aristotelis De anima... Venetiis apud Juntas, 1586, folio 133 vuelto. (Segunda edición) 
sean, tiembla y se estremece cuando por primera vez lo escucha, por sola la aprehensión, sin que intervenga el juicio... La simple percepción del mal induce a huirle; la simple percepción del bien, a buscarle». ${ }^{762}$

Tampoco admitía Miguel de Palacios que de la sensación se dedujese lógicamente la conciencia. "Cosas muy diversas, escribe, son el sentir y el saber que se siente. La primera de estas operaciones es directa, la segunda refleja. En el hombre mismo suelen andar separadas, cuanto más en el bruto. El que éste sienta, no implica en manera alguna que reflexione». ${ }^{763}$

En esto, como en otras cosas de su réplica, anduvo Palacios discreto y sagaz, y puso verdaderamente el dedo en la llaga. Gómez Pereira se defendió habilísimamente, dando cierta especiosidad a su paradoja, pero poniéndose a dos dedos del materialismo.

$\mathrm{Al}$ año siguiente (1556) apareció en la misma villa de Medina, centro entonces de gran comercio de libros, uno, hoy rarísimo, con el título de Endecálogo contra Antoniana Margarita, sin duda por constar de once proposiciones. No he visto este opúsculo, pero ustedes tienen en Madrid dos ejemplares, uno en la Biblioteca Nacional, entre los libros que fueron de D. Serafín E. Calderón, y otro en la colección de Salvá, que hoy posee D. Ricardo Heredia. ${ }^{764}$ Yo sólo puedo decir, por testimonio de D. Andrés Piquer en su Discurso sobre el sistema del Mechanismo, que el Endecálogo está escrito en romance (contra lo que generalmente se usaba en libros de filosofía), y tiene la forma de un diálogo satírico y burlesco, en que hablan el simio, el murciélago, el cocodrilo, el león, el águila, la ballena, el lobo, el elefante y otros animales, y presentan a Júpiter una demanda criminal contra Gómez Pereira, por haberlos despojado de la posesión de sentidos, apetitos, etc. Nombran procurador, hacen un pedimento, y alcanzan favorable sentencia. «Por la lectura de este diálogo (ańade Piquer), se echa de ver cuán extravagante pareció a los españoles la opinión de Pereira, que después fue recibida con tanto aplauso fuera de España por su novedad, y se ve también que el autor del Endecálogo era más satírico que filósofo». Morejón añade que en la mayor parte del opúsculo, el autor se entrega a

762 «Vereris enim si sensu praedita sint bruta, ratione item esse praedita... Primum enim facile tibi dicerem, vim sensitivam interiorem esse solum aprehensivam, et non judicativam, in brutis», etc., etc. (Segunda edición)

763 «Sunt enim duae mutationes diversae, et sentire, et sentire se sentire. Altera quidem directa est, ut nosti, altera reflexa. Quare dissociantur saepissime in hominibus, necdum in brutis. Fieri igitur poterit brutum sensionem habere et sensu potiri, citra reflexionem»... (Lo mismo las Objectiones que la Apología, están reimpresas al fin de la tercera edición de la Antoniana). (Segunda edición)

764 Después he visto el que posee D. Aureliano Fernández-Guerra. (Tercera edición) 
impertinentes digresiones históricas sobre el Gran Capitán, sobre las guerras de Italia y África, y otros mil asuntos que nada tienen que ver con la filosofía, ni con la Antoniana.

El divino Francisco Vallés atacó la doctrina de Gómez Pereira, aunque sin nombrarle, en el capítulo LV de la Sacra Philosophia. "Un escritor nuestro (dice), por no conceder a los brutos la razón, temeroso (a lo que sospecho) de tener que atribuirles asimismo la inmortalidad, les negó hasta el sentido, explicando todas sus operaciones por naturales simpatías y antipatías. Admitida esta tesis, síguese una de dos cosas: o que nadie siente sino el hombre, o que todos los animales están dotados de razón y entendimiento. ${ }^{765}$ La primera opinión es absurda, porque en tal caso ninguna fe podremos dar a nuestros sentidos, y es verdadera locura el negar que tienen sensibilidad unos entes a quienes vemos huir del peligro, acudir a la voz y al reclamo, observar las leyes de la amistad y de la enemistad, etc. Dejado aparte este delirio, resta considerar si los brutos poseen alguna manera de razón». Y de hecho Vallés se la otorga: "Certe rationem aliquam esse brutis negare non possumus citra proterviam» y lo prueba por sus maravillosas operaciones, haciendo una brillante retorsión de los argumentos de Gómez Pereira en pro de la tesis contraria: «Si negamos a los brutos la razón, hemos de negarles el sentido; pues cómo se conocen las facultades sino por sus actos, y los actos sino por sus operaciones?». ${ }^{766} \mathrm{El}$ mismo procedimiento lógico que llevó al autor de la Margarita a asentar el automatismo, convenció a Vallés de que todo animal era racional, aunque con razón muy diversa de la humana, no sólo en grados, sino en la misma esencia, por ser el entendimiento humano capaz de las ideas puras: «ex sese nata est (mens) ratiocinari simpliciter et circa quidvis». Por lo cual corrigió la antigua definición del hombre en estos términos: animal científico o capaz de ciencia, es decir, de conocimiento ordenado, metódico y dependiente de los universales. De otro pasaje se deduce que concedía a los brutos la simple cogitación, cum praesensione finis, pero sin elección de

765 «Quidam nostratium nuper, ne brutis concederet rationem, timens (arbitror) ne et immortalitatem cogeretur concedere, sensum etiam abstulit, negavitque ulli praeter hominem esse sensum, sed quaecumque brutis sensu quodam agi viderentur, sympathia quadam et antipathia potius agi, et naturae magis quam animae esse opera», etc. (Segunda edición)

766 «Sed et opinio ipsa per se est absurda: nulla enim fides haberi potest sensibus nostris, proceditque dubitatio, usque ad insaniam, si quae cernimus intuitu quarundam rerum perterrita fugere, sursum quibusdam rebus allici, pulsata vociferari, amicitiae et inimicitiae leges observare, sensum ullum habere negaverimus.» (Pág. 413 de la Sacra Philosophia). Debe leerse todo el capítulo, que abunda en curiosas y notables observaciones. (Segunda edición) 
medios. Lo cual le indujo a afirmar con buen sentido que sólo por analogía debía llamarse racionales a las bestias, aunque tuvieran imaginación y estimativa, que él llama razón sensitiva.

La paradoja de Gómez Pereira, discutida en Espańa tan ampliamente como hemos visto, pasó ultra-puertos en el siglo xviI, y alcanzó mucha notoriedad cuando la expuso Descartes, por encontrarla ajustada al divorcio que él ponía entre el pensamiento y la extensión, entre la materia y el espíritu. La opinión cartesiana es más sencilla y menos ingeniosa que la de Gómez Pereira. Los animales no son más que materia, y están sujetos a las leyes del mecanismo: son autómatas (palabras que no está escrita en la Antoniana). Escribe Descartes en la quinta parte del Discurso del Método: «Por estos dos medios podemos conocer la diferencia entre el hombre y las bestias. Cosa es digna de notarse que no haya hombre tan necio, ignorante e insensato que no sea capaz de juntar unas cuantas palabras y dar a entender su pensamiento; lo cual no hace ningún animal, por perfecto y hábil que le supongamos. Y no es por falta de órganos, puesto que vemos a las picazas y a los papagayos pronunciar palabras como nosotros, pero no hablar, porque no tienen conciencia de lo que dicen. Por el contrario, los sordo-mudos, careciendo de órganos, estando por ende más incapacitados que las bestias, inventan por sí propios algunos signos, y se hacen entender de los que habitualmente los tratan. Lo cual prueba, no sólo que las bestias tienen menos razón que el hombre, sino que absolutamente carecen de ella. ${ }^{767} \mathrm{Ni}$ hemos de confundir las palabras con los movimientos naturales que indican las pasiones, y que pueden ser imitados por máquinas lo mismo que por animales, ni creer con los antiguos que las bestias hablan, aunque no entendamos su lenguaje; cosa imposible, puesto que sus órganos son proporcionados a los nuestros. A lo cual se agrega que muchos animales muestran industria grande y mayor que la nuestra en muchas operaciones, y son del todo inhábiles para muchas otras; lo cual prueba, no que tengan entendimiento, pues entonces sería superior al nuestro y nos vencerían en todo, sino que carecen de alma, y que sólo la naturaleza guía sus actos según la disposición de sus órganos, a la manera que un reloj, compuesto sólo de ruedas y resortes, cuenta las horas y mide el tiempo mejor que nosotros». ${ }^{768}$

767 Todo este argumento está calcado en otro de Gómez Pereira que ya citó y tradujo Chinchilla en sus Anales de la Medicina Española: "Si los brutos tienen bastante juicio y razón para verificar acciones tan sublimes, ¿por qué no aprenden a comunicarse con los hombres, si ya no por medio de la palabra, a lo menos por acciones y movimientos, como los sordo-mudos?». (Segunda edición)

768 OEuvres de Descartes, ed. Jules Simon, pág. 39. (Segunda edición) 
Si en las primeras líneas Descartes glosa a Gómez Pereira, en las últimas compendia lo que había dicho Vallés, copiando hasta sus palabras textuales y sus ejemplos: "Quare cum illorum peritiam non agnoscamus, superest ut ad peritiam authoris referatur velut quod horologium, motu gnomonis et pulsatione cymbali, metiatur et distinguat nostra tempora, refertur ad peritiam artificis...». ${ }^{769}$

En la Respuesta a las objeciones de Arnauld repitió Descartes «que el único principio de movimiento en los brutos era la disposición de los órganos y la continua afluencia de espíritus animales producidos por el calor del corazón, que atenúa y sutiliza la sangre».

En la Respuesta a las sextas objeciones hechas por diversos teólogos y geómetras, se jactó de haber probado con razones fortísimas el automatismo de las bestias, sin nombrar para nada a los españoles, que tanto habían especulado sobre esta materia. Objetáronle algunos que aquella opinión sabía a materialismo, y él afirmó que la opinión contraria inducía a creer de la misma naturaleza, y sólo diversas en grados, el alma del hombre y la del bruto, comprometiendo el dogma de la inmortalidad. Más adelante veremos la relación que Gómez Pereira ponía entre ambas doctrinas.

Al fin de su docta y acre Censura Philosophiae Cartesianae, puso el sapientísimo obispo de Avranches, Pedro Daniel Huet, una especie de catálogo de los plagios de Descartes. Allí textualmente dice: ${ }^{770}$ "Nadie defendió con más calor, ni enseñó más a las claras esta doctrina (la del automatismo) que Gómez Pereira en su ANTONIANA MARGARITA, el cual, rompiendo las cadenas del Lyceo en que habia sido educado, y dejándose llevar de la libertad de su genio, divulgó en España ésta y otras muchas paradojas.»

De Huet tomó esta especie Bayle, primero en las Nouvelles de la République des lettres, y después en su famoso Diccionario, donde trata bastante del asunto, y repite algunos argumentos de Gómez Pereira, aunque de segunda mano, porque no llegó a ver su libro. Los discípulos y biógrafos de Descartes procuraron defenderle, alegando que leía poco, que la Antoniana era muy rara, y no parecía natural que hubiese llegado a sus manos: presunciones harto débiles, al lado del convencimiento que a mi parecer resulta de todo lo expuesto. Y aun suponiendo que no conociera la Antoniana, pudo haber

769 Descartes dice: «Ainsi qu'on voit qu'une horloge, qui n'est compos que de roues et de ressorts peut compter les heures et mesurer le temps, plus justement que nous avec toute nostre prudence». La traducción es literal. (Segunda edición)

770 «At nemo doctrinam hanc vel tradidit apertius vel fortius propugnavit quam Gometius Pereira, qui in Antoniana sua Margarita, perfractis Lycei, in quo educatus fuerant, repagulis, et ingenii sui libertati obsecutus, novum hoc Hispaniae paradoxum, aliaque multa proposuit.» (Censura Philosophiae Cartesianae... Venetiis, 1734). (Segunda edición) 
tenido noticia de ella por cualquiera de sus impugnadores, y sobre todo por la Philosophia Sacra de Vallés, que tenía muy leída.

Para acabar de una vez esta materia ya enojosa, apuntaré las opiniones de otros filósofos nuestros que después de Descartes tocaron la cuestión del alma de los brutos.

El médico judío Isaac Cardoso, en su Philosophia Libera, calificada de opus sane egregium por Fr. Zeferino González, escribe que el alma de los brutos es corporal, y se reduce a la armonía de los elementos. Y como el fuego es el elemento más sutil, ardiente y movible, de aquí que el alma sea una partícula ígnea que, templada por otros elementos, produce en el animal admirables operaciones. ${ }^{711}$ Que esta doctrina desciende de la de Gómez Pereira, es indudable, aunque tiene asimismo precedentes en Galeno, que confundió el alma con el temperamento.

El P. Feijoo trató de la racionalidad de los brutos en un agradable discurso, que es el noveno del tomo III del Teatro crítico. No da muestras de conocer la Antoniana Margarita sino por las referencias de Bayle, y se inclina a la opinión de los que negaron que Descartes hubiese leído el libro del médico castellano. Pero se equivoca de todo en todo al aseverar que éste no tuvo séquito alguno, y que su doctrina cayó muy luego en olvido, cuando de lo contrario dan testimonio las objeciones de Palacios, el Endecálogo, y las obras de Vallés e Isaac Cardoso, el segundo de los cuales invoca a cada paso, con respeto grande, la autoridad de Gómez Pereira.

Por lo que hace a la cuestión en sí misma, el P. Feijoo, sin afirmar positivamente cosa alguna, se inclina a la sentencia más admitida, que niega a los brutos discurso y les concede sentimiento, aunque no deja de proponer y esforzar algunos argumentos en pro de la racionalidad, defendida por Vallés entre los modernos y por Lactancio entre los antiguos. Para el benedictino de Oviedo, la racionalidad no implica espiritualidad, y el alma de los brutos, sin ser materia, puede ser forma material, esto es, dependiente de la materia en el hacerse, en el ser y en el conservarse. ${ }^{772}$ Hay que advertir que para el P. Feijoo no implicaba contradicción la existencia de un ente medio entre materia y espiritu. Al contrario: con la invención de ese medio juzgaba haber hallado un argumento invencible contra los materialistas del siglo XvIII, que,

771 «Colligimus ergo animam corpoream non esse aliud quam elementorum harmoniam, et cum praecipua operatio igni attribuatur, cum sit subtilior, ardentior ac mobilior, anima erit pars illa ignea animalibus admixta, quae aliis elementis temperata mirabiles edidit operationes.» (Ph. Libera, Venetiis, 1673). (Segunda edición)

772 Obras escogidas del P. Fr. Benito Jerónimo Feijoo. (Edición de Rivadeneyra). Páginas 130 a 141. (Segunda edición) 
apoderándose de la opinión de Descartes y Gómez Pereira, inferían que si las operaciones de los brutos proceden de puro mecanismo, otro tanto debe acontecer con las acciones humanas, en todo semejantes, y que si la materia es capaz de sentir, también puede serlo de pensar. ${ }^{773}$

El célebre médico y elegante filósofo D. Andrés Piquer, en su Discurso sobre el sistema del Mecanismo, ${ }^{774}$ escribe: "Los nuestros (filósofos), en los tiempos pasados no han tenido reparo de llamar en los brutos alma al principio de sus operaciones, como lo hacen en el hombre, dando ocasión a que, compendiando ambos principios en una idea, les atribuyesen los poco advertidos y los impíos idénticas facultades. Al principio, pues, interno, que en el hombre y en las bestias produce las sensaciones, vegetación, nutrición y cuantas acciones conducen a sostener la vida, lo llamaremos psyche..., y al principio que en el hombre ejercita la razón con libertad e inteligencia, lo llamaremos alma (pneuma), para evitar la confusión y conformarnos con el uso común de nuestra lengua. Las puras sensaciones se hallan en los brutos; las sensaciones con conocimiento, en los hombres». Piquer había leído la Antoniana, el Endecálogo y la Philosophia Sacra, que cita y juzga con acierto. Es reminiscencia pereirista la de este pasaje: «Al modo que el hierro se va hacia el imán y las pajas al ámbar, se van los brutos hacia los objetos que impresionan sus órganos sensibles». La psyche de Piquer es material; es, como él dice, «la flor de la materia», y no difiere mucho de la partícula ígnea de Isaac Cardoso, ni de la materia tenuisima y refinada de Gassendi.

En concepto de D. Juan Pablo Forner, sobrino, y discípulo en muchas cosas, de Piquer, «los brutos tienen facultad de sentir, pero ajena enteramente de conocimiento reflexivo: de manera que su facultad de sentir no pasa más allá de la sensación. La sensación obra en la fantasía representando las imágenes, para que éstas pongan en movimiento los conatos siempre uniformes del apetito... En suma: el bruto siente, imagina, apetece, se mueve, pero no conoce. Todos sus actos dependen del principio brutal que en ninguna manera puede llamarse alma». Porque es de advertir que Forner admitía dos principios en el hombre: el racional y el sensitivo. Este último, común

773 Vide: carta 2a del tomo V de las Cartas Eruditas, y también la carta última del tomo anterior. En defensa de la opinión del P. Feijoo escribió un portugués en lengua castellana el muy interesante libro que se titula: Propugnación de la racionalidad de los Brutos. Carta Apologética en respuesta a la carta Crítica, que un docto anónimo (francés) escribió al M. R. P. M. Fr. Benito Gerónimo Feyjóo, impugnando el discurso $9^{\circ}$ del tomo tercero de su Theatro Critico... escrita por Miguel Pereira de Castro Padrao. Lisboa, imp. de Francisco Luis Ameno, 1753. $4^{\circ}$. (Tercera edición)

774 Discurso de D. Andrés Piquer, médico de Cámara de S. M., sobre el sistema del Mecanismo... Madrid, Ibarra, 1768, pág. 83. (Segunda edición) 
con los brutos, no era para él substancia, sino una energía vital o principio activo, semejante al de las planta. ${ }^{775}$

Otros tratadistas de filosofía del siglo pasado y comienzos del presente no dieron en tan singulares opiniones, contentándose, por lo general, con las proposiciones de Wolfio, que supuso inmateriales, pero no espirituales, perecederas por aniquilación, y en ninguna manera inmortales, las almas de los brutos.

Una cita más, y concluyo. Para Balmes, en quien renació con nueva gloria nuestra tradición filosófica, el alma del bruto no es material, porque la materia no siente; tampoco es espíritu, por no ser inteligente ni libre el principio activo en el animal. Su naturaleza es desconocida: su final destino también. No perecerá por corrupción, porque no es orgánica. Quizá será aniquilada (Balmes admite la aniquilación); quizá al ser absorbida de nuevo en el piélago de la naturaleza, prosigue ejerciendo su actividad en diversos sentidos y animando nuevos seres. ${ }^{776}$

Basta con estas indicaciones históricas sobre un punto que no es de mera curiosidad. El desarrollarlas fuera asunto de una larga monografía. Otras materias de mayor trascendencia llaman y solicitan nuestra atención en el libro de Gómez Pereira.

II. Modos de conocimiento. - Especies inteligibles. - Para apreciar debidamente el mérito y originalidad del filósofo de Medina, es necesario fijarse en su teoría del conocimiento. El único método que para llegar a ella preconiza y defiende es la experiencia psicológica. «Antes de explicar las nociones internas y externas del alma humana, debo prevenir a mis lectores que juzguen de la verdad de lo que digo por lo que ellos mismos, en el sentir o en el entender, hayan experimentado y experimenten. No se trata aquí de cuestiones cosmográficas, donde conviene creer al maestro, sino que se discuten y explican las operaciones de nuestro espíritu, de las que todos tenemos plena conciencia». ${ }^{777}$

775 Forner desarrolló con grande extensión y novedad esta doctrina en las ilustraciones a sus Discursos filosóficos sobre el hombre. (Madrid 1787, páginas 182 a 199 y 296 a 321). (Segunda edición)

776 Filosofía fundamental, tomo II, cap. II, 3a ed., de Barcelona, 1860, páginas 12 a 16. (Segunda edición)

777 «Explicaturus animae notiones interiores exterioresque, omnibus haec lectoribus suadere volo, ea, quae a me dicentur, vera futura si qui mentem meam his scriptis noverint, sese cum absentia aut praesentia cognoscant, sic, prout ego fateor, sentire aut intelligere ea experti fuerint... Non enim hic agitur de situ orbis, ubi fidem docenti adhibere expedit... sed actus animae discutiuntur explicanturque, quorum quivis... conscius est». (Segunda edición) 
Admitida como único criterio psicológico la experiencia interna, la tacita cognitio, mal podía resistir a los ataques de Gómez Pereira la doctrina escolástica, que él formula así: «Convienen todos en afirmar que nuestra alma no puede sentir ni entender nada, si no se modifica por algún accidente realmente distinto de su propia esencia. De donde infieren que el conocimiento es realiter distinto del sujeto cognoscente». ${ }^{778}$ A todo lo cual se agregaba la invención de las especies inteligibles, por analogía con las sensibles.

Gómez Pereira rechaza todo esto. En primer lugar, las especies no son sensaciones, y la sensación no se verifica sin la atención o animadversión de la facultad sensitiva. La impresión (affectus) en el órgano y la atención son sus únicas condiciones. En cuanto al conocimiento, no es cosa distinta de la facultad de conocer, ni ésta se distingue tampoco del alma. El conocimiento puede ser intuitivo o abstractivo. El conocimiento intuitivo envuelve siempre una afirmación de existencia. "Nihil aliud est hominem cognoscere distincte intuitive aliquam rem quam animam illius esse certissimam existentiae rei». Lo cual no implica que el conocimiento sea verdadero, porque hay sensaciones deceptorias.

Las ideas o nociones son el alma misma modificada diversamente ( $A n i$ mam ipsam taliter se habentem, tantum universas notiones suas esse»). La visión no es más que un estado o modus habendi del alma, provocado por otro modus habendi que es la atención $n^{779}$. «Si me preguntas en qué consisten estas modificaciones del alma, te diré que no las conozco a priori, sino a posteriori y por sus efectos; pero conjeturo que guardan cierta proporción con los diferentes estados».

No realmente, sino por un procedimiento racional, podemos separar el conocimiento, de la facultad de conocer, y ésta es la esencia del alma. ( Impossibile enim existimamus cognitionem ullam esse rem distinctam entitative a cognoscente»)

778 «Conveniunt omnes non posse animam nostram quidquam sentire aut intelligere, si ipsa ullo non afficiatur accidente realiter a se distincto. Ad eandem normam inferunt ipsi fatendum fore nullum cognoscens dici tale sine cognitione realiter distincta a cognoscente». (Segunda edición)

779 «Quid sit illa animae attentio sine qua visio gigni non potest? Si dixerint quod sit aliquod accidens distinctum ab ipsa anima, quaero cum ad productionem visionis figurae illud in anima sit, cur non sufficiat ad producendum aliorum objectorum visionem? Restat ergo nequaquam dicendam esse attentionem animae accidens ullum ab anima distinctum, sed eandem volentem taliter se habere circa illud objectum qualiter non se habet circa alia. Ergo si hoc, sine quo visio celebrari non potest, modum habendi animae certum esse probavi, cur visionem ipsam etiam modum habendi animae non appellabimus ut est? Si a me interroges quid sit ille modus habendi animae dictus attentio ut quo differat ab alio modo dicto visio, et modi habendi animae quid sint... dicam me eos modos non cognoscere, sed conjectari eos proportionales esse diversis sitibus corporum nostrorum». (Segunda edición) 
Aplicando el mismo principio a las sensaciones que él llama exteriores, prueba que no son entes, ni accidentes corpóreos ni espirituales: sólo resta que sean modos del alma. La sensación no nace del objeto y de la facultad, sino de la facultad sola: a sola vi sensitrice. Los fantasmas que son causa ocasional de la sensación, difieren del alma y son corpóreos: «quid ab homine sejunctum et in homine inclusum. El alma es libre en cuanto al conocimiento de sí misma, pero no en cuanto al de los fantasmas, que muchas veces se le presentan sin quererlo ella. ${ }^{780}$

Combate luego Gómez Pereira la proposición de San Agustín: "Illa informatio sensus quae visio dicitur, a solo imprimitur corpore quod videtun,, en lo cual, como advierte el autor de la Antoniana, claro se ve que el Doctor Hiponense confundió la impresión con la sensación o percepción. El alma necesita atender para ser modificada y sentir. El mismo Santo parece reconocerlo en este otro pasaje: "Gignitur ergo ex re non visibili visio, sed non ex sola visione, nisi adsit et videns".

Añade Gómez Pereira que da visión es la atención del alma que se siente afectada por el objeto, («modus habendi animae animadvertentis se affectam»); y niega que se vea sólo la especie, sino el objeto mismo mediante la impresión.

No respeta el atrevido reformador la antigua clasificación de las facultades del alma. Para él no existe el sentido común a la manera que lo entendían los peripatéticos, "sensus qui ab Aristotele communis dicitur, quo judicantur sensilia absentia et discernuntur ea quae variorum sunt sensuum». ${ }^{781}$ Este sentido, que discernía las percepciones de los demás, solían localizarle los escolásticos en la parte anterior del cerebro. Pero Gómez Pereira nota que si este sentido común es facultad orgánica, será del todo inútil, o habrá dos sensaciones. Para juzgar las cosas sensibles comunes, v. gr., el movimiento y la quietud, el número, la magnitud, etc., tampoco vale el tal sentido común, porque estas cosas no son sensibles per se, sino per accidens, conforme a la opinión de los nominalistas, a la cual Gómez Pereira se inclina. ¿Y quién sostendrá que es necesario para distinguir las percepciones de los demás sentidos? «¿Para qué inventas esa facultad orgánica interior, cuando para

780 En otro lugar ańade: «Sed non aliud est videre aliquam rem aut alio ullo sensu sentire quam animam per modum a me explicitum certam esse existentiae coloris cogniti intuitive». (Segunda Edición)

781 Vives, De anima et vita, pág. 32 (ed. Basilea, 1538). La verdadera opinión de Aristóteles sobre el sentido común es bastante diversa; pero aquí no trato de lo que debía entenderse, sino de lo que se entendía en tiempo de Gómez Pereira. Por lo demás, véase el cap. II, lib. III del tratado aristotélico De anima, y los comentarios de Trendelemburg y Saint Hilaire. (Segunda edición) 
dar razón de lo que nosotros experimentamos, es a saber, que existe una potencia que distingue entre los objetos de los diversos sentidos, basta decir que el alma, informando el ojo, conoce el color, e informando el pie siente en él la frialdad, y afectada en el órgano del olfato percibe el olor, etc., y que ella sola es la que juzga y distingue entre varias sensaciones, y aun entre los actos de varias facultades? Y si esto afirmamos, ¿para qué sirve ese vano sentido común puesto en la parte syncipital? ¡Como si no bastaran los cinco exteriores!». ${ }^{782}$

No hay distinción real entre la facultad sensitiva y la intelectiva, ni entre el conocimiento directo de lo singular y el conocimiento por reflexión. El uno depende del otro, y la misma alma que conoce lo universal percibe también lo singular («eamdem animam quae universale cognoscit, et singulare percipere»). El alma misma, sin ningún accidente distinto de ella, es virtud sensitiva y virtud intelectiva, y es sentido común cuando discierne las percepciones de los cinco sentidos. ${ }^{783}$

Tampoco es facultad orgánica la fantasía, que Avicena supuso colocada en la parte anterior de la cabeza para guardar los fantasmas. A lo de la localización replica el autor que, herida o lesionada dicha parte anterior, no se pierde la memoria; al contrario de lo que sucede si se hiere la parte posterior. Por lo cual niega que haya semejante facultad ni que se distinga de la memoria.

Tampoco admite la imaginativa como exterior, pero sí como facultad interior de componer y dividir, que no se distingue de la esencia del alma. Otro tanto acontece con la estimativa. La memoria, sí, es facultad externa y localizada en el occipucio, como lo comprueban los experimentos. Las potencias que no se distinguen del alma no tienen órganos especiales a su servicio. ${ }^{784}$

782 «Cur machinaris illam intimam facultatem organicam, cum ad rationem reddendam eorum quae in nobis experimur, esse scilicet aliquam vim quae distinguit inter objecta diversorum sensuum, sufficit hos externos sensus ponere et dicere quod anima informans oculum, colorem modo dicto cognoscit, et eodem numero stans in pede, frigiditatem inductam in eo sentit, et affecta in organo olfactus odores percipit... eamque esse illud unum quod inter diversa discernit, et etiam inter diversarum facultatum actus? Quod si asseveraretur... ut quid inanis ille sensus communis situs in syncipite fingetur? Frustra nempe, cum exteriores quinque sufficiant!» (Segunda edición)

783 «Anima ipsa sine ullo accidente... est virtus sentiens aut intelligens... et appellatur sensus communis cum quinque sensibilium propriorum differentiam percipit». (Segunda edición)

784 «Nullam organicam facultatem iis facultatibus quae ab anima non distinguuntur, assignamus...» (Tercera Edición). 
Hemos llegado a las entrañas del libro, a la discusión contra las especies inteligibles; y como éste es punto de capital importancia, en que Gómez Pereira se adelantó más de dos siglos a Reid, me permitirá V. que sea un tanto prolijo y acumule extractos para convencer, si es posible, a los incrédulos.

¿Cómo se verifica el conocimiento? La explicación escolástica, según Gómez Pereira la expone, era ésta: "Cuando el entendimiento desea conocer lo universal, pone delante de la imaginativa los fantasmas de algunos individuos de aquella especie conocidos antes: prescinde de todas las condiciones individuales, convierte el fantasma así modificado en especie inteligible, y por este método, abstraídas todas las particulares condiciones que distinguen un ser de otro, queda desnuda y escueta la naturaleza del ser, que, por medio de las especies inteligibles, produce en el entendimiento un acto de intelección universal, y esta intelección es un accidente espiritual distinto del mismo entendimiento.»

Toda esta fantasmagoría se disipa ante las siguientes observaciones del médico de Medina del Campo: ${ }^{785}$

"Ante todo, de los fantasmas no pueden extraerse las especies inteligibles, por ser el fantasma cosa corpórea y las especies inmateriales. Y si suponen que de la corrupción del fantasma nacen las especies inteligibles que guían al conocimiento de lo universal, engáńense de todo punto. Porque ni el fantasma se corrompe después de la intelección de lo universal, dado que seguimos conociendo y recordando como antes, ni, aunque se corrompa, puede ser nunca materia para especies inteligibles, como una piedra no es materia para producir un ángel. Absurdo es suponer que tengamos la facultad de sacar lo espiritual de lo corpóreo. Como los agentes intelectuales no obran sobre la materia, es imposible que de la conjunción entre el fantasma corpóreo y una forma intelectual, corno es el alma, resulte un ser incorpóreo.»

«Me responderás con los tomistas, que la luz del entendimiento (lumen inellectus) produce ese fenómeno, y te volveré a preguntar qué luz es la que el entendimiento comunica a los fantasmas para producir la especie inteligible como de materia ex qua... No puede el entendimiento transmitir al fantasma su propia substancia inteligible, que sólo Dios crea. Y aunque el

785 «Nullo modo percipere valeo qualiter vere dici possit ex eodem fieri species intelligibilis. Nam si id velint, quod, corrupto ipso, gignatur species intelligibilis, ducens in cognitionem universalis, mille modis a vero discedunt. Nam neque phantasma corrumpitur post universalem intellectionem, cum non minus mediante eodem cujusvis alterius rei recordemur quam prius, neque et si corrumperetur, materia esse potest speciei intelligibilis, plus quam lapis materia esse valet naturas angelicae. Absurdum quippe est existimare nobis inesse vim gignendi aliquid spirituale ex corporea re, cum materia corporum subjici non potest intellectricibus rebus, sic ut ex eadem et intellectrice forma incorporea res resultet». (Segunda edición) 
entendimiento participe de ella, en modo alguno puede crear una substancia espiritual en el fantasma, que es substancia corpórea. Ni dará al fantasma ningún accidente espiritual, porque éstos (fuera de un milagro) no caben en las cosas corpóreas. La luz del entendimiento no da, pues, al fantasma virtud para producir las especies inteligibles». ${ }^{786}$

$\mathrm{Ni}$ la especie inteligible puede ser engendrada por el entendimiento mediante la consideración del fantasma, separando de él por abstracción propia las que llaman condiciones individuales, y produciendo luego la especie inteligible que represente lo universal, porque si así fuera, de trabajo excusado calificaríamos el del entendimiento en fabricar la especie o apariencia de lo universal, que él conoce antes y de un modo más exquisito. Y no se entiende por qué esa representación ha de tener existencia más perfecta fuera que dentro del alma, siendo así que ésta la contiene por alta manera, como la causa a su afecto, al globo que aquella Venus Charita (esto es, graciosa), pintada por Apeles, distaba mucho de la Venus que el mismo Apeles había concebido en su mente, porque ni los órganos le obedecieron en todo, ni logró vencer las resistencias del material, ni cumplir perfectamente sus anhelos. Y si en esta obra externa no logró su propósito el inmortal artífice, verosímil será que el entendimiento en ninguna manera puede engendrar una especie que retrate lo universal tan al vivo como ya lo conoce y posee la inteligencia misma, productora de la especie». ${ }^{787} \mathrm{Y}$ aun dado que esta especie o similitud fuera del todo exacta, "frustra fit per plura quod potest fieri per pauciora».

786 «Statim a te sciscitabor quid conferat intellectus hic phantasmati lumine suo, ut valeat cum illo producere ex se speciem intelligibilem, velut ex materia ex qua, aut ex agente, et nihil quod inductum fuerit in phantasmate ab intellectu sufficiet vires eidem tribuere ullius rei recensitae. Namque intellectus phantasmati substantiam intelligibilem non tribuet, cum solus Deus possit hanc creare. Et quamvis ipse intellectus hujus facultatis particeps sit, nequaquam posset in phantasmate quod substantia corporea est, substantiam aliam spiritualem creare. Neque accidens ullum spirituale concedet, cum hoc inesse cifra miraculum corporeis rebus non valeat: restat ergo nihil conferri posse phantasmati, quod aequet vim producendi speciem intelligibilem». (Segunda Edición)

787 «Neque species intelligibilis gigni potest ab intellectu per considerationem phantasmatis, sejungendo ab eodem animadversione propria eas quas individui conditiones nominant, et post speciem intelligibilem gignendo quae universale ibi repraesentet, quoniam si ista fieret, in ea intellectus fabricasset speciem universalis, quod ipse prius ac exquisitius intelligit, quam species valeat illud referre. Porro nequaquam intelligi potest, speciem referentem universale genitam ab intellectu, non habere, (jam quod caetera sileam) in repraesentando perfectius esse in intellectu qui eminenter eam continet, ut causa quaevis proprium effectum, quam extra, ut illa Venus Charita singulari cura depicta, quam maxime distabat ab ea quam Apelles, ejusdem author, mente propria conceperat; sed cum certissimus organa tam viventia quam inanimata quibus ipsa depicta fuit, non sic in totum obtemperata fuisse illustri pictori prout ipse cupiebat, membris et 
La experiencia de cada uno demuestra que el entendimiento puede alcanzar lo universal sin la consideración de ningún fantasma. Tampoco la noción de una cosa singular y cuantitativa puede dar al entendimiento la facultad de conocer lo universal, porque las cosas indivisibles sólo se perciben y conocen por una facultad indivisible. Los que inventaron estas especies cayeron en el mismo yerro que un pintor que dijera: «Yo que nunca he visto elefantes, ni sé cuál es su forma ni su figura, voy a formar una noción mental que me represente al elefante». ¿Cómo ha de pintar nadie lo que no ha visto ni concibe?». ${ }^{788}$

Al leer esta briosa refutación, en que hasta el estilo de Gómez Pereira toma una elocuencia desusada; al oírle defender con tanta energía los fueros del conocimiento directo, tal y como la experiencia nos le muestra, ¿quién no cree tener a la vista una página psicológica de la escuela escocesa? ¿Serán inútiles estas lecciones, hoy que el renovado escolasticismo enseña y sostiene aún la conversión del fantasma en especie inteligible por la luz del entendimiento agente?

Aun había otras malezas que desbrozar en este campo, y Gómez Pereira prosiguió lógico e inflexible, deduciendo que la intelección no es producida por ningún objeto o facultad distinta del entendimiento, ni puede llamarse accidente, sino que es la inteligencia misma, modificada de cierto modo (taliter se habens); negando que fuese necesaria una nueva entidad para entender lo que antes no se entendía, cuando bastaba con una simple modificación; y repitiendo una y otra vez, antes de Descartes, que la esencia del alma era el pensamiento (actus intellectus idem cum anima), de cuyo principio sacó el partido que adelante veremos en su tratado De la inmortalidad del alma. A los teólogos les dice: «Si Dios concediese intelección a la piedra, ¿la llamaríamos sujeto inteligente? De ninguna manera, porque el pensamiento no está en su esencia». ${ }^{789}$

En la cuestión de los universales, Gómez Pereira es nominalista, pero a su modo. Lo universal es para él un término incomplexo, que se predica univoce

fabrilibus ferramentis resistentibus, artifex egregius voti compos esse non valuit», etc., etc. (Segunda Edición)

788 «Haec cognitio nequaquam potest dare intelectui facultatem cognoscendi universale, quod indivisibiliter percipitur et a facultate indivisibili noscitur. Tandem intelligant qui has species intelligibiles finxerunt, ut eisdem intellectus cognoscat universale, in eum errorem sic opinantes incidere, in quem incidisset pictor qui referret: quia conscius mihi sum me nunquam elephantem neque ejus figuram vidisse, neque cujus formae erat audivisse, volo fingere elephantem qui mihi in mente repraesentet eum. Stultum est enim putare posse pingi aliquid quod prius a pictore conceptum non sit.»

789 «i Deus abstulisset intellectionem ab anima intelligente et eandem lapidi inhaesisset, lapis esset dicendus intelligens? Nullo modo». (Segunda Edición) 
de muchas cosas diferentes en especie o en número. ${ }^{790} \mathrm{El}$ conocimiento de los universales es de dos maneras: confuso o distinto. Universal confuso es el todo respecto de sus partes. Universales distintos son la substancia y los otros nueve predicamentos, con todo lo que cae bajo cada una de las categorías (dentro de la substancia, el cuerpo, el animal, etcétera). ${ }^{791}$ Lo universal confuso es conocido antes que lo singular; el todo antes que las partes, y así sucesivamente. «Primero decimos éste es un ente o un cuerpo, que éste es un animal o un hombre; y primero éste es un padre o ésta es una madre, que éste es Antonio o ésta Margarita. Por eso los niños llaman a todos los hombres padres, y madres a todas las mujeres». ${ }^{792}$

El conocimiento arranca de los universales confusos: de allí pasa a los singulares, y por eso tenemos siempre un conocimiento vago del objeto de la ciencia antes de estudiarla ${ }^{793}$. Los universales distintos no son conocidos por sí mismos, sino por accidente, per accidens, mediante los sentidos interiores y exteriores. Sin haber visto los accidentes del caballo (color, figura, magnitud) no tenemos idea de la substancia del caballo.

A los universales distintos se llega por abstracción. El pasaje siguiente, notable por la delicadeza del análisis psicológico y por la propiedad y limpieza de la expresión, explicará de qué modo:

«Yo nunca diré que entiendo lo que por experiencia sé que nunca he entendido, y escribiré sólo las operaciones intelectuales de que puedo decirme testigo ocular. Cuando deseo conocer la substancia de una pared blanca y cuadrada, aparto mi entendimiento de la blancura, de la cantidad, de la figura, del sitio y de las demás condiciones individuales de aquella pared, todas las cuales yo he conocido antes por los sentidos exteriores o concebido abstractamente por la imaginación. Finjo mentalmente que la blancura, la cantidad, el número, etc., pueden dividirse y separarse de la substancia en que residen, y entonces adquiero la noción de ésta. Nunca la he conocido en sí

790 «Est enim universale (relicta illa distinctione qua in efficiendo Deus dicitur universalis causa, et in essendo ideae Platonis etiam universale) terminus incomplexus, vocalis aut scriptus, qui de pluribus differentibus specie aut numero quidquid univoce praedicat». (Segunda Edición)

791 «Haec mentis cognitio duplex esse potest, confusa scilicet aut distincta... Nomino confusum universale totum respectu suarum partium. Universale distinctum porro est substantia, corpus, animal, haec omnia in praedicamento substantiae sita et caetera novem genera quae decem praedicamenta constituunt.» (Segunda Edición)

792 «Universalia illa quae confusa nominantur, notiora nobis sunt quam singularia eorundem. Totum enim quod universale confusum dicitur, notius est nobis quam suae partes, et hoc ens aut hoc corpus quam hoc animal vel hic homo, et hic pater aut haec mater quam hic Antonius aut haec Margarita», etc. (Segunda Edición)

793 Esta observación es ya de Aristóteles en la Física. (Segunda Edición) 
misma, porque está velada por los accidentes; pero tampoco necesito formar una especie inteligible que me la represente, sino que vengo a su noción por la noción de los accidentes. Al contemplar mi entendimiento que aquellos accidentes varían a cada paso, sucediéndoles otros, infiero por necesidad la existencia de un objeto en que residan los accidentes que se corrompen y los que de nuevo se engendran. Y así que infiero esto, conozco el sujeto, sin intermedio de especie alguna, sin que importe nada al entendimiento que el objeto sea o deje de ser como él lo entiende. Así se conoce lo real y lo fantástico: la quimera, v. gr., trayendo a la memoria partes de animales ya conocidos. Éste es el conocimiento por abstracción (abstractive noscitur)». ${ }^{794}$

Refuta luego a los realistas y a los partidarios de las especies inteligibles o conceptualistas, y añade: «Todas las conclusiones matemáticas se van deduciendo unas de otras, sin generación de ninguna especie».

«Los objetos inteligibles se distinguen de los sensibles en que no producen inmutación formal en nuestros órganos, ni son conocidos por sí, sino por el intermedio de otros. Los seres indivisibles: Dios, los ángeles, las inteligencias y las almas, se conocen por la noción de las cosas sensibles. Invisibilia Dei a creatura mundi».

Niega Gómez Pereira todo conocimiento intuitivo. Para formar una imagen o especie inteligible de Dios, de los ángeles y del alma, sería preciso conocer antes el objeto, del cual la especie es copia. ${ }^{795}$ Además, la experiencia no nos informa de tal conocimiento intuitivo.

794 «Neque intelligi a me fatebor quae me nunquam intelligere potuisse expertus fuero... sed dumtaxat id scripturis mandabo, cujus ipse testis oculatus dici vere possim. Ergo cupiens ego parietis albi et cuadrati substantiam intelligere, averto mentem meam a consideratione albedinis et quantitatis et figurae et situs et ubi et aliarum conditionum individualium illius parietis, quas universas ipse aut prius exterioribus sensibus cognoveram aut abstractive olim imaginatione conceperam, cognitionemque elicio rei nunquam sensatae, justa, subjecti eorum. Fingo enim posse albedinem, quantitatem, figuram, numerum et caetera sejungi separarique ab ea substantia quae subjectum ipsorum est, et tunc notionem ejusdem habeo. Neque ut hanc substantiam noscam, quae nunquam ulla sui specie me afficit (cum tecta accidentibus semper incedat) oportet in mente nostra aliquem speciem intelligibilem gigni, quae ipsam repraesentet, sed ut rationem nostri in notionem illius, quod nunquam noveram, divenio per notionem aliorum, justa, suorum accidentium; cum enim intellectus noster contemplatur accidentia illa passim variari, aliis succedentibus, statim infert subjectum aliquod eorum quae nunc genita sunt et aliorum quae corrupta fuere, cui insint, necessario esse... quod cum infert, subjectum noscit, ad quod noscendum nulla specie referente subditam illam substantiam utitur, neque intellectum interest, an etiam realiter tale subjectum quale intelligit sit aut non sit...» (Segunda Edición)

795 «Deus, angeli, anima quae indivisibilia sunt, a viatoribus intelliguntur, nulla specie ab eodem nostro intellectu genita, quia intuitive nosceretur, quod falsum esse omnes experimur. Quaecumque indivisibilia sunt, ut Deus, angeli, intelligentiae et animae, 
"Lo universal no se halla en los entes; todos son singulares. Lo universal, como conocido, tiene ser en el entendimiento. Conocemos la quimera; luego existe. Por lo demás, toda la cuestión de los universales se funda en el antiguo error de los gramáticos, que tomaron por sustantivos una infinidad de connotativos o adjetivos que designaban cualidades o accidentes, y no individuos». ${ }^{796}$

«El alma, como activa, es entendimiento agente; como pasiva, es intelecto posible». ("Anima intellectrix dicitur intellectus possibilis in quantum nata est omnia fieri ad affectionem proprii organi, ab omnibus sensilibus rebus nati affici»). El omnia fieri está tomado en el sentido de Aristóteles.

Hasta aquí el autor fielmente expuesto y compendiado. Apuntemos ahora los resultados de la especulación noológica de la Antoniana Margarita, para que se vea de un golpe la trascendencia de sus afirmaciones.

$1^{\circ} \mathrm{El}$ único criterio en cuestiones psicológicas es la experiencia interna.

$2^{\circ}$ La sensación (bajo este nombre comprende Gómez Pereira las percepciones) no se verifica sin la atención o animadversión del alma, ni puede confundirse con la impresión o afección en el órgano. La sensación no nace del objeto y de la facultad sensitiva, sino que es una modificación o modus habendi del alma.

$3^{\circ}$ La intelección o acto de entender no se distingue de la inteligencia, ni ésta de la esencia del alma.

4o El conocimiento es directo, sin especies o imágenes intermedias, como lo prueban a una el razonamiento y la experiencia.

$5^{\circ}$ No existe un sentido común. La facultad de discernir las percepciones no se distingue de la esencia del alma.

60 La imaginación o fantasía es facultad interior y no orgánica ni localizada. Lo mismo la cogitativa o estimativa.

$7^{\circ}$ La memoria es facultad orgánica, y reside en la parte posterior de la cabeza.

$8^{\circ}$ La facultad sensitiva y la intelectiva no se distinguen más que en grados. El conocimiento principia por la sensación. Así conocemos los objetos externos.

$9^{\circ}$ Conocemos los universales por abstracción. Así se forman las ideas de substancia y causa.

noscuntur ex aliarum rerum notione. Invisibilia Dei a creatura mundi». (Segunda Edición)

796 «Universale in entibus non reperiri; omnia enim singularia sunt. Universale ut cognitum tantum habet esse in intellectu. Chimeram noscimus, ergo est». (Segunda Edición) 
$10^{\circ}$ No hay conocimiento intuitivo.

$11^{\circ}$ Los universales sólo tienen realidad en la mente.

$12^{\circ}$ De la noción de los objetos sensibles nos elevamos a la de los indivisibles.

No está, sin embargo, en estas proposiciones la doctrina psicológica completa y definitiva de Gómez Pereira. Lo más curioso anda oculto en el tratado De animae immortalitate, que estudiaré luego. Allí veremos que no hay motivos para calificarle de sensualista, aunque hasta ahora las apariencias sean fatales.

Como partidario de la experiencia interna, figura el autor de la Antoniana entre los padres de la moderna psicología, representada especialmente por los escoceses e ingleses. Verdad es que aun en esta parte le precedió Vives. Su tratado De anima et vita no es más que el desarrollo de este principio: "Anima quid sit, nibil interest nostra scire: qualis autem et quae ejus opera, permultum, nec qui jussit ut ipsi nos nossemus, de essentia animae sensit, sed de actionibus... Opera autem omnibus pene sensibus et internis et externis cognoscimus». ${ }^{797}$ Por eso Vives, en la obra citada, raciocina poco y observa mucho. Gómez Pereira, aunque emplea el procedimiento dialéctico contra las teorías escolásticas, basa siempre las suyas en la observación.

En la identificación del acto de entender, del entendimiento y de la esencia del alma, precedió el filósofo de Medina a Descartes. "Tria igitur in eo ipso agnoscit Cartesius quod unum idemque esse dixerat: facultatem scilicet cogitandi, cogitationem et ideam", dice Huet. ${ }^{798}$ Para no extremar la semejanza, conviene tener presente que Gómez Pereira no admite ideas al modo cartesiano ni platónico, y que es francamente nominalista.

Como adversario de las especies inteligibles (invención de los árabes o de los escolásticos, nunca conocida por Aristóteles ${ }^{799}$, a quien malamente se la achacó Reid), tenía Gómez Pereira por únicos predecesores a los nominales, y especialmente a Durando. De ellos aprendió el gran principio de que «no se han de multiplicar los entes sin necesidad», tan elogiado por Leibnitz. ${ }^{800}$

797 De anima et vita, pág. 39, lib. I. (Segunda Edición)

798 Censura Philosophiae Cartesianae, pág. 111. (Segunda Edición)

799 Vide Hauréau, Idées-Images en sus Singularités historiques et littéraires (París, 1861). Yerra, sin embargo, el historiador de la escolástica en atribuir a Ockam lo que fue gloria de Durando de S. Pourçain, como noto en el texto. (Segunda Edición)

800 «Secta nominalium, omnium inter scholasticas profundissima et hodiernae reformatae philosophandi rationi congruentissima est... Generalis autem regula est qua nominales passim utuntur: entia non esse multiplicanda praeter necessitatem... quae (sententia) etsi obscurius proposita, huc redit, hypothesim eo esse meliorem quo simpliciorem... Ex hac jam regula nominales deduxerunt omnia in rerum natura explicari 
Además, uno de los argumentos de Gómez Pereira se encuentra también en Durando: «El entendimiento, que es virtud reflexiva, se conoce a sí mismo y a sus facultades por certidumbre y casi experimentalmente. (Gómez Pereira suprimió el casi, porque para él la experiencia interna es más cierta e infalible que la externa). Así sabemos por experiencia que existe en nosotros el principio de la inteligencia. Si en ella hubiese especies, conoceríamos con certidumbre su existencia en nosotros, como conocemos los demás actos y hábitos de nuestro entendimiento». ${ }^{801}$

Guillermo Occam, el más arrojado de los nominalistas, escribió: «Pluralitas non est ponenda sine necessitate, sed non apparet necessitas ponendi tales species productas... ab objectis, quia omnes istae species non possunt sentiri ab aliquo sensu». ${ }^{802}$ De Durando y de Occam tomaron estos argumentos los nominalistas de París y de Salamanca, y en la última de estas escuelas debió de oírlos Gómez Pereira de boca de algún discípulo de Alfonso de Córdoba pero tras de añadirles novedad y fuerza, imaginó otros muchos tan profundos e ingeniosos, y los enlazó por tal arte, que no sin motivo podemos darle la palma entre todos los predecesores de Reid, y afirmar que ninguno mejor que él comprendió y expuso la doctrina del cocimiento directo, de la cual los nominales no tuvieron más que atisbos y vislumbres.

En psicología experimental, Gómez Pereira está, a no dudarlo, más adelantado que la filosofía de su tiempo, más que la del siglo xvir, más que Bacon, más que Descartes. Ninguno observa ni analiza como él los fenómenos de la inteligencia. El lord Canciller es casi extrańo a estas cuestiones: le absorben demasiado la clasificación de las ciencias y el método inductivo. Es partidario de la experiencia, y toma puesto en las filas de los nominalistas. Pero su experiencia predilecta es la externa, con la cual adelantan y prosperan las ciencias naturales. De la interna habla poco y confusamente.

posse, etsi universalibus et formalitatibus realibus prorsus careatur, qua sententia nihil verius, nihil nostri temporis philosopho dignius» (Tercera Edición). Leibnitz, De stylo philosophico Marii Nizolii, al frente de su edición, (Francfort, 1670) del célebre libro de Nizolio De veris principiis et vera ratione philosophandi, publicado por primera vez en 1553. (Segunda Edición)

801 «Intellectus, cum sit virtus reflexiva, cognoscit se et ea quae sunt in eo per certitudinem et quasi experimentaliter. Unde experimur nos intelligere et habere in nobis principium quo intelligimus. Si ergo in intellectu nostro esset aliqua talle species, videtur quod possumus per certitudinem cognoscere eam esse in nobis, sicut cognoscimus per certitudinem alia quae sunt in intellectu nostro, tam actus quam habitus». (No tengo las obras de Durando, y tomo esta cita de Jourdain, La Philosophia di S. Tommaso d'Aquino. Traducción italiana, Florencia, 1859). (Segunda Edición)

802 Apud Jourdain, op. cit. (tomo II, pág. 138). (Segunda Edición) 
Como todos los grandes lógicos, estudia más que nada en el entendimiento el lado pragmático.

En cuanto a Descartes, el Dr. Reid ha notado que de la antigua teoría de la percepción, sólo rechaza una fase. «Esta teoría (dice el patriarca de la escuela escocesa) puede dividirse en dos partes: la primera establece que las imágenes, especies o formas de los objetos externos proceden del objeto y entran por los sentidos al entendimiento; la segunda es que no percibimos en sí mismo el objeto externo, sino sólo su imagen o especie inteligible. La primera parte ha sido refutada por Descartes con sólidos argumentos; pero la segunda, ni él ni sus discípulos la pusieron nunca en duda, estando todos muy persuadidos de que no percibimos el objeto, sino su imagen representativa. Esta imagen, que los peripatéticos llaman especie, él la llamó idea, cambiando sólo el nombre, pero admitiendo la cosa». ${ }^{803}$

En honor de la verdad, debo advertir que estas explicaciones del Dr. Reid no están muy conformes con el significado que dan a la idea cartesiana los modernos espiritualistas, como Bordás Demoulin y Martín Mateos, ni quizá se ajusta a la verdadera de Descartes, aunque en los escritos de éste pueden hallarse proposiciones casi contradictorias en este punto. Que rechazaba los fantasmas se deduce de este pasaje de la Dióptrica: "Observandum praeterea animam nullis imaginibus ab objectis ad cerebrum missis egere ut sentiat, contra quam communiter philosophia nostri statuerunt». ${ }^{804}$ Pero contra las especies no tiene ninguna refutación directa. Tampoco ha de entenderse la idea de Descartes en el sentido platónico, porque (como advirtió Hamilton) el autor del Discurso del Método extiende el sentido de esta palabra a los objetos de nuestra conciencia en general ${ }^{805}$. Yo bien sé que el doctor Brown, disidente de la escuela escocesa, afirmó en sus Lectures on

803 «That theory may be divided into two parts: the first that images, species or forms of external objects, come from the object, and enter by the avenues of the senses to the mind: the second part is that the external object itself is not perceived, but only the species or image of it in the mind. The first part Descartes and his followers rejected and refuted by solid arguments, but the second part, neither he nor his followers have thought of calling in question, being persuaded it is only a representative image in the mind of the external object that we perceive, and not the object itself. And this image, which the peripatetics called a species, he call an idea changing the name, while he admite the thing». (Segunda Edición)

804 Cap. IV, ses. 6a Vide, sobre el juicio de Reid acerca de la doctrina de Descartes, una nota de Dugald Stewart en sus Elements of the Philosophy of the Human Mind. (London, 1837). (Segunda Edición)

805 «The fortune of this word is curious. Employed by Plato to express the real forms of the intelligible world, in lofty contrast to the unreal images of the sensible, it was lowered only when Descartes extended it to the objects of our consciousness in general». 
the Philosophy of the mind que la opinión de Descartes era diametralmente opuesta a la que Reid le atribuía; pero basta leer la brillante refutación que de aquella obra hizo Guillermo Hamilton, para convencerse de que Descartes admitía una representación mental (como si dijéramos: especie inteligible) distinta del objeto conocido y del conocimiento mismo, «and consequently that in the act el knowledge the representation is really distinct from the cognition propern.

Malebranche presentó como doctrina cartesiana la de las representaciones distintas de la percepción, y fue refutado por Arnauld, el cual sostuvo, como Gómez Pereira, que todas nuestras percepciones son modificaciones del alma; pero añadió: esencialmente representativas. La representación, ni aun en ese sentido la admite Gómez Pereira; ni tampoco Reid, que, partidario acérrimo del conocimiento directo, califica el parecer de Arnauld de tentativa desgraciada de reconciliación entre dos opuestas doctrinas.

En el precioso Ensayo que cité antes, probó Hamilton evidentemente que ni Locke ni otros filósofos de menor cuenta dejaron de admitir el sistema de la representación en una o en otra forma. Leibnitz rechaza ciertamente las especies inteligibles, pero es para sustituirlas con hipótesis de otro género, no menos opuestas a la teoría de la percepción directa.

La gloria de haberla asentado sobre firmísimos fundamentos pertenece a la escuela de Edimburgo, y especialmente al doctor Reid. No es mi intento disminuir en un ápice el mérito de esta prudente y sabia escuela, que fundó en el sentido canon el sistema del realismo natural, destruyendo para siempre la hipótesis de la representación, con la cual (dice Hamilton) no hay medio entre el materialismo y el idealismo. ${ }^{806}$ Pero séame lícito pedir algún recuerdo y alguna justicia para los antiguos nominalistas, para Durando y Occam, y sobre todo para Gómez Pereira, cuyo nombre se enlaza con una de las mayores y más positivas, aunque menos ruidosas, conquistas de la ciencia. Las brillantes concepciones a priori, los sistemas germánicos de lo absoluto, van uno tras otro desapareciendo; pero quedarán en pie el hecho de conciencia primitivo e irreductible, la observación psicológica y la crítica que de ella nace.

¿Osaré decir que en estos resultados han influido, más de lo que parece, Vives, Gómez Pereira y otros filósofos peninsulares?

(Hamilton, en el artículo titulado Philosophy of perception, impreso por primera vez en la Revista de Edimburgo de octubre de 1830). (Segunda Edición)

806 «On the hypothesis of a representative perception, there is, in fact, no salvation from materialism on the one side, short of idealism on the other». (Segunda Edición) 
El Dr. Miguel de Palacios, en sus Objectiones ya citadas, combate, en el sentido de la escolástica tradicional, dos de las paradojas que en psicología sentó Pereira: la identificación del acto de sentir y de la facultad sensitiva: la no existencia del sentido común. Pero sus argumentos, aunque presentados con habilidad, son débiles, y Gómez Pereira lleva la ventaja en esta parte de su sistema.

III. Principios de las cosas naturales. - La materia prima._La substancia y el accidente, etc. - En el campo de la psicología fue donde ejercitó principalmente su actividad Gómez Pereira; pero tampoco dejó de sostener atrevidas novedades físicas y ontológicas en algunas cuestiones que trató por incidencia y a modo de digresión. Una de ellas fue la de principiis rerum naturalium, que no resolvió en sentido platónico como Fox Morcillo, ni aristotélico como Benito Pererio, sino inclinándole al atomismo, no tanto, sin embargo, que podamos decir con Isaac Cardoso: Gomezius Pereira in sua ANTONIANA MARGARITA, Aristotelem deserens, in castra Democriti se recepit. ${ }^{807}$ Aunque sea evidente la inclinación de Gómez Pereira a la física corpuscular, no me atrevo a decir que se pasase a los reales de Demócrito. La exposición siguiente mostrará su verdadera doctrina.

Empieza por apuntar, siguiendo a Aristóteles, los pareceres de los antiguos filósofos mecánicos, dinámicos, etc.; refiere luego el del mismo Aristóteles, según resulta de la Física, y añade los de Hipócrates y Galeno. En seguida comienza a impugnar los tres principios de la Escuela: materia, forma y privación; pero sobre todo la materia prima. Los elementos se corrompen del todo por la acción de disposiciones contrarias a su conservación, y se engendran de la corrupción de los otros, sin que preexista materia alguna. «Ninguna generación se verifica sin la corrupción de otro ente; ninguna corrupción sin la generación de un nuevo ser». ${ }^{808}$

«La materia prima es inútil, según el axioma de que no se han de multiplicar los entes sin necesidad. Es condición de la materia ser un todo compuesto (totum compositum): por consiguiente, la materia prima será generable y corruptible, se resolverá en otra, y ésta en otra usque ad infinitum, o hasta que lleguemos a los elementos, verdaderos principios de las cosas. Si no es materia como la materia que conocemos, sólo resta que sea mera potencia de la forma, capacidad de recibirla, y por ende cosa vana y ficticia, ente de

807 Philosophia Libera. (Segunda Edición)

808 «Elementa in totum corrumpuntur per actionem eorum quae inducunt contrarias dispositiones suae conservationi et de nova gignuntur... ubi alia corrupta fuere, citra ullius materiae existentiam... Nulla generatio fieri valet sine alterius entis corruptione, neque ulla corruptio absque alicujus entis nova naturali generatione.» (Segunda Edición) 
razón, porque la inherencia no es distinta de la cosa inherente, como la cantidad no se puede separar de la cosa quanta, ni la figura de la cosa figurada.»

"iPor ventura podremos llamar a la materia prima, potencia de todo el compuesto, entendiendo que en la composición no tiene otro ser que el ser total de la cosa? Pero, ¿cómo hemos de decir que tiene el mismo ser de la cosa compuesta, sino afirmando que el compuesto y el componente son una sola y misma cosa? Y entonces tendrán que confesar los escolásticos que la parte componente es igual al todo compuesto. Ajeno es de todo buen discurso imaginar que la materia no tiene más ser que el que recibe de la forma, y que de ambas resulta un solo ente. Si la forma da su ser a la materia, las dos entidades vienen a convertirse en una sola. Acaso supondrás que la materia da primero el ser a la forma, cuando ésta es educida o sacada de la potencia de la misma materia, y que después, de la unión de ella y de la forma, resulta el todo esencial; pero esto es un delirio». ${ }^{809} \mathrm{Y}$ entonces, ¿quién da el ser a la materia?»

«Más verosímil será afirmar que los principios de la substancia corpórea y mixta son los cuatro elementos que sucesivamente se engendran y corrompen. De esta manera no habrá necesidad de fingir entidades que ni percibimos en sí mismas ni conocemos por sus efectos, como ese fantasma de la materia prima». ${ }^{810}$

Verdad es que la distinción de materia y forma servía de base a la doctrina del compuesto humano de los teólogos; pero Gómez Pereira no se detiene por eso. «Sospecho, dice, que los grandes teólogos, atentos a la especulación de las cosas dignas y al cuidado de la salvación de las almas, despreciaron no pocas veces la observación de las cosas naturales, y cayeron así en algunos

809 «An potentia totius compositi materia prima dicatur, intelligendo ipsam in toto composito nullum esse habere quam in quod est totius. Quomodo aliquid intelligi potest componere aliud quod idem esse cum re composita habeat, nisi illam rem compositam esse idem numero cum re componente intelligant, et sic partem componentem esse idem toti composito, fatebuntur? Et formam non minus quam materiam idem esse toti dicant, quod implicat... Fingete enim materiam ex se nullum esse habere, sed suum esse a forma illi conferri, et ex utrisque unicum ens resultare, a captu hominum... alienissimum iudicatur... Primo quod si forma dat esse materiae, vel suum esse datura est vel aliud. Si suum esse, jam duae entitates idem essent... Fortassim opinaberis materiam primo dare esse formae cum a potentia ejusdem eliciatur, ac postea ex ea et forma educta resultare totum essentiale, quod non minus delirium est.» (Segunda Edición)

810 «Vereque similius dixerit qui principia corporae substantiae mixtae esse elementa quatuor testaretur, ac illorum quodlibet corrumpi omnino posse existimasset, corruptoque sucedere elementum ejusdem speciei cum corrumpente, fateretur: hac enim assertione non fingitur entitas quae nec seipsam ostendit, neque ullum sui ipsius effectum sentimus, ut cum materia prima ficta machinatur.» (Segunda Edición) 
errores». Poco importa que Santo Tomás hable de materia y forma en el hombre: sus razones minime probant, porque está en contra la experiencia. ${ }^{811}$

También escribió algo Gómez Pereira acerca de la Educción de las formas de la potencia de la materia, impugnando la opinión de un grave doctor moderno a quien no nombra, según el cual, educirse las formas de la matena, de la cual todas, excepto el alma racional, dependen, es convertirse la potencia en acto, el fieri en esse.

Los elementos son entes corpóreos, simplicísimos, los más imperfectos entre todas las substancias corpóreas, porque son los menos compuestos, y la esencia de la materia es la composición.

De las mil cuestiones, muchas veces menudas y fútiles, que Gómez Pereira promueve acerca de la generación y corrupción, no haré memoria, porque sólo conduciría a molestar a V. y a hacer olvidar a los lectores los verdaderos principios físicos de la Antoniana.

Como adversario de las formas substanciales, Gómez Pereira tiene innegable importancia; pero no es el único ni el primero en España. Antes que él había escrito Dolese en sentido francamente atomista su Suma de filosofía y medicina, libro que no he llegado a ver, pero que encuentro citado por Isaac Cardoso, autoridad de gran peso en todo lo que a nuestra ciencia se refiere: «En España, Pedro Dolese, caballero valenciano, de profesión médico, publicó una Suma de filosofía y medicina en que sigue a Demócrito, y defiende sus opiniones acerca de los principios naturales, los átomos y la incorruptibilidad de los elementos». ${ }^{812}$ Dolese es el más antiguo de los atomistas modernos; a lo menos así lo afirma Isaac Cardoso, que sabía bien la historia de estas controversias. ${ }^{813}$

Contra las formas substanciales se levantaron principalmente los médicos. Además de Gómez Pereira, las combatió Francisco Vallés en su Philosophia Sacra. "Regnabat pacifice et feliciter sane regnabat (escribe el jesuita Ulloa) in scholis omnibus Europae, aristotelicorum entis naturalis systema, compositio nimirum ex materia et forma reciproce distinctis. Sed medici duo Hispani, alter complutensis Valles, satis notus ex Sacra sua Philosophia, gallegus alter Pereira,

811 Adviértase que aquí no hago más que exponer la doctrina de la Antoniana. Por lo demás, antes me inclino a la doctrina del compuesto humano, y menos inconvenientes veo en ella, que en el dualismo de Gómez Pereira y Descartes. (Segunda Edición)

812 «Petrus Dolese in Hispania, medicus et eques Valentinus, Summam Philosophiae et Medicinae edidit, Democriti philosophiam sequutus, illiusque placita de principiis rerum naturalium, de atomis, de elementorum incorruptibilitate.» (Segunda Edición)

813 «Suscitavit primum Petrus Dolese Valentinus...» (Philosophia Libera, pág. 10) (Segunda Edición) 
haud ignotus ex sua Margarita Antoniana, enti naturali quod bene se habebat mederi volentes, ipsum necavere». ${ }^{814}$

Vallés confiesa que en sus primeros escritos y en sus lecciones de física había defendido la materia prima, pero que ya la consideraba como hipótesis inventada para los más rudos ("hypothesim quandam esse ob rudiores confictam»). Para Vallés, los principios son los elementos, que están en potencia en las cosas concretas, en acto en ninguna parte. ${ }^{815} \mathrm{Ni}$ existen, ni han existido ni pueden existir puros y sin mezcla, ni tienen formas substanciales. Los que llamamos elementos, son cuerpos de composición más sencilla y más próxima a la naturaleza elemental, pero en ninguna manera simples. La forma de la cosa es su esencia. Los seres se dividen en corpóreos e incorpóreos no en materiales e inmateriales, a no ser que llamemos materia al conjunto de los cuerpos. El principio de individuación no es la materia, sino la cantidad. ${ }^{816}$ El modo como Vallés explica y defiende estas ideas, no es para tratado de pasada. Día vendrá en que yo escriba de propósito acerca de la Sacra Philosophia. Ahora baste advertir que en lo esencial conviene su autor con Gómez Pereira, afirmando la corruptibilidad de los elementos. De la alteración nace la generación. «Si no existiera en los seres una lucha por la existencia, o nada se engendraría, o la generación de cada cosa procedería hasta lo infinito». Citaré las palabras textuales: "Data autem est rebus a natura parente ea contrarietas et necessitas pugnandi ad generationem: quia si aliter quam per pugnam generare possent, neque talem repugnandi vim haberent, aut nibil generaretur, aut generatio rei cujusque procederet in infinitum». «Nada atajaría el progreso de la generación (añade) si todas las cosas no se pusiesen recíprocamente límites, peleando entre sí. Por eso fue necesario que hubiese entre las cosas lid y contrariedad, y que unas se engendrasen de otras, aunque no tienen una materia común». ${ }^{817}$ Tal es el sentido de la

814 Phis. speculat. prol. Citado por Laverde, Ensayos, pág. 354. (Segunda Edición)

815 «Elementa prima sunt potentia in rebus concretis, actu vero nullibi... Ut nullibi munda sint aut fuerint unquam, aut etiam esse possint... Elementis primis nullas formas substantiales attribuo...» (Pág. 27 de la Sac. Phil.) «Rei naturalis forma nihil aliud est quam res ipsa qua haec et talis.» (Segunda Edición)

816 «Principium quod vocant individuationis non esse materiam sed quantitatem. Et tota rerum universalium proprius dividitur in corpoream et corpore carentem substantiam, quam in materialem et immaterialem, nisi quis his nominibus easdem res intelligat.» (Segunda Edición)

817 «Nihil enim esset quod medium poneret rei cujuspiam productioni, nisi omnes sibi ponerent mutuo, mutuo repugnando. Necesse fuit contrarietatem indere, eaque contrarietas necessitatem affert ut res ex rebus fiant, etsi communem materiam non habeant.» (Vallés Sac. Ph., páginas 524 y 25.). (Segunda Edición) 
lucha por la existencia en el sistema de Vallés. Los elementos diversamente combinados forman todos los cuerpos, que en continua lucha se alteran y destruyen para dar lugar a nuevas composiciones, que sólo se diferencian en la cantidad. Si los antiguos ponían la vida del Universo en el amor, Vallés en la contrariedad y discordia. ${ }^{818}$

Esta doctrina tuvo mucho séquito en Alcalá. Isaac Cardoso cita, entre sus defensores, a Torrejón, que será sin duda el teólogo Pedro Fernández Torrejón, autor de un comentario o exposición de la física de Aristóteles, así rotulado: Antiquae Philosophiae enucleatio per expositionem in octo libros Physicorum; y al médico Barreda, autor de un tratado de temperamentos. Uno y otro pertenecen ya al siglo XVII, porque la tradición atomística (llamémosla así siguiendo a Cardoso, aunque el nombre no sea del todo exacto) no se interrumpió entre nosotros un momento. Fuera de aquí, todos los reformadores filosóficos de mediados y fines de aquel siglo convinieron en rechazar las formas substanciales, inclinándose los más al mecanismo y algunos al dinamismo. Gassendi redujo a sistema las concepciones atomísticas de Demócrito y Leucipo. Siguiéronle muchos, y entre los españoles Isaac Cardoso, que dedicó todo el primer libro de su Philosophia Libera, impresa en 1673, a tratar de principiis rerum naturalium, mostrándose acre y tenaz en la reprensión de Aristóteles. «¿Cuánto no se hubieran reído (dice) Demócrito, Platón, Empédocles y Anaxágoras, si hubieran oído que la privación es el principio de las cosas, y que hay una materia nuda e informe, de cuyo vientre, como del caballo Troyano, proceden todas las formas, que, sin embargo, están sólo en potencia, produciéndose, por consiguiente, de la nada todos los seres naturales? El mismo Heráclito lloraría al oír tan monstruosa enseñanza. Si la privación es nada, ¿̨por qué se la cuenta entre los principios?». 819

"¿Y qué es la materia prima? ¿Será un punto o un cuerpo? No puede ser cuerpo, porque no tiene forma ni cantidad. Si es punto, dependerá de otro sujeto en quien persista, y, por tanto, no será principio. Si es cuerpo, no será ya pura potencia tendrá cantidad, porque todo cuerpo es quanto. Vacío no será, porque los escolásticos no concederán que se dé vacío en la naturaleza. ¿Dónde está, pues, ese cuerpo insensible, sin cualidad ni cantidad; dónde ese fantasma o vana sombra? $\mathrm{Ni}$ en los elementos, ni en el

818 Empédocles admitía, como es sabido, las dos fuerzas. (Segunda Edición)

819 «Quid riderent Democritus, quid Plato, Empeclocles et Anaxagoras, si privationem audirent rerum esse principium, si quandam nudam materiam confinctam et informem, et illius ventre exiri formas, tamquam ex equo Trojano», etc., etc. (Phil. Lib., pág. 2.) (Segunda Edición) 
cielo, ni en los mixtos...; en parte alguna, a no ser en nuestro pensamiento. ¿Y cómo ha de crear nuestro pensamiento entes naturales? Los principios de toda composición natural, no son lógicos, ni gramaticales, sino reales, naturales, físicos, sensibles». ${ }^{820}$ Vaginam et amphoram formarum, llama por donaire a la materia prima.

Cardoso difiere de Vallés en un punto muy importante: sostiene la incorruptibilidad de los elementos, y procura comprobarla con razones y experiencias, tomadas algunas de ellas de Maignan y Beligardo.

En la cuestión de atomis et illorum natura, el médico hebreo se declara partidario de D'Olesa y de Gassendi: «Doctrina de atomis tametsi apud vulgares Philosophos male audiat, tamen iis qui libertatem in philosophando sortiuntur, verissima existimatur... utpote quae melius rerum causas earumque affectiones asserit». Los átomos son: «minima et indivisibilia rerum naturalium principia, ex quibus componuntur et in quae ultima fit resolutio. Vocantur semina rerum, elementa primae magnitudinis, prima corpora, et apud Pithagoricos unitates. Solida sunt ac inanis expertia, individua, insectilia, insensibilia ac invisibilia corpuscula, et quamvis sint partes individuae, non sunt instar puncti mathematici, sed ita sunt solidae, compactae et minimae ut dividi nequeant, infrangibiles ob exiguitatem, invisibiles ob parvitatem». ${ }^{821}$

Cardoso desarrolló largamente estos principios, y su libro, a pesar de ser judaizante el autor, fue muy leído y apreciado en Espańa tomando puesto en las bibliotecas de conventos y Universidades. Además, se conocía directamente a Gassendi y a Maignan, cuyas doctrinas, así como las de Descartes, fueron ya tenidas en cuenta por Caramuel. Y aun algunos españoles entablaron polifónica con los atomistas de ultra-puertos. El P. Palanco, obispo de Jaén, publicó un Dialogus physico-theologicus contra philosophiae novatores. Replicóle el P. Saguens, de la Orden de los Mínimos, en su Atomismus demonstratus.

Iba entrando el siglo xviII, y creciendo el número de adeptos de la filosofía corpuscular. Defendiéronla el P. Juan de Nájera, en su Maignanus Redivivus, y el presbítero Guzmán en su Diamantino escudo atomístico; ${ }^{822}$ pero más que todos se distinguió el insigne valenciano P. Vicente Tosca, restaurador de la manera de filosofar crítica, libre y amplia que llamamos vivismo. Atendiendo a su doctrina sobre los principios de los cuerpos le he

820 "Quid erit, quaeso, talis materia. Eritne punctum aut corpus? Corpus non erit; quia nec formam nec quantitatem habet... Si punctum est, indigebit alio subjecto in quo persistat, ac proinde non erit primum subjectum... Si corpus est, ergo jam non erit pura potentia». etc. (Página 4.) (Segunda Edición)

821 Philosoph. Lib., pág. 9. (Segunda Edición)

822 Vide Laverde, Ensayos, pág. 305. (Segunda Edición) 
apellidado alguna vez gassendista; pero lo cierto es que en el conjunto de su doctrina no se ató a ningún sistema extranjero, porque era hombre de «larga experiencia y contemplación, de indecible amor a la verdad y libertad en profesarla; que supo contenerse donde convenía, y no dejarse llevar ni de las preocupaciones de la antigüedad ni de los halagos de las novedades modernas; amigo de elegir de cada secta filosófica lo que mejor le parecía». ${ }^{823}$ Y por eso dijo un célebre satírico del siglo pasado (que a veces hablaba en veras), impugnando a Vernei (alias el Barbadiño): «El insigne valenciano Vicente Tosca, no sólo nos dió larga noticia de todas las recientes sectas filosóficas, sino que aun se empeñó... en que había de introducirlas en España, desterrando de ella la aristotélica. No logró del todo su empeńo, pero lo consiguió en gran parte, porque en los reinos de Valencia y de Aragón se perdió del todo el miedo al nombre de Aristóteles; se examinaron sus razones sin respetar su autoridad, y se conservaron aquellas opiniones suyas que se hallaron estar bien establecidas. Y al mismo tiempo se abrazaron otras de los modernos que parecieron puestas en razón de manera, que en las universidades de aquellos dos reinos se tiene tanta noticia de lo que han dicho los novísimos terapeutas de la naturaleza, como se puede tener en la mismísima Berlín». ${ }^{824}$

En la difusión del experimentalismo y de la filosofía natural influyó cuanto es sabido el P. Feijoo, aunque en la cuestión de principiis anduvo indeciso y no se atrevió a prescindir de las formas substanciales, como hacían Tosca y sus discípulos.

Volvamos al libro de Gómez Pereira, que, por ser un semillero de ideas y de paradojas, me hace caer a la continua en interminables digresiones. El resto de su cosmología más se distingue por la extravagancia que por los aciertos. Notaré sólo una teoría del fuego, bastante rara y original. «Investiguemos (dice) si en la concavidad de la luna existe un fuego elemental que excede en décupla proporción a la mole del aire, o si el tal fuego es una vetusta fábula de los poetas, semejante a los Campos Elíseos, a la Stigia y a las infernales furias, pues no parecen muy fuertes las razones que se traen para probar la existencia de ese inmenso fuego, y la verdad es que Aristóteles anduvo dudoso en esta parte».

Tras este comienzo, era de esperar una negación rotunda; pero esta vez Gómez Pereira nos da chasco. «A mi parecer (dice), hay en la región superior

823 Mayáns, dedicatoria del libro intitulado Cartas morales, militares etcétera. (Madrid, por Juan de Zúñiga, 1734.) Varias veces reimpreso. (Segunda Edición)

824 El P. Isla, en Fr. Gerundio de Campazas, pág. 118 de las Obras escogidas de aquel jesuita, edición Rivadeneyra. (Segunda Edición) 
que linda con el cielo una substancia cálida y seca, no desemejante por su consistencia al aire. Llamémosle fuego o exhalación: poco importa... Este fuego entra en la composición de todos los mixtos... Si quieres experimentarlo, mete la mano en las entrańas, especialmente en el corazón, de un animal medio muerto, tenla algún rato, y sentirás un calor grande y como de llama. El mismo ardor notarás en la descomposición de las lanas o de los estiércoles, o de otros mixtos semejantes. El fuego inferior que decimos llama no es simple como éste, sino compuesto». ${ }^{825}$

Vallés imaginó otra teoría del fuego mucho más ingeniosa, y adoptada después por Boerhaave. Para el médico de Alcalá, como para el de Leyden, no existe ese fantástico fuego elemental en el orbe de la luna; el fuego en ninguna parte se encuentra separado, sino que es el alma del mundo, el padre de toda generación, el agente universal de las combinaciones, el que mantiene y alimenta todo ser, el espíritu de Dios que corría sobre as aguas. Todas estas cosas están defendidas en la Filosofía Sacra, ${ }^{826}$ y la concepción no carece de grandeza.

No me detendré en una porción de extrañas cuestiones físicas que trata Gómez Pereira, y que luego trató Cardoso con soluciones no menos extrañas. Pero sí advertiré que el autor de la Antoniana anduvo muy en lo cierto al defender que sólo una causa extrínseca (forinseca causa) puede inducir el alma vegetativa y sensitiva en el feto, y cuando prueba contra los expositores de Aristóteles «semen non esse animatum».

De ontología trató poco nuestro autor; pero en eso poco cortó por lo sano, negando una porción de distinciones que establecía la ciencia escolástica. A juicio suyo, los realistas habían confundido los accidentes reales y distintos de la substancia (blanco, negro, caliente, dulce, etc.) con los que no son más que distinciones intelectuales.

Para separar los accidentes que en realidad son distintos, señaló dos métodos:

«Son distintos los accidentes que producen impresión diversa en la parte sensitiva, y nos traen la noción de una cosa nueva. Así distinguimos la blancura de la leche, de su dulzura, percibiendo con los ojos la primera y con el gusto la segunda. Si ambas fuesen la misma cosa en la leche, uno de los dos

825 «Expedit discurrere an... ignis elementum simile huic nostro sub cavo orbis lunaris situm est, excedens aeris molem in decupla proportione, an id sit commentum quoddam ac quaedam vetusta fictio similis poetarum campis Elysiis, etc... Est ergo meum decretum in supera regione coelo contermina substantiam quamdam calidam siccamque esse», etcétera, etc. (Segunda Edición)

826 Vide principalmente las páginas 28, 29, 30, 31, 457, etc. (Segunda Edición) 
juicios habría de ser falso o deceptorio. De la misma suerte distinguimos la substancia de Sócrates de su blancura, porque la substancia queda y el color se muda. Y por la misma razón distinguimos de la substancia el olor y las demás cualidades realmente distintas. Pero en este juicio podemos engañarnos, porque a veces la substancia se modifica, perdiendo la figura, la cuantidad y otros accidentes, que no por eso son separables de la substancia. Entonces tenemos otro medio de distinguirlos. Podemos alterar a nuestro arbitrio la cantidad, la figura, el lugar, etc., de la cosa; pero no su color, ni su sabor, ni su olor. No podemos trocar lo blanco en negro, ni lo fétido en oloroso, ni lo caliente en frío. Al contrario: estas cualidades nos afectan en ocasiones contra nuestra voluntad. Además, hay muchas substancias incoloras, inodoras, etc.; pero ninguna sin cantidad o sin figura, porque estos accidentes no se distinguen realmente de la substancia». ${ }^{827}$

Prueba más adelante que las relaciones no se distinguen de los fundamentos ni de los términos, y que Aristóteles jamás admitió tales distinciones reales, sino meramente lógicas, así en las Categorías como en la Metafísica.

En cuanto a la percepción de los universales de accidente (el color en general), la cuestión es sencilla: o se consideran como singulares, y entonces se perciben como sensibilia per se, o como verdaderos universales y entonces se conocen per accidens y por el entendimiento. ${ }^{828}$

Aun lleva más allá su horror a las distinciones reales. Para él, el ente no se distingue de la esencia, ni ésta de la existencia, y así debió de entenderlo Santo Tomás, aunque sus expositores lo expliquen de otro modo. "Illa essentia quae concipitur cum ipsa non sunt, pastea cum sunt et existunt, est illa sua existentia. Concipimus quae sunt et quae non sunt eodem modo». Esta cuestión capital de la Metafísica (que Suárez resuelve del mismo modo), está tratada muy de paso en la Antoniana.

827 «Illa tamen habenda sunt accidentia realiter distincta a substantia, a quibus si homo parte sensitiva afficeretur, notionem novan rei sensisset. Ideo distinctas res esse quae sunt, sensibus cognoscimus, quia vel diversis in locis contineri ea percipimus, et sic singulares substantias Socratis et Platonis, et hujus lapidis et illius lupi... quod non simul ac penetrative se habeant... vel quod res penetrative se habentes, ac simul existentes, aliter sensus nostros afficiant. Ideo enim albedinem lactis distingui a dulcedine ejusdem indicamus, quod oculis percipimus nitorem albi, et gustu dulcorem lactis» etc., etc. (Segunda Edición)

828 «Utrum accidentium universalia per accidens, an per se sensibilia sint... Unica distinctione posita... aut accidentia considerantur ut singularia sunt, et sic sensu ut sensibilia propria percipiuntur, aut ut aliquid commune cum aliis habentia, et sic intellectu et per accidens, cognoscuntur.» (Segunda Edición) 
En la no distinción de ciertos accidentes entitativos, siguió Gómez Pereira a los antiguos nominalistas, especialmente a Occam y a Gregorio de Rímini, y tuvo a su vez muchos secuaces. Vallés, en las Controversias, ${ }^{829}$ negó que la cantidad se distinguiese de la substancia. El mismo parecer llevaron muchos escolásticos, principalmente Jesuitas, como Pedro Hurtado de Mendoza, Torrejón y Rodrigo de Arriaga. ${ }^{830}$ Francisco de Oviedo, también de la Compañía, identificó con el cuerpo la figura. Y así otros, otras cualidades. No hay que decir si Isaac Cardoso se acostaría a las mismas opiniones, tan conformes a las novísimas filosofías cartesiana y gassendista.

El valenciano Benito Pererio, en su elegante tratado De communibus omnium rerum naturalium principiis, no admite distinción entre la esencia y la existencia, separándose en éste y en otros puntos de la doctrina de Santo Tomás ${ }^{831}$ con aquel espíritu de libre indagación que en el siglo XVI solía acompañar a los pensadores Jesuitas.

Miguel de Palacios, en sus Objectiones, dejó pasar sin impugnación todas las novedades hasta aquí expuestas, excepto la negación de la materia prima, y la teoría de la generación y corrupción, que es su consecuencia.

IV. Tratado de la inmortalidad del alma. - En la página 496 del volumen que voy recorriendo, acaba lo que propiamente se llama Antoniana Margarita; pero a continuación se leen dos tratados adicionales. Del primero, poco hay que decir. Titúlase Paraphrasis in tertium librum Aristolelis De anima. Gómez Pereira, apartándose, como desde el principio advierte, del camino de todos los expositores, trata de conciliar la doctrina del Estagirita con la suya, interpretándola en sentido muy lato, pero con agudeza. Opina, como Cardillo de Villalpando, ${ }^{832}$ Martínez de Brea ${ }^{833}$ y casi todos los nuestros, que Aristóteles creyó en la inmortalidad del alma. La paráfrasis va acompañada de algunas notas en letra más menuda. Allí vuelve a sostener el automatismo de las bestias.

829 Francisci Vallesii Covarruviani, Controversiarum Medicarum et Philosophicarum... Editio quarta... Venetiis, apud Paulum Meietum, 1591, 4º 14 páginas sin foliar, una blanca y 323 folios. (Segunda Edición)

830 Cítalos a todos Isaac Cardoso, lib. I, quaest. XV, De quantitate. (Segunda Edición)

831 Benedicti Pererii Societatis Jesu, De communibus omnium rerum naturalium principiis et affectionibus, libri XV... Venetiis, 1586. Libro VI, De forma. (Segunda Edición)

832 Apología Aristotelis adversus eos, qui ajunt sensisse animam cum corpore extingui... Auctore Gasparo Cardillo Villalpandeo. Compluti, ex officina Joannis Britonii, 1560. (Me valgo de la reimpresión de Cerdá en los Opúsculos). (Segunda Edición)

833 Tractatus que ex Peripatetica Schola Animae immortalitas asseritur et probatur. Segontiae, 1575, folio; al fin de su comentario al tratado De anima. (Segunda Edición) 
Como ilustración a esta paráfrasis, sigue otro fragmento, en que el autor repite que las sensaciones e intelecciones no son actos diversos del que siente y entiende, por ser el sentir y entender la esencia del alma, no obstante el parecer contrario de los escolásticos, a quienes procura convencer trayendo pasajes de Aristóteles y de San Agustín, De Trinitate, en su abono.

El segundo tratado se rotula así:

"De immortalitate animorum Antonianae Margaritae, ubi potiora quae de re hac scripta sunt, adducuntur et solvuntur, et novae rationes, quibus a mortalitate rationalis anima vindicatur, proponuntur».

Gómez Pereira depara haber leído todas las apologías de la inmortalidad del alma, sin que ninguna le convenciese, por lo cual va a refutarlas una por una. En cuanto a él, ha encontrado argumentos de tanta fuerza como las demostraciones matemáticas, argumentos ignorados hasta entonces, como se ha ignorado siempre la cuadratura del círculo.

La primera parte del tratado, más se puede llamar de la mortalidad que de la inmortalidad; y si no estuviera yo bien convencido de la libertad filosófica que reinaba en la España del siglo Xvi, motivo tendría para admirarme de que el Santo Oficio hubiera permitido la impresión, y el cardenal Silíceo admitido la dedicatoria de un libro en que se tienen por vanas y de poco momento, y se critican ásperamente las razones todas en que la humanidad venía fundando una de sus más indestructibles creencias, para darla luego un fundamento más o menos sólido, pero nacido de una opinión psicológica individual, que pugnaba con la generalmente admitida en las escuelas.

El primer documento que en esta cuestión de la inmortalidad se presenta, es el Fedón platónico, diálogo admirable que ha infundido en tantos el dulce deseo de la muerte. Pero Gómez Pereira permanece sordo a aquel encanto: todo aquello de la fértil Ftia que se lee en el Critón, le parece retórica pura: retórica el argumento fundado en la justicia de las penas y de las recompensas. "Rhetoricam plus quam Physicam sapiunt». Las razones puramente filosóficas de Platón son muy débiles, por estar fundadas en el sistema de la transmigración y de la reminiscencia, que el autor de la Margarita rechaza con toda energía.

En representación de los platónicos cristianos viene San Agustín con su libro De immortalitate animae, pero sus razonamientos (prosigue imperturbable el médico de Medina) son nullius valoris, y además están faltos de todo enlace lógico. El mismo Santo reconoció el poco orden y la oscuridad de aquel tratado, en sus Retractiones. Tiempo perdido será el que invirtamos en destruir estas cavilaciones, porque no habrá nadie tan ignorante de la 
Dialéctica que no pueda desatarlas fácilmente; pero temo que algunos se dejen llevar de la autoridad y nombre del escritor, no pensando las palabras, sino el autor, den crédito a sus discursos». ${ }^{834} \mathrm{Y}$, en efecto, ¡qué cosa más fútil que este modo de razonar: toda ciencia es eterna, la ciencia está en el alma; luego el alma es eterna! Este argumento sólo servirá para probar la inmortalidad de la especie, el intelecto uno. No menos vano le parece este otro: «La razón es inmortal, y el alma no se puede separar de la razón; luego el alma es inmortal». Este argumento, sin embargo, aunque no expuesto con bastante precisión, es en la substancia idéntico a otro de Gómez Pereira y de Descartes, que veremos luego.

Después de haber tratado tan cavalièrement a San Agustín, la emprende con el Peripato. De Aristóteles dice poco, porque el Estagirita nunca trató de propósito esta cuestión, y anduvo oscuro en ella.

Pero ¿qué diremos (continúa) de Averroes, ese hombre rudo, crassae et confusae Minervae, bárbaro, y antes caliginator que expositor? Ni él ni los demás árabes sabían griego ni latín. Se dejaron guiar por intérpretes, asimismo indoctos, ciegos que guiaban a otros ciegos y les hacían caer en el hoyo. Gómez Pereira, tras estas invectivas, que estaban de moda entre los filósofos del Renacimiento, aconseja a sus lectores que no pierdan el tiempo ni la paciencia leyendo las paráfrasis de Averroes, impresas en 1552 por los Juntas, ni menos su libro de medicina intitulado Colliget.

Averroes es el padre del famoso argumento escolástico Intellectus recipiens omnes formas materiales debet esse denudatus a substancia recepti. Pero si el entendimiento ha de ser inmaterial porque recibe formas materiales, claro está que para recibir las inmateriales debe de ser material. El argumento es, pues, contraproducente. Fuera de esto, todas las razones de Averroes y de la escolástica se fundan en la doctrina de las especies inteligibles, del intelecto agente y del posible, fantasmas ya destruídos o ahuyentados por Gómez Pereira. El cual aquí persigue y anonada a los partidarios del intelecto uno, con las razones generalmente usadas en la escuela contra el panteísmo, o más bien monopsiquismo averroísta, pero expuestas con mucha fuerza.

Los que quieren demostrar la inmortalidad del alma, suponiéndola partícula de la esencia divina, yerran en los fundamentos teológicos. Los que acuden al Lumen intellectus, que transforma en inteligibles las especies

834 «Nullum laborem nec tempus ego consumpturus in huinsmodi cavillis solvendis, quod credam paucos peritos Dialecticae non eos facillime extricare posee, nisi vererer auctoritate scriptoris aliquos adeo irretitos fuisse, ut non verba, sed auctorem pensando, jam omnimodam fidem illis rationibus ab eis tributam.» (Segunda Edición) 
sensibles, se apoyan en un sistema errado sobre los modos de conocer, y en la vana distinción de dos clases de entendimiento.

Antes de entrar en la exposición de sus inauditos argumentos, Gómez Pereira, que se repite a cada paso, vuelve a traer a cuento el automatismo de las bestias, y vuelve a emprenderla con San Agustín, que en su libro De quantitate animae, se mostró más teólogo que físico, plus theologicis negotiis vacavit quam physicis.

La razón primera y capital que Gómez Pereira aduce en pro de la inmortalidad del alma, es la que después adoptó Descartes, y que se conoce en las escuelas con el nombre de prueba cartesiana. Está fundada en el dualismo humano y en la independencia de las operaciones del alma, que tiene el cuerpo por instrumento. En estos términos desarrolla el médico español su argumento:

El alma puede ejecutar sin el cuerpo sus principales operaciones (el entender): luego puede vivir sin el cuerpo, porque no depende de él, como depende el accidente de la substancia, en el ser, ni en el conservarse, ni necesita de las disposiciones del sujeto para reparar las partes perdidas, porque como es inmaterial, no tiene partes. El alma ejerce sin el cuerpo, no sólo la operación de entender, sino la de sentir, porque una y otra son operaciones inmanentes... El alma no tiene instrumentos con que (quibus) hacer sus obras, sino por medio de los cuales (per quae) las haga, porque en el estado actual no puede prescindir de los sentidos. ${ }^{835} \mathrm{El}$ alma racional que informa el cuerpo es semejante a un hombre encerrado en una cárcel, puesto dentro de un enrejado y sumergido en profundo sopor, del cual sólo le despierta algún golpe en el enrejado o algún objeto visible, odorífero, gustoso, etc., que por alguna de las ventanas se le ofrece. Entonces despierta sobresaltado, y siente los golpes en la red, o percibe por una ventana los colores y las luces, por otra el sabor, etc.

Los objetos exteriores que impresionan nuestros órganos no concurren a la sensación de otra manera que como el que despierta a un hombre dormido. ¿Podremos llamar a este hombre causa de nuestro conocimiento e intelección? Causa eficiente en ninguna manera: ocasión sí, porque sin él no

835 «Ut anima sine corpore potest praecipuas operationes exequi... sic sine eodem potest manere, quia non ab eo pendet in esse et conservari, ut accidentia, a subdita substantia, nec eget subjecti dispositionibus ut restituat partes amissas, quod anima rationalis, indivisibilis cum sit, nullas partes habet quas amittere possit... Porro humana anima non tantum intelligendi operationes sine corpore efficit, verum et sentiendi... Instrumentis propriis non utente ut quibus opera fiant, sed per quae ut media exequantur.» (Segunda Edición) 
se hubiera verificado aquella sensación. Pero sólo el hombre que dormía es el verdadero productor de sus actos de sentir y entender. Y si me preguntas de qué utilidad sirve el cuerpo al alma, puesto que no concurre a producir la sensación ni la intelección, te responderé que sirve para despertarla y excitarla, porque mientras anda unida a este cuerpo corruptible, no puede percibir nada sin que antes se verifique una alteración en cualquiera de los sentidos. Pero la sensación nace solamente del alma, y no debe confundirse con la impresión hecha por el objeto en el órgano. ${ }^{836}$

De las operaciones del alma no puede aducirse otro testimonio que la experiencia interna. Ella nos dice que el alma no se conoce a sí misma, si antes no la impresiona algún objeto extrínseco... Por eso en nosotros ha de preceder siempre alguna noción de cosa extrínseca al conocimiento del alma que se conoce a sí misma. Esta consecuencia es evidente. Y de aquí se seguirá también que esa noción sólo puede servir de antecedente para que el alma saque después el consiguiente, procediendo así: «Conozco que yo conozco algo. Todo lo que conoce es; luego yo soy». ${ }^{837}$ Aquí tenemos el famoso cogito cartesiano, mal formulado en Gómez Pereira lo mismo que en

836 «Fingenda quippe est rationalis anima informans corpus esse hominem inclusum in carcere quodam... qui homo semper sopore quodam correptus esset, nisi tum cum vel reticulum sensibiliter percutitur aut per fenestras... aliquod objectum visibile per unam, aut audibile per alteram, seu gustabile per aliam... neque exterioribus afficientibus objectis non aliter ad sensationem concurrentibus quam qui excitat hominem dormientem, dicitur cognitionis et intellectionis ejusdem causa, non quidem efficiens, sed sine qua sensatio illa facta non esset... solo homine qui dormiebat suorum actuum sentiendi et intelligendi vero productore. Cum enim quaeritur in quem usum deserviat corpus animae, si nec ad sensationem nec intellectionem producendam concurrat ipsum? Respondendum est ut... excitet eamdem quae dum corpus hoc corruptibile informat, nullam rem extrinsecam neque intrinsecam percipere valeat, nisi prius tactus aut alter ex quatuor sensibus alteretur... Sensationem tantum gigni ab anima post affectionem ab objecto factam.» (Segunda Edición)

837 «Porro si memores estis eorum quae parum supra legistis, anima, dum corpus hoc corruptibile informat, nihil percipit, nisi ab extrinsecis objectis exterius vel a phantasmatibus interius afficiatur ad affectionem organorum exteriorum aut interiorum, alias nempe semper sopitam et veluti somno oppressam esse eventus docet. Nullam nempe aliam probationem posse adduci in hujusmodi de anima negotiis nisi quam quivis de suis actibus experitur... Si ergo res ita habet, ut a me assertum est, animam ipsam seipsam noscere non posse, nisi prius ab altero relatorum, scil. objecto extrinseco vel phantasmate afficiatur, certum erit... Unde nobis aliqua rei extrinsecae praecessura necessario erit cognitionem animae seipsam noscentis. Consequentia haec satis nota est. Hinc quae ulterius etiam sequetur, si haec preccessura est, non in alium usum deservire valebit quam ut sit quoddam antecedens cognitum ex quo anima post eliciat consequens, scil. quod ipsa seipsam noscit, sic procedendo: Nosco me aliquid noscere, et quidquid noscit est; ergo ego sum.» (Segunda Edición) 
Descartes, pero idéntico. Ni como silogismo ni como entimema (reducible como todos los entimemas a un silogismo) resiste el más leve ataque. ¿De dónde saca Gómez Pereira la proposición: todo lo que conoce es, si hasta ahora no ha conocido más que objetos sensibles? ¿Con qué derecho dice Descartes luego, sobreentendiendo la mayor de un silogismo, cuando ha empezado por dudar de todo? Ni uno ni otro prueban la proposición: todo lo que conoce existe. ¿Será ésta una de las universales confusas, cuyo conocimiento precede, según Gómez Pereira, al de los singulares?

Evidentemente, el cogito cartesiano y pereirista sólo tiene fuerza incontrastable como hecho y afirmación de conciencia (de qua quivis conscius est, dice Gómez Pereira). Descartes lo reconoció muy bien en su réplica a las objeciones recogidas por el P. Mersenne: «Cuando conozco que soy una cosa que piensa, esta primera noción no está sacada de ningún silogismo; y cuando alguno dice: yo pienso, luego soy, no infiere del pensamiento la existencia como por medio de un silogismo, sino como cosa conocida en sí misma, por simple inspección del espíritu». ${ }^{838}$ En tal sentido, el cogito es la base del psicologismo moderno.

Gómez Pereira, como salido de las filas del nominalismo, no podía extremar tanto sus conclusiones. Harto hacía con separar del todo las operaciones del espíritu de las de la materia, e identificar el pensamiento con la esencia del alma, y repetir que es tan evidente la experiencia que tenemos de nuestros actos internos, como la que adquirimos de las cosas extrínsecas; ${ }^{839}$ todo lo cual es cartesianismo puro y neto.

No conozco más que otros dos autores que antes de la publicación del discurso del Método formularan un razonamiento análogo al de Descartes. El primero es San Agustín, en aquellas sabidas palabras contra los Académicos: "Nulla in his vero academicorum argumentorum formido dicentium: Quid si falleris? Si enim fallor, sum, nam qui non est, utique nec falli potest: ac per hoc sum, si fallon;; argumento que repite en el libro II De libero arbitrio, casi en idénticos términos.

El segundo es Fr. Bernardo Ochino, famoso hereje italiano, de peregrina historia, discípulo de nuestro Juan de Valdés. En su catecismo, impreso en Basilea en 1561 (que no he visto sino citado por Rosmini), uno de los interlocutores dice: «Me parece que existo, pero no estoy seguro. Quizá me engañe». Y replica el maestro: "Es imposible que lo que no existe crea que existe: tú crees que existes; luego existes. —Cierto es», dice el discípulo.

838 Descartes, OEuvres, ed. Jules Simon, pág. 170. (Segunda Edición)

839 «Non enim minus evidentes sunt res quas de nostris actibus experimur quam illae quae de extrinsecis rebus habentur.» (Segunda Edición) 
Ochino divulgó esto años después de la impresión de la Antoniana; pero en la manera de presentar el argumento hay poca semejanza, por lo cual no le tengo por plagiario. Tampoco el argumento de San Agustín se parece mucho en la forma al de Descartes. ${ }^{840}$

El segundo argumento de Gómez Pereira por la inmortalidad del alma dice así: «Toda forma ${ }^{841}$ puede dejar el sujeto que informa y tomar otro nuevo: puede abandonar uno y otro, y existir sola. De este género es el alma racional; luego podrá existir por sí y sin el cuerpo informado. Además, no habrá objeto que exteriormente la afecte, y como interiormente no tiene principio de corrupción, será eterna». ${ }^{842}$

«En todo el curso de esta obra hemos mostrado que el alma es indivisible, no como un punto, sino como un ángel, u otra de las substancias separadas; es decir, toda en todo el cuerpo, y toda en cada una de sus partes. Separada del cuerpo, no se llamará forma; pero tampoco permanecerá ociosa, antes ejercerá, con mayor pureza que cuando informaba al cuerpo, su obra principal, la de entender, puesto que ya he demostrado antes que la intelección nace del alma sola. Cuando deje el cuerpo, entenderá por otro modo más perfecto todos los entes, sin necesidad de ser excitada por los objetos exteriores. Más natural es que el espíritu entienda sin el cuerpo que no unido a él». ${ }^{843}$

La tercera prueba está fundada en la identidad del alma: «¿Quién, a no ser un insano y un delirante, podrá negar que conoció en su infancia algunas cosas de que se acuerda en su vejez? Lo cual sería imposible si el alma no fuese una e idéntica en todas las edades». ${ }^{844}$

840 Las condiciones que Gómez Pereira señala para el conocimiento interior son las siguientes: «Haec, puta, anima semper sibi praesens, non se semper noscit quia indiget ex naturae facto pro statu isto excitatore et voluntatis imperio ut se noscat.» (Segunda Edición)

841 Recuérdese que la forma no tiene para Gómez Pereira el mismo sentido que para los escolásticos. (Segunda Edición)

842 «Quaecumque forma potest subjectum quod informat relinquere et alium novum acquirere, poterit utrumque deserere et sola esse: sed anima rationalis est hujusmodi, ergo ipsa per se et sine corpore durare potest, et ex exuto derelictoque, non est amplius qui eam extrinsece possit afficere, nec ullum intrinsecum pricipium habet quo corrumpatur: ergo aeterna erit.» (Segunda Edición)

843 «Per universum hoc opus ostendimus animam esse indivisibilem non ut punctus sed ut angelus vel alia de substantiis separatis, tota scilicet in toto et tota in qualibet parte... Primitus enim forma corporis dicebatur, et sejuncta a corpore non talis dicitur", etc., etc. (Segunda Edición)

844 «Quis enim nisi delirus et insanus negare poterit se aliqua in infantia cognovisse quorum in senectute recordatur», etc., etc. (Segunda Edición) 
Entran luego las razones que llama retóricas; es a saber: la justicia divina, la sed de lo absoluto, etc., y mezclado con ellas una especie de comentario a la égloga $4^{\text {a }}$ de Virgilio. En el argumento del consenso común, cita la creencia de los indios en la inmortalidad, «según me lo han participado, dice, mi hermano y mi sobrino, que han vivido muchos años entre ellos (ex fratre et nepote qui per multos annos apud Indos vixerunt)».

Finalmente, desata las razones que suelen alegarse contra la inmortalidad.

$1^{\text {a }}$ El entendimiento crece, se desarrolla y decae con la edad. Gómez Pereira contesta que lo que se altera no es el entendimiento, sino sus operaciones, a causa de la debilidad de los órganos o instrumentos. Notoria inconsecuencia es ésta después de haber afirmado que los actos intelectuales no se distinguen del entendimiento.

$2^{\text {a }}$ Inutilidad del alma después de la muerte por falta de órganos de los sentidos. A esto replica que el alma separada puede entender de más perfecto modo que unida, porque el cuerpo sólo le sirve de estorbo.

Las demás objeciones eran fútiles, y Gómez Pereira las desata sin dificultad.

A nadie sorprendan el atrevido estilo y singular proceder de este tratado. Sobre las pruebas de immortalitate reinaba gran libertad en las escuelas. Escoto y Cayetano afirmaron que la inmortalidad era verdad de fe, y, como tal, indemostrable por razones naturales. Lo que en aquellos piadosos escolásticos nació de excesiva desconfianza en las luces de la razón, fue cómodo efugio en la escuela de Padua para cubrir impiedades. Pedro Pomponazzi dijo que el dogma de la inmortalidad era verdadero, según la fe; falso, según la razón. ${ }^{845}$

Quizá no andaba muy distante de este sentir su comprofesor y amigo, el ilustre sevillano Juan Montes de Oca, autor de unas importantes y desconocidas lecciones sobre el libro III De anima. ${ }^{846}$ En ellas, después de refutar con crítica aguda y sutil el famoso argumento «Omne recipiens debet esse denudatum a substantia recepti», y las demás pruebas averroistas.

845 Sobre los libros de Pomponazzi y sus controversias con Agustín Nipho, Contarini, etc., véase el erudito libro de Fiorentino y la reciente publicación de los comentarios De anima, hecha por Luis Ferri. (Roma, en las Actas de la Academia de los Linceos). (Segunda Edición)

846 He visto dos códices de ellas: el mejor y más antiguo pertenece a la Biblioteca de San Marcos, de Venecia; el otro a la Nacional, de París. Yo tengo un extenso extracto formado con presencia de ambos. En la Marciana vi, además, las lecciones de Montes de Oca sobre los libros I y IV De coelo, y sobre el I y II de la Física de Aristóteles, dadas respectivamente en los años 1522 y 1523 . Montes de Oca comenzó a explicar en Padua en 1520, con el estipendio de 600 monedas de plata, sueldo que se le acrecentó al año siguiente. Murió en 1524, sucediéndole en la cátedra el averroísta Marco Antonio Zimara. (Vide Facciolati, Fasti Gymnasii Patavini, 1757, tomo II, página 274.) (Segunda Edición) 
tomistas, etc., hasta entonces presentadas, acaba diciendo: «quod nulla est ratio naturalis quae cogat intellectum ad assentiendum quod anima sit immortalis... Assentiendum est quod anima sit immortalis solo verbo Christi... ". Verdad es que añade que tampoco las pruebas de la mortalidad concluyen, y procura escudarse, en cuanto a lo primero, con la autoridad de Escoto; pero al decir a sus discípulos: «Si tuvieseis razones naturales, creeríais en la inmortalidad más de lo que creéis», harto induce a sospechar que también a él le habían tocado los vientos de duda que corrían en la escuela paduana. Por lo menos, no se libra de temeridad notoria, enseńando y escribiendo tales opiniones en 1521, después del decreto del Concilio Lateranense de 19 de diciembre de 1512. Quizá este mismo decreto le obligó a expresarse con menos claridad y más cautela, porque en otras muchas cosas va de acuerdo con Pomponazzi.

Desde Montes de Oca hasta Uriel de Acosta, no sé que ningún español dudase de la inmortalidad del alma. ¿Qué importaba que algunos de los argumentos alegados en pro de ella fuesen débiles, cuando la creencia en un destino superior tiene sus raíces en lo más hondo de la conciencia humana? Por sostener esta verdad lidiaron bizarramente Sebastián Fox Morcillo, con las armas del platonismo; ${ }^{847}$ Cardillo de Villalpando y Martínez de Brea, con las del peripatetismo; D. Pedro de Navarra y otros, en concepto de moralistas. Pero ninguno mostró tanta novedad y atrevimiento como Gómez Pereira al fundar la inmortalidad de nuestro espíritu en la independencia de sus actos y en el conocimiento que el alma tiene de sí misma. Sólo se le acerca en méritos Juan de Mariana en su hermoso tratado De morte et immortalitate, no impreso hasta 1609, medio siglo después de la Antoniana. ${ }^{848}$ Pero el jesuita talaverano, que anduvo tan feliz al desarrollar el argumento platónico anima se ipsam movet, no vió toda la trascendencia y el alcance del Animus a corpore non dependet, y en su exposición se muestra harto débil.

Descartes no hacía otra cosa que repetir el razonamiento de Gómez Pereira cuando escribía: «Concebimos claramente el espíritu, es decir, una substancia que piensa, sin el cuerpo, es decir, sin una substancia extensa...

847 Vide principalmente In Platonis dialogum qui Phaedro seu de animorum immortalitate inscribitur, Sebastiani Foxii Morzilli Hispalensis Commentarii. Basileae, per Jaonnem Oporinum, 1556. (El ejemplar que poseo de esta edición, primera y única, está encuadernado con los comentarios del mismo Fox Morcillo al Timeo y a la República) (Segunda Edición)

848 Vide Joannis Marianae... Tractatus VII, Coloniae Agrippinae, sumptibus Antonii Hierati. El De monte et immortalitate es el último de los tratados. (Segunda Edición) 
Luego, a lo menos, por la omnipotencia de Dios, el espíritu puede existir sin el cuerpo, y el cuerpo sin el espíritu». El autor de la Antoniana no tuvo necesidad de hacer intervenir la omnipotencia de Dios en una prueba de filosofía natural. Nótese que él profesaba, más o menos mitigado, el sensualismo de los nominalistas; con lo cual es más de admirar su clara comprensión de la naturaleza del espíritu.

He terminado el análisis del libro de Gómez Pereira, no más que en sus puntos y cuestiones esenciales. ${ }^{849}$ Para acabar de caracterizarle añadiré que su autor, como casi todos nuestros grandes pensadores, era hijo sumiso de la Iglesia y excelente católico. Quiza por esto, y a pesar de sus audacias de otra índole, no será acepto a los modernos impíos, que a tal extremo han traído a nuestra desdichada patria. En cuanto a mí, no puedo menos de mirar con admiración y simpatía al hombre que, independiente y desligado de toda autoridad científica, sólo dobló la frente ante la eterna verdad, escribiendo: "Quapropter nequis putet nos pertinaci cervice perstituros, in nonnullo errore, si forte ignari eum dictaverimus, confitemur, nos ipsos et nostra scripta subjici correctioni Summi Pontificis ac Ecclesiae Romanae».

Con ser gentil, dijo ya nuestro Séneca, el más antiguo de los filósofos ibéricos: Parere deo, libertas. Pocos de sus sucesores han sido infieles a esta máxima.

Y ahora, ¿qué me falta para cumplir, aunque mal, mi propósito en esta carta? Lo primero advertir que la Antoniana tiene al fin una tabla de erratas, precedida de una advertencia al lector: Cautio lectoribus observanda, antequam opus hoc legere aggrediantur, y un índice de las cosas notables de la obra. (Index sive tabula eorum quae in hoc opere reperiuntur)

Lo segundo, formar una especie de catálogo de los escritores que hasta ahora han hablado (casi todos de pasada) de la Antoniana, y notar sus aciertos o errores. Pero ya esta carta crescit in immensum, y me parece oportuno dar de mano a la tal lista, limitándome a citar algunos nombres que marcan ciertas alternativas en la manera de estimar y juzgar, por lo general de segunda mano, a Gómez Pereira.

Ya hablé de las cuestiones promovidas por el libro al tiempo de su aparición, y de lo que de él escribieron en el siglo Xviı Huet, Bayle e Isaac

849 Entre las opiniones e ideas sueltas de Gómez Pereira, que omito porque no me he propuesto hacer un compendio de su obra, sino un análisis, esté el principio quae continuantur seipsis continuari, confirmado por este otro: corpora homogenea partibus ejusdem rationis unita sunt, lo cual ilustra con ejemplos y observaciones curiosas.

Tampoco es despreciable esta cuestión, que no es la única de materia estética en la Antoniana: An aliqua naturaliter sint pulchra, alia deformia, an sic ex usu vel Dei imperio talia sint. (Segunda Edición) 
Cardoso. Pero Huet, con ser tan erudito, no debió de leer entero el libro, puesto que no señala más analogías entre su doctrina y la de Descartes que el automatismo. Bayle sólo le conoció de oídas, como él mismo confiesa. Sólo Cardoso da muestras de tenerle estudiado y convertido en substancia propia.

En el siglo xvir le menciona Feijoo sin haberle visto, y más tarde Martín Martínez. Excitada la curiosidad de algunos, tuvo no sé quién la feliz idea de reimprimirle en 1759 con esmero grande; pero su intento salió vano, porque a los pocos años, y como por virtud mágica, el libro volvió a ser tan raro como antes. Pero ya se conocía mejor la doctrina física y psicológica de Pereira, y muchos le citaban como primer innovador filosófico, sobre todo en lo relativo a las formas substanciales. En este sentido dijo el P. Isla en su novela famosa: «Dejo a un lado que el famoso Antonio Gómez Pereira no fue inglés, francés, italiano ni alemán, sino gallego, por la gracia de Dios, y del obispado de Tuy, como quieren unos, o portugués, como desean otros; pero sea esto o aquello (que yo no he visto su fe de bautismo), al cabo español fue, y no se llamó Jorge, como se le antojó a monsieur el abad (sic) Ladvocat, compendiador del Diccionario de Moreri, y no tuvo por bien de corregirlo su escrupuloso traductor, sin duda por no faltar a la fidelidad. Pues es de pública notoriedad en todos los estados de Minerva, que este insigne hombre, seis años antes que hubiese en el mundo Bacon de Verulam, más de ochenta antes que naciese Descartes, treinta y ocho antes que Pedro Gassendi fuese bautizado en Chantersier, más de ciento antes que Isaac Newton hiciese los primeros puchericos, en Volstrope, de la provincia de Lincoln, los mismos con corta diferencia antes que Guillermo Godofredo, barón de Leibnitz, se dejase ver en Leipzig, envuelto en las secundinas..., ya había hecho el proceso al pobre Estagirita, y había llamado a juicio sus principales máximas, principios y axiomas». 850

En términos parecidos, aunque con manera mas científica, juzgaron la importancia de la Antoniana, Piquer, Forner, Ulloa y otros, cuyos pareceres quedan ya referidos. El P. Castro, autor de una docta aunque indigesta Apología por la teología escolástica, particularizó más. «Es fácil (dice) descubrir en la Antoniana algunos otros principios de la nueva filosofía; v. gr., que no se distinguen de la substancia del alma sus conocimientos, que éstos no son otra cosa que diversos modos de ser o de saberse, que no todas las que llaman cualidades sensibles son accidentes entitativos de los cuerpos, y otras cosas que, hasta que se demuestre lo contrario, deben merecerle el distinguido 
honor de ser el primer innovador en materia de filosofía, el ejemplar de imitación y la causa, siquiera ocasional, de los nuevos sistemas». ${ }^{851}$

El abate Lampillas escribió que «después de Vives y antes de Bruno, abrió nueva senda a la filosofía el español Gómez Pereira, el cual tuvo valor de publicar... nuevo sistema de física, contrario al de Aristóteles, estableciendo nuevos principios opuestos a la materia y formas substanciales de las escuelas». Los de más juicios del siglo XviII están calcados en éste.

En el siglo xix el nombre de Gómez Pereira ha tenido menos notoriedad, por el general abandono de nuestras gloriosas tradiciones. Los dos historiadores de la medicina española, señores Morejón y Chinchilla, juzgaron bajo un parcial aspecto la Antoniana, e hicieron de ella justísimos elogios, y aun más del tratado De las fiebres. Chinchilla expuso con bastante fidelidad, pero muy en compendio, la opinión de Gómez Pereira sobre el alma de los brutos, dando claras muestras de no haber leído otra cosa alguna del libro.

En un erudito opúsculo sobre descubrimientos de los españoles atribuídos a los extranjeros, que dió a luz el escritor santanderino D. Ramón Ruiz de Eguílaz, hombre curioso y aficionado a estas investigaciones (sobre las cuales escribió un libro extenso, que no llegó a imprimirse), apareció por primera vez (que yo sepa) el silogismo de Gómez Pereira Nosco me aliquid nosse... como original del entimema cartesiano. Cundió esta especie, y reprodújola en su ingenioso discurso de entrada en la Academia Española el Sr. Campoamor. De allí la tomaron los Sres. Vidart, Salmerón y muchos otros. Hoy ha entrado en el general comercio científico, por lo menos en España.

Para las posteriores vicisitudes del nombre de Gómez Pereira, pueden verse mis Polémicas, así las coleccionadas como las que andan todavía sueltas, aunque con noticia de su dueño.

Aun tengo que ańadir una noticia, y por cierto la más lastimosa. A fines del año pasado oí que varios miembros influyentes de la Sociedad de Bibliófilos trataban de reimprimir la Margarita, y aun se me preguntó por tercera persona dónde habría algún ejemplar que pudiera servir de texto para la reproducción. Excuso decir a $\mathrm{V}$. el júbilo que me causó la noticia. A los pocos meses, la Sociedad publica un libro. Mi gozo en un pozo: la obra reimpresa no era la Antoniana, sino el Libro del potro y descendencia de los caballos Guzmanes. Confieso que toqué el cielo con las manos, y que en mis adentros maldije de la bibliofilia y del primero que tuvo tal manía en el mundo. Cuatro o cinco sociedades de bibliófilos tenemos en España: a ninguna se le ha ocurrido publicar un solo libro de filosofía. ¿Qué importa

851 Citado por Laverde, Ensayos críticos, pág. 354. (Segunda Edición) 
averiguar si hubo o no un español que se anticipase a Descartes, a Gassendi y a Reid en la discusión de las formas substanciales o de las especies inteligibles? Lo que importa es poner en claro los oficios del mozo del bacín ${ }^{852} \mathrm{o}$ el modo de melesinar los halcones. ${ }^{853}$

Si yo fuera capitalista, poco tardaría en hacer una copiosa y regia edición de la Antoniana y de otros muchos libros filosóficos españoles. Pero como no lo soy, ruego a $\mathrm{V}$., con lágrimas en los ojos, que si conoce y trata a alguno de esos señores filo-biblion, que entienden en el gobierno y manejo de la dicha Sociedad, les pida por Dios y la Virgen Santísima que reimpriman la Antoniana (acompañada de las Objectiones y del Endecálogo), no ya por ser libro de importancia filosófica (consideración que no ha de hacerles mella), sino por ser rarísimo y muy difícil de adquirir a ningún precio. Dígales $\mathrm{V}$. que, por lo menos, vale tanto y es tan digno de conservarse como el Libro del potro, y que hasta puede hombrear sin desdoro con las Campañas de Carlos V, de Cereceda, y con el Henrique fi de Oliva. Dígales V...; pero no les diga nada, porque sería predicar en desierto.

A los sabios que no son bibliófilos y que desprecian la ciencia indígena, creyendo con simplicidad colombiana que hoy empieza nuestro movimiento filosófico, gracias al trasiego de ideas vertidas a medio mascar en el Ateneo y en las Revistas, me limitaré a decirles, con palabras más autorizadas que las mías, como que son de uno de los más profundos a la vez que más modestos pensadores españoles de nuestro siglo, del inolvidable Dr. Llorens, profesor que fue de metafísica en la Universidad barcelonesa: «Cuando la civilización de un pueblo ha salido de sus corrientes primitivas; cuando la masa de sus ideas es más bien un agregado informe que un conjunto ordenado, y su energía natural se ha ido gastando en empresas poco meditadas o en imitaciones serviles, no hay que esperar que la importación de una doctrina filosófica venga a llamar la vida a un cuerpo desfallecido y exhausto. Podrá acontecer en ocasiones que un sistema filosófico, que lisonjee la pasión o se enlace con opiniones prácticas favoritas, se propague fácilmente y aun tome cierto aire que haga sospechar la existencia de un pensamiento propio, mas, venidos al hecho, se desvanecerá esta apariencia cuando fijemos la vista en lo hondo de la sociedad donde esto aconteciere, que allí descubriremos, o una degeneración de su constitución íntima, o un antagonismo entre el elemento propio y el extrańo; accidentes todos que no pueden menos de traer a mal término la vida nacional». «El pensamiento

852 Libro de la Cámara Real del príncipe D. Juan. (Segunda Edición)

853 Libro de las aves de caza. (Segunda Edición) 
filosófico no es un nuevo elemento de la conciencia humana, sino una forma especial que el contenido de la conciencia va tomando: por manera, que la masa de ideas elaboradas por cada pueblo debe ser la materia sobre la cual se ejercite la actividad filosófica». Y en otra parte ańade. "El pensamiento filosófico viene naturalmente a formar parte de aquel organismo invisible que, existiendo en el seno de cada nación, determina su individualidad». ${ }^{854}$ Esto dijo Llorens en 1854, cuando el desorden de las ideas y el desprecio a la tradición no habían llegado al punto en que hoy los vemos. Lo mismo, aunque con menos gravedad y elocuencia, he procurado yo inculcar en más de una ocasión. Sigo creyendo y afirmando que en España llevamos, hace más de medio siglo, errado el camino en todo. El que seguimos, sólo puede conducirnos a la aniquilación y a la muerte de nuestra conciencia nacional. Deus tale omen avertat.

Aparte Dios tan mal agüero, mi respetable amigo, y déjenos ver de nuevo a esta pobre y maltratada Espańa, ya que no temida en Flandes ni respetada en Trento, a lo menos cristiana y española en la ciencia como en la vida. No pretendo yo (¿ni quién tal pretendiera?) restaurar la variada trama de ideas y opiniones, a veces opuestas y aun contradictorias, que desde Séneca hasta Balmes, y aun más acá, constituyen lo que llamamos filosofía española. Quiero sólo que renazca el espíritu nacional a que Llorens se refería, ese espíritu que vive y palpita en el fondo de todos nuestros sistemas, y les da cierto aire de parentesco, y traba y enlaza hasta a los más discordes y opuestos.

Adiós, mi Sr. D. Juan; harto he molestado a V. con las inauditas prolijidades de esta carta. Téngala por recuerdo de su apasionado amigo.

Marcelino Menéndez Pelayo

854 Oración inaugural de la Universidad de Barcelona en 1854. (Segunda Edición) 



\section{LA PATRIA DE RAMON SIBIUDA (RAIMUNDO SABUNDE)}

\section{Un inconnu célèbre. Recherches historiques et critiques sur Raymond de Sebonde, par l'Abbé D. Reulet. Paris, V. Palmé; 1875, 324 pp.}

\section{I}

T eí meses ha en el Polybiblion (revista bibliográfica católica) un articulito o compterendu, en que por incidencia, y cual cosa sabida y notoria, se hablaba de la patria provenzal de R. Sabunde, con referencia a una monografía del abate Reulet, autor de este descubrimiento. Causóme no poco pesar la nueva; pues, admirando como admiro al autor del Liber creaturarum, no podía yo llevar con paciencia que se nos despojase de esta gloria filosófica, haciendo tolosano al que por catalán tuvieron y juzgaron todos los doctos, desde el abad Trithemio acá. Pero como tengo natural propensión a creer todas las malas noticias, di asenso, con ligereza sobrada (lo confieso), a la indicación del Polybiblion, y aun la repetí en dos pobres ensayos míos, por creer entonces oportuno no hacer hincapié en títulos dudosos o controvertibles, sino en los ciertos y averiguados de nuestra ciencia. Después he tenido ocasión de leer la memoria del abate Reulet; y visto que no prueba lo que intenta, ni por asomos, me creo en la obligación de hacer entera penitencia de mi pecado. No es otro el fin ni otra la causa de haberse escrito estas líneas.

A ninguno de mis escasos lectores parecerá nuevo ni peregrino el nombre de Sabunde. Por grande que sea el olvido en que yacen los monumentos de nuestro pasado científico, no quiero ni debo suponer que este olvido se extienda a la Teología Natural. El atrevido propósito de su autor, aunque los méritos de la ejecución no correspondieran, bastaría para librar de la oscuridad su nombre. En el último y decadente período de la escolástica, cuyo imperio se dividían místicos y nominalistas, apareció en Tolosa un profesor 
barcelonés que, sin pertenecer a ninguna de las banderías militantes, ni ajustarse al método y forma universalmente adoptados en las aulas, antes puesta la mira en la reforma del método y de toda enseñanza, como si obedeciera a la poderosa voz del Renacimiento que comenzaba a enseñorearse del arte, concibió la traza de un libro único, no fundado en autoridades divinas ni humanas que, sin alegar textos de ningún doctor, llegase a la inteligencia de todos; libro fundado en la observación y en la experiencia, y sobre todo en la experiencia de cada cual dentro de sí mismo. "Nulla autem certior cognitio quam per experientiam, et máxime per experientiam cujuslibet intra seipsum». Trazó, pues, una Teología Natural, en que la razón fuese demostrando y leyendo, cual si escritos estuviesen en el gran libro de las criaturas, todos los dogmas de la religión cristiana. El plan era audaz y no libre de peligros, que a las veces evitó mal Sabunde; pero la concepción misma es indicio claro de su vigorosísimo entendimiento. Al desarrollarle mostróse potente en la argumentación, abundante en los recursos, y hasta inspirado y fecundo a veces en el estilo, libre a la continua de arideces escolásticas.

El libro había nacido en tiempo y sazón convenientes, y su éxito fue brillante, aunque más bien fuera que dentro de las escuelas. Difundido en abundantes copias por Francia, Italia y Alemania, llegó a ser estampado por los tórculos de Deventer en 1484 (si es que no existe edición anterior, como algunos sospechan), y entre los últimos años del siglo XV y todo el XVI aparecieron más de doce ediciones del primitivo texto, sin que fuera obstáculo la prohibición que del Prólogo de Sabunde hizo el Concilio de Trento. Suprimióse el prólogo, y la obra siguió imprimiéndose sin otra mudanza. Y como su extensión y lo incorrecto de su latín retrajesen a muchos de su lectura, acudieron dos elegantes humanistas, admiradores de Sabunde, Pedro Dorland y Juan Amós Comenio, con sendos extractos rotulados Viola animae y Oculus fidei. Y por si algo faltaba a la mayor difusión y renombre de la doctrina de Raimundo, un caballero gascón, antítesis viva del piadoso catedrático del siglo Xv, se entretuvo en verter la Teología Natural en encantadora prosa francesa que aquel escéptico caballero hablaba y escribía como pocos o ninguno la han vuelto a escribir y hablar. No satisfecho con esto, tomó pie del libro de Sabunde para su más extenso y curioso ensayo, que con título de Apología (aunque de todo tiene menos de esto) anda desde entonces en manos de todos los aficionados a ingeniosas filosofías y a desenfados de estilo.

El Liber creaturarum, que por tales caminos había llegado a la cumbre de la celebridad, mantúvose desde entonces en estimación honrosa, y si no muy leído, continuó siendo muy citado, a veces con oportunidad escasa. 
De la patria del autor nadie dudaba, hasta que el abate Reulet publicó su paradoja intitulada, como dicho queda, Un célebre desconocido. Veamos si hace fuerza su alegato.

Aunque el escrito de que voy a hablar no tiene más de 316 páginas en dozavo, fácilmente pudiera reducírsele a menor volumen, con sólo suprimir algunas de las infinitas amplificaciones y redundancias en que se complace su autor. Es el estilo del abate Reulet elegante, pero desleído y falto de nervio, abundando además en ornamentos y amenidades de dudoso gusto. Pero no conviene hacer hincapié en los defectos de un libro que tiene partes recomendables, y demuestra haber sido trabajado con amore e interés hacia el asunto. Divídese en dos secciones, concernientes, la primera a Sabunde, la segunda a su libro.

En la Biblioteca de Tolosa se guarda un precioso códice del Liber creaturarum. Por la descripción del abate Reulet vemos que el tal manuscrito es un volumen de 280 hojas, en $4^{\circ}$, con profusión de adornos y miniaturas. Los títulos de los capítulos están en letra colorada, y en la foliatura síguese la numeración romana. La inscripción final dice a la letra:

"Et sic explicit Liber Creaturarum (seu Naturae) seu Liber de Homine... inchoatus et inceptus in alma universitate venerabilis studii Tholosani, anno Domini millesimo quadringentesimo tricesimo quarto et completus et terminatus in eadem universitate anno 1436 in mense Februarii, undecima die, quae fuit dies sabbati», etc.

La importancia de este documento salta a la vista. Hasta hoy ignorábamos la fecha precisa en que fue escrito el Libro de las Criaturas. Cónstanos hoy que se empezó en 1434, y que su autor le puso término en el mes de febrero de 1436. Pero aún no ha acabado la nota final del códice tolosano.

«Hic liber est Berengarii Operarii, auctoritate regis notarii, Tholosae habitatoris, extractus a consimili copia magistri Alrici de Rupe, etiam notarii ibidem: et correctas per ambos jam dictos notarios subscriptos cum originali libro manu reverendi magistri Ramundi Sibiude (sic) in sacra pagina, in artibus et in medicina magistri... finitus corrigi die mercurii Cinerum, XIII mensis Februarii, anno ab incarnatione D. mill. quadringentesimo tricesimo sexto. Cujus quidem compilatoris vita functi penultima Aprilis eodem anno", etc.

Otra revelación inesperada. Raimundo Sabunde murió en abril de 1436, dos meses después de haber dado cima a su Teología Natural. La contradicción aparente entre las fechas del libro y de la copia ha sido discretamente salvada por el abate Reulet, mediante la diferencia entre el cómputo eclesiástico 
que Sabunde, como profesor, debió seguir, y el vulgar que forzosamente adoptaban los notarios. Éstos debieron de acabar la confrontación de su copia en 13 de febrero de 1437. La autoridad de semejante traslado, que para nosotros hace veces de original, no puede ser más decisiva, y merece bien de las letras el abate Reulet por este su único descubrimiento, aunque, entusiasmado con él, ha querido darle más valor del que realmente tiene, y convertirle en arma para su antiespañola pretensión. Veamos cómo.

La primera dificultad que acerca de Sabunde se ofrece, es su nombre, que ha sido escrito de todas estas maneras: Sebeide, Sabunde, Sebundius, Sabundanus, Sebundus, Sebon, St.-Sebeide, y en cinco o seis formas más. La más antigua y autorizada parece la de los notarios tolosanos, que escriben Sibiude. No me parece de grande importancia tal cuestión, aunque Reulet la discute en forma y largamente, explicando a su manera los cambios y trastrueques que en el nombre de Ramon hicieron copistas y editores, guiados generalmente por razones eufónicas. Pero conviene advertir que en España nunca hemos llamado al filósofo catalán Sabeydem ni Sant-Sebeide, por más que nos cuelgue este milagro su biógrafo y añada que tan exóticos nombres se ajustan a las conveniencias de nuestra lengua. Sabunde o Sebunde se ha escrito siempre del lado acá del Pirineo, y a nada conducen los rasgos de sprit que con esta ocasión se permite el clérigo francés.

Llegamos al nudo de la cuestión, al capítulo de la patria. El abad Trithemio que en 1494 publicó su Catálogo de escritores eclesiásticos, afirma en él que Sabunde era natione Hispanus. Sinforiano Champier, en los primeros años del siglo xvi, lo repite. Montaigne hace correr de gente en gente la misma aserción. El docto Maussac, en los prolegómenos al Pugio Fidei de Fr. Ramón Martí, impreso en 1651, adelanta más: llama a Sabunde natural de Barcelona y profesor en Tolosa. Desde entonces todos los críticos e historiadores de la filosofía han repetido estos datos.

El abate Reulet se levanta a contradecirlos, y con toda la jactancia francesa (aquí de bastante mal gusto) anuncia que las pretensiones del Ebro van a sucumbir ante los derechos del Garona. ¿Y qué derechos son ésos? ¿Ha parecido la partida del bautismo de Sabunde? ¿Se ha encontrado la indicación de su patria en algún registro de la Universidad de Tolosa? ¿Hay el más insignificante documento que disculpe tales fanfarronadas? No hay más que la rotunda afirmación del abate Reulet, escritor de 1875, contra el testimonio del abad Trithemio, en 1498, cuando aún debían de vivir gentes que conocieron a Sabunde.

¿Y cómo ha querido invalidar semejante prueba el apologista de la causa francesa? Fantaseando con escasa formalidad crítica un cuadro de novela, en 
que el abad Trithemio aparece en su celda hojeando el Libro de las Criaturas, para redactar el artículo concerniente a Sabunde, a quien llamó español, ¿a qué no saben mis lectores por qué? ¡Porque en un manuscrito citado en una Historia del Languedoc se habla de un magister Hispanus, médico del conde Raimundo de Tolosa, en 1242! Y, ¡ya se ve!, el pobre Trithemio tomó el rábano por las hojas, confundiendo a un filósofo del siglo xv con un médico oscuro del XIII, del cual hay noticia en un manuscrito. ¿Y qué prueba tenemos de que Trithemio hubiera visto semejante manuscrito? Y suponiendo que le viera, ¿por qué hemos de suponerle capaz de un yerro tan enorme e inexplicable? ¿Puede llamarse a este modo de razonar procedimiento critico?

Que Trithemio, aunque laborioso y muy erudito, era a veces ligero. Está bien; pero ¿quién prueba que lo haya sido en este caso? En reglas de crítica, y tratándose de un autor del siglo xv, la palabra de los contemporáneos o inmediatamente posteriores vale y hace fuerza, mientras no haya datos en contrario.

Tampoco los hay para destruir la afirmación de Maussac respecto a la patria barcelonesa de Sabunde. Maussac sabía demasiado para confundir a Sabunde con San Raimundo de Peñafort. Anchas tragaderas debe de tener el que consienta en atribuir tal desatino al ilustrador del Pugio Fidei. Por lo demás, es cómodo, ya que no muy ingenioso, este medio de explicarlo todo y desembarazarse de las dificultades. ¿Quién ha dicho a Reulet que Maussac no tuvo datos o documentos, que hoy desconocemos, para poner en Barcelona, y no en otra ciudad de Espańa, la cuna de Sabunde? ¿Los ha presentado él buenos ni malos para hacer a su héroe hijo de Tolosa? ¿No confiesa que todos los analistas tolosanos guardan acerca de él alto silencio, y que la tradición local asimismo calla?

Pruebas de hecho no alega ninguna el abogado de Francia; conjeturas, una sola, que le parece fortísima, pero que es débil y deleznable, por descansar en un falso supuesto: la lengua. Dista mucho, en verdad, de ser clásico el latín del Libro de las Criaturas; pero muy de ligero ha procedido Reulet al asentar que está lleno de galicismos. Razón tiene cuando estima por de ningún valor el texto de Montaigne: "Ce livre est basti d'un espagnol baragouiné en terminaisons latines», si por español se entiende el castellano; pero tal interpretación sería aquí absurda. ¿Cómo se le ha de ocurrir a nadie que Sabunde, catalán del siglo xv, hablase castellano? ¿No es esto olvidar del todo la historia literaria de la Península?

Dícenos el abate Reulet que él sabe el español (sic), y que no ha encontrado castellanismos en la Teología Natural. ¿Y cómo los había de encontrar, si Sabunde fue barcelonés? ¿Ignora el respetable clérigo que los barceloneses, lo 
mismo ahora que en el siglo xv, no tienen por lengua materna el castellano, sino el catalán, es decir, una lengua de oc, hermana del provenzal, hermana de la lengua de Tolosa, donde se escribió el Libro de las Criaturas, en un latín bastante malo, que abunda en catalanismos por ser catalán el autor, y en provenzalismos porque había residido mucho tiempo en Tolosa, y en repeticiones y desaliños y redundancias como todos los libros de profesores no literatos, y más en el siglo Xv?

Déjese, pues, el abate Reulet de traer a cuento la lengua española, frase malsonante y rara vez oída de nuestros clásicos, que se preciaron siempre de escribir en castellano. Tan española es la lengua catalana como la castellana o la portuguesa. Lo que conviene averiguar es si son realmente galicismos las frases de Sabunde que con dudosa exactitud filológica apellida así el crítico, sin distinguir tampoco el francés del Norte del del Mediodía.

¿Por qué han de ser francesas y no catalanas, o castellanas, o italianas, o de cualquiera otra lengua romance, expresiones tan sencillas como éstas: Volo quod omnes dicant bonum de me; Hoc est clavis et secretum totius cognitionis? ¿No son españolas de buena ley estas otras: Quiero que todos digan bien de mi. Esta es la llave y el secreto de todo conocimiento? ¿No se puede y debe decir en catalán: Aquesta es la clau de tot coneixement, y en toscano: Questa è la chiave ed il segreto, etc.? ¿Estará el galicismo en el uso frecuente de la partícula quod por ut? Pero ¿quién no sabe que éste es resabio general de la escolástica? En otro caso habría que declarar francés al mismo Santo Tomás de Aquino.

De este tenor son casi todas las pruebas alegadas por Reulet; algunas hasta contraproducentes. El necesse est quod in homine, etc., sigue mejor el giro castellano. Necesario es que en el hombre haya algo que siempre dure, que el de la francesa Il est necessaire. El despreciativo de ipso nullum computum facimus es provenzalismo o italianismo, pero no buen francés del Norte, aunque haya pasado al lenguaje familiar. La repetición de los pronombres personales, sobre todo del nos, aunque contraria a la índole suelta y generosa de las lenguas peninsulares, está en los hábitos académicos y profesorales: nosotros dijimos, nosotros creemos.

En las palabras que como francesas cita, anda aún más desacertado el abate Reulet. Brancha es traducción del catalán branca, y no del francés branche, como bladum lo es de blé (trigo). ¿Y no es algo inocente poner como galicismos las expresiones unus cattus (un gato), omnes culpabiles (todos los culpables), addiscere ad legendum (aprender a leer)?

Argumento que prueba demasiado, nada prueba. Sabunde, como todos los malos latinos, tendía a la construcción directa y atada, con poco o ningún 
hipérbaton, por oraciones de sum, es, fui y primeras de activa. Esto es lo que su biógrafo llama construcción francesa, cuando realmente es el modo de decir propio de todo el que escribe con dificultad una lengua, atento sólo a la claridad y enlace lógico de las ideas.

Con todos estos poderosísimos argumentos mezcla el buen clérigo sabrosas burlas a propósito del énfasis castellano, que nos hace llamar batallas a todas las escaramuzas (v. gr.: la escaramuza de Pavía, la de San Quintín, la de Bailén, las de Zaragoza, etc.). Con todo lo cual, si su tesis no gana mucho, a lo menos el autor logrará fama de hombre de sprit o de chispa, como decimos por acá. Dios le dé buena manderecha, y mejor gusto y novedad en sus gracias.

De todo lo expuesto se deduce que el abate Reulet no ha alegado razón chica ni grande que invalide la autoridad de Trithemio. Seguimos, pues, contando a Sabunde en el número de nuestros filósofos. Los documentos, sólo con documentos, no con vanas conjeturas, se destruyen.

\section{III}

Si en la primera parte de este artículo no he podido menos de decir mucho mal de la memoria de Reulet, depárame en cambio grata tarea el retazo de su libro en que expone y juzga las producciones de Sabunde; y digo mal las producciones, puesto que una sola nos queda, conforme demuestra con buenas razones nuestro abate. La Viola animae, compendio del Liber creaturarum, en seis diálogos de elegante latín y sabroso estilo, es obra del brabanzón Pedro Dorland, y así lo indican los versos laudatorios que, a usanza del tiempo, acompañan a la Violeta en la impresión de Milán de 1517. Y fuera de la diferencia de estilo entre este libro y el de las Criaturas, acaban de persuadirnos de la verdad los elogios que el compendiador hace de Sabunde, y que en boca de éste fueran impropios y desmesurados. En la Violeta, pues (que en 1616 fue trasladada al castellano por Fr. Antonio de Ares con rótulo de Diálogos de la naturaleza del hombre), lo que a Sabunde pertenece no es la forma, sino la doctrina; lo propio acontece con el Oculus fidei, compendio más árido y menos feliz, que en 1661 estampó en Amsterdam el sociniano Juan Amós Comenio. Sólo por un inexplicable yerro de José Escalígero ha podido atribuirse a Sabunde el Pugio fidei del insigne orientalista catalán Fr. Ramón Martí, obra de erudición rabínica maravillosa, cuando del autor de la Teología Natural ni siquiera consta (y puede muy bien dudarse) que supiera hebreo. El único escrito de Sabunde, aparte de su obra magna, fue, pues, las Quaestiones Controversae citadas por Trithemio, sin que de ellas quede otra memoria. Tampoco es imposible que hubiese compuesto Quodlibetos, como Josías Simler y Possevino afirman. 
Limpio ya de malezas el terreno, procedía estudiar el Libro de las Criaturas, primero por el lado bibliográfico, y luego al modo crítico. Halo intentado, no sin fortuna, el erudito francés, aunque la parte bibliográfica peque de ligera y sucinta, mucho más si la cotejamos con el excelente estudio que en la Revista de Instrucción pública (año 1857) estampó el modesto y malogrado bibliotecario de Oviedo, Sr. Suárez Bárcena. Las ediciones citadas (aunque sin descripción bibliográfica) por Reulet llegan a dieciséis, o, mejor dicho, a quince, pues la existencia de la primera de Deventer, 1480, es muy incierta, y sólo se afirma por una referencia del Lexicon de Ebert, quien acaso la confundió con otra hecha en la misma ciudad en 1484. Lo mismo las ediciones incunables que las impresas en la primera mitad del siglo XvI, insertan el prólogo, y son, por ende, las más apreciables. Ni Reulet indica ni yo he podido averiguar la fecha de la más antigua de las expurgadas; pero el prólogo falta ya en la de Venecia, 1581, que poseo. Todos los textos impresos, incluso el moderno de Solsbach (1852), adolecen de alteraciones y faltas (no siempre tan substanciales como Reulet imagina), cotejados con los códices del siglo XV (en la Biblioteca Nacional de París hay tres), y especialmente con el de Tolosa. Urge, pues, una reimpresión esmerada y completa del Liber creaturarum, y a los españoles nos toca hacerla. Mengua sería que mientras los libros de jineta y de caza salen del polvo, permanecieran en él los más gloriosos testimonios de nuestra intelectual cultura. Todavía no anda en castellano la Teología Natural, que Montaigne en el siglo xvi tradujo al francés y puso sobre su cabeza. Sabunde, entre nosotros, es principalmente conocido por los Diálogos de Fr. Antonio de Ares (libro muy raro) y por la versión de un rifacimento italiano, vulgarizada pocos años ha en la Librería Religiosa.

En ocasión más oportuna hablaremos de Sabunde considerado como filósofo. 
INSTAURARE OMNIA IN CHRISTO

\section{Carta al Sr. D. Juan Valera, de la Academia Española}

$\mathrm{M}$ i carísimo amigo: Gracias mil por la brillante carta con que ha respondido V. a la mía de Florencia, de abril de 1877, dándole más importancia que la que en sí tenía, y honrando a su autor con excesivos, aunque en boca de $\mathrm{V}$. harto sinceros, elogios. Gracias también por la claridad con que V. ha explicado su opinión en los puntos en que disentíamos (más en apariencia que en realidad), proporcionándome con esto bien templadas armas, y abriéndome fácil y expedito camino para acabar esta amistosa escaramuza, que no quiero llamar polémica. Seré brevísimo, porque apremia el tiempo para la publicación de la segunda Ciencia Española, de la cual serán el mejor remate y corona las epístolas de usted.

Confieso que al comenzar a leer la última a que contesto, sentí cierta pena de ver a V. apadrinar las anti-estéticas y peligrosas opiniones de cierta escuela, cuyos descarríos han merecido más de una vez las censuras de la Iglesia y de toda sana filosofía, especialmente de aquella en cuyas banderas V. sigue. Dolíame de ver convertido a V. en tradicionalista de la noche a la mañana. Que el abate Gaume (a quien Dios haya perdonado) condenara, en Le Ver Rongeur, en La Revolución y en cien partes más, el Renacimiento, y se empeñara en entroncar con él todas las herejías, errores y revoluciones modernas de Norte y Mediodía, de Oriente y Occidente, atribuyéndolo todo, con pobre y estrecho criterio, al estudio de los clásicos, ni más ni menos que esos historiadores progresistas que lo explican todo por la Inquisición y los Jesuitas, lamentable es, pero nada extraño. Al cabo, Gaume era tradicionalista, y, en consonancia con los principios de su escuela, debió de discurrir así: todo lo que el hombre hace o ha hecho, entregado a las fuerzas de su 
razón natural y sin el auxilio de la revelación, es malo, vitando y pernicioso. Es así que los paganos no tuvieron lumbre de la revelación: luego debemos hacer con sus libros un auto de fe, abrir cuenta nueva, y figurarnos que no hubo más que hebreos en el mundo hasta que vino Nuestro Señor Jesucristo.

Tales raciocinios, reducidos aquí a su forma más precisa y seca, moverían a risa, si lo piadoso de la intención no los disculpase. Esto es lisa y llanamente sancta simplicitas. Y es, además, con leve diferencia, una de las proposiciones heréticas de Lutero, condenadas por la Bula de León X: «que todas las virtudes de los paganos y todas sus ciencias especulativas son vicios y errores».

¡Pero V., discípulo de Santo Tomás, y por ende de Aristóteles; sectario de una escuela pagana, en cosmología, en antropología y hasta en ética y política; V., a quien el tradicionalismo ha de parecerle uno de los más funestos errores que han afligido a la Iglesia; V., que tan briosamente afirma el poder y las fuerzas naturales de la razón humana; V., de cuyos labios he oído que tiene al Estagirita por hombre casi divino por lo admirable de su teoría de la materia y de la forma; V., que acepta y pone sobre su cabeza todas esas enseñanzas griegas, se me había de convertir en eco de ese sentimentalismo a la francesa, entre devoto y atrabiliario, que aquí han representado sólo algunos periodistas religiosos, discípulos de Donoso Cortés! ¿Qué dirían Melchor Cano y su maestro Francisco de Vitoria, el Sócrates de la teología española, si levantasen la cabeza? ¡Pues qué!, ¿imagina V. que en el auto de fe que Gaume o sus amigos hiciesen, habían de escapar inmunes la Metafísica, ni el Organon, ni la Política del hijo de Nicómaco, aunque la sombra de Santo Tomás los escudase? Capaces eran de quemar a Santo Tomás mismo por haber gastado el tiempo en comentar esas profanidades, y a San Agustín por sus aficiones platónicas, y a San Jerónimo por sus alińos ciceronianos, y a San Juan Crisóstomo por la pícara afición que tenía a Aristófanes, y a San Basilio por aquel tratado suyo Del provecho que se saca de los antiguos, y a todos los Padres de la Iglesia, en suma, por lo mucho que se acordaban de las ollas de Egipto. Y entonces la educación católica no sería aquella amplia, generosa y espléndida de las Universidades de los tiempos medios, ni la del siglo xvi, en que San Carlos Borromeo hacía imprimir para los jóvenes milaneses las comedias de Terencio, sino una educación hipócrita, raquítica y endeble, incapaz de resistir al más leve ataque de la impiedad moderna, que no es ignorante y ligera como la del siglo pasado, sino docta, razonadora y fría (en todas partes menos en España, se entiende), y que busca armas en todos los arsenales de la erudición sagrada y profana. No es que se pretenda hacer étnicos a los muchachos desde los bancos de la escuela: lo que deseamos es unir en fecundo y estrecho abrazo, como lo han estado 
en todas las grandes épocas de la Iglesia, el estudio de ambas antigüedades, para que dentro de un espíritu cristiano, ortodoxo y purísimo, la vida, la animación, la serenidad y la armonía lo penetren e informen todo, así en la ciencia como en el arte.

Pero repito que V. está con nosotros, y en manera alguna con Gaume y los suyos. V. es un espíritu recto y delicado, amante de todo lo que es verdad y belleza, y V. no puede condenar ni quemar lo que sus maestros adoraron. Su carta de V. hace tales concesiones, que ellas bastan para tejer mi defensa. Un solo punto nos separa, y éste es una cuestión de nombre: el distinto significado que damos a la palabra Renacimiento. V. le limita a los siglos xv y XVI; se fija en algunos aspectos suyos, en las aberraciones de algunos artistas, $y$ enérgicamente le condena. Pero el Renacimiento no es eso, ni así lo entiendo yo, ni así le he entendido nunca, y V. mismo va a darme la razón. ¿ No llama V. verdadero Renacimiento al de su adorado siglo XIII? ¿Y Renacimiento de qué?, pregunto yo. ¿Acaso del espíritu cristiano, que no estaba muerto, y que fue poderosísimo en toda la Edad Media? ¿Quizá de la ciencia de los Padres? ¡Pero cómo, si éstos eran la habitual lectura de entonces! Algo renacería para que aquello pudiera llamarse Renacimiento. Y venimos a sacar en consecuencia que este algo es la ciencia pagana de Aristóteles, mejor interpretada por Santo Tomás que por los anteriores y es el arte de Dante, que toma por guía y maestro a un pagano, salva de las llamas eternas a los gentiles que se le antoja, llena su trilogía de símbolos y alegorías mitológicas (a veces con muy mal gusto), dándoles, eso sí, todo el sentido católico que V. quiera; y llama a Jesucristo el sumo Jove que fue crucificado por nosotros:

«E se licito m’è, o sommo Giove,

Che fostin terra per noi crocifisso,

Son li giusti occhi tuoi rivolti altrove.»

Ya sé que como se trata de Dante, a quien hemos convenido en llamar el poeta católico por excelencia, se encontrarán a esto mil disculpas, y volveremos al arte simbólico y al alto sentido, etcétera, etc.; pero, con franqueza: ¿qué diría V. si encontrase esas enormidades en un pobre poeta del Renacimiento, en Sannazaro o en Vida? ¿No tocaría V. el cielo con las manos? Pues de esa injusticia me quejo yo, y diré siempre a los admiradores incondicionales del siglo XIII, que no es muy puesto en razón tirar piedras al tejado del vecino teniendo de vidrio el propio, ni hay para qué escandalizarse tanto de la inofensiva pedantería de llamar a los cardenales Padres conscriptos. Ya ve V. que el llamar Júpiter a Dios, tampoco fue invención de los humanistas. Cosas son éstas que, después de todo, más atacan los fueros del buen gusto 
que los del dogma. ¿Cree V. que ninguno de aquellos paganos del tiempo de León X era bastante inocente para tomar por lo serio esas retóricas e imaginarse que vivía en la Roma imperial, y que iba a tornar a levantarse el ara de la Victoria, abrirse las puertas de Jano bifronte, caer la blanca víctima del Clitumno bajo la segur del sacrificador, y humear de nuevo el incienso ante las aras de Júpiter Capitolino? Todo esto no pasaba de ser un dulce recuerdo, bueno para dicho en verso o en oraciones de aparato; una pura convención académica, como lo ha sido en tiempos más cercanos el amor a los trajes, usos y muebles de la Edad Media, traído por el Romanticismo. Si el Renacimiento no hubiera sido más que eso, antes deberíamos calificarle de pueril y ñońo, que de cosa mala y vitanda, como Vds. hacen.

Yo entiendo el Renacimiento de un modo más amplio: para mí, lo que hubo en el siglo Xvi no fue más que el remate, el feliz complemento de la obra de reacción contra la barbarie que siguió a las invasiones de los pueblos del Norte: para mí, la historia de la Edad Media no es más que la gran batalla entre la luz latina y cristiana y las tinieblas germánicas. A esta obra, que llamo grande y santa, contribuyeron por igual Casiodoro y Boecio en la corte del rey Teodorico, San Martín Dumiense entre los suevos de Galicia, San Isidoro y sus discípulos entre los visigodos, Alcuino y Teodulfo en la corte de Carlo Magno. Lo que estos hombres sabían no era más que una empobrecida reliquia, pero reliquia al cabo, de la antigua ciencia profana y sagrada, y al hacer entrar en el espíritu de los bárbaros algo de la lógica de Aristóteles, de la gramática de Prisciano y Donato, de la moral de Séneca, hacían obra de Renacimiento, como la hacía San Eulogio al llevar a Córdoba, cual solaz para los mozárabes en la horrenda persecución que sobre ellos pesaba, las obras de Virgilio, Horacio y Juvenal. Y obra de Renacimiento hacía el mismo Carlo Magno en su tentativa de imperio; y a la causa latina servía Gregorio VII al poner su planta sobre la dura cerviz de los Emperadores alemanes. Todo el que en medio de la desmembración y desorden de la Edad Media tuvo un pensamiento de unidad social o científica, fue precursor del Renacimiento. Y lo fueron los que en Occidente dilataron el conocimiento de Aristóteles, y lo fue su maestro de V. Santo Tomás, que le cristianizó. Y como no el más ni el menos, sino la esencia misma de las cosas, determina el carácter de toda gran evolución histórica, no me negará V. que el movimiento de los siglos XIV, XV y XVI es una prolongación del anterior, pues tan hijo del Renacimiento y tan pagano es el que comenta a Aristóteles como el que comenta a Platón..., el que estudia a Homero como el que estudia a Virgilio, el que sabe griego como el que sabe latín; y si absolvemos a Gualtero de Chatillon, y a José Iscano, 
y a Benoit de Saint-More y a todos los que en la Edad Media escribieron malos poemas sobre el cerco de Troya, o las hazañas de Alejandro, u otros temas clásicos por el estilo, no sé por qué hemos de condenar a los que con mejor estilo y más limados versos hicieron lo mismo en el siglo XVI. La medida debe ser una para todos; y yo, por más que hago, no puedo do encontrar esa zanja entre el modo antiguo y el nuevo, ni sé a punto fijo cuándo dejó de gritarse jarriba!, y empezó a gritarse jabajo!, como V., con más poesía que exactitud, dice. Porque, francamente, entre un viejo fabliau francés y un cuento de Boccaccio, ni en el asunto ni en la desvergüenza de la narración hallo diferencia alguna, y sólo la veo en ser más elegante y donairoso el estilo del novelador de Certaldo. Y si le escandaliza a usted la Mandrágora de Maquiavelo o la Calandra de Bibiena, no me escandalizan a mi menos los brutales desahogos del cruzado Guillermo de Poitiers, o los feroces serventesios de nuestro Guillermo de Bergadá, y váyase lo uno por lo otro. Fácil es tejer un ramillete de poesías de la Edad Media, así latinas como vulgares, que son una verdadera spintria. Pero ni esto prueba nada contra la Edad Media, ni lo que V. dice va contra el Renacimiento, sino contra los desafueros de algunos artistas que, con Renacimiento o sin él, hubieran hecho de las suyas. Citando hechos particulares y aberraciones de unos y de otros, toda causa se puede defender, pero sin llegar a resultado ni sentencia alguna. Abominaciones, errores y pecados, en todos tiempos hay, y no son patrimonio ni afrenta de una época sola. ¡Ojalá fuera verdad lo que usted dice de que la carne estuvo subordinada al espíritu en la Edad Media!

Usted reconoce y acata la grandeza de los filósofos y artistas gentiles, atribuyéndola, no sólo a los restos de la primitiva tradición, sino a los poderosos esfuerzos de la razón humana en todo su vigor natural (sic). Usted, atento a aquellas palabras del Apóstol: Instaurare omnia in Christo, llama restauración al Cristianismo, y no dice que destruyese lo antiguo, sino que lo purificó y lo transfiguró todo, completando la antigua filosofía, y aprovechando el elemento social del paganismo antiguo. ¿Qué más defensa necesito yo? ¿No estamos conformes en todo? ¿No es esto lo que con su habitual agudeza ha dicho nuestro amigo Letamendi: la Grecia en gracia de Dios? Y después de esto, ¿qué significa el que usted, sin duda por involuntario olvido de esta su apología del paganismo (voz tan complexa, como que abraza una civilización entera), venga a confundirle luego con la idolatría? ¿O que, convertido involuntariamente, como tantos otros católicos, en eco de las diatribas protestantes contra Roma, censure indirectamente a los Pontífices por el amor con que miraron el arte renacido? Pues qué, ¿̧hay algún parentesco (sacrilegio es sólo el pensarlo) entre la Iglesia y la barbarie? 
Repito que en lo substancial estamos conformes. Usted encuentra bien que se aprovechen los elementos de la sociedad antigua convertidos y depurados: eso mismo digo yo. A V. le parece mal que se anteponga en absoluto (nota bene) Homero a la Biblia y Platón a San Pablo: yo creo lo mismo. Tiene V. por una profanación el representar a la Virgen con las formas de Venus, y yo lo tengo, no sólo por una profanación, sino por un error estético que el verdadero clasicismo reprueba. Usted confiesa las ventajas que en la esfera filológica y en otras hizo el Renacimiento. ¿Qué es, pues, lo que nos separa? El persistir V. en llamar Renacimiento a una sola de sus fases, y no de las más decisivas, a la venida de los griegos de Constantinopla, como si, admitido todo lo que se dice de esos pobres griegos (que, después de todo, no lo dude V., son autores poco leídos, y por nadie menos que por el abate Gaume), bastara la publicación de dos o tres gramáticas griegas ni de algún indigesto comentario sobre Platón, para hacer a la Europa, pagana primero, protestante después, y revolucionaria por último. ¡Qué pícaros griegos!

El hermoso y clarísimo entendimiento de V. no puede asentir a tales filosofías de la historia. Usted sabe que nunca de causas tan pequeñas han nacido tan grandes efectos.

Usted dice que el Renacimiento clásico no hacía falta, porque ya venía verificándose, y a mí no me parece mal que continuara, por la misma razón. Si sabíamos ya latín, bueno era que aprendiésemos griego; si sabíamos algo de la poesía de los antiguos, tampoco estaba de más que conociésemos su escultura.

Usted cree que las imitaciones que se hicieron entonces fueron ridículas e impotentes. Ésta es cuestión de gustos, y a mí me agradan mucho las silvas de Policiano, y me encanta Fr. Luis de León imitando las odas morales de Horacio y el himno de Aristóteles a Hermias. Todo eso de formas muertas tampoco me convence; porque si la forma es bella, resplandece con eterna y no marchita juventud, y V. sabe y siente como los platónicos que, aunque la Venus Urania descienda al sepulcro, resurgirá siempre tan hermosa y radiante como al principio. No hay preocupación, ni sistema, ni escolástica, que resista a la pura luz de la belleza.

Que en el siglo XVI no gustaba la arquitectura gótica. Error de gusto, pero que no contradice a ningún artículo del Credo ni definición dogmática.

Emparentar el Renacimiento con la Reforma es un lugar común que me parece muy poco fundado. El Renacimiento es cosa demasiado complexa, y la Reforma es una herejía harto sencilla, para que sea dable confundirlos. Concediendo que entre los italianos hubiera impíos, materialistas y paganos de toda especie, faltaría demostrar que profesaban la doctrina del 
servo arbitrio y de la fe sin las obras, para identificarlos con los discípulos de Lutero. Y si se me responde que éste se parecía a Pomponio Leto, a Machiavelli y a Pomponazzi en ser revoltoso y díscolo, contestaré que el desorden y la rebelión son en el mundo harto más viejos que el Renacimiento y la Reforma, y que los romanos y los griegos: como que el primer protestante fue aquel príncipe de la luz que dijo: «Pondré mi trono sobre el Aquilón, y seré semejante al Altísimo». ¡Pues qué!, ¿ no ha habido herejías e impiedad en el mundo cuando no se estudiaba a los clásicos? Lutero era sencillamente un bárbaro, y V. confiesa que él no comprendió una palabra de los esplendores de la Roma de los Médicis. Y esa decantada cultura de las Universidades alemanas no era más que una barbarie pedantesca, que se reducía al conocimiento material de los textos, sin que tuviera nada que ver con la penetración íntima y profunda del espíritu de la antigüedad, que había en Italia. Lutero fue quien declaró que todas las virtudes de los gentiles habían sido vicios, quien execró el paganismo de la Roma papal; y su discípulo el dulce Melanchton, en quien bajo la corteza humanística duraba la herrumbre germánica, no se cansó de acusar a los cristianos de haber apostatado en las aras de Platón, tomando de él la doctrina del libre albedrío. Sólo con Aristóteles transigió, y esto más en la Dialéctica y en la Ética, que en la filosofía propiamente dicha.

Con Renacimiento y sin Renacimiento hubiera sido el siglo xv una edad viciosa y necesitada de reforma, dados los precedentes de la Edad Media. Sólo que en el siglo $\mathrm{x}$, por ejemplo, había vicios y no había esplendor de ciencias y artes, y en el siglo xv brillan y florecen tanto éstas, que a muchos críticos les hacen incurrir en el paralogismo: post hoc, o más bien juxta hoc, ergo propter hoc, sin considerar que, en último caso, no es el arte el que corrompe a la sociedad, sino la sociedad la que corrompe al arte, puesto que ella le hace y produce. Y esta sociedad había sido producida y educada por aquellos benditos siglos medios, en que el concubinato, la simonía, la rapiña, el hierro de los Emperadores y la ambición de los barones toscanos, dilaceraron la Iglesia hasta llevarla a aquel lamentable estado, que así describe y deplora el cardenal Baronio (pondré sus palabras en latón, para que no me saquen los ojos los extáticos adoradores de aquella edad de hierro): "Quam foedissima Ecclesiae romanae facies, quum Romae dominarentur potentissimae aeque ac sordidissimae meretrices, quorum arbitrio mutarentur sedes, darentur episcopatus, et quod auditu horrendum et infandum est, intruderentur in sedem Petri eorum amasii pseudo-pontifices, qui non sunt nisi ad consignanda tantum tempera in Catalogo Romanorum Pontificum, scripti.) ¿Prefiere usted estos pontificados al gloriosísimo de León X, cuyo nombre 
no deshonra, por otra parte, ningún hecho vituperable? ¿O le agradan más los tiempos en que la Iglesia era abofeteada en Anagni y conducida como vil cautiva a Aviñón? ¿Se han perdido por ventura los escritos de San Pedro Damiano, que tan claramente nos dice que ningún vicio, aun de los más nefandos y contra naturaleza, era extraño a los clérigos de su tiempo? ¿Por ventura han perecido los libros De consideratione de San Bernardo, o el Planctus ecclesiae de Álvaro Pelayo, o el mismo poema de Dante, para que concedamos tan de barato que todo era luz y virtudes en la Edad Media, y que hasta que vinieron esos pobres griegos a enseñar gramática estábamos como en el paraíso? A no ser que toda la gente mala de la Edad Media fueran humanistas en profecía.

Me cita V. el testimonio de Erasmo contra el Renacimiento, y yo respondo: $1^{\circ}$, que Erasmo no es la personificación del Renacimiento, porque, como los demás septentrionales, se quedó en la erudición y no penetró en el espíritu artístico; $2^{\circ}$, que las invectivas de Erasmo contra los ciceronianos de Italia no son más que un despique literario por lo mucho que ellos se habían burlado de su latín y de lo plúmbeo de sus gracias.

Otro tanto digo de la frase de Alberto Carpi de que «en Alemania todos los amantes de las bellas letras se habían hecho fautores de Lutero». Lo primero que convendría averiguar es si había entonces algún alemán que pudiera llamarse amante de las buenas letras, en el sentido que hubieran dado a estas palabras Bembo o Sadoleto.

$Y$ aun dando por supuesto lo que se quiera suponer, ¿qué tiene que ver el neo-platonismo de Florencia, ni el materialismo de Pomponazzi, ni la impiedad política de Maquiavelo, con el fatalismo fideista y la superstición escrituraria de los luteranos? Sólo en ser herejías y errores pueden parecerse.

Lo de que el Renacimiento propiamente tal no había penetrado en España, sólo probaría, en caso de ser verdad, que habíamos sido más incultos y rudos que los demás meridionales, y no sería para alegado como título de gloria; pero (a Dios gracias) creo que esta suposición está refutada en todo el curso de este libro y en otros escritos míos. La verdad es, sí, que a nuestro Renacimiento no podemos acusarle de ninguno de los pecados que se achacan al italiano, y que, después de todo, no son suyos esenciales, sino peculiares de algunos de sus representantes.

No puede ser más delicado ni galante el modo como usted cierra su epístola. Y yo, correspondiendo en lo posible a él, no diré, ni ahora ni en adelante, una palabra más que pueda interpretarse como desdeñosa del tomismo, aunque en justa reciprocidad deseo que no se ensańen Vds, en términos tan generales con el Renacimiento, en el cual hay muchas cosas 
buenas y bellas, y que todo hombre de buen gusto (y V. le tiene exquisito) debe reconocer y venerar. Ni me parece buen modo de servir a la Iglesia el suponer que tantos y tan ilustres Pontífices, y tantos y tan venerables Obispos, modelos de costumbres y doctrina, como Jerónimo Vida, Sadoleto y Antonio Agustín, fueran tan necios que no comprendieran nunca el estrago que hacían en la sociedad con su aficiones gentílicas.

Acordes, como lo estamos, en lo esencial, sólo haré alguna leve indicación sobre otros puntos secundarios que trata V. en su carta. Así, diré:

$1^{\circ}$ Que Santo Tomás tomó de Aristóteles bastante más que el método, pues tomó toda su doctrina cosmológica acerca de los principios de los seres, toda su doctrina ideológica del entendimiento agente y posible (bien o mal entendida, que esto no es ahora del caso), toda su lógica, y de la Etica y la Política cuanto era compatible con la doctrina católica. Usted sabe muy bien que ni aun sus más ardientes admiradores tienen a Santo Tomás por un filósofo original e inventivo, ni miran su sistema como una creación filosófica nueva, sino como una vasta síntesis, en que se aplaude sobre todo la grandeza del conjunto. Por eso la Santidad de León XIII, en su reciente Encíclica, lo que alaba principalmente en Santo Tomás es el haber reunido y congregado los miembros antes dispersos. Santo Tomás no puede ser llamado con entera propiedad fundador de un sistema: es un filósofo derivado de Aristóteles y de los Padres.

$2^{\circ}$ Que no puede sostenerse que Santo Tomás supiera griego, pues aunque se hallan palabras griegas en sus escritos (como noân, Plh y otros muchos vocablos técnicos, cuyo valor discute), las toma siempre de las versiones latinas de Aristóteles; ni más ni menos que el gran número de voces griegas que se usan y explican en los modernos tratados de medicina y ciencias naturales no nos autorizan para calificar de helenistas a sus autores. Lo que hay que aplaudir en Santo Tomás es la diligencia que tuvo en proporcionarse distintas versiones, y compararlas entre sí, y aun en encargar otras nuevas (pero todavía muy imperfectas) a Moerbeka y algún otro. Por esta razón, y por lo que su sagacidad natural le hizo adivinar, es benemérito Santo Tomás del texto de Aristóteles, y debe contársele entre los precursores del Renacimiento, que continuó la tarea de corregir y depurar los textos y las versiones.

$3^{\circ}$ Que si los herejes escolásticos nada prueban contra la escolástica, tampoco los impíos italianos que V. menciona (ninguno de los cuales es humanista de primera talla) prueban nada contra el humanismo. Ex nobis prodierunt, sed non erant ex nobis, pueden contestar $\mathrm{Vd}$ s., y podemos contestar nosotros, con las palabras de San Juan. Y si no parece del todo justo atribuir a una escuela filosófica los errores de algunos de sus adeptos, todavía 
lo es menos hacer responsable de ellos a un movimiento filológico, pues no se ve aquí relación alguna entre la causa y el efecto.

$4^{\circ}$ Que bien averiguado está que no eran tomistas de profesión los que trabajaron en la Políglota, sino discípulos unos del humanismo y otros de la tradición rabínica; y bien sabidos son sus nombres: Nebrija, Diego López de Stúniga, el Comendador Griego, Vergara, Alfonso de Zamora, Alcalá, Coronel, etcétera. Y lo racional era que para una empresa filológica se buscase a los que mejor sabían el hebreo y el griego, y no a los que mejor disputaban simpliciter y secundum quid, al modo de las escuelas.

$5^{\circ}$ Que no es lo mismo ser Dominico que tomista, y que Fr. Tomás Campanella fue lo primero, pero no lo segundo, y no bastan todas las ingeniosidades del P. Zeferino para hacerle entrar en el gremio.

6. ${ }^{\circ}$ Que Pomponazzi era escolástico, aunque no tomista, y considerado como escritor, pasaba por un bárbaro entre los cultos ingenios de su tiempo, y era del todo extraño a los estudios helénicos.

$7^{\circ}$ Que al cargo de que los escolásticos olvidaron un poco la experimentación, me contesta V. citando a Miguel Scoto, averroísta, y que, por lo tanto, queda, según V., excluido del gremio: a Raimundo Lulio, a quien en rigor no se le puede llamar escolástico; a los alquimistas, que tampoco lo eran, y a Vicente de Beauvais, mero compilador. Ni basta que Aristóteles fuera partidario de la experimentación para decir que también lo serían los escolásticos, pues éstos, con dos o tres excepciones, prefirieron al estudio de la naturaleza el de las obras del Estagirita.

$8^{\circ}$ Que cuanto más lea a Melchor Cano, más me convenzo de que no es escolástico sino discípulo de Vives (con quien fue injusto, como con tantos otros) y escritor del Renacimiento. Pues cabalmente lo que caracteriza y da valor propio al libro de Melchor Cano, es lo que ni sońó Santo Tomás ni pudo sońarse en la Edad Media: la crítica de las fuentes de conocimiento, el criticismo aplicado a la teología. Idea era ésta que no podía brotar en tiempos de ignorancia filológica e histórica como fueron los anteriores al siglo XVI, e idea era tan nueva y peregrina, aun en ese mismo siglo, que el canciller Bacon contaba todavía entre los desiderata de las ciencias particulares el estudio de los respectivos tópicos, lugares o fuentes. ¿Cómo he de tener por escolástico a un hombre que con tanto desdén habla de las cuestiones relativas al principio de individuación, y aun a los universales? Ciertamente que si Melchor Cano hubiera sido un dominico vulgar que se hubiera limitado a exponer mejor o peor lo que en Santo Tomás había aprendido, nadie se acordaría de él a estas fechas. Porque supo escribir y porque trajo algo nuevo a la ciencia, dura hoy venerada su memoria. 
9o No se puede admitir esa compenetración tan absoluta que ustedes suponen entre la teología tomista y la filosofía, pues bien se puede estar de acuerdo con las conclusiones teológicas de Santo Tomás, sin que para esto sea preciso declararse partidario de la doctrina peripatética de la materia y de la forma y no de la hipótesis atomística; sin que sea necesario tampoco admitir toda la fantasmagoría de las especies inteligibles, y del entendimiento agente y posible, sino antes bien propugnando la doctrina del realismo natural y del conocimiento directo. Y tan teólogo tomista puede ser el que niegue la distinción entre la esencia y la existencia, como el que la admita. Yo no tengo inconveniente en decirme tomista, si el tomismo se entiende en el sentido amplio en que le toma nuestro actual Pontífice (gran partidario de los estudios clásicos, entre paréntesis). Después de decir en su hermosa Encíclica que «maestros posteriores desarrollaron con abundante fruto las semillas que esparció el Doctor Angélico», no se descuida de apuntar sabiamente que «si en los doctores escolásticos se halla algo tratado con demasiada sutileza, o con poca consideración, o algo que no concierte bien con los descubrimientos posteriores, o que de cualquier modo no parezca probable, de ninguna manera debe proponerse como dechado de imitación». Sí así se entiende el tomismo (y éste es el único sentido autorizado por la Cabeza visible de la Iglesia), soy tomista; pero no si se me quiere imponer, como última razón de todo, la doctrina cerrada de la Summa, y aun ésta, no como la entienden los Jesuitas, sino como la quieren los Dominicos, y no sólo en lo esencial y en lo que se relaciona con la teología, sino en una multitud de problemas antropológicos y cosmológicos que entregó Dios a las disputas de los hombres: y no sólo en la doctrina, sino en el método y forma, y hasta en el estilo, de suerte que la filosofía católica venga a reducirse a un puro y escueto comentario de uno de los comentadores de Aristóteles, sin que en ella entre nada del criticismo de Vives, ni del experimentalismo baconiano (en lo que no tiene de exclusivo), ni de las observaciones psicológicas de la escuela escocesa, ni lo que en la lógica inductiva han adelantado los positivistas, ni de los modernos estudios filológicos que han restaurado del todo la historia de la filosofía griega, ni nada, en suma, de lo que Santo Tomás no alcanzó o no supo. No; la filosofía cristiana y tomista, si lo es de veras, no puede caer en ese particularismo estrecho, que si le daría fácil victoria sobre el eclecticismo francés o el idealismo alemán y todos los sistemas a priori, cada día más decadentes, la dejaría impotente para resistir la furiosa avenida de las hordas positivistas, de los lógicos ingleses, de los escritores críticos, de los filósofos de la asociación de ideas y de la inducción, que desde los laboratorios químicos y los anfiteatros anatómicos amenazan a la sana Metafísica, después de haber 
exterminado casi la Metafísica vacía y nebulosa de allende el Rhin. Aquí está el peligro verdadero: no en los trampantojos krausistas o hegelianos; y si la batalla ha de darse, forzoso es presentarnos con armas tan buenas como las suyas. La crítica histórica y literaria, las lenguas sabias, las ciencias naturales, la antropología en todas sus ramas, la lógica en todas sus formas y procedimientos, las ciencias escriturarias y patrísticas, todo esto debe ser el principal estudio del apologista católico, en vez de afincarse tanto en cuestiones que ya pasaron, en errores que ya no volverán y que nadie sigue ni defiende. Todo lo que Santo Tomás tiene de teólogo y filósofo cristiano es admirable y vividero: lo que tiene de filósofo peripatético y medioeval puede y debe discutirse, y en algunos casos abandonarse. Por algo han pasado seis siglos desde el siglo XIII. Y V. comprende muy bien que es tal la fuerza expansiva del entendimiento en las cuestiones de tejas abajo que, aunque aparente estar sumiso a una doctrina y a un nombre, siempre halla algún resquicio por donde recobrar su libertad prístina; y así como en nombre de Aristóteles han lidiado entre sí alejandristas y averroístas, panteístas e individualistas, tomistas y escotistas, moros y cristianos, así vendrá a suceder que esa filosofía tomista que Vds. proclaman (y en la cual Santo Tomás, si levantase la cabeza, vería ya muchas novedades), a fuerza de adiciones, enmiendas e interpretaciones, quedará tan desemejante de lo que fue en sus principios, como aquella famosa nave de Atenas en la cual se sustituía cada ańo una pieza nueva a las viejas y gastadas, hasta que no quedó ninguna de las que había tenido en tiempo de Teseo. Quiéranlo ustedes o no, la restauración tomista lleva este camino, y vale más ser franco como los Jesuitas, y decir, como dice el P. Jungmann en el prólogo de su Estética (y quizá sea esto lo único bueno que contiene su obra): «No es nuestro intento significar con el nombre de filosofía cristiana la de ningún periodo ni tiempo particular, ni de ningún sistema ni escuela determinados, sino la que tiene siempre presente que toda sabiduría viene de Dios, o, lo que es lo mismo, el conjunto ordenado y científico de conclusiones del pensamiento racional que convienen bajo todos conceptos con la divina revelación».

En suma: el espíritu general, el sentido, la mente del Angélico Doctor, no la letra que mata. Y decimos del Angélico Doctor, por ser la suya la más vasta y grandiosa de todas las concepciones filosóficas cristianas, pero obra humana al fin, y que en sus pormenores admite y reclama controversia.

Así entiendo la filosofía cristiana, y aplaudo y bendigo su restauración, sin que para seguir su lábaro importe gran cosa el ser aristotélico o platónico, ni mucho menos el profesar tal o cual doctrina sobre los modos del conocimiento. Ni creo que esa restauración tenga nada que ver con las aficiones 
clásicas ni con el Renacimiento. Quédese el confundir estas cosas para el abate Gaume y otros cejijuntos y severos Aristarcos, de quienes podemos decir con el poeta, que «ni les sientan los Dioses a su mesa, ni les admiten las Diosas a su lecho».

No les dé V. oídos, pues muchas veces (no quiero creer que a ciencia y conciencia) han falsificado la historia, achacando, verbigracia, a Policiano un desprecio por los Salmos de que no hay el menor vestigio en sus obras (que tengo muy leídas), y que pugna con todo lo que sabemos de su vida y gusto literario.

El espíritu de V. es demasiado alto y generoso para dar asenso a tales invenciones, anécdotas y cuentecillos, y condenar por ellos el arte y la civilización en una de sus épocas más espléndidas. Usted tiene alma de artista, y gusta sin duda de coronarse con las flores de la antigua sabiduría, y repite conmigo aquella plegaria de Teócrito:

"iHaz que las Gracias sean

Compañeras eternas de mi vida!»

P. D. Como me precio de católico sincero, sin ambages ni restricciones mentales, y quizá en ésta y otras cartas, donde hablo de la escolástica y de Santo Tomás, se me haya deslizado alguna frase poco exacta o que suene a irreverencia, o algo, en suma, que de cualquier modo pueda dar fundado pretexto a que algún escritor racionalista tenga la mala ocurrencia de citarme en apoyo de sus lucubraciones (si es que merezco ser citado), desde luego retiro tales palabras, y las doy por no dichas, a lo menos en ese sentido, sin que esto obste en nada a la libertad que tengo y deseo conservar íntegra en todas las materias opinables de ciencia y arte, al modo de aquellos espańoles de otros tiempos cuyas huellas, aunque de lejos y longo intervallo, procuro seguir, no captivando mi entendimiento sino en las cosas que son de fe, como dijo el Brocense. 



\title{
APÉNDICE- SEGUNDA PARTE
}

\section{Contestación de don Alejandro Pidal y Mon a la carta in dubiis libertas}

\author{
«Encontrando demasiado tirante el arco por una parte, \\ probó a doblarle por la otra, quizá con exceso.» \\ (Carta de Menéndez y Pelayo. La España, 21 abril 77)
}

Sr. D. Marcelino Menéndez y Pelayo.

Querido amigo: La carta de V., a que contesto, cayó sobre mí como una bomba; rompiese en mis propias manos la pluma con que había empezado a refutar el extenso artículo del racionalista Sr. Perojo, publicado en el último número de la Revista Contemporánea sobre La Ciencia Española, y aunque a ninguno cedo en fe y entusiasmo, juzguéme débil y sin fuerzas, y, sobre todo, sin autoridad para contestar a V. como se debía.

El desaliento y la tristeza que de mi ánimo se hallan apoderados con el repugnante espectáculo que diariamente presencio en las columnas de ciertos periódicos que, cerradas para todas las grandezas del movimiento católico y las luchas científicas, sólo se abren a la calumnia, a la injuria y a la acusación contra sus hermanos los católicos; las tareas políticas, que tanto absorben la actividad del espíritu, distrayéndole de los libros y asuntos literarios; y, sobre todo, la previsión de los grandes males que al renacimiento filosófico de nuestra patria acarrearían sus ataques de V. a la escolástica, si no se le oponían, como fuerte dique que atajara el mal en su nacimiento, la autoridad científica y doctrinas del algún nombre ilustre en la república 
filosófica, hicieron que cuando volví a tomar la pluma, no lo hiciese para responder a V., sino para invitar privadamente a los grandes filósofos escolásticos, a los sabios hijos de Santo Domingo, a los esclarecidos discípulos de Santo Tomás, para que, saliendo a la palestra, contrarrestasen los esfuerzos de V. en contra del renacimiento escolástico en España. Quizá, si no las mismas, análogas o semejantes causas les obligaron a deplorar en silencio que el joven erudito, que tan valientes asaltos acababa de dar a la impiedad y al racionalismo, volviese ahora sus armas contra la filosofía tomista, única filosofía cristiana que ha quedado en pie y que reverdece con vigor después de la inundación del racionalismo. Lo cierto es que, si bien me animaron a la pelea, suministrándome armas defensivas con que acudir a los flacos de mi coraza, me dejaron a mí solo el empeño; a mí, siempre impotente para medirme con V., pero mucho más en la presente ocasión y en el presente estado de mi ánimo; estado de postración y abatimiento, más propicio para el recogimiento y la meditación que para la lucha.

Pero, sea como quiera, heme aquí casi sin libros también, pues plúgome no abrir casi ninguno, no porque pueda sin ellos, como usted, inundar con prodigiosa erudición estas páginas, sino por falta de ánimo y de tiempo, y por hacer más explicable mi torpeza. Heme aquí, repito, como David enfrente del gigante Goliat; como David, sin fuerzas, pero armado de la honda escolástica, cuyos disparos, bien que por más certera y ruda mano dirigidos, dieron ya en tierra con otros gigantes que salieron a desafiar a tan alta filosofía desde los campos del Renacimiento, de la Reforma y de la Enciclopedia.

Bien se me alcanza que rechazará V. este papel, que, con justicia, sin embargo, en la ocasión presente, le atribuyo de enemigo de la filosofía de Santo Tomás, recordándome que, si en sus cartas a Laverde la colmó ya de elogios, en ésta, a que contesto, con ser su objeto probar que el vivismo no era inferior al tomismo, califica V. a éste de «el más firme valladar que en España hallan las invasiones racionalistas», asegurando que le «aquejaba el temor de haber hablado con irreverencia del tomismo, tan luminoso, tan sublime y tan sesudo sistema», rogándome que "no considerase esta carta como escrito anti-tomista», pues V., aunque sin serlo todavía, «venera, respeta y acata el tomismo como el más fervoroso de sus adeptos», conviniendo que «el Ángel de las Escuelas tiene por patria el mundo y a la humanidad por discípulo».

Pero si bien es cierto que $\mathrm{V}$. no es enemigo substancial y sistemático del tomismo, no lo es menos que las preocupaciones humanistas a que V. se confiesa un tanto accesible, le asaltaron de tal manera en esa Florencia, «en esa moderna Atenas», como usted la llama, «donde aun vagan las som- 
bras de Lorenzo el Magnífico y de Angelo Poliziano», que, sin detenerse a contemplar la sombra más augusta por cierto del ilustre Savonarola, se entregó usted a sus naturales inclinaciones, dejándose llevar de las corrientes apacibles de la literatura renaciente, hasta dar más importancia a la forma que al fondo; nota característica que domina en su carta de V., y que es el eco que a través del baluarte de su fe y de su ciencia resuena en su trabajo, eco producido por el grito de rebeldía que levanta en la sociedad la carne, reivindicando sus derechos sobre el espíritu, espíritu y carne vueltos, si no a su primitiva concordia, a su ordenada subordinación en los grandes días de la Edad Media.

«Obra santa y grande» llama V. a la obra del Renacimiento; y he aquí, amigo mío, la clave de sus erradas apreciaciones. La obra del Renacimiento ni fue grande ni santa, como no fue santa ni grande la obra de la Reforma. La grandeza y la santidad fueron los caracteres de la verdadera reforma y del verdadero Renacimiento, que tuvieron lugar, aquélla en el siglo XvI, por medio de los grandes teólogos escolásticos reunidos en Trento; éste en el siglo XIII, por medio de aquel irresistible movimiento de condensación, depuración y adelanto que se apoderó de todas las inteligencias y corazones en todas las esferas de la vida, y del que, como causa y efecto a la vez, aparece, como dominándole, impulsándole y dirigiéndole, la gran figura del teólogo y filósofo escolástico Santo Tomás de Aquino.

Y como éste es el nudo vital de sus apreciaciones y el foco de donde irradian los tiros que en la carta de V. se dirigen a la ciencia y a la literatura de la edad cristiana por excelencia, creo más conducente al asunto y al fin que me propongo, herir con mano firme y de una vez en el corazón de sus doctrinas, que irme de rama en rama y de espina en espina para abatir el árbol peligroso que $\mathrm{V}$. ha levantado, y que, a pesar de mi flaqueza, confío en que ha de venir al suelo en cuanto aplique a su robusto tronco la acerada segur de la incontrastable lógica escolástica.

Y para proceder con método, fijemos bien de antemano el sentido histórico de la palabra Renacimiento.

Es indudable que, merced a los restos de las primitivas revelaciones conservados por la tradición, más o menos desfigurados, y a los poderosos esfuerzos de la razón humana en todo su vigor natural, se habían elevado antes del cristianismo, en medio de las aberraciones del espíritu, esclavo incondicional de la carne en los antiguos días, monumentos de imperecedera grandeza en casi todos los ramos del saber humano.

La personalidad humana, posesionada ya de la conciencia de su propio valer, se había proclamado a sí misma enfrente de la tiranía de la madre 
naturaleza, entre cuyos brazos se perdía y como se anegaba después de la revuelta ocasionada por el pecado original el hombre racional y libre. Platón y Aristóteles en filosofía, Homero y Demóstenes en el arte de la palabra, Fidias y Praxíteles en las artes plásticas, habían llegado a la meta del progreso posible en la antigüedad, sustrayendo con mano firme y vigorosa la individualidad humana, en cuyo conocimiento basaban la sabiduría, a la absorbente presión de la totalidad panteísta en que, perdida la luz de la revelación, se había anegado el hombre, al verse débil y solo, ante las imponentes manifestaciones de una naturaleza exuberante y virgen.

Pero si la razón natural, en sus condiciones más propicias para su total desarrollo, les había permitido fijar con caracteres inmortales los eternos fundamentos de toda obra intelectual, esa misma razón, privada de la luz sobrenatural que da la gracia, no les había impedido caer en todos los crímenes y vicios que solicitan y tientan a todo ser racional en este valle de miserias. Así es que el progreso intelectual, falto del apoyo y de la luz del progreso moral, empezó a caer por la pendiente de la decadencia con dirección a la sima de la barbarie.

Entonces vino el Cristianismo, y esta doctrina celestial, cuyo fin está contenido en aquellas palabras casi divinas caídas de los labios del Apóstol: Instaurare omnia in Christo, empezó por restaurar lo más esencial, las almas, que restauró, no con las ciencias y las letras, sino con las virtudes.

Las ciencias y las letras, que se bautizaron entonces, se bautizaron ya viejas. Eran catecúmenos decrépitos. Las artes decapitaron a Júpiter, para colocar sobre sus hombros la cabeza de Jesucristo, y el Cristianismo, que necesitaba salir de las catacumbas, no pudiendo habitar en los santuarios de la abominación, improvisó sus templos en las basílicas.

Lo principal estaba ya conseguido. El camino del cielo estaba expedito para las almas.

Pero el Cristianismo es divino, y como divino fecundo, con fecundidad que todo lo abarca. Así fue que, una vez restauradas las almas en Cristo, emprendió la restauración de todo lo demás, y, en medio de las vicisitudes humanas, y a través de luchas y de azares, conservando siempre el elemento natural y operando siempre sobre lo existente, mejorando sin destruir, lo purificó y lo transfiguró todo, restaurándolo todo en Cristo; y completando la antigua filosofía con las verdades de la revelación, formó la teología escolástica; y combinando el elemento socialista del paganismo culto con el elemento individualista del paganismo bárbaro, formó el organismo político, jurídico y económico de la Cristiandad; y utilizando los adelantos que en el metro y la rima habían hecho los antiguos, y hasta las alegorías paganas, dándoles 
su verdadero sentido trascendental, e inspirándolo todo en el espíritu de la nueva ley, nos dio la Divina Comedia; y hasta las piedras mismas, informadas por la divina aspiración, se escalonaron hacia el cielo, formando en el espacio, como si las sostuvieran las alas de la fe, con los arcos ojivales de la catedral, el templo verdaderamente cristiano.

Y no nos venga la erudición demostrando el proceso de la mecánica, la genealogía de la ornamentación, la génesis del simbolismo; que no ignoramos que, además de ser esto prueba de lo mismo que sostenemos, Dios se vale de causas naturales para sobrenaturales efectos; que la historia, hija de la humana libertad, es la apoteosis de la Providencia divina; y ciertamente, cuando el primer déspota infame eligió para primer suplicio de su primer esclavo la cruz, no sospechaba que conspiraba de antemano a la exaltación de esa misma cruz, que de suplicio del esclavo había de convertirse en árbol de libertad, cuya savia fuese la sangre de un Dios, siendo su fruto la redención del universo.

El hecho es que el ideal cristiano estaba patente. La hora de su realización, marcada en el plan divino, se había ido preparando por medio y a despecho de los mismos hombres y de los mismos enemigos eternos de Dios. Pero Dios que, por no sé qué ley histórica, que respetuosamente reverencio, pero que humanamente deploro, nunca nos permite realizar por completo los ideales, abre los pliegues de su manto misterioso para dejárnoslos entrever, y luego nos los cierra, como si quisiera enseñarnos que su realización absoluta sólo es posible en el cielo. Todos los monumentos ideales de la humanidad están incompletos, lo mismo los poemas que las catedrales, que las grandes empresas de los héroes del cristianismo. Parece que el pecado original, que destruyó aquel magnífico plan del universo armónico, se cierne sobre todas las obras de los hombres; su concepción es maravillosa, su ejecución empieza bajo magníficos auspicios; pero a lo mejor sobreviene la catástrofe, y la obra queda interrumpida.

Esto le sucedió a la Edad Cristiana. A través de invasiones y de peligros, en medio de luchas y de tinieblas, entrevió el ideal de todas las cosas atraídas hacia su perfección por la cruz en que, Rey del Universo redimido, se levantaba Nuestro Señor Jesucristo. Con los pies sumidos en el lodo que salpica la tierra, pero fija la vista en el cielo, presentaban unánimes aquellas generaciones todas las cosas a su Dios, idealizándolas y transfigurándolas a la luz de su ideal divino. Casi lo habían conseguido ya, cuando sobrevino la ineludible catástrofe. Cerró Dios los entreabiertos pliegues de su manto. Bajó el hombre sus miradas hacia la tierra, y al grito de jarriba!', que había resonado en todos los corazones exaltados por el ideal celeste, sucedió el 
grito de;abajo!, que hizo resonar en su centro la torpe voz de las groseras realidades.

Y, como todo lo que se verifica en la historia, a la consecución de este tristísimo fin conspiraron, con el plan de Dios que lo permitía, el abuso que el hombre hizo de su libertad propia en todas las esferas de su acción, y las infernales maquinaciones del abismo.

El paganismo, esto es, la idolatría, o sea la adoración del demonio con el culto del vicio, en que nos sumió el pecado original (destronado por la redención de las almas, más tarde de la sociedad, y por último de las ciencias, de las letras y de las artes), se había refugiado en el misterioso seno de las herejías durante el tiempo de la fe en la Edad Cristiana; pero apenas vio que la humanidad bajaba a la tierra sus ojos, antes fijos en el cielo, la llamó con su cántico de sirena por la voz de las letras renacidas; tomó posesión del cuerpo de los ídolos, aun no despojados de las cabezas postizas de los santos, se infiltró en brazos de la forma en el fondo de las obras científicas; de la cabeza de los sabios que teorizaban el vicio para no avergonzarse de cometerlo, se corrió al brazo de los reyes, ansiosos de esgrimir las dos espadas que les presentaba el cesarismo pagano, y si no pudo sentar su trono en el tabernáculo, subió las gradas del altar, y con la venia de los mismos Pontífices tomó posesión de los retablos.

Gramáticos, legistas, artistas y monarcas llevaron a cabo la descristianización de las artes, de las letras, de las ciencias y de la política en ese período que se conoce en la historia con el nombre de Renacimiento. La religión no se podía descristianizar, pero podía forzársela a habitar en aquellos templos que no había querido ocupar cuando, abandonando las catacumbas, había tomado posesión de las basílicas.

Y lo que no se puede, se intenta. El paganismo, fingiendo avergonzarse de sí mismo, como los estoicos se avergonzaban de los epicúreos, intentó posesionarse de la religión con el nombre de la Reforma, y destruir sus dogmas, proclamando el cesarismo en política, el sensualismo en las costumbres, el fatalismo en la conciencia, el racionalismo en el entendimiento, el paganismo, en fin; y en brazos de estos vientos que asolaron la mitad de Europa, se meció el monstruo de la Revolución, que, en vez del Papa-Rey, quiere el César ateo, que ofrece en la Roma de los ídolos víctimas humanas en holocausto a Luzbel, el ángel de la revuelta, que cree llegada ya por fin la hora suprema de su desquite contra Dios.

Tal fue la obra del Renacimiento, que, causa a la vez que pretexto y ocasión de la Reforma, inició la restauración del paganismo, proclamado hoy abiertamente por la Revolución cosmopolita. 
Así, pues, conste que entiendo por Renacimiento el movimiento pagano que, predominando sobre el elemento cristiano en la Edad Media, tuerce el camino de la civilización cristiana, presentándola como ideal en artes, ciencias, letras, política, costumbres y religión; la sociedad que cae al otro lado de la cruz.

Todo el que trate de aprovechar los elementos de aquella sociedad, depurándolos y convirtiéndolos para hacerlos servir en su respectiva esfera al ideal cristiano, no es renaciente. Eslo, por el contrario, todo el que, aunque conserve la significación cristiana, busca su expresión ideal en las fórmulas del Paganismo.

No entiendo por Renacimiento el hablar mejor el latín ni el griego; el esculpir mejor que los artistas de la Edad Cristiana. Entiendo por Renacimiento el anteponer en absoluto Homero a la Biblia, y Platón a San Pablo; representar a la Virgen María con las formas de Venus, y proclamar la omnipotencia del César sobre la libertad de reinos y repúblicas, asilos de las libertades locales, que, organizadas en la gran Etnarquia cristiana, navegan, regidas por el navío almirante, que las conduce en ordenada escuadra (dejando al respectivo piloto el interior gobierno de cada nave), al fin último de hombres y naciones juntamente.

Y para entendernos de una vez, llamo Renacimiento a lo que la historia se lo llama, a la invasión del paganismo, que, con la venida de los griegos arrojados de Constantinopla, hace de la Europa cristiana, que acudía a las alturas de la gloria, la Europa pagana primero, protestante después y revolucionaria por último, que hoy miramos abismarse en la insondable sima de la barbarie.

Y sentado esto, claro es que para mí, como tampoco para usted seguramente, no puede ser obra grande ni santa la obra del Renacimiento. Que a la manera de todas las herejías y de todos los males en la historia, haya sido causa ocasional de bienes, no lo niego. Que en determinadas esferas, en la filológica, por ejemplo, haya producido incontestables ventajas, lo aseguro con completa seguridad; pero que estos bienes y ventajas compensen de tal modo sus extravíos, ni menos los justifiquen hasta el punto de considerar el Renacimiento como una obra santa, lo rechazo con toda convicción, y estoy seguro de que, entendido el Renacimiento así, tampoco V. lo admite.

Aunque V. seguramente no, no faltará quien repita al leer mi opinión sobre ambos momentos de la historia, toda esa serie de lugares comunes sobre épocas bárbaras y de tinieblas, de superstición y de ignorancia, con que se atrevieron a bautizar a la Edad Media los pedantescos renacientes. Usted, mejor que yo, sabe el valor y significación de esas palabras en boca de 
humanistas y protestantes, volterianos y secuaces de la revolución que nos deshonra; y $\mathrm{V}$., mejor que yo también, sabe a qué han quedado reducidas, después de los trabajos de Chateaubriand, Schlegel, Lenoir, Caumont, Guizot, Thierry, Ozanam, Montalembert, Müller, Leo, Vogt, Hurter, Ranke y tantos otros como han puesto de manifiesto las incontestables grandezas de aquella edad, que no podrán nunca comprender las almas enamoradas de los ideales griegos y romanos.

No; la verdad es que el Renacimiento pagano, es decir, Renacimiento del paganismo, no hacía falta, a mi ver, dando por supuesto la maldad y el error del que el cristianismo había destruido y aniquilado, sustituyéndole como religión y como doctrina; y Renacimiento clásico, esto es, renacimiento de la ciencia, de las letras, de la política y las artes de las épocas paganas, no hacía falta tampoco, si se habría de comprar a tanta costa, por las siguientes razones:

$1^{\text {a }}$ Porque ya se venía verificando desde mucho antes, o, mejor, porque, no habiéndose perdido nunca por completo el caudal, se iba aumentando poco a poco, depurándolo, purificándolo e incorporándolo a la ciencia cristiana.

2a Porque mejor que volviendo a él mediante parodias ridículas por lo impotentes, y serviles imitaciones de sus obras literarias y artísticas, convenía volver, como habían empezado los grandes hombres de la Edad Cristiana, acudiendo a las fuentes perennes del saber y a los inagotables veneros de la inspiración, abiertos por Dios en el gran libro de la naturaleza, para recorrer cuyas páginas tenían sus hombres la luz preclara de la fe, en lugar de la antorcha vacilante de la razón, única que habían tenido los paganos.

$3^{\text {a }}$ Porque siendo la forma como irradiación suprema del fondo de que es expresión y manifestación completa, la forma literaria y artística completa de los errores paganos, no podía convenir sino deshaciéndola de nuevo, para informar sus elementos con la doctrina opuesta, de modo que pudiera servir de expresión a las verdades cristianas.

Y $4^{\text {a }}$ Porque era, como lo confesaron los mismos que lo intentaban, materialmente imposible la vuelta a una sociedad muerta, cuyas claves literarias nos eran desconocidas y cuyos resortes artísticos nos estaban vedados.

La historia confirma ampliamente estas aserciones de la razón.

El verdadero renacimiento del saber y de la virtud, del bien, de la belleza y de la verdad, cuyos elementos guardó la Iglesia en sus altares, depositarios de la gracia, en sus dogmas, y en sus claustros y archivos, conservadores de la tradición y fideicomisarios de las letras, lo verificaron, personificándolo, a despecho de los embates de la barbarie pagana y del paganismo bárbaro, Santo Domingo y San Francisco en las costumbres, Santo Tomás en la ciencia, San Buenaventura en la mística, Roger Bacon y Vicente de Beauvais en las 
ciencias, Dante en la literatura y Gioto en el arte, precedidos, acompañados y seguidos de aquella pléyade de santos, sabios, místicos y artistas que hicieron del siglo xiII el gran siglo de la Edad Cristiana.

De tal modo que, a no ser por la consabida catástrofe, la civilización hubiera llegado a su plenitud sobre la tierra en esos mismos siglos XIV, XV y xvi, en que, a pesar de haber sobrevenido, todavía florecieron una Santa Catalina de Sena, un Savonarola, un Fray Angélico y los doctores del Concilio Tridentino, en los que, tanto por el hábito que vestían como por la ciencia con que iluminaban los senderos de su virtud, de su religión y de su arte, se veía, a través del Renacimiento y la Reforma, cómo la verdadera Reforma y el verdadero Renacimiento del mundo estaban en aquellos hombres del siglo XIII, cuyas religiones profesaban, cuyos escritos estudiaban para aplicarlos, y cuya obra magna colocaban en el mismo siglo de León X, junto con las Sagradas Escrituras, al uno y otro lado de la cruz de Nuestro Señor Jesucristo.

Y mientras tanto, los que se llaman renacientes, cuando en realidad debieran llamarse desenterradores, poseídos de un vértigo suicida, y sin mirar adónde había conducido a los griegos de Constantinopla el abandono de la unidad y con ella del espíritu y de las letras cristianas, acogen con trasportes de exaltación y de locura cada fugitivo que, escapando de la cimitarra de Mahometo, aborda a Italia trayéndoles la peste entre los pliegues de sus afeminadas vestiduras, entonan cánticos alrededor de cada manuscrito que aparece, y se forman en procesión para honrar cada estatua que se descubre. Las letras y las ciencias que profesaron un San Agustín y un Santo Tomás, son calificadas de bárbaras. Época de barbarie se llama a la Edad Cristiana, Religión de los bárbaros al Cristianismo, gótica con desprecio a la arquitectura religiosa; y mientras, al culto de Jesucristo sucede el de Platón, y a los divinos rostros de las vírgenes y los ángeles, los rostros de las rameras en los altares, y a la gran ciencia escolástica el aristotelismo no purificado, el averroísmo redivivo, el neoplatonismo divinizado, y un eclecticismo más repugnante que el de la escuela de Alejandría; y el cesarismo renace en toda su desnudez, y los nombres cristianos se abandonan por bárbaros, latinizando los prenombres o tomando en su lugar los paganos, y se llama Júpiter a Dios, diosa a la Virgen, Padres conscriptos a los cardenales, augures a los obispos y asnos a los monjes; Savonarola es quemado vivo por los adoradores del Renacimiento, y Lutero acecha el momento de tomar por asalto, como Mahometo, la Constantinopla romana, arrojando sobre el Occidente una nube de bárbaros no menos temible que la que acababa de caer sobre el Oriente, ambas semejantes a las que habían arrasado en el siglo v la antigua sociedad pagana. 
No creo que V. me tache de exageración estas líneas; su asombrosa erudición de $\mathrm{V}$. anotará seguramente con la memoria y la imaginación estas páginas mejor que yo pudiera hacerlo en muchos días revolviendo libros y papeles.

Pero por si alguno que no posea, no ya la colosal erudición de V., pero ni aun la pobre y cada vez más arruinada que yo supe juntar, creyera exageradas estas líneas, tachándolas de vanas y huecas declamaciones, cúmpleme recordarle aquí las obras de aquellos renacientes, la mayor parte eclesiásticos, como Ficino, que daba culto a Platón, manteniendo siempre encendida delante de su imagen una lámpara; que llamaba al Criton su segundo evangelio, y, parodiando el Evangelio de San Juan, aplicaba las palabras referentes al Verbo de Dios a Juan de Médicis, reservando a Lorenzo del mismo nombre las palabras relativas al Padre Eterno; de aquel Ficino que ayudaba a morir al gran Cosme de Médicis, al Padre de las letras renacidas, leyéndole las obras de Platón, cuya lectura prefiere aquel pagano a los últimos consuelos del sacerdote; del ilustre renaciente Pomponio Leto, que se arrodillaba todos los días ante un altar erigido a Rómulo, y que fundó una de aquellas academias en que se sacrificaba anualmente un macho cabrío en el aniversario de la fundación de Roma, y que se negaba a leer obra alguna en latín, posterior a la decadencia del Imperio, incluso los Santos Padres y la Biblia; de aquel Bessarión, que anunciaba la muerte de su maestro, el impío Gemisto, diciendo que ya podía emprender en el cielo con los espíritus celestes la mistica danza de Baco; de aquel Policiano, que se quejaba de que se prefiriesen los salmos de David a sus propias composiciones; de aquel Bembo, que escribía a Sadoleto que no leyese las Epístolas de San Pablo, para que su latín bárbaro no corrompiera su gusto con aquellas futilidades indignas de hombres serios; de aquel Beroaldo, que canta sus amores sacrílegos, y sus hijos sacrílegos también, en versos que, juntamente con su piedad, alaba Bembo; de aquel Sannazaro, que no pronunciaba el nombre de Jesús porque no era latino; de aquel Sadoleto, que, a pesar de su austera piedad, recitaba de memoria los versos más impúdicos de Bautista el Mantuano; de aquellos Guicciardini y Maquiavelo, que consideraban la religión como un gran medio de gobierno y de represión, por el imperio que ejercía sobre los tontos, a pesar de que la religión y la Iglesia habían acarreado la ruina y la deshonra de Italia; escritores cuyas obras protegían, sin embargo, aquellos pontífices del Renacimiento que llamaban inteligencia hermosa a Lutero, que se valían de la excomunión para proteger la propiedad literaria del Ariosto, que se despojaban de la púrpura y se coronaban de laurel para improvisar versos latinos ante la exhumación de un estatua de la antigüedad, y que se 
coronaban de modo que hubiera podido preguntarse si era el Pontífice de la religión pagana el que iba a coronarse, pues a las alegorías e inscripciones gentílicas se unían los elogios de cardenales como Bembo, el cual decía al tribunal apostólico que León X había sido elegido por el favor de los dioses inmortales, llamando diosa lauretana a la Virgen de Loreto, y haciendo escribir al Papa mismo cartas en que, llamándose a la Santísima Virgen diosa, se pedía el auxilio de un monarca por los hombres y por los dioses.

$\mathrm{Y}$ todo esto, mientras acaso en el fondo de misteriosos antros se realizaban ya las últimas consecuencias del Renacimiento pagano, inscribiendo su nombre Pomponio Leto como Pontífice máximo del Paganismo renacido, y tejiéndose la corona de lauro que apareció suspendida sobre la puerta de la habitación del médico de Adriano VI al día siguiente de la inesperada muerte de este Papa, enemigo del Renacimiento; corona en torno de la cual se leía: "Al libertador de la patria, el Senado y el pueblo romano».

No quiero alargar más esta carta, que al fin y al cabo va dirigida a V., recordándole cómo, a pesar de todos estos errores, la obra del Renacimiento literario fue incompleta, pues si la adoración de todo lo pagano pudo rehabilitar los vicios del Paganismo, el arte griego no pudo resucitar a impulso de aquel falso movimiento de galvanismo, extraño a todas las energías de la vida. El mismo idioma latino perdió su precisión filosófica en los escritores renacientes, sin haber adquirido, por propia confesión, la elegancia y la fluidez de los grandes escritores clásicos, cuyo uso, norma del lenguaje según ellos, y cuya pronunciación les fueron totalmente desconocidos.

Pero aunque comprendo que como literato sostenga V. la superioridad del latín del Renacimiento sobre el latín de la Edad Media, no lo comprendo si lo sostiene V. como filósofo. "La belleza de una obra científica es naturalmente púdica, ha dicho un filósofo de este siglo, y esquiva todo ornamento que no sea la propiedad en los vocablos y el orden de su disposición en el discurso». ¡Qué bueno fuera que Santo Tomás, por ejemplo, en vez de aquel estilo cuya densidad metálica ensalzaba Gratry, y cuya exactitud precisa enamoraba a Balmes, que decía que Santo Tomás pesaba las palabras como metal precioso, estilo que comparaba Lacordaire con los «lagos límpidos», y con los «cielos transparentes», porque dejan ver la verdad en sus mayores profundidades, como aquellos deja ver los peces y las estrellas, y que el P. Secchi compara, por su celeste serenidad, "con el mismo verbo de Dios», usara un estilo de Renacimiento en que, después de invocar a los dioses y a las musas, sacrificara a la triste parodia de una frase de Cicerón, la precisión de una palabra técnica de la que pendiera la inteligencia de un misterio divino de la religión católica! 
No; las lenguas no son ni pueden ser Fetiches, objeto eterno e impasible de la adoración de las generaciones que pasan; la lengua tiene que ser, ante todo, fiel expresión de nuestros pensamientos, y a una nueva religión y a una nueva ciencia, un nuevo idioma. Sólo que, así como la religión católica no destruía la naturaleza, ni la sociedad, ni la ciencia, sino que las purificaba y dirigía, así la Iglesia no destruyó el latín, antes bien hizo de él su propia lengua, menos armoniosa acaso a los oídos de un retórico, pero más propia para explicar los sublimes principios de la metafísica cristiana, informada por los misterios divinos de la religión católica.

Vives, el mismo Vives, a quien V. tanto respeta, lo dijo, si no mienten los autores, en estas tres científicas palabras: «A christianis christiane». Que lejos de considerar como bárbaras, como hacían los renacientes italianos, las letras sagradas, decir que los escritores cristianos eran iguales con frecuencia en elegancia y belleza, y a veces superiores a los antiguos.

Deshecha, a mi parecer, esta clave fundamental del error, o mejor de la preocupación que avasalla hoy su ingenio, seducido por los brillantes recuerdos de una literatura que $\mathrm{V}$. posee y en cuyos senos ha penetrado V. tan adelante, merced al gran conocimiento de las lenguas sabias de la antigüedad que V. tiene, réstame sólo recordar, que si bien es cierto que, además de la soberbia, de la codicia y de la lujuria del heresiarca y de sus corifeos, fue efecto también la Protesta de la envidia salvaje de los herejes (pudiéndose considerar la Reforma como brutal retroceso del grosero espíritu germánico contra el espíritu latino cultivado y brillante en aquellos días), no es menos cierto que la Reforma encontró pretexto y causas a la vez en el malhadado Renacimiento, que le dio ocasión con sus vicios, y fuerza con sus elementos, que le preparó el terreno, descristianizando las muchedumbres, y que le franqueó la entrada en la cristiandad, siendo causa de que no se le pusiera pronto y enérgico remedio, y de que los sabios renacientes, más fuertes en Platón que en los Santos Padres, no esgrimieran armas contundentes contra el monstruo de la herejía, hasta que de España, sobre todo, vinieron aquellos grandes escolásticos, hijos fieles de Santo Tomás, que, más apartados del movimiento renaciente, combatieron a la Reforma con las bien templadas armas de la Edad Media.

Lutero, discípulo del humanista Trebonius, asombro, según Melanchton, de la academia de Erfurth por sus conocimientos renacientes, que le hacen ensañarse, joven aún, contra la barbarie escolástica, y despreciar las Sagradas Escrituras, hasta el punto de confesar que a los veinte años no había leído una línea, y que hasta cuando herido por el rayo, abandonó la vida mundanal por el convento, llevaba debajo del brazo, como preciosas reliquias, a Plauto 
y a Virgilio; Lutero, encanto de la Universidad de Wittenberg, foco del humanismo en Alemania; Lutero, que, haciendo coro a Hutten, a Reuchlin y a Erasmo en sus burlas sangrientas contra la Edad Cristiana, contra la escolástica y contra las Órdenes religiosas, esa trinidad odiada por el Renacimiento, la Revolución y la Reforma, se deshace en elogios de las bellas letras, del latín y del griego renacientes; Lutero, que ante la Roma de los Médicis siente retorcerse en sus entrańas el torcedor de la envidia, que le hace deprimir lo que ambiciona, y que, como aventurero que en día de saco entra a sangre y fuego en una ciudad para gozarse con sus riquezas y placeres y destruir las que no puede utilizar, arrojando el nombre de sus vicios a la frente ensangrentada de sus víctimas, clama contra los vicios paganos que cuidadosamente guarda entre los pliegues de su hábito, para adorarlos en Alemania; Lutero, que mientras esmalta sus sermones con los nombres adorados del Renacimiento, quema con las Sagradas Escrituras las obras de Santo Tomás, tan odiadas de los renacientes, y que mientras proclama la emancipación del pensamiento, la emancipación de la carne y la emancipación del Estado, esto es, el racionalismo, el sensualismo y el cesarismo, los tres principios fundamentales del paganismo que rehabilitó el Renacimiento, se desata en diatribas contra Santo Tomás y la iglesia tomistica, como llama a la Iglesia católica, prueban evidentemente lo que ya dijo Erasmo del Renacimiento y la Reforma: «Ego posui ovum, Lutherus exclusit».

Y no se olvide V. que Erasmo es, a la vez que juez autorizadísimo en la materia, prueba incontrastable de lo que afirmo.

Erasmo era la personificación del Renacimiento por excelencia. No es pedante como Pomponio Leto, ni ignorante como Pomponazzi; no es pagano como Ficino; y aunque para él vale más saber griego que saber todo lo demás, y aunque no se cansa de atacar a la escolástica, a los frailes y a la Edad Media, y aunque el pobre Lutero, según él, no ha cometido más pecados que atentar contra la tiara de los Pontífices y contra la panza de los monjes, se conserva, al menos exteriormente, dentro del campo católico, y, sin embargo, V. recuerda aquel dicho común tan elocuente que atestigua la casi identidad de estas dos personificaciones y de estos dos movimientos: "Aut Erasmus lutherizat, aut Lutherus erasmizat».

No, no cabe negarlo. Los críticos modernos más amantes del Renacimiento y más enemigos de la Reforma, lo confiesan; por más que no hace mucho que el original Letamendi haya llamado al Renacimiento la Grecia en gracia de Dios, frase que hubiera seguramente indignado a los renacientes italianos, más cuidadosos y amantes que de la gracia de Dios, de las gracias y de los dioses. Pero aun disculpando a los renacientes, no se puede negar que 
en ellos encontró, aun a pesar suyo, sus auxiliares la herejía, sin contar los que la siguieron, que no fueron en menor número; pues, como el conde Alberto de Carpi escribía a Erasmo, que lo reconocía también: "Entre los alemanes, todos los amantes de las bellas letras se han convertido en fautores de Lutero».

Como en Italia, aparte aquellos espíritus inconscientes y tímidos que siempre se detienen en las premisas, los demás se habían entregado al paganismo por completo, no puede negarse, so pena de negar la historia, lo que con frase elocuente confiesa un partidario del Renacimiento en nuestros días: "Que la tea de la Reforma se encendía en la antorcha del Renacimiento».

Por las mismas razones que nos prueban de dónde nos vino la enfermedad, se prueba de dónde nos vino el remedio.

A la sociedad cristiana paganizada no le quedaban más que tres caminos: o morir pagana como Cosme de Médicis en brazos de Platón, o precipitarse en brazos de Lutero con Melanchton, o volver los ojos a la fe de los grandes días del Cristianismo, como el Magnífico Lorenzo volvía en sus últimos instantes los moribundos ojos, apartándolos de las maravillas neo-paganas que decoraban su estancia, al tosco Crucifijo de madera que le presentaba la diestra del mártir tomista Savonarola.

Europa siguió este último camino, y Europa se salvó. Recordando que allá en el siglo XIII, en el momento más crítico de su existencia, cuando por todas partes la cercaban peligros, Santo Tomás la salvó, con su doctrina, de los errores aristotélicos, averroístas y escolásticos, del cesarismo pagano, del fatalismo oriental, del antimonarquismo universitario, del racionalismo y panteísmo claustral, del kabalismo judaico y del misticismo de los herejes, volvió los ojos a esta doctrina, con la que Juan de Montenegro había vencido a los griegos en el Concilio de Florencia, y Torquemada había brillado en Basilea, y Fr. Diego de Deza había comprendido a Colón, y Cayetano había asombrado a Italia y a Alemania, y Vitoria había restaurado las Universidades europeas; y llamando en su auxilio a los grandes tomistas alemanes como Getino, polacos como Stono, ingleses como Fischer, italianos como Tomás de Vio, clamó con ronco acento hacia España, donde el Renacimiento propiamente tal no había penetrado apenas; donde el estudio de las lenguas sabias se utilizaba imprimiendo la Políglota complutense, en vez de las obras impúdicas de la antigüedad pagana; donde en lugar de Erasmo brillaba Vives, y donde, como efecto a la vez que como causa de todo esto, se cultivaba el estudio de Santo Tomás; y España entonces abrió los claustros gloriosos de sus conventos y sus Universidades, y envió contra el monstruo de la Reforma aquel batallón sagrado de teólogos tomistas que pelearon en Trento, derrotando al protestantismo para siempre con la doctrina de Santo 
Tomás de Aquino, que a cada paso se consultaba, deteniendo las deliberaciones hasta conocer su opinión, a pesar del desprecio con que la cubría el Renacimiento; plagiándole hasta sus palabras mismas para ponerlas en los decretos del Concilio, a pesar de estar escritas en latín bárbaro, según los pedantescos renacientes, y colocando su obra magistral, la Summa, juntamente con las Sagradas Escrituras, en la cima más culminante de la cristiandad verdaderamente renacida, y esto en pleno siglo XVI.

En tanto Lutero, ejecutando la sentencia que contra unas y otras había fulminado el Renacimiento, las quemaba, constituyéndose en su verdugo; y tanto él como todos sus secuaces, considerando a los renacientes, o como adversarios de escaso mérito y valor, o como auxiliares, sólo decían al atacar los alcázares del Cristianismo: "Tolle Thomam et dissipabo ecclesiam Dei». A lo que los doctores cristianos, defendiéndolos, contestaban, arrojando de sus manos a los adoradores de Platón: "Consulamus divum Thomam».

Que tanto en uno como en otro campo, venidos ya a las manos y metidos en lo más recio de la pelea, se procuraba, para herir en el corazón, despojar al enemigo de su pavés, y si buscaban las armas más templadas los enemigos de la cristiandad, la cristiandad del siglo xvi no encontraba escudo más resistente para defenderse ni arma de mejor temple para atacar, que la doctrina de Santo Tomás, forjada en los grandes días de la Edad Media por aquel gigante de la escolástica.

Aun considerando a los renacientes incompletos que pelearon por la verdad, los Papas que los habían preferido a los tomistas, debieron recordar aquella fábula del pastor que trocó su fuerte y poderoso mastín por diez gozques pequeños, creyendo resguardar mejor su rebaño, y que cuando vino el lobo, tuvo que buscar de prisa su mastín, porque los ladradores gozquecillos no impedían el destrozo de sus ovejas.

Si V., que es uno de los hombres que más respeto y admiro, no sólo por su erudición asombrosa en tan cortos años reunida, sino por su crítica atinada y lúcido criterio, se detiene, dejando aparte toda pasión de polémica y toda impresión de momento y de lugar, a considerar estas razones, no dudo, ni por un instante, que, aparte tales diferencias, convendrá V. conmigo en lo substancial, confesándome sin rebozo que la mayor parte de los cargos que V. hizo al tomismo, fueron alardes de ingenio y de erudición con que $\mathrm{V}$. quiso, parodiando los actos académicos de otros días, probar que se podían defender los excesos del Renacimiento, acaso con cierta secreta satisfacción del amor propio envanecido, producida por la íntima convicción de que entre los que cultivamos las letras no había ninguno capaz de deshacer su tesis de V., aun teniendo de su parte el auxilio de la razón y el testimonio de la historia. 
Yo, después que V. me confiese lo primero, no tengo reparo en confesarle lo segundo. Así es que, en vez de pelear contra usted, lo que hago es un llamamiento a su sentido moral, para que, no abusando más de la broma, sin deslustrar el mérito de Vives y las grandezas del Renacimiento español, que soy el primero en proclamar, contribuya $\mathrm{V}$. con su recto juicio y su prodigiosa ilustración al glorioso Renacimiento cristiano, a que, después de tres siglos de Reforma, de Enciclopedia y de Revolución, estamos asistiendo en nuestros días.

Si V., atento a la voz de este llamamiento amistoso, no ve en estas páginas una tesis que combatir, ni en esta discusión un juego de retóricos, y encerrándose dentro de sí, y posponiendo sus tentaciones literarias y su arsenal de erudición a su deber filosófico, trata $V$. de restablecer toda la verdad en la cuestión presente, trocándose de mi adversario en mi maestro, nada me quedará ya más que hacer sino soltar la pluma, para batir con más facilidad las palmas, al ver cómo V. me enseña las paradas y respuestas que tienen las estocadas y tajos con que V. me maltrató en su epístola.

¡Qué carta entonces la de V., amigo mío! ¡Qué gran vindicación de la Edad Media! ¿Qué panegírico de la escolástica y del tomismo! Qué flagelación de los excesos del Renacimiento! ¡Qué análisis tan profundo del Renacimiento español, tan distinto del italiano! Como abogado del diablo en la causa de beatificación de la Edad Cristiana, el cual, al ver que por torpeza de sus defensores va a quedar sin honor el varón justo a quien tuvo por exigencias de su papel que atacar, restablece en su réplica la verdad sobre las virtudes de su alma y sobre la santidad de su vida, así V. en esta carta deshará con mayor crítica y erudición los cargos que amontonó $\mathrm{V}$. en su acusación primera.

De seguro empezará $V$. acusándome de que no supe leer su epístola, en la que, además de los elogios ya citados sobre Santo Tomás y su doctrina, me recuerda $\mathrm{V}$. que «hablaba como bibliógrafo español», y no como filósofo, al ponderar autores anti-escolásticos; que a la escolástica llamó V., «no una, sino las dos terceras partes de nuestra filosofía»; que a pesar de que "el neotomismo cobra de día en día fuerzas mayores en España, y que sus secuaces son tan respetables por su número como por su saber», «sería una herejía científica considerar inútil una reimpresión más de las obras de Santo Tomás en nuestra patria», a pesar "de haber sido tantas veces reproducidas por la estampa, de ser tan conocidas, de encontrarse en todas las bibliotecas y en todas las manos, y cuando en todo el orbe cristiano se trabaja sin cesar sobre sus admirables escritos y en cien formas se le expone y se le reproduce»; que aunque $\mathrm{V}$. «no es todavía tomista, quizá lo será mañana», pues aunque, hoy por hoy, «es vivista», «el vivismo no es adverso al tomismo, ni mucho 
menos»; antes bien lo considera "como un hermano mayon», razón por la que usted «lo venera, respeta y acata como puede hacerlo el más fervoroso de sus adeptos». Que si bien habló V. del bárbaro estiércol de la escolástica, debajo del cual se hallaba oro, según Leibniz, añadió V. que Leibnitz «se equivocaba en lo del estiércol, como todos los de su época»; y que si bien dice V. que aplaude las invectivas del Renacimiento contra la barbarie de la escuela, a renglón seguido tiene V. cuidado de ańadir «que no es usted partícipe de la preocupación, en otro tiempo general, contra el lenguaje y estilo de los escolásticos», porque «sabe que, habiéndose encontrado con un latín decadente y de malas condiciones para la filosofía, crearon una lengua y un estilo especiales, analíticos y precisos», en la que "escribieron con vigor y con fuerza», y que aunque Santo Tomás de Aquino sobresalga más «como pensador que como artista, no ha de ser V. el que haga observaciones literarias tratándose de un Santo Tomás de Aquino»; que al ponderar la obra de Vives no halla V. mayor elogio para él que compararla con la obra de Santo Tomás, y que, al ensalzar a los tomistas del Renacimiento, no encuentra V. alabanza más grande que llamarlos «dignos discípulos de Santo Tomás de Aquino». Que tiene V. buen cuidado en advertir que por lo general «no fueron tomistas los escolásticos que sucumbieron a la Reforma»; y, finalmente, que aunque «suscribe $V$. con todo el entusiasmo de que es capaz a los elogios que yo hice de los tomistas españoles, que constituyen una de las páginas más brillantes de nuestra historia científicas, le aqueja a V. «el temor de haber hablado con irreverencia del luminoso, sublime y fecundo tomismo», por lo que encarecidamente me ruega «no considere su carta como un escrito anti-tomista, sino como palabras ligeras con que V., «encontrando demasiado tirante el arco por una parte, probó a doblarlo por la otra, quizá con exceso»; y después de darme esta lección preliminar para que "aprecie su posición de V. respecto al tomismo», me irá $\mathrm{V}$. enseñando los quites propios de cada acusación con estas o parecidas palabras.

$\mathrm{Al}$ cargo de que el tomismo no es la verdad total, porque ésta se encuentra en la deseada armonía de Platón y Aristóteles, y Santo Tomás sólo tuvo en cuenta a Aristóteles, y Aristóteles incompleto, pues no le conoció en sus fuentes como le conocieron los renacientes, V. contestará diciendo que Santo Tomás tuvo en cuenta a Platón, como se echa de ver en los elementos platónicos que se hallan en sus obras, y que tomó, no sólo de Platón mismo, sino de San Agustín y demás Padres de la Iglesia griega y latina que le siguieron y de los místicos que le estudiaron; que lo que tomó de Aristóteles principalmente fue el método; y como lo que Santo Tomás tuvo que hacer fue, más que un tratado crítico sobre Aristóteles, una creación filosófica nueva en vista de 
los problemas suscitados por estos genios de la filosofía, y una refutación de sus errores, tal como entonces empozoñaban a la cristiandad, le fue más útil conocerlo como lo conoció entonces, completado con nuevos errores y comentarios, para bien de la cristiandad y de la filosofía; y esto sin olvidar que escritores muy graves sostienen que Santo Tomás leyó a Aristóteles en griego, y sin olvidar que, a instancia suya, lo tradujo el famoso Guillermo de Moerbeka, renombrado orientalista.

Que al cargo «de que la escuela con Averroes y antes de Averroes había sido un semillero de herejes, como Scoto Erígena, Berengario, Abelardo y Roscelin», V. contestaría que estos herejes salieron en tiempo de la escolástica, y a su lado, pero no salieron de ella, sino a pesar de ella, como todas las herejías salieron de las verdades dogmáticas y de la Escritura, pero no producidas por éstas, sino a pesar y con ocasión de éstas; y de la escuela salieron los que las derrotaron, como San Francisco, San Anselmo y San Bernardo, Guillermo de Champeaux, Hugo y Ricardo de San Víctor, Alberto Magno, Alejandro de Hales, Enrique de Gante, y finalmente Santo Tomás, que los enterró bajo el inmenso peso de su gloria.

Que al cargo de que obreros del Renacimiento y no tomistas eran los que trabajaban en la Políglota complutense, se debe contestar: primero, que falta averiguar si eran o no tomistas algunos de los que trabajaron en la Políglota; y segundo, que no se puede en justicia llamar obreros del Renacimiento (que llamaba a las Escrituras letras bárbaras, posponiendo su estudio al de Platón y alguno al de sus propias obras) a los que imprimían tan soberbiamente en sus primeros tomos la Vulgata, tan despreciada por el Renacimiento y quemada después por la Reforma, sino más bien obreros que trabajaban por impedir que el Renacimiento paganizase nuestra patria, y que lo que está averiguado es que, si no lo fueron, no fue porque no pudieran serlo, pues tomistas eran Agustín Justiniani, autor de la Octapla, y Sanctes Pagnino, autor de obras que aun hoy son muy estimadas de los orientalistas, y que escribieron al mismo tiempo que se imprimía la Políglota complutense, mientras venía al seno de la Iglesia el famoso orientalista Pablo de Santa María (convertido por la lectura de las obras de Santo Tomás), y su hijo y sucesor en el obispado de Burgos, D. Alfonso de Cartagena; y esto sin contar los grandes orientalistas compañeros de Santo Tomás en religión y doctrina, como Fr. Hugo y Fr. Pedro, enviados por Gregorio IX a conferenciar con los griegos, y que tan brillante papel desempeñaron en Nicea y Ninfea; como Raimundo Martí, autor de la obra del Pugio Fidei, que plagia un escritor en el Renacimiento; y sus siete compańeros destinados por el capítulo de la Orden en Toledo para desempeñar cátedras de estudios orientales, como 
las que por el mismo tiempo abrieron los frailes Predicadores en Murcia, Játiva y Estella; como Pablo Cristiano y Puigventos y demás hijos de Santo Domingo, que San Raimundo de Peñafort asignó al estudio y enseñanzas de estas lenguas; como Fr. Aroldo de Florencia y los Dominicos que escribieron contra errores graecorum; como los sabios hermanos de Santo Tomás que, tres siglos antes de que se imprimiese la Políglota, presentaban a Europa una Biblia de cuatro tomos en folio, fruto de la reunión, comparación y estudio de gran número de manuscritos antiguos, griegos, hebreos y latinos; como Guillermo de Moerbeka, que trasladó del griego al latín varios libros de Aristóteles a instancia de Santo Tomás de Aquino; como el célebre Bonacursio, que escribió en griego el Thesaurus fidei, obra llena de erudición y de ciencia; como Gofredo de Waterfodia, y como Nicolao de Florencia, y Andrés Dato y tantos otros Dominicos que, en medio de la general rudeza, cultivaron el griego, el árabe y el hebreo, no para resucitar las obras impúdicas del arte antiguo, sino para defender a la religión y a la civilización europea de los errores orientales que amenazaban hacer del Oriente un bajo imperio o un estado del Asia, los cuales merecieron atraer por sus heréticas cavilaciones y por su fatalismo panteísta la barbarie asoladora de Omar o el azote cruel de Mahometo.

Que el cargo de que Pomponazzi dudó de la inmortalidad del alma siendo escolástico, y no se levantó a responderle ningún tomista, sino un peripatético clásico, Nipho, se refuta constestando que Pomponazzi fue un aristotélico renaciente a la sombra de Alejandro de Afrodisia, muy ensalzado por los protestantes y los racionalistas, y tan poco escolástico, que llamaba ilusiones y decepciones falsas y absurdas a las doctrinas de Santo Tomás, y afirmaba que sólo consentirle en aceptar sus doctrinas, imposibles según él, y en someterse a las Sagradas Escrituras, por obedecer a Platón, «que dice que es una impiedad no creer en los dioses ni en los hijos de los dioses». Que a este renaciente naturalista le contestaron, además de Nipho (que entre paréntesis era panteísta), Alejandro Achillini, que, aunque averroísta, era escolástico; Contarini, de ilustre familia veneciana, que fue después cardenal; Ambrosio, arzobispo de Nápoles, y los tres frailes, probablemente tomistas, Bartolomé de Pisa, Jerónimo Banellière y Silvestre Pereira, sin contar aquel ermitaño de Nápoles que le denunciaba como hereje e impío, mientras el ilustre renaciente, el famoso cardenal Bembo, lo defendía delante de la corte romana, sosteniendo que su libro De immortalitate no encerraba nada contrario a la verdad; sin olvidar que mientras Pomponazzi y sus amigos se quejaban continuamente de los portadores de hábito que, educados con la doctrina tomista, les perseguían en sus errores, los obreros del Renacimiento 
se adherían a las doctrinas de Pomponazzi, como lo hicieron Simón Porta, Lázaro Bonamico, Julio César Escalígero, Santiago Zabarella, Daniel Bárbaro, Simón Porcio, cuya obra sobre el alma era más digna de un puerco que de un hombre, «según Gessner»; Andrés Cesalpino, partidario de la generación espontánea; Galeotto Marcio, protegido por los reyes y los pontífices, y obligado a retractarse por los tomistas Dominicos, y tantos otros sofistas como florecieron en el Renacimiento, al calor de aquella filosofía, verdadero producto híbrido de mezclas tan extrañas, y cuya personificación más ilustre es el famoso Juan Pico de la Mirándola, educado en la corte de Lorenzo de Médicis con aquellas doctrinas mixtas, compuestas de kábala y gnosticismo, neoplatonismo y judaísmo, revestidas con el brillante manto de la literatura clásica, y adornadas con trofeos de Aristóteles, Averroes y Epicuro, doctrinas que le hacen caer en la herejía, de la que, a semejanza de la sociedad que simboliza, sólo se levanta cuando, abandonando sus errores renacientes, muere en brazos de los hermanos de Santo Tomás de Aquino.

Que al cargo de que el tomismo era incapaz de acabar con el averroísmo, se contesta con la lectura de las obras de Santo Tomás, especialmente de la Summa contra gentiles, con la expresión de los mismos renacientes, que dijeron por boca del mismo Pomponazzi que «los averroístas fueron de tal modo fustigados por Santo Tomás, que no les quedó otro recurso que vomitar contra él injurias», y por el testimonio de la cristiandad, que celebró con magníficas y colosales frescos por manos de Gozzoli, de Gaddi y de Traini el triunfo de Santo Tomás de Aquino, debajo de cuyos pies victoriosos se revuelca impotente, vencido, con el Gran comento en la mano, el temible Averroes.

Que al cargo de que los escolásticos olvidaron un poquito la experimentación, se contesta, no sólo con recordar a Miguel Scoto, Vicente de Beauvais, el gran Roger Bacon, Ramon Llul y los alquimistas, y sobre todo a Alberto el Magno, a quien tanto pondera por sus observaciones naturalistas Humboldt, sino con las mismas palabras de la acusación; pues habiendo sido, por lo general, la física escolástica un comentario de Aristóteles, si Aristóteles no descuidó la experimentación, tampoco la descuidaron los escolásticos, pudiendo además añadirse, a guisa de posdata, los nombres de Alejandro Spina, inventor de los anteojos; Domingo Ceva, que escribió sobre gnomónica; Ignacio Dante, «uno de los matemáticos más insignes que brillaron en la corte del gran Cosme de Médicis»; que, no sólo fueron escolásticos, sino hasta tomistas y Dominicos, coronando estos nombres con el de Tomás Campanella, que, sin dejar de ser tomista, se dedicó con ardor a la experimentación, fundando antes que Bacon, sobre este procedimiento exclusivo, el estudio de las ciencias naturales. 
Que al cargo formulado con las palabras barbarie de la escuela, sinónimo en su carta de V. de barbarie literaria, esto es, que Santo Tomás y los grandes escolásticos de la Edad Media no escribieron un latín digno de Cicerón y de Virgilio, se debe responder: primero, que la belleza de la forma en una obra filosófica consiste en la claridad y la precisión más que en la elegancia de los giros y en lo castizo de las palabras; segundo, que no es razón juzgar del fondo por la forma, y que los famosos renacientes, que todo lo sacrificaban a escribir como Cicerón, nunca pudieron conseguirlo, acusándose mutuamente de su impotente ignorancia, y confesando que mejor que ellos hablarían el latín los palafreneros de Roma. Finalmente, ¿cómo no recordar estas palabras, arrancadas por la manía pedantesca de los renacientes italianos al mismo Erasmo, tan enemigo de la Edad Cristiana y de los frailes, y tan adorador del latín y del griego? «Es maravilla, exclama dirigiéndose a los renacientes italianos, cómo rebajáis a los Santos Padres de la Iglesia, a los grandes escritores de la Edad Media, a Santo Tomás, a Escoto, a Durando y demás. No halláis palabras con que denunciar su BARBARIE, y, sin embargo, considerando el caso con sangre fría, esos GRANDES HOMBRES, que no hacen alardes de ser elocuentes ni ciceronianos, SON MÁS CICERONIANOS QUE TODOS VOSOTROS JUNTOS». Erasmo lo prueba con las enseñanzas mismas de los clásicos y la confesión de los renacientes, que califican de gran escritor (esto es, de ciceroniano) al que habla bien, exigiendo para merecer este nombre dos condiciones precisas: conocer a fondo el asunto, $y$ tener corazón y convicción para expresarlo. "Ahora bien, añadía irritado Erasmo: probadme que los escritores cristianos no conocen las cosas de que hablan ni tienen el corazón y la convicción para expresarlas».

Es evidente: el latín escolástico les parecía bárbaro a los paganos renacientes, porque no comprendían las ideas de que era expresión, y así como el latín pagano no podía servir al cristianismo, al paganismo renaciente no podía servir de intérprete el latín cristiano. Por eso nosotros, al oír cómo llaman bárbaro el latín de la Iglesia los renacientes, no podemos menos de recordar aquel verso de Ovidio:

\section{"Barbarus hic ego sum quia non intelligor ulli.»}

Erasmo, además de probar a los renacientes que, según su criterio, también Cicerón fue un bárbaro, puesto que empleó palabras desconocidas y nuevas, se burla de los que quieren hacer nuevos Cicerones con el estudio del latín pagano, diciéndoles que harán charlatanes, pero no grandes oradores y escritores como el antiguo cónsul; y tenía razón Erasmo: si la palabra supone el pensamiento, el calor y la vida, ¿qué vida y qué calor podía tener 
el pensamiento pagano en una sociedad, a pesar de todo, cristiana, en boca de eclesiásticos y después de quince siglos de cristianismo? A esto sólo cabe responder que, continuando el Renacimiento pagano, hubiéramos podido olvidar del todo el cristianismo, y acaso entonces hubiéramos llegado a escribir como Cicerón; lo que no valía seguramente la pena de deshacer la obra de Cristo; pues esto sí que sería barbarie, y barbarie del peor género.

Y contestados estos cargos, me recordaría $V$., en auxilio de mis palabras sobre el amor que las Universidades profesaron al luminoso tomismo, la historia de la Universidad de Alcalá, fundada por el ilustre Cisneros, y de la cual dice D. Vicente de la Fuente que «tiene la gloria de haber vivido y muerto tomista desde su fundación hasta su último instante», "teniendo la honra de morir abrazada a la Summa»; y como prueba de que aun en las épocas de más decadencia científica en nuestra patria tuvo elocuentes defensores el tomismo que se opusieran a la invasión cartesiana, me citaría V. el nombre célebre de Alvarado, conocido con el pseudónimo de El Filósofo rancio; y en prueba de que la tradición tomista no se interrumpe en España, a Balmes, educado en el Seminario tomista de Vich, consagrado a Santo Tomás por su madre, y que sus biógrafos nos presentan meditando sobre la Summa; y para justificar nuestros elogios a los tomistas espańoles, a que V. con tanto entusiasmo suscribe, nos presentaría a nuestros místicos, que, como V. dijo en aquella incomparable carta Perojina, "tomaron los orígenes de su doctrina en la no interrumpida serie de místicos cristianos, en San Agustín, en Hugo de San Víctor, Gersón y San Buenaventura, amamantándose en las obras atribuidas con error al Areopagita» (elementos todos que se encuentran depurados y sintetizados en las obras de Santo Tomás), haciéndole a V. exclamar con evidente justicia que «nuestra mística sólo difiere de la de la Edad Media en la perfección artística, y en un poco de platonismo, que entró durante el Renacimiento»; y me recordaría usted que Santa Teresa, si no estudió autores escolásticos, encontró dirección y guía a las exaltaciones de su amor espiritual y místico en los tomistas Dominicos que estaban encargados de su dirección de espíritu al principio, y en los tomistas Carmelitas, autores de los Salmanticenses, que la dirigieron después. Además, me dirá V. cosas que ni siquiera sospecho, y que ha recogido V. de seguro en sus profundas y vastas investigaciones científicas en los archivos y bibliotecas del mundo sabio.

Y después de recordarme todo esto, me traerá V. a la memoria, como desagravio artístico de Santo Tomás, la influencia de su doctrina en Dante, y por Dante en las escuelas pictóricas que iniciaron y llevaron a cabo, elevándolo a su mayor perfección, el progreso artístico en Italia, y sus famosos himnos, 
aquellos himnos traducidos y puestos en música por los poetas y los artistas religiosos más célebres de la edad contemporánea, y de los cuales por sólo cuatros versos decía el poeta Santeuil que daría gustoso todas sus obras; y no dejaría en olvido la resurrección de sus principios extáticos en el santo y mártir Savonarola, que aparece en la orgía artística del Renacimiento como un nuevo Pedro el Ermitańo, que predica la cruzada de todas las virtudes contra los vicios renacientes, a fin de arrancar el sepulcro que Dios tiene en los altares de manos del paganismo renacido, mientras enfrente de las tiránicas teorías de Maquiavelo, cuyo libro El Príncipe llamaba el déspota Federico II el Breviario de los reyes, coloca las doctrinas políticas de Santo Tomás; y la reacción que hoy mismo en nuestros días se levanta contra el realismo grosero de las artes en las obras de Félix, Taparelli, Jungmann y Marchese, que vuelven a buscar la determinación y guía de sus investigaciones estéticas en las obras de Santo Tomás, punto de partida inevitable de todo progreso filosófico en sí y en su aplicación a todas las esferas de la ciencia y del arte.

Y finalmente, y para acabar, a modo de lección práctica de dialéctica, me enseñará $V$. cómo se deshace el ingenioso sofisma con que V. quiso mostrarme a qué extremos puede llegar un ingenio y una erudición como la de V., cuando, por probar el ingenio o la paciencia del adversario, se propone sostener una paradoja tan contraria a la opinión corriente, como que Melchor Cano no fue discípulo de Santo Tomás, sino de Vives.

Este sofisma empieza por separar, para oponer, lo que en este sentido es inseparable, como es la teología de la filosofía en la escolástica, olvidando que, aunque distintas en su origen, formaron en los escritos de Santo Tomás un perfecto organismo, en el que compenetrándose se completan, siendo, por lo tanto, imposible ser lógicamente tomistas en teología sin serlo en filosofía, como se puede ver estudiando la relación de la cuestión de la gracia con la cuestión de la naturaleza y la causalidad eficiente; la que liga la cuestión del sacramento de la Eucaristía con la de la esencia o concepto de los accidentes; la que encadena la de la naturaleza, existencia y propagación del pecado original con la teoría del compuesto humano y de la generación substancial del hombre; la que une y aprieta estrechamente la de los actos humanos, la de las virtudes y vicios, la de las pasiones, la de la voluntad y el libre albedrío, y hasta la de la vida eterna con los fundamentos y desarrollos de su ética y de su psicología, relaciones que podríamos ir señalando en todos los puntos de la doctrina de Santo Tomás, y que plenamente confirma, a modo de contraprueba, la inevitable y perpetua consecuencia con que de toda derivación tomista en las cuestiones teológicas se desprende una derivación filosófica de las doctrinas de Santo Tomás, como plenamente 
se ve en el congruismo, que, puesto enfrente de la gracia eficaz en teología, exigió que se presentase inmediatamente, como teoría filosófica, el concurso simultáneo enfrente del principio de la promoción física. Este sofisma sigue señalando como carácter principal para filiar las escuelas y los sistemas filosóficos el estilo literario del autor que los explica y los defiende, con lo cual se echa por tierra toda la genealogía filosófica, pues ninguno de los tomistas de hoy escribe como Santo Tomás y los tomistas del siglo XIII, ni éstos como Aristóteles, ni aun hoy Vera escribe como Hegel, ni Tiberghien escribe como Krause, ni es posible que, variado el gusto literario con las épocas y generaciones, pudiera trascender ninguna doctrina filosófica, ni continuar ninguna escuela, si éstas hubieran de clasificarse, no por sus soluciones científicas, sino por su estilo literario.

Este sofisma continúa valiéndose de la palabra forma como equívoca para diferenciar la de Santo Tomás de la de Melchor Cano, y, aparentando referirse sólo al estilo, se refiere en realidad al método, suponiendo así diferencias donde hay sólo identidad, como sucede en el método que usaron Melchor Cano y Santo Tomás, que no es otro que el método escolástico, que consiste en proponer la cuestión, presentar los argumentos en contra, establecer su tesis con las pruebas correspondientes y contestar a las objeciones.

Este sofisma pretende apoyarse en unas palabras de Melchor Cano sobre quién es superior, si Aristóteles o Platón (cuando después de todo viene a coincidir con Santo Tomás en dar la preferencia a Aristóteles con cierta moderación y completándolo con doctrinas platónicas) (Probanda vero magis est divi Thomae opinio, ut adhibeatur moderatio quaedam), para deducir de aquí que no sigue la doctrina de Santo Tomás, cuando no rechaza en sus obras ni una sola de sus teorías teológicas ni filosóficas, antes bien le vemos citarlas y aprobarlas a cada paso, como sucede, sobre todo, en su obra Relectiones de sacramentis, y calificarlo de vivista, cuando él mismo dijo, sin que lo invalide el confesarlo (que es otra de las habilidades del sofisma), que si Vives señaló con acierto las causas de la corrupción de las ciencias, no anduvo tan atinado en proponer los remedios, lo cual (con permiso del sofisma) quiere decir que, en vez de declararse partidario de su filosofía, se declara abiertamente su contrario.

Sofisma al cabo que prueba, por lo absurdo y descomunal, el grado de sutileza de su claro ingenio y la opulencia de su atesorada erudición, que le ponen a V. en estado de asentar y casi probar, como cosa cierta y evidente, lo que es contrario a la realidad y a la común opinión de todos los doctos.

Lo mismo podría decir del suarismo presentado como doctrina distinta de la de Santo Tomás, que en casi todo lo que no sea relativo a las exigencias 
de la doctrina congruista y en algún otro punto como la distinción entre la esencia y la existencia, es idéntica al tomismo, habiendo bastante más distancia de ciertos pretendidos suaristas al gran Suárez, que de éste a Santo Tomás; pero no quiero alargar ya más esta carta, que por lo pesada e indigesta, lo machacona y llena de repeticiones, y por lo hinchado del estilo, parece una producción de los pedantescos renacientes. Más valiera que, siguiendo el método escolástico, hubiera desenvuelto en dos cuartillas una serie de proposiciones que, probadas a posteriori y lógicamente encadenadas entre sí, fueran, al par que una demostración teórica, una demostración práctica de las excelencias del escolasticismo.

Pero ¿qué hacer?: ya está escrita, y sin contestar a Perojo, de quien dio V. tan buena cuenta (y mucho siento no poder aceptar sus elogios, porque no me creo digno de merecerlos), teniendo a orgullo reconocer la inmensa superioridad de V. sobre mí, y dejando a un lado las ya para mí secundarias cuestiones referentes a la ciencia espańola, termino con un ruego que fervientemente le dirijo.

No sé lo que contestará V. a esta carta; pero puede V. darle dos contestaciones: una, que me atrevería a llamar contestación de erudito; otra, que calificaré de contestación de crítico y de filósofo. La primera consiste en desenterrar, cosa para V., que tiene una biblioteca en la cabeza, sumamente fácil, todas las acusaciones que el Renacimiento primero, la Reforma después, el Cartesianismo más tarde, la Enciclopedia en seguida y el Racionalismo contemporáneo hoy, han formulado contra la Escolástica. A esta carta podría yo contestar victoriosamente después de muchos días de trabajo, de meditación y de consulta; pero como en el terreno de la erudición nuestras fuerzas son muy desiguales, me costaría mucho trabajo vencer, aun teniendo la razón de mi parte. La segunda consiste en colocarse en el observatorio de la crítica filosófica e histórica, y, dejando aparte toda pasión y toda paradoja, apreciar los principios fundamentales, los efectos históricos y los resultados finales de los sistemas filosóficos en sus relaciones con la religión, con la política, con las artes, con las letras, con las ciencias y con la sociedad en que se formaron. A esta contestación no tendría más respuesta que dar que mi total aprobación. Estoy seguro de ello.

Lo conozco a V. demasiado para saber que si V. (cuyo prodigioso saber en edad tan temprana es un misterio que sólo puede explicarse reconociendo en $\mathrm{V}$. un talento comprensivo organizador y sintético, que haya determinado a priori una dirección profunda y vasta en sus posteriores estudios, una memoria colosal, fácil y tenaz, como que conserva estereotipado para siempre lo que fugazmente atravesó por delante de los ojos y de los oídos, 
y una aplicación portentosa, por la vocación intelectual y por la resistencia física que supone) se propone, elevándose sobre toda pasión de polémica y toda preocupación literaria, determinar fijamente el valor de la doctrina de Santo Tomás de Aquino, ha de rendir V. a esta gran manifestación científica de la verdad católica un homenaje profundo y completo, como el que espontáneamente ha rendido V. a la Inquisición española en su obra de civilización, en el transcurso de sus cartas.

Si así no lo hiciera $V$., impotente yo para contrarrestar sus ataques, sólo me restaría apelar, como ahora apelo, del erudito que se colocó en un siglo que no era el nuestro, para esgrimir armas definitivamente relegadas al panteón del olvido por el fallo de la crítica histórica, y del erudito que, pertrechado con interminable arsenal de hechos sueltos y al parecer contrarios, apedrease el monumento levantado por esos hechos mismos completos y encadenados, o a pesar de ellos, por la historia, al eminente crítico, teológico, filosófico, histórico y literario autor de la Historia de los heterodoxos españoles.

Alejandro Pidal y Mon 



\section{LA CIENCIA ESPAÑOLA \\ Marcelino Ménéndez Pelayo}

Esta nueva edición de La ciencia española se atiene al índice y los textos de la tercera edición de la obra (1887-1889), que fue la última compuesta y revisada por Menéndez Pelayo, pero incluye como anexos los textos añadidos a la obra en la Edición Definitiva por Miguel Artigas y, en la Edición Nacional, por Enrique Sánchez Reyes y Rafael Balbín Lucas. Por otra parte, esta edición dispone de un conjunto de estudios introductorios realizados por reconocidos especialistas que sitúan La ciencia española en su tiempo y en el nuestro, estudiándola desde el punto de vista historiográfico, argumentativo y bibliográfico. Además, el capítulo «Historia de las ediciones» diferencia y estudia la génesis de las cinco ediciones históricas de la obra, desde la primera en un volumen, de 1876, hasta la Edición Nacional en tres gruesos volúmenes, de 1953-1954, que fue vertida en el Menéndez Pelayo Digital (1999), pasando por la segunda edición en un volumen, de 1880, la tercera edición en tres volúmenes, de 1887-1889, y la cuarta en dos volúmenes, de 1933. Por lo que estos estudios preliminares no sólo aportan al lector una perspectiva actualizada de la obra, sino que también contribuyen a mostrarla desmitificada en su génesis histórica. El texto de esta edición de La ciencia española es básicamente el mismo de la Edición Nacional, que fue establecido con cuidado modélico por los editores a partir del texto de la tercera edición, teniendo en cuenta las dos primeras ediciones y los escasos manuscritos de la obra conservados entre los papeles del maestro. Sólo se han corregido algunas erratas menores. Finalmente, para esta edición se ha revisado a fondo el índice de autores citados por Menéndez Pelayo. 